\title{
Euro-Asian Transport Linkages
}

Paving the way for a more efficient Euro-Asian transport
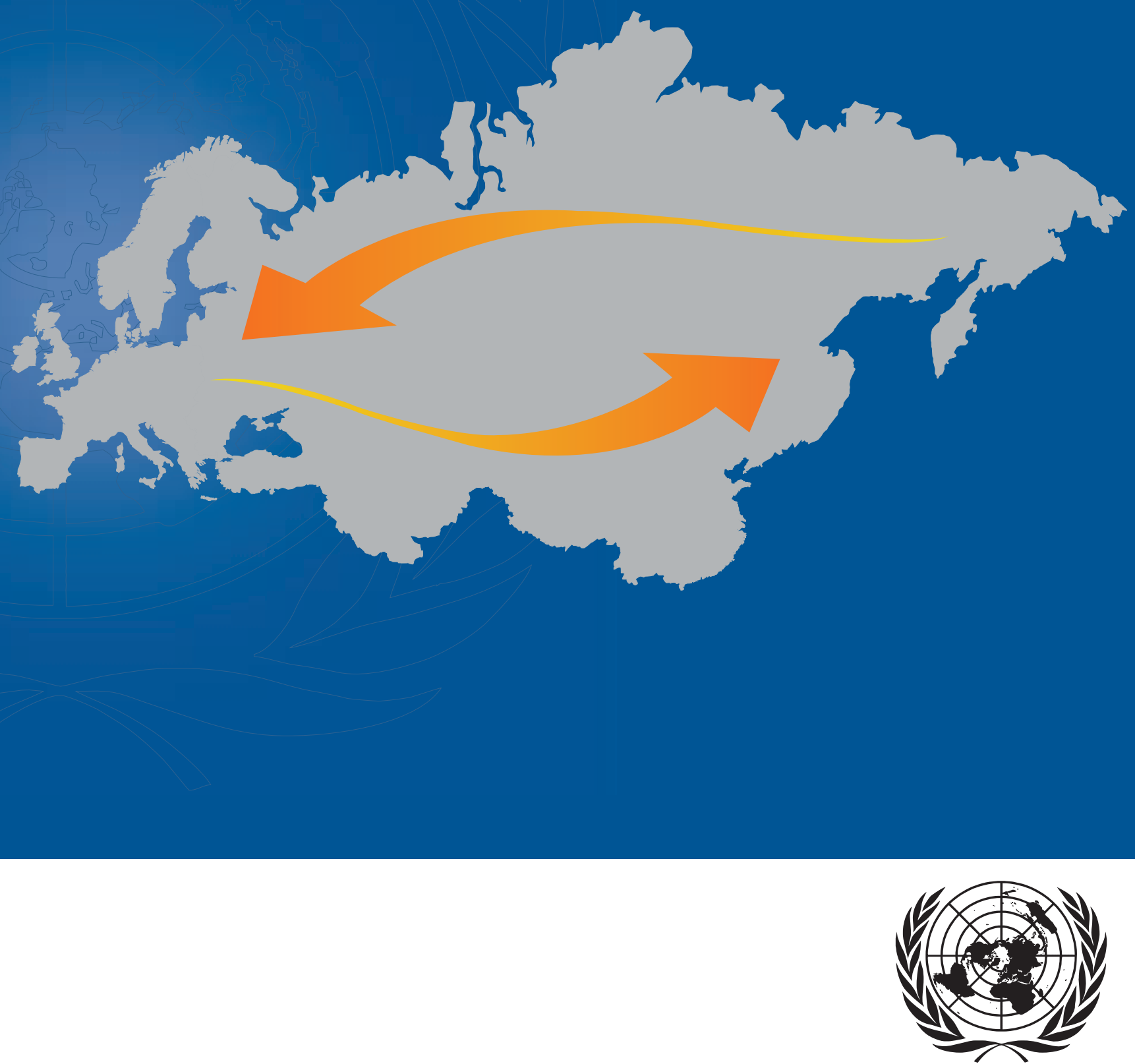

UNITED NATIONS 


\title{
EURO-ASIAN TRANSPORT LINKAGES
}

\author{
PHASE II
}

\section{Expert Group Report}

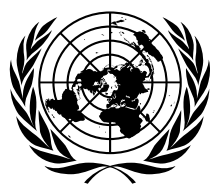

UNITED NATIONS

New York and Geneva, 2012 


\section{NOTE}

Symbols of United Nations documents are composed of capital letters combined with figures. Mention of such a symbol indicates a reference to a United Nations document.

The designations employed and the presentation of the material in this publication do not imply the expression of any opinion whatsoever on the part of the secretariat of the United Nations concerning the legal aspects, status of any country, territory, city or area, or of its authorities, nor do they concern the delimitation of their frontiers or boundaries. The maps and country reports are only for information purposes. Related data was sent by the countries concerned and the respective content is their complete responsibility. In the few cases that countries did not provide data, the secretariat provided data from available sources. The UN Group of Experts on Geographical Names (UNGEGN) under the Department of Economic and Social Affairs (DESA) in the United Nations Secretariat (http://unstats.un.org/unsd/geoinfo/UNGEGN/ default.html) deals with names on the basis of Member State driven initiatives. 


\section{United Nations Economic Commission for Europe}

The United Nations Economic Commission for Europe (UNECE) is one of the five United Nations regional commissions, administered by the Economic and Social Council (ECOSOC). It was established in 1947 with the mandate to help rebuild post-war Europe, develop economic activity and strengthen economic relations among European countries, and between Europe and the rest of the world. During the Cold War, UNECE served as a unique forum for economic dialogue and cooperation between East and West. Despite the complexity of this period, significant achievements were made, with consensus reached on numerous harmonization and standardization agreements.

In the post-Cold War era, UNECE acquired not only many new Member States, but also new functions. Since the early 1990s the organization has focused on analyses of the transition process, using its harmonization experience to facilitate the integration of Central and Eastern European countries into the global markets.

UNECE is the forum where the countries of Western, Central and Eastern Europe, Central Asia and North America - 56 countries in all - come together to forge the tools of their economic cooperation. That cooperation concerns economics, statistics, environment, transport, trade, sustainable energy, timber and habitat. The Commission offers a regional framework for the elaboration and harmonization of conventions, norms and standards. The Commission's experts provide technical assistance to the countries of South-East Europe and the Commonwealth of Independent States. This assistance takes the form of advisory services, training seminars and workshops where countries can share their experiences and best practices.

\section{Transport in UNECE}

The UNECE Inland Transport Committee (ITC) facilitates the international movement of persons and goods by inland transport modes. It aims to improve competitiveness, safety, energy efficiency and security in the transport sector. At the same time it focuses on reducing the adverse effects of transport activities on the environment and contributing effectively to sustainable development. The ITC is a:

- Centre for multilateral transport standards and agreements in Europe and beyond, e.g. regulations for dangerous goods transport and road vehicle construction at the global level

- Gateway for technical assistance and exchange of best practices

- Promoter of multi-country investment planning

- Substantive partner for transport and trade facilitation initiatives

- Historic centre for transport statistics.

For more than six decades, ITC has provided a platform for intergovernmental cooperation to facilitate and develop international transport while improving its safety and environmental performance. The main results of this persevering and important work are reflected in more than 50 international agreements and conventions which provide an international legal framework and technical regulations for the development of international road, rail, inland water and intermodal transport, as well as dangerous goods transport and vehicle construction. Considering the needs of the transport sector and its regulators, UNECE offers a balanced approach to and treatment of facilitation and security issues alike. 


\section{Table of Contents}

United Nations Economic Commission for Europe ...........................................................

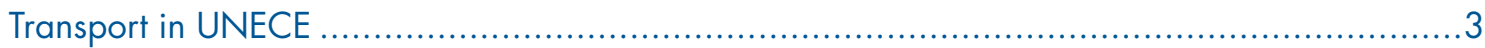

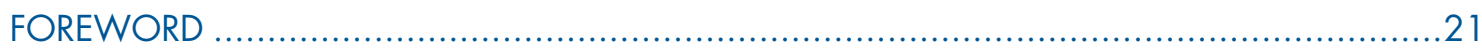

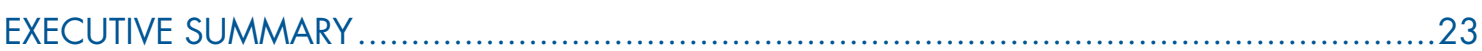

PART I - EURO-ASIAN TRANSPORT FLOWS, STATISTICS AND TRENDS ............. 29

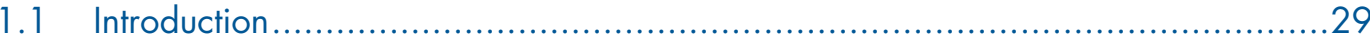

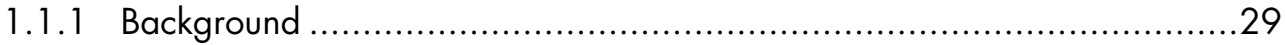

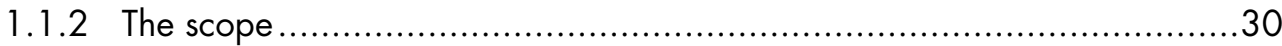

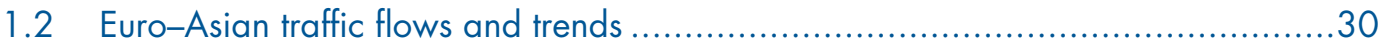

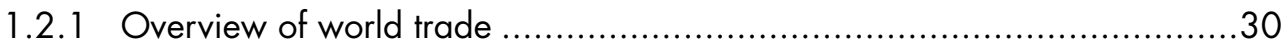

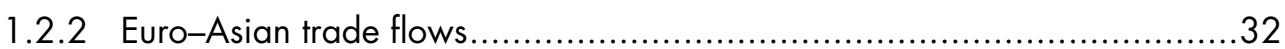

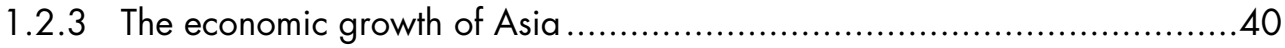

1.2.4 Container freight transport between Asia and Europe ...........................44

1.2.5 Landlocked Countries ........................................................................49

1.3 Merchandise trade among EATL countries ..................................................50

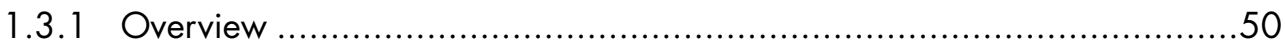

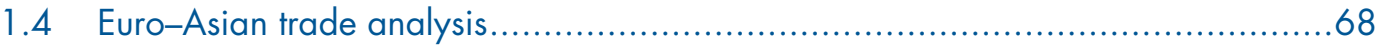

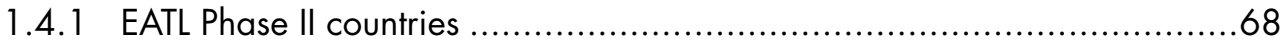

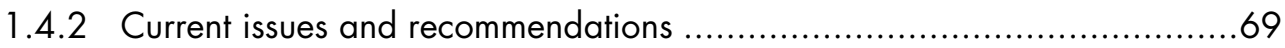

\section{PART II - COMPARISON OF EURO-ASIAN INLAND TRANSPORT WITH}

EXISTING MARITIME ROUTES.........................................................73

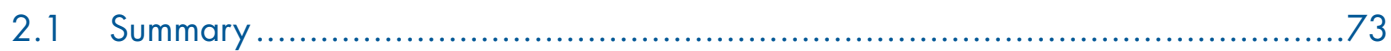

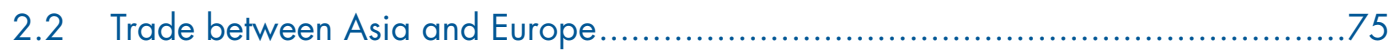

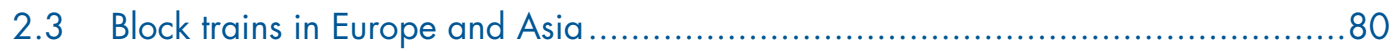

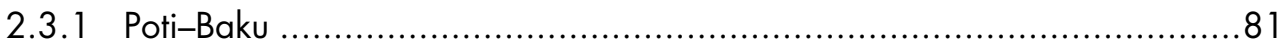

2.3.2 Vostochny, Moscow, Novosibirsk, Taganrog (Hyundai), Izhevsk (KIA),

Naberezhnye Chelny (Ssang Yong), Uzbekistan (GM Daewoo) and

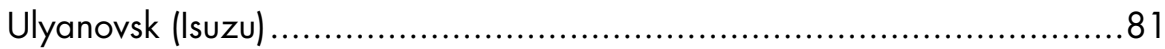

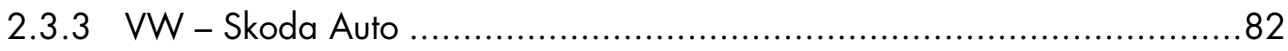

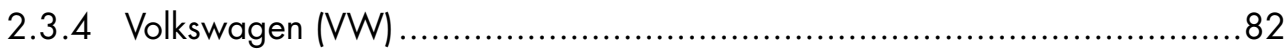

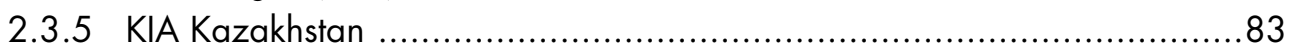

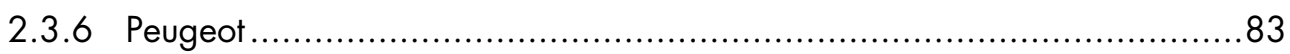

2.3.7 CD Cargo Czech Republic...............................................................84

2.3.8 Trains listed by the Organization for Cooperation of Railways ...............84

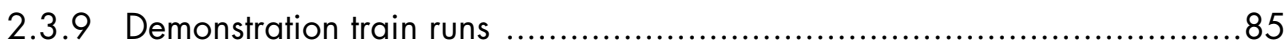

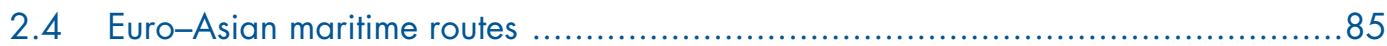

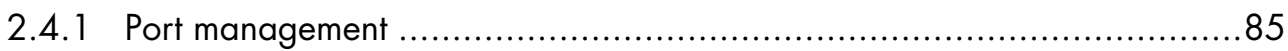

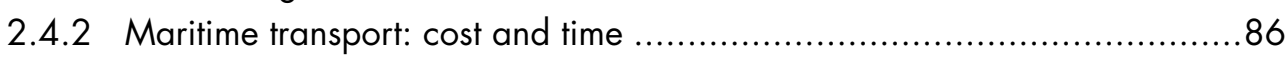

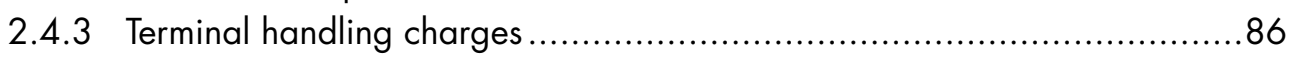

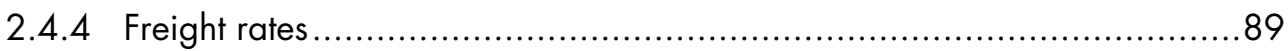

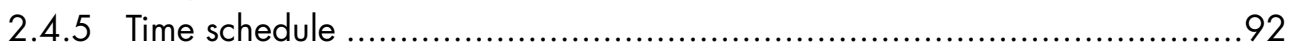

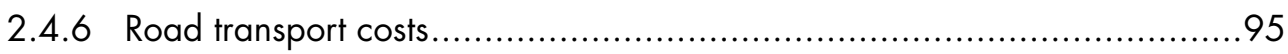




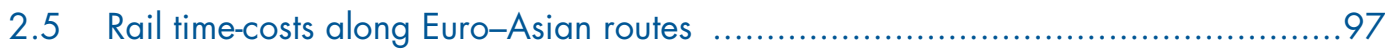

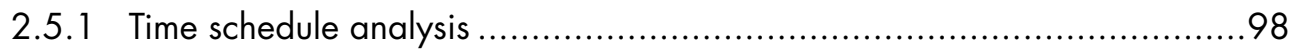

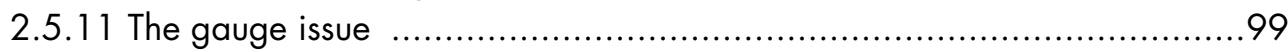

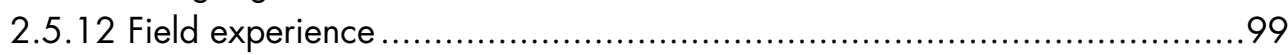

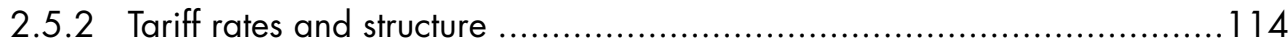

2.6 Comparison of rail and maritime transport along EATL routes .........................11 11

2.6.1 Comparative analysis of EATL rail and maritime transport...................118

2.6.2 Case study: Car manufacturers along the Euro-Asia transport links.........139

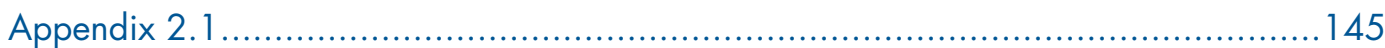

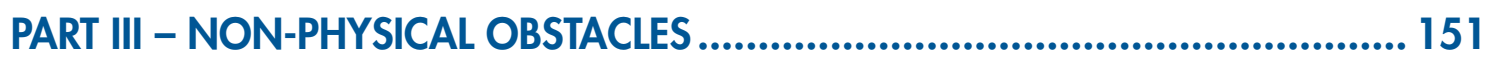

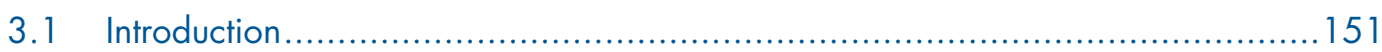

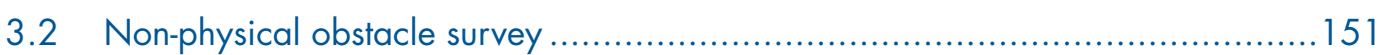

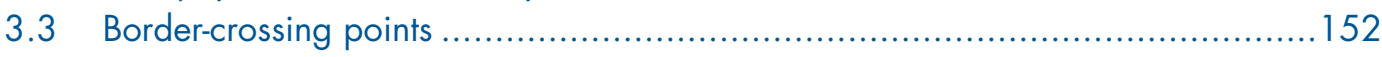

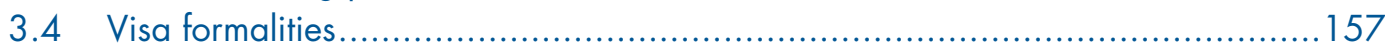

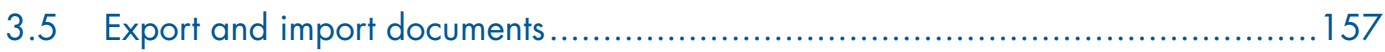

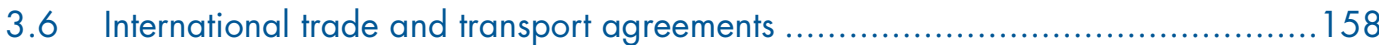

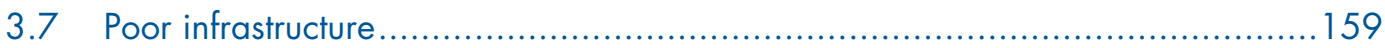

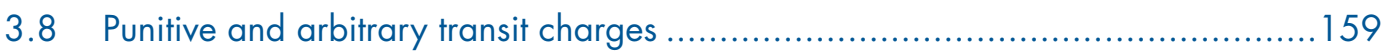

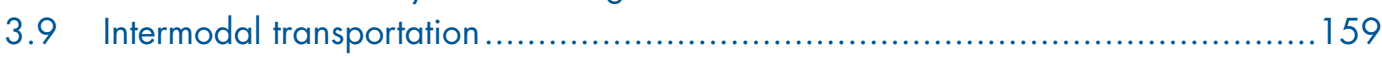

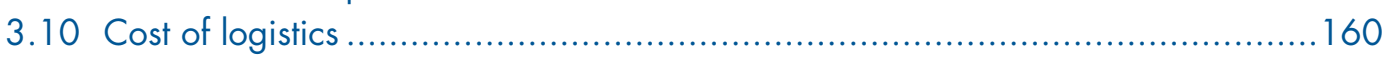

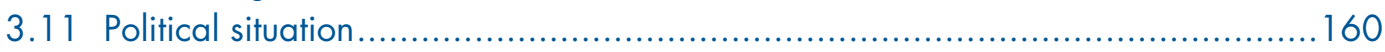

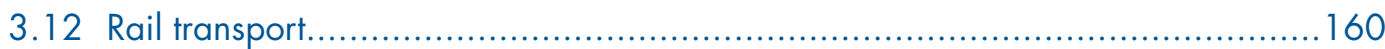

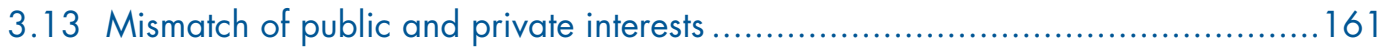

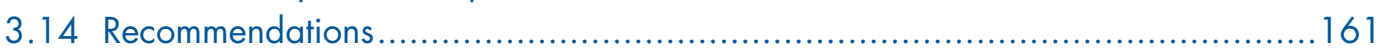

PART IV - TRANSPORT INFRASTRUCTURE ALONG EURO-ASIAN LINKAGES .... 167

4.1 Reviewing, extending and updating priority routes identified in Phase I ............167

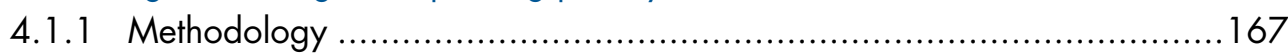

4.1.11 Background information on the identification of main Euro-Asian inland transport routes under the UNECE-UNESCA EATL project (Phase I) ......... 167

4.1.12 Methodological framework for the extension of EATL routes to newly

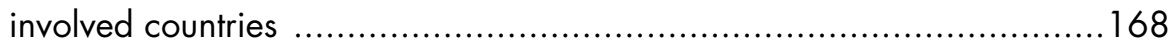

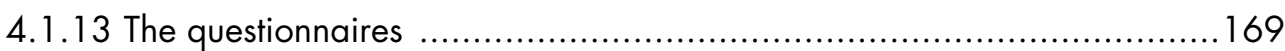

4.1.2 Description of Euro-Asian transport linkages..................................171

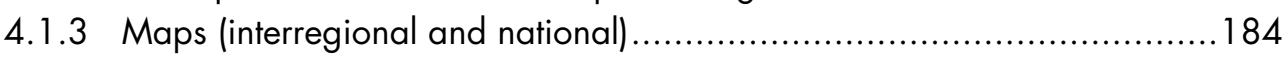

4.1.31 Presentation of interregional maps - RAlL .............................................184

4.1.32 Presentation of interregional maps - ROADS .................................... 198

4.1.33 Presentation of interregional maps - INLAND WATERWAYS AND PORTS ...210

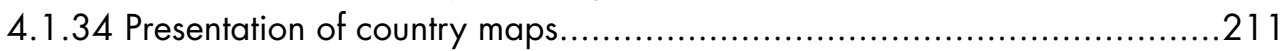

4.2 Reviewing, extending and updating priority projects identified in Phase I...........240

4.2.1 Methodology for project prioritization ...........................................240

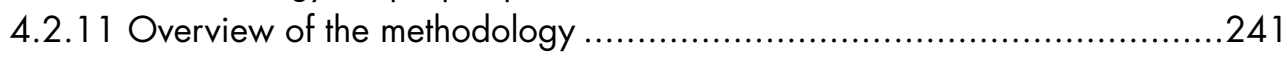

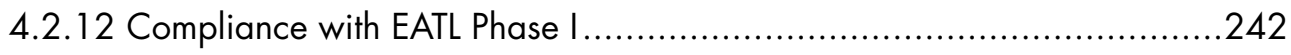

4.2.13 Important conditions for the prioritization exercise ..............................242

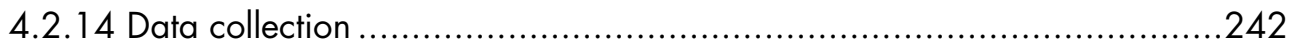

4.2.15 Additional information upon original submission ................................243

4.2.2 Implementation of priority projects identified in Phase I.......................245 
4.2.21 Summary results

4.2.3 Updating EATL priority infrastructure projects and developing an EATL Investment Plan

4.2.31 Input received

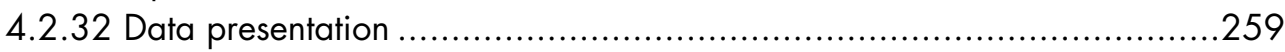

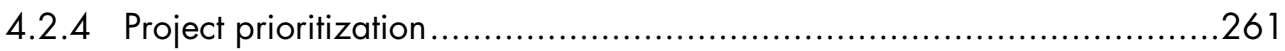

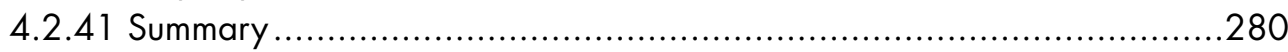

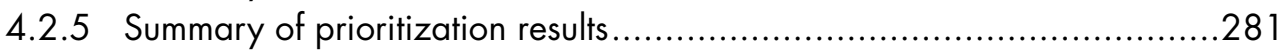

4.2.6 EATL Phase II Investment Plan .................................................282

4.2.7 Project Prioritization per EATL Priority Route ....................................283

4.2.8 Conclusions and recommendations .............................................287

Appendix 4.1 TEMPLATES B for EATL Phase I Countries ...........................................28

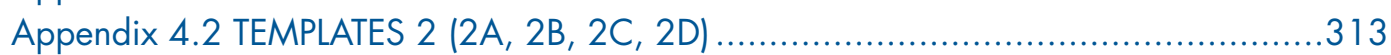

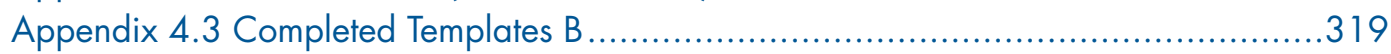

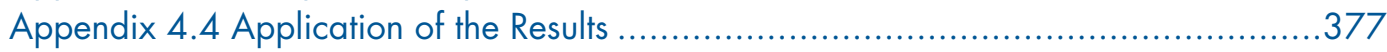

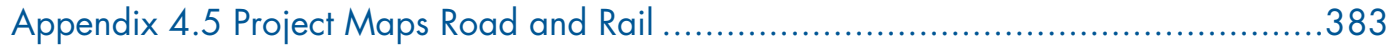

Appendix 4.6 Project prioritization per EATL Priority Route....................................431

\section{PART V - GEOGRAPHIC INFORMATION SYSTEM (GIS) INTERNET} APPLICATION

5.1 GIS in the Euro-Asian transport linkages project..........................................443

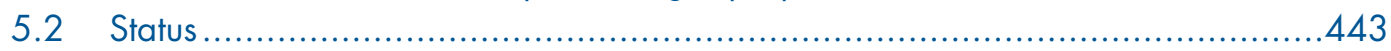

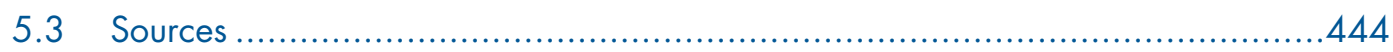

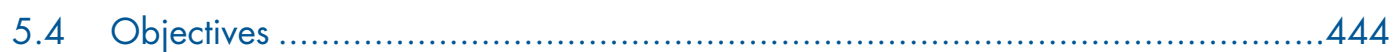

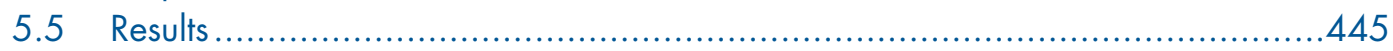

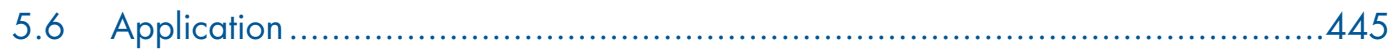

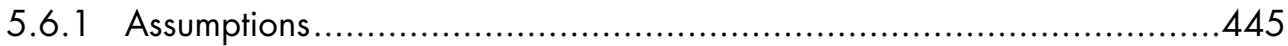

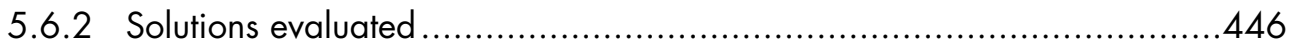

5.6.3 Application presentation.............................................................449

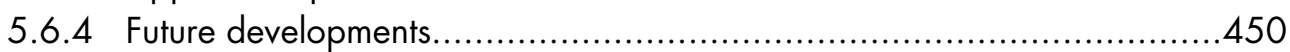

Appendix 5.1 Acronyms and Definitions related to the GIS ...............................453

PART VI - STRENGTHS, WEAKNESSES, OPPORTUNITIES AND THREATS

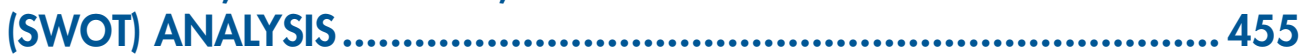

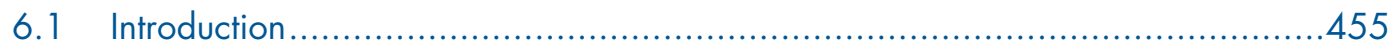

6.2 Elaboration of a SWOT analysis for EATL inland transport connections .............455

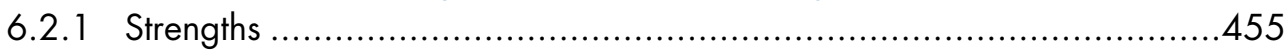

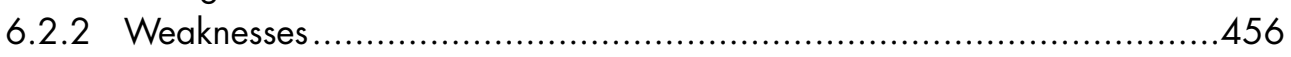

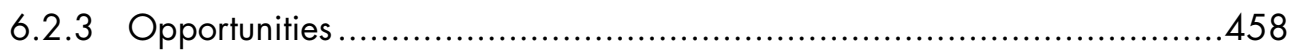

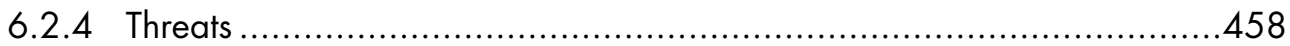

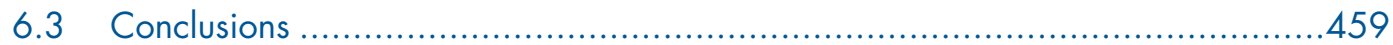

PART VII - REVIEW OF INTERNATIONAL TRANSPORT NETWORKS AND INITIATIVES LINKING ASIA AND EUROPE....................................461

7.1 United Nations transport networks in the EATL region ....................................461

7.2 Trans-European Motorway and Trans-European Railway .................................466

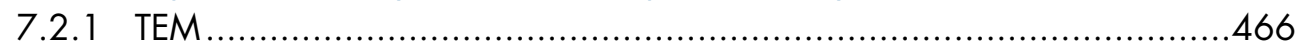

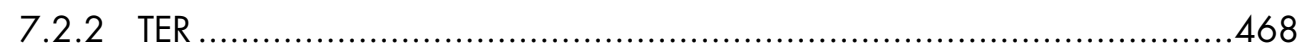

7.2.3 TEM and TER Master Plan revision ……....................................468 
7.3 United Nations Economic and Social Commission for Asia and the Pacific ........470

7.3.1 Relevant initiatives/projects.

7.4 United Nations Special Programme for the Economies of Central Asia ..............472

7.4.1 Relevant initiatives/projects.........................................................473

7.5 United Nations Office of the High Representative for the Least Developed

Countries, Landlocked Developing Countries and Small Island Developing States 476

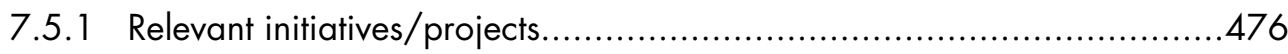

7.6 United Nations Conference on Trade and Development.................................477

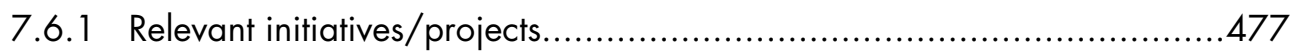

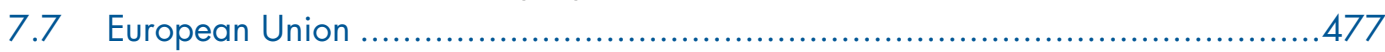

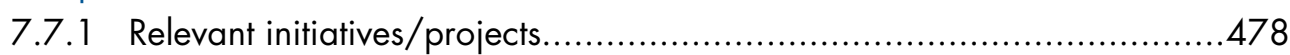

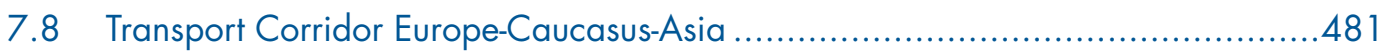

7.9 Organization for Security and Co-operation in Europe ...................................482

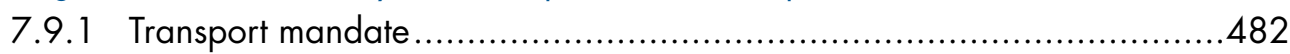

7.9.2 Transport activities .....................................................................483

7.9.21 Developing the OSCE/UNECE Handbook of Best Practices at Border

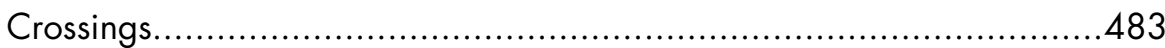

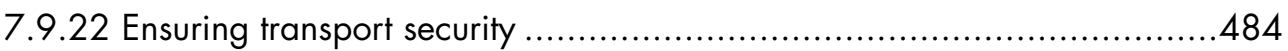

7.9.23 Promoting the implementation of international legal instruments ..............484

7.9.24 Fostering good governance and anti-corruption ..............................484

7.9.25 Preventing and detecting illegal transboundary waste transportation ......485

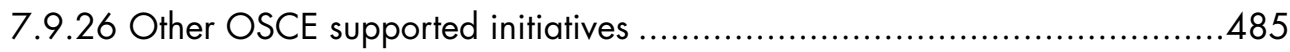

7.10 Organization of the Black Sea Economic Cooperation (BSEC) ........................485

7.10.1 Relevant initiatives/projects.....................................................486

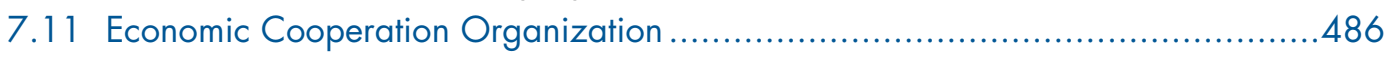

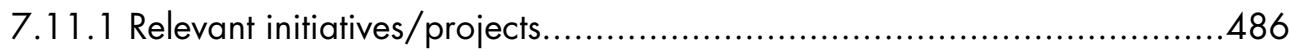

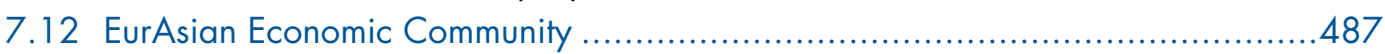

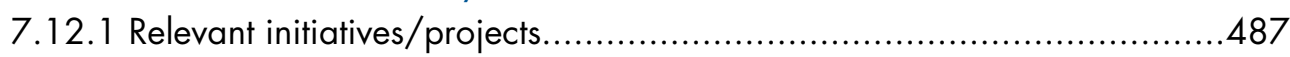

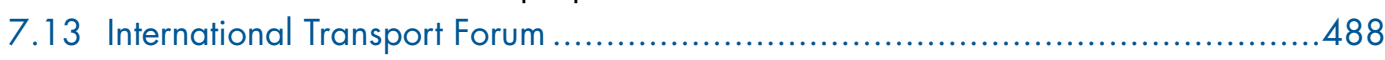

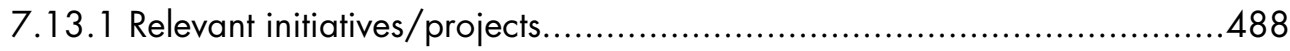

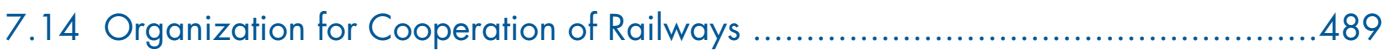

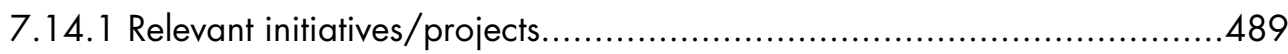

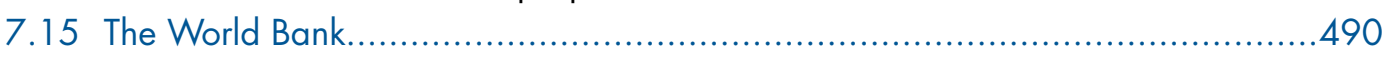

7.15.1 Relevant initiatives/projects.................................................490

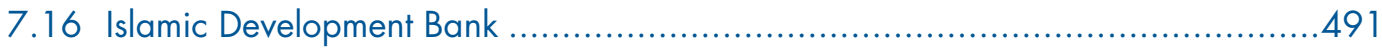

7.16.1 Relevant initiatives/projects.........................................................491

7.16.1.1 IDB Group Infrastructure Strategic Plan (1431 H-1433H /

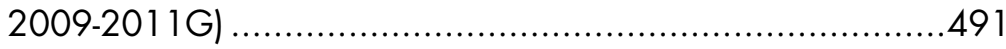

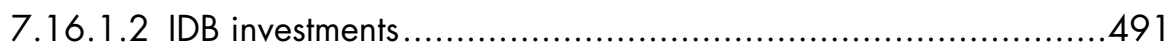

7.17 Asian Development Bank .....................................................................492

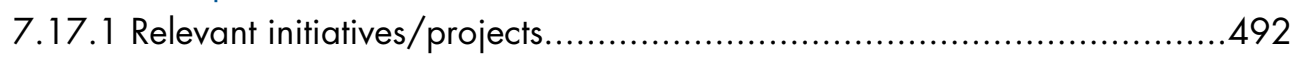

7.18 European Bank for Reconstruction and Development .................................495

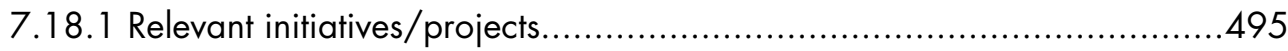

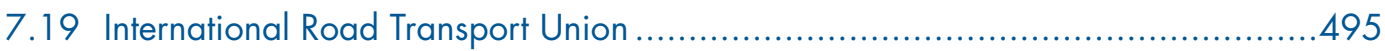

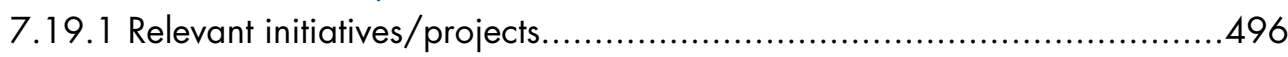


PART VIII - CONCLUSIONS

PART IX - RECOMMENDATIONS ..............................................................503

ANNEX I - COUNTRY REPORTS ...............................................................5 517

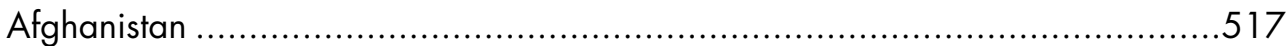

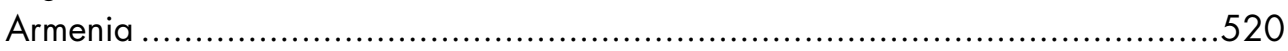

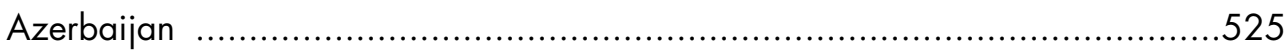

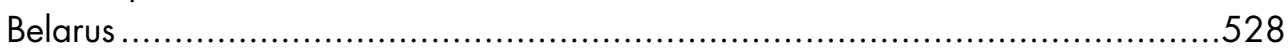

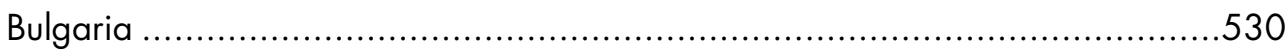

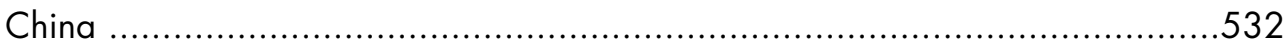

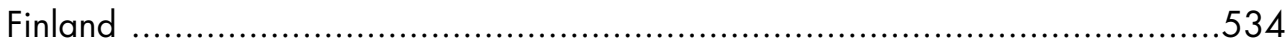

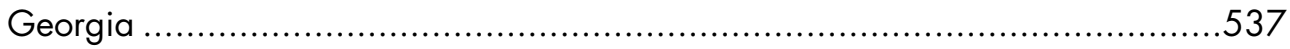

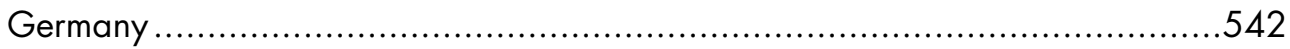

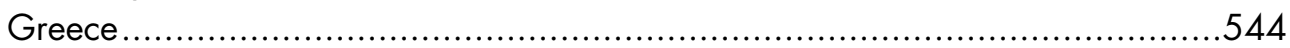

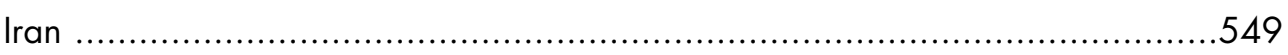

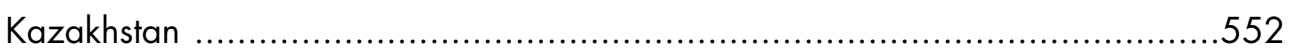

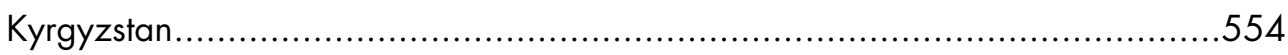

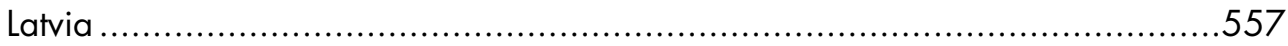

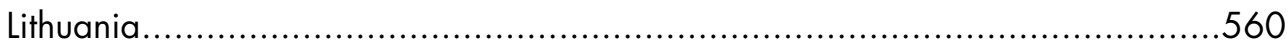

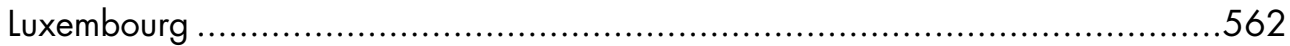

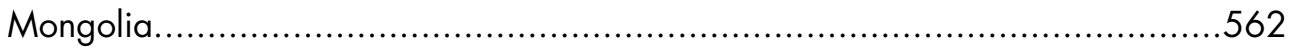

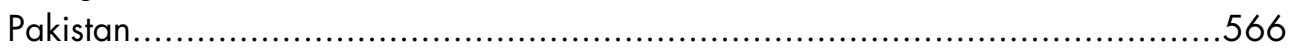

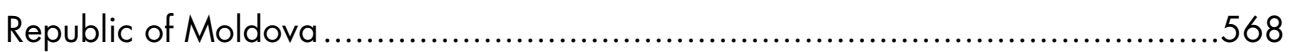

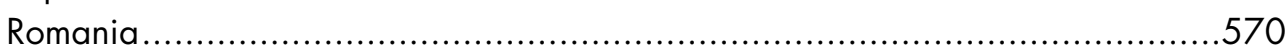

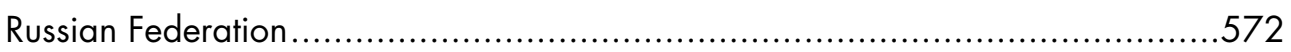

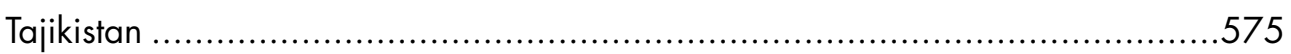

The former Yugoslav Republic of Macedonia ................................................578

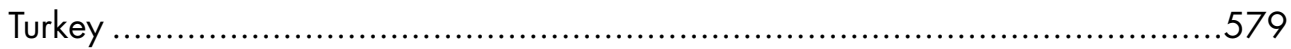

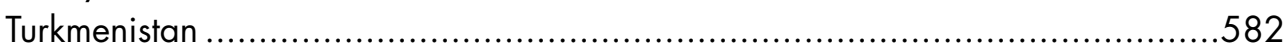

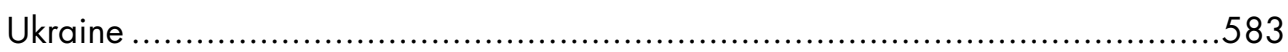

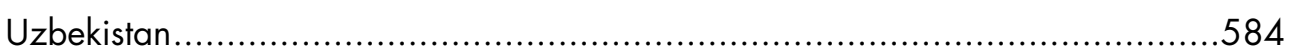

\section{ANNEX II - SUMMARY LIST OF INTERNATIONAL UNECE LEGAL} INSTRUMENTS IN THE FIELD OF TRANSPORT .........................................591

I. MAIN INTERNATIONAL UNECE TRANSPORT CONVENTIONS ......................591

A. Transport Infrastructure Agreements..........................................................591

B. Main Road Traffic and Road Safety Conventions .....................................592

C. Agreements on Regulations for the Construction of Vehicles............................592

D. Other Road Transport Conventions .............................................................593

E. Border-Crossing Facilitation Conventions ....................................................594

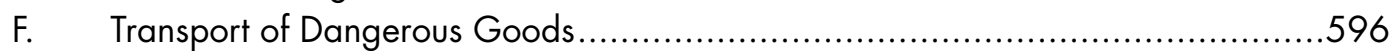

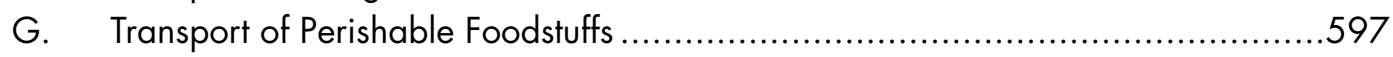




\section{List of Tables}

1.1 Growth in the volume of world merchandise trade by selected region and economy, 2000-2009

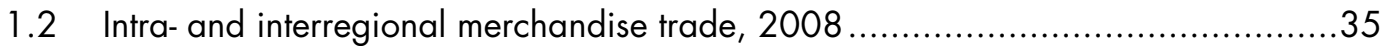

1.3 EU-27 trade value with China by transport mode (in million euros) ......................37

1.4 Transport travel times from Asian origins to Finland........................................40

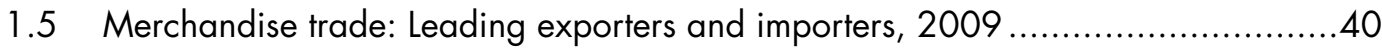

1.6 World merchandise trade by region and selected country, 2009 .....................42

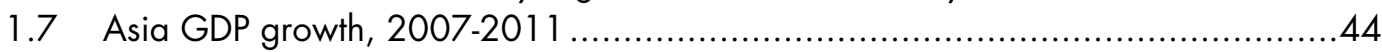

1.8 Freight rates (market averages) per TEU on the three major liner trade routes (\$ per TEU and percentage change) ..................................................48

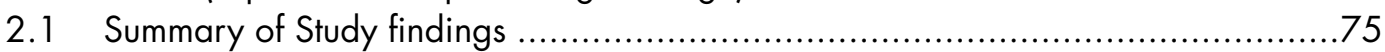

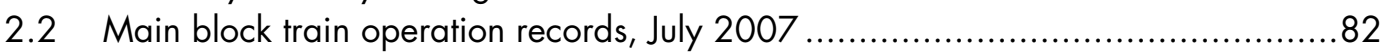

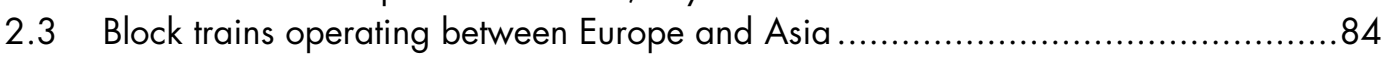

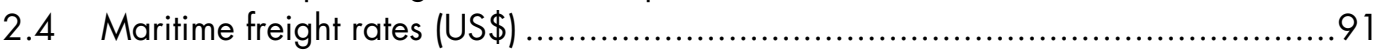

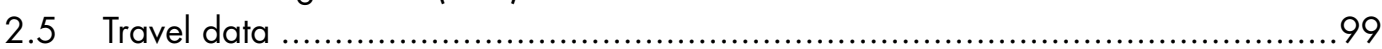

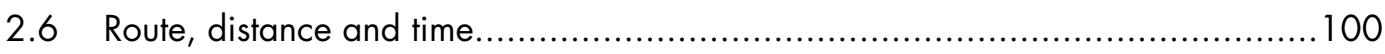

3.1 Europe-Asia Transport Links (EATL) border-crossing point obstacles,

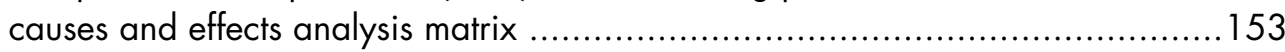

3.2 Reducing land border-crossing point time delaysng point time delays ................ 162

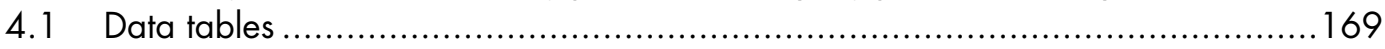

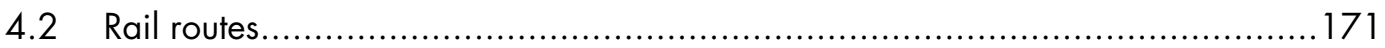

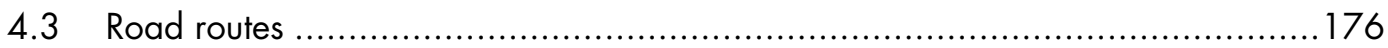

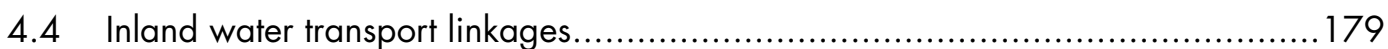

4.5 Inland river ports along selected inland water transport linkages .................... 180

4.6 Maritime ports considered in EATL Phase II ............................................... 182

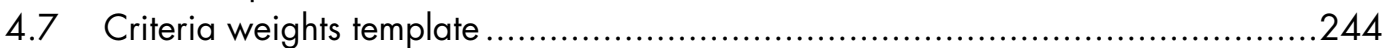

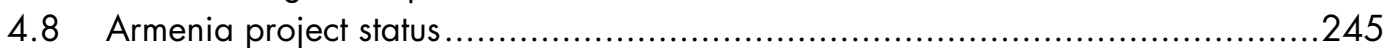

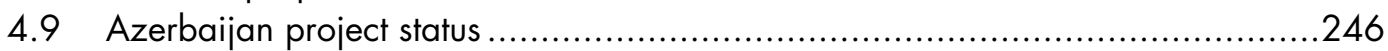

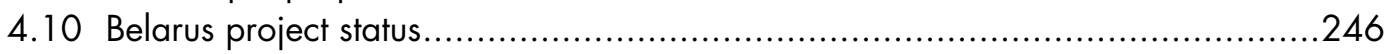

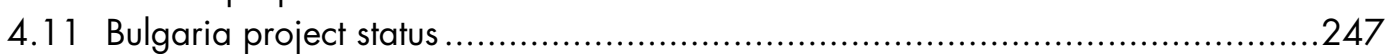

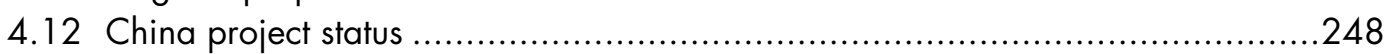

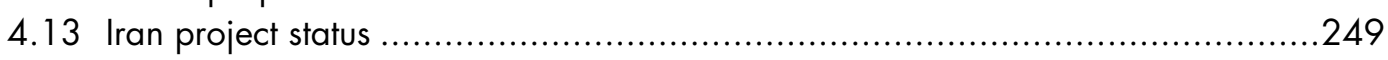

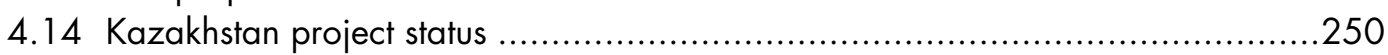

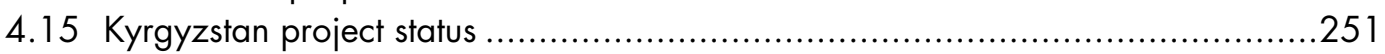

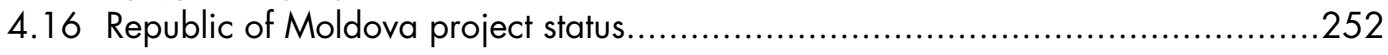

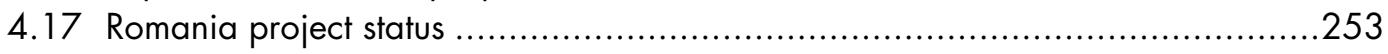

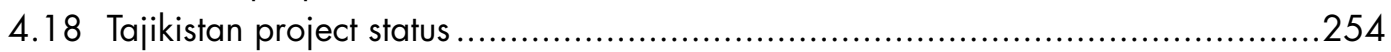

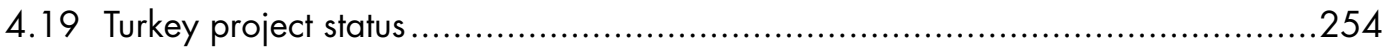

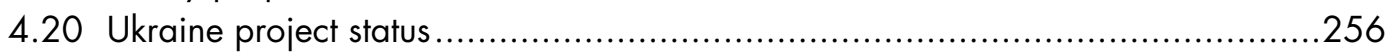

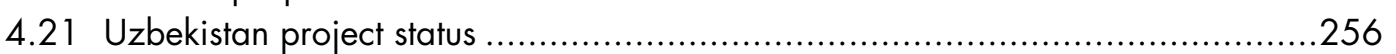

4.22 Summary of EATL Phase I project status ......................................................258

4.23 Data submitted by countries for all projects, per type of infrastructure ................260

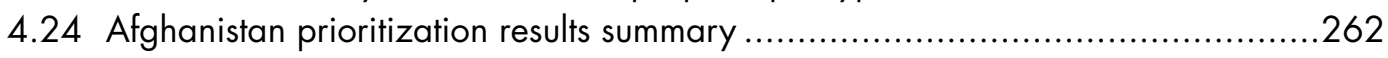

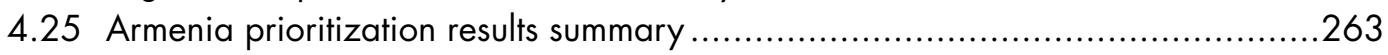

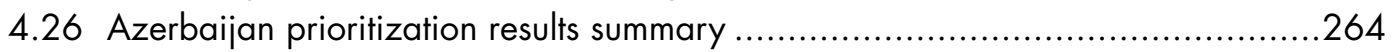

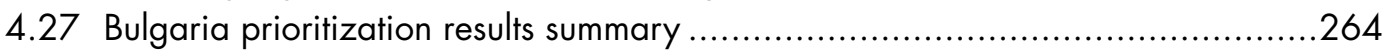

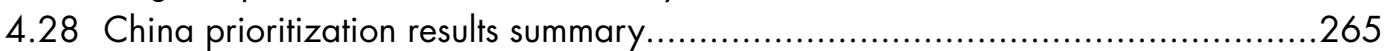

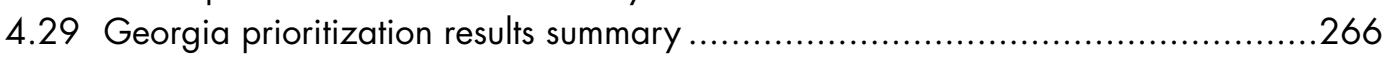




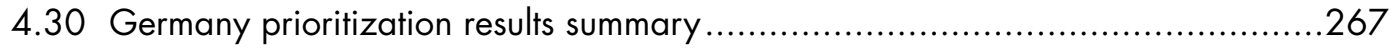

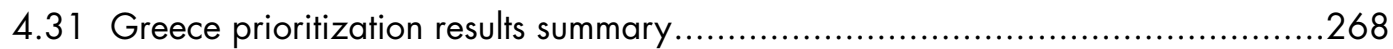

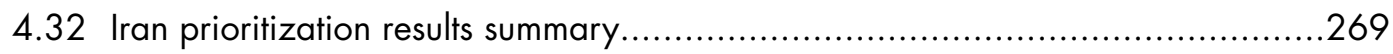

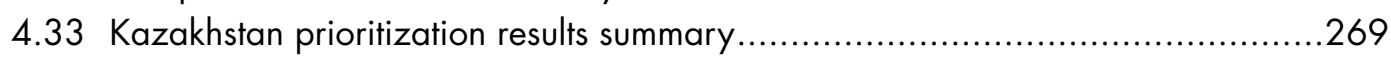

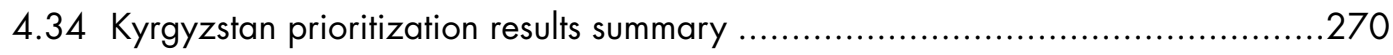

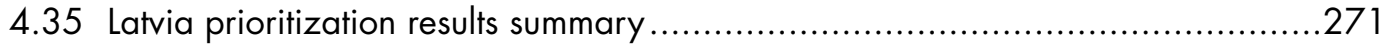

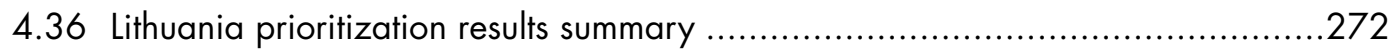

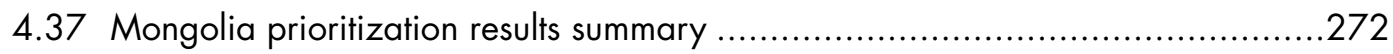

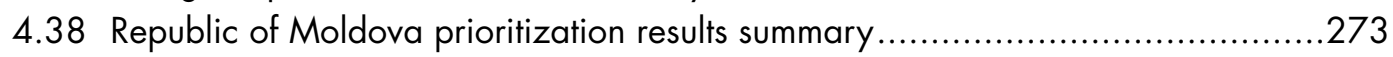

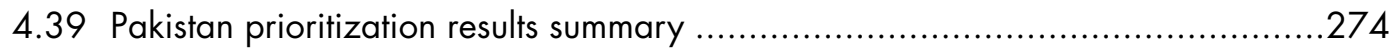

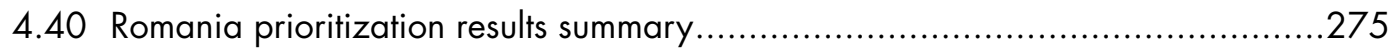

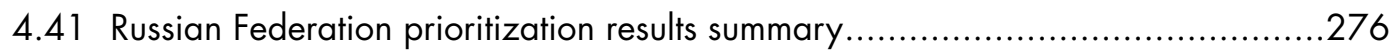

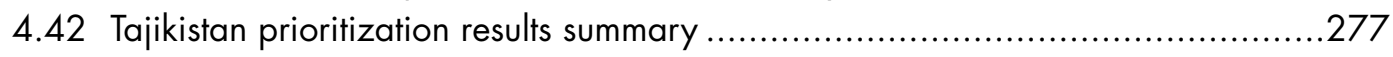

4.43 The former Yugoslav Republic of Macedonia prioritization results summary........277

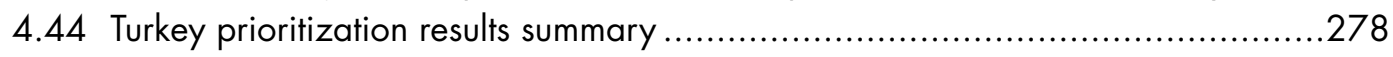

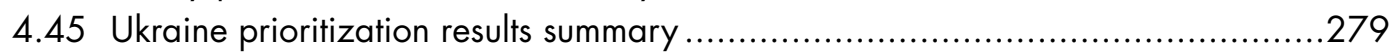

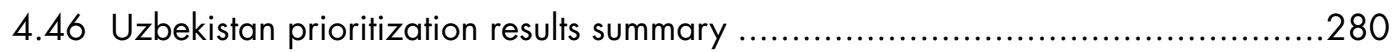

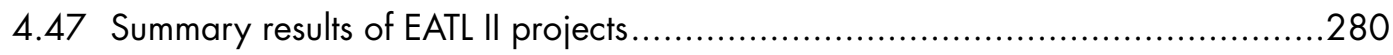

4.48 EATL Phase II Transport Infrastructure Investment Plan (in billion US\$).................282

4.49 EATL Phase II Transport Infrastructure Investment Implementation Time Plan .........283

4.50 Prioritization of Investment per EATL Road Route ..........................................285

4.51 Prioritization of Investment per EATL Rail Route .............................................286

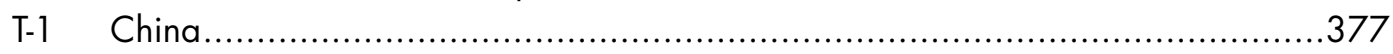

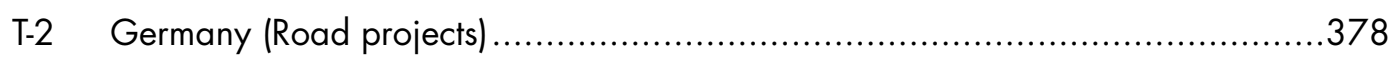

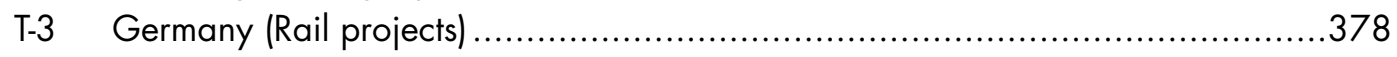

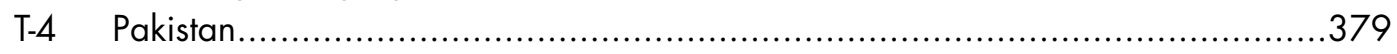

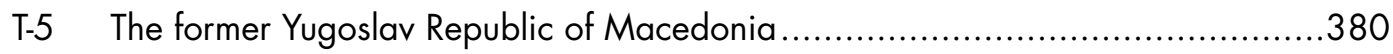

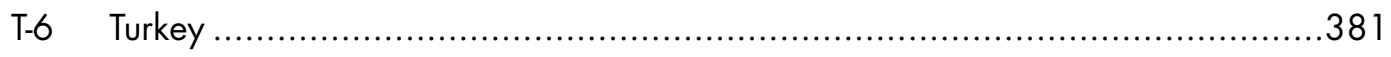

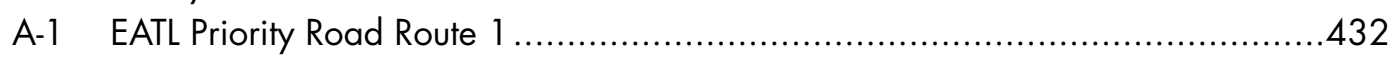

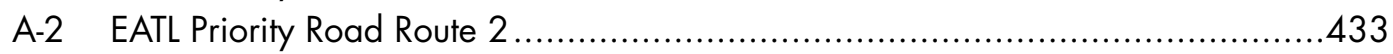

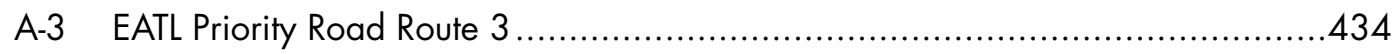

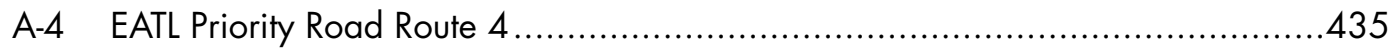

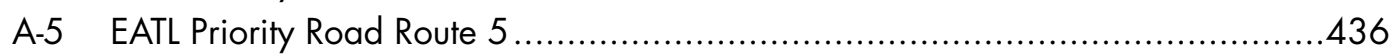

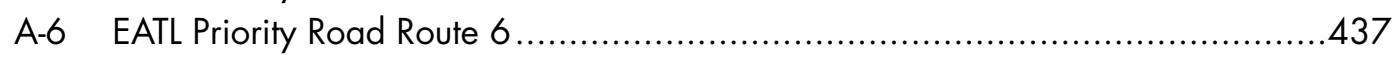

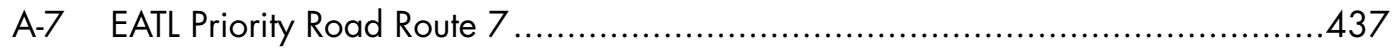

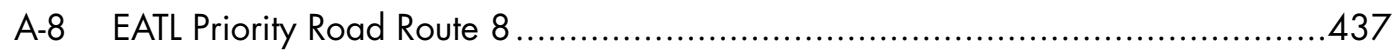

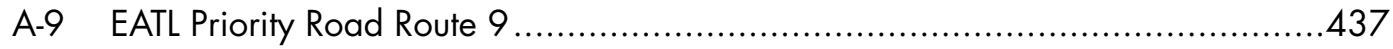

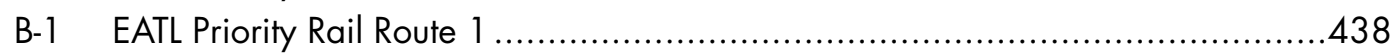

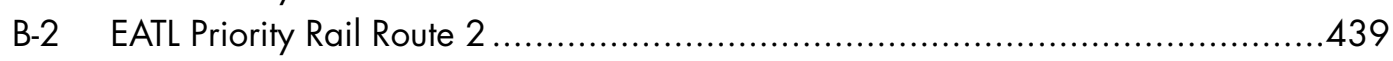

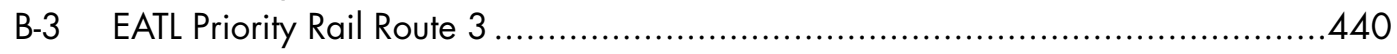

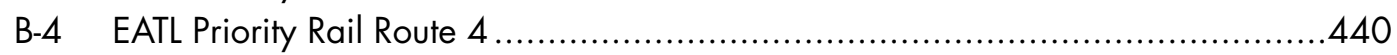

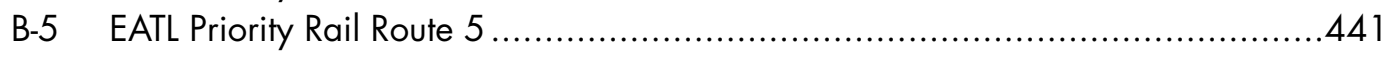

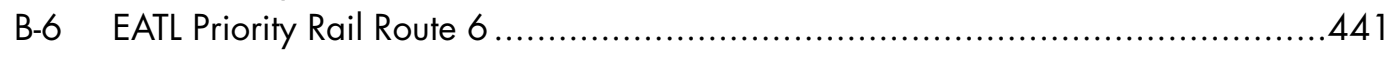

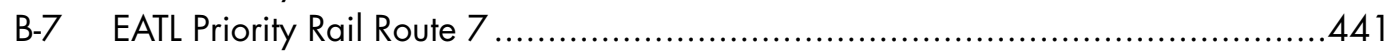

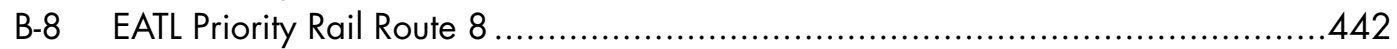

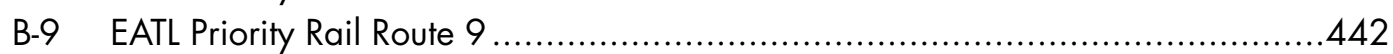

6.1 EATL inland transport connection SWOT analysis ......................................460 
A 1.1 Contribution of transport and communication to GDP in Armenia, 2000-2010

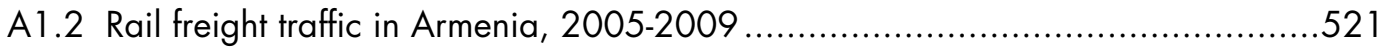

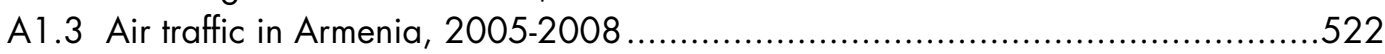

A 1.4 Public transport users - Urban and interurban in Armenia.............................522

A1.5 Roads of Belarus programme priorities and estimated costs...........................529

A 1.6 Modernization of railway corridors in Belarus ............................................529

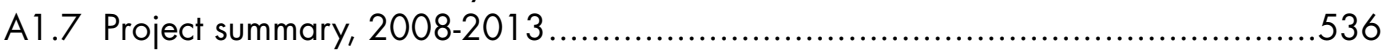

A1.8 International Truck Transportation by Regime in Georgia ..............................538

A1.9 Transported cargo by regime in Georgia (million tons) .................................538

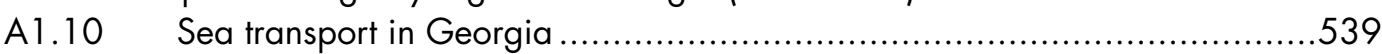

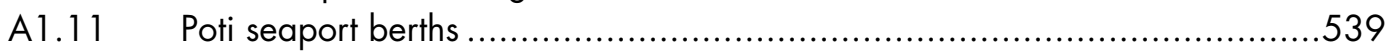

A1.12 Poti seaport cargo volumes and main infrastructure ..............................540

A1.13 Batumi seaport cargo volumes and main infrastructure ..........................54

A1.14 Modal split of freight transport in Greece, 2008-2009 ...........................544

A1.15 Modal split of passenger transport in Greece, 2007-2009 …..................544

A1.16 People killed in inland transport accidents in Greece, 2008-2010 .............545

A1.17 Freight and passenger railway transport, 2009-2010 ….....................545

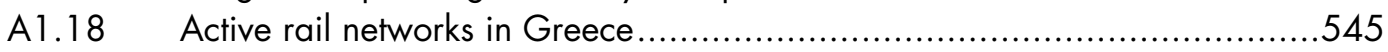

A1.19 Rail networks under construction in Greece ........................................546

A1.20 Rail infrastructure expenditure in Greece............................................546

A1.21 Passengers embarked and disembarked in Greece, 2008-2009 ..............547

A1.22 Passenger traffic at major seaports in Greece, 2007-2009 ......................547

A1.23 Maritime transport of goods in main ports, 2008-2009 ..........................547

A1.24 Border-crossing points of Greece ...................................................54

A1.25 Road transport infrastructure in Latvia ................................................55

A1.26 National and international freight transport by rail in Latvia, 2008-2010 ......558

A 1.27 Cargo loaded and unloaded from domestic and foreign vessels at

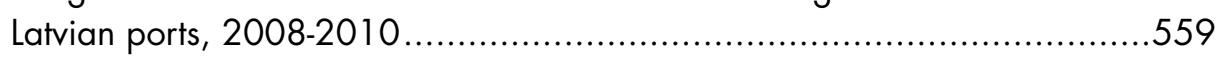

A1.28 Passenger and cargo turnover at Riga airport, 2008-2010 .....................559

A1.29 Modes of transport in Mongolia, 2007-2010 ......................................563

\section{List of Figures}

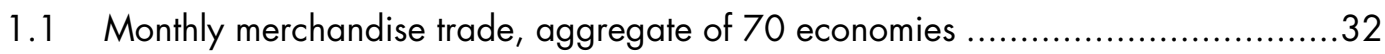

1.2 World merchandise exports by region, 2007-2009 ......................................32

1.3 Regional share in world merchandise exports, 2000 and $2008 \ldots \ldots \ldots \ldots \ldots \ldots . . . . . . . . . . .33$

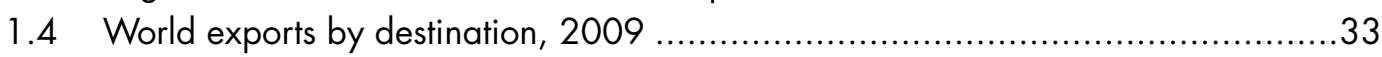

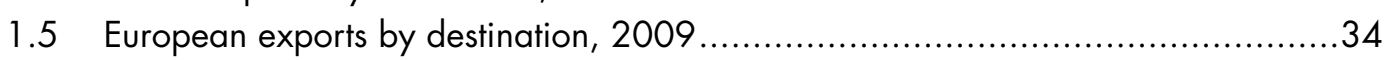

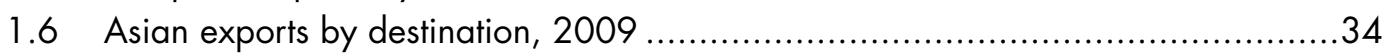

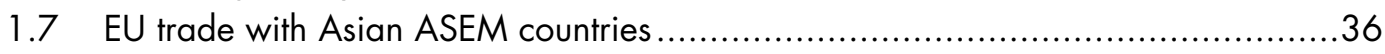

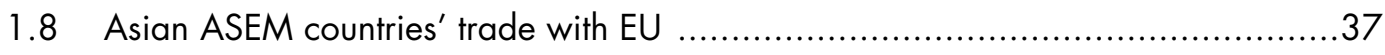

1.9 Turkey trade volumes with the EU-27 by transport mode ...................................38

1.10 Turkey trade volumes with Asia by transport mode ...........................................38

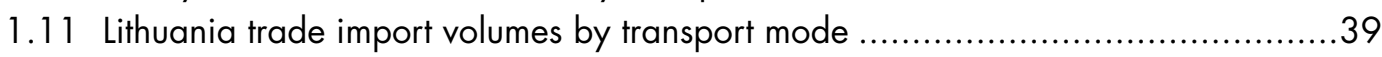

1.12 Lithuania trade export volumes by transport mode ...........................................39

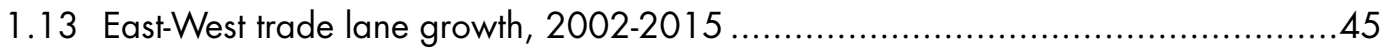

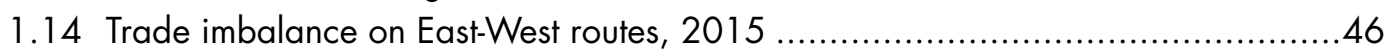

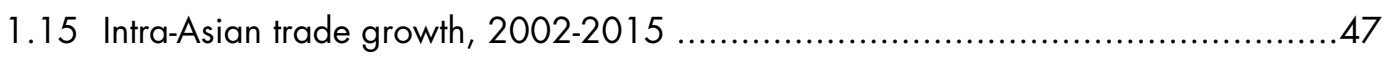




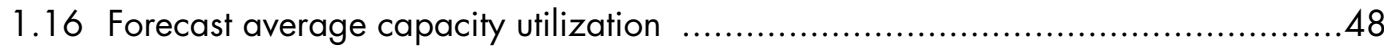

1.17 Maritime container port transport (EU-Asia-26), 2005 (thousand tons/year) ..............49

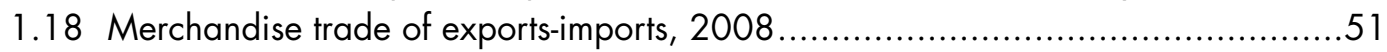

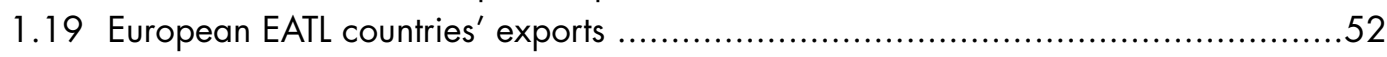

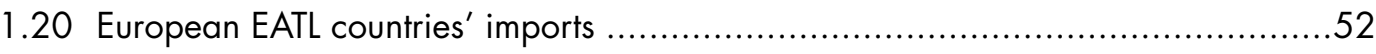

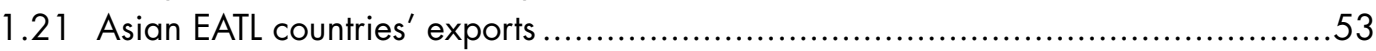

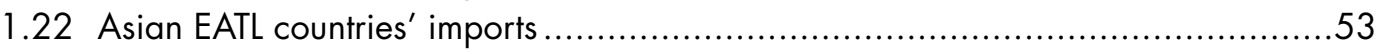

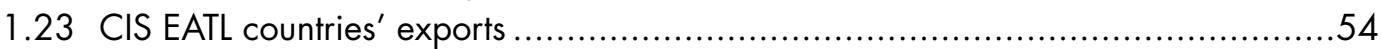

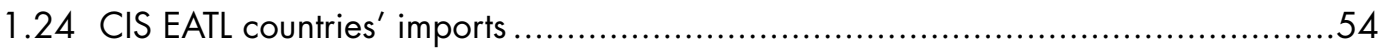

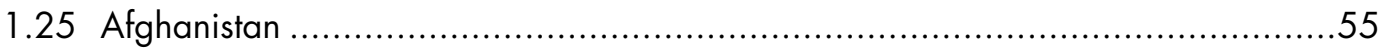

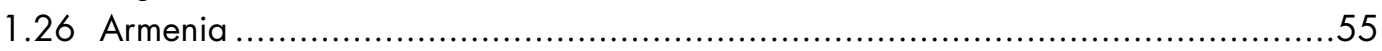

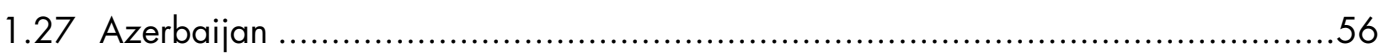

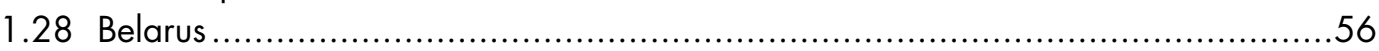

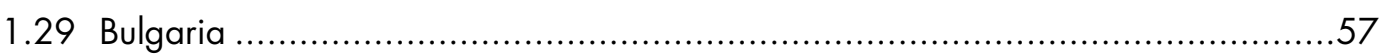

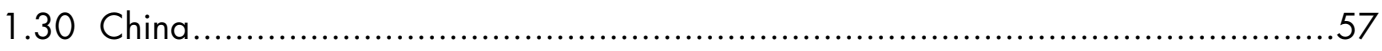

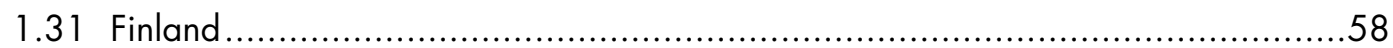

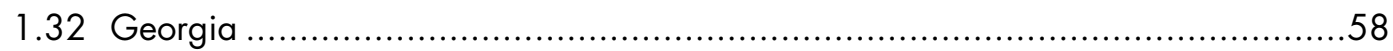

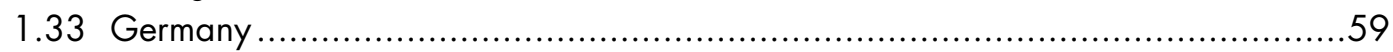

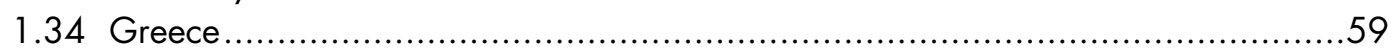

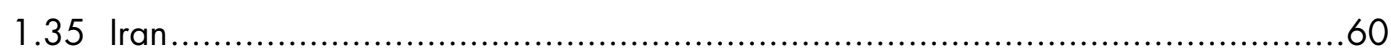

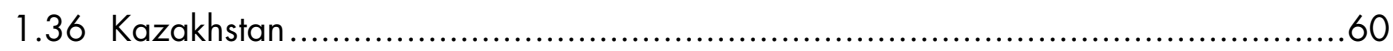

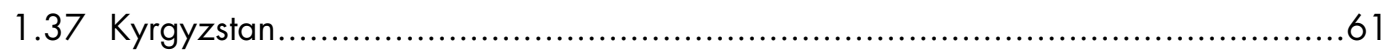

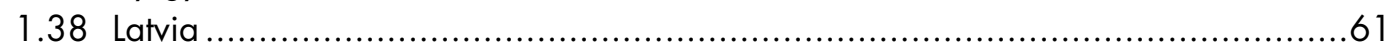

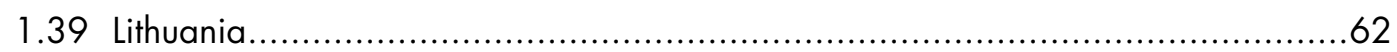

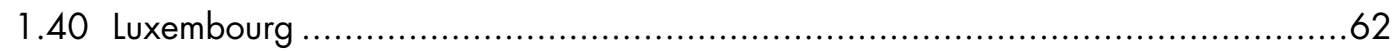

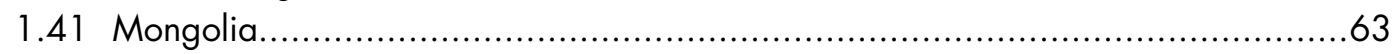

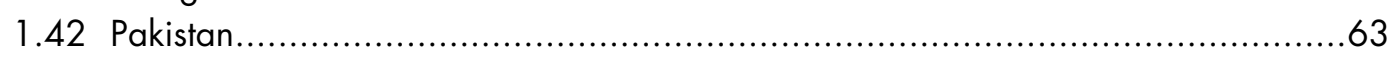

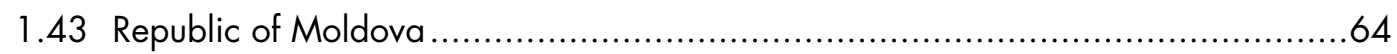

1.44 Romania

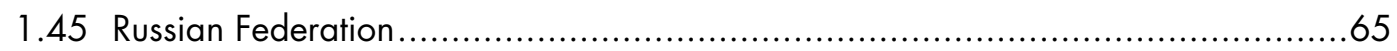

1.46 Share of road haulage import and export, 2009 …..........................................65

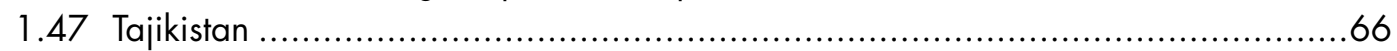

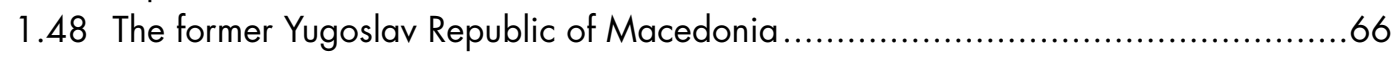

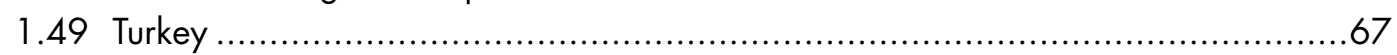

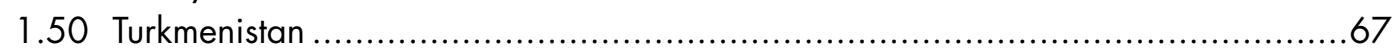

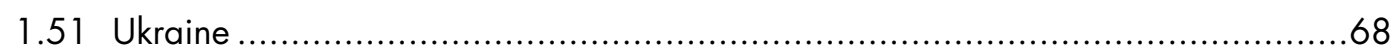

2.28 World exports - imports, first quarter of the year ........................................ 76

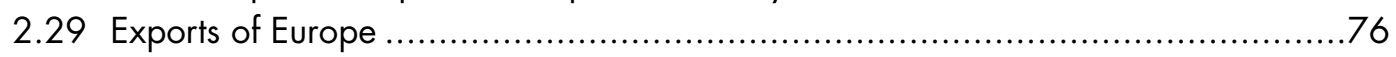

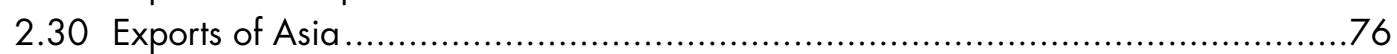

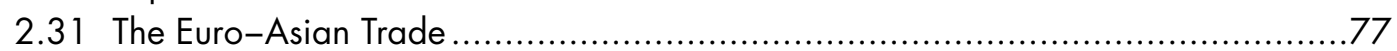

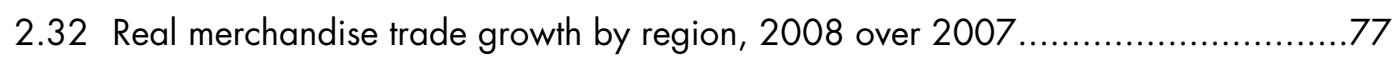

2.6 Exports and imports of the European countries of the EATL project ......................78

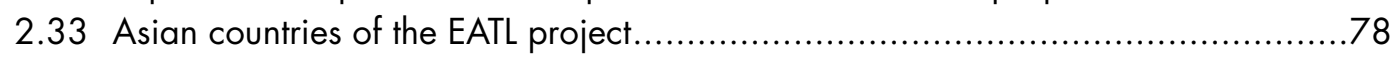

2.34 Annual percentage in GDP of world merchandise exports in real value,

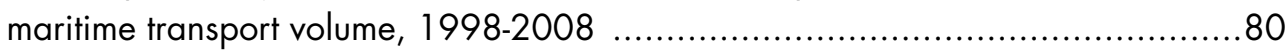

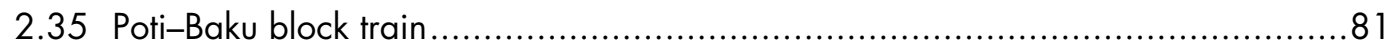

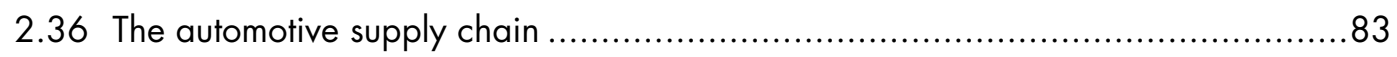

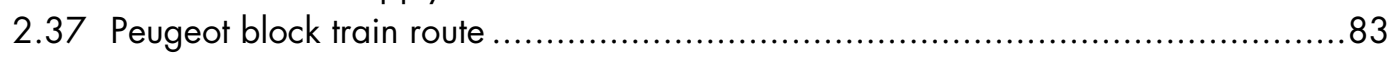


2.38 CD Cargo block train. .84

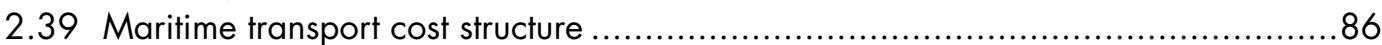

2.40 Split of terminal handling charges between shipper and ship operator ................87

2.41 Terminal handling charges by port for ten largest shipping operators, April-June 2009.

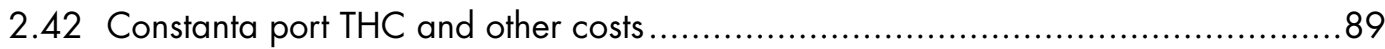

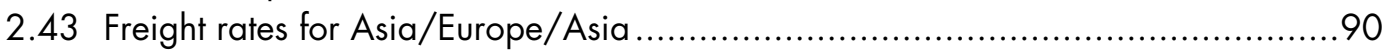

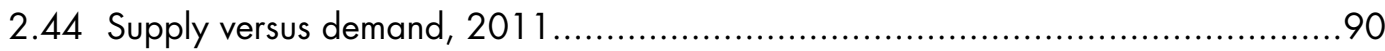

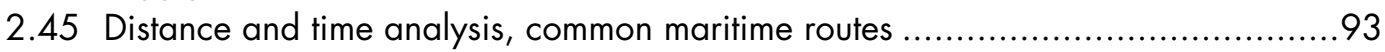

2.46 Road transport involvement in maritime transport...........................................96

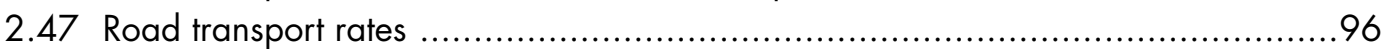

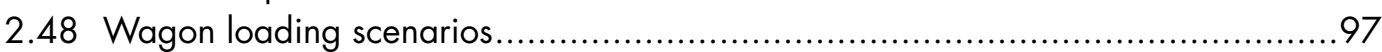

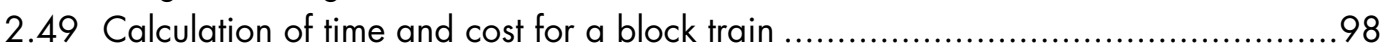

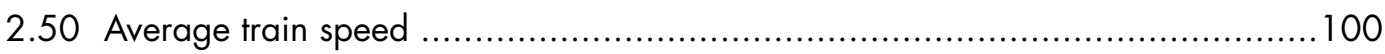

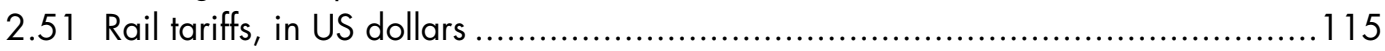

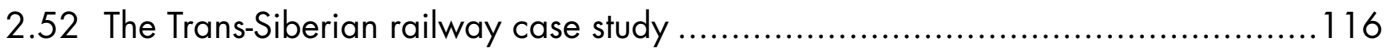

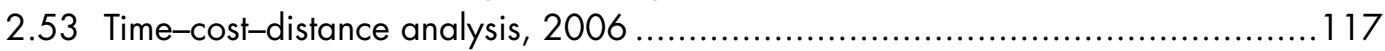

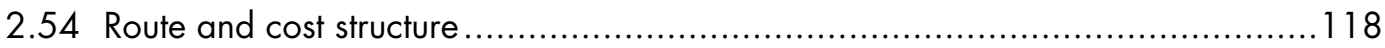

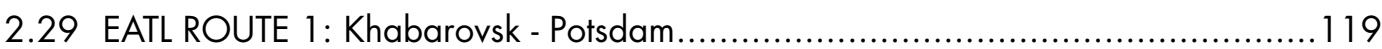

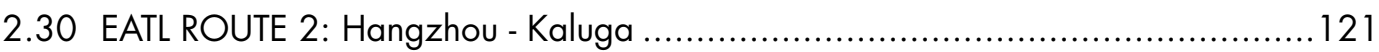

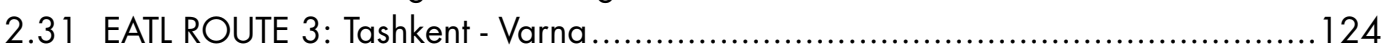

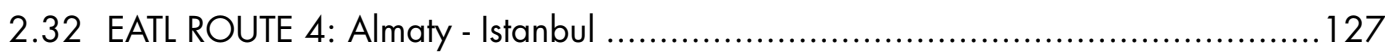

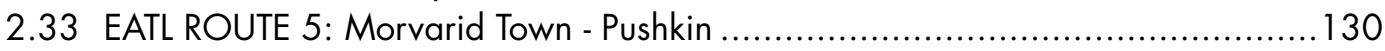

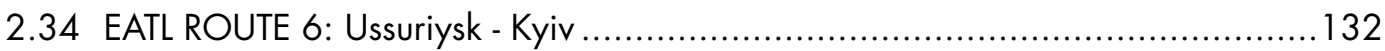

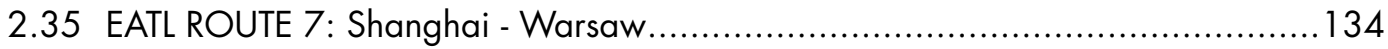

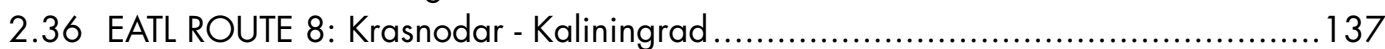

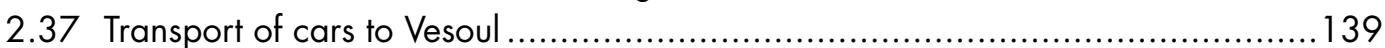

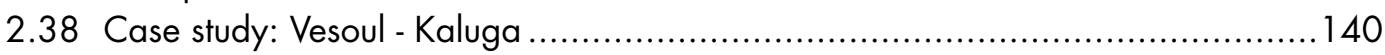

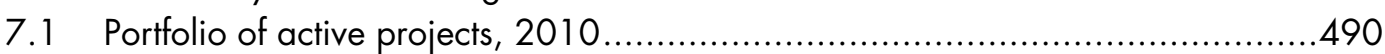

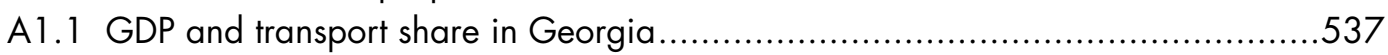

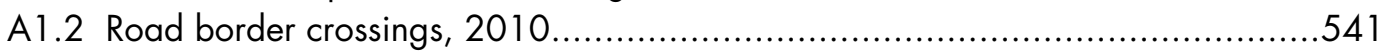

\section{List of Map}

4.1 UNECE Euro-Asian Links Project Phase II - Rail routes ...................................... 184

4.2 UNECE Euro-Asian Links Project Phase II - Extensions of rail routes ................... 185

4.3 UNECE Euro-Asian Links Project Phase II - Extensions of rail routes ....................186

4.4 UNECE Euro-Asian Links Project Phase II - Rail routes ..................................187

4.5 UNECE Euro-Asian Links Project Phase II - Rail routes Group 1 .......................188

4.6 UNECE Euro-Asian Links Project Phase II - Rail routes Group 2 .......................189

4.7 UNECE Euro-Asian Links Project Phase II - Rail routes Group 3 ....................... 190

4.8 UNECE Euro-Asian Links Project Phase II - Rail routes Group 4 ........................191

4.9 UNECE Euro-Asian Links Project Phase II - Rail routes Group 4 ....................... 192

4.10 UNECE Euro-Asian Links Project Phase II - Rail routes Group 5 ...................... 193

4.11 UNECE Euro-Asian Links Project Phase II - Rail routes Group 6 ........................ 194

4.12 UNECE Euro-Asian Links Project Phase II - Rail routes Group 7 .......................195

4.13 UNECE Euro-Asian Links Project Phase II - Rail routes Group 8 ........................196

4.14 UNECE Euro-Asian Links Project Phase II - Rail routes Group 9 ....................... 197 
4.15 UNECE Euro-Asian Links Project Phase II - Road routes ...................................198

4.16 UNECE Euro-Asian Links Project Phase II - Road routes ...................................199

4.17 UNECE Euro-Asian Links Project Phase II - Extensions of road routes ..................200

4.18 UNECE Euro-Asian Links Project Phase II - Road routes Group 1 .....................201

4.19 UNECE Euro-Asian Links Project Phase II - Road routes Group 2 ......................202

4.20 UNECE Euro-Asian Links Project Phase II - Road routes Group 3 .....................203

4.21 UNECE Euro-Asian Links Project Phase II - Road routes Group 4 ......................204

4.22 UNECE Euro-Asian Links Project Phase II - Road routes Group 5 ......................205

4.23 UNECE Euro-Asian Links Project Phase II - Road routes Group 6 .......................206

4.24 UNECE Euro-Asian Links Project Phase II - Road routes Group 7 .....................207

4.25 UNECE Euro-Asian Links Project Phase II - Road routes Group 8 ......................208

4.26 UNECE Euro-Asian Links Project Phase II - Road routes Group 9 ......................209

4.27 UNECE Euro-Asian Links Project Phase II - Inland water transport and inland ports ...2 10

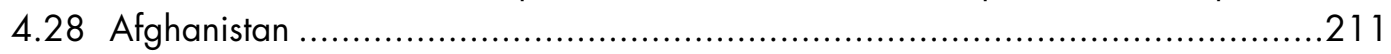

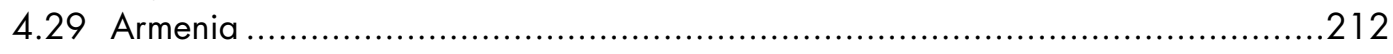

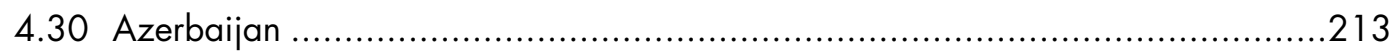

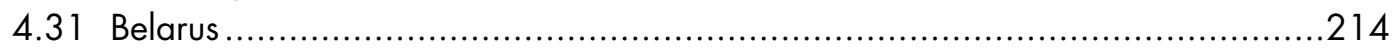

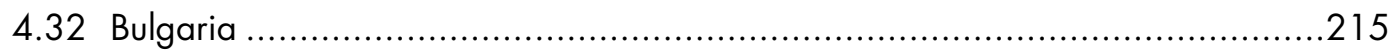

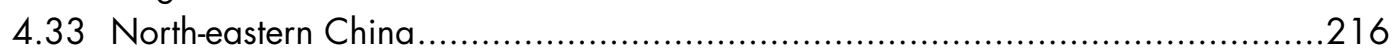

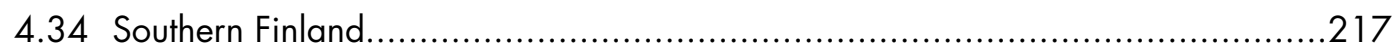

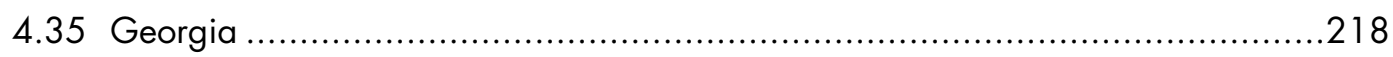

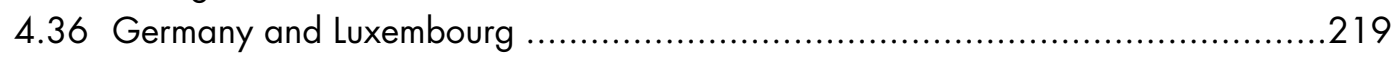

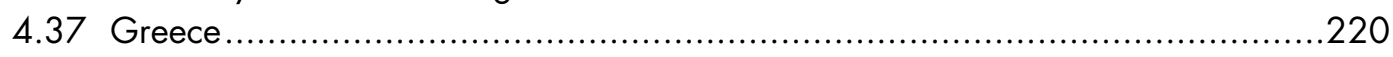

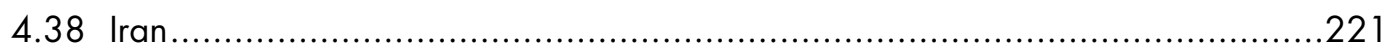

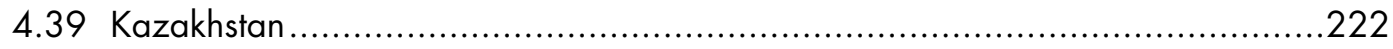

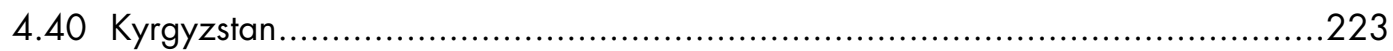

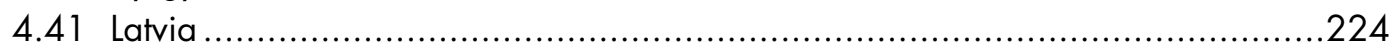

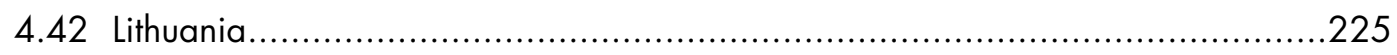

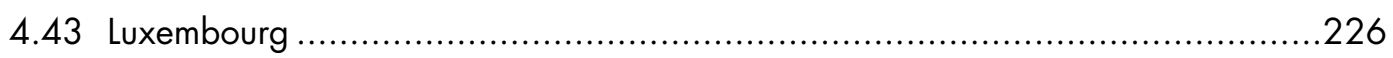

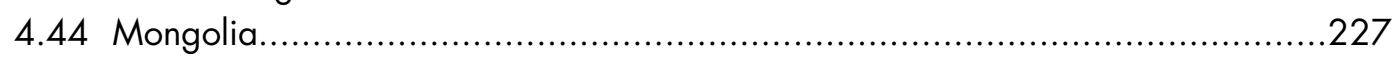

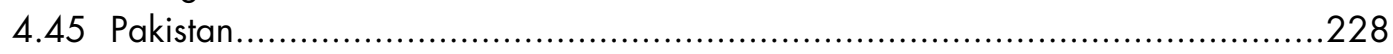

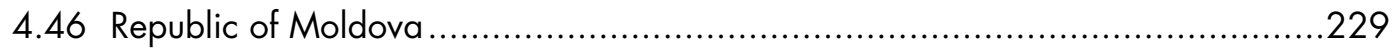

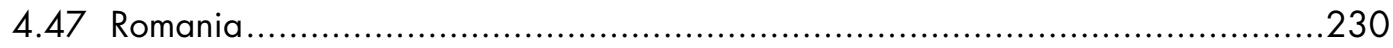

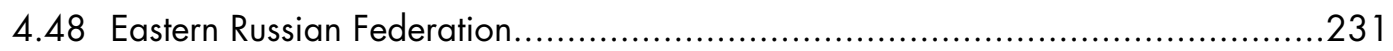

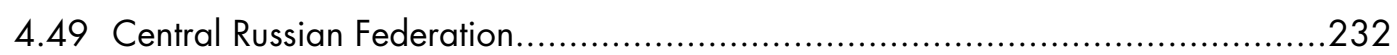

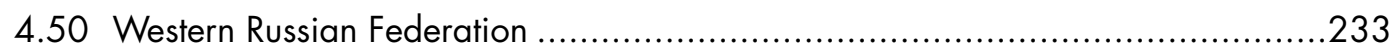

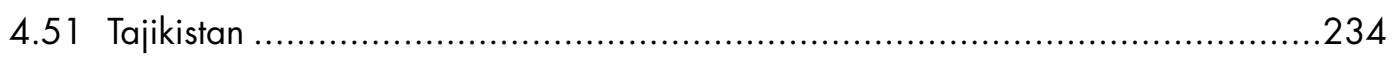

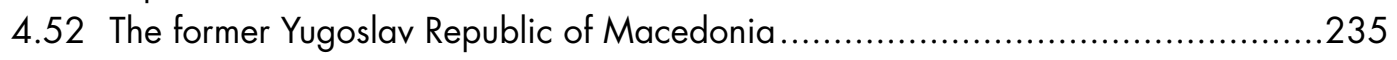

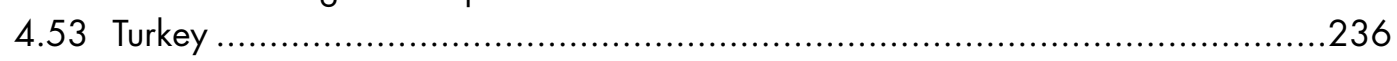

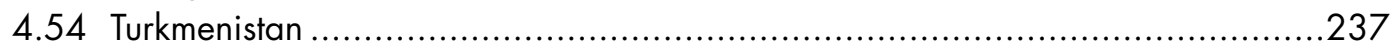

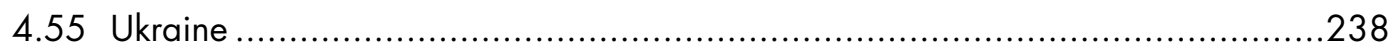

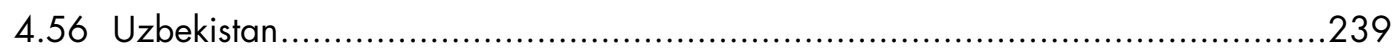




\section{Road}

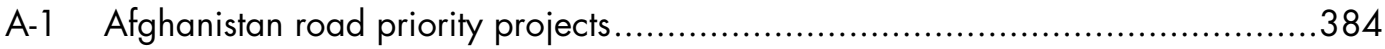

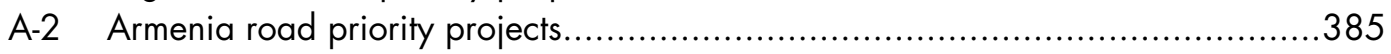

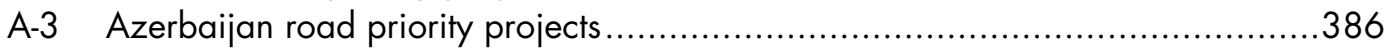

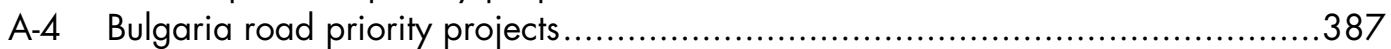

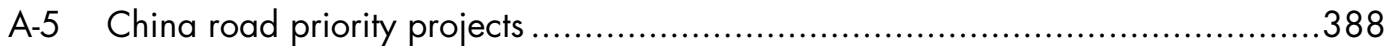

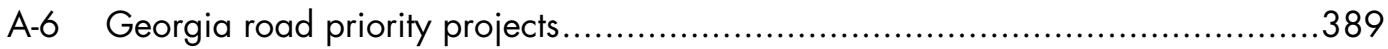

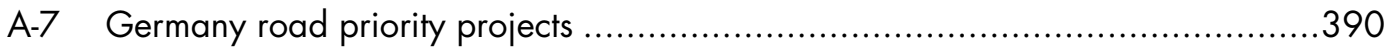

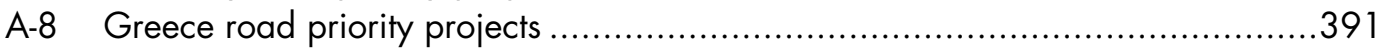

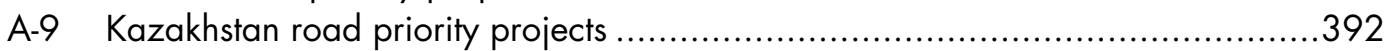

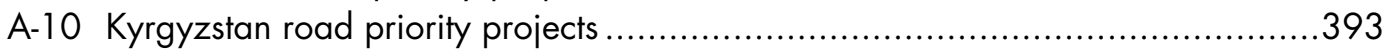

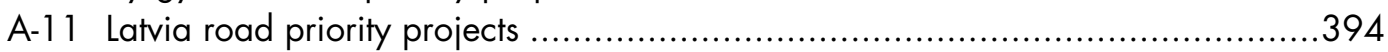

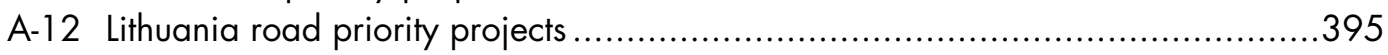

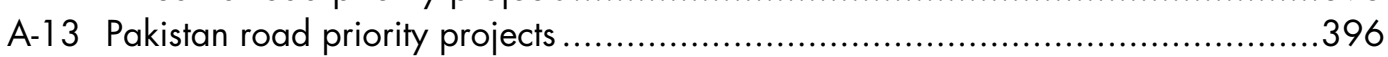

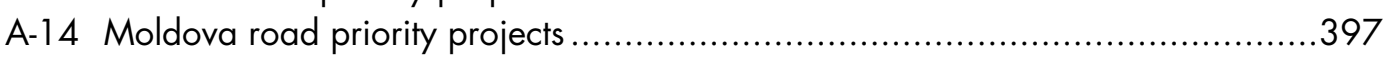

A-15 Eastern part of the Russian Federation road priority projects ..........................398

A-16 North-Western part of the Russian Federation road priority projects ..................399

A-17 Russian Federation - Central Region road priority projects............................400

A-18 Tajikistan road priority projects..............................................................401

A-19 The former Yugoslav Republic of Macedonia road priority projects ..................402

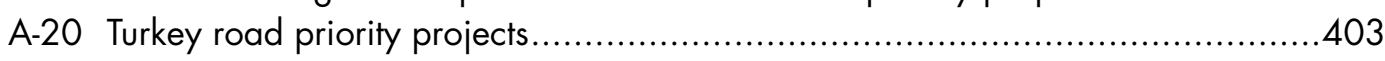

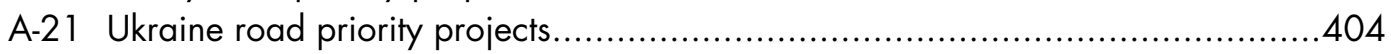

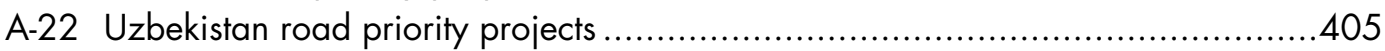

Rail

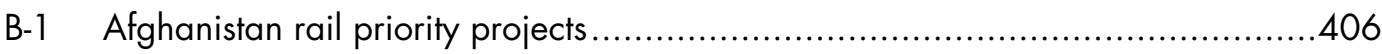

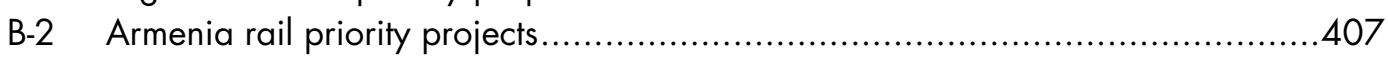

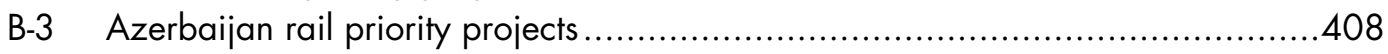

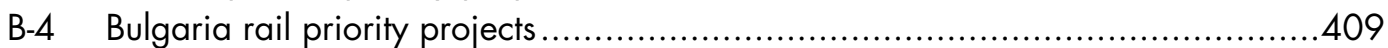

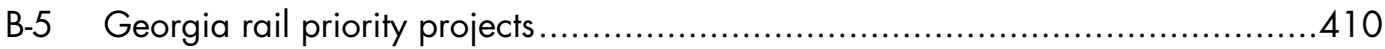

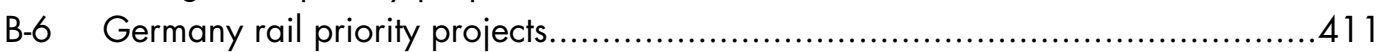

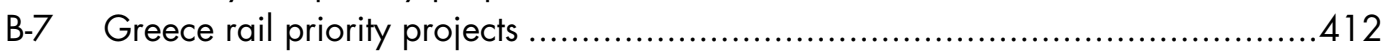

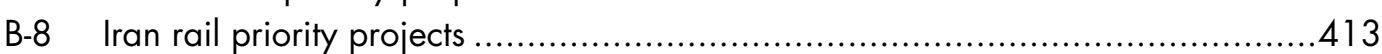

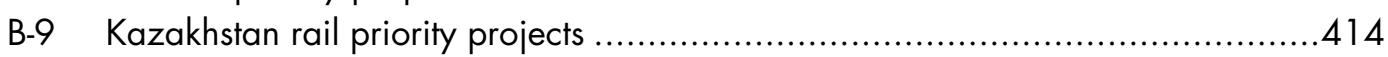

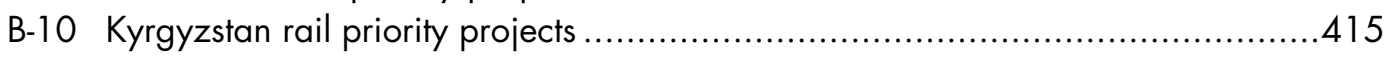

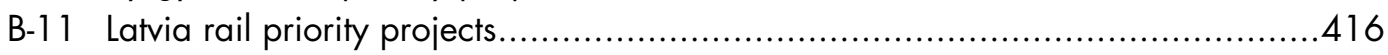

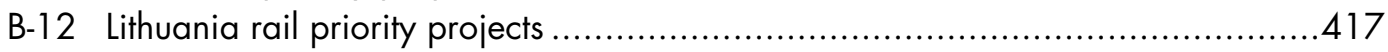

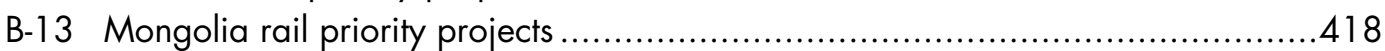

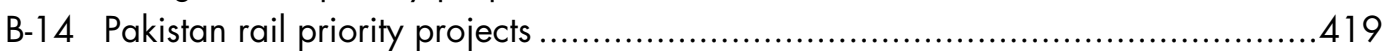

B-15 Republic of Moldova rail priority projects .............................................420

B-16 Eastern Russian Federation rail priority projects ..........................................421

B-17 North-Western part of the Russian Federation rail priority projects ...................422

B-18 Russian Federation St Petersburg region rail priority projects ..........................423

B-19 South-Western part of the Russian Federation rail priority projects....................424

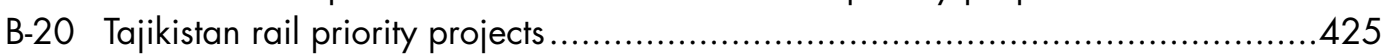

B-2 1 The former Yugoslav Republic of Macedonia rail priority projects ...................426

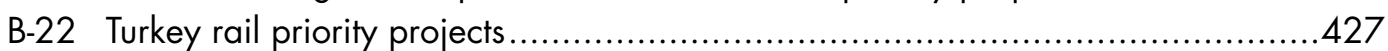

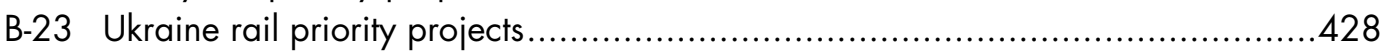

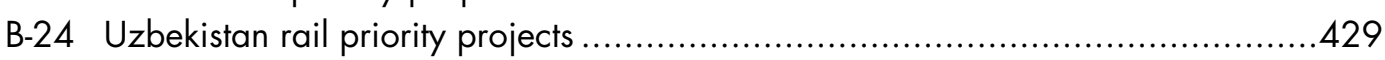


7.1 International E Road Network European Agreement on Main International Traffic Arteries (AGR)

7.2 European Agreement on Main International Railway Lines (AGC)

European Agreement on Important International Combined Transport Lines and Related Installations (AGTC).

7.3 European Agreement on Main Inland Waterways of International Importance (AGN).

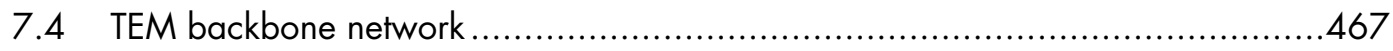

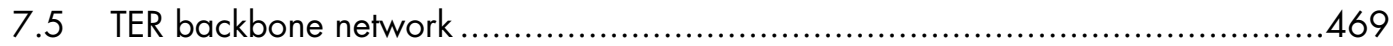

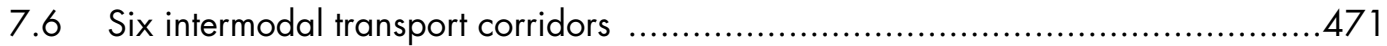

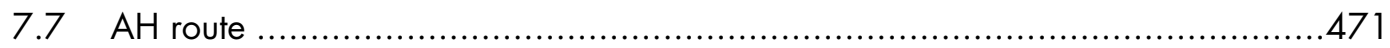

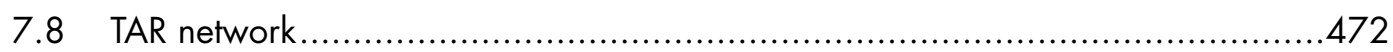

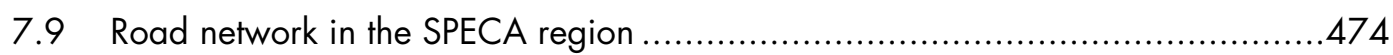

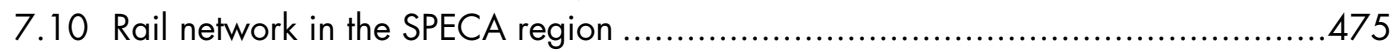

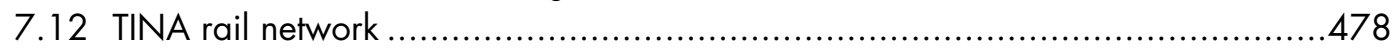

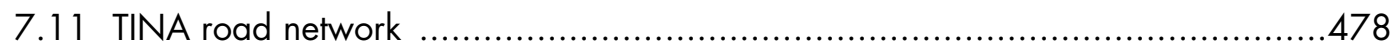

7.13 TEN-T network and TEN-T priority projects ...............................................479

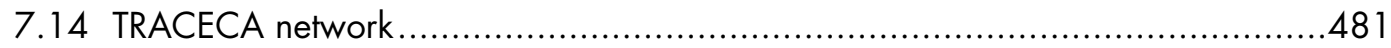

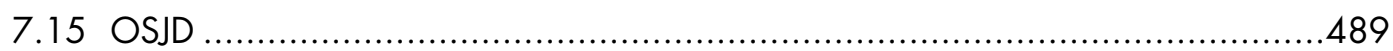

7.16 Six Central Asia regional economic cooperation corridors .............................493

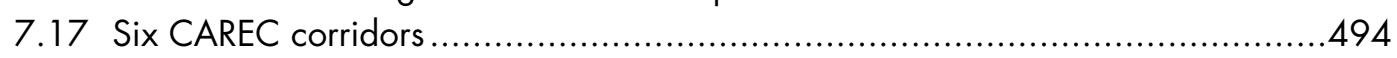

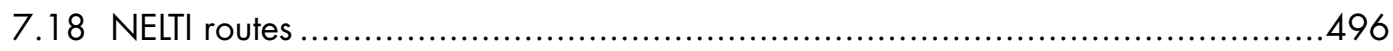

\section{List of Abbreviations}

ADB Asian Development Bank

ADN European Agreement concerning the International Carriage of Dangerous

ADR Goods by Inland Waterways Goods by Road

AETR European Agreement concerning the Work of Crews of Vehicles engaged in International Road Transport

AGC European Agreement on Main International Railway Lines

AGN European Agreement on Main Inland Waterways of International Importance

AGR European Agreement on Main International Traffic Arteries

AGTC European Agreement on Important International Combined Transport Lines and Related Installations

AH Asian Highway network

ASEAN Association of Southeast Asian Nations

ASEM Asia-Europe Meeting

ASYCUDA Automated System for Customs Data

ATP Agreement on the International Carriage of Perishable Foodstuff and on the Special Equipment to be used for such Carriage

BCP Border-Crossing Points

BSEC Organization of the Black Sea Economic Cooperation

CAREC Central Asia Regional Economic Cooperation 


\begin{tabular}{|c|c|}
\hline \multirow{3}{*}{$\begin{array}{l}\mathrm{CIS} \\
\mathrm{CLN}\end{array}$} & Commonwealth of Independent States \\
\hline & Convention relating to the Limitation of the Liability of Owners of Inland \\
\hline & Navigation Vessels \\
\hline \multirow[t]{2}{*}{$\mathrm{CMNI}$} & Convention on the Contract for the Carriage of Goods by Inland \\
\hline & Waterway \\
\hline \multirow[t]{2}{*}{ CMR } & Convention on the Contract for the International Carriage of Goods by \\
\hline & Road \\
\hline \multirow[t]{2}{*}{ CRTD } & Convention on Civil Liability for Damage caused during Carriage of \\
\hline & Dangerous Goods by Road, Rail and Inland Navigation Vessels \\
\hline CVN & $\begin{array}{l}\text { Convention on the Contract for the International Carriage of Passengers } \\
\text { and Luggage by Inland Waterway }\end{array}$ \\
\hline CVR & $\begin{array}{l}\text { Convention on the Contract for the International Carriage of Passengers } \\
\text { and Luggage by Road }\end{array}$ \\
\hline EATL & Euro-Asian Transport Linkages \\
\hline EBRD & European Bank for Reconstruction and Development \\
\hline ECA & Economic Commission for Africa \\
\hline ECLAC & Economic Commission for Latin America and the Caribbean \\
\hline ECMT & European Conference of Ministers of Transport \\
\hline $\mathrm{ECO}$ & Economic Cooperation Organization \\
\hline ECOSOC & Economic and Social Council \\
\hline ESCAP & Economic and Social Commission for Asia and the Pacific \\
\hline ESCWA & Economic and Social Commission for Western Asia \\
\hline EU & European Union \\
\hline EurAsEC & EurAsian Economic Community \\
\hline GATT & General Agreement on Tariffs and Trade \\
\hline GDP & Gross Domestic Product \\
\hline GIS & Geographic Information System \\
\hline HRM & Human Resource Management \\
\hline ICD & Inland Clearing Depot \\
\hline ICT & Information and Communications Technology \\
\hline IDB & Islamic Development Bank \\
\hline IFI & International Financial Institutions \\
\hline INM & Inland/Border Crossing and Other Projects \\
\hline INW & Inland Waterway Projects \\
\hline IRR & Internal Rate of Return \\
\hline IRU & International Road Transport Union \\
\hline ISO & International Standards Organization \\
\hline ISPA & Instrument for Structural Policies for Pre-Accession \\
\hline ITC & Inland Transport Committee \\
\hline ITF & International Transport Forum \\
\hline ITS & Intelligent Transport Systems \\
\hline IWT & Inland Water Transport \\
\hline MAR & Maritime Projects \\
\hline MoS & Motorways of the Sea \\
\hline NELTI & New Eurasian Land Transport Initiative \\
\hline NFP & National Focal Points \\
\hline OCEEA & Office of the Co-ordinator of OSCE Economic and Environmental Activities \\
\hline OECD & Organisation for Economic Co-operation and Development \\
\hline
\end{tabular}




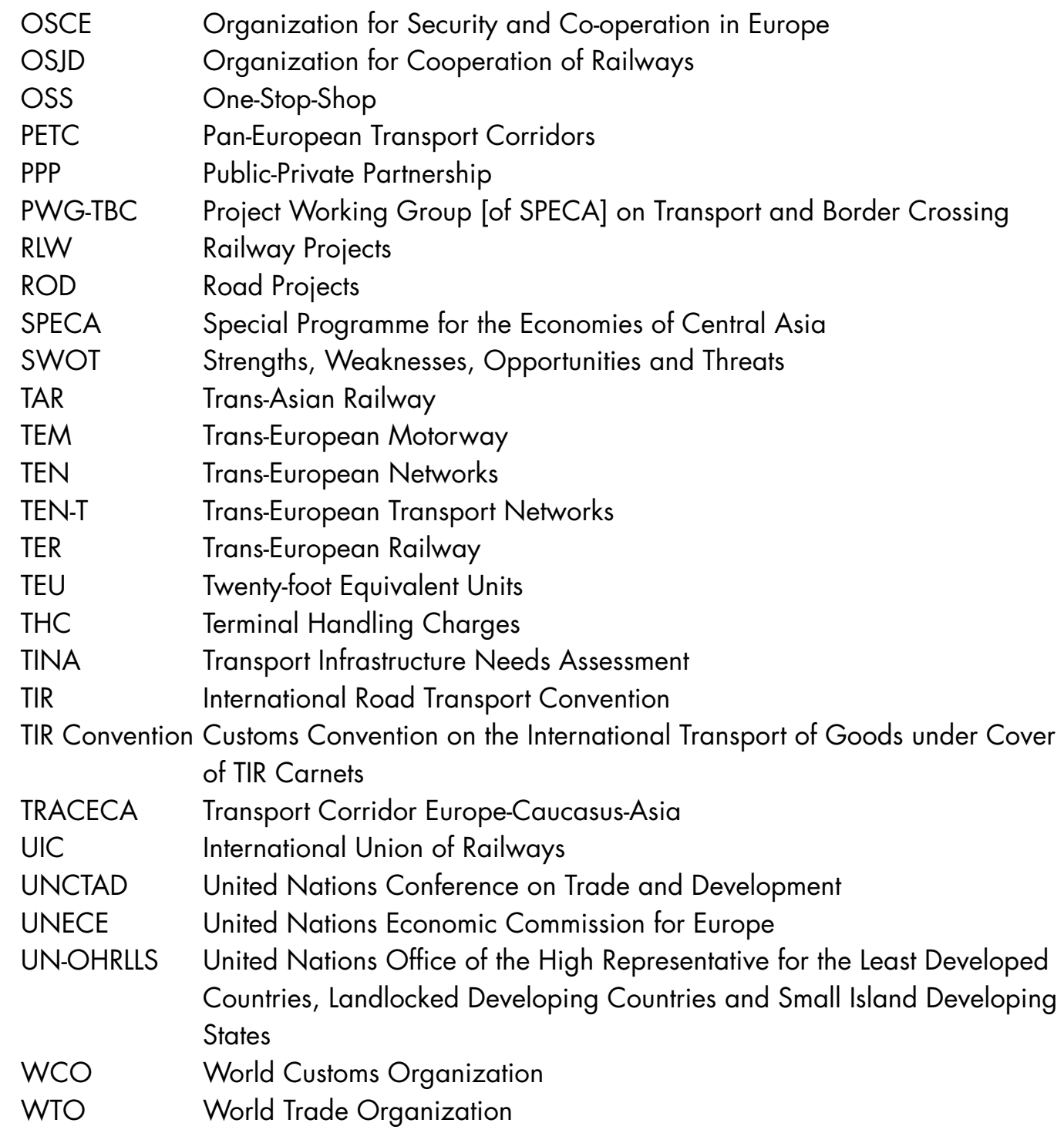

\section{Some of the Internet addresses provided as references throughout this Report were available at the time of writing but may not longer be accessible.}




S

\section{FOREWORD}

The UNECE Euro-Asian Transport Linkages (EATL) Phase II Study represents the final result of a long collaborative effort between participating Member Countries and the United Nations on the Development of Euro-Asian Transport Links project.

Departing from the conclusions of Phase I implemented jointly by UNECE and UNESCAP between 2003 and 2007, the present Study is far more than an update. Beyond the substantive results, it showcases the close collaboration among the National Focal Points from 27 countries along the Euro-Asian land-bridge involved in Phase II (2008-2011) who were supported by the UNECE secretariat and external consultants.

The globalization of economies and trade generates continuous growth in the transport of goods between Europe and Asia. At present, goods between the two continents are carried mostly by maritime transport through increasingly congested straits, ports and hinterland connections. The development of safe, secure and efficient inland Euro-Asian transport links, in addition to providing more transport options for trade, is essential for the socioeconomic development of countries in the region and for their integration into the global economy, which is especially important for the landlocked developing countries.

It has already been noted that the development of Euro-Asian inland transport solutions is a long-term undertaking that requires strong political will and the commitment of the countries concerned, as well as intensive follow-up work. The results presented in this Study confirm the strong commitment to a global partnership for development from all participating countries and provide a solid basis for the continuation of concerted efforts in the future.

More importantly, the main result of the Study is the updated EATL Investment Plan that can form the basis for more detailed and rigorously vetted national investment strategies. This EATL Investment Plan includes 311 priority transport infrastructure projects along the main EuroAsian routes for a total cost of US $\$ 215$ billion. The study also includes the analysis of non-physical obstacles and the comparative study of sea and overland transport options. All these analyses have led to recommendations that can be the backbone of ambitious trade and transport facilitation programmes. In addition, the project resulted in the development of a Geographic Information System (GIS) database and related Internet applications about the EATL infrastructure and development projects that could serve as a twenty-first century tool to promote multi-country investment planning in an innovative way.

Such high-quality results were made possible thanks to the skills and determination of participating countries' National Focal Points, as well as the dedicated work of UNECE staff and external consultants. Their work was supported by donations from the Government of the Russian Federation, as well as other EATL governments, the Organization of the Black Sea Economic Cooperation (BSEC) and the Economic Cooperation Organization (ECO), which hosted several events under the auspices of the EATL project. The Organization for Security and Co-operation in Europe (OSCE) also contributed to the organization and partial financing of several Expert Group meetings.

I would like to thank all those who contributed and encourage all governments along the EATL routes and other stakeholders, such as international financial institutions, to undertake the steps necessary for the progressive implementation of the recommendations contained in this Study.

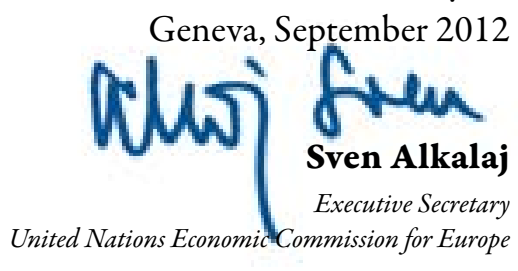




S I O

\section{EXECUTIVE SUMMARY}

UN support for the development of transport connections between Europe and Asia has a long history. The global project entitled "Capacity-building for Developing Interregional Land and Land-cum-sea Transport Linkages” carried out between 2003 and 2007 included a component focusing specifically on Euro-Asian transport links. It identified main Euro-Asian transport linkages of international importance in order to connect the European and Asian networks. The EATL routes in Phase II of the project were extended to seven newly involved countries, thus covering 27 countries $^{1}$. As a result of this phase, 9 EATL road routes, 9 EATL rail routes, 17 water transport links, 52 inland river ports and 70 maritime ports were identified. 311 transport infrastructure priority projects with a total cost of US $\$ 215$ billion were included in the final list, out of which 188 were identified as high priority with a total cost of US $\$ 78$ billion. In addition to the transport investment needs assessment, i.e. the EATL updated Investment Plan, a comparison of rail and maritime transport links was made; the non-physical obstacles to international transport along the EATL routes were reviewed; a SWOT analysis of the EATL land links was carried out. Furthermore, a Geographic Information System (GIS) data-base was set up and GIS maps developed showing the planned projects.

\section{Transport investment needs assessment}

The primary goal of Phase II was the revision of EATL priority transport infrastructure projects identified in Phase I and the development of an up-dated international Investment Plan for new projects that would entail a consistent and realistic short-, medium- and long-term investment strategy for the identified EATL routes. This included an extensive inventory of specific road, rail, inland waterway, maritime port, inland terminal and other infrastructure projects for the 27 participating countries, together with their estimated budget and an implementation timetable.

Initially, a review and assessment of the status of the implementation of the EATL Phase I priority projects were carried out. Accordingly, around $\mathbf{5 3}$ per cent of the priority projects included in Phase I were completed, while 25 per cent have been carried over as part of EATL Phase II, whereas for the remaining projects no detailed information was provided for their status.

The prioritization of new projects to be included in the transport investment needs assessment along EATL routes used a methodology to identify the needs based on the governments' project proposals. These were grouped according to their implementation time periods (four periods were used). The methodology applied was identical to the one developed for the purpose of EATL Phase I project prioritization to ensure consistency between the two EATL phases. It had three stages:

- identification of projects based on pre-set criteria (their readiness and funding possibilities, as well as commonly shared objectives of responsible authorities, national or international, and the collection of readily available information/ data)

- analysis according to available data related to criteria, such as serving international connectivity; promoting solutions to the particular transit transport needs of the landlocked developing countries; connecting low income and/or least developed countries to major European and Asian markets; crossing natural barriers; removing bottlenecks; raising sub-standard sections to meet international standards; or filling missing links

1 The EATL participating countries are: Afghanistan, Armenia, Azerbaijan, Belarus, Bulgaria, China, Finland, Georgia, Germany, Greece, Iran, Kazakhstan, Kyrgyzstan, Latvia, Lithuania, Luxembourg, Mongolia, Pakistan, Republic of Moldova, Romania, Russian Federation, Tajikistan, the former Yugoslav Republic of Macedonia, Turkey, Turkmenistan, Ukraine and Uzbekistan. As a result of Poland's recent joining the EATL initiative, now it is 28 EATL Member Countries. 
in the identified routes; having a high degree of maturity, and high social and minimal environmental impact.

- Time Period classification/prioritization according to the project's total score, applying the Multi-Criteria Analysis.

Transport infrastructure projects proposed for inclusion in the updated EATL Investment Plan consisted of the non-completed EATL Phase I and the new projects added in Phase II. The Plan includes an extensive inventory of specific road, rail, inland waterway projects and maritime/ inland terminal development projects at a country level for each of the 27 participating countries. The prioritization exercise was also carried out at route level, for each of the identified Road and Rail routes, for the purpose of establishing the investment cost that has already been secured at the route level. The project inventory is based on up-dated data provided by 23 countries. For the four other countries, the original data provided in EATL Phase I was used. It contains estimated investment costs and a realistic implementation time table.

The implementation of all 311 priority projects identified as critical to improve the entire EATL network would require as much as US $\mathbf{2 1 5}$ billion. Thirty-six per cent of this amount, corresponding to the high priority projects, was already secured at the time of this Report. On the other hand, out of these priority projects 188 were rated as high priority and they require US\$ 78 billion.

\section{Comparison of rail and maritime transport between Asia and Europe}

Growing international trade between Europe and Asia has a major impact on transport flows and consequently on the future development of Euro-Asian transport links. In this context, the social and economic development of transit and landlocked developing countries along EATL routes is particularly important. The analysis of trade flows among the 27 countries participating in the EATL Phase II Study indicated that, in general, China's export represents a high percentage of total Asian exports to Europe. In addition, significant growth has been noted in intra-Asian trade flows.

Maritime routes naturally dominate the transport of goods from Asia to Europe. The vast distances between the two continents, combined with numerous border crossings, political instability, rent-seeking practices, the lack of security, delays at borders and unpredictability discourage the use of inland transport. In addition, simple comparisons between maritime and land transport costs often lead to the conclusion that the land bridge is not financially competitive. For example, comparing the cost and time required for the transport of a container from Shanghai port to Hamburg port by maritime versus inland transport can lead to wrong conclusions. In reality, products carried by containers are transported from production to final consumption areas, which are often far away from ports. As a result, logistics managers must compare the total costs of the entire supply chain, which include road transport costs of moving containers from/ to the warehouse/port, terminal handling charges, and documentation and other administrative costs.

Railway transport can be more competitive both in terms of time and cost when production areas are situated relatively far from the ports, such as in China and India, and cargo is destined for southern or eastern European countries.

Therefore, another objective of this Study was to compare the existing Euro-Asian maritime routes with selected EATL rail routes. The methodology used for the analysis was simple and pragmatic. It compared Euro-Asian maritime and rail links from the perspective of a logistics manager of a company that produces goods in a particular location that need to be delivered to another location. 
Nine scenarios were analysed. In all scenarios, rail transport performed better than maritime in terms of travel time. The Study showed that Euro-Asian rail transport, and its intermodal combination with maritime and road transport, is a feasible and competitive transport option provided that efficient rail corridor management is established, governments are willing to cooperate and rail companies serve customers' needs in an effective manner along the whole corridor.

\section{The non-physical obstacles to international transport along EATL routes}

Another integral part of EATL Phase II was the identification of non-physical obstacles to transport. The result of the analysis indicated a mismatch between the interests and perception of the public and private sectors. For example, the importance of national trade and transport facilitation committees, or any other forms of public and private partnership arrangements, was considered high or low depending on which sector the response came from.

While the availability and quality of transport infrastructure is improving, albeit slowly and not along the entire network, the management of road infrastructure and rail operations raises concerns in many places. The level of computerization or the use of information and communications technologies in transport and in certain customs administrations must still be improved significantly. Several operational issues pertaining to border crossings remain to be addressed. For example, governments and border-control agency staff manage bordercrossing point assets but are not accountable for queue lengths, delays, congestion or added costs to consumers.

Nevertheless, the growing number of good practices provides hope that improvements are under way. For instance the one-stop border clearance process in Belarus takes place at one single location for all types of border controls. This includes customs, passport control, as well as veterinary and health controls. The useful result is that no party has to stop at the checkpoint more than once. The main benefit of this one-stop procedure is that the total clearance time at the checkpoints is significantly reduced so that it lasts not more than 15 minutes. Another example of a good practice is the Authorised Economic Operators "Gold list" programme in Georgia. This programme provides simplified import procedures for high-value and high volume trades that have demonstrated a strong history of compliance. The number of companies taking advantage of this programme has grown to over 200 at present. These are examples of the implementation of internationally recognised good practices.

\section{SWOT analysis of EATL land transport links}

The strengths, weaknesses, opportunities and threats (SWOT) analysis carried out on land transport links provided useful information on their respective attributes, potential for further development, as well as related risks.

The priority routes identified by the EATL Phase II project have promising potential for transportation between Europe and Asia, primarily taking into account the significant transit capability of land routes through northern Eurasia, which at present are greatly under-utilized. The development of these land transport routes would provide alternatives to existing maritime routes. In addition, better EATL routes would contribute to better connectivity among the Central Asian countries, which would enhance their economic integration and strengthen their cohesion. As several countries along the Euro-Asian routes are landlocked, improved connectivity within the region and through the region to main markets, as well as to sea ports, could be a key development goal. The investment needs identified here must be converted to bankable projects that can be implemented in the foreseeable future if the EATL countries wish 
to reap all the benefits of their cooperation in the needs assessment. Improved connections at distinctive sections of roads and railways are important, but not adequate. Connections must also be improved between the transport modes; the road and rail networks must be linked and their connection to inland ports and terminals, dry ports, logistics centres is warranted. Transport and logistics services on improved infrastructure require facilitation that includes not only reduced waiting times at borders, but also more sophisticated measures for seamless transportation. These are only some examples of the implementation of internationally recognised good practices. There are many more such cases. However as long as they remain positive exceptions and not part of corridor based or network-wide daily operations integrated in the philosophy to serve traders and transport operators as customers, the results remain limited and the economic distance stays longer than the geographic one.

\section{Conclusions and recommendations}

The EATL Phase II project has resulted in an updated assessment of transport investment needs along EATL routes at the multi-county level, which is referred to as the updated EATL Investment Plan. The transport projects have been evaluated from the standpoint of their relevance and importance for international traffic and their value to connect Asia and Europe. Moreover, the exercise resulted in a unique database on EATL countries' transport networks and their development plans. Furthermore, Geographic Information System (GIS) maps that offer valuable information in an interactive manner have been developed ${ }^{2}$. In collaboration with the participating governments, UNECE is ready to maintain this database with the intention that it will help the governments underpin their national transport investment strategies and the hope that international financial institutions and other donors will find it useful as available information will accelerate the start of investment projects. The Study also resulted in a more seasoned analysis of the Euro-Asian railway links in comparison to maritime transport. The results of the analysis could help in the emancipation of railways, and could be used as anchors for further railway reforms to improve railway services for trade between the two continents. The transport and border-crossing facilitation review and analysis should be used in conjunction with the recently published OSCE-UNECE Handbook of Best Practices at Border Crossings A Trade and Transport Facilitation Perspective (2012). However this part of the EATL Study offers concrete examples and highlights certain specific issues to be addressed. This, together with the SWOT analysis serves as the basis for the recommendations that, once implemented, could shorten the economic distance between EATL countries. It is also expected to boost political support for often painful reforms in the transport sector, border crossing facilitation, as well as in the management of large-scale transport investment programs.

The Study also argues that user-friendly and well-functioning EATL corridors, efficient customs transit regimes, the implementation of international trade and transport conventions, the elimination of rent-seeking and the overall improvement of transport and logistics services can reduce time and costs to transport operators and traders, and ultimately to end-consumers.

Finally, the Study lists a number of recommendations in the areas of infrastructure development, facilitation and sectorial policies. A selection of the key recommendations can be read in Box 1. These lay the groundwork for the continuation of the EATL project, stipulating the needs and issues that could potentially be addressed in a subsequent third phase.

\footnotetext{
2 http://apps.unece.org/eatl/
} 


\section{Key Recommendations of the EATL Project}

\section{Recommendations on Infrastructure Development}

- obtain and provide the necessary financial resources for the implementation of transport investment projects along the priority road and rail routes

- improve infrastructure in order to provide a technically viable and commercially attractive alternative to maritime transport

- coordinate national infrastructure investment plans and their implementation

- include the EATL programme in national investment plans and programmes

- improve large scale-investment and programme management at multi-country, national and project levels alike

\section{Recommendations on Facilitation}

- significantly simplify procedures and practices, and improve the equipment, infrastructure and skills of officials at border-crossing points

- ensure the interoperability of systems

- identify and remove physical bottlenecks on a routine basis

- make benefit and use of available customs transit systems, like the TIR

- use containers

- simplify visa requirements and formalities

- standardize trade and transport documents; eventually make use of electronic documents to achieve paperless trade and transport documentation

- reduce and remove the hidden costs of transport and transport-related services, as well as the non-physical barriers

- as a priority, accede to and implement The International Convention on the Harmonization of Frontier Control of Goods, 1982

- modernize transport and trade legislation and accede to relevant international conventions for border crossing facilitation (see Annex II)

- increase the security of vehicles, crew and cargo in transport and transit

- share experiences and implement internationally recognized best practices

\section{Recommendations on Policy}

- develop national transport master plans using EATL achievements as a backbone

- design and implement needed reforms of the transport sector, border crossing facilitation and of the management of large-scale transport investment programmes

- reduce the pressure that might arise from domestic transport and trade-related monopolies

- ensure that the country fits well into the production, supply and transport chain of modern production

- improve the monitoring of infrastructure and the execution of transport facilitation plans

- set targets as benchmarks for the appraisal of policy achievements

- accede to the UN conventions and agreements facilitating international transport (see Annex II)

- support the expansion of trade, not only between the EU and Far East, but also along segments of the EATL routes

- encourage public-private partnerships in infrastructure development

- improve the exchange and implementation of international best and good practices

- improve data collection and dissemination and improve overall transport statisticst 


\section{EURO-ASIAN TRANSPORT FLOWS, STATISTICS AND TRENDS}

\subsection{Introduction}

\subsubsection{Background}

Globalization has led to significant increases in trade and transport between Asia and Europe. While most of the traffic has used (increasingly congested) maritime routes, further development of inland transport routes would provide additional credible and competitive transport options. Once established, these efficient and integrated inland routes could become an effective tool for the economic development and integration of the Euro-Asian region, including facilitating greater participation in the globalization process by Central Asia's landlocked countries.

To address issues of inadequate transport infrastructure, internationally un-harmonized transport rules and cumbersome, costly and time-consuming border-crossing procedures, the UNECE and UNESCAP worked closely in 2003-2007 with governments of the Euro-Asian region as part of a global UN Development Account Capacity-building Project. The following 18 countries participated: Afghanistan, Armenia, Azerbaijan, Belarus, Bulgaria, China, Georgia, Iran, Kazakhstan, Kyrgyzstan, Republic of Moldova, Romania, Russian Federation, Tajikistan, Turkey, Turkmenistan, Ukraine and Uzbekistan. Greece joined the project activities in 2005.

The project's results included the identification of main Euro-Asian inland transport routes, the prioritization of infrastructure projects, the development of a Geographic Information System (GIS) database, a first analysis of non-physical obstacles, the organization of six national capacitybuilding workshops and the publication of the final Study.

The first phase of the Euro-Asian Transport Linkages (EATL) project ended in 2008 with the Ministerial Meeting in Geneva, where high-level representatives of 19 countries signed a joint statement on the future development of Euro-Asian transport links, calling for the continuation of the EATL project in 2008-2011.

In 2006, the Inland Transport Committee (ITC) had asked the secretariat, together with ESCAP, to present a joint proposal that would ensure the continuation of the project in a new Phase II. In early 2008, the UNECE began establishing an institutional structure to make further EATL work possible. At its seventieth session, on 19-21 February 2008, ITC agreed to establish a Group of Experts on Euro-Asian Transport Links and adopted its terms of reference. The primary objective of the Expert Group was to ensure monitoring and coordination of the activities related to developing efficient, safe and secure Euro-Asian inland transport links.

The UNECE invited governments to nominate National Focal Points (NFP) who would actively contribute to the work of the EATL Group of Experts in Phase II. Related international organizations and international financial institutions (IFI) were also invited to take an active role in the work. In response, 27 governments nominated National EATL Focal Points (Afghanistan, Armenia, Azerbaijan, Belarus, Bulgaria, China, Finland, Georgia, Germany, Greece, Iran, Kazakhstan, Kyrgyzstan, Latvia, Lithuania, Luxembourg, Mongolia, Pakistan, Republic of 
Moldova, Romania, Russian Federation, Tajikistan, the former Yugoslav Republic of Macedonia, Turkey, Turkmenistan, Ukraine and Uzbekistan).

One major issue that has an impact on transport and consequently on the future development of Euro-Asian transport linkages is the growing merchandising trend between Europe and Asia, as well as the social and economic development of transit and landlocked developing countries involved in the EATL project. To this end, the present Study explores the flows and trends of both inland and maritime transport routes between Europe and Asia, as well as among the EATL Phase II participating countries themselves, in order to ascertain the current needs for transportation.

\subsubsection{The scope}

The scope of this section is the review, collection and consolidation of existing statistics, flows and trends on EATL routes, for both maritime and inland transport. The information was collected by desk review, as well as in consultation with the secretariat and the countries involved. The purpose of the Report is to highlight the repercussions of the growth of merchandise trade between the continents of Europe and Asia, and among the respective countries participating in the EATL Phase II project, on the transport system, addressing the key issues related to this rise in volume transported over long distances. The growth and trade acceleration is of particular importance for the volumes transported, the means of transport used and the construction of infrastructure along the proposed EATL Phase II routes. The Report focuses on the following topics:

- Europe-Asia transport flows and trends

- container transport flows and trends

- landlocked country trade issues

- trade analysis of EATL II participating countries

- conclusions and recommendations

\subsection{Euro-Asian traffic flows and trends}

\subsubsection{Overview of world trade}

International merchandise trade continued to increase rapidly during the first half of 2008 until September of that year, when the impact of the global financial crisis became evident. According to the World Trade Organization (WTO), the recent crisis brought about a 12 per cent drop in the volume of world trade in 2009, which was the sharpest decline recorded in more than 70 years and significantly higher than most economists had predicted. Table 1.1 presents the annual percentage change in the volume of merchandise trade by selected regions for 2008 and 2009. 
Table 1.1 - Growth in the volume of world merchandise trade by selected region and economy, 2000-2009

\begin{tabular}{|c|c|c|c|c|c|c|}
\hline & \multicolumn{3}{|c|}{ Exports } & \multicolumn{3}{|c|}{ Imports } \\
\hline Annual Percentage Change & 2000-2009 & 2008 & 2009 & 2000-2009 & 2008 & 2009 \\
\hline \multicolumn{7}{|l|}{ Merchandise } \\
\hline World & 3 & 2 & -12 & 3 & 2 & -13 \\
\hline North America & 1 & 2 & -15 & 1 & -3 & -17 \\
\hline Canada & -2 & -6 & -18 & 1 & 1 & -17 \\
\hline Mexico & 1 & 1 & -15 & 1 & 4 & -20 \\
\hline United States & 2 & 6 & -14 & 1 & -4 & -17 \\
\hline South and Central America & 4 & 1 & -8 & 6 & 13 & -17 \\
\hline Europe & 2 & 0 & -15 & 1 & -1 & -15 \\
\hline European Union (27) & 2 & 0 & -15 & 1 & -1 & -15 \\
\hline Norway & 1 & 0 & -3 & 3 & 3 & -14 \\
\hline Switzerland & 2 & 2 & -15 & 1 & 3 & -10 \\
\hline $\begin{array}{l}\text { Commonwealth of Independent } \\
\text { States (CIS) }\end{array}$ & 6 & 2 & -5 & 11 & 17 & -26 \\
\hline Asia & 8 & 6 & -11 & 6 & 5 & -8 \\
\hline Australia & 2 & 6 & -5 & 7 & 10 & -11 \\
\hline China & 17 & 9 & -11 & 15 & 4 & 3 \\
\hline Hong Kong SAR & -4 & -11 & -1 & 2 & -2 & -6 \\
\hline India & 12 & 15 & -3 & 13 & 18 & -3 \\
\hline Japan & 2 & 3 & -25 & 1 & -1 & -13 \\
\hline Six East Asian traders* & 6 & 4 & -8 & 3 & 4 & -13 \\
\hline
\end{tabular}

* Hong Kong SAR; Malaysia; Republic of Korea; Singapore; Taiwan Province of China; and Thailand.

Source: http://www.wto.org/english/res_e/statis_e/its2009_e/

Further, world trade is currently following a faster than expected recovery, since WTO economists predicted a rebound in 2010 with growth of 13.5 per cent. According to WTO figures released on 2 June 2010 of "year-on-year" quarterly comparisons, the value of world merchandise trade was around 25 per cent higher in the first three months of 2010 than in the same period in 2009, global exports rose by 27 per cent, while imports rose slightly less, at 24 per cent. Monthly statistics for 70 economies representing approximately 90 per cent of world trade indicate that merchandise trade declined in January and February 2010, then rose sharply in March, as depicted in Figure 1.1. It should be noted that despite the steep fall in global trade due to the recent economic crisis, Asia outperformed the rest of the world in 2009, with its exports decreasing 18 per cent that year, the smallest nominal decline of any region. Asia's imports also fell less than the world average ( 21 per cent), as shown in Figure 1.2. 
Figure 1.1 - Monthly merchandise trade, aggregate of 70 economies

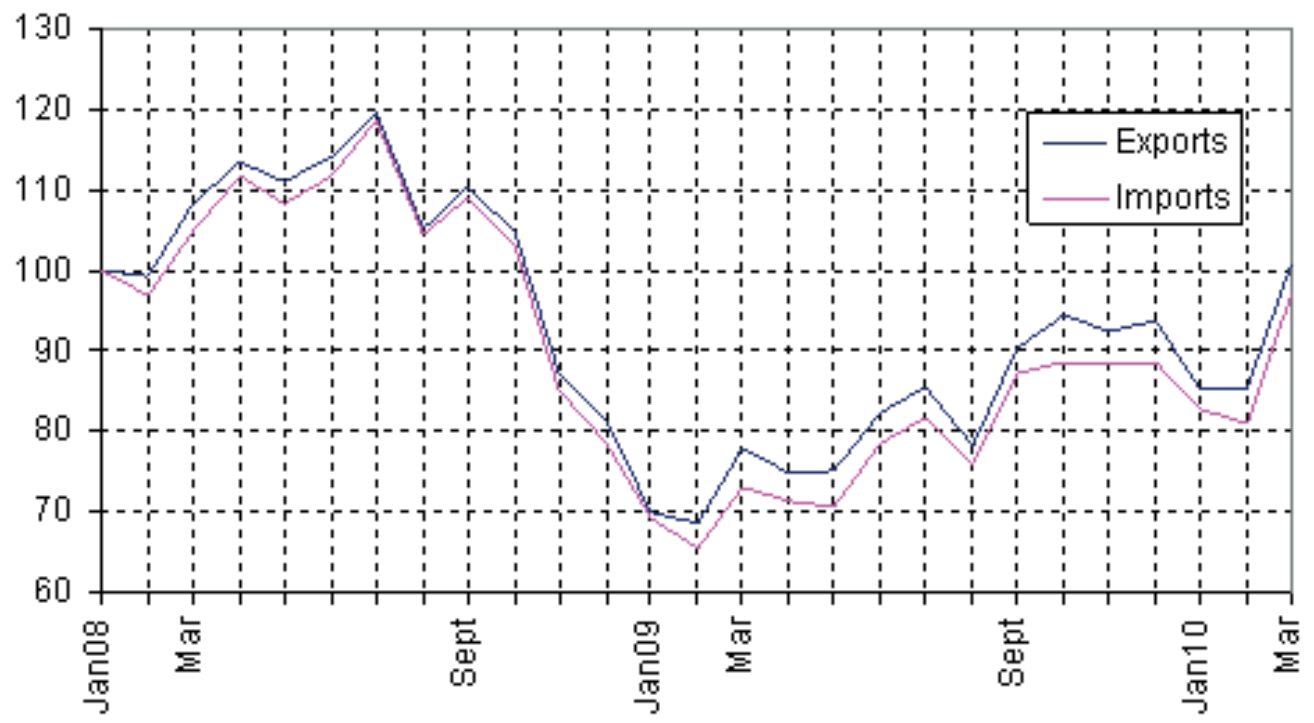

Source: WTO

Figure 1.2 - World merchandise exports by region, 2007-2009

\section{(Vearcto-year percentage change in curent US dallars)}

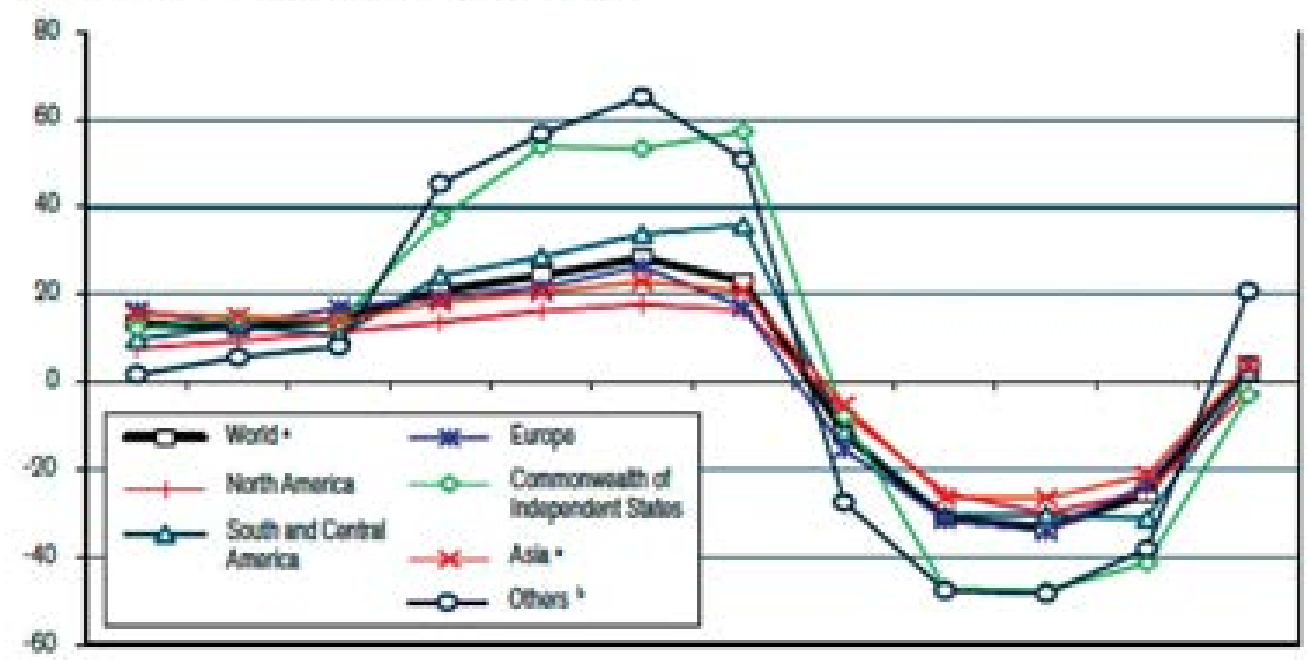

200001 200702 $200703200704200801 \quad 200802 \quad 200803 \quad 200804 \quad 200901200002 \quad 200903200904$

a Includes signifcant te-exports.

b Includes Africa and Widis East.

Source INF, International Financial Stalisfics; Eurostat, Comeat Database, National stafistics, Global Trade Atlas.

Source: WTO

\subsubsection{Euro-Asian trade flows}

The 60 countries involved in Euro-Asian trade represent more than half of the world's gross domestic product (GDP) and more than 60 per cent of the world's population. Their share was approximately 70 per cent of global trade, as illustrated in Figure 1.3 for 2000 and 2008 (WTO). More specifically, in 2009, 42 per cent of world merchandise trade exports originated in Europe, 26 per cent in Asia, 17 per cent in North America , 4 per cent in the Middle East and in South and Central America, and 3 per cent in Africa and in Commonwealth of Independent States (CIS) (Figure 1.4). 
Figure 1.3 - Regional share in world merchandise exports, 2000 and 2008

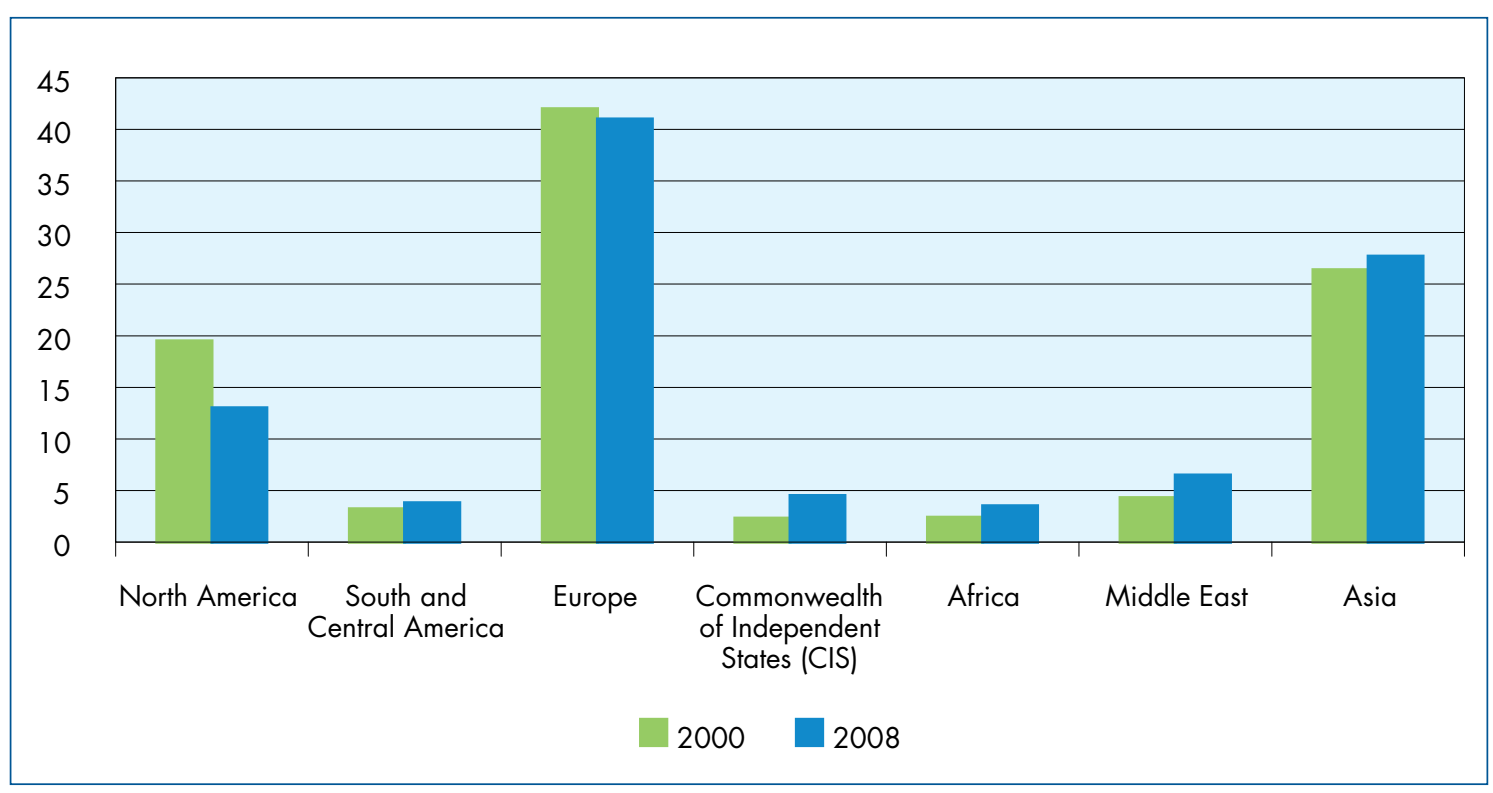

Source: http://www.wto.org/english/res_e/statis_e/its2009_e/its09_charts_e.htm

Figure 1.4 - World exports by destination, 2009

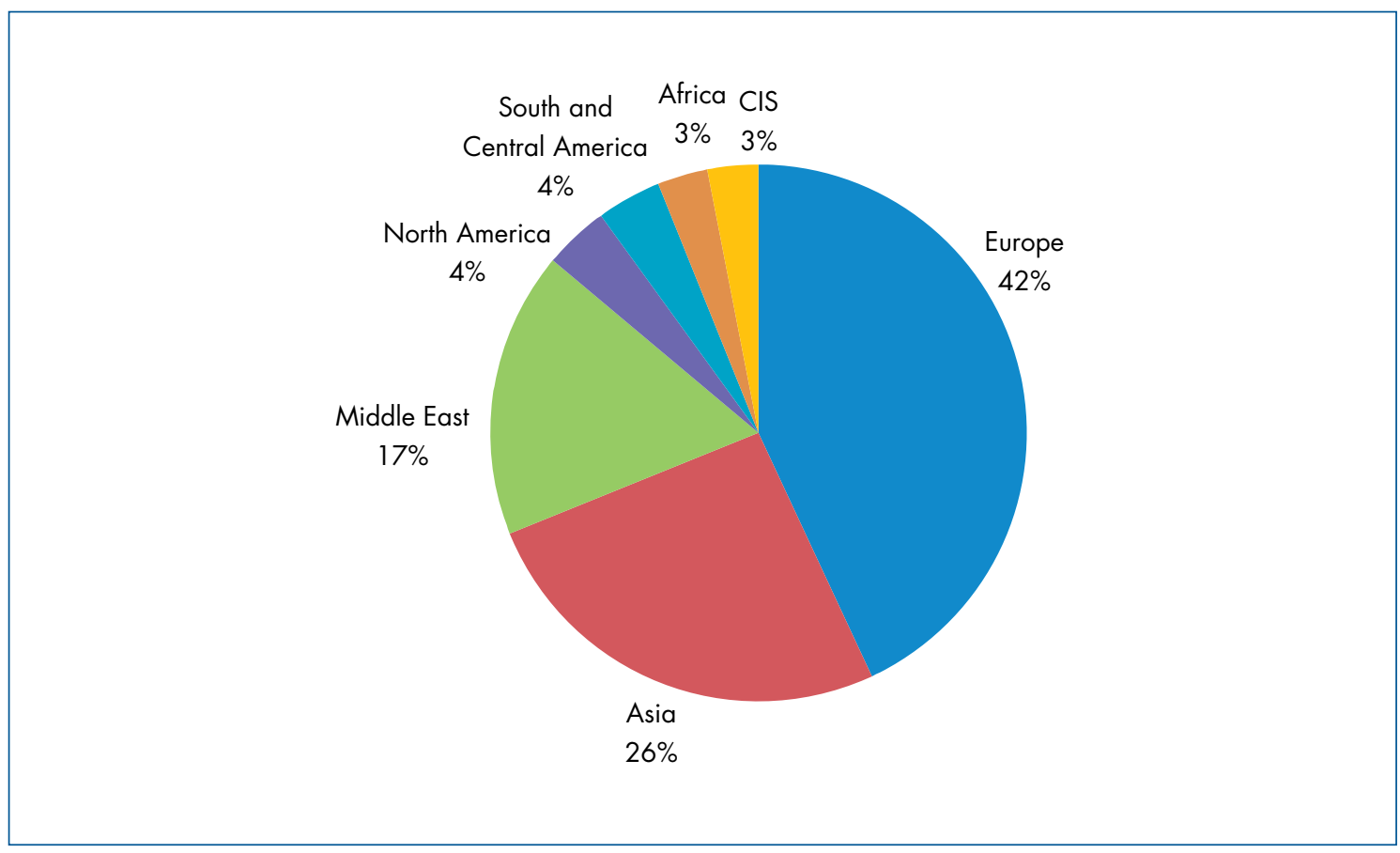

According to the WTO, in 2009, 72 per cent of Europe's exports went to European countries, 8 per cent to Asia, 7 per cent to North America and only 3 per cent to CIS countries, while 52 per cent of Asian countries' exports went to Asia, 18 per cent to Europe and North America, and only 2 per cent to CIS countries, as shown in Figures 1.5 and 1.6, respectively. Similar figures were recorded for 2008, as per Table 1.2. 
Figure 1.5 - European exports by destination, 2009

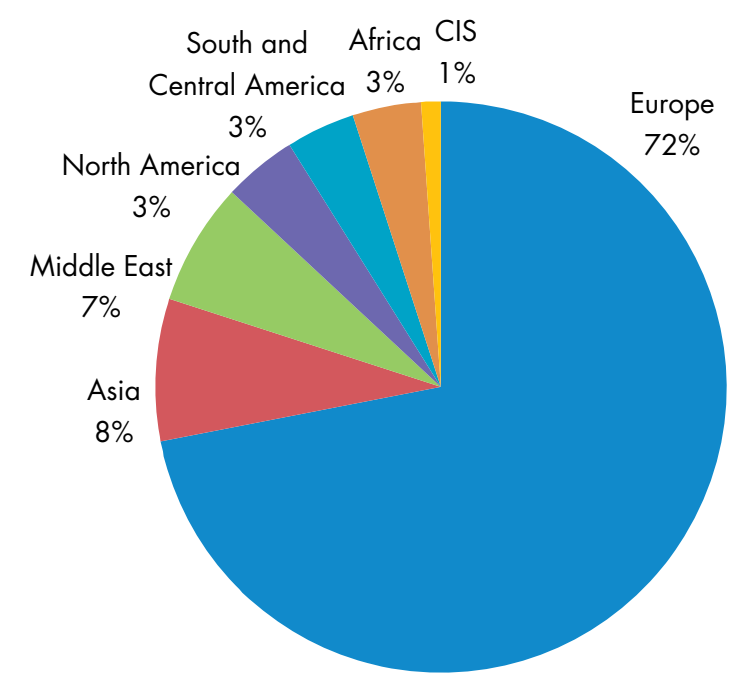

Figure 1.6 - Asian exports by destination, 2009

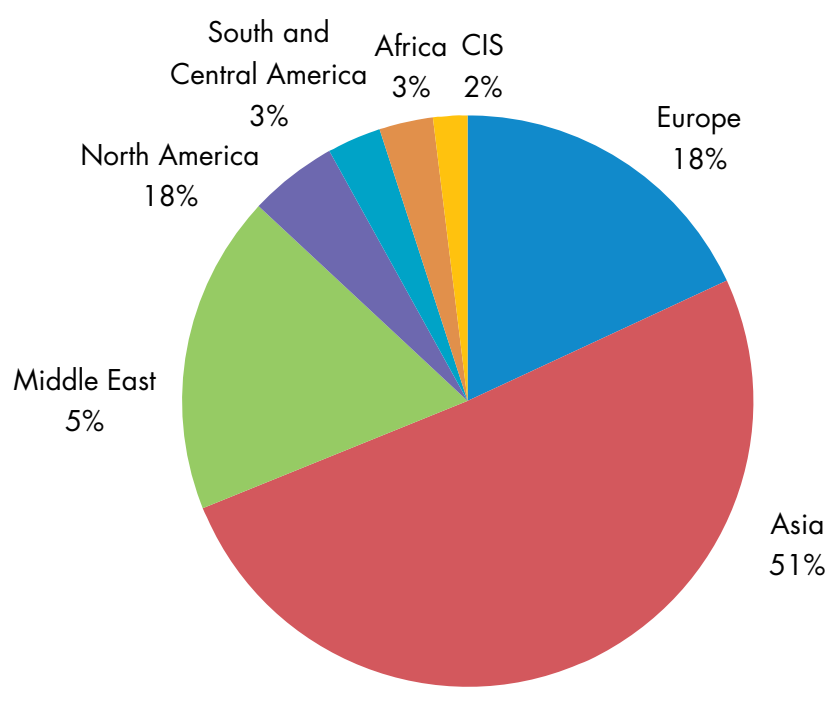

Based on the above, Asia contributes one fourth of world trade in goods, where about half of Asia's exports are conducted within the region. In parallel to growing intraregional trade, Asia's interregional trade has also grown over time, with Europe and North America becoming the two largest destinations of Asia's exports. 
Table 1.2 - Intra- and interregional merchandise trade, 2008

\begin{tabular}{|c|c|c|c|c|c|c|c|c|}
\hline \multicolumn{9}{|c|}{ Destination } \\
\hline Origin & North America & $\begin{array}{c}\text { South and } \\
\text { Central } \\
\text { America }\end{array}$ & Europe & CIS & Africa & Middle East & Asia & World \\
\hline \multicolumn{9}{|l|}{ Value } \\
\hline World & 2708 & 583 & 6736 & 517 & 458 & 618 & 3903 & 15717 \\
\hline North America & 1014.5 & 164.9 & 369.1 & 16.0 & 33.6 & 60.2 & 375.5 & 2035.7 \\
\hline $\begin{array}{l}\text { South and } \\
\text { Central America }\end{array}$ & 169.2 & 158.6 & 121.3 & 9.0 & 16.8 & 11.9 & 100.6 & 599.7 \\
\hline Europe & 475.4 & 96.4 & 4695.0 & 240.0 & 185.5 & 188.6 & 486.5 & 6446.6 \\
\hline $\begin{array}{l}\text { Commonwealth } \\
\text { of Independent } \\
\text { States (CIS) }\end{array}$ & 36.1 & 10.1 & 405.6 & 134.7 & 10.5 & 25.0 & 76.8 & 702.8 \\
\hline Africa & 121.6 & 18.5 & 218.1 & 1.5 & 53.4 & 14.0 & 113.9 & 557.8 \\
\hline Middle East & 116.5 & 6.9 & 125.5 & 7.2 & 36.6 & 122.1 & 568.9 & 1021.2 \\
\hline Asia & 775.0 & 127.3 & 801.0 & 108.4 & 121.3 & 196.4 & 2181.4 & 4353.0 \\
\hline \multicolumn{9}{|c|}{ Share of regional trade flows in each region's total merchandise exports } \\
\hline World & 17.2 & 3.7 & 42.9 & 3.3 & 2.9 & 3.9 & 24.8 & 100.0 \\
\hline North America & 49.8 & 8.1 & 18.1 & 0.8 & 1.7 & 3.0 & 18.4 & 100.0 \\
\hline $\begin{array}{l}\text { South and } \\
\text { Central America }\end{array}$ & 28.2 & 26.5 & 20.2 & 1.5 & 2.8 & 2.0 & 16.8 & 100.0 \\
\hline Europe & 7.4 & 1.5 & 72.8 & 3.7 & 2.9 & 2.9 & 7.5 & 100.0 \\
\hline $\begin{array}{l}\text { Commonwealth } \\
\text { of Independent } \\
\text { States (CIS) }\end{array}$ & 5.1 & 1.4 & 57.7 & 19.2 & 1.5 & 3.6 & 10.9 & 100.0 \\
\hline Africa & 21.8 & 3.3 & 39.1 & 0.3 & 9.6 & 2.5 & 20.4 & 100.0 \\
\hline Middle East & 11.4 & 0.7 & 12.3 & 0.7 & 3.6 & 12.0 & 55.7 & 100.0 \\
\hline Asia & 17.8 & 2.9 & 18.4 & 2.5 & 2.8 & 4.5 & 50.1 & 100.0 \\
\hline \multicolumn{9}{|c|}{ Share of regional trade flows in world merchandise exports } \\
\hline World & 17.2 & 3.7 & 42.9 & 3.3 & 2.9 & 3.9 & 24.8 & 100.0 \\
\hline North America & 6.5 & 1.0 & 2.3 & 0.1 & 0.2 & 0.4 & 2.4 & 13.0 \\
\hline $\begin{array}{l}\text { South and } \\
\text { Central America }\end{array}$ & 1.1 & 1.0 & 0.8 & 0.1 & 0.1 & 0.1 & 0.6 & 3.8 \\
\hline Europe & 3.0 & 0.6 & 29.9 & 1.5 & 1.2 & 1.2 & 3.1 & 41.0 \\
\hline $\begin{array}{l}\text { Commonwealth } \\
\text { of Independent } \\
\text { States (CIS) }\end{array}$ & 0.2 & 0.1 & 2.6 & 0.9 & 0.1 & 0.2 & 0.5 & 4.5 \\
\hline Africa & 0.8 & 0.1 & 1.4 & 0.0 & 0.3 & 0.1 & 0.7 & 3.5 \\
\hline Middle East & 0.7 & 0.0 & 0.8 & 0.0 & 0.2 & 0.8 & 3.6 & 6.5 \\
\hline Asia & 4.9 & 0.8 & 5.1 & 0.7 & 0.8 & 1.2 & 13.9 & 27.7 \\
\hline
\end{tabular}

Source: http://www.wto.org/english/res_e/statis_e/its2009_e/ 


\section{Euro-ASEM trade}

The Asia-Europe Meeting (ASEM), an informal process of dialogue and cooperation bringing together the 27 European Union Member States and the European Commission with 19 Asian countries and the Association of Southeast Asian Nations (ASEAN), has released figures for the evolution of the trade balance of the European Union (EU) with Asian ASEM countries, presented in Figures 1.7 and 1.8 respectively. An increase in trade value is observed for both imports and exports in both directions during the period from 2005 to 2008, preceding the steep fall commencing in 2009 and attributed to the financial crisis. Nevertheless, EU imports from Asian countries are on average twice as large as exports in the opposite direction.

Figure 1.7 - EU trade with Asian ASEM countries

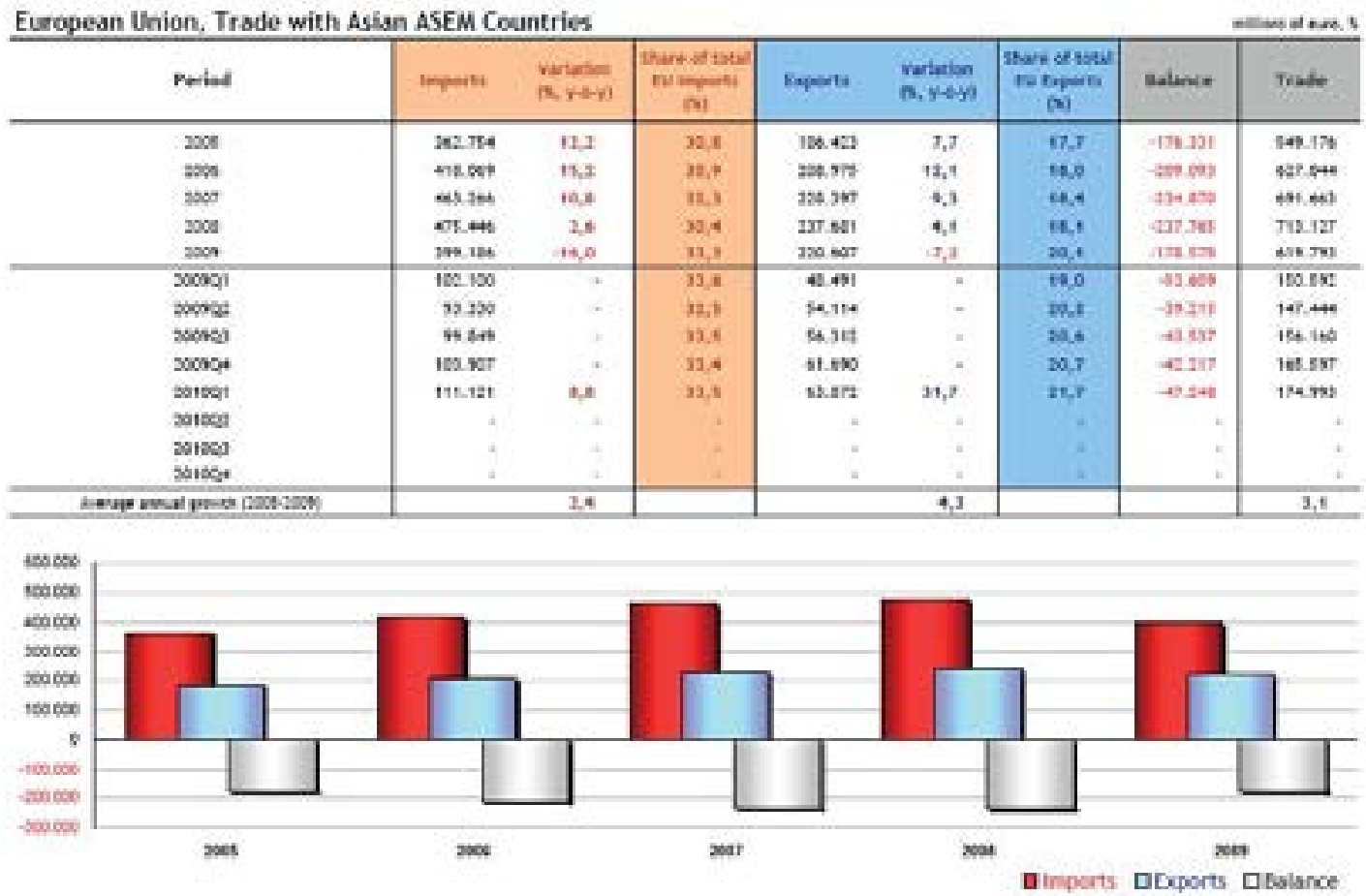


Figure 1.8 - Asian ASEM countries' trade with EU

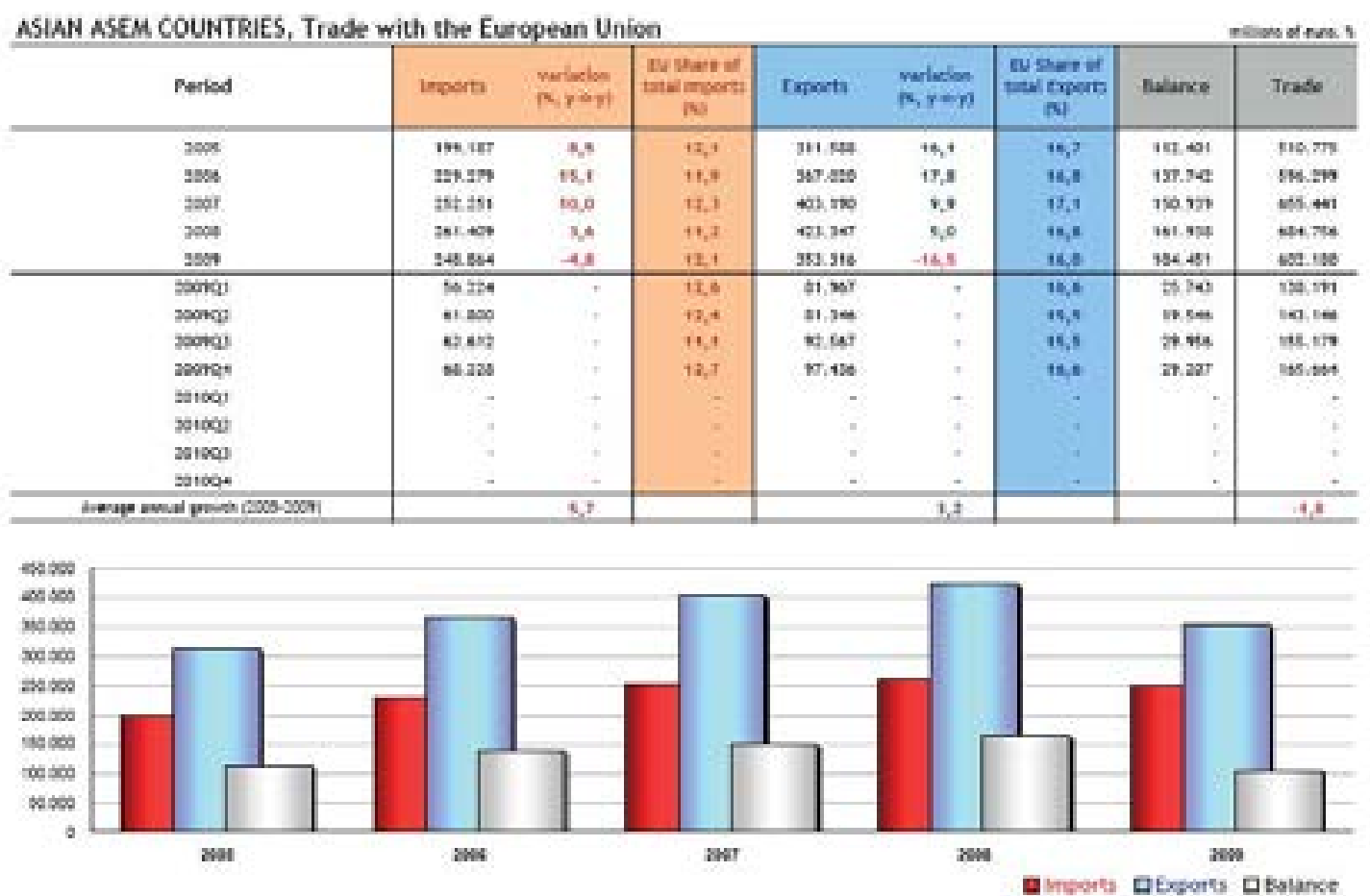

Source: Asia-Europe Meeting (ASEM), Report, A European Commission foundation

\section{EU-China trade}

Table 1.3 - EU-27 trade value with China by transport mode (in million euros)

\begin{tabular}{|c|c|c|c|c|c|c|c|c|c|c|}
\hline $\begin{array}{c}\text { EU 27 } \\
\text { with } \\
\text { China }\end{array}$ & $\begin{array}{c}\text { Oct. } \\
2009\end{array}$ & $\begin{array}{c}\text { Nov. } \\
2009\end{array}$ & $\begin{array}{c}\text { Dec. } \\
2009\end{array}$ & $\begin{array}{c}\text { Jan.-Dec. } \\
2009\end{array}$ & $\begin{array}{c}\text { Jan. } \\
2010\end{array}$ & $\begin{array}{c}\text { Feb. } \\
2010\end{array}$ & $\begin{array}{c}\text { Mar. } \\
2010\end{array}$ & $\begin{array}{c}\text { Apr. } \\
2010\end{array}$ & $\begin{array}{c}\text { May. } \\
2010\end{array}$ & $\begin{array}{c}\text { Jun. } \\
2010\end{array}$ \\
\hline SEA & 11610 & 9957 & 10015 & 126925 & 11916 & 11348 & 12993 & 11268 & 12797 & 15266 \\
\hline RAIL & 116 & 107 & 88 & 1239 & 109 & 79 & 124 & 128 & 135 & 147 \\
\hline AIR & 3872 & 4871 & 3846 & 43638 & 3926 & 3656 & 4575 & 4109 & 4864 & 4708 \\
\hline
\end{tabular}

Source: Eurostat

Based on data provided by the EU statistical office Eurostat (Table 1.3) for the recent period of October 2009 to June 2010, the bulk of EU-27 trade (both imports and exports) with China, continues to be transported by sea. The second largest share in value corresponds to air transport, while rail accounts for the lowest share. 


\section{EU-Turkey trade}

Similar findings are obtained from the analysis of merchandise trade between Turkey and the EU and Asia in 2009, depicted in Figures 1.9 and 1.10 below.

Figure 1.9 - Turkey trade volumes with the EU-27 by transport mode

\section{Turkey Trade Volumes with the EU-27 by Transport Mode}

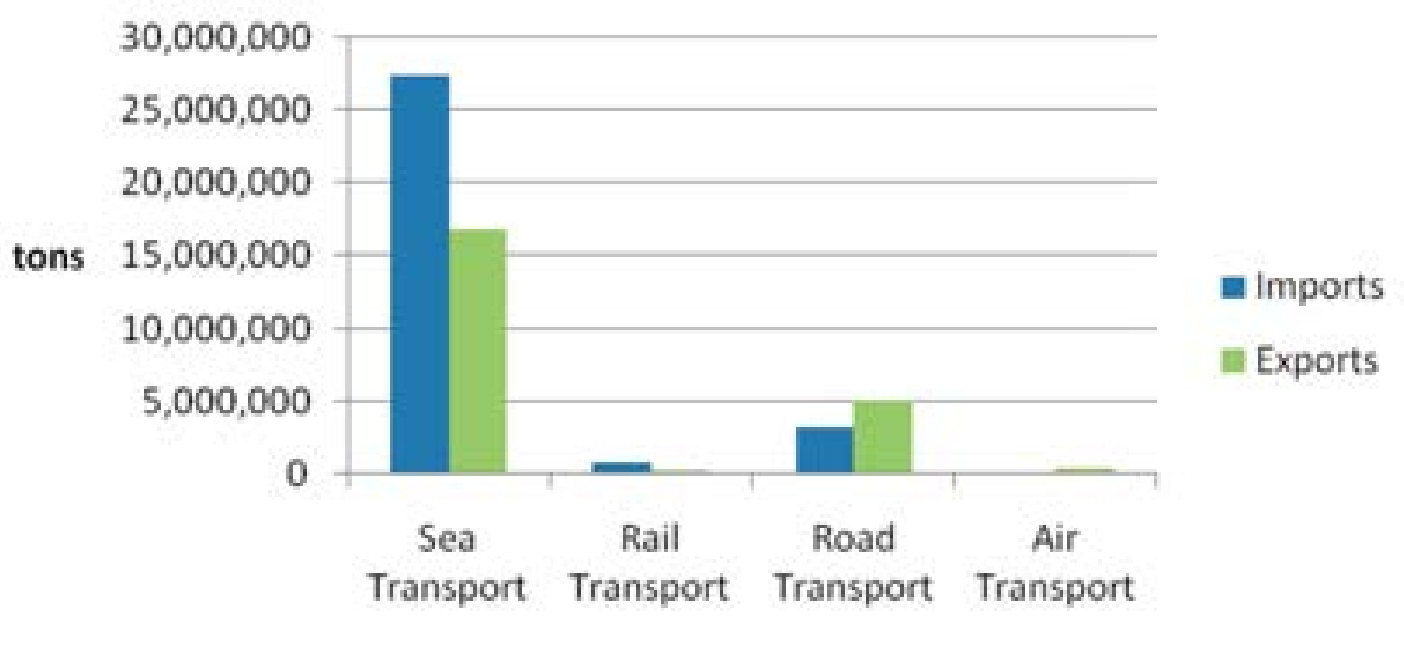

Source: Turkey NFP

Figure 1.10 - - Turkey trade volumes with Asia by transport mode

\section{Turkey Trade Volumes with Asia by Transport Mode}

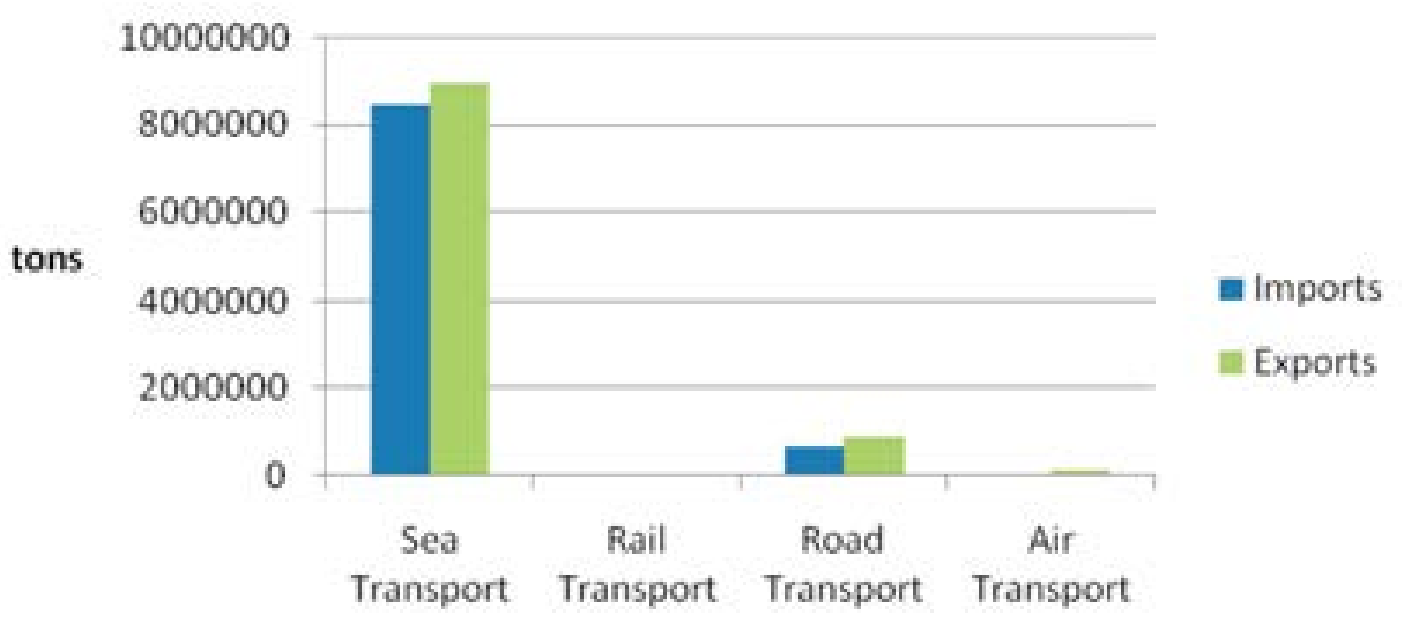

Source: Turkey NFP 


\section{Lithuanian trade}

Similarly, Figures 1.11 and 1.12 illustrate the imports and exports of Lithuania with the other EU countries and other EATL participating countries by transport mode.

Figure 1.11 - Lithuania trade import volumes by transport mode

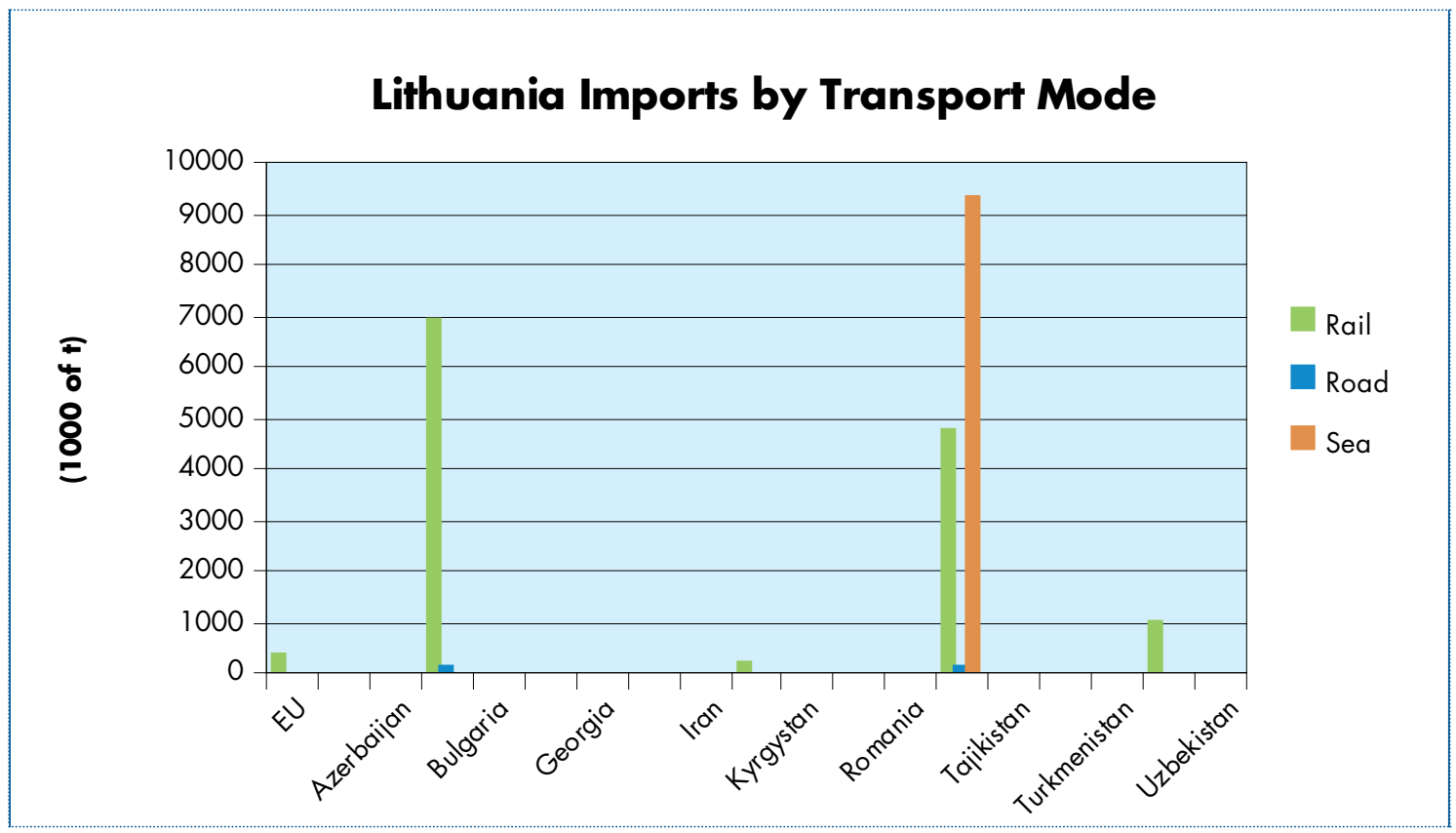

Source: Lithuania NFP

Figure 1.12 - Lithuania trade export volumes by transport mode

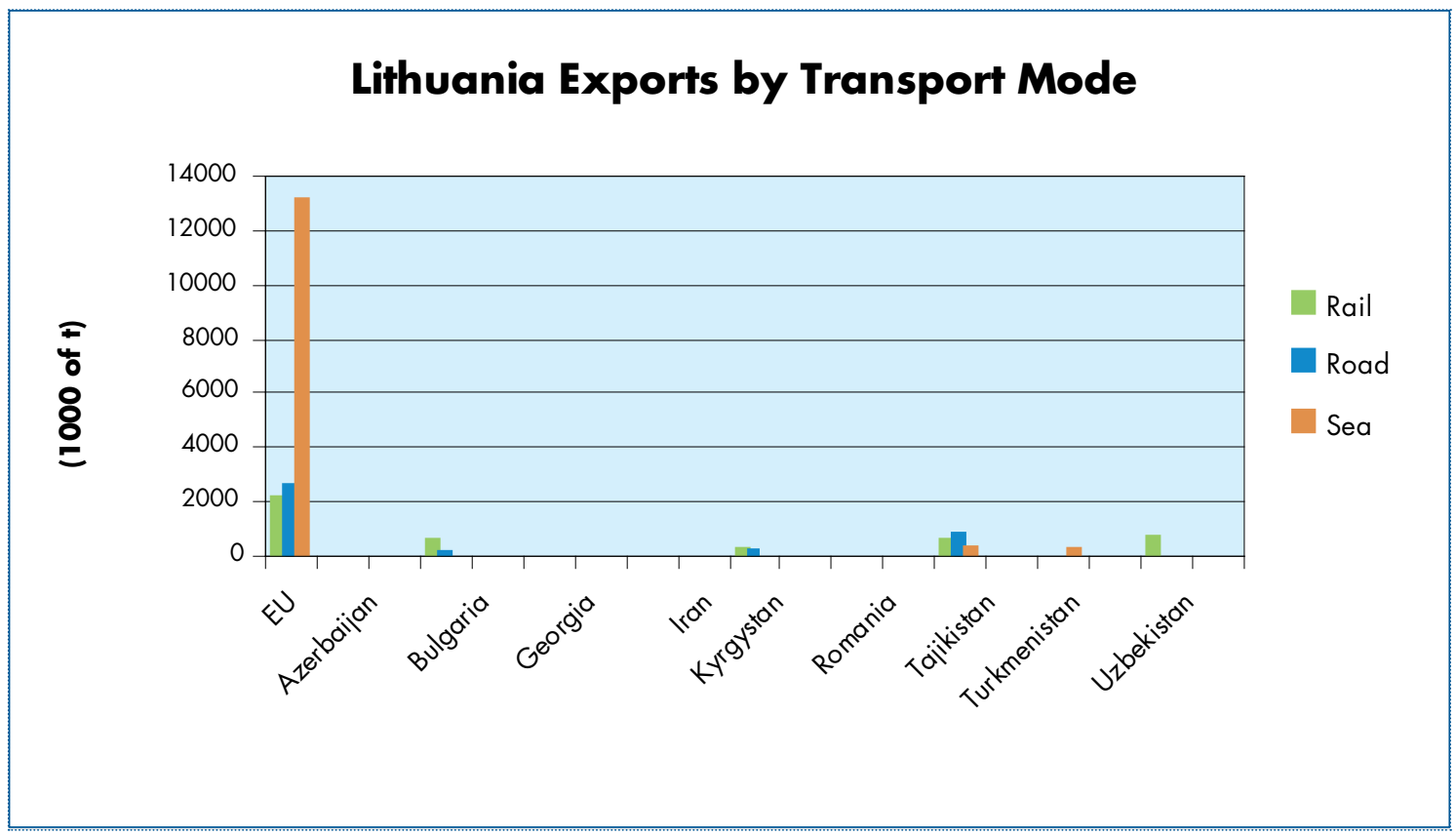

Source: Lithuania NFP 


\section{Transport of containerized cargo}

The volumes of international containerized cargo shipped using rail or road transport between China and Europe are currently very limited. Rail transport, in particular, using the Trans-Siberian railway, which with its branches represents the most important railway connection between Europe and the Far East, may account for up to 3-4 per cent of the current volume, mainly from northern China. The share of railway freight transport in long-distance international transport is modest but has significant potential in certain connections. Road transport accounts for even less.

A good comparison of the Trans-Siberian and all-water routes in terms of transport times is presented in Table 1.4. It appears that in terms of the time required to get from major ports in Japan, China and the Republic of Korea to Finland, the Trans-Siberian route is faster.

Table 1.4 - Transport travel times from Asian origins to Finland

\begin{tabular}{|c|c|c|c|}
\hline Routes & Busan (ROK) & Kobe (Japan) & Shangai (Chian) \\
\hline All-water & 35 days & 35 days & 35 days \\
\hline Trans-Siberian & $18-22$ days & 24 days & 26 days \\
\hline
\end{tabular}

Source: Oksana et al (2006)

\subsubsection{The economic growth of Asia}

As described in the previous section, the volume of international trade between Europe and Asia has been growing sharply in recent years. This is mainly driven by the development and emergence of new economies in Asia, and economic expansion in China. Also, the newly industrialized countries of Asia have seen their trade flows rebound more strongly than those of developed economies, suggesting that much of their recent growth could be attributed to the trade within Asia.

According to the WTO (Table 1.5), as of 2008 China surpassed Germany to become the world's largest exporter of manufactured goods.

Table 1.5 - Merchandise trade: Leading exporters and importers, 2009

\begin{tabular}{|c|c|c|c|c|c|c|c|c|c|}
\hline Rank & Exporters & Value & Share & $\begin{array}{c}\text { Annual per cent } \\
\text { change }\end{array}$ & Rank & Importers & Value & Share & $\begin{array}{c}\text { Annual per cent } \\
\text { change }\end{array}$ \\
\hline 1 & China & 1202 & 9.6 & -16 & 1 & United States & 1604 & 12.7 & -26 \\
\hline 2 & Germany & 1121 & 9.0 & -22 & 2 & China & 1006 & 8.0 & -11 \\
\hline 3 & United States & 1057 & 8.5 & -18 & 3 & Germany & 931 & 7.4 & -21 \\
\hline 4 & Japan & 581 & 4.7 & -26 & 4 & France & 551 & 4.4 & -22 \\
\hline 5 & Netherlands & 499 & 4.0 & -22 & 5 & Japan & 551 & 4.4 & -28 \\
\hline 6 & France & 475 & 3.8 & -21 & 6 & United Kingdom & 480 & 3.8 & -24 \\
\hline 7 & Italy & 405 & 3.2 & -25 & 7 & Netherlands & 446 & 3.5 & -23 \\
\hline 8 & Belgium & 370 & 3.0 & -22 & 8 & Italy & 410 & 3.2 & -26 \\
\hline 9 & $\begin{array}{l}\text { Korea, } \\
\text { Republic of }\end{array}$ & 364 & 2.9 & -14 & \multirow{2}{*}{9} & $\begin{array}{l}\text { Hong Kong, } \\
\text { China }\end{array}$ & 353 & 2.8 & -10 \\
\hline 10 & United Kingdom & 351 & 2.8 & -24 & & $\begin{array}{l}\text { - retained } \\
\text { imports }^{a}\end{array}$ & 91 & 0.7 & -8 \\
\hline
\end{tabular}




\begin{tabular}{|c|c|c|c|c|c|c|c|c|c|}
\hline Rank & Exporters & Value & Share & $\begin{array}{c}\text { Annual per cent } \\
\text { change }\end{array}$ & Rank & Importers & Value & Share & $\begin{array}{c}\text { Annual per cent } \\
\text { change }\end{array}$ \\
\hline \multirow{3}{*}{11} & $\begin{array}{l}\text { Hong Kong, } \\
\text { China }\end{array}$ & 330 & 2.6 & -11 & 10 & Belgium & 351 & 2.8 & -25 \\
\hline & $\begin{array}{l}\text { - domestic } \\
\text { exports }\end{array}$ & 15 & 0.1 & -9 & 11 & Canada & 330 & 2.6 & -21 \\
\hline & - re-exports ${ }^{a}$ & 314 & 2.5 & -11 & 12 & $\begin{array}{c}\text { Korea, Republic } \\
\text { of }\end{array}$ & 323 & 2.6 & -26 \\
\hline 12 & Canada & 316 & 2.5 & -31 & 13 & Spain & 290 & 2.3 & -31 \\
\hline 13 & $\begin{array}{l}\text { Russian } \\
\text { Federation }\end{array}$ & 304 & 2.4 & -36 & \multirow{2}{*}{14} & Singapore & 246 & 1.9 & -23 \\
\hline \multirow{3}{*}{14} & Singapore & 270 & 2.2 & -20 & & $\begin{array}{l}\text { - retained } \\
\text { imports }^{b}\end{array}$ & 114 & 0.9 & -28 \\
\hline & $\begin{array}{l}\text { - domestic } \\
\text { exports }\end{array}$ & 138 & 1.1 & -21 & 15 & India & 244 & 1.9 & -24 \\
\hline & - re-exports & 132 & 1.1 & -19 & 16 & Mexico & 242 & 1.9 & -24 \\
\hline 15 & Mexico & 230 & 1.8 & -21 & 17 & $\begin{array}{l}\text { Russian } \\
\text { Federation }\end{array}$ & 192 & 1.5 & -34 \\
\hline 16 & Spain & 218 & 1.7 & -23 & 18 & Taipei, Chinese & 175 & 1.4 & -27 \\
\hline 17 & Taipei, Chinese & 204 & 1.6 & -20 & 19 & Australia & 165 & 1.3 & -17 \\
\hline 18 & Saudi Arabia ${ }^{a}$ & 189 & 1.5 & -40 & 20 & Switzerland & 156 & 1.2 & -15 \\
\hline 19 & $\begin{array}{l}\text { United Arab } \\
\text { Emirates }^{a}\end{array}$ & 75 & 1.4 & -27 & 21 & Poland & 147 & 1.2 & -30 \\
\hline 20 & Switzerland & 173 & 1.4 & -14 & 22 & Austria & 144 & 1.1 & -22 \\
\hline 21 & Malaysia & 157 & 1.3 & -21 & 23 & Turkey & 141 & 1.1 & -30 \\
\hline 22 & India & 155 & 1.2 & -20 & 24 & $\begin{array}{l}\text { United Arab } \\
\text { Emirates }^{a}\end{array}$ & 140 & 1.1 & -21 \\
\hline 23 & Australia & 154 & 1.2 & -18 & 25 & Thailand & 134 & 1.1 & -25 \\
\hline 24 & Brazil & 153 & 1.2 & -23 & 26 & Brazil & 134 & 1.1 & -27 \\
\hline 25 & Thailand & 152 & 1.2 & -14 & 27 & Malaysia & 124 & 1.0 & -21 \\
\hline 26 & Austria & 137 & 1.1 & -24 & 28 & Sweden & 119 & 0.9 & -29 \\
\hline 27 & Poland & 134 & 1.1 & -21 & 29 & Czech Republic & 105 & 0.8 & -26 \\
\hline 28 & Sweden & 131 & 1.0 & -29 & 30 & Saudi Arabia ${ }^{a}$ & 92 & 0.7 & -20 \\
\hline 29 & Norway & 121 & 1.0 & -30 & & & & & \\
\hline 30 & Indonesia & 120 & 1.0 & -14 & & & & & \\
\hline \multicolumn{2}{|c|}{ Total of above } & 10244 & 82.2 & - & & Total of above ${ }^{d}$ & 10323 & 81.6 & - \\
\hline & World & 12461 & 100.0 & -23 & & World ${ }^{d}$ & 12647 & 100.0 & -23 \\
\hline
\end{tabular}

a Secretariat estimates.

bSingapore's retained imports are defined as imports less re-exports

'Imports are valued f.o.b.

${ }^{d}$ Includes significant re-exports or imports for re-export.

Source: WTO 
Between 2005 and 2008, China's exports of manufactured goods grew at an annual average rate of 12 per cent, three times that of Germany (Table 1.6). While EU exports outside the European Union still remain at the top of the list, the gap with China has been constantly narrowing. On the import side, China remains second in the list of major importers.

Growth prospects for Asia in the next two years improved following somewhat surprising growth in the second half of 2009. According to figures produced by the Asian Development Bank, presented in Table 1.7, GDP in 2011 was projected to grow by 5.9 per cent for Central Asia, and by 7.7 per cent for East Asia. The three economies that shrank during 2009 (Hong Kong SAR, Mongolia and Taiwan Province of China) are expected to recover. In addition, growth in all of Central Asia's economies was expected in 2010-2011, favoured by higher oil prices and recovery in the Russian Federation, the major trade and financial partner country. Kazakhstan's non-oil economy was expected to hold its overall growth down to 2.5 per cent, while the Armenian and Georgian economies were projected to turn around with slower growth (about 2 per cent). In Kyrgyzstan and Tajikistan, expansion was expected to accelerate slightly, to about 4-6 per cent (Outlook, 2010).

Table 1.6 - World merchandise trade by region and selected country, 2009

\begin{tabular}{|c|c|c|c|c|c|c|c|c|c|c|}
\hline & \multicolumn{5}{|c|}{ Exports } & \multicolumn{5}{|c|}{ Imports } \\
\hline & \multirow{2}{*}{$\begin{array}{l}\text { Value } \\
2009\end{array}$} & \multicolumn{4}{|c|}{ Annual percentage change } & \multirow{2}{*}{$\begin{array}{l}\text { value } \\
2009\end{array}$} & \multicolumn{4}{|c|}{ Annual percentage change } \\
\hline & & 2005-09 & 2007 & 2008 & 2009 & & 2005-09 & 2007 & 2008 & 2009 \\
\hline World & 12147 & 4 & 16 & 15 & -23 & 12385 & 4 & 15 & 16 & -24 \\
\hline North America & 1602 & 2 & 11 & 11 & -21 & 2177 & -1 & 6 & 8 & -25 \\
\hline United States & 1057 & 4 & 12 & 12 & -18 & 1604 & -2 & 5 & 7 & -26 \\
\hline Canada & 316 & -3 & 8 & 9 & -31 & 330 & 1 & 9 & 7 & -21 \\
\hline Mexico & 230 & 2 & 9 & 7 & -21 & 242 & 1 & 10 & 10 & -24 \\
\hline $\begin{array}{l}\text { South and central } \\
\text { Americaa }\end{array}$ & 461 & 6 & 14 & 21 & -24 & 444 & 10 & 25 & 30 & -25 \\
\hline Brazil & 153 & 7 & 17 & 23 & -23 & 134 & 15 & 32 & 44 & -27 \\
\hline $\begin{array}{l}\text { Other South and Central } \\
\text { Americaa }\end{array}$ & 308 & 6 & 13 & 20 & -24 & 311 & 9 & 23 & 25 & -25 \\
\hline Europe & 4995 & 3 & 16 & 11 & -23 & 5142 & 3 & 16 & 12 & -25 \\
\hline European Union (27) & 4567 & 3 & 16 & 11 & -23 & 4714 & 3 & 16 & 12 & -25 \\
\hline Germany & 1121 & 4 & 19 & 9 & -22 & 931 & 5 & 16 & 12 & -21 \\
\hline France & 475 & 1 & 11 & 9 & -21 & 551 & 2 & 14 & 14 & -22 \\
\hline Netherlands & 499 & 5 & 19 & 16 & -22 & 446 & 5 & 18 & 18 & -23 \\
\hline United Kingdom ${ }^{b}$ & 351 & -2 & -2 & 5 & -24 & 480 & -2 & 4 & 2 & -24 \\
\hline Italy & 405 & 2 & 20 & 8 & -25 & 410 & 2 & 16 & 8 & -26 \\
\hline $\begin{array}{l}\text { Commonwealth of } \\
\text { Independent states (CIS) }\end{array}$ & 452 & 7 & 21 & 35 & -36 & 332 & 11 & 35 & 32 & -33 \\
\hline Russian Federation $^{c}$ & 304 & 6 & 17 & 33 & -36 & 192 & 11 & 36 & 31 & -34 \\
\hline Africa & 379 & 5 & 18 & 28 & -32 & 400 & 12 & 23 & 27 & -16 \\
\hline South Africa & 63 & 5 & 20 & 16 & -22 & 72 & 4 & 12 & 12 & -28 \\
\hline
\end{tabular}




\begin{tabular}{|c|c|c|c|c|c|c|c|c|c|c|}
\hline & \multicolumn{5}{|c|}{ Exports } & \multicolumn{5}{|c|}{ Imports } \\
\hline & \multirow{2}{*}{$\begin{array}{l}\text { Value } \\
2009\end{array}$} & \multicolumn{4}{|c|}{ Annual percentage change } & \multirow{2}{*}{$\begin{array}{l}\text { value } \\
2009\end{array}$} & \multicolumn{4}{|c|}{ Annual percentage change } \\
\hline & & 2005-09 & 2007 & 2008 & 2009 & & 2005-09 & 2007 & 2008 & 2009 \\
\hline Africa less South Africa & 317 & 5 & 17 & 31 & -33 & 328 & 14 & 27 & 32 & -13 \\
\hline Oil exporters ${ }^{d}$ & 204 & 3 & 17 & 34 & -40 & 129 & 16 & 29 & 39 & -11 \\
\hline Non oil exporters & 113 & 9 & 16 & 23 & -17 & 199 & 13 & 27 & 28 & -14 \\
\hline Middle east & 691 & 6 & 16 & 33 & -33 & 493 & 10 & 25 & 28 & -18 \\
\hline Asia & 3566 & 6 & 16 & 15 & -18 & 3397 & 6 & 15 & 21 & -21 \\
\hline China & 1202 & 12 & 26 & 17 & -16 & 1006 & 11 & 21 & 18 & -11 \\
\hline Japan & 581 & -1 & 10 & 9 & -26 & 551 & 2 & 7 & 23 & -28 \\
\hline India & 155 & 12 & 23 & 30 & -20 & 244 & 14 & 29 & 40 & -24 \\
\hline $\begin{array}{l}\text { Newly industrialized } \\
\text { economies }(4)^{\mathrm{e}}\end{array}$ & 853 & 4 & 11 & 10 & -17 & 834 & 4 & 11 & 17 & -24 \\
\hline \multicolumn{11}{|l|}{ Memorandum items: } \\
\hline Developing economies & 4697 & 7 & 17 & 19 & -22 & 4432 & 8 & 19 & 22 & -20 \\
\hline MERCOSUR & 217 & 7 & 18 & 24 & -22 & 186 & 13 & 31 & 41 & -28 \\
\hline ASEAN 9 & 814 & 6 & 12 & 14 & -18 & 724 & 5 & 13 & 21 & -23 \\
\hline EU (27) extra-trade & 1525 & 4 & 17 & 13 & -21 & 1672 & 3 & 16 & 17 & -27 \\
\hline $\begin{array}{l}\text { Least Developed } \\
\text { Countries (LDCs) }\end{array}$ & 125 & 11 & 25 & 32 & -27 & 144 & 13 & 24 & 29 & -11 \\
\hline
\end{tabular}

Source: WTO 
Table 1.7 - Asia GDP growth, 2007-2011

\begin{tabular}{|c|c|c|c|c|c|c|c|c|c|c|}
\hline \multicolumn{6}{|c|}{ Table 1 Growth rate of GDP (\% per year) } & \multicolumn{5}{|c|}{ Table 2 Inflation (\% per year) } \\
\hline Subregion/economy & 2007 & 2008 & 2009 & 2010 & 2011 & 2007 & 2008 & 2009 & 2010 & 2011 \\
\hline Central Asia & 12.0 & 6.1 & 2.7 & 4.7 & 5.9 & 11.2 & 16.5 & 5.9 & 6.7 & 6.6 \\
\hline Azerbaijan & 25.1 & 10.8 & 9.3 & 9.5 & 9.7 & 16.7 & 20.8 & 1.5 & 5.8 & 6.0 \\
\hline Kazakhstan & 8.9 & 3.3 & 1.2 & 2.5 & 3.5 & 10.8 & 17.3 & 7.3 & 6.8 & 6.5 \\
\hline East Asia & 10.4 & 7.3 & 5.9 & 8.3 & 7.7 & 3.9 & 5.4 & 0.0 & 3.3 & 3.0 \\
\hline China, People's Rep. of & 13.0 & 9.6 & 8.7 & 9.6 & 9.1 & 4.8 & 5.9 & -0.7 & 3.6 & 3.2 \\
\hline Hong Kong, China & 6.4 & 2.1 & -2.7 & 5.2 & 4.3 & 2.0 & 4.3 & 0.5 & 2.2 & 2.8 \\
\hline Korea, Rep. of & 5.1 & 2.3 & 0.2 & 5.2 & 4.6 & 2.5 & 4.7 & 2.8 & 3.0 & 3.0 \\
\hline Taipei,China & 6.0 & 0.7 & -1.9 & 4.9 & 4.0 & 1.8 & 3.5 & -0.9 & 1.5 & 1.6 \\
\hline South Asia & 8.7 & 6.4 & 6.5 & 7.4 & 8.0 & 5.6 & 9.3 & 5.6 & 6.0 & 6.0 \\
\hline Bangladesh & 6.4 & 6.2 & 5.9 & 5.5 & 6.3 & 7.2 & 9.9 & 6.7 & 7.5 & 7.8 \\
\hline India & 9.2 & 6.7 & 7.2 & 8.2 & 8.7 & 4.8 & 8.3 & 3.6 & 5.0 & 5.5 \\
\hline Pakistan & 6.8 & 4.1 & 2.0 & 3.0 & 4.0 & 7.8 & 12.0 & 20.8 & 12.0 & 8.0 \\
\hline Sri Lanka & 6.8 & 6.0 & 3.5 & 6.0 & 7.0 & 15.8 & 22.6 & 3.5 & 6.5 & 8.0 \\
\hline Southeast Asia & 6.5 & 4.3 & 1.2 & 5.1 & 5.3 & 4.1 & 8.8 & 2.7 & 4.5 & 4.5 \\
\hline Indonesia & 6.3 & 6.0 & 4.5 & 5.5 & 6.0 & 6.4 & 9.8 & 5.0 & 5.6 & 6.2 \\
\hline Malaysia & 6.2 & 4.6 & -1.7 & 5.3 & 5.0 & 2.0 & 5.4 & 0.6 & 2.4 & 3.0 \\
\hline Philippines & 7.1 & 3.8 & 0.9 & 3.8 & 4.6 & 2.8 & 9.3 & 3.2 & 4.7 & 4.5 \\
\hline Singapore & 8.2 & 1.4 & -2.0 & 6.3 & 5.0 & 2.1 & 6.6 & 0.6 & 2.3 & 2.0 \\
\hline Thailand & 4.9 & 2.5 & -2.3 & 4.0 & 4.5 & 2.2 & 5.4 & -0.9 & 3.5 & 3.0 \\
\hline Viet Nam & 8.5 & 6.2 & 5.3 & 6.5 & 6.8 & 8.3 & 23.0 & 6.9 & 10.0 & 8.0 \\
\hline The Pacific & 5.0 & 5.4 & 2.3 & 3.7 & 5.0 & 3.6 & 9.5 & 5.2 & 5.1 & 5.4 \\
\hline Fiii Islands & -0.5 & -0.1 & -2.5 & -0.5 & 0.5 & 4.8 & 7.7 & 3.7 & 3.4 & 3.1 \\
\hline Papua New Guinea & 7.2 & 6.7 & 4.5 & 5.5 & 7.7 & 0.9 & 10.6 & 7.6 & 7.1 & 7.7 \\
\hline Developing Asia & 9.6 & 6.6 & 5.2 & 7.5 & 7.3 & 4.4 & 6.9 & 1.5 & 4.0 & 3.9 \\
\hline
\end{tabular}

Source: Asian Development Bank, Outlook 2010

\subsubsection{Container freight transport between Asia and Europe}

Maritime transport is currently the dominant mode of cargo transport between Asia and Europe with an associated steep growth of containerized trade between Asia and Europe. Maritime container ship traffic increased by 71 per cent and average ship size increased by 55 per cent between 1997 and 2006 (Vallouis, 2010). Container trade volume on the Asia-Europe route reached 13.7 million twenty-foot equivalent units (TEU) in 2002. Asia-Europe maritime trade is projected to grow at an average rate of 5.6 per cent per annum until 2015, as illustrated in Figure 1.13. It should be noted, however, that this growth rate covers the whole of Asia-Europe trade, including some already mature markets, such as northern Europe-Japan, which are expected to grow only slowly. Other trade routes, between East Asia and the Mediterranean and between India and all parts of Europe, are expected to grow more rapidly than the above rate. 
Figure 1.13 - East-West trade lane growth, 2002-2015

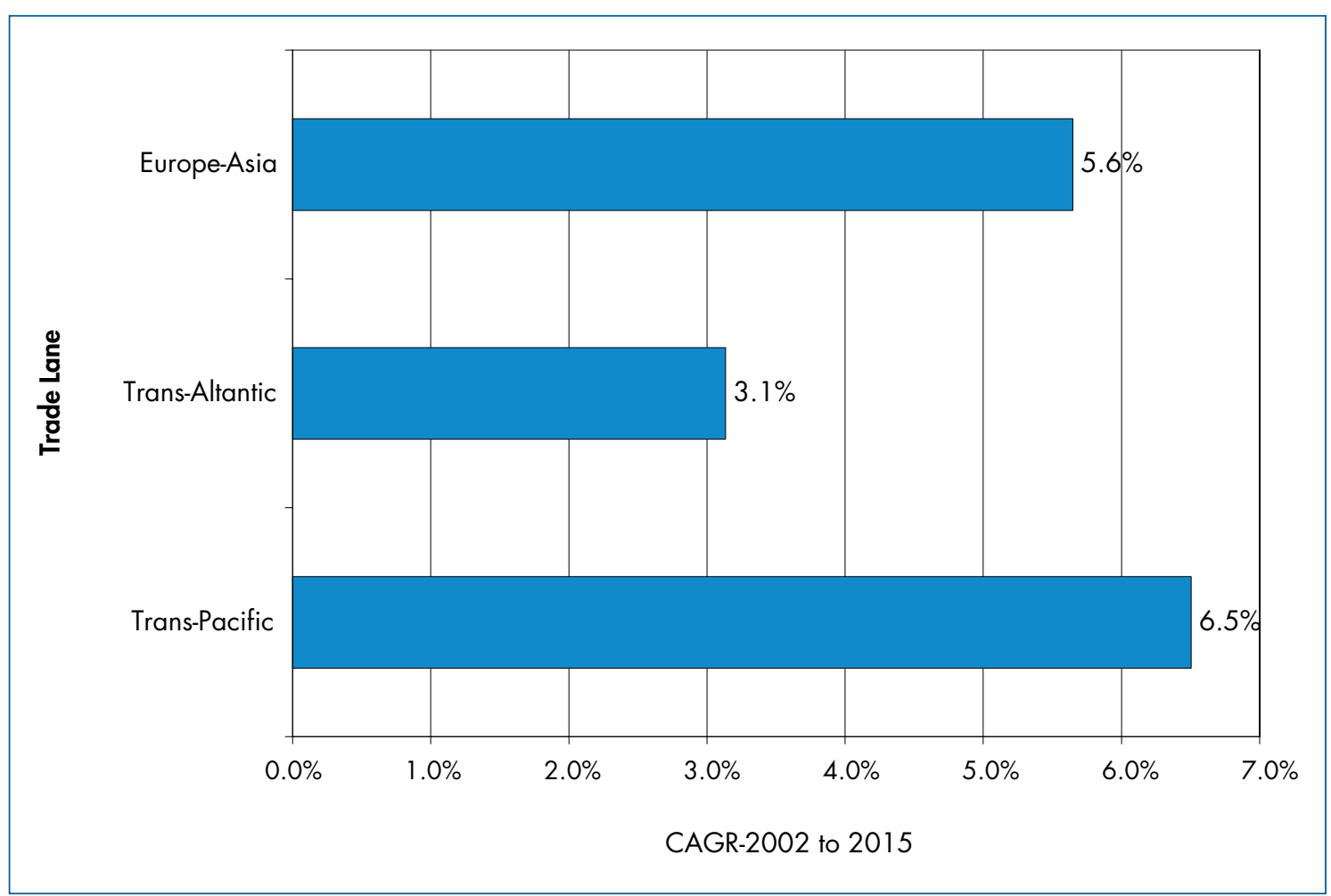

Source: www.unescap.org/ttdw/.../TFS.../pub_2398_ch4.pdf

One of the key features of container trade today is imbalance, with more containers leaving Asia full than those coming back. This imbalance has been recorded since as early as 1997, particularly with respect to Asian trade with northern Europe. Current estimates are that westbound TEU numbers now exceed eastbound by approximately 25 per cent and, according to forecasts, the trade imbalance on the Asia-Europe route will be further increased to around 34 per cent in 2015, as depicted in Figure 1.14. Westbound volumes are expected to increase from 7.6 million to 16 million TEU at an average rate of 5.9 per cent per annum over the forecast period, compared to the estimated rate of growth of 5.4 per cent for eastbound volumes from 6.1 million to 12 million TEU during the same period. 
Figure 1.14 - Trade imbalance on East-West routes, 2015

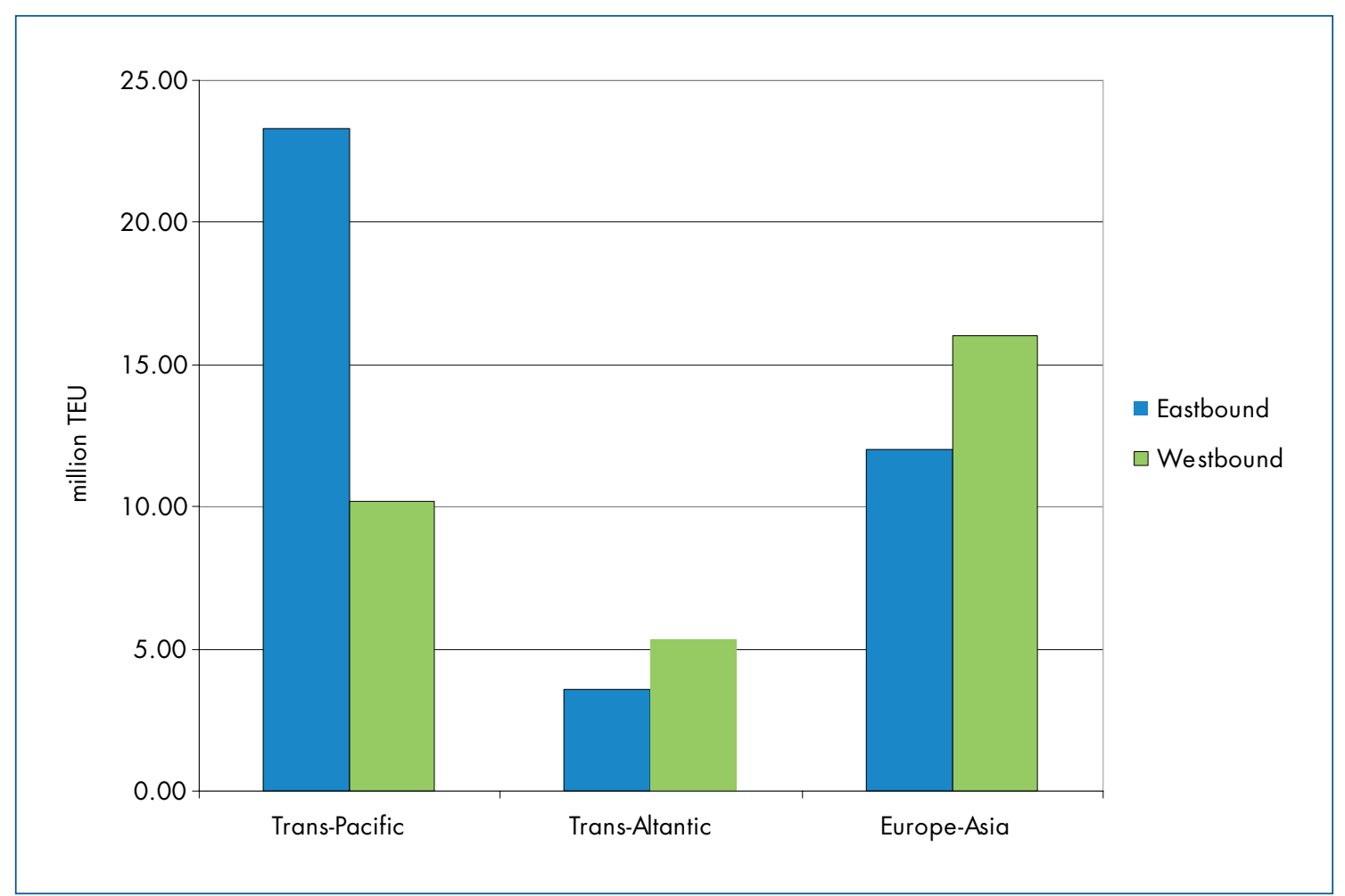

Source: www.unescap.org/ttdw/.../TFS.../pub_2398_ch4.pdf

Intra-Asian trade, especially trade to and from East Asia and South Asia is expected to grow substantially in the future. China, including Hong Kong SAR and Taiwan Province of China, will continue to dominate intra-Asian trade with an expected growth rate of 9.3 per cent per annum during the 2002-2015. Estimates show that South Asian country trade with other Asian countries will increase at an average rate of 10.4 per cent over the same period. In particular, the trade between these two subregions is expected to increase by more than 12 per cent annually (Figure 1.15). 
Figure 1.15 - Intra-Asian trade growth, 2002-2015

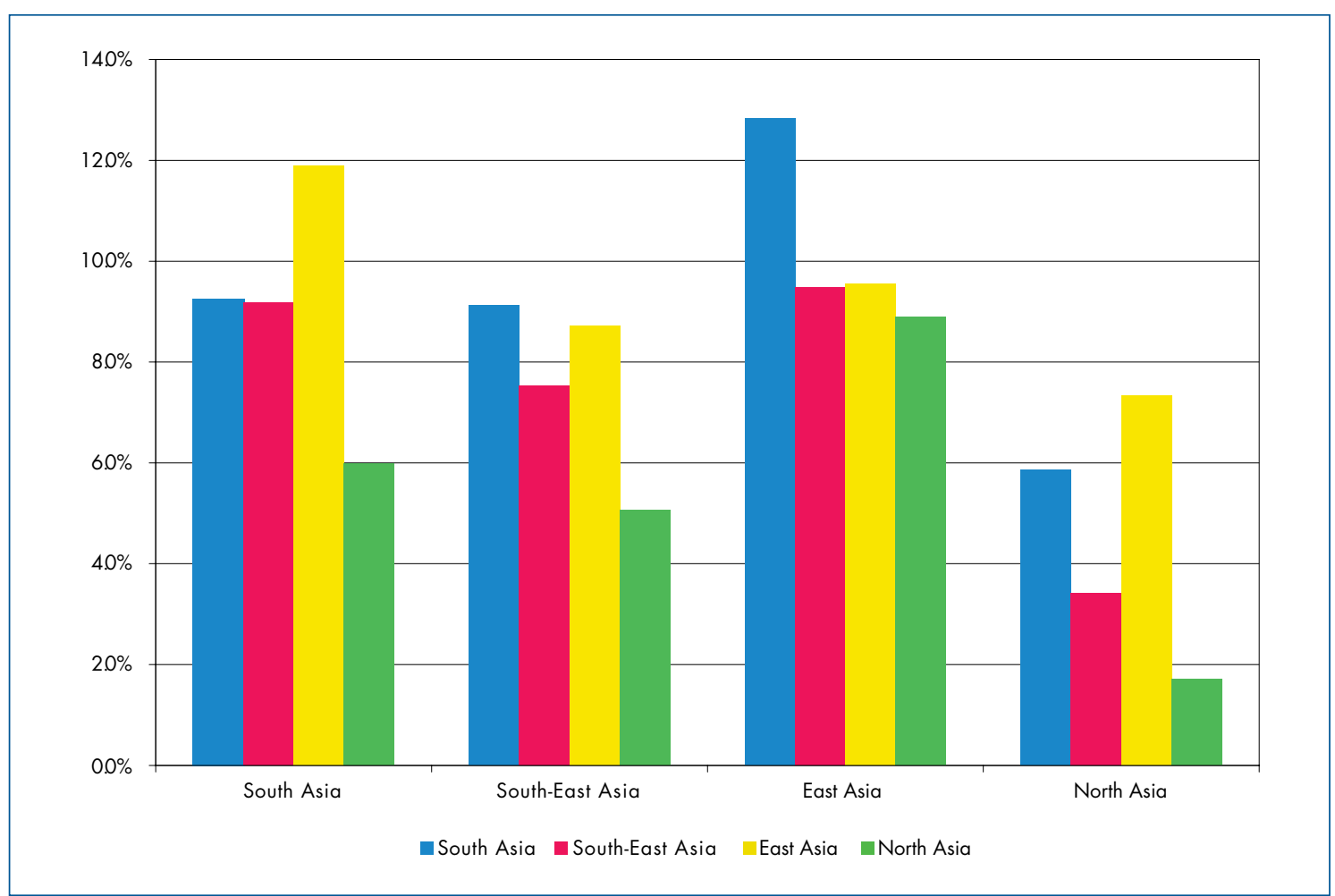

Source: www.unescap.org/ttdw/.../TFS.../pub_2398_ch4.pdf

The growth of container trade between Europe and Asia has promped the use of larger and more efficient vessels and rates that have fallen to extremely low levels, such as US\$ 742 per TEU from Europe to Asia, as shown in Table 1.8. The most important repercussion was, however, the emergence of major hubs in the Mediterranean, northern Europe and Asia. To this end, there is growing concern with regard to port congestion and the saturation of access to hinterland from ports.

Container throughput for the ports of China has increased from 19.4 million TEU in 2000 to 118.3 million TEU in 2008, equivalent to an average annual growth of 25.4 per cent for this period, while in South and South-West Asia, port container throughput has almost tripled from 2000 to 2008, as growth averaged some 16 per cent annually (ESCAP, 2009). Figure 1.16 illustrates forecasted average port capacity utilization by region, showing that ports in South-East Asia were expected to approach full capacity by the end of 2011. 
Table 1.8 - Freight rates (market averages) per TEU on the three major liner trade routes (\$ per TEU and percentage change)

\begin{tabular}{|c|c|c|c|c|c|c|c|}
\hline & & \multicolumn{2}{|c|}{ Trans-Pacific } & \multicolumn{2}{|c|}{ Europe-Asia } & \multicolumn{2}{|c|}{ Transatlantic } \\
\hline \multirow{9}{*}{ চ্ণি } & & Asia-Us & Us-Asia & Europe-Asia & Asia-Europe & Us-Europe & Europe-Us \\
\hline & First quarter & 1643 & 737 & 755 & 1549 & 1032 & 1692 \\
\hline & Change (\%) & -2 & -5 & -5 & 0 & -3 & -4 \\
\hline & Second quarter & 1675 & 765 & 744 & 1658 & 1067 & 1653 \\
\hline & Change (\%) & 2 & 4 & -1 & 7 & 3 & -2 \\
\hline & Third quarter & 1709 & 780 & 792 & 2014 & 114 & 1667 \\
\hline & Change (\%) & 2 & 2 & 6 & 21 & -89 & 1 \\
\hline & Fourth quarter & 1707 & 794 & 959 & 2109 & 1175 & 1707 \\
\hline & Change (\%) & 0 & 2 & 21 & 5 & 931 & 2 \\
\hline \multirow{8}{*}{ ర్సి } & First quarter & 1757 & 845 & 1064 & 2030 & 1261 & 1637 \\
\hline & Change (\%) & 3 & 6 & 11 & -4 & 7 & 4 \\
\hline & Second quarter & 1844 & 987 & 1104 & 1937 & 1381 & 1610 \\
\hline & Change (\%) & 5 & 17 & 4 & -5 & 10 & 2 \\
\hline & Third quarter & 1934 & 1170 & 1141 & 1837 & 1644 & 1600 \\
\hline & Change (\%) & 5 & 19 & 3 & -5 & 19 & -1 \\
\hline & Fourth quarter & 1890 & 1196 & 1109 & 1619 & 1731 & 1600 \\
\hline & Change (\%) & -2 & 2 & -3 & -12 & 5 & 0 \\
\hline \multirow{4}{*}{ ஜ્సે } & First quarter & 1670 & 913 & 853 & 1023 & 1481 & 1325 \\
\hline & Change (\%) & -12 & -24 & -23 & -37 & -14 & -17 \\
\hline & Second quarter & 1383 & 802 & 742 & 897 & 1431 & 1168 \\
\hline & Change (\%) & -21 & -12 & -13 & -12 & -3 & -12 \\
\hline
\end{tabular}

Source: "Review of Maritime Transport 2009"

Figure 1.16 - Forecast average capacity utilization

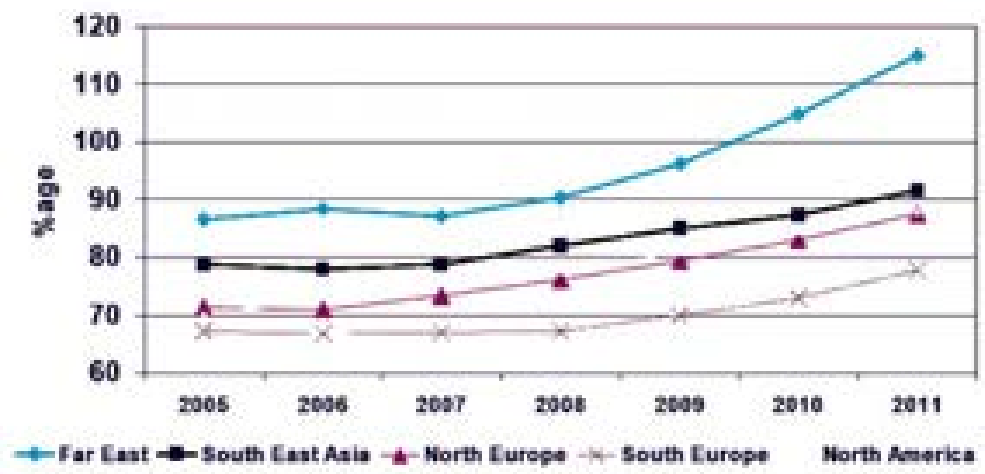

Source: (Drewry Shipping Consultants Ltd www.drewry.co.uk) 
The growth of trade in Asia triggered the emergence of large, main hubs in the Mediterranean; these hubs had previously been located almost exclusively on the northern edge of Europe and once dominated the transatlantic trade, as depicted in Figure 1.17. For the northern ports, the arrivals of containers loaded in Asia (in red) are slightly higher than the departures (in green). Mediterranean ports clearly receive more from Asia than they send to the continent.

Figure 1.17 - Maritime container port transport (EU-Asia-26), 2005 (thousand tons/year)

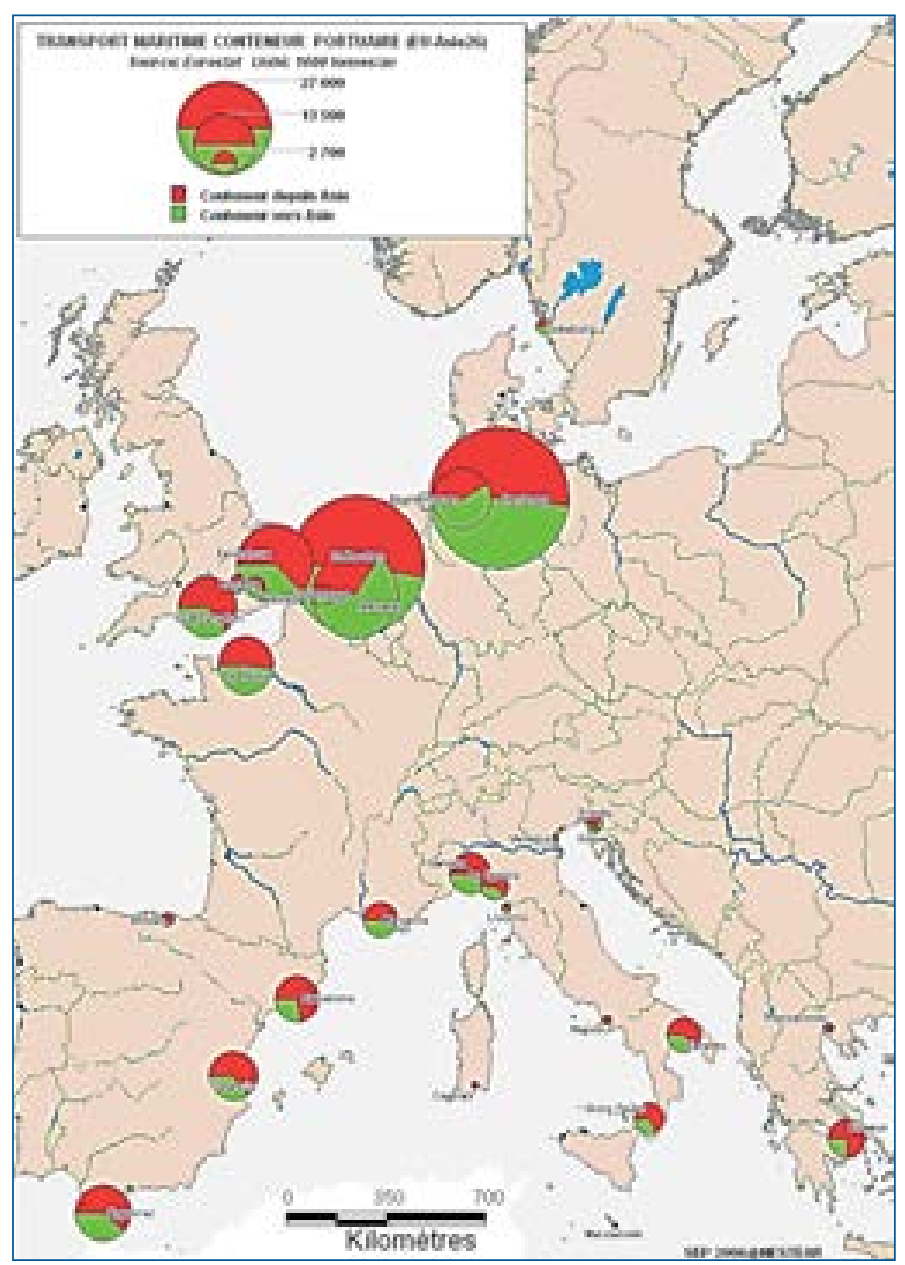

Source: Vallouis, Plan bleu

Despite the above, this predominant form of distribution has led to the progressive saturation of ports in northern Europe and, thus, many European and Asian logistics operators are gradually beginning to move part of the distribution in Europe towards the south Mediterranean. In addition, distribution from southern Europe reduces the maritime navigation time of large ships from Asia by three to four days. It is still a slow process, but traffic has been increased in the ports of Barcelona, Marseilles and Genoa.

\subsubsection{Landlocked Countries}

Of the 31 landlocked developing countries in the world, 12 are located in Asia. The following nine took part in the EATL Phase II Study: Afghanistan, Armenia, Azerbaijan, Kazakhstan, Kyrgyzstan, Mongolia, Tajikistan, Turkmenistan and Uzbekistan.

Evidence has long demonstrated that the geography and lack of access to, and great distance from, the sea suppresses both per capita income and economic growth. In absolute per capita incomes, landlocked countries fail to compete against coastal ones, mainly due to their low 
participation in world trade. Therefore, their dependence on a limited number of commodities for their export earnings, their lack of territorial access to the sea and their remoteness from world markets make landlocked developing countries, as a group, among the poorest of the developing countries.

For these countries, trade and transport costs relate more to operations than to infrastructure capacity, due to the fragmentation of the supply chain in a poorly regulated transit process. Timeconsuming border-crossing and customs procedures, complicated non-standard documentation, the lack of skills in the transport sector, additional "overheads" for unnecessary services, charges and bribes, in both the public and private sectors, are some of the factors that can add 50 per cent or more to transport costs between a port and a landlocked country (ESCAP, 2003). As a result, the delivery costs of imports are higher, exports are less competitive and attraction for foreign investment is significantly reduced.

The Almaty Ministerial Conference in 2003 was the first global initiative to specifically address the problems of landlocked developing countries, launching the Almaty Programme of Action calling for joint efforts by transit and landlocked countries to revise their regulatory frameworks affecting trade movements and to improve their trade-related infrastructure. Since the Almaty Conference, international support to landlocked countries has increased substantially.

The United Nations General Assembly held a midterm review of the Almaty Programme of Action in 2008. The midterm review for the Euro-Asian region was held in Bangkok. The meeting acknowledged that much work had been undertaken at the national, subregional and regional levels by landlocked and transit developing countries in the implementation of the Almaty Programme of Action. Specific action-oriented recommendations and deliverables aimed at: strengthening the harmonization of legal regimes, adopting an integrated approach to trade and transport facilitation, eliminating physical and non-physical bottlenecks to transport, and promoting integrated training programmes in both the public and private sectors, establishing national transit and trade facilitation committees, completing missing links, promoting intermodal transport and developing integrated transport corridors and logistics services, as well as mobilizing domestic and external resources.

A review prepared by the World Bank (2008) concluded that between 2003 and 2007, the export value of landlocked countries more than doubled, while that of transit countries increased rather less, as global exports rose 60 per cent. In addition, per capita incomes increased by about 28 per cent, slightly less than the equivalent increase of transit countries but still well above the global average. Nevertheless, in absolute values, landlocked countries' trade and incomes still lag far behind those of transit countries and the global average.

With regard to EATL landlocked countries, recent economic development within Asia as well as growing intraregional trade create the demand for these countries to become "land-linking" countries and to provide effective transit services to their neighbours. To this end, both landlocked and neighbouring transit countries can benefit from actions taken to increase the efficiency of transit transport and enhance regional cooperation, as is the case of the Euro-Asian transport links exercise.

\subsection{Merchandise trade among EATL countries}

\subsubsection{Overview}

This section presents a brief analysis of the merchandise trade volumes among the countries participating in the EATL Phase II Study, based on data obtained from the WTO database for 2008. These data are believed to be good approximations for representing the general conditions 
of merchandise trade among the EATL countries, since they were collected one year prior to the global economic crisis. Figure 1.18 presents the total merchandise trade of exports and imports of each participating country in millions of dollars for 2008. It is evident that China and Germany are the highest exporters/importers among the EATL Phase II participating countries.

Figure 1.18 - Merchandise trade of exports-imports, 2008

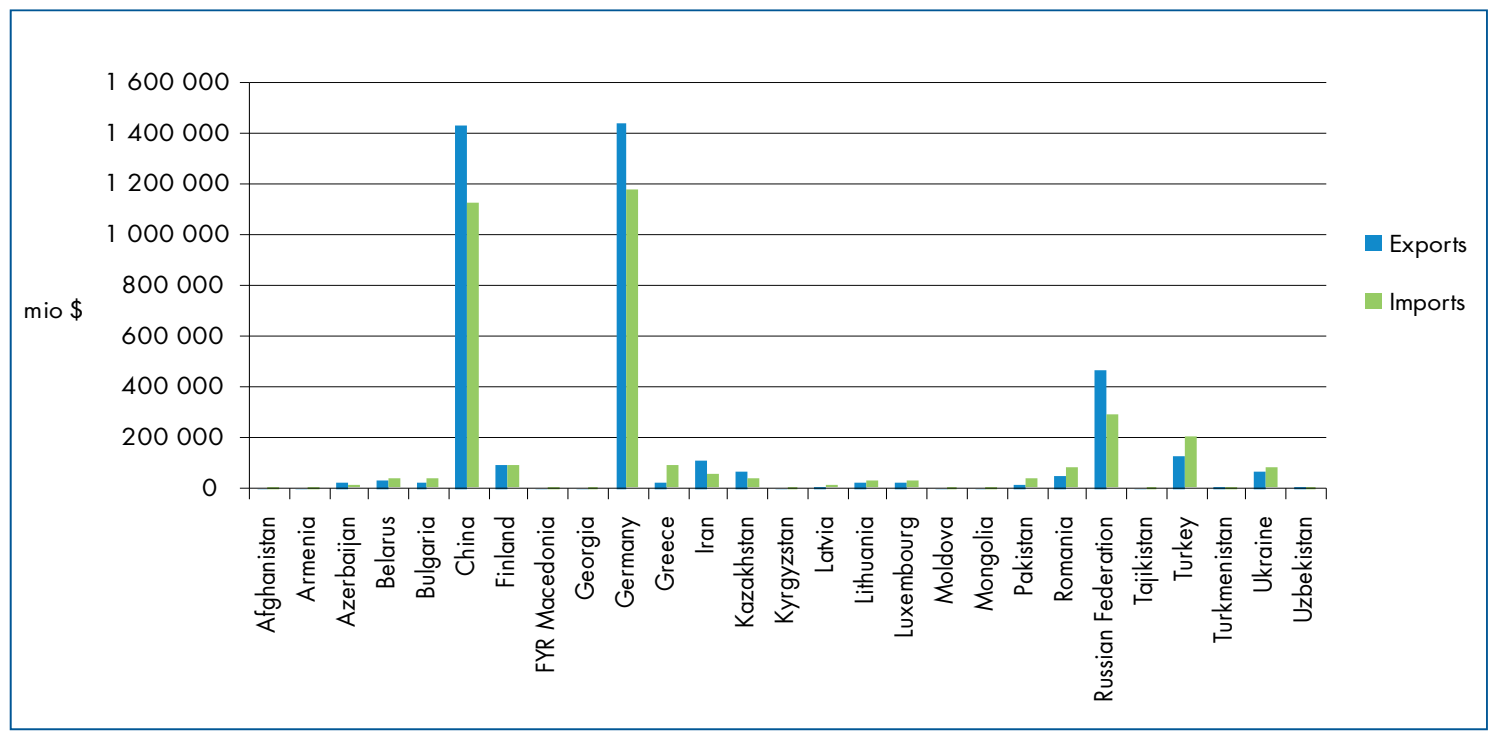

For the purpose of the analysis, the 27 countries participating in the EATL Phase II project were grouped in the following three categories:

- European countries: Bulgaria, Finland, Germany, Greece, Latvia, Lithuania, Luxembourg, Romania, the former Yugoslav Republic of Macedonia and Turkey

- Asian countries: Afghanistan, China, Iran, Mongolia and Pakistan

- CIS (Commonwealth of Independent States) countries: Armenia, Azerbaijan, Belarus, Georgia, Kazakhstan, Kyrgyzstan, Republic of Moldova, Russian Federation, Tajikistan, Turkmenistan, Ukraine and Uzbekistan.

The European countries participating in the study export an average of 90 per cent of goods to other European countries, 4 per cent to Asian countries and 6 per cent to CIS countries. The average import of goods is 78 per cent from other European countries, 12 per cent from Asian countries and 10 per cent from CIS countries. These findings are depicted in Figures 1.19 and 1.20. It is evident that the vast majority of European countries' trade is taking place within the region itself. 
Figure 1.19 - European EATL countries' exports

\section{European EATL Countries Exports}

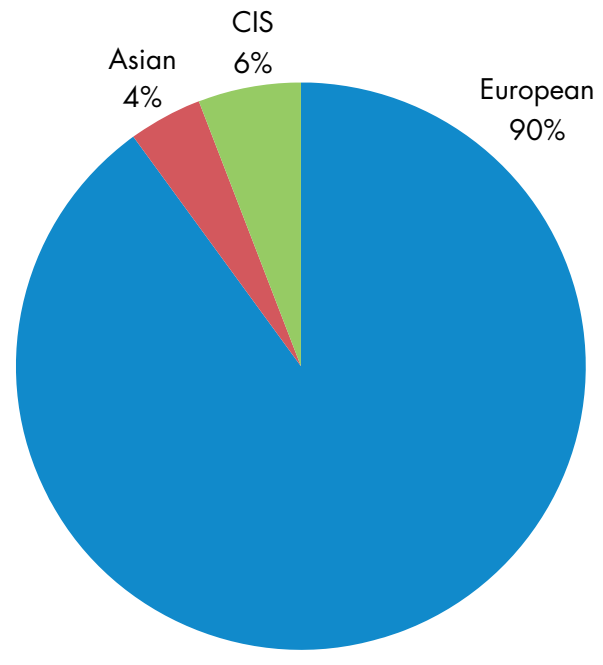

Figure 1.20 - European EATL countries' imports

\section{European EATL Countries Imports}

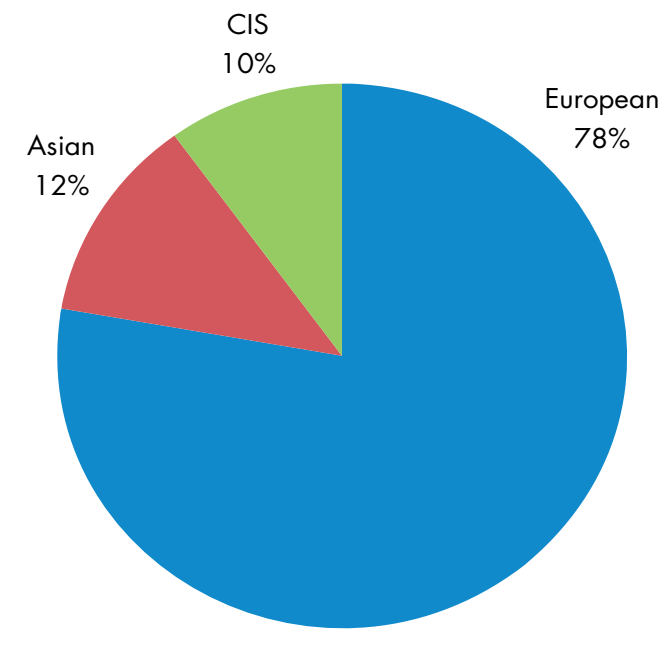

The Asian countries export an average of 99 per cent of goods to European countries, and 1 per cent to other Asian countries. Their average import of goods is 58 per cent from European countries, 42 per cent from other Asian countries and approximately 1 per cent from CIS countries. These figures are depicted in Figures 1.21 and 1.22. The high percentage of Asian exports to Europe represents mainly China's domination in Asia's trade with Europe. On the other hand, imports are far more balanced between Europe and Asia, stipulating the growth of Asia's intraregional trade. 


\section{Asian EATL Countries Exports}

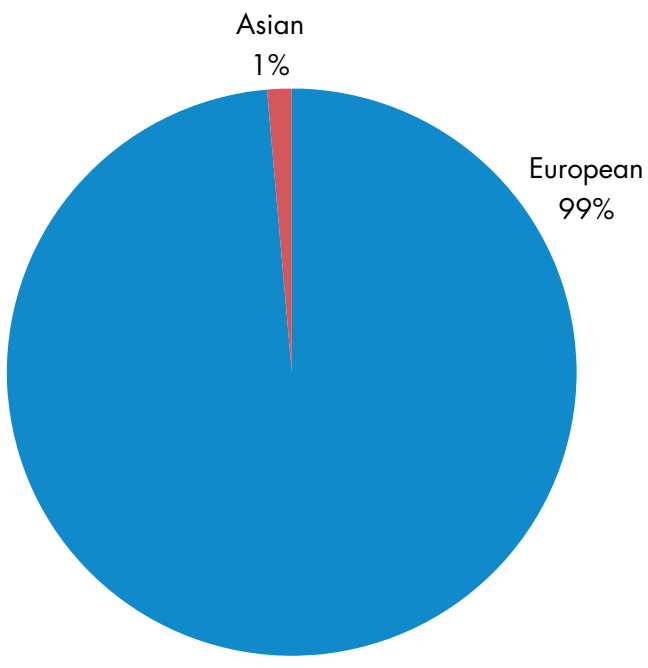

Figure 1.22 - Asian EATL countries' imports

\section{Asian EATL Countries Imports}

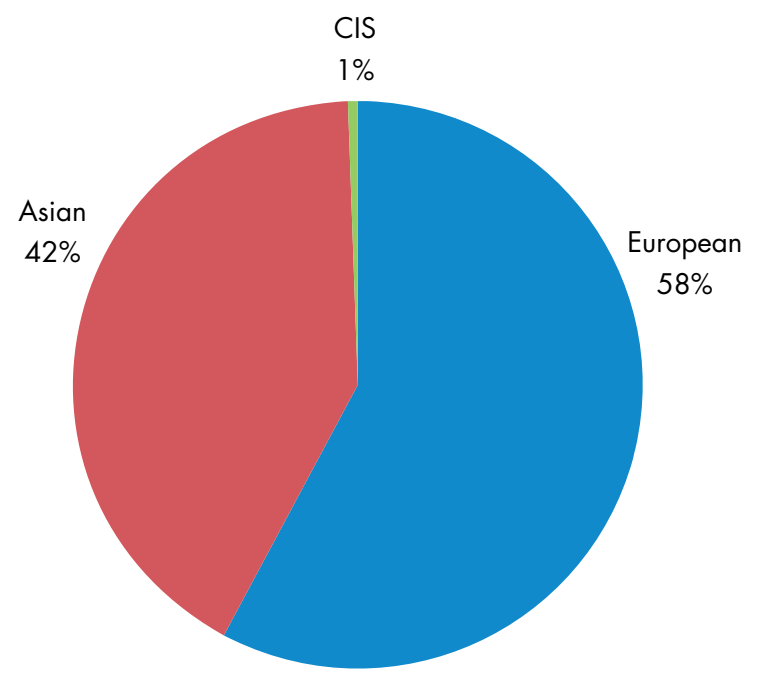

The CIS countries in the EATL project export an average of 76 per cent of goods to European countries, 6 per cent to Asian countries and 18 per cent to other CIS countries. Their average import of goods is 55 per cent from European countries, 15 per cent from Asian countries and 30 per cent from other CIS countries, as depicted in Figures 1.23 and 1.24. 


\section{CIS EATL Countries Exports}

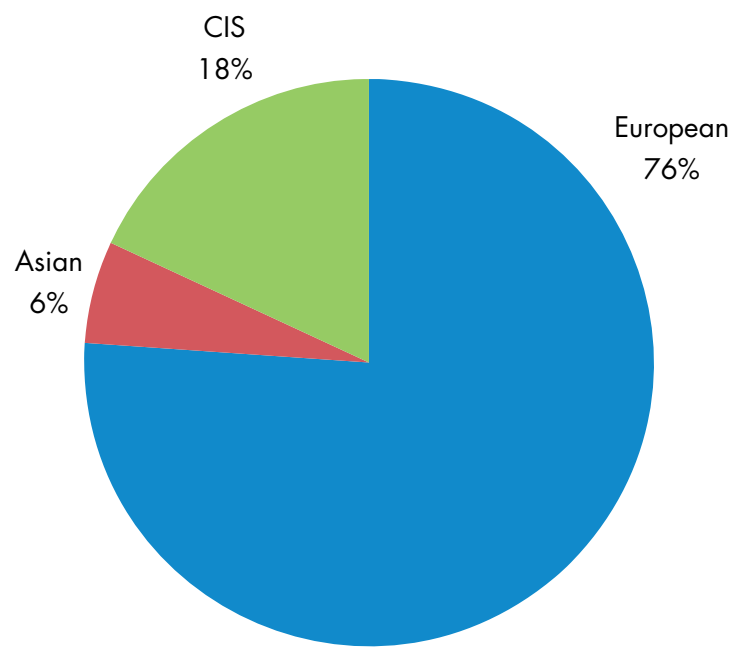

Figure 1.24 - CIS EATL countries' imports

\section{CIS EATL Countries Imports}

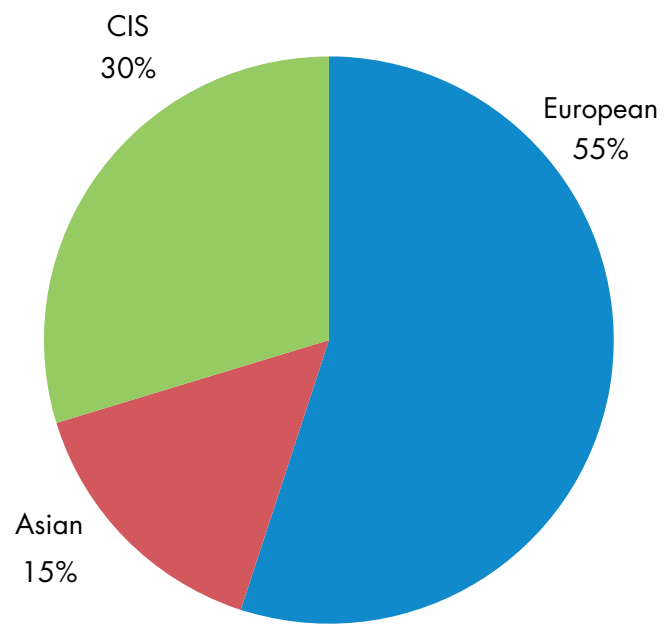

The above data illustrate that the highest share of EATL CIS countries' exports and imports is to and from European countries. Nevertheless, a fair amount of intraregional trade is taking place within CIS countries, especially imports. Trade with Asian countries has the lowest share, albeit not negligible.

The breakdown of the share of exports by destination and imports by origin is presented for each country in the figures that follow. 
Figure 1.25 - Afghanistan

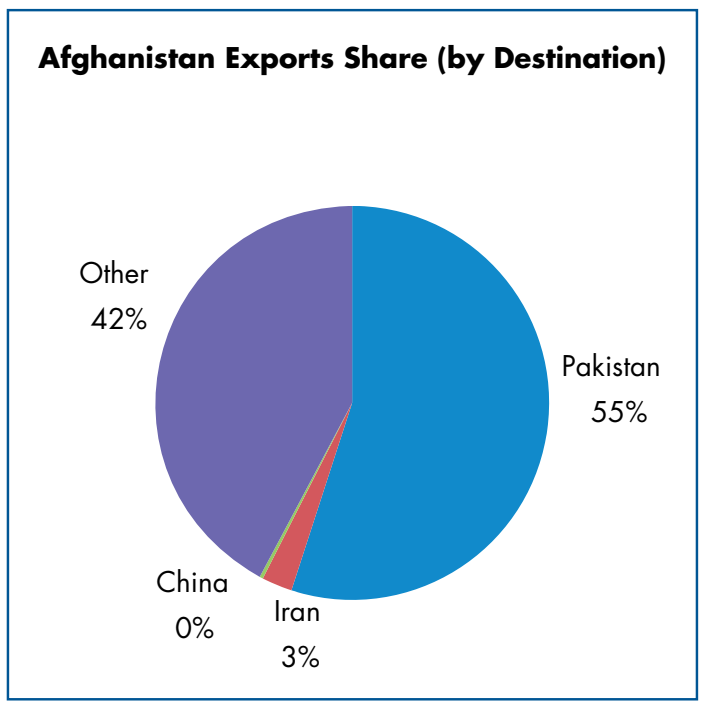

Afghanistan Imports Share (by Origin)

Afghanistan's highest share of exports of goods is to Pakistan, while the country's highest share of imported goods is from countries other than those participating in the EATL Phase II project.

Figure 1.26 - Armenia
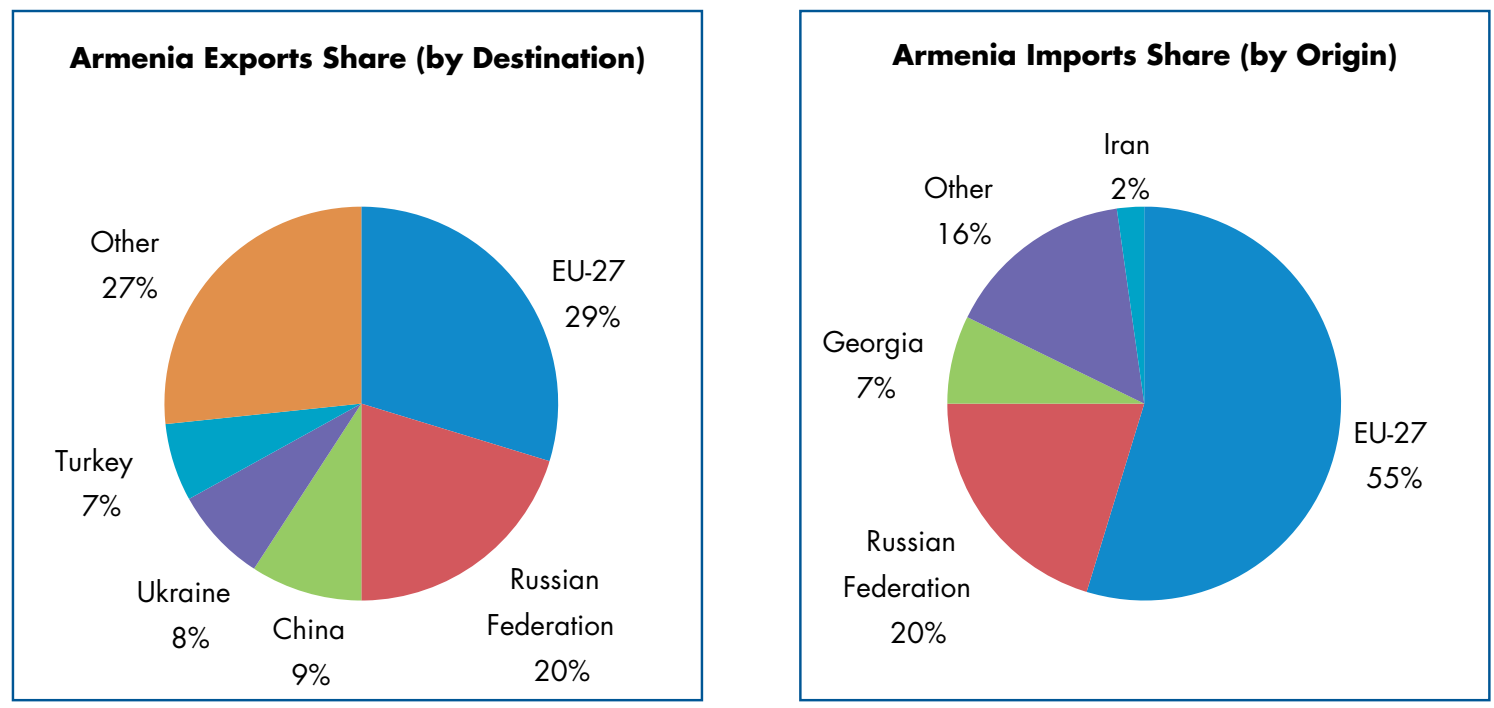

Armenia's highest share of exports as well as imports of goods is to and from the EU. 
Figure 1.27 - Azerbaijan
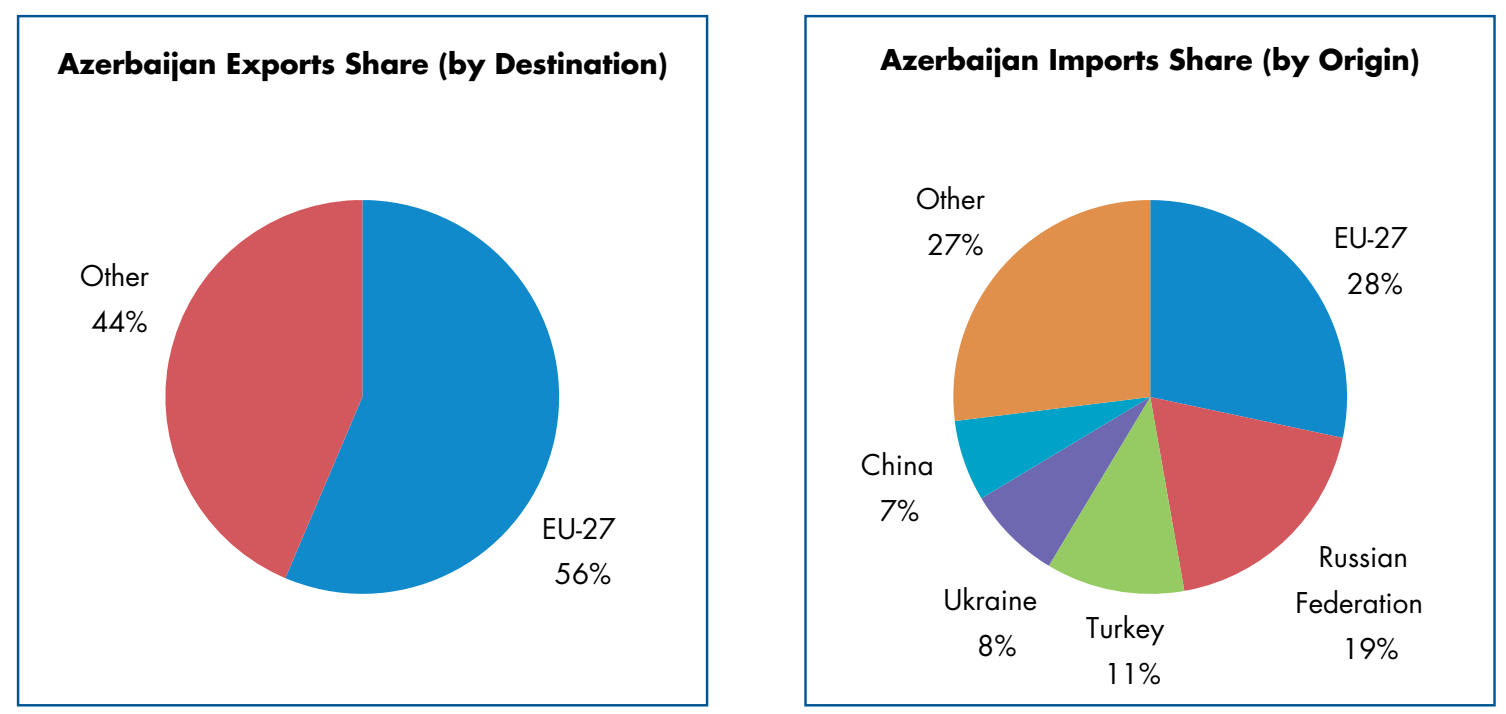

Azerbaijan's highest share of exports as well as imports of goods is to and from the EU.

Figure 1.28 - Belarus
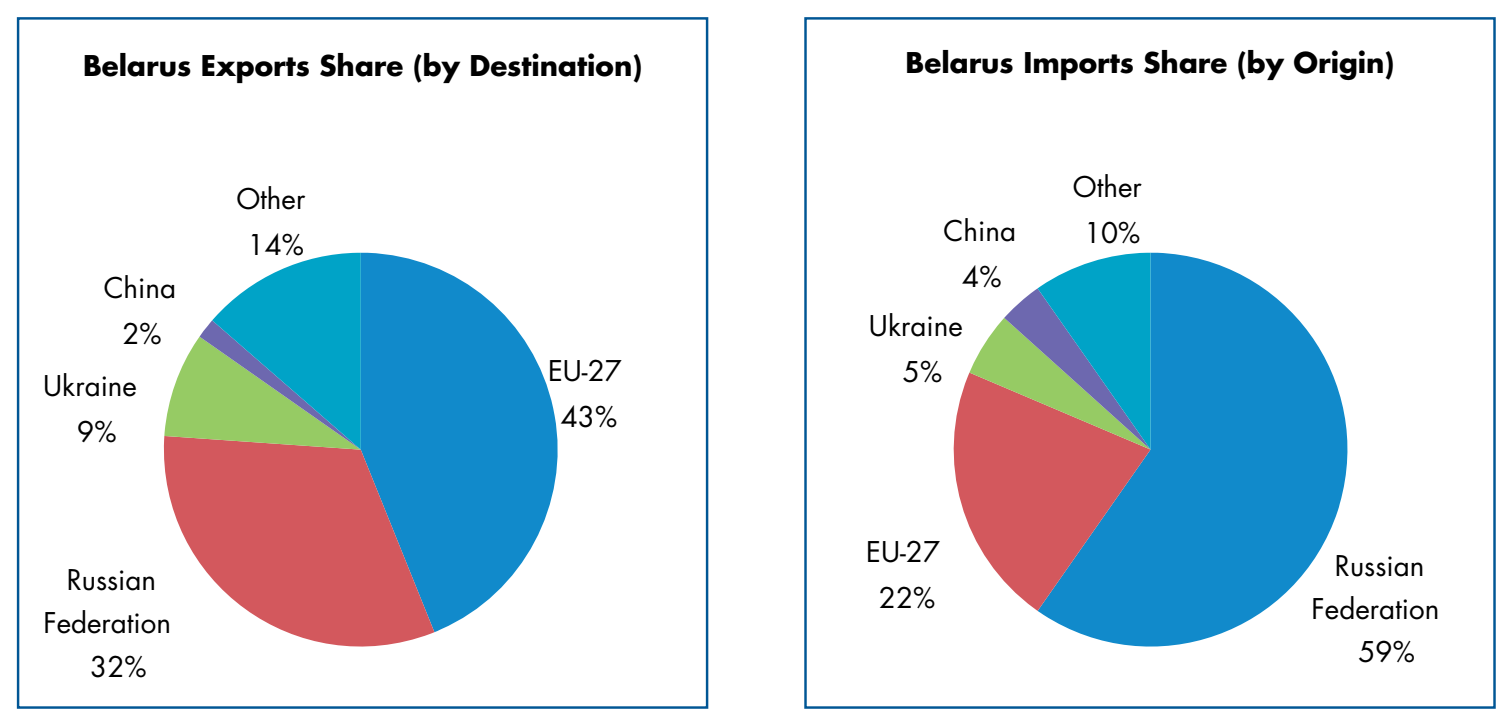

Belarus' highest share of exports of goods is to the EU, while its highest share of imports is from the Russian Federation. 
Figure 1.29 - Bulgaria
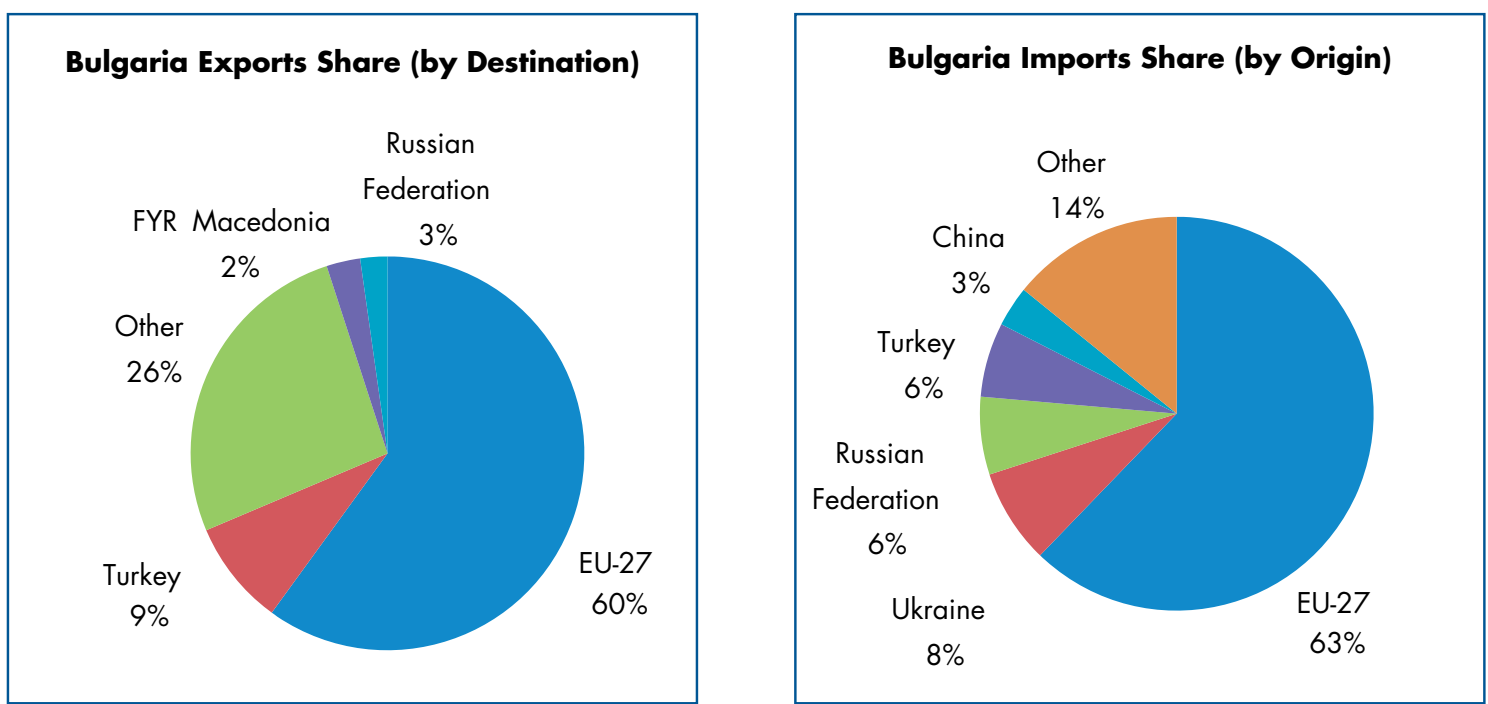

Bulgaria's highest share of exports as well as imports of goods is to and from the EU.

Figure 1.30 - China
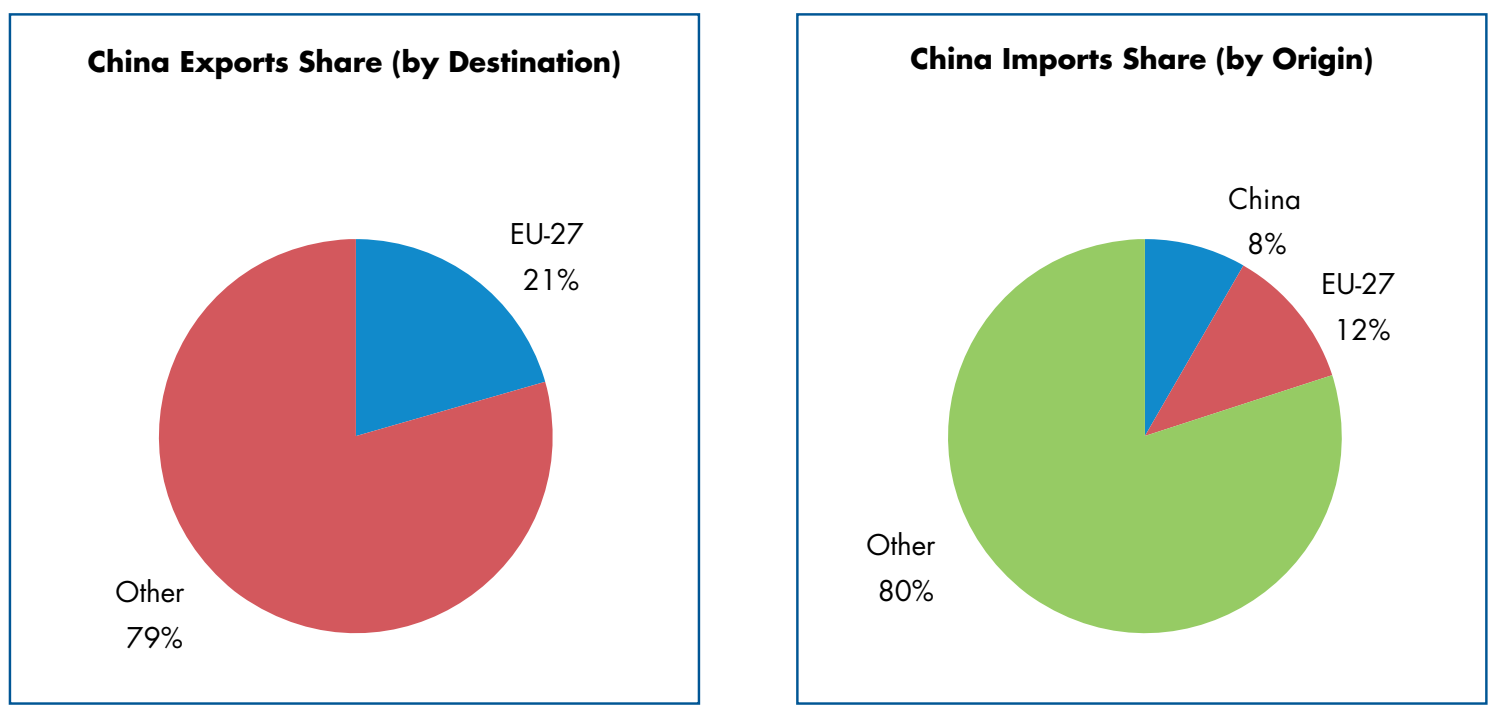

China's highest share of exports as well as imports of goods is to and from countries other than those participating in the EATL Phase II project (such as the USA, Japan and the Republic of Korea). A fair share represents the country's trade with the EU. 
Figure 1.31 - Finland
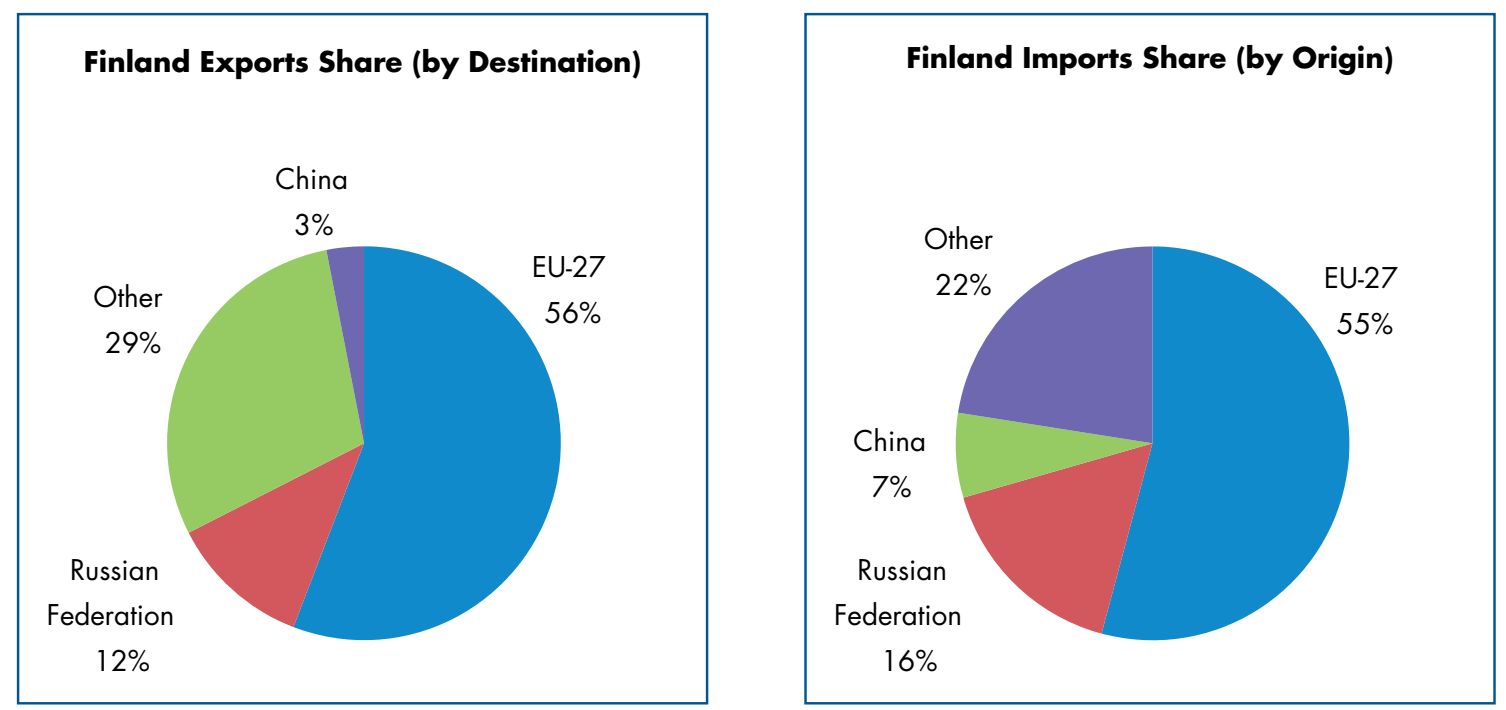

Finland's highest share of exports as well as imports of goods is to and from the EU. In addition, trade with the Russian Federation is not negligible.

\section{Figure 1.32 - Georgia}
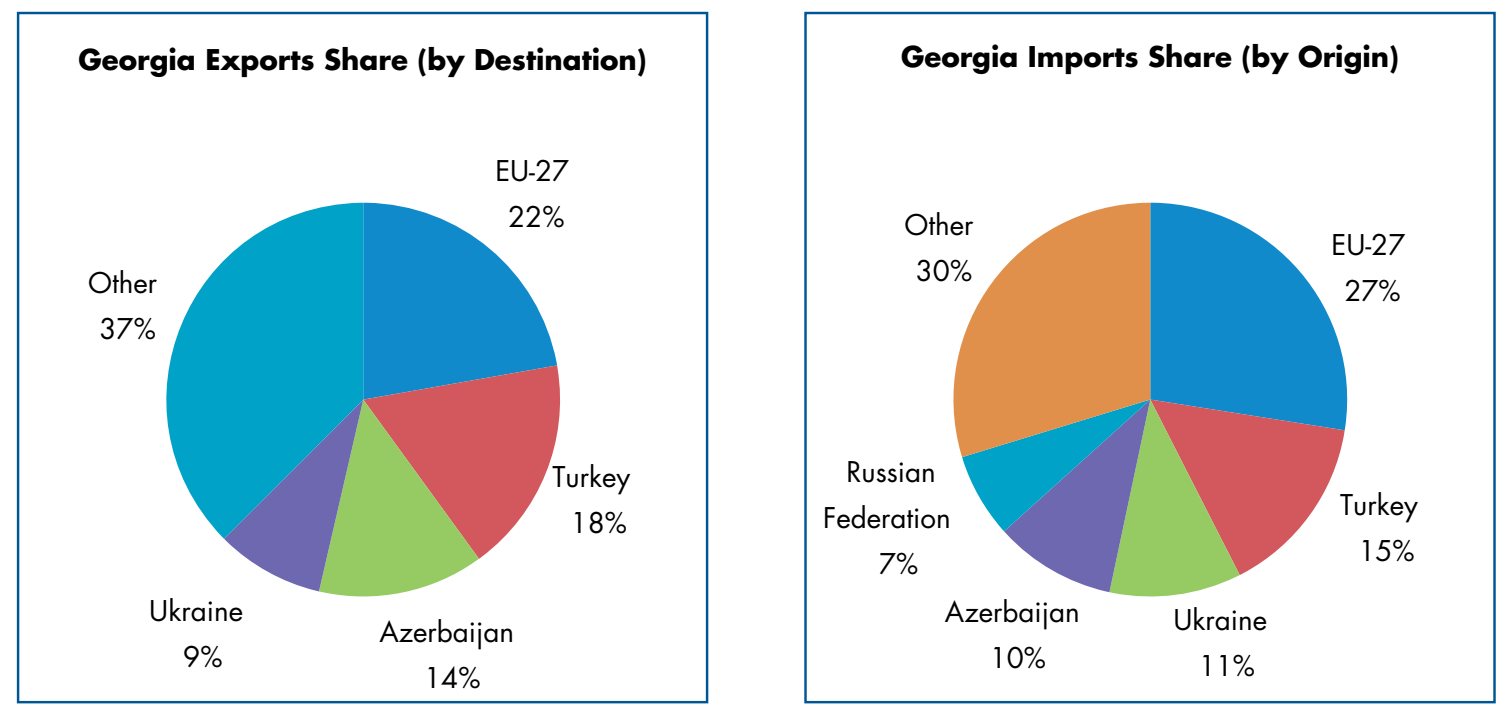

Georgia's highest share of exports as well as imports of goods is to and from countries other than those participating in the EATL Phase II project. Nevertheless, a fair percentage of both exports and imports is between the EU and Turkey. 
Figure 1.33 - Germany
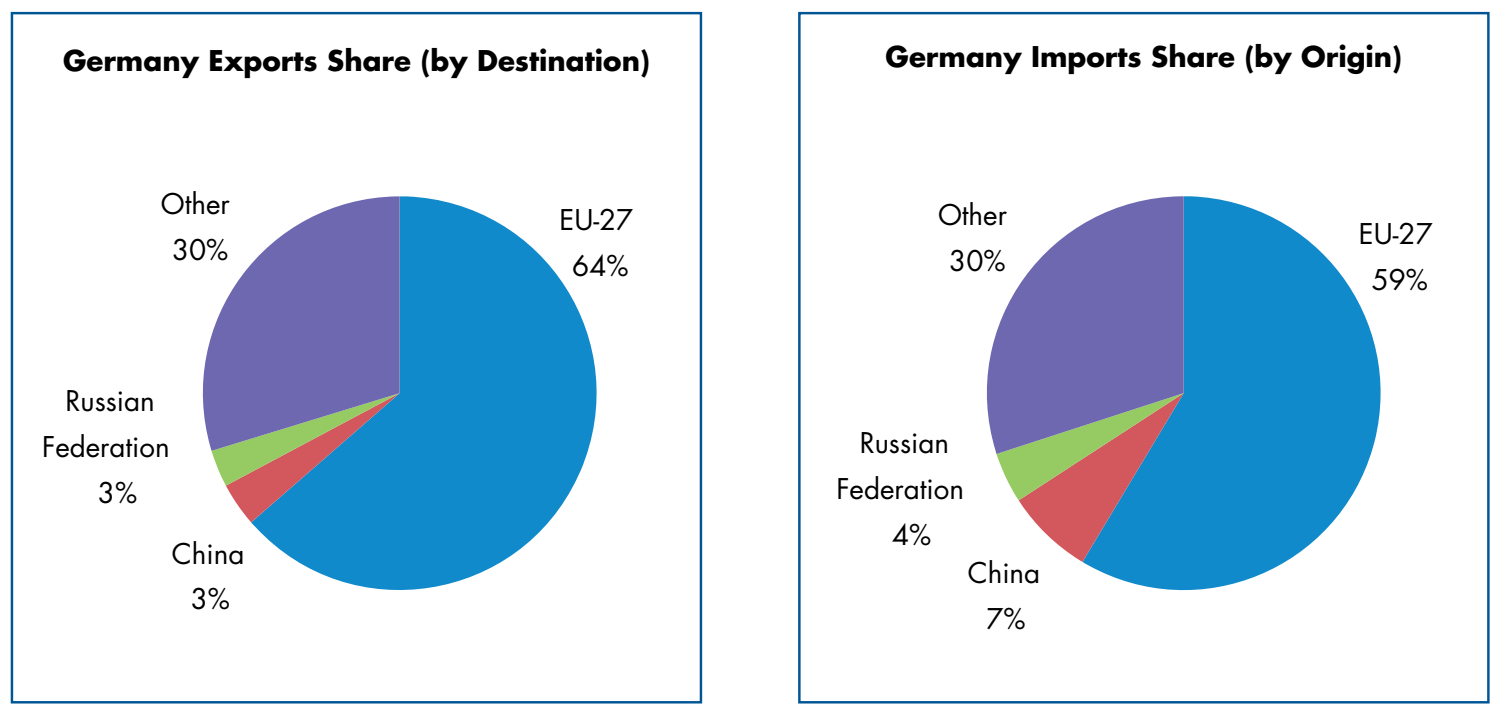

Germany's highest share of exports as well as imports of goods is to and from the EU.

Figure 1.34 - Greece
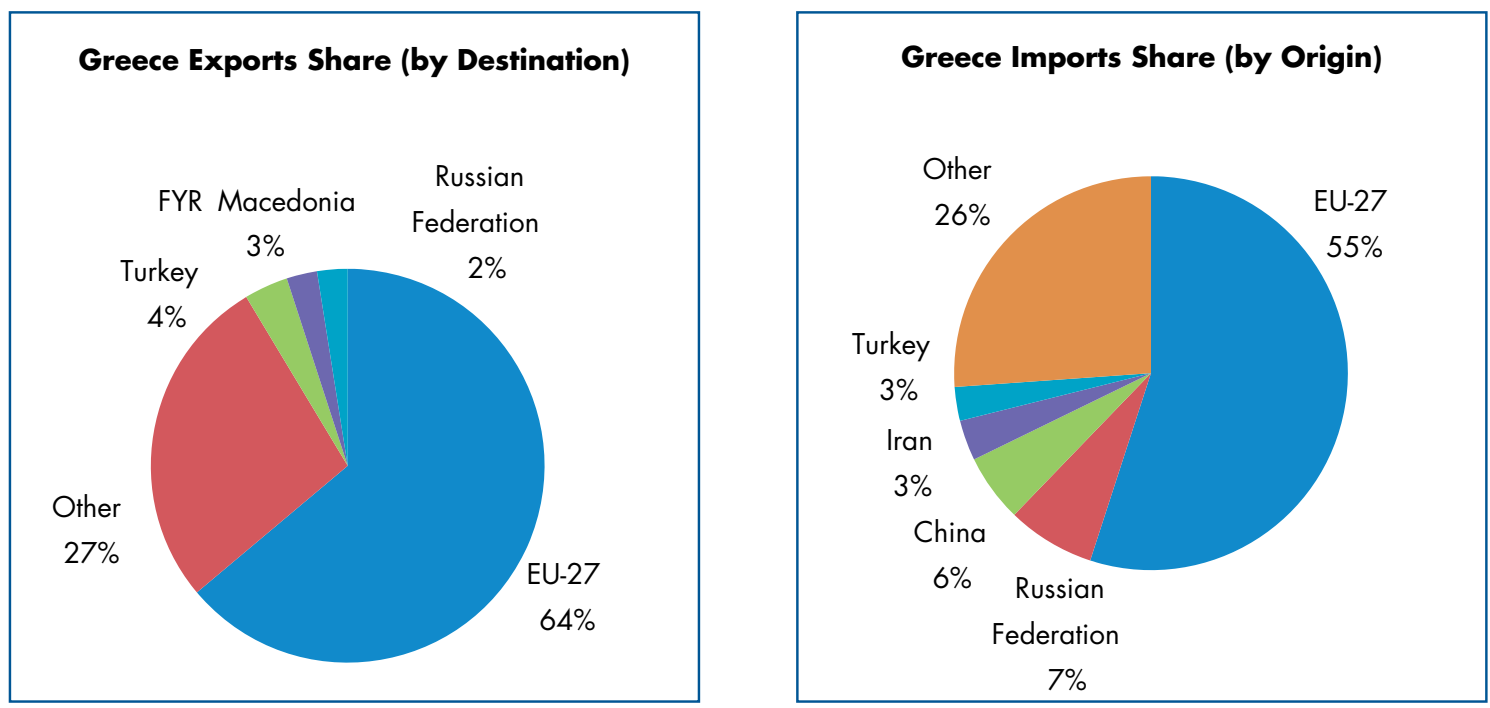

Greece's highest share of exports as well as imports of goods is to and from the EU. 
Figure 1.35 - Iran
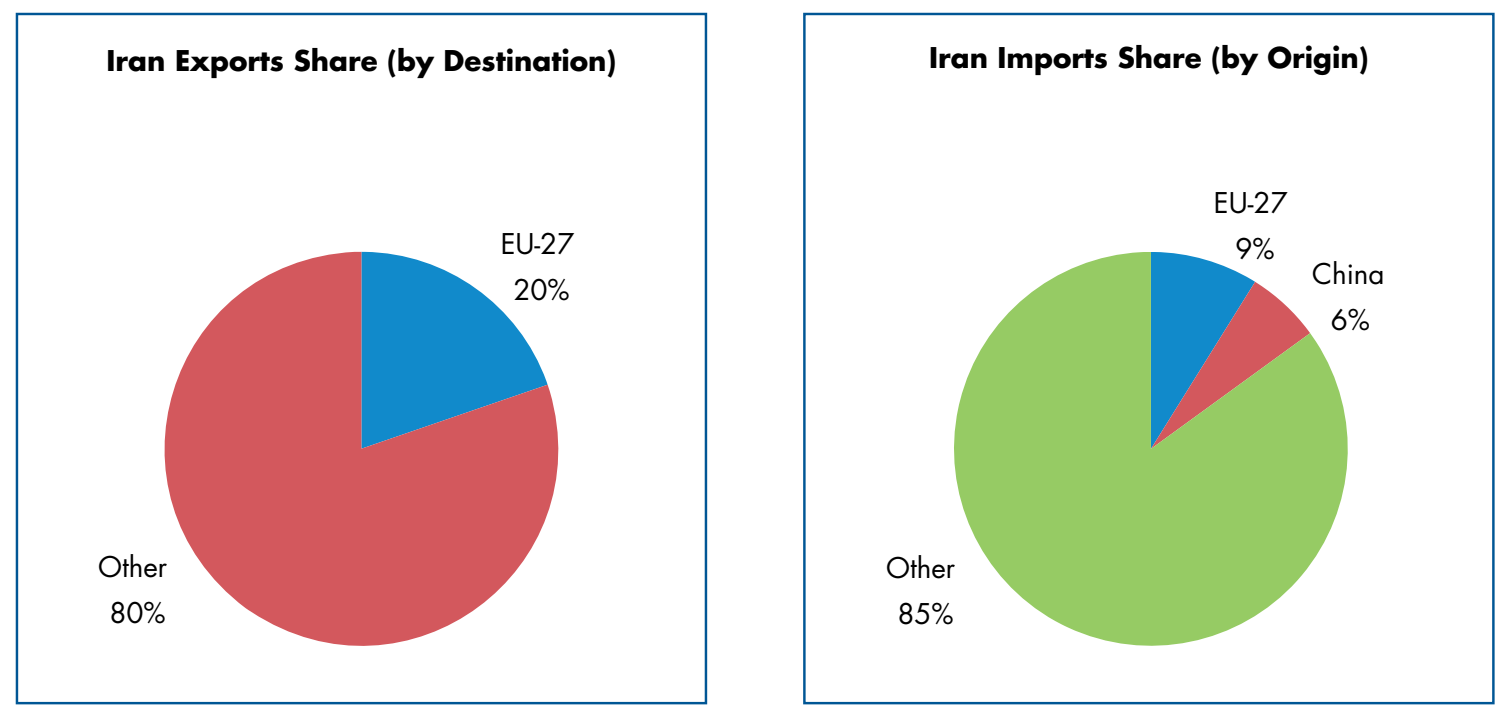

Iran's highest share of exports as well as imports of goods is to and from countries other than those participating in the EATL Phase II project (such as India, Japan and the United Arab Emirates). A fair share of trade is, however, conducted with the EU.

Figure 1.36 - Kazakhstan
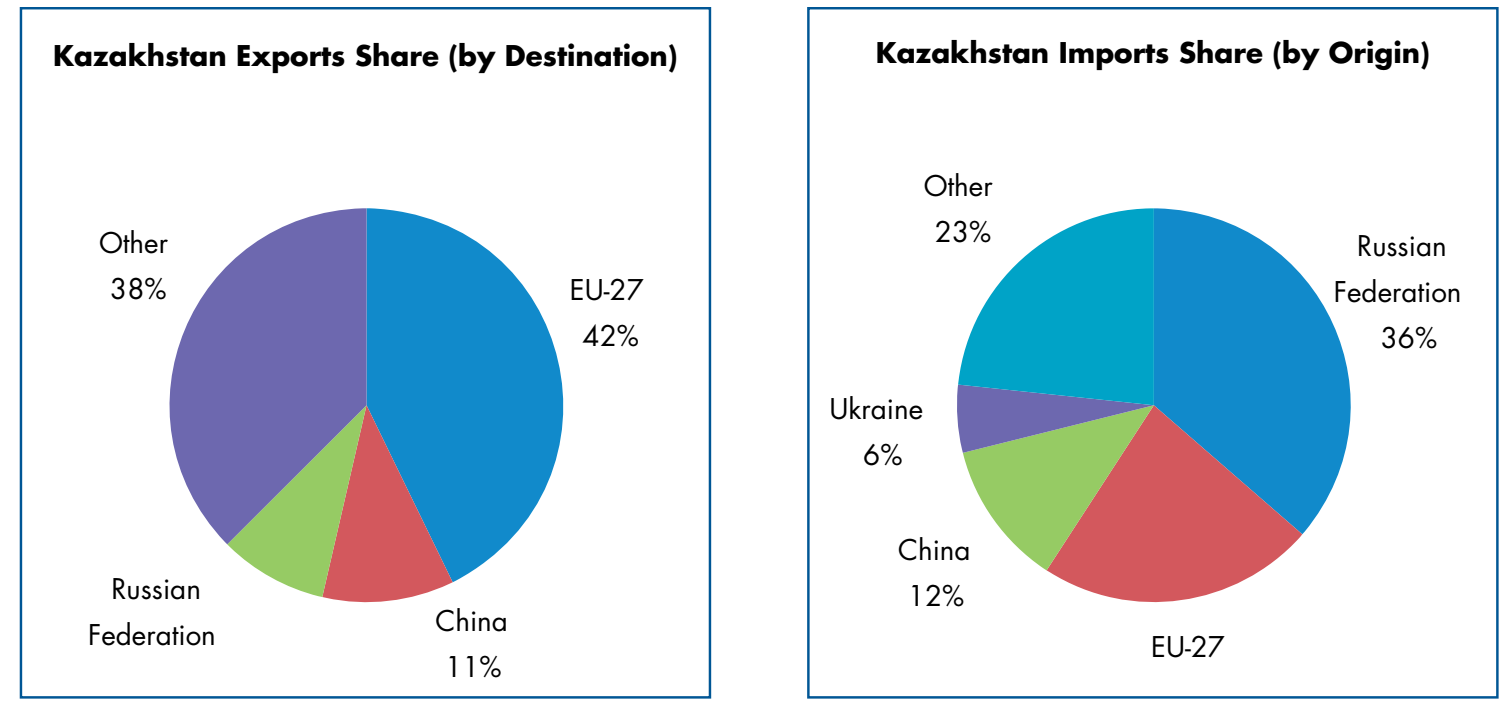

Kazakhstan's highest share of exports of goods is to the EU, while the country's highest share of imported goods is from the Russian Federation. 
Figure 1.37 - Kyrgyzstan
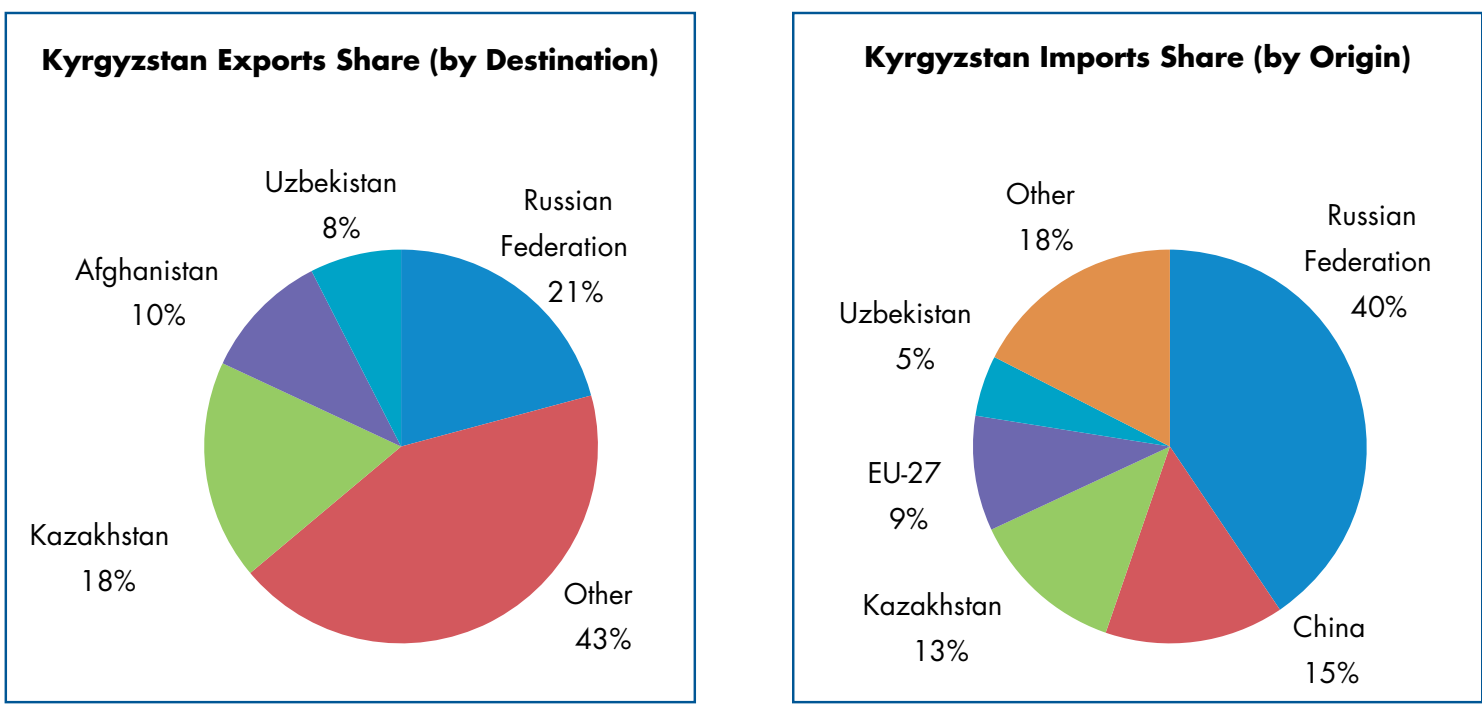

Kyrgyzstan's highest share of exports of goods is to countries other than those participating in the EATL Phase II project, while the country's highest share of imported goods is from the Russian Federation.

Figure 1.38 - Latvia
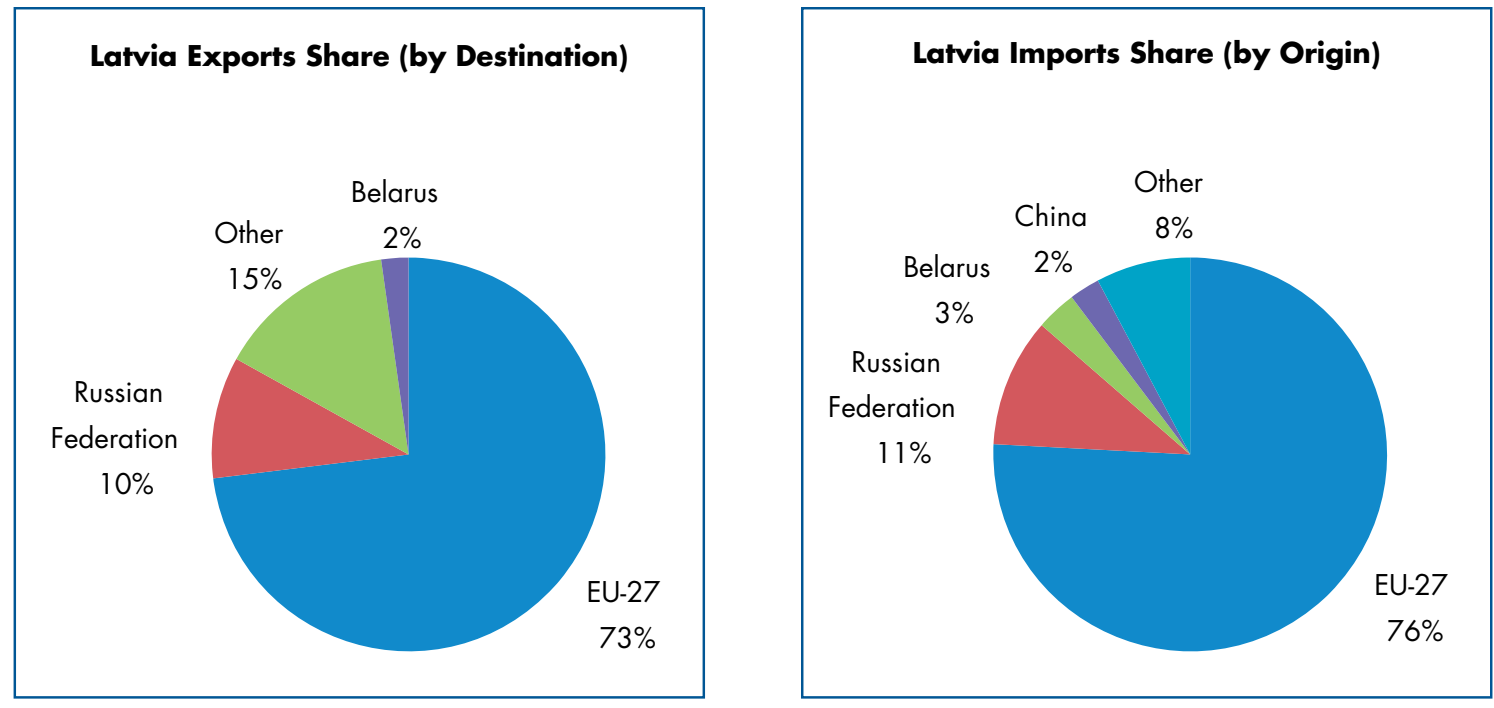

Latvia's highest share of exports as well as imports of goods is to and from the EU. Exports and imports to and from the Russian Federation should also be noted. 
Figure 1.39 - Lithuania
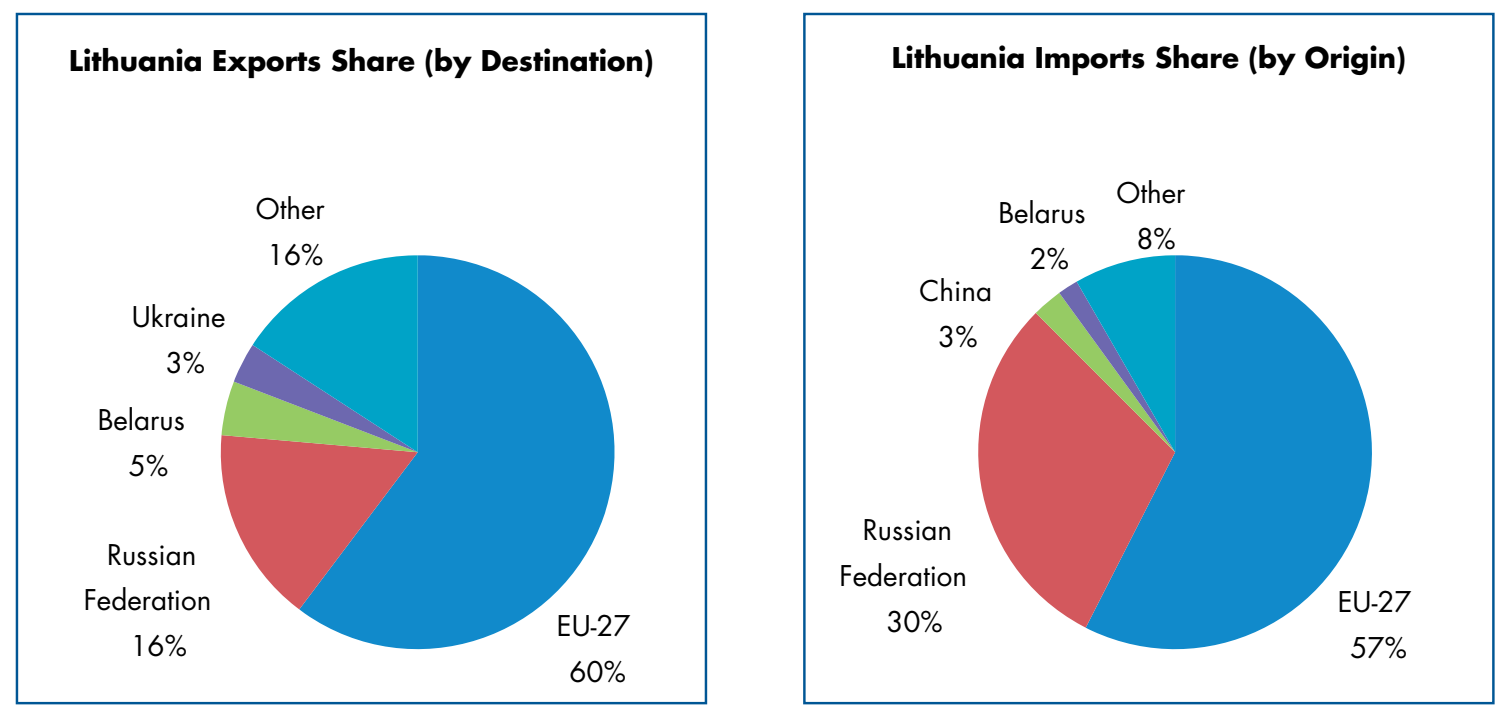

Lithuania's highest share of exports as well as imports of goods is to and from the EU.

Figure 1.40 - Luxembourg
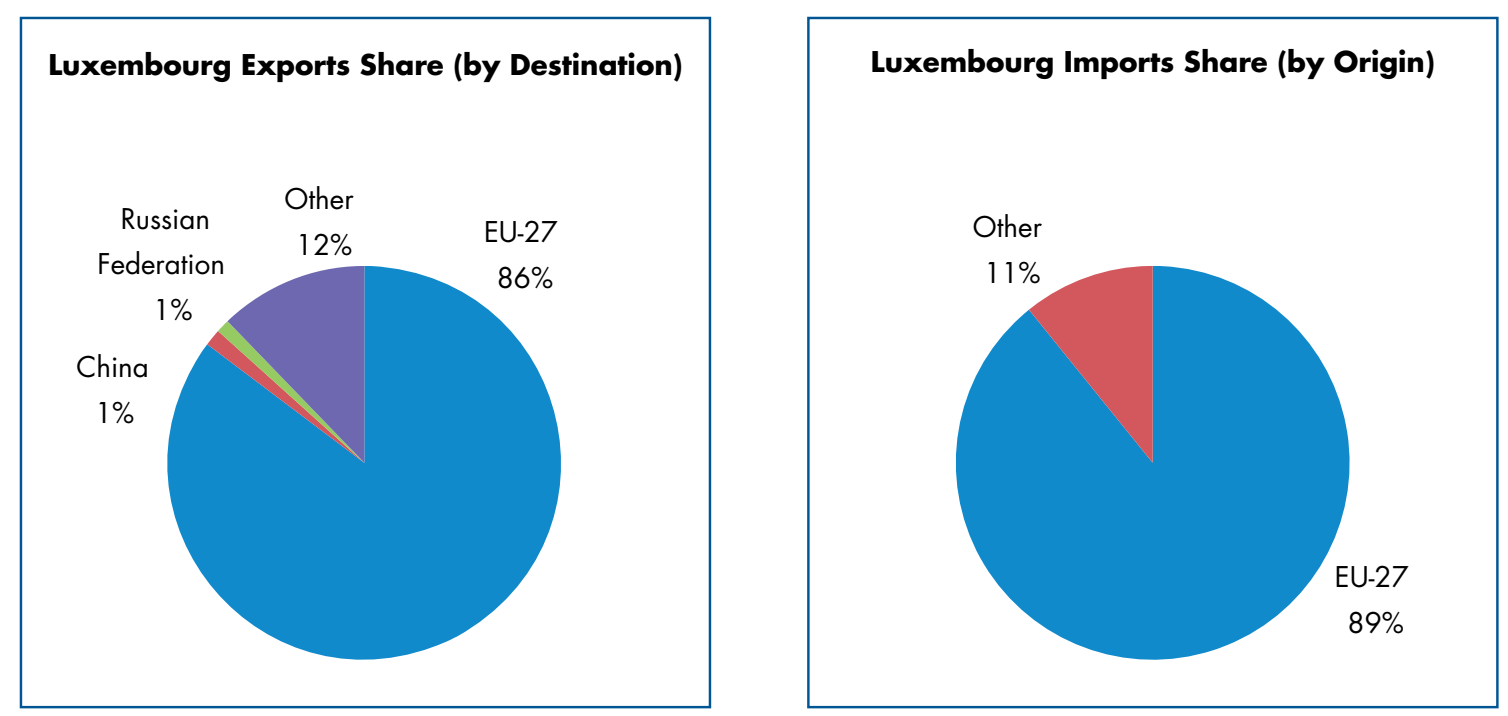

Luxembourg's highest share of exports as well as imports of goods is to and from the EU. 
Figure 1.41 - Mongolia

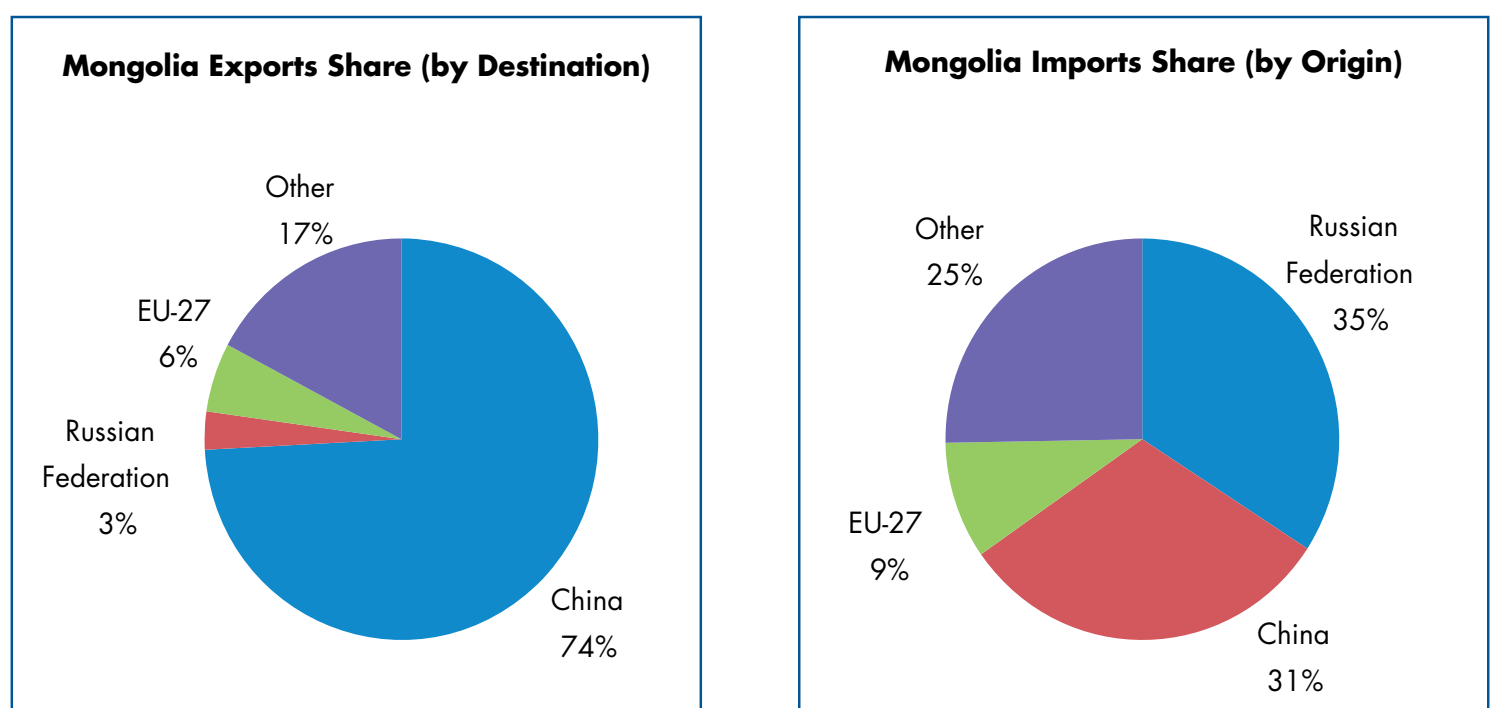

Mongolia's highest share of exports is to China, while its highest share of imported goods is from the Russian Federation.

Figure 1.42 - Pakistan
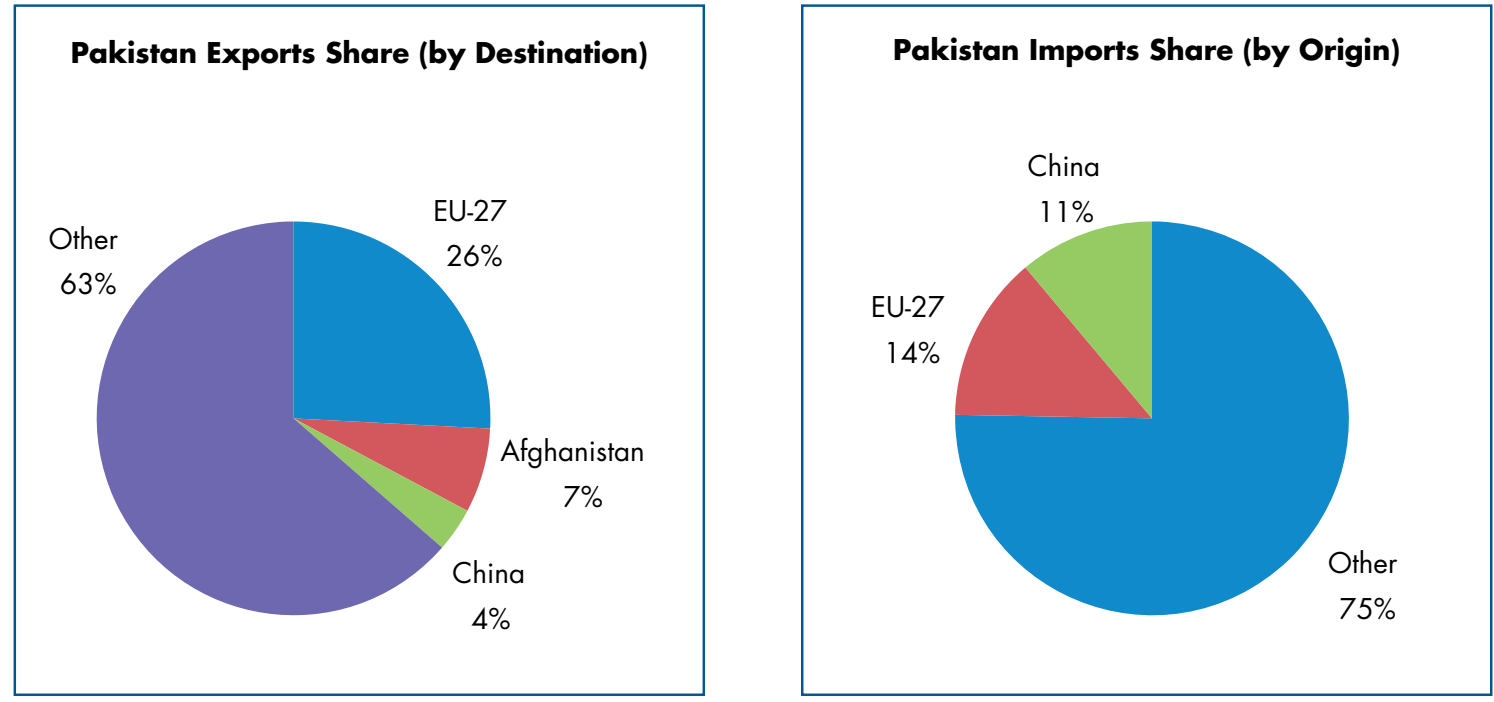

Pakistan's highest share of exports as well as imports of goods is to and from countries other than those participating in the EATL Phase II project (such as the United States and the Kingdom of Saudi Arabia). A fair percentage of trade is also conducted with the EU. 
Figure 1.43 - Republic of Moldova
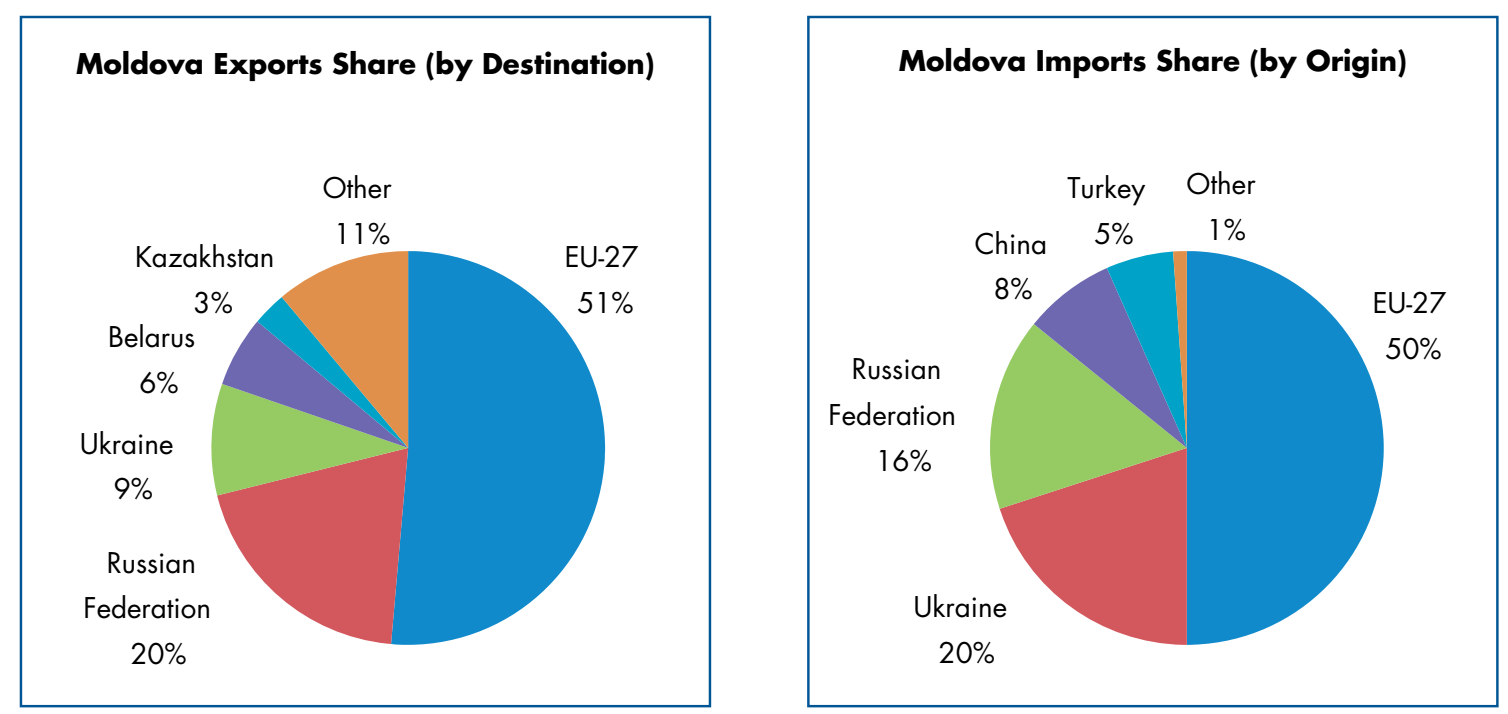

The Republic of Moldova's highest share of exports as well as imports of goods is to and from the EU. Nevertheless, the Republic of Moldova is also trading with other CIS countries, such as the Russian Federation and Ukraine.

Figure 1.44 - Romania
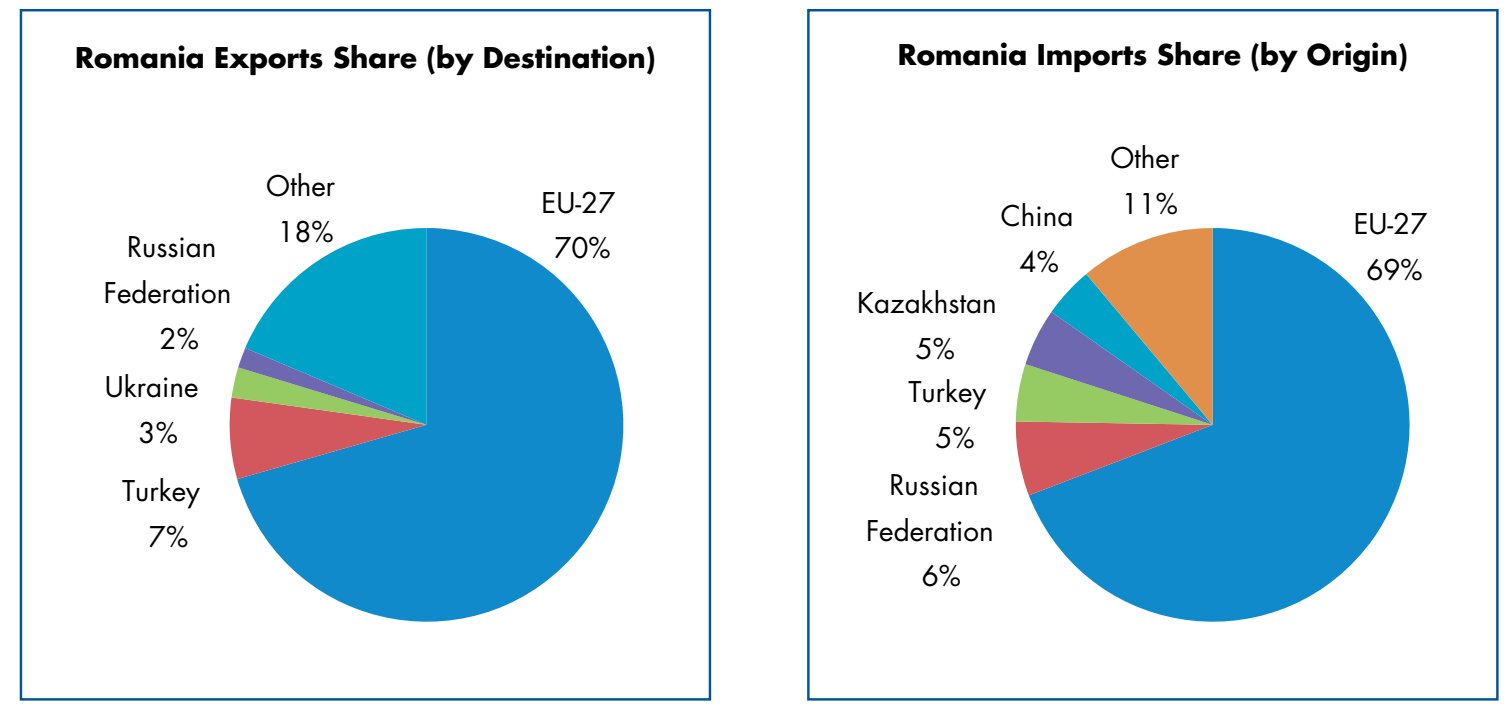

Romania's highest share of exports as well as imports of goods is to and from the EU. 
Figure 1.45 - Russian Federation
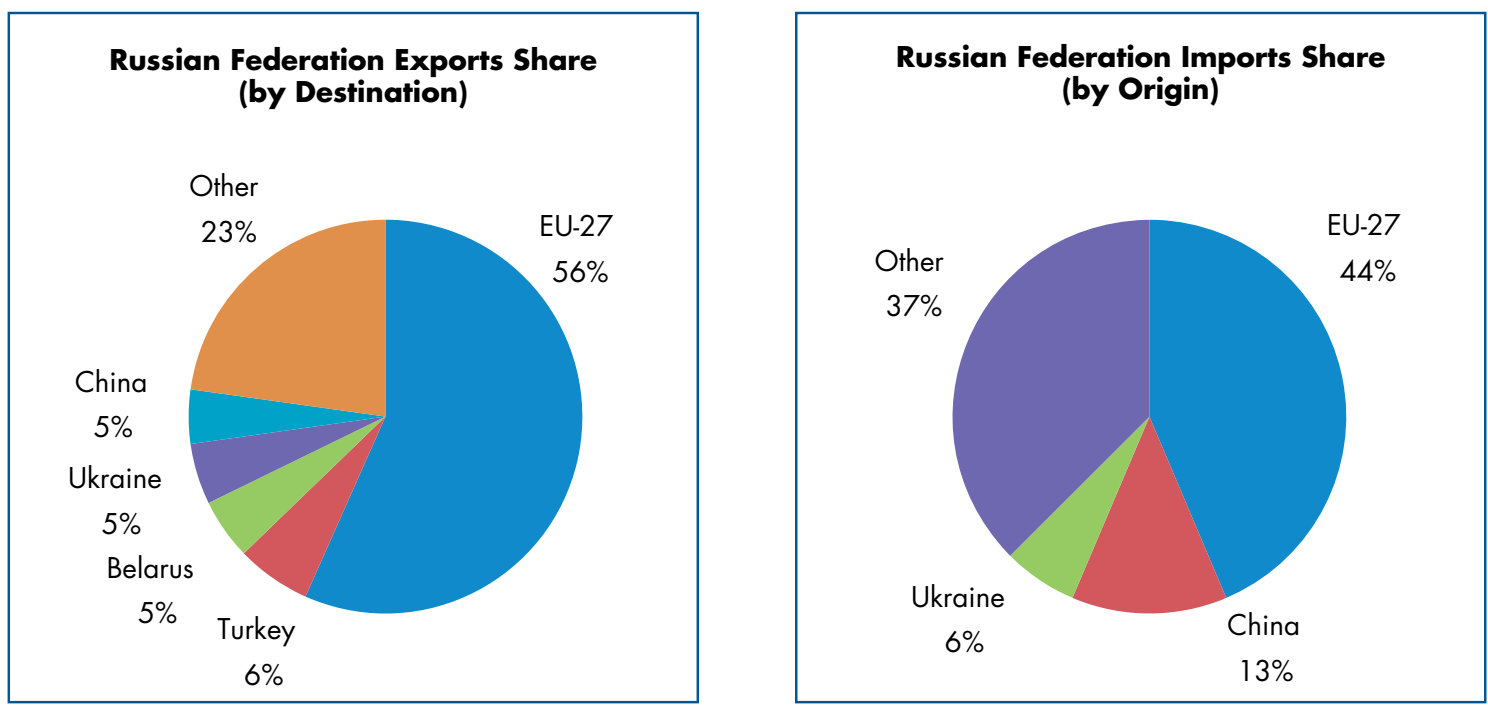

The Russian Federation's highest share of exports as well as imports of goods is to and from the EU. In addition, Figure 1.46 depicts the percentage share of the Russian Federation's imports and exports transported by road to the rest of the EATL countries for 2009 , as these were provided by the national representative.

Figure 1.46 - Share of road haulage import and export, 2009

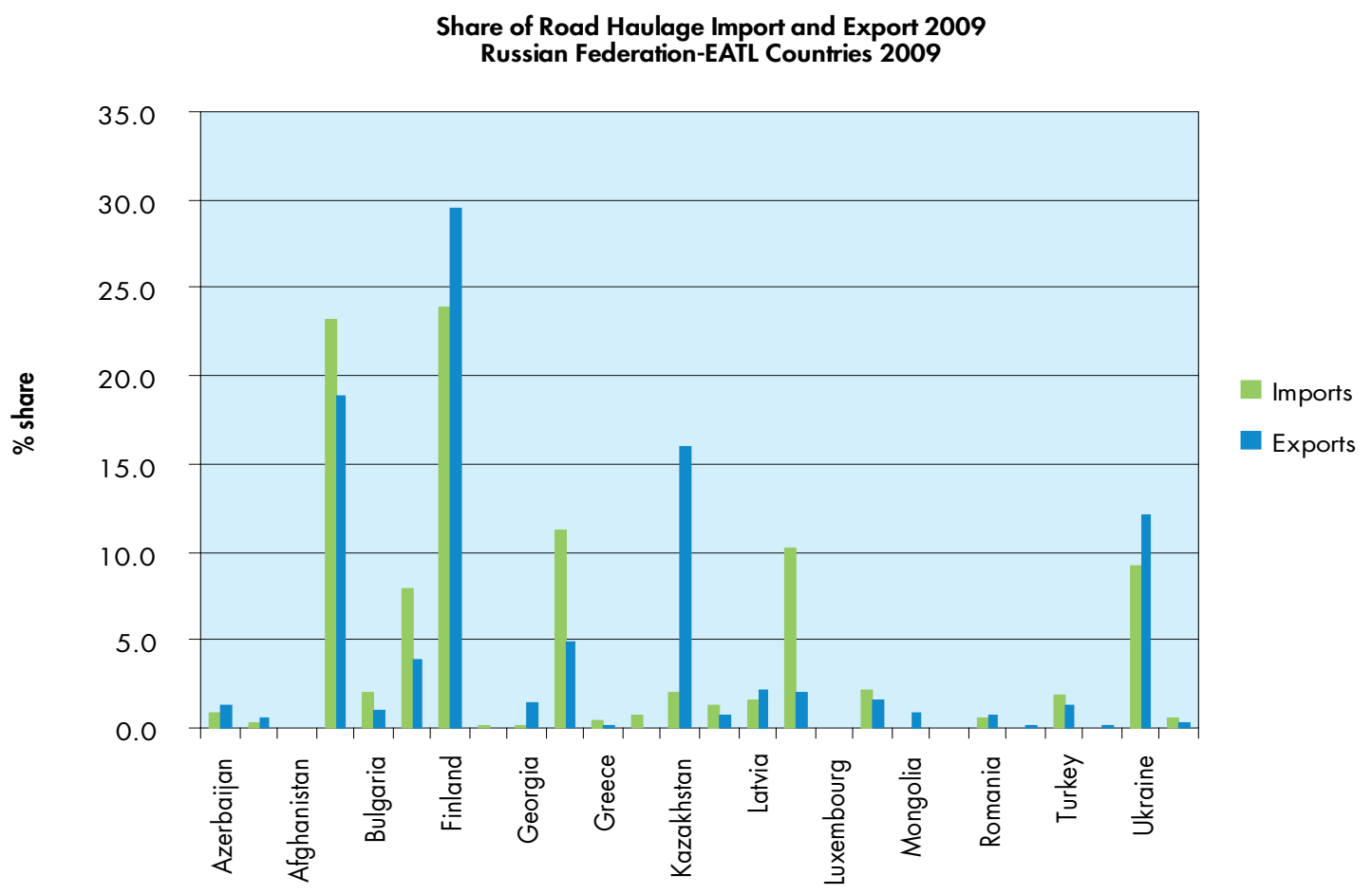

Source: National Focal Point 
Figure 1.47 - Tajikistan
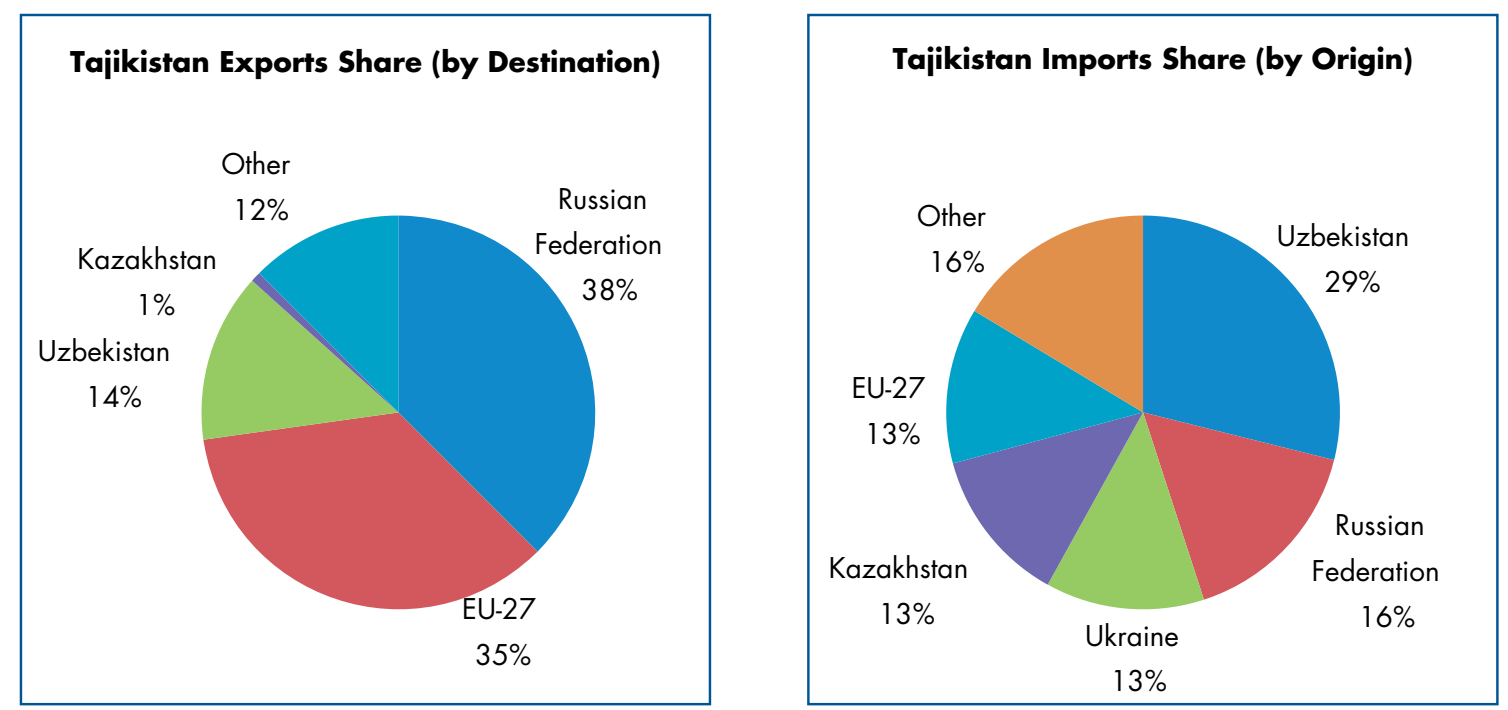

Tajikistan's highest share of exports is to the Russian Federation, while its highest share of imports is from Uzbekistan. Also, a fair share of exports is to the EU.

Figure 1.48 - The former Yugoslav Republic of Macedonia
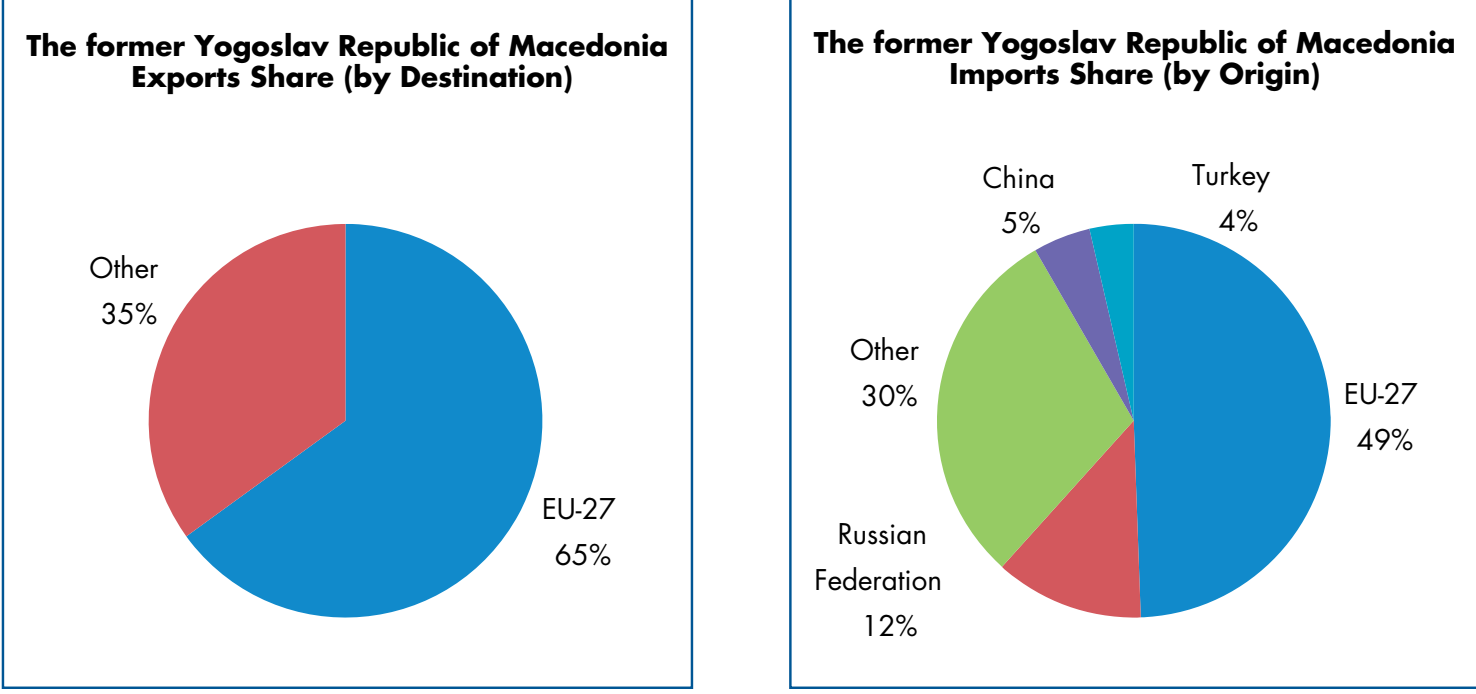

The former Yugoslav Republic of Macedonia's highest share of exports as well as imports of goods is to and from the EU. 
Figure 1.49 - Turkey
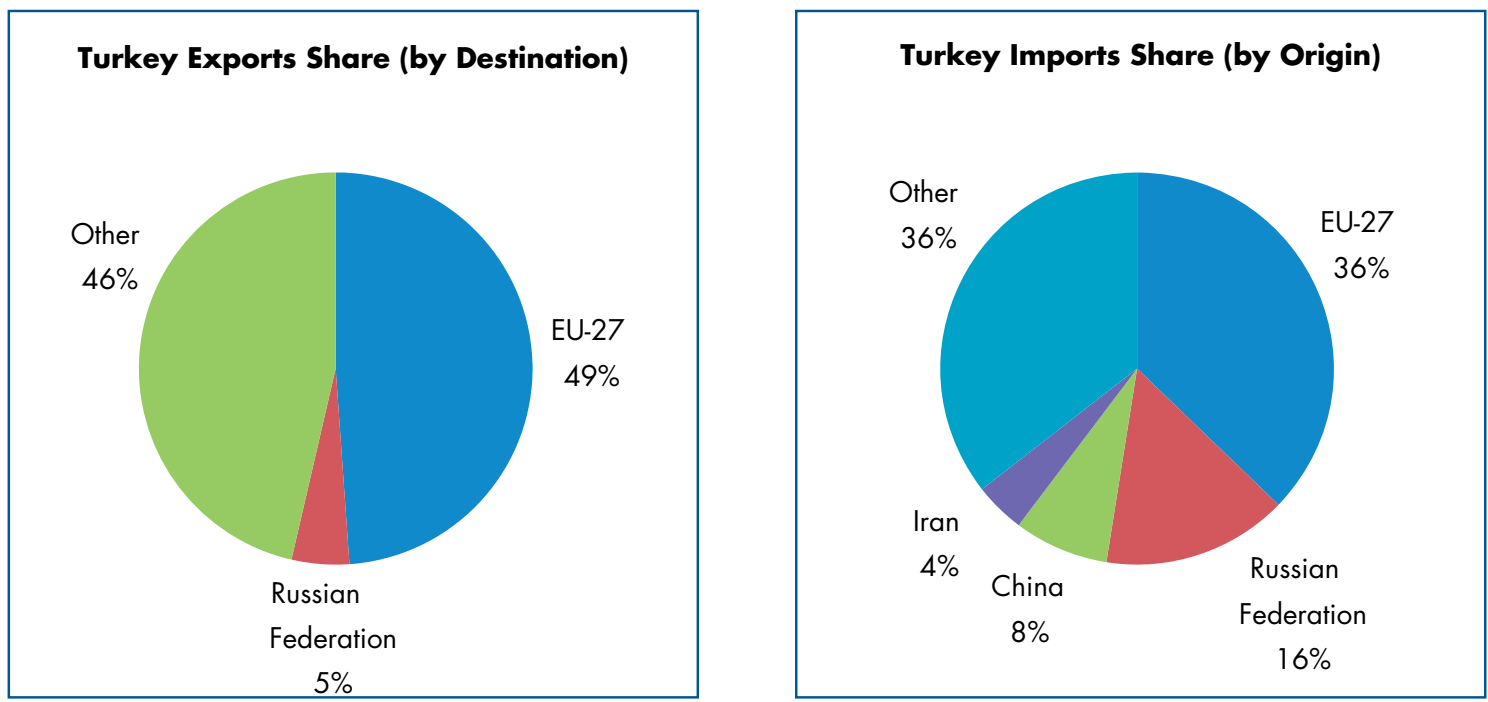

Turkey's highest share of exports as well as imports of goods is to and from the EU.

Figure 1.50 - Turkmenistan

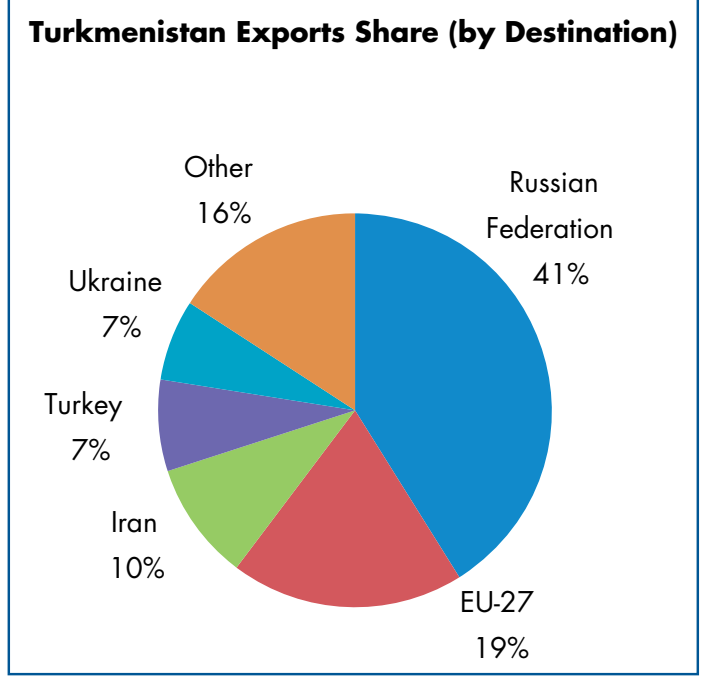

Turkmenistan Imports Share (by Origin)

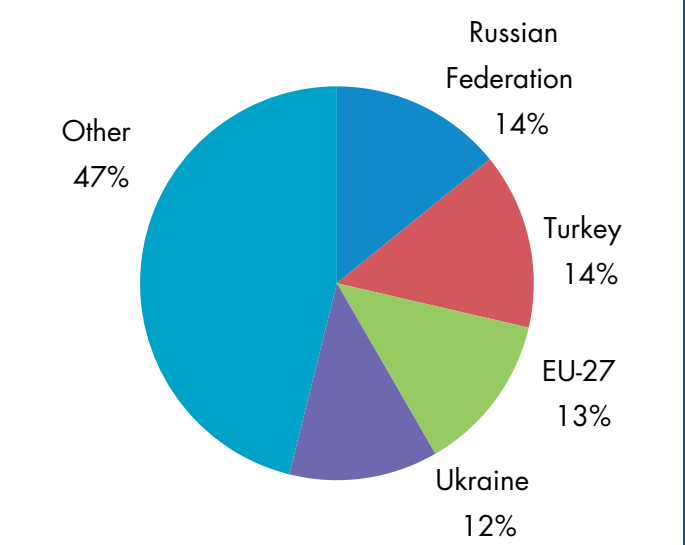

Turkmenistan's highest share of exports is to the Russian Federation, while its highest share of imports is from countries other than those participating in the EATL Phase II project. 

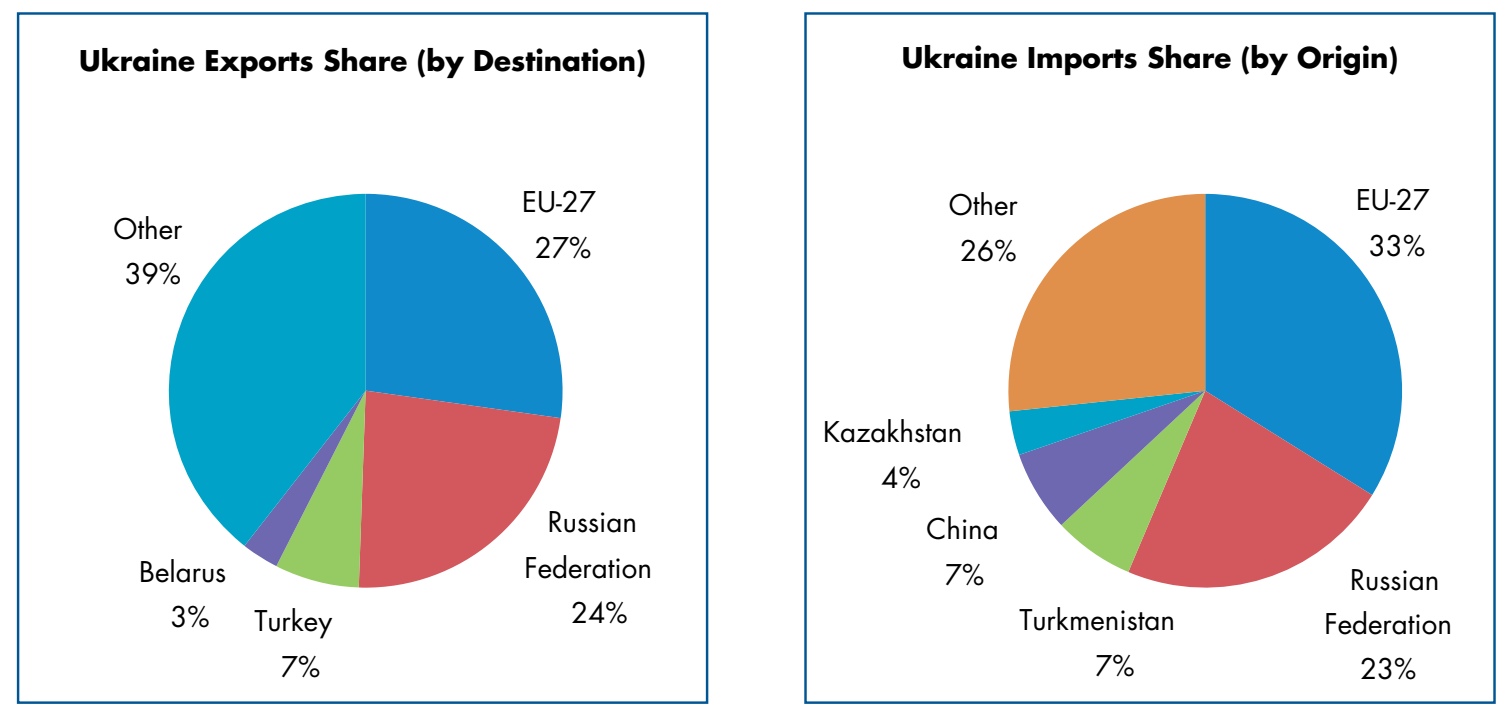

Ukraine's highest individual share of exports as well as imports of goods is to and from the EU. Trade with the Russian Federation is also important.

\section{Uzbekistan}

No data is available for merchandise trade volumes and shares.

\subsection{Euro-Asian trade analysis}

Within the general framework of globalization and market liberalization, trade growth between Europe and Asia has accelerated rapidly in recent years, partly as a result of the development of eastern Asian countries, mainly China, but also due to the growth of the economies of the Russian Federation and Central Asian countries, as well as that of other countries, such as India and Turkey. This has resulted in a wider spatial spread of trade flows, with flows not just between the extremities of the two continents, but also among major centres and hubs within the interior of Eurasia. The latter is, therefore, crucial for defining the main routes for international trade between Asia and Europe. In addition, besides the trade along the Europe-Asia corridors, trade among Asian countries themselves has also begun to develop rapidly.

The impact of economic growth on international transport between Europe and Asia is fundamental, not only on volume, but also on the transportation infrastructure and services offered, by all transport modes involved - maritime, land and even air. Therefore, this growth and trade acceleration is of particular importance for the volumes transported, the means of transport used and the construction of infrastructure along the proposed EATL Phase II routes.

\subsubsection{EATL Phase II countries}

An analysis of trade flows carried out for the 27 countries participating in the EATL Phase II Study indicated in general a high percentage of Asian exports to Europe, representing mainly China's domination in Asia's trade with Europe. Asia's imports come mainly from Europe and Asia, demonstrating the growth of Asia's intraregional trade. To this end, proposed EATL routes should foster Asian countries' (Afghanistan China, Iran, Mongolia, Pakistan) connection to European routes, as well as the following connections of intraregional trade in particular: 
- Afghanistan-Pakistan

- Iran-China

- Mongolia-China

The highest share of EATL CIS countries' exports and imports is to and from the European countries. Therefore, EATL routes should concentrate on these routes and particularly on Europe's connections with Armenia, Azerbaijan, Belarus, Georgia, Kazakhstan, Republic of Moldova, Russian Federation, Turkmenistan and Ukraine that report the highest shares of trade with Europe.

A fair amount of intraregional trade is conducted within CIS countries, reflecting mostly Russian Federation trade with other CIS countries, such as Kazakhstan, Kyrgyzstan, Republic of Moldova, Tajikistan and Turkmenistan. Emphasis should also be given to the following connections:

- Belarus-Ukraine

- Republic of Moldova-Ukraine

- Tajikistan-Uzbekistan

Although trade with Asian countries has the lowest share, albeit not negligible, EATL routes should serve the following connections:

- Kazakhstan-China

- Kyrgyzstan-China

- Russian Federation-China

- Russian Federation-Mongolia

\subsubsection{Current issues and recommendations}

Today maritime transport is the dominant transport mode for Euro-Asian trade flows, and trade growth is increasingly concentrated - partly because of the increase in vessel size - on a certain number of major maritime hubs in both Europe and Asia. At the same time, push for productivity gains reduce the number of these ports. The implications for port operations and associated hinterland transport connections are, therefore, considerable. As already described, the existing capacity of ports is insufficient, with several rapidly approaching full capacity. There is also growing concern about congestion and saturation problems with regard to land access to ports, as well as safety and security issues from maritime traffic concentrating at certain points along the defined routes between maritime hubs. Traffic concentration, both at the port and hinterland levels, is particularly evident in the case of China, where there are several constraints in access to the hinterland. Moreover, even if good hinterland access is assumed, ports continue to serve limited hinterland, considering the vast distances in the trade flows over the entire Eurasia region.

An additional challenge for international transportation operators is trade imbalance, with a large number of empty containers being transported. This phenomenon is particularly evident in Asia.

The above needs call for the diversification of existing routes and the opening up of alternative ones between Europe and Asia or, in some cases, the revival of old trade routes such as the Silk Road and further strengthening of the Trans-Siberian route. To this end, the identification and establishment of EATL routes is of utmost importance.

The most viable additional transport alternative to maritime transport that meets the needs of the increasing trade volumes would be that of inland haulage, which could absorb considerable portions of the expected increased transport demand in the future. Today, land transport is positioned as a link in the chain of maritime transport as a means of access to ports, and also as 
the primary mode of transport over long distances across some parts of the Russian Federation and Central Asia to Europe and China. Distances by land between Europe and Asia are generally shorter than distances by sea, especially for origin/destination points that lie deep inland in these two continents. In addition, road and rail routes serve several origins/destinations along their paths, thus improving accessibility to a large number of remote regions within Central Asia in particular, and giving international access to landlocked countries, permitting them to participate in international trade and becoming part of the worldwide supply chains.

Efficient rail service is becoming the best option for port to hinterland extensions. Transcontinental Eurasian land corridors will not reach the level of maritime transport any time soon. There is, however, a niche market for this transcontinental traffic through Eurasian land corridors (Emerson and Vinokurov, 2009), provided that railway transport is able to offer competitive tariffs and times of delivery for the high-value and low-weight categories of goods. The efficient operation of East-West rail lines, such as the Trans-Siberian railway and the northern Trans-Asian corridor through China, will make significant additional capacity (of several million TEUs) possible. In addition, these corridors will serve the expanding trade of CIS countries with Europe and China, as well as the expanding intraregional trade within Asia.

The main barrier to the development of a rail transport alternative is the price of services, which will probably be higher than current container transport by sea. Nevertheless, with the improvement of operating conditions of existing rail infrastructure in terms of line modernization, longer trains, better utilization of rolling stock and personnel, together with the development of new missing links, rail costs may well reduce substantially.

Finally, the potential value of road transport should not be ruled out, including over long distances, as demonstrated by Turkish freight services to Central Asia (ECMT, 2006). Such transport might be of value to expand intraregional trade, since it provides denser coverage linking main inland points of trade concentration. In addition, road haulage substitutes that of rail where there are geographical barriers to rail operation, as in the case of Turkish haulage services to Central Asia.

Based on the above, the priority routes identified by the EATL Phase II project constitute a promising prospect for transportation between Europe and Asia, primarily taking into account the vast transit potential of land routes through northern Eurasia, which at present are greatly underused. The development of these inland transport routes would provide additional EuroAsian transport solutions, supplementing the existing maritime routes while at the same time becoming a development tool for many countries along the Euro-Asian region, including for the landlocked countries.

Nevertheless, the investment plan identified within the framework of the project should ensure that the road, rail, inland waterway and maritime modes are combined to their best advantage, and that infrastructure interoperability is guaranteed while barriers to the efficient operation of related transport services are removed, in order to achieve high-quality coverage for all the countries involved.

\section{References}

Asian Development Bank (2010). Asian Development Outlook 2010: Macroeconomic Management Beyond the Crisis. Mandaluyong City, Manila.

Emerson, M. and E. Vinokurov (2009). Optimisation of Central Asian and Eurasian TransContinental Land Transport Corridors. EU-Central Asia Monitoring Working Paper No. 7. EUCAM. 
European Commission (2012). Asia-Europe Meeting (ASEM). Asian ASEM Countries: EU Bilateral Trade and Trade with the World. Available from http://trade.ec.europa.eu/doclib/ docs/2006/september/tradoc_113472.pdf.

European Conference of Ministers of Transport (2006). Transport Links between Europe \& Asia. ECMT Publications, Paris.

Oksana I., T. Toikka and O.P Hilmola (2006). Eurasian Container Transportation Market: Current Status and Future Development Trends with Consideration of Different Transportation Modes. Research Report 179. Lappeenranta University of Technology. Available from http:// kouvola.lut.fi/files/download/Research_Report_179_Nora.pdf.

United Nations Conference on Trade and Development (2009). Review of Maritime Transport, 2009. Report by the UNCTAD secretariat. New York and Geneva. Available from http://unctad. org/en/docs/rmt2009_en.pdf.

United Nations Economic and Social Commission for Asia and the Pacific (2003). Transit Transport Issues in Landlocked and Transit Developing Countries. Landlocked Developing Countries Series, No. 1. New York. Available from http://www.unescap.org/ttdw/Publications/ TFS_pubs/pub_2270/pub_2270_fulltext.pdf.

United Nations Economic and Social Commission for Asia and the Pacific (2009). Review of Developments in Transport in Asia and the Pacific, 2009. New York.

Vallouis, Philippe (2010). Maritime Transport of Goods in the Mediterranean: Outlook 2025, Blue Plan Papers 7, Plan Bleu. Valbonne. Available from http://www.planbleu.org/publications/ Cahier7_transport_EN.pdf.

World Bank (2008). Improving Trade and Transport for Landlocked Developing Countries: World Bank contributions to implementing the Almaty Programme of Action, A report for the midterm review. Washington, D.C.: The International Bank for Reconstruction and Development/ World Bank. Available from http://siteresources.worldbank.org/INTRANETTRADE/ Resources/Improving_Trade_Transport_for_Landlocked_Countries.pdf. 


\section{COMPARISON OF EURO-ASIAN INLAND TRANSPORT WITH EXISTING MARITIME ROUTES}

\subsection{Summary}

International trade and production processes are complex. Trade and logistics managers are constantly trying to minimize trading risk, secure delivery and maximize profits. Today, high production and logistics costs often result in uncompetitive products. Products must also be brought to market in a timely manner. Product quality should be high in comparison to what competitors offer. Therefore, decisions involving "where to produce", "how to transport", "how to distribute" and "which day to release/distribute" the products are not only crucial for the effectiveness of international trade, but also of paramount importance for the success of businesses.

In efforts to remain competitive and create new market opportunities, manufacturers are always seeking to minimize production cost, including logistics costs, while responding to customers' needs to ensure high levels of customer satisfaction. Over past decades, the need to reduce production costs has driven many production sites to Asia. This geographic shift in production has generated two new management issues: production away from consumption and longer supply chains. It appears that the higher costs of longer supply chains have been offset by the lower production cost.

To minimize the overall cost of products, manufacturers are faced with a new challenge, i.e. how to reduce supply chain costs. Alternative transport solutions are constantly evaluated. Even a product that entails no production cost but that requires three months to reach its market may be uncompetitive. Therefore, companies are not striving to minimize costs but seek instead the most favourable overall combination of factors: the right product for the right market at the right time and at the right price.

Today, maritime transport dominates the transport of goods from Asia to Europe. The vast distance, combined with political instability, hidden costs, the lack of security, delays at borders and unpredictability, discourage the use of inland transport between Europe and Asia. In addition, maritime transport rates are often incorrectly compared to the rates of inland transport modes. For instance, comparing only the cost and time required for a container to be moved from the Shanghai to the Hamburg port by maritime versus inland transport can lead to wrong conclusions. In reality, products carried by containers are not reaching final destinations at ports, but are waiting to be shipped, as production and consumption areas are often far from ports. As a result, logistics managers must compare the costs over the entire route, which include truck costs associated with moving containers to and from the warehouse/port, terminal handling charges, and document and other administrative costs.

For example, more than 90 per cent of containers arriving at the port of Rotterdam are transported to other countries - many even to South-East Europe. Therefore, to compare the costs of maritime and rail transport of a container from some location "A" 1,500 km away from Shanghai to its final destination in a South-East European country "B" via Rotterdam port, the 
cost comparison cannot be limited only to the transport cost between Shanghai and Rotterdam. One must compare the route from location "A", i.e. the place where the container is loaded with cargo, and location " $\mathrm{B}$ ", the place where the container is delivered/unloaded. If the comparison results favour the rail transport, both in terms of time and costs, then there is excellent potential for developing alternative transport scenarios using inland and/or combined transport means. Trains could be more competitive in relation to time and cost when production areas are situated relatively far from, for example, the ports of China and India and production is destined for southern or eastern European countries.

The development of block trains along Euro-Asian inland transport routes can be considered the lifeline for landlocked countries in Central Asia. Block trains can change landlocked countries into land-linked countries. This could come about if a neutral, non-stop, regular rail service were established along the Euro-Asian links, operating with a flexible corridor management mechanism that would offer similar services to those of liner shipping companies (inland "shipping lines"). The ultimate target is to develop a block train network in Central Asia and beyond, where one train feeds the other with cargo and where they altogether constitute a modern and efficient transport system.

The aim of this section is to compare existing Euro-Asian maritime routes with selected rail routes identified in the EATL project. The methodology used for this analysis is simple and pragmatic. It compares Euro-Asian maritime and rail links from the perspective of a logistics manager of a company that produces goods in some particular location that need to be delivered to another location.

As part of this exercise, customized questionnaires for each participating country along its rail and main maritime lines were distributed. Considering a low response rate to these questionnaires, additional information was collected, including published and the author's own research.

The block train time schedule can be obtained easily on the basis of the actual train run. Tariff rates per container or per container kilometre are the result of complex calculations, which depend on many parameters and are subject to frequent changes. This complexity was reflected in the state rail companies' answers.

Border-crossing delays are not the focus of this section. The model used here crucially depends on the willingness of governments to minimize stopovers at borders. However, all other possible stopover factors were analysed and included in the calculation of the average train speed. It was thus possible to develop realistic time schedules. Some forwarding companies contributed significantly by providing actual freight rates for maritime transport.

In five of the nine scenarios analysed, rail transport performed better than maritime transport, both in terms of costs and time. However, in all nine scenarios, rail transport performed better than maritime transport as concerns time.

Successful and competitive rail services along the Euro-Asian transport links are not an alternative to maritime transport. The Study showed that Euro-Asian rail transport and its combination with maritime and road transport is a feasible and competitive transport option. The establishment of efficient corridor management, governments' willingness to cooperate and rail companies' effective responses to market needs are prerequisites to guaranteeing regular and efficient rail services along the EATL routes.

The following table summarizes the findings of the Study. 
Table 2.1 - Summary of Study findings

\begin{tabular}{|c|c|c|c|c|c|c|c|}
\hline \multirow{2}{*}{ Scenarios } & \multicolumn{2}{|c|}{ Route } & \multicolumn{2}{|c|}{ Rail } & \multicolumn{2}{c|}{ Maritime } & \multicolumn{2}{c|}{ Best Transport Means } \\
\cline { 3 - 8 } & & Cost (\$) & Time (hrs) & Cost (\$) & Time (hrs) & Cost & Time \\
\hline $\begin{array}{c}\text { Scenario 1: } \\
\text { EATL Route 1 }\end{array}$ & $\begin{array}{c}\text { Khabarovsk } \\
\text { (Russian Fed.) to } \\
\text { Potsdam (Germany) }\end{array}$ & 6967.00 & 341 & 6533 & 589 & Maritime & Rail \\
\hline $\begin{array}{c}\text { Scenario 2: } \\
\text { EATL Route 2 }\end{array}$ & $\begin{array}{c}\text { Hangzhou (China) to } \\
\text { Kaluga (Russian Fed.) }\end{array}$ & 4714.65 & 277 & 6786 & 624 & Rail & Rail \\
\hline $\begin{array}{c}\text { Scenario 3: } \\
\text { EATL Route 3 }\end{array}$ & $\begin{array}{c}\text { Tashkent (Uzbekistan) } \\
\text { to Varna (Bulgaria) }\end{array}$ & 5946.00 & 165 & 7550 & 529 & Rail & Rail \\
\hline $\begin{array}{c}\text { Scenario 4: } \\
\text { EATL Route 4 }\end{array}$ & $\begin{array}{c}\text { Almaty (Kazakhstan) } \\
\text { to Istanbul (Turkey) }\end{array}$ & 5881.00 & 250 & 4970 & 672 & Maritime & Rail \\
\hline $\begin{array}{c}\text { Scenario 5: } \\
\text { EATL Route 5 }\end{array}$ & $\begin{array}{c}\text { Morvarid (Iran) to } \\
\text { Pushkin (Russian Fed.) }\end{array}$ & 6390.50 & 256 & 3310 & 374 & Maritime & Rail \\
\hline $\begin{array}{c}\text { Scenario 6: } \\
\text { EATL Route 6 }\end{array}$ & $\begin{array}{c}\text { Ussuriysk (Russian } \\
\text { Fed.) to Kyiv (Ukraine) }\end{array}$ & 5857.00 & 289 & 6290 & 463 & Rail & Rail \\
\hline $\begin{array}{c}\text { Scenario 7: } \\
\text { EATL Route 7 }\end{array}$ & $\begin{array}{c}\text { Shanghai (China) to } \\
\text { Warsaw (Poland) }\end{array}$ & 8937.00 & 446 & 6300 & 569 & Maritime & Rail \\
\hline $\begin{array}{c}\text { Scenario 8: } \\
\text { EATL Route 8 }\end{array}$ & $\begin{array}{c}\text { Krasnodar } \\
\text { (Russian Fed.) to } \\
\text { Kaliningrad (Russia) }\end{array}$ & 1595.00 & 70 & 5050 & 225.2 & Rail & Rail \\
\hline $\begin{array}{c}\text { Case } \\
\text { Study /Car } \\
\text { Manufacturer }\end{array}$ & $\begin{array}{c}\text { Vesoul (France) to } \\
\text { Kaluga } \\
\text { (Russian Fed.) }\end{array}$ & 2107.00 & 101 & 6300 & 163 & Rail \\
\hline
\end{tabular}

This analysis is divided into five sections. The first two illustrate and analyse the trade between Asia and Europe and the existing block trains in operation. The third presents the Euro-Asian maritime routes and offers a cost analysis with actual data, including terminals, administrative and road transport costs. The next section focuses on rail transport, analysing the economics of rail transport and the cost structures of rail routes. It also presents a detailed analysis of rail routes for each participating country, including distance analysis, time schedule evaluation and tariff structure. In the last chapter, maritime and rail transport for the EATL routes are compared. Selected points of origin (locations A) and destination (locations B) across the EATL routes are used to create different scenarios where maritime and rail transport are compared. The selection of the points of origin and destination was based on various criteria, such as the importance of trade destinations, the importance for landlocked countries and the distance from the busiest ports. A case study for car manufacturers using Euro-Asian transport linkages is also presented.

\subsection{Trade between Asia and Europe}

After the sharpest decline in more than 70 years, world trade was set to rebound in 2010 by growing at 9.5 per cent according to WTO economists (Figure 2.1). Exports from developed economies were expected to increase by 7.5 per cent in volume terms over the course of the year, while shipments from the rest of the world (including developing economies and the Commonwealth of Independent States) were expected to rise by around 11 per cent as the world was expected to emerge from recession.

The expected expansion was predicted to help recover some, but not all, of the ground lost in previous years when the global economic crisis sparked a 12.2 per cent (2009) contraction in the volume of global trade - the largest such decline since World War II. 
The value of world merchandise trade was about 25 per cent higher in the first three months of 2010, year-on-year (Figure 2.1). Global exports rose by 27 per cent, while imports increased slightly less.

Figure 2.28 - World exports - imports, first quarter of the year
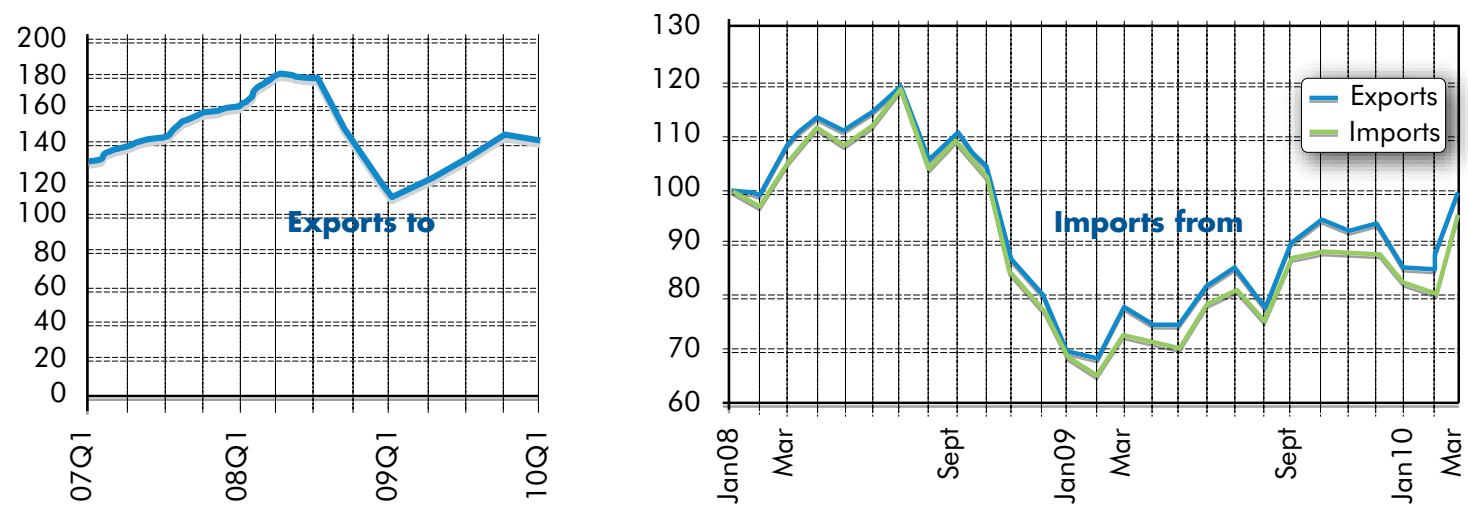

Source: WTO, 2010

Forty-three per cent of world exports originated in Europe, 25 per cent in Asia, 17 per cent in North America and 3 per cent in CIS countries according to the WTO.

Also according to the WTO, 74 per cent of Europe's exports are intra-European, 8 per cent are destined for Asia, 7 per cent for North America and 4 per cent for CIS countries (Figure 2.2). One half of Asian countries' exports stays in Asia, 18 per cent go to Europe, 18 per cent to North America and 2 per cent go to CIS countries (Figures 2.3 and 2.4).

Figure 2.29 - Exports of Europe

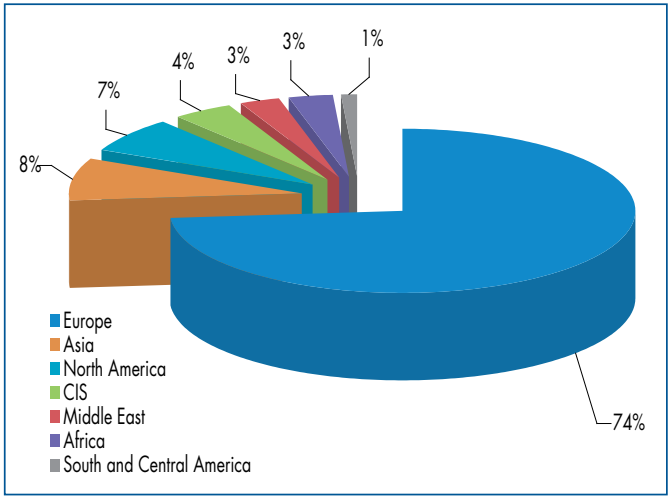

Source: WTO data
Figure 2.30 - Exports of Asia

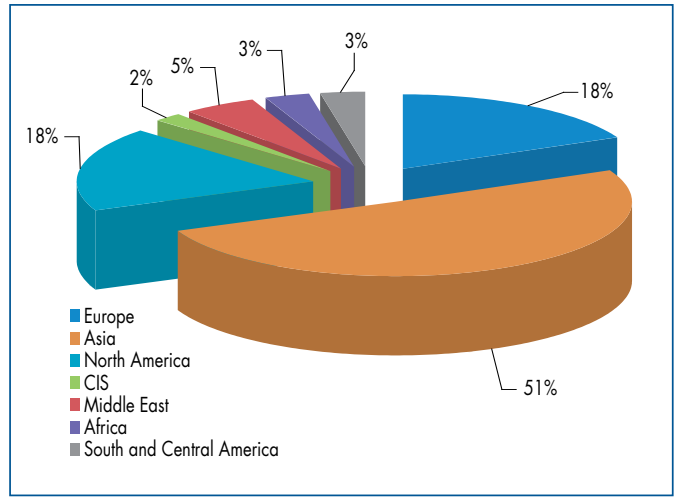

Source: WTO data 
Figure 2.31 - The Euro-Asian Trade

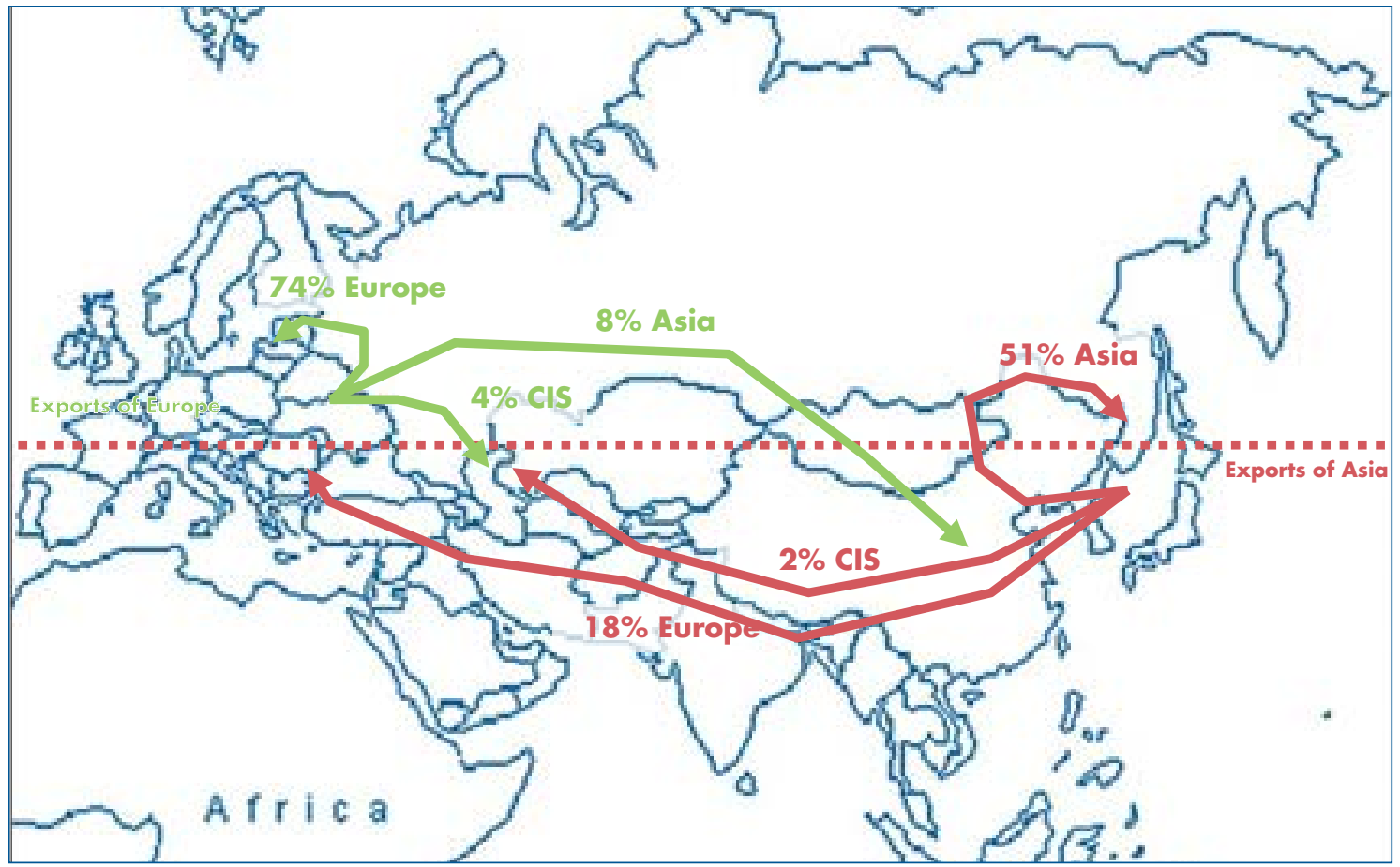

Source: WTO data

Figure 2.5 illustrates the annual percentage change of imports and exports by region (2008 over 2007) - one year before the economic crisis. As indicated, Asia's exports and imports grew by more than 4 per cent, while Europe's imports decreased by 1 per cent and its exports increased by 0.5 per cent.

Figure 2.32 - Real merchandise trade growth by region, 2008 over 2007

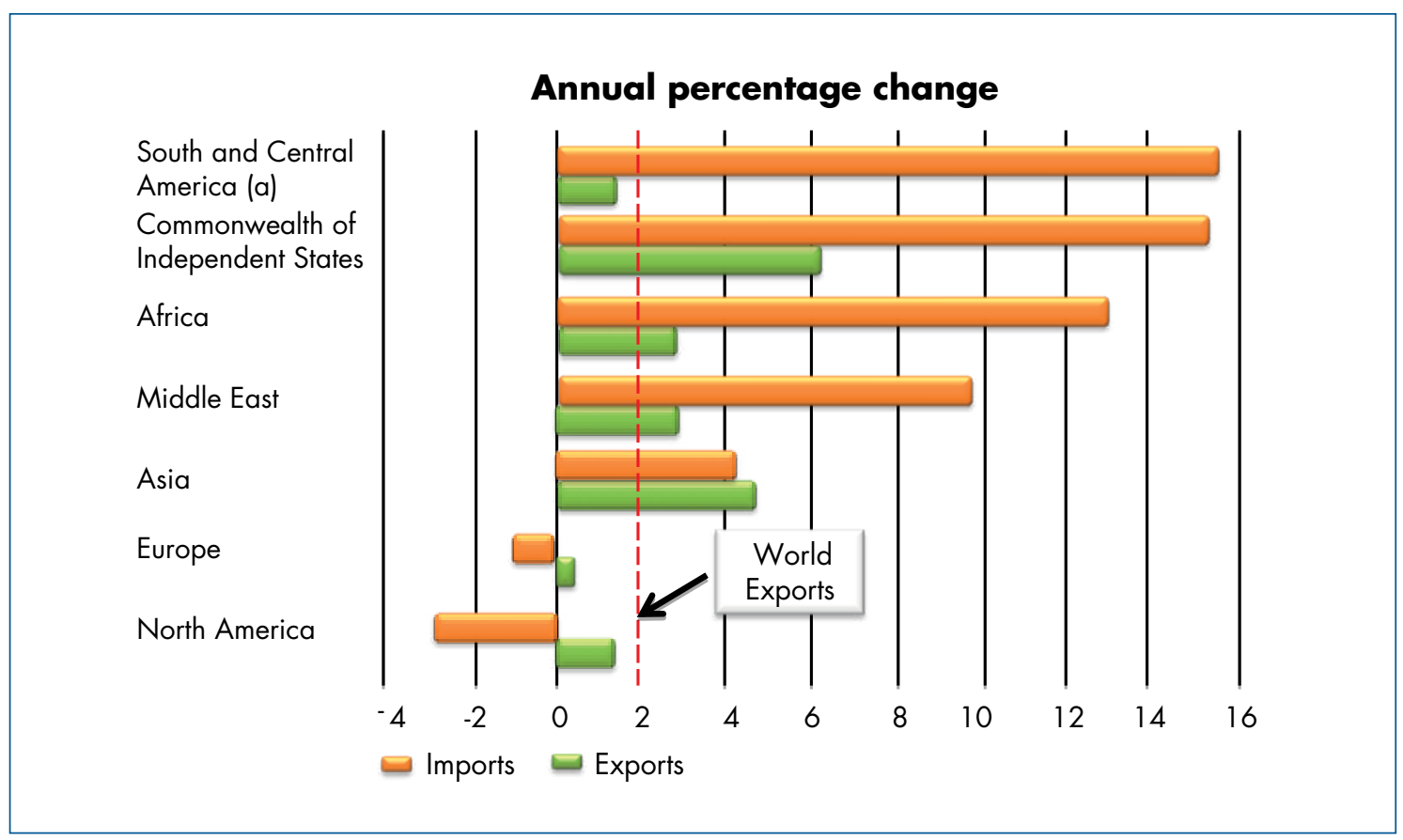

Source: European Community Ship owners Association, Annual Report, 2008-2009 
The seven European countries involved in the EATL project export about 70 per cent of goods to other European countries, 3 per cent to Asian countries and 5 per cent to CIS countries. They import 63 per cent from other European countries, 7 per cent from Asian countries and 9 per cent from CIS countries (Figure 2.6).

These countries' exports shares are: agricultural products 15 per cent, fuel and mining products 16 per cent and manufacturing products 68 per cent. Imports shares are: agricultural products 10 per cent, fuel and mining products 19 per cent and manufacturing products 69 per cent.

Figure 2.6 - Exports and imports of the European countries of the EATL project
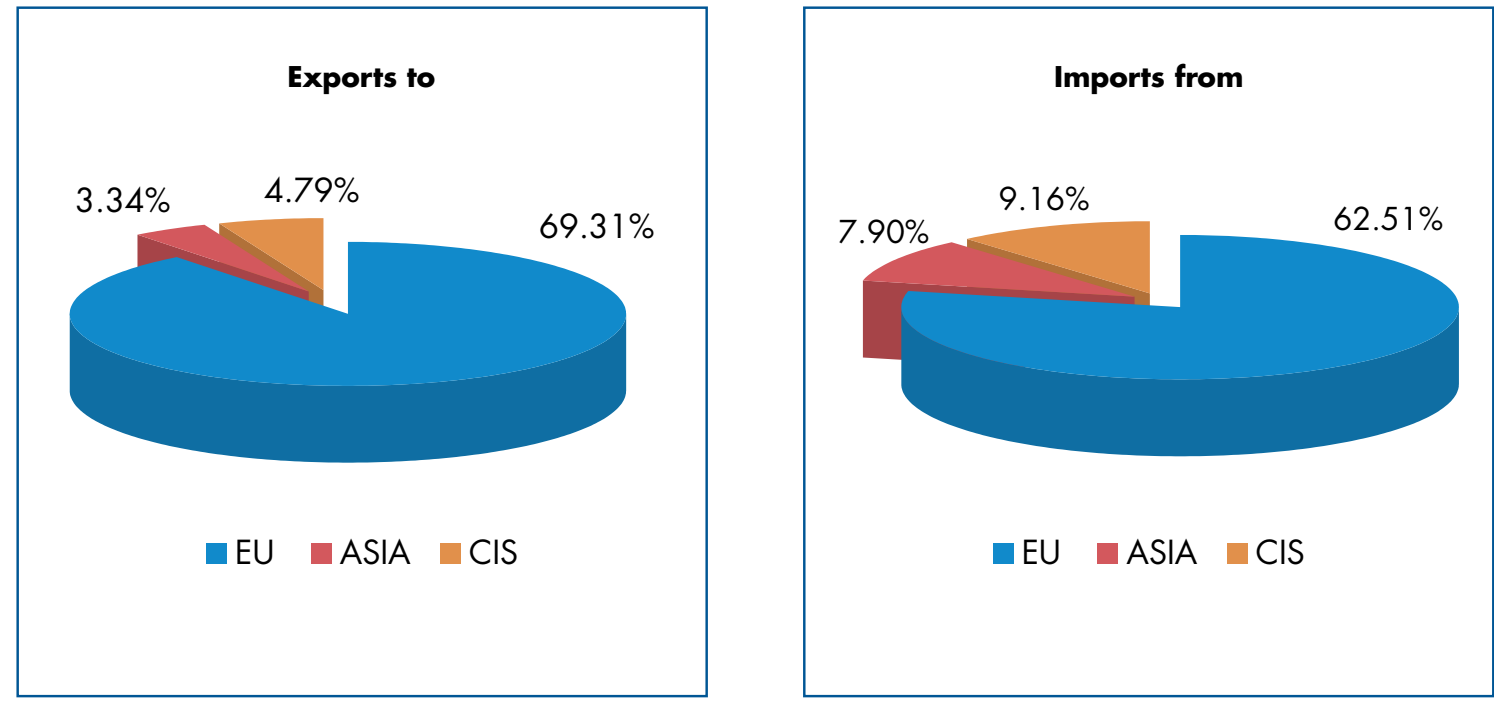

Source: WTO data

The 16 Asian countries of the EATL project export on average 31 per cent of goods to European countries, 17 per cent to other Asian countries and 18 per cent to CIS countries. These countries import 21 per cent from European countries, 18 per cent from other Asian countries and 24 per cent from CIS countries (Figure 2.7).

Exports of agricultural products represent 11 per cent, fuel and mining products 40 per cent and manufacturing products 34 per cent, while imports of agricultural products make up 10 per cent and fuel and mining products 19 per cent.

Figure 2.33 - Asian countries of the EATL project
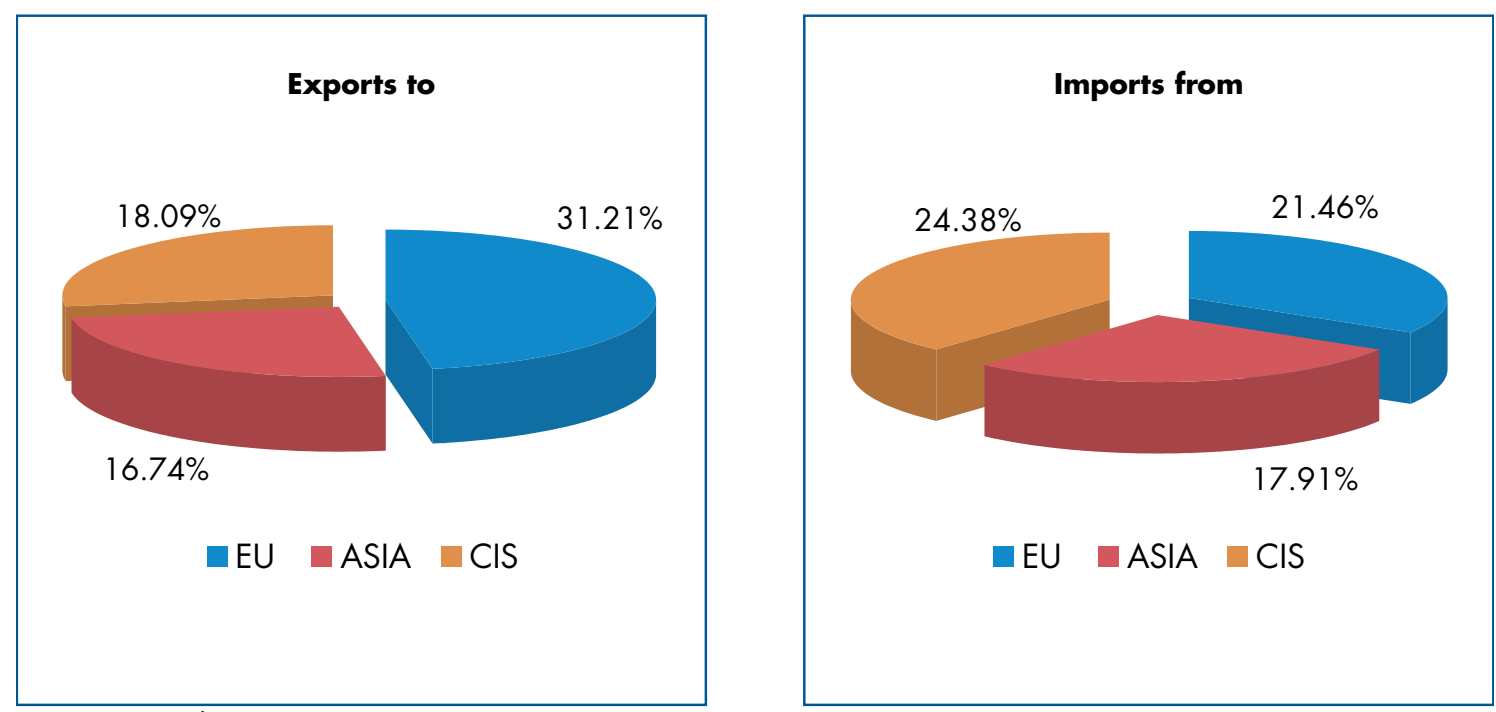
The European Conference of Ministers of Transport (ECMT) $)^{3}$ shows that trade between the two continents has accelerated sharply in recent years. This is partly because of the economic development of East Asian countries, mainly China, but also as a result of the growth of the economies of the Russian Federation and Central Asian states. This has caused a wider geographical dispersal of trade flows, a phenomenon that is crucially important for defining the main routes for international trade between Asia and Europe.

One of the key features of world container trade is an imbalance of incoming/outgoing containers. The fact that more full containers leave Asia than return has created a major challenge for international transport operators. Industry estimates of these imbalances vary significantly. However, for the three main intercontinental trade links: Asia-Pacific, Asia-Europe and TransAtlantic, the imbalances have grown significantly with more than half of the containers on the Asia-Pacific and the Asia-Europe route going back to Asia empty. Similar imbalances also existed a decade ago but in the 20-30 per cent range.

Currently, maritime transport dominates cargo shipping between Asia and Europe. The maritime operators have significantly expanded capacity to meet the demand; this has been reflected in the sustained double-digit annual growth. For high-value and time-sensitive cargo, the use of air transport has seen a similar expansion.

The volumes of international containerized cargo shipped by rail or road transport between Asia (China) and Europe are currently very limited. Rail transport, in particular the TransSiberian railway, accounts for 3-4 per cent of the total volume. This volume originates mainly from northern China and the Republic of Korea. Road transport accounts for less than 1 per cent of the containerized trade between China and Europe in volume terms. ${ }^{4}$

Congestion in trans-shipment ports is also an issue. Transport operators can address it through the routing of a container and the trimming of their networks. Congestion in ports of origin and destination are much more complex and involve a wider range of factors, including port terminals, customs facilities and operators organizing the incoming and outgoing intermodal transport of the cargo by truck, rail or barge. Naturally, it does not matter much to the end customer if a container is delayed because of an issue in a trans-shipment port or the port terminal at the origin/destination, or if it is caused by bottlenecks pertaining to parts of the intermodal transport executed by rail or trucking companies. ${ }^{5}$

Greater trade between Europe and Asia has resulted in the faster growth of maritime container traffic ( 6 per cent per year). This phenomenon has been accompanied by the use of larger vessels and by shipping rates that have fallen to very low levels ( $\$ 700$ per TEU from Europe to Asia).

Overall, Europe-Asia trade points towards two factors in favour of the diversification of routes and the opening up of new inland routes:

- Maritime transport's virtual monopoly on trade between Europe and Asia. This is causing increasing problems in land access to seaports (in addition, the push for productivity gains tends to reduce the number of such ports). Obligatory points of passage between maritime hubs concentrate shipping traffic. This may pose a serious safety problem (risk of accidental pollution) and a serious security problem (vulnerability to attack).

\footnotetext{
${ }^{3}$ European Conference of Ministers of Transport and OECD, Transport Links between Europe and Asia, (Paris, 2006). Available from http://internationaltransportforum.org/pub/pdf/06Europe-Asia. pdf.

${ }^{4}$ The Chamber of Commerce of the United States, Land Transport Options between Europe and Asia: Commercial Feasibility Study (Washington, 2006). Available from http://www.internationaltransportforum.org/Proceedings/ Border2009/USChamberOfCommerce2.pdf.

${ }^{5}$ European Community Shipowners' Associations, Annual Report 2008-2009 (Brussels, 2009). Available from http://archive-be.com/page/16023/2012-05-20/http://www.ecsa.be/ar/Rapport\%202008-2009.pdf.
} 
- The growth in traffic between continental countries, particularly in Central Asia, along the Europe-Asia land routes. Besides trade along the Europe-Asia corridors, trade within the region itself is developing, reinforcing the necessity to improve the corridors.

Figure 2.34 - Annual percentage in GDP of world merchandise exports in real value, maritime transport volume, 1998-2008

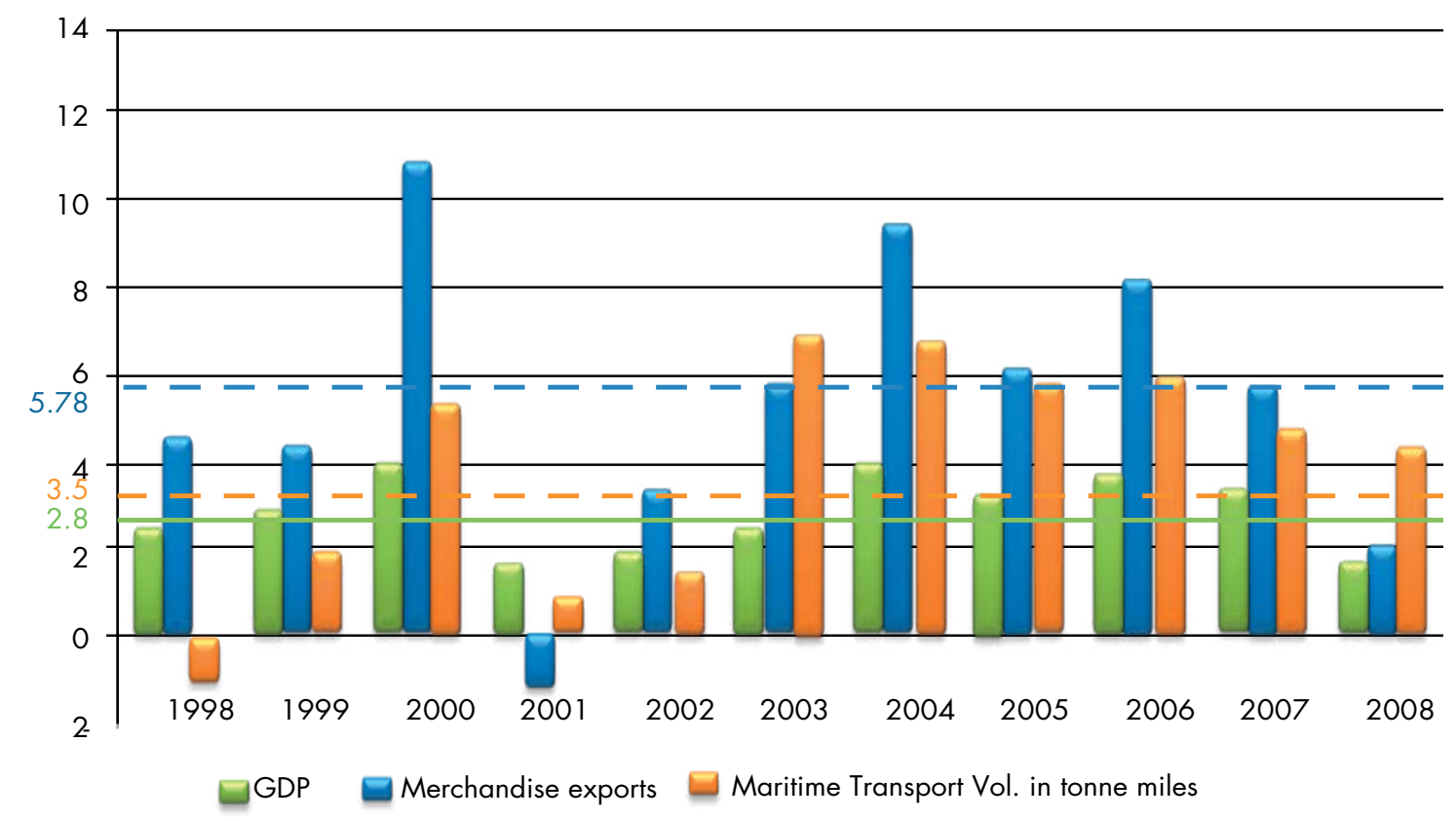

Source: European Community Shipowners' Associations, Annual Report, 2008-2009

Despite efforts to develop efficient inland links, maritime transport will likely remain a dominant mode in the Europe-Asia transport market. While shipping companies and ports may be able to cope with the expected increase in maritime traffic, particularly container traffic (Figure 2.8), inland transport modes for hauls between ports and their hinterland connections will not. The risk of saturation on road networks to these ports is high, while rail and inland waterways often have insufficient capacity. It is therefore important for governments to take the necessary action, particularly in the area of infrastructure, to improve land access to seaports. Developing appropriate rail or inland waterway links and facilitating intermodal transfer between inland and waterway modes need to be re-engineered.

In 2010, UNECE Transport Division published a study entitled "Hinterland Connections of Seaports". The study examines the ways in which seaports and their hinterland connections can help to improve supply chain performance through the removal of bottlenecks and improvement in the efficiency and sustainability of port hinterland links in the UNECE region. ${ }^{6}$

\subsection{Block trains in Europe and Asia}

This section describes block trains operating along the Euro-Asian links and provides a list of block train demonstration runs performed recently. The major block trains operating with some regularity at present are those organized for particular clients. Some trials have been organized by freight forwarders as well, but they have not had great success.

6 United Nations Economic Commission for Europe, Hinterland Connections of Seaports (New York and Geneva, 2010). Available from http://www.unece.org/fileadmin/DAM/trans/doc/2010/itc/ECE-TRANS-210.pdf. 


\subsubsection{Poti-Baku}

Figure 2.35 - Poti-Baku block train

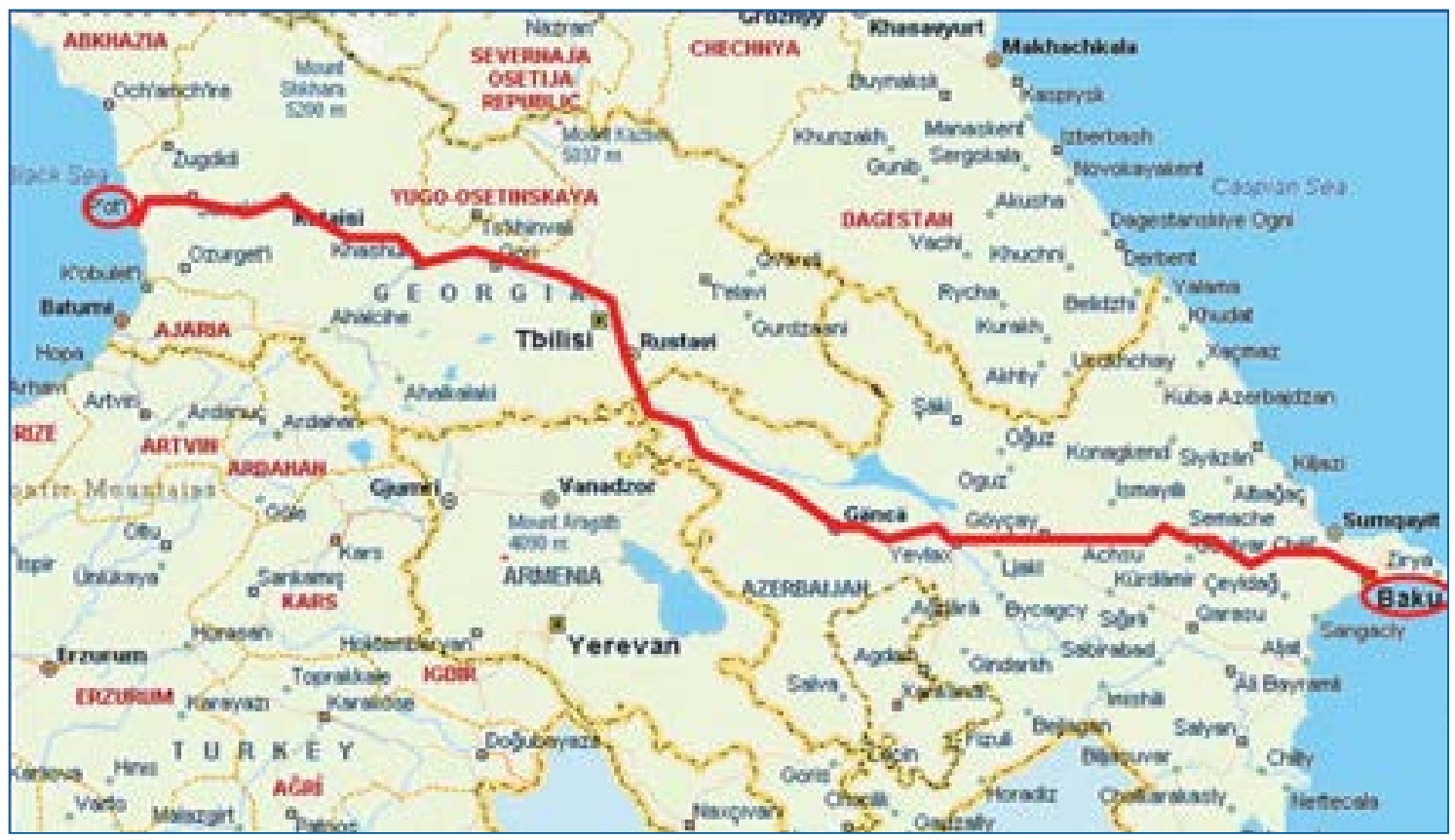

Source: POLZUG Intermodal Group

A container block train between Poti (Georgia) and Baku (Azerbaijan) ${ }^{7}$ is operated by POLZUG Intermodal Group (Figure 2.9).

The service carries containers from the Black Sea to the Caspian Sea. The container trains are made up of wagons of the same type. With no stopping for assembly and disassembly, the block train offers high-volume customers an economic alternative to regular rail freight operations or road transport. From Baku onwards, shipment continues by ferry across the Caspian Sea to Aktau, Kazakhstan, for rail transport to Central Asia.

\subsubsection{Vostochny, Moscow, Novosibirsk, Taganrog (Hyundai), Izhevsk (KIA), Naberezhnye Chelny (Ssang Yong), Uzbekistan (GM Daewoo) and Ulyanovsk (Isuzu)}

Mitsui \& Co. Ltd" has established a "Trans Siberian Route (TSR) Agent Team" that provides "Cargo Container Express Train Service" utilizing the Trans-Siberian railway to deliver cargo from Asian ports to Russian Federation/CIS city terminals.

Features of these block trains:

- Special trains are composed of a minimum of 31 and maximum of 37 wagons, which are 80 -foot (24-metre) long. The number of wagons can vary between 31 and 37, setting train capacity at 62-74 containers, based on 40 -foot (12-metre) containers. The maximum formation length for one block train is 1,000 metres in accordance with Russian Federation law.

- Routes are predetermined in advance. In case of a conventional train, the train stops are determined by each railway controlling section, a process that decreases traceability. With block trains, stops are minimized and the transit station is predetermined. This feature improves the ability to trace cargo.

\footnotetext{
7 Based on Thomas L. Gallagher, The Journal of Commerce Online - News Story (8 March 2009).

8 Based on TRANS SIBERIAN RAILWAY, Block Train Service, Mitsui \& Co. Ltd. Available from http://www.mitsui-tsr. com/en/service/index2.html.
} 
- Without changes in wagon formation, lead times are shorter and regularity is secured. (The block train running time from Vladivostok to Moscow is 11 to 12 days. Efforts to shorten the lead time to 7 days are ongoing).

- This service was started by customers in the Republic of Korea as a dedicated transport method to supply parts to an assembly factory in the Russian Federation.

Table 2.2 - Main block train operation records, July 2007

\begin{tabular}{|c|c|c|c|c|c|}
\hline Destination & Point of origin & $\begin{array}{c}\text { Frequency per } \\
\text { week }\end{array}$ & $\begin{array}{c}\text { Training running } \\
\text { days }\end{array}$ & Rail operator & Freight owner \\
\hline Taganrog & Vostochny & 3 & 11 & Russkaya Troyka & $\begin{array}{c}\text { Hyundai Motor } \\
\text { Company }\end{array}$ \\
\hline Izhevsk & $\begin{array}{c}\text { Vostochny } \\
\text { Nakhodka }\end{array}$ & $7-8$ & 9 & $\begin{array}{c}\text { Russkaya Troyka } \\
\text { F.E.Trans }\end{array}$ & Kia Motors \\
\hline Moscow & Vostochny & 1 & $11-12$ & Russkaya Troyka & $\begin{array}{c}\text { Various unspecified } \\
\text { freight owners }\end{array}$ \\
\hline Moscow & Vladivostok & 1 & $11-12$ & Russkaya Troyka & $\begin{array}{c}\text { Various unspecified } \\
\text { freight owners }\end{array}$ \\
\hline $\begin{array}{c}\text { Saryagach, } \\
\text { Uzbekistan }\end{array}$ & Vostochny & 2 & 14 & $\begin{array}{c}\text { Trans Container } \\
\text { Unico Logistics }\end{array}$ & $\begin{array}{c}\text { GM Daewoo Motor } \\
\text { Company }\end{array}$ \\
\hline $\begin{array}{c}\text { Chelny, } \\
\text { Naberezhnye }\end{array}$ & $\begin{array}{c}\text { Vostochny } \\
\text { Nakhodka }\end{array}$ & 3 & $9-10$ & F.E.Trans & $\begin{array}{c}\text { Sangyong Motor } \\
\text { Company }\end{array}$ \\
\hline
\end{tabular}

* The point of origin for Russkaya Troyka block train for various unspecified customers shifted to the Vladivostok port in February 2009.

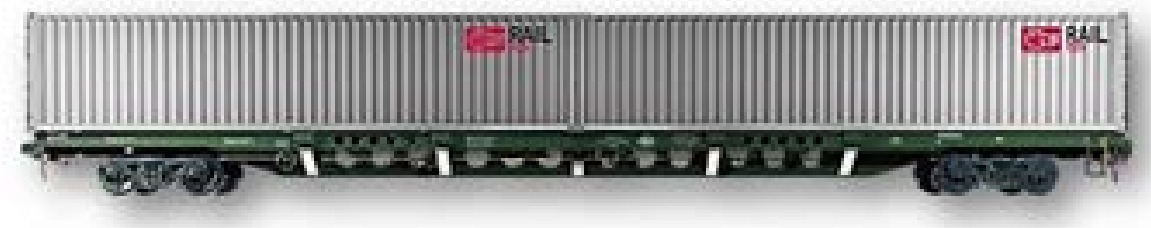

Photo: 80-foot wagon

Two security guards are placed in the locomotive. For 38 wagon formations, a convoy wagon is connected in the centre which normally has two security guards posted (this is compulsory in accordance with Russian Federation law). In the unlikely event of disengaging the wagons, the train conductor is made aware of the situation by a drop in brake pressure.

\subsubsection{VW - Skoda Auto}

This project of integrated container trains was started in 2002. The route begins from the Czech Republic in the direction of Mladá Boleslav-Kaluga and from Slovakia in the direction of Velká Ida-Kaluga through the border station Malaszewicze (Poland)-Brest (Belarus). It delivers disassembled VW and ŠKODA brand cars to an assembly plant in Kaluze (Russian Federation). The size and importance of the project makes it among the biggest in the European Union. There are 14 pairs of trains per week from Mladá Boleslav to Kaluga and 11 from Velká Ida to Kaluga.

\subsubsection{Volkswagen (VW)}

With TransContainer (a Russian Railway intermodal company), Volkswagen (VW) operates container block trains carrying on average 116 TEU of components from Brest to Kaluga near Moscow.

Since 2008, the trains have brought auto parts made by Volkswagen from the Czech Republic via Brest to the automotive plant in Kaluga (Russian Federation) on the Brest-Kaluga route. In the first half of 2008, 139 trains were launched on the route, delivering 15,920 TEU. 
Figure 2.36 - The automotive supply chain

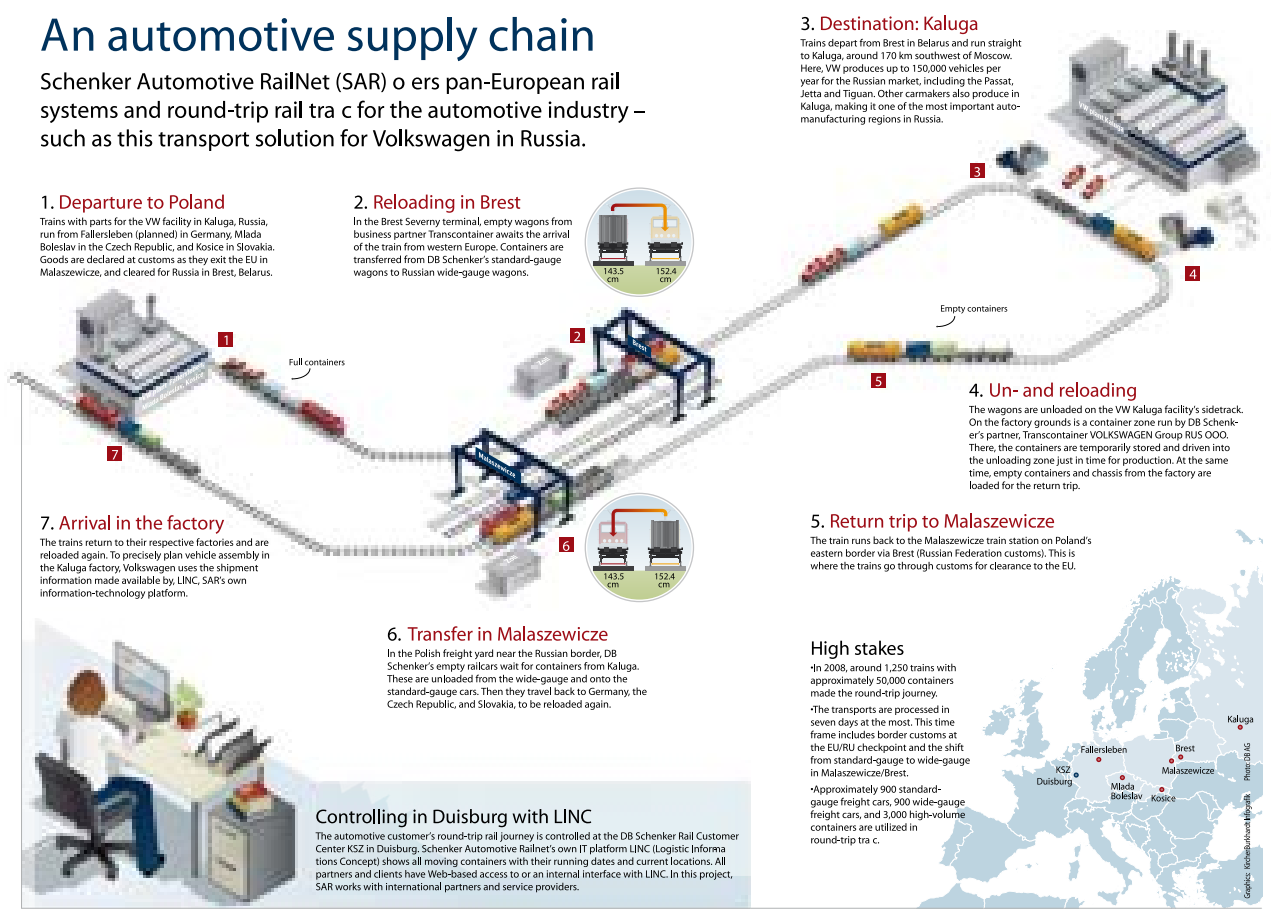

Source: DB Schenker

\subsubsection{KIA Kazakhstan}

Asia Auto's Kazakhstan plant was established in 2003. Currently, it produces models such as Lada Niva, Skoda Octavia and Superb, Chevrolet Captiva, Lacetti and Epica and Cadillac Escalade. An assembly of three new Kia models was launched in 2010. The company has organized some block trains from Bandar Abbas (Iran) to Kazakhstan.

\subsubsection{Peugeot}

Over 140 cars are transported per day from Sochaux and Mulhouse and 60 from Zeebrugge (Belgium) to Vesoul for disassembling. Then the block train runs from France (Vesoul) to the Russian Federation (Kaluga) loaded with semi-knocked-down auto parts to be assembled in Kaluga (Figure 2.11).

Figure 2.37 - Peugeot block train route

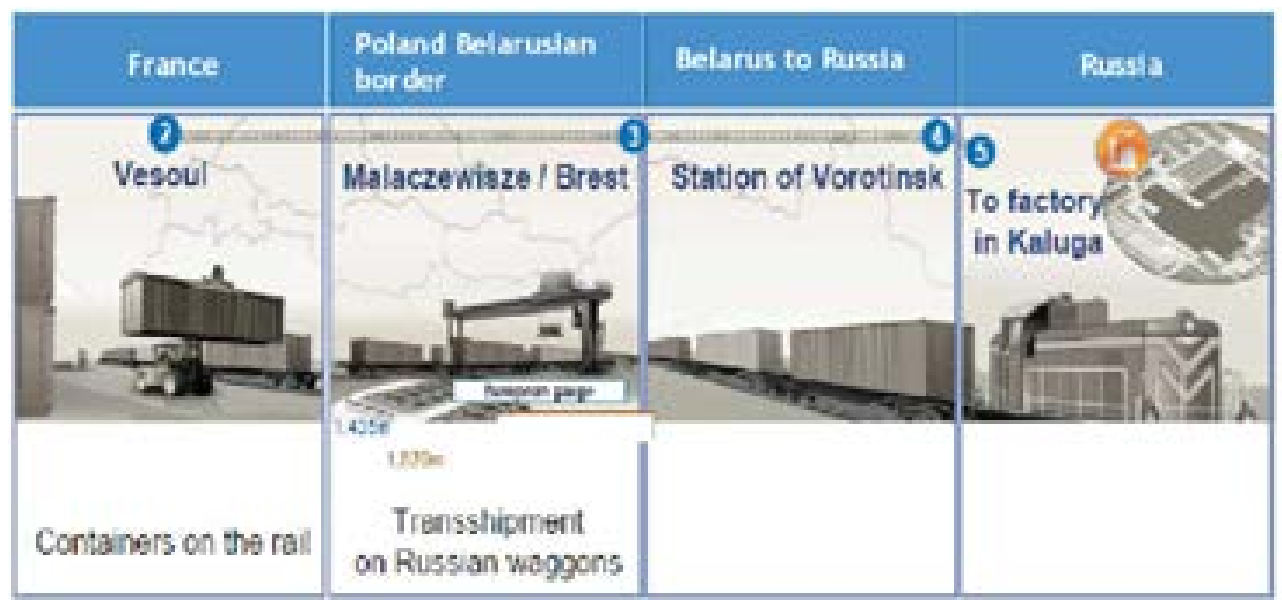

Source : Peugeot 
This block train travels 6,000 $\mathrm{km}$ round trip, uses 400 dedicated wagons, 1,200 dedicated containers round trip and 80 trucks for final deliveries.

\subsubsection{Cargo Czech Republic}

Figure 2.38 - CD Cargo block train

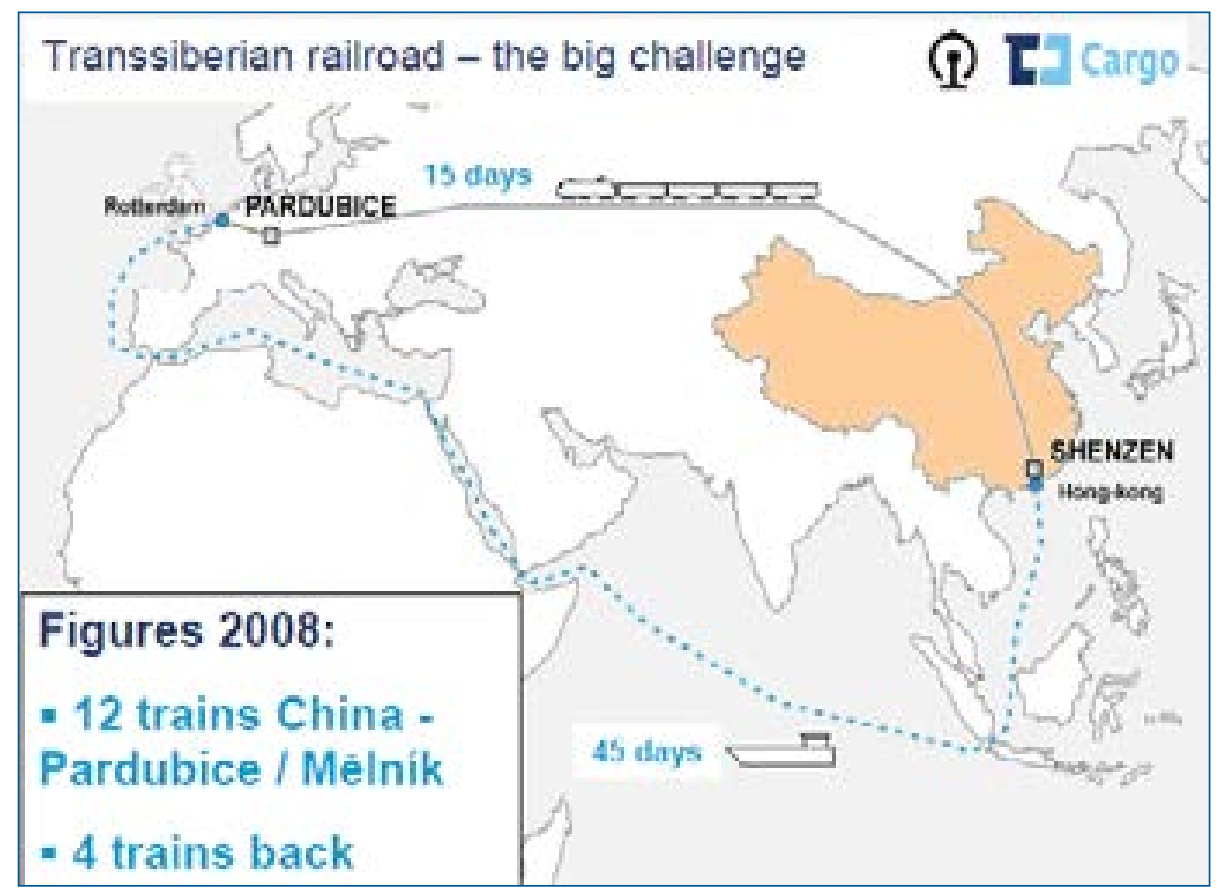

Source: CD Cargo

In 2008, ČD Cargo, a logistics and forwarding company based in the Czech Republic, operated 12 block trains from the Czech Republic to China (Pardubice/Melnik-Shenzen).

\subsubsection{Trains listed by the Organization for Cooperation of Railways}

Every year the Organization for Cooperation of Railways (OSJD) publishes a list of all block/ container trains that operate in its region. The table shows the latest available list.

Table 2.3 - Block trains operating between Europe and Asia

\begin{tabular}{|c|c|c|c|}
\hline i.d. & Train description & Type of train & Frequency \\
\hline 1208 & $\begin{array}{c}\text { Berlin - Kunzevo (Russian Fed.), } \\
\text { "Ostwind" }\end{array}$ & Containers & 3 times per week \\
\hline 1276 & $\begin{array}{l}\text { Brest - Ilijezk (Russian Fed.) - Arys } \\
\text { (Kazakhstan) "Kasachischer Vektor" }\end{array}$ & Containers & 2 times per week \\
\hline 1406 & $\begin{array}{l}\text { Brest - Nauschki (Russian Fed.) - Ulan } \\
\text { Bator (Mongolia) - Huh Hoto (China) }\end{array}$ & Containers & 2 times per week \\
\hline $1251 / 1252$ & $\begin{array}{c}\text { Almaty (Kazakhstan) - Dostyk } \\
\text { (Kazakhstan) / Alaschankou (China) }\end{array}$ & Containers & 6 times per week \\
\hline $1402 / 1401$ & $\begin{array}{c}\text { Lianyunggang (China) - Alaschankou } \\
\text { (China) / Dostyk Kazakhstan - Assake } \\
\text { (Uzbekistan) }\end{array}$ & Containers & 1 time per week \\
\hline $1401 / 1402$ & $\begin{array}{c}\text { Tianjin (China) - Alaschankou (China) } \\
\text { / Dostyk (Kazakhstan) - Almaty } \\
\text { (Kazakhstan) }\end{array}$ & Containers & 3 times per week \\
\hline
\end{tabular}




\subsubsection{Demonstration train runs}

Some international organizations and private companies have performed demonstration runs of block train to evaluate their effectiveness. Some are presented below:

- From Tianjin (China) to Ulaanbaatar (Mongolia) in 3 days 3.5 hours over the $1,691 \mathrm{~km}$ distance (November 2003).

- From Lianyungang (China) to Almaty (Kazakhstan) in 7 days 6 hours over the $5,020 \mathrm{~km}$ distance (April 2004)

- From Brest (Belarus) to Ulaanbaatar (Mongolia) in 8 days 21 hours over the 7,180 km distance (June 2004).

- From Nakhodka (Russian Federation) to Malaszewicze (Poland) in 12 days and 8 hours over the $10,335 \mathrm{~km}$ distance (July 2004). ${ }^{9}$

- Beijing-Hamburg container train. To demonstrate the potential of container service by rail, the Beijing-Hamburg train was launched from Beijing in January 2008. The train made the $9,780 \mathrm{~km}$ route in 15 days. It passed through the territory of China, Mongolia, Russian Federation, Belarus, Poland and Germany. On the same day, a memorandum of understanding was signed and a joint working group was set up to arrange rail service on the China-Western Europe route. ${ }^{10}$

- Economic Cooperation Organization (ECO) organized in 2009 demonstration train from Islamabad to Istanbul in 11 days with many restrictions, mainly for night travel on the territory of Pakistan, over the $6,566 \mathrm{~km}$ distance. ${ }^{11}$

\subsection{Euro-Asian maritime routes}

\subsubsection{Port management}

The latest data available on world container traffic show that in 2010,560 million TEU moves were registered.

Singapore dropped its lead as the world's busiest port in terms of the total number of TEU moves, growing only by 0.9 per cent. Shanghai overtook Singapore with the growth rate of 17.8 per cent, while Hong Kong remained in the third place.

Congestion is one of the biggest port problems. Certain vulnerabilities in global supply chains exist and when the goods move from one mode to another, as they do in the ports, the risk of encountering problems rises. Ideally, when a ship arrives in a port, a berth is waiting and the cargo handling facilities swing smoothly into action. When no berth is available, and the ship has to swing around its anchor awaiting its turn, delays are caused right down the supply chain and costs accumulate.

Port congestion is caused by a number of factors. Perhaps there has been a period of exceptionally bad weather, making it difficult to work cargo with ships delayed both at sea and in port. An unexpected accident may reverberate right down the supply chain. ${ }^{12}$

An increase in trade can also cause port congestion as ports have limited ability to quickly adjust to such increases. The extraordinary growth in international trade caused by the surge in

9 United Nations Economic and Social Commission for Asia and the Pacific (ESCAP), "Development of Asia-Europe Rail Container Transport through Block-trains - Trans-Asian Railway Northern Corridor". Available from http:// www.unescap.org/ttdw/common/TIS/TAR/Container\%20Block-trains.asp.

10 DB SCHENKER, 2009.

11 ECO Secretariat, http://www.ecosecretariat.org.

12 In an Australian port, a bulk carrier damaged an iron ore loader. As a result, about half of the port's capacity to unload was put out of action for months. 
Chinese exports has caught much of the port industry napping. Port investment in many countries has lagged behind, while years of planning are often required before the construction of new port facilities, or the dredging of deeper channels for bigger and more productive ships, can even begin. It is not merely the non-availability of berths that causes congestion. The cargo has to be cleared away from a discharging berth before other ships can start to discharge, and there may be landside congestion hampering the delivery and carriage of goods. Inadequate roads or railways may be a long-standing problem - one that perhaps is getting even worse.

\subsubsection{Maritime transport: cost and time}

Movement of goods by maritime transport does not only include sea transport. By its nature, maritime transport is intermodal transport and often as many as three means of transport are involved: ship, truck and rail (Figure 2.13). The maritime transport cost structure comprises five components: (1) the cost of moving cargo from the shipper to the port of origin (typically) by truck; (2) the terminal handling charges at the port of origin; (3) the freight rate from the port of origin to the port of destination; (4) the terminal handling charges at the port of destination; and (5) the cost of transport from the port of destination to the final client (typically) by truck.

Figure 2.39 - Maritime transport cost structure

\begin{tabular}{c|c|c|c|c|c|}
$\begin{array}{c}\text { Road Transport from } \\
\begin{array}{c}\text { Shipper to Port of } \\
\text { Origin }\end{array}\end{array}$ & $\begin{array}{c}\text { Terminal Handling } \\
\text { Charges at the Port of } \\
\text { Origin }\end{array}$ & $\begin{array}{c}\text { Freight Rate [Port } \\
\text { of Origin to Port of } \\
\text { Destination] }\end{array}$ & $\begin{array}{c}\text { Terminal Handling } \\
\text { Charges at the Port of } \\
\text { Destination }\end{array}$ & $\begin{array}{c}\text { Road Transport from } \\
\text { Port of Destination to } \\
\text { Final Client }\end{array}$ \\
\hline
\end{tabular}

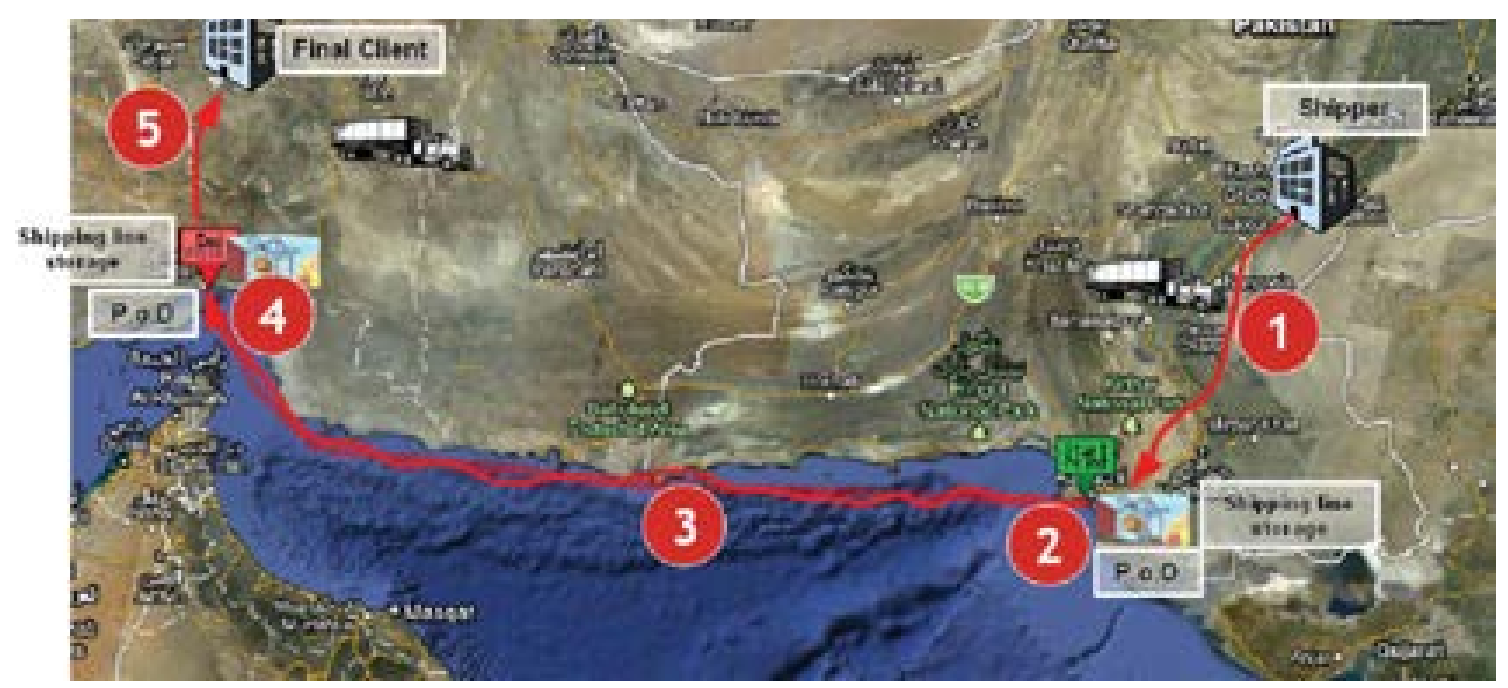

\subsubsection{Terminal handling charges}

Terminal handling charges (THC) are charged by shipping lines to recover payments to container terminals for loading and unloading cargo. Shippers at the port of origin are responsible for paying THC at the port of loading. This is defined as the origin THC. The consignees, or buyers, are responsible for paying the freight rate and THC upon discharge at the port of destination, known as the destination charge. This is consistent with the regulations of the International Chamber of Shipping. Most shipping lines have introduced separate charges for freight rates and THC. 
Figure 2.40 - Split of terminal handling charges between shipper and ship operator

\begin{tabular}{|l|l|c|}
\hline \multicolumn{1}{|c|}{ ACTIVITY } & COVERED BY \\
\hline 01 & Delivery MT and receiving full (+ all associated clerical work and reporting) & THC \\
\hline $\mathbf{0 2}$ & Inspection and reporting condition of container/ completion interchange & THC \\
\hline $\mathbf{0 3}$ & Inspection and reporting of seals and wiring removal invalied labels, re-sealing & THC \\
\hline $\mathbf{0 4}$ & Movement of container on/from chassis, berge or wagon & THC \\
\hline 05 & Internal transport of container to or from stack & THC \\
\hline 06 & Handling container into or out of stack & THC \\
\hline 07 & Reporting of chassis, berge and wagon activities in and or out of terminal & THC \\
\hline 08 & Storage of full container within time limits defined by Conference & THC \\
\hline 09 & Take laden box out of stack & THC \\
\hline 10 & Internal transport from stack to ship's side under hook & THC \\
\hline 11 & Move of container from ship's side to ship's rail & THC \\
\hline 12 & Move of container from ship's rail to ship's cell & Freight rate \\
\hline 13 & Opening and closing hatch covers & Freight rate \\
\hline 14 & Lashing of container & Freight rate \\
\hline 15 & Physical and clerical planning of vessel operation + reporting & Freight rate \\
\hline 16 & Overtime & Freight rate \\
\hline 17 & Wharfage & Freight rate \\
\hline
\end{tabular}

Source: PortStrategy, July 2005, Mercator Media

Given the relative stability of THC, albeit at varying levels according to trade routes, the ratio of THC to sea freight rate varies according to freight rates.

The following figure illustrates THC by port for the ten largest shipping operators.

Figure 2.41 - Terminal handling charges by port for ten largest shipping operators, April-June 2009

\begin{tabular}{|cl|c|c|}
\cline { 3 - 3 } \multicolumn{1}{c|}{} & \multicolumn{2}{|c|}{ Barcelona } \\
\hline 1 & Maersk/SAF & 20ft & 40ft \\
\cline { 2 - 3 } 2 & MSC & $€ 155$ & $€ 155$ \\
3 & CMA CGM & $€ 170$ & $€ 170$ \\
4 & Evergreen & $€ 160$ & \\
5 & Hapag Lloyd & $€ 120$ & $€ 140$ \\
6 & COSCO & $€ 125$ & $€ 125$ \\
7 & APL & $€ 255$ & $€ 255$ \\
8 & China Shipping & $€ 150$ & $€ 150$ \\
9 & NYK & $€ 210$ & $€ 210$ \\
10 & MOL & $€ 160$ & $€ 160$ \\
\hline
\end{tabular}

\begin{tabular}{|c|c|c|c|}
\hline & & \multicolumn{2}{|c|}{ Constanza } \\
\hline & & $20 \mathrm{ft}$ & $40 \mathrm{ft}$ \\
\hline 1 & Maersk/SAF & $\$ 200$ & $\$ 245$ \\
\hline 2 & MSC & & \\
\hline 3 & CMA CGM & $\$ 75$ & $\$ 130$ \\
\hline 4 & Evergreen & & \\
\hline 5 & Hapag Lloyd & $\$ 345$ & $\$ 418$ \\
\hline 6 & cosco & & \\
\hline 7 & APL & $\$ 90$ & $\$ 130$ \\
\hline 8 & China Shipping & $\$ 130$ & $\$ 130$ \\
\hline 9 & NYK & & \\
\hline 10 & $\mathrm{MOL}$ & $\$ 40$ & $\$ 90$ \\
\hline
\end{tabular}

\begin{tabular}{|c|c|c|c|}
\hline & & \multicolumn{2}{|c|}{ Hamburg } \\
\hline & & $20 \mathrm{ft}$ & $40 \mathrm{ft}$ \\
\hline 1 & Maersk/SAF & $€ 190$ & $€ 190$ \\
\hline 2 & MSC & $€ 180$ & $€ 180$ \\
\hline 3 & CMA CGM & $€ 185$ & $€ 185$ \\
\hline 4 & Evergreen & $€ 200$ & $€ 200$ \\
\hline 5 & Hapag Lloyd & $€ 210$ & $€ 210$ \\
\hline 6 & $\operatorname{cosco}$ & $€ 180$ & $€ 180$ \\
\hline 7 & APL & $€ 210$ & $€ 210$ \\
\hline 8 & China Shipping & $€ 200$ & $€ 200$ \\
\hline 9 & NYK & $€ 200$ & $€ 200$ \\
\hline 10 & $\mathrm{MOL}$ & $€ 210$ & $€ 210$ \\
\hline
\end{tabular}

\begin{tabular}{|c|c|c|c|}
\hline & & \multicolumn{2}{|c|}{ Hong Kong } \\
\hline & & $20 \mathrm{ft}$ & $40 \mathrm{ft}$ \\
\hline 1 & Maersk/SAF & HK $\$ 2,050$ & HK $\$ 2,750$ \\
\hline 2 & MSC & & \\
\hline 3 & CMA CGM & $H K \$ 2,065$ & $\mathrm{HK} \$ 2,750$ \\
\hline 4 & Evergreen & $\mathrm{HK} \$ 2,065$ & $\mathrm{HK} \$ 2,750$ \\
\hline 5 & Hapag Lloyd & HK\$2,065 & $\mathrm{HK} \$ 2,750$ \\
\hline 6 & $\operatorname{cosco}$ & & \\
\hline 7 & APL & $\mathrm{HK} \$ 1,800$ & $\mathrm{HK} \$ 2,650$ \\
\hline 8 & China Shipping & & \\
\hline 9 & NYK & $\mathrm{HK} \$ 1,400$ & $\mathrm{HK} \$ 2,000$ \\
\hline 10 & $\mathrm{MOL}$ & HK\$2,065 & $\mathrm{HK} \$ 2,750$ \\
\hline
\end{tabular}




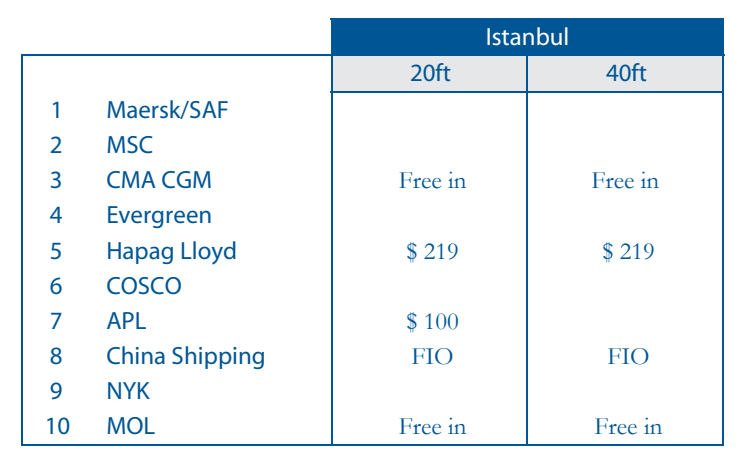

\begin{tabular}{|cl|c|c|}
\multicolumn{1}{c|}{} & \multicolumn{2}{c|}{ Piraeus } \\
\hline \multirow{2}{*}{1} & Maersk/SAF & 20ft & 40ft \\
\cline { 2 - 3 } 2 & MSC & & \\
3 & CMA CGM & Free in & Free in \\
4 & Evergreen & & \\
5 & Hapag Lloyd & $€ 112$ & $€ 112$ \\
6 & COSCO & & \\
7 & APL & FIO & FIO \\
8 & China Shipping & & \\
9 & NYK & & \\
10 & MOL & & \\
\hline
\end{tabular}

\begin{tabular}{|cl|c|c|}
\multicolumn{1}{c|}{} & \multicolumn{2}{c|}{ Pusan } \\
\hline $\mathbf{1}$ & Maersk/SAF & 20ft & 40ft \\
\cline { 2 - 4 } 2 & MSC & 100,000 & 135,000 \\
3 & CMA CGM & 101,000 & 137,000 \\
4 & Evergreen & 100,000 & 136,000 \\
5 & Hapag Lloyd & 101,000 & 137,000 \\
$\mathbf{6}$ & COSCO & & \\
7 & APL & 101,000 & 137,000 \\
8 & China Shipping & & \\
9 & NYK & 150,000 & 210,000 \\
10 & MOL & 100,000 & 136,000 \\
\hline
\end{tabular}

\begin{tabular}{|ll|c|c|}
\cline { 3 - 3 } \multicolumn{1}{c|}{} & \multicolumn{2}{|c|}{ Rotterdam } \\
\hline 1 & Maersk/SAF & $20 \mathrm{ft}$ & $40 \mathrm{ft}$ \\
\cline { 2 - 3 } 2 & MSC & $€ 185$ & $€ 185$ \\
3 & CMA CGM & $€ 175$ & $€ 175$ \\
4 & Evergreen & $€ 160$ & $€ 160$ \\
5 & Hapag Lloyd & $€ 200$ & $€ 160$ \\
6 & COSCO & $€ 140$ & $€ 200$ \\
7 & APL & $€ 190$ & $€ 140$ \\
8 & China Shipping & $€ 170$ & $€ 190$ \\
9 & NYK & $€ 160$ & $€ 170$ \\
10 & MOL & $€ 200$ & $€ 160$ \\
\hline
\end{tabular}

\begin{tabular}{|cl|c|c|}
\cline { 3 - 3 } \multicolumn{1}{c|}{} & \multicolumn{2}{c|}{ Shanghai } \\
\hline 1 & Maersk/SAF & RMB 475 & RMB 750 \\
\cline { 3 - 4 } 2 & MSC & At cost & At cost \\
3 & CMA CGM & RMB 1,297 & RMB 1,297 \\
4 & Evergreen & RMB 370 & RMB 560 \\
5 & Hapag Lloyd & RMB 460 & RMB 720 \\
6 & COSCO & RMB 374 & RMB 564 \\
7 & APL & RMB 476 & RMB 750 \\
8 & China Shipping & & \\
9 & NYK & RMB 880 & RMB 1,300 \\
10 & MOL & RMB 480 & RMB 720 \\
\hline
\end{tabular}

\begin{tabular}{|cl|c|c|}
\cline { 3 - 3 } \multicolumn{1}{c|}{} & \multicolumn{2}{c|}{ Shenzen } \\
\cline { 3 - 4 } 1 & Maersk/SAF & RMB 958 & RMB 1,849 \\
2 & MSC & RMB 1,297 & RMB 0 \\
3 & CMA CGM & RMB 370 & RMB 560 \\
4 & Evergreen & RMB 965 & RMB 1,842 \\
5 & Hapag Lloyd & & \\
6 & COSCO & RMB 476 & RMB 750 \\
7 & APL & & \\
8 & China Shipping & RMB 1,400 & RMB 2,300 \\
9 & NYK & RMB 965 & RMB 1,842 \\
10 & MOL &
\end{tabular}

\begin{tabular}{|cl|c|c|}
\cline { 3 - 3 } \multicolumn{1}{c|}{} & \multicolumn{2}{|c|}{ Singapore } \\
\hline 1 & Maersk/SAF & SGD 190 & SGD 270 \\
\cline { 2 - 3 } 2 & MSC & & \\
3 & CMA CGM & SGD 182 & SGD 270 \\
4 & Evergreen & SGD 182 & SGD 270 \\
5 & Hapag Lloyd & SGD 182 & SGD 270 \\
6 & COSCO & & \\
7 & APL & SGD 182 & SGD 270 \\
8 & China Shipping & & \\
9 & NYK & SGD 170 & SGD 170 \\
10 & MOL & SGD 182 & SGD 270 \\
\hline
\end{tabular}

\begin{tabular}{|ll|c|c|}
\multicolumn{1}{c|}{} & \multicolumn{2}{|c|}{ ST. Petersburg } \\
\hline \multirow{2}{*}{1} & Maersk/SAF & $20 \mathrm{ft}$ & $40 \mathrm{ft}$ \\
\cline { 2 - 4 } 2 & MSC & $\$ 290$ & $\$ 290$ \\
3 & CMA CGM & $\$ 370$ & \\
4 & Evergreen & $\$ 250$ & $\$ 370$ \\
5 & Hapag Lloyd & $\$ 220$ & $\$ 220$ \\
6 & COSCO & $\$ 200$ & $\$ 200$ \\
7 & APL & $\$ 300$ & $\$ 300$ \\
8 & China Shipping & $\$ 300$ & $\$ 300$ \\
9 & NYK & $\$ 250$ & $\$ 250$ \\
10 & MOL & $\$ 220$ & $\$ 220$ \\
\hline
\end{tabular}

Source: Terminal handling charges during and after the liner conference era, European Commission, 5 October 2009

The handling charges quoted by forwarders are slightly different as they include a profit margin (Figure 2.16). As indicated in the figure, THC costs amount to $\$ 175$ while all the other costs total $\$ \mathbf{5 3 0}$ ! Therefore, for the purpose of comparison, THC costs will be increased by 250 per cent to reflect "other costs". 
Figure 2.42 - Constanta port THC and other costs

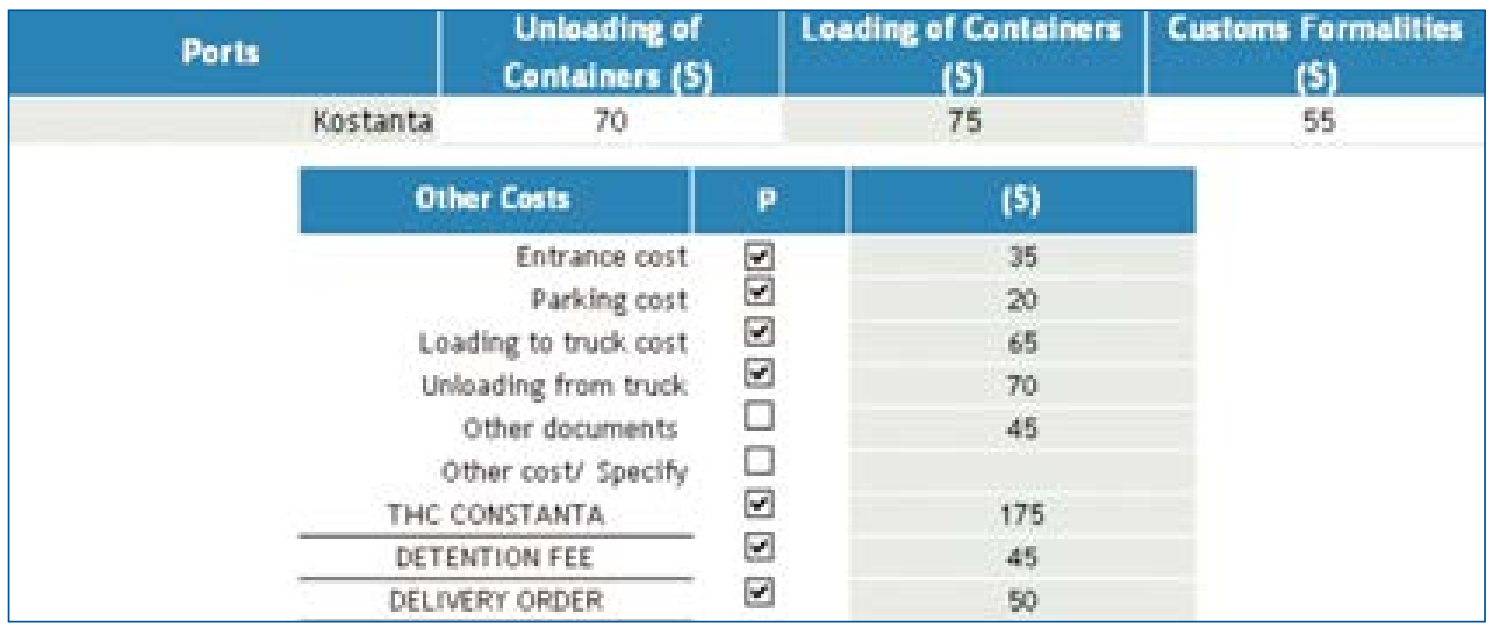

Source: Romanian Forwarders Association 2010

\begin{tabular}{|c|c|c|c|c|c|c|c|c|c|c|}
\hline \multirow{2}{*}{\multicolumn{3}{|c|}{ Continen }} & \multirow{2}{*}{\multicolumn{2}{|c|}{ 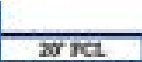 }} & \multirow{2}{*}{\multicolumn{2}{|c|}{$20 \mathrm{MTT}$}} & \multirow{2}{*}{\multicolumn{2}{|c|}{$40 \mathrm{raz}$}} & \multirow{2}{*}{\multicolumn{2}{|c|}{$6 \mathrm{MTr}$}} \\
\hline & & & & & & & & & & \\
\hline 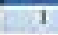 & 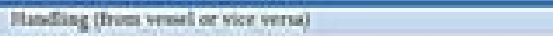 & Unit & US: & 500 & Eso & 400 & cos & 10800 & 10 & 5000 \\
\hline 2 & Lif esuf & * & tso & 200 & ESO & 3600 & tso & 2500 & 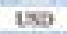 & 1500 \\
\hline 3 & 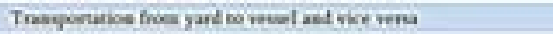 & s & use & 1500 & 130 & 1800 & LSD & 2500 & $1 \times 0$ & 2000 \\
\hline 4 & sthing pods beth & triet & tso & 3500 & tas & 2000 & tao & 4000 & $1 \leq 0$ & 2300 \\
\hline s & 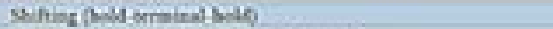 & - & two & 600 & 130 & 3500 & 100 & Nom & $1 \times 5$ & 400 \\
\hline 6 & 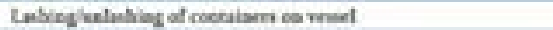 & - & & & & Lso & 600 & & & \\
\hline 7 & Chaniref cootiven & - & & & & ESD & 800 & & & \\
\hline 8 & 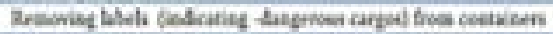 & * & & & & $1 \times 0$ & 2000 & & & \\
\hline 9 & 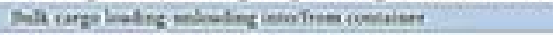 & $t=$ & & & & Sad & $27 \infty$ & & & \\
\hline 10 & 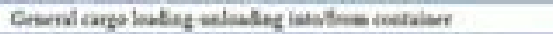 & $=$ & & & & 18 & 1200 & & & \\
\hline II & 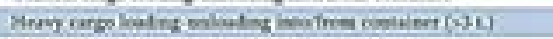 & Ares & ingtes & onerit & Aling & Gerores & $\cos 20$ & eneralc & $\operatorname{arcsc} 10$ & \\
\hline 12 & 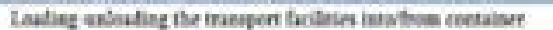 & Nowend & gronte & peritien & iato & aragen & Ahcer: & ant Cors & aten & 131 \\
\hline 1 & 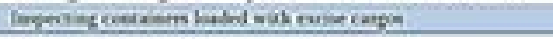 & +4 & & & & 189 & $\$ 60$ & & & \\
\hline tu & 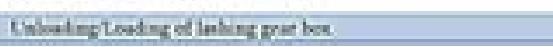 & $v e$ & & & & tso & $130 \infty$ & & & \\
\hline is & searat: & $\begin{array}{l}\text { Uaid } \\
\text { perdep }\end{array}$ & txo & 300 & teso & 100 & $\csc$ & 900 & $1 \times 0$ & 200 \\
\hline & 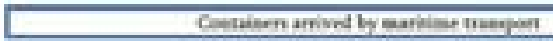 & & & & ente & $\Delta y^{2}$ & 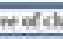 & thenty & & \\
\hline & 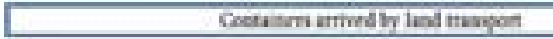 & & & & $\mathrm{t}_{\mathrm{n} 0}$ & deps: f & ivetes & $\operatorname{serg}$ & & \\
\hline & & & & $=$ & $\Rightarrow$ & & $\begin{array}{l}\text { bieds? } \\
\text { lentris }\end{array}$ & $\begin{array}{l}\text { Mentic } \\
\text { inomens }\end{array}$ & was & \\
\hline
\end{tabular}

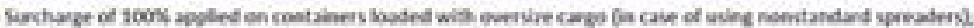

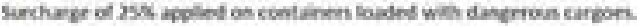

Source: Port of Poti

\subsubsection{Freight rates}

Figure 2.17 illustrates the freight rates along the Asia-Europe route from 1993 to 2007. Significant fluctuations in these freight rates result in similar fluctuations in the THC/freight rate ratio. The THC/freight ratio on average has been in the 10-15 per cent range on the Asia to North Europe route on a destination basis. 
Figure 2.43 - Freight rates for Asia/Europe/Asia

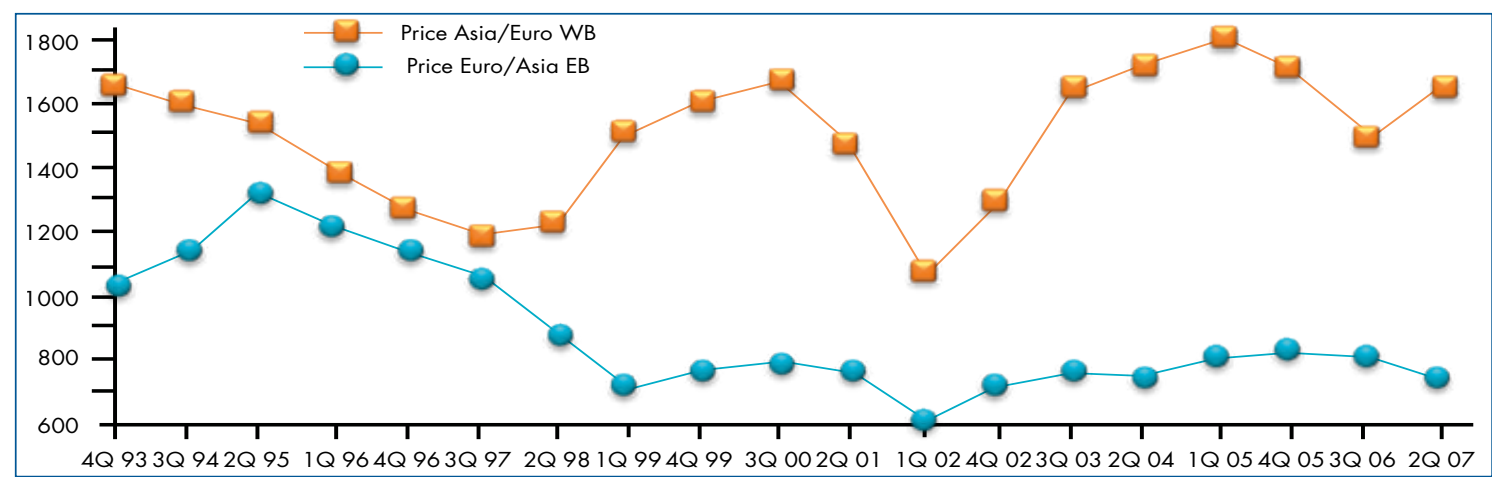

Source: Containerisation International Freight Facts

In the short term, freight rates are driven by the relationship of supply and demand for shipping. In the longer term, the available capacity also influences freight rates. Figure 2.18 shows a relationship between demand and supply that translates into freight rate volatility. The 1991 and 2001, recessions with their consequent drop in cargo demand coinciding with excess shipping capacity supply resulted in declining freight rates. Equally, the end of the recession coincided with sharp increases in freight rates.

Figure 2.44 - Supply versus demand, 2011

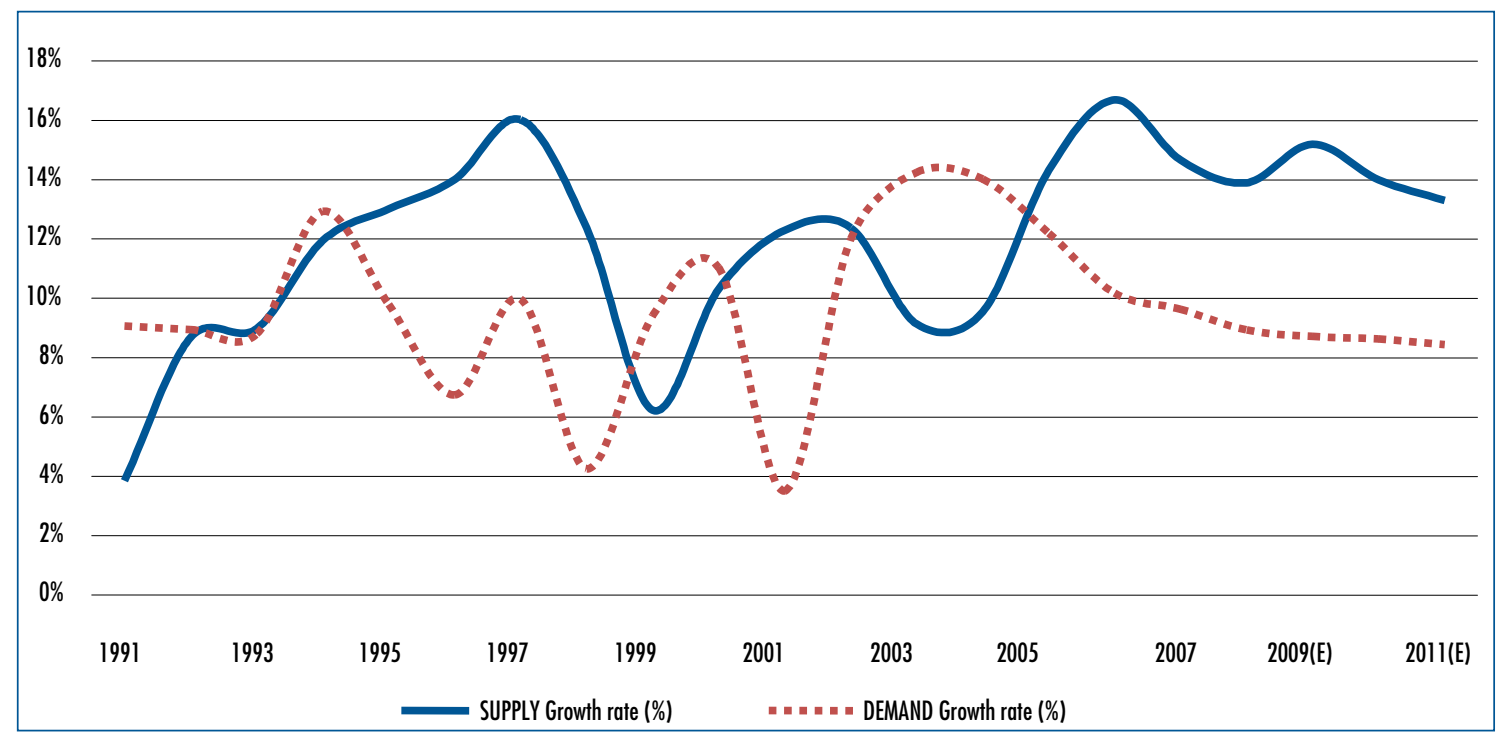

Source: Drewry's Annual Container Market Review 2007-2008, supplemented by AXS Liner 2008

Increasingly, shippers are negotiating "all-in" rates in which the three elements of sea freight, surcharges and terminal handling charges are included. In the 2008-2009 recession, freight rates collapsed with spot rates from Asia to northern Europe as low as $\$ 100$.

The following are maritime freight rates for 20-foot and 40-foot containers from the ports of Shanghai, Constanta, Varna and Bandar Abbas to anywhere in the world (data collected in May-June 2010). 
Table 2.4 - Maritime freight rates (US\$)

\section{FROM}

XINGANG/QINGDAO/DALIAN [China] (US\$)

\begin{tabular}{|c|c|c|c|}
\hline \multicolumn{4}{|c|}{ TO } \\
\hline Middle East & $20^{\prime} / 40 / 40^{\prime} \mathrm{HCl}^{13}$ & & $20^{\prime} / 40 / 40^{\prime} \mathrm{HC}$ \\
\hline Dubai/Jebel Ali & $1500 / 2400 / 2400$ & B.Abbas & $1600 / 2500 / 2500$ \\
\hline Abu Dhabi & $1700 / 2800 / 2800$ & Sharjah & $1700 / 2800 / 2800$ \\
\hline Dammam & $1600 / 2500 / 2500$ & Riyadh & $1800 / 2900 / 2900$ \\
\hline Bahrain & $1800 / 2900 / 2900$ & Doha & $1900 / 3$ 100/3 100 \\
\hline Kuwait & $1700 / 2800 / 2800$ & Muscat & $1800 / 2900 / 2900$ \\
\hline Um quaser & $2300 / 3700 / 3700$ & & \\
\hline India and Pakistan & $20^{\prime} / 40 / 40^{\prime} \mathrm{HC}$ & & $20^{\prime} / 40 / 40^{\prime} \mathrm{HC}$ \\
\hline Karachi/qasim & $1500 / 2400 / 2400$ & Nahva sheva & $1500 / 2400 / 2400$ \\
\hline Colombo & $1400 / 2300 / 2300$ & Chennai/madras & $1450 / 2400 / 2400$ \\
\hline Calcutta & $1700 / 2700 / 2700$ & Haldia & $1700 / 2700 / 2700$ \\
\hline Tuticorin & $1600 / 2600 / 2600$ & Cochin & $1600 / 2600 / 2600$ \\
\hline Red Sea & $20^{\prime} / 40 / 40^{\prime} \mathrm{HC}$ & & $20^{\prime} / 40 / 40^{\prime} \mathrm{HC}$ \\
\hline Jeddah & $1900 / 3000 / 3000$ & Aden & $1550 / 2600 / 2600$ \\
\hline Aqaba & $2000 / 3200 / 3200$ & Hodeidah & 2 100/3 400/3400 \\
\hline Sokhna & $2000 / 3200 / 3200$ & Port sudan & $2300 / 3800 / 3800$ \\
\hline \multicolumn{3}{|c|}{ Main ports of South-East Asia } & $20^{\prime} / 40 / 40^{\prime} \mathrm{HC}$ \\
\hline \multicolumn{3}{|c|}{$\begin{array}{l}\text { SINGAPORE/PORT KELANG/SURABAYA/JAKARTA/PASIR GUDANG/PENANG/ } \\
\text { SAMARANG/SURABAYA/BALAWAN }\end{array}$} & $700 / 900 / 900$ \\
\hline \multicolumn{3}{|c|}{ Main ports of West Mediterranean } & $20^{\prime} / 40 / 40^{\prime} \mathrm{HC}$ \\
\hline \multicolumn{3}{|c|}{$\begin{array}{l}\text { BARCELONA/ FOS/VALENCIA/NAPLES/LA SPEZIA/GIOIA TAURO/ } \\
\text { LIVORNO(LEGHON)/VENICE/ MARSEILLES }\end{array}$} & 2 100/3 800/3900 \\
\hline \multicolumn{3}{|c|}{ Main ports of East Mediterranean } & $20^{\prime} / 40 / 40^{\prime} \mathrm{HC}$ \\
\hline \multicolumn{3}{|c|}{$\begin{array}{l}\text { ISTANBUL/PORT SAID/GEMLIK/HYDARPASA/IZMIR/MERSIN/ ALEXANDRIA/ } \\
\text { DAMIETTA/BEIRUT/LATTAKIA }\end{array}$} & $2500 / 4600 / 4700$ \\
\hline \multicolumn{3}{|c|}{ Main ports of Europe } & $20^{\prime} / 40 / 40^{\prime} \mathrm{HC}$ \\
\hline \multicolumn{3}{|c|}{$\begin{array}{l}\text { ANTWERP/ HAMBURG/ROTTERDAM/ LE HAVRE /FELEXSTOWE/ SOUTHAMPTON/ } \\
\text { BREMEN/BREMEN HARVEN / DUNKIRK }\end{array}$} & $2150 / 3900 / 4000$ \\
\hline \multicolumn{3}{|c|}{ Main ports of Black Sea } & $20^{\prime} / 40 / 40^{\prime} \mathrm{HC}$ \\
\hline \multicolumn{3}{|c|}{ CONSTANTA/ODESSA/ILLICHEVSK/VARNA/NOVOROSSIYSK/POTI } & $2400 / 4300 / 4300$ \\
\hline \multicolumn{3}{|c|}{ Main ports of Japan and the Republic of Korea } & $20^{\prime} / 40 / 40^{\prime} \mathrm{HC}$ \\
\hline \multicolumn{3}{|c|}{ JAPAN AND THE REPUBLIC OF KOREA } & $100 / 200 / 200$ \\
\hline
\end{tabular}




\section{FROM}

Costanza Port (Romania) (US\$)

\begin{tabular}{|c|c|c|c|}
\hline & \multicolumn{3}{|c|}{ TO } \\
\hline Kaliningrad & $2500 / 3700 /-$ & Busan & $20^{\prime}$ GP/ 40' GP / 40' HC \\
\hline Lianyungang & $2600 / 4500 /-$ & Barcelona & $900 / 1300 /-$ \\
\hline Rotterdam & $1400 / 2100 /-$ & Odessa & $1350 / 2$ 050/- \\
\hline Hamburg & $1400 / 2100 /-$ & & $750 / 1250 /-$ \\
\hline \multicolumn{2}{|r|}{ FROM }
\end{tabular}

Varna Port (Bulgaria) (US\$)

\begin{tabular}{|c|c|c|c|}
\hline \multicolumn{4}{|c|}{ TO } \\
\hline & $20^{\prime} \mathrm{GP} / 40^{\prime} \mathrm{GP} / 40^{\prime} \mathrm{HC}$ & & $20^{\prime} \mathrm{GP} / 40^{\prime} \mathrm{GP} / 40^{\prime} \mathrm{HC}$ \\
\hline Kaliningrad & $1680 / 2769 /-$ & Busan & $1660 / 2920 /-$ \\
\hline Lianyungang & 2 170/3 880/- & Barcelona & $995 / 1450 /-$ \\
\hline Rotterdam & $950 / 1590 /-$ & Odessa & 1 100/2 200/- \\
\hline Hamburg & 1 120/1 670/- & Shangai & $2060 / 3$ 650/- \\
\hline Vladivostok & 3 060/5 460/- & & \\
\hline \multicolumn{4}{|c|}{ FROM } \\
\hline \multicolumn{4}{|c|}{ Bandar Abbas (US\$) } \\
\hline \multicolumn{4}{|c|}{ TO } \\
\hline & $20^{\prime} / 40^{\prime}$ & & $20^{\prime} / 40^{\prime}$ \\
\hline Karachi & $400 / 600$ & Ezmir & $1000 / 1750$ \\
\hline Istanbul & $1000 / 1650$ & Shanghai & $850 / 1550$ \\
\hline Rotterdam & $650 / 980$ & Hamburg & $650 / 980$ \\
\hline
\end{tabular}

\subsubsection{Time schedule}

A standard container ship speed is about 25 knots while at "slow steaming", container ships travel at 20-22 knots. Recently, speeds have been further reduced with the introduction of "extra slow steaming", i.e. ships operating at speeds of 17-19 knots or less. In 2010, "extra slow steaming" absorbed 554,000 TEU - about the magnitude of currently laid-up capacity. ${ }^{14}$

Figure 2.19 shows the time schedule in days and distance in nautical miles $(\mathrm{nm})$ of the most common maritime routes. common maritime routes. ${ }^{15}$

14 Dynamar: Dynaliners 11/2010, reporting data from AXS-Alphaliner, 4 June 2010.

15 These routes have been calculated by using the online maritime calculator http://www.axsmarine.com/public. 
Figure 2.45 - Distance and time analysis, common maritime routes

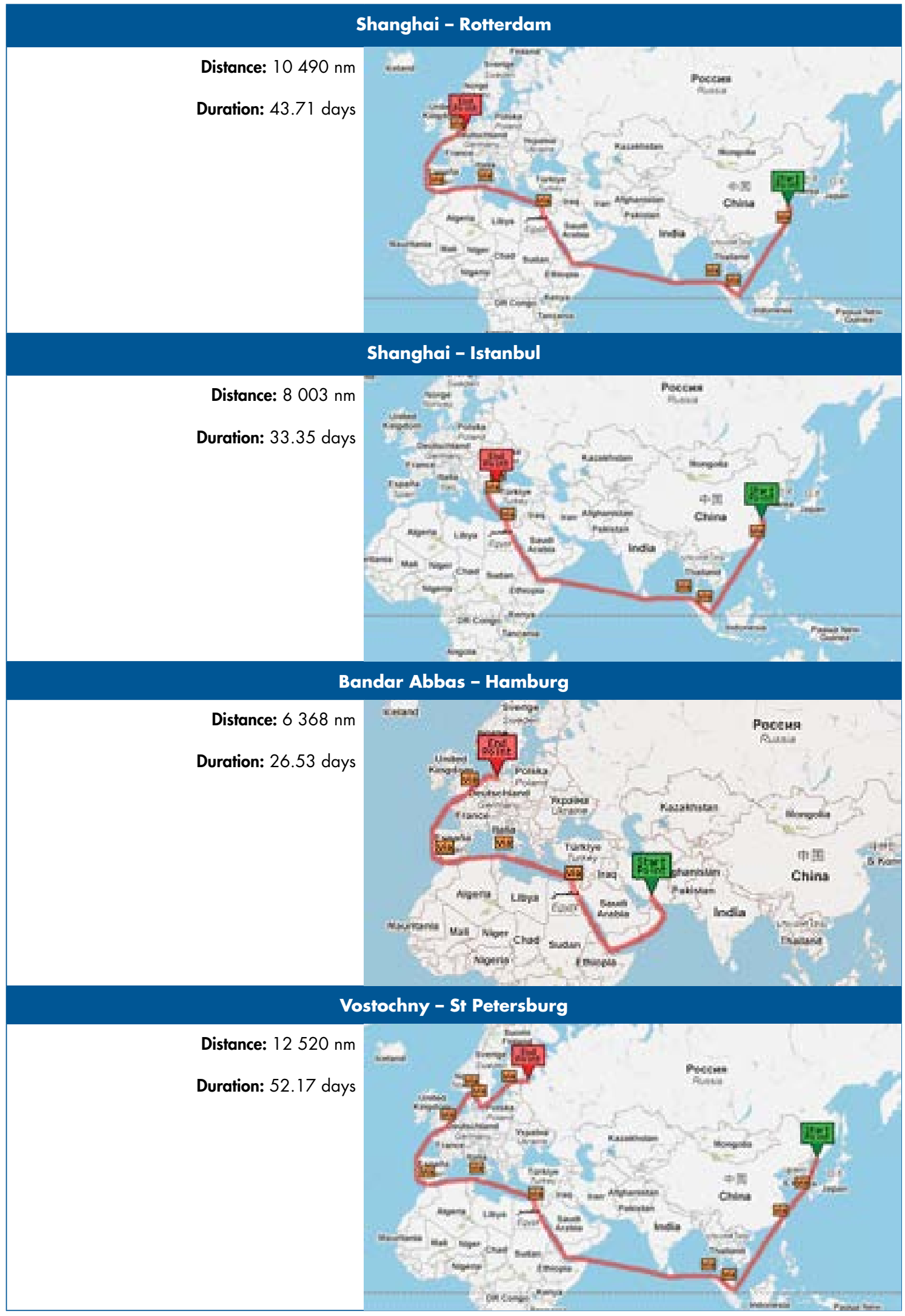




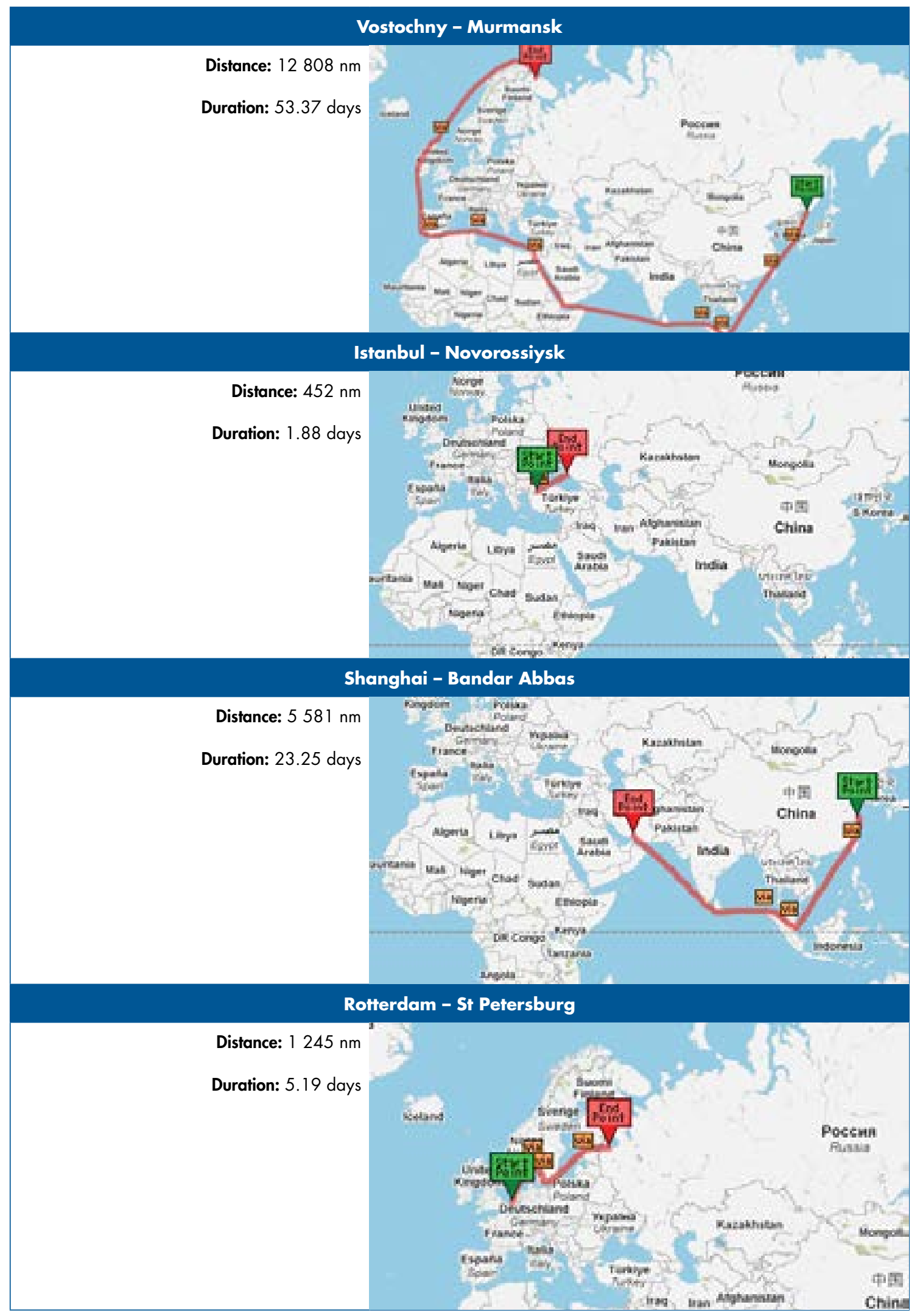




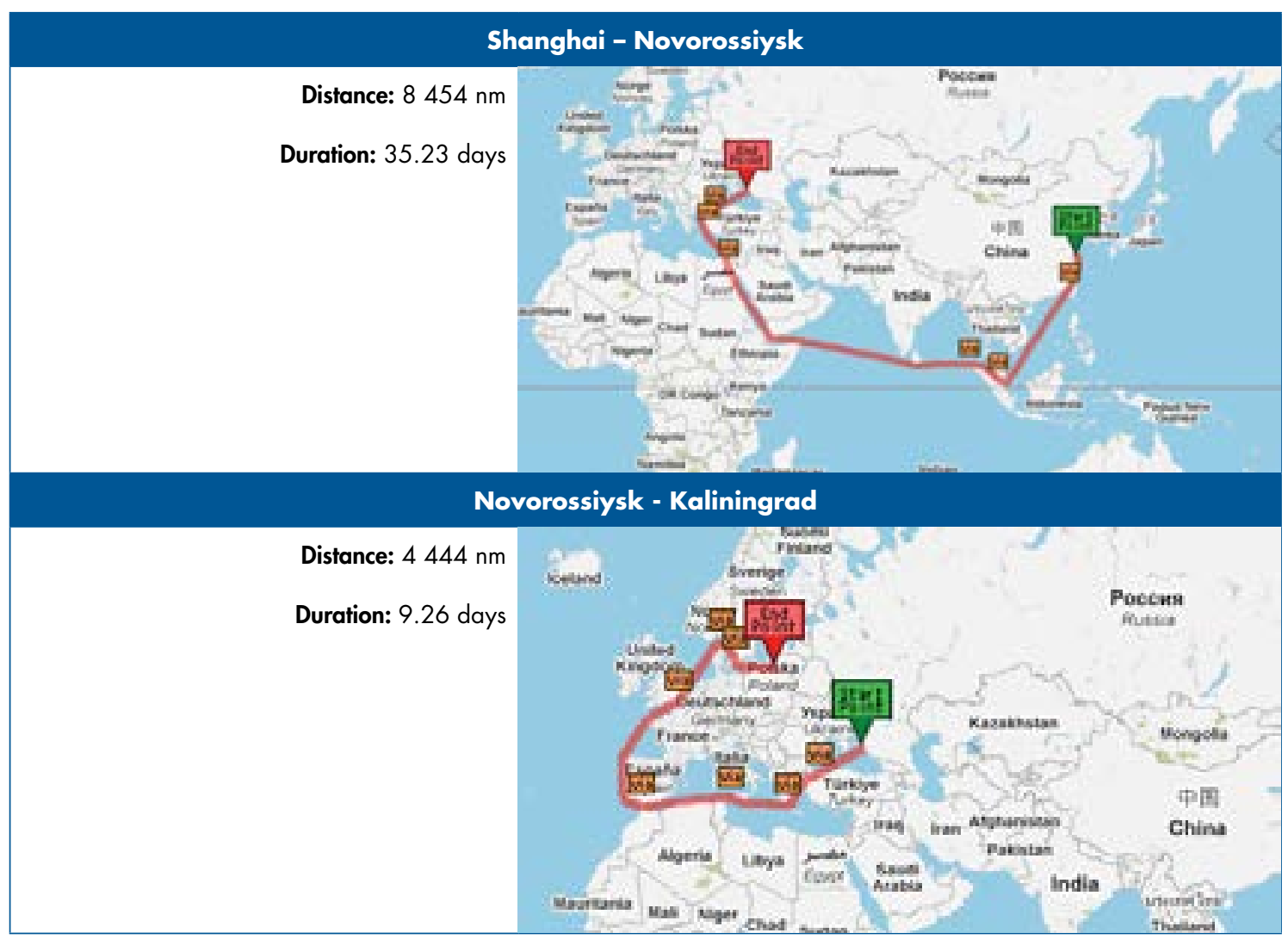

Source: www.axsmarine.com/

\subsubsection{Road transport costs}

Road transport costs are one of important components of maritime shipping. Trucks move containers from the shipper to the port of origin and from the port of destination to the final client. Most of the time, road transport to these destinations is round trip as the truck picks up the empty containers from the storage place of the shipping lines/forwarders - normally close to the port - brings it to the shippers' warehouse, waits for the container to be loaded and, finally, moves the loaded container to the port of origin. The same, albeit the other way around, happens in the port of destination/unloading station where the truck picks up the loaded container from the container freight station of the port/station, brings it to the warehouse of the final client, waits until it is unloaded and then brings back the empty container to the storage place of the shipping line. 
Figure 2.46 - Road transport involvement in maritime transport

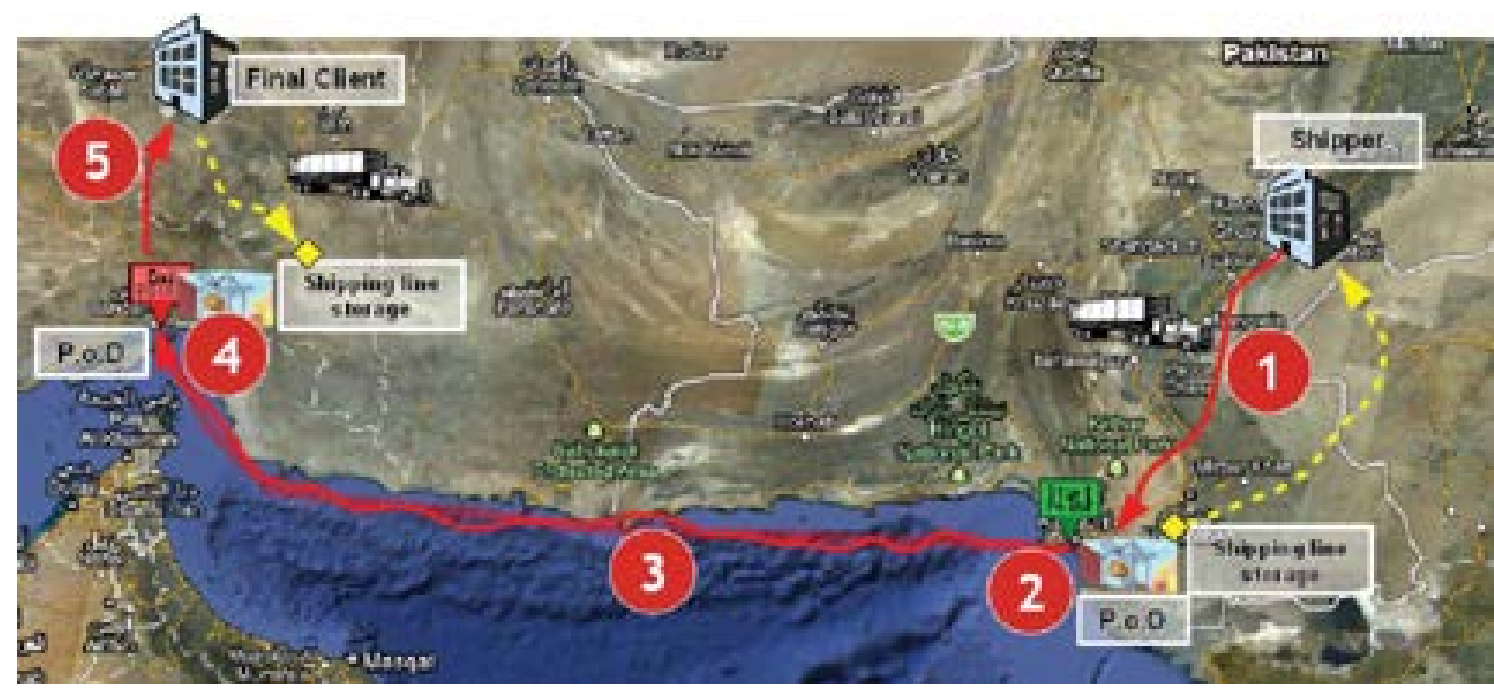

It is important to know how much it costs, in each country, for a truck to transport containers from the port to a final client or shipper in a $20-\mathrm{km}$ radius of the port. That distance is normally the average distance from a port to logistics or manufacturing areas. Figure 2.21 provides the flat rates for a truck delivering a container (20- or 40-foot) in a $20-\mathrm{km}$ radius of the port (data collected in June 2010).

Figure 2.47 - Road transport rates

\begin{tabular}{|c|c|}
\hline Country & Cost of road transport (in \$) \\
\hline Afghanistan & 150 \\
\hline Armenia & 140 \\
\hline Azerbaijan & 160 \\
\hline Belarus & 180 \\
\hline Bulgaria & 195 \\
\hline China & $100-200$ \\
\hline Georgia & 180 \\
\hline Germany & $250-350$ \\
\hline Greece & 250 \\
\hline Iran & $50-150$ \\
\hline Kazakhstan & $120-180$ \\
\hline Kyrgyzstan & 130 \\
\hline Latvia & 230 \\
\hline Mongolia & 120 \\
\hline Poland & $200-280$ \\
\hline Republic of Moldova & 150 \\
\hline Romania & $150-250$ \\
\hline Russian Federation & $80-200$ \\
\hline Tajikistan & 130 \\
\hline
\end{tabular}




\begin{tabular}{|c|c|}
\hline Country & Cost of road transport (in \$) \\
\hline Turkey & $180-300$ \\
\hline Turkmenistan & 130 \\
\hline Ukraine & $150-250$ \\
\hline Uzbekistan & $100-150$ \\
\hline
\end{tabular}

In general, international road transport costs are quite similar. From Istanbul to Western Europe, the rate is $€ 0.82-0.92$ per $\mathrm{km}$ and from Western Europe to Istanbul is $€ 0.9-1$. From Istanbul to Almaty, Kazakhstan the rate is $\$ 1-1.4 / \mathrm{km}$ and in the other direction it is $\$ 0.8-1$ per $\mathrm{km}$. The rate of $\$ 1.4$ per $\mathrm{km}$ for long distances appears to be the average tariff.

\subsection{Rail time-costs along Euro-Asian routes}

Comparing maritime and rail routes requires a thorough analysis of shipping time and cost per container. The cost-per-container analysis is easier to perform than the time analysis because railway tariffs are typically available.

Figure 2.48 - Wagon loading scenarios

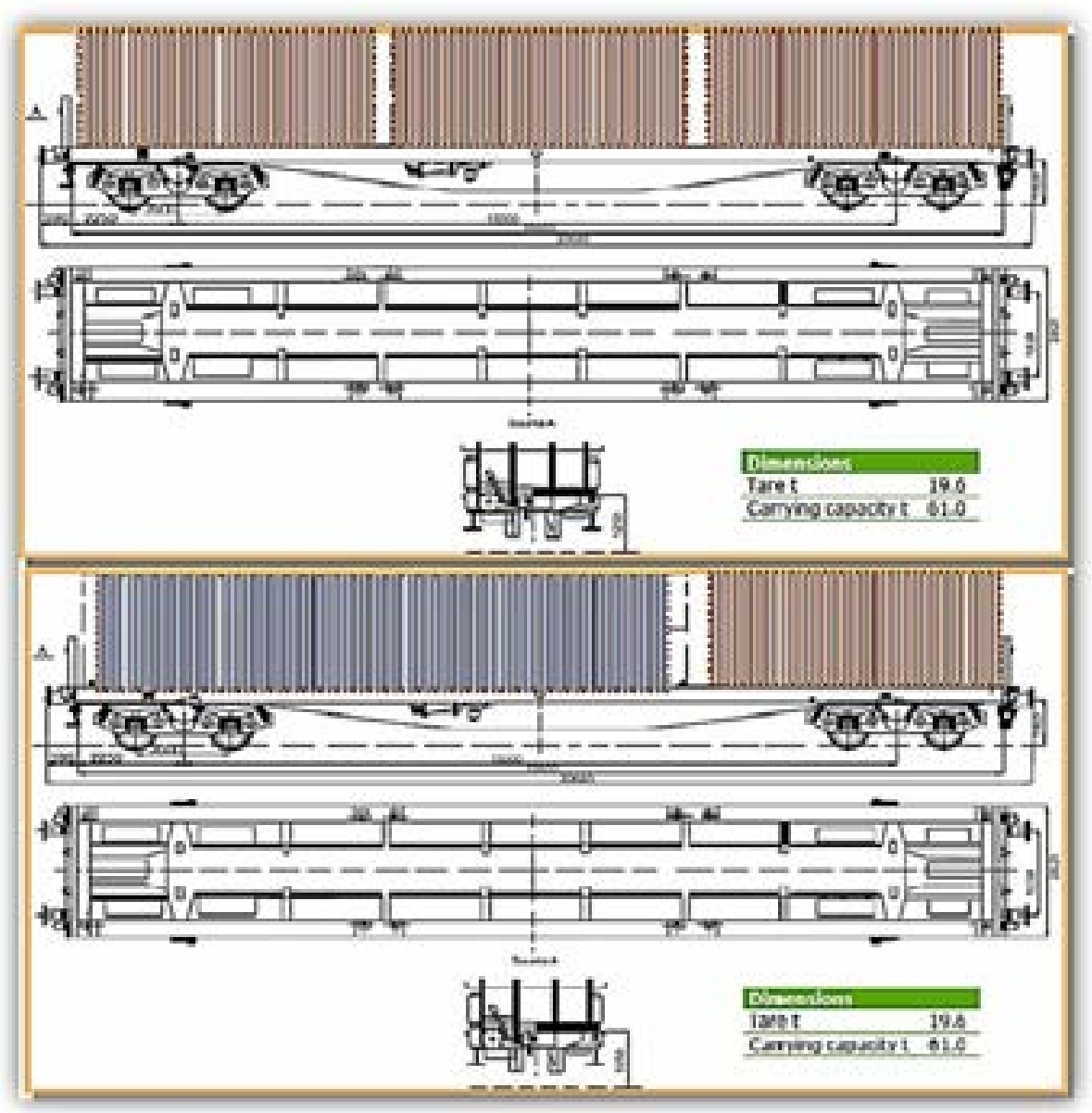

Source: Author's publications

The time schedule is more difficult to assess. Determining the time schedule of a block train is a complicated task and often requires a simulation or a demonstration run to identify all the issues and make appropriate calculations. (The majority of railways did not reply to questions relating to 
time in the UNECE questionnaire: see Appendix 2.I.) The maximum loading point, or optimal loading scenario, refers to the number of containers that can be loaded on a train (Figure 2.22). The train, including the locomotive's power to pull, and each wagon have weight and loading restrictions that should be respected. Theoretically, one International Standards Organization (ISO) container wagon can hold three 20-foot containers or one 40-foot container and one 20foot container. Because of the weight restrictions, one 40-foot container or one 20-foot container is normally loaded. Sometimes, cargo permitting (cotton, for instance) or when there are empty containers to load, then two 20-foot containers can also be loaded or, less frequently, one 40-foot container and one 20-foot. These different "types" of containers - 40-foot, 20 -foot - typically weigh less than 15 tons. Also, the transport of empty 20 -foot or 40 -foot containers is charged differently.

The cost structure is the most difficult part of this analysis. Normally, rail organizations do not know the cost of their operations. This is mainly because of their organizational structure, where investments in infrastructure and operations form part of the same company.

For this comparisonexercise, points of origin and points of destination of interest are identified and these points "compose" the block train time schedule and cost according to the information analysis for each country participating on this route. Figure 2.27 illustrates the calculation of time-cost analysis for the block trains of the study. This includes three steps: (a) road transport from the shipper to the loading station; (b) rail service; (c) road transport to the final shipper.

Figure 2.49 - Calculation of time and cost for a block train

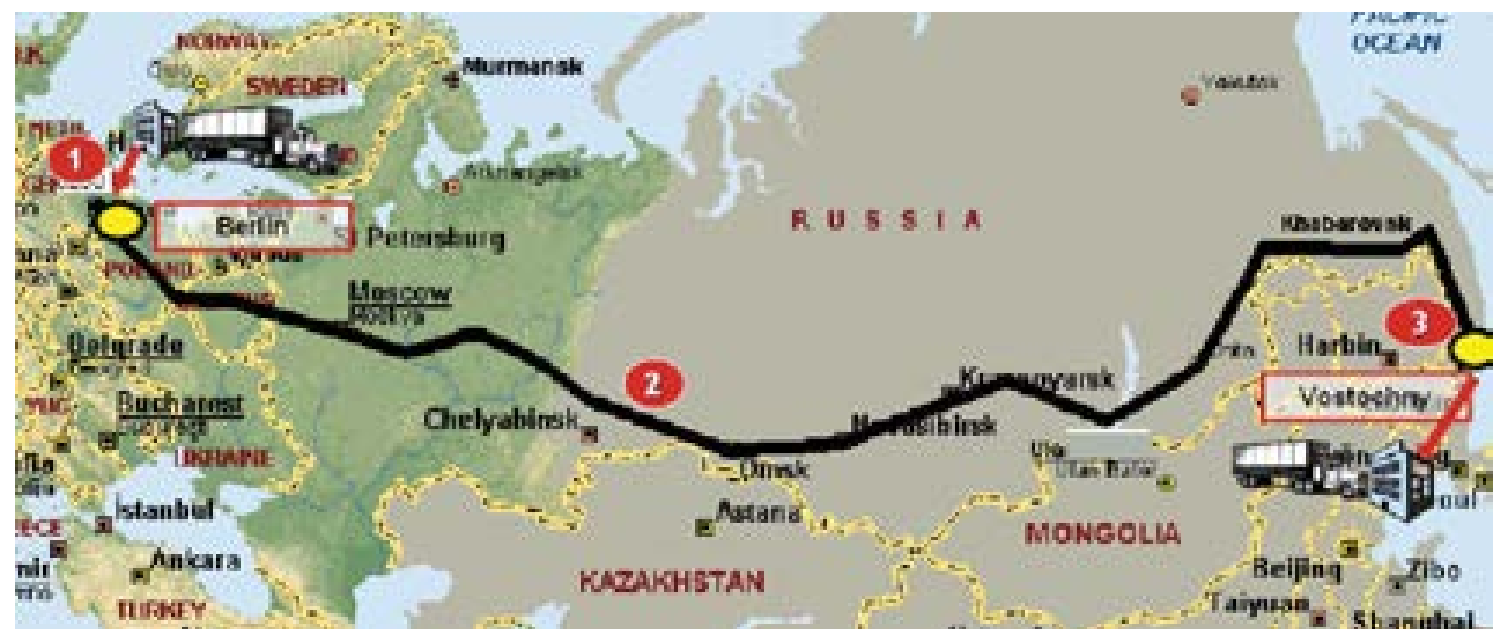

Transport of container by truck from original shipper to main train station to be loaded on the train, loading/documentation expenses

2 Block train service: Rail transport of container from Berlin to Vostochny Composition of time schedule and tariff costs

3 Delivery of the container by truck from the final unloading station to the final shipper. Unloading/ documentation expenses

Source: Author's publications

\subsubsection{Time schedule analysis}

The formulation of an integrated time schedule for a block train is a complex task. The number of countries, operating conditions in these countries, stopovers and the reasons for these stopovers all directly influence the time schedule. Regional characteristics are also important and constitute significant factor. For instance, in CIS countries, there are trans-shipment stopovers due to gauge 
changes and security. In western European countries, there are stopovers because of passenger train priority. All these reasons influence the final time schedule and time-schedule operators should analyse all parameters in order to finalize total travelling time, departure and arrival time.

The timetable of a block train is as important as its operation. The timetable and its reliability are the most important marketing tools of train operators, even more so than tariffs, and track and trace services. The development of the timetable and its reliable implementation is a particularly difficult and laborious task, not only because of the usual factors that influence transportation but also because of the particularities of a specific route.

\subsubsection{The gauge issue}

The standard rail gauge of $1,435 \mathrm{~mm}$ has been adopted in many parts of the world, across North America and most of Western Europe. It accounts for about 60 per cent of the world's railways. Other gauges have been adopted, such as the broad gauge $(1,520 \mathrm{~mm})$ in the former Soviet Union, accounting for about 17 per cent of railways. This makes integration of rail services difficult since both freight and passengers are required to change from one railway system to the other in France and Spain, Eastern and Western Europe, and between the Russian Federation and China. The potential of the Euro-Asian land bridge is limited in part by these gauge differences.

\subsubsection{Field experience}

After personally experiencing demonstration train runs, mainly in Central Asia and the Balkans, the author was able to collect actual data for travelling times in different countries.

The speed of the train is calculated using the following formula:

$$
\text { Average travelling time }(\mathbf{k m} / \mathrm{hr})=\frac{\text { Total route kilometres }}{\text { Total travelling time (travelling + stopovers) }}
$$

Table 2.5 - Travel data

\begin{tabular}{|c|c|c|c|c|}
\hline id & Country runs & Total km travelled & Total time (hrs) & Avg speed (km/hr) \\
\hline 1 & Iran & 2345 & 112.20 & 21.00 \\
\hline 2 & Turkey & 1995 & 84.00 & 23.00 \\
\hline 3 & Turkmenistan & 469 & 32.15 & 14.00 \\
\hline 4 & Kazakhstan & 969 & 27.56 & 35.00 \\
\hline 5 & Bulgaria & 174 & 11.00 & 16.00 \\
\hline 6 & Greece & 170 & 8.00 & 21.25 \\
\hline 7 & Uzbekistan & 670 & 40.18 & 17.00 \\
\hline \multicolumn{5}{|c|}{ Published Case Studies } \\
\hline id & Route runs & Total km travelled & Total time (days) & Avg speed \\
\hline 8 & Peking - Hamburg ${ }^{16}$ & 9992 & 15 & 27.75 \\
\hline 9 & Vesoul-Kaluga ${ }^{17}$ & 3000 & 5 & 25.00 \\
\hline 10 & Tran Siberian ${ }^{18}$ & 9349 & 11 & 35.00 \\
\hline 11 & $\begin{array}{l}\text { Tianjin (China) to Ulaanbaatar } \\
\text { (Mongolia) }\end{array}$ & 1691 & 3 & 22.40 \\
\hline
\end{tabular}

16 DB Block Train, "Railway Market" - GEE Review No 1, 2008.

17 PEUGEOT BLOCK TRAIN, Committee on International Transport (CIT) Newsletter, February 2010.

18 Tran-Siberian Block Train, presented by Russian Railways at UNECE meeting. 


\begin{tabular}{|c|c|c|c|c|}
\hline id & Country runs & Total km travelled & Total time (hrs) & Avg speed (km/hr) \\
\hline 12 & $\begin{array}{c}\text { Lianyungang (China) to Almaty } \\
\text { (Kazakhstan) }\end{array}$ & 5020 & 7 & 28.80 \\
\hline 13 & $\begin{array}{c}\text { Brest (Belarus) to Ulaanbaatar } \\
\text { (Mongolia) }\end{array}$ & 7180 & 12 & 30.70 \\
\hline 14 & $\begin{array}{c}\text { Nakhodka (Russian Federation) to } \\
\text { Malaszewicze (Poland) }\end{array}$ & 10335 & 11 & 35.00 \\
\hline 15 & Islamabad to Istanbul20 & 6566 & 24.9 \\
\hline
\end{tabular}

Figure 2.24 summarizes the average train speed in the three regions.

Figure 2.50 - Average train speed

\begin{tabular}{|c|c|c|}
\hline EU & Asia $^{21}$ & CIS \\
\hline $26 \mathrm{~km} /$ hour & $21 \mathrm{~km} /$ hour & $34 \mathrm{~km} /$ hour \\
\hline
\end{tabular}

Source: Author's analysis

This is not the actual speed of the train but the speed of the total travelling time, meaning actual travelling time and stopovers.

These average train speeds are applied to time schedules wherever actual data were unavailable. ${ }^{22}$ It should be noted that waiting times at borders are not an important factor for this kind of service - block trains - mainly because they are a result of government or state-owned railway agreements. In these cases, border crossings are part of the common consensus concerning the operations of these trains, which implies non-stop rail service.

\section{Table 2.6 - Route, distance and time}

\section{Afghanistan}

Afghanistan is a large, landlocked country with movements severely limited by rugged terrain. The country has less than $25 \mathrm{~km}$ of railroad track, which is used for shipping goods to/from Turkmenistan and Uzbekistan.

\section{Armenia}

\begin{tabular}{|c|c|c|c|}
\hline \multicolumn{4}{|c|}{ Bagratashen - (Georgian border) - Akhuryan (Turkish border) } \\
\cline { 1 - 3 } id & Route & Distance $(\mathrm{km})$ & Time (hours) \\
\hline $\mathbf{1}$ & Bagratashen - Uzunla & 48.0 & \\
\cline { 1 - 3 } $\mathbf{2}$ & Uzunla - Tumanyan - Kirovakan & 37.6 & \\
\hline 3 & Kirovakan - Spitak - Gyumri - Akhuryan & 75.5 & \\
\hline \multicolumn{2}{|c|}{ TOTAL } & 161.0 & 8 \\
\hline
\end{tabular}

19 This was a demonstration run organized by UNESCAP.

20 This was a demonstration run organized by ECO.

${ }^{21}$ Asian countries excluding those that are CIS members.

22 When no actual data concerning distance in kilometres between stations or even for the whole length of one country's railroads were available, combined data from Google earth, Autoroute Microsoft GIS software and different maps were used. 


\section{Azerbaijan}

\begin{tabular}{|c|c|c|c|}
\hline \multicolumn{4}{|c|}{ Astara- (Iranian border) - Beyuk Kesik (Georgian border) } \\
\cline { 1 - 3 } id & Route & Distance $(\mathrm{km})$ & Time (hours) \\
\hline $\mathbf{1}$ & Astara - Lenkoran - Bal'yany - Quazimamad & 235.0 & \\
\hline $\mathbf{2}$ & Quazimamad - Kyurdamir - Udzhary - Yevlakh & 276.0 \\
\hline 3 & Yevlakh - Dilmameldi - Tauz & 88.2 & \\
\hline 4 & Tauz - Akstafa - Beyuk Kesik & 67.8 & \\
\hline & TOTAL & 667.0 & 32.25 \\
\hline
\end{tabular}

\section{Belarus}

\begin{tabular}{|c|c|c|c|}
\hline \multicolumn{3}{|c|}{ Redki (Russian Federation border) - Brest (Polish border) } \\
\cline { 1 - 2 } id & Route & Distance $(\mathrm{km})$ & Time (hours) \\
\hline $\mathbf{1}$ & Redki - Orsha & 45.9 & \\
\hline $\mathbf{2}$ & Orsha - Minsk & 221.3 & \\
\hline $\mathbf{3}$ & Minsk - Brest & 346.0 & \\
\hline \multicolumn{2}{|c|}{ TOTAL } & 613.2 & 18 \\
\hline
\end{tabular}

Novaya Guta - (Ukrainian border) - Brest (Polish border)

\begin{tabular}{|c|c|c|c|}
\hline id & Route & Distance $(\mathrm{km})$ & Time (hours) \\
\hline 1 & Novaya Guta - Gomel & 22.0 & \\
\hline 2 & Gomel - Minsk & 298.1 & \\
\hline 3 & Minsk - Brest & 346.0 & \\
\hline \multicolumn{2}{|r|}{ TOTAL } & 666.1 & 20 \\
\hline
\end{tabular}

Novaya Guta - (Ukrainian border) - Gudogay (Lithuanian border)

\begin{tabular}{|c|c|c|c|}
\hline id & Route & Distance $(\mathrm{km})$ & Time (hours) \\
\hline 1 & Novaya Guta - Gomel & 22.0 & \\
\hline 2 & Gomel-Minsk & 298.1 & \\
\hline 3 & Minsk - Gudogay & 100.0 & \\
\hline 4 & Gudogay - Lithuanian borders & 45.0 & \\
\hline \multicolumn{2}{|r|}{ TOTAL } & 465.0 & 14 \\
\hline
\end{tabular}




\section{Bulgaria}

\begin{tabular}{|c|c|c|c|}
\hline \multicolumn{4}{|c|}{ Kulata (Greek border) - Ruse (Romanian border) } \\
\hline id & Route & Distance $(\mathrm{km})$ & Time (hours) \\
\hline 1 & Kulata - Sofia & 174.0 & \\
\hline 2 & Sofia - Mezdra & 83.5 & \\
\hline 3 & Mezdra - Pleven & 101.0 & \\
\hline 4 & Pleven - Gorna Orjahoviga & 119.3 & \\
\hline 5 & Gorna Orjahoviga - Ruse & 13.0 & \\
\hline \multicolumn{2}{|r|}{ TOTAL } & 490.8 & 19.5 \\
\hline
\end{tabular}

\section{China}

\begin{tabular}{|c|c|c|c|}
\hline \multicolumn{4}{|c|}{ Shanghai port (China) - Alataw Shankou (Kazakhstan border) } \\
\hline id & Route & Distance $(\mathrm{km})$ & Time (hours) \\
\hline $\mathbf{1}$ & Shanghai - Nanjing & 269.10 & \\
\hline $\mathbf{2}$ & Nanjing - Xuzhou & 287.53 \\
\hline $\mathbf{3}$ & Xuzhou - Xian & 754.27 \\
\hline $\mathbf{4}$ & Xian - Lanzhou & 506.39 \\
\hline $\mathbf{5}$ & Lanzhou - Shulehe & 437.21 & \\
\hline $\mathbf{6}$ & Shulehe - Urumci & 1199.82 & \\
\hline $\mathbf{7}$ & Urumci - Alataw Shankou & 430.19 & \\
\hline & TOTAL & 3884.51 & \\
\hline
\end{tabular}

\section{Georgia}

\begin{tabular}{|c|c|c|c|}
\hline \multicolumn{3}{|c|}{ Gardabani (Azerbaijan border) - Poti (Georgian port) } & Time (hours) \\
\hline id & Route & Distance (km) & \\
\hline $\mathbf{1}$ & Gardabani - Vell & 34.81 & \\
\hline $\mathbf{2}$ & Vell - Tbilisi & 13.60 \\
\hline $\mathbf{3}$ & Tbilisi - Kashuri & 104.04 \\
\hline $\mathbf{4}$ & Kashuri - Kutaisi & 78.32 \\
\hline $\mathbf{5}$ & Kutaisi - Samtredia & 32.17 & \\
\hline $\mathbf{6}$ & Samtredia - Poti & 54.69 & \\
\hline & TOTAL & 317.63 & \\
\hline
\end{tabular}




\section{Germany}

\begin{tabular}{|c|c|c|c|}
\hline \multicolumn{3}{|c|}{ Oder (Polish border) - Hamburg (German port) } & \multirow{2}{*}{ Time (hours) } \\
\hline id & Route & Distance $(\mathrm{km})$ & \\
\hline $\mathbf{1}$ & Oder - Berlin & 114.5 & \\
\hline $\mathbf{2}$ & Berlin - Wittenberge & 188.5 \\
\hline $\mathbf{3}$ & Wittenberge - Ludwigslust & 52.4 & \\
\hline $\mathbf{4}$ & Ludwigslust - Hamburg & 118.4 & 18.3 \\
\hline
\end{tabular}

\section{Greece}

\begin{tabular}{|c|c|c|c|}
\hline \multicolumn{2}{|c|}{ Athens - Pireaus (Greek capital) - Promachon (Bulgarian border) } \\
\hline id & Route & Distance $(\mathrm{km})$ & Time (hours) \\
\hline $\mathbf{1}$ & Athens - Lianokladion & 157.07 & \\
\hline $\mathbf{2}$ & Lianokladion - Paleofarsalos & 45.13 \\
\hline $\mathbf{3}$ & Paleofarsalos - Larissa & 37.62 \\
\hline $\mathbf{4}$ & Larissa - Thessalonica & 300.18 \\
\hline $\mathbf{5}$ & Thessalonica - Strimon & 120.00 \\
\hline $\mathbf{6}$ & Strimon - Promachon & 50.00 & \\
\hline & TOTAL & 710 & \\
\hline
\end{tabular}

\section{Iran}

\begin{tabular}{|c|c|c|c|}
\hline \multicolumn{2}{|c|}{ Zahedan (Pakistani border) - Kapikoy (Turkey) } \\
\hline id & Route & 288 \\
\hline 1 & Zahedan - Bam & 225 \\
\hline $\mathbf{2}$ & Bam - Kerman & 216 \\
\hline 3 & Kerman- Bafgh & 117 \\
\hline $\mathbf{4}$ & Bafgh - Yazd & 363 \\
\hline $\mathbf{5}$ & Yazd - Kashan & 81 \\
\hline $\mathbf{6}$ & Kashan - Mohammadieh & 123 \\
\hline $\mathbf{7}$ & Mohammadieh - Aprin & 144 \\
\hline $\mathbf{8}$ & Aprin - Qazvin & 171 \\
\hline $\mathbf{9}$ & Qazvin - Zanjan & 124 \\
\hline 10 & Zanjan - Mianeh & 168 \\
\hline 11 & Mianeh - Maraqeh & 129 \\
\hline 12 & Maraqeh - Tabriz & 151 \\
\hline 13 & Tabriz - Samas & 40 \\
\hline 14 & Sarmas - Razi & 5 \\
\hline 15 & Razi - Kapikoy & \\
\hline & TOTAL & \\
\hline
\end{tabular}


Iran (continued)

\begin{tabular}{|c|c|c|c|}
\hline \multicolumn{4}{|c|}{ Bandar Abbas (Iranian port) - Sarakhs (Turkmen border) } \\
\hline id & Route & Distance $(\mathrm{km})$ & Time (hours) \\
\hline 1 & Bandar Abbas - Sirjan & 359 & \\
\hline 2 & Sirjan - Mobarakeh & 321 & \\
\hline 3 & Mobarakeh - Tabas & 275 & \\
\hline 4 & Tabas - Torbat Heydarieh & 334 & \\
\hline 5 & Torbat Heydarieh - Sarakhs & 330 & \\
\hline \multicolumn{2}{|r|}{ TOTAL } & 1619 & 52 \\
\hline
\end{tabular}

\begin{tabular}{|c|c|c|c|}
\hline \multicolumn{3}{|c|}{ Kapikoy (Turkish border) - Sarakhs (Turkmen border) } & Time (hours) \\
\hline id & Route & Distance (km) & \\
\hline $\mathbf{1}$ & Kapikoy - Razi & 40 \\
\hline $\mathbf{2}$ & Razi - Samas & 151 \\
\hline $\mathbf{3}$ & Samas - Tabriz & 129 \\
\hline $\mathbf{4}$ & Tabriz - Maraqeh & 168 \\
\hline $\mathbf{5}$ & Maraqeh - Mianeh & 124 \\
\hline $\mathbf{6}$ & Mianeh - Zanjan & 171 \\
\hline $\mathbf{7}$ & Zanjan - Qazvin & 144 \\
\hline $\mathbf{8}$ & Qazvin - Aprin & 223 \\
\hline $\mathbf{9}$ & Aprin - Semnan & 560 \\
\hline 10 & Semnan - Neyshabur & 257 \\
\hline 11 & Neyshabur - Sarakhs & 1972 \\
\hline
\end{tabular}

\section{Kaliningrad}

\begin{tabular}{|c|c|c|c|}
\hline \multicolumn{4}{|c|}{ Lithuanian border - Kaliningrad (Russian Federation) } \\
\hline id & Route & Distance $(\mathrm{km})$ & Time (hours) \\
\hline 1 & Lithuanian borders - Kaliningrad & 145 & \\
\hline \multicolumn{2}{|c|}{ TOTAL } & 145 & 4.2 \\
\hline
\end{tabular}




\section{Kazakhstan}

\begin{tabular}{|c|c|c|c|}
\hline \multicolumn{4}{|c|}{ Almaty (Kazakhstan) - Sary Agash (Uzbek border) } \\
\cline { 1 - 2 } id & Route & Distance (km) & Time (hours) \\
\hline $\mathbf{1}$ & Almaty - Otar & 156 & \\
\hline $\mathbf{2}$ & Otar - Shu & 155 \\
\hline $\mathbf{3}$ & Shu - Taraz & 233 & \\
\hline $\mathbf{4}$ & Taraz - Tulkubas & 31 & \\
\hline $\mathbf{5}$ & Tulkubas - Shymkent & 187 & \\
\hline & Shymkent - Arys & 79 & \\
\hline & Arys - Sary Agash & 128 & 28 \\
\hline
\end{tabular}

Ucharal (Chinese border) - Petropavi (Russian Federation border)

\begin{tabular}{|c|c|c|c|}
\hline id & Route & Distance $(\mathrm{km})$ & Time (hours) \\
\hline $\mathbf{1}$ & Ucharal - Moynly & 494.00 & \\
\hline $\mathbf{2}$ & Moynly - Karaganda & 452.23 \\
\hline $\mathbf{3}$ & Karaganda - Astana & 190.33 \\
\hline $\mathbf{4}$ & Astana - Kokchetav & 301.44 & \\
\hline $\mathbf{5}$ & Kokchetav - Petropavi & 219.00 & \\
\hline & TOTAL & 1657 & 48 \\
\hline
\end{tabular}

\begin{tabular}{|c|c|c|c|}
\hline \multicolumn{4}{|c}{ U.B. (Uzbek border) - (Russian Federation border) } \\
\cline { 1 - 2 } id & Route & Distance $(\mathrm{km})$ & \multicolumn{2}{|c|}{ Time (hours) } \\
\hline $\mathbf{1}$ & U.B. - Beyneu & 29.73 & \\
\hline $\mathbf{2}$ & Beyneu - Makat & 123.56 & \\
\hline $\mathbf{3}$ & Makat - Atyrau & 226.59 & \\
\hline $\mathbf{4}$ & Atyrau - Russian Fed. borders & 722.81 & 21.5 \\
\hline
\end{tabular}

\begin{tabular}{|c|c|c|c|}
\hline \multicolumn{3}{|c|}{ Ucharal (Chinese border) - Sary Agash (Uzbek border) } & Time (hours) \\
\hline id & Route & Distance (km) & \\
\hline $\mathbf{1}$ & Ucharal - Almaty & 765.97 \\
\hline $\mathbf{2}$ & Almaty - Otar & 156 \\
\hline $\mathbf{3}$ & Otar - Shu & 155 \\
\hline $\mathbf{4}$ & Shu - Taraz & 233 \\
\hline $\mathbf{5}$ & Taraz - Tulkubas & 187 \\
\hline $\mathbf{6}$ & Tulkubas - Shymkent & 79 \\
\hline $\mathbf{7}$ & Shymkent - Arys & 128 \\
\hline $\mathbf{8}$ & Arys - Sary Agash & 1734.97 & \\
\hline & TOTAL & & \\
\hline
\end{tabular}




\section{Kyrgyzstan}

\begin{tabular}{|c|c|c|c|}
\hline \multicolumn{4}{|c|}{ Bishkek (capital) - Batyr (Kazakh border) } \\
\cline { 1 - 2 } id & Route & Distance $(\mathrm{km})$ & Time (hours) \\
\hline $\mathbf{1}$ & Bishkek - Kara Balta & 62 & \\
\hline $\mathbf{2}$ & Kara Balta - Batyr & 53 & \\
\hline \multicolumn{2}{|c|}{ Total } & 115 & 7.5 \\
\hline
\end{tabular}

\section{Latvia}

\begin{tabular}{|c|c|c|c|}
\hline \multicolumn{4}{|c|}{ Zilupe (Russian Federation border) - Riga port } \\
\cline { 1 - 3 } id & Route & Distance $(\mathrm{km})$ & Time (hours) \\
\hline $\mathbf{1}$ & Zilupe - Rezekne & 60.6 & \\
\hline $\mathbf{2}$ & Rezekne - Koknese & 137.7 & \\
\hline $\mathbf{3}$ & Koknese - Aizkraukle & 12.4 & \\
\hline $\mathbf{4}$ & Aizkraukle - Riga & 87.8 & 12 \\
\hline
\end{tabular}

\section{Lithuania}

\begin{tabular}{|c|c|c|c|}
\hline \multicolumn{4}{|c|}{ (Kaliningrad border) - Godogay (Ukrainian border) } \\
\cline { 1 - 3 } id & Route & Distance $(\mathrm{km})$ & Time (hours) \\
\hline $\mathbf{1}$ & Gudogay - Vilnious & 31.75 & \\
\hline $\mathbf{2}$ & Vilnious - Prienai & 84.77 & \\
\hline $\mathbf{3}$ & Prienai - Vilkaviskis & 59.63 & \\
\hline $\mathbf{4}$ & Vilkaviskis - Borders & 27.00 & \\
\hline & TOTAL & 203.15 & 6 \\
\hline
\end{tabular}

\section{Republic of Moldova}

\begin{tabular}{|c|c|c|c|}
\hline \multicolumn{4}{|c|}{ Ungheni (Romanian border) - Kuchurgan (Ukrainian border) } \\
\cline { 1 - 2 } id & Route & Distance $(\mathrm{km})$ & Time (hours) \\
\hline $\mathbf{1}$ & Ungheni - Chisinau & 74.1 & \\
\hline $\mathbf{2}$ & Chisinau - Revaka & 25.1 & \\
\hline $\mathbf{3}$ & Revaka - Bender & 34.4 & \\
\hline $\mathbf{4}$ & Bender - Kuchurgan & 43.1 & \\
\hline & TOTAL & 176.7 & 8.67 \\
\hline
\end{tabular}


Mongolia

\begin{tabular}{|c|c|c|c|}
\hline \multicolumn{2}{|c|}{ (Chinese border) - (Russian Federation border) } \\
\cline { 1 - 3 } id & Route & Distance (km) & Time (hours) \\
\hline 1 & Chinese borders - Ulaan Bataar & 636.35 & \\
\hline $\mathbf{2}$ & Ulaan Bataar - Russian Fed. borders & 240.61 & 42.25 \\
\hline
\end{tabular}

\section{Poland}

\begin{tabular}{|c|c|c|c|}
\hline \multicolumn{3}{|c|}{ Terespol (Belarusian border) - Rzepin (German border) } \\
\cline { 1 - 2 } id & Route & Distance $(\mathrm{km})$ & \multirow{2}{*}{ Time (hours) } \\
\hline $\mathbf{1}$ & Terespol - Warszawa & 191.9 & \\
\hline $\mathbf{2}$ & Warszawa - Kutno & 123.0 & \\
\hline $\mathbf{3}$ & Kutno - Poznan & 183.7 & \\
\hline $\mathbf{4}$ & Poznan - Rzepin & 163.7 & \multirow{2}{*}{25.8} \\
\hline
\end{tabular}

Medyka (Ukrainian border) - Warsaw (capital)

\begin{tabular}{|c|c|c|c|}
\hline \multicolumn{4}{|c|}{ Medyka (Ukrainian border) - Warsaw (capital) } \\
\hline id & Route & Distance $(\mathrm{km})$ & Time (hours) \\
\hline $\mathbf{1}$ & Medyka - Warsaw & 373 & \\
\hline \multicolumn{2}{|c|}{ TOTAL } & 373 & 14.34 \\
\hline
\end{tabular}

\section{Romania}

\begin{tabular}{|c|c|c|c|}
\hline \multicolumn{2}{|c|}{ Constanta (port) - Bucharest (capital) } \\
\cline { 1 - 2 } id & Route & Distance $(\mathrm{km})$ & Time (hours) \\
\hline $\mathbf{1}$ & Constanta - Medgidia & 37.1 & \\
\hline $\mathbf{2}$ & Medgidia - Fetesti & 40.1 & \\
\hline $\mathbf{3}$ & Fetesti - Bucharest & 145.4 & \\
\hline & TOTAL & 222.6 & 9 \\
\hline
\end{tabular}


Romania (continued)

\begin{tabular}{|c|c|c|c|}
\hline \multicolumn{3}{|c|}{ Giurgiu (Bulgarian border) - Vicsani (Ukrainian border) } & Time (hours) \\
\hline id & Route & Distance $(\mathrm{km})$ & \\
\hline $\mathbf{1}$ & Giurgiu - Bucharest & 62.6 & \\
\hline $\mathbf{2}$ & Bucharest - Ploiesti & 78.9 \\
\hline $\mathbf{3}$ & Ploiesti - Buzau & 70.5 \\
\hline $\mathbf{4}$ & Buzau - Focsani & 46.3 \\
\hline $\mathbf{5}$ & Focsani - Adjud & 100.0 \\
\hline $\mathbf{6}$ & Adjud - Roman & 69.8 \\
\hline $\mathbf{7}$ & Roman - Pascani & 69.8 \\
\hline $\mathbf{8}$ & Pascani - Suceava & 20.7 \\
\hline $\mathbf{9}$ & Suceava - Vicsani & 569.5 \\
\hline
\end{tabular}

Giurgiu (Bulgarian border) - Jijia (Moldovan border)

\begin{tabular}{|c|c|c|c|}
\hline id & Route & Distance $(\mathrm{km})$ & Time (hours) \\
\hline $\mathbf{1}$ & Giurgiu - Bucharest & 62.6 \\
\hline $\mathbf{2}$ & Bucharest - Ploiesti & 58.9 \\
\hline $\mathbf{3}$ & Ploiesti - Buzau & 70.9 \\
\hline $\mathbf{4}$ & Buzau - Focsani & 70.5 \\
\hline $\mathbf{5}$ & Focsani - Adjud & 46.3 \\
\hline $\mathbf{6}$ & Adjud - Roman & 100.0 \\
\hline $\mathbf{7}$ & Roman - Pascani & 69.8 \\
\hline $\mathbf{8}$ & Pascani - lasi & 21.8 \\
\hline $\mathbf{9}$ & lasi - Jijia & 41.8 \\
\hline
\end{tabular}




\section{Russian Federation}

\begin{tabular}{|c|c|c|c|}
\hline \multicolumn{3}{|c|}{ Moscow (Russian Federation) - Vostochny (Russian Federation) } & Time (hours) \\
\hline id & Route & Distance (km) & 836 \\
\hline $\mathbf{1}$ & Moscow - Kirov & 238 \\
\hline $\mathbf{2}$ & Kirov - Yekaterinburg & 1546 \\
\hline $\mathbf{3}$ & Yekaterinburg - Omsk & 629 \\
\hline $\mathbf{4}$ & Omsk - Novosibirsk & 778 \\
\hline $\mathbf{5}$ & Novosibirsk - Krasnoyarsk & 1056 \\
\hline $\mathbf{6}$ & Krasnoyarsk - Irkutsk & 1018 \\
\hline $\mathbf{7}$ & Irkutsk - Chita & 1679 \\
\hline $\mathbf{8}$ & Chita - Belogorsk & 661 \\
\hline $\mathbf{9}$ & Belogorsk - Khabarovsk & 908 \\
\hline 10 & Khabarovsk - Vostochny & 9349 \\
\hline
\end{tabular}

St Petersburg (Russian Federation port) - Moscow (capital)

\begin{tabular}{|c|l|c|c|}
\hline id & \multicolumn{1}{|c|}{ Route } & Distance $(\mathrm{km})$ & Time (hours) \\
\hline $\mathbf{1}$ & St Petersburg - Moscow & 860 & \\
\hline \multicolumn{2}{|l|}{ TOTAL } & 860 & 25.5 \\
\hline
\end{tabular}

St Petersburg (Russian Federation port) - (Kazakh border)

\begin{tabular}{|c|c|c|c|}
\hline id & Route & Distance $(\mathrm{km})$ & Time (hours) \\
\hline $\mathbf{1}$ & St Petersburg - Moscow & 860.00 \\
\hline $\mathbf{2}$ & Moscow - Ryazan & 183.89 \\
\hline $\mathbf{3}$ & Ryazan - Tambov & 237.11 \\
\hline $\mathbf{4}$ & Tambov - Saratov & 344.23 \\
\hline $\mathbf{5}$ & Saratov - Volgograd & 330.54 \\
\hline $\mathbf{6}$ & Volgograd - Aksarayskaya & 373.78 \\
\hline $\mathbf{7}$ & Aksarayskaya - Kazakhstan borders & 85.37 & \\
\hline & TOTAL & 2415 & \\
\hline
\end{tabular}


Russian Federation (continued)

\begin{tabular}{|c|c|c|c|}
\hline \multicolumn{3}{|c|}{ Giurgiu (Bulgarian border) - Jijia (Moldovan border) } & Time (hours) \\
\hline id & Route & Distance (km) & \\
\hline $\mathbf{1}$ & Giurgiu - Bucharest & 62.6 \\
\hline $\mathbf{2}$ & Bucharest - Ploiesti & 70.9 \\
\hline $\mathbf{3}$ & Ploiesti - Buzau & 70.5 \\
\hline $\mathbf{4}$ & Buzau - Focsani & 46.3 \\
\hline $\mathbf{5}$ & Focsani - Adjud & 100.0 \\
\hline $\mathbf{6}$ & Adjud - Roman & 69.8 \\
\hline $\mathbf{7}$ & Roman - Pascani & 21.8 \\
\hline $\mathbf{8}$ & Pascani - lasi & 41.8 \\
\hline $\mathbf{9}$ & lasi - Jijia & 542.6 \\
\hline
\end{tabular}

Moscow (Russian Federation) - Vostochny (Russian Federation)

\begin{tabular}{|c|c|c|c|}
\hline id & Route & Distance $(\mathrm{km})$ & Time (hours) \\
\hline 1 & Moscow - Kirov & 836 & \\
\hline 2 & Kirov - Yekaterinburg & 238 & \\
\hline 3 & Yekaterinburg - Omsk & 1546 & \\
\hline 4 & Omsk - Novosibirsk & 629 & \\
\hline 5 & Novosibirsk - Krasnoyarsk & 778 & \\
\hline 6 & Krasnoyarsk - Irkutsk & 1056 & \\
\hline 7 & Irkutsk - Chita & 1018 & \\
\hline 8 & Chita-Belogorsk & 1679 & \\
\hline 9 & Belogorsk - Khabarovsk & 661 & \\
\hline 10 & Khabarovsk - Vostochny & 908 & \\
\hline \multicolumn{2}{|r|}{ Total } & 9349 & 275.6 \\
\hline
\end{tabular}

\begin{tabular}{|c|c|c|c|}
\hline \multicolumn{4}{|c|}{ St Petersburg (Russian Federation port) - Moscow (capital) } \\
\hline id & \multicolumn{1}{|c|}{ Route } & Distance (km) & Time (hours) \\
\hline 1 & St Petersburg - Moscow & 860 & \\
\hline \multicolumn{2}{|c|}{ TOTAL } & 860 & 25.5 \\
\hline
\end{tabular}




\begin{tabular}{|c|c|c|c|}
\hline \multicolumn{4}{|c|}{ St Petersburg (Russian Federation port) - (Kazakh border) } \\
\hline id & Route & Distance $(\mathrm{km})$ & Time (hours) \\
\hline 1 & St Petersburg - Moscow & 860.00 & \\
\hline 2 & Moscow - Ryazan & 183.89 & \\
\hline 3 & Ryazan - Tambov & 237.11 & \\
\hline 4 & Tambov - Saratov & 344.23 & \\
\hline 5 & Saratov - Volgograd & 330.54 & \\
\hline 6 & Volgograd - Aksarayskaya & 373.78 & \\
\hline 7 & Aksarayskaya - Kazakhstan borders & 85.37 & \\
\hline \multicolumn{2}{|r|}{ TOTAL } & 2415 & 71 \\
\hline
\end{tabular}

\begin{tabular}{|c|c|c|c|}
\hline \multicolumn{4}{|c|}{ Solovey (Ukrainian border) - Vladivostok (Russian Federation port) } \\
\hline id & Route & Distance $(\mathrm{km})$ & Time (hours) \\
\hline 1 & Solovey - Liski & 135.00 & \\
\hline 2 & Liski -Penza & 448.26 & \\
\hline 3 & Penza - Samara & 344.44 & \\
\hline 4 & Samara - Kurgan & 1015.33 & \\
\hline 5 & Kurgan - Omsk & 513.06 & \\
\hline 6 & Omsk - Novosibirsk & 629.00 & \\
\hline 7 & Novosibirsk - Krasnoyarsk & 778.00 & \\
\hline 8 & Krasnoyarsk - Irkutsk & 1056.00 & \\
\hline 9 & Irkutsk - Chita & 1018.00 & \\
\hline 10 & Chita-Belogorsk & 1679.00 & \\
\hline 11 & Belogorsk - Khabarovsk & 661.00 & \\
\hline 12 & Khabarovsk - Vladivostok & 908.00 & \\
\hline & TOTAL & 9185.09 & 270 \\
\hline
\end{tabular}

\begin{tabular}{|c|c|c|c|}
\hline \multicolumn{2}{|c|}{ Gukovo (Ukrainian border) - (Kazakh border) } \\
\cline { 1 - 2 } & Route & Distance (km) & Time (hours) \\
\hline $\mathbf{1}$ & Gukovo - Volgograd & 390.40 & 373.78 \\
\hline $\mathbf{2}$ & Volgograd - Aksarayskaya & 85.37 & \\
\hline $\mathbf{3}$ & Aksarayskaya - Kazakhstan borders & 849.55 & 25 \\
\hline
\end{tabular}


Russian Federation (continued)

\begin{tabular}{|c|c|c|c|}
\hline \multicolumn{3}{|c|}{ Novorossiysk (Russian Fed. port) - Uspenskaya (Ukrainian border) } \\
\hline id & Route & Distance $(\mathrm{km})$ & Time (hours) \\
\hline $\mathbf{1}$ & Novorossiysk - Krasnodar & 100.86 & \\
\hline $\mathbf{2}$ & Krasnodar - Rostov & 250.60 \\
\hline $\mathbf{3}$ & Rostov - Uspenskaya & 86.73 & \\
\hline \multicolumn{2}{|c|}{ TOTAL } & 438.20 & 13 \\
\hline
\end{tabular}

\section{Tajikistan}

\begin{tabular}{|c|c|c|c|}
\hline \multicolumn{4}{|c|}{ Dushanbe (capital) - Saryasiya (Uzbek border) } \\
\hline id & Route & Distance $(\mathrm{km})$ & Time (hours) \\
\hline 1 & Dushanbe - Pahtaabad & 44 & \\
\hline 2 & Pahtaabad - Saryasiya & 5 & \\
\hline & TOTAL & 49 & 3.5 \\
\hline
\end{tabular}

\section{Turkey}

\begin{tabular}{|c|c|c|c|}
\hline \multicolumn{3}{|c|}{ Kapikoy (Iranian border) -Haydarpasa (Istanbul) } & Time (hours) \\
\hline id & Route & Distance $(\mathrm{km})$ & \\
\hline $\mathbf{1}$ & Kapikoy - Van & 113.96 \\
\hline $\mathbf{2}$ & Van - Tatvan & 335.09 \\
\hline $\mathbf{3}$ & Tatvan - Elazig & 118.77 \\
\hline $\mathbf{4}$ & Elazig - Malatya & 223.21 \\
\hline $\mathbf{5}$ & Malatya - Bostankaya & 197.39 \\
\hline $\mathbf{6}$ & Bostankaya - Kayseri & 379.94 \\
\hline $\mathbf{7}$ & Kayseri - Ankara & 576.61 & \\
\hline $\mathbf{8}$ & Ankara - Haydarpasa & 1944.97 \\
\hline
\end{tabular}

\section{Turkmenistan}

\begin{tabular}{|c|c|c|c|}
\hline \multicolumn{3}{|c|}{ Farap (Uzbek border) - Sarakhs (Iranian border) } & \multirow{2}{*}{ Time (hours) } \\
\hline id & Route & Distance (km) & \\
\hline $\mathbf{1}$ & Farap - Turkmenabat & 22 & \\
\hline $\mathbf{2}$ & Turkmenabat - Mary & 243 & \\
\hline 3 & Mary - Sarakhs & 204 & 32.25 \\
\hline
\end{tabular}




\section{Ukraine}

\begin{tabular}{|c|c|c|c|}
\hline \multicolumn{3}{|c|}{ Krasnaya (Russian Federation border) - Mostiska (Polish border) } \\
\cline { 1 - 3 } id & Route & Distance (km) & Time (hours) \\
\hline $\mathbf{1}$ & Krasnaya - Krasnoarmeysk & 252.1 & \\
\hline $\mathbf{2}$ & Krasnoarmeysk - Fastov & 710.8 \\
\hline $\mathbf{3}$ & Fastov - Zhmerinka & 262.5 & \\
\hline $\mathbf{4}$ & Zhmerinka - Temopol & 255.7 & \\
\hline $\mathbf{5}$ & Temopol - Mostiska & 207.0 & \\
\hline & TOTAL & 1688.1 & 50 \\
\hline
\end{tabular}

\section{Solovey (Russian Federation border) - Kyiv (capital)}

\begin{tabular}{|c|c|c|c|}
\hline id & Route & Distance $(\mathrm{km})$ & Time (hours) \\
\hline $\mathbf{1}$ & Solovey - Kharkov & 152.41 & \multirow{2}{*}{123.57} \\
\cline { 1 - 3 } $\mathbf{2}$ & Kharkov - Poltava & 302.79 & \\
\hline $\mathbf{3}$ & Poltava - Kyiv & 578.77 & 14 hrs \\
\hline
\end{tabular}

Kvashino (Russian Federation border) - Chernihiv (Belarusian border)

\begin{tabular}{|c|c|c|c|}
\hline id & Route & Distance $(\mathrm{km})$ & Time (hours) \\
\hline 1 & Kvashino - Donetsk & 80.14 & \\
\hline 2 & Donetsk - Dnepropetrovsk & 213.83 & \\
\hline 3 & Dnepropetrovsk - Fastov & 410.53 & \\
\hline 4 & Fastov - Kyiv & 60.25 & \\
\hline 5 & Kyiv - Nizhym & 116.00 & \\
\hline 6 & Nizhym - Chernihiv & 65.48 & \\
\hline 7 & Chernihiv- Belarusian borders & 67.56 & \\
\hline \multicolumn{2}{|r|}{ TOTAL } & 1013.79 & 30 \\
\hline
\end{tabular}

\section{Uzbekistan}

\begin{tabular}{|c|c|c|c|}
\hline \multicolumn{3}{|c|}{ Sary Agash (Kazakh border) - Khodjadavlet (Turkmen border) } \\
\cline { 1 - 2 } id & Route & Distance (km) & Time (hours) \\
\hline $\mathbf{1}$ & Sary Agash - Tashkent & 10 & \\
\hline $\mathbf{2}$ & Tashkent - Khavast & 119 \\
\hline $\mathbf{3}$ & Khavast - Marokand & 202 & \\
\hline $\mathbf{4}$ & Marokand - Bukhara & 249 & \\
\hline $\mathbf{5}$ & Bukhara - Khodjadavlet & 90 & \\
\hline & TOTAL & 670 & 40.3 \\
\hline
\end{tabular}


Uzbekistan (continued)

\begin{tabular}{|c|c|c|c|}
\hline \multicolumn{3}{|c|}{ (Kazakh border) - Khodjadavlet (Turkmen border) } & Time (hours) \\
\hline id & Route & Distance $(\mathrm{km})$ & \\
\hline $\mathbf{1}$ & Kazakhstan borders - Nukus & 395.00 & \\
\hline $\mathbf{2}$ & Nukus - Miskin & 175.73 \\
\hline $\mathbf{3}$ & Miskin - Uchkuduk & 226.42 \\
\hline $\mathbf{4}$ & Uchkuduk - Navoi & 276.33 \\
\hline $\mathbf{5}$ & Navoi - Bukhara & 93.00 & \\
\hline $\mathbf{6}$ & Bukhara - Khodjadavlet & 90.00 & \\
\hline & TOTAL & 1256.48 & \\
\hline
\end{tabular}

\begin{tabular}{|c|c|c|c|}
\hline \multicolumn{3}{|c|}{ Sary Agash (Kazakh border) - Kazakh border } \\
\hline id & Route & Distance $(\mathrm{km})$ & Time (hours) \\
\hline $\mathbf{1}$ & Sary Agash - Tashkent & 10.00 \\
\hline $\mathbf{2}$ & Tashkent - Khavast & 119.00 \\
\hline $\mathbf{3}$ & Khavast - Marokand & 202.00 \\
\hline $\mathbf{4}$ & Marokand - Navoi & 143.00 \\
\hline $\mathbf{5}$ & Navoi - Uchkuduki & 276.33 \\
\hline $\mathbf{6}$ & Uchkuduki - Miskin & 226.42 \\
\hline $\mathbf{7}$ & Miskin - Nukus & 175.73 \\
\hline $\mathbf{8}$ & Nukus - Kazakhstan borders & 395.00 \\
\hline
\end{tabular}

\subsubsection{Tariff rates and structure}

Many tariffs are applied in rail transport - even within the same country. Factors that typically influence tariff structures and their level are:

- Different tariffs for the same routes are quoted by forwarders and state rail organizations.

- State rail organizations charge different clients differently. A forwarder, a shipper, a small trader with one container or a big manufacturer with 1,000 containers per year pay different tariffs.

- The actual, charged tariffs are different from the published tariffs.

- Tariffs differ depending on whether:

- it is bulk or container cargo

- it is carried in wagons or by a block train

- the client is a forwarder or a shipper

- the amount of cargo is large

- it is a long-term contract with a guarantee for the quantity

- terms of payment are favourable or not

- $\$ / €$ per train kilometre or per container, or container kilometres etc. 
Figure 2.25 provides tariff rates in US dollars that are currently applied in some countries. All actual tariffs were provided through questionnaires or directly to the author by the rail organizations (and not by forwarders or shippers). They are average rates which could be reduced through further negotiation but which are used here. In general, these tariffs are adequate to illustrate average pricing. The regional average was used where there was no information on the tariffs in a country.

Figure 2.51 - Rail tariffs, in US dollars

\begin{tabular}{|c|c|c|c|c|c|c|}
\hline & $\begin{array}{l}20^{\prime} \text { full } \\
\text { container (per } \\
\text { container) }\end{array}$ & $\begin{array}{c}40^{\prime} \text { full } \\
\text { container } \\
\text { (per container) }\end{array}$ & $\begin{array}{c}20^{\prime} \text { full container } \\
\text { (per km) }\end{array}$ & $\begin{array}{c}40^{\prime} \text { full } \\
\text { container (per } \\
\text { km) }\end{array}$ & $\begin{array}{l}20^{\prime} \text { empty } \\
\text { container } \\
\text { (per km) }\end{array}$ & $\begin{array}{l}40^{\prime} \text { emply } \\
\text { container } \\
\text { (per km) }\end{array}$ \\
\hline Afghanistan & & & - & - & & \\
\hline Armenia & & & 0.52 & 0.64 & & \\
\hline Azerbaijan & & & 0.52 & 0.64 & & \\
\hline Belarus & & & 0.48 & 0.55 & & \\
\hline Bulgaria & & & 0.75 & 0.85 & & \\
\hline China & & & 0.40 & 0.50 & & \\
\hline Georgia & & & 0.48 & 0.55 & & \\
\hline Germany & & & 0.75 & 0.85 & & \\
\hline Greece & & & 0.75 & 0.85 & & \\
\hline Iran & 747 & 1093 & 0.46 & 0.68 & 0.23 & 0.34 \\
\hline Kazakhstan & 614 & 989 & 0.64 & 1.03 & 0.31 & 0.48 \\
\hline Kyrgyzstan & & & 0.48 & 0.55 & & \\
\hline Latvia & & & 0.75 & 0.85 & & \\
\hline Mongolia & & & 0.40 & 0,50 & & \\
\hline Poland & & & 0.75 & 0.85 & & \\
\hline $\begin{array}{c}\text { Republic of } \\
\text { Moldova }\end{array}$ & & & 0.48 & 0.55 & & \\
\hline Romania & & & 0.75 & 0.85 & & \\
\hline $\begin{array}{l}\text { Russian } \\
\text { Federation }\end{array}$ & & & 0.48 & 0.55 & & \\
\hline Tajikistan & & & 0.55 & 0.75 & & \\
\hline Turkey & 621 & 822 & 0.31 & 0.41 & 0.23 & 0.29 \\
\hline Turkmenistan & 692 & 1254.8 & 1.4 & 2.6 & & \\
\hline Ukraine & & & 0.48 & 0.55 & & \\
\hline Uzbekistan & 462.58 & 832.24 & 0.64 & 1.4 & 0.38 & 0.67 \\
\hline
\end{tabular}




\subsection{Comparison of rail and maritime transport along EATL routes}

\section{The Trans-Siberian railway route ${ }^{23}$}

A model has already been developed to compare two alternative transportation routes: the Trans-Siberian rail route and maritime routes. This model does not provide a comparison of the two transport options with identical points of origins and destinations but determines the conditions under which the "watershed" or the final destination should move further West or East, depending on the increase in tariffs of maritime or rail transport. Simulation scenarios are also studied to determine the exact location of the "watershed".

Figure 2.52 - The Trans-Siberian railway case study

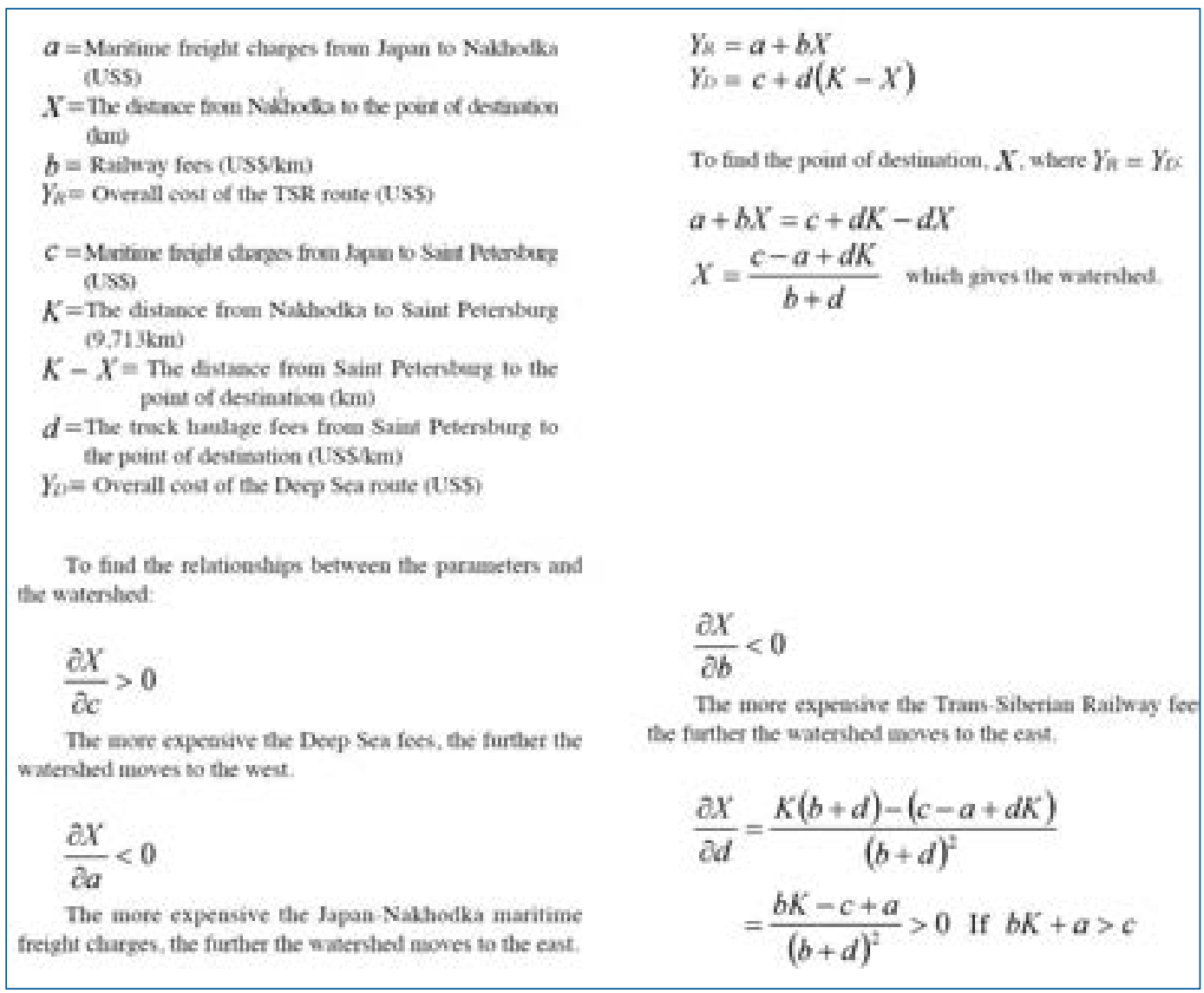

As long as the cost of transportation via the TSR route to Saint Petersburg $(b K+a)$ is higher than the cost of transportation via the Deep Sea route to Saint Petersburg $(c)$, then a rise in truck haulage fees will move the watershed to the west. Hypothetically, regarding transportation bound for Saint Petersburg, if the TSR route were cheaper than the Deep Sea route, there would be a situation where the watershed ceased to be inside Russia, as it is thought all freight would use the TSR route.

\section{Simulation results}

Case I (Basic Model): Assumes values of US\$ 1,000 for the maritime freight charges from Japan to Nakhodka ( $a$ ) and US\$2,500 for the Deep Sea charges to Saint Petersburg $(c)$. For the railway fees, the $9,314 \mathrm{~km}$ between Nakhodka and Moscow is taken as costing $\$ 4,000$, meaning that $b=\mathrm{US} \$ 0.43 / \mathrm{km}$. For truck haulage fees the $400 \mathrm{~km}$ between Saint Petersburg and Moscow

${ }^{23}$ Hisako Tsuii, "The Global Financial Crisis and Trans-Siberian Railway Transportation", ERINA REPORT, vol. 89 (September 2009). 
is taken as costing US $\$ 1,500$, meaning that $b=\mathrm{US} \$ 3.75 / \mathrm{km}$. Under these assumptions $X=$ $9,072 \mathrm{~km}$ and the watershed lies $242 \mathrm{~km}$ east of Moscow.

Case II: When the maritime freight charges from Japan to Nakhodka ( $a$ ) are raised from US\$ 1,000 to US\$2,000, the watershed moves to a point $481 \mathrm{~km}$ east of Moscow. Japan-Nakhodka maritime freight charges are widely held to be approximately US\$1,000 more expensive than those between the ROK and Nakhodka, and if all other conditions are equal, it can be considered that the watershed for Japan lies further east than is the case for the ROK.

Source: Hisako Tsuji, The Global Financial Crisis and Trans-Siberian Railway Transportation ERINA REPORT, vol. 89, 2009

\section{The UNESCAP block train report ${ }^{24}$}

United Nations ESCAP conducted an analysis of the development of block trains for the Central Asian region, specifically for Kazakhstan and Uzbekistan. This analysis produced the following results.

Figure 2.53 - Time-cost-distance analysis, 2006
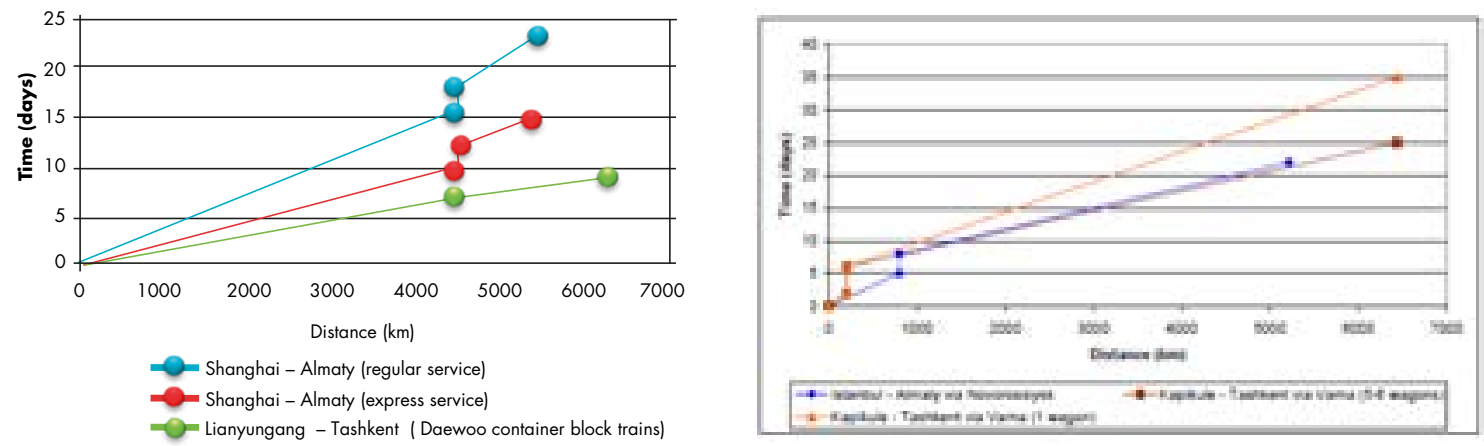

Source: UNESCAP

Minimum and maximum transit times for regular and express rail services from ports in China to Kazakhstan are 15 and 23 days respectively (Figure 2.27). The significant difference of eight days is partly caused by the transfer time at the border between China and Kazakhstan, which includes break-of-gauge, trans-shipping and processing of customs documentation. Meanwhile, data on the container block trains established for shipments from Daewoo Corporation in the Republic of Korea via the Chinese port of Lianyungang reveal that a transit time of nine days is possible.

The existing break-of-gauge points at Drushba/Alashankou (China/Kazakhstan), Sarakhs (Turkmenistan/Iran) and Brest (Belarus/Poland) are operational hindrances, but do not cause exceptional delays compared with the existing institutional barriers which represent the main reasons for long waiting times and delays at border-crossing points. Reported transit times for railway transport routes between destinations in Central Asia and various ports vary between 9 and 35 days.

24 United Nations Economic and Social Commission for Asia and the Pacific http://www.unescap.org/ttdw/ common/TIS/TAR/operationalization.asp. 


\subsubsection{Comparative analysis of EATL rail and maritime transport}

The route and cost structure is determined as presented in Figure 2.28.

Figure 2.54 - Route and cost structure

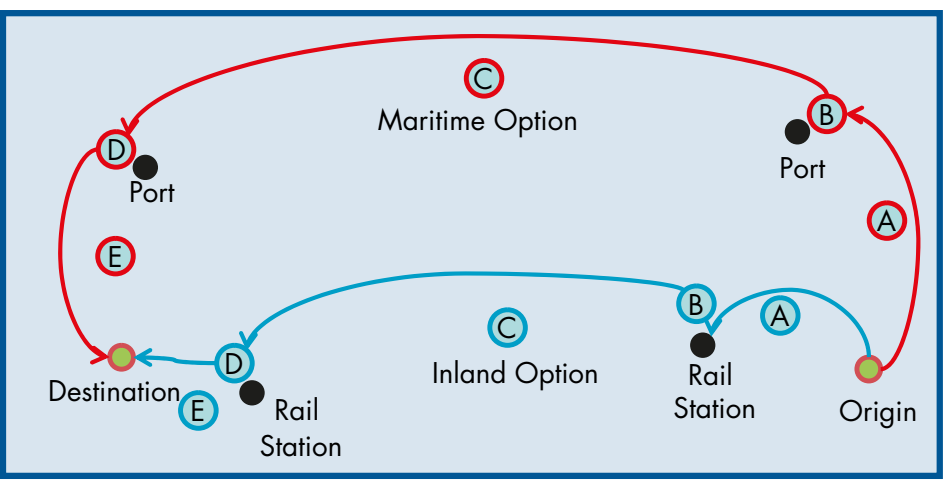
(A) Truck cost
(B) THC / Port costs
(C) Maritime
(D) THC / Port costs
(E) Truck cost
(A) Truck cost
(B) Loading / doc
costs
(C) Rail cost
(D) Unloading / doc
(E) Truck cost

Source: Author's analysis

- Identify the origin of the cargo/shipper ("Origin")

- Identify the final destination where the cargo is to be delivered ("Destination")

- Identify the maritime and inland route between "Origin" and "Destination"

\section{Maritime transport option}

- Identify the closest port to "Origin" location

- Calculate the distance $(\mathrm{km})$ for road transport (by truck) from the "Origin" location to the closest port; calculate the corresponding cost

- Calculate the port costs, such as handling and other costs

- Identify the closest and most convenient port for the "Destination" location; calculate the travelling time and costs from one port to another

- Calculate the costs at the port of close to "Destination"

- Calculate the distance $(\mathrm{km})$ for road transport (by truck) from that port to the "Destination" location B; calculate the corresponding costs

\section{Inland transport option}

- Calculate the distance $(\mathrm{km})$ for road transport from the "Origin" location to the closest train (loading) station

- Calculate the costs at the loading station, such as loading, documentation, customs

- Determine the time schedule for the rail service and the corresponding cost

- Calculate the costs at the unloading station

- Calculate the distance $(\mathrm{km})$ and costs for road transport from the unloading station to the "Destination" location 
Figure 2.29 - EATL ROUTE 1: Khabarovsk - Potsdam

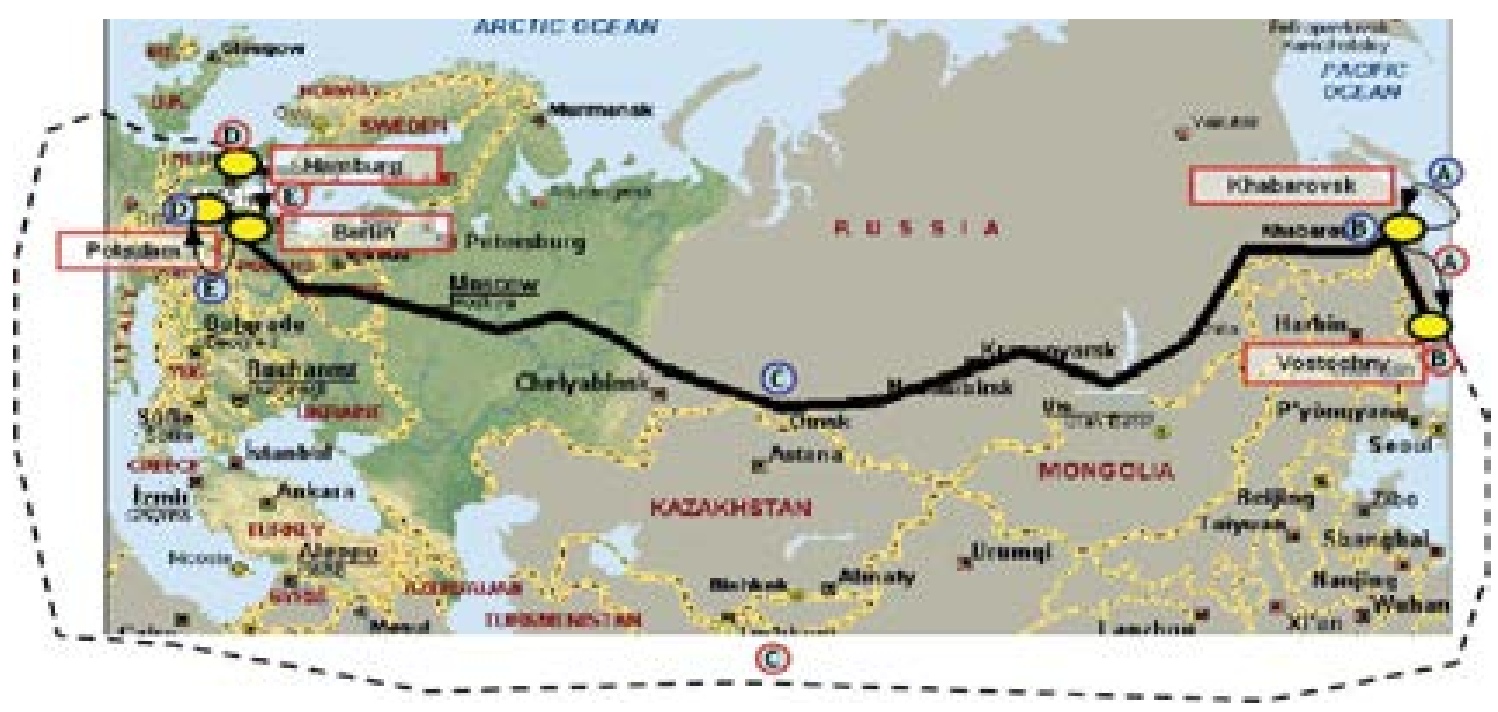

\section{Maritime Transport}

\section{Rail Transport}
(A) Truck cost
(D) THC / Port costs
(A) Truck cost
(D) Unloading / other costs
(B) THC / Port costs
(E) Truck cost
(B) Loading / other costs
(E) Truck cost
(C) Maritime cost
(C) Rail cost

EATL ROUTE 1: Khabarovsk (Russian Federation -Origin) - Potsdam (Germany - Destination)

\begin{tabular}{|c|c|c|c|}
\hline Route & $\mathrm{km}$ & $\operatorname{Cost}(\$)$ & Time (hrs) \\
\hline Khabarovsk - Vostochny port (by road) & 653 & 783 & 9 \\
\hline Vostochny port THC costs & - & 300 & - \\
\hline Vostochny port other costs & - & 320 & - \\
\hline Vostochny port - Hamburg port (by sea) & 21414 & 4200 & 1080 \\
\hline Hamburg port THC costs & - & 180 & - \\
\hline Hamburg port other costs & - & 250 & - \\
\hline Hamburg port - Potsdam (by road) & 282 & 500 & 4 \\
\hline Total maritime transport & 21414 & 5250 & 1080 \\
\hline Total road transport & 935 & 1283 & 13 \\
\hline TOTAL & 22349 & 6533 & 1093 \\
\hline \multicolumn{4}{|c|}{ INLAND TRANSPORT: Khabarovsk - Potsdam } \\
\hline Route & $\mathrm{km}$ & $\operatorname{Cost}(\$)$ & Time (hrs) \\
\hline Khabarovsk - Khabarovsk rail station by road & 20 & 150 & 2 \\
\hline Khabarovsk rail station loading cost & - & 30 & - \\
\hline Khabarovsk rail station other costs & - & 40 & - \\
\hline Russian Federation (Vostochny - Redki) by rail & 9779 & 5378 & 288 \\
\hline
\end{tabular}




\section{MARITIME TRANSPORT: Khabarovsk (via Vostochny Port) - Potsdam (via Hamburg Port)}

\begin{tabular}{|l|c|c|c|}
\hline Belarus (Redki - Brest) by rail & 613 & 337 & 18 \\
\hline Poland (Terespol - Rzepin) by rail & 662 & 562 & 26 \\
\hline Germany (Oder - Berlin) by rail & 114 & 100 & 5 \\
\hline Potsdam rail station unloading cost & - & 45 & - \\
\hline Potsdam rail station other costs & - & 75 & - \\
\hline Potsdam rail station - Potsdam by road & 20 & 250 & 2 \\
\hline Total rail transport & 11168 & 6567 & 337 \\
\hline Total road transport & 40 & 400 & 4 \\
\hline TOTAL & 11208 & 6967 & 341 \\
\hline
\end{tabular}

\section{COMPARISON STUDY BY USING THE COST/TIME/DISTANCE METHODOLOGY}

\section{Time Distance Plot}

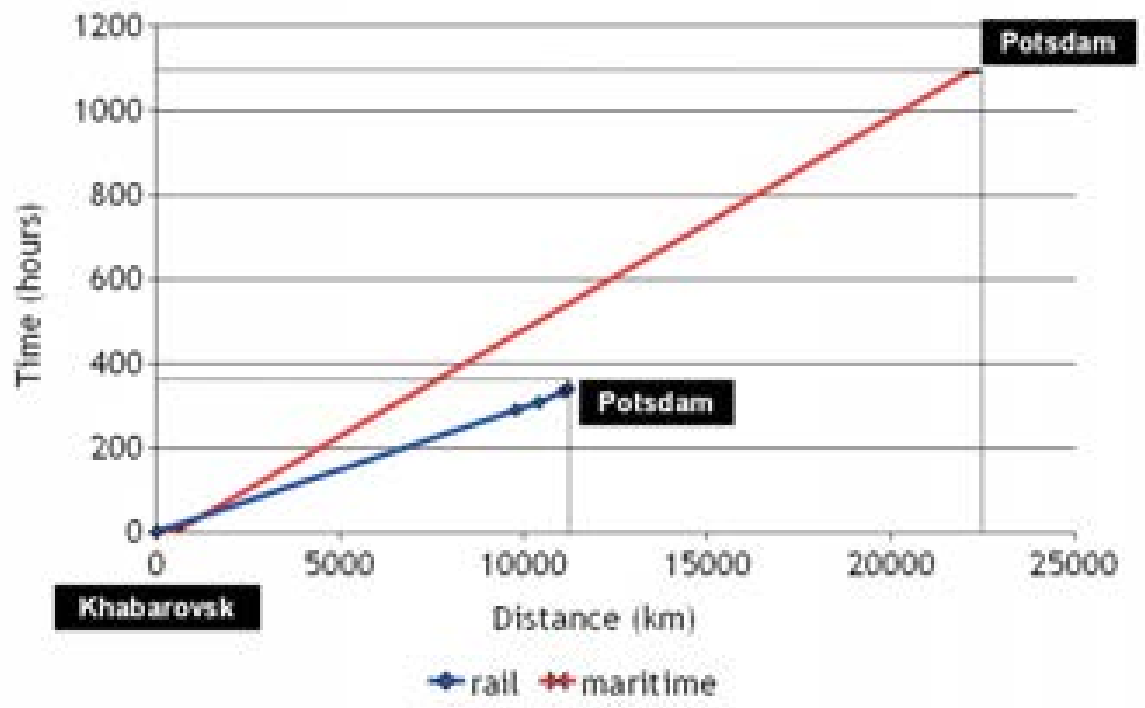

The total travelling time for the block train is 341 hours, which is 14 days and 5 hours, of which 2 hours was the trip by truck in the Russian Federation, 2 hours the trip by truck in Germany (Potsdam) and the 14-day and 1-hour trip by train. The total travelling time with ocean transport was 1,093 hours (45 days and 13 hours), of which 9 hours was the road transport in the Russian Federation, 4 hours the road transport in Germany and 1,080 hours the maritime transport (45 days). There is a difference of 31 days and 8 hours. It should be noted that the maritime transport travelling time was calculated as the absolute number of nautical miles multiplied by 22 knots (average ship speed), but normally there are further delays as there are no direct connections among all the ports. The time difference can only be expected to be longer. 
Cost - Distance Plot

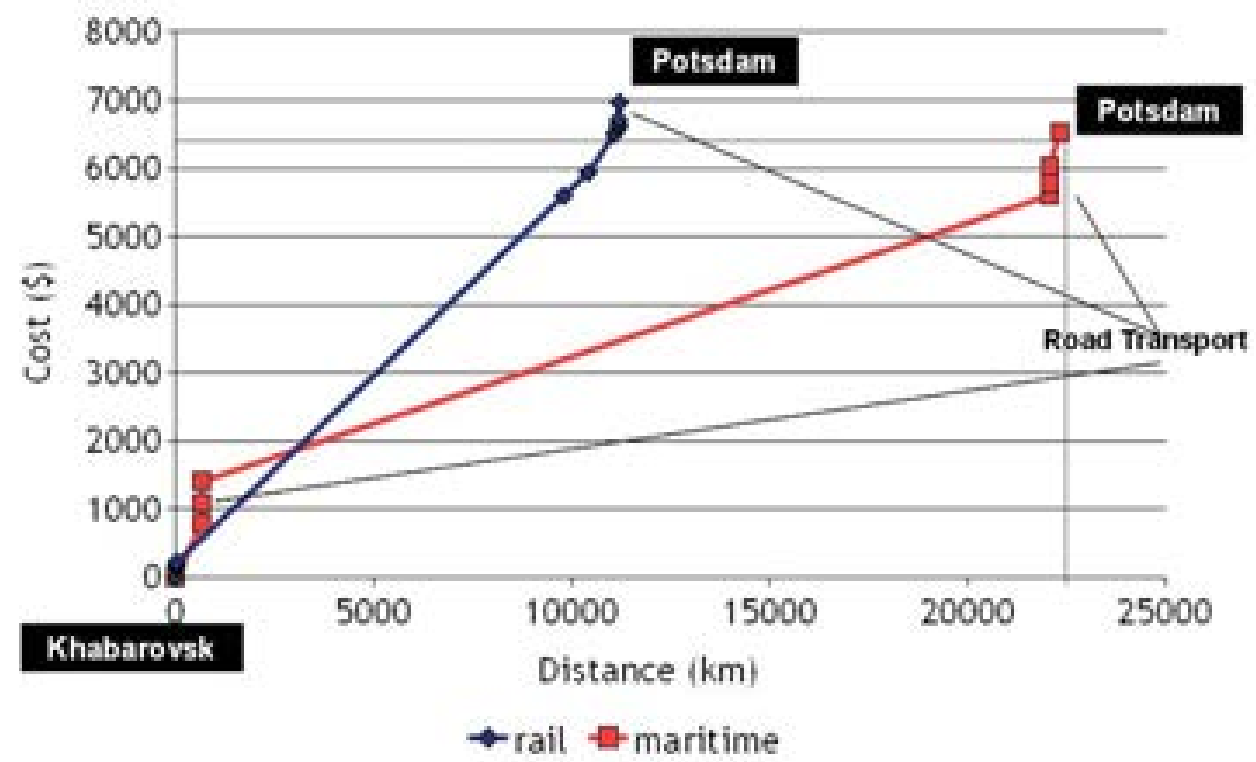

The train option costs $\$ 434$ more than the maritime transport option.

Figure 2.30 - EATL ROUTE 2: Hangzhou - Kaluga

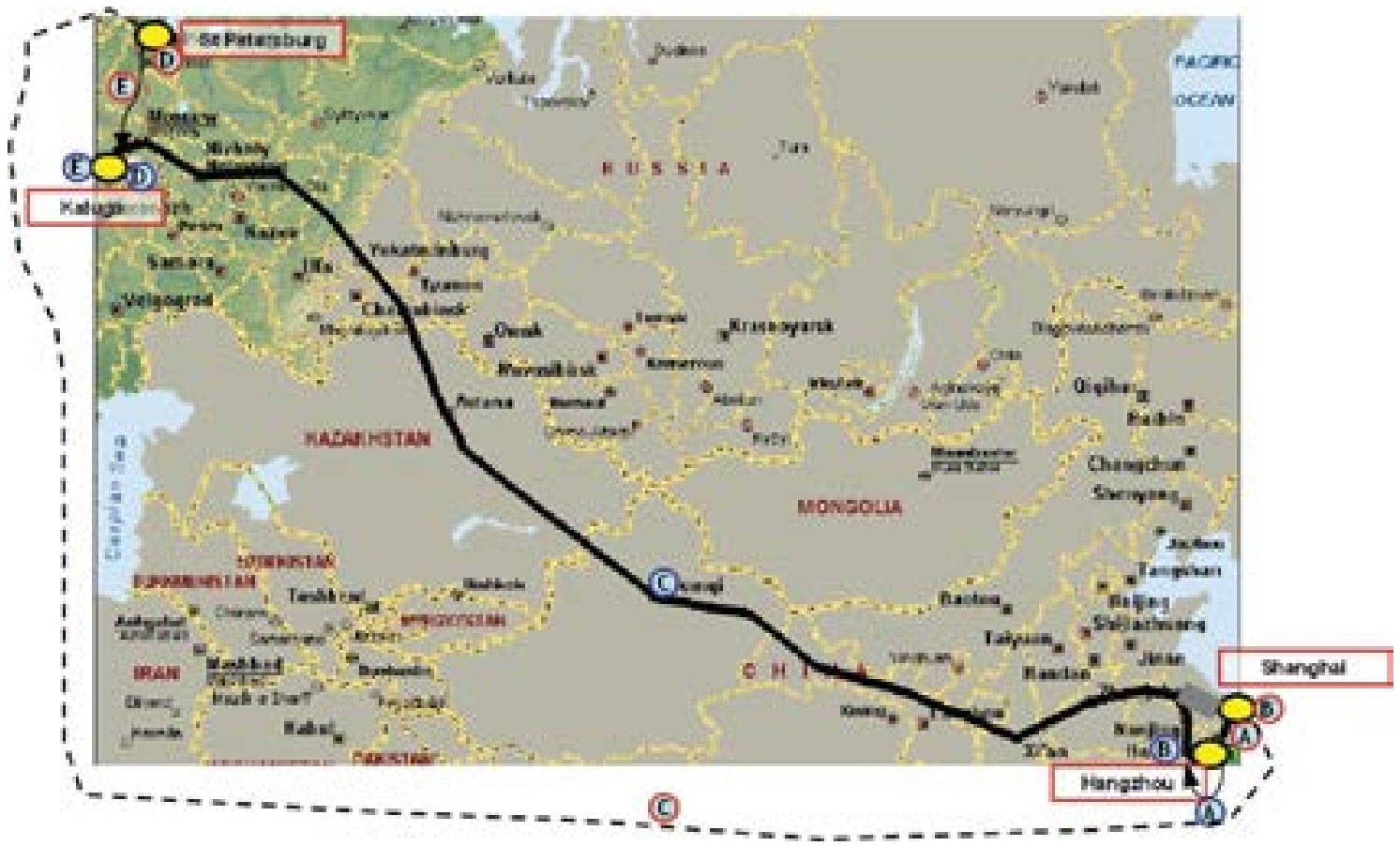

Rail Transport
(A) Truck cost
(D) THC / Port costs
(A) Truck cost
(D) Unloading / other costs
(B) THC / Port costs
(E) Truck cost
(B) Loading / other costs
(E) Truck cost
(C) Maritime cost
(C) Rail cost 
EATL ROUTE 2 Hangzhou (China-Origin) to Kaluga (Russian Federation- Destination)

\begin{tabular}{|c|c|c|c|}
\hline Route & $\mathrm{km}$ & $\operatorname{Cost}(\$)$ & Time (hrs) \\
\hline Hangzhou - Shanghai port by road & 158 & 220 & 2 \\
\hline Shanghai port THC costs & - & 100 & - \\
\hline Shanghai port other costs & - & 150 & - \\
\hline Shanghai port - St Petersburg port by sea & 21733 & 5000 & 624 \\
\hline St Petersburg port THC costs & - & 250 & - \\
\hline St Petersburg port other costs & - & 250 & - \\
\hline St Petersburg port - Kaluga by road & 680 & 816 & 11 \\
\hline Total maritime transport & 21733 & 5750 & 624 \\
\hline Total road transport & 838 & 1036 & 13 \\
\hline TOTAL & 22571 & 6786 & 637 \\
\hline \multicolumn{4}{|c|}{ RAlL TRANSPORT: Hangzhou - Kaluga } \\
\hline Route & $\mathrm{km}$ & $\operatorname{Cost}(\$)$ & Time(hrs) \\
\hline Hangzhou - Hangzhou rail station by road & 20 & 100 & 2 \\
\hline Hangzhou rail station loading cost & - & 25 & - \\
\hline Hangzhou rail station other costs & - & 30 & - \\
\hline China (Shanghai - Alataw) by rail & 3884.51 & 1942.25 & 185 \\
\hline Kazakhstan (Ucharal - Petropavi) by rail & 1657 & 1706.7 & 48 \\
\hline Russian Federation (Petropavi - Kaluga) by rail & 1374 & 755.7 & 40 \\
\hline Kaluga rail station unloading cost & - & 25 & - \\
\hline Kaluga rail station other costs & - & 30 & - \\
\hline Kaluga rail station - Kaluga by road & 20 & 100 & 2 \\
\hline Total rail transport & 6915.51 & 4514.65 & 273 \\
\hline Total road transport & 40 & 200 & 4 \\
\hline TOTAL & 6955.51 & 4714.65 & 277 \\
\hline
\end{tabular}




\section{COMPARISON STUDY BY USING THE COST/TIME/DISTANCE METHODOLOGY}

\section{Time - Distance Plot}

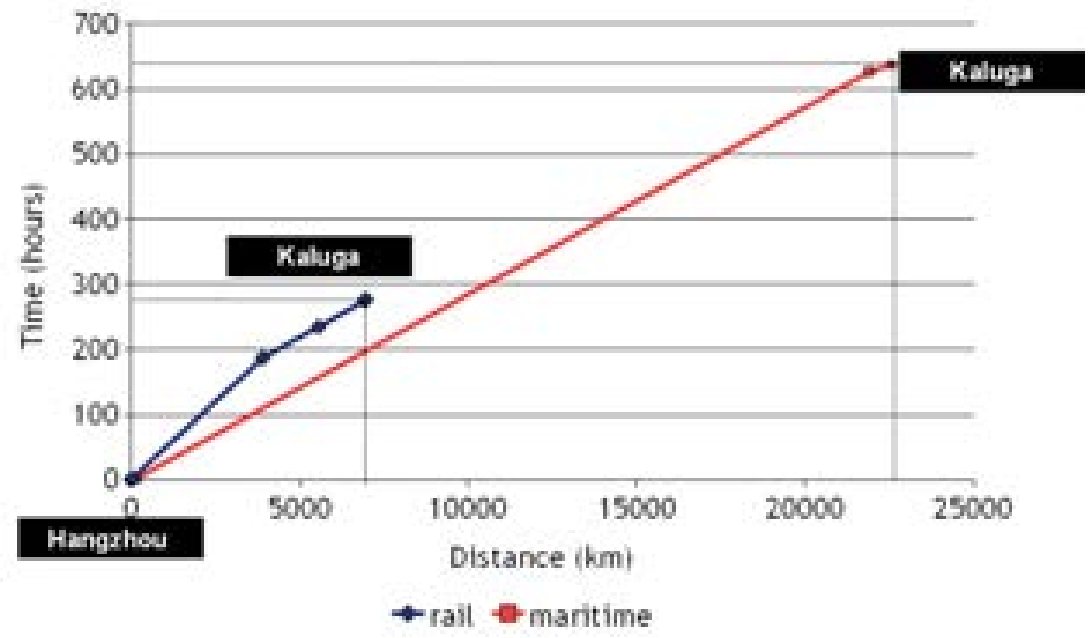

The ocean freight needs 26 days to reach Kaluga while the rail needs 11 days and 13 hours.

\section{Cost - Distance Plot}

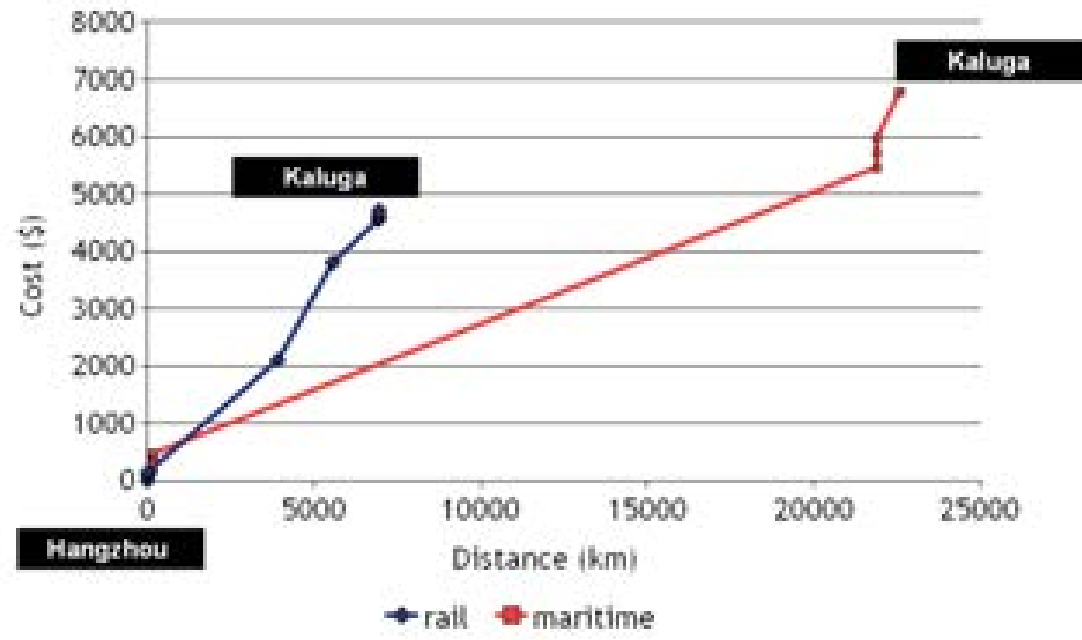

The maritime transport is more expensive (by $\$ 2,071)$ than the rail transport. 
Figure 2.31 - EATL ROUTE 3: Tashkent - Varna

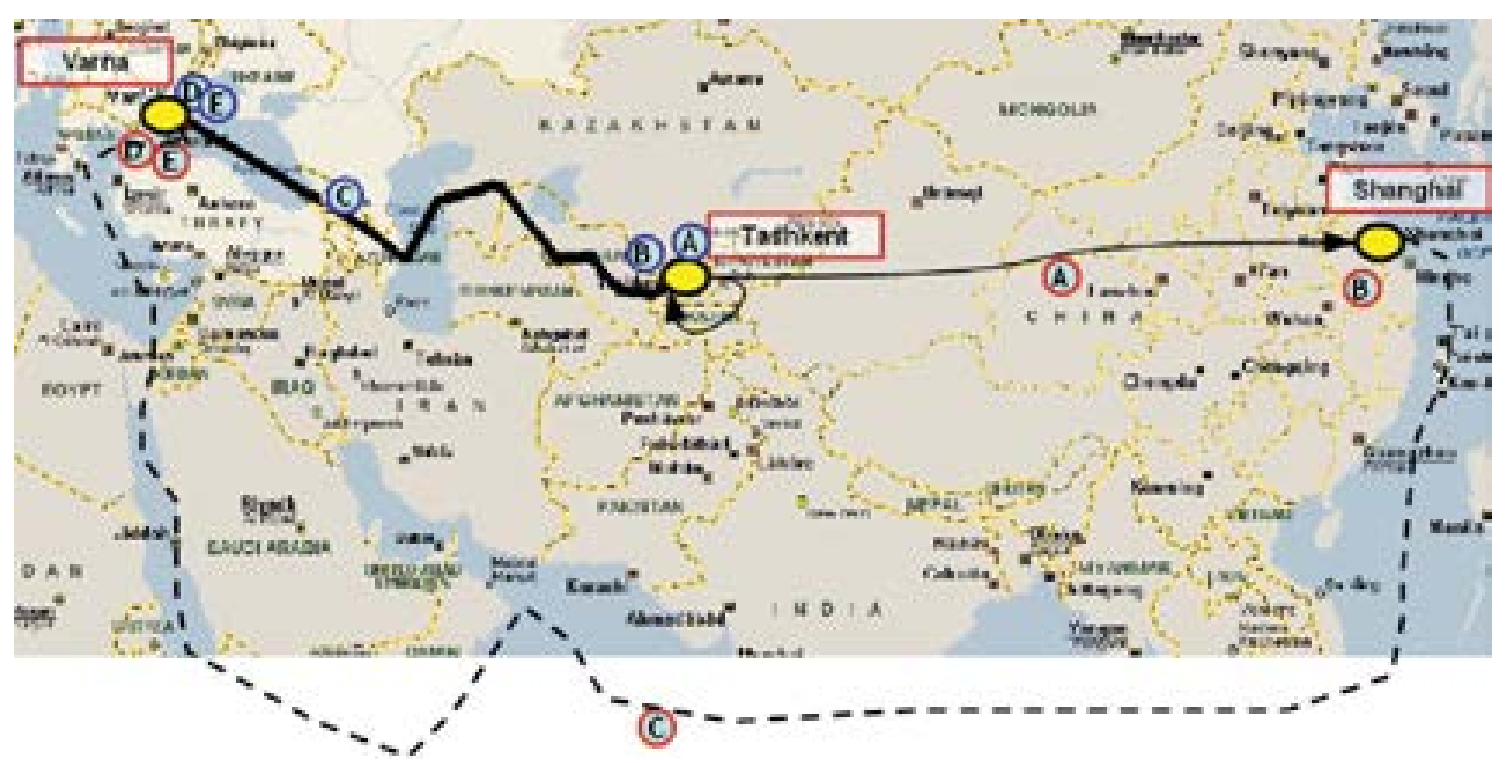

Maritime Transport

Rail Transport
(A) Truck cost
(D) THC / Port costs
(A) Truck cost
(D) Unloading / other costs
(B) THC / Port costs
(E) Truck cost
(B) Loading / other costs
(E) Truck cost
(C) Maritime cost
(C) Rail cost

EATL ROUTE 3 Tashkent (Uzbekistan - Origin) to Varna (Bulgaria - Destination)

\begin{tabular}{|l|c|c|c|}
\hline \multicolumn{1}{|c|}{ MARITIME TRANSPORT: Tashkent (via Shanghai port) - Varna (via Varna port) } \\
\hline Tashkent - Shanghai port by road & km & Cost(\$) & Time(hrs) \\
\hline Shanghai port THC costs & 4920 & 3000 & 96 \\
\hline Shanghai port other costs & - & 100 & - \\
\hline Shanghai port - Varna port by sea & 15066 & 3650 & 432 \\
\hline Varna port THC costs & - & 250 & - \\
\hline Varna port other costs & - & 250 & - \\
\hline Varna port - Varna by road & 20 & 150 & 1 \\
\hline Total maritime transport & 15066 & 4400 & 432 \\
\hline Total road transport & 4940 & 3150 & 97 \\
\hline
\end{tabular}




\begin{tabular}{|c|c|c|c|}
\hline \multicolumn{4}{|c|}{ RAIL TRANSPORT: Tashkent - Varna } \\
\hline Route & $\mathrm{km}$ & $\operatorname{Cost}(\$)$ & Time(hrs) \\
\hline Tashkent - Tashkent rail station by road & 20 & 120 & 1 \\
\hline Tashkent rail station loading cost & - & 25 & - \\
\hline Tashkent rail station other costs & - & 30 & - \\
\hline Uzbekistan by rail & 1547.48 & 2166.40 & 95 \\
\hline Kazakhstan by rail & 450 & 464 & 13.26 \\
\hline Caspian sea by ferry & 375 & 300 & 5 \\
\hline Azerbaijan by rail & 535.86 & 343 & 25.83 \\
\hline Georgia by rail & 317.63 & 175 & 9.30 \\
\hline Port Poti costs & - & 300 & - \\
\hline Black sea by ferry & 1135 & 1800 & 14 \\
\hline Varna rail station unloading cost & - & 35 & - \\
\hline Varna rail station other costs & - & 35 & - \\
\hline Varna rail station - Varna by road & 20 & 150 & 1 \\
\hline Total rail transport & 2850.97 & 3275 & 144 \\
\hline Total sea transport & 1510 & 2400 & 19 \\
\hline Total road transport & 40 & 270 & 2 \\
\hline TOTAL & 4400.97 & 5946 & 165 \\
\hline
\end{tabular}




\section{COMPARISON STUDY BY USING THE COST/TIME/DISTANCE METHODOLOGY}

Time - Distance Plot

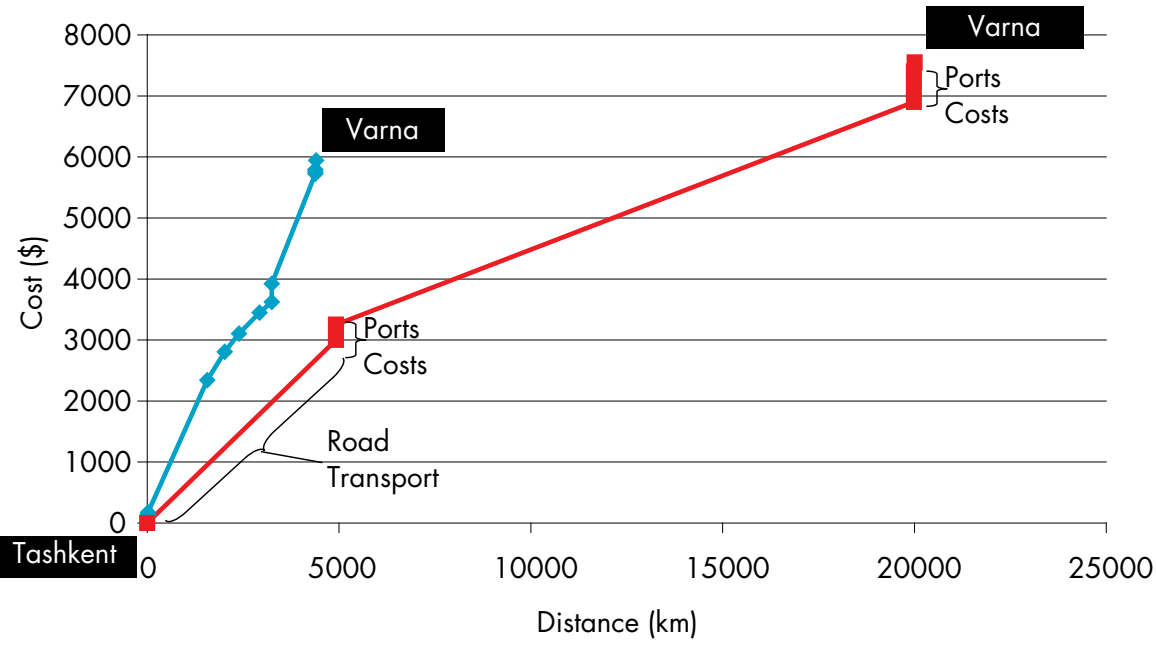

Cost - Distance plot

$\rightarrow$ Rail $\rightarrow$-Maritime

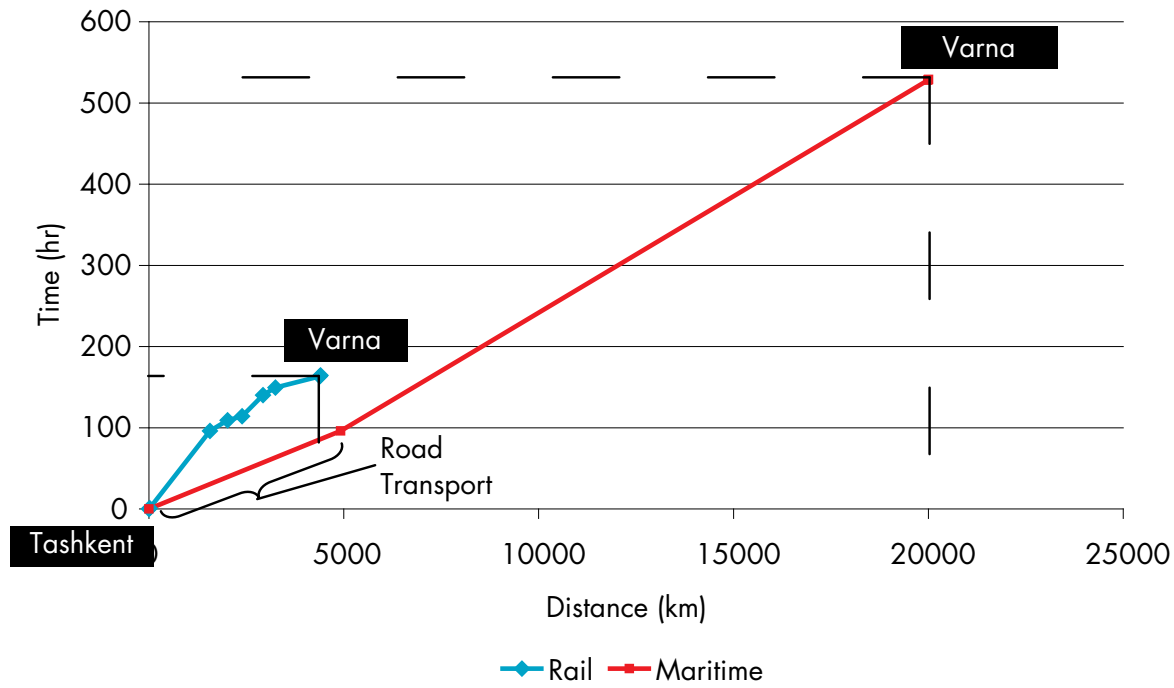


Figure 2.32 - EATL ROUTE 4: Almaty - Istanbul

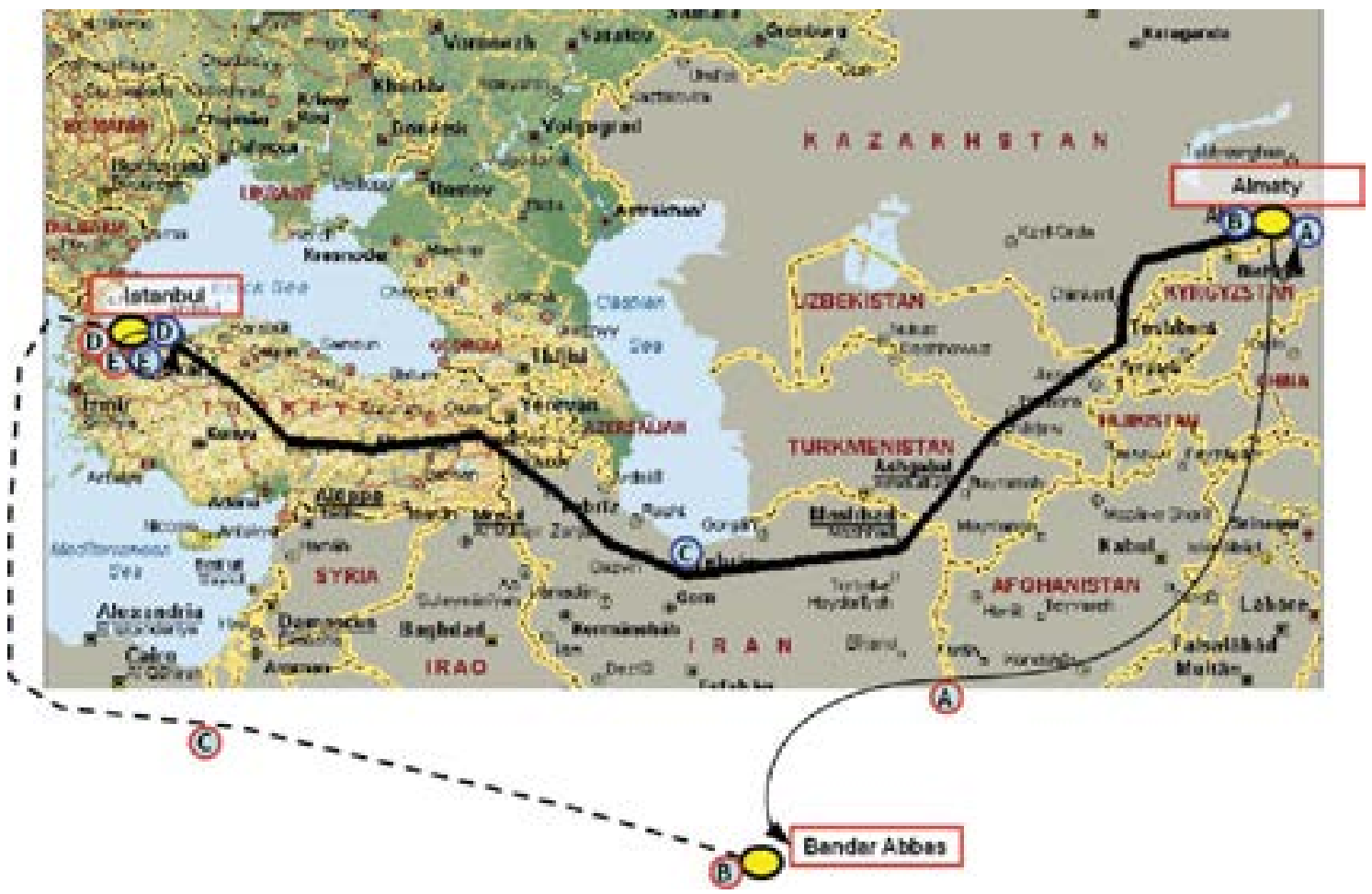

\section{Maritime Transport}

\section{Rail Transport}
(A) Truck cost
(D) THC / Port costs
(A) Truck cost
(D) Unloading / other costs
(B) THC / Port costs
(E) Truck cost
(B) Loading / other costs
(E) Truck cost
(C) Maritime cost
(C) Rail cost

EATL ROUTE 4 Almaty (Kazakhstan - Origin) to Istanbul (Turkey - Destination)

\begin{tabular}{|l|c|c|c|}
\hline \multicolumn{1}{|c|}{ Moute } & km & Cost(\$) & Time(hrs) \\
\hline Almaty - Bandar Abbas port by road & 2873 & 2300 & 71 \\
\hline Bandar Abbas port THC costs & - & 150 & - \\
\hline Bandar Abbas port other costs & - & 150 & - \\
\hline Bandar Abbas port - Istanbul port by sea & 6711 & 1650 & 25 days \\
\hline Istanbul port THC costs & - & 220 & - \\
\hline Istanbul port other costs & - & 220 & - \\
\hline Istanbul port - Istanbul by road & 20 & 300 & 1 \\
\hline Total maritime transport & 6711 & 2370 & 600 \\
\hline Total road transport & 2893 & 2600 & 72 \\
\hline TOTAL & 9604 & 4970 & 672 \\
\hline
\end{tabular}




\begin{tabular}{|c|c|c|c|}
\hline \multicolumn{4}{|c|}{ RAIL TRANSPORT: Almaty - Istanbul } \\
\hline Route & km & $\operatorname{Cost}(\$)$ & Time(hrs) \\
\hline Almaty - Almaty rail station by road & 20 & 150 & 1 \\
\hline Almaty rail station loading cost & - & 30 & - \\
\hline Almaty rail station other costs & - & 30 & - \\
\hline Kazakhstan by rail & 969 & 998 & 28 \\
\hline Uzbekistan by rail & 670 & 938 & 40 \\
\hline Turkmenistan by rail & 469 & 1220 & 32 \\
\hline Iran by rail & 1972 & 1340 & 63 \\
\hline Turkey by rail & 1945 & 800 & 85 \\
\hline Istanbul rail station unloading cost & - & 30 & - \\
\hline Istanbul rail station other costs & - & 45 & - \\
\hline Istanbul rail station - Istanbul by road & 20 & 300 & 1 \\
\hline Total rail transport & & 5431 & \\
\hline Total road transport & 40 & 450 & 2 \\
\hline TOTAL & 6065 & 5881 & 250 \\
\hline
\end{tabular}

\section{COMPARISON STUDY BY USING THE COST/TIME/DISTANCE METHODOLOGY}

\section{Time - Distance Plot}

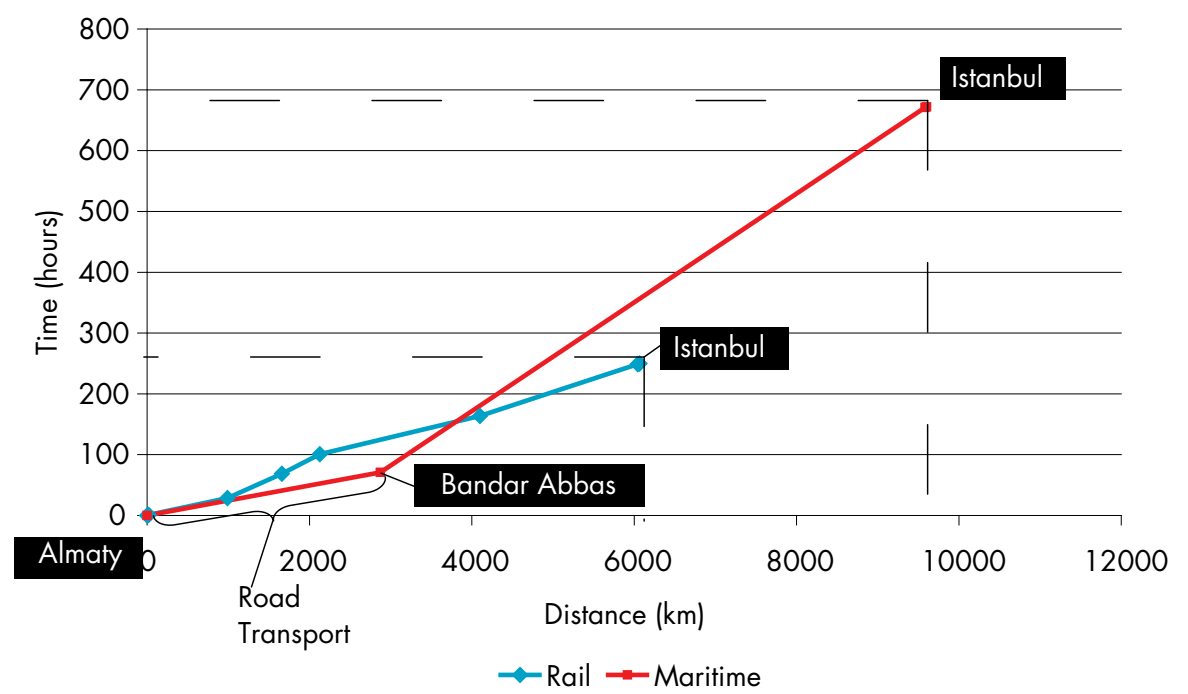

The ocean freight takes 28 days to reach location $B$ and rail needs 10 days; a difference of 18 days. This is acceptable as the distance from Almaty to the first port, Bandar Abbas, is far $(2,873 \mathrm{~km})$ - a distance that should also be served by train. Kazakhstan is a landlocked country and the location of Almaty makes the logistics challenging. Today, cargo from Istanbul 
to Almaty is served via Novorossiysk port in the Russian Federation and by train to Almaty. A look at the map suggests the rail option is more competitive than maritime, but the cost analysis shows different results.

\section{Cost - Distance Plot}

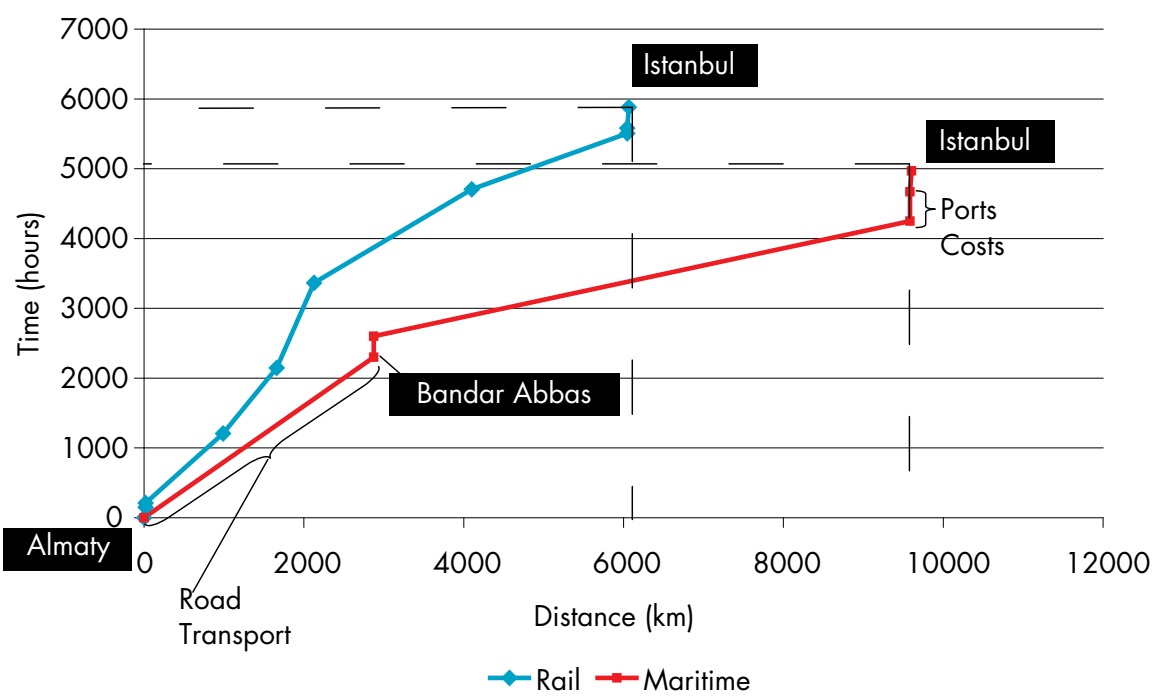

The two routes' cost difference is \$911. The plot clearly shows the extremely high rail charges in Turkmenistan and Kazakhstan. Because of the long distance between Almaty and the port of Bandar Abbas in Iran and the high road rates, one would expect that maritime transport would be less competitive than rail, but that is not the case. On the contrary, it is actually cheaper. The non-existence of harmonized tariffs in the countries of Central Asia, and the effect this has upon trade, is evident. 


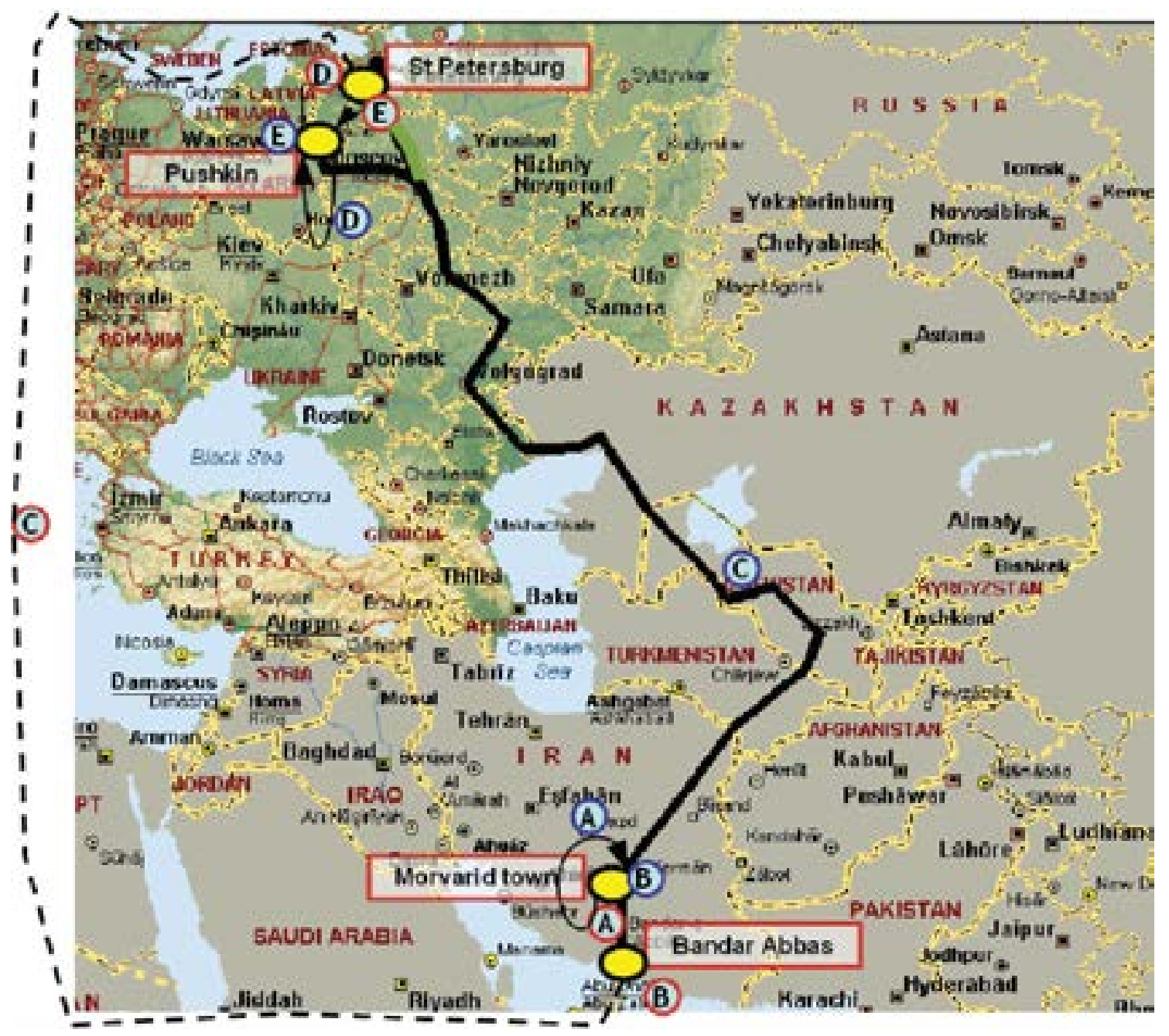

\begin{tabular}{|c|c|}
\hline Maritime Transport & Rail Transport \\
\hline (D) THC / Port costs & (D) Unloading / other costs \\
\hline (B) THC / Port costs (E) Truck cost & (B) Loading / other costs (E) Truck cost \\
\hline (C) Maritime cost & (C) Rail cost \\
\hline
\end{tabular}


EATL ROUTE 5 Morvarid Town (Iran) to Pushkin (Russian Federation)

\begin{tabular}{|c|c|c|c|}
\hline \multicolumn{4}{|c|}{$\begin{array}{l}\text { MARITIME TRANSPORT: Morvarid (via Bandar Abbas port) - Pushk } \\
\text { RAIL TRANSPORT: Morvarid - Pushkin }\end{array}$} \\
\hline Route & $\mathrm{km}$ & $\operatorname{Cost}(\$)$ & Time(hr) \\
\hline Morvarid to Morvarid rail station by road & 16.7 & 50 & 1 \\
\hline Morvarid rail station loading cost & - & 25 & - \\
\hline Morvarid rail station other costs & - & 30 & - \\
\hline Iran by rail & 1619 & 1100 & 52 \\
\hline Turkmenistan by rail & 469 & 1219 & 32 \\
\hline Uzbekistan by rail & 1256.5 & 1759 & 77.5 \\
\hline Kazakhstan by rail & 722.8 & 744.5 & 21.5 \\
\hline Russian Federation by rail & 2415 & 1328 & 71 \\
\hline Pushkin rail station unloading cost & - & 30 & - \\
\hline Pushkin rail station other costs & - & 45 & - \\
\hline Pushkin rail station - Pushkin by road & 20 & 60 & 1 \\
\hline Total rail transport & 6482.29 & 6280.5 & 255 \\
\hline Total road transport & 36.7 & 110 & 2 \\
\hline TOTAL & 6519 & 6390.5 & 257 \\
\hline
\end{tabular}

\section{COMPARISON STUDY BY USING THE COST/TIME/DISTANCE METHODOLOGY}

Time - Distance plot

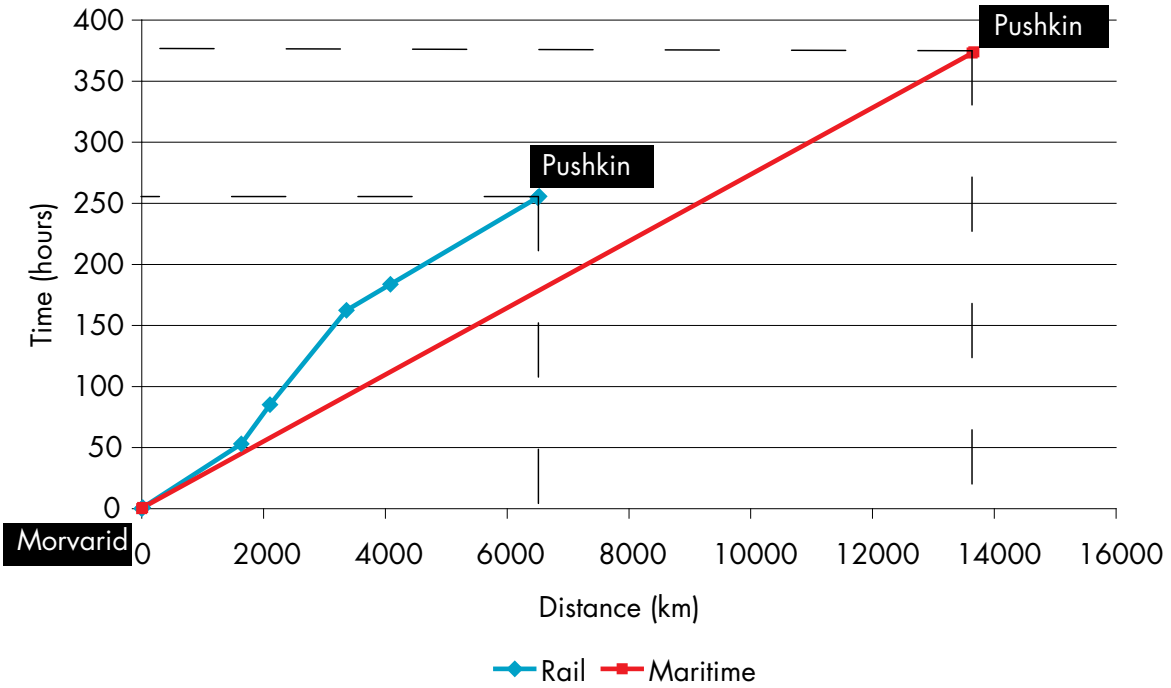




\section{Cost Distance Plot}

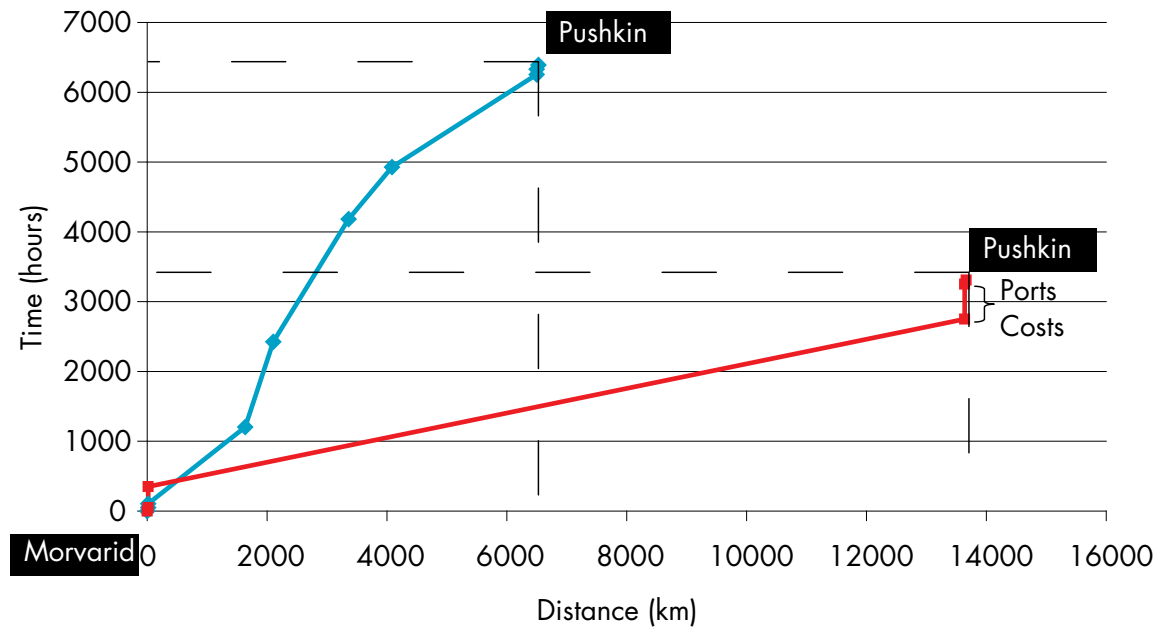

$\rightarrow$ Rail $\rightarrow-$ Maritime

Figure 2.34 - EATL ROUTE 6: Ussuriysk - Kyiv

EATL ROUTE 6 Ussuriysk (Russian Federation - Origin) to Kyiv (Ukraine - Destination)

\begin{tabular}{|l|c|c|c|}
\hline \multicolumn{1}{|c|}{ MARITIME TRANSPORT: Vladivostok port - Odessa port } & km & Cost(\$) & Time(hrs) \\
\hline Ussuriysk - Vladivostok port by road & 118 & 140 & 1.5 \\
\hline Vladivostok port THC costs & - & 250 & - \\
\hline Vladivostok port other costs & - & 250 & - \\
\hline Vladivostok port - Odessa port by sea & 16947 & 4900 & 456 \\
\hline Odessa port THC costs & - & 200 & - \\
\hline Odessa port other costs & - & 200 & 6.5 \\
\hline Odessa port - Kyiv by road & 436.25 & 350 & 456 \\
\hline Total maritime transport & 16947 & 5800 & 8 \\
\hline Total road transport & 554.25 & 490 & 463 \\
\hline
\end{tabular}




\begin{tabular}{|c|c|c|c|}
\hline Route & $\mathrm{km}$ & $\operatorname{Cost}(\$)$ & Time(hrs) \\
\hline Ussuriysk - Ussuriysk rail station by road & 20 & 140 & 1.5 \\
\hline Ussuriysk rail station loading cost & - & 35 & - \\
\hline Ussuriysk rail station other costs & - & 35 & - \\
\hline Russian Federation by rail & 9185 & 5052 & 270 \\
\hline Ukraine by rail & 579 & 320 & 17 \\
\hline Kyiv rail station unloading cost & - & 30 & - \\
\hline Kyiv rail station other costs & - & 45 & - \\
\hline Kyiv rail station - Kyiv by road & 20 & 200 & 1 \\
\hline Total rail transport & 9764 & 5517 & 287 \\
\hline Total road transport & 40 & 340 & 2.5 \\
\hline TOTAL & 9804 & 5857 & 289 \\
\hline
\end{tabular}

\section{COMPARISON STUDY BY USING THE COST/TIME/DISTANCE METHODOLOGY}

\section{Time - Distance Plot}

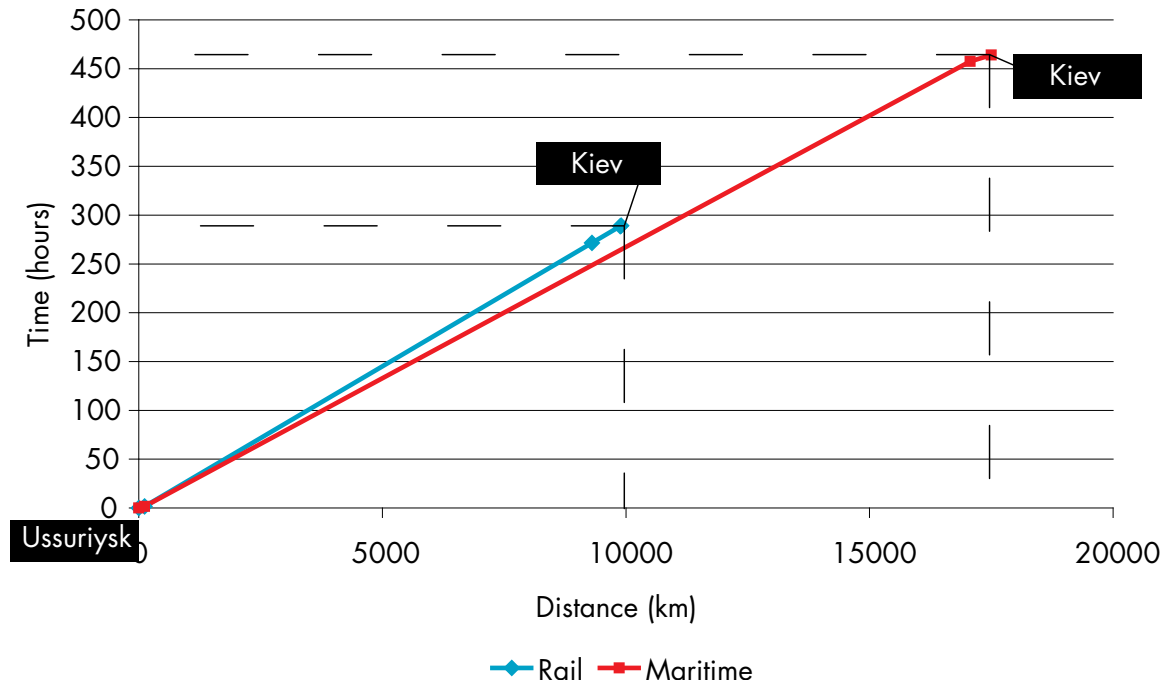

The time difference between different transport modes is more or less 7 days. In combination with the cost difference, the time difference becomes an advantage. The benefit of this route is that trains have to cross only two countries, both with great railway traditions, with the highest average total travelling speed of $34 \mathrm{~km}$ per hour. These conditions make railways in this case study more competitive than maritime transport. 
Cost - Distance Plot

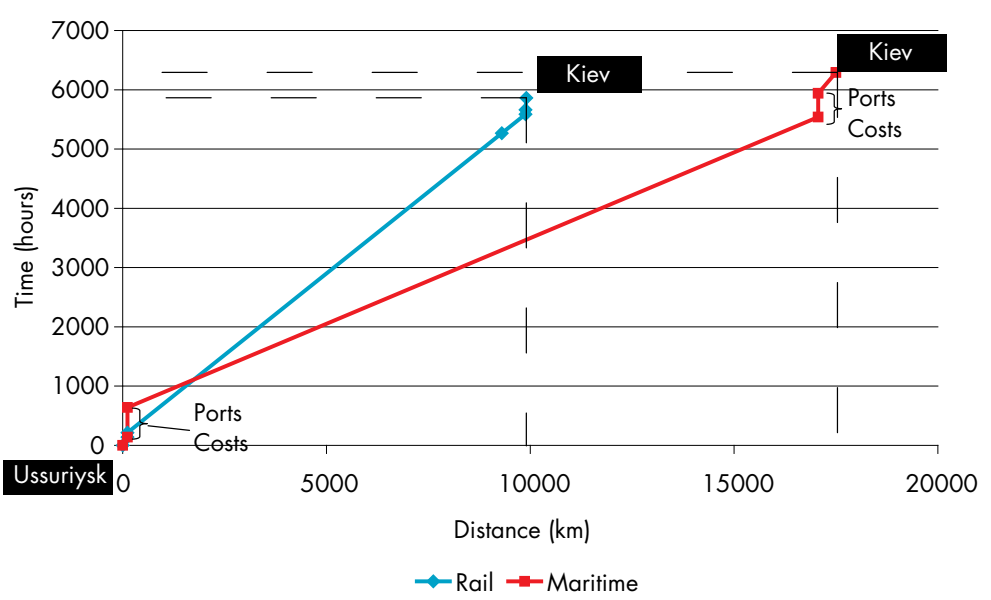

The cost difference of $\$ 433$ is not large, but it is enough to make railways more competitive than maritime transport.

Figure 2.35 - EATL ROUTE 7: Shanghai - Warsaw

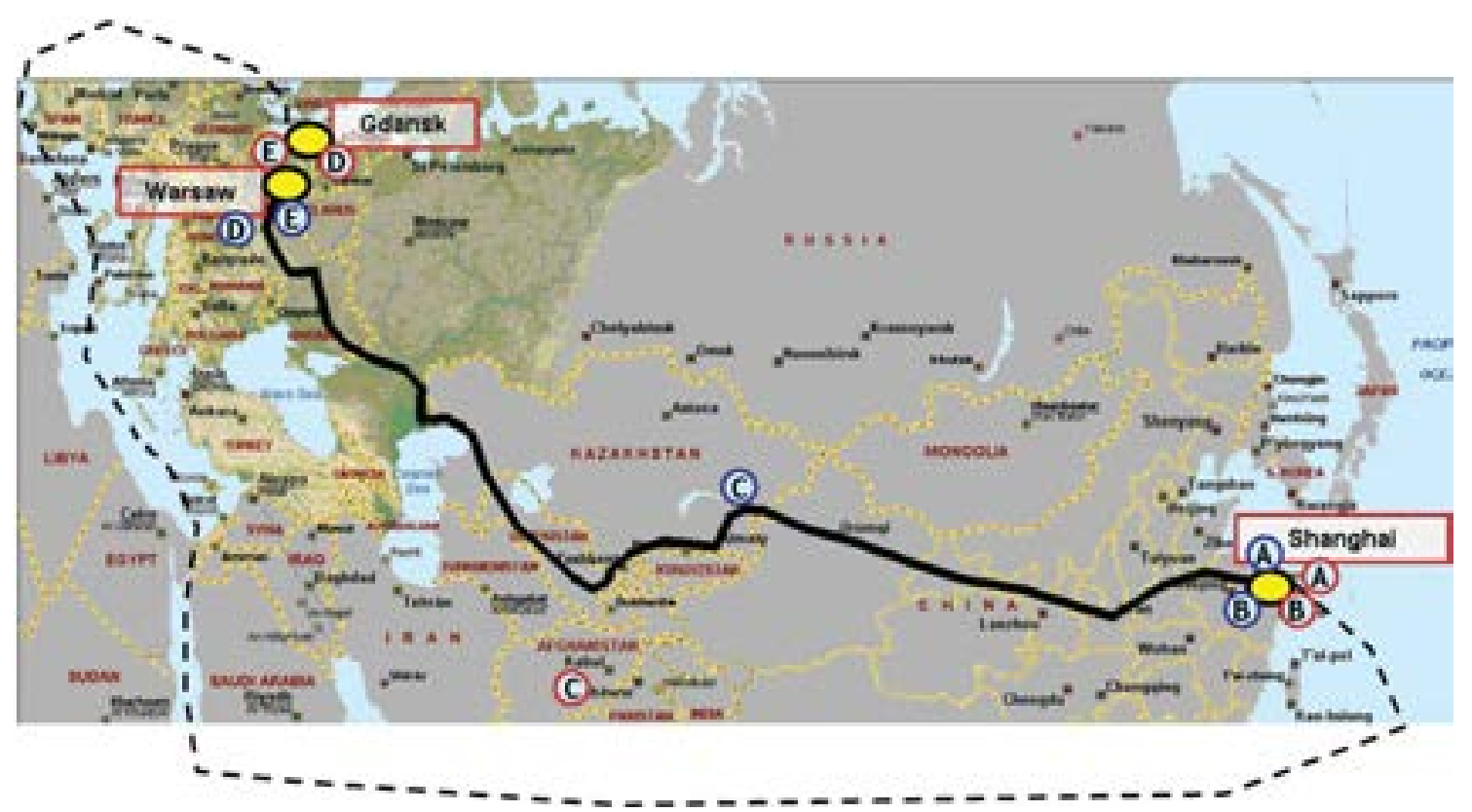

Maritime Transport

Rail Transport
(A) Truck cost
(D) THC / Port costs
(A) Truck cost
(D) Unloading / other costs
(B) THC / Port costs
(E) Truck cost
(B) Loading / other costs
(E) Truck cost
(C) Maritime cost
(C) Rail cost 
EATL ROUTE 7 Shanghai (China - Origin) to Warsaw (Poland - Destination)

\begin{tabular}{|c|c|c|c|}
\hline \multicolumn{4}{|c|}{ MARITIME TRANSPORT: Shanghai port - Gdansk port } \\
\hline Route & $\mathrm{km}$ & $\operatorname{Cost}(\$)$ & Time(hrs) \\
\hline Shanghai - Shanghai port by road & 20 & 200 & 1 \\
\hline Shanghai port THC costs & - & 100 & - \\
\hline Shanghai port other costs & - & 150 & - \\
\hline Shanghai port - Gdansk port by sea & 20888 & 4900 & 564 \\
\hline Gdansk port THC costs & - & 250 & - \\
\hline Gdansk port other costs & - & 250 & - \\
\hline Gdansk port - Warsaw by road & 330 & 450 & 4 \\
\hline Total maritime transport & 20888 & 5650 & 564 \\
\hline Total road transport & 350 & 650 & 5 \\
\hline TOTAL & 21238 & 6300 & 569 \\
\hline \multicolumn{4}{|c|}{ RAIL TRANSPORT: Shanghai rail station - Warsaw rail station } \\
\hline Route & $\mathrm{km}$ & $\operatorname{Cost}(\$)$ & Time(hrs) \\
\hline Shanghai - Shanghai rail station by road & 20 & 200 & 1 \\
\hline Shanghai rail station loading cost & - & 25 & - \\
\hline Shanghai rail station other costs & - & 30 & - \\
\hline China by rail & 3884.5 & 1942.25 & 185.5 \\
\hline Kazakhstan by rail & 1735 & 2532 (total) & 53 \\
\hline Uzbekistan by rail & 1547.5 & 2166 & 95 \\
\hline Kazakhstan by rail & 723 & - & 21.5 \\
\hline Russian Federation by rail & 849.5 & 467 & 25 \\
\hline Ukraine by rail & 1688 & 928 & 50 \\
\hline Poland by rail & 373 & 317 & 14.5 \\
\hline Warsaw rail station unloading cost & - & 35 & - \\
\hline Warsaw rail station other costs & - & 45 & - \\
\hline Warsaw rail station - Warsaw by road & 20 & 250 & 1 \\
\hline Total rail transport & & 8487 & 444 \\
\hline Total road transport & 40 & 450 & 2 \\
\hline TOTAL & 10800 & 8937 & 446 \\
\hline
\end{tabular}




\section{COMPARISON STUDY BY USING COST/TIME/DISTANCE METHODOLOGY}

\section{Time - Distance Plot}

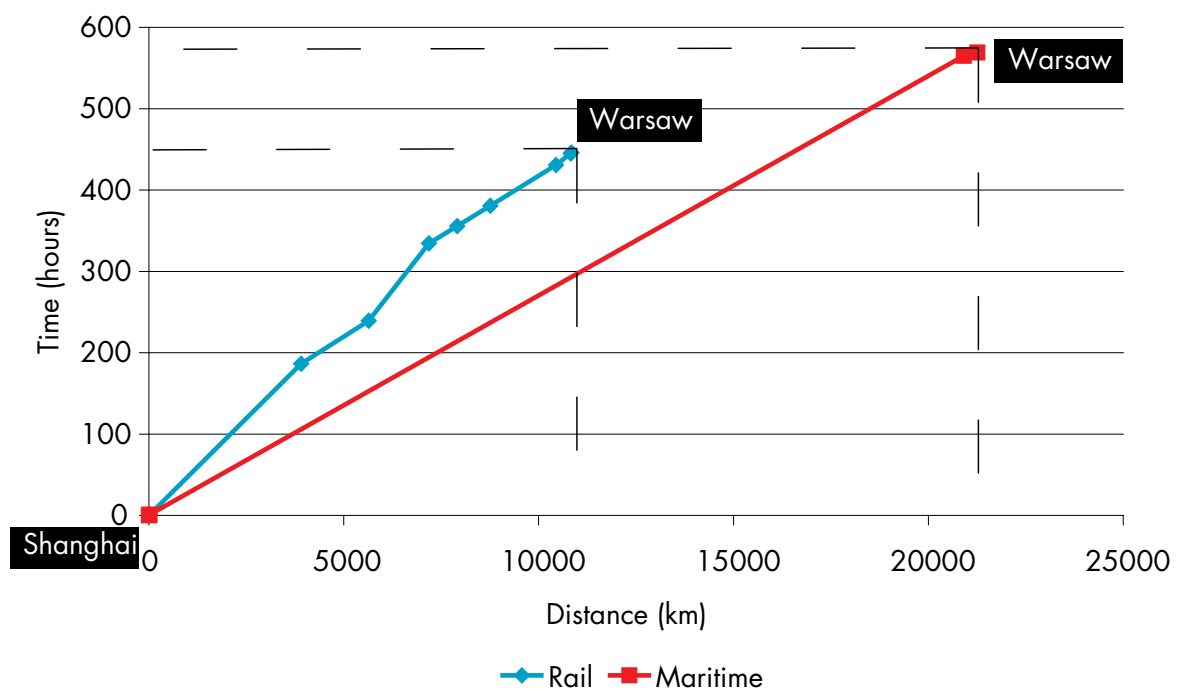

Connecting China with Poland via the countries of Central Asia does not appear competitive for railways. The time difference is only 5 days less for the railways. A block train that operates according to normal conditions (not supported by governments) is likely to waste 5 days due to delays at border crossings.

\section{Cost - Distance Plot}

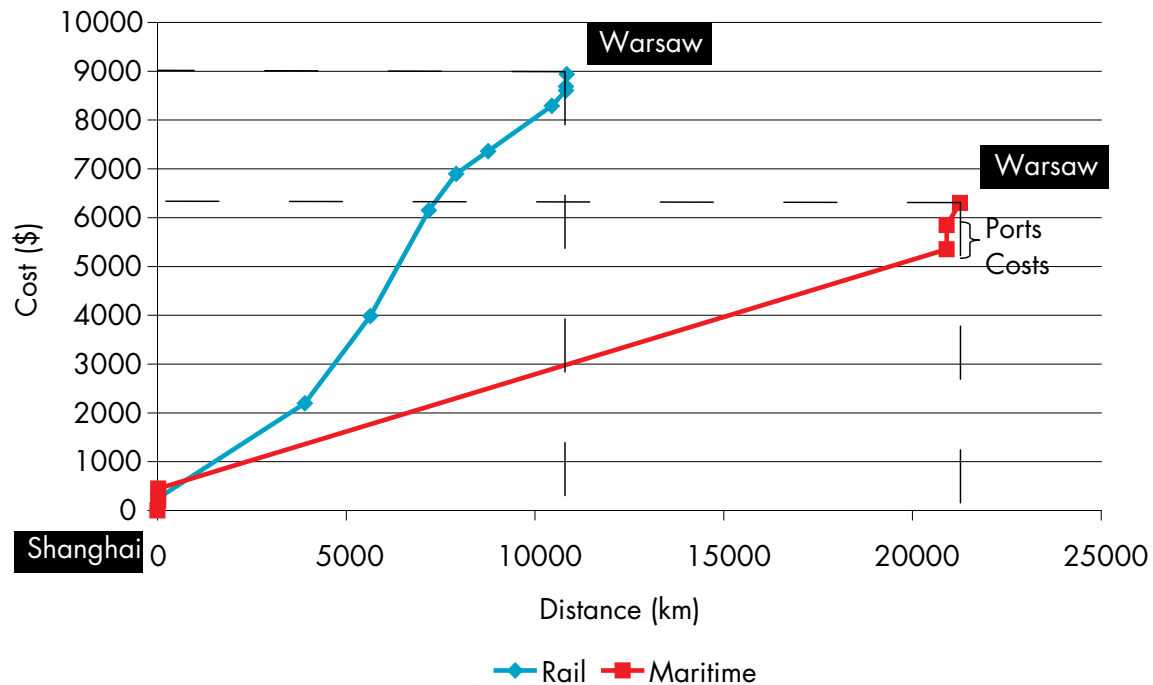

The cost difference is large: $\$ 2,637$. The railway passes through 7 countries (twice through Kazakhstan) and there are 10,840 total rail kilometres, a greater distance than connecting China with Germany. 
Figure 2.36 - EATL ROUTE 8: Krasnodar - Kaliningrad

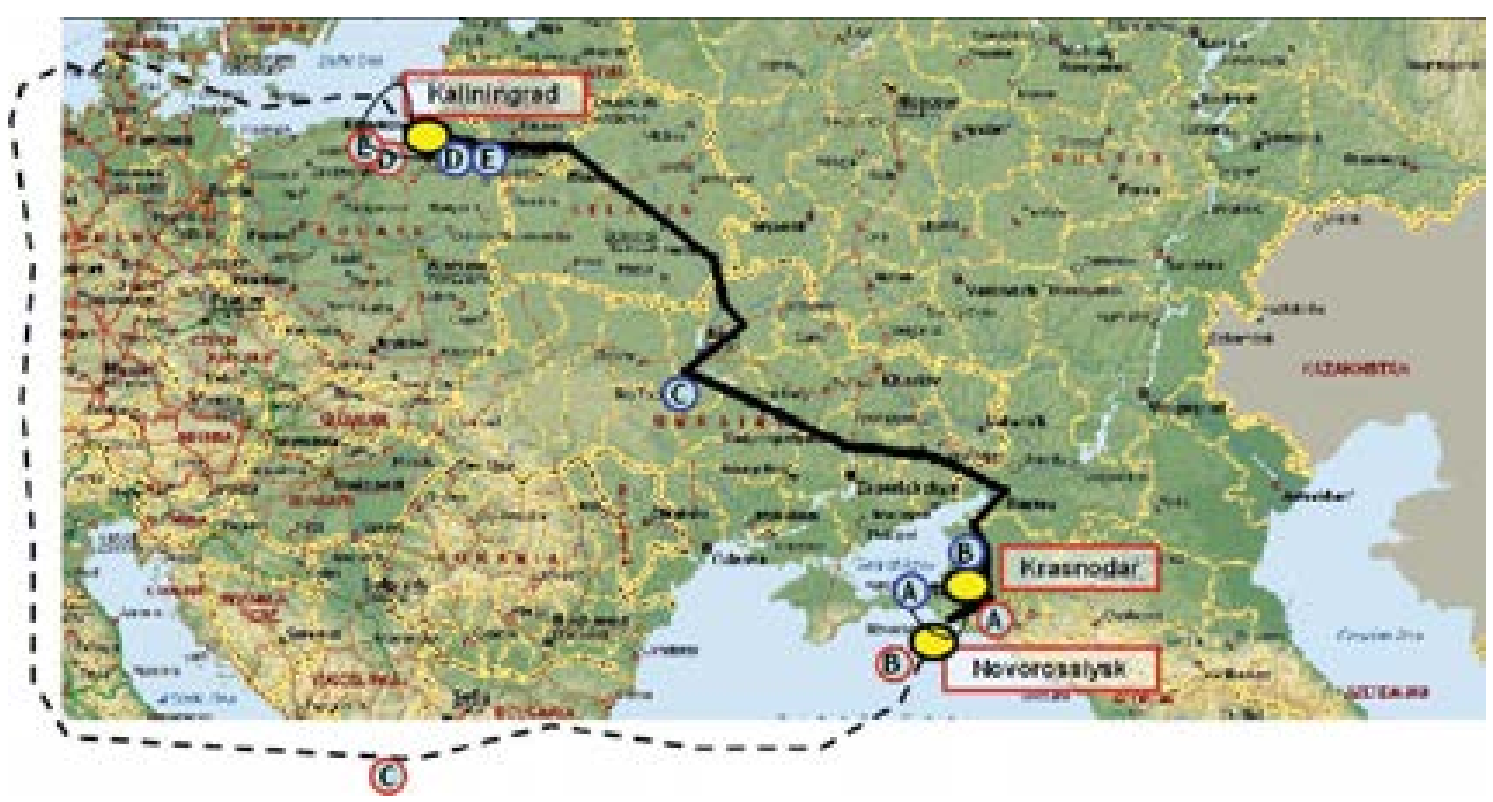

\section{Maritime Transport}

Rail Transport
(A) Truck cost
(D) THC / Port costs
(A) Truck cost
(D) Unloading / other costs
(B) THC / Port costs
(E) Truck cost
(B) Loading / other costs
(E) Truck cost
(C) Maritime cost
(C) Rail cost

EATL ROUTE 8 Krasnodar (Russian Federation -Origin) to Kaliningrad (Russian Federation - Destination)

\begin{tabular}{|l|c|c|c|}
\hline \multicolumn{1}{|c|}{ MARITIME TRANSPORT: Novorossiysk port - Kaliningrad port } & km & Cost(\$) & Time(hrs) \\
\hline Krasnodar - Novorossiysk port by road & 105 & 150 & 2 \\
\hline Novorossiysk port THC costs & - & 250 & - \\
\hline Novorossiysk port other costs & - & 250 & 222 \\
\hline Novorossiysk port - Kaliningrad port by sea & 8230 & 3900 & - \\
\hline Kaliningrad port THC costs & - & 150 & - \\
\hline Kaliningrad port other costs & - & 250 & 1 \\
\hline Kaliningrad port - Kaliningrad by road & 20 & 100 & 222 \\
\hline Total maritime transport & 8230 & 4800 & 3 \\
\hline Total road transport & 125 & 250 & 225 \\
\hline TOTAL & 8355 & 5050 & \\
\hline
\end{tabular}




\begin{tabular}{|c|c|c|c|}
\hline Route & $\mathrm{km}$ & $\operatorname{Cost}(\$)$ & Time(hrs) \\
\hline Krasnodar - Krasnodar rail station by road & 20 & 150 & 2 \\
\hline Krasnodar rail station loading cost & - & 25 & - \\
\hline Krasnodar rail station other costs & - & 30 & - \\
\hline Russian Federation by rail & 438 & 241 & 13 \\
\hline Ukraine by rail & 1014 & 558 & 30 \\
\hline Belarus by rail & 465 & 256 & 14 \\
\hline Lithuania by rail & 203 & 112 & 6 \\
\hline Kaliningrad by rail & 145 & 78 & 4 \\
\hline Kaliningrad rail station unloading cost & - & 20 & - \\
\hline Kaliningrad rail station other costs & - & 25 & - \\
\hline Kaliningrad rail station - Kaliningrad by road & 20 & 100 & 1 \\
\hline Total rail transport & 2265 & 1345 & 67 \\
\hline Total road transport & 40 & 250 & 3 \\
\hline TOTAL & 2305 & 1595 & 70 \\
\hline
\end{tabular}

\section{COMPARISON STUDY BY USING THE COST/TIME/DISTANCE METHODOLOGY}

\section{Time - Distance Plot}

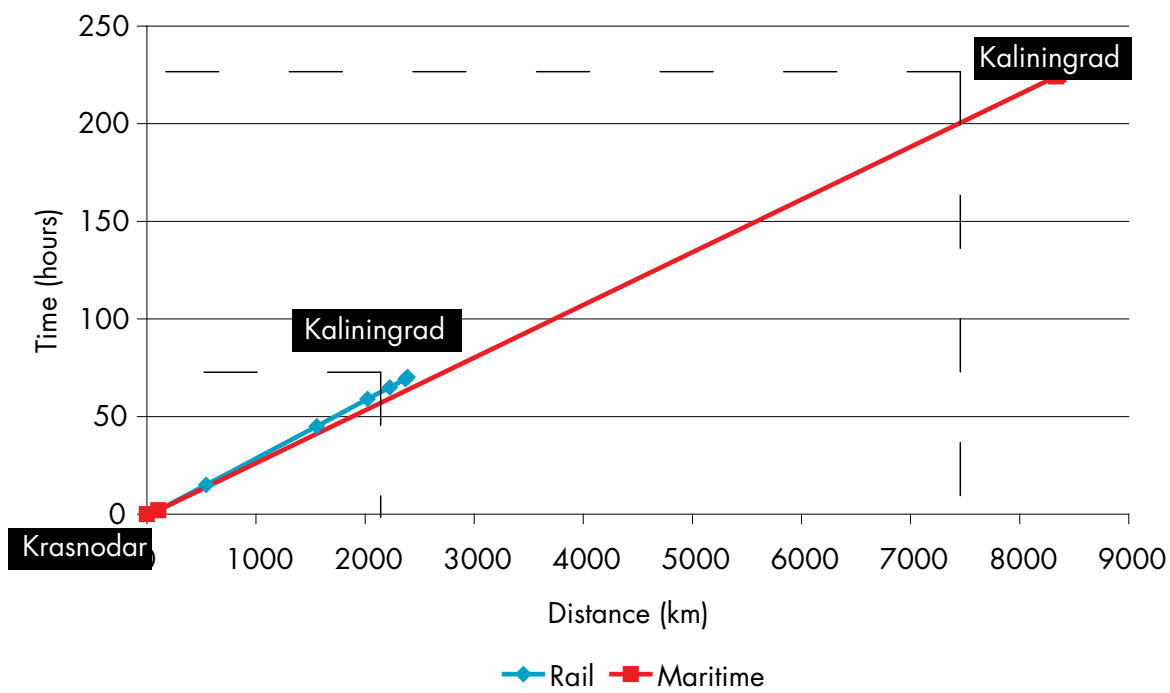

This case study is dominated by railways. Rail is very competitive in connecting these 5 countries, which are all CIS. The time difference is 7 days. 


\section{Cost - Distance Plot}

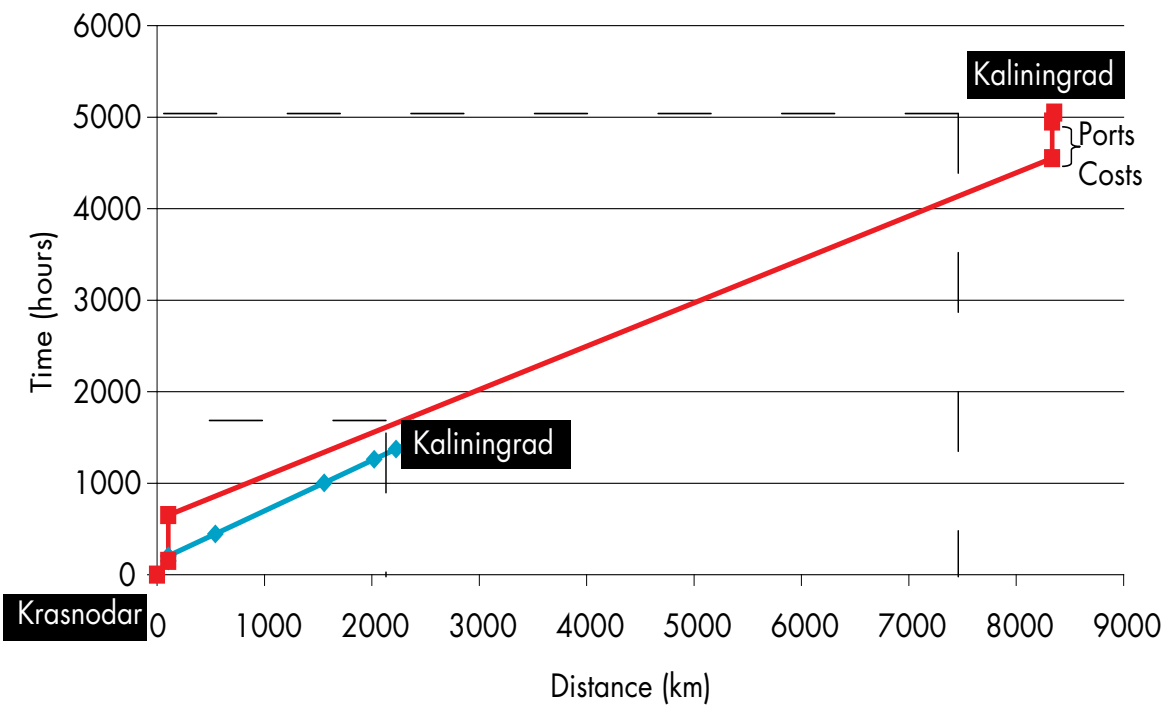

$\leadsto$ Rail $\rightarrow$ Maritime

The cost difference is the biggest in all scenarios as railways are $\$ 3,455$ cheaper than maritime transport.

\subsubsection{Case study: Car manufacturers along the Euro-Asia transport links}

Peugeot - Citroen - Mitsubishi Automobiles - Kaluga Russian Federation

\section{A multimodal project}

This multimodal and logistics project includes $6,000 \mathrm{~km}$ round trip, 400 dedicated wagons, 1,200 dedicated containers and 80 trucks. It is used for the transport of parts from eastern France to the Russian Federation to be assembled in Kaluga.

Figure 2.37 - Transport of cars to Vesoul
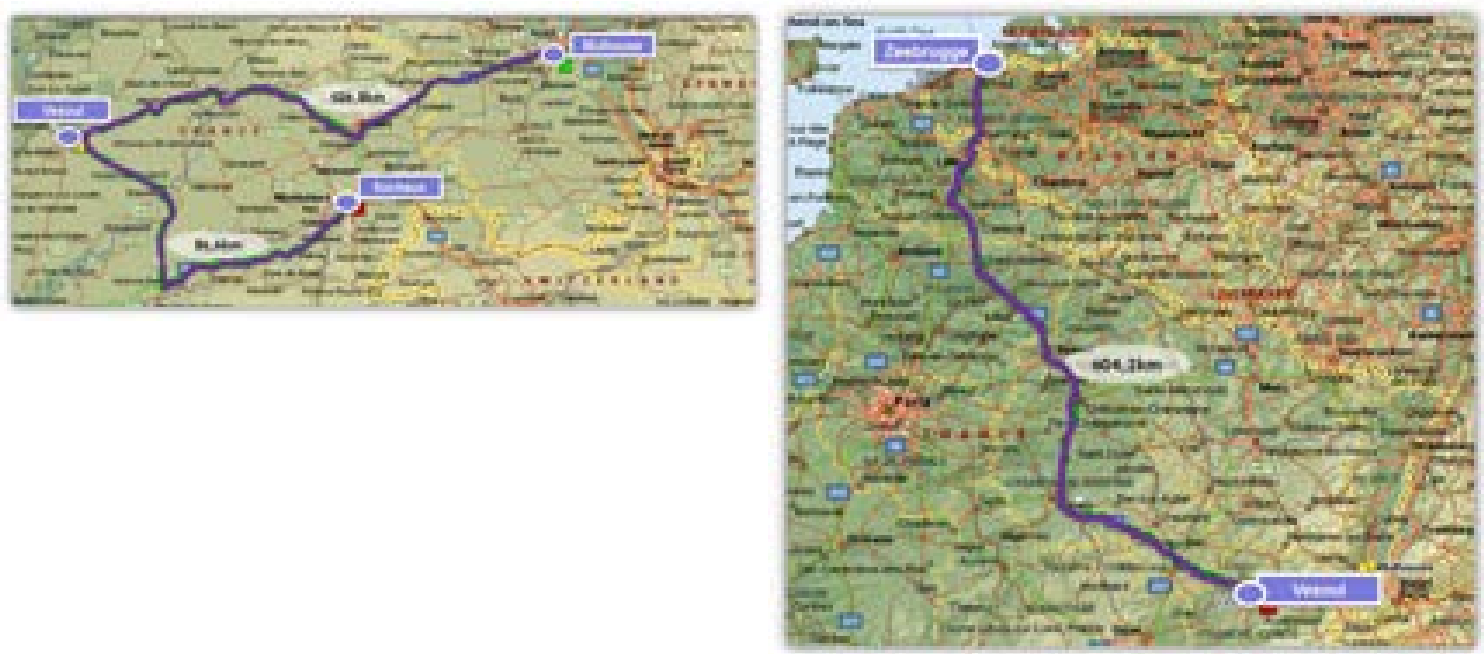

Step 1: Transport of 144 cars (308 \& C4 models) per day from Sochaux (France) and Mulhouse (France) and 60 from Zeebrugge (Belgium) to Vesoul (France) for disassembly.

Step 2: In Vesoul, the containers are loaded on the block train and start their trip to the Russian Federation.

Step 3: At the Polish-Belarusian border, the containers are trans-shipped onto wide-gauge trains.

Step 4: The train passes from Belarus to the Russian Federation station of Vorotinsk.

Step 5: The train arrives at the factory in Kaluga.

Step 6: The finished cars are transported from Kaluga to the GEFCO car compound in Bykovo (Moscow). 


\section{Analysis of alternative options}

Figure 2.38 - Case study: Vesoul - Kaluga

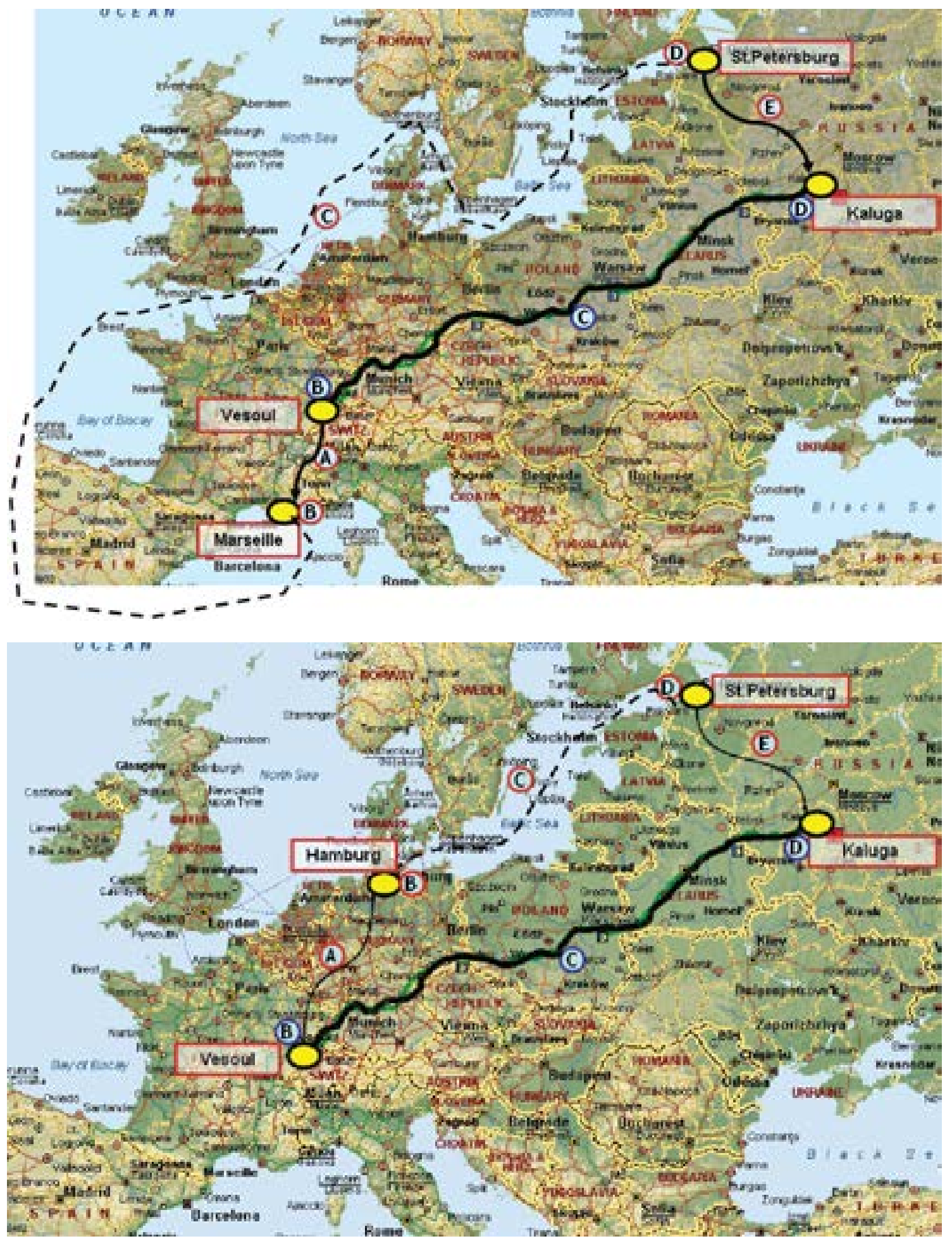




\section{Rail Transport}
(A) Truck cost
(D) THC / Port costs
(A) Truck cost
(D) Unloading / other costs
(B) THC / Port costs
(E) Truck cost
(B) Loading / other costs
(E) Truck cost
(C) Maritime cost
(C) Rail cost

PCMA RUS LLC - Case study from Vesoul (France) to Kaluga (Russian Federation)

\begin{tabular}{|c|c|c|c|}
\hline Route & $\mathrm{km}$ & $\operatorname{Cost}(\$)$ & Time(hrs) \\
\hline Vesoul - Marseilles port by road & 608 & 750 & 9 \\
\hline Marseilles port THC costs & - & 200 & - \\
\hline Marseilles port other costs & - & 200 & - \\
\hline Marseilles port - St Petersburg port by sea & 6098 & 3900 & 163 \\
\hline St Petersburg port THC costs & - & 250 & - \\
\hline St Petersburg port other costs & - & 250 & - \\
\hline St Petersburg port - Kaluga by road & 873 & 750 & 36 \\
\hline Total maritime transport & 6098 & 3900 & 163 \\
\hline Total road transport & 1481 & 1500 & 45 \\
\hline TOTAL & 7579 & 5400 & 208 \\
\hline
\end{tabular}

6.8 days or 163.2 hours $(3,293 \mathrm{~nm}=6,098 \mathrm{~km})$

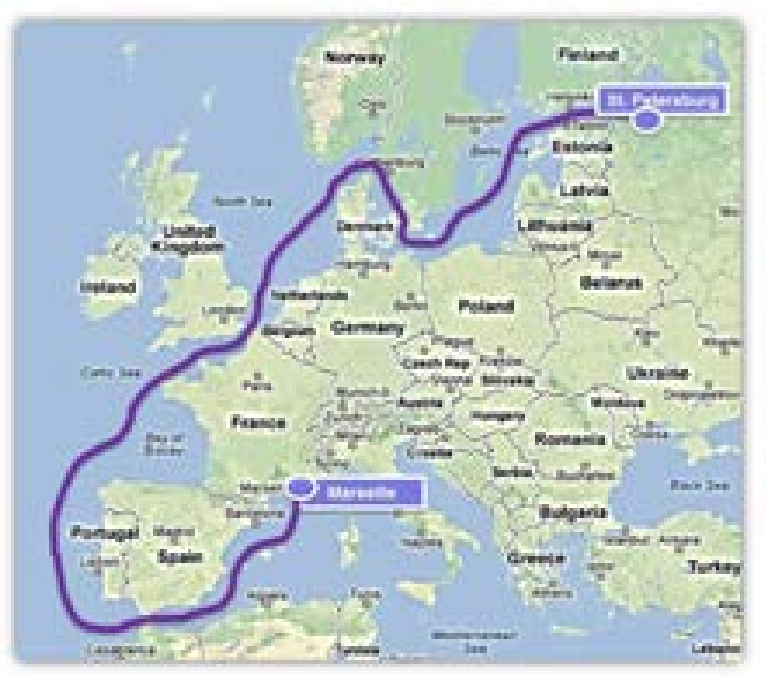

608 km (9 hours) + 873.8 km (1 day \& 12 hours)

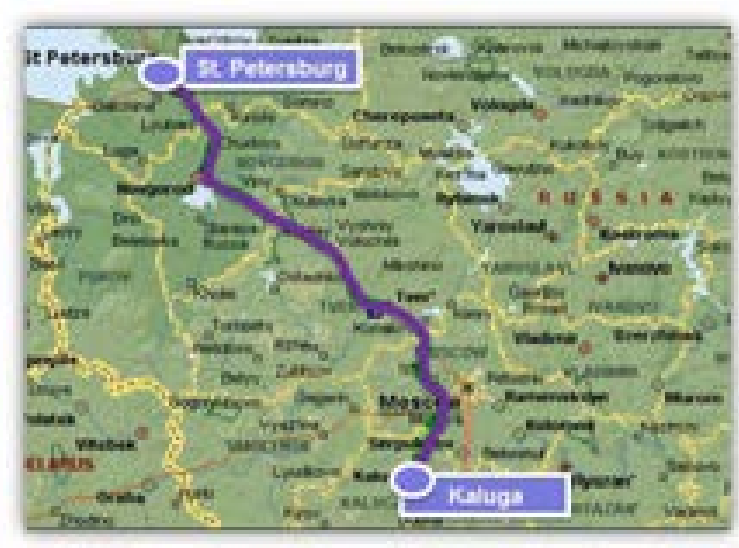




\begin{tabular}{|l|c|c|c|}
\hline \multicolumn{4}{|c|}{ MARITIME TRANSPORT: Vesoul (via Hamburg port) - to Kaluga (via St Petersburg port) } \\
\hline Vesoul - Hamburg port by road & km & Cost(\$) & Time(hrs) \\
\hline Hamburg port THC costs & 913 & 1000 & 12 \\
\hline Hamburg port other costs & - & 200 & - \\
\hline Hamburg port - St Petersburg port by sea & - & 200 & - \\
\hline St Petersburg port THC costs & 1150 & 1200 & 120 \\
\hline St Petersburg port other costs & - & 250 & - \\
\hline St Petersburg port - Kaluga by road & - & 250 & - \\
\hline Total maritime transport & 873 & 750 & 36 \\
\hline Total road transport & 1150 & 2100 & 120 \\
\hline \multicolumn{1}{|c|}{ TOTAL } & 1786 & 1750 & 48 \\
\hline
\end{tabular}

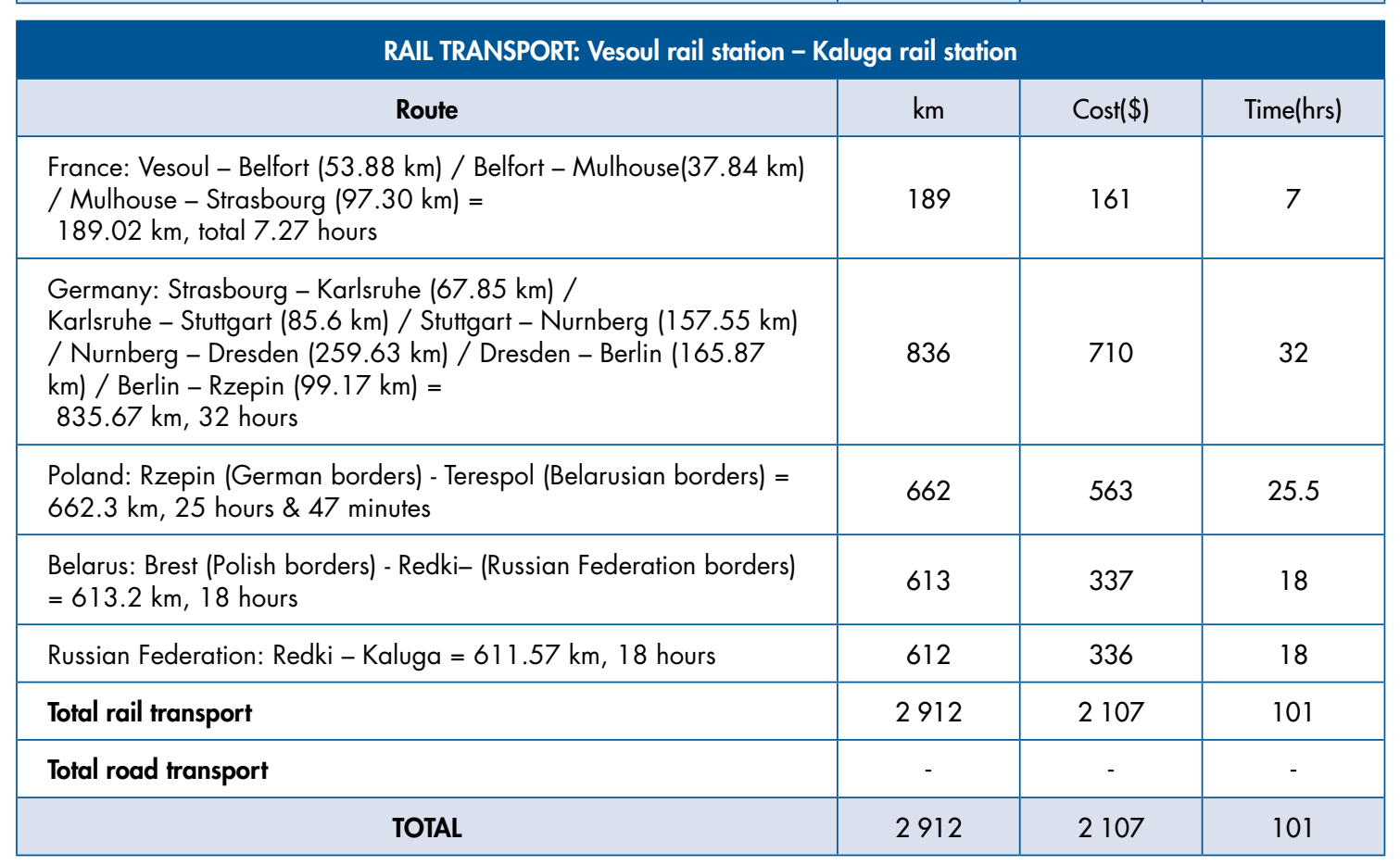




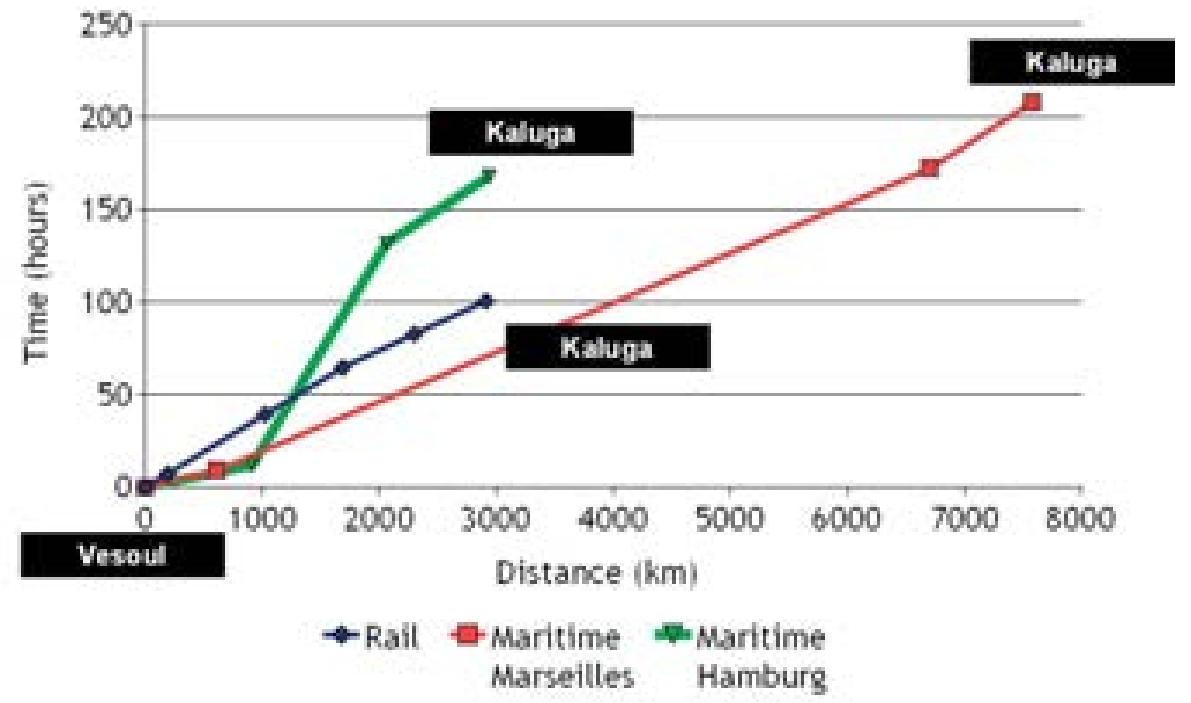

Cost - Distance Plot

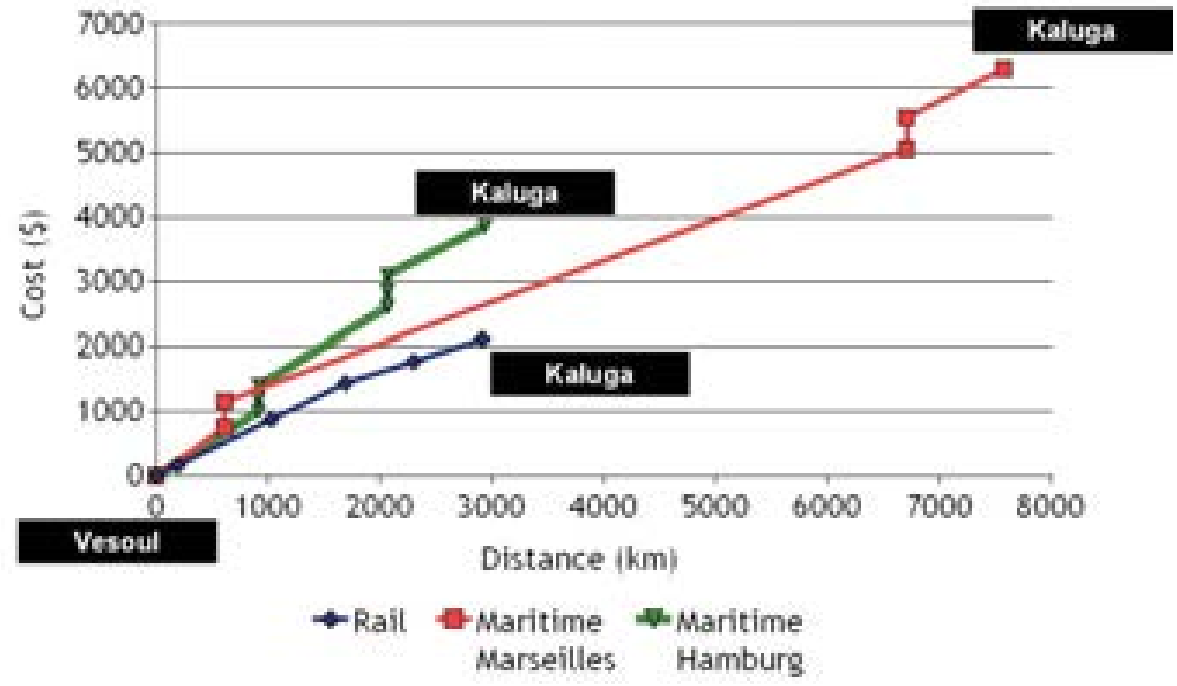

The results illustrate that the selected transport route for this case study appears to be the optimal one. The train used 5 days less and cost \$3,293 less (Marseilles) or \$1,743 less (Hamburg). 


\section{Appendix 2.1}

\section{Survey}

As part of the exercise, customized questionnaires (see below) for rail and road for every participating country were developed and distributed to rail organizations and freight forwarding associations. Six completed questionnaires and five unofficial responses were received.

\section{Forwarders Questionnaire}

\section{Questionnaire \\ UNECE Expert Group on Euro Asian Transport Links (EATL)}

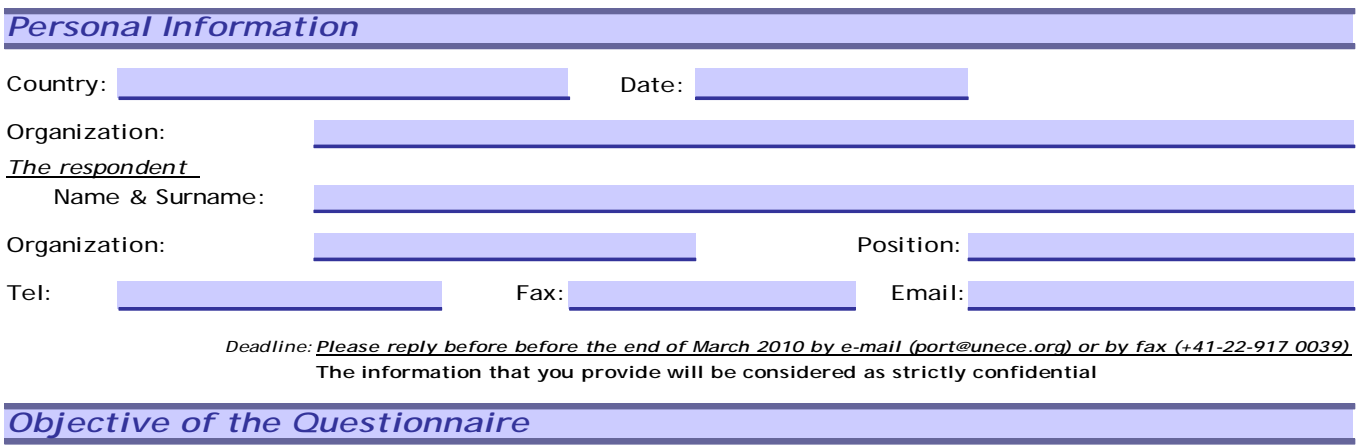

This Questionnaire aims to compare the performance of EATL (time-cost) routes with relevant maritime-based routes (port to port plus inland sections) and identify conditions under which EATL options would be competitive.

\begin{tabular}{|c|c|c|c|c|c|c|}
\hline \multirow[t]{2}{*}{ Ref } & \multirow[t]{2}{*}{ Maritime Route } & \multirow[t]{2}{*}{ Time (Days) } & \multicolumn{4}{|c|}{$\begin{array}{l}\text { Cost (\$) } \\
\text { (in the parenthesis please indicate the cost for } \\
\text { the opposite direction) }\end{array}$} \\
\hline & & & TEU & & FEU & \\
\hline 1 & Busan - Bandar Abbas & & ( & ) & ( & ) \\
\hline 2 & Shanghai - Bandar Abbas & & ( & ) & i & ) \\
\hline 3 & Vladivostok - Bandar Abbas & & ( & ) & i & ) \\
\hline 4 & Bandar Abbas - Rotterdam & & ( & ) & ( & ) \\
\hline 5 & Bandar Abbas - Hamburg & & ( & ) & i & ) \\
\hline 6 & Bandar Abbas - Barcelona & & 1 & ) & i & ) \\
\hline 7 & Bandar Abbas -Antwerp & & 1 & ) & ( & ) \\
\hline 8 & Bandar Abbas - Riga & & ( & ) & i & ) \\
\hline 9 & Bandar Abbas - Tallinn & & ( & ) & ( & ) \\
\hline 10 & Bandar Abbas - Klaipeda & & 1 & ) & ( & ) \\
\hline 11 & Bandar Abbas -Yokohama & & 1 & ) & ( & ) \\
\hline 12 & Bandar Abbas - Murmansk & & 1 & ) & ( & ) \\
\hline 13 & Bandar Abbas - St. Petersburg & & 1 & ) & ( & ) \\
\hline 14 & Bandar Abbas - Odessa & & 1 & ) & ( & ) \\
\hline 15 & Bandar Abbas - Kaliningrad & & 1 & ) & ( & ) \\
\hline 16 & Bandar Abbas - Thessalonica & & 1 & ) & 1 & ) \\
\hline 17 & Bandar Abbas - Varna & & 1 & ) & ( & ) \\
\hline 18 & Bandar Abbas - Costanta & & ( & ) & ( & ) \\
\hline 19 & Bandar Abbas - Novorossiysk & & ( & ) & 1 & ) \\
\hline 20 & Bandar Abbas - Kavkaz & & 1 & ) & ( & ) \\
\hline 21 & St. Petersburg - Shanghai & & 1 & ) & ( & ) \\
\hline 22 & St. Petersburg - Rotterdam & & 1 & ) & 1 & ) \\
\hline 23 & St. Petersburg - Barcelona & & ( & ) & ( & ) \\
\hline 24 & St.Petersburg - Vladivostok & & ( & ) & ( & ) \\
\hline
\end{tabular}




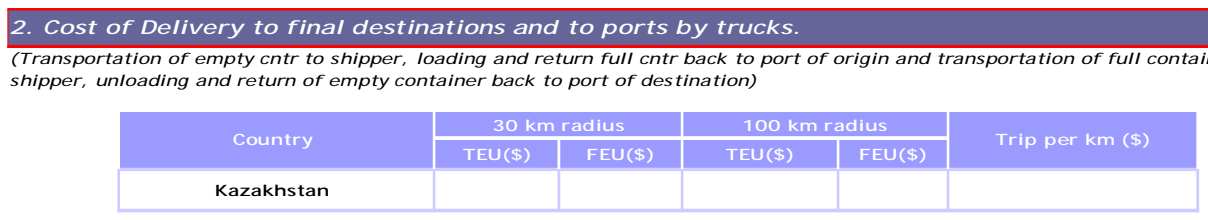

\section{Cost of value added services in ports}

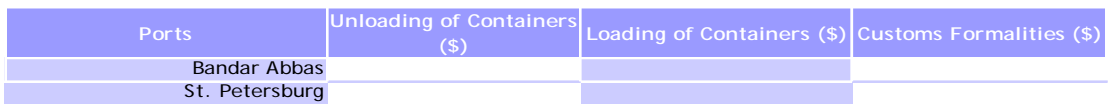

\begin{tabular}{r|r|r} 
Other Costs & (\$) \\
Entrance cost & Parking cost & \\
Loading to truck cost & \\
Unloading from truck \\
Other documents \\
Other cost/ Specify \\
\hline
\end{tabular}

\begin{tabular}{|c|c|c|c|c|c|}
\hline Train & Train Services & $\begin{array}{l}\text { Cost per container TEU } \\
\text { (FEU) }\end{array}$ & $\begin{array}{l}\text { Total time (days / } \\
\text { hours) }\end{array}$ & Total Km & $\begin{array}{l}\text { Capacity in } \\
\text { Containers }\end{array}$ \\
\hline 1406 & $\begin{array}{l}\text { Brest (Belarus) - Nauschki (Russia), Ulan } \\
\text { Bator (Mongolia) - Huh Hoto (China) }\end{array}$ & $(1)$ & & & \\
\hline 1208 & $\begin{array}{c}\text { Berlin (Germany) - Kunzevo (Russia) } \\
\text { "Ostwind" }\end{array}$ & $(\quad)$ & & & \\
\hline $\begin{array}{r}1251 / \\
1252\end{array}$ & $\begin{array}{c}\text { Almaty (Kazakhstan) - Dostyk (Kazakhstan) - } \\
\text { Alaschankou (China) }\end{array}$ & $(1)$ & & & \\
\hline $\begin{array}{r}1402 / \\
1401\end{array}$ & $\begin{array}{c}\text { Lianyungang (China)- Alaschankou - Dostyk - } \\
\text { Saryagasch (Kazakhstan) - Assake } \\
\text { (Uzbekistan) }\end{array}$ & ( ) & & & \\
\hline \multirow[t]{2}{*}{$\begin{array}{r}1401 / \\
1402\end{array}$} & $\begin{array}{c}\text { Tianj in (China) - Alaschankou (China)/ } \\
\text { Dostyk (Kazakhstan) - Almaty (Kazakhstan) }\end{array}$ & $(1)$ & & & \\
\hline & $\begin{array}{l}\text { Shenzhen, Alaschankou (China) - Dostyk } \\
\text { (Kazakhstan) - Llezk, Susemka (Russia) - } \\
\text { Zernovo, Cop (Ukraine) - Hungary }\end{array}$ & $(1)$ & & & \\
\hline $\begin{array}{r}1418 / \\
1417\end{array}$ & $\begin{array}{c}\text { Klaipeda (Lithuania) - Radviliskis - Eglaine } \\
\text { (Latvia) - Posinj (Russia) - Sebesh (Russia) - } \\
\text { Ozinki (Russia) - Aktobe, Almaty } \\
\text { (Kazakhstan) }\end{array}$ & ( ) & & & \\
\hline 1407 & $\begin{array}{c}\text { Shenzhen (China) - Ulan Bator (Mongolia) - } \\
\text { Nauschki (Russia) - Brest (Belarus) - } \\
\text { Maleszewicze (Poland) }\end{array}$ & $(1)$ & & & \\
\hline 1409 & $\begin{array}{c}\text { Beij ing (China) - Ulan Bator (Mongolia) - } \\
\text { Nauschki (Russia) - Brest (Belarus) - } \\
\text { Maleszewicze (Poland) - Hamburg (Germany) }\end{array}$ & $(\quad)$ & & & \\
\hline
\end{tabular}




\begin{tabular}{|r|r|}
\hline Reasons for delays or high costs & by truck \\
\hline Border crossing: technical operations & \\
\hline Border crossing: customs procedures & by rail \\
\hline Border crossing: police controls \\
other controls \\
Unofficial stopovers \\
\hline Safety - Cannot travel during the night \\
\hline Unnecessary inspections (provide examples) \\
\hline Hidden costs (please specify) \\
\hline Documents (CMR - TIR - CIM - SMGS etc) \\
Visa procedures \\
\hline Other factors (specify) \\
\hline
\end{tabular}

\section{Rail Organizations Questionnaire}

\section{Questionnaire \\ UNECE Expert Group on Euro Asian Transport Links (EATL)}

Personal Information
Country:
Organization:
The respondent
Name \& Surname:
Organization:
Tel:
Objective of the Q Uestionnaire
The overall objective is to compare the (time-cost) performance of EATL routes with relevant maritime-based routes (port to port plus
inland sections) and identify conditions under which EATL options would be competitive.
This survey focuses on the information necessary to estimate and compare the duration and costs of the EATL routes using container
block trains and competing routes based on deep-sea shipping in combination with road transport to final destination.
These questions aim to collect the following data on operations of block trains: (1) time schedule of the specific route (km analysis,
stopover analysis, time analysis), (2), main tariffs and any additional charges, (3) train capacity (number of wagons), (4) information
on consignment notes, and (5) investment projects that would improve the operation of trains.



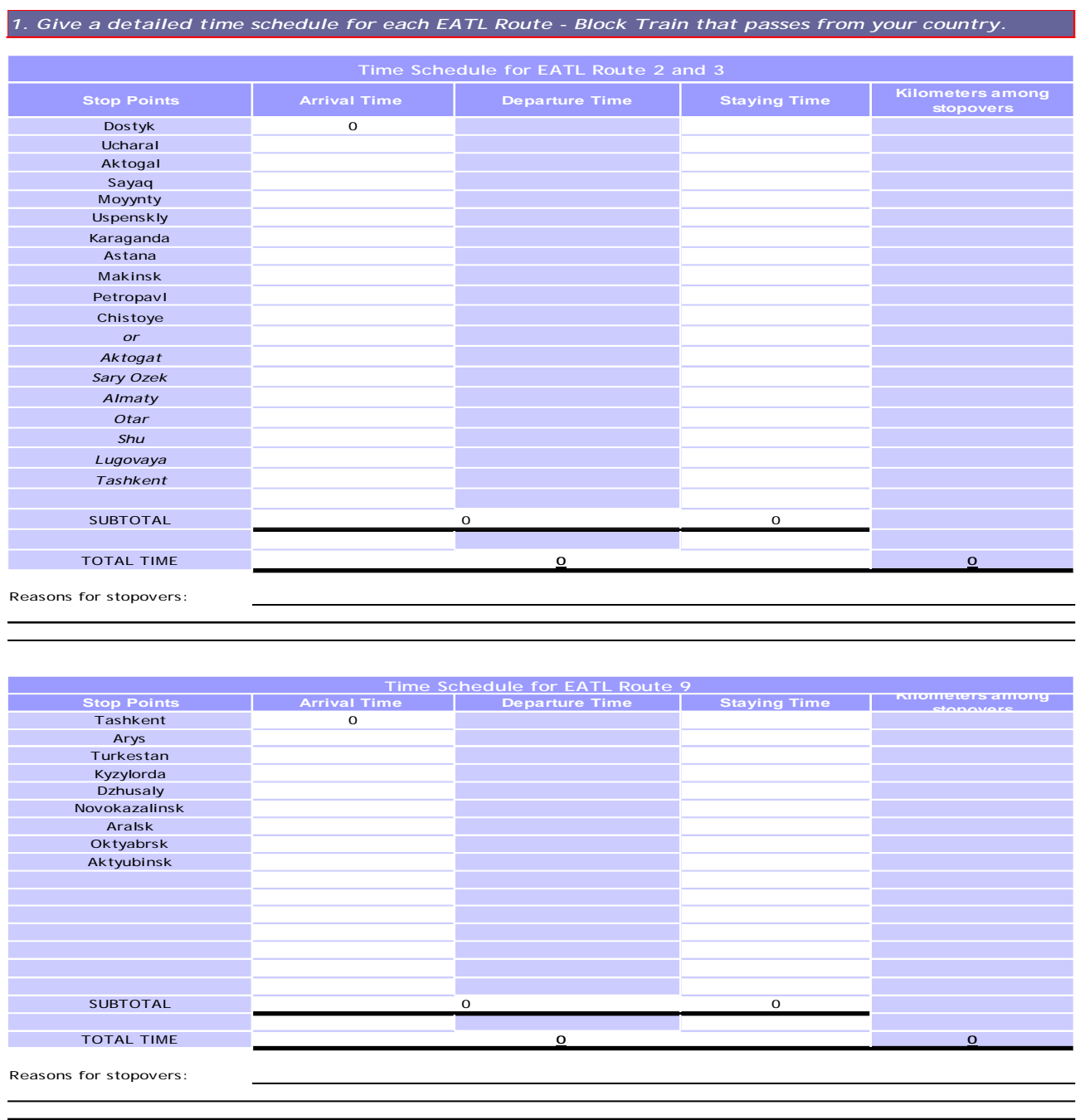

2. Tariffs. Please indicate the tariffs and additional charges for the operations of the block train.

\begin{tabular}{|cl|}
\hline Use of railloads, wagons and locomotives & euros per kilometer \\
\hline Loading of containers to the train & euros per movement \\
\hline Unloading of containers from the train & euros per movement \\
\hline Fill in of the appropriate papers & euros per paper \\
\hline Ferry Transportation Costs & euros per container or wagon \\
\hline Ferry Loading Costs & euros per container or wagon \\
\hline Ferry Unloading costs & euros per container or wagon \\
\hline Other Expenses & \\
\hline
\end{tabular}


How many container wagons can one locomotive of your rail organization pull?

4. Consignment Notes

\begin{tabular}{|c|}
\hline \begin{tabular}{c} 
What kind of consignment notes do you use? \\
\hline CIM \\
\hline SMGS \\
\hline Common CIM/ SMGS \\
\hline Local \\
\hline Other
\end{tabular} \\
\hline
\end{tabular}

5. Investment Projects.

Indicate ayy kind of investensats inci, bogder atariom, marahalling yards, etc) that would faciltate the

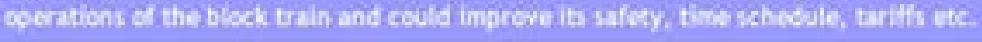

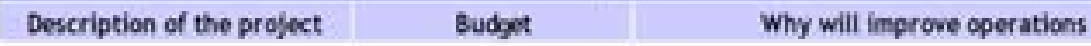




\subsection{Introduction}

Transport and trade in the EATL region is obstructed not only by the physical bottlenecks related to geographical constraints and poor infrastructure, but also by non-physical obstacles, such as unharmonized laws, regulations, policies, procedures and practices. The objective of this section is to address the issues hindering the smooth and efficient operation of the proposed EATL network. The region's key non-physical bottlenecks were identified, as well as their significance and impact for EATL participating countries, together with recommendations on key actions to alleviate them.

\subsection{Non-physical obstacle survey}

In view of the above, a survey was designed within the framework of the EATL Phase II Study for the purpose of identifying the non-physical obstacles to transport. To this end, the "NonPhysical Obstacle Survey" included two set of questionnaires, related to five EATL road routes and eight EATL rail routes. The questionnaires were specifically designed and addressed to such users as customs broker associations, customs broker companies, and transport companies using the EATL road and rail routes within each participating country. In total, over 1,000 questionnaires were sent to the related target groups in the EATL region.

According to the results of the survey, border-crossing points have been identified as the major bottleneck for transport and trade in the EATL region, a situation that cannot be alleviated solely by necessary infrastructure improvements. Other significant bottlenecks are related to accession to international trade and transport agreements, such as, in particular the TIR Convention, 1975 and the Harmonization Convention, 1982 (see Box 2), intermodal transport infrastructure and services and logistic costs and services. Finally, the absence of regional cooperation in related matters is the main cause for the lack of reliability in transit transport.

Box 2 - Major UNECE Conventions for border crossing facilitation

The Customs Convention on the International Transport of Goods under Cover of TIR Carnets (TIR Convention, 1975) permits the international carriage of goods by road from one customs office of departure in one country to a customs office of arrival in another country, through as many countries as necessary, without any intermediate frontier check of the goods carried. This requires a number of precautionary measures, such as customs control and secure sealing at the office of departure, or prescriptions for the design of the load compartment or the container, in order to avoid smuggling. To cover duties and taxes at risk throughout the journey, an international guaranteeing chain has been established. The International Road Transport Union (IRU) has been authorized distribute the international Customs transit and guarantee document, the so-called TIR Carnets and to manage the international guarantee system. The overall supervision of the TIR Convention and its application in all Contracting States falls within the responsibility of the TIR Administrative 
Committee and its TIR Executive Board (TIRExB), both being inter-governmental bodies. While the TIR Convention was drawn up originally for Europe only, this system has gradually been extended to other areas in the world, including Central Asia, the Middle East, North Africa and Latin America. The TIR system may also be applied to goods carried in containers, provided that at least a portion of the journey is undertaken by road. Sixty-seven States and the European Community are Contracting Parties to the TIR Convention. More than 40,000 operators are authorized to use the TIR system and more than 3 million TIR transports are carried out per year.

The International Convention on the Harmonization of Frontier Controls of Goods (Harmonization Convention, 1975) establishes commonly agreed requirements for coordinated border management and reduction of border formalities as well as the number and duration of all types of border controls of goods, be it for health reasons (medicosanitary, veterinary, phytosanitary), for reasons of compliance with technical standards or for quality inspections in general, and applies to all goods being imported, exported or in transit. Fifty-five States and the European Community are Contracting Parties to this Convention. In 2008, a new Annex to the Convention on road transport came into force. This is the first time that an annex to the Harmonization Convention deals with a particular mode of transport, i.e. road transport, in recognition of the fact that the road transport industry should be considered as the main beneficiary of the facilitation measures set out in the Convention. The new Annex covers, inter alia, facilitation of visa procedures for professional drivers, standardized weighing operations and international vehicle weight certificate, minimum infrastructure requirements for efficient border crossing points and provisions to monitor the border crossing performance. A similar annex for rail border crossing came into force at the end of 2011.

\subsection{Border-crossing points}

Based on the results of the "Non-Physical Obstacle Survey", related studies, and visits and interviews at several border-crossing points (BCP) of the Study area, Table 3.1 presents an overview of the current border-crossing obstacles in the EATL region, together with their related causes and effects. 


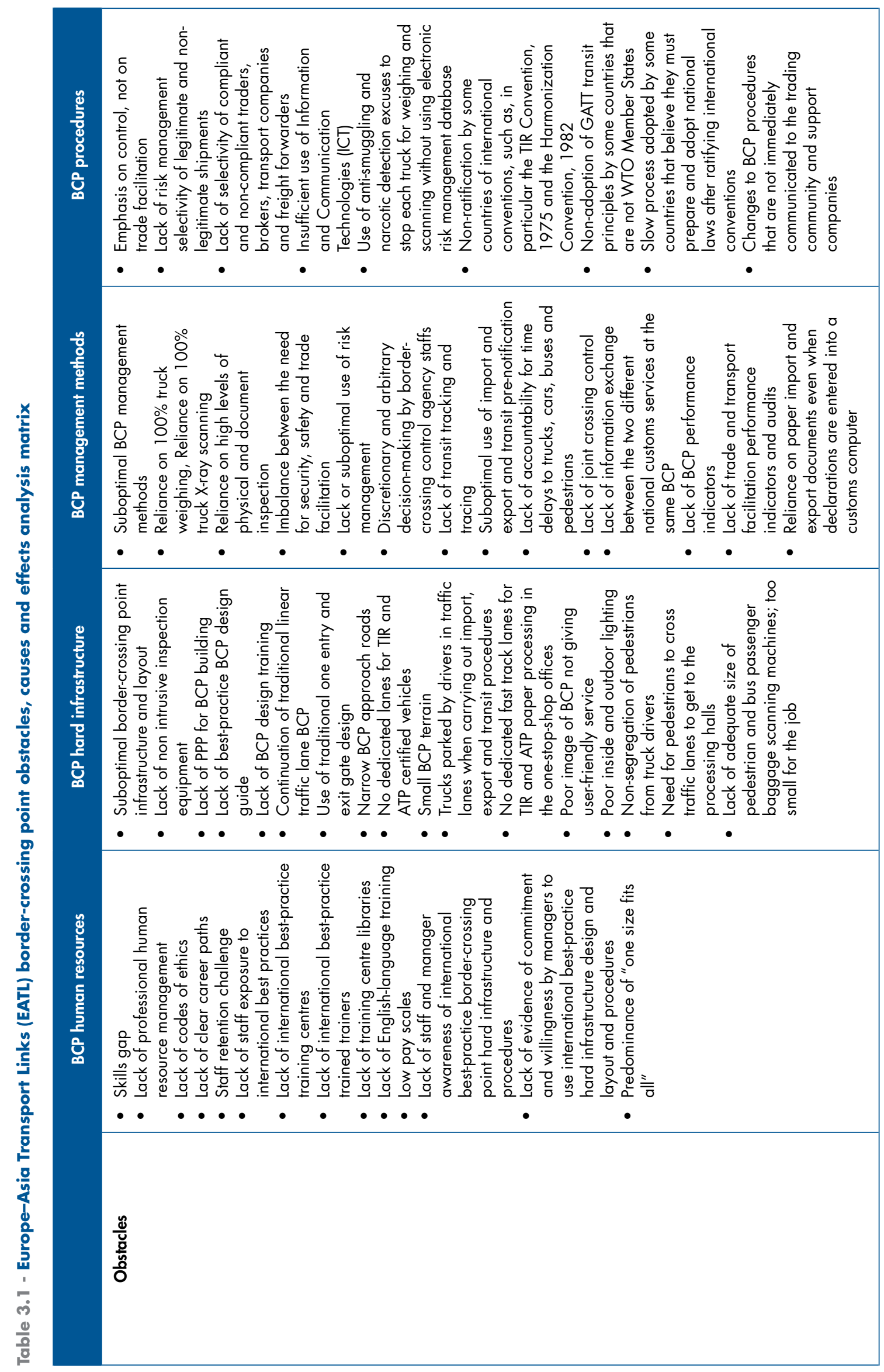




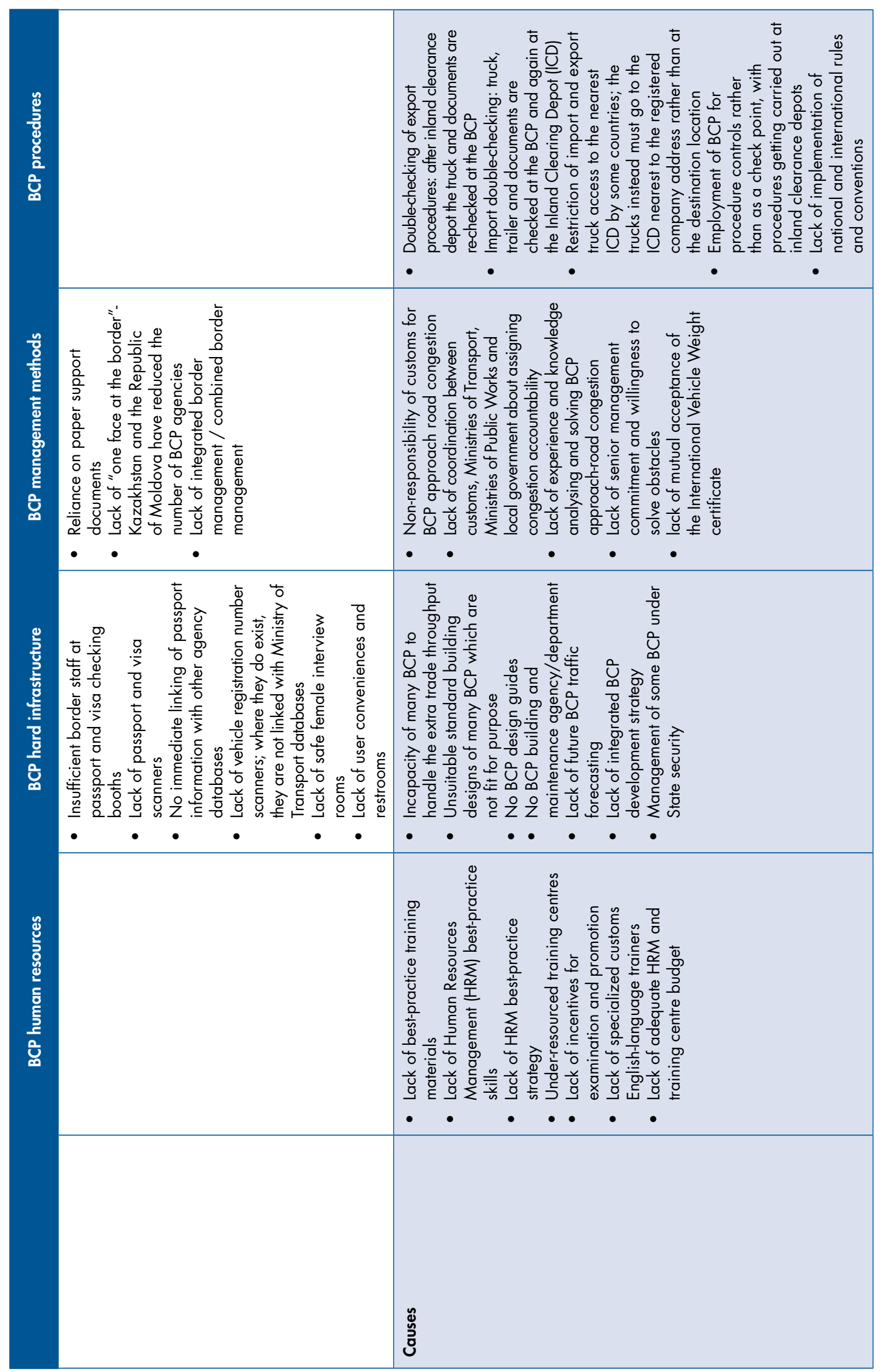




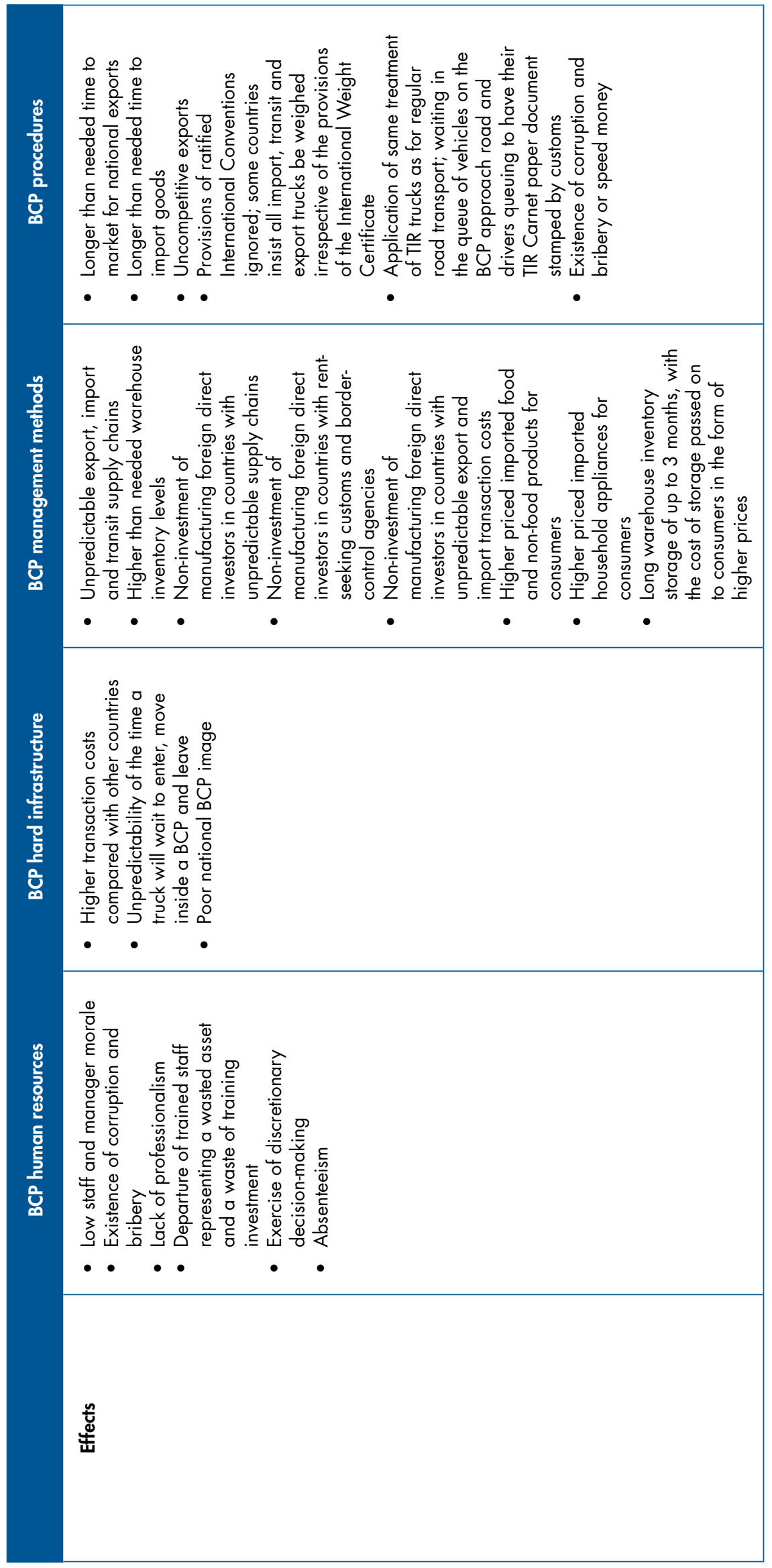


Customs procedures are an obligatory process in all international road shipments involving border crossings and are the single greatest cause of vehicle delays on delivery routes between Asia and Europe. Despite the World Customs Organization's International Convention on the Simplification and Harmonization of Customs Procedures (Revised Kyoto Convention) of 1999, the UN International Convention on the Harmonization of Frontier Controls of Goods of 1982 and the UN Customs Convention on the International Transport of Goods under cover of TIR Carnets (TIR Convention, 1975), customs regulations in practice continue to differ both in terms of requirements and procedures. In addition, there is no integrated information system or information exchange and, in a number of transit countries, customs posts are poorly equipped and employ out-of-date IT equipment that fails to provide data on cargo in a timely manner. As yet, an universally applicable computerized transit system is missing, despite ongoing attempts by contracting parties and the UN to computerize the TIR system (eTIR Project).

Examples of relatively "smooth" and "hard" border-crossing points in the EATL Study area are the following. 25

- Smooth: Russian Federation-Belarus (EATL road routes 1 and 2); Republic of MoldovaUkraine (EATL road route 4); Ukraine-Poland (EATL road route 1 and 3); BelarusPoland (EATL road route 1 and 2) and Georgia-Turkey (EATL road route 4).

- Hard: Turkmenistan-Azerbaijan (EATL road routes 4 and 6); Russian FederationKazakhstan $^{26}$ (EATL road routes 1, 2, and 3); Kazakhstan-Kyrgyzstan (EATL road routes 3 and 4); Iran-Turkey (EATL road route 5); Kyrgyzstan-Uzbekistan (EATL road route 5$)$.

In most transit countries, border crossings are effectively doubled, since drivers have to complete exit procedures at the border to leave the territory of one country, only to be met with exactly the same procedures at the same border crossing to enter the next country. In addition, cumbersome procedures, including 100 per cent full physical inspection that requires cargo unloading and loading, as well as the numerous customs forms to be completed, result in long waiting times. The lack of standardized documents, computerized, paperless customs procedures for import, export and transit, the "Single Window" system and one-stop clearance facilities further aggravates the problem. After completing customs formalities, drivers need to queue separately in another location for phytosanitary and veterinary controls. This means that the same driver needs to queue multiple times to go through a single border point. Moreover, at most borders there is lack of dedicated lanes for urgent or TIR cargo. The availability and cost of parking space, together with safety issues, are also considered barriers at border-crossing points.

With regard to the staff, the following shortcomings were observed: (a) lack of quality and training; (b) poor language skills; (c) insufficient motivation combined with low salaries and, hence, very low productivity in many cases; (d) questionable ethical conduct, resulting in widespread corruption and smuggling.

Very importantly, there is a lack of coordination between customs bodies in neighbouring countries. Most EATL transit countries in Asia do not conduct joint customs inspections, or operate during the same hours. There exists, as yet, no international network(s) for the secure exchange of Customs related data across borders. Efforts to achieve this are undertaken by the World Customs Organisation with its Globally Networked Customs (GNC) Project and by UNECE (eTIR Project), but progress is slow due to lack of funds and political unwillingness.

\footnotetext{
${ }^{25}$ New Eurasian Land Transport Initiative (NELTI), Final Report: Analysis of monitoring data collected on NELTI Project Routes in 2008-2009, NEA Transport Research Institute (Netherlands) in cooperation with the International Road Transport Union (IRU), p. 29.

${ }^{26}$ After 1 June 2011, Kazakhstan joined the Customs Union.
} 
Finally, alterations to customs regulations are not always communicated to all relevant parties in the international transport market in a timely fashion, infringing the basic provisions of international conventions.

\subsection{Visa formalities}

Procedures related to visa issuance also have a strong negative impact on the shipment of cargo from along EATL routes, due to the following issues:

(i) Because of multiple border crossings along each proposed route, drivers will have to obtain visas for several transit countries.

(ii) In a number of countries, drivers' visas are not issued at the border, but only at the Consular Sections of their embassies in the country of the driver's residence. This means that drivers are forced to temporarily relinquish their passport, which leads to the loss of potential working hours. In addition, if the visa has to be processed en route in another transit state, further delays will occur. Kyrgyz, Tajik and Turkish hauliers, for example, are faced with this problem when travelling through Turkmenistan.

(iii) The procedures for issuing visas are frequently discriminatory - given equal conditions, drivers from one country obtain visas quicker and with fewer formalities than drivers from other countries.

(iv) The visa procedures in the transit countries are not synchronized (either in the list of documents required, the charges or the length of time required for processing).

(v) In a number of cases, drivers undertaking international road shipments are required to present a greater number of documents than ordinary tourists (such as company licences, their own driver's licence, vehicle information, etc.).

(vi) A number of countries do not offer long-term multi-entry visas.

(vii) Long processing times and high consular charges are a serious disincentive (for example an entry visa for Iran takes up to two weeks to process and a transit visa is issued for a maximum of 10 days).

\subsection{Export and import documents}

The number of export documents varies among EATL participating countries. Georgia, ${ }^{27}$ which requests exporters to prepare only four documents, is regarded as a regional best practice, particularly when compared to other EATL participating countries such as Tajikistan, which requests eleven documents, Afghanistan and Uzbekistan ten, Belarus and Kazakhstan nine, while Azerbaijan, China, Kyrgyzstan and the Russian Federation require their exporters to complete eight documents. ${ }^{28}$

Good practice examples related to import documentation include Armenia requiring seven, Bulgaria six, China five, the Republic of Moldova seven and Georgia requiring only four import documents. In comparison, several other EATL countries require importers to complete up to ten documents: Afghanistan, Azerbaijan, Belarus and the Russian Federation. Kazakhstan requires its importers to complete twelve documents and Uzbekistan requires eleven import documents.

In addition to the above, EATL landlocked countries are presumed to need more days to export a container than countries with seaports: it takes on average 82 days to send an export from Tajikistan, 76 days to send an export from Kazakhstan, 74 days to send an export from

27 World Bank, Doing Business, Trading Across Borders, 2011.

28 Ibid., See Annex 1: Trading Across Borders in the EATL region. 
Afghanistan and 71 and 63 days from Uzbekistan and the Kyrgyzstan, ${ }^{29}$ respectively. EATL bestpractice countries include Georgia with 10 days, Romania with 12 days, Armenia with 13 days and Turkey with 14 days. ${ }^{30}$

With regard to imports, best practices include Georgia and Romania with 13 days, Turkey with 15 days, and Bulgaria with 17 days leading the EATL region. The highest number of days required for handling and clearing imports are in Uzbekistan, 92 days, Tajikistan, 83 days, Afghanistan, 77 days and Kazakhstan, 62 days.

\subsection{International trade and transport agreements}

Currently, the legal framework for undertaking international road cargo shipments between Asia and Europe is mainly based on bilateral intergovernmental agreements on international road transport. These govern the procedures and conditions for undertaking international shipments and contain provisions for preferential conditions, created for hauliers on a mutual basis, as well as conditions for transborder access to markets, including stipulations for transit shipments. On the basis of these bilateral agreements, national bodies issue their hauliers a fixed number (an "agreed contingent") of permits, which grant the right to travel through the territories of the countries specified. The transit countries, through which the Euro-Asian routes run have, to date, counted more than 140 bilateral agreements with countries in Europe and Asia, of which 75 govern transport between two transit states.

The most important issues related to the above are: ${ }^{31}$

(i) International bilateral agreements on road transport lay down differing legal conditions for undertaking cargo shipments between pairs of individual countries. This relates both to preferential conditions with regard to taxes and levies, as well as the existing procedures for issuing permits.

(ii) A number of agreements (for example the agreements with China) indicate specific routes and border crossings that may be used for shipments, and forbid hauliers from using border crossings via third countries. This leads to restrictions in selecting delivery routes.

(iii) The fact that quotas of permits issued have to be equally matched necessitates numerous rounds of negotiations, while the shortage of permits leads to significant delays incurred by hauliers before departing for an operation and/or at border crossings. The distribution of permits is also linked in certain cases to corruption and discrimination towards individual hauliers. The quota system for shipments, i.e. the mutually agreed restriction of the number of permits issued, is a glaring obstacle to trade and should be removed according to the principles of the World Trade Organization.

29 Ibid., See Annex 1 for a list of the disparity in the number of days some countries take to clear imports and exports.

30 The average amount of days to export a container from the Republic of Moldova according to the Doing Business figures takes 32 days. The results of several interviews with exporting companies, and with customs managers at inland clearance depots and with customs staffs and managers at land border-crossing points with Romania and Ukraine, the author in Moldova during December 2011 does not immediately support this figure because exporters report on average one day to prepare all export documents and another day to get the container to the customs inland export clearing depot and from the depot to the border-crossing point either with Romania or Ukraine. The container might take several hours or all day to cross both sides of the same border-crossing point depending on traffic volumes.

${ }^{31}$ New Eurasian Land Transport Initiative (NELTI), Final Report: Analysis of monitoring data collected on NELTI Project Routes in 2008-2009, NEA Transport Research Institute (Netherlands) in cooperation with the International Road Transport Union (IRU), p. 23. 
(iv) Bilateral agreements impede the principal of "free transit" (due to procedures for issuing transit permits, limits to the numbers of permits issued, etc.). The restrictive quotas of permits for transit shipments on the territory of certain CIS Member States are in direct contradiction to Article V of the General Agreement on Tariffs and Trade (GATT-94) on the "Freedom of Transit", which forms a basic standard for the World Trade Organization.

(v) The limitation (by means of quotas or bans) of shipments to "third countries" is also a serious obstacle to access to markets. The distribution or sale of permits for "third countries" is frequently accompanied by discriminatory processes and corruption.

(vi) The procedures for agreeing and issuing permits are frequently accompanied by bureaucratic licences and abuse.

\subsection{Poor infrastructure}

Non-physical obstacles to international road and rail transport cannot be excluded from the impact of inadequately designed border-crossing point infrastructure and equipment, as well as inadequate transport infrastructure linking border-crossing points. Furthermore, certain countries located their border-crossing points 20 years ago at river bridges, or have border-crossing point approach roads that traverse the middle of villages, causing vehicle congestion. Opportunities to improve transport links and border-crossing points exist, as per the infrastructure priority projects identified by EATL Phase I and Phase II Studies. Nevertheless, public and private stakeholders need more exposure to international best-practice transport, logistics and border-crossing point infrastructure design and management methods to realize the full benefits of investment in hard infrastructure, modern non-intrusive detection equipment and different ways to manage expensive border-crossing point assets.

\subsection{Punitive and arbitrary transit charges}

High transit fees and restrictive permits for international road transport and high transit tariffs for rail are constraining intra-Asian trade and trade with Europe. International road permit quotas that reduce competition are adopted throughout Central Asia, while road transit fees in certain countries in effect are charges on access to the market rather than charges for infrastructure use. They usually discriminate between operators from different countries, between permit and non-permit holders, and between domestic and foreign operators. The fees are often unclear and changed without notice.

\subsection{Intermodal transportation}

One of the principal problems encountered in the region is the crossings by ferry over the Caspian and Black Seas. Although the situation with the Black Sea ferry crossings is currently stable, the one in the Caspian Sea is significantly more complicated. Trucks travelling from Asia to Europe face delays due to the lack of ferry timing information, and because ferries are primarily geared to transport railway containers (railway companies are given preference on embarkation). The small quota of ferry slots allocated to lorries leads to queues and lengthy delays in ports, made worse by the short validity period of Turkmen transit visas for drivers. In view of the latter, the development of intermodal transport linkages, coordinating road and maritime connections over the Caspian Sea, requires particular attention in the near future. 


\subsection{Cost of logistics}

Landlocked country access to world markets depends on the availability of trade corridors and transit systems; several EATL countries are landlocked, namely Afghanistan, Armenia, Azerbaijan, Kazakhstan, Kyrgyzstan, Mongolia, Tajikistan, Turkmenistan and Uzbekistan. Landlocked economies are primarily affected by a high cost of freight services and a high degree of unpredictability in transportation time. The main sources of costs are not only physical constraints, but widespread rent activities and severe flaws in the implementation of the transit and logistic systems, which prevent the emergence of reliable logistics services. Delays and the low degree of reliability and the unpredictability of services create severe disincentives to invest and increase total logistics costs.

In addition, the reasons for supply chain fragmentation are: (i) the initiation of transit, often as a cumbersome process as final clearance takes place in the gateway country; (ii) inadequate Carnets and guarantee systems or the poor implementation of good transit systems (TIR); ${ }^{32}$ (iii) the uniform implementation of transit controls, irrespective of the principal's reliability and competence; (iv) convoy or escort systems not only on risky cargo or insecure vessels (open trucks), but also on containers; (v) excessive controls en route, paving the way for additional illegal controls; (vi) obsolete freight regulations; and (vii) regulatory barriers that impact the market structure and the quality of key support services (brokers, finance, insurance and other).

The three areas with the largest potential gains in total logistics costs are the following: (i) any measure that enhances supply chain predictability and thereby reduces hedging costs; (ii) measures, some of which may be part of broader governance reforms, that reduce rent-seeking activities and, therefore, overhead logistics costs; and (iii) market structure reform by moving from a cartel/syndicate freight organization to an efficient market structure, inducing decreases in the fixed cost of transportation.

Finally, several tools can assist officials and practitioners to analyse and benchmark trade and logistics performance, the key one being the World Bank Trade and Transport Facilitation Assessment: A Practical Toolkit for Country Implementation. ${ }^{33}$ The Republic of Moldova is using this method in 2011 and 2012 as part of its World Bank funded project to prepare a new transport and logistics strategy. ${ }^{34}$

\subsection{Political situation}

The political instability of certain countries is an additional barrier to trade, and internal unrest has in certain cases resulted in periods of closed borders (as was the case in Kyrgyzstan).

\subsection{Rail transport}

Rail transport encounters fewer causes of delay than road transport. The three main reasons for railway delays include: (i) railway security; (ii) waiting in queue; and (iii) change in railway gauge. Railway security is a mandatory service provided by Chinese Railways that places an armed

32 The author's findings at several land border-crossing points in 2011 in Central Asia include: (i) trucks queue at BCP approach roads with non-TIR trucks; (ii) TIR truck drivers must register their TIR Carnets with customs at BCP; (iii) there are no physical TIR fast-track lanes; and (iv) there are no dedicated one-stop-shop desks to handle TIR Carnets at $\mathrm{BCP}$.

${ }^{33}$ World Bank, Trade and Transport Facilitation Assessment: A Practical Toolkit for Country Implementation (Washington, D.C., 2010). Available from hittp://siteresources.worldbank.org/EXTTLF/Resources/Trade\&Transport_ Facilitation_Assessment_Practical_Toolkit.pdf.

${ }^{34}$ World Bank executed Trust Fund, "Moldova: Trade Facilitation through Improved Transport and Logistics Performance", Support to the Government of Moldova for the preparation of a Transport and Logistics Strategy (Washington, D.C., 2011). 
officer on the train, which often causes severe delays. The waiting time in queue for rail transport is caused by the lack of rolling stocks, such as locomotives and rail wagons. For example, Mongolia has 50 locomotives but the lack of maintenance and their condition only allow 30 to be used. Certain EATL countries use $1,520 \mathrm{~mm}$ broad gauge; China and Afghanistan use 1,435 mm standard gauge. Therefore, cargo transfer is needed at "break of gauge" rail interchange points near the border with China, for example. The time spent to change gauges also causes significant delays. The situation worsens when there are not enough tracks for cargo transfer or when there is a long queue of trains during peak periods. Containerization is an efficient way to minimize cost and time delays due to gauge differences. ${ }^{35}$ Railway transport is less exposed to unofficial payments and rail cargo suffers less damage during transit. Freight forwarders located in Central Asia and the Caucasus argue that rail transport is more predictable than road transport because there are less borders to cross and less stops along the route.

\subsection{Mismatch of public and private interests}

The conclusion drawn from visits to several border-crossing points and interviews with national and international exporting and importing companies is that the interests of private industry, government, transport and border-control agencies do not match. The Ministries of Transport and border-control agencies are concerned with border-crossing security, safety and revenue collection issues; in certain cases, their concerns are addressed through a control approach that does not balance them with the needs for national trade facilitation. On the other hand, private industry needs are different, because companies trying to clear export and import shipments deal with delays along their chosen supply routes, paying extra costs as a result. Their staff focus efforts on tracking their shipments and search for expediting solutions by interfacing with government and border-crossing point officials. Some private exporting and importing companies do not expect policy, procedure and management change and continue to trade despite the challenges, passing on additional transaction costs to the consumer.

\subsection{Recommendations}

Based on the key non-physical obstacles identified above, a set of recommendations follows, aimed at setting the base for further actions for EATL participating countries to alleviate the nonphysical barriers to transport and trade.

Table 3.2 presents a summary of current challenges in border-crossing point procedures and management methods, together with proposed measures to tackle them, taking into consideration hard infrastructure, design layout, management method and policy. The findings and proposed solutions are based on empirical evidence from several large and small borders crossing point in the EATL region.

\footnotetext{
35 The lack of containerization in Central Asia is an issue that needs research because the lack of containers used in national and regional road and rail transport might lessen trade and add costs.
} 
Table 3.2 - Reducing land border-crossing point time delaysng point time delays ${ }^{36}$

\begin{tabular}{|c|c|c|c|c|c|}
\hline No. & Challenges (findings) & $\begin{array}{l}\text { Current average } \\
\text { procedure time }\end{array}$ & Possible solutions & New estimated time & $\begin{array}{l}\text { Estimated time } \\
\text { savings }\end{array}$ \\
\hline \multirow[t]{2}{*}{1} & Outside BCP & & & & \\
\hline & $\begin{array}{l}\text { Vehicle congestion and queuing: } \\
\text { trucks, cars and buses wait } \\
\text { together in one or two traffic } \\
\text { lanes; usually blocking each } \\
\text { lane to other traffic. }\end{array}$ & $\begin{array}{l}120-480 \\
\text { minutes }\end{array}$ & $\begin{array}{l}\text { Truck queuing } \\
\text { eliminated were } \\
\text { several dedicated } \\
\text { truck and TIR and } \\
\text { ATP truck lanes } \\
\text { to be installed at } \\
\text { each large and } \\
\text { small BCP. BCP } \\
\text { approach roads } \\
\text { need widening. }\end{array}$ & $\begin{array}{l}\text { 10-120 minutes. } \\
\text { Congestion might } \\
\text { occur during } \\
\text { seasonal peaks } \\
\text { or when export } \\
\text { and import traffic } \\
\text { volume grows } \\
\text { in the future, } \\
\text { overwhelming } \\
\text { the BCP } \\
\text { infrastructure. }\end{array}$ & $\begin{array}{l}110-480 \\
\text { minutes }\end{array}$ \\
\hline 2 & BCP Customs Control Zone & & & & \\
\hline & $\begin{array}{l}\text { Import procedure } \\
\text { (i) Entry gate process: Truck } \\
\text { drivers get out of the truck } \\
\text { cab to enter the Border Guard } \\
\text { kiosk where Border Guard staff } \\
\text { checks if truck drivers have valid } \\
\text { passports and valid import cargo } \\
\text { documents before allowing them } \\
\text { entry. Where there is no kiosk, } \\
\text { the driver stays in the cab. This } \\
\text { check is reportedly to eliminate } \\
\text { the possibility that truck drivers } \\
\text { might get passed different } \\
\text { documents while parked in the } \\
\text { truck parking area. There is often } \\
\text { a vehicle registration number } \\
\text { plate and radiological scanner. } \\
\text { These checks apply to trucks with } \\
\text { TIR Carnets and CMR documents; } \\
\text { (ii) Border Guard stops each } \\
\text { truck and inspects inside the truck } \\
\text { cab; } \\
\text { (iii) Truck weighing and } \\
\text { dimension check: truck moves } \\
\text { from entry gate to the Stop sign } \\
\text { on the truck-only traffic lane. } \\
\text { Truck waits at the Stop sign and } \\
\text { closed entry gate to the weighing } \\
\text { point for the channel red light to } \\
\text { change to green. Customs staff } \\
\text { controls the weighing point and } \\
\text { after giving the truck the green } \\
\text { light, the truck moves through } \\
\text { the weighing point and stops } \\
\text { at the Stop sign and closed exit } \\
\text { gate to the weighing point. The } \\
\text { truck waits while the computer } \\
\text { completes the information } \\
\text { database processing. If there is } \\
\text { no record of deviation, the red } \\
\text { light at the weighing point exit } \\
\text { gate turns to green and the exit } \\
\text { gate is electrically lifted; }\end{array}$ & $\begin{array}{l}\text { Average time } \\
2 \text { minutes } \\
\text { Average time } \\
5-6 \text { minutes }\end{array}$ & $\begin{array}{l}\text { The Border Guard } \\
\text { might sit with } \\
\text { Customs staff } \\
\text { inside each truck } \\
\text { lane processing } \\
\text { booth. } \\
\text { Truck weighing } \\
\text { only for trucks } \\
\text { without a weight } \\
\text { certificate or if } \\
\text { there is information } \\
\text { or intelligence } \\
\text { indicating a risk. } \\
\text { Risk management } \\
\text { using risk analysis } \\
\text { is in action. }\end{array}$ & 2 minutes & $\begin{array}{l}0 \\
0-6 \text { minutes }\end{array}$ \\
\hline
\end{tabular}

${ }^{36}$ Based on visits to many border-crossing points in the EATL region in 2010 and 2011. 


\begin{tabular}{|c|c|c|c|c|c|}
\hline No. & Challenges (findings) & $\begin{array}{l}\text { Current average } \\
\text { procedure time }\end{array}$ & Possible solutions & New estimated time & $\begin{array}{l}\text { Estimated time } \\
\text { savings }\end{array}$ \\
\hline & $\begin{array}{l}\text { (iv) The truck moves to a truck } \\
\text { parking area and the driver } \\
\text { leaves the truck and walks to } \\
\text { the other side of the terminal } \\
\text { building, where one of two traffic } \\
\text { lanes is no longer used, to enter } \\
\text { the One-Stop-Shop office inside } \\
\text { the terminal; } \\
\text { (v) One-Stop-Shop (OSS): six } \\
\text { border-control agency controls } \\
\text { and processing take place inside } \\
\text { the OSS office. Not all OSS staff } \\
\text { is located in one office because } \\
\text { the office space is not large } \\
\text { enough to accommodate about } \\
10 \text { to } 12 \text { staff and managers. } \\
\text { The OSS office counter has name } \\
\text { plates for each border-control } \\
\text { agency. Customs staff carries out } \\
\text { sanitary and transport document } \\
\text { checks before carrying out import } \\
\text { customs procedures. Phyto- and } \\
\text { quarantine document checks are } \\
\text { carried out by specialist agency } \\
\text { staff. There is only one entry door } \\
\text { for drivers and they must use } \\
\text { the same door to leave. There } \\
\text { is no space inside for drivers to } \\
\text { prepare documents. Customs } \\
\text { staff sends copies of documents } \\
\text { to the Central Office as part of } \\
\text { the Automatic Delivery System } \\
\text { of the State Customs Committee. } \\
\text { This process is for TIR Carnet } \\
\text { trucks and CMR trucks; there is no } \\
\text { exception or fast-track TIR lane. } \\
\text { TIR truck drivers have the Carnet } \\
\text { document checked, stamped } \\
\text { and signed (authenticated); a } \\
\text { copy remains with customs. } \\
\text { This procedure does not include } \\
\text { secondary (in-depth) truck and } \\
\text { cargo physical inspection and } \\
\text { does not include quarantine or } \\
\text { phytosanitary cargo inspection; } \\
\text { (vi) Truck driver identification card } \\
\text { or passport and, if necessary, } \\
\text { visa are checked by the Border } \\
\text { Guard; } \\
\text { (vii) Truck driver walks to truck } \\
\text { and moves to the exit gate. } \\
\text { Customs tells Border Guard } \\
\text { the truck has completed all } \\
\text { procedures. Truck driver gives } \\
\text { a copy of the form from the six } \\
\text { border-control agencies (talon/ } \\
\text { coupon), with six border-crossing } \\
\text { signatures, to the Border Guard. }\end{array}$ & $\begin{array}{l}\text { Average } \\
\text { reported time } \\
\text { about } 25- \\
40 \text { minutes } \\
\text { depending } \\
\text { on the time } \\
\text { of day (non- } \\
\text { peak) and } \\
\text { time of week; } \\
\text { Mondays } \\
\text { tend to be } \\
\text { busy days }\end{array}$ & $\begin{array}{l}\text { With several } \\
\text { dedicated truck } \\
\text { lanes at each BCP, } \\
\text { there is no need } \\
\text { for truck to move } \\
\text { to a truck parking } \\
\text { area to carry out } \\
\text { import procedures. } \\
\text { Pre-notification } \\
\text { and import and } \\
\text { export trucks } \\
\text { getting processed } \\
\text { at ICDs eliminates } \\
\text { processing at } \\
\text { BCP. The BCP is } \\
\text { a check point. } \\
\text { The future Single } \\
\text { Window system } \\
\text { might help reduce } \\
\text { BCP procedure } \\
\text { times and clerical } \\
\text { entry time for } \\
\text { each declaration. } \\
\text { Some customs } \\
\text { administrations } \\
\text { have started } \\
\text { collaborative } \\
\text { border } \\
\text { management; } \\
\text { Customs staff } \\
\text { checks transport } \\
\text { and sanitary } \\
\text { documents. } \\
\text { Passport and visa } \\
\text { get scanned either } \\
\text { by the Border } \\
\text { Guard or by } \\
\text { Customs staff (One } \\
\text { Face at the Border) } \\
\text { during primary } \\
\text { control at the truck } \\
\text { lane booth. } \\
\text { Driver stays in the } \\
\text { cab, complying } \\
\text { with the Revised } \\
\text { Kyoto Convention } \\
\text { recommendation. } \\
\text { If the BCP is used } \\
\text { as a check point } \\
\text { with booths in truck } \\
\text { lanes, this part is } \\
\text { eliminated except } \\
\text { for Border Guard } \\
\text { or Customs staff } \\
\text { pressing the button } \\
\text { to lift the electronic } \\
\text { exit gate. }\end{array}$ & 2 minutes & $\begin{array}{l}23-40 \\
\text { minutes }\end{array}$ \\
\hline
\end{tabular}




\begin{tabular}{|c|c|c|c|c|c|}
\hline No. & Challenges (findings) & $\begin{array}{l}\text { Current average } \\
\text { procedure time }\end{array}$ & Possible solutions & New estimated time & $\begin{array}{l}\text { Estimated time } \\
\text { savings }\end{array}$ \\
\hline & BCP IMPORT TIME TOTAL & $\begin{array}{l}46-63 \\
\text { minutes }\end{array}$ & & 6-15 minutes & $\begin{array}{l}35-59 \\
\text { minutes }\end{array}$ \\
\hline & $\begin{array}{l}\text { Export } \\
\text { (i) Border Guard lifts BCP entry } \\
\text { gate if there is space in the truck } \\
\text { traffic lane. Using this method } \\
\text { results in BCP approach road } \\
\text { congestion and truck delays. The } \\
\text { Border Guard checks if the truck } \\
\text { driver has a passport and export } \\
\text { documents; } \\
\text { (ii) Truck moves to the vehicle } \\
\text { weighing and dimension check } \\
\text { point Stop sign. The truck moves } \\
\text { through this point after the red } \\
\text { light changes to green. The truck } \\
\text { stops at the Stop sign, red light } \\
\text { and closed exit gate; } \\
\text { (iii) One-Stop-Shop (many small } \\
\text { BCP do not have OSS facilities): } \\
\text { the driver gets out of the truck to } \\
\text { walk to the passport check and } \\
\text { then to the One-Stop-Shop in the } \\
\text { BCP terminal building to process } \\
\text { export cargo, truck registration } \\
\text { and insurance documents. This } \\
\text { process is the same for TIR } \\
\text { Carnet trucks and CMR trucks; } \\
\text { there is no fast-track TIR lane. } \\
\text { TIR truck drivers have the Carnet } \\
\text { document checked, stamped and } \\
\text { signed (authenticated); a copy } \\
\text { remains with customs. Inside } \\
\text { the OSS, the driver gets six } \\
\text { border- crossing control agency } \\
\text { stamps and six signatures on } \\
\text { two copies of the "coupon", } \\
\text { which determines the driver has } \\
\text { completed all export procedures. } \\
\text { While the truck driver is having } \\
\text { the documents processed, no } \\
\text { other truck can enter the truck } \\
\text { traffic lane; } \\
\text { (iv) The driver goes back to the } \\
\text { truck and moves to the BCP exit } \\
\text { gate where he gives a copy of } \\
\text { the coupon/talon to the Border } \\
\text { Guard. The Border Guard is told } \\
\text { verbally by customs staff that the } \\
\text { truck can pass. }\end{array}$ & $\begin{array}{l}\text { Average } \\
\text { time 20-25 } \\
\text { minutes }\end{array}$ & $\begin{array}{l}\text { There is no need } \\
\text { for the six control } \\
\text { agency coupon } \\
\text { if each truck gets } \\
\text { checked at a truck } \\
\text { lane booth. The } \\
\text { truck remains under } \\
\text { control while parked } \\
\text { alongside the booth. } \\
\text { The truck is released } \\
\text { by customs and/ } \\
\text { or by the Border } \\
\text { Guard by pressing } \\
\text { the button for the } \\
\text { electronic gate. } \\
\text { Each lane might } \\
\text { have an entry and } \\
\text { exit gate. The booth } \\
\text { must be at the height } \\
\text { of the truck drivers' } \\
\text { cab window. }\end{array}$ & 5 minutes & $\begin{array}{l}10-15 \\
\text { minutes }\end{array}$ \\
\hline & BCP EXPORT TIME & $\begin{array}{l}32-38 \\
\text { minutes }\end{array}$ & & 15 minutes & $\begin{array}{l}20-25 \\
\text { minutes }\end{array}$ \\
\hline & $\begin{array}{l}\text { Transit and empty vehicles: } \\
\text { same procedures and times as } \\
\text { for export }\end{array}$ & & & & \\
\hline
\end{tabular}




\begin{tabular}{|c|l|l|l|l|l|}
\hline No. & \multicolumn{1}{|c|}{ Challenges (findings) } & $\begin{array}{l}\text { Current average } \\
\text { procedure time }\end{array}$ & Possible solutions & New estimated time & $\begin{array}{l}\text { Estimated time } \\
\text { savings }\end{array}$ \\
\hline 3 & Neutral zone & $\begin{array}{l}\text { Currently many customs } \\
\text { administrations do not have } \\
\text { formal or informal information } \\
\text { sharing or management meetings } \\
\text { with the customs administrations } \\
\text { on the other side of each } \\
\text { BCP. Therefore, instigating } \\
\text { Joint Customs Controls is a } \\
\text { challenge. There does not seem } \\
\text { to be a desire for Joint Customs } \\
\text { Controls. Customs administration } \\
\text { managements do not have } \\
\text { mandates to develop Joint } \\
\text { Customs Controls. Many small } \\
\text { and large BCP have trucks, cars } \\
\text { and buses waiting in the neutral } \\
\text { zone because one side of the } \\
\text { same BCP might not process those } \\
\text { vehicles at the same speed. }\end{array}$ & & & \\
\hline
\end{tabular}

Additional specific recommendations for EATL participating countries with regard to BCP procedures and infrastructure are the following:

(i) record and analyse the reasons for border-crossing point approach-road congestion, queuing and time delays and make BCP approach road design recommendations and other $\mathrm{BCP}$ hard infrastructure, BCP management methods and export and import as well as transit procedure policy recommendations

(ii) develop a generic Border-Crossing Point Design Guide for small and large bordercrossing points. BCP best-practice examples, such as the Sarp/Sarpi road border-crossing point between Georgia and Turkey and others should be taken into consideration.

(iii) study the reasons why certain recommendations in Annex 8 to the 1982 International Convention on the Harmonization of Frontier Controls of Goods are not being implemented and why customs administrations conduct 100 per cent physical inspection on incoming goods instead of adopting a risk-based management approach

(iv) upgrade BCP, equipping them with modern surveillance methods for security (vehicle scanning equipment, etc.), as well as the necessary IT infrastructure and supportive systems successfully operating in other BCP, such as the electronic Single Window system and the Automated System for Customs Data (ASYCUDA)

(v) examine the skills of customs and other border-control agency staff and focus on efforts to build human capacity (training, educational programmes, etc.)

(vi) study the willingness, commitment and legal ability to prepare and use Joint Customs Controls. Use a gap analysis method identifying barriers and opportunities to use Joint Customs Controls. Use best-practice Joint Customs Controls models, such as at Republic of Moldova-Ukraine and Georgia-Turkey.

(vii) develop and implement Border-Crossing Point Performance Indicators to evaluate the results of investment projects and changes in procedures

(viii) use integrated information systems, as well as the electronic Single Window system, for electronic data submission to reduce the number of import and export documents

(ix) explore the possibility of simplifying visa requirements, together with synchronizing visa issuing procedures and introducing long-term multi-entry visas 
Another best practice related to the above that could be adopted within the greater EATL region is the Customs Union agreement among Belarus, Kazakhstan and the Russian Federation. On 1 July 2010, a customs code was established between Kazakhstan and the Russian Federation, coming into force a few days later in Belarus. This second stage led to the adoption of common external tariffs. In the third stage, customs clearance and control procedures at the KazakhRussian Federation border were scheduled to be abolished by 1 July 2011. (Such measures were implemented at the Belarus-Russian Federation border in July 2010.) The development of a single economic space among the three countries advanced during 2012.

Further to the above, the formulation of and participation in regional multilateral agreements on international transportation (with multilateral permits) can become one of the key measures, providing a solution to the problem of revising existing bilateral agreements.

With regard to infrastructure investments, EATL participating countries should continue to support the development of Euro-Asian transport links and concentrate their efforts on securing investments for the realization of the identified priority infrastructure projects.

Finally, with regard to transport route corridor and logistic obstacles, the following are proposed for EATL participating countries:

(i) identify the legal and institutional impediments to intermodality and recommend policy and operational measures promoting intermodal transport modes

(ii) identify the legal and institutional impediments to the greater use of containers on road and rail transport routes and recommend policy and operational measures, which will promote containerization and will assist a number of EATL countries in accessing the global trade market

(iii) implement policies to achieve the largest potential reductions in total logistics costs

(iv) study the feasibility of modern and efficient Caspian Sea ferry operations between Azerbaijan, Kazakhstan and Turkmenistan and use best-practice ferry examples in Turkey and other European countries to describe efficient operations and the benefits of scheduled vessel sailings

(v) explore the option of privatizing State ferry operators, which could contribute to changing institutional and management methods and achieving best practices pertaining to international ferry operations

(vi) promote intermodal integration through the development of hinterland ports in the region (including Port hinterland studies for Aktau, Baku, Poti and Turkmenbashi seaports and comparative analysis of international port hinterland studies)

(vii) explore railway freight reform, the modernization of management structures and operating management methods; identify the commitment and willingness to reform and modernize systems plus the need and skills gap analysis of railway management skills

(viii) explore the willingness and ability of two State railway organizations to develop and operate block container train services

(ix) report and prepare a guide for modern logistics centre management methods, including design and layout, physical standards, operating management methods together with needs and a skills gap analysis 


\section{TRANSPORT INFRASTRUCTURE ALONG EURO-ASIAN LINKAGES}

\subsection{Reviewing, extending and updating priority routes identified in Phase I}

\subsubsection{Methodology}

4.1.11 Background information on the identification of main Euro-Asian inland transport routes under the UNECE-UNESCA EATL project (Phase I)

In 2001, the General Assembly approved the project entitled "Capacity-building for Developing Interregional Land and Land-cum-sea Transport Linkages” (2002-2006). The project included a component focusing specifically on Euro-Asian transport links. The overall objectives of the project were: i) to assist Member States of the Economic Commission for Africa (ECA), the Economic Commission for Europe (ECE), the Economic and Social Commission for Asia and the Pacific (ESCAP), the Economic and Social Commission for Western Asia (ESCWA) and the Economic Commission for Latin America and the Caribbean (ECLAC) in strengthening their national capacities for developing interregional land and land-cum-sea transport links; and ii) to promote interregional cooperation to facilitate interregional trade and tourism.

Within this overall framework, in 2003 ECE and ESCAP jointly began implementing the project component on developing Euro-Asian transport links. The following countries were invited to participate and designate Focal Points: Afghanistan, Armenia, Azerbaijan, Belarus, Bulgaria, China, Georgia, Iran, Kazakhstan, Kyrgyzstan, Republic of Moldova, Romania, Russian Federation, Tajikistan, Turkey, Turkmenistan, Ukraine and Uzbekistan. In 2004, Greece, during its chairmanship-in-office of the Organization of the Black Sea Economic Cooperation (BSEC), expressed the wish to be associated with the activities of the project.

A major first step of the project was to identify, through consensus, the main Euro-Asian transport linkages of international importance that may form the basis for the extension of Pan-European Transport Corridors (PETC) towards eastern Asia, and the extension of Asian transport networks towards Europe. National Focal Points agreed that the four Euro-Asian transport corridors presented in the "ECE-ESCAP Strategic Vision" be used as the starting point for discussions. ${ }^{37}$ Within each of these broad corridors, however, it was necessary to identify the Euro-Asian transport linkages/routes.

Given that all of the countries participating in the project are Contracting Parties and/or Members of the UNECE European Agreement on Main International Traffic Arteries (AGR) and/or the UNESCAP Asian Highway Agreement and the UNECE European Agreement on Main International Railway Lines (AGC) and/or the UNESCAP Trans-Asian Railway Network Agreement, it was agreed that these networks be used as the basis for the route alignments.

37 United Nations Economic commission for Europe, Background Documents. Available from http://www.unece. org/trans/main/eatl/background.html. 
Moreover, a number of qualifications were deemed necessary. Therefore the identification of the routes was based on the following criteria:

- They are within recognized UNECE/UNESCAP networks.

- Not all links in these networks should be included, only those most relevant.

- Proposed routes should be of Euro-Asian importance.

- Inland water routes and major seaports should also be considered. ${ }^{38}$

- Transport interchange and cargo storage points, including inland container depots and border-crossing facilities, should be considered as integral parts of the routes.

- They should have borders with EATL participating countries.

- The consensus of neighbouring countries is needed, with their readiness to contribute to their development.

- Ideally, selected routes should either already be operational or should be in an advanced state of "readiness" for operation. This "readiness" encompasses both a technical perspective and the perspective of political willingness.

In four Expert Group Meetings under the project, government representatives from these countries identified the main Euro-Asian rail, road and inland waterway routes to be considered for priority development and the main trans-shipment points along these routes.

Once countries agreed on the routes that would form the "Euro-Asian transport linkages", country experts provided a huge amount of data ${ }^{39}$ on technical characteristics and the performances of main rail, road and inland water transport infrastructure, border-crossing points, ferry links, intermodal terminals and ports along the identified Euro-Asian routes..$^{40}$ There inputs were facilitated through a uniform questionnaire prepared by UNECE and UNESCAP secretariats.

The Meeting of Ministers of Transport of countries in the Euro-Asian region, held on 19 February 2008, in Geneva, inter alia, confirmed its support for the development of EuroAsian transport links and endorsed the priority routes and projects identified in Phase I of the EATL project.

\subsubsection{Methodological framework for the extension of EATL routes to newly involved countries}

It is therefore understood that the extension of EATL routes under EATL Phase II addresses only the newly involved countries. To ensure consistency of the newly proposed routes, their selection should be based on the same criteria used under EATL Phase I. Furthermore, to ensure the smooth integration of the new routes into the well established structure under EATL Phase I, the following additional conditions should be met:

- Proposed routes should connect to existing EATL routes. ${ }^{41}$

- Spelling of towns/stations/ports, etc., should be consistent with the nomenclature used in international agreements.

- Proposals should include the provision of related data.

The end of December 2009 was set as the deadline for the submission of proposals and related data (technical characteristics and the performances of main rail, road and inland water transport infrastructure, border-crossing points, ferry links, intermodal terminals and ports) along the identified Euro-Asian routes.

\footnotetext{
38 Air transport was not addressed in the framework of the EATL Project.

39 Used also for the creation of a GIS database and related maps developed by the project.

40 United Nations Economic Commission for Europe, EATL Phase 1, Introduction. Available from http://www.unece. org/trans/main/eatl/intro.html

${ }^{41}$ Refer to the routes and maps shown in the "Joint Study on Developing Euro-Asian Transport Linkages", pp. 59113.
} 
In view of the limited time available, National Focal Points of newly involved countries were invited to be ready with their proposals on road, rail and inland water routes during the 3 rd Expert Group Meeting, held in Istanbul on 11-13 November 2009. The submission of data on technical characteristics and performances followed after the identification of the routes.

\subsubsection{The questionnaires}

The questionnaires circulated to the National Focal Points by the secretariat were divided into two main categories. First, those addressed to newly involved countries; second, those addressed to all other countries aimed at updating the data already submitted under the EATL Phase I.

Table 4.1 - provides an overview of the type of templates included in the questionnaire of the first category.

National Focal Points of other countries received a file containing the tables with the existing data of their country, which were to be completed and/or updated as appropriate.

\section{Table 4.1 - Data tables}

1. Road transport infrastructure On Euro-Asian Transport linkages

\begin{tabular}{|l|l|c|c|c|c|c|c|c|c|c|c|c|}
\hline From & To & $\begin{array}{c}\text { AGR } \\
\text { Reference } \\
\text { No. (if } \\
\text { applicable) }\end{array}$ & $\begin{array}{c}\text { Road } \\
\text { Class } \\
\text { AGR }\end{array}$ & $\begin{array}{c}\text { Asian } \\
\text { Highway } \\
\text { (AH) } \\
\text { Reference } \\
\text { No. (iff } \\
\text { applicable) }\end{array}$ & $\begin{array}{c}\text { Road } \\
\text { Class } \\
\text { AH }\end{array}$ & $\begin{array}{c}\text { Length } \\
\text { (km) }\end{array}$ & $\begin{array}{c}\text { Number } \\
\text { of Lanes } \\
\text { (total) }\end{array}$ & $\begin{array}{c}\text { Road } \\
\text { Condition } \\
\text { (Good, Fair } \\
\text { or Poor) }\end{array}$ & $\begin{array}{c}\text { Annual } \\
\text { Average } \\
\text { Daily } \\
\text { Traffic }\end{array}$ & $\begin{array}{c}\text { Road } \\
\text { Toll } \\
\text { (if any) } \\
\text { Y/N }\end{array}$ & $\begin{array}{c}\text { Movement } \\
\text { of ISO } \\
\text { Containers } \\
\text { Possible? } \\
\text { Y/N }\end{array}$ & $\begin{array}{c}\text { Current } \\
\text { Bottlenecks } \\
\text { or Missing } \\
\text { Links }\end{array}$ \\
\hline & & & & & & & & & & & \\
\hline
\end{tabular}

Table 4.1 - (continued)

2. RAlL transport infrastructure on euro-asian transport linkages

\begin{tabular}{|l|l|c|c|c|c|c|c|c|c|c|c|c|}
\hline From & To & $\begin{array}{c}\text { AGC } \\
\text { Reference } \\
\text { No. (if } \\
\text { applicable) }\end{array}$ & $\begin{array}{c}\text { AGTC } \\
\text { Reference } \\
\text { No. (if } \\
\text { applicable) }\end{array}$ & $\begin{array}{c}\text { Trans-Asian } \\
\text { Railway } \\
\text { (TAR) } \\
\text { Y/N }\end{array}$ & $\begin{array}{c}\text { Length } \\
\mathbf{( k m )}\end{array}$ & $\begin{array}{c}\text { Track } \\
\text { Gauge } \\
\text { (mm) }\end{array}$ & $\begin{array}{c}\text { Number } \\
\text { of tracks } \\
\text { (DT=double, } \\
\text { ST=single) }\end{array}$ & $\begin{array}{c}\text { Traction } \\
\text { (E=electri- } \\
\text { fied, } \\
\text { NE=non- } \\
\text { electrified) }\end{array}$ & $\begin{array}{c}\text { Loading } \\
\text { Gauge } \\
\text { (UIC) }\end{array}$ & $\begin{array}{c}\text { Max. } \\
\text { Load } \\
\text { per } \\
\text { Axle } \\
\text { (Tons) }\end{array}$ & $\begin{array}{c}\text { Siding } \\
\text { Length }\end{array}$ & $\begin{array}{c}\text { Missing } \\
\text { Links or } \\
\text { Bottlenecks }\end{array}$ \\
\hline & & & & & & & & & & & \\
\hline
\end{tabular}

Table 4.1 - (continued)

3. inland waterwayS on Euro-Asian Transport Linkages

\begin{tabular}{|l|l|c|c|c|c|c|c|c|c|c|}
\hline From & To & $\begin{array}{c}\text { AGN } \\
\text { Reference } \\
\text { No. (if } \\
\text { applicable) }\end{array}$ & $\begin{array}{c}\text { Shared } \\
\text { with (Other } \\
\text { Countries' } \\
\text { Bordering } \\
\text { Waterway) }\end{array}$ & $\begin{array}{c}\text { Length } \\
(\mathrm{km})\end{array}$ & $\begin{array}{c}\text { Max. } \\
\text { Admissible } \\
\text { Low } \\
\text { Navigable } \\
\text { Water Level }\end{array}$ & $\begin{array}{c}\text { Min. Bridge } \\
\text { Clearance } \\
\text { at Highest } \\
\text { Navigable } \\
\text { Water Level }\end{array}$ & $\begin{array}{c}\text { Lock } \\
\text { Dimensions }\end{array}$ & $\begin{array}{c}\text { Location } \\
\text { of Links } \\
\text { to Other } \\
\text { Modes (Rail, } \\
\text { Road) }\end{array}$ & Bottlenecks & $\begin{array}{c}\text { Missing } \\
\text { Links }\end{array}$ \\
\hline & & & & & & & & & & \\
\hline
\end{tabular}




\section{Table 4.1 - (continued)}

4. MARITIME ports on euro-asian transport linkages

\begin{tabular}{|l|c|c|c|c|c|c|c|c|c|c|c|c|}
\hline Name & $\begin{array}{c}\mathrm{X} \\
\text { Coordinate }\end{array}$ & $\begin{array}{c}\mathrm{Y} \\
\text { Coordinate }\end{array}$ & $\begin{array}{c}\text { Maximum } \\
\text { Draft } \\
\text { Vessels } \\
\text { Served (m) }\end{array}$ & $\begin{array}{c}\text { Types of } \\
\text { Ships/ } \\
\text { Cargo } \\
\text { (General, } \\
\text { Bulk, } \\
\text { Container) }\end{array}$ & $\begin{array}{c}\text { Bulk } \\
\text { Handling } \\
\text { Capacity } \\
\text { (Tons/day) }\end{array}$ & $\begin{array}{c}\text { Container } \\
\text { Handling } \\
\text { Capacity } \\
\text { (TEU/day) }\end{array}$ & $\begin{array}{c}\text { ICD in } \\
\text { Port? } \\
\text { Y/N }\end{array}$ & $\begin{array}{c}\text { Rail } \\
\text { Connection } \\
\text { in Port? } \\
\text { Y/N }\end{array}$ & $\begin{array}{c}\text { IWT } \\
\text { Connection? } \\
\text { Y/N }\end{array}$ & $\begin{array}{l}\text { Liner Services } \\
\text { (Containers) }\end{array}$ & $\begin{array}{c}\text { liner } \\
\text { Services } \\
\text { (Rail Ferry) }\end{array}$ & $\begin{array}{c}\text { Liner } \\
\text { Services } \\
\text { (General } \\
\text { Cargo) }\end{array}$ \\
\hline & & & & & & & & & & & \\
\hline & & & & & & & & & & & \\
\hline
\end{tabular}

Table 4.1 - (continued)

5. INLAND WATER ports on euro-asian transport linkages

\begin{tabular}{|l|c|c|c|c|c|c|c|c|c|c|} 
Name & $\begin{array}{c}\mathrm{X} \\
\text { Coordinate }\end{array}$ & $\begin{array}{c}\mathrm{Y} \\
\text { Coordinate }\end{array}$ & $\begin{array}{c}\text { AGN } \\
\text { Reference } \\
\text { No. (if } \\
\text { applicable) }\end{array}$ & $\begin{array}{c}\text { Maximum } \\
\text { Draft (m) }\end{array}$ & $\begin{array}{c}\text { Types } \\
\text { of Ships } \\
\text { Handled }\end{array}$ & $\begin{array}{c}\text { Bulk cargo } \\
\text { Handling } \\
\text { Capacity } \\
\text { (Tons/day) }\end{array}$ & $\begin{array}{c}\text { Container } \\
\text { Handling } \\
\text { Capacity } \\
\text { (TEU/day) }\end{array}$ & $\begin{array}{c}\text { ICD in } \\
\text { Port? } \\
\text { Y/N }\end{array}$ & $\begin{array}{c}\text { Rail } \\
\text { Connection } \\
\text { in Port? } \\
\text { Y/N }\end{array}$ & $\begin{array}{c}\text { Majior } \\
\text { Difficulties } \\
\text { and Plans for } \\
\text { Improvement }\end{array}$ \\
\hline & & & & & & & & & \\
\hline & & & & & & & & & & \\
\hline
\end{tabular}

\section{Table 4.1 - (continued)}

6. INLAND CONTAINER DEPOTS, INTERMODAL Freight terminals and FREIGHT VILLAGES/LOGISTIC CENTRES on euro-asian transport linkages

\begin{tabular}{|c|c|c|c|c|c|c|c|c|c|} 
Name & $\begin{array}{c}\mathrm{X} \\
\text { Coordinate }\end{array}$ & $\begin{array}{c}\mathrm{Y} \\
\text { Coordinate }\end{array}$ & $\begin{array}{c}\text { Transport } \\
\text { Modes } \\
\text { Served }\end{array}$ & $\begin{array}{c}\text { Handling } \\
\text { Facilities }^{43}\end{array}$ & $\begin{array}{c}\text { Bulk Cargo } \\
\text { Handling } \\
\text { Capacity } \\
\text { (Tons/day) }\end{array}$ & $\begin{array}{c}\text { Container } \\
\text { Handling } \\
\text { Capacity } \\
\text { (TEU/day) }\end{array}$ & $\begin{array}{c}\text { Open Storage } \\
\text { Space }\end{array}$ & $\begin{array}{c}\text { Covered } \\
\text { Storage } \\
\text { Space } \\
\left(\mathrm{m}^{2}\right)\end{array}$ & $\begin{array}{c}\text { Customs } \\
\text { Services } \\
\text { Available? } \\
\text { Y/N }\end{array}$ \\
\hline & & & & & & & & & \\
\hline
\end{tabular}




\subsubsection{Description of Euro-Asian transport linkages}

Selected Euro-Asian rail, road and inland water transport routes and inland river ports for further development and cooperation

Table 4.2 - Rail routes

\begin{tabular}{|c|c|c|c|c|}
\hline & & Comment & AGC & TAR* $^{*}$ \\
\hline 1. & $\begin{array}{c}\text { Bremenhaven - Bremen - Hamburg - Berlin/Seddin } \\
\text { - Frankfurt (Oder) (border GER) - Border POL - } \\
\text { Kunowice - Poznan - Warsawa - Terespol (border } \\
\text { POL) - Brest - Minsk - Moscow - Nizhniy Novgorod } \\
\text { - Perm - Yekaterinburg - Omsk - Novosibirsk - Ulan } \\
\text { Ude - Karimskaya - Vladivostok (Port)/Vostochny } \\
\text { (Port) }\end{array}$ & $\begin{array}{l}\text { PETC 2; } \\
\text { OSJD } 1\end{array}$ & $\begin{array}{l}\text { E20, CE20, C45/2 } \\
\text { CE55 }\end{array}$ & Y \\
\hline 1.a. & $\begin{array}{c}\text { Hanko (port)/Turku (port) - Helsinki - } \\
\text { Riihimäki - Kouvola - Vainikkala } \\
\text { (border FIN) - Luzhaika (border } \\
\text { RUS) - Buslovskaya - St Petersburg (Port) -Moscow } \\
\text { - Yekaterinburg }\end{array}$ & $\begin{array}{l}\text { PETC 9; } \\
\text { OSJD } 16\end{array}$ & $\mathrm{E} 10, \mathrm{E} 20$ & $\mathrm{Yl}$ \\
\hline 1.b. & Mostiska/ Chop - Lvov - Moscow & PETC 5, 9; OSJD3 & E30, E95 & $\mathrm{N}$ \\
\hline 1.c. & $\begin{array}{l}\text { Tavshet - Irkutsk - Ulan Ude - Naushki (border } \\
\text { RUS) - Sukhbaatar (Border MON) - Ulaan Bataar - } \\
\text { Zamyn Udd (Border MON) - Erenhot (Border CHN) } \\
\text { - Beijing - Tianjin (port) and to Jinan - Nanjing }\end{array}$ & OSJD $1 \mathrm{e}$ & $\mathrm{N}$ & $\mathrm{Y}$ \\
\hline 1.d. & Karimskaya - Zabaykalsk - Border with China & & $\mathrm{N}$ & Y \\
\hline 1.e. & $\begin{array}{l}\text { (Kaliningrad Port) - Nesterov (border RUS) - } \\
\text { Kybartai (border LTU) - Kazlu Ruda - Kaunas } \\
\text { - Kaisiadorys - Vilnius - Kena (border LTU) - } \\
\text { Gudagai (border BLR) - Maladzecna - Minsk }\end{array}$ & & $\mathrm{C} 20 / 3$ & NA \\
\hline 1.f. & Novosibirsk - Lokot - Aktogai & & $\mathrm{N}$ & Y \\
\hline 1.g. & $\begin{array}{l}\text { Sassnitz port -(ferry crossing) - Baltiysk - (ferry } \\
\text { crossing) - Ust-Luga - St Petersburg }\end{array}$ & & & \\
\hline 1.h. & $\begin{array}{c}\text { Ventspils (port) - Tukums II - Jelgava - Krustpils - } \\
\text { Rezekne - Zilupe (border LVA) - Raz. Posini (border } \\
\text { RUS) - Novosokol'niki - Ržev - Moscow }\end{array}$ & & $\begin{array}{l}\mathrm{C} 12 / \\
\mathrm{CE} 12\end{array}$ & N \\
\hline 1.i. & Liepaja (port) - Jelgava & & $\mathrm{C} 12 / \mathrm{C} 12$ & $\mathrm{~N}$ \\
\hline $1 . j$ & $\begin{array}{l}\text { Riga-Krustpils-Daugavpils-Indra (border LVA)- } \\
\text { Bigosovo (border BLR)-Polack-Vicebsk-Orsha-Zlobin }\end{array}$ & & $\begin{array}{c}\mathrm{C} 14 \text { (AGC)/CE14, } \\
\text { C95/2 (AGTC) }\end{array}$ & $\mathrm{N}$ \\
\hline 1.k. & $\begin{array}{l}\text { Sassnitz port (Germany) - Draugyste } \\
\text { (Klaipeda port, LTU) - Siauliai - } \\
\text { Radviliskis - Kaunas (Mukran - } \\
\text { Draugyste is a ferry crossing) }\end{array}$ & & $\mathrm{C} 20 / 3$ & \\
\hline 2. & $\begin{array}{c}\text { Bremenhaven - Bremen - Berlin/Seddin - Frankfurt } \\
\text { (Oder) (border GER) - Border POL - Kunowice - } \\
\text { Poznan - Warsawa - Terespol (border POL) - Brest - } \\
\text { Minsk - Moscow - Yekaterinburg - Kurgan - Astana } \\
\text { - Drujba - Urumqi - Lianyungang (Port)/Shanghai } \\
\text { (Port) }\end{array}$ & PETC 2; OSJD 1 & $\begin{array}{c}\text { E20, E24, CE20, C45/2 } \\
\text { CE55 }\end{array}$ & Y \\
\hline 2.a. & $\begin{array}{l}\text { Hanko (port)/Turku (port) - Helsinki - } \\
\text { Riihimäki - Kouvola - Vainikkala } \\
\text { (border FIN) - Luzhaika (border } \\
\text { RUS) - Buslovskaya - St Petersburg (Port) - } \\
\text { Moscow - Yekaterinburg }\end{array}$ & $\begin{array}{l}\text { PETC 9; } \\
\text { OSJD } 16\end{array}$ & $\mathrm{E} 10, \mathrm{E} 20$ & $\mathrm{Y}$ \\
\hline
\end{tabular}




\begin{tabular}{|c|c|c|c|c|}
\hline & & Comment & AGC & TAR $^{*}$ \\
\hline 2.b. & $\begin{array}{l}\text { (Kaliningrad Port) - Nesterov (border } \\
\text { RUS) - Kybartai (border LTU) - } \\
\text { Kazlu Ruda - Kaunas - } \\
\text { Kaisiadorys - Vilnius - Kena } \\
\text { (border LTU) - Gudagai (border } \\
\text { BLR) - Maladzecna - Minsk }\end{array}$ & & $\mathrm{C} 20 / 3$ & NA \\
\hline 2.c. & $\begin{array}{c}\text { Ekaterinburg - Chelyabinsk - Taranovskaya - } \\
\text { Zaayatskaya - Tobol - Astana }\end{array}$ & & $\mathrm{N}$ & Y \\
\hline $2 \mathrm{~d}$. & $\begin{array}{l}\text { Sassnitz port (Germany) - Draugyste } \\
\text { (Klaipeda port, LTU) - Siauliai - } \\
\text { Radviliskis - Kaunas (Mukran - } \\
\text { Draugyste is a ferry crossing) }\end{array}$ & & $\mathrm{C} 20 / 3$ & \\
\hline 2.e & Berlin - Dresden & & & \\
\hline $2 . f$ & Sassnitz port - Berlin & & CE55 & \\
\hline 3. & $\begin{array}{c}\text { Curtici - Arad - Bucharest - Constanta (Port) - Poti/ } \\
\text { Batumi (Port)/( Kulevi - - Kolkheti - Senaki) - Tbilisi } \\
\text { - Baku (Port) - Aktau (Port) - Beineu - Nukus - } \\
\text { Uchkuduk - Navoi - Tashkent - Shymkent - Almaty } \\
\text { - Dostyk - Alataw Shankou - Lianyungang (Port)/ } \\
\text { Shanghai (Port) }\end{array}$ & $\begin{array}{l}\text { PETC 4, TRACECA; } \\
\text { OSJD } 6 a, 8,10,2,5\end{array}$ & $\begin{array}{l}\text { E54, } \\
\text { E562, E60, } \\
\text { E50 }\end{array}$ & Y \\
\hline 3.a. & $\begin{array}{c}\text { Baku (Port) - Turkmenbashi (Port) - Ashgabat - } \\
\text { Chardzhou - Bukhara - Navoi }\end{array}$ & TRACECA; OSJD 10 & E60 & Y \\
\hline 3.b. & $\begin{array}{c}\text { Tbilisi - Sadakhlo - Gyumri - Yerevan - Gavar } \\
\text { - Meghri - Nourdouz - Jolfa (Yerevan - Gavar - } \\
\text { Meghri - Nourdouz - Jolfa under study) }\end{array}$ & TRACECA & E692 & Y \\
\hline 3.c. & Balychi - Bishkek - Lugovaya & TRACECA & NA & Y \\
\hline 3.d. & $\begin{array}{c}\text { Tashkent - Kanibadam - Andizhan - Kara Suu - } \\
\text { Turugart - Kashi - Urumqi (Jalalabad - Turugart - } \\
\text { Kashi section under construction) }\end{array}$ & TRACECA & E696 & Y \\
\hline 3.e. & Dushanbe - Termez - [Turkmenistan] - Bukhara & TRACECA & E695 & Y \\
\hline 3.f. & $\begin{array}{l}\text { Mersin (Port) / Iskenderun (Port) - Malatya - } \\
\text { Dogukapi - Gyumri - Sadakhlo - Tbilisi }\end{array}$ & TRACECA & E70, E692, E97 & Y \\
\hline 3.g. & $\begin{array}{c}\text { Ungheni - Chisinau - Bendery - Kuchurgan - } \\
\text { Rozdil'na - Odessa (Port) / llyichevsk (Port) - } \\
\text { Poti/Batumi (Port) }\end{array}$ & $\begin{array}{l}\text { TRACECA; } \\
\text { OSJD } 5 a, 7\end{array}$ & E95 & NA \\
\hline 3.h. & $\begin{array}{l}\text { Border with FYROM - Sofia - Pleven - } \\
\text { Varna (Port) - Poti/Batumi (Port) }\end{array}$ & PETC 8 & E680 & NA \\
\hline 3.i. & $\begin{array}{c}\text { Curtici - Arad - Timisoara - Craiova - Bucharest - } \\
\text { Giurgiu - Russe - Kaspichan - Varna (Port) - } \\
\text { Poti/Batumi (Port) }\end{array}$ & PETC 10, 8 & $\begin{array}{l}\text { E66, E56, E95, } \\
\text { E660,E680 }\end{array}$ & NA \\
\hline 3.j. & $\begin{array}{c}\text { Dragoman - Sofia - Gorna - Burgas (Port) - } \\
\text { Poti/Batumi (Port) }\end{array}$ & & $\mathrm{E} 70, \mathrm{E} 720$ & NA \\
\hline 3.k. & Ungheni - lasi - Bucharest - Giurgiu & & E95 & NA \\
\hline 3.1. & $\begin{array}{c}\text { Bukhara - Karshi - }[\text { Turkmenistan] - Termez - } \\
\text { Kurgan- T'ube - Kul'ab }\end{array}$ & TRACECA & E695 & Y \\
\hline 3.m. & $\begin{array}{l}\text { Kars - Akhalkalaki - Tbilisi (Kars - Akhalkalaki } \\
\text { section under construction) }\end{array}$ & & E692 & Y \\
\hline 3.n. & $\begin{array}{c}\text { Tashkent - Angren - Pap - Andijan (Angren - } \\
\text { Pap section under construction) }\end{array}$ & & E696 & Y \\
\hline
\end{tabular}




\begin{tabular}{|c|c|c|c|c|}
\hline & & Comment & AGC & TAR $^{*}$ \\
\hline 3.o. & $\begin{array}{c}\text { Chisinau - Revaca - Cainari - Giurgiulesti (river } \\
\text { port) - Galati (port) }\end{array}$ & & E95, E560 & NA \\
\hline 3.p. & Ungheni - Balti - Vapnyarka & & & \\
\hline 4. & $\begin{array}{c}\text { Dragoman - Sofia - Svilengrad - Kapikule - } \\
\text { Istanbul - Haydarpasa (Port) - Izmit - (Derince Port) } \\
\text { - Ankara - Malatya - Kapikoye - Razi - Qazvin } \\
\text { - Tehran - Sarakhs - Sarahs - Mary - Chardzou } \\
\text { - Navoi - Tashkent - Shymkent - Almaty - Dostyk } \\
\text { - Alataw Shankou - Lianyungang (Port)/Shanghai } \\
\text { (Port) }\end{array}$ & $\begin{array}{c}\text { PETC 4, 8, 10; OSJD 6, } \\
\text { 10, 2, 5; } \\
\text { TRACECA }\end{array}$ & $\begin{array}{l}\text { E70, E60, } \\
\text { E50 }\end{array}$ & Y \\
\hline 4.a. & Mersin (Port) / Iskenderun (Port) - Malatya & & E97 & Y \\
\hline 4.b. & $\begin{array}{c}\text { Nyichevsk (Port) - Samsun (Port) - Kalin - } \\
\text { Sivas - Bostankaya } \\
\text { (rail ferry planned) }\end{array}$ & TRACECA & E97, E70 & Y \\
\hline 4.c. & $\begin{array}{c}\text { Tehran - Qom - Meybod - Yazd - Bafgh - Kerman } \\
\text { - Zahedan - Mirjaveh (border IRN) - Koh-i-Taftan } \\
\text { (border PAK) - Dalbandin - Spezand - Rohri - } \\
\text { Hyderabad - Karachi (port) / Karachi - Rohri } \\
\text { - Lahore - Rawalpindi - Islamabad - Peshawar } \\
\text { (Kerman - Zahedan under construction). }\end{array}$ & & NA & Y \\
\hline 4.d. & $\begin{array}{c}\text { Aliağa - Menemen - Izmir (Port) - Balikesir - } \\
\text { Eskisehir }\end{array}$ & & E74 & Y \\
\hline 4.e. & $\begin{array}{l}\text { Izmir (Port) - Usak - Afyon - Yenice - } \\
\text { Mersin (Port)/ Iskenderun (Port) }\end{array}$ & & E97 & $\mathrm{N}$ \\
\hline 4.f. & Pehlivankoy - Uzun-kopru - Border with Greece & & NA & NA \\
\hline 4.g. & Ilychevsk (Port) - Derince (Port) - Izmit & & & NA \\
\hline 4.h. & Constanta (Port) - Derince (Port) - Izmit & & & NA \\
\hline 4.i. & $\begin{array}{c}\text { Constanta (Port) / Kavkaz (Port) - Samsun (Port) } \\
\text { (rail ferry) }\end{array}$ & & & NA \\
\hline 4.j. & $\begin{array}{c}\text { Irmak - Çankırı - Cerkeş - İsmetpaşa - } \\
\text { Karabük - Zonguldak }\end{array}$ & TRACECA & & \\
\hline 4.k. & $\begin{array}{l}\text { Frontier with TR and BG borders - } \\
\text { Alexandroupolis - Komotini - } \\
\text { Drama [Kavala port terminal Nea } \\
\text { Karvali] - Serres - Thessaloniki - } \\
\text { Athens - Piraeus - Neo Ikonion } \\
\text { Container Terminal (Piraeus Port) }\end{array}$ & & $\begin{array}{l}\text { C70/2 } \\
\text { CE85 }\end{array}$ & \\
\hline 4.I. & $\begin{array}{l}\text { Thessaloniki - Idomeni (border GR) - } \\
\text { Gevgelia (border fYRoM) - Skopje }\end{array}$ & & CE85 & NA \\
\hline 4.m. & $\begin{array}{l}\text { Thessaloniki - Promachon (Border GR) - } \\
\text { Kulata (Border BG) - Sofia }\end{array}$ & & CE855 & NA \\
\hline 4.n. & $\begin{array}{c}\text { Bujanovac (Serbia) - Tabanovce } \\
\text { (fYRoM) - Kumanovo and other border } \\
\text { to fYRoM- Skopje }\end{array}$ & Rail route $3 \mathrm{i}$ & & \\
\hline 4.o. & $\begin{array}{c}\text { Bulgaria Border Crossing - Deve Bair } \\
\text { (FYROM) - Kriva Palanka - } \\
\text { Beljakovce - Kumanovo - Skopje } \\
\text {-Kicevo (fYRoM) - Struga - } \\
\text { Lin (ALB) }\end{array}$ & Rail route $3 \mathrm{i}$ & & \\
\hline
\end{tabular}




\begin{tabular}{|c|c|c|c|c|}
\hline & & Comment & AGC & TAR* \\
\hline 5. & $\begin{array}{c}\text { Hanko (port)/Turku (port) - Helsinki - } \\
\text { Riihimäki - Kouvola - Vainikkala } \\
\text { (border FIN) - Luzhaika (border } \\
\text { RUS) - Buslovskaya - St Petersburg (Port) - } \\
\text { Volgograd - Astrakhan (Port) - Alya (Port) - Anzali } \\
\text { (Port) - Rasht - Qazvin - Tehran - Qom - Meybod } \\
\text { - Bafgh - Bandar Abbas (Port) (Anzali - Rasht - } \\
\text { Qazvin section under construction) }\end{array}$ & $\begin{array}{l}\text { PETC 9; } \\
\text { OSJD } 11\end{array}$ & $\begin{array}{l}\text { E10, E99, } \\
\text { E50 }\end{array}$ & Y \\
\hline 5.a. & $\begin{array}{c}\text { Astrakhan (Port) - Alya (Port) - Amirabad (Port) - } \\
\text { Garmsar - Tehran }\end{array}$ & & NA & Y \\
\hline 5.b. & $\begin{array}{c}\text { Astrakhan (Port) - Samur - Yalama - Baku - Astara } \\
\text { (Azerbaijan) - Astara (Iran) - Rasht (Astara - } \\
\text { Astara - Rasht section under study) }\end{array}$ & OSJD 11 & $\begin{array}{l}\text { E60, } \\
\text { E694 }\end{array}$ & Y \\
\hline 5.c. & $\begin{array}{l}\text { Astrakhan (Port) - Askarayskaya - Ganyuchikino } \\
\text { - Makat - Beineu - Nukus - Uchkuduk - Bukhara - } \\
\text { Chardzhou - Sarahs - Sarakhs - Mashhad - Bafgh }\end{array}$ & TRACECA & $\begin{array}{l}\text { E50, } \\
\text { E597 }\end{array}$ & Y \\
\hline 5.d. & Alya (Port) - Aktau (Port) - Beineu & & E597 & Y \\
\hline 5.e. & $\begin{array}{c}\text { Tehran - Qom - Arak - Ahvaz - Bandar Emam } \\
\text { (Port) }\end{array}$ & & NA & Y \\
\hline 5.f. & \begin{tabular}{|c} 
Tehran - Kashan - Badrud - Esfahan - Shiraz - \\
Bushehr (Port) (Esfahan - Shiraz - Bushehr planned)
\end{tabular} & & NA & Y \\
\hline 5.g. & $\begin{array}{c}\text { Bafgh - Kerman - Fahrai - Chabahar (Port) (Fahrai } \\
\text { - Chabahar planned) }\end{array}$ & & NA & Y \\
\hline 5.h. & Murmansk (Port) - St Petersburg & & NA & $\mathrm{N}$ \\
\hline 6. & $\begin{array}{c}\text { Luxembourg - border LUX - border FRA Thionville } \\
\text { - Metz - Remilly - Forback (border FRA) - } \\
\text { Saarbrucken (border GER) Ludwigshafen - } \\
\text { Mannheim - Frankfurt (M) - Hanau - Erfurt } \\
\text { - Leipzig - Dresden - Gorlitz (border GER) - } \\
\text { Zgorzelec (border POL) - Wroclaw - Katowice - } \\
\text { Krakow - Przemysl - Medyka - } \\
\text { Mostiska (border UKR) - Mostiska/ Chop/Yagudin } \\
\text { - Lvov - Kyiv - Kharkov - Liski - Samara - Ufa } \\
\text { - Kurgan - Omsk - Novosibirsk - Ulan Ude - } \\
\text { Karimskaya - Vladivostok (Port)/Vostochny (Port) }\end{array}$ & PETC 3, 5 & $\begin{array}{l}\text { E30, } \\
\text { E24, CE23, } \\
\text { CE40, } \\
\text { CE32, } \\
\text { CE30 }\end{array}$ & Y \\
\hline 6.a. & $\begin{array}{c}\text { Chisinau - Bender - Rozdil'na - Zhmerynka - Fastiv } \\
\text { - Kyiv - Nizhyn - Konotop - Zrnove/Chernigiv - } \\
\text { Gornostaivka }\end{array}$ & PETC 9 & E95 & NA \\
\hline 6.b. & $\begin{array}{c}\text { Tavshet - Irkutsk - Ulan Ude - Naushki (border RUS) } \\
\text { - Hoit (Border MON) - Ulaan Bataar - Zamyn Udd } \\
\text { (Border MON) - Erenhot (Border } \\
\text { CHN) - Beijing - Tianjin (port) and } \\
\text { to Jinan - Nanjing - Shanghai (Port) }\end{array}$ & & E20 & Y \\
\hline 6.c. & Karimskaya - Zabaykalsk - Border with China & & NA & Y \\
\hline 6.d. & $\begin{array}{c}\text { Aktau (port) - Beyneu - Makat - Kandagach - } \\
\text { Nikeltay - Chelyabinsk }\end{array}$ & TRACECA & E30, E50, E597 & $\mathrm{T}$ \\
\hline 7. & $\begin{array}{c}\text { Mostiska/ Chop - Lvov - Zhmerynka - Fastov - } \\
\text { Znamianka - Dnipropetrovsk - Debaltseve - Krasna } \\
\text { Mogyla(UKR)/Gukovo(RUS) - Likhaya - Volgograd } \\
\text { - Aksarayskaya - Makat - Beineu - Nukus - } \\
\text { Uchkuduk - Navoi - Tashkent - Shymkent - } \\
\text { Almaty - Dostyk - Alataw Shankou - } \\
\text { Lianyungang (Port)/Shanghai (Port) }\end{array}$ & PETC 3,5 ; TRACECA & $\begin{array}{l}\text { E30, E50, } \\
\text { E593, } \\
\text { E597 }\end{array}$ & Y \\
\hline
\end{tabular}




\begin{tabular}{|c|c|c|c|c|}
\hline & & Comment & AGC & TAR $^{*}$ \\
\hline 8. & $\begin{array}{c}\text { Mostiska/ Chop - Lvov - Fastov - Krasnoarmeysk - } \\
\text { Kvashino - Uspenskaya - Rostov-na-Donu - Veseloe } \\
\text { - Gandtiadi - Senaki - Tbilisi - Alyat - Astara } \\
\text { (Azerbaijan) - Astara (Iran) (Astara - } \\
\text { Astara section under construction) }\end{array}$ & PETC 3, 5; TRACECA & $\begin{array}{l}\text { E30, E50, } \\
\text { E593, } \\
\text { E99, } \\
\text { E60 }\end{array}$ & $Y$ \\
\hline 8.a. & Tbilisi - Gyumri - Yerevan & TRACECA & E694 & Y \\
\hline 8.b. & $\begin{array}{c}\text { Kaliningrad (Port) - (Lithuania) - Minsk - } \\
\text { Gornosaivka - Nizhyn - Kyiv }\end{array}$ & & E95 & NA \\
\hline 8.c. & Kavkaz (Port) - Novorossiysk (Port) - Krasnodar & & E99 & Y \\
\hline 8.d. & $\begin{array}{c}\text { Varna (Port) - Kavkaz (Port) - (ferry link) Poti/ } \\
\text { Batumi (Port) }\end{array}$ & & NA & $N$ \\
\hline 8.e. & $\begin{array}{c}\text { Riga - Krustpils - Daugavpils - Indra } \\
\text { (border LVA) - Bigosovo (border } \\
\text { BLR) - Polak - Vicebsk - Orsha - } \\
\text { Zlobin }\end{array}$ & $\begin{array}{l}\text { Connect to Rail Route } \\
\text { 8.b. }\end{array}$ & $\begin{array}{l}\text { C14/ } \\
\text { CE14, } \\
\text { C95/2 }\end{array}$ & \\
\hline 9. & \begin{tabular}{|c|} 
Hanko (port)/Turku (port) - Helsinki - \\
Riihimäki - Kouvola - Vainikkala \\
(border FIN) - Luzhaika (border \\
RUS) - Buslovskaya - Moscow - Ryazan - Orenburg \\
- Aktyubinsk - Kandagach - Aris - Tashkent \\
- Bukhara - Karshi - Tashguzar - Baysun - \\
Kumchurgan - Termez - Galaba - \\
Hairatan (border of Afghanistan )
\end{tabular} & TRACECA & $\begin{array}{l}\mathrm{E} 10, \mathrm{E} 24, \mathrm{E} 30, \mathrm{E} 50 \\
\mathrm{E} 695\end{array}$ & $Y$ \\
\hline 9.a. & $\begin{array}{c}\text { Ryazan - Aksarayskaya - Makat - Karakalpakiya - } \\
\text { Uchkuduck - Navoi - Bukhara }\end{array}$ & TRACECA & E50, E597 & Y \\
\hline 9.b. & $\begin{array}{c}\text { Rostov-na-Donu - Volgograd - Baskunchak - } \\
\text { Aksarayskaya }\end{array}$ & & E99, E50 & $Y$ \\
\hline 9.c. & $\begin{array}{l}\text { Bukhara - Karshi - Tashguzar - Baysun - } \\
\text { Kumchurgan - Sariacia - Dushanbe - Vaghdad }\end{array}$ & & E695 & $Y$ \\
\hline 9.d. & $\begin{array}{c}\text { Volgograd - Tikhoretskaya - Krasnodar - } \\
\text { Novorossiysk }\end{array}$ & & & \\
\hline
\end{tabular}

Notes:

* The Intergovernmental Agreement on the Trans-Asian Railway was adopted in 2005 and signed by 18 countries in 2006. It is open for signature and accession to all ESCAP Member States. The last column in the above table indicates those sections of TAR that are also part of the EATL project.

1. Itineraries in blue refer to new EATL Phase II routes.

2. Numbering is indicative only.

3. Turkey's border with Armenia is currently closed. 


\begin{tabular}{|c|c|c|c|}
\hline & & AGR & AH \\
\hline 1. & $\begin{array}{c}\text { Turku (port) - Helsinki -Vaalima - (border RUS) - Torfyanovka - St Petersburg } \\
\text { (Port)- Moscow - Nizhniy Novgorod - Ekaterinburg - Omsk - Novosibirsk } \\
\text { - Krasnoyarsk - Irkutsk - Ulan Ude - Chita - Belogorsk - Khabarovsk - } \\
\text { Ussuriysk - Vladivostok (Port)/Vostochny (Port)/Nakhodka (Port) }\end{array}$ & $\begin{array}{l}\text { E105, } \\
\text { E22 }\end{array}$ & $\begin{array}{l}\mathrm{AH} 8 \\
\mathrm{AH} 6 \\
\mathrm{AH} 30\end{array}$ \\
\hline 1.a. & $\begin{array}{c}\text { Bremenhaven - Bremen - Hamburg - Berlin/Seddin - Frankfurt (Oder) } \\
\text { (border GER) - Border POL - Kunowice - Poznan - } \\
\text { Warsawa - Terespol (border POL) - Brest - Minsk - Moscow }\end{array}$ & $\mathrm{E} 85, \mathrm{E} 30$ & AH6 \\
\hline 1.b. & $\begin{array}{l}\text { (Luxembourg - border LUX - border FRA - Thionville - Metz - Remilly - } \\
\text { Forback (border FRA) - Saarbrucken (border GER) } \\
\text { Ludwigshafen - Mannheim - Frankfurt (M) - Giessen - Eisenach - Gera - } \\
\text { Dresden - Gorlitz (border GER) - Legnica - Wroclaw - Katowice - Krakow } \\
\text { - Przemysl - Medyka - Mostiska) /Chop - Lvov - Kyiv - Moscow }\end{array}$ & $\mathrm{E} 40, \mathrm{E} 101$ & NA \\
\hline 1.c. & Moscow - Yaroslavl - Vologda - Archangelsk (Port) & E115 & NA \\
\hline 1.d. & Semipalatinsk - Novossibirsk & $\mathrm{N}$ & $\mathrm{N}$ \\
\hline 1.e. & $\begin{array}{c}\text { (Ventspils (port) - Tukums) / (Liepaja (port)) - Riga - Jekabpils - Rezekne } \\
\text { - Ludza - Terehova (border LVA) - Buracki (border RUS) - Velikie Luki - } \\
\text { Moscow - Efremov - Voronezh - Rostov-na-Donu (Port) }\end{array}$ & & \\
\hline 1.f. & $\begin{array}{l}\text { Riga-Jekabpils-Daugavpils- Kraslava- Paternieki (border LVA)- } \\
\text { Grigorovshchina (border BLR)-Polack-Vicebsk-Orsha-Zlobin }\end{array}$ & A6 & $\mathrm{N}$ \\
\hline 1.g. & $\begin{array}{c}\text { Sassnitz port (Germany sea link) - Draugyste (Klaipeda port, LTU) - Kaunas - } \\
\text { Vilnius - Medininkai (border LTU) - Minsk }\end{array}$ & & \\
\hline 1.h. & $\begin{array}{c}\text { Berlin - Neubrandenburg - Stralsund - Sassnitz port (Germany sea link) - } \\
\text { Draugyste (Klaipeda port, LTU) }\end{array}$ & & \\
\hline 2. & $\begin{array}{c}\text { (Bremenhaven - Bremen - Hamburg - Berlin/Seddin - Frankfurt (Oder) } \\
\text { (borderGER) - Border POL - Kunowice - Poznan - Warsawa - Terespol } \\
\text { (border POL) - Brest / (Sassnitz port (Germany sea link) - Draugyste } \\
\text { (Klaipeda port, LTU) - Klaipeda (port) - Kaunas - Vilnius - Medininkai } \\
\text { (border LTU) - Minsk - Moscow - Nizhniy Novgorod - Ufa - Chelyabinsk } \\
\text { - Kurgan - Petropavlovsk - Astana - Almaty - Khorgos - Jinghe - Urumqi - } \\
\text { Xi'an - Lianyungang (Port) / Shanghai (Port) }\end{array}$ & $\begin{array}{l}\text { E85, } \\
\text { E30, } \\
\text { E125 }\end{array}$ & $\begin{array}{l}\text { AH6, } \\
\text { AH64, } \\
\text { AH7 } \\
\text { AH60 }\end{array}$ \\
\hline 2.a. & $\begin{array}{c}\text { Turku (port) - Helsinki -Vaalima - (border RUS) - Torfyanovka - } \\
\text { St Petersburg - Moscow }\end{array}$ & $\mathrm{E} 18, \mathrm{E} 105$ & $\mathrm{AH} 8$ \\
\hline 2.b. & $\begin{array}{c}\text { Petropavlovsk - Omsk - Pavlodar - Semipalatinsk - Georgievka - Taskesken } \\
\text { - Ucharal - Dostyk - Alatawshankou - Kuitun - Urumqi }\end{array}$ & E127 & $\begin{array}{l}\text { AH60, } \mathrm{AH} 68, \\
\text { AH5 }\end{array}$ \\
\hline 2.c. & $\begin{array}{c}\text { Moscow - Samara - Uralsk - Aktobe - Dossor - Makat - Beyneu - } \\
\text { Nukus - Navoi - Tashkent - Almaty }\end{array}$ & $\mathrm{E} 121, \mathrm{E} 38$ & $\mathrm{AH} 60, \mathrm{AH} 63, \mathrm{AH} 61$ \\
\hline 2.d. & Chelyabinsk - Kaerak - Kostani - Astana & $\mathrm{E} 123,016$ & $\mathrm{AH7}$ \\
\hline 2.e. & Archangelsk - Perm - Yekaterinburg - Kurgan - Petropavlovsk & $\mathrm{N}$ & $\mathrm{N}$ \\
\hline 3. & $\begin{array}{c}\text { Luxembourg - border LUX - border FRA - Thionville - Metz - Remilly } \\
\text { - Forback (border FRA) - Saarbrucken (border GER) Ludwigshafen - } \\
\text { Mannheim - Frankfurt (M) - Giessen - Eisenach - Gera - Dresden - Gorlitz } \\
\text { (border GER) - Legnica - Wroclaw - Katowice - Krakow - Przemysl - } \\
\text { Medyka - Mostiska (border UKR) - Lvov - Kyiv - Kipti - Bachivsk(UKR)/ } \\
\text { Troebortne(RUS) or Kharkiv - Goptivka(UKR)/Nekhoteevka(RUS) - Kursk } \\
\text { - Saratov - Ozinki - Uralsk - Aktyubinsk - Karabutak - Aralsk - Kyzylorda } \\
\text { - Shymkent - Almaty - Khorgos - Jinghe - Urumqi - Xi'an - Lianyungang } \\
\text { (Port) / Shanghai (Port) }\end{array}$ & $\begin{array}{l}\text { E40, E95, } \\
\text { E101, E38 }\end{array}$ & AH61 \\
\hline 3.a. & $\begin{array}{c}\text { Chop - Uzhgorod - Mukacevo - Stryei - Lviv - Kyiv - Kharkiv - Kamensk - } \\
\text { Shahtinskiy - Volgograd - Astrakhan - Atyrau - Beyneu - Nukus - Bukhara } \\
\text { - Navoi - Samarkand - Tashkent - Shymkent }\end{array}$ & $\mathrm{E} 40$ & $\begin{array}{l}\text { AH70, } \\
\text { AH8, AH63, AH5 }\end{array}$ \\
\hline 3.b. & Yagodyn - Kovel - Sarny - Korosten - Kyiv & E373 & NA \\
\hline 3.c. & $\begin{array}{c}\text { Kaliningrad (Port) - Tolpaki - Nesterov - (border RUS) - Kybertai (border } \\
\text { LTU) - Marijampole - Kaunas -Vilnius - Minsk - Gomel - Kyiv }\end{array}$ & $\begin{array}{l}\text { E28, E271, } \\
\text { E95 }\end{array}$ & NA \\
\hline
\end{tabular}




\begin{tabular}{|c|c|c|c|}
\hline & & AGR & $\mathbf{A H}$ \\
\hline 3.d. & $\begin{array}{c}\text { Mostiska/Chop - Uzhgorod - Mukacevo - Stryei - Ternopol - } \\
\text { Khmelnitski - Vinnitza - Uman - Kirovograd - Dnepropetrovsk - } \\
\text { Donetsk - Rostov-na-Donu - Armavir - Mineralijnie Vodi - } \\
\text { Vladikavkaz - (Tbilisi) - Makhachkala (Port) - Aktau (Port) - Beyneu }\end{array}$ & $\begin{array}{l}\text { E50 } \\
\text { E121 }\end{array}$ & $\mathrm{AH} 70$ \\
\hline 3.e. & $\begin{array}{c}\text { Moscow - Efremov - Voronezh - Rostov-na-Donu - Krasnodar - Novorossijsk } \\
\text { (Port) - Kavkaz (Port) - (rail ferry) Samsun (Port) / Poti/Batumi (Port) / } \\
\text { Burgas (Port) }\end{array}$ & $\begin{array}{l}\text { E115, } \\
\text { E97 }\end{array}$ & NA \\
\hline 3.f. & $\begin{array}{c}\text { Sofia - Popvica - Stara Zagora - Burgas (Port) - Kavkaz (Port) - } \\
\text { Novorossysk (Port) - Poti/Batumi (Port) }\end{array}$ & E773 & NA \\
\hline 3.g. & Khazan - Orenburg - Sol'lletsk -Aktyubinsk (Kaz) & & \\
\hline 4. & $\begin{array}{c}\text { Nadlac - Arad - Bucharest - Constanta (Port) - Poti/Batumi (Port) - Tbilisi } \\
\text { - Alat - Baku (Port) - Aktau (Port) - Beyneu - Nukus - Bukhara - Tashkent } \\
\text { - Shymkent - Bishkek - Almaty - Sary-Ozek - Khorgos - Urumqi - Xi'an - } \\
\text { Lianyungang (Port) / Shanghai (Port) }\end{array}$ & $\begin{array}{l}\text { E68, E60, } \\
\text { E121, } \\
\text { E40, E60 }\end{array}$ & $\begin{array}{l}\mathrm{AH} 5, \mathrm{AH} 70 \\
\mathrm{AH} 63, \mathrm{AH} 62\end{array}$ \\
\hline 4.a. & $\begin{array}{c}\text { Tbilisi - Sadakho - Yerevan - Eraskh - Goris - Kapan - Megri - (Agarak) - } \\
\text { Nourdouz - Jolfa (Iran) - Eyvoghli }\end{array}$ & E117 & AH82 \\
\hline 4.b. & $\begin{array}{c}\text { Ruse - Giurgiu - Bucharest - Urziceni - Marasesti - Albita - Leucheni - } \\
\text { Chisinau - Odessa (Port) - Poti/Batumi (Port) }\end{array}$ & $\begin{array}{l}\text { E85, E581, } \\
\text { E58 }\end{array}$ & NA \\
\hline 4.c. & $\begin{array}{c}\text { Nova Guta(BY)/Novi Yarylovychi(UKR) - Chrnigiv - Kyiv - Odessa (Port) / } \\
\text { llyichevsk (Port) - Poti/Batumi (Port) }\end{array}$ & E95 & NA \\
\hline 4.d. & Sofia - Pleven - Ruse - Varna (Port) - Poti/Batumi (Port) & $\begin{array}{l}\text { E79, E83, } \\
\text { E85, E70 }\end{array}$ & NA \\
\hline 4.e. & $\begin{array}{c}\text { Merzifon - Samsun (Port) - Trabzon (Port) - Sarp (Turkey) - Sarpi (Georgia) - } \\
\text { Batumi (Port) - Poti (Port) }\end{array}$ & $\begin{array}{l}\text { E95, } \\
\text { E70 }\end{array}$ & $\mathrm{AH} 5$ \\
\hline 4.f. & Baku (Port) - Turkmenbashi (Port) - Ashgabhat - Mary - Bukhara & E60 & $\mathrm{AH} 5$ \\
\hline 4.g. & Bishkek - Naryn - Torugart - Kashi & $\mathrm{E} 125$ & AH61 \\
\hline 4.h. & Shymkent - Merket - Almaty & NA & $\mathrm{AH} 5$ \\
\hline 4.i. & $\begin{array}{l}\text { Brest - territory of Belarus - border with Ukraine - territory of Ukraine - } \\
\text { border with the Republic of Moldova - Chisinau - Odessa (Port) / llyichevsk } \\
\text { (Port) - Poti (Port) / Batumi (Port) }\end{array}$ & E30, E85 & NA \\
\hline 4. i. & Batumi (Port) - Hopa - Kars - Gyumri - Yerevan & E70 & $\mathrm{AH} 5$ \\
\hline 4.k. & Chisinau - Giurgiulesti (river port) & E584 & NA \\
\hline 4.I. & Gyumri - Erzurum & E691, E80 & NA \\
\hline 4.m. & Odessa (Port) / Ilyichevsk (Port) - Samsun (port) / Trabzon (port) & NA & NA \\
\hline 4.n. & Samsun (Port) / Trabzon (Port) - Poti/Batumi (Port) & NA & NA \\
\hline 4.o. & Djulfa (Azerbaijan) - Nakhichevan - Sadarak - Border with Turkey & E99 & $N$ \\
\hline 4.p. & Bishkek - Chaldovar - Suusamyr - Dzatal Abad - Uzgen - Osh & & \\
\hline 5. & $\begin{array}{c}\text { Border with Serbia /FYRM - Sofia - Kapikule - Istanbul - (Haydarpasa Port) - } \\
\text { Izmit (Derince Port) - Merzifon - Refahiye - Gurbulak - Bazargan - Eyvoghli } \\
\text { - Tabriz - Qazvin - Tehran - Semnan - Damghan - Sabzevar - Mashhad } \\
\text { - Dogharoun - Islam Qala - Herat - Mazar-i-Sharif - Termez - Guzar } \\
\text { - Samarkand - Bekabad - Aybek - Khodjent - Kanibadam- Andarkhan - } \\
\text { Kokand - Andizhan - Osh - Sary-Tash - Irkeshtam - Kashi - Urumqi - Xi'an } \\
\text { - Lianyungang (Port)/ Shanghai (Port) }\end{array}$ & $\begin{array}{l}\text { E80 } \\
\text { E60 } \\
\text { E006 }\end{array}$ & $\begin{array}{l}\mathrm{AH1}, \mathrm{AH} 5, \mathrm{AH} 85, \\
\mathrm{AH} 77, \mathrm{AH} 65\end{array}$ \\
\hline 5.a. & \begin{tabular}{|} 
Tehran - (Saveh - Salafchegan) - Qom - Yazd - Anar - Kerman - Zahedan \\
- Mirjaveh - Dalbandin - Mastung - Bela - Karachi - Hyderabad - Sukkur - \\
Bahawalpur - Multan - Okara - Lahore - Kharian - Rawalpindi - Hasanabdal \\
- Mansehra - Besham - Chilas - Gilgit - Kunjerab (border Pakistan - China) \\
- Taxkorgan - Kashi (Kashgar)
\end{tabular} & NA & $\mathrm{AH} 2$ \\
\hline 5.b. & $\begin{array}{c}\text { Nadlac - Arad - Timisoara - Lugoj - Carasebes - Dr.-Turnu - Severin - } \\
\text { Craiova - Calafat - Vidin - Botevgrad - Sofia }\end{array}$ & $\begin{array}{l}\text { E70, } \\
\text { E79 }\end{array}$ & NA \\
\hline
\end{tabular}




\begin{tabular}{|c|c|c|c|}
\hline & & AGR & AH \\
\hline 5.c. & $\begin{array}{l}\text { Istanbul (Kınalı Junction) - Kesan - Ipsala (Greek/Turkish Border Gate) } \\
\text { / (Svilengrad - Ormenio - Soufli) - Alexandroupolis (port) - Kommotini } \\
\text { - Xanthi - Kavala (port) - Thessaloniki (port) - Veria - Metsovo - loanina - } \\
\text { Igoumenitsa (port)/ (Doliana - Jergucat) }\end{array}$ & E90, E84 & NA \\
\hline 5.d. & Mashhad - Sarakhs - Tejen & NA & $\mathrm{AH} 75$ \\
\hline 5.e. & $\begin{array}{c}\text { Mazar-i-Sharif - Polekhumri - Kabul - Jalalabad - Torkham - Peshawar } \\
\text { - Mansehra - Besham - Chilas - Gilgit - Kunjerab (border Pakistan - China) - } \\
\text { Taxkorgan - Kashi (Kashgar) }\end{array}$ & NA & $\mathrm{AH76}, \mathrm{AH7}, \mathrm{AHI}$ \\
\hline 5.f. & Mazar-i-Sharif - Polekhumri - Nizhniy Pani - Dushanbe - Sary-Tash & $\mathrm{E} 123, \mathrm{E} 60$ & $\mathrm{AH} 76, \mathrm{AH7}, \mathrm{AH} 65$ \\
\hline 5.g. & $\begin{array}{c}\text { Sherkhan Bandar(Afganistan)- Nizhniy Panj - Dushanbe - Vahdat- } \\
\text { Jirgatal(Tajikistan)- Karamik (Kyrgyzstan) }\end{array}$ & E123, E60 & $\mathrm{AH7}, \mathrm{AH} 65$ \\
\hline 5.h. & $\begin{array}{l}\text { Termez - Sariasiya- Dushanbe - Vakhdat - Kulob - Khorugh - Murgab - } \\
\text { Kulma-Karasu (China) }\end{array}$ & $\begin{array}{l}\text { E60, E009, } \\
\text { E008 }\end{array}$ & $\mathrm{AH} 65, \mathrm{AH} 66, \mathrm{AH} 4$ \\
\hline 5.i. & Constanta (Port) - Haydarpasa (Port) & NA & NA \\
\hline 5.j. & Ilyichevsk (Port) - Derince (Port) & NA & NA \\
\hline 5.k. & Tashkent - Aybek - Kodjent - Kanibadam - Andarkhan - Kokand & E006 & AH7 \\
\hline 5.I. & $\begin{array}{c}\text { Tashkent - Aybek - Khodjent -Dushanbe-Kurgantube-Nijniy Panj-Sherkhan } \\
\text { Bandar(Afganistan) }\end{array}$ & & $\mathrm{AH7}$ \\
\hline 5.m. & $\begin{array}{c}\text { Izmit Bati } 2 \text { Junction - Yalova - (D575-K1 1) Junction - Bursa - Motorway Link } \\
\text { Road - Bursa Bati K131 - Karacabey Junction - Bigadiç Junction - Gölcük } \\
\text { Junction - Izmir - Ceşme / Çiğli - Menemen - Aliağa - Bergama Junc. - } \\
\text { Çandarlı }\end{array}$ & E881 & $\mathrm{N}$ \\
\hline 5.n. & $\begin{array}{l}\text { Hisarönü (Filyos) - Caycuma - Zonguldak Junc. - Devrek -Mengen - } \\
\text { Yeniçağa Gerede Junc. - Yeniçağ K23 Junc. - Gerede - Ankara - Aksaray } \\
\text { - (Konya Ereğli) Junction - Pozanti - Mersin (port) }\end{array}$ & $\begin{array}{l}\text { E89, E90, } \\
\text { E982 }\end{array}$ & \\
\hline 5.o. & $\begin{array}{c}\text { Sofia - Blagoevgrad - Kulata - Promachon - Thessaloniki - Larissa - Athens } \\
\text { - Pireaus }\end{array}$ & & \\
\hline 5.p. & $\begin{array}{c}\text { Karachi - Bela - Wad - Kalat - Quetta - Chamman - Kandahar - Heart - } \\
\text { Eslam Qualeh - SangBast - Sarakhs - Tejen }\end{array}$ & & \\
\hline 5.q. & $\begin{array}{c}\text { Herat - Kandahar - Chamman - Quetta - Zhob - D.I. Khan - Peshawar - } \\
\text { Islamabad }\end{array}$ & & \\
\hline 5.r. & $\begin{array}{c}\text { Bujanovac (Serbia) - Tabanovce (fYRoM) - Kumanovo - Skopje - Dracevo - } \\
\text { Titov Veles - Negotino - Smokvica - Gevgelija - Idomeni -Agios Athanasios } \\
\text { - Thessaloniki - Larissa - Athens - Pireaus (Port) - Neo lkonio (Piraeus } \\
\text { Container Terminal) }\end{array}$ & E75 & \\
\hline 5.s. & $\begin{array}{c}\text { Border (Bulgaria) - Kriva Palanka - Kumanovo - Skopje - Tetovo - Gostivar } \\
\text { - Kicevo - Struga - Border (Albania) }\end{array}$ & $\begin{array}{l}E-852, E-65, \\
E-75, E-871\end{array}$ & \\
\hline 6. & $\begin{array}{l}\text { Turku (port) - Helsinki -Vaalima - (border RUS) - Torfyanovka - } \\
\text { St Petersburg - Moscow - Volgograd - Astrakhan/Alya (Port) - } \\
\text { Anzali (Port) - Qazvin - Tehran - Bandar Abbas (Port) }\end{array}$ & $\begin{array}{c}\text { E105, } \\
\text { E119, E40 }\end{array}$ & $\begin{array}{l}\mathrm{AH} 8, \mathrm{AH} 1, \mathrm{AH} 2, \\
\quad \mathrm{AH} 70\end{array}$ \\
\hline 6.a. & $\begin{array}{c}\text { Astrakhan (Port) - Alya (Port) - Samur - Yalama - Baku (Port) - Astara } \\
\text { (Azerbaijan) - Astara (Iran) - Qazvin - Tehran }\end{array}$ & E119 & $\mathrm{AH} 8$ \\
\hline 6.b. & Astrakhan (Port) - Amirabad (Port) - Sari & NA & $\mathrm{AH} 70$ \\
\hline 6.c. & Astrakhan (Port) - Alya (Port) - Aktau (Port) - Beineu & E121 & $\mathrm{AH} 70$ \\
\hline 6.d. & Qazvin - Saveh - Ahvaz - Bandar Emam (Port) & NA & $\mathrm{AH} 8$ \\
\hline 6.e. & $\begin{array}{c}\text { Thessaloniki (Port) - Kavala - Xanthi - Kommotini -Alexandroupolis - Ipsala } \\
\text { (Greek/Turkish border) - Kesan - Lapseki - Bursa - Eskisehir - Sivrihisar } \\
\text { - Ankara - Aksaray - Pozanti (link to Mersin) - Adana - Gaziantep - } \\
\text { Sanliurfa - Mardin - Habur (border with Iraq) - Zakho - Tebriz - Quazvin } \\
\text { - Tehran - Qom - Esfahan - Shiraz - Bushehr (Port) }\end{array}$ & E90, E982 & $\mathrm{AH} 72, \mathrm{AH} 84$ \\
\hline 6.f. & $\begin{array}{c}\text { Eserdar - Gudurolum - Inche Boroun - Gorgan - Sari - Semnan - Damghan } \\
\text { - Yazd - Anar - Bandar Abbas (Port) }\end{array}$ & E 121 & $\mathrm{AH} 70$ \\
\hline
\end{tabular}




\begin{tabular}{|c|c|c|c|}
\hline 6.g. & $\begin{array}{c}\text { Astrakhan - Atyrau (Port) - Makat - Beyneu - Aktau (Port) - Turkmenbashi } \\
\text { (Port) - Ashgabat - Tegen - Saras - Sarakhs - Mashhad - Birjand - } \\
\text { Nehbandan - Dastak - Zahedan - Chabahar (Port) }\end{array}$ & $\begin{array}{c}\text { AGR, E121, } \\
\text { E60 }\end{array}$ & AH70, AH5, AH75 \\
\hline 7. & $\begin{array}{r}\text { Murmansk (Port) - Petrozavodsk - St Petersburg (Port) - Pskov - Ostrov - } \\
\text { Gomel - Kyiv - Odessa (Port) / Ilyichevsk (Port) }\end{array}$ & E105, E95 & NA \\
\hline 8. & $\begin{array}{c}\text { Ulan-Ude - Ivolginsk - Gusinoozersk - Kyakhta (border RUS) - Altanbulag/ } \\
\text { border/-Ulaanbaatar-Zamiin-Uud/border/-990 km - Erenhot (Border CHN) } \\
\text { - Jining - Beijing - to Tianjin (port) and to Cangzhou - Xuzhou - Nanjing }\end{array}$ & AH3 \\
\hline 9. & $\begin{array}{c}\text { Novosibirsk - Barnaul - Bijsk - Gorno-Altaysk - Tashanta -Uulaanbaishint } \\
\text {-Ulgii-Khovd-Yarant -border (749 km) - Qinghe - Karatunggu - Ertai - } \\
\text { Jiangiunmiao - Xidi - Miquan - Urumqi }\end{array}$ & AH4 \\
\hline
\end{tabular}

Notes:

1. Itineraries in blue refer to new EATL Phase II routes.

2. Numbering is indicative only.

3. Turkey's border with Armenia is currently closed.

Table 4.4 - Inland water transport linkages

\begin{tabular}{|c|c|c|c|}
\hline & Country & From - To & $\begin{array}{l}\text { E- No. or other } \\
\text { international ref. No. }\end{array}$ \\
\hline 1 & Bulgaria & Danube km 610 - km 374 & Corridor VII, E-80 \\
\hline 2 & Lithuania & Klaipeda - Jurbarkas - Kaunas & E41 \\
\hline 3 & Kazakhstan & $\begin{array}{c}\text { Sr.Trekinskiy Yar - Peshnoi island - entering buoy of Uralo-Caspian } \\
\text { channel (the Ural river) }\end{array}$ & \\
\hline 4 & $\begin{array}{l}\text { Republic of } \\
\text { Moldova }\end{array}$ & $\begin{array}{l}\text { Prut river from the mouth to Ungheni } \\
\qquad(0-559 \mathrm{~km})\end{array}$ & E 80-07 \\
\hline 5 & $\begin{array}{l}\text { Republic of } \\
\text { Moldova }\end{array}$ & $\begin{array}{l}\text { Dniester river from the port Belgorod-Dnestrovsky (Ukraine) to } \\
\text { Bender }(0-667 \mathrm{~km})\end{array}$ & E 90-03 \\
\hline 6 & Romania & Danube km 1075 - km 863 & Corridor VII E-80 \\
\hline 7 & Romania & Danube km 863 - km 175 & Corridor VII E-80 \\
\hline 8 & Romania & Danube km 175 - Mm 0 & Corridor VII E-80 \\
\hline 9 & Romania & Danube - Black Sea Canal & $\mathrm{E}-80-14$ \\
\hline 10 & Romania & Poarta Alba - Midia - Navodari Canal & E-80-14-01 \\
\hline 11 & Russian Federation & $\begin{array}{l}\text { St Petersburg - Svir - Cherepovets - Rybinsk - Nizhniy Novgorod } \\
\text { - Kazan - Samara - Saratov - Volgograd - Krasnoarmeysk - } \\
\text { Astrakhan (port) - Caspian Sea (includes Volgo-Baltiyskiy Vodniyput) }\end{array}$ & $\begin{array}{l}\text { North-South Waterway } \\
\text { (NSW), E-50 }\end{array}$ \\
\hline 12 & Russian Federation & $\begin{array}{c}\text { (Rybinsk) - Moskva - Riazan - Nizkhniy Novgorod (includes Kanal } \\
\text { im. Moskvi) }\end{array}$ & NSW, E-50-02 \\
\hline 13 & Russian Federation & $\begin{array}{c}\text { Azov - Rostov-na-Donu - Oust-Donetsk - Krasnoarmeysk - } \\
\text { Astrakhan (port) - Caspian Sea }\end{array}$ & NSW4, NSW, E-90 \\
\hline 14 & Turkey & Lake Van (Tatvan - Van) & \\
\hline 15 & Ukraine & Route No.9 Dniper river (on regulate condition) & $\mathrm{E}-40$ \\
\hline 16 & Ukraine & $\begin{array}{l}\text { River Danube, border between Ukraine/Republic of Moldova - cape } \\
\text { Izmailskii Chatal }\end{array}$ & $E-80$ \\
\hline 17 & Ukraine & $\begin{array}{c}\text { Danube-Kilia Arm, cape Izmailskii Chatal -sea approach canal } \\
\text { (Bistroe Arm Outlet) }\end{array}$ & $E-80-09$ \\
\hline
\end{tabular}

Notes:

1. Linkages in blue refer to new EATL Phase II routes.

2. Numbering is indicative only. 
Table 4.5 - Inland river ports along selected inland water transport linkages

\begin{tabular}{|c|c|c|}
\hline & Country & Name and Location \\
\hline 1 & Bulgaria & Port Complex Rousse (P 80-56) Danube, km 489 300, km 496050 \\
\hline 2 & Bulgaria & Rousse East \\
\hline 3 & Bulgaria & Rousse West \\
\hline 4 & Bulgaria & Port Complex Lom (P 80-53) Danube, km 742300 \\
\hline 5 & Bulgaria & Port Vidin, Danube, from km 785400 to 793500 \\
\hline 6 & Kazakhstan & Atyrau River Port (Ural) \\
\hline 7 & Kazakhstan & Pavlodar River Port (Ural) \\
\hline 8 & Republic of Moldova & Bender (P 90-03-02), Dniester, km 228 \\
\hline 9 & Republic of Moldova & Rîbni®a, Prut \\
\hline 10 & Republic of Moldova & Ungheni, Prut \\
\hline 11 & Republic of Moldova & Giurgiule区ti (P 80-62) Danube, km 133 \\
\hline 12 & Romania & Sulina, Danube, $\mathrm{km} 0$ \\
\hline 13 & Romania & Tulcea (P 80-64), $34 \mathrm{Mm}-42 \mathrm{Mm}$ \\
\hline 14 & Romania & Gala冈i (P 80-61), Danube, 76 Mm - 160 km \\
\hline 15 & Romania & Braila (P 80-60), Danube, 168.5-172.0 km \\
\hline 16 & Romania & Medgidia (P 80-14-01), Danube-Black Sea Canal, 37.5 km \\
\hline 17 & Romania & Cernavoda (P $80-59$ bis), Danube, 298 km \\
\hline 18 & Romania & Calara冈i (P 80-59), Danube, 370.5 km \\
\hline 19 & Romania & Giurgiu (P 80-57), Danube, 493 km \\
\hline 20 & Romania & Calafat, Danube, km 795 \\
\hline 21 & Romania & Drobeta Turnu Severin (P 80-51), Danube, $931 \mathrm{~km}$ \\
\hline 22 & Romania & Or囚ova (P 80-50), Danube, 954 km \\
\hline 23 & Romania & Moldova Veche, Danube, 1048 km \\
\hline 24 & Russian Federation & St Petersburg River Port (P 50-02) Neva, km 1385 \\
\hline 25 & Russian Federation & Yaroslavl River Port (P 50-05) Volga, km 520 \\
\hline 26 & Russian Federation & Nizhni Novgorod River Port (P 50-06) Volga, km 907 \\
\hline 27 & Russian Federation & Kazan River Port (P 50-07) Volga, km 1313 \\
\hline 28 & Russian Federation & Samara River Port (P 50-09) Volga, km 1746 \\
\hline 29 & Russian Federation & Volgograd River Port (P 50-11) Volga, km 2560 \\
\hline 30 & Russian Federation & Ust-Donetsk River Port (P 90-05) Don, km 2997 \\
\hline 31 & Russian Federation & Rostov-na-Donu River Port (P 90-05) Don, km 3134 \\
\hline 32 & Russian Federation & Azov River Port (P 90-03) Don, km 3168 \\
\hline 33 & Russian Federation & Yeysk River Port (P 90-02) Don, Taganrog Bay of the Azov Sea \\
\hline 34 & Turkey & Tatvan Port (rail ferry port on Lake Van) \\
\hline 35 & Turkey & Van Port (rail ferry port on Lake Van) \\
\hline 36 & Ukraine & Reni (P 80-63) Danube, 128 km Danube \\
\hline
\end{tabular}




\begin{tabular}{|c|c|c|}
\hline & Country & Name and Location \\
\hline 37 & Ukraine & Izmail (P 80-09-01), Danube-Kilia Arm, km 93 \\
\hline 38 & Ukraine & Kiliia (P 80-09-02), Danube-Kilia Arm, km 48 \\
\hline 39 & Ukraine & Ust'-Dunaisk (P 80-09-03), Danube-Kilia Arm, km 1 \\
\hline 40 & Ukraine & Belhorod-Dnestrovskii (P 90-03-01), Dnestrovskii Liman, Black Sea \\
\hline 41 & Ukraine & Kherson (P 40-12), Dniper, km 28 \\
\hline 42 & Ukraine & Kyiv River Port \\
\hline 43 & Ukraine & Odessa River Port, Black Sea \\
\hline 44 & Ukraine & Cherkassy river port (P 40-06), Dniper, km 653 \\
\hline 45 & Ukraine & Kremechuk river port (P 40-07), Dniper, km 541 \\
\hline 46 & Ukraine & Dneprodzerzhinsk river port (P 40-08), Dniper, km 429 \\
\hline 47 & Ukraine & Dnepropetrovsk river port (P 40-09), Dniper, km 393 \\
\hline 48 & Ukraine & Zaporizhya river port Stock insurer company «Ukrrechfloł» (P 40-10), Dniper, km 308 \\
\hline 49 & Ukraine & Nova Kakhovka river port (P 40-11), Dniper, km 96 \\
\hline 50 & Ukraine & Khersonskii river port, Stock insurer company «Ukrrechfloł» Dniper \\
\hline 51 & Uzbekistan & Termez (River Port Amu Darya) \\
\hline
\end{tabular}

Notes:

1. Blue text refers to new EATL ports.

2. Numbering is indicative only.

3. Where relevant, references to the European Agreement on Inland Waterways of International Importance (AGN) are indicated. 
Table 4.6 - Maritime ports considered in EATL Phase II

\begin{tabular}{|c|c|c|c|}
\hline Country & Name & Location and details & Types of ships handled \\
\hline AZE & Baku & 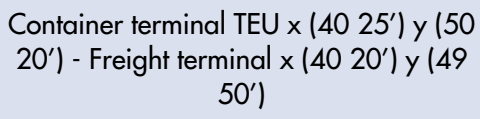 & $\begin{array}{c}\text { Ro-Ro, ferry, dry cargo and tanker } \\
\text { ships }\end{array}$ \\
\hline BGR & Burgas & $\begin{array}{l}\text { Container, freight and oil terminals (42 } \\
\qquad 29^{\prime} \mathrm{N} 2729^{\prime} \mathrm{E} \text { ) }\end{array}$ & $\begin{array}{c}\text { General and bulk cargo containers, } \\
\text { refrigerator, liquid cargo and oil } \\
\text { products }\end{array}$ \\
\hline BGR & Varna & $\begin{array}{l}\text { Container and freight terminals (43 12' } \\
\qquad N 2755^{\prime} \text { ) }\end{array}$ & $\begin{array}{c}\text { General and bulk cargo, containers, } \\
\text { installations for handling liquid } \\
\text { chemicals }\end{array}$ \\
\hline $\mathrm{CHN}$ & Lianyungang & Lianyungang & All \\
\hline $\mathrm{CHN}$ & Shanghai & Shanghai & All \\
\hline $\mathrm{CHN}$ & Tanggu & Tanggu & \\
\hline DEU & Bremmenhaven & Bremmenhaven & \\
\hline DEU & Sassnitz & Sassnitz & \\
\hline FIN & Hanko & Hanko & \\
\hline FIN & Turku & Turku & \\
\hline GEO & Batumi & Batumi, berths $1,2,3$ & Oil Products \\
\hline GEO & Batumi Seaport & Batumi, All & All \\
\hline GEO & Poti Seaport & Poti, All & All \\
\hline GRC & Alexandroupolis & Freight and passenger terminals & Passenger, ferry, freight \\
\hline GRC & Igoumenitsa & Freight and passenger terminals & Passenger, ferry, freight \\
\hline GRC & Kavala & Freight and passenger terminals & Passenger, ferry, freight \\
\hline GRC & Piraeus & All & All \\
\hline GRC & Thessaloniki & All & All \\
\hline IRN & Amirabad & Freight and Ro-Ro terminals & Freight and Ro/Ro \\
\hline IRN & Bandar Abbas & $\begin{array}{l}\text { Container, Ro-Ro, passenger, freight } \\
\text { terminals }\end{array}$ & Container, freight, passenger, Ro-Ro \\
\hline IRN & Bandar Anzali & Freight and Ro-Ro terminals & Freight and Ro-Ro \\
\hline IRN & Bandar Emam & Container, freight, Ro-Ro terminal & Container, freight, Ro-Ro \\
\hline ROM & Constanta & All & All \\
\hline ROM & Mangalia & - & - \\
\hline ROU & Midia - Navodari & $4420^{\prime} \mathrm{N}, 2841^{\prime} \mathrm{E}$ & \\
\hline RUS & Alya (Olya) & - & - \\
\hline RUS & Arkhangel'sk & All & All \\
\hline RUS & Astrakhan Port & All & All \\
\hline RUS & Gavan Vysotsk & - & \\
\hline RUS & Kaliningrad & All & All \\
\hline RUS & Kandalaksha & - & - \\
\hline RUS & Kavkaz & Ferry and freight & Ferry and freight \\
\hline RUS & Khabarovsk & All & All \\
\hline RUS & Makhachkala & Freight and passenger & Freight and passenger \\
\hline
\end{tabular}




\begin{tabular}{|c|c|c|c|}
\hline Country & Name & Location and details & Types of ships handled \\
\hline RUS & Murmansk & All & All \\
\hline RUS & Novorossiysk & All & All \\
\hline RUS & Sankt-Petersburg & St Petersburg All & All \\
\hline RUS & Taganrogskiy & Taganrog All & All \\
\hline RUS & Temryukskiy Rukav & Temryuk & \\
\hline RUS & Tuapse & - & - \\
\hline RUS & Ust-Luga & - & - \\
\hline RUS & Vladivostok & All & All \\
\hline RUS & Vostochnyy Port & - & - \\
\hline RUS & Vyborg & - & - \\
\hline TKM & Bekdash & - & - \\
\hline TKM & Turkmenbashy & All & All \\
\hline TUR & Çandarli & Izmir & Container and freight \\
\hline TUR & Derince & Izmit Bay & All \\
\hline TUR & Filyos & Zonguldak & All \\
\hline TUR & Haydarpasa & Istanbul & All \\
\hline TUR & Iskenderun & Iskenderun & All \\
\hline TUR & Izmir & Izmir & All \\
\hline TUR & Mersin & Mersin & All \\
\hline TUR & Mersin Container & Mersin & Container \\
\hline TUR & Samsun & Samsun & All \\
\hline TUR & Trabzon & Trabzon & All \\
\hline UKR & Bilhorod-Dnistrovs'kyy & Belhorod-Dnestrovskii & - \\
\hline UKR & Illichivs'k & All & All \\
\hline UKR & Mykolayiv & - & - \\
\hline UKR & Odesa & All & All \\
\hline UKR & Ust'Dunaisk & Zhebriianska Bay & \\
\hline
\end{tabular}




\subsubsection{Maps (interregional and national)}

4.1.31 Presentation of interregional maps - RAIL

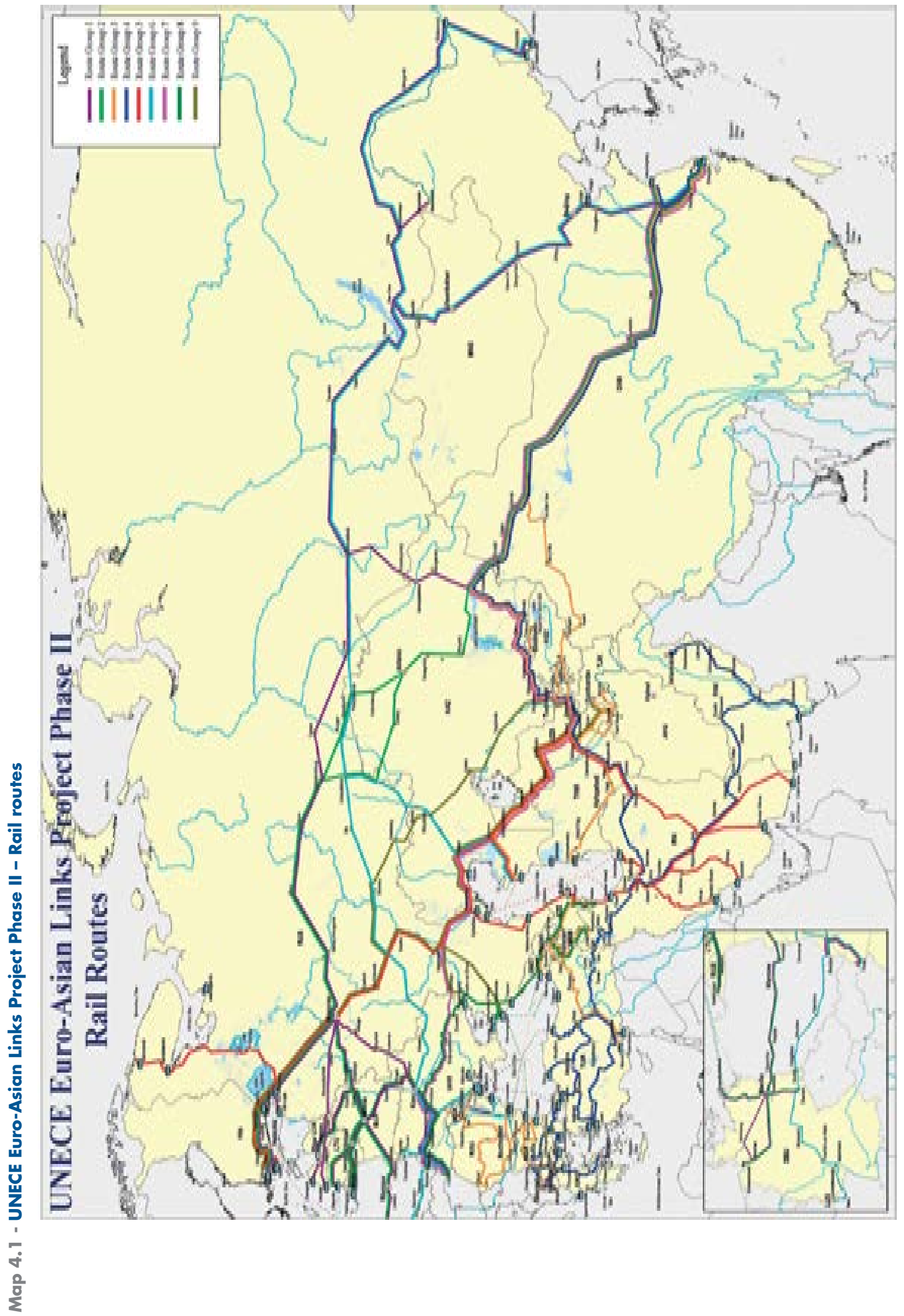




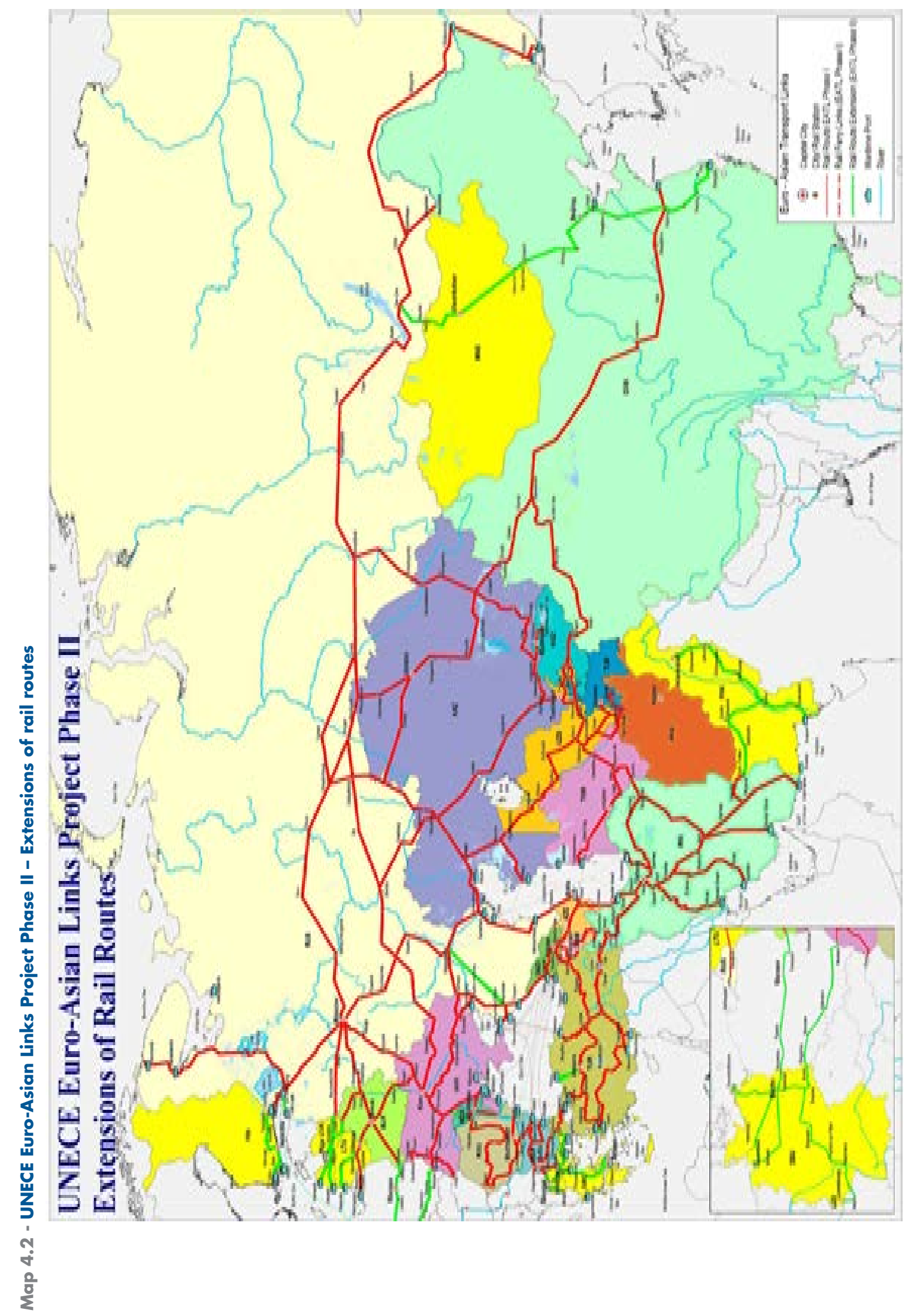




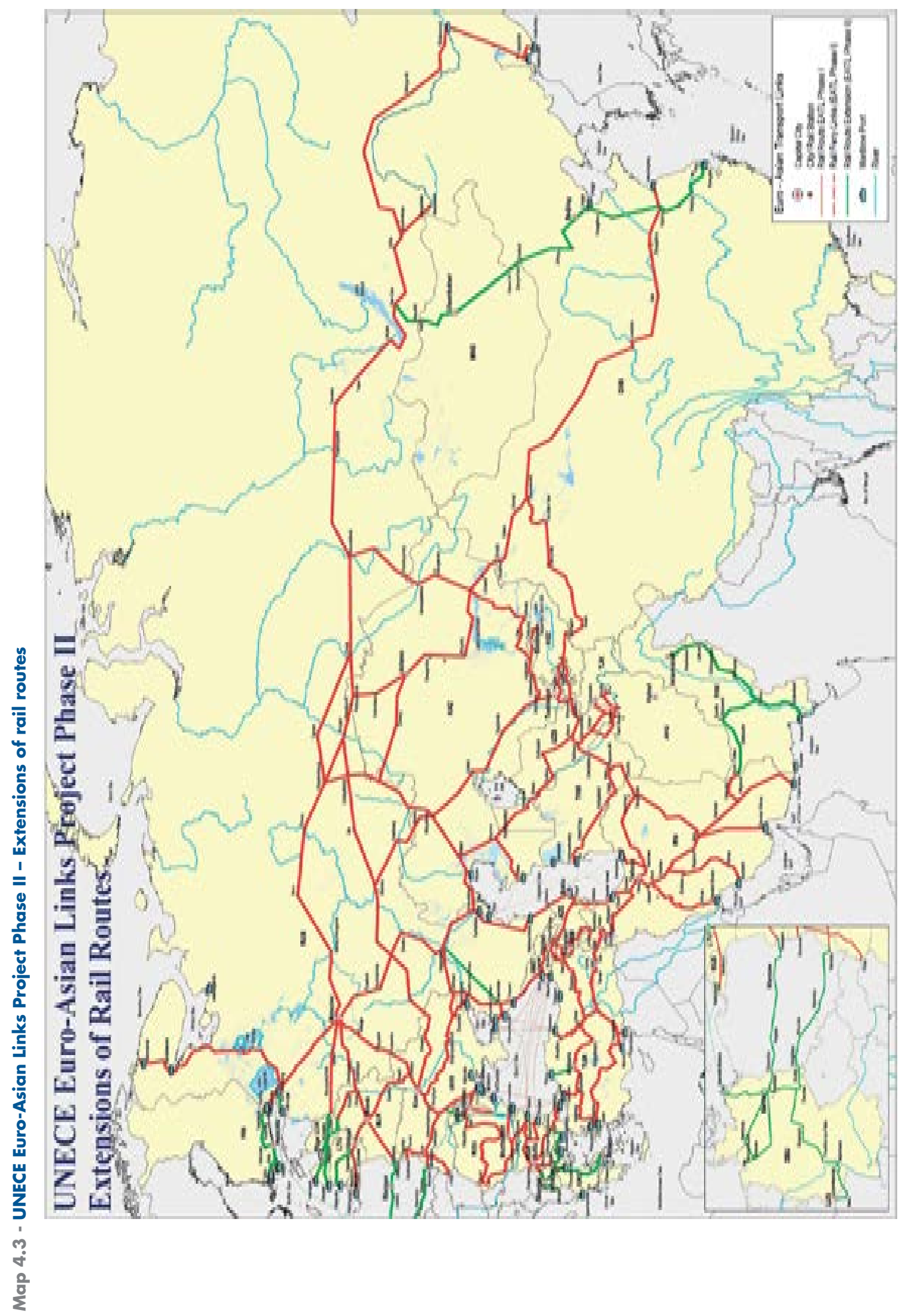




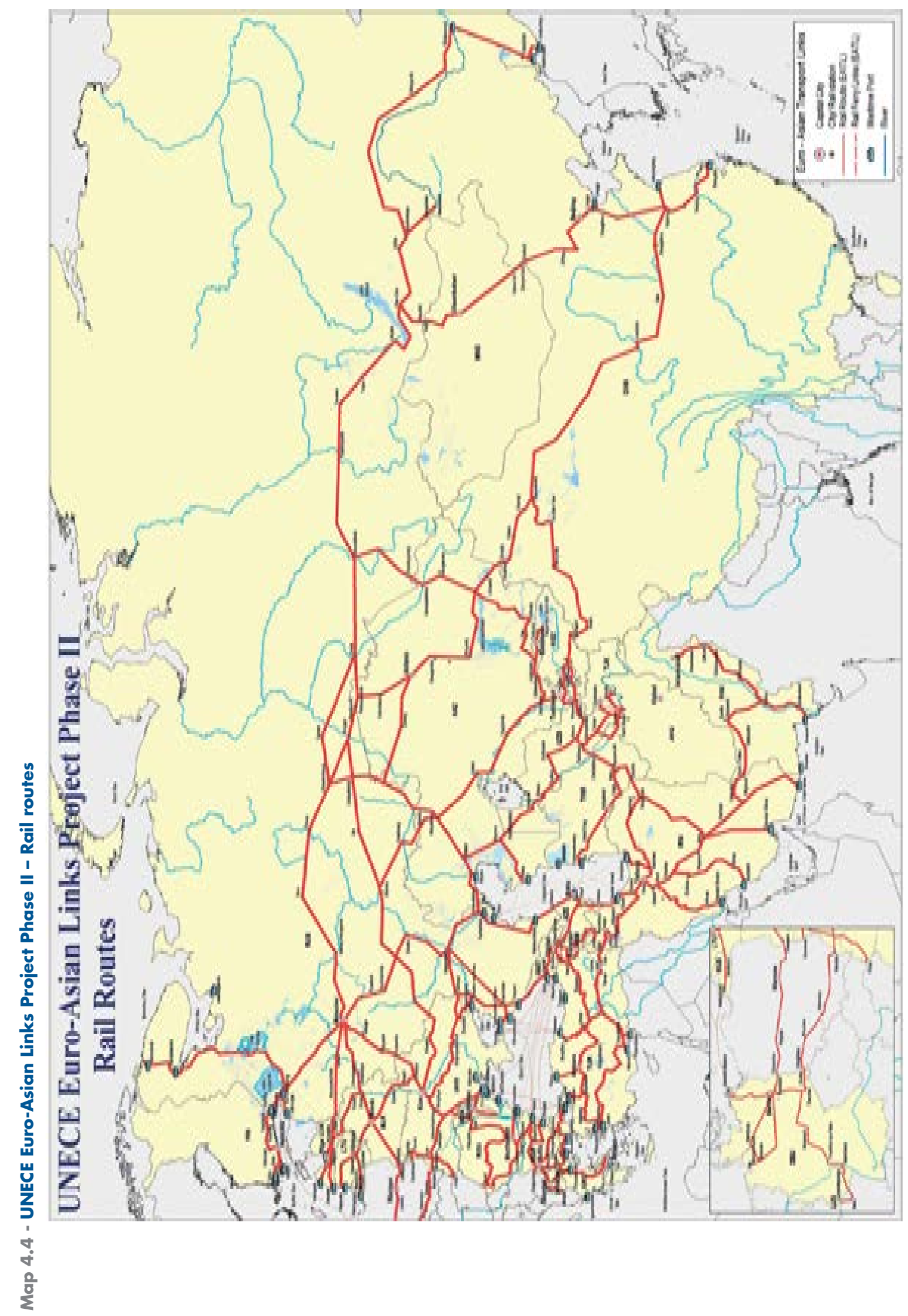




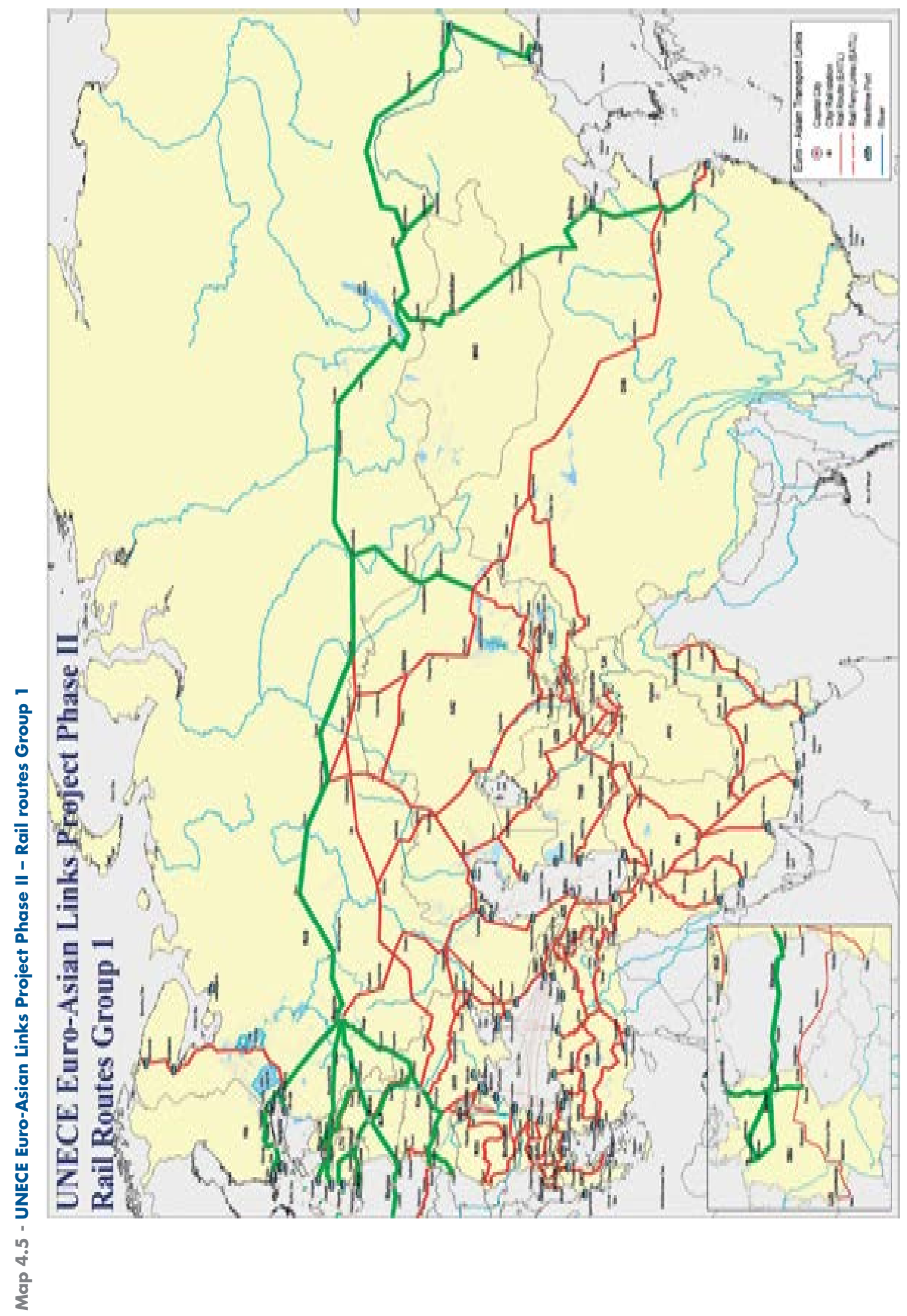




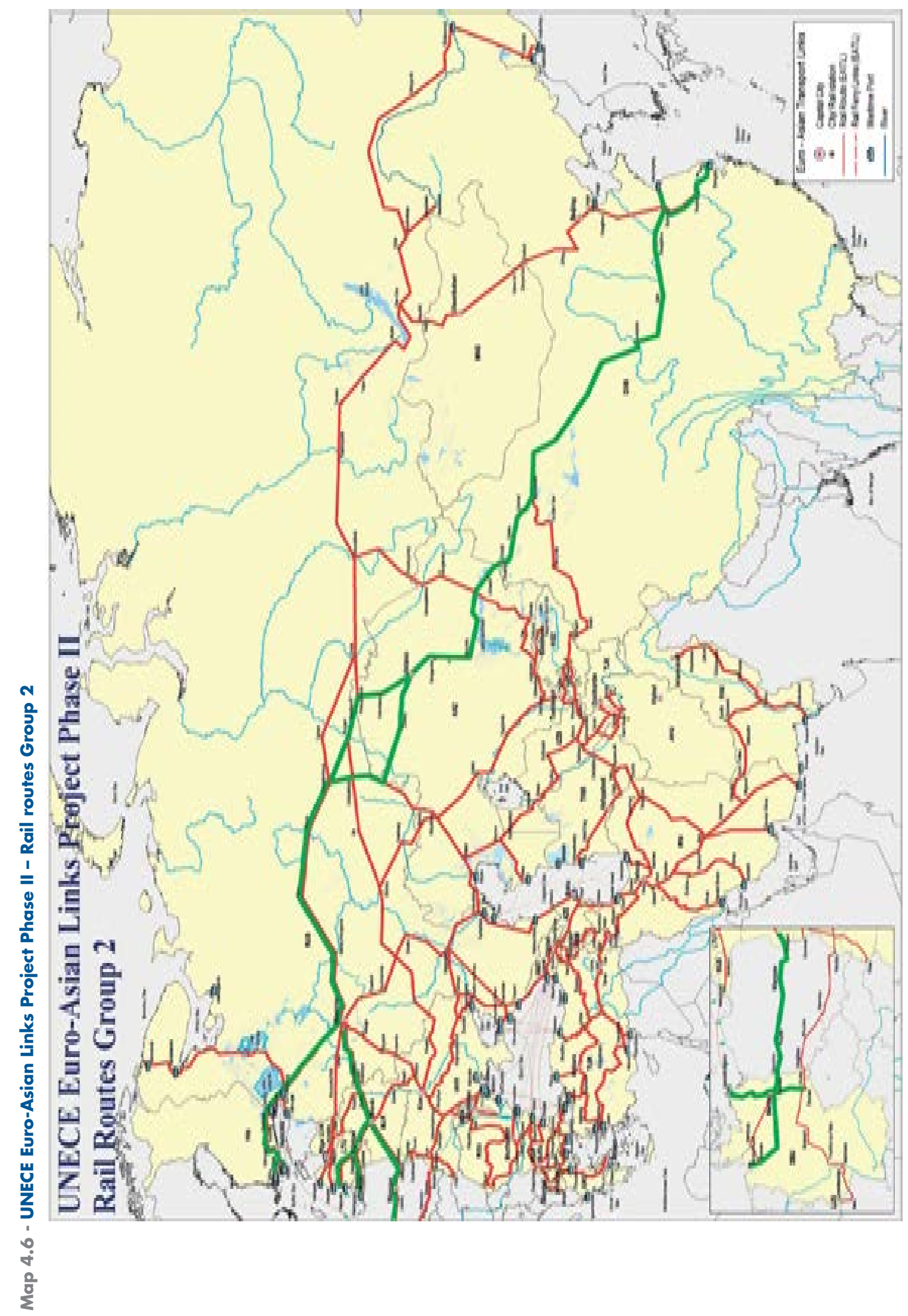




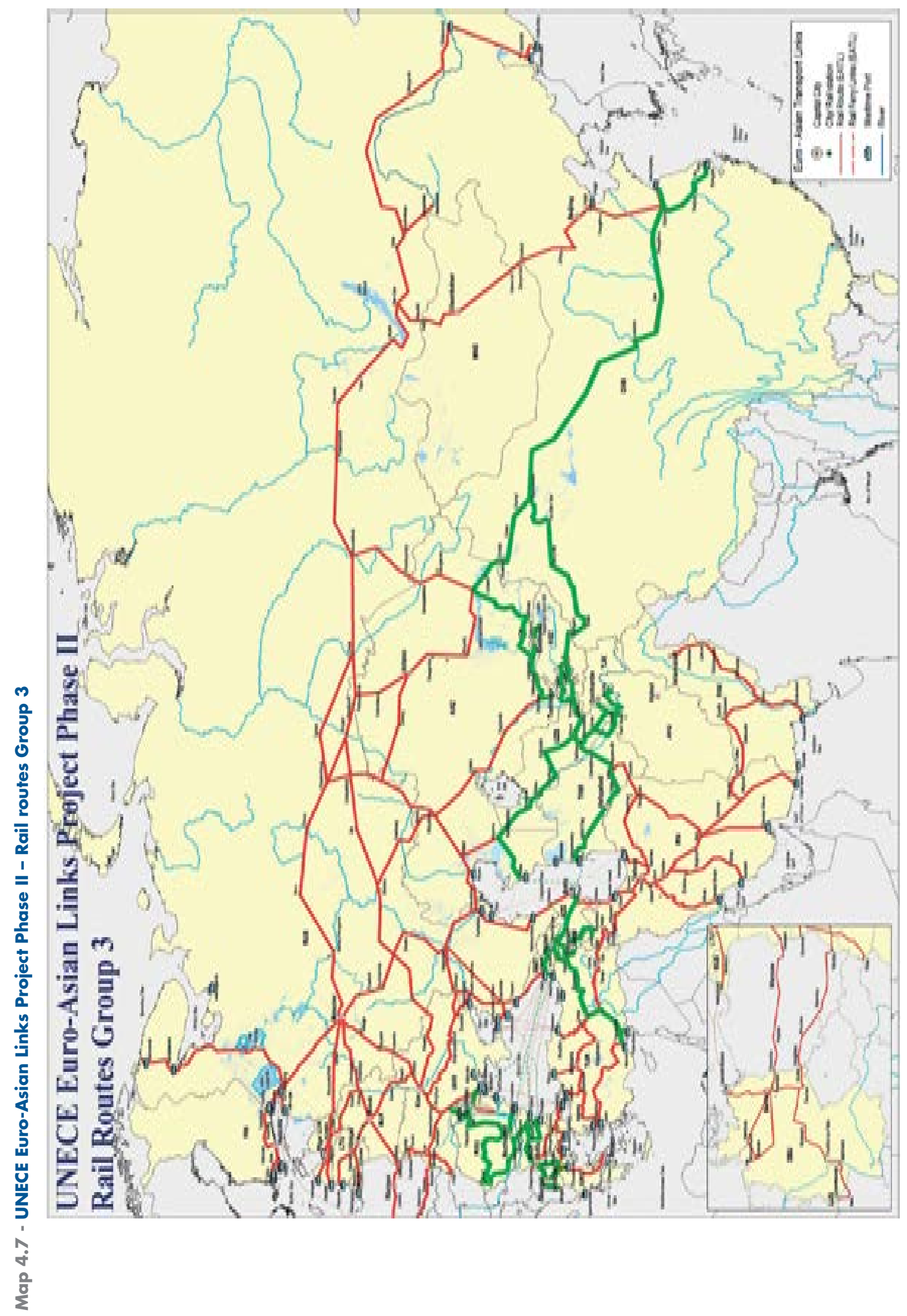




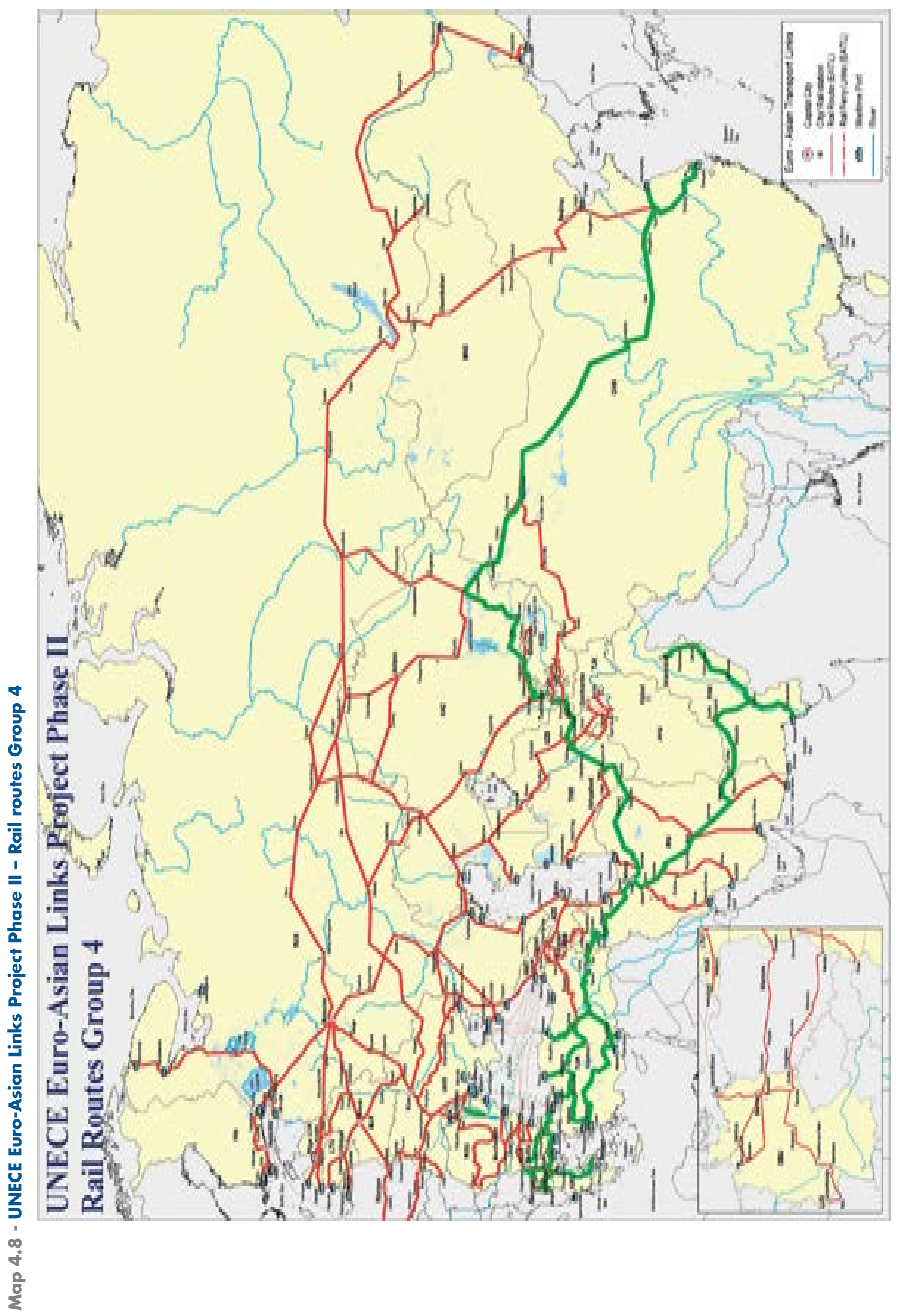




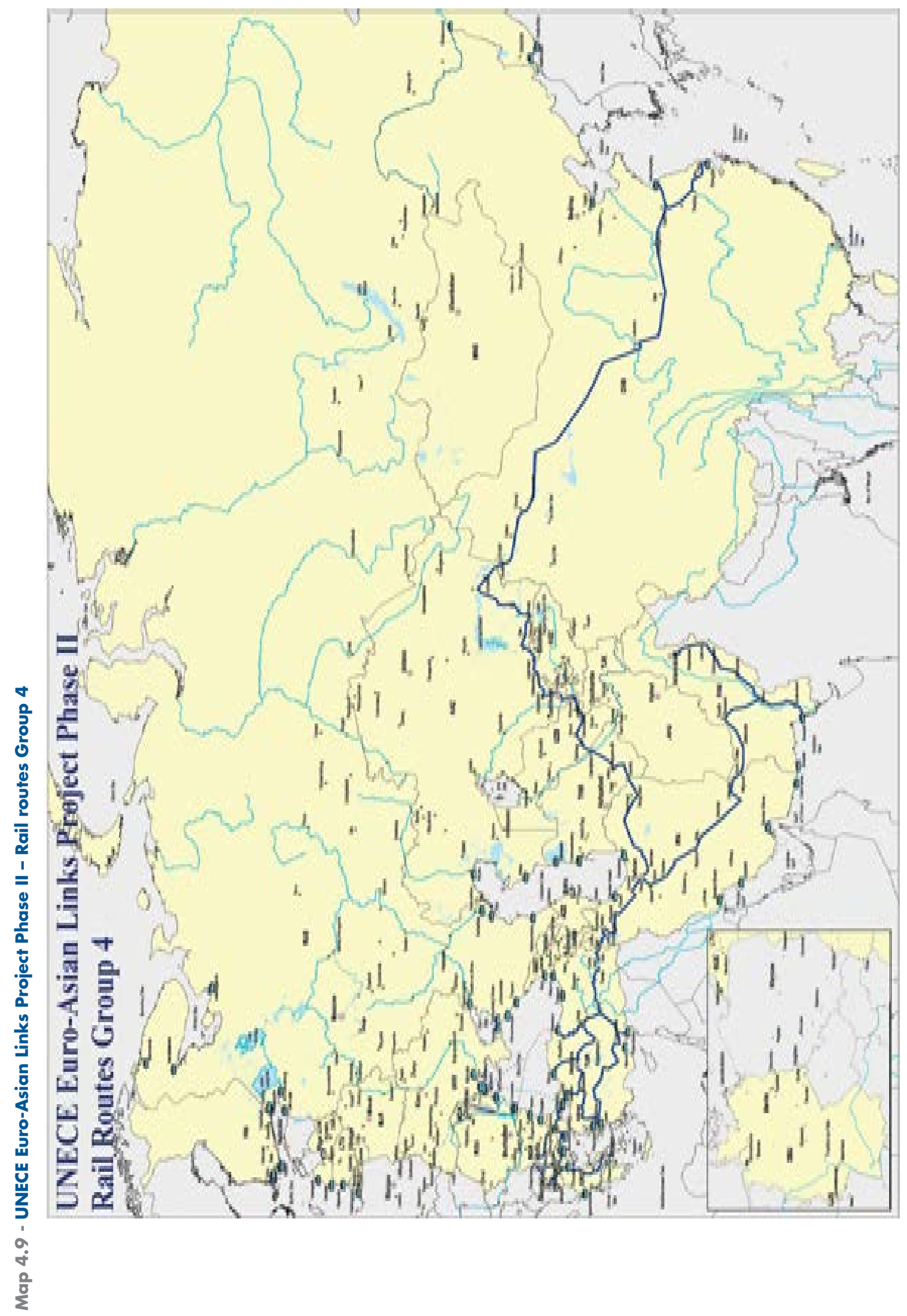




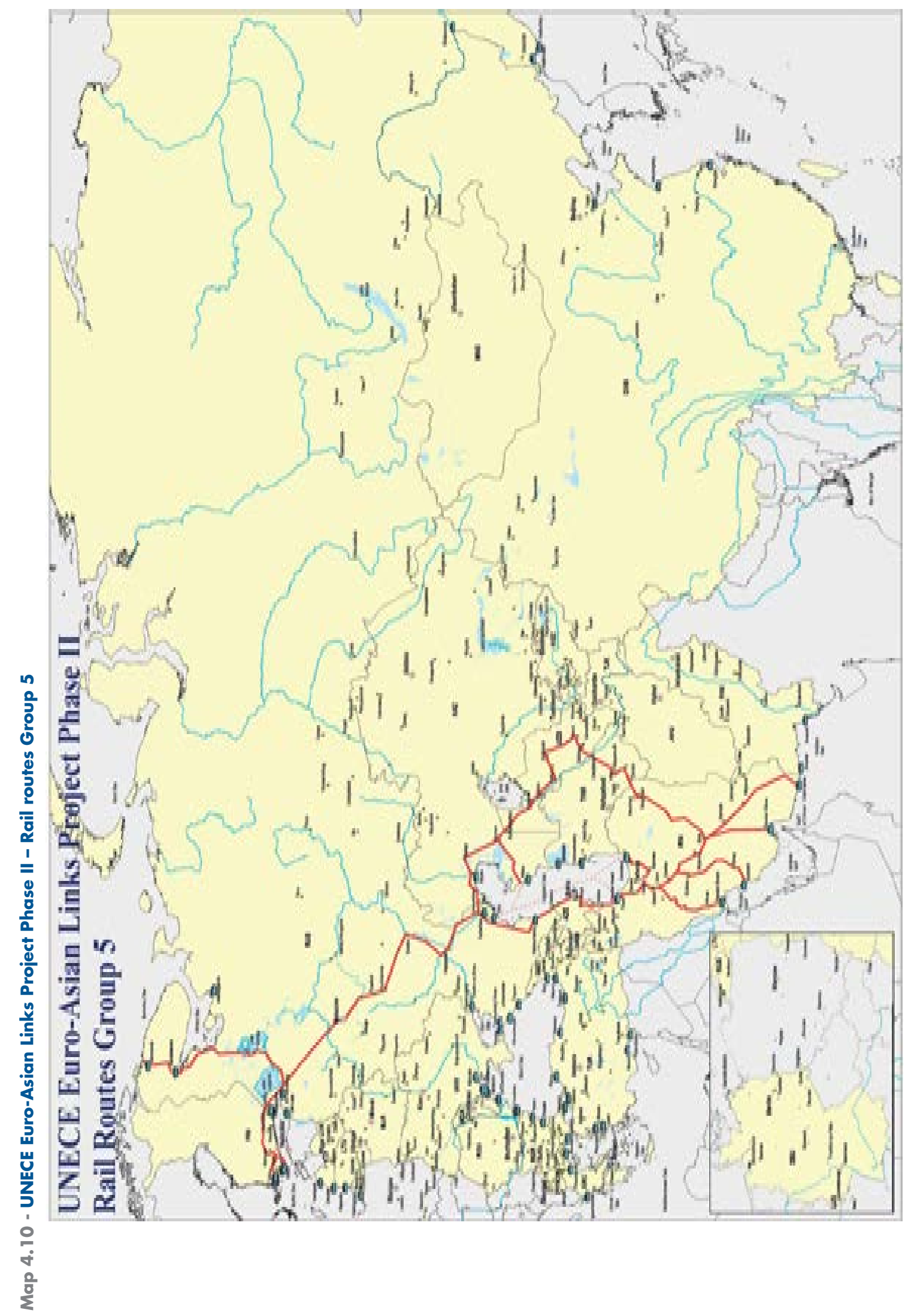




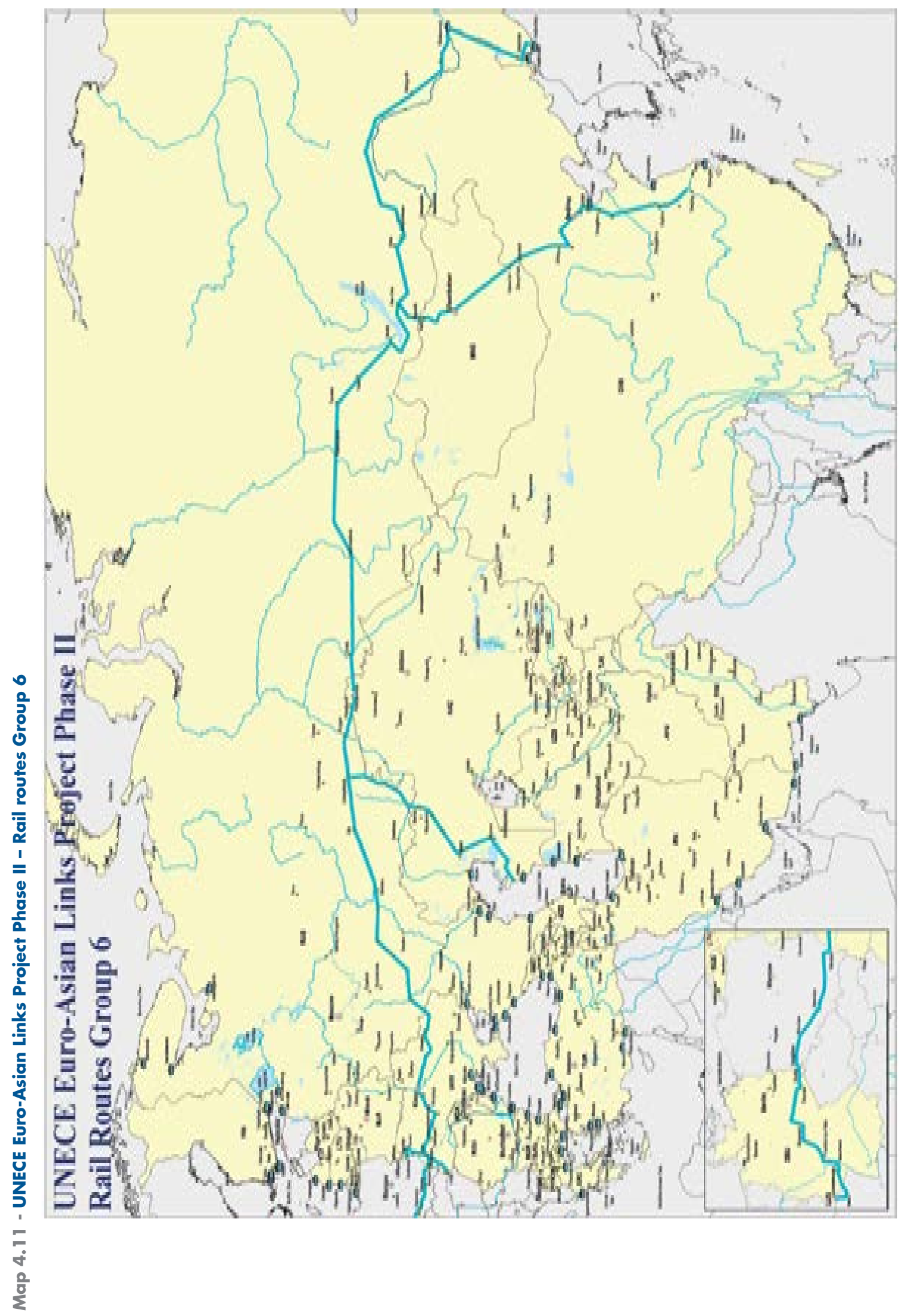




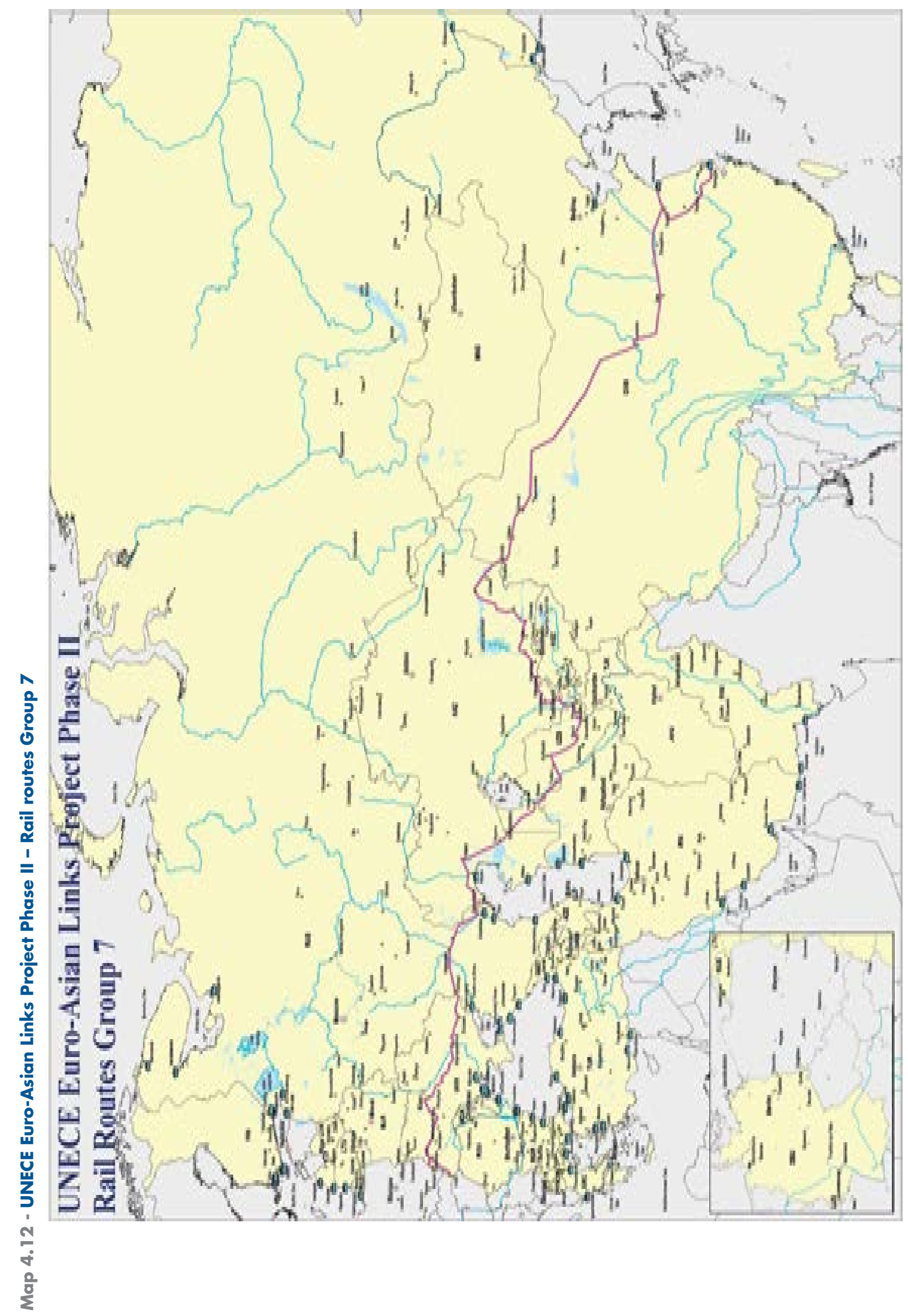




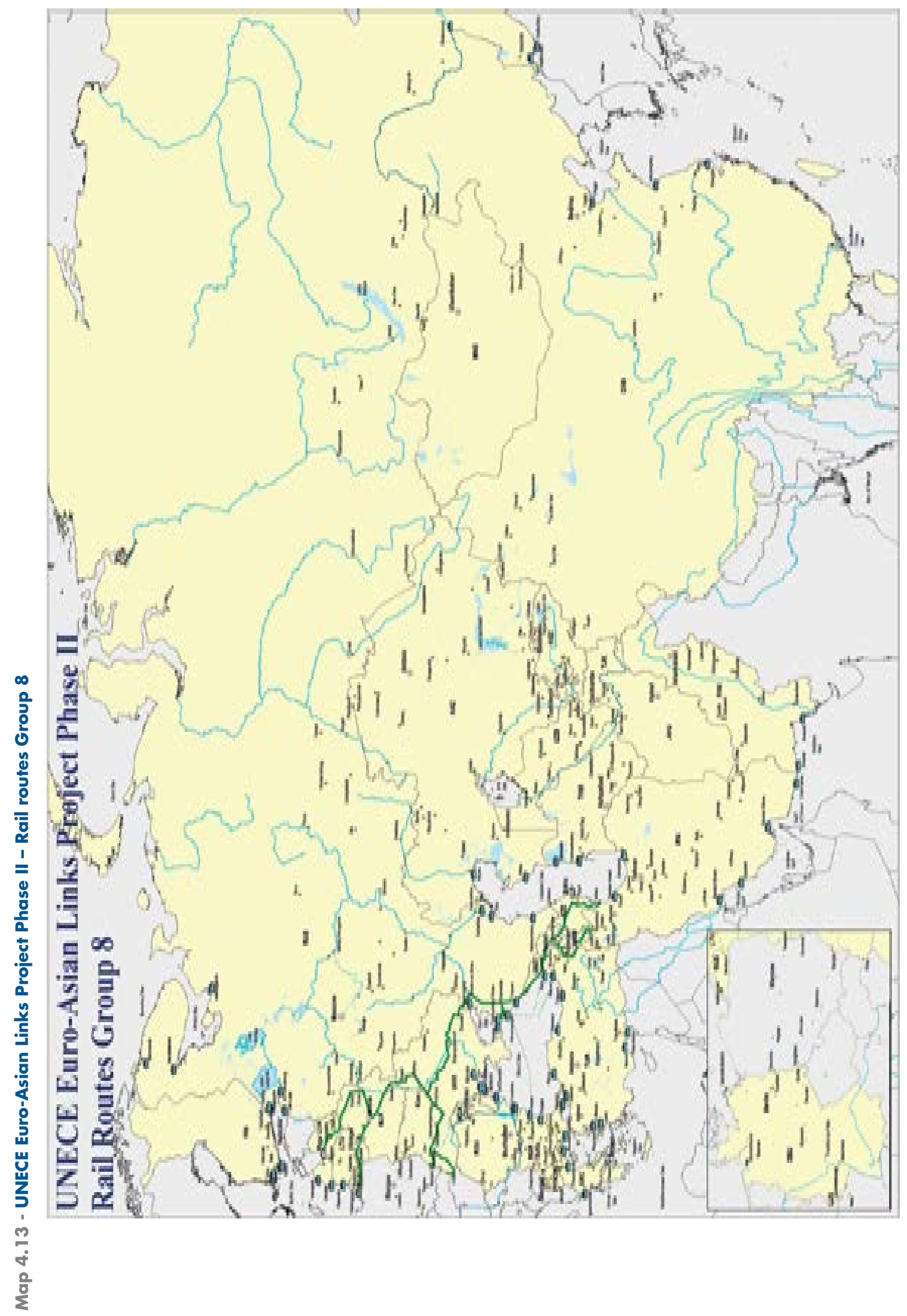




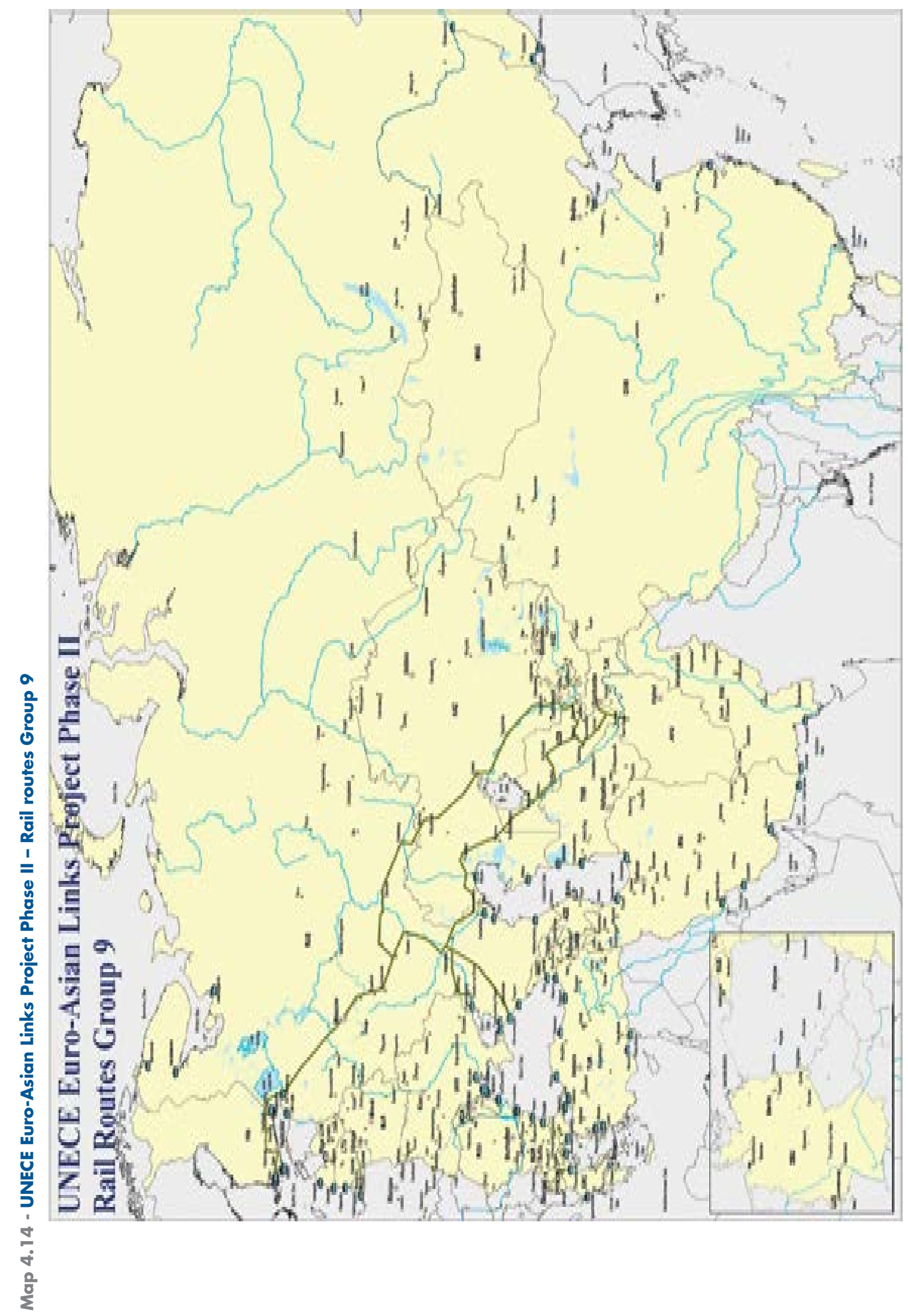


4.1.32 Presentation of interregional maps - ROADS

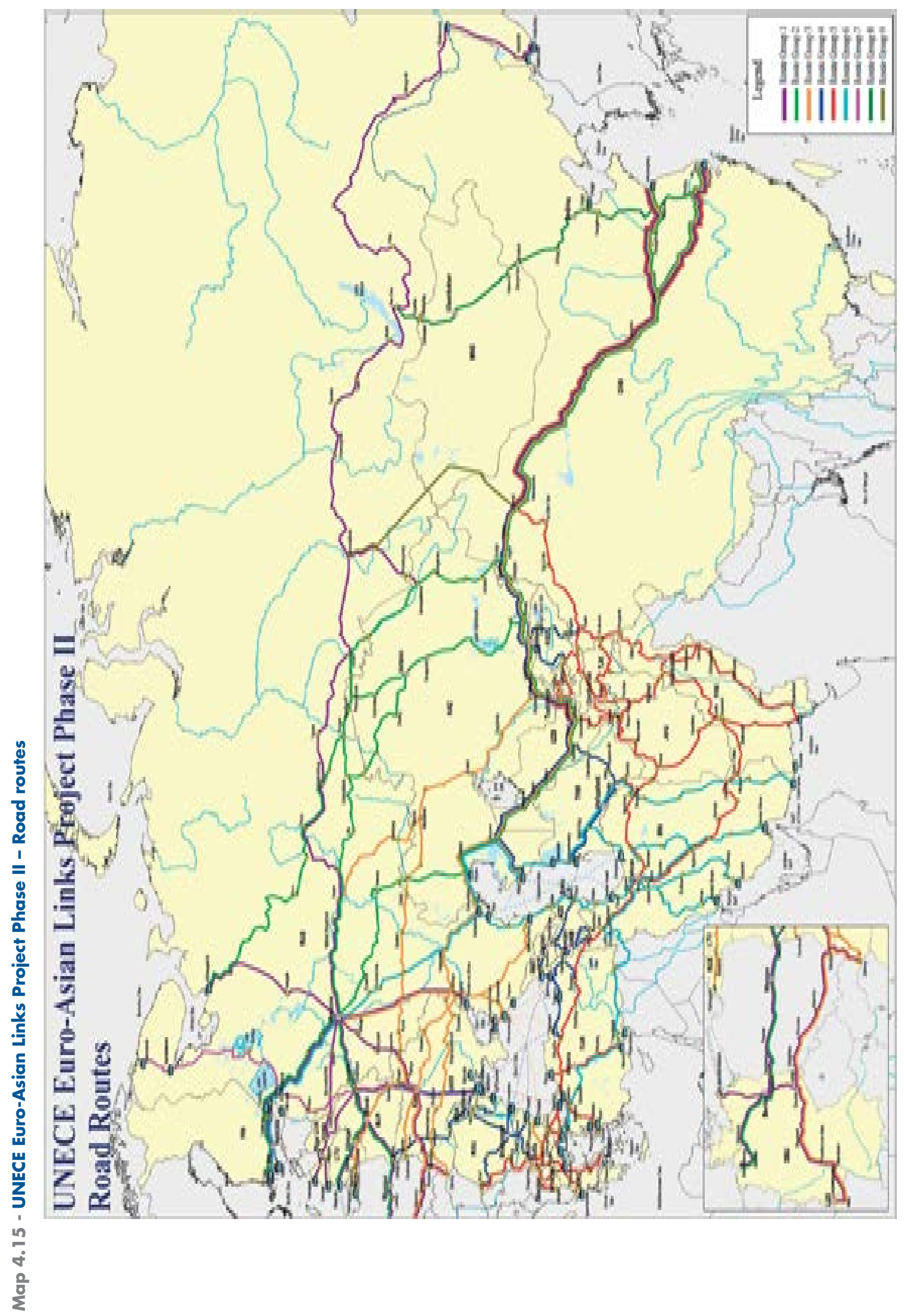




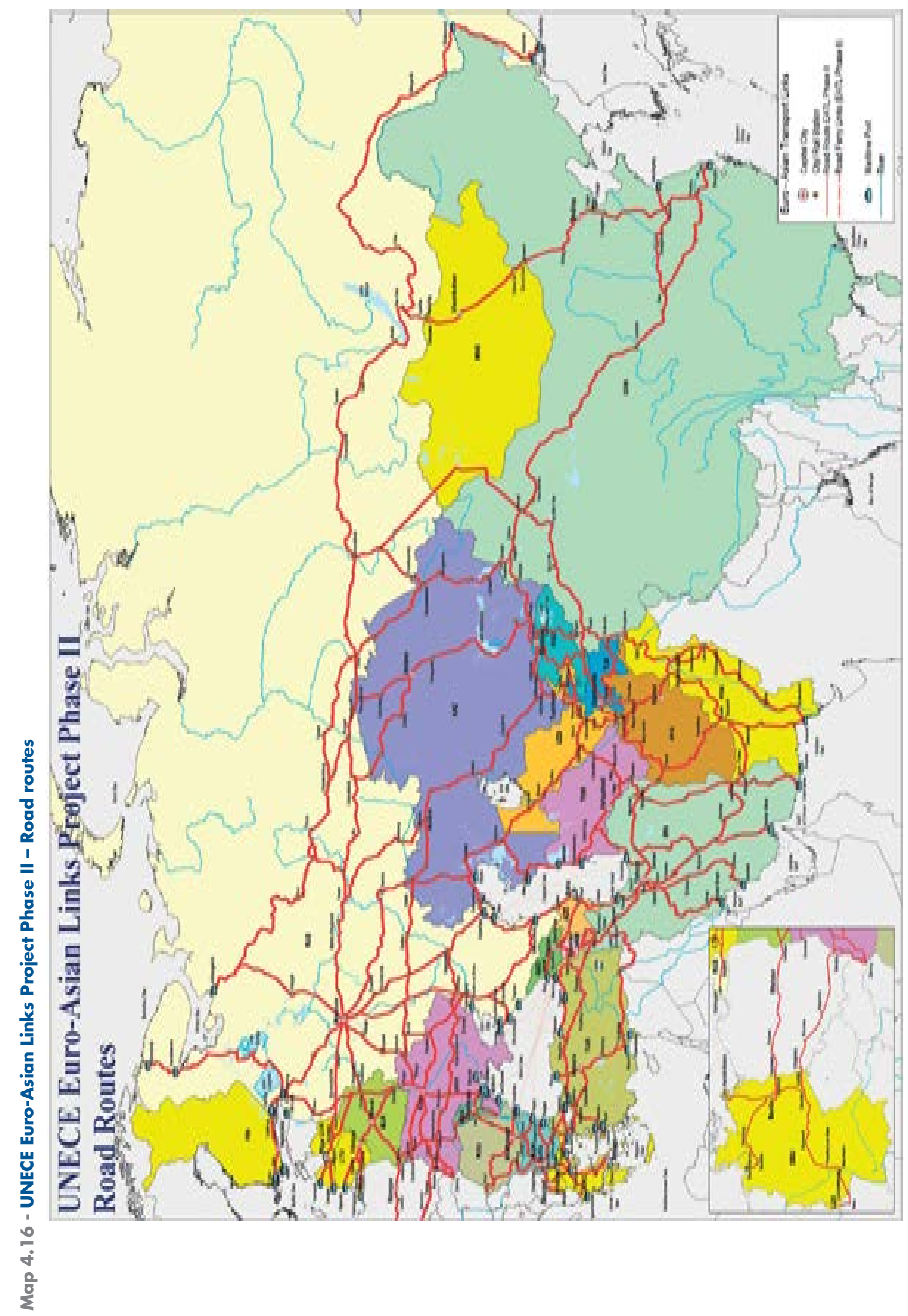




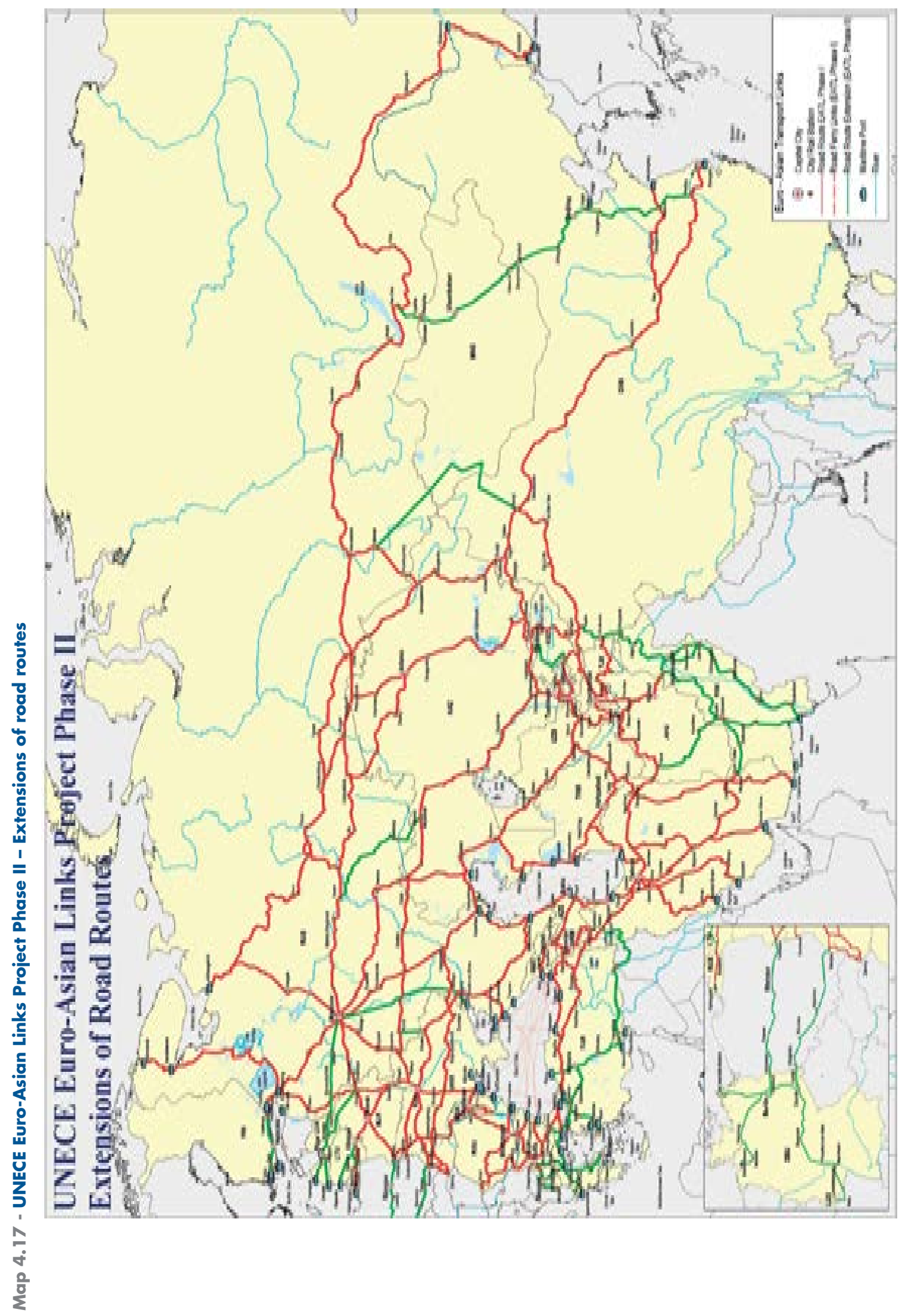




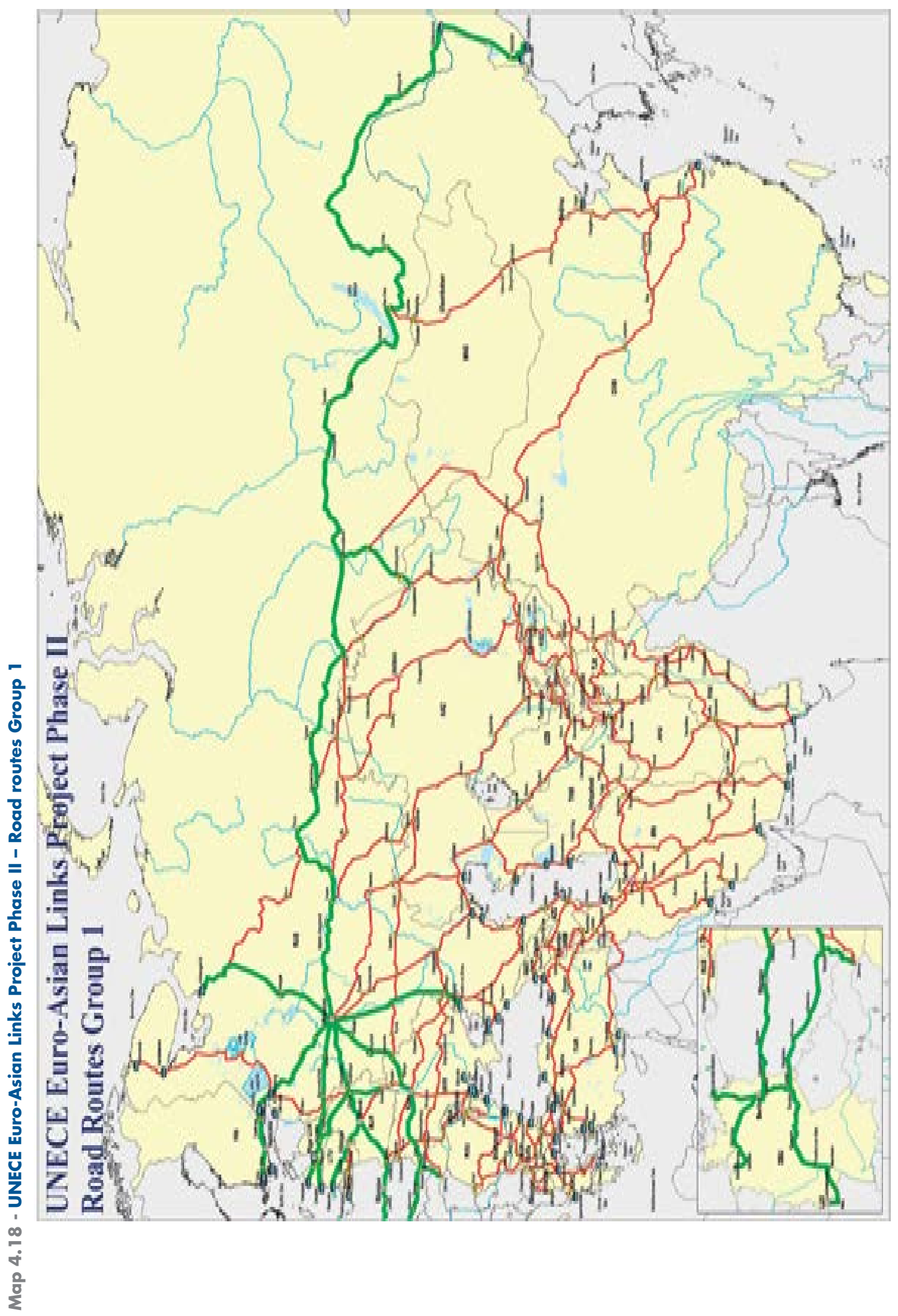




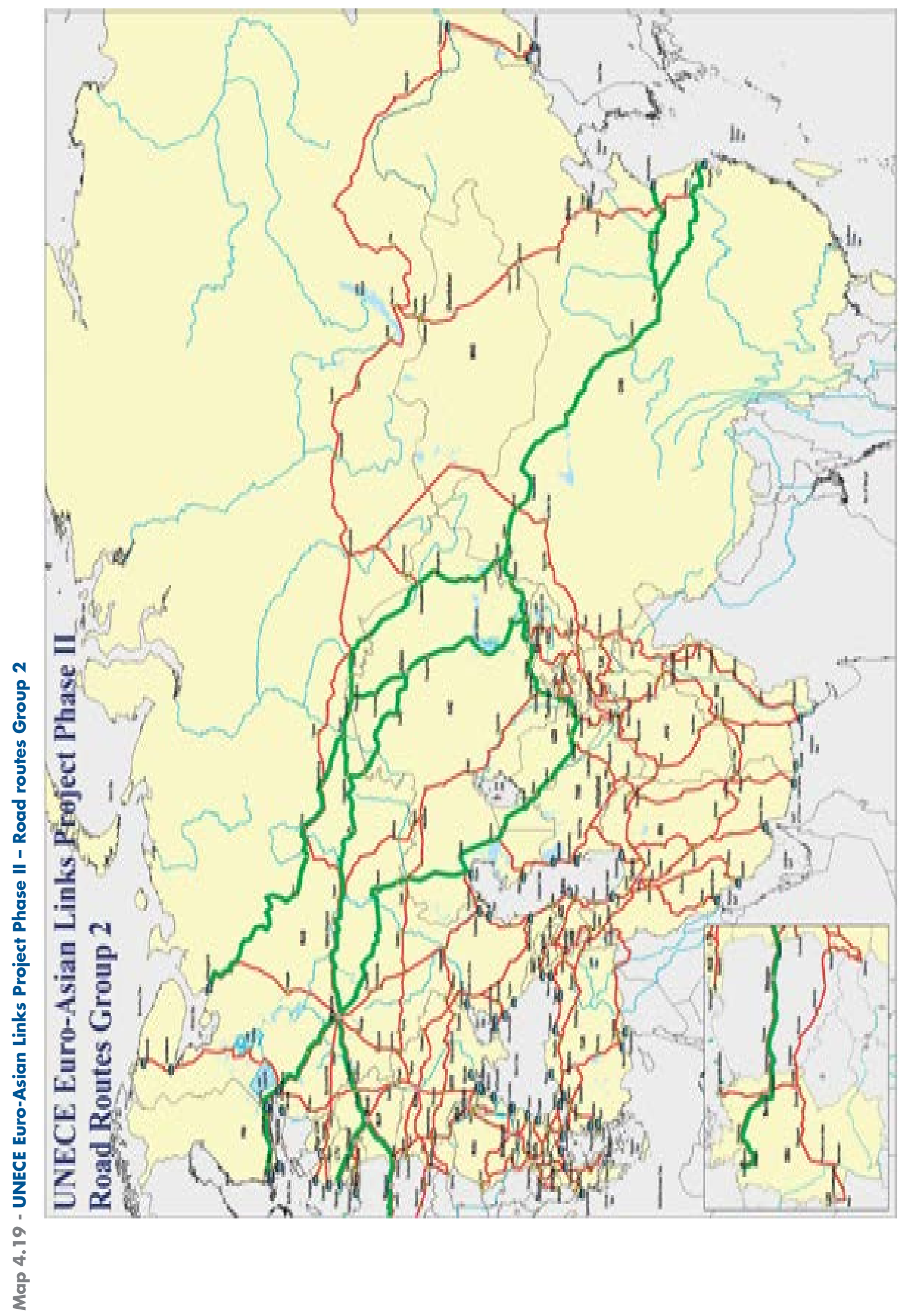




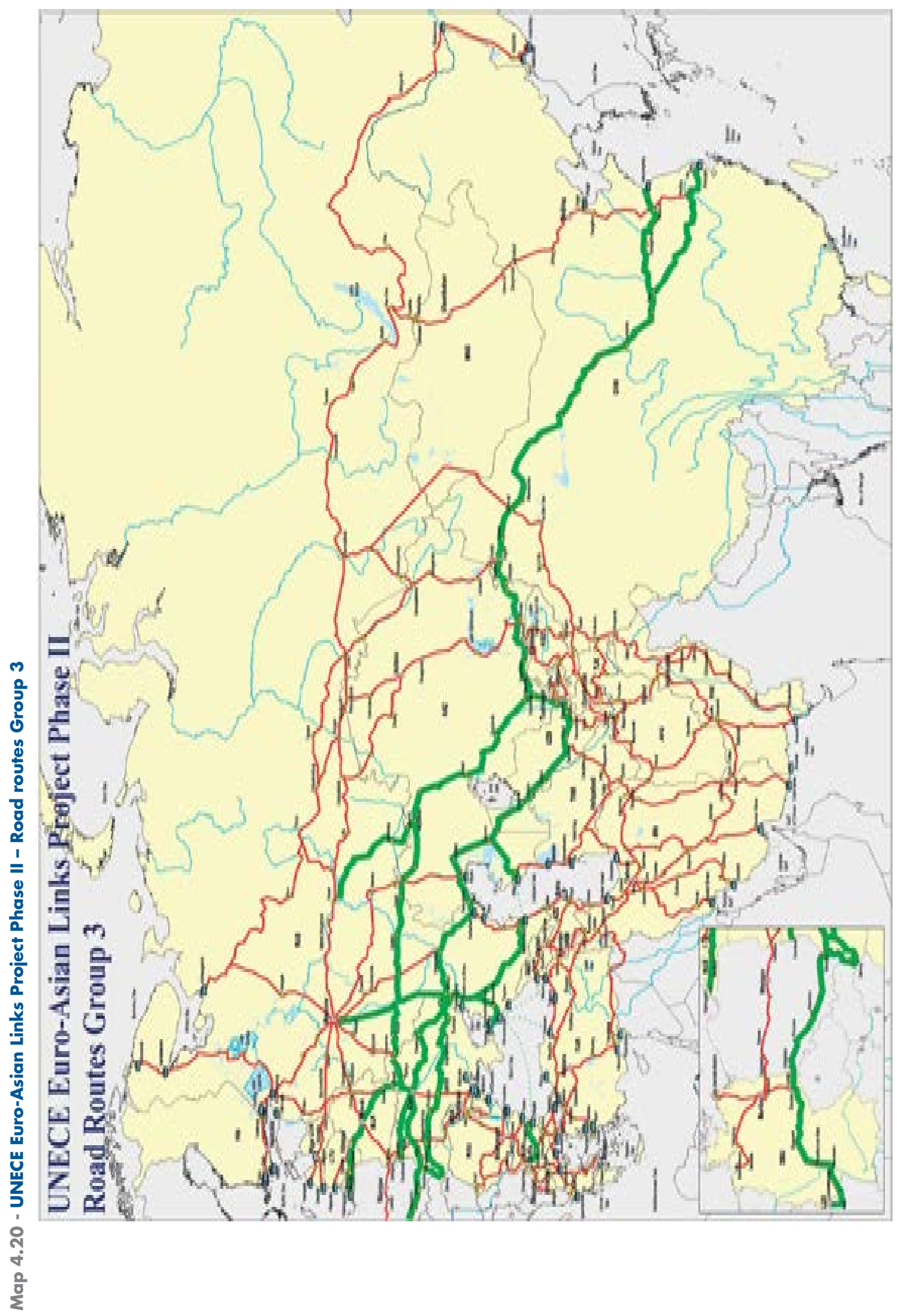




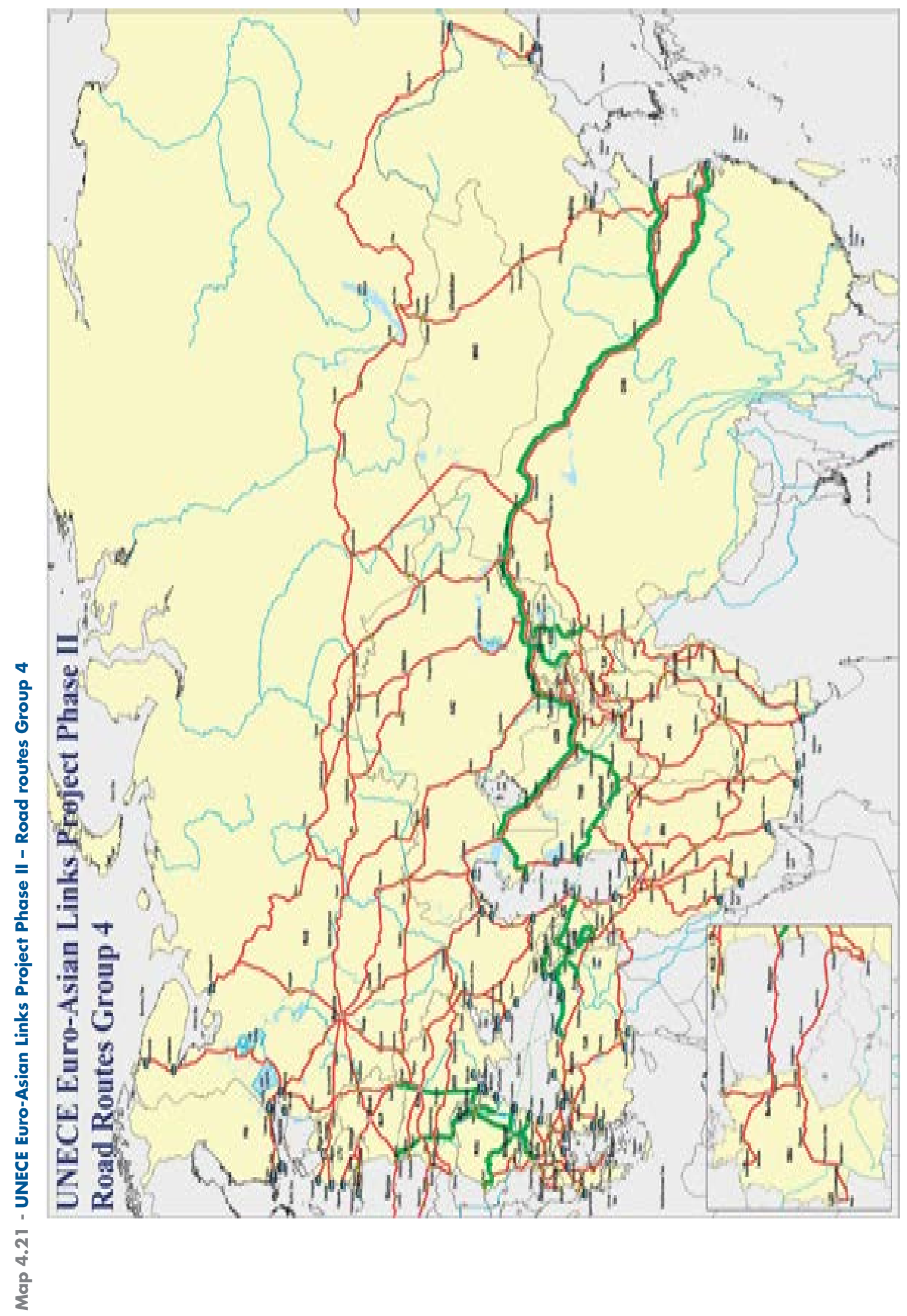




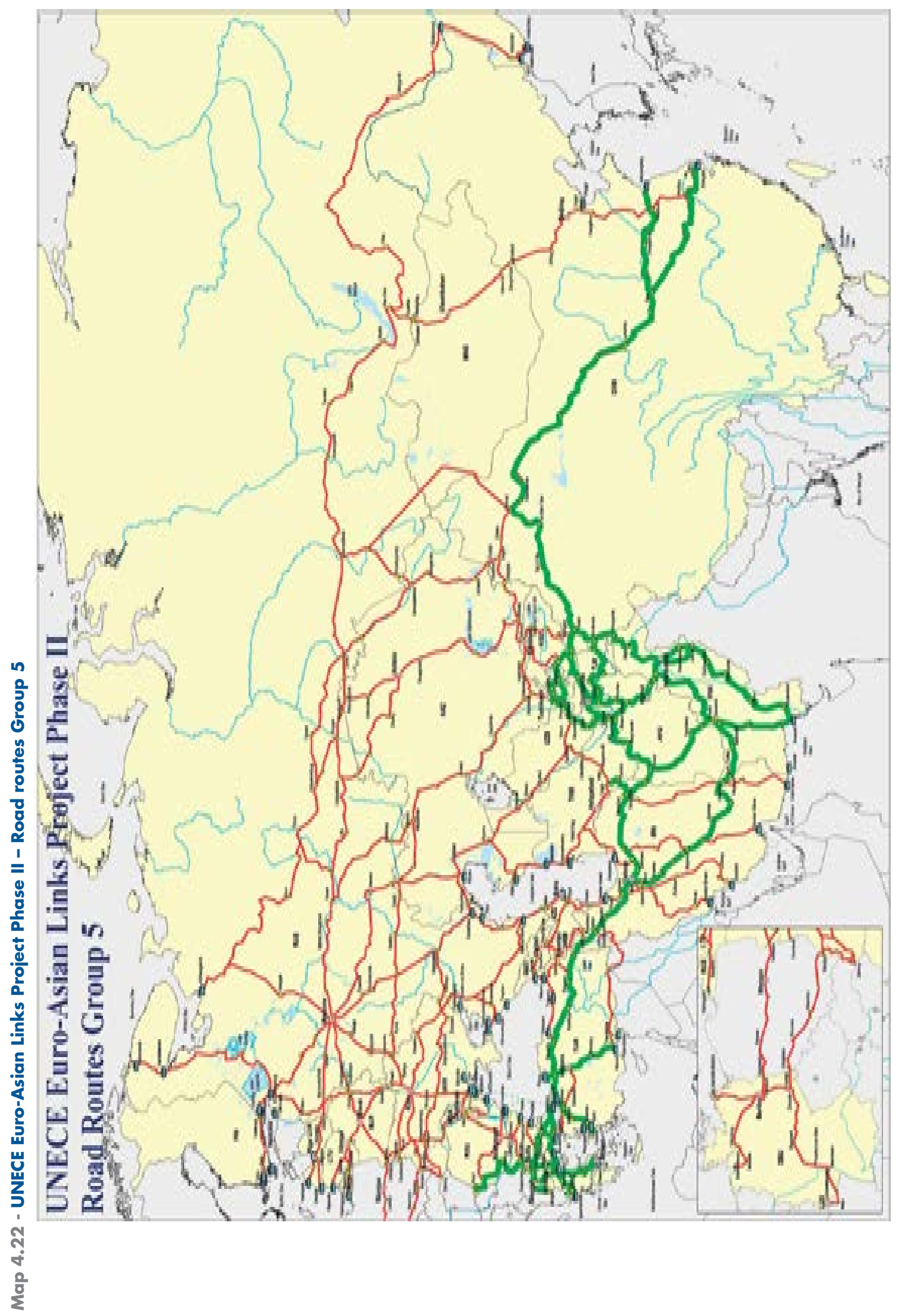




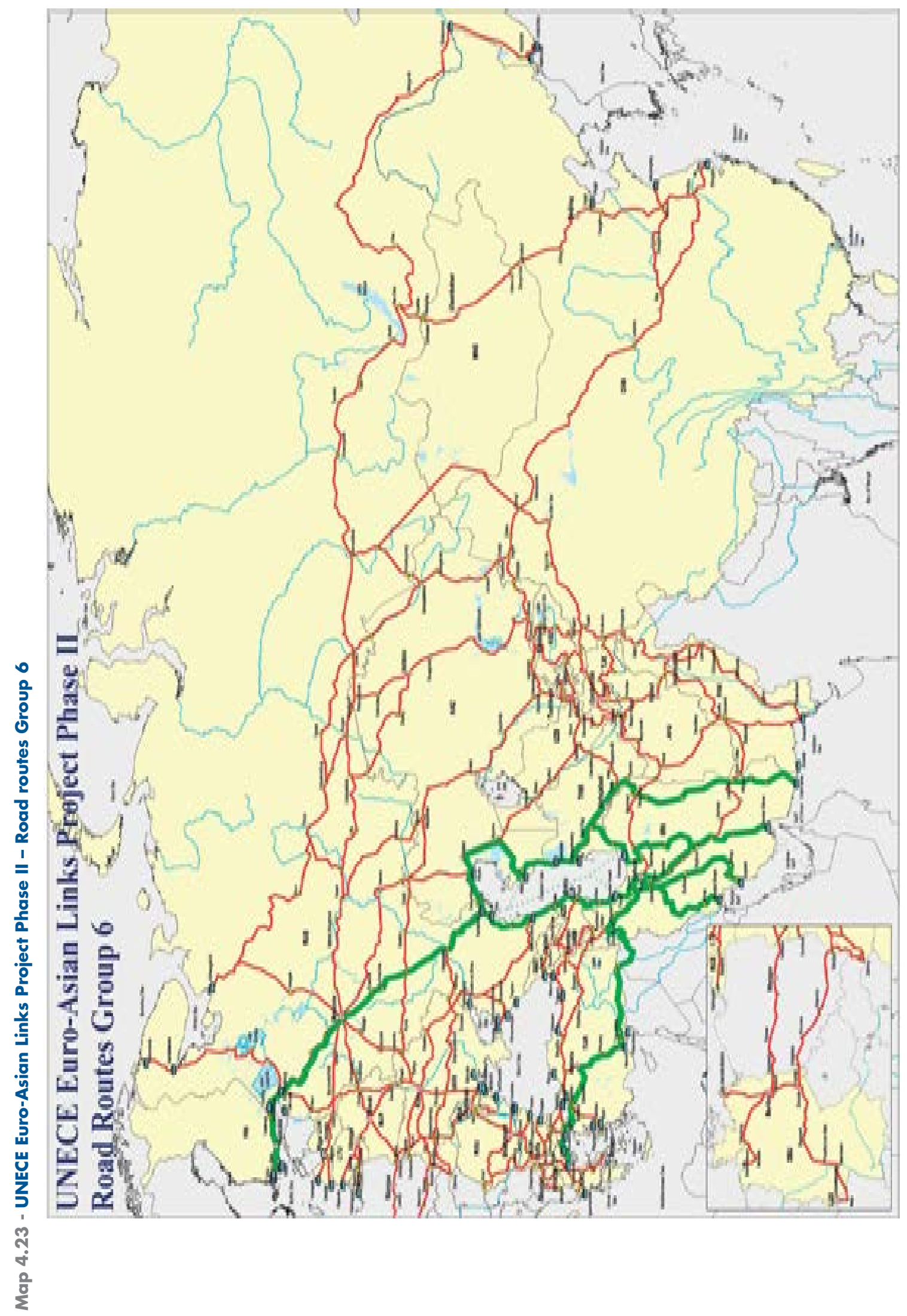




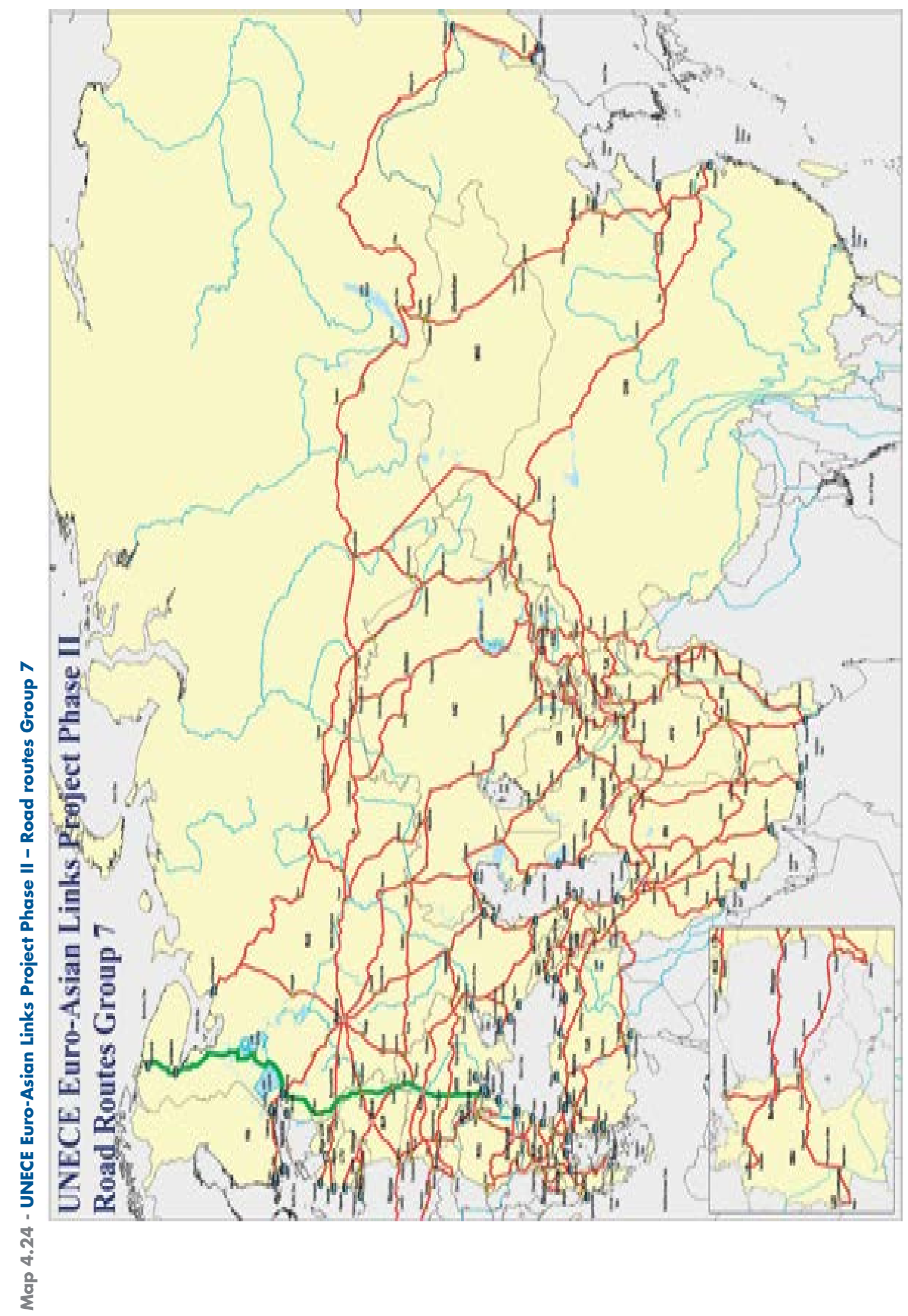




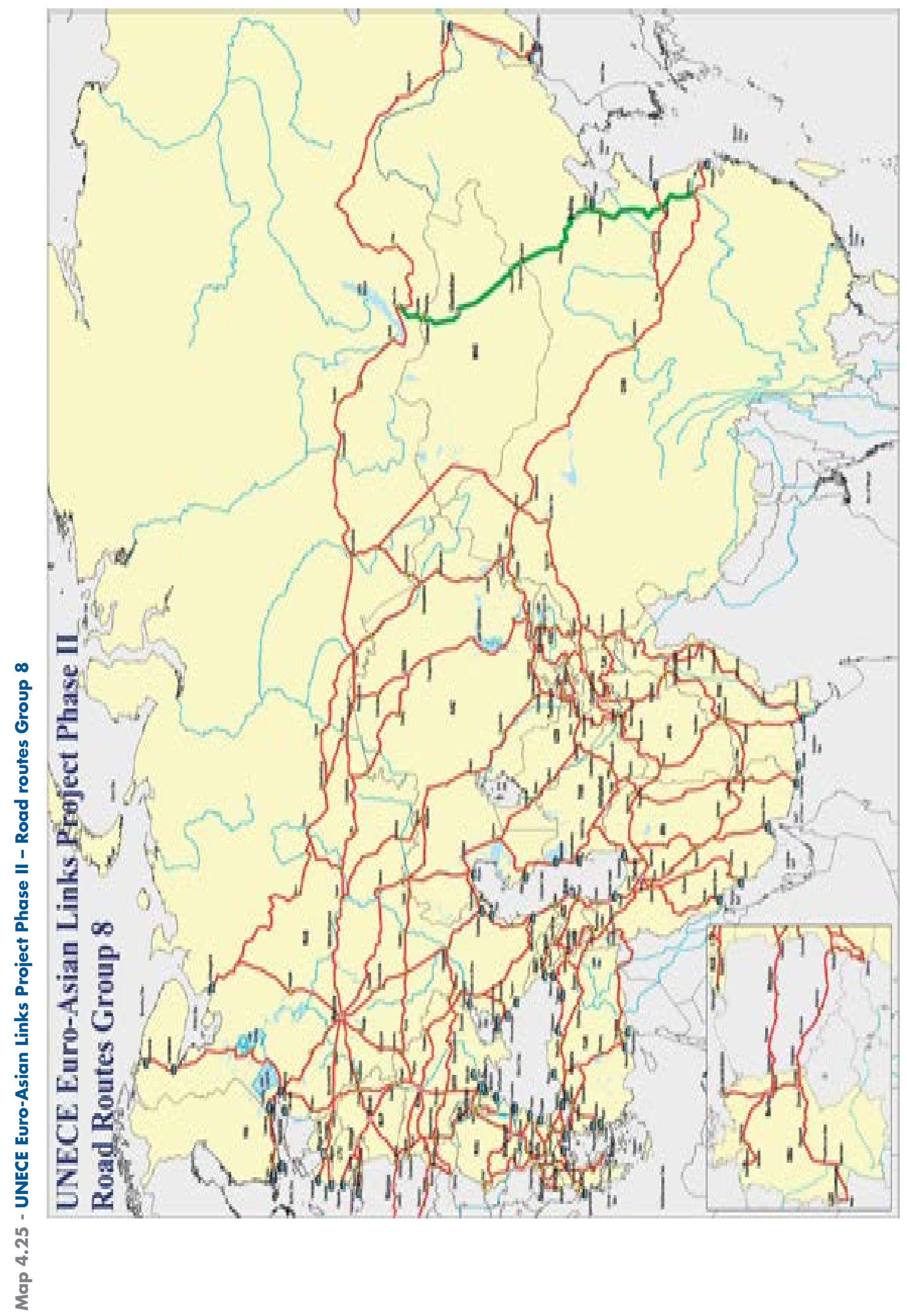




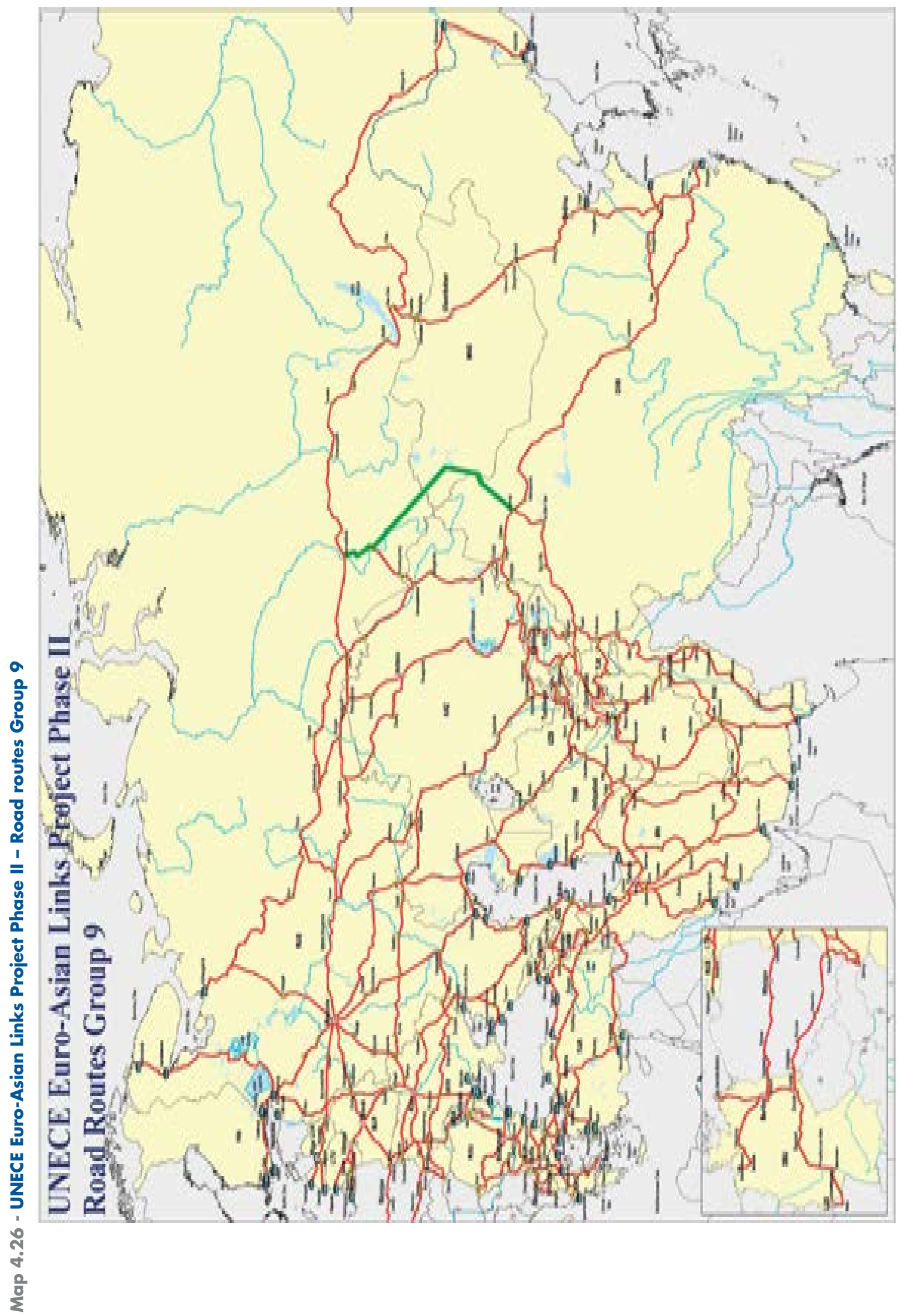


4.1.33 Presentation of interregional maps - INLAND WATERWAYS AND PORTS

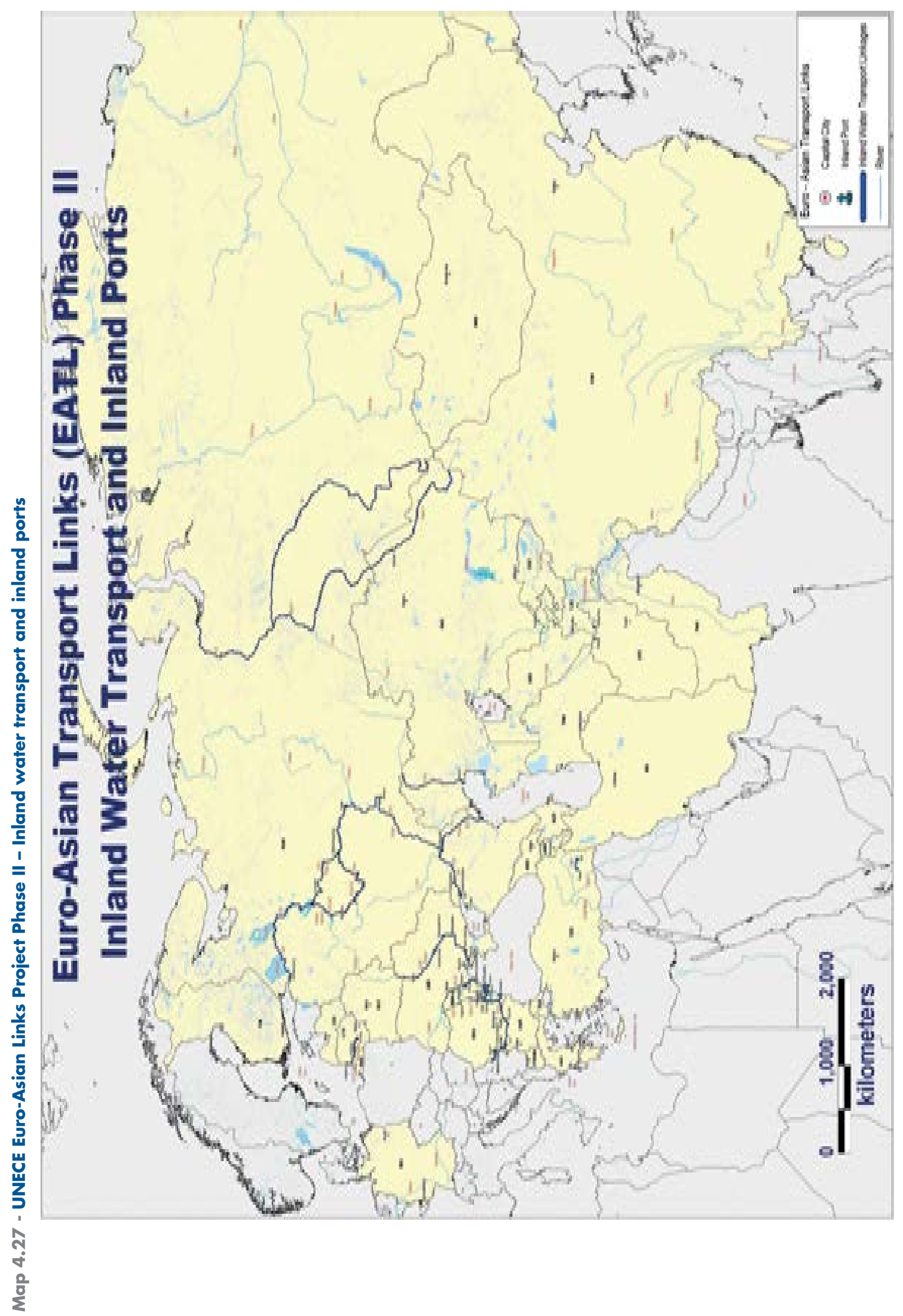




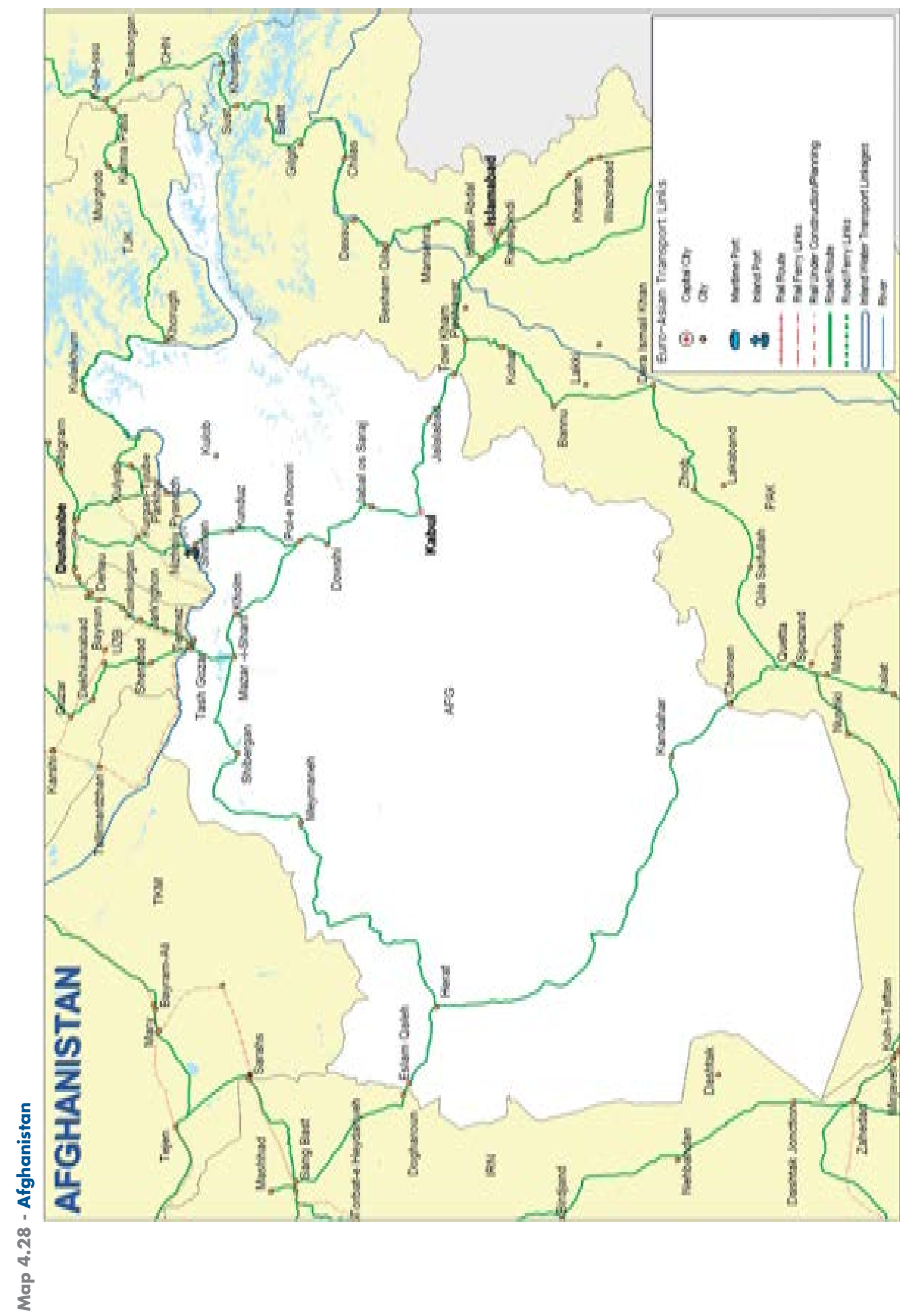




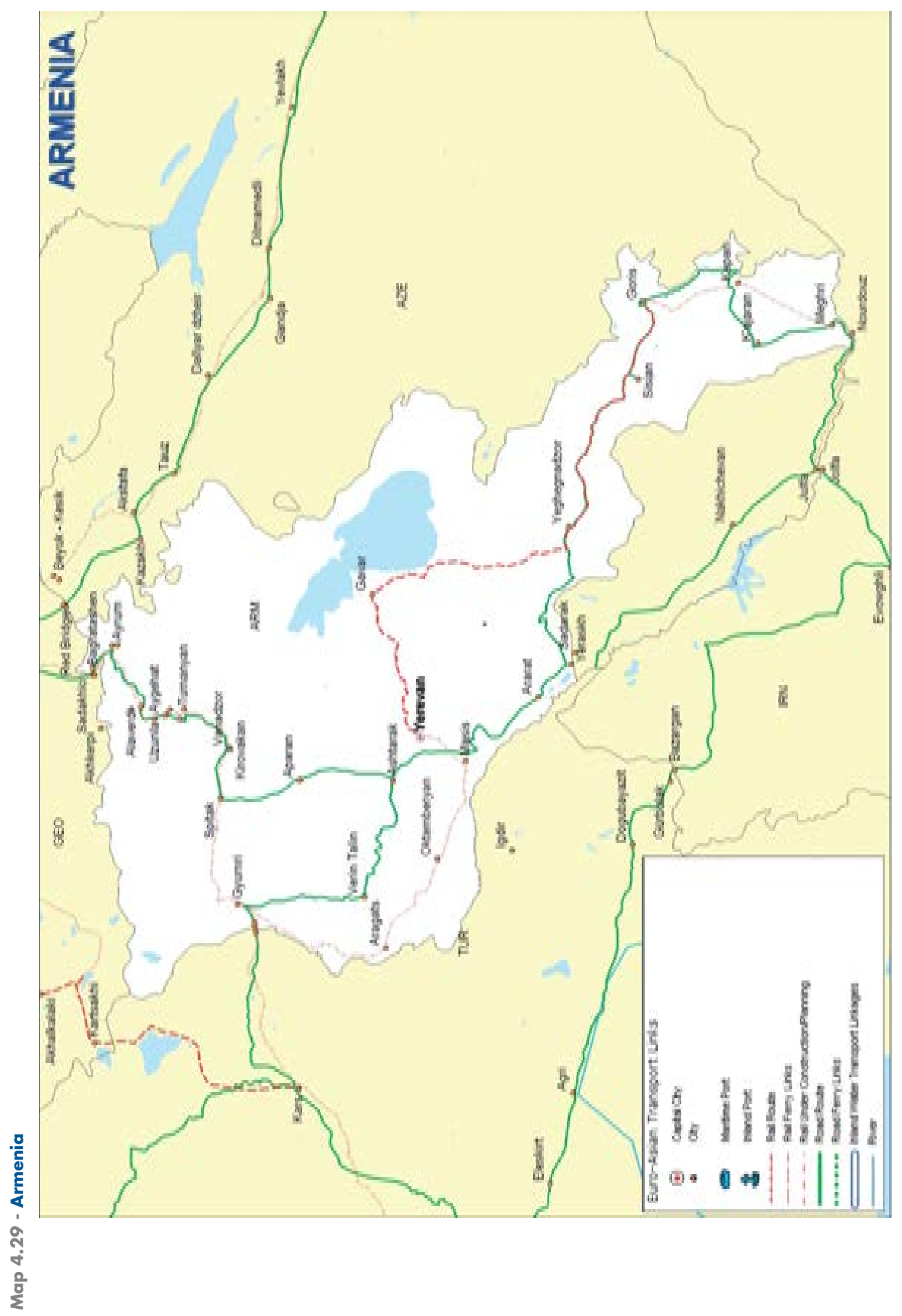




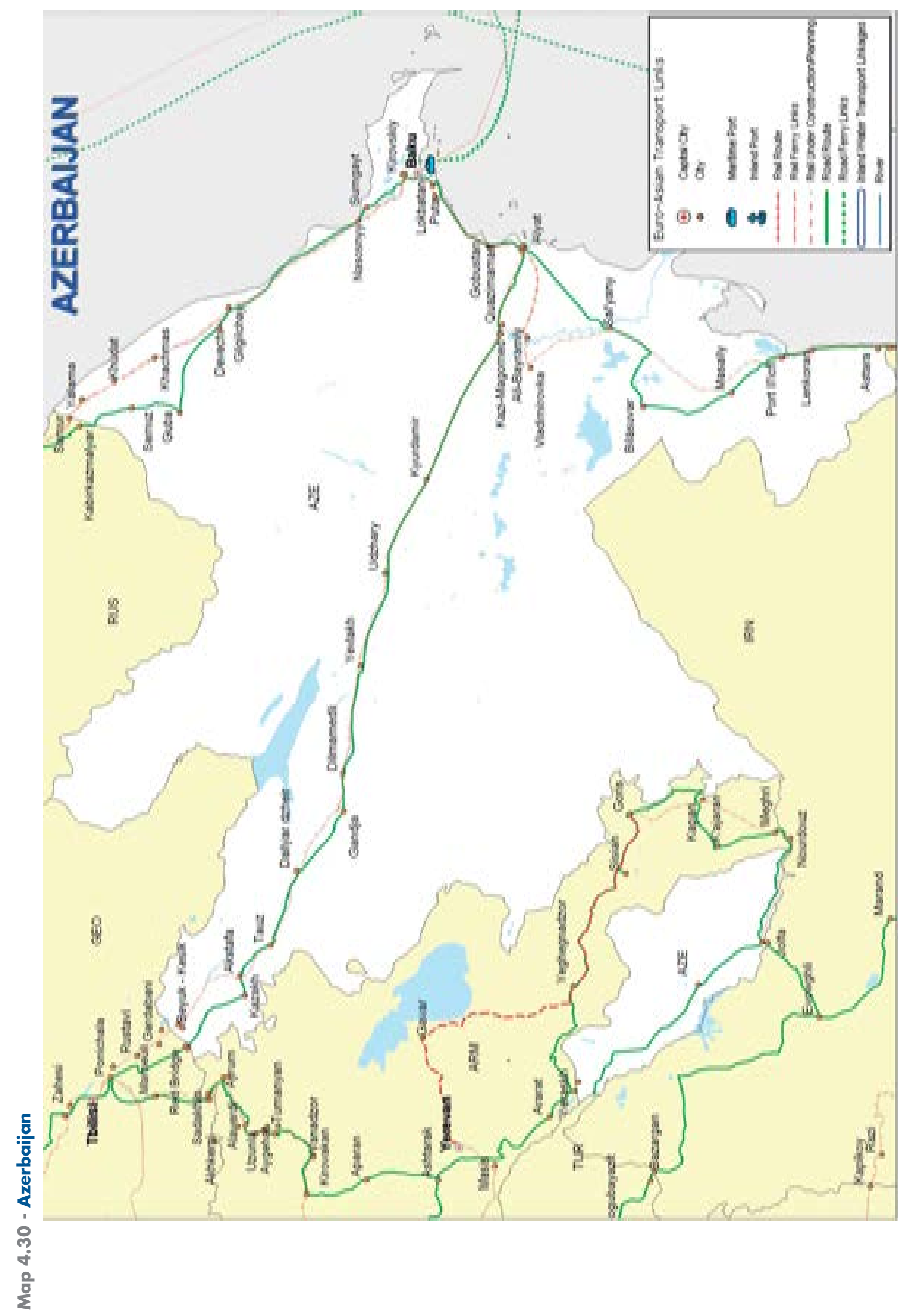




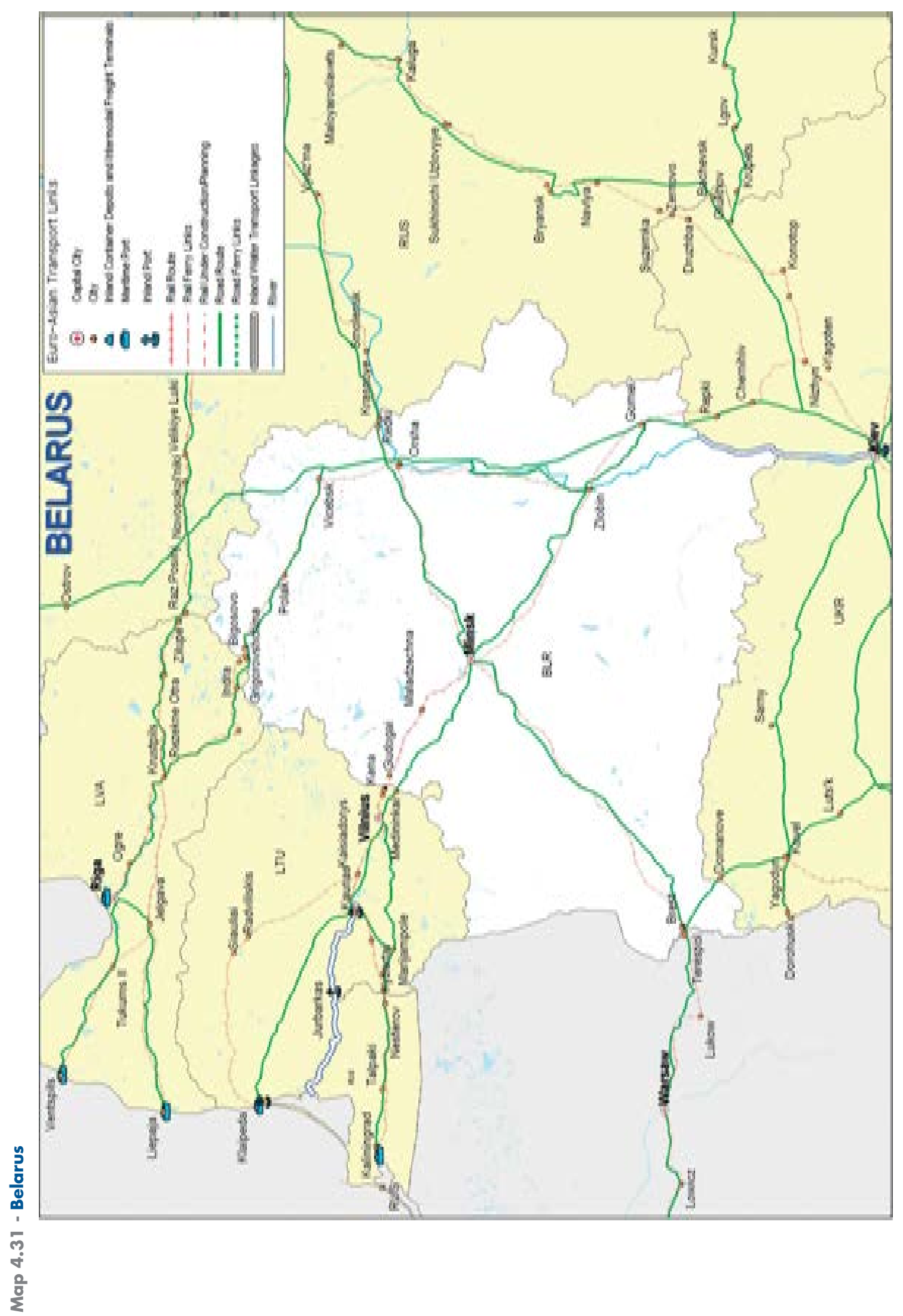




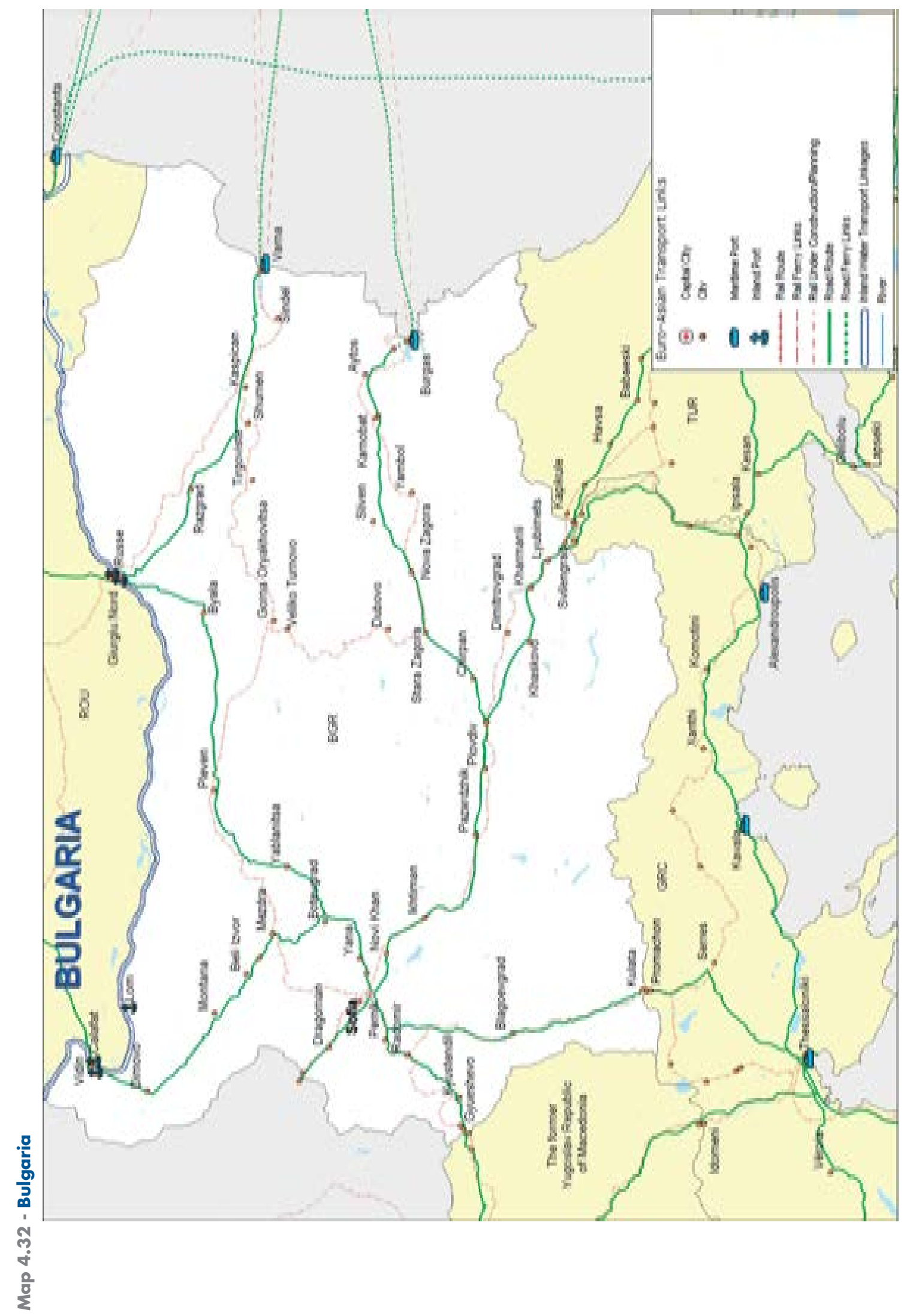




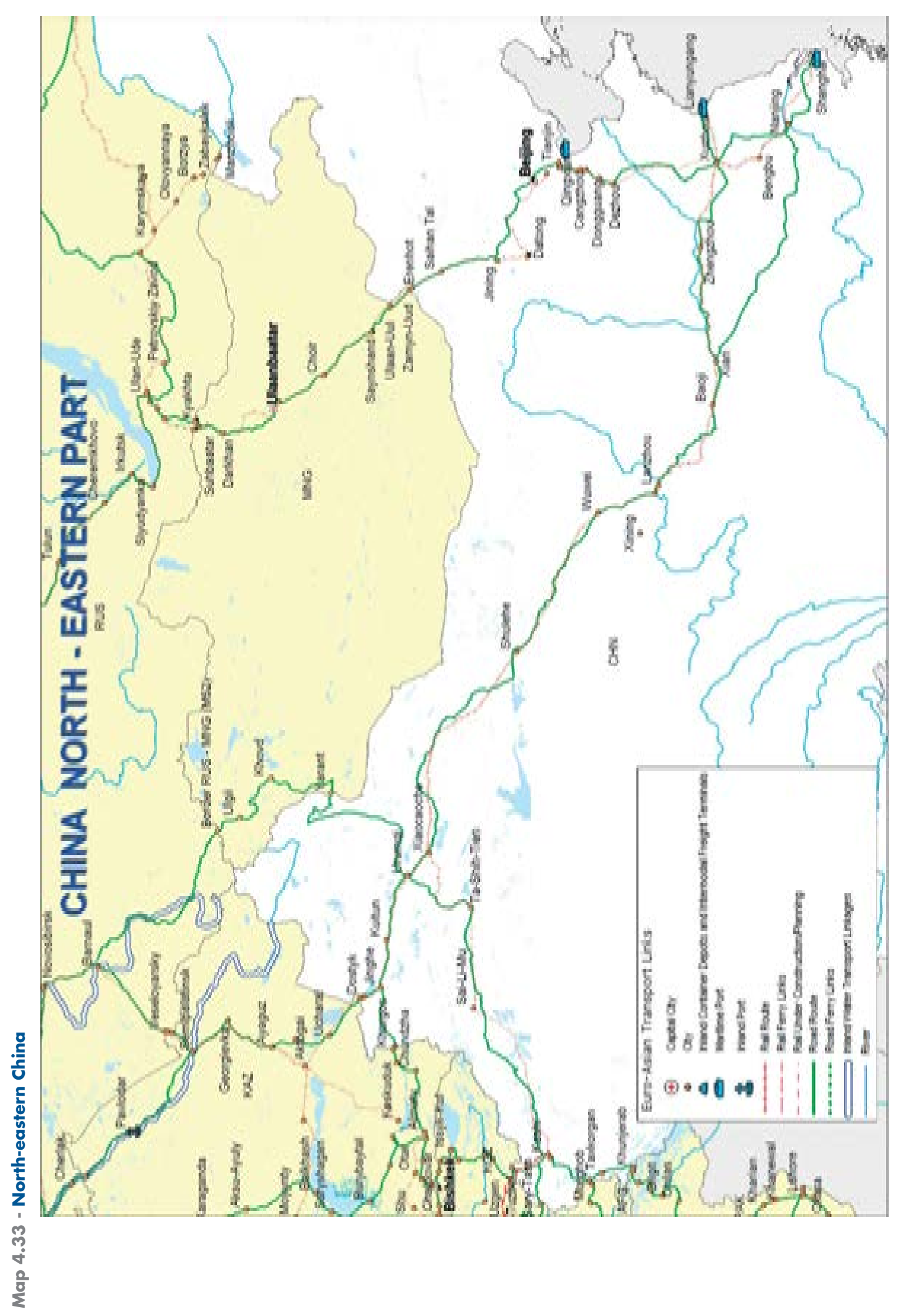




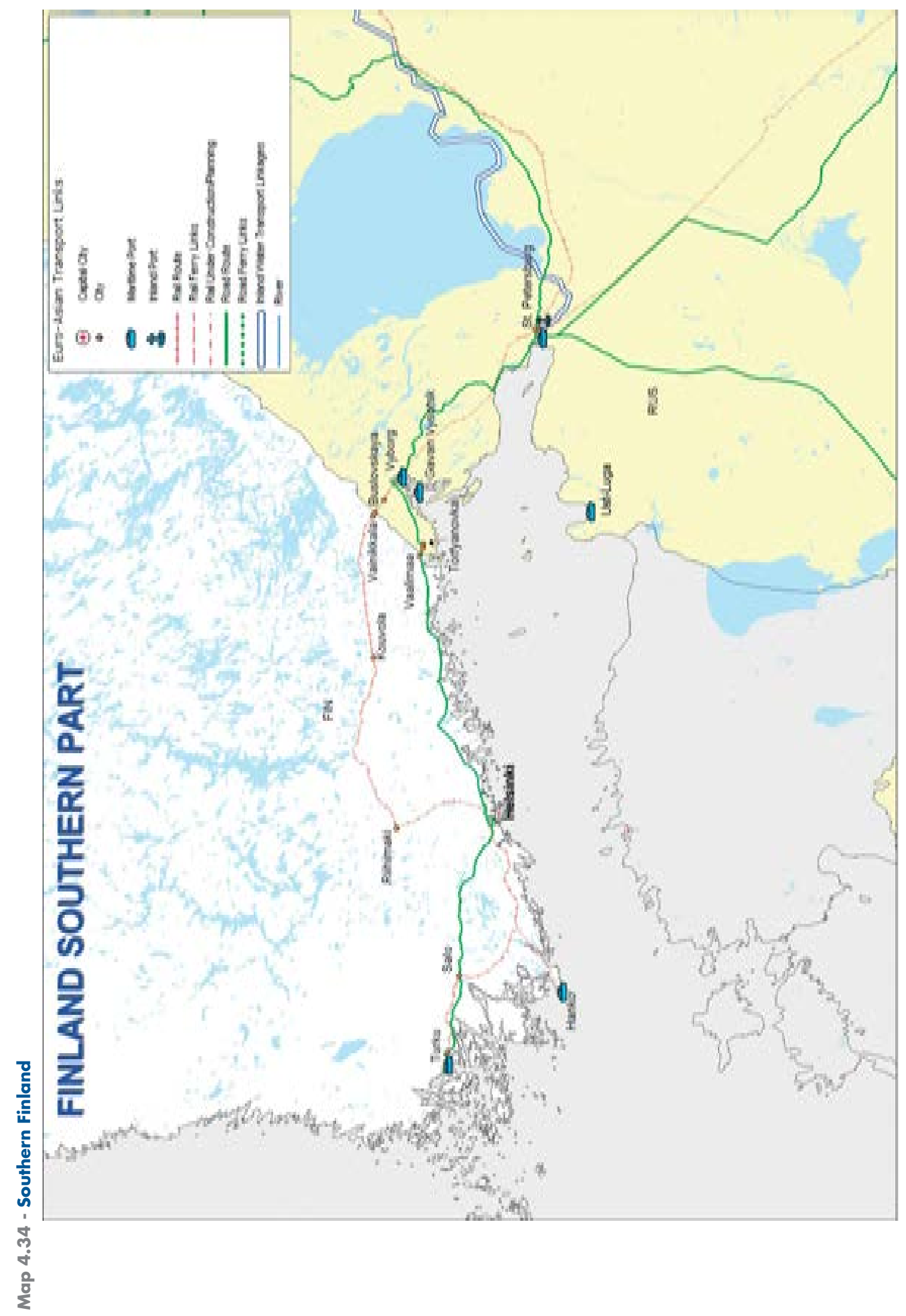




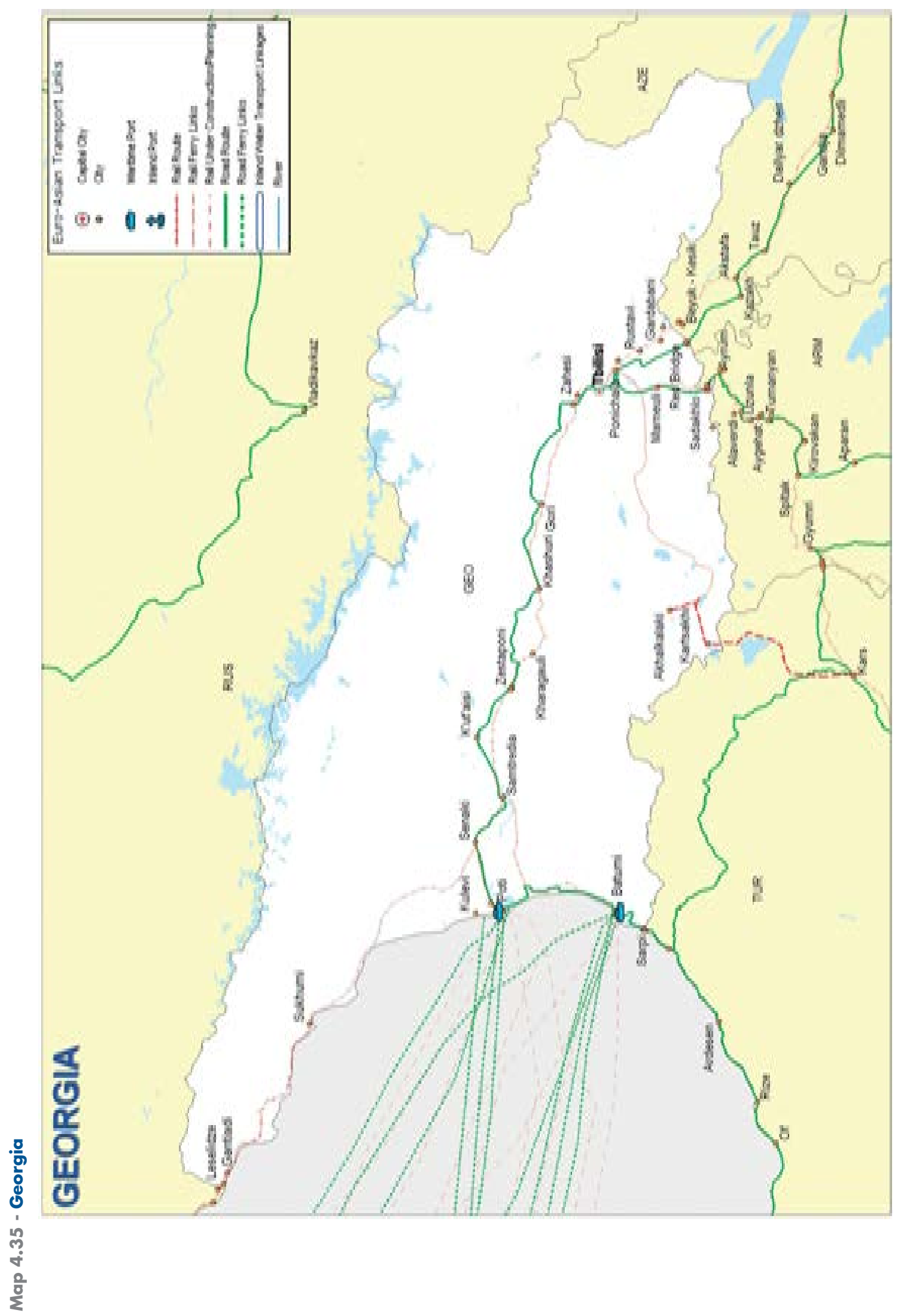




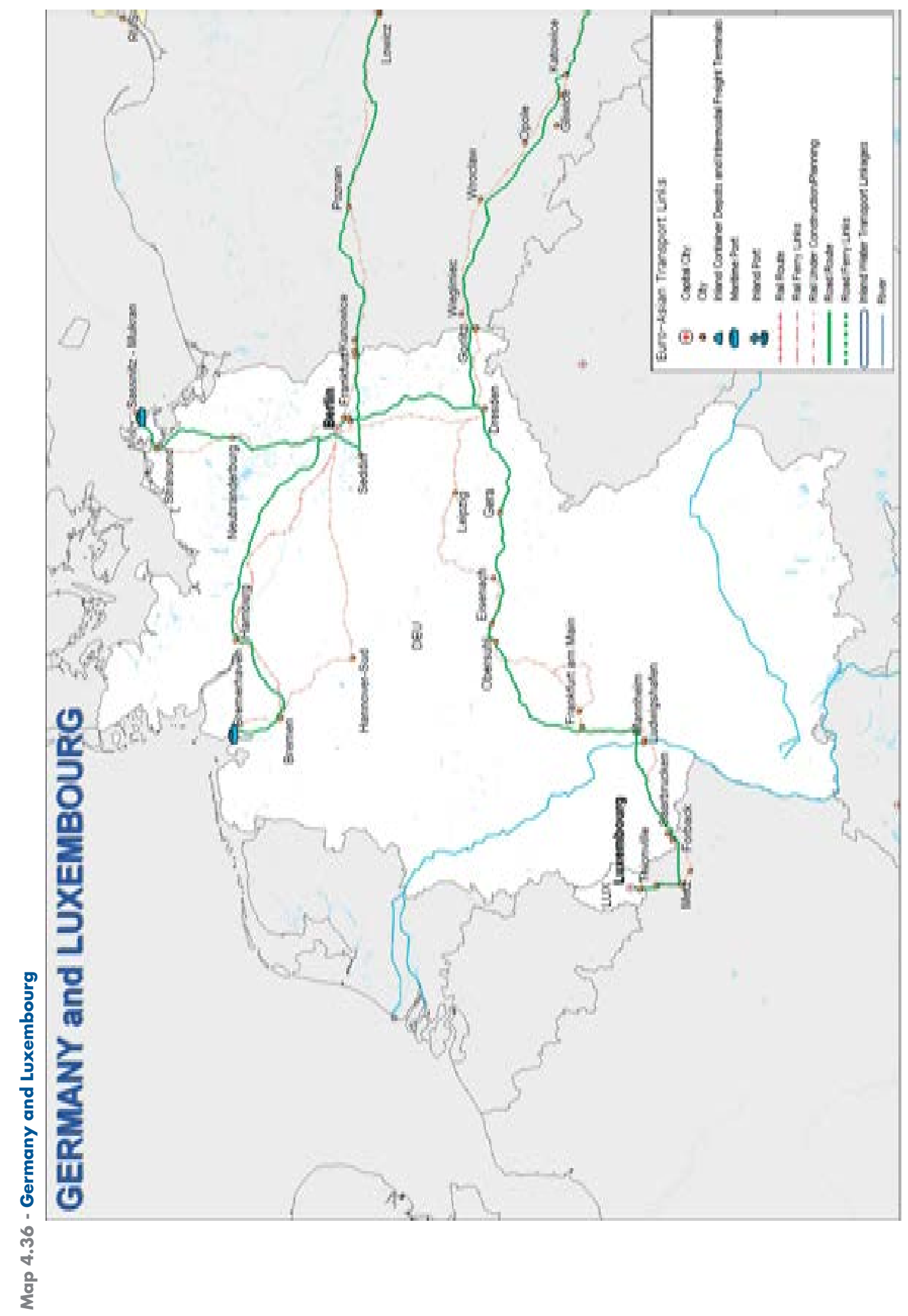




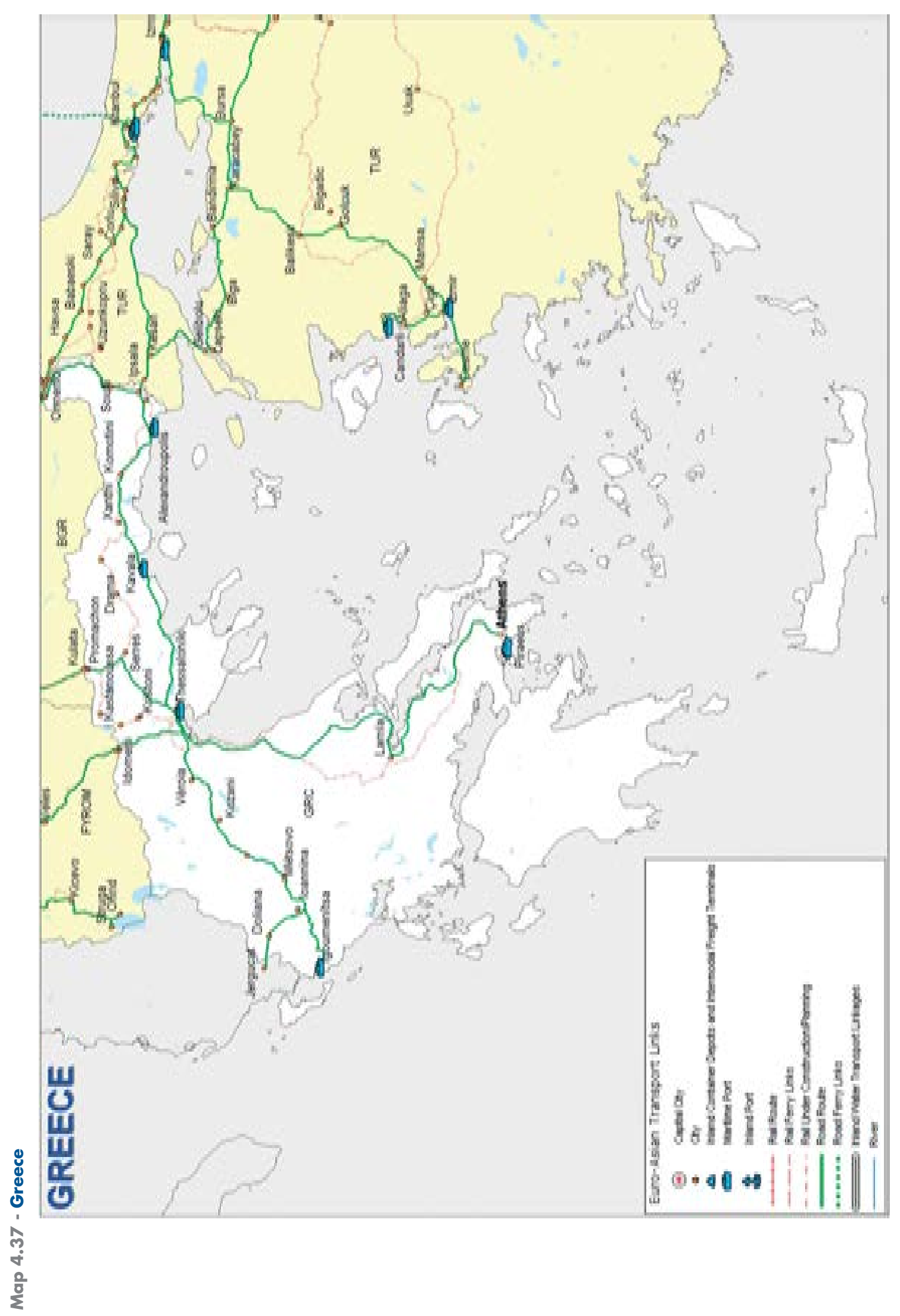




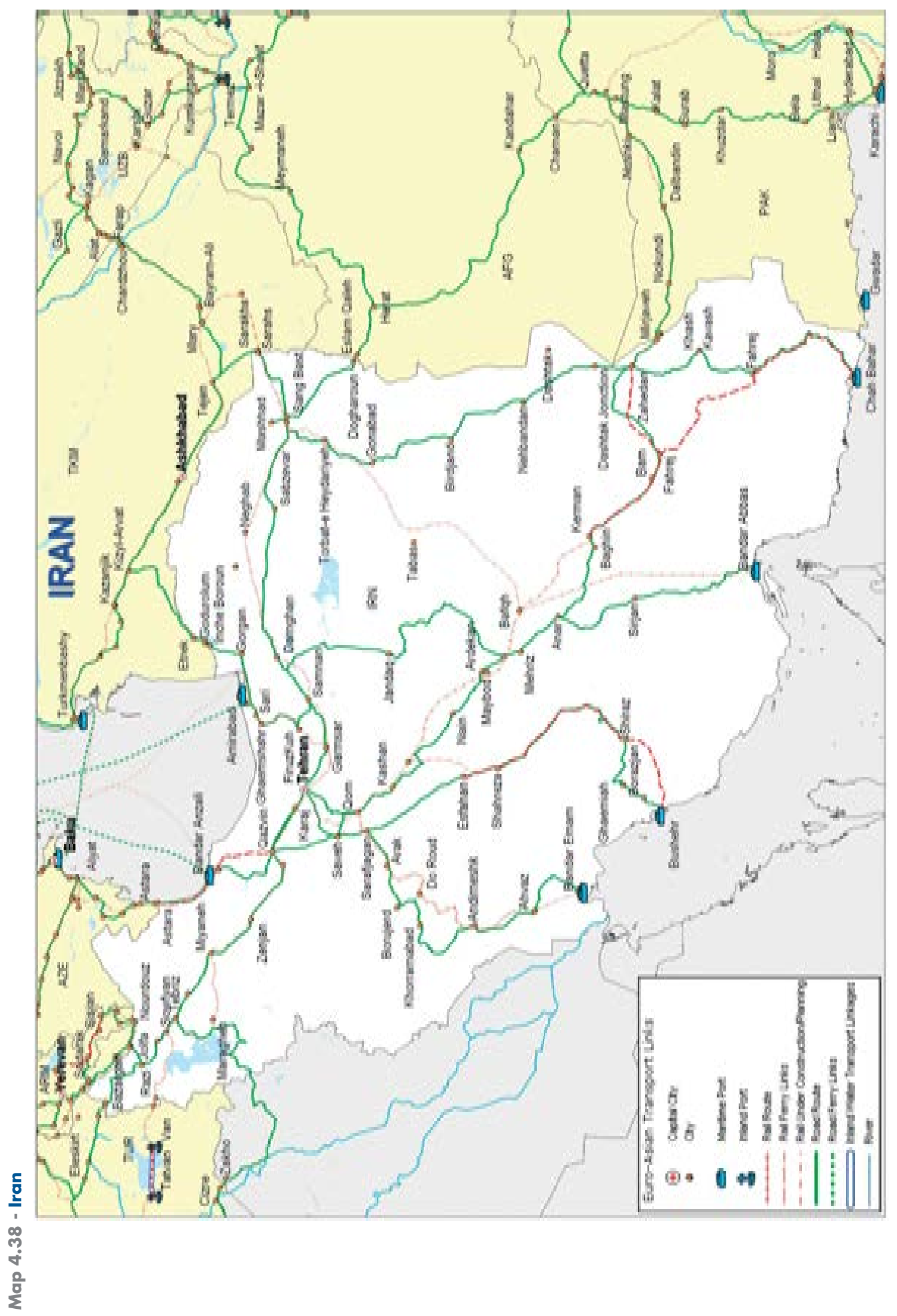




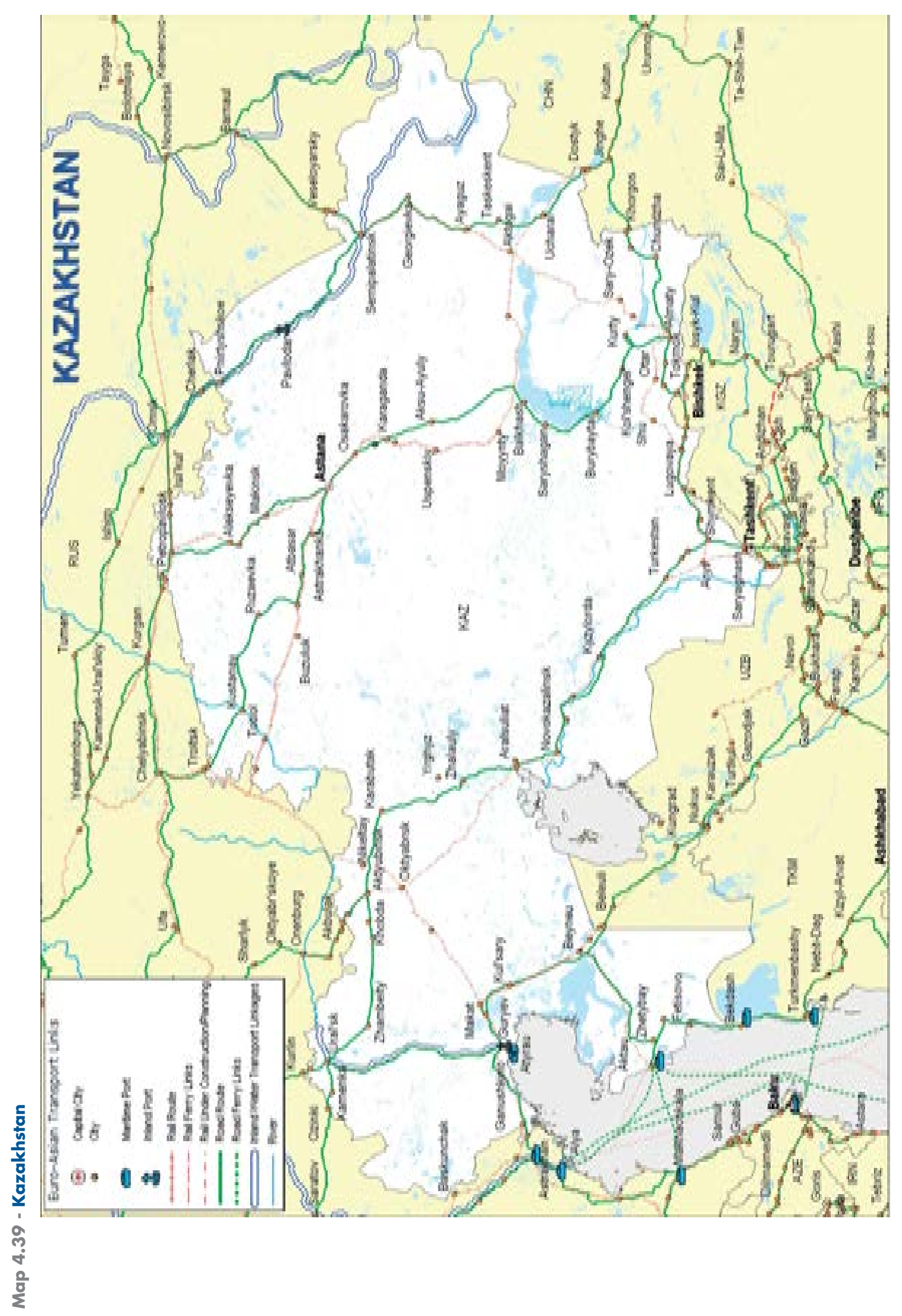




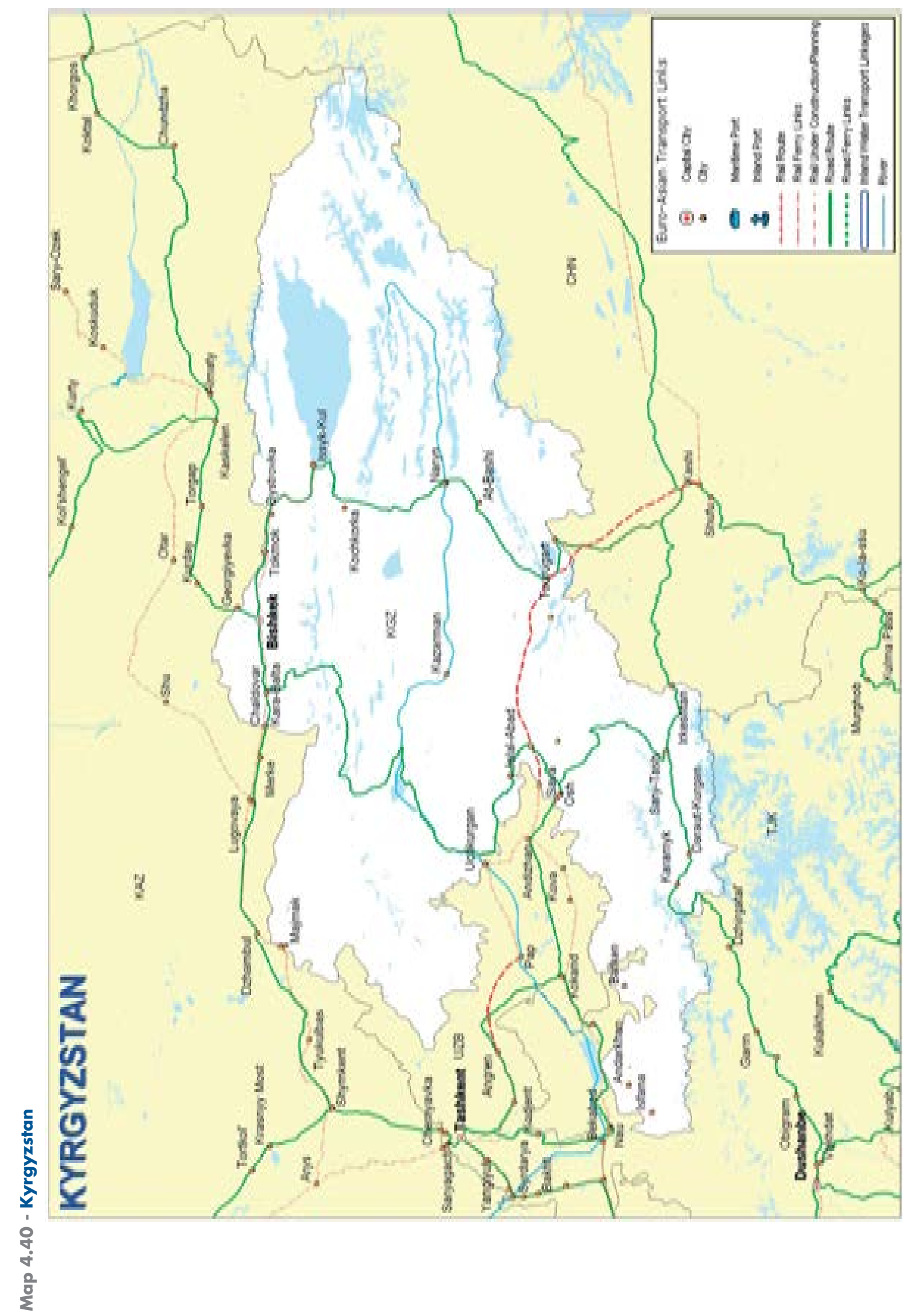




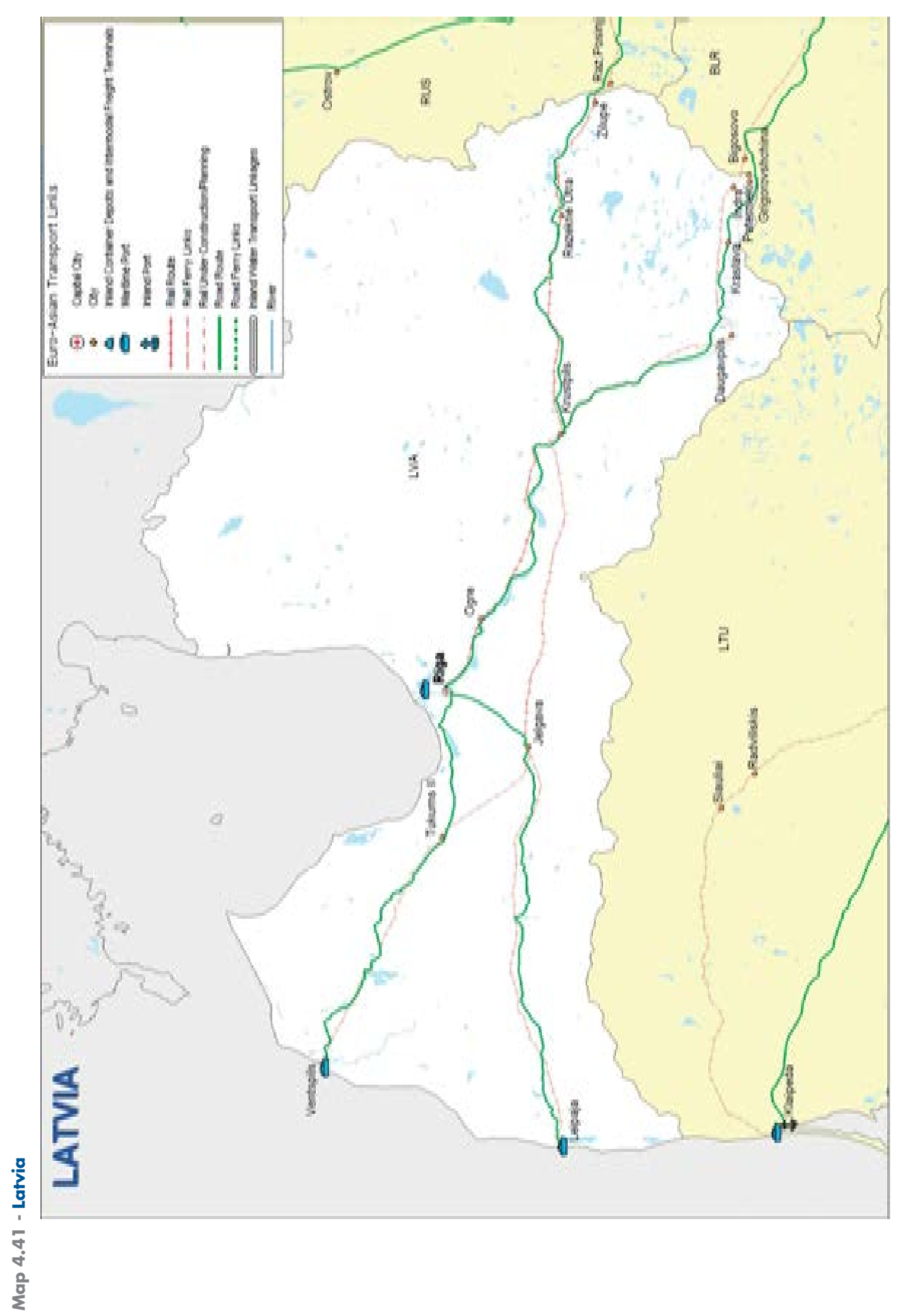




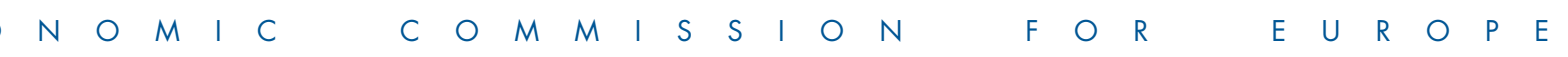

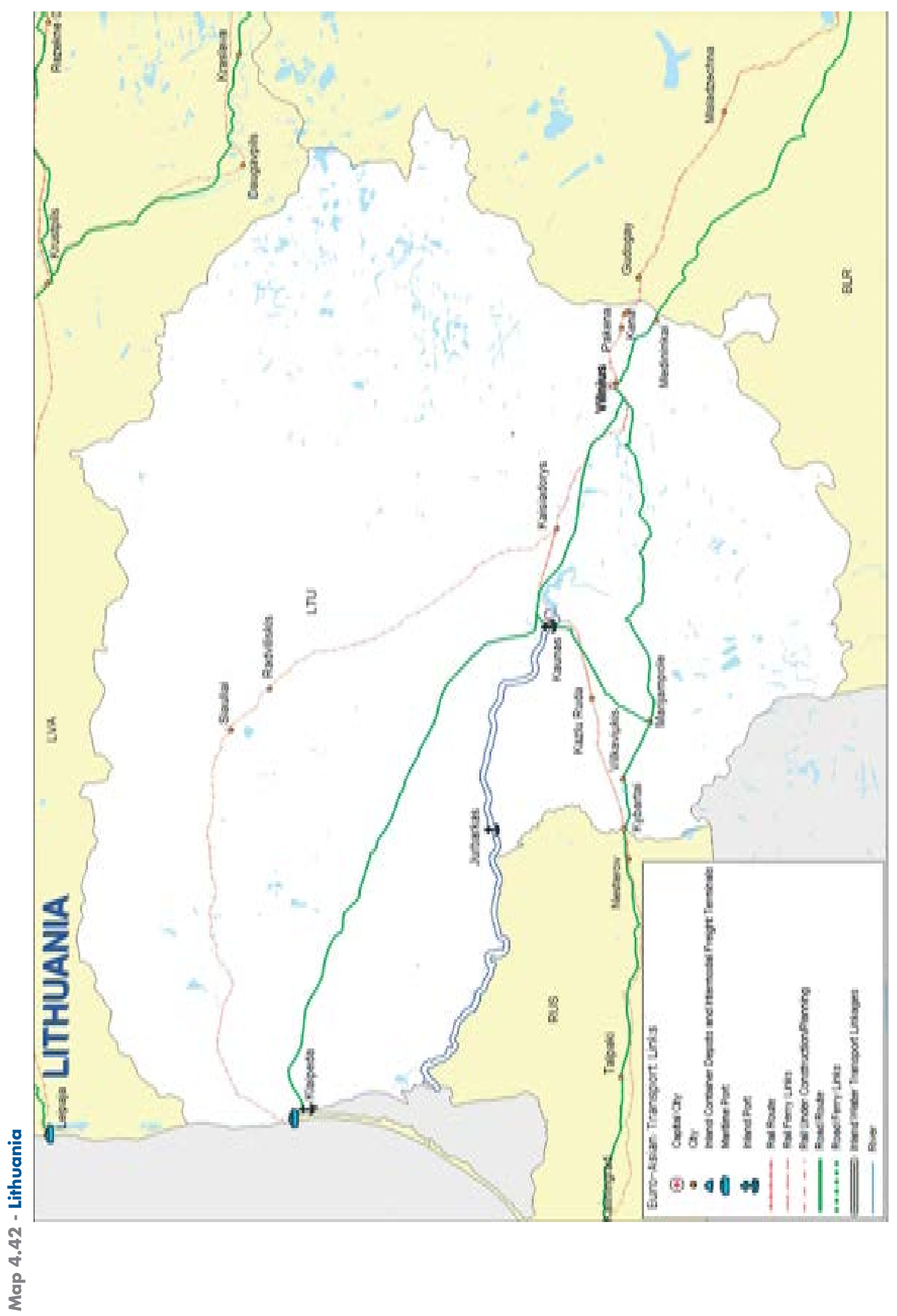




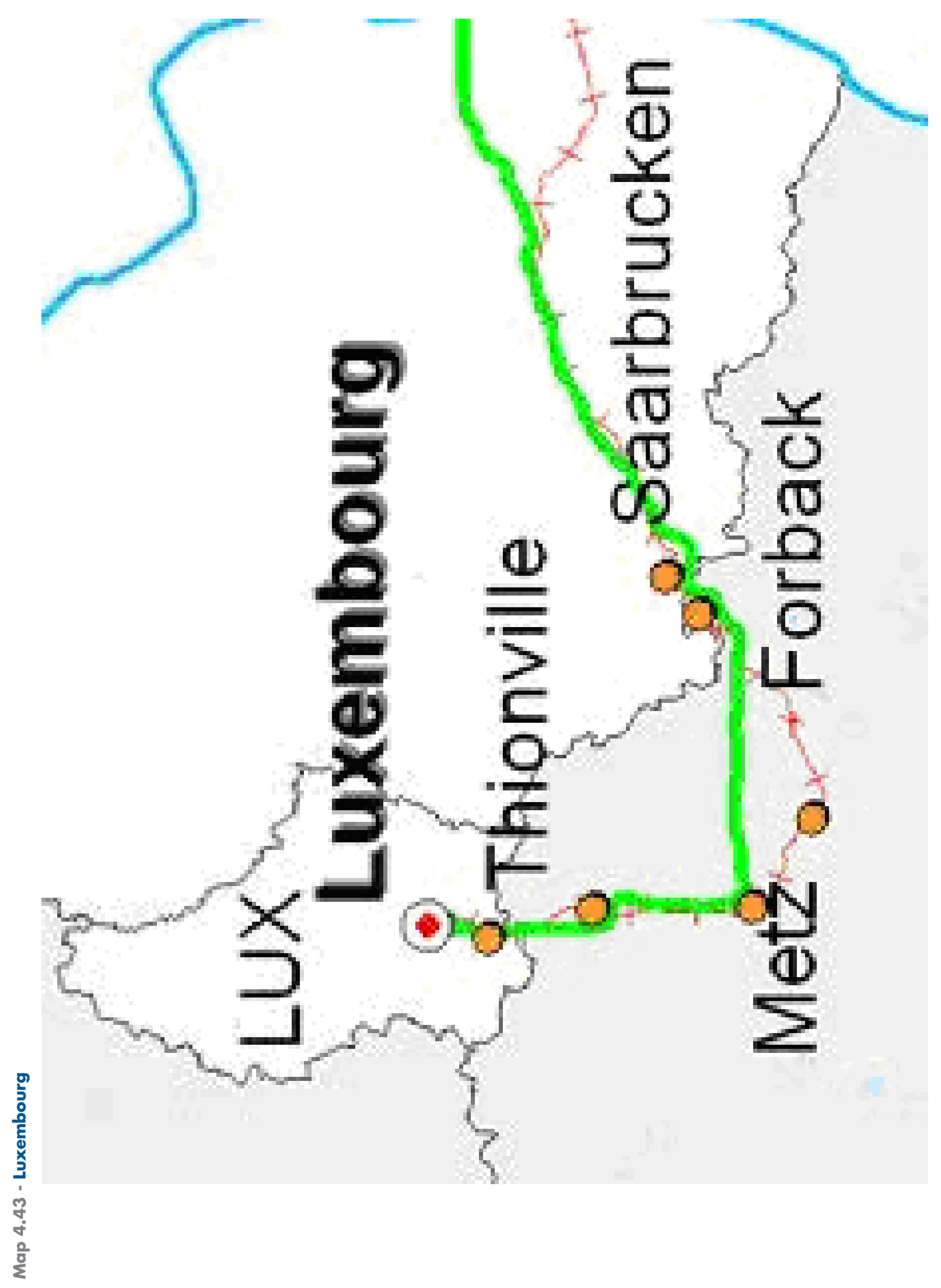




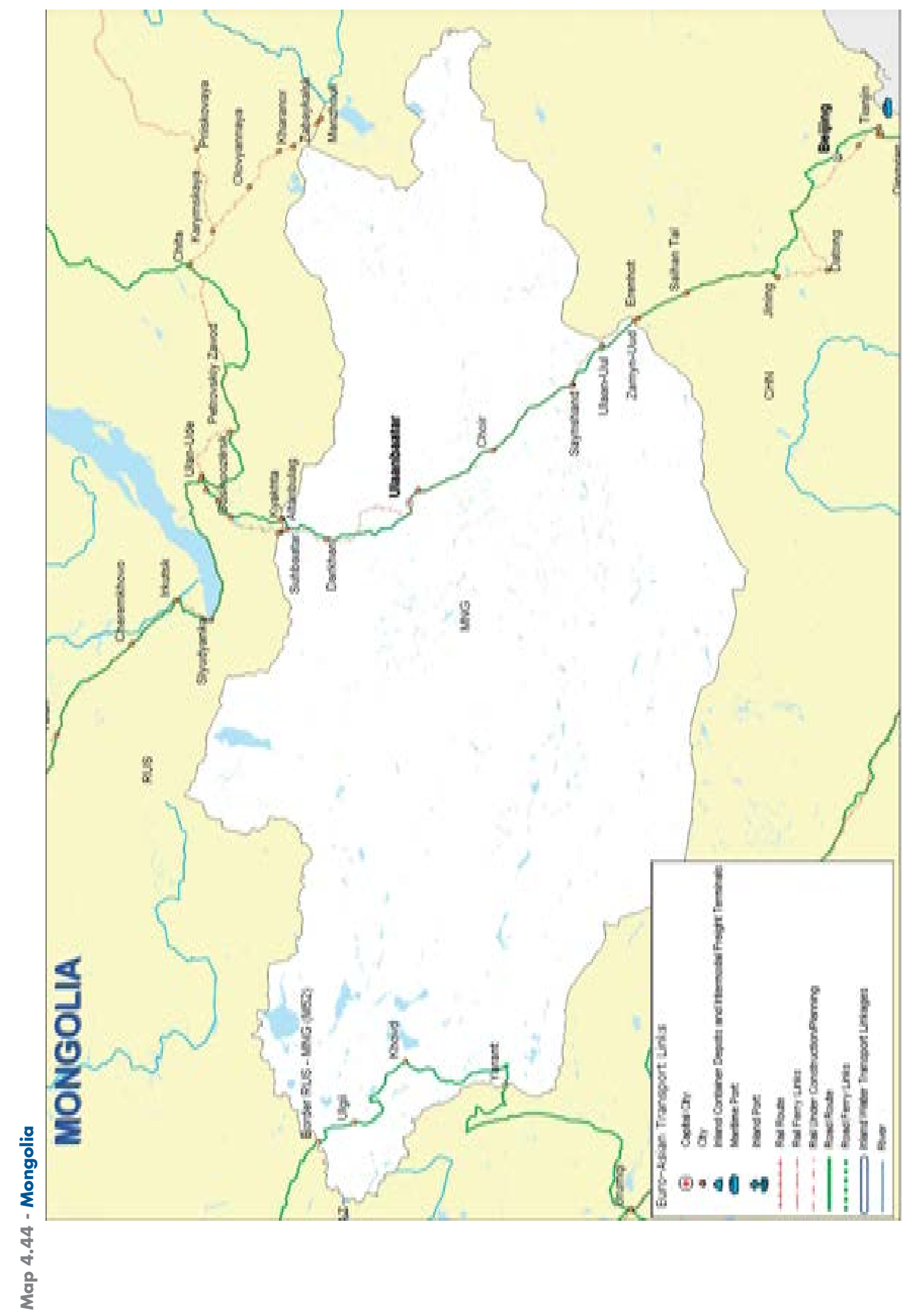




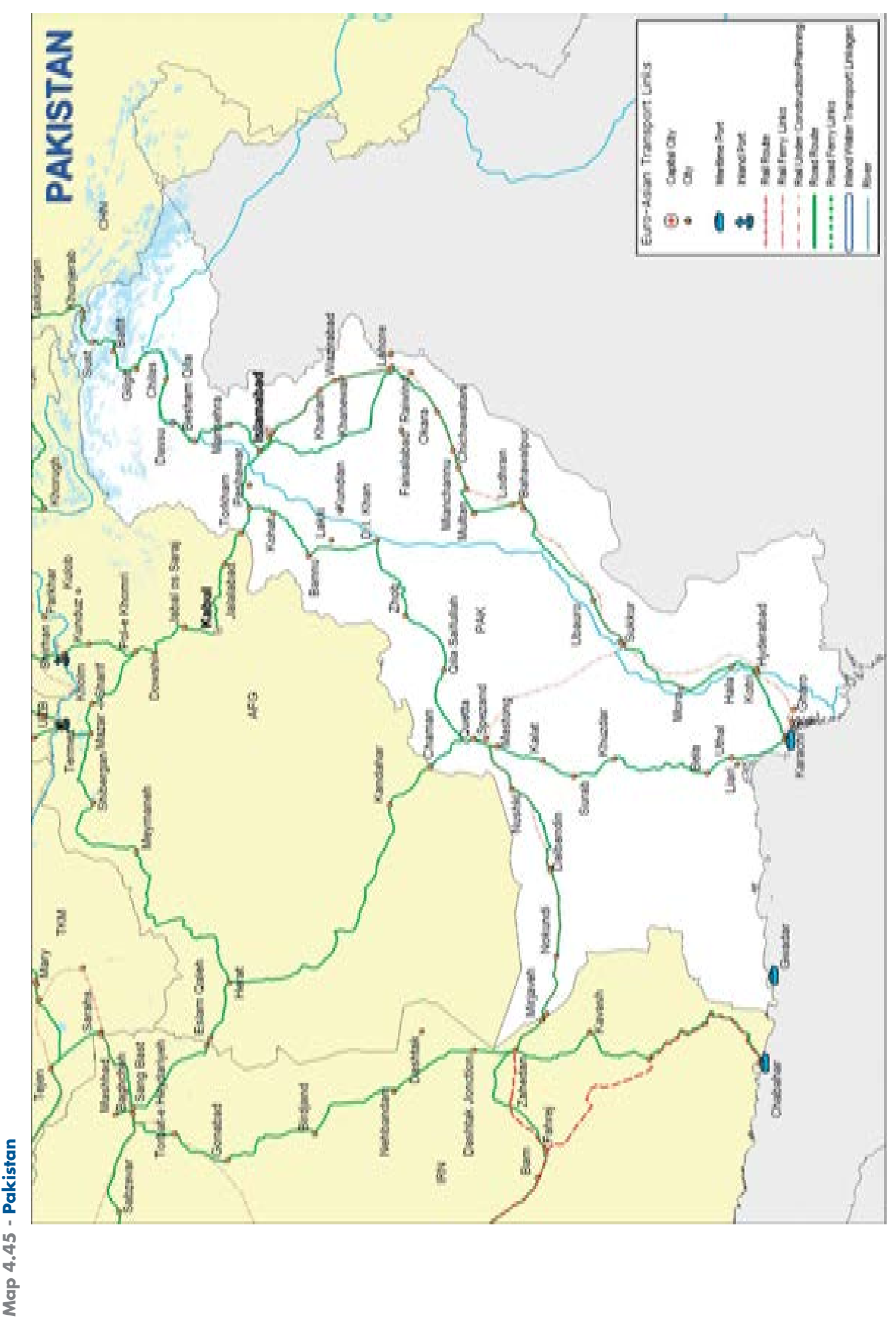




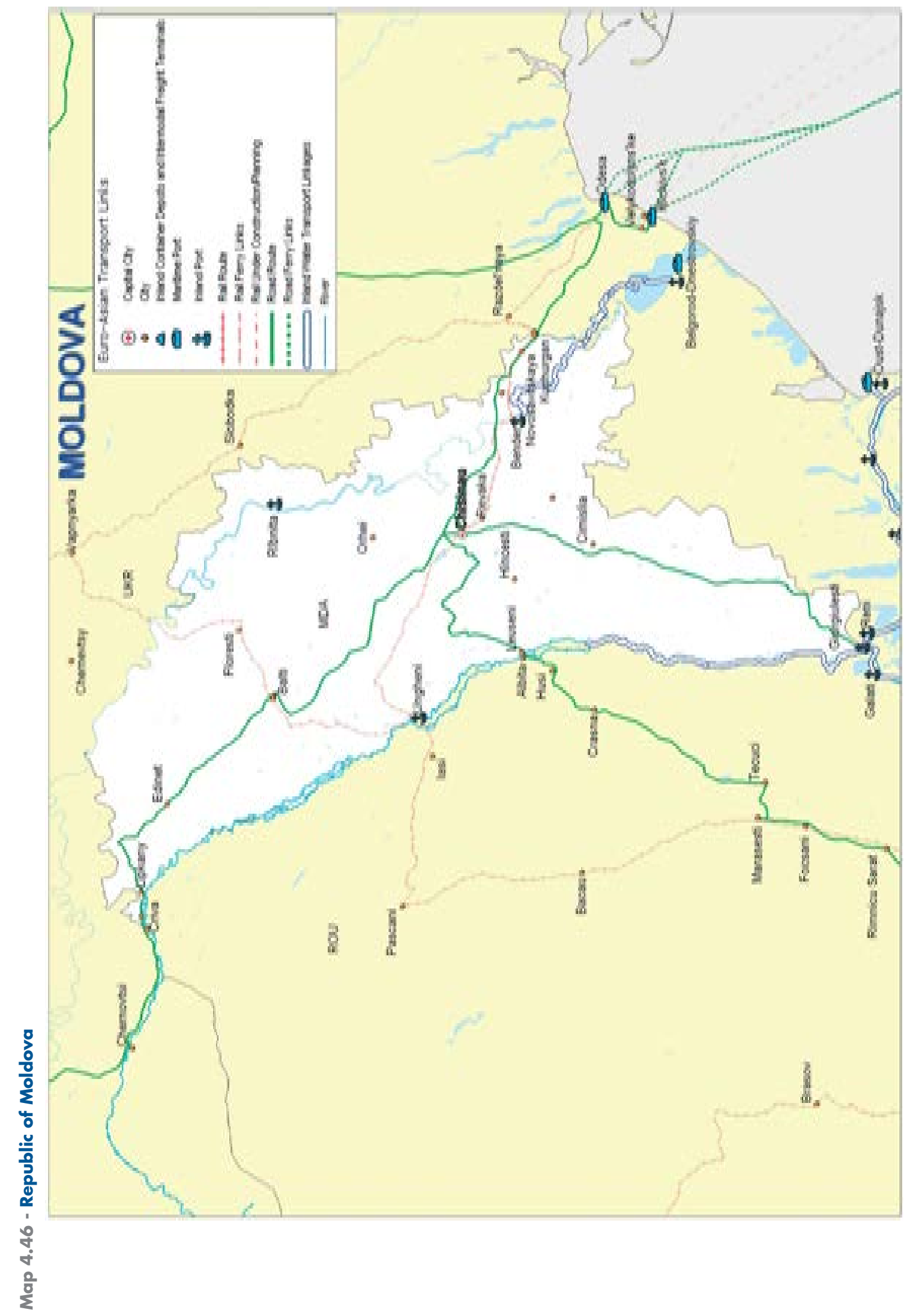




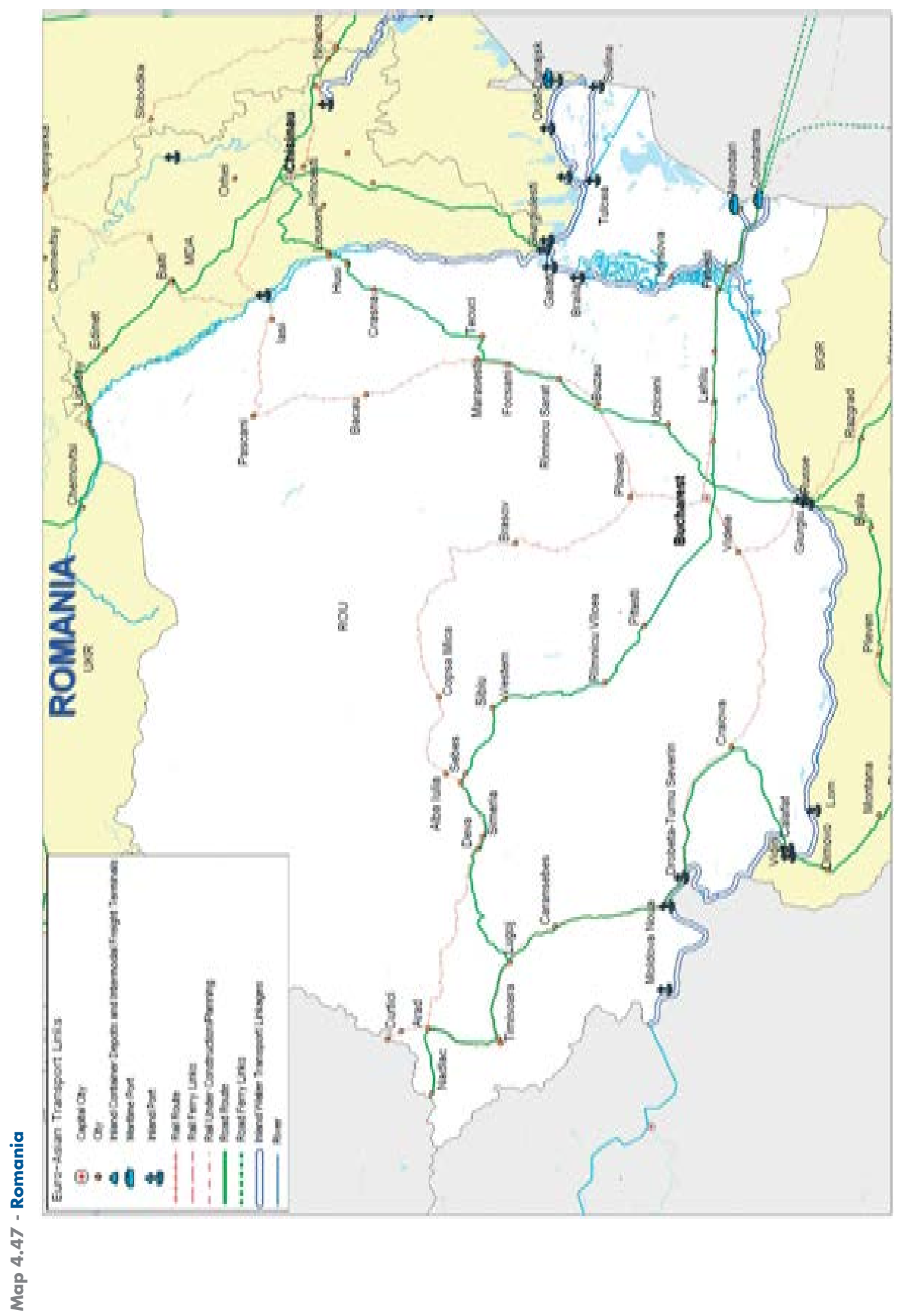




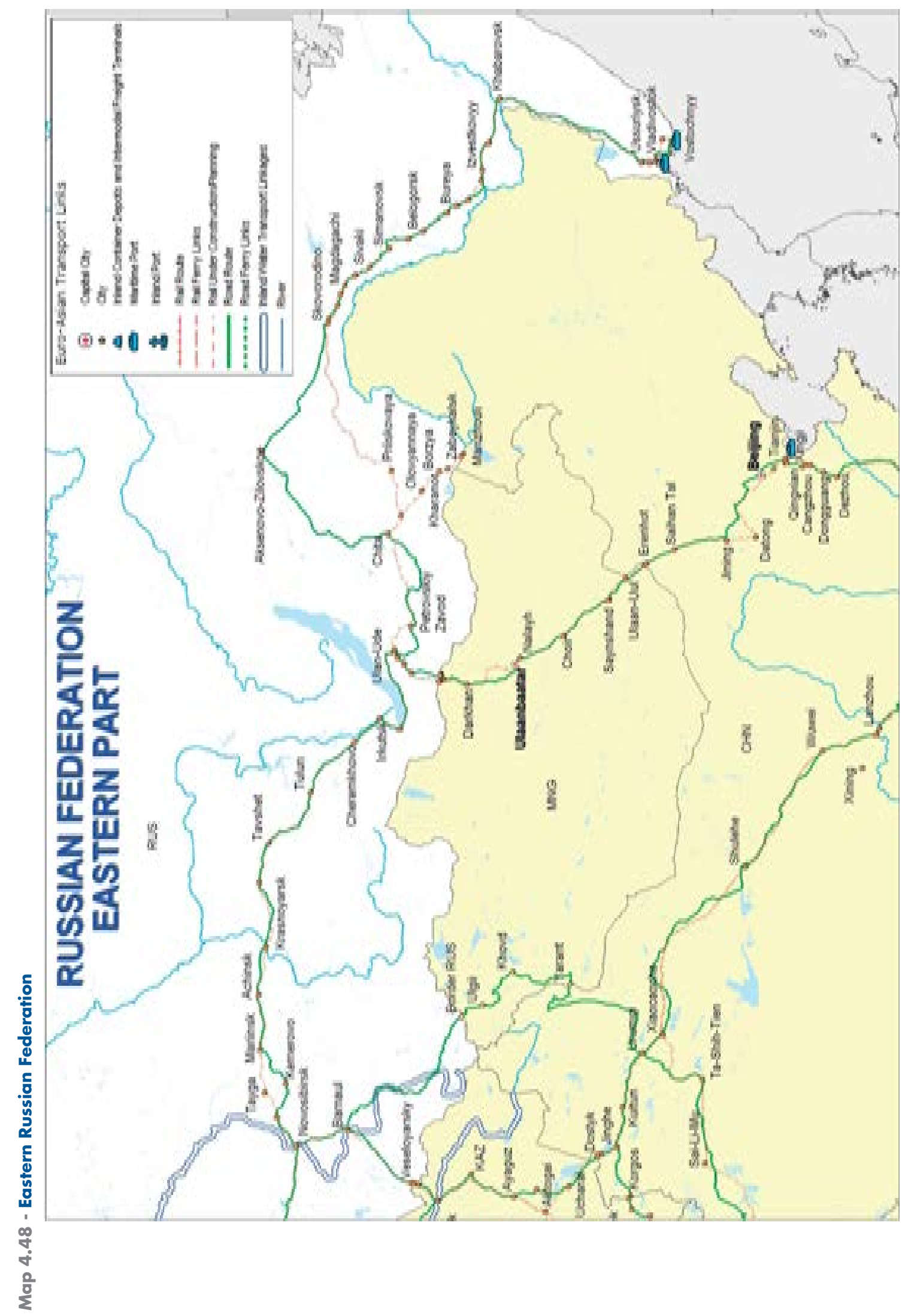




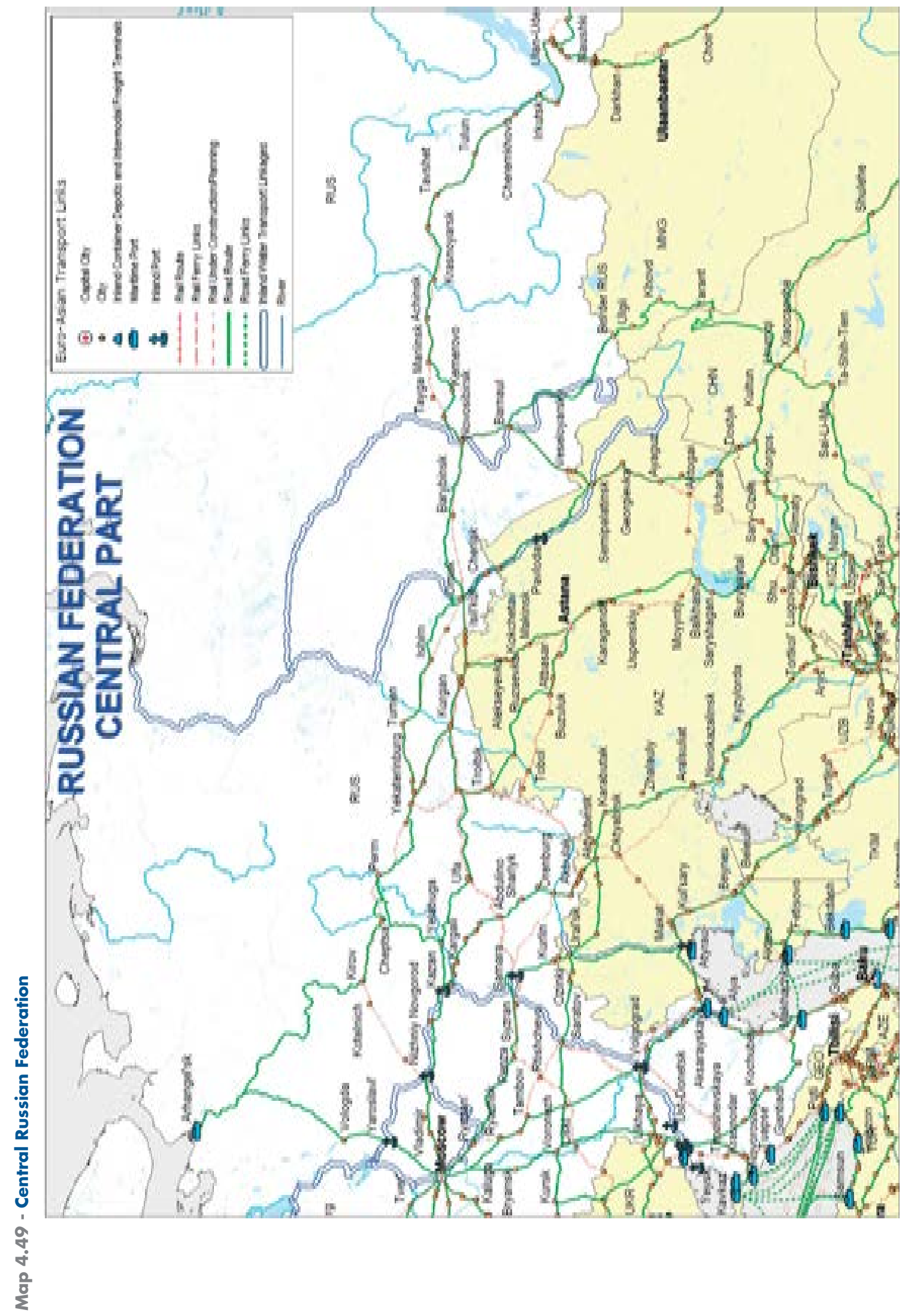




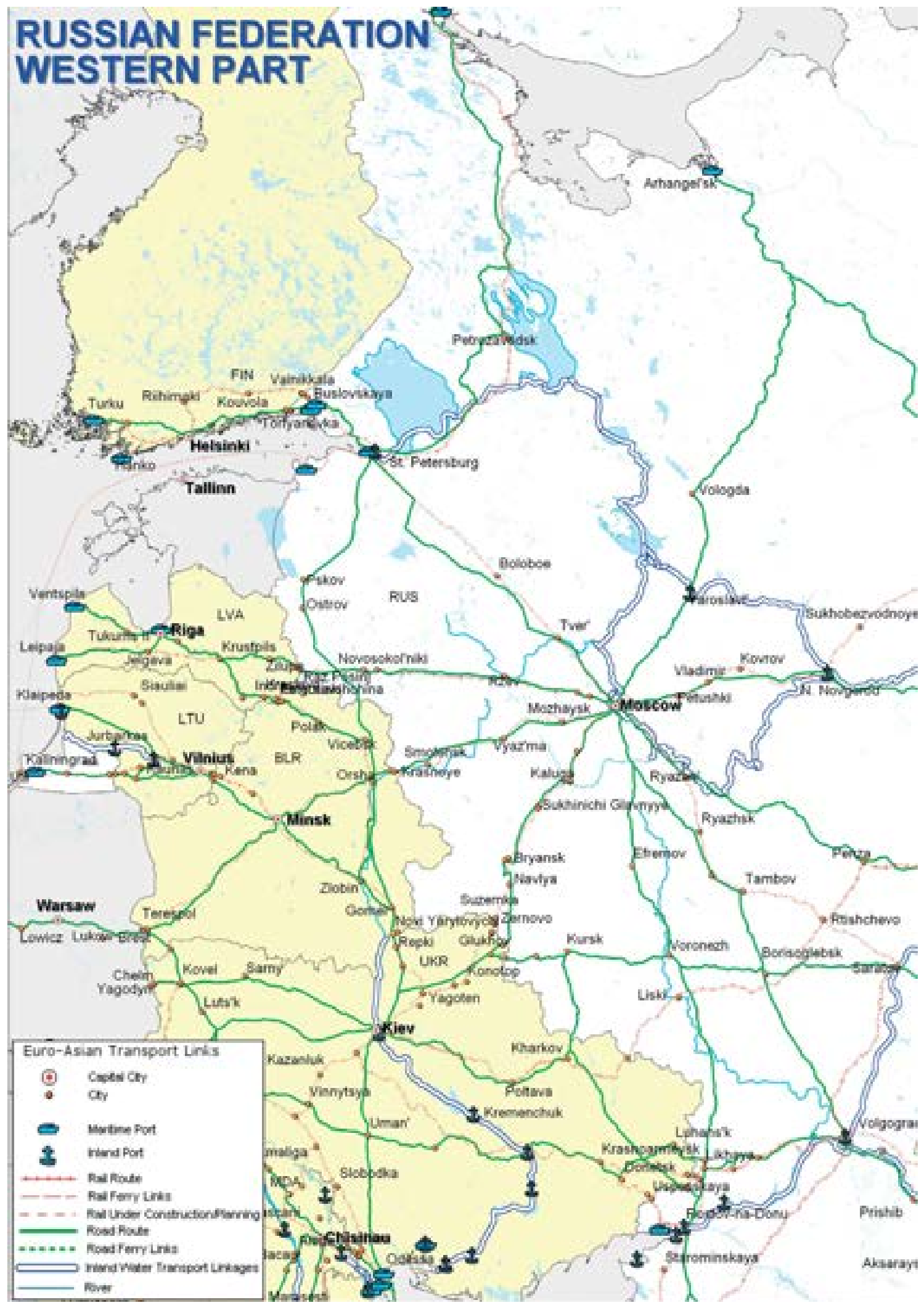




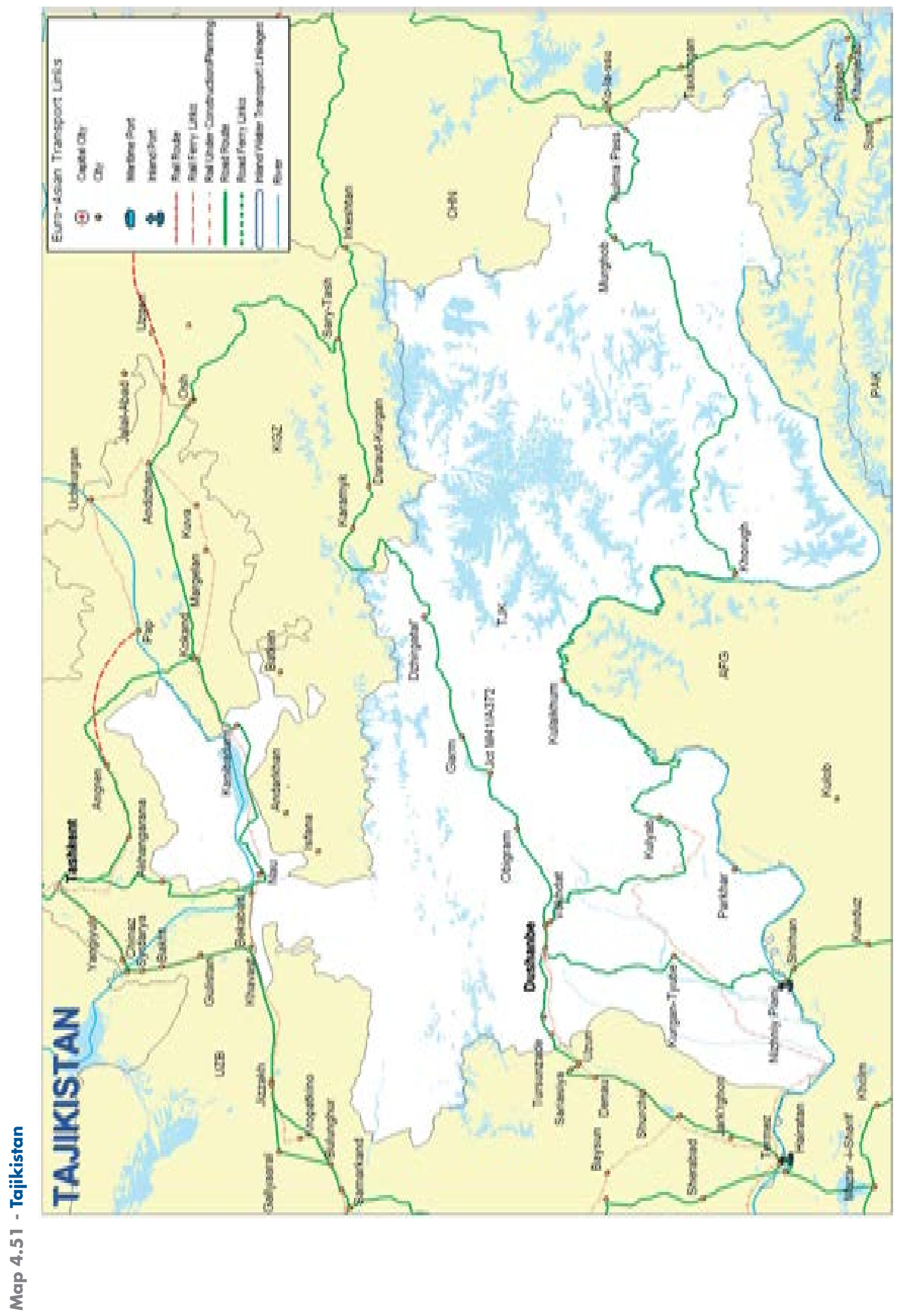




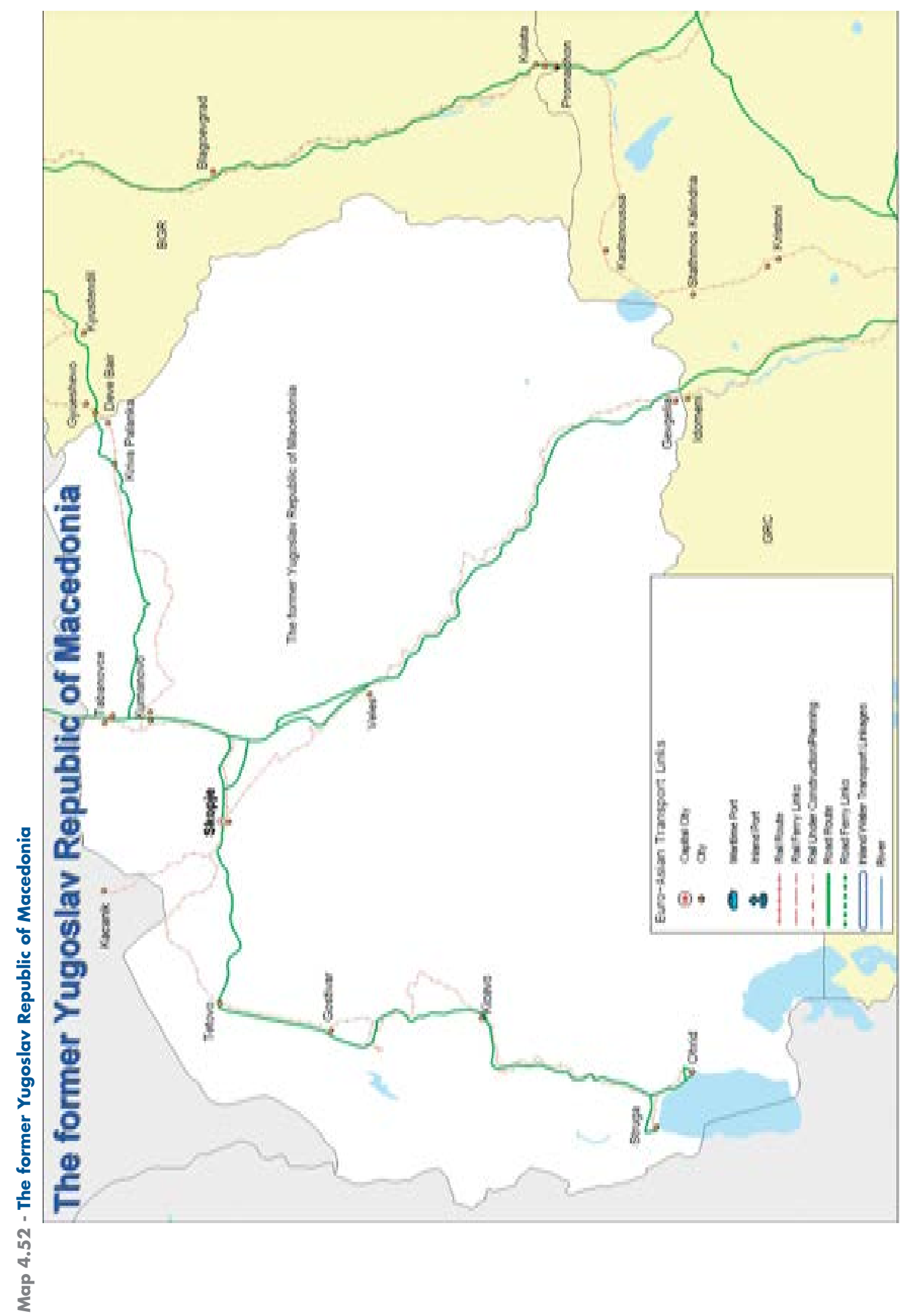




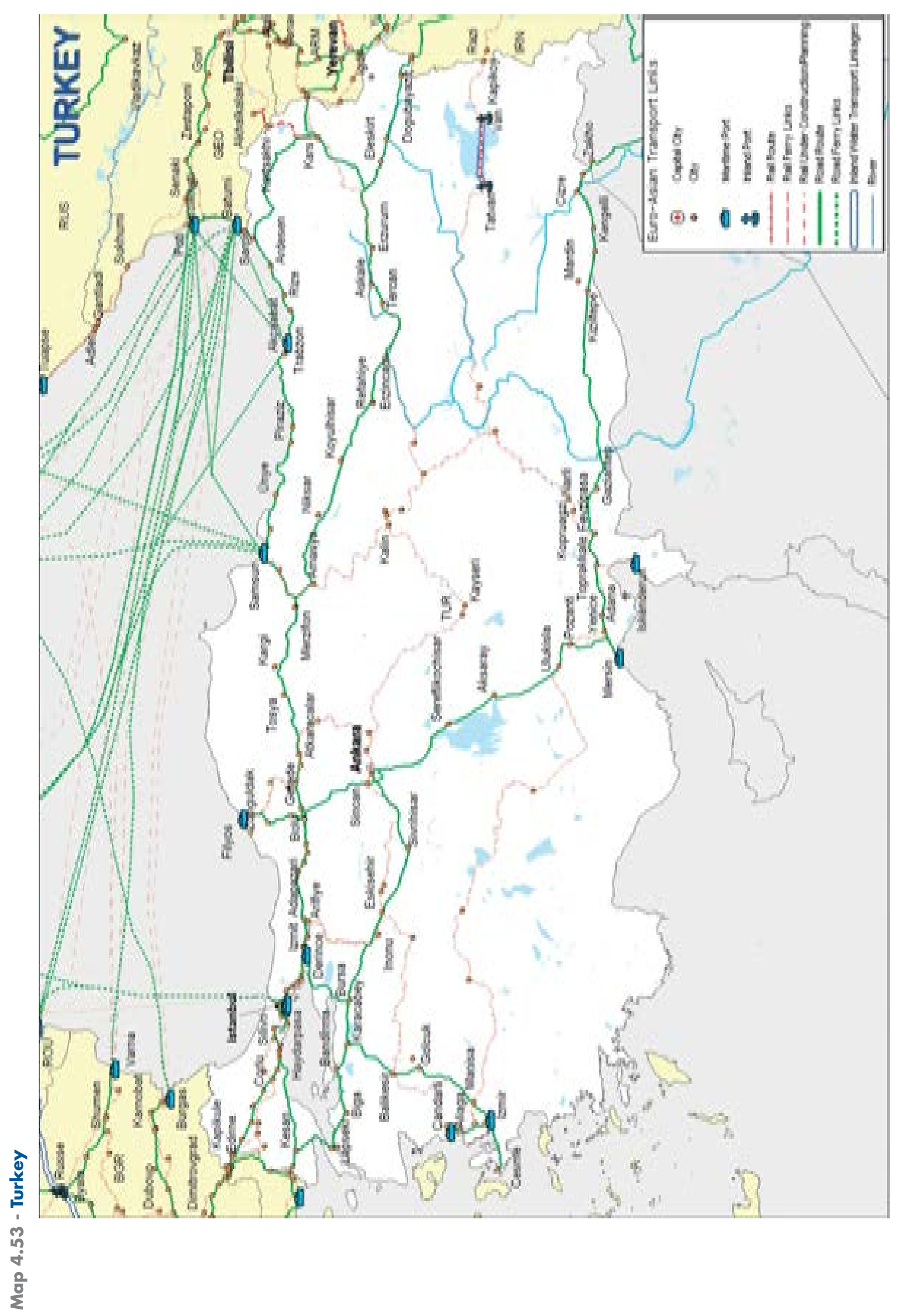




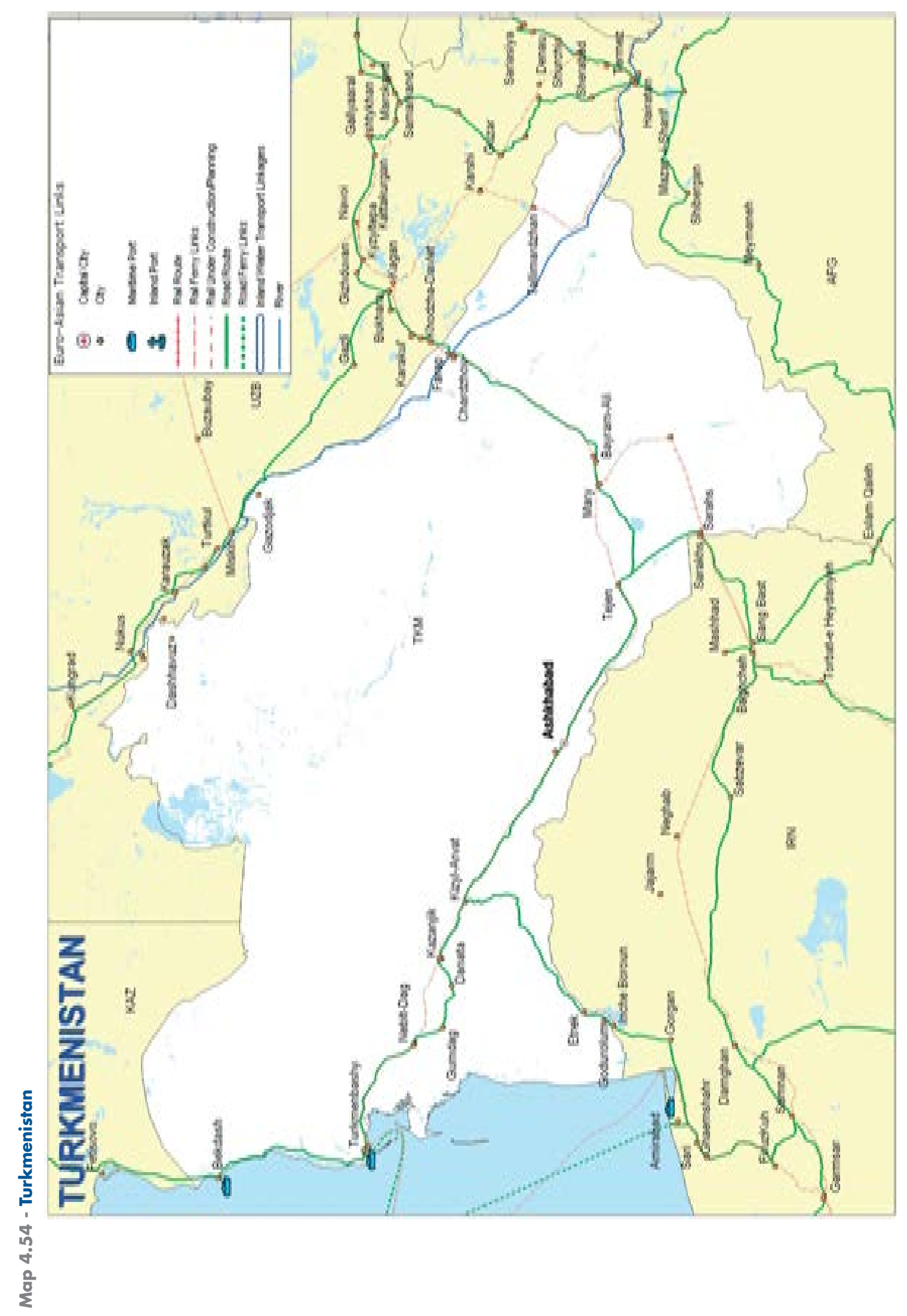




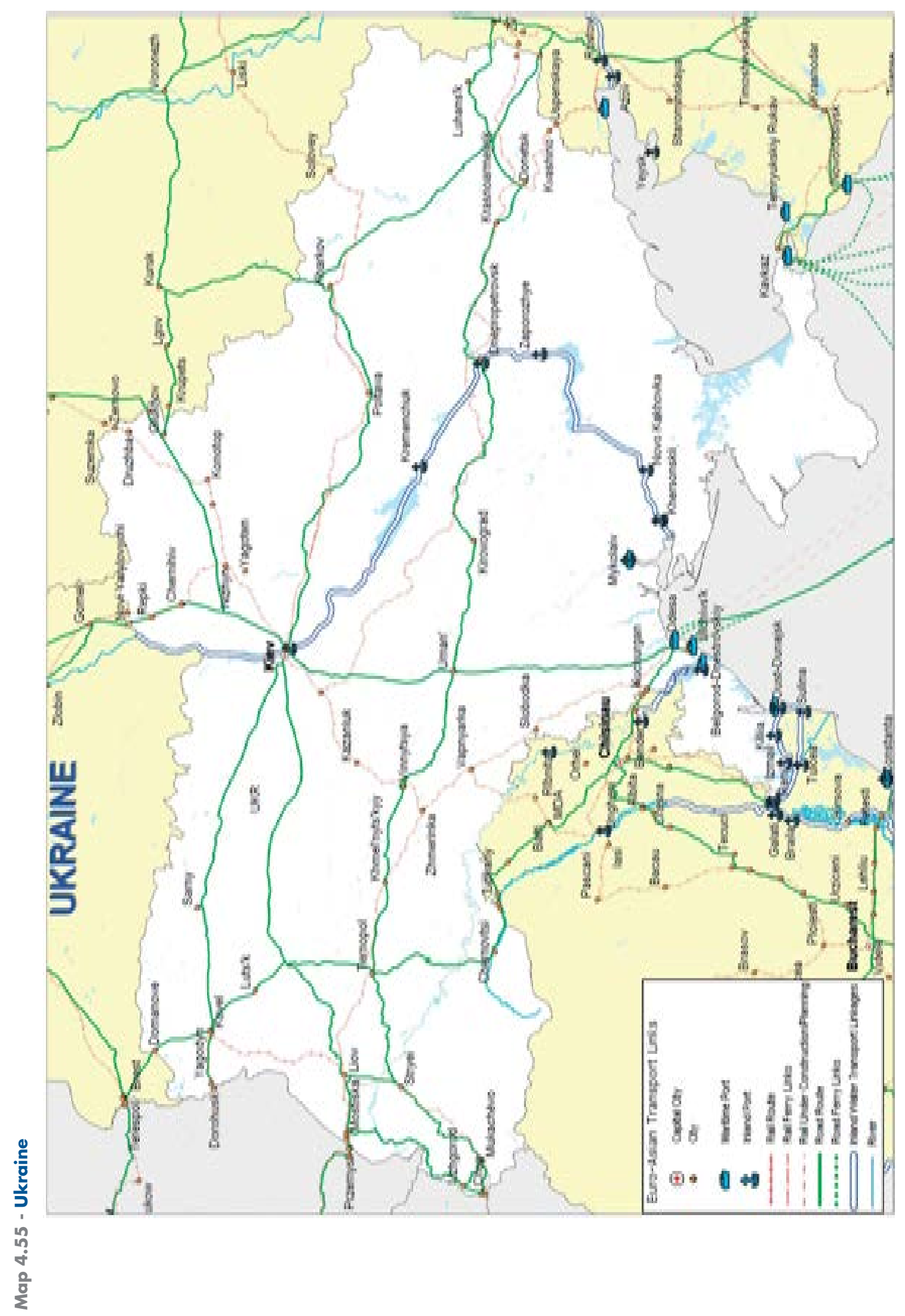




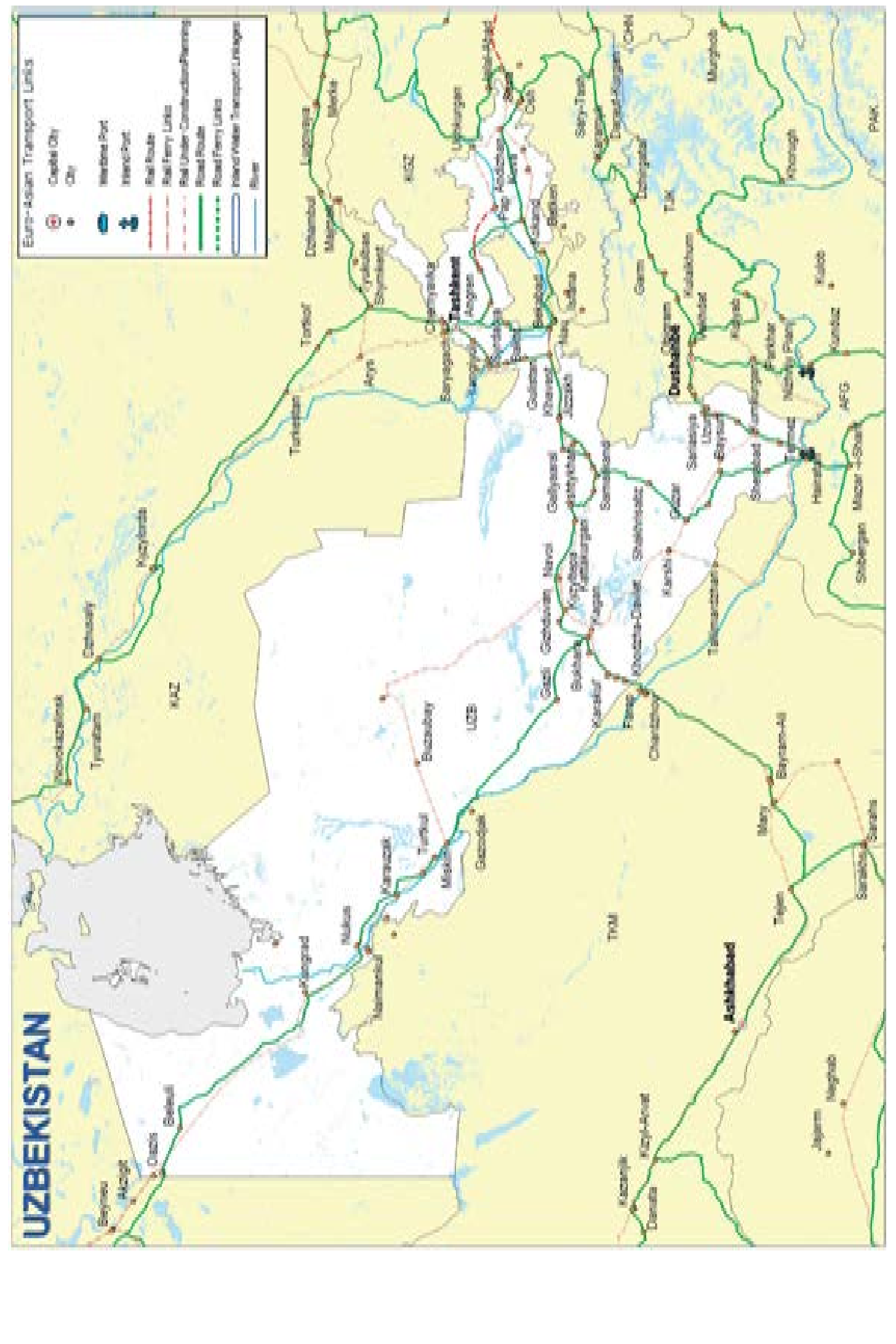




\subsection{Reviewing, extending and updating priority projects identified in Phase I}

An Investment Plan of priority projects was developed and presented during the EuroAsian Transport Linkages project Phase I, based on the proposals of the 18 countries that participated (Afghanistan, Armenia, Azerbaijan, Belarus, Bulgaria, China, Georgia, Iran, Kazakhstan, Kyrgyzstan, Republic of Moldova, Romania, Russian Federation, Tajikistan, Turkey, Turkmenistan, Ukraine and Uzbekistan).

All transport infrastructure projects proposed along the identified EATL Phase I were subjected to a structured evaluation based on prioritization methodology developed by an external consultant - and approved by the National Focal Points of the countries involved - with the scope to develop the international Investment Plan for the EATL project Phase I.

Activities foreseen for Phase II included the revision (updating) of the EATL priority transport infrastructure projects and the development of an international Investment Plan. To this end, a review and update of the list of EATL Phase I priority projects was carried out, and a new interregional Investment Plan of priority projects was developed, based on new country inputs received for the new priority projects submitted under Phase II of the project.

More specifically, this section includes the following:

- an overview of the methodology developed for the prioritization of the proposed projects to be included in the new EATL Phase II Investment Plan. The type of data required for the elaboration of the proposed methodology was also identified, together with the data collection process designed and employed for the purpose of the analysis.

- an assessment of the status of implementation of projects identified under EATL Phase I, including the review and update of those to be included in the new Investment Plan in Phase II.

- collection and analysis of the information on new projects based on country inputs for Phase II.

- project prioritization through the application of the proposed methodology and development of the new Investment Plan in Phase II.

\subsubsection{Methodology for project prioritization}

The framework for the prioritization of new proposed projects to be included in the EATL Phase II Investment Plan entails the development of a methodology for the identification of proposed projects and their grouping into one of the specified implementation time periods. The proposed methodology is identical to the one developed for EATL Phase I project prioritization, to ensure consistency between the two EATL phases. The latter was developed by external consultant and is well documented in the related Report. ${ }^{44}$ Nevertheless, a brief description of the methodology is included in the present document for reasons of completeness.

The method proposed is straightforward, and based on the well-established multi-criteria analysis. The application of the method identifies the projects that are likely to be implemented in selected time periods (in the short term, medium term, long term), and at the same time address the specific objectives of the countries, as well as the international character of the projects.

This method establishes preferences among options by reference to an explicit set of objectives that the decision-making body (e.g. a Ministry of Transport/Infrastructure) has identified, and for which it has established measurable criteria to assess the extent to which the objectives have been

44 United Nations Economic Commission for Europe and Economic and Social Commission for Asia and the Pacific, Joint Study on Developing Euro-Asian Transport Linkages (New York and Geneva, 2008). 
achieved. These criteria are defined through observations, discussions, experimentation and trialand-error processes. Although inherent subjectivity is associated with this method, it is believed to bring a degree of structure, analysis and openness to classes of decision. The preferences are merely related to the time frames/periods of the projects' implementation. Four time frames/ periods were selected, as described below.

Consequently, no evaluation was carried out for the projects, since this would have required a vigorous feasibility study for each project with the same measurement values, followed by project cross-evaluation among the participating countries. Nevertheless, in those cases where the countries had carried out an evaluation/feasibility study, the results of those studies (e.g. IRR) were taken into consideration.

\subsubsection{Overview of the methodology}

The proposed methodological framework for project prioritization was structured in three phases, i.e. identification, analysis and time period classification, in order to ensure the inclusion of the sum of all proposed EATL projects in the revision of the EATL investment strategy.

The definition of "project", as specified in the original EATL methodology, follows:

Definition of project: A project is considered a new construction or the upgrade/ rehabilitation of a transport infrastructure section. Also, a project can be the construction or the upgrade/rehabilitation of a transport terminal/port (maritime or inland waterways), etc. The infrastructure section can vary in length, however it should constitute an expenditure of at least 10 million dollars. An exception of the latter mentioned rule applies if the project involves a missing link or a bottleneck.

Based on the above, the following types of projects were considered in the prioritization exercise:

I. Projects submitted in EATL Phase I completed during the period that elapsed, and EATL Phase I projects for which no change was reported.

II. Updated or revised EATL Phase I projects, including those for which additional data were provided.

III. Any new projects submitted, from both the group of countries that participated in EATL Phase I and the new countries involved in EATL Phase II.

The phases of the proposed methodology are briefly described below:

\section{Phase A - Identification}

The identification phase entails the recording of prospective projects, based on their readiness and funding possibilities, as well as the commonly shared objectives of the authorities in charge, whether national or international, and the collection of readily available information/data regarding these projects.

\section{Phase B - Analysis}

The analysis is carried out via the application of the well-established multi-criteria approaches, such as the direct analysis of criteria performance, the paired comparison matrix and the MultiAttribute Utility Theory). Both approaches were used in the original EATL Phase I Investment Plan.

It should be noted that the set of criteria used were the same as those employed in EATL Phase I. 


\section{Phase C - Time period classification}

In the final phase, the selection of projects is carried out according to their "performance" score. Based on the latter, projects are classified into four time period categories (I, II, III and IV), each related to a specified time horizon, as follows:

- Category I: projects that have secured funding, that are ongoing and expected to be completed in the near future (up to 2013).

- Category II: projects that may be funded or whose plans are approved and are expected to be implemented rapidly (up to 2016).

- Category III: projects that require additional investigation for final definition before likely financing and implementation (up to 2020).

- Category IV: projects that require further investigation for final definition and scheduling before possible financing, including projects for which insufficient data exists (most likely to be implemented after 2020).

\subsubsection{Compliance with EATL Phase I}

Although the same EATL Phase I methodology was also applied in EATL Phase II, a number of issues were taken into account:

- Updating EATL projects entailed the identification and grouping of projects into one of four implementation time periods that are not the same as those specified in EATL Phase I, since the time periods considered in Phases I and II differed. The proposed implementation periods and categories for EATL Phase II are described in the previous paragraph.

- A number of projects under EATL Phase I were placed in category IV due to the lack of essential data. In cases when this data became available during the data collection stage of EATL Phase II, the results of which could have allowed them to score higher, the projects were placed in one of the other three categories (I, II or III) in the new Investment Plan.

- Projects placed into a specific category in Phase I for which no change was reported in Phase II remained in the same category in the new Investment Plan.

\subsubsection{Important conditions for the prioritization exercise}

The key conditions for the prioritization exercise were the following:

- Projects along the main EATL routes identified under Phase II.

- Projects not along identified EATL Phase II routes but considered of national importance were assigned to a Reserve category.

- Projects with secured funding were directly considered for Category I.

- Projects without committed funding, with partial committed funding or in the planning phase required further analysis (Phase B of the methodology) that was carried out to set implementation priorities, against common shared objectives.

- As the analysis was based on data collected from the countries, projects without any data were automatically classified as lowest priority in terms of implementation (Category IV).

\subsubsection{Data collection}

The data collection process for the revision of the original EATL Phase I and the development of the new Investment Plan for Phase II required the input from countries divided in the following three main categories:

IV. Projects identified under EATL Phase I, involving only the 15 countries that submitted data (i.e. Armenia, Azerbaijan, Belarus, Bulgaria, China, Georgia, Iran, Kazakhstan, Kyrgyzstan, Republic of Moldova, Romania, Tajikistan, Turkey, Ukraine and Uzbekistan). This relates to Case A of data collection described below. 
V. New project proposals from the 15 countries that participated in EATL Phase I, as well as project proposals of those that did not submit any data during EATL Phase I (i.e. Afghanistan, Russian Federation, Turkmenistan). This relates to Case B of data collection described below.

VI. New project proposals from newly involved countries (Finland, Germany, Greece, Latvia, Lithuania, Luxembourg, Mongolia and the former Yugoslav Republic of Macedonia). This relates to Case $\mathrm{B}$ for data collection below.

Based on the above, two distinct cases were identified with regard to data collection; (i) Case A, referring to projects identified under EATL Phase I, involving only the 15 countries mentioned above; and (ii) Case B, including the new project proposals by all countries involved in EATL Phase II.

\section{Case A}

For projects already submitted under EATL Phase I, each participating country was asked to review and update the related information for each of these projects. The National Focal Points separately received Templates B (B1, B2, B3, B4) containing the data of their respective country, as originally submitted. The templates appeared in excel format, as presented in Appendix 4.I, having been completed by the external consultant: the already submitted projects under EATL Phase I are listed in the white cells of these forms, while the associated data already submitted appear in the yellow cells. Thus, each of the 15 countries was asked to verify existing data and update and/or complete the data in the yellow cells for each of the projects.

Templates B (B1, B2, B3, B4) for each country that submitted data under EATL Phase I included the following:

- Template B1: Road projects existing in EATL Phase I

- Template B2: Railway projects existing in EATL Phase I

- Template B3: Inland waterway projects existing in EATL Phase I

- Template B4: Ports (sea and inland waterway), Inland container depot/Intermodal freight terminal/Freight village/Logistic centre existing in EATL Phase I

Templates B were all considered crucial to fulfil the requirements for the review of EATL Phase I, that is, to assess the implementation status, review and update the projects identified and allocate the projects in the appropriate time period classification.

Case B

With regard to new project proposals to be submitted, the new countries that joined EATL Phase II and those that participated in the EATL Phase I prioritization exercise received a uniform Questionnaire for each transport mode - Templates 2 (2A, 2B, 2C, 2D).

Examples of Templates 2 (2A, 2B, 2C, 2D) are presented in Appendix 4.2 and include the following:

- Template 2A: Road and related infrastructure Project Fiche

- Template 2B: Rail and related infrastructure Project Fiche

- Template 2C: Inland waterways and related infrastructure Project Fiche

- Template 2D: Ports (sea and inland waterway), Inland container depot/Intermodal freight terminal/Freight village/Logistic centre and related infrastructure Project Fiche

\subsubsection{Additional information upon original submission}

Additional information on the EATL projects was requested from counties that submitted their respective input. Therefore, the following information was requested following original submissions: 
For Case A - Templates B(1-4):

- Information on the reasons the implementation of projects had been delayed, if applicable.

- The cost adjustment amount from 2007 to 2008, since project costs appeared in 2007 prices.

- Expenses accrued so far (2009), as a percentage of the project's total cost.

- Percentage of the public works budget allocated.

- The country's GDP for 2007.

- Recommendations in the cases of non-secured funding regarding potential funding sources to cover the amounts for which funds had not been secured.

For Case B - Templates 2 (A-D):

- Expenses accrued so far (2009), as a percentage of the project's total cost.

- Percentage of the public works budget allocated.

- GDP (for 2008).

- Recommendations regarding potential sources of funding in the cases of non-secure funding, if applicable.

- Reasons the project implementation had been delayed, if applicable.

In addition to the above, through their NFP the countries were asked - if they so wished and for the purpose of the analysis carried out under Part B of the methodology - to provide their own weights, with appropriate justification, by completing the following table (Table 4.7):

Table 4.7 - Criteria weights template

\begin{tabular}{|c|c|c|c|}
\hline $\begin{array}{l}\text { Criterion } \\
\text { Weight }\end{array}$ & Description of Criterion & $\begin{array}{l}\text { Default Weight } \\
\text { (as used in EATL Phase I) }\end{array}$ & $\begin{array}{l}\text { Weight Provided } \\
\text { by Country }\end{array}$ \\
\hline \multicolumn{4}{|c|}{ CLUSTER A } \\
\hline Wcal & $\begin{array}{l}\text { Serving international connectivity (reaching a } \\
\text { border-crossing point or providing connection } \\
\text { to a link that is a border crossing) }\end{array}$ & 3.13 & \\
\hline WcA2 & $\begin{array}{l}\text { Promoting solutions to the particular transit transport } \\
\text { needs of the landlocked developing countries }\end{array}$ & 9.38 & \\
\hline WCA3 & $\begin{array}{l}\text { Connecting low income and/or least developed } \\
\text { countries to major European and Asian markets }\end{array}$ & 19.79 & \\
\hline Wca4 & $\begin{array}{l}\text { Crossing natural barriers, removing bottlenecks, } \\
\text { raising substandard sections to meet international } \\
\text { standards, or filling missing links in the TEM network }\end{array}$ & 17.71 & \\
\hline \multicolumn{2}{|r|}{ Total A } & 50 & 50 \\
\hline \multicolumn{4}{|c|}{ CLUSTER B } \\
\hline WсB 1 & $\begin{array}{l}\text { Having a high degree of maturity, in order } \\
\text { to be carried out quickly (i.e. project stage) }\end{array}$ & 40.00 & \\
\hline WсB2 & Environmental and social impacts & 10.00 & \\
\hline \multicolumn{2}{|r|}{ Total B } & 50 & 50 \\
\hline \multicolumn{2}{|r|}{ Total } & 100 & 100 \\
\hline
\end{tabular}




\subsubsection{Implementation of priority projects identified in Phase I}

The scope of this stage was to assess the status of implementation of the projects identified under EATL Phase I. The status report was based on the inputs received from the 15 countries that had originally submitted data under EATL Phase I, which were asked to review and update the related information for each of these projects for the purpose of the current Study. It should be noted that the information sent to each respective country was based on their original input submitted under Phase I, with additional or complementary information received following the formal completion of the EATL Phase I Study. The EATL Phase I Project Status is presented on a country basis below, with respective projects classified under the following four key categories:

- Completed

- Updated and part of the EATL Phase II Study

- Not realized

- No information on the status of the project

\section{Afghanistan}

Afghanistan did not submit information for the EATL Phase I Study.

\section{Armenia}

Armenia proposed 9 projects in total under EATL Phase I:

- 4 road projects (all classified as Priority I)

- 5 rail projects (2 classified as Priority I and 3 classified as Priority IV)

Armenia did not submit revised information. According to the original information:

Table 4.8 - Armenia project status

\begin{tabular}{|c|c|c|c|c|c|c|}
\hline Network & ID & Description & Completed & $\begin{array}{l}\text { Part of EATL } \\
\text { Phase II }\end{array}$ & $\begin{array}{l}\text { Not } \\
\text { realized }\end{array}$ & No info \\
\hline Road & ARM-ROD-01 & $\begin{array}{c}\text { Rehabilitation of: highways and } \\
\text { bridges }\end{array}$ & $\checkmark$ & & & \\
\hline Road & ARM-ROD-02 & $\begin{array}{l}\text { Road maintenance and } \\
\text { rehabilitation (every year) }\end{array}$ & $\checkmark$ & & & \\
\hline Road & ARM-ROD-03 & $\begin{array}{l}\text { Investigation of: } 62 \text { road bridges } \\
\text { and design of documents }\end{array}$ & $\checkmark$ & & & \\
\hline Road & ARM-ROD-04 & Rehabilitation of: 62 road bridges & $\checkmark$ & & & \\
\hline Rail & ARM-RLW-01 & $\begin{array}{l}\text { Rehabilitation of: railway tracks } \\
\qquad(70 \mathrm{~km})\end{array}$ & $\checkmark$ & & & \\
\hline Rail & ARM-RLW-02 & $\begin{array}{l}\text { Investigation of: railway bridges } \\
\text { and design of documents }\end{array}$ & $\checkmark$ & & & \\
\hline Rail & ARM-RLW-03 & Rehabilitation of: railway bridges & & & & ? \\
\hline Rail & ARM-RLW-04 & $\begin{array}{l}\text { Development of: Armenian } \\
\text { Railway: rehabilitation (110 km) }\end{array}$ & & & & ? \\
\hline Rail & ARM-RLW-05 & $\begin{array}{l}\text { Construction of: new railway } \\
\text { (Gavar - Martuni - Jermuk - Sisian } \\
\text { - Kapan - Meghri - Merand (IIR) }\end{array}$ & & & & ? \\
\hline
\end{tabular}




\section{Azerbaijan}

Azerbaijan proposed 10 projects in total under EATL Phase I:

- 7 road projects (all classified as Priority I)

- 1 rail project (classified as Priority I)

- 2 port projects ( 1 classified as Priority I and 1 classified as Priority IV)

According to new information submitted by Azerbaijan:

Table 4.9 - Azerbaijan project status

\begin{tabular}{|c|c|c|c|c|c|c|}
\hline Network & ID & Description & Completed & $\begin{array}{l}\text { Part of EATL } \\
\text { Phase II }\end{array}$ & $\begin{array}{l}\text { Not } \\
\text { realized }\end{array}$ & No info \\
\hline Road & AZT-ROD-01 & $\begin{array}{c}\text { Rehabilitation of: Gazimamad - } \\
\text { Kurdamir, E60 }\end{array}$ & $\checkmark$ & & & \\
\hline Road & AZT-ROD-02 & Rehabilitation of: Kurdamir - Ujar & & $\checkmark$ & & \\
\hline Road & AZT-ROD-03 & Rehabilitation of: Ujar- Yevlakh & $\checkmark$ & & & \\
\hline Road & AZT-ROD-04 & Rehabilitation of: Yevlakh - Gandja & & $\checkmark$ & & \\
\hline Road & AZT-ROD-05 & Rehabilitation of: Ganja - Gazakh & $\checkmark$ & & & \\
\hline Road & AZT-ROD-06 & $\begin{array}{c}\text { Rehabilitation of: Gazakh - Georgian } \\
\text { Border }\end{array}$ & & $\checkmark$ & & \\
\hline Road & AZT-ROD-07 & $\begin{array}{l}\text { Reconstruction of: Russian Federation } \\
\text { border - Baku - Iranian Border, E1 } 19\end{array}$ & & $\checkmark$ & & \\
\hline Rail & AZT-RLW-01 & $\begin{array}{l}\text { Construction of: "North-South" } \\
\text { transport corridor Europe - Asia }\end{array}$ & & & & ? \\
\hline Port & AZT-MAR-01 & $\begin{array}{l}\text { Reconstruction of: Sea station of } \\
\text { International Trade Port of Baku }\end{array}$ & & $\checkmark$ & & \\
\hline Port & AZT-MAR-02 & $\begin{array}{l}\text { Reconstruction of: Ferry Terminal of } \\
\text { International Trade Port of Baku }\end{array}$ & & & & ? \\
\hline
\end{tabular}

\section{Belarus}

Belarus proposed 4 projects in total under EATL Phase I:

- 3 road projects (all classified as Priority I)

- 1 rail project (classified as Priority I)

Belarus did not submit revised information. According to the original information:

Table 4.10 - Belarus project status

\begin{tabular}{|c|c|c|c|c|c|c|}
\hline Network & ID & Description & Completed & $\begin{array}{l}\text { Part of EATL } \\
\text { Phase II }\end{array}$ & $\begin{array}{c}\text { Not } \\
\text { realized }\end{array}$ & No info \\
\hline Road & BL-ROD-01 & $\begin{array}{l}\text { Upgrade of: MI/E30 road, section } \\
\text { from } \mathrm{km} 1.7 \text { to } \mathrm{km} 9.8\end{array}$ & $\checkmark$ & & & \\
\hline Road & BL-ROD-02 & $\begin{array}{l}\text { Upgrade of: M1/E30 road, section } \\
\text { from Telmy to Kozlovichi } 21 \mathrm{~km}\end{array}$ & $\checkmark$ & & & \\
\hline Road & BL-ROD-03 & $\begin{array}{l}\text { Upgrade of: MI/E30 road, section } \\
\text { from } 573 \mathrm{~km} \text { to } 603 \mathrm{~km}\end{array}$ & $\checkmark$ & & & \\
\hline Rail & BL-RLW-01 & $\begin{array}{c}\text { Organization of: speed traffic of } \\
\text { passenger trains (section Krasnoje- } \\
\text { Minsk-Brest) }\end{array}$ & $\sqrt{ }$ & & & \\
\hline
\end{tabular}




\section{Bulgaria}

Bulgaria proposed 24 projects in total under EATL Phase I:

- 15 road projects (12 classified as Priority I and 3 as Priority IV)

- 7 rail projects (all classified as Priority I)

- 1 port project (classified as Priority I)

- 1 inland waterway project (classified as Priority I)

According to new information submitted by Bulgaria:

Table 4.11 - Bulgaria project status

\begin{tabular}{|c|c|c|c|c|c|c|}
\hline Network & ID & Description & Completed & $\begin{array}{l}\text { Part of EATL } \\
\text { Phase II }\end{array}$ & $\begin{array}{l}\text { Not } \\
\text { realized }\end{array}$ & No info \\
\hline Road & BG-ROD-01 & $\begin{array}{l}\text { Construction of: Motorway } \\
\text { "Trakia" Lot } 1\end{array}$ & $\checkmark$ & & & \\
\hline Road & BG-ROD-02 & $\begin{array}{l}\text { Construction of: Motorway } \\
\text { "Trakia" Lot } 5\end{array}$ & $\checkmark$ & & & \\
\hline Road & BG-ROD-03 & $\begin{array}{l}\text { Rehabilitation of: Corridor } 9 \\
\text { Stara Zagora - Kazanlak }\end{array}$ & $\checkmark$ & & & \\
\hline Road & BG-ROD-04 & $\begin{array}{c}\text { Rehabilitation of: Corridor } 4 \\
\text { Sofia - Botevgrad }\end{array}$ & $\checkmark$ & & & \\
\hline Road & BG-ROD-05 & $\begin{array}{l}\text { Rehabilitation of: Corridor } 8 \\
\text { Sliven - Burgas }\end{array}$ & $\checkmark$ & & & \\
\hline Road & BG-ROD-06 & $\begin{array}{c}\text { Rehabilitation of: Corridor } 4 \\
\text { Vidin - Montana }\end{array}$ & $\checkmark$ & & & \\
\hline Road & BG-ROD-07 & $\begin{array}{l}\text { Rehabilitation of: Corridor } 4 \\
\text { Vladaia - Daskalovo } \\
\text { (Express road) }\end{array}$ & $\checkmark$ & & & \\
\hline Road & BG-ROD-08 & $\begin{array}{c}\text { Rehabilitation of: Corridor } 4 \\
\text { Vladaia - Daskalovo } \\
\text { (Ordinary road) }\end{array}$ & $\checkmark$ & & & \\
\hline Road & BG-ROD-09 & $\begin{array}{c}\text { Rehabilitation of: Corridor } 10 \\
\text { Kalotina - Sofia }\end{array}$ & $\checkmark$ & & & \\
\hline Road & BG-ROD-10 & $\begin{array}{c}\text { Rehabilitation of: Corridor } 8 \\
\text { Varna - Burgas }\end{array}$ & $\checkmark$ & & & \\
\hline Road & BG-ROD-11 & $\begin{array}{c}\text { Rehabilitation of: Corridor } 8 \\
\text { Kjustendil - Sofia }\end{array}$ & $\sqrt{ }$ & & & \\
\hline Road & BG-ROD-12 & $\begin{array}{l}\text { Construction of: Corridor } 4 \\
\text { "Liulin" Motorway }\end{array}$ & $\checkmark$ & & & \\
\hline Road & BG-ROD-13 & $\begin{array}{l}\text { Construction of: Motorway } \\
\text { "Trakia" Lot 2, 3, } 4\end{array}$ & & $\checkmark$ & & \\
\hline Road & BG-ROD-14 & $\begin{array}{l}\text { Construction of: Motorway } \\
\text { "Marica" }\end{array}$ & & $\checkmark$ & & \\
\hline Road & BG-ROD-15 & $\begin{array}{l}\text { Construction of: Motorway } \\
\text { "Cherno more" }\end{array}$ & & & & $?$ \\
\hline Rail & BG-RLW-01 & $\begin{array}{l}\text { Electrification and upgrade of: } \\
\text { Plovidiv-Svilengrad railway line } \\
\text { (E070) }\end{array}$ & & $\checkmark$ & & \\
\hline Rail & BG-RLW-02 & $\begin{array}{l}\text { Electrification of: Dragoman- } \\
\text { Kalotina BS railway line (E070) }\end{array}$ & & $\checkmark$ & & \\
\hline Rail & BG -RLW-03 & $\begin{array}{c}\text { Modernization and } \\
\text { electrification of: Radomir- } \\
\text { Gueshevo railway line (T855) }\end{array}$ & & $\checkmark$ & & \\
\hline
\end{tabular}




\begin{tabular}{|c|c|c|c|c|c|c|}
\hline Network & ID & Description & Completed & $\begin{array}{l}\text { Part of EATL } \\
\text { Phase II }\end{array}$ & $\begin{array}{c}\text { Not } \\
\text { realized }\end{array}$ & No info \\
\hline Rail & BG -RLW-04 & $\begin{array}{l}\text { Modernization of } \\
\text { Vidin-Sofia-Kulata railway } \\
\text { line (T056+E855) }\end{array}$ & & $\checkmark$ & & \\
\hline Rail & BG -RLW-05 & $\begin{array}{l}\text { Modernization of: Sofia- } \\
\text { Dragoman railway line }\end{array}$ & & $\checkmark$ & & \\
\hline Rail & BG -RLW-06 & $\begin{array}{l}\text { Modernization of: Sofia- } \\
\text { Plovdiv-Burgas/Varna railway } \\
\text { line (E070+E720+E951) }\end{array}$ & & $\checkmark$ & & \\
\hline Rail & BG -RLW-07 & $\begin{array}{l}\text { Restoration of: design } \\
\text { parameters Sofia-Karlovo- } \\
\text { Zimnitsa railway line }\end{array}$ & & $\checkmark$ & & \\
\hline $\begin{array}{c}\text { Inland } \\
\text { Waterway }\end{array}$ & BG-INW-01 & $\begin{array}{l}\text { Rehabilitation, reconstruction } \\
\text { and modernization of: } \\
\text { port of Lom }\end{array}$ & & $\checkmark$ & & \\
\hline Port & BG-MAR-01 & Expansion of: Port of Bourgas & $\checkmark$ & & & \\
\hline
\end{tabular}

\section{China}

China proposed 8 projects in total under EATL Phase I:

- 6 road projects (classified as Priority I)

- 2 maritime projects (both classified as Priority II)

According to new information submitted by China:

Table 4.12 - China project status

\begin{tabular}{|c|c|c|c|c|c|c|}
\hline Network & ID & Description & Completed & $\begin{array}{l}\text { Part of EATL } \\
\text { Phase II }\end{array}$ & $\begin{array}{l}\text { Not } \\
\text { realized }\end{array}$ & No info \\
\hline Road & & Kashi-Honqilaf Road & $\checkmark$ & & & \\
\hline Road & & Sailimu Lake-Horgos & $\checkmark$ & & & \\
\hline Road & & Road upgrade: Kuerle-Akesu (AH4) & & & & $?$ \\
\hline Road & & Road upgrade: Akesu-Atushi(AH4) & & & & $?$ \\
\hline Road & & $\begin{array}{l}\text { Road upgrade: Kashi-Irkestan Road } \\
\text { AH65 }\end{array}$ & & $\checkmark$ & & \\
\hline Road & & Wuqia-Turgart AH61 & $\checkmark$ & & & \\
\hline Port & & $\begin{array}{c}\text { Container berths in Phase Three of } \\
\text { Miaoling, Lian Yungang }\end{array}$ & $\checkmark$ & & & \\
\hline Port & & Alumina berth of Lian Yungang & & & & $?$ \\
\hline
\end{tabular}

\section{Georgia}

Georgia proposed 49 projects in total under EATL Phase I:

- 4 road projects (all classified as Priority I) which were completed

- 21 rail projects (all classified as Priority IV)

- 24 port projects (all classified as Priority IV)

According to new information submitted by Georgia:

- All road projects were completed.

- The majority of rail projects was either completed or not realized (2 projects were submitted under EATL Phase II).

- No information was given on port projects. 


\section{Iran}

Iran proposed 44 projects in total under EATL Phase I:

- 34 road projects ( 31 classified as Priority I, 2 as Priority II and 3 as Priority III)

- 10 rail projects ( 5 classified as Priority I, 3 as Priority II and 2 as Priority III)

Iran did not submit revised information. According to the original information:

Table 4.13 - Iran project status

\begin{tabular}{|c|c|c|c|c|c|c|}
\hline Network & ID & Description & Completed & $\begin{array}{l}\text { Part of EATL } \\
\text { Phase II }\end{array}$ & $\begin{array}{l}\text { Not } \\
\text { realized }\end{array}$ & No info \\
\hline Road & IR-ROD-01 & Upgrading of: Astara - Rasht & $\checkmark$ & & & \\
\hline Road & IR-ROD-02 & Upgrading of: Anzali - Rasht & $\checkmark$ & & & \\
\hline Road & IR-ROD-03 & Construction of: Rasht - Qazvin & $\checkmark$ & & & \\
\hline Road & IR-ROD-04 & Construction of: Qazvin - Saveh & & & & $?$ \\
\hline Road & IR-ROD-05 & $\begin{array}{c}\text { Construction of: Ahvaz - Bandar } \\
\text { Emam }\end{array}$ & & & & $?$ \\
\hline Road & IR-ROD-06 & Rehabilitation of: Naeen-Ardekan & $\checkmark$ & & & \\
\hline Road & IR-ROD-07 & Rehabilitation of: Ardekan - Yazd & $\checkmark$ & & & \\
\hline Road & IR-ROD-08 & Rehabilitation of: Mehriz - Anar & $\checkmark$ & & & \\
\hline Road & IR-ROD-09 & Rehabilitation of: Anar - Sirjan & $\checkmark$ & & & \\
\hline Road & IR-ROD-10 & $\begin{array}{c}\text { Construction of: Sirjan - Bandar } \\
\text { Abbas }\end{array}$ & & & & $?$ \\
\hline Road & IR-ROD-11 & $\begin{array}{l}\text { Rehabilitation of: Sirjan - Bandar } \\
\text { Abbas (Accomplished) }\end{array}$ & $\checkmark$ & & & \\
\hline Road & IR-ROD-12 & Upgrade of: Semnan - Damghan & $\checkmark$ & & & \\
\hline Road & IR-ROD-13 & Construction of: Jandagh - Ardekan & $\checkmark$ & & & \\
\hline Road & IR-ROD-14 & Upgrade of: Sarakhs - Sangbast & $\sqrt{ }$ & & & \\
\hline Road & IR-ROD-15 & $\begin{array}{l}\text { Upgrade of: Baghcheh - Torbat } \\
\text { Heydarieh }\end{array}$ & $\checkmark$ & $\checkmark$ & & \\
\hline Road & IR-ROD-16 & $\begin{array}{c}\text { Construction of: Torbat Heydarieh - } \\
\text { Gonabad }\end{array}$ & & $\checkmark$ & & \\
\hline Road & IR-ROD-17 & Upgrade of: Gonabad - Birjand & & $\checkmark$ & & \\
\hline Road & IR-ROD-18 & Rehabilitation of: Zahedan - Khash & $\checkmark$ & & & \\
\hline Road & IR-ROD-19 & Rehabilitation of: Khash - Iranshahr & & $\checkmark$ & & \\
\hline Road & IR-ROD-20 & Construction of: Iranshahr - Chabahar & $\checkmark$ & & & \\
\hline Road & IR-ROD-21 & Upgrade of: Shahreza - Shiraz & $\checkmark$ & & & \\
\hline Road & IR-ROD-22 & Rehabilitation of: Jolfa - Eyvoghli & $\checkmark$ & & & \\
\hline Road & IR-ROD-23 & Rehabilitation of: Eyvoghli - Marand & $\sqrt{ }$ & & & \\
\hline Road & IR-ROD-24 & Rehabilitation of: Marand - Tabriz & $\checkmark$ & & & \\
\hline Road & IR-ROD-25 & Rehabilitation of: Tabriz - Bostanabad & $\checkmark$ & & & \\
\hline Road & IR-ROD-26 & Construction of: Tabriz - Zanjan & $\checkmark$ & & & \\
\hline Road & IR-ROD-27 & Upgrade of: Damghan - Sabzevar & $\checkmark$ & & & \\
\hline Road & IR-ROD-28 & Upgrade of: Sabzevar - Baghcheh & $\checkmark$ & & & \\
\hline Road & IR-ROD-29 & Upgrade of: Anar - Baghein & $\checkmark$ & & & \\
\hline
\end{tabular}




\begin{tabular}{|c|c|c|c|c|c|c|}
\hline Network & ID & Description & Completed & $\begin{array}{c}\text { Part of EATL } \\
\text { Phase II }\end{array}$ & $\begin{array}{c}\text { Not } \\
\text { realized }\end{array}$ & No info \\
\hline Road & IR-ROD-30 & $\begin{array}{c}\text { Rehabilitation of: Sangbast - } \\
\text { Dogharun }\end{array}$ & $\checkmark$ & & \\
\hline Road & IR-ROD-31 & Upgrading of: Qazvin - Saveh & $\checkmark$ & & & \\
\hline Road & IR-ROD-32 & $\begin{array}{c}\text { Construction of: Khorramabad - } \\
\text { Andimeshk }\end{array}$ & & & & \\
\hline Road & IR-ROD-33 & Upgrade of: Sirjan - Bandar Abbas & $\checkmark$ & & & \\
\hline Road & IR-ROD-34 & Construction of: Bazargan - Tabriz & & $\checkmark$ & & \\
\hline Rail & IR-RLW-01 & Construction of: Anzali - Rasht & & $\checkmark$ & & \\
\hline Rail & IR-RLW-02 & Construction of: Rasht - Qazvin & $\checkmark$ & & & \\
\hline Rail & IR-RLW-03 & Construction of: Esfahan - Shiraz & $\checkmark$ & & & \\
\hline Rail & IR-RLW-04 & Construction of: Tabriz - Mianeh & $\checkmark$ & & & \\
\hline Rail & IR-RLW-05 & Construction of: Bam - Zahedan & $\checkmark$ & & & \\
\hline Rail & IR-RLW-06 & Construction of: Astara - Rasht & & $\checkmark$ & $\checkmark$ & \\
\hline Rail & IR-RLW-07 & Construction of: Bam - Chabahar & & $\checkmark$ & & \\
\hline Rail & IR-RLW-08 & Construction of: Zahedan - Mirjaveh & & & & \\
\hline Rail & IR-RLW-09 & Construction of: Shiraz - Bushehr & & & & \\
\hline Rail & IR-RLW-10 & $\begin{array}{c}\text { Construction and upgrade of: Tehran } \\
\text { - Esfahan }\end{array}$ & & & \\
\hline
\end{tabular}

\section{Kazakhstan}

Kazakhstan proposed 14 projects in total under EATL Phase I:

- 14 road projects (all classified as Priority I)

According to new information submitted by Kazakhstan, all projects were completed.

Table 4.14 - Kazakhstan project status

\begin{tabular}{|c|c|c|c|c|c|c|}
\hline Network & ID & Description & Completed & $\begin{array}{l}\text { Part of EATL } \\
\text { Phase II }\end{array}$ & $\begin{array}{l}\text { Not } \\
\text { realized }\end{array}$ & No info \\
\hline Road & KZ-ROD-01 & $\begin{array}{l}\text { Rehabilitation of: motorway } \\
\text { Almaty - Gulshad on the sections } \\
\text { Almaty - Gulshad, Akchatau - } \\
\text { Karagandy }\end{array}$ & $\checkmark$ & & & \\
\hline Road & KZ-ROD-02 & $\begin{array}{l}\text { Reconstruction of: passage } \\
\text { through Karagandy }\end{array}$ & $\checkmark$ & & & \\
\hline Road & KZ-ROD-03 & $\begin{array}{l}\text { Rehabilitation of: motorway } \\
\text { Karagandy-Astana }\end{array}$ & $\checkmark$ & & & \\
\hline Road & KZ-ROD-04 & $\begin{array}{l}\text { Reconstruction of: highway } \\
\text { network in Western Kazakhstan }\end{array}$ & $\checkmark$ & & & \\
\hline Road & KZ-ROD-05 & $\begin{array}{l}\text { Development of: highway system } \\
\text { (Almaty-Bishkek) }\end{array}$ & $\checkmark$ & & & \\
\hline Road & KZ-ROD-06 & $\begin{array}{c}\text { Reconstruction of: motorway } \\
\text { Aktau - Atyrau }\end{array}$ & $\checkmark$ & & & \\
\hline Road & KZ-ROD-07 & $\begin{array}{l}\text { Reconstruction of: motorway } \\
\text { Astana-Kostanai-Chelyabinsk }\end{array}$ & $\checkmark$ & & & \\
\hline Road & KZ-ROD-08 & $\begin{array}{l}\text { Reconstruction of: motorway } \\
\text { Omsk-Pavlodar-Maikapchagai }\end{array}$ & $\checkmark$ & & & \\
\hline
\end{tabular}




\begin{tabular}{|c|c|c|c|c|c|c|}
\hline Network & ID & Description & Completed & $\begin{array}{l}\text { Part of EATL } \\
\text { Phase II }\end{array}$ & $\begin{array}{l}\text { Not } \\
\text { realized }\end{array}$ & No info \\
\hline Road & KZ-ROD-09 & $\begin{array}{l}\text { Reconstruction of: motorway } \\
\text { Borovoye-Kokshetau- } \\
\text { Petropavlovsk- border of RF }\end{array}$ & $\checkmark$ & & & \\
\hline Road & KZ-ROD-10 & $\begin{array}{c}\text { Reconstruction of: motorway } \\
\text { border of the RF - Uralsk - } \\
\text { Aktobe }\end{array}$ & $\checkmark$ & & & \\
\hline Road & KZ-ROD-11 & $\begin{array}{l}\text { Reconstruction of: motorway } \\
\text { Karabutak - Irghiz - border of } \\
\text { Kyzylordinskaya oblast }\end{array}$ & $\checkmark$ & & & \\
\hline Road & KZ-ROD-12 & $\begin{array}{l}\text { Reconstruction of: motorway } \\
\text { Kyzylorda - Zhezkazgan - } \\
\text { Pavlodar - Uspenka - } \\
\text { border of the RF }\end{array}$ & $\checkmark$ & & & \\
\hline Road & KZ-ROD-13 & $\begin{array}{c}\text { Reconstruction of: motorway } \\
\text { Usharal - Dostyk }\end{array}$ & $\checkmark$ & & & \\
\hline Road & KZ-ROD-14 & $\begin{array}{c}\text { Reconstruction of: motorway } \\
\text { border of Uzbekistan - (towards } \\
\text { Tashkent) - Shymkent - } \\
\text { Taraz - Almaty - Khorgos }\end{array}$ & $\checkmark$ & & & \\
\hline
\end{tabular}

\section{Kyrgyzstan}

Kyrgyzstan proposed 7 projects in total under EATL Phase I:

- 6 road projects (all classified as Priority I)

- 1 rail project (classified as Priority IV)

According to new information submitted by Kyrgyzstan, all projects were completed.

Table 4.15 - Kyrgyzstan project status

\begin{tabular}{|c|c|c|c|c|c|c|}
\hline Network & ID & Description & Completed & $\begin{array}{c}\text { Part of EATL } \\
\text { Phase II }\end{array}$ & $\begin{array}{l}\text { Not } \\
\text { realized }\end{array}$ & No info \\
\hline Road & KG-ROD-01 & $\begin{array}{l}\text { Rehabilitation of: } \\
\text { ща motorway Bishkek-Osh }\end{array}$ & $\checkmark$ & & & \\
\hline Road & KG-ROD-02 & $\begin{array}{l}\text { Section ща motorway } \\
\text { (61-161 km), incl. tunnel } \\
\text { at the Too-Ashoo crossing }\end{array}$ & $\checkmark$ & & & \\
\hline Road & KG-ROD-03 & $\begin{array}{c}\text { Section ща motorway } \\
(247-324 \mathrm{~km} ; 360-414 \mathrm{~km})\end{array}$ & $\checkmark$ & & & \\
\hline Road & KG-ROD-04 & $\begin{array}{c}\text { Section motorway } \\
(426-498 \mathrm{~km}, 614-664 \mathrm{~km})\end{array}$ & $\checkmark$ & & & \\
\hline Road & KG-ROD-05 & $\begin{array}{l}\text { Rehabilitation of: motorway } \\
\text { Jalal-Abad - Uzgen and } \\
\text { detour station Madaniyat' }\end{array}$ & $\checkmark$ & & & \\
\hline Road & KG-ROD-06 & $\begin{array}{l}\text { Rehabilitation of: motorway } \\
\text { Bishkek-Georgevka' }\end{array}$ & $\checkmark$ & & & \\
\hline Rail & KG-RLW-01 & New Rolling Stock & $\checkmark$ & & & \\
\hline
\end{tabular}




\section{Republic of Moldova}

The Republic of Moldova proposed 9 projects in total under EATL Phase I:

- 5 road projects (all classified as Priority IV)

- 3 rail projects ( 1 classified as Priority I, 2 as Priority IV)

- 1 inland waterway project (classified as Priority I)

The Republic of Moldova did not submit revised information. According to the original information:

\section{Table 4.16 - Republic of Moldova project status}

\begin{tabular}{|c|c|c|c|c|c|c|c|}
\hline Network & ID & & Description & Completed & $\begin{array}{l}\text { Part of EATL } \\
\text { Phase II }\end{array}$ & $\begin{array}{l}\text { Not } \\
\text { realized }\end{array}$ & No info \\
\hline Road & MD-ROD-01 & $\begin{array}{l}\text { Improvement of: Road } \\
\text { and roadside services } \\
\text { along the Moldovan } \\
\text { component of Corridor IX } \\
\text { by modernizing an 18-km } \\
\text { Chişinău bypass }\end{array}$ & & & $\checkmark$ & & \\
\hline Road & MD-ROD-02 & $\begin{array}{l}\text { Improvement of: Road and } \\
\text { roadside services along a } \\
153-\mathrm{km} \text { road on border } \\
\text { with Romania - Leuşeni - } \\
\text { Chişinău - Dubăsari - the } \\
\text { border with Ukraine }\end{array}$ & & & $\checkmark$ & & \\
\hline Road & MD-ROD-03 & $\begin{array}{l}\text { Improvement of: } 217-\mathrm{km} \\
\text { road Chişinău - Cimislia } \\
\text { - Comrat - Vulcăneţti - } \\
\text { Giurgiuleşti - the border } \\
\text { with Romania }\end{array}$ & & & $\checkmark$ & & \\
\hline Road & MD-ROD-04 & $\begin{array}{l}\text { Rehabilitation of: } 68-\mathrm{km} \\
\text { road Sarateni Vechi - Bălţi }\end{array}$ & & & $\checkmark$ & & \\
\hline Road & MD-ROD-05 & $\begin{array}{l}\text { Rehabilitation of: } 136-\mathrm{km} \\
\text { road Bălţi - Criva }\end{array}$ & & & $\checkmark$ & & \\
\hline Rail & MD-RLW-01 & $\begin{array}{l}\text { Construction of: } 44-\mathrm{km} \\
\text { railway line Revaca- } \\
\text { Cainari (a missing link } \\
\text { between the Moldovan } \\
\text { components of Corridor IX, } \\
\text { CE-95 and } \\
\text { E-560 main lines) }\end{array}$ & & & $\checkmark$ & & \\
\hline Rail & MD-RLW-02 & $\begin{array}{l}\text { Electrification of: } 211-\mathrm{km} \\
\text { railway line on border } \\
\text { with Ukraine - Bender - } \\
\text { Chişinău - Ungheni - the } \\
\text { border with Romania }\end{array}$ & & & $\checkmark$ & & \\
\hline Rail & MD-RLW-03 & $\begin{array}{l}\text { Construction of: } 54-\mathrm{km} \\
\text { railway line Cahul - } \\
\text { Giurgiuleşti }\end{array}$ & & & $\checkmark$ & & \\
\hline $\begin{array}{l}\text { Inland } \\
\text { Waterway }\end{array}$ & MD-INW-01 & $\begin{array}{l}\text { Construction of: } \\
\text { Giurgiuleşti port complex } \\
\text { on the territory of the } \\
\text { Republic of Moldova at the } \\
\text { mouth of the Danube river, } \\
\text { including the terminal } \\
\text { of oil product processing } \\
\text { and a new oil refinery }\end{array}$ & & & $\checkmark$ & & \\
\hline
\end{tabular}




\section{Romania}

Romania proposed 12 projects in total under EATL Phase I:

- 7 port projects ( 3 classified as Priority I and 4 classified as Priority IV)

- 5 inland waterway projects ( 3 classified as Priority I, 1 as Priority II and 1 as Priority IV)

According to new information submitted by Romania:

Table 4.17 - Romania project status

\begin{tabular}{|c|c|c|c|c|c|c|}
\hline Network & ID & Description & Completed & $\begin{array}{l}\text { Part of EATL } \\
\text { Phase II }\end{array}$ & $\begin{array}{l}\text { Not } \\
\text { realized }\end{array}$ & No info \\
\hline Port & RO-MAR-01 & $\begin{array}{l}\text { Construction of: Container } \\
\text { Terminal on Pier II S }\end{array}$ & $\checkmark$ & & & \\
\hline Port & RO-MAR-02 & $\begin{array}{l}\text { Construction of: } \\
\text { Passenger Terminal }\end{array}$ & $\checkmark$ & & & \\
\hline Port & RO-MAR-03 & $\begin{array}{l}\text { Constanta Port Environment } \\
\text { and Infrastructure project }\end{array}$ & $\checkmark$ & & & \\
\hline Port & RO-MAR-04 & $\begin{array}{c}\text { Extension of: North } \\
\text { Breakwater in Constanta Port }\end{array}$ & & $\checkmark$ & & \\
\hline Port & RO-MAR-05 & $\begin{array}{l}\text { Construction of: } \\
\text { Cereal Terminal }\end{array}$ & $\checkmark$ & & & \\
\hline Port & RO-MAR-06 & $\begin{array}{l}\text { Construction of: } \\
\text { Liquid Gas Terminal }\end{array}$ & & & & ? \\
\hline Port & RO-MAR-07 & $\begin{array}{c}\text { Construction of: Mineral } \\
\text { Oil Terminal }\end{array}$ & & & & ? \\
\hline $\begin{array}{c}\text { Inland } \\
\text { Waterway }\end{array}$ & RO-INW-01 & $\begin{array}{l}\text { Bank protection of: Sulina } \\
\text { Channel. Signalling and } \\
\text { topohydrographical } \\
\text { Measurements system } \\
\text { on the Danube }\end{array}$ & & $\checkmark$ & & \\
\hline $\begin{array}{l}\text { Inland } \\
\text { Waterway }\end{array}$ & RO-INW-02 & $\begin{array}{c}\text { Improvement of: Condition for } \\
\text { Navigation on the Danube, } \\
\text { km 375-175, Calarasi -Braila } \\
\text { sector }\end{array}$ & & $\checkmark$ & & \\
\hline $\begin{array}{l}\text { Inland } \\
\text { Waterway }\end{array}$ & RO-INW-03 & $\begin{array}{l}\text { Implementation of: VTMIS } \\
\text { (Vessel Traffic Management } \\
\text { Information System on } \\
\text { Danube, Romanian sector }\end{array}$ & & $\checkmark$ & & \\
\hline $\begin{array}{l}\text { Inland } \\
\text { Waterway }\end{array}$ & RO-INW-04 & $\begin{array}{l}\text { Activation and development } \\
\text { of: river maritime - } \\
\text { sector in Constanta Port }\end{array}$ & & $\checkmark$ & & \\
\hline $\begin{array}{c}\text { Inland } \\
\text { Waterway }\end{array}$ & RO-INW-05 & $\begin{array}{l}\text { Improvement of: Navigation } \\
\text { on the Danube, } \\
\mathrm{km} 875-375 \text {, Romanian - } \\
\text { Bulgarian sector }\end{array}$ & & $\checkmark$ & & \\
\hline
\end{tabular}




\section{Russian Federation}

The Russian Federation did not submit information for the EATL Phase I Study.

\section{Tajikistan}

Tajikistan proposed 5 projects in total under EATL Phase I:

- 4 road projects (all classified as Priority IV)

- 1 rail project (classified as Priority IV)

Tajikistan did not submit revised information. According to the original information, all projects should have been completed.

Table 4.18 - Tajikistan project status

\begin{tabular}{|c|c|c|c|c|c|c|}
\hline Network & ID & Description & Completed & $\begin{array}{l}\text { Part of EATL } \\
\text { Phase II }\end{array}$ & $\begin{array}{l}\text { Not } \\
\text { realized }\end{array}$ & No info \\
\hline Road & TJK-ROD-01 & $\begin{array}{c}\text { Rehabilitation and } \\
\text { reconstruction of: highway } \\
\text { Qurghonteppa- } \\
\text { Dusti-Nizhniy Panj }\end{array}$ & $\checkmark$ & & & \\
\hline Road & TJK-ROD-02 & $\begin{array}{l}\text { Investment project } \\
\text { Dushanbe - Termez }\end{array}$ & $\checkmark$ & & & \\
\hline Road & TJK-ROD-03 & $\begin{array}{c}\text { Post Fotekhobod, Buston, } \\
\text { Sogd region }\end{array}$ & $\checkmark$ & & & \\
\hline Road & TJK-ROD-04 & Post Bratstvo Tursun-zoda & $\checkmark$ & & & \\
\hline Rail & TJK-RLW-01 & $\begin{array}{l}\text { Improvement of: regional } \\
\text { railway Bekobod - } \\
\text { Konibodom } \\
\text { (Republic of Tajikistan) }\end{array}$ & $\checkmark$ & & & \\
\hline
\end{tabular}

\section{Turkey}

Turkey proposed 23 projects in total under EATL Phase I:

- 12 road projects ( 7 classified as Priority I and 5 classified as Priority III)

- 7 rail projects (2 classified as Priority I and 5 as Priority II)

- 4 port projects (all classified as Priority IV)

According to new information submitted by Turkey:

Table 4.19 - Turkey project status

\begin{tabular}{|c|c|c|c|c|c|c|}
\hline Network & ID & Description & Completed & $\begin{array}{l}\text { Part of EATL } \\
\text { Phase II }\end{array}$ & $\begin{array}{l}\text { Not } \\
\text { realized }\end{array}$ & No info \\
\hline Road & TU-ROD-01 & $\begin{array}{l}\text { Upgrade of: Sarp Border } \\
\text { Gate to Piraziz }\end{array}$ & $\checkmark$ & & & \\
\hline Road & TU-ROD-02 & Upgrade of: Piraziz to Ünye & $\checkmark$ & & & \\
\hline Road & TU-ROD-03 & Upgrade of: Ünye to Çarşamba & $\checkmark$ & & & \\
\hline Road & TU-ROD-04 & Upgrade of: Samsun to Kavak & $\checkmark$ & & & \\
\hline Road & TU-ROD-05 & Upgrade of: Kavak to Merzifon & $\checkmark$ & & & \\
\hline Road & TU-ROD-06 & $\begin{array}{c}\text { Upgrade of: Koyulhisar to Niksar } \\
\text { Junction }\end{array}$ & & $\checkmark$ & & \\
\hline Road & TU-ROD-07 & $\begin{array}{l}\text { Upgrade of: Niksar } \\
\text { Junction to Amasya }\end{array}$ & & $\checkmark$ & & \\
\hline
\end{tabular}




\begin{tabular}{|c|c|c|c|c|c|c|}
\hline Network & ID & Description & Completed & $\begin{array}{l}\text { Part of EATL } \\
\text { Phase II }\end{array}$ & $\begin{array}{l}\text { Not } \\
\text { realized }\end{array}$ & No info \\
\hline Road & TU-ROD-08 & $\begin{array}{c}\text { Upgrade of: Gerede-15.Divison } \\
\text { Border }\end{array}$ & & $\checkmark$ & & \\
\hline Road & TU-RO-09 & $\begin{array}{l}\text { Upgrade of: 15.Division } \\
\text { Border to Osmancık }\end{array}$ & & $\checkmark$ & & \\
\hline Road & TU-ROD-10 & $\begin{array}{c}\text { Upgrade of: Osmancık-Saraycık } \\
\text { to Merzifon }\end{array}$ & & $\checkmark$ & & \\
\hline Road & TU-ROD-11 & $\begin{array}{c}\text { Upgrade of: } 4 \text {.Division Border- } \\
\text { Kurşunlu-llgaz to (Kastamonu - } \\
\text { Korgun) Junction }\end{array}$ & & $\checkmark$ & & \\
\hline Road & TU-ROD-12 & $\begin{array}{l}\text { Upgrade of: (Kastamonu -Korgun) } \\
\text { Junction -Tosya to 7.Division Border }\end{array}$ & & $\checkmark$ & & \\
\hline Rail & TU-RLW-01 & $\begin{array}{l}\text { Construction of: Ankara-Istanbul } \\
\text { High-Speed Railway (PHASE 1) }\end{array}$ & & $\checkmark$ & & \\
\hline Rail & TU-RLW-01 & $\begin{array}{l}\text { Construction of: Ankara-Istanbul } \\
\text { High-Speed Railway (PHASE 2) }\end{array}$ & & $\checkmark$ & & \\
\hline Rail & TU-RLW-02 & $\begin{array}{l}\text { Istanbul } 145 \text { Rail Tunnel Crossing and } \\
\text { rehabilitation of: Gebze-Halkalı } \\
\text { Railway Line }\end{array}$ & & $\checkmark$ & & \\
\hline Rail & TU-RLW-03 & $\begin{array}{c}\text { Signalling and telecommunication: } \\
\text { Boğazköprü-Ulukışla-Yenice-Mersin- } \\
\text { Adana-Toprakkale }\end{array}$ & & $\checkmark$ & & \\
\hline Rail & TU-RLW-04 & $\begin{array}{c}\text { Construction of: Ankara- Sivas New } \\
\text { Railway }\end{array}$ & & $\checkmark$ & & \\
\hline Rail & TU-RLW-05 & $\begin{array}{c}\text { Construction of: Kars-Tblisi } \\
\text { New Railway }\end{array}$ & & $\checkmark$ & & \\
\hline Rail & TU-RLW-06 & $\begin{array}{c}\text { Construction of: Lake Van Northern } \\
\text { Crossing }\end{array}$ & & $\checkmark$ & & \\
\hline Port & TU-MAR-01 & Rehabilitation of: Port of Derince & $\checkmark$ & & & \\
\hline Port & TU-MAR-02 & $\begin{array}{c}\text { Modernization of facilities at: İzmir } \\
\text { port and dredging in: } \\
\text { İzmir Bay }\end{array}$ & $\checkmark$ & & & \\
\hline Port & TU-MAR-03 & $\begin{array}{l}\text { Construction of: second } \\
\text { container terminal at Mersin Port }\end{array}$ & & $\checkmark$ & & \\
\hline Port & TU-MAR-04 & $\begin{array}{c}\text { Construction of: container terminal } \\
\text { at İskenderun Port }\end{array}$ & & & $\checkmark$ & \\
\hline
\end{tabular}

\section{Turkmenistan}

Turkmenistan did not submit information for the EATL Phase I Study.

${ }^{45}$ For further clarification on the subject, see official communications received by the Governments of the Russian Federation and Turkey, as well as the extract of document ECE/TRANS/SC.2/GEURL/2011/9 of the Working Party on Rail Transport, Group of Experts towards Unified Railway Law, the Report of the Group of Experts at its second session in Geneva, held on 7 October 2011 (this can be found in Annex I of this document). 


\section{Ukraine}

Ukraine proposed 7 projects in total under EATL Phase I:

- 2 rail projects (classified as Priority I)

- 1 port project (classified as Priority I)

- 4 inland waterway projects (2 classified as Priority I and 2 as Priority IV)

Ukraine did not submit revised information. According to the original information:

\section{Table 4.20 - Ukraine project status}

\begin{tabular}{|c|c|c|c|c|c|c|}
\hline Network & ID & Description & Completed & $\begin{array}{l}\text { Part of EATL } \\
\text { Phase II }\end{array}$ & $\begin{array}{c}\text { Not } \\
\text { realized }\end{array}$ & No info \\
\hline Rail & UKR-RLW-01 & $\begin{array}{l}\text { Development of: Ukrainian rails purchase } \\
\text { of modern track technique } \\
\text { for modernization and maintenance } \\
\text { of track at section Lvov - Schmerinka-Kyiv }\end{array}$ & $\checkmark$ & & & \\
\hline Rail & UKR-RLW-02 & $\begin{array}{l}\text { High-speed passenger traffic at } \\
\text { Ukrainian rails. Building of: Beskidskiy } \\
\text { tunnel (Pan-European Transport } \\
\text { Corridor №5); passenger coach } \\
\text { purchase; track technique purchase }\end{array}$ & $\checkmark$ & & & \\
\hline Port & UKR-MAR-01 & $\begin{array}{l}\text { Trade port Illichevsk, } \\
\text { multimodal terminal }\end{array}$ & & & & $?$ \\
\hline $\begin{array}{c}\text { Inland } \\
\text { Waterway }\end{array}$ & UKR-INW-01 & \begin{tabular}{|} 
Pan-European Transport Corridor № 3 \\
Dnipro- Visla -Oder (including Dnipro \\
deep-way - Dnipro mouth -Pripiyat \\
mouth) - 1000 km, Pripiyat- Dnipro- \\
Bygskiy channel - Western Byg until the \\
Western Byg flows into the Visla - \\
$1026 \mathrm{~km}$; Visla waterway - \\
Budgoschuskiy channel -Odra - $554 \mathrm{~km}$
\end{tabular} & & & & $?$ \\
\hline $\begin{array}{l}\text { Inland } \\
\text { Waterway }\end{array}$ & UKR-INW-02 & $\begin{array}{c}\text { Pan-European Transport Corridor № 9, } \\
\text { North - South Western } \\
\text { Dvina (Dyagava) -Dnipro }\end{array}$ & & & & $?$ \\
\hline $\begin{array}{c}\text { Inland } \\
\text { Waterway }\end{array}$ & UKR-INW-03 & $\begin{array}{l}\text { Pan-European Transport Corridor } \\
\text { № } 7 \text { Rein-Main-Dynai Dynai - Black Sea }\end{array}$ & & & & ? \\
\hline $\begin{array}{c}\text { Inland } \\
\text { Waterway }\end{array}$ & UKR-INW-04 & $\begin{array}{c}\text { Deep-water navigable Dynai and } \\
\text { Black Sea connection (Dynai mouth } \\
\text { at the territory of Ukraine, } \\
\text { Odesskiy region) }\end{array}$ & & & & $?$ \\
\hline
\end{tabular}

\section{Uzbekistan}

Uzbekistan proposed 15 projects in total under EATL Phase I:

- 5 road projects (classified as Priority I)

- 8 rail projects ( 5 classified as Priority I and 3 classified as Priority III)

- 2 port projects ( 1 classified as Priority I and 1 classified as Priority IV)

Uzbekistan did not submit revised information. According to the original information:

Table 4.21 - Uzbekistan project status

\begin{tabular}{|c|c|c|c|c|c|c|} 
Network & ID & Description & Completed & $\begin{array}{c}\text { Part of EATL } \\
\text { Phase II }\end{array}$ & $\begin{array}{c}\text { Not } \\
\text { realized }\end{array}$ & No info \\
\hline Road & UZB-ROD-01 & $\begin{array}{c}\text { Rehabilitation and reconstruction } \\
\text { of: } 152 \text { km of Samarkand-Termez } \\
\text { road (section of TransAfghan } \\
\text { international transport Corridor) }\end{array}$ & $\checkmark$ & & \\
\hline
\end{tabular}




\begin{tabular}{|c|c|c|c|c|c|c|}
\hline Network & ID & Description & Completed & $\begin{array}{c}\text { Part of EATL } \\
\text { Phase II }\end{array}$ & $\begin{array}{l}\text { Not } \\
\text { realized }\end{array}$ & No info \\
\hline Road & UZB-ROD-02 & $\begin{array}{l}\text { Construction and reconstruction } \\
\text { works of: road sections Ukraine } \\
\text { border-Volgograd-Astrahan- } \\
\text { Atirau-Beineu-Tashkent highway } \\
\text { (main section of international } \\
\text { transport Corridor E-40) }\end{array}$ & $\checkmark$ & & & \\
\hline Road & UZB-ROD-03 & $\begin{array}{l}\text { Feasibility study and } \\
\text { reconstruction and rehabilitation } \\
\text { works of: } 500 \mathrm{~km} \text { of Kungrad- } \\
\text { Jaslik-Beineu road }\end{array}$ & $\checkmark$ & & & \\
\hline Road & UZB-ROD-04 & $\begin{array}{l}\text { Construction and rehabilitation of: } \\
\text { Tashkent-Andijan-Osh-Saritash- } \\
\text { Irkeshtam-Kashgar road } 940 \text { km }\end{array}$ & & & & $?$ \\
\hline Road & UZB-ROD-05 & $\begin{array}{l}\text { Rehabilitation of: } 125 \mathrm{~km} \text { of } \\
\text { Angren-Pap mountain road }\end{array}$ & & & & $?$ \\
\hline Rail & UZB-RLW-01 & $\begin{array}{l}\text { Reconstruction of: } 341 \mathrm{~km} \text { of } \\
\text { railroad, and laying of fibre line } \\
\text { (Samarkand-Hodjadavlet) }\end{array}$ & $\checkmark$ & & & \\
\hline Rail & UZB-RLW-02 & $\begin{array}{l}\text { Construction of: } 232 \mathrm{~km} \text { of } \\
\text { railroad, and } 68 \mathrm{~km} \text { of railroad } \\
\text { Reconstruction Tasgguzar- } \\
\text { Boysun-Kumkurgan }\end{array}$ & $\checkmark$ & & & \\
\hline Rail & UZB-RLW-03 & $\begin{array}{l}\text { Electrification of } 114 \mathrm{~km} \text { of } \\
\text { railroad line Tukimachi-Angren }\end{array}$ & $\checkmark$ & & & \\
\hline Rail & UZB-RLW-04 & $\begin{array}{l}\text { Reconstruction of: } 139 \mathrm{~km} \text { of } \\
\text { railroad line Marokand-Karshi }\end{array}$ & & $\checkmark$ & & \\
\hline Rail & UZB-RLW-05 & $\begin{array}{l}\text { Reconstruction of: railroad station } \\
\text { Termez-Galaba, including bridge } \\
\text { through the river Amudarya } \\
\text { laying telecommunication links }\end{array}$ & $\checkmark$ & & & \\
\hline Rail & UZB-RLW-06 & $\begin{array}{l}\text { Construction and electrification of: } \\
118 \mathrm{~km} \text { new railroad Angren-Pap } \\
\text { line with mountain tunnel }\end{array}$ & & & & $?$ \\
\hline Rail & UZB-RLW-07 & $\begin{array}{l}\text { Reconstruction of: } 79 \mathrm{~km} \text { of } \\
\text { Dialalabad-Karasu-Andijan } \\
\text { railroad section }\end{array}$ & & & & $?$ \\
\hline Rail & UZB-RLW-08 & $\begin{array}{l}\text { Reconstruction of: } 700 \mathrm{~km} \text { of } \\
\text { Aktau-Beineu-Kungrad railroad } \\
\text { section }\end{array}$ & & & & $?$ \\
\hline $\begin{array}{l}\text { Freight } \\
\text { Terminal }\end{array}$ & UZB-INM-01 & $\begin{array}{l}\text { Construction of: Karakalpaliya } \\
\text { customs control complex, which } \\
\text { will control rail and } \\
\text { road transportation }\end{array}$ & & & & $?$ \\
\hline $\begin{array}{l}\text { Freight } \\
\text { Terminal }\end{array}$ & UZB-INM-02 & $\begin{array}{l}\text { Modernization and supply with } \\
\text { a modern equipment of: country } \\
\text { customs control complexes } \\
\text { and main customs points }\end{array}$ & $\checkmark$ & & & \\
\hline
\end{tabular}




\subsubsection{Summary results}

Table 4.22 presents a summary of the status of projects submitted under EATL Phase I from the countries that offered data.

According to the summary results:

- 53 per cent of projects were completed.

- 25 per cent of projects became part of EATL Phase II.

- 3 per cent of projects were not realized.

- For 20 per cent of projects, no information on their status was made available.

Table 4.22 - Summary of EATL Phase I project status

\begin{tabular}{|c|c|c|c|c|c|}
\hline \multirow[b]{2}{*}{ Country } & \multicolumn{4}{|c|}{ STATUS } & \multirow[b]{2}{*}{ Total } \\
\hline & Completed & $\begin{array}{l}\text { Part of EATL } \\
\text { Phase II }\end{array}$ & Not realized & No info & \\
\hline Afghanistan & & & & & 0 \\
\hline Armenia & 6 & & & 3 & 9 \\
\hline Azerbaijan & 3 & 5 & & 2 & 10 \\
\hline Belarus & 4 & & & & 4 \\
\hline Bulgaria & 13 & 10 & & 1 & 24 \\
\hline China & 4 & 1 & & 3 & 8 \\
\hline Georgia & 18 & 2 & 5 & 24 & 49 \\
\hline Iran & 29 & 12 & & 3 & 44 \\
\hline Kazakhstan & 14 & & & & 14 \\
\hline Kyrgyzstan & 7 & & & & 7 \\
\hline Republic of Moldova & 2 & 7 & & & 9 \\
\hline Romania & 4 & 6 & & 2 & 12 \\
\hline Russian Federation & & & & & 0 \\
\hline Tajikistan & 5 & & & & 5 \\
\hline Turkey & 7 & 15 & 1 & & 23 \\
\hline Turkmenistan & & & & & 0 \\
\hline Ukraine & 2 & & & 5 & 7 \\
\hline Uzbekistan & 8 & 1 & & 6 & 15 \\
\hline Total & 126 & 59 & 6 & 49 & 240 \\
\hline
\end{tabular}

\subsubsection{Updating EATL priority infrastructure projects and developing an EATL Investment Plan}

The scope of this section is to analyse the information on new projects based on country inputs, prioritize them by applying the proposed methodology and include them in the new EATL Phase II Investment Plan. The goal is to present a consistent and realistic short-, medium- and longterm investment strategy for the identified EATL routes. This included an extensive inventory of specific road, rail, inland waterway, maritime port, inland terminal and other infrastructure projects for the 27 participating countries, together with their estimated budget and pragmatic investment time plan for implementation. 
The analysis was based on the:

- review and update of projects identified under EATL Phase I

- methodology and related assumptions for the prioritization of new proposed projects included in the new EATL Phase II Investment Plan

\subsubsection{Input received}

Of the 27 countries that participated in this project, countries submitted data through their NFPs on the projects under evaluation.

- Countries that submitted updated and new data

(It should be noted that in certain cases insufficient data was provided.)

Afghanistan, Armenia, Azerbaijan, Bulgaria, China, Georgia, Germany, Greece, Iran, Latvia, Lithuania, Kazakhstan, Kyrgyzstan, Mongolia, Pakistan, Republic of Moldova, Romania, Russian Federation, Tajikistan, the former Yugoslav Republic of Macedonia, Turkey, Ukraine, Uzbekistan

\section{- Countries that did not submit updated or new data}

Belarus, Finland, Luxembourg, Turkmenistan

\subsubsection{Data presentation}

Each project was assigned a unique Project ID specifying the country, the transport mode and a specific number. The following abbreviations were introduced for country identification: Afghanistan (AFG), Armenia (ARM), Azerbaijan (AZE), Belarus (BLR), Bulgaria (BGR), China (CHN), Finland (FIN), Georgia (GEO), Germany (DEU), Greece (GRC), Iran (IRN), Kazakhstan (KAZ), Kyrgyzstan (KGZ), Latvia (LVA), Lithuania (LTU), Luxembourg (LUX), Mongolia (MNG), Pakistan (PAK), Republic of Moldova (MDA), Romania (ROU), Russian Federation (RUS), Tajikistan (TJK), the Former Yugoslav Republic of Macedonia (FYROM), Turkey (TUR), Turkmenistan (TKM), Ukraine (UKR), Uzbekistan (UZB).

The following abbreviations were introduced for the type of infrastructure identification in Project ID: road projects (ROD), railway projects (RLW), maritime projects (MAR), inland waterway projects (INW), inland/border crossing and other projects (INM).

Table 4.23 presents the number of projects submitted by each country per type of infrastructure under the two distinct categories, i.e. those that are along proposed EATL routes and those that are of national importance, thus belonging to the Reserve Category.

Appendix 4.3 presents the completed templates of project information, for all projects considered for EATL Phase II, for each of the participating countries. 


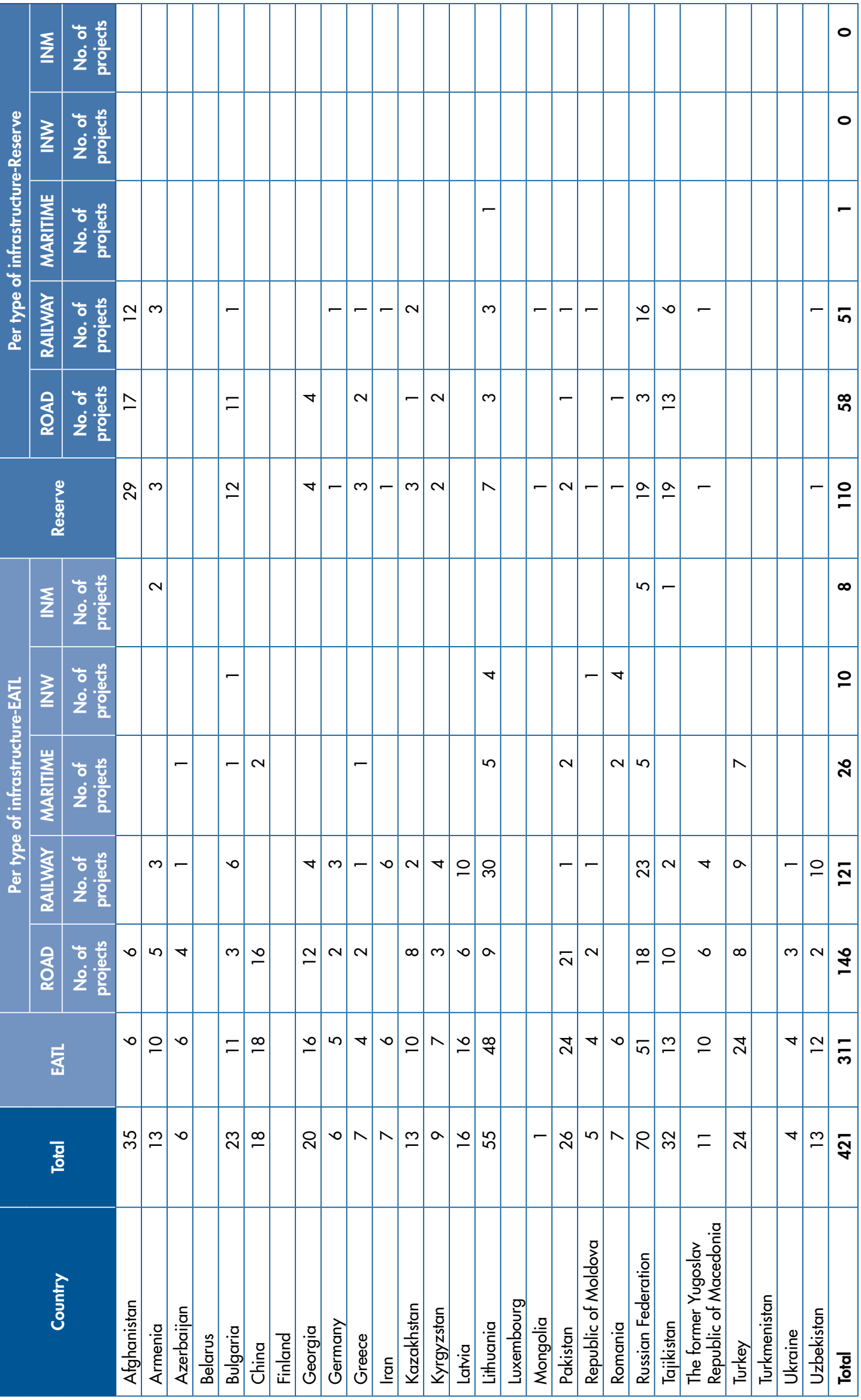




\subsubsection{Project prioritization}

This section presents the results of the prioritization of the projects considered under EATL Phase II at the country level. Projects together with their associated costs are presented:

I. By type of infrastructure:

- Road projects (ROD)

- Railway projects (RLW)

- Maritime projects (MAR)

- Inland waterway projects (INW)

- Inland/border crossing and other projects (INM)

II. By priority category:

- Category I: projects that have secured funding, that are ongoing and expected to be completed in the near future.

- Category II: projects that may be funded or whose plans are approved and are expected to be implemented rapidly (up to 2016).

- Category III: projects that require additional investigation for final definition before likely financing and implementation (up to 2020).

- Category IV: projects that require further investigation for final definition and scheduling before possible financing, including projects for which insufficient data exists (most likely to be implemented after 2020).

\section{- Completed projects}

- Reserve category: projects along other important routes and of national importance that may be included in EATL routes in the future.

The application of the methodology was based on the updated data received from each country involved. Nevertheless, the application of the methodology was not feasible in most cases due to the limited availability of data. In those cases, the missing information was either collected from other sources or the project was categorized on the basis of available data. This is explicitly defined in each case. The cases for which the methodology was applied are presented in detail in Appendix 4.4 .

In addition, projects in the Reserve category were not evaluated and hence not included in the prioritization exercise.

Project costs are depicted in billions of United States dollars. Where necessary, an average conversion rate for 2010 was used. ${ }^{46}$

\section{Afghanistan}

Afghanistan proposed 35 projects in total. More specifically:

- 23 Road projects

- 6 along proposed EATL routes

- 1 with committed funding and thus belonged in Category I

- 5 were classified as category IV due to lack of information on funding

- 17 were considered of national importance

- 12 Rail projects, all of national importance

According to available information, 1 per cent of funding was secured.

The above information, complete with project costs, is summarized in Table 4.24 - below, while Map A-1 and Map B-1 in Appendix 4.5 depict the location of the road and rail projects, respectively.

${ }^{46}$ Available from http://www.x-rates.com/d/USD/EUR/hist2010.html. 
Table 4.24 - Afghanistan prioritization results summary

\begin{tabular}{|c|c|c|c|c|c|c|c|c|c|}
\hline & & & \multirow{2}{*}{ All } & \multicolumn{6}{|c|}{ Per Priority Category } \\
\hline & & & & I & II & III & IV & Completed & Reserve \\
\hline \multicolumn{3}{|c|}{ No. of projects } & 35 & 1 & & & 5 & & 29 \\
\hline \multicolumn{3}{|c|}{ Cost* of projects } & $>3.020$ & 0.003 & & & $>0.225$ & & $>2.792$ \\
\hline \multirow{10}{*}{ 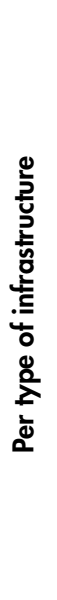 } & \multirow{2}{*}{$R O D$} & No. of projects & 23 & 1 & & & 5 & & 17 \\
\hline & & Cost $^{*}$ of projects & $>2.149$ & 0.003 & & & $>0.225$ & & 1.921 \\
\hline & \multirow{2}{*}{$R L W$} & No. of projects & 12 & & & & & & 12 \\
\hline & & Cost ${ }^{*}$ of projects & $>0.871$ & & & & & & $>0.871$ \\
\hline & \multirow{2}{*}{ MAR } & No. of projects & & & & & & & \\
\hline & & Cost* of projects & & & & & & & \\
\hline & \multirow{2}{*}{ INW } & No. of projects & & & & & & & \\
\hline & & Cost $^{*}$ of projects & & & & & & & \\
\hline & \multirow{2}{*}{ INM } & No. of projects & & & & & & & \\
\hline & & Cost $^{*}$ of projects & & & & & & & \\
\hline
\end{tabular}

* in billion US\$

\section{Armenia}

Armenia proposed 13 projects in total, including 10 along proposed EATL routes. More specifically:

- 5 Road projects:

- All along proposed EATL routes

- All with committed funding, thus belonged in Category I

- 6 Rail projects: ${ }^{47}$

3 along EATL routes

- According to available information, these were classified as Category IV (at launch of tender but financing not secured yet)

3 were considered of national importance

- 2 Other projects ${ }^{48}$ (Logistic centres):

All along proposed EATL routes

According to available information, these were classified as Category II (Transport Strategy 2009-2019 to be completed in 2015).

According to available information, 17 per cent of funding was secured.

47 European Neighbourhood and Partnership Instrument, Transport Dialogue and Interoperability between the EU and lts Neighbouring Countries and Central Asian Countries, First TRACECA Investment Forum, Brussels, Belgium, 12 October 2010 "Priority Projects-Fact Sheets".

48 Organization for Security and Co-operation in Europe, Transport Sector in Armenia, 19th OSCE Economic and Environmental Forum, Second Preparatory Meeting, Druskininkai, Lithuania, 4-5 April 2011 . Available from http:// www.osce.org/eea/76425. 
The above information, complete with project costs, is summarized in Table 4.25 below, while Map A-2 and Map B-2 in Appendix 4.5 depict the location of the road and rail projects, respectively.

Table 4.25 - Armenia prioritization results summary

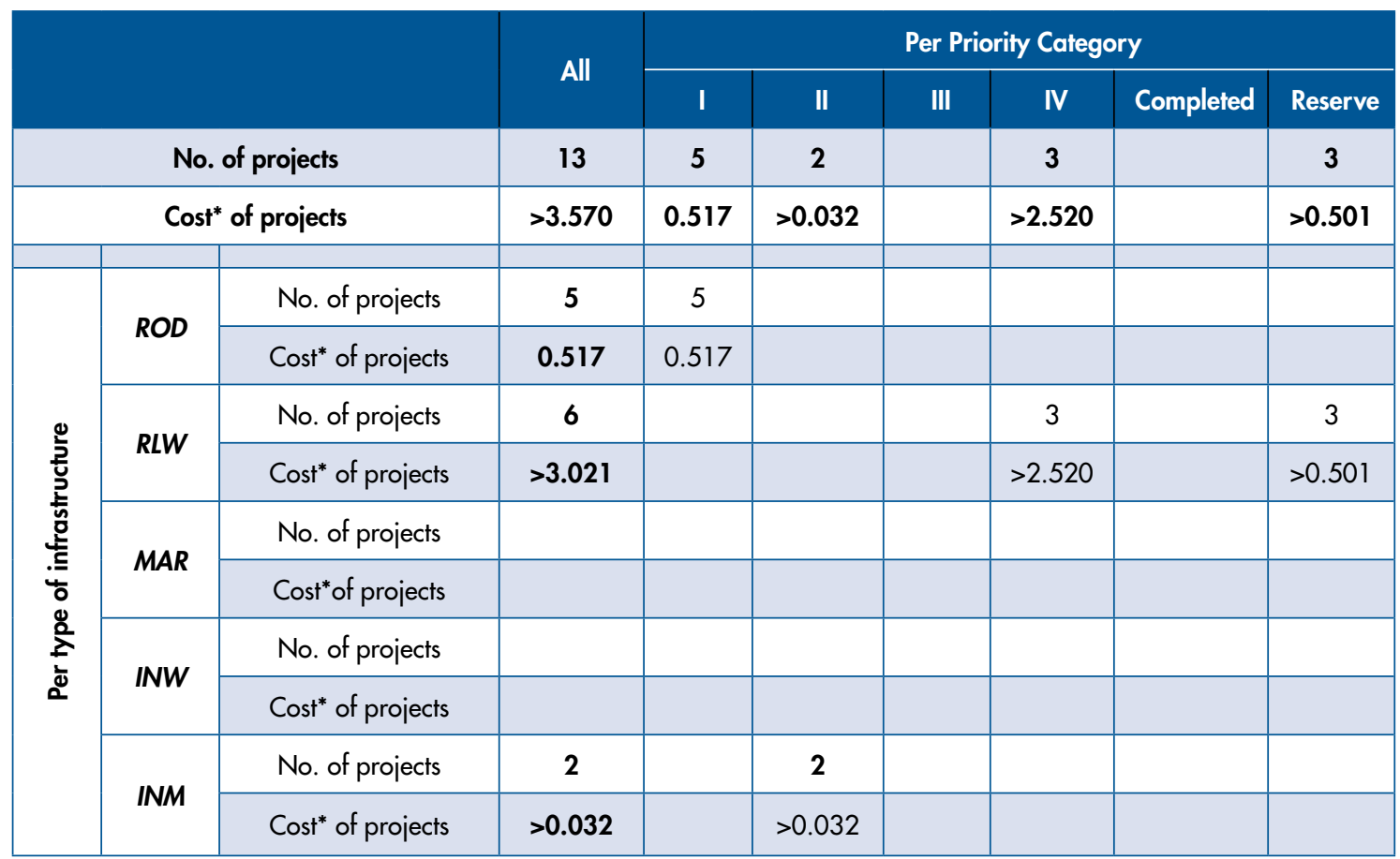

* in billion US\$

\section{Azerbaijan}

Azerbaijan proposed 6 projects in total, all along proposed EATL routes. All have committed funding and, thus, belonged in Category I. With regard to infrastructure type, the breakdown is as follows:

- 4 Road projects

- 1 Rail project

- 1 Port project

According to available information, 100 per cent of funding was secured.

The above information, complete with project costs, is summarized in Table 4.26 below, while Map A-3 and Map B-3 in Appendix 4.5 depict the location of the road and rail projects, respectively. 
Table 4.26 - Azerbaijan prioritization results summary

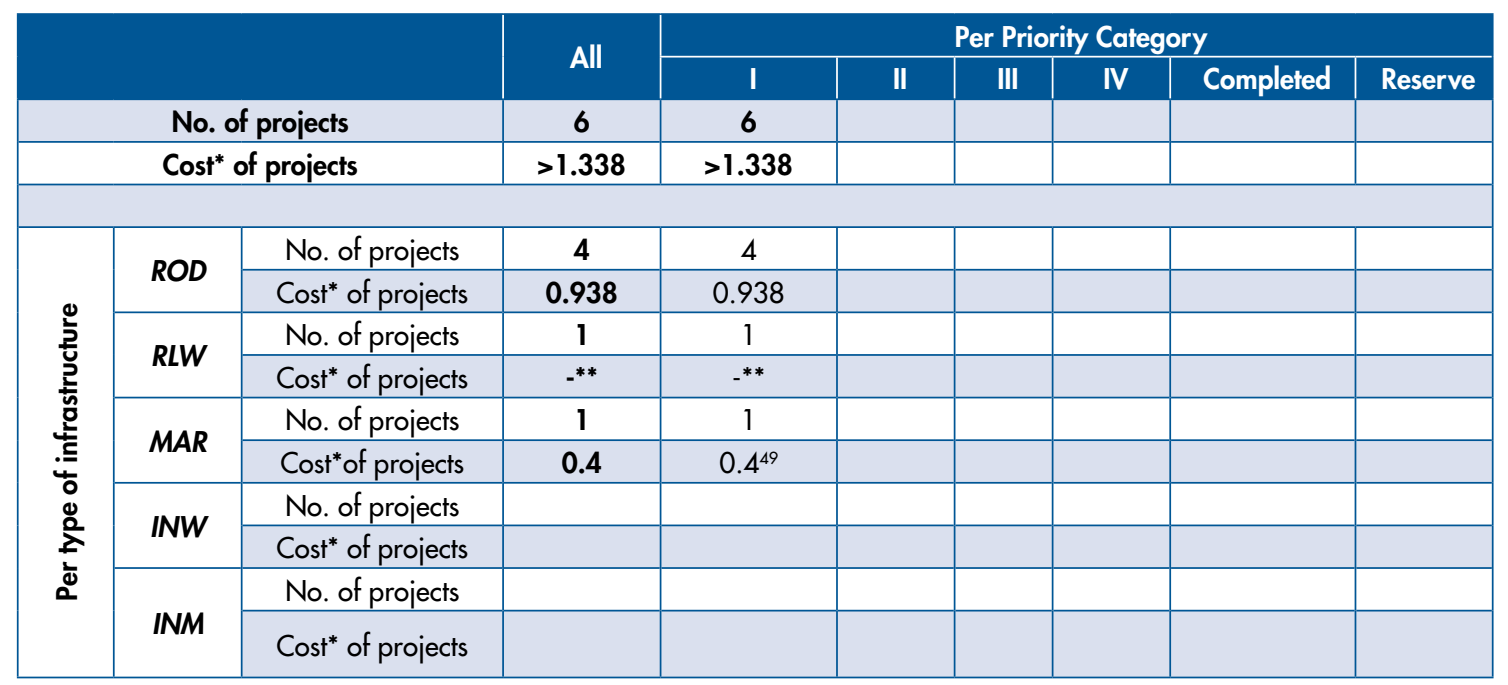

* in billion US\$

** no cost estimate provided

\section{Belarus}

Belarus did not submit any data for the purpose of the EATL Phase II Study. According to original information, all projects submitted under EATL Phase I should have been completed.

\section{Bulgaria}

Bulgaria proposed 23 projects in total, as follows:

- 14 Road projects

- 3 along proposed EATL routes; according to available information:

- 2 were classified as Category I

- 1 was classified as Category II

- 11 were considered of national importance

- 7 Rail projects

- 6 along proposed EATL routes with committed funding, thus belonged in Category I

- 1 was considered of national importance

- 1 Maritime Port project was completed

- 1 Inland Waterway project for which no information was given, classified as Category IV

According to available information, 93 per cent of the funding was secured.

The above information, complete with project costs, is summarized in Table 4.27 below, while Map A-4 and Map B-4 in Appendix 4.5 respectively depict the location of the road and rail projects, respectively.

Table 4.27 - Bulgaria prioritization results summary

\begin{tabular}{|c|c|c|c|c|c|c|c|}
\hline & \multirow{2}{*}{ All } & \multicolumn{6}{|c|}{ Per Priority Category } \\
\hline & & I & II & III & IV & Completed & Reserve \\
\hline No. of projects & 23 & 8 & 1 & & 1 & 1 & 12 \\
\hline Cost* of projects & $>8.097$ & $>7.172$ & 0.332 & & $-* *$ & 0.193 & 0.4 \\
\hline
\end{tabular}

${ }^{49}$ New Baku Sea International Trade Port commissioned in 2011. Available from http://www.abc.az/eng/ news/23628.html. 


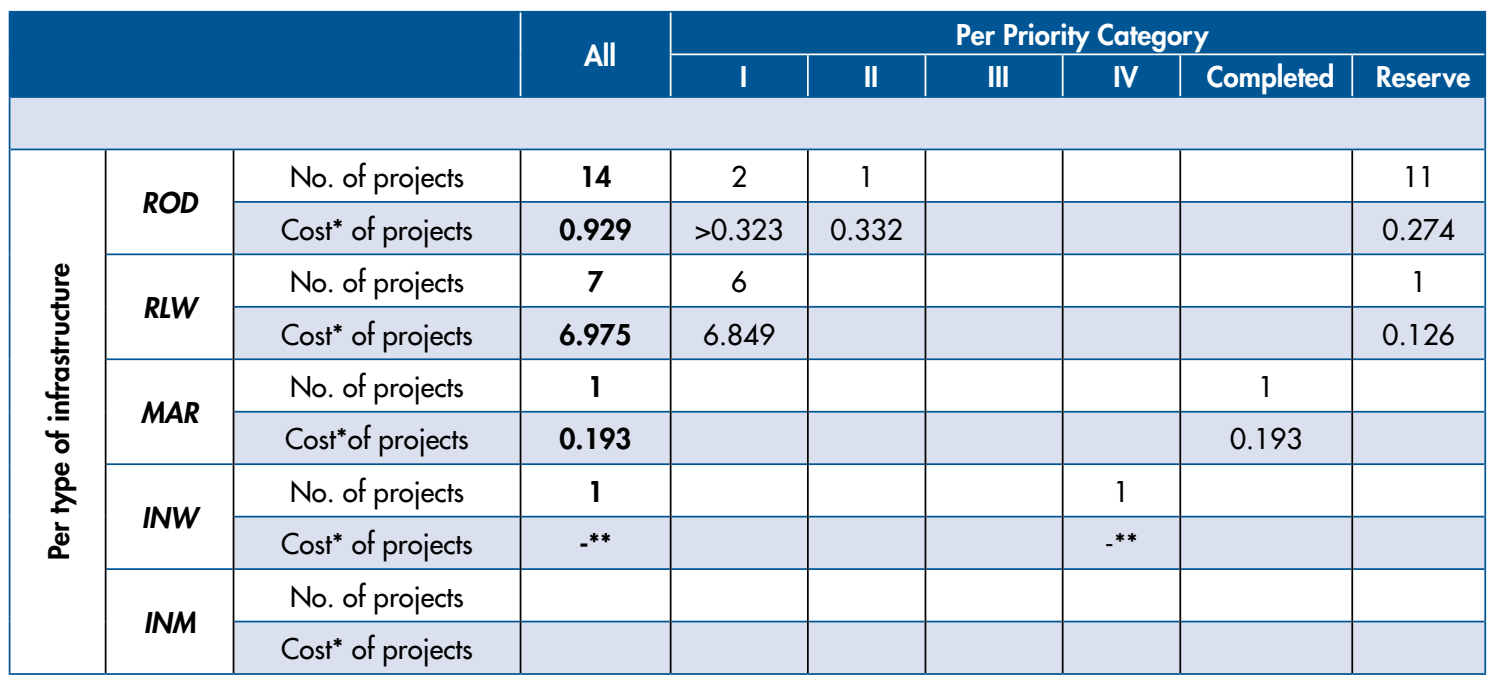

* in billion US\$

** no cost estimate provided

\section{China}

China proposed 18 projects in total, all along proposed EATL routes, as follows:

- 16 Road projects:

- 6 with committed funding, thus belonged in Category I

- Of the remaining 10, according to the application of the prioritization methodology:

- 9 were classified as Category II

- 1 was classified as Category III

- 2 Port projects committed funding, thus belonged in Category I

According to available information, 57 per cent of the funding was secured.

The above information, complete with project costs, is summarized in Table 4.28 - below, while Map A-5 in Appendix 4.5 depicts the location of the road projects. The results of applying the methodology are presented in Appendix 4.4.

Table 4.28 - China prioritization results summary

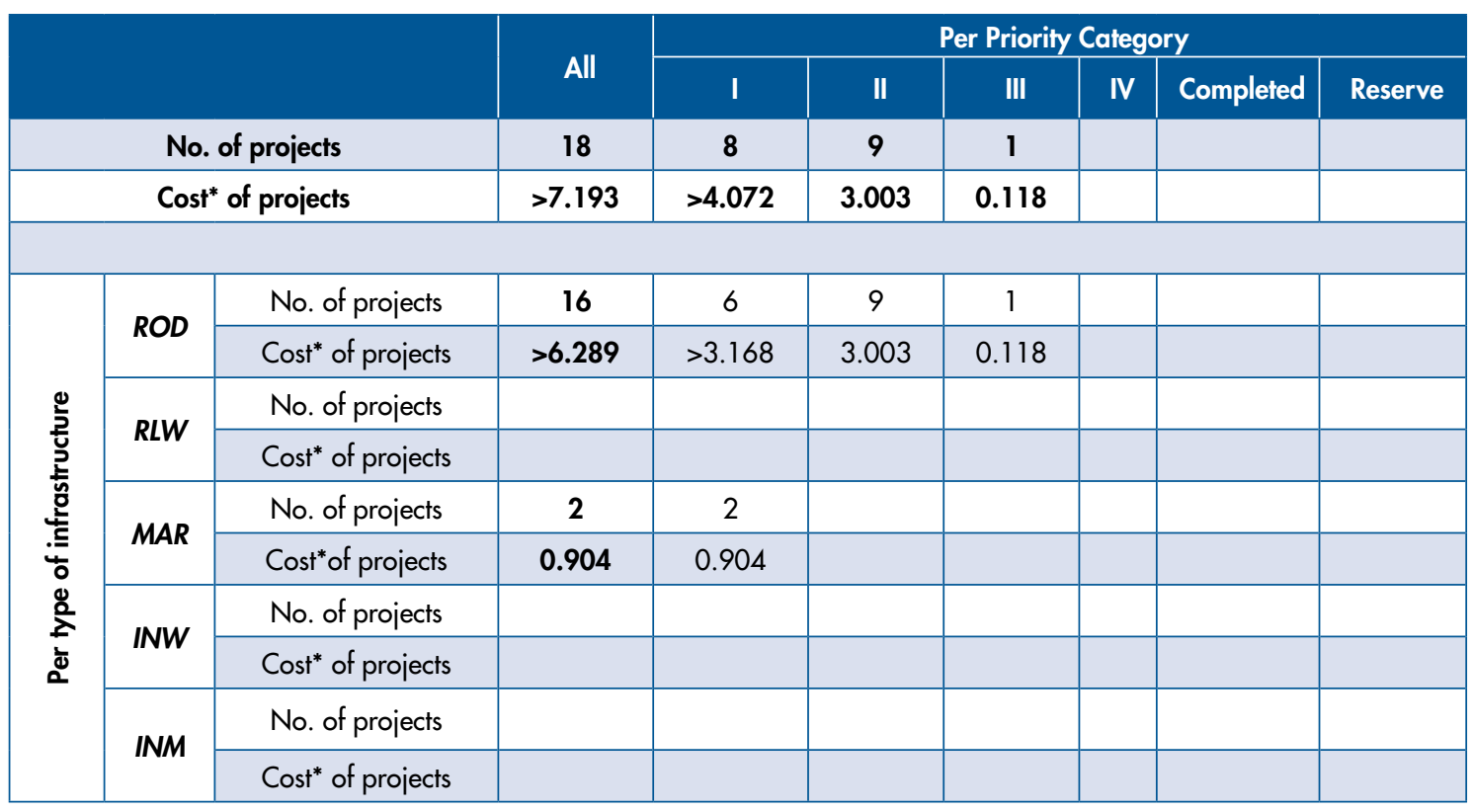

* in billion US\$ 


\section{Finland}

Finland did not submit any data for the purpose of the EATL Phase II Study.

\section{Georgia}

Georgia proposed 20 projects in total, as follows:

- 16 Road projects

- 12 along proposed EATL routes

- 6 with committed funding and, thus, were classified as Category I

- For the remaining 6 , limited information was given and, thus, they were classified as Category IV

- 4 were considered of national importance

- 4 Rail projects, all along proposed EATL routes:

- 2 received committed funding, and thus were classified in Category I

- According to available information, 1 project was classified as Category II and 1 as Category IV

According to available information, 71 per cent of the funding was secured.

The above information, complete with project costs, is summarized in Table 4.29 below, while Map A-6 and Map B-5 in Appendix 4.5 depict the location of the road and rail projects, respectively.

Table 4.29 - Georgia prioritization results summary

\begin{tabular}{|c|c|c|c|c|c|c|c|c|c|}
\hline & & & \multirow{2}{*}{ All } & \multicolumn{6}{|c|}{ Per Priority Category } \\
\hline & & & & I & II & III & IV & Completed & Reserve \\
\hline \multicolumn{3}{|c|}{ No. of projects } & 20 & 8 & 1 & & 7 & & 4 \\
\hline \multicolumn{3}{|c|}{ Cost ${ }^{*}$ of projects } & $>1.427$ & 0.972 & 0.399 & & $-* *$ & & $>0.056$ \\
\hline \multirow{10}{*}{ 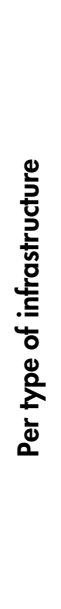 } & \multirow{2}{*}{$R O D$} & No. of projects & 16 & 6 & & & 6 & & 4 \\
\hline & & Cost ${ }^{*}$ of projects & $>0.495$ & 0.439 & & & $-* *$ & & $>0.056$ \\
\hline & \multirow{2}{*}{$R L W$} & No. of projects & 4 & 2 & 1 & & 1 & & \\
\hline & & Cost $^{*}$ of projects & $>0.932$ & 0.533 & 0.399 & & $-* *$ & & \\
\hline & \multirow{2}{*}{$M A R$} & No. of projects & & & & & & & \\
\hline & & Cost* of projects & & & & & & & \\
\hline & \multirow{2}{*}{ INW } & No. of projects & & & & & & & \\
\hline & & Cost* of projects & & & & & & & \\
\hline & \multirow{2}{*}{ INM } & No. of projects & & & & & & & \\
\hline & & Cost $^{*}$ of projects & & & & & & & \\
\hline
\end{tabular}

* in billion US\$

** no cost estimate provided 


\section{Germany}

Germany proposed 6 projects in total, as follows:

- 2 Road projects along proposed EATL routes

- Based on the application of the evaluation methodology, they were classified as Category IV

- 4 Rail projects

- 3 along EATL routes, 1 of which was completed

- Based on applying the evaluation methodology:

- 1 was classified as Category III

- 1was classified as Category IV

- 1 was considered of national importance

According to available information, no funding was secured.

The above information, complete with project costs, is summarized in Table 4.30 below, while Map A-7 and Map B-6 in Appendix 4.5 depict the location of the road and rail projects, respectively. The results of applying the methodology are presented in Appendix 4.4.

Table 4.30 - Germany prioritization results summary

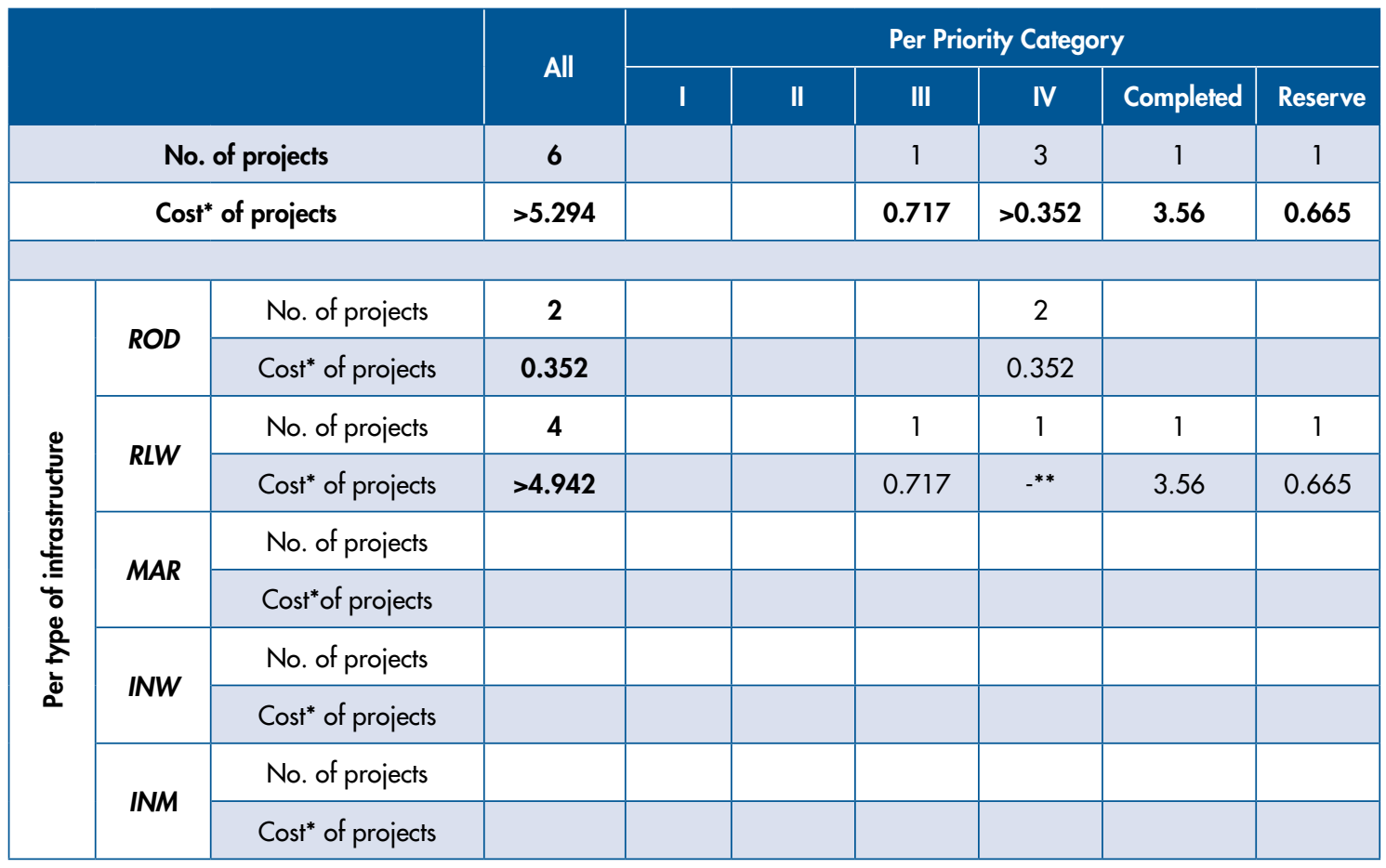

* in billion US\$

** no cost estimate provided 


\section{Greece}

Greece proposed 7 projects in total, as follows:

- 4 Road projects

- 2 along EATL routes, with committed funding, thus belonged in Category I

- 2 were considered of national importance

- 2 Rail projects

- 1, partly along an EATL route, was classified as Category I

- 1 was considered of national importance

- 1 Port project

- Along an EATL route with committed funding, thus belonging in Category I

According to available information, 100 per cent of funding was secured.

The above information complete with project costs is summarized in Table 4.31 below, while Map A-8 and Map B-7 in Appendix 4.5 depict the location of the road and rail projects.

Table 4.31 - Greece prioritization results summary

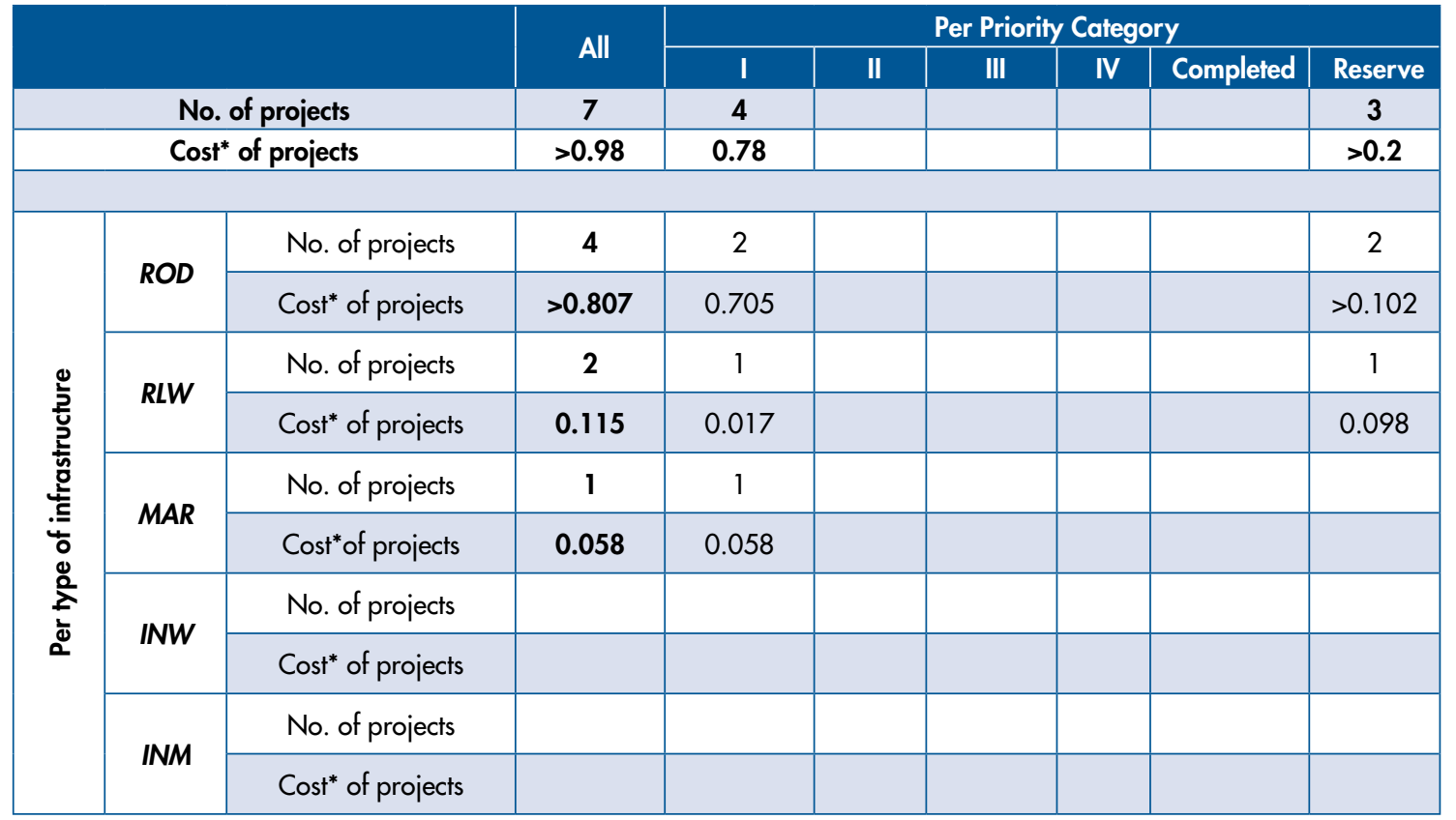

\section{Iran}

Iran did not submit information for the purpose of the EATL Phase II Study.

According to other available information, ${ }^{50} 7$ rail projects were proposed, including 6 along proposed EATL routes, with 1 considered of national importance. Based on the available information:

- 5 were classified as Category I

- 1 was classified as Category II

According to available information, 65 per cent of funding was secured.

The above information, complete with project costs, is summarized in Table 4.32 below, while Map B-8 in Appendix 4.5 depicts the location of the rail projects.

50 Presentation by the representative from Iran at the first regional workshop of Euro-Asian transport links project Phase II, entitled "Facilitation of Euro-Asia transport in the ECO region" in Tehran on 27-29 April 2009. 
Table 4.32 - Iran prioritization results summary

\begin{tabular}{|c|c|c|c|c|c|c|c|c|c|}
\hline & & & \multirow{2}{*}{ All } & \multicolumn{6}{|c|}{ Per Priority Category } \\
\hline & & & & I & II & III & IV & Completed & Reserve \\
\hline \multicolumn{3}{|c|}{ No. of projects } & 7 & 5 & 1 & & & & 1 \\
\hline \multicolumn{3}{|c|}{ Cost* of projects } & 3.878 & 2.528 & 1.35 & & & & $-* *$ \\
\hline \multirow{10}{*}{ 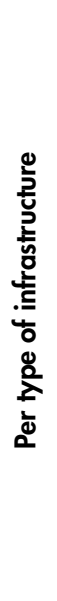 } & \multirow{2}{*}{$R O D$} & No. of projects & & & & & & & \\
\hline & & Cost $^{*}$ of projects & & & & & & & \\
\hline & \multirow{2}{*}{ RLW } & No. of projects & 7 & 5 & 1 & & & & 1 \\
\hline & & Cost $^{*}$ of projects & 3.878 & 2.528 & 1.35 & & & & -** \\
\hline & \multirow{2}{*}{$M A R$} & No. of projects & & & & & & & \\
\hline & & Cost* of projects & & & & & & & \\
\hline & \multirow{2}{*}{ INW } & No. of projects & & & & & & & \\
\hline & & Cost ${ }^{*}$ of projects & & & & & & & \\
\hline & \multirow{2}{*}{ INM } & No. of projects & & & & & & & \\
\hline & & Cost ${ }^{*}$ of projects & & & & & & & \\
\hline
\end{tabular}

* in billion US\$

** no cost estimate provided

\section{Kazakhstan}

Kazakhstan proposed 13 projects in total, as follows:

- 9 Road projects

- 8 along EATL routes

- 1 was considered of national importance

- 4 Rail projects

- 2 along EATL routes

- 2 were considered of national importance

Based on relevant information, ${ }^{51}$ all projects proposed along EATL routes went ahead, and thus belonged in Category I.

According to available information, 100 per cent of funding was secured.

The above information complete with project costs is summarized in Table 4.33 - below, while Map A-9 and Map B-9 in Appendix 4.5 depict the location of the road and rail projects, respectively.

Table 4.33 - Kazakhstan prioritization results summary

\begin{tabular}{|c|c|c|c|c|c|c|c|}
\hline \multirow{2}{*}{ No. of projects } & \multirow{2}{*}{ All } & \multicolumn{7}{|c|}{ Per Priority Category } \\
\cline { 4 - 8 } & & I & II & III & IV & Completed & Reserve \\
\hline Cost $^{*}$ of projects & 13 & 10 & & & & & 3 \\
\hline
\end{tabular}

51 CAREC Report, "Kazakhstan: Country Progress Report on the Implementation Action Plan for the Transport and Trade Facilitation Strategy", 22 April 2009 and

Presentation of the Kazakh delegate: "Development of Road and Rail Transport Infrastructure, Kazakhstan. Vienna November 2010 on the occasion of the OSCE/UNECE Conference on the Financing of Transport Infrastructure. 


\begin{tabular}{|c|c|c|c|c|c|c|c|c|c|}
\hline & & & \multirow{2}{*}{ All } & \multicolumn{6}{|c|}{ Per Priority Category } \\
\hline & & & & I & II & III & IV & Completed & Reserve \\
\hline \multirow{10}{*}{ 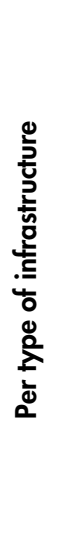 } & ROD & No. of projects & 9 & 8 & & & & & 1 \\
\hline & & Cost* of projects & 7.841 & 7.411 & & & & & 0.43 \\
\hline & RLW & No. of projects & 4 & 2 & & & & & 2 \\
\hline & & Cost* of projects & 2.648 & 1.507 & & & & & 1.141 \\
\hline & MAR & No. of projects & & & & & & & \\
\hline & & Cost* of projects & & & & & & & \\
\hline & INW & No. of projects & & & & & & & \\
\hline & & Cost* of projects & & & & & & & \\
\hline & INM & No. of projects & & & & & & & \\
\hline & & Cost* of projects & & & & & & & \\
\hline
\end{tabular}

* in billion US\$

\section{Kyrgyzstan}

Kyrgyzstan proposed 9 projects in total, as follows:

- 5 Road projects

- 3 along EATL routes, with committed funding, and thus belonged in Category I

- 2 were considered of national importance

- 4 Rail projects along EATL routes

- According to available information:

- 1 was classified as Category II

- 3 were classified as Category IV

According to available information, 20 per cent of funding was secured.

The above information, complete with project costs, is summarized in Table 4.34 below, while Map A-10 and Map B-10 in Appendix 4.5 depict the location of the road and rail projects, respectively.

Table 4.34 - Kyrgyzstan prioritization results summary

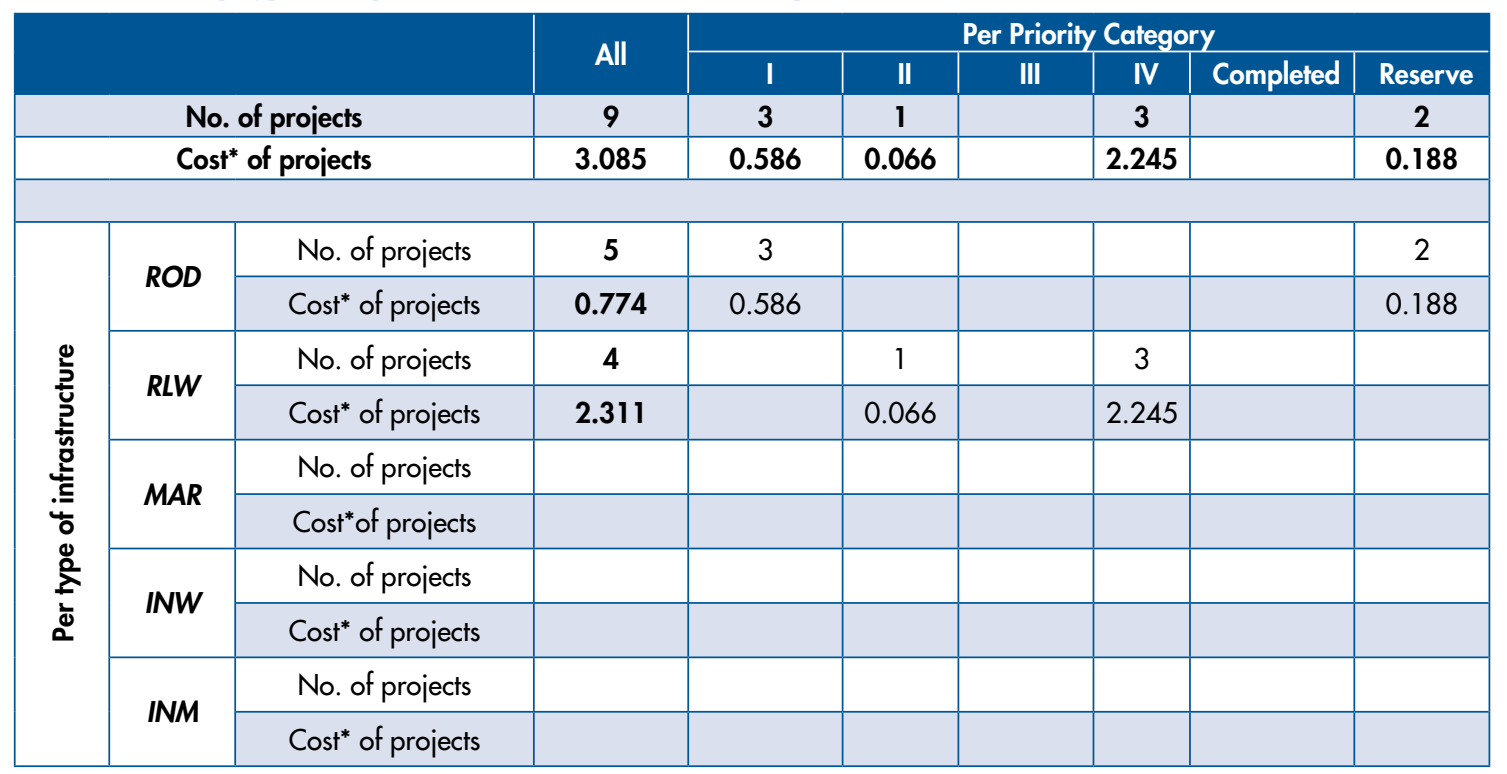

* in billion US\$ 


\section{Latvia}

Latvia proposed 16 projects in total, all along proposed EATL routes, as follows:

- 6 Road projects

- 3 with committed funding, and thus belonged in Category I

- For 3, no information on sources of funding was made available and hence were classified as Category IV

- 10 Rail projects

- 8 with committed funding, and thus belonged in Category I

- For 2, no information on sources of funding was made available and hence were classified as Category IV

Based on available information, 25 per cent of funding was secured.

The above information, complete with project costs, is summarized in Table 4.35 below, while Map A-11 and Map B-11 in Appendix 4.5 depict the location of the road and rail projects, respectively.

Table 4.35 - Latvia prioritization results summary

\begin{tabular}{|c|c|c|c|c|c|c|c|c|c|}
\hline \multicolumn{10}{|c|}{ Per Priority Category } \\
\hline & & & All & \multicolumn{4}{|c|}{ Per Priority Category } & & Reserve \\
\hline \multicolumn{3}{|c|}{ No. of projects } & 16 & 11 & & & 5 & & \\
\hline \multicolumn{3}{|c|}{ Cost* of projects } & 3.683 & 0.925 & & & 2.758 & & \\
\hline \multirow{11}{*}{ 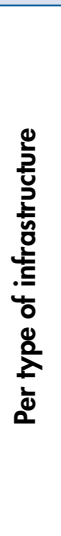 } & \multirow{3}{*}{$R O D$} & & & & & & & & \\
\hline & & No. of projects & 6 & 3 & & & 3 & & \\
\hline & & Cost ${ }^{*}$ of projects & 0.967 & 0.365 & & & 0.602 & & \\
\hline & \multirow{2}{*}{$R L W$} & No. of projects & 10 & 8 & & & 2 & & \\
\hline & & Cost* of projects & 2.716 & 0.560 & & & 2.156 & & \\
\hline & \multirow{2}{*}{ MAR } & No. of projects & & & & & & & \\
\hline & & Cost" of projects & & & & & & & \\
\hline & \multirow{2}{*}{ INW } & No. of projects & & & & & & & \\
\hline & & Cost* of projects & & & & & & & \\
\hline & \multirow{2}{*}{ INM } & No. of projects & & & & & & & \\
\hline & & Cost* of projects & & & & & & & \\
\hline
\end{tabular}

* in billion US\$

\section{Lithuania}

Lithuania proposed 55 projects in total, as follows:

- 12 Road projects

- 9 along EATL routes, with committed funding, and thus belonged in Category I

- 3 were considered of national importance

- 33 Rail projects

- 30 along EATL routes, with committed funding, and thus belonged in Category I

- 3 were considered of national importance

- 6 Maritime projects

- 5 along EATL routes, with committed funding, and thus belonged in Category I

- 1 was considered of national importance 
- 4 Inland Waterway projects

- All along EATL routes, with committed funding, and thus belonged in Category I

Based on available information, 100 per cent of funding was secured.

The above information, complete with project costs, is summarized in Table 4.36 below, while Map A-12 and Map B-12 in Appendix 4.5 depict the location of the road and rail projects, respectively.

Table 4.36 - Lithuania prioritization results summary

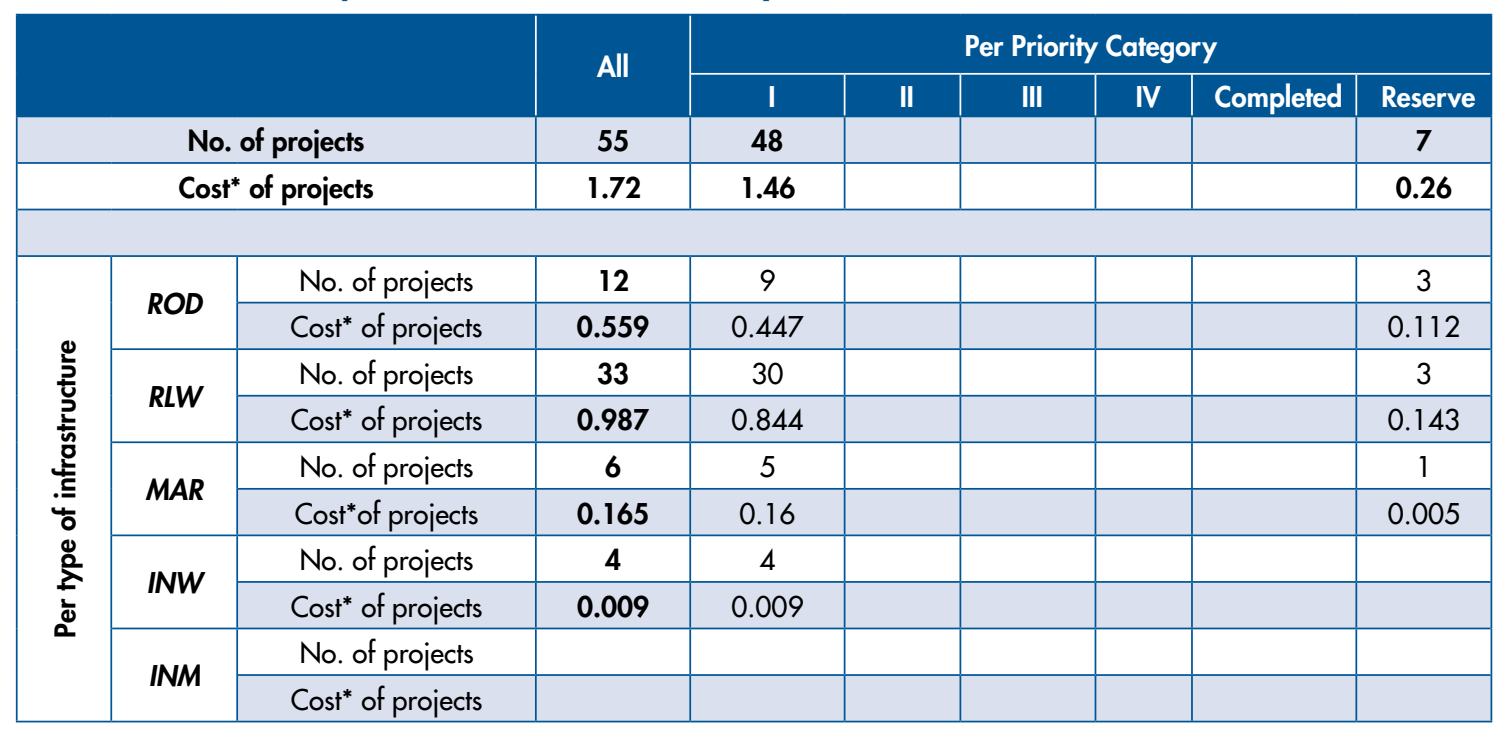

* in billion US\$

\section{Luxembourg}

Luxembourg did not submit any data for the purpose of the EATL Phase II Study.

\section{Mongolia}

Mongolia proposed one rail project of national importance, the cost of which is presented in Table 4.37 below, while Map B-13 in Appendix 4.5 depicts the location of the project.

Table 4.37 - Mongolia prioritization results summary

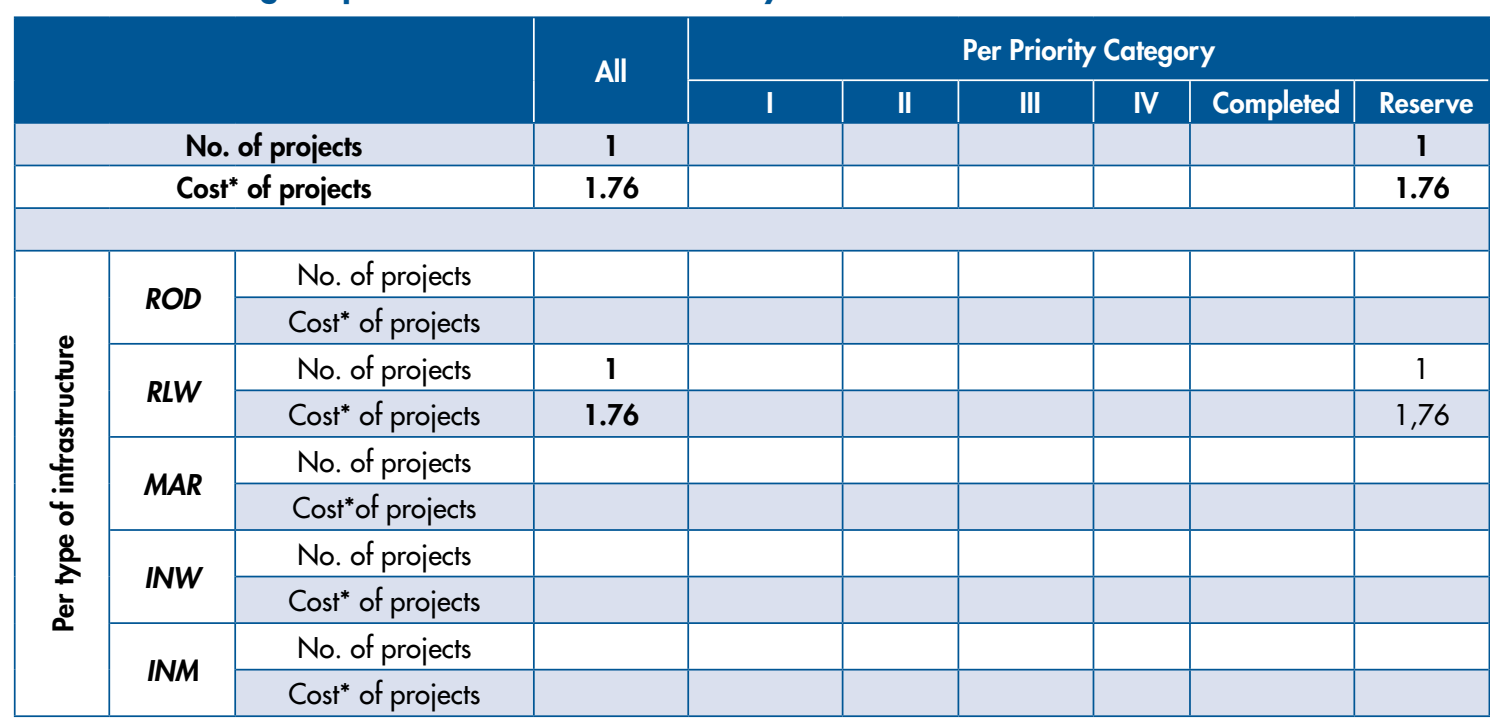

* in billion US\$ 


\section{Republic of Moldova}

The Republic of Moldova proposed 5 projects in total, as follows:

- 2 Road projects, along proposed EATL routes, of which according to available information:

- 1 had committed funding and thus belonged in Category I

- 1 was classified as Category III

- 2 Rail projects

- 1 along proposed EATL routes, classified as Category IV

- 1 was considered of national importance

- 1 Inland Waterway project along EATL routes with committed funding, thus belonging in Category I

Based on available information, 49 per cent of funding was secured.

The above information, complete with project costs, is summarized in Table 4.38 below, Map A-14 and Map B-15 in Appendix 4.5 depict the location of the road and rail projects, respectively.

Table 4.38 - Republic of Moldova prioritization results summary

\begin{tabular}{|c|c|c|c|c|c|c|c|c|c|}
\hline \multicolumn{10}{|c|}{ Per Priority Category } \\
\hline & & & All & I & II & III & IV & Completed & Reserve \\
\hline \multicolumn{3}{|c|}{ No. of projects } & 5 & 2 & & 1 & 1 & & 1 \\
\hline \multicolumn{3}{|c|}{ Cost* of projects } & 0.871 & 0.387 & & 0.092 & 0.317 & & 0.075 \\
\hline \multirow{10}{*}{ 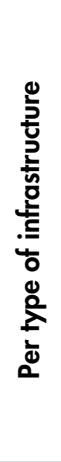 } & \multirow{2}{*}{$R O D$} & No. of projects & 2 & 1 & & 1 & & & \\
\hline & & Cost* of projects & 0.229 & 0.137 & & 0.092 & & & \\
\hline & \multirow{2}{*}{$R L W$} & No. of projects & 2 & & & & 1 & & 1 \\
\hline & & Cost* of projects & 0.392 & & & & 0.317 & & 0.075 \\
\hline & \multirow{2}{*}{ MAR } & No. of projects & & & & & & & \\
\hline & & Cost*of projects & & & & & & & \\
\hline & \multirow{2}{*}{ INW } & No. of projects & 1 & 1 & & & & & \\
\hline & & Cost* of projects & 0.25 & 0.25 & & & & & \\
\hline & \multirow{2}{*}{ INM } & No. of projects & & & & & & & \\
\hline & & Cost* of projects & & & & & & & \\
\hline
\end{tabular}

* in billion US\$

\section{Pakistan}

Pakistaproposed 26 projects in total, as follows:

- 22 Road projects

- 21 along proposed EATL routes, of which, based on the application of the prioritization methodology

- 10 with committed funding and belonged in Category I

- 10 were classified as Category II

- 1 was classified as category III

- 1 was considered of national importance

- 2 Rail projects

- 1 along proposed EATL routes, for which limited information was given and thus classified as Category IV

- 1 was considered of national importance 
- 2 Maritime projects along proposed EATL routes

- 1 was completed

- 1 for which limited information was given and thus classified as Category IV

Based on available information, 56 per cent of funding was secured.

The above information, complete with project costs, is summarized in Table 4.39 below, while Map A-13 and Map B-14 in Appendix 4.5 depict the location of the road and rail projects, respectively. The results of the evaluation methodology are presented in Appendix 4.4.

Table 4.39 - Pakistan prioritization results summary

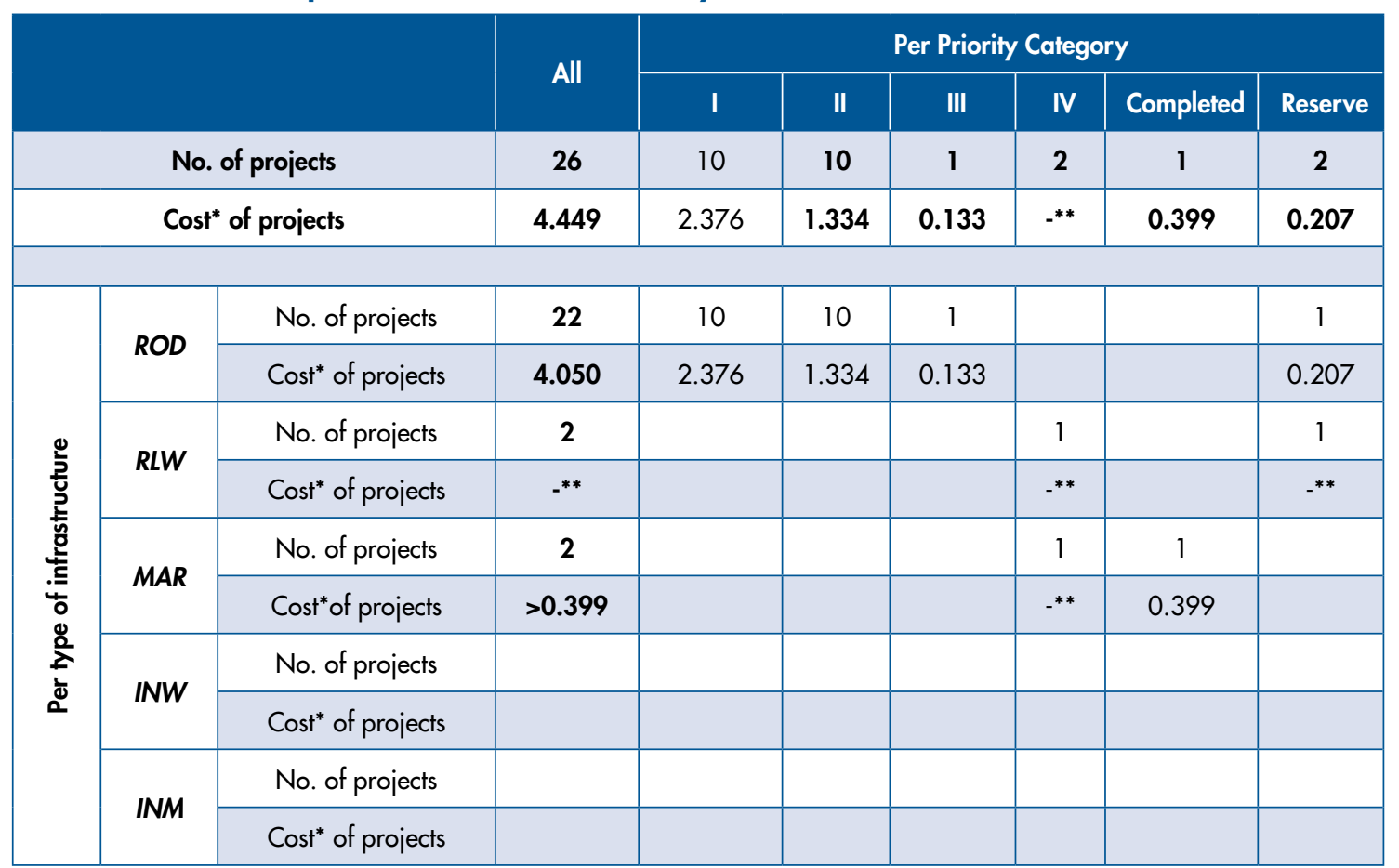

* in billion US\$

\section{Romania}

Romania proposed 7 projects in total, as follows:

- 1 Road project of national importance

- 2 Maritime projects along proposed EATL routes

- 1 with committed funding, thus belonging to Category I

- 1 for which limited information was available, and thus classified as Category IV

- 4 Inland Waterway projects along proposed EATL routes

- 3 with committed funding, and thus belonged in Category I

- 1 classified as Category II

Based on available information, 42 per cent of funding was secured.

The above information, complete with project costs, is summarized in Table 4.40. . 
Table 4.40 - Romania prioritization results summary

\begin{tabular}{|c|c|c|c|c|c|c|c|c|c|}
\hline & & & \multirow{2}{*}{ All } & \multicolumn{6}{|c|}{ Per Priority Category } \\
\hline & & & & I & II & III & IV & Completed & Reserve \\
\hline \multicolumn{3}{|c|}{ No. of projects } & 7 & 4 & 1 & & 1 & & 1 \\
\hline \multicolumn{3}{|c|}{ Cost* of projects } & 9.843 & 0.273 & 0.245 & & 0.125 & & 9.2 \\
\hline \multirow{10}{*}{ 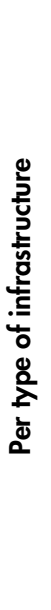 } & \multirow{2}{*}{$R O D$} & No. of projects & 1 & & & & & & 1 \\
\hline & & Cost ${ }^{*}$ of projects & 9.200 & & & & & & 9.2 \\
\hline & \multirow{2}{*}{$R L W$} & No. of projects & & & & & & & \\
\hline & & Cost* of projects & & & & & & & \\
\hline & \multirow{2}{*}{ MAR } & No. of projects & 2 & 1 & & & 1 & & \\
\hline & & Cost ${ }^{*}$ of projects & 0.286 & 0.161 & & & 0.125 & & \\
\hline & \multirow{2}{*}{ INW } & No. of projects & 4 & 3 & 1 & & & & \\
\hline & & Cost ${ }^{*}$ of projects & 0.357 & 0.112 & 0.245 & & & & \\
\hline & \multirow{2}{*}{ INM } & No. of projects & & & & & & & \\
\hline & & Cost ${ }^{*}$ of projects & & & & & & & \\
\hline
\end{tabular}

* in billion US\$

\section{Russian Federation}

The Russian Federation proposed 70 projects in total, as follows:

- 21 Road projects

- 18 along proposed EATL routes, of which according to available information

- 2 were classified as Category I

- 15 were classified as Category II

- 1 was classified as Category IV

- 3 were considered of national importance

- 39 Rail projects

- 23 along proposed EATL routes, of which according to available information :

- 6 were classified as Category I

- 10 were classified as Category II

- 7 were classified as Category IV

- 16 were considered of national importance

- 5 Maritime projects along proposed EATL routes, for which limited information was given, and thus were classified as Category IV

- 5 Intermodal Terminal projects along proposed EATL routes, with committed funding, and thus belonged in Category I

Based on available information, 16 per cent of funding was secured.

The above information, complete with project costs, is summarized in Table 4.41 below, while Maps A-15-A-17 and Maps B-16-B-19 in Appendix 4.5 depict the location of the road and rail projects, respectively. 
Table 4.41 - Russian Federation prioritization results summary

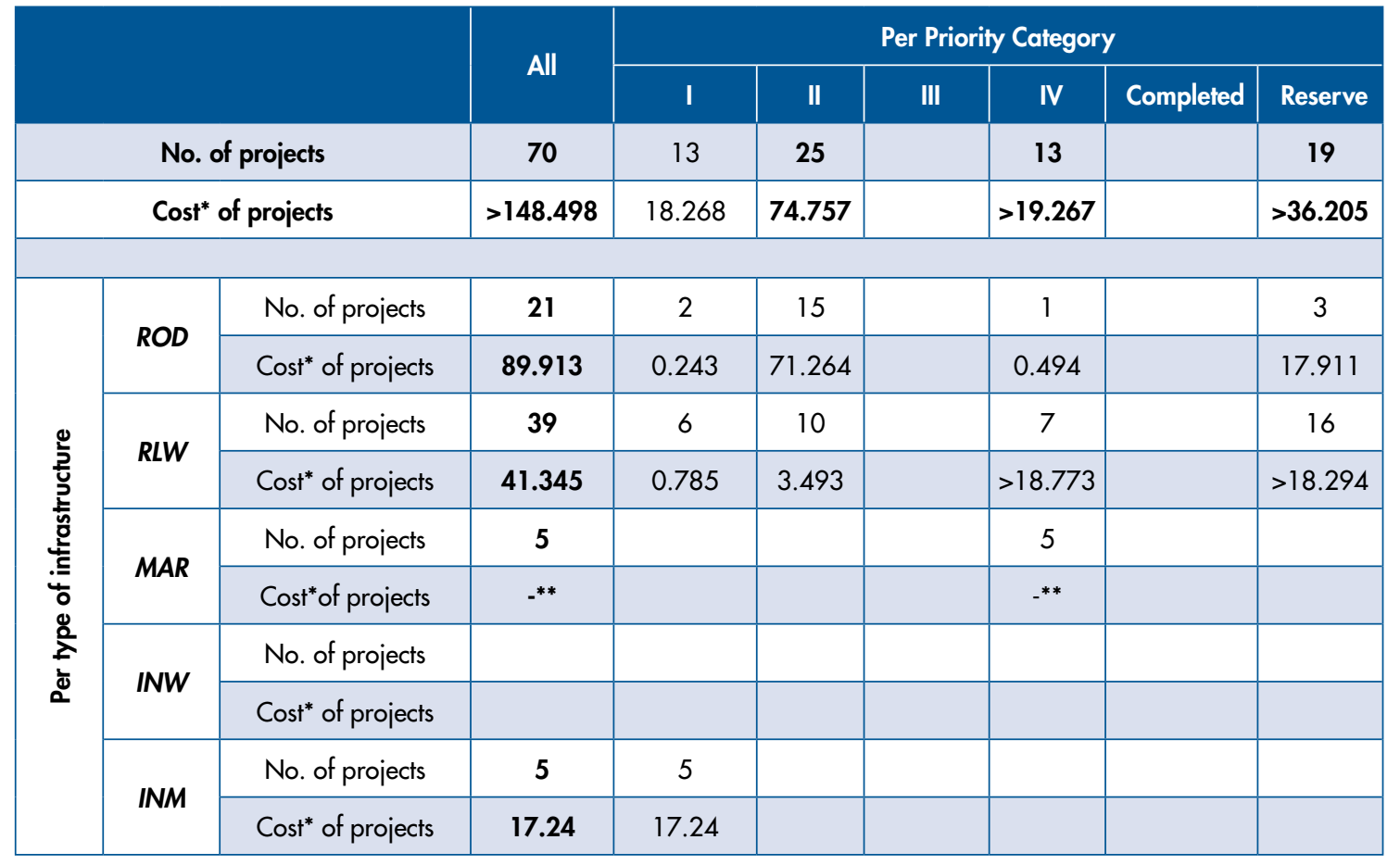

* in billion US\$

** no cost estimate provided

\section{Tajikistan}

Tajikistan proposed 32 projects in total, as follows:

- 23 Road projects

- 10 along proposed EATL routes, out of which

- 7 with committed funding, and thus belonged in Category I

- 3 for which limited information was given and were classified as Category IV

- 13 were considered of national importance

- 8 Rail projects

- 2 along proposed EATL routes, for which funding had not yet been secured, and thus were classified as Category IV

- 6 were considered of national importance

- 1 Intermodal Terminal project along proposed EATL routes, for which funding had not yet been secured, and thus was classified as Category IV

Based on available information, 55 per cent of funding was secured.

The above information, complete with project costs, is summarized in Table 4.42 below, while Map A-18 and Map B-20 in Appendix 4.5 depict the location of the road and rail projects, respectively. 
Table 4.42 - Tajikistan prioritization results summary

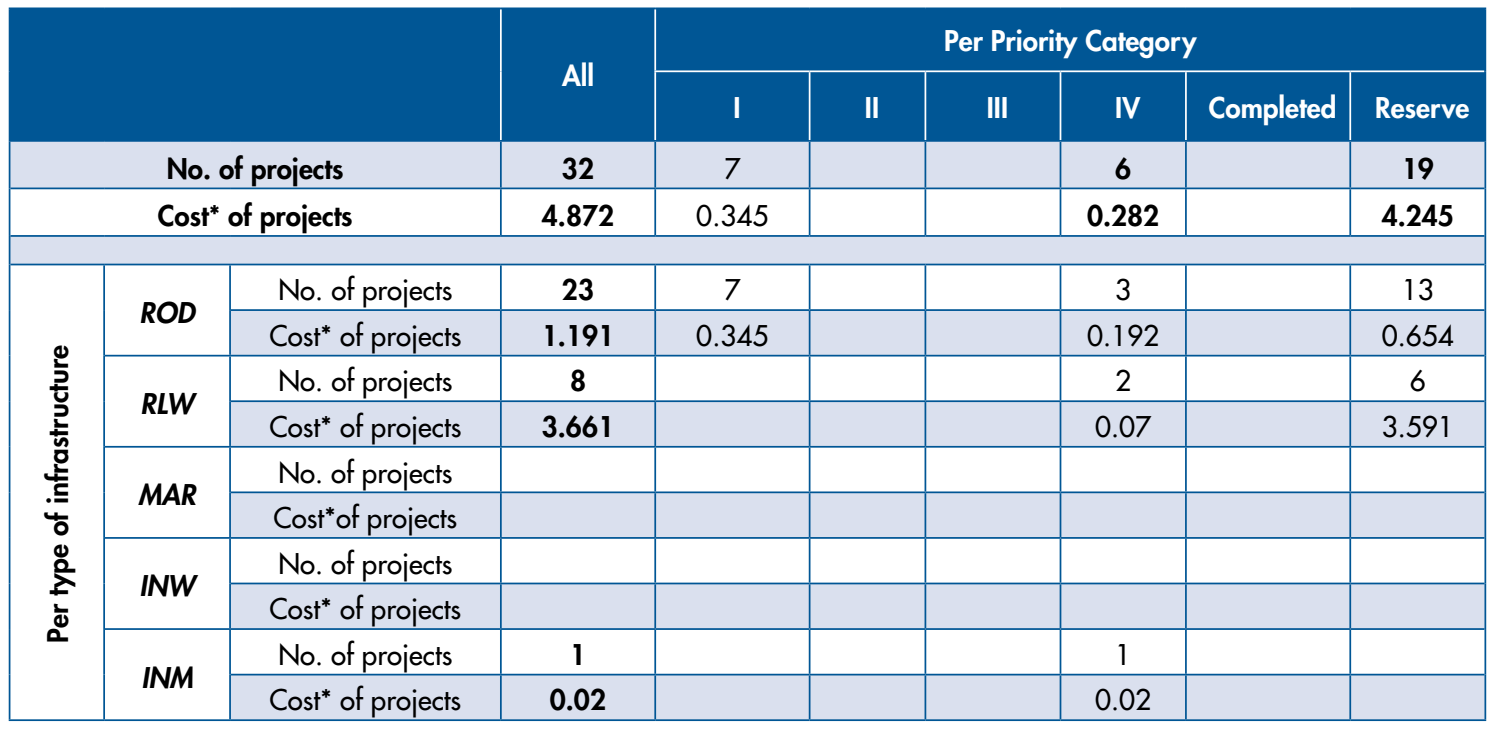

* in billion US\$

\section{The former Yugoslav Republic of Macedonia}

The former Yugoslav Republic of Macedonia proposed 11 projects in total, as follows:

- 6 Road projects

- all along EATL routes

- all belonged in Category I according to the information received

- 5 Rail projects

- 4 along proposed EATL routes, which were classified as Category II based on the application of the methodology

- 1 was considered of national importance

Based on available information, 58 per cent of funding was secured.

The above information, complete with project costs, is summarized in Table 4.43 below, while Map A-19 and Map B-21 in Appendix 4.5 depict the location of the road and rail projects, respectively. The results of applying the methodology are presented in Appendix 4.4.

Table 4.43 - The former Yugoslav Republic of Macedonia prioritization results summary

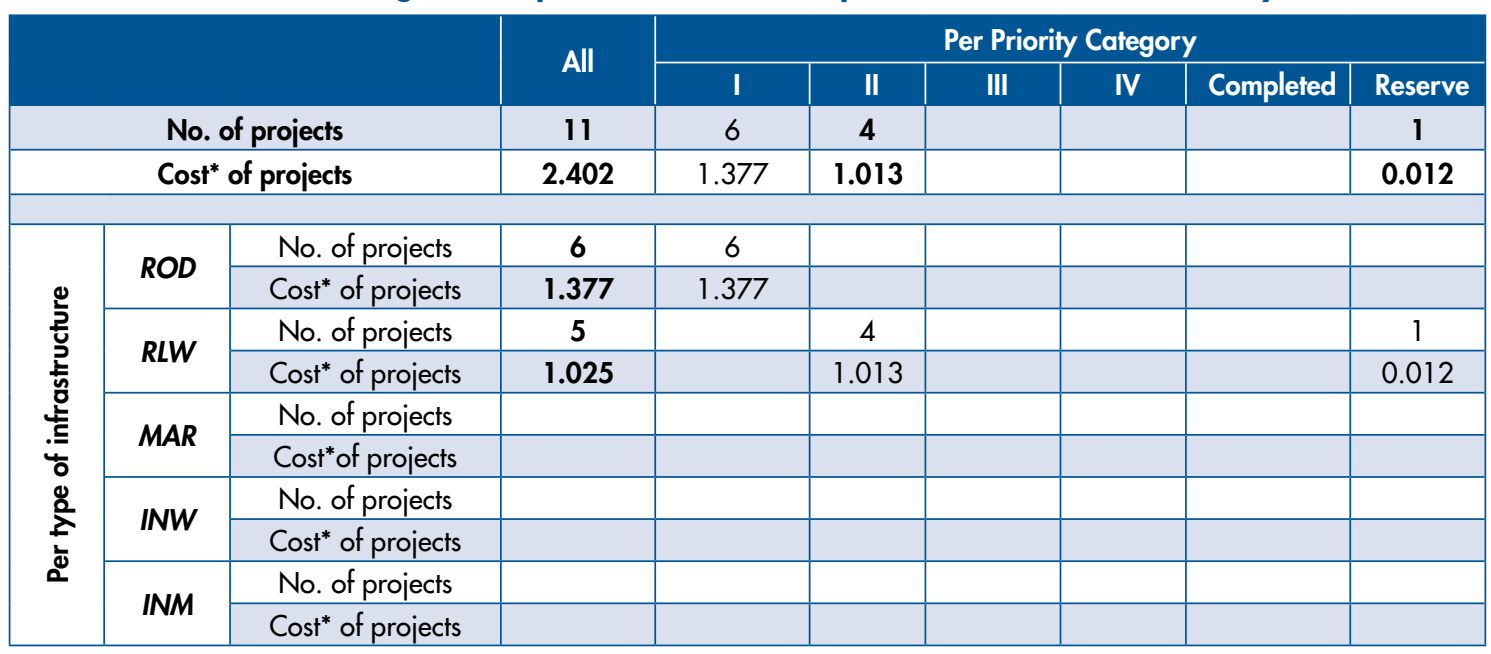

* in billion US\$ 


\section{Turkey}

Turkey proposed 24 projects in total, all along proposed EATL routes. Based on the evaluation methodology applied to the road and rail projects:

- 8 road projects

- 5 with committed funding, thus belonged in Category I

- 3 were classified as Category II

- 9 rail projects

- 5 with committed funding, thus belonged in Category I

- 1 was classified as Category II

- 1 was classified as Category III

- 2 were classified as Category IV

- 7 port projects

- 5 with committed funding, thus belonged in Category I

- 2 were classified as Category II

Based on available information, 52 per cent of funding was secured.

The above information, complete with project costs, is summarized in Table 4.44 below, while Map A-20 and Map B-22 in Appendix 4.5 depict the location of the road and rail projects, respectively. The results of applying the methodology are presented in Appendix 4.4.

Table 4.44 - Turkey prioritization results summary

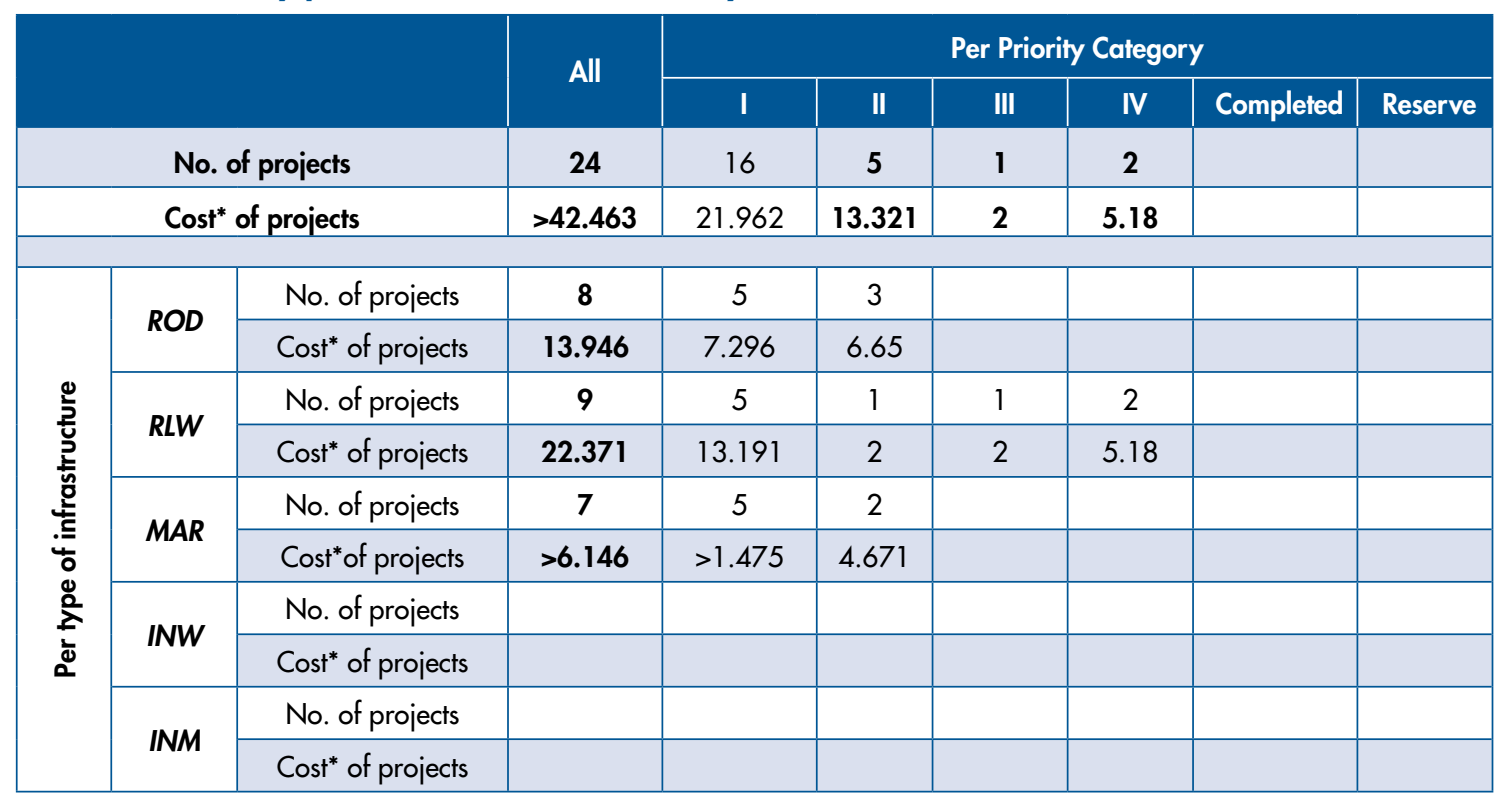

* in billion US\$

\section{Turkmenistan}

Turkmenistan did not submit any data for the EATL Phase II Study.

\section{Ukraine}

Ukraine proposed 4 projects in total, all along proposed EATL, as follows:

- 3 Road projects, of which according to available information:

- 2 were classified as Category I

- 1 was classified as Category II 
- 1 Rail project with committed funding, thus belonging to Category I

Based on available information, 71 per cent of funding was secured.

The above information, complete with project costs, is summarized in Table 4.45 below, while Map A-21 and Map B-23 in Appendix 4.5 depict the location of the road and rail projects, respectively.

Table 4.45 - Ukraine prioritization results summary

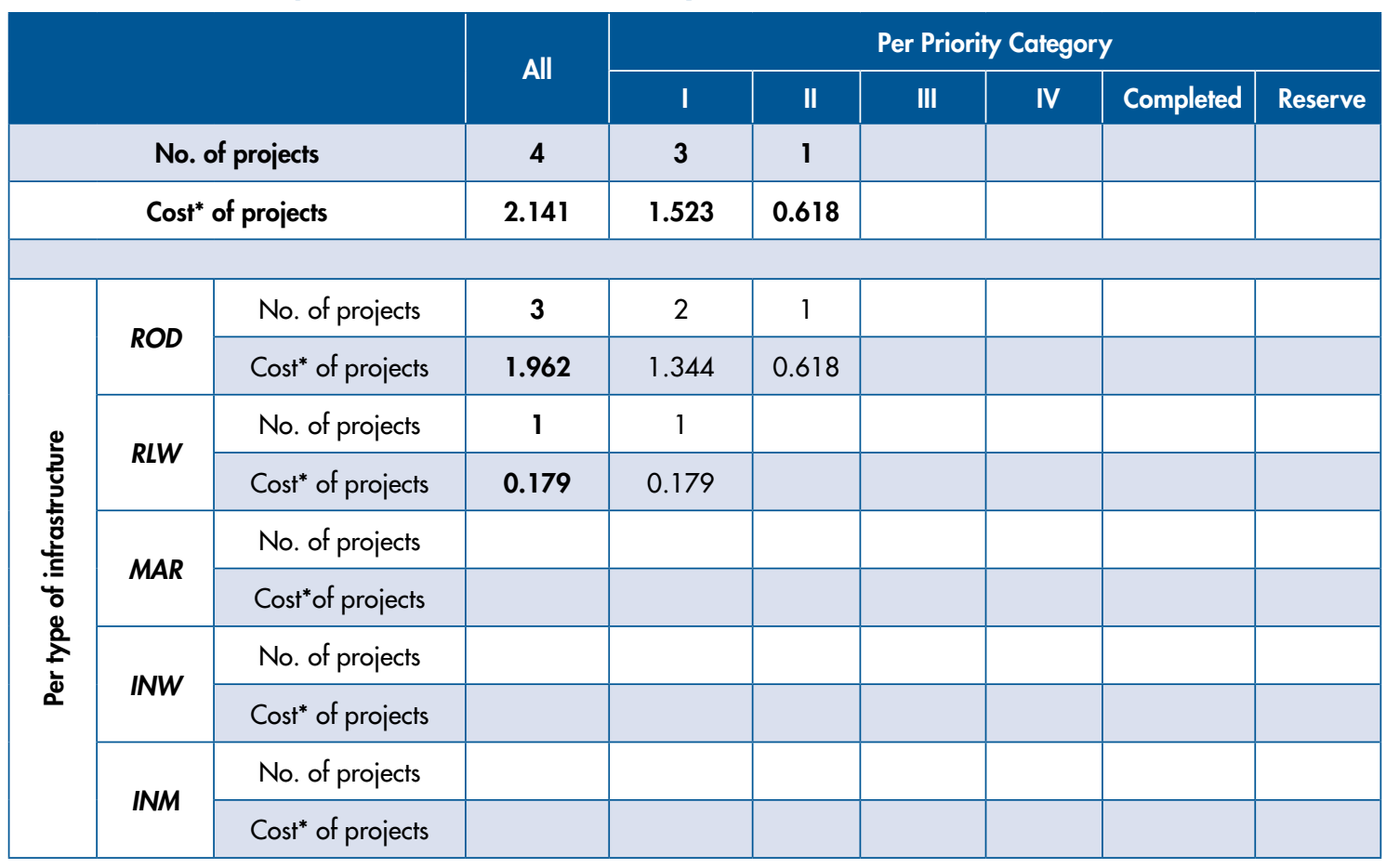

* in billion US\$

\section{Uzbekistan}

Uzbekistan proposed 13 projects in total, as follows:

- 2 Road projects

- all along proposed EATL routes

- according to available information, they were classified as Category I

- 11 Rail projects ${ }^{52}$

- 10 along proposed EATL routes, of which according to available information

- 8 had committed funding, and thus belonged in Category I.

- 2 were classified as Category II

- 1 was considered of national importance

Based on available information, 69 per cent of funding was secured.

The above information, complete with project costs, is summarized in Table 4.46 below, while Map A-22 and Map B-24 in Appendix 4.5 depict the location of the road and rail projects, respectively.

52 Uzbekistan Railways Presentation: Railway Network of Uzbekistan and Central Asia Regional Economic Cooperation, Uzbekistan: Country Progress Report on the Implementation Action Plan for the Transport and Trade Facilitation Strategy, 30 April 2009. Available from http://www.carecprogram. org/uploads/events/2009/8th-TSCC/TTFS-Country-Progress-Report-UZB.pdf. 
Table 4.46 - Uzbekistan prioritization results summary

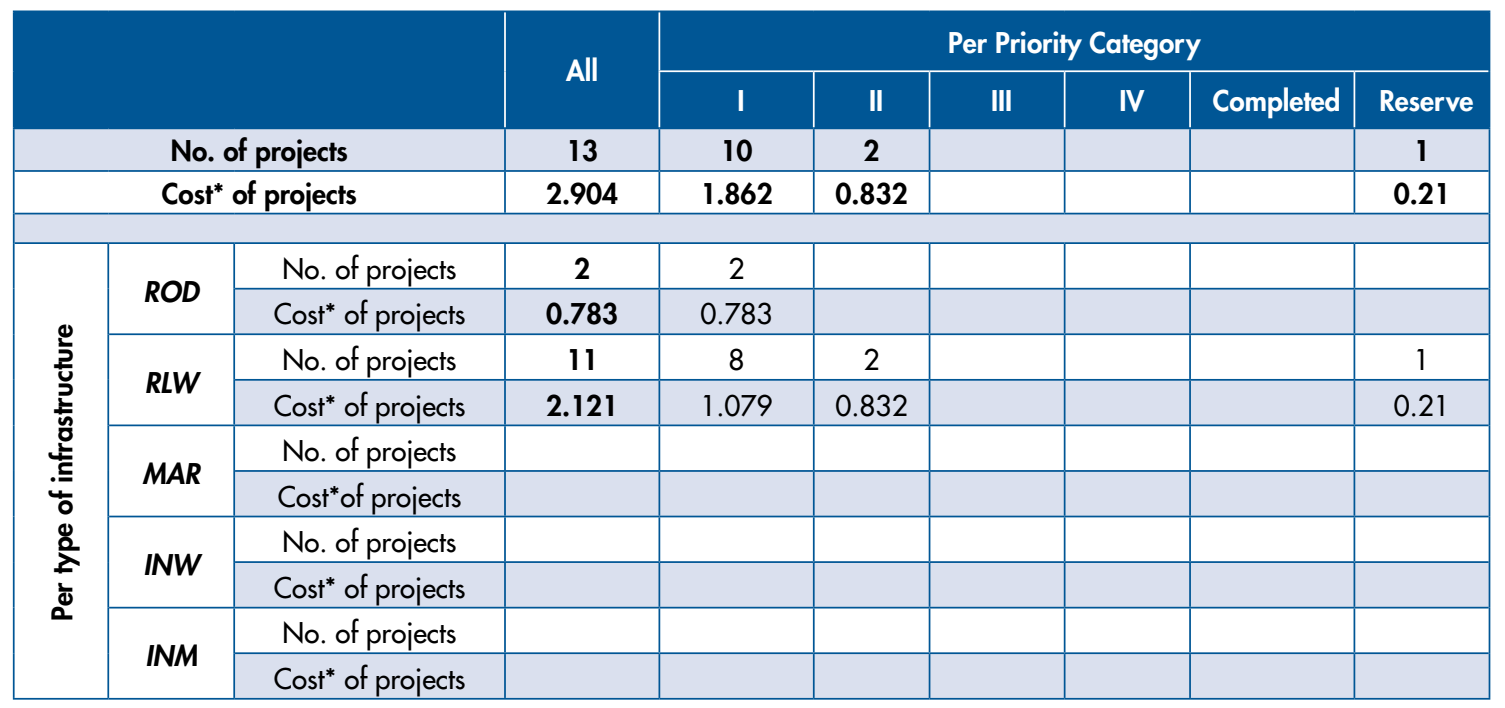

* in billion US\$

\subsubsection{Summary}

In total, 421 projects were proposed by the participating countries, of which 311 were identified to be along the proposed EATL Phase II routes, with an estimated total cost of US\$ 215 billion.

Of these 311 projects:

- 3 were completed

- 188 were Category I projects

- 63 were Category II projects

- 5 were Category III projects

- 52 were Category IV projects

The above results, together with project costs, are presented in Table 4.47 per type of infrastructure.

Table 4.47 - Summary results of EATL II projects

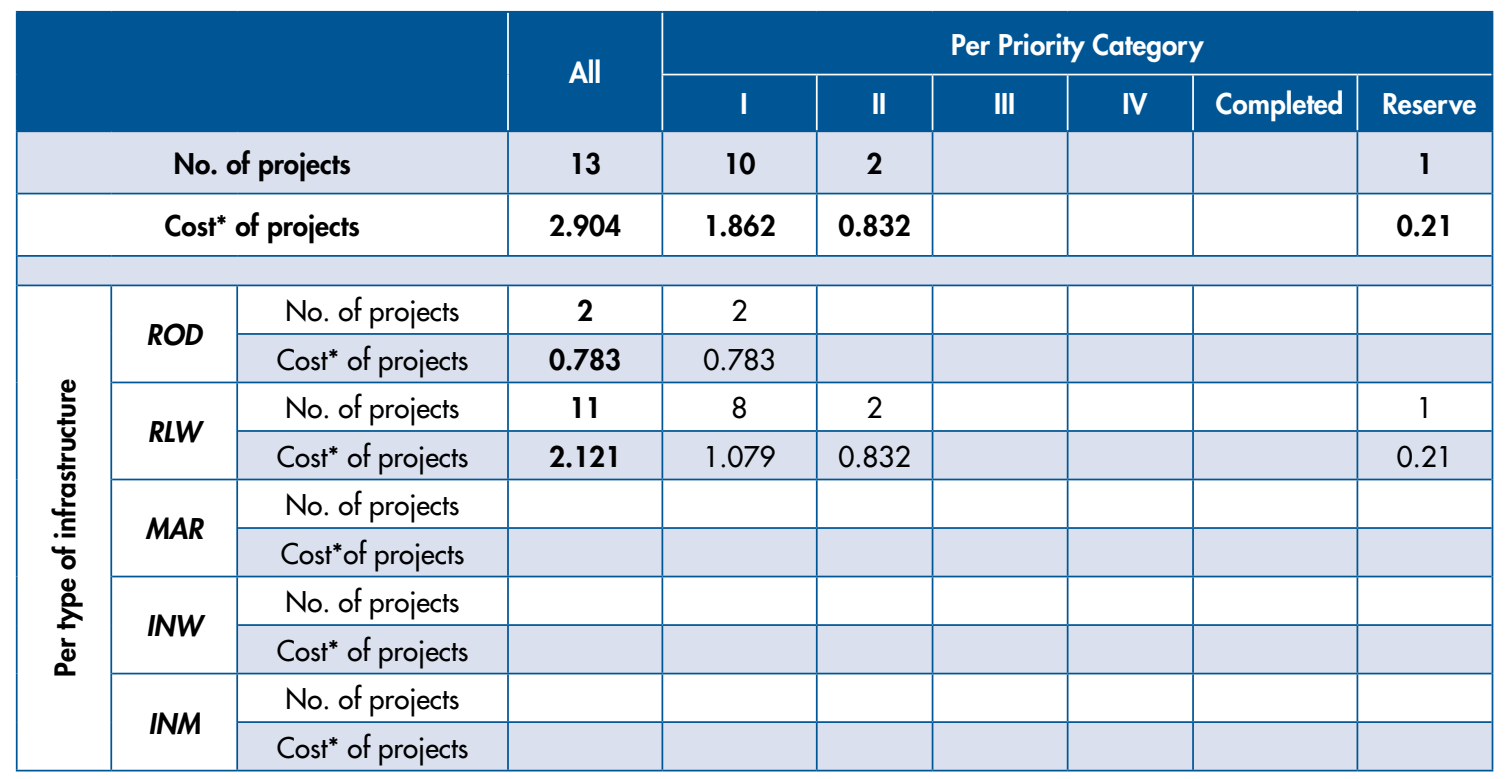

* in billion US\$ 


\subsubsection{Summary of prioritization results}

The countries proposed a total number of $\mathbf{4 2 1}$ infrastructure projects, amounting to total costs of approximately US\$ 274 billion. Of the latter, 311 projects were along proposed EATL Phase II routes, costing a total of approximately US\$ 215 billion. The remaining 110 projects were considered of national importance with a total value of approximately US\$ 58.5 billion.

Of the 311 projects along proposed EATL Phase II routes:

- 146 were road projects ( 47 per cent), with an estimated value of $\$ 114$ billion, representing 53 per cent of the total investment cost.

- 121 were railway projects (39 per cent), with an estimated value of $\$ 75$ billion, representing 35 per cent of the total investment cost.

- $\mathbf{4 4}$ were other projects (14 per cent), with an estimated value of $\$ 26$ billion, representing 12 per cent of the total investment cost.

Secured funding for the total number of EATL projects amounted to 36 per cent.

Further, the results of the prioritization exercise are summarized below per type of project and priority category.

Results: summary per road project priorities and cost

- 58 per cent of road projects were classified as Category I, with an estimated value of $\$ 28.8$ billion, representing 25 per cent of total investment costs for road projects.

- 26 per cent of road projects were classified as Category II, with an estimated value of $\$ 83.2$ billion, representing 73 per cent of total investment costs for road projects.

- 2 per cent of road projects were classified as Category III, with an estimated value of $\$ 0.3$ billion, representing 0.3 per cent of total investment costs for road projects.

- 14 per cent of road projects were classified as Category IV, with an estimated value of $\$ 1.9$ billion, representing 1.6 per cent of total investment costs for road projects.

Results: summary per rail project priorities and cost

- 62 per cent of railway projects were classified as Category I, with an estimated value of $\$ 28$ billion, representing 38 per cent of total investment costs for rail projects.

- 16 per cent of railway projects were classified as Category II, with an estimated value of $\$ 9$ billion, representing 12 per cent of total investment costs for rail projects.

- 2 per cent of railway projects were classified as Category III, with an estimated value of $\$ 2.7$ billion, representing 4 per cent of total investment costs for rail projects.

- 19 per cent of railway projects were classified as Category IV, with an estimated value of $\$ 31.3$ billion, representing 42 per cent of total investment costs for rail projects.

- 1 per cent of rail projects were completed, with an estimated value of $\$ 3.6$ billion, representing 5 per cent of total investment costs for rail projects.

Results: summary per other project priorities and cost

- 64 per cent of other projects were classified as Category I, with an estimated value of $\$ 20.8$ billion, representing 79 per cent of total investment costs for other projects.

- 11 per cent of other projects were classified as Category II, with an estimated value of $\$ 4.9$ billion, representing 19 per cent of total investment costs for other projects.

- 20 per cent of other projects were classified as Category IV, with an estimated value of $\$ 0.1$ billion, representing 1 per cent of total investment costs for other projects.

- 5 per cent of other projects were completed, with an estimated value of $\$ 0.6$ billion, representing 2 per cent of total investment costs for other projects. 


\subsubsection{EATL Phase II Investment Plan}

The analysis of their implementation plans demonstrated that:

- 1 per cent of proposed projects for the EATL network was completed.

- 60 per cent of proposed projects for the EATL network were expected to be completed in the near future.

- 20 per cent of proposed projects for the EATL network were expected to be completed by 2016.

- 2 per cent of proposed projects for the EATL network were expected to be completed by 2020.

- For 17 per cent of proposed projects for the EATL network, it was unknown when they might be completed, since further investigation was necessary before definition and scheduling, and possible financing were secured.

The EATL Phase II Transport Infrastructure Investment Plan is depicted in Table 4.48 with related project costs presented in billion United States dollars. The available/ secured percentage of funding is also shown in Table 4.48. Implementation of the time plan is presented in Table 4.49 .

Table 4.48 - EATL Phase II Transport Infrastructure Investment Plan (in billion US\$)

\begin{tabular}{|c|c|c|c|c|c|c|c|}
\hline \multicolumn{8}{|c|}{ EATL PROJECTS } \\
\hline \multirow{2}{*}{ Country } & \multirow{2}{*}{$\begin{array}{l}\text { EATL Total } \\
\text { Cost }\end{array}$} & \multicolumn{5}{|c|}{ PRIORITY CATEGORY } & \multirow{2}{*}{$\begin{array}{l}\text { \% Funding } \\
\text { Secured }\end{array}$} \\
\hline & & I & II & II & IV & COMPLETED & \\
\hline Afghanistan & 0.228 & 0.003 & 0.000 & 0.000 & 0.225 & 0.000 & $1 \%$ \\
\hline Armenia & 3.069 & 0.517 & 0.032 & 0.000 & 2.520 & 0.000 & $17 \%$ \\
\hline Azerbaijan & 1.338 & 1.338 & 0.000 & 0.000 & 0.000 & 0.000 & $100 \%$ \\
\hline \multicolumn{8}{|l|}{ Belarus } \\
\hline Bulgaria & 7.697 & 7.172 & 0.332 & 0.000 & 0.000 & 0.193 & $93 \%$ \\
\hline China & 7.193 & 4.072 & 3.003 & 0.118 & & 0.000 & $57 \%$ \\
\hline \multicolumn{8}{|l|}{ Finland } \\
\hline Georgia & 1.371 & 0.972 & 0.399 & 0.000 & 0.000 & 0.000 & $71 \%$ \\
\hline Germany & 4.629 & 0.000 & 0.000 & 0.717 & 0.352 & 3.560 & $0 \%$ \\
\hline Greece & 0.780 & 0.780 & 0.000 & 0.000 & 0.000 & 0.000 & $100 \%$ \\
\hline Iran & 3.878 & 2.528 & 1.350 & 0.000 & 0.000 & 0.000 & $65 \%$ \\
\hline Kazakhstan & 8.918 & 8.918 & 0.000 & 0.000 & 0.000 & 0.000 & $100 \%$ \\
\hline Kyrgyzstan & 2.897 & 0.586 & 0.066 & 0.000 & 2.245 & 0.000 & $20 \%$ \\
\hline Latvia & 3.683 & 0.925 & 0.000 & 0.000 & 2.758 & 0.000 & $25 \%$ \\
\hline Lithuania & 1.460 & 1.460 & 0.000 & 0.000 & 0.000 & 0.000 & $100 \%$ \\
\hline \multicolumn{8}{|l|}{ Luxembourg } \\
\hline \multicolumn{8}{|l|}{ Mongolia } \\
\hline Pakistan & 4.242 & 2.376 & 1.334 & 0.133 & 0.000 & 0.399 & $56 \%$ \\
\hline Republic of Moldova & 0.796 & 0.387 & 0.000 & 0.092 & 0.317 & 0.000 & $49 \%$ \\
\hline Romania & 0.643 & 0.273 & 0.245 & 0.000 & 0.125 & 0.000 & $42 \%$ \\
\hline Russian Federation & 112.293 & 18.268 & 74.758 & 0.000 & 19.267 & 0.000 & $16 \%$ \\
\hline Tajikistan & 0.627 & 0.345 & 0.000 & 0.000 & 0.282 & 0.000 & $55 \%$ \\
\hline $\begin{array}{l}\text { The former Yugoslav } \\
\text { Republic of Macedonia }\end{array}$ & 2.390 & 1.377 & 1.013 & 0.000 & 0.000 & 0.000 & $58 \%$ \\
\hline Turkey & 42.463 & 21.962 & 13.321 & 2.000 & 5.180 & 0.000 & $52 \%$ \\
\hline \multicolumn{8}{|l|}{ Turkmenistan } \\
\hline Ukraine & 2.141 & 1.523 & 0.618 & 0.000 & 0.000 & 0.000 & $71 \%$ \\
\hline Uzbekistan & 2.694 & 1.862 & 0.832 & 0.000 & 0.000 & 0.000 & $69 \%$ \\
\hline Total & 215 & 78 & 97 & 3 & 33 & 4 & $36 \%$ \\
\hline
\end{tabular}




$\mathrm{S}$

S

Table 4.49 - EATL Phase II Transport Infrastructure Investment Implementation Time Plan

\begin{tabular}{|c|c|c|c|c|c|c|c|}
\hline \multirow{2}{*}{ Country } & \multirow{2}{*}{ Projects } & \multicolumn{5}{|c|}{ EATL Projects Implementation Progress } & \multirow{2}{*}{$\begin{array}{c}\begin{array}{c}\text { Project } \\
\text { Funding }\end{array} \\
\% \text { Secured }\end{array}$} \\
\hline & & Completed & $\begin{array}{l}\text { Up to } \\
2013\end{array}$ & $\begin{array}{l}2013- \\
2016\end{array}$ & $\begin{array}{l}2016- \\
2020\end{array}$ & $\begin{array}{c}2020- \\
\text { unknown }\end{array}$ & \\
\hline AFG & 6 & $0 \%$ & $17 \%$ & $0 \%$ & $0 \%$ & $83 \%$ & $1 \%$ \\
\hline ARM & 10 & $0 \%$ & $50 \%$ & $20 \%$ & $0 \%$ & $30 \%$ & $17 \%$ \\
\hline AZE & 6 & $0 \%$ & $100 \%$ & $0 \%$ & $0 \%$ & $0 \%$ & $100 \%$ \\
\hline \multicolumn{8}{|l|}{ BLR } \\
\hline BGR & 11 & $9 \%$ & $73 \%$ & $9 \%$ & $0 \%$ & $9 \%$ & $93 \%$ \\
\hline CHN & 18 & $0 \%$ & $44 \%$ & $50 \%$ & $6 \%$ & $0 \%$ & $57 \%$ \\
\hline \multicolumn{8}{|l|}{ FIN } \\
\hline GEO & 16 & $0 \%$ & $50 \%$ & $6 \%$ & $0 \%$ & $44 \%$ & $71 \%$ \\
\hline DEU & 5 & $20 \%$ & $0 \%$ & $0 \%$ & $20 \%$ & $60 \%$ & \\
\hline GRC & 4 & $0 \%$ & $100 \%$ & $0 \%$ & $0 \%$ & $0 \%$ & $100 \%$ \\
\hline IRN & 6 & $0 \%$ & $83 \%$ & $17 \%$ & $0 \%$ & $0 \%$ & $65 \%$ \\
\hline KAZ & 10 & $0 \%$ & $100 \%$ & $0 \%$ & $0 \%$ & $0 \%$ & $100 \%$ \\
\hline KGZ & 7 & $0 \%$ & $43 \%$ & $14 \%$ & $0 \%$ & $43 \%$ & $20 \%$ \\
\hline LVA & 16 & $0 \%$ & $69 \%$ & $0 \%$ & $0 \%$ & $31 \%$ & $25 \%$ \\
\hline LTU & 48 & $0 \%$ & $100 \%$ & $0 \%$ & $0 \%$ & $0 \%$ & $100 \%$ \\
\hline \multicolumn{8}{|l|}{ LUX } \\
\hline \multicolumn{8}{|l|}{ MNG } \\
\hline PAK & 24 & $4 \%$ & $42 \%$ & $42 \%$ & $4 \%$ & $8 \%$ & $56 \%$ \\
\hline MDA & 4 & $0 \%$ & $50 \%$ & $0 \%$ & $25 \%$ & $25 \%$ & $49 \%$ \\
\hline ROU & 6 & $0 \%$ & $67 \%$ & $17 \%$ & $0 \%$ & $17 \%$ & $42 \%$ \\
\hline RUS & 51 & $0 \%$ & $25 \%$ & $49 \%$ & $0 \%$ & $25 \%$ & $16 \%$ \\
\hline TJK & 13 & $0 \%$ & $54 \%$ & $0 \%$ & $0 \%$ & $46 \%$ & $55 \%$ \\
\hline FYROM & 10 & $0 \%$ & $60 \%$ & $40 \%$ & $0 \%$ & $0 \%$ & $58 \%$ \\
\hline TUR & 24 & $0 \%$ & $67 \%$ & $21 \%$ & $4 \%$ & $8 \%$ & $52 \%$ \\
\hline \multicolumn{8}{|l|}{ TKM } \\
\hline UKR & 4 & $0 \%$ & $75 \%$ & $25 \%$ & $0 \%$ & $0 \%$ & $71 \%$ \\
\hline UZB & 12 & $0 \%$ & $83 \%$ & $17 \%$ & $0 \%$ & $0 \%$ & $69 \%$ \\
\hline \multirow{3}{*}{$\begin{array}{c}\text { EATL } \\
\text { NETWORK }\end{array}$} & & \multicolumn{5}{|c|}{ EATL Projects Implementation Progress } & \multirow{2}{*}{$\begin{array}{l}\text { \% Funding } \\
\text { Secured }\end{array}$} \\
\hline & Projects & Completed & $\begin{array}{l}\text { Up to } \\
2013\end{array}$ & $\begin{array}{l}2013- \\
2016\end{array}$ & $\begin{array}{l}2016- \\
2020\end{array}$ & $\begin{array}{c}2020- \\
\text { unknown }\end{array}$ & \\
\hline & 311 & $1 \%$ & $60 \%$ & $20 \%$ & $2 \%$ & $17 \%$ & $36 \%$ \\
\hline
\end{tabular}

\subsubsection{Project Prioritization per EATL Priority Route}

In addition to the project prioritization at the country level, the prioritization exercise was carried out at the route level, for road and rail infrastructure projects only, along the identified priority EATL road and rail routes, respectively. A brief analysis is presented in the following, while results are summarised in Tables 4.50 and 4.51, for the road and rail routes respectively.

It should be noted that there are several projects (both road and rail) that are included in more than one road or rail route, since there are overlapping sections/segments amongst the EATL routes identified. For the purpose of the current analysis, and in order to avoid any double counting, each project cost is included only once in a single route, with an indication that the same project is located in another route(s), if this is the case. For the other route(s), the project is included with 0 cost. The estimation of costs for each route is presented in detail in Appendix 4.6. 


\section{EATL Road Routes}

\section{Road Route 1}

28 projects are included in EATL Road Route 1 from Germany, Latvia, Lithuania, Russian Federation and Ukraine, 18 out of which are also included in any of Road Routes 2, 3 and 6. The total investment cost for the route amounts to $\$ 4,31$ billion, out of which $\$ 3,343$ billion is for non-EU countries, which is not secured. The investment cost for EU countries amounts to $\$ 0,967$ billion, out of which $\$ 0,365$ billion has been secured.

\section{Road Route 2}

32 projects are included in EATL Road Route 2 from China, Germany, Kazakhstan, Lithuania, Russian Fed, and Uzbekistan, 29 out of which are also included in any of Road Routes 1, 3, 4, 5 and 6. The total investment cost for the route amounts to $\$ 41,935$ billion, out of which $\$ 41,136$ billion is for non-EU countries, with $\$ 4,69$ billion of this having been secured. The investment cost for EU countries amounts to $\$ 0,799$ billion, out of which $\$ 0,447$ billion has been secured.

\section{Road Route 3}

29 projects are included in EATL Road Route 3 from Bulgaria, China, Germany, Kazakhstan, Lithuania, Russian Fed, Ukraine and Uzbekistan, 20 out of which are also included in any of Road Routes $1,2,4,5$ and 6 . The total investment cost for the route amounts to $\$ 38,539$ billion, out of which $\$ 38,217$ billion is for non-EU countries, with $\$ 4,75$ billion of this having been secured. Theinvestment cost for EU countries amounts to $\$ 0,323$ billion, out of which $\$ 0,873$ billion has been secured.

\section{Road Route 4}

39 projects are included in EATL Road Route 4 from Armenia, Azerbaijan, China, Georgia, Kazakhstan, Kyrgyzstan, Moldova and Uzbekistan, 15 out of which are also included in any of Road Routes 2, 3, 5 and 6. The total investment cost for the route amounts to $\$ 2,853$ billion, out of which $\$ 2,853$ billion is for non-EU countries, with $\$ 2,761$ billion of this having been secured.

\section{Road Route 5}

71 projects are included in EATL Road Route 5 from Afghanistan, Bulgaria, China, FYROM, Greece, Kazakhstan, Kyrgyzstan, Pakistan, Tajikistan and Turkey, 8 out of which are also included in any of Road Routes 2, 3, and 4. The total investment cost for the route amounts to $\$ 24,897$ billion, out of which $\$ 23,859$ billion is for non-EU countries, with $\$ 13,34$ billion of this having been secured. The investment cost for EU countries amounts to $\$ 1,037 \mathrm{billion}$, out of which $\$ 0,705$ billion has been secured.

\section{Road Route 6}

5 projects are included in EATL Road Route 6 from Azerbaijan, Kazakhstan, and the Russian Federation, 3 out of which are also included in any of Road Routes 1,2, 3, and 4. The total investment cost for the route amounts to $\$ 1,434$ billion, out of which $\$ 1,434$ billion is for nonEU countries, with $\$ 0,829$ billion of this having been secured.

\section{Road Route 7}

1 project is included in EATL Road Route 7 from the Russian Federation (non-EU). The total investment cost amounts to $\$ 0,088$ billion, which is not secured.

\section{Road Route 8}

No projects are included in EATL Road Route 8.

\section{Road Route 9}

1 project is included in EATL Road Route 9 from the Russian Federation (non-EU). The total investment cost amounts to $\$ 0,156$ billion, which has been secured. 
Table 4.50-Prioritization of Investment per EATL Road Route

\begin{tabular}{|c|c|c|c|c|c|c|c|}
\hline $\begin{array}{l}\text { Road } \\
\text { Route } \\
\text { Number }\end{array}$ & Countries & $\begin{array}{l}\text { Number of } \\
\text { Projects }\end{array}$ & $\begin{array}{l}\text { Project } \\
\text { Total Cost } \\
\text { (Billion \$) }\end{array}$ & Non-EU & EU & $\begin{array}{l}\text { Priority I } \\
\text { Non-EU } \\
\text { (Billion \$) }\end{array}$ & $\begin{array}{l}\text { Priority I } \\
\text { EU } \\
\text { (Billion \$) }\end{array}$ \\
\hline 1 & $\begin{array}{l}\text { Germany, Latvia, Lithuania, } \\
\text { Russian Federation, Ukraine }\end{array}$ & 28 & $4,31^{*}$ & $3,343^{*}$ & $0,967^{*}$ & -* & $0,365^{*}$ \\
\hline 2 & $\begin{array}{c}\text { China, Germany, Kazakhstan, } \\
\text { Lithuania, Russian Federation, } \\
\text { Uzbekistan }\end{array}$ & 32 & 41,935 & 41,136 & 0,799 & 4,690 & 0,447 \\
\hline 3 & $\begin{array}{l}\text { Bulgaria, China, Germany, } \\
\text { Kazakhstan, Lithuania, Russian } \\
\text { Fed, Ukraine, Uzbekistan }\end{array}$ & 29 & $38,539^{*}$ & $38,217^{*}$ & $0,323^{*}$ & $4,750^{*}$ & $0,873^{*}$ \\
\hline 4 & $\begin{array}{c}\text { Armenia, Azerbaijan, China, } \\
\text { Georgia, Kazakhstan, Kyrgyzstan, } \\
\text { Moldova, Uzbekistan }\end{array}$ & 39 & $2,853^{*}$ & $2,853^{*}$ & -* & $2,761^{*}$ & -* \\
\hline 5 & $\begin{array}{l}\text { Afghanistan, Bulgaria, China, } \\
\text { FYROM, Greece, Kazakhstan, } \\
\text { Kyrgyzstan, Pakistan, Tajikistan, } \\
\text { Turkey }\end{array}$ & 71 & $24,897^{*}$ & $23,859^{*}$ & $1,037^{*}$ & $13,340^{*}$ & $0,705^{*}$ \\
\hline 6 & $\begin{array}{c}\text { Azerbaijan, Kazakhstan, Russian } \\
\text { Federation }\end{array}$ & 5 & $1,434^{*}$ & $1,434^{*}$ & $-*$ & $0,829^{*}$ & -* \\
\hline 7 & Russian Federation & 1 & 0,088 & 0,088 & - & - & - \\
\hline 8 & - & - & - & - & - & - & - \\
\hline 9 & Russian Federation & 1 & 0,156 & 0,156 & - & 0,156 & - \\
\hline & & Total Cost & 114,212 & & $\begin{array}{l}\text { Priority I } \\
\text { Total Cost }\end{array}$ & 15,846 & 13,068 \\
\hline
\end{tabular}

*Part of total cost (certain projects' costs have been allocated to other routes see Appendix 4.6)

\section{EATL Rail Routes}

\section{Rail Route 1}

50 projects are included in EATL Rail Route 1 from Germany, Latvia, Lithuania, Russian Federation and Ukraine, 43 out of which are also included in any of Rail Routes 2, 5, 8 and 9. The total investment cost for the route amounts to $\$ 23,638$ billion, out of which $\$ 21,357$ billion is for non-EU countries, with $\$ 0,208$ billion of this having been secured. The investment cost for EU countries amounts to $\$ 2,282$ billion, out of which $\$ 1,404$ billion has been secured.

\section{Rail Route2}

38 projects are included in EATL Rail Route 2 from Germany, Kazakhstan, Lithuania and Russian Federation, all of which are included in any of Rail Routes 1, 3, 4, 5, 7, 8 and 9.

\section{Rail Route 3}

35 projects are included in EATL Rail Route 3 from Armenia, Azerbaijan, Bulgaria, the former Yugoslav Republic of Macedonia, Georgia, Kazakhstan, Kyrgyzstan, Moldova, Tajikistan, Turkey and Uzbekistan, 22 out of which are also included in any of Rail Routes 2, 4, 5, 7, 8 and 9. The total investment cost for the route amounts to $\$ 7,579$ billion for non-EU countries, out of which $\$ 1,574$ billion has been secured.

\section{Rail Route 4}

27 projects are included in EATL Rail Route 4 from Bulgaria, the former Yugoslav Republic of Macedonia, Greece, Iran, Kazakhstan, Pakistan, Turkey and Uzbekistan, 12 out of which are also included in any of Rail Routes 2, 3, 7 and 9. The total investment cost for the route amounts to $\$ 32,739$ billion, out of which $\$ 25,873$ billion is for non-EU countries, with $\$ 15,235$ billion of this having been secured. The investment cost for EU countries amounts to $\$ 6,866$ billion, which has been secured. 


\section{Rail Route 5}

17 projects are included in EATL Rail Route 5 from Iran, Russian Federation and Uzbekistan, 12 out of which are also included in any of Rail Routes 1,2, 3, 7 and 9. The total investment cost for the route amounts to $\$ 4,51$ billion for non-EU countries, out of which $\$ 2,314$ billion has been secured.

\section{Rail Route 6}

3 projects are included in EATL Rail Route 6 from Germany, Russian Federation and Ukraine, 1 out of which is also included in Rail Routes 1,7 , and 8 . The total investment cost for the route amounts to $\$ 0,013$ billion for non-EU countries, which has been secured.

\section{Rail Route 7}

7 projects are included in EATL Rail Route 7 from Kazakhstan, Ukraine and Uzbekistan, all of which are included in any of Rail Routes 1,2, 3, 4, 5, 6, 8 and 9.

\section{Rail Route 8}

29 projects are included in EATL Rail Route 8 from Armenia, Azerbaijan, Georgia, Latvia, Lithuania, Russian Federation and Ukraine, 25 out of which are also included in any of Rail Routes 1, 2, 3, 6, 7 and 9. The total investment cost for the route amounts to $\$ 2,084$ billion, out of which $\$ 0,089$ billion is for non-EU countries, with $\$ 0,041$ billion of this having been secured. The investment cost for EU countries amounts to $\$ 1,995$ billion, which is not secured.

\section{Rail Route 9}

19 projects are included in EATL Rail Route 9 from the Russian Federation, Tajikistan and Uzbekistan, 18 out of which are also included in any of Rail Routes 1, 2, 3, 4, 5, 7 and 9. The total investment cost for the route amounts to $\$ 0,638$ billion for non-EU countries, out of which $\$ 0,415$ billion has been secured.

Table 4.5 1-Prioritization of Investment per EATL Rail Route

\begin{tabular}{|c|c|c|c|c|c|c|c|}
\hline $\begin{array}{l}\text { Rail } \\
\text { Route } \\
\text { Number }\end{array}$ & Countries & $\begin{array}{l}\text { Number } \\
\text { of } \\
\text { Projects }\end{array}$ & $\begin{array}{c}\text { Project Total } \\
\text { Cost } \\
\text { (Billion \$) }\end{array}$ & Non-EU & EU & $\begin{array}{l}\text { Priority I } \\
\text { Non-EU } \\
\text { (Billion \$) }\end{array}$ & $\begin{array}{l}\text { Priority I EU } \\
\text { (Billion \$) }\end{array}$ \\
\hline 1 & $\begin{array}{l}\text { Germany, Latvia, Lithuania, } \\
\text { Russian Federation, Ukraine }\end{array}$ & 50 & 23,638 & 21,357 & 2,282 & 0,208 & 1,404 \\
\hline 2 & $\begin{array}{c}\text { Germany, Kazakhstan, Lithuania, } \\
\text { Russian Federation }\end{array}$ & 38 & -* & -* & -* & -* & -* \\
\hline 3 & $\begin{array}{c}\text { Armenia, Azerbaijan, Bulgaria, } \\
\text { the former Yugoslav Republic of } \\
\text { Macedonia, Georgia, Kazakhstan, } \\
\text { Kyrgyzstan, Moldova, Tajikistan, } \\
\text { Turkey, Uzbekistan }\end{array}$ & 35 & $7,579^{*}$ & $7,579^{*}$ & -* & $1,574^{*}$ & -* \\
\hline 4 & $\begin{array}{c}\text { Bulgaria, FYROM, Greece, Iran, } \\
\text { Kazakhstan, Pakistan, Turkey, } \\
\text { Uzbekistan }\end{array}$ & 27 & $32,739^{*}$ & $25,873^{*}$ & $6,866^{*}$ & $15,235^{*}$ & $6,866^{*}$ \\
\hline 5 & $\begin{array}{l}\text { Iran, Russian Federation, } \\
\text { Uzbekistan }\end{array}$ & 17 & $4,510^{*}$ & $4,510^{*}$ & - & $2,314^{*}$ & - \\
\hline 6 & $\begin{array}{c}\text { Germany, Russian Federation, } \\
\text { Ukraine }\end{array}$ & 3 & $0,013^{*}$ & $0,013^{*}$ & -* & $0,013^{*}$ & - \\
\hline
\end{tabular}




\begin{tabular}{|c|c|c|c|c|c|c|c|}
$\begin{array}{c}\text { Rail } \\
\text { Route } \\
\text { Number }\end{array}$ & Countries & $\begin{array}{c}\text { Number } \\
\text { of } \\
\text { Projects }\end{array}$ & $\begin{array}{c}\text { Project Total } \\
\text { Cost } \\
\text { (Billion \$) }\end{array}$ & Non-EU & EU & $\begin{array}{c}\text { Priority I } \\
\text { Non-EU } \\
\text { (Billion \$) }\end{array}$ & $\begin{array}{c}\text { Priority I EU } \\
\text { (Billion \$) }\end{array}$ \\
\hline $\mathbf{7}$ & Kazakhstan, Ukraine, Uzbekistan & 7 & $-*$ & $-*$ & - & $-*$ & - \\
\hline $\mathbf{8}$ & $\begin{array}{c}\text { Armenia, Azerbaijan, Georgia, } \\
\text { Latvia, Lithuania, Russian } \\
\text { Federation, Ukraine }\end{array}$ & 29 & $2,084^{*}$ & $0,089^{*}$ & $1,995^{*}$ & $0,041^{*}$ & - \\
\hline $\mathbf{9}$ & $\begin{array}{c}\text { Russian Federation, Tajikistan, } \\
\text { Uzbekistan }\end{array}$ & 19 & $0,638^{*}$ & $0,638^{*}$ & - & $0,415^{*}$ & - \\
\hline & Total Cost & $\mathbf{7 1 , 2 0 2}$ & & $\begin{array}{c}\text { Priority } \\
\text { I Total } \\
\text { Cost }\end{array}$ & $\mathbf{1 9 , 8 0 1}$ & $\mathbf{8 , 2 7 0}$ \\
\hline
\end{tabular}

*Part of total cost (certain projects' costs have been allocated to other routes, see Appendix 4.6)

\subsubsection{Conclusions and recommendations}

A total of 311 infrastructure projects along EATL Phase II routes were proposed in the Study and included in the updated EATL Investment Plan. The majority were road projects. Implementation of the EATL network as a whole required approximately $\$ 215$ billion, of which only 36 per cent were secured.

According to the results of the analysis, only 1 per cent of the EATL network was completed, while over half of the proposed projects were planned to be completed in the near future. On the other hand, the analysis yielded that for 17 per cent of proposed projects for the EATL network, it was unknown when they might be completed, since further investigation was necessary before definition and scheduling, plus possible financing were secured for the projects. It should, however, be noted that the lack of information regarding the status, start and end dates, sources of funding and percentage of secured funding of those proposed projects, as well as the complete omission of information from Belarus, Finland, Luxembourg and Turkmenistan, contributed significantly to the latter outcome. Hence, the above figures could potentially be different were information to become available.

Based on the above, it can be ascertained that the implementation of EATL Phase II network is a long-term process that requires, first and foremost, the political will and commitment of all the countries involved. To see it to fruition will also require continuous close cooperation among EATL Member Countries, between them and their immediate neighbouring countries, the respective National Focal Points and the UNECE.

To this end, a number of actions could be recommended with regard to data collection, monitoring, GIS mapping update/maintenance, continuous revision/updating of the Investment Plan and funding securitization, as well as regarding certain technical and institutional aspects.

Finally, in addition to the projects located along the identified EATL Phase II routes, most participating countries proposed infrastructure projects beyond those specified routes, which were considered to be of national importance in the analysis. Depending on the significance and the priorities set for these national projects, as well as their potential to impact the established connections with EATL routes, it is proposed that they be considered for inclusion in a future revision of the EATL network. 


\section{Appendix 4.1}

\section{TEMPLATES B for EATL Phase I Countries}
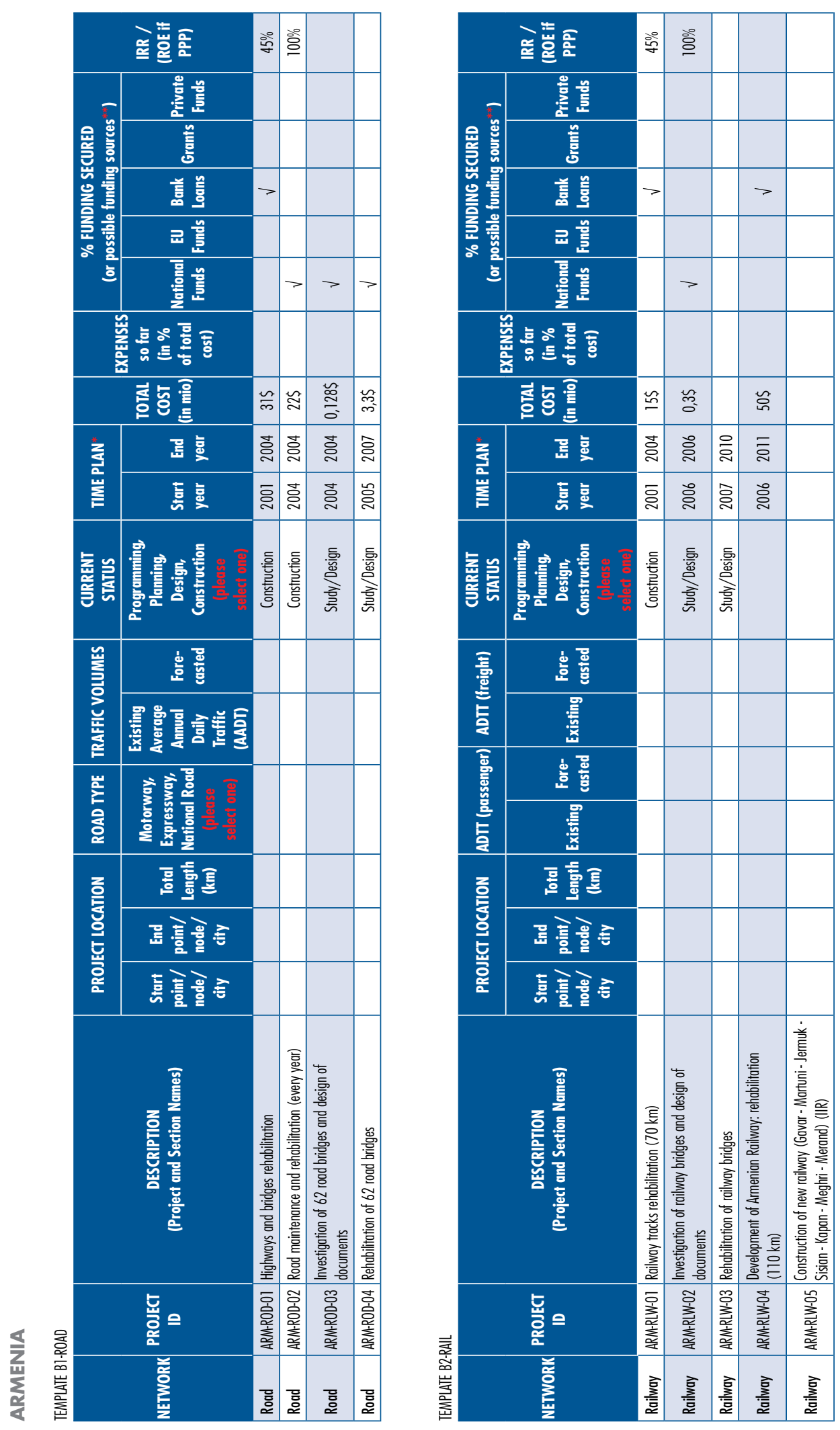


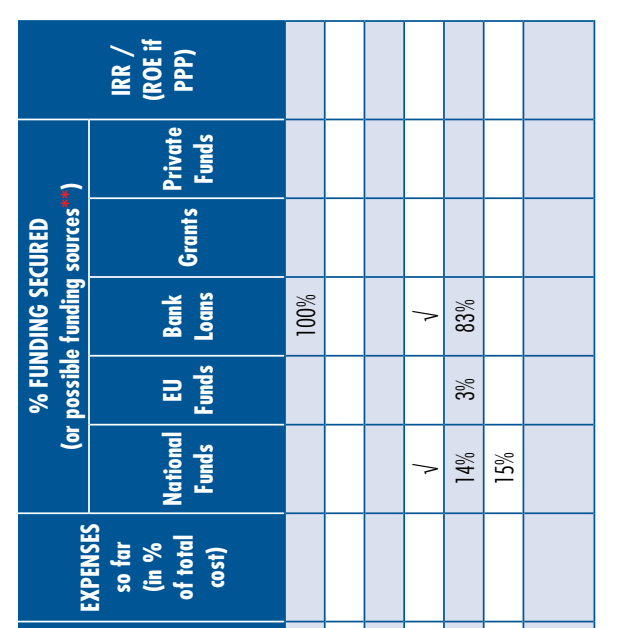

\begin{tabular}{|c|c|c|c|c|c|}
\hline \multicolumn{2}{|c|}{ 言望豆 } & $\tilde{\sigma}$ & & $\ddot{g}$ & \\
\hline 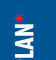 & 蛋总 & छे ? & & & : \\
\hline$\underline{\underline{\underline{s}}}$ & $\underline{\underline{n}}$ & వి & & & : \\
\hline
\end{tabular}

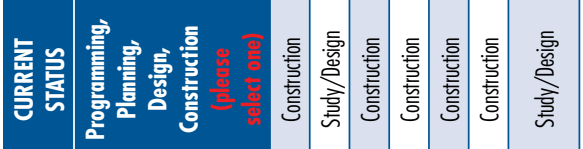

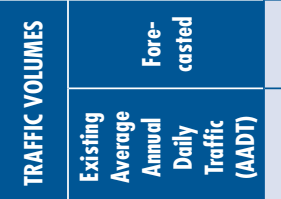

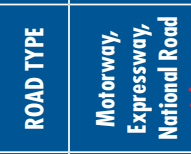

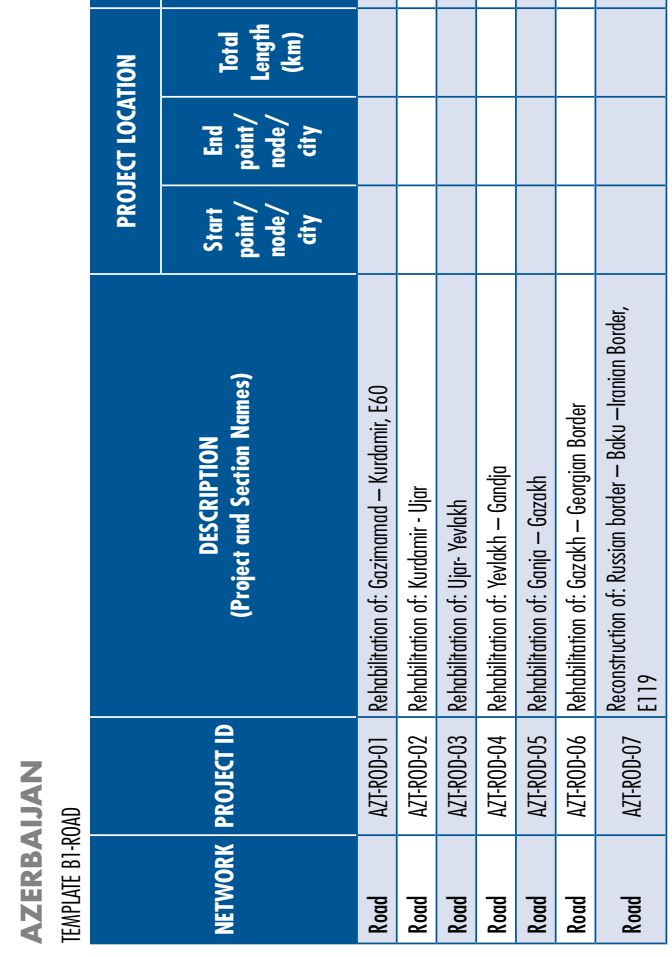

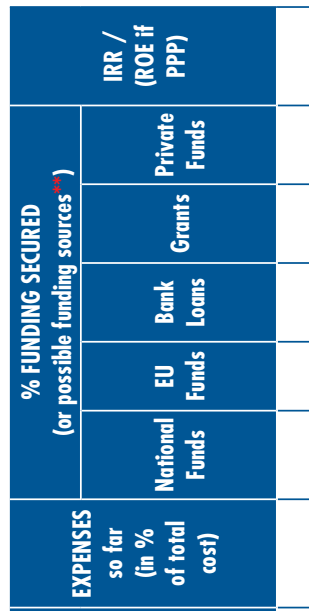

\begin{tabular}{|c|c|}
\hline \multicolumn{2}{|c|}{ 言氮毫 } \\
\hline$\xi$ & 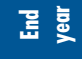 \\
\hline 㟝 & 志 \\
\hline
\end{tabular}
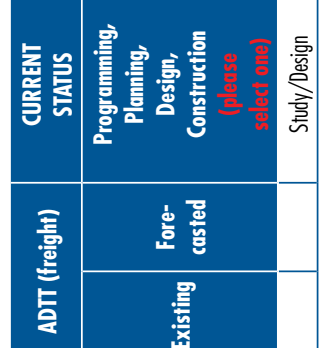

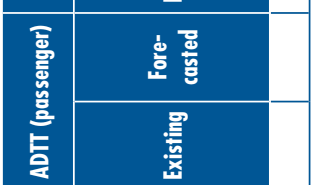
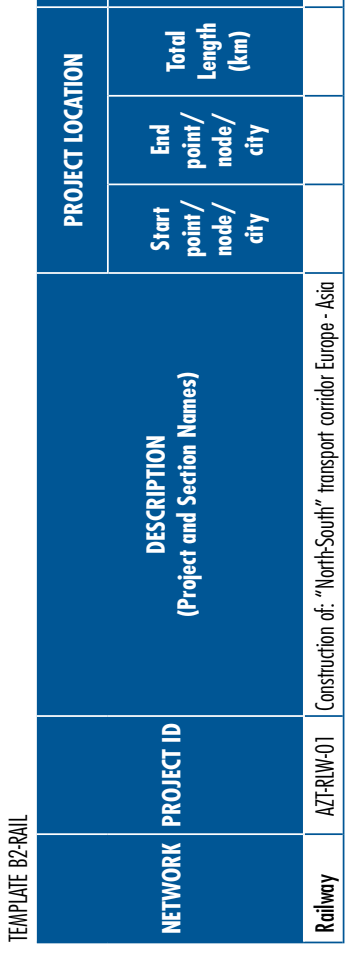
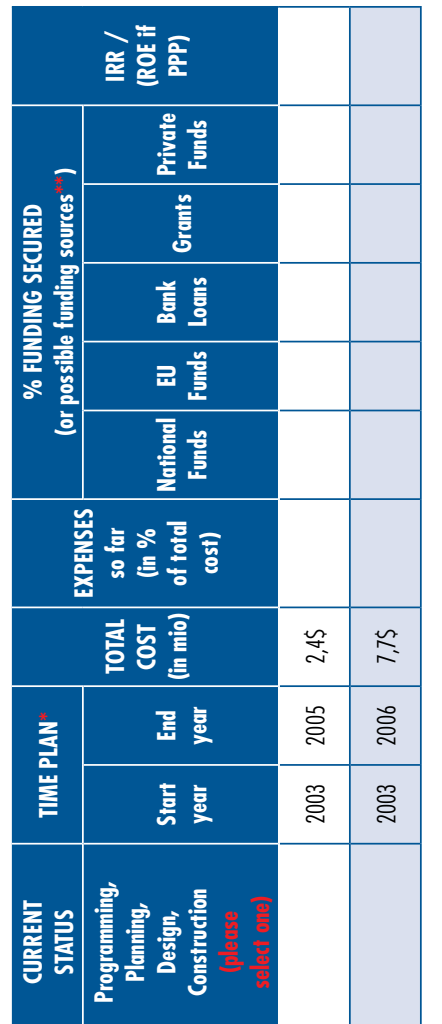

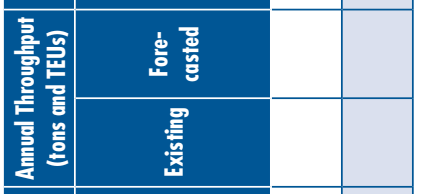

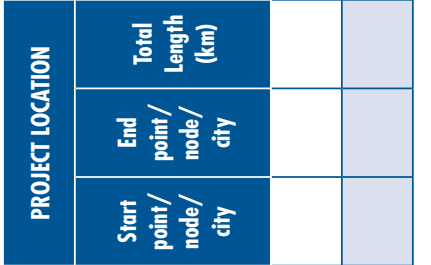

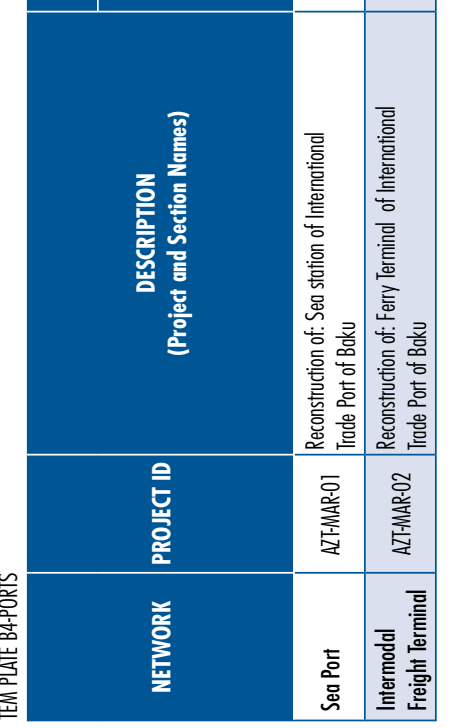



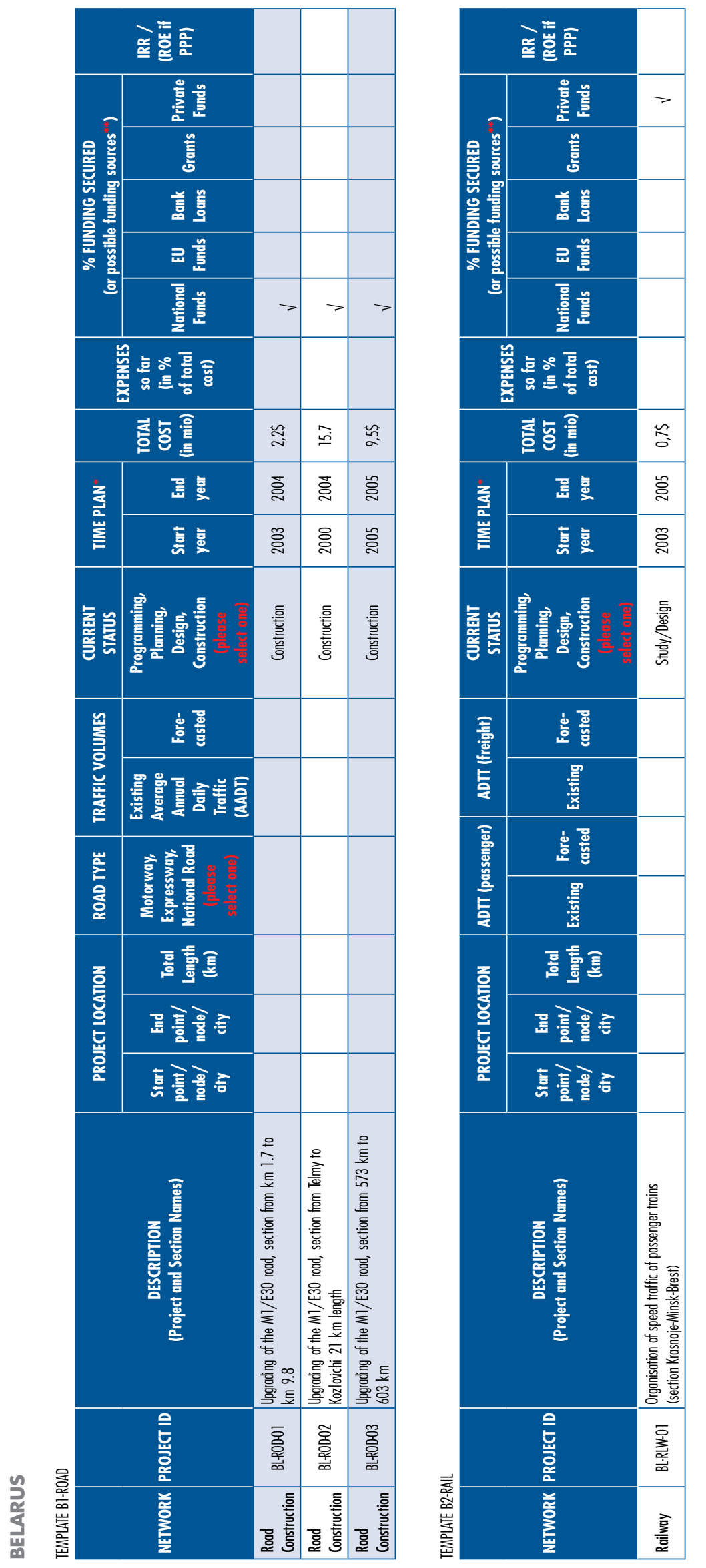


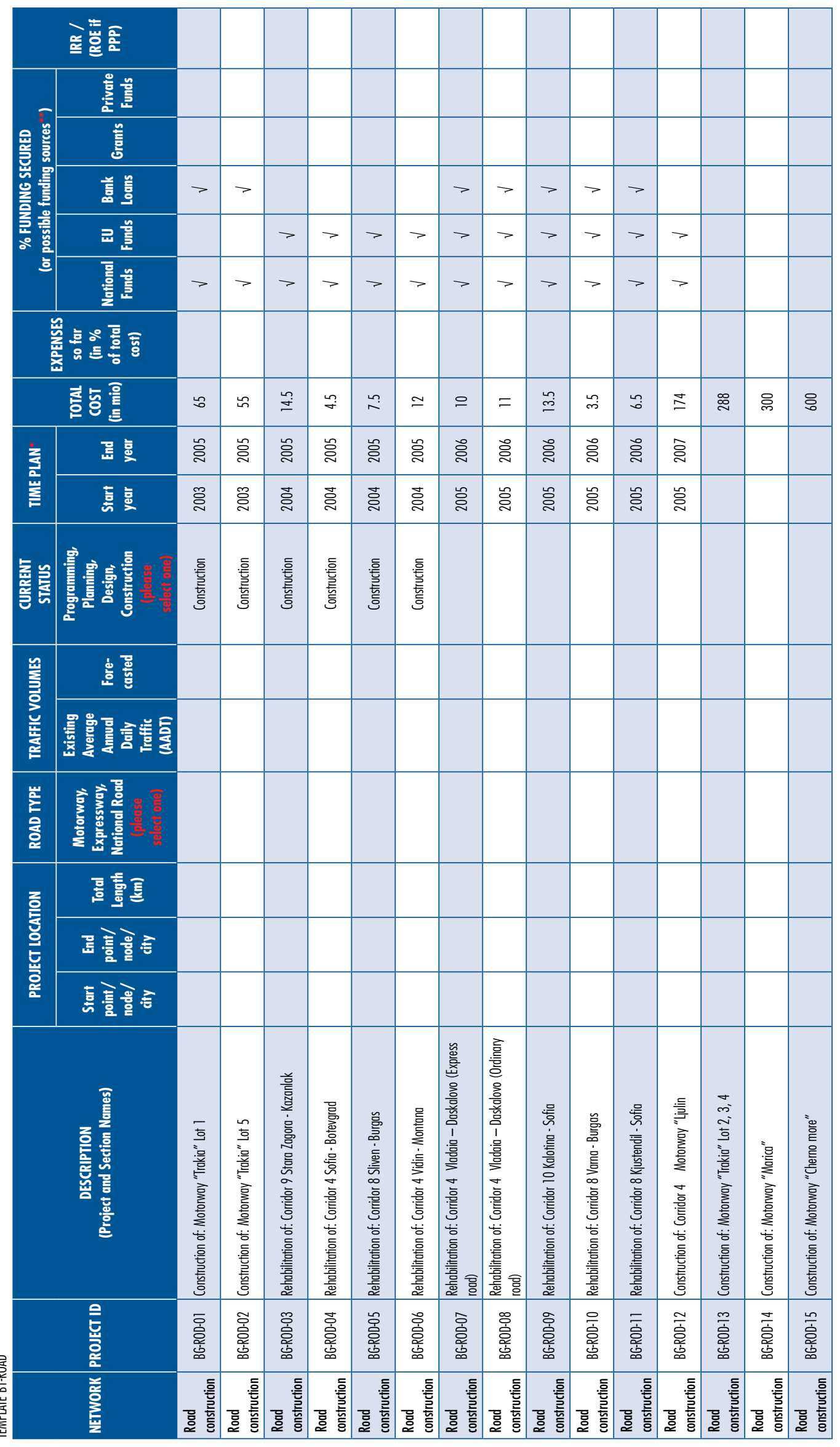




\begin{tabular}{|c|c|c|c|c|c|c|c|c|}
\hline & 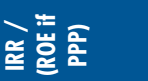 & ळे & ळे & ळे & 客 & | & 窎 & 害 \\
\hline & 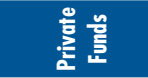 & & & & & & & \\
\hline 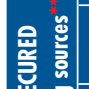 & 言 & & & & & & & \\
\hline 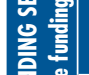 & 高 & 离 & & & & & & \\
\hline 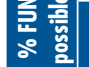 & 루 & 怼 & & 今े & 突 & 品 & 方 & 高 \\
\hline $\overrightarrow{\mathbf{b}}$ & 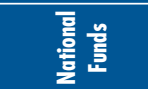 & $\stackrel{\varrho}{\doteq}$ & $>$ & $\ddot{\mathrm{D}}$ & ڤे & ¿ & 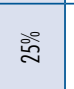 & ڤ̊ํㅇ \\
\hline 产 & 홍을 응 & & & & & & & \\
\hline & 言氮尊 & 峞 & $\Psi$ & 总 & 惫 & 岕 & $\underset{\aleph \alpha}{\stackrel{\varpi}{~}}$ & 岕 \\
\hline$z$ & 畐壱 & 음 & ఏ్రి & $\stackrel{\infty}{\grave{2}}$ & $\overline{\bar{\alpha}}$ & 亏 & $\stackrel{n}{\bar{\alpha}}$ & 음 \\
\hline 岸 & 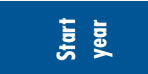 & 离 & ఏ్م & 음 & 음 & 음 & ఏ人 & 总 \\
\hline 商爰 & 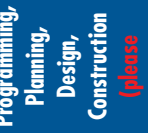 & 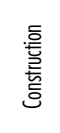 & 部 & 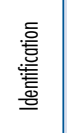 & 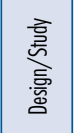 & \begin{tabular}{|l|} 
\\
喜 \\
言
\end{tabular} & $\begin{array}{l}\text { 总 } \\
\text { 言 } \\
\text { a }\end{array}$ & $\begin{array}{l}\text { 总 } \\
\text { 言 }\end{array}$ \\
\hline 悪 & ㅎㅎㅎ & & & & & & & \\
\hline $\bar{E}$ & 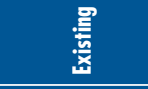 & \pm & $\approx$ & n & $F$ & 品 & $\bar{\infty}$ & 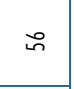 \\
\hline 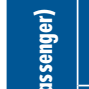 & 这 & & & & & & & \\
\hline 产 & $\begin{array}{l}\frac{9}{\overline{7}} \\
\frac{1}{x} \\
\end{array}$ & $\approx$ & $=$ & $=$ & $\approx$ & $\tilde{m}$ & $\Xi$ & के \\
\hline 흡 & 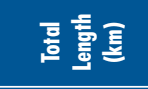 & $\Xi$ & $\cong$ & $\infty$ & $\nexists$ & $\approx$ & 8 & శ్లి \\
\hline 总 & 롤 言总 & & & & & & & \\
\hline 을 & 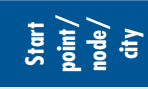 & & & & & & & \\
\hline & 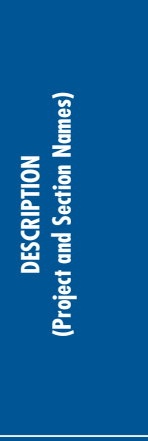 & 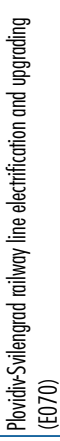 & 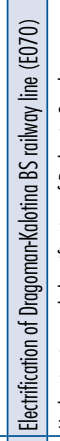 & 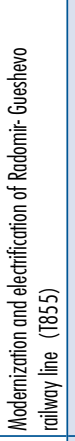 & 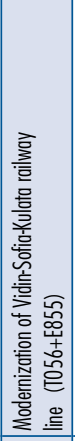 & 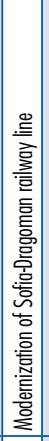 & 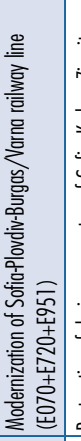 & 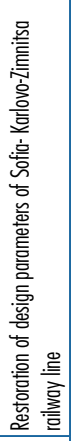 \\
\hline & $\begin{array}{l}\text { 을 } \\
\text { 빙 } \\
\text { 올 }\end{array}$ & 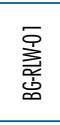 & 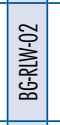 & 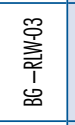 & \begin{tabular}{|l|}
$\mathbf{c}$ \\
产 \\
I \\
d \\
\end{tabular} & 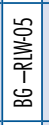 & 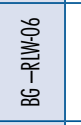 & \begin{tabular}{|l|} 
帝 \\
产 \\
足 \\
\end{tabular} \\
\hline & 产 & $\frac{\text { 高 }}{\text { 言 }}$ & 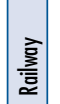 & $\frac{\text { 产 }}{\underline{\underline{\underline{z}}}}$ & 亨 & $\mid \frac{\mathbf{z}}{\overline{\frac{1}{2}}}$ & 亨 & 亨 \\
\hline
\end{tabular}

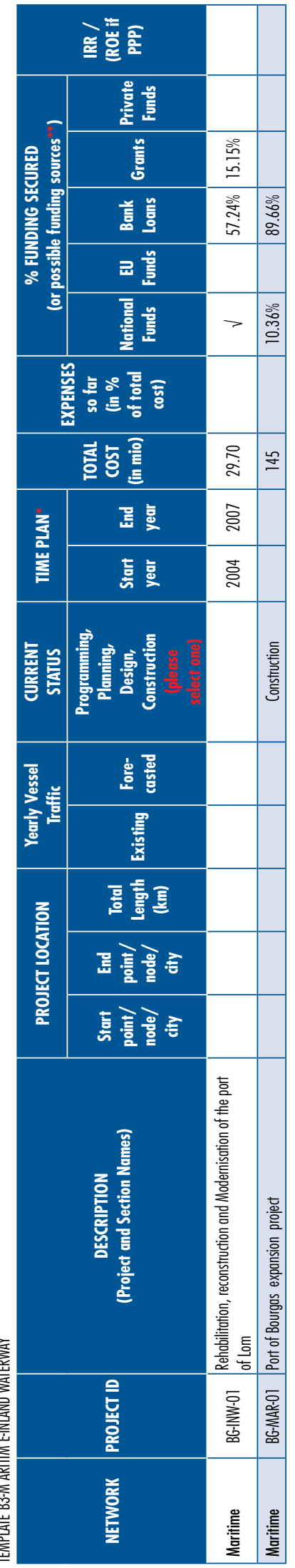




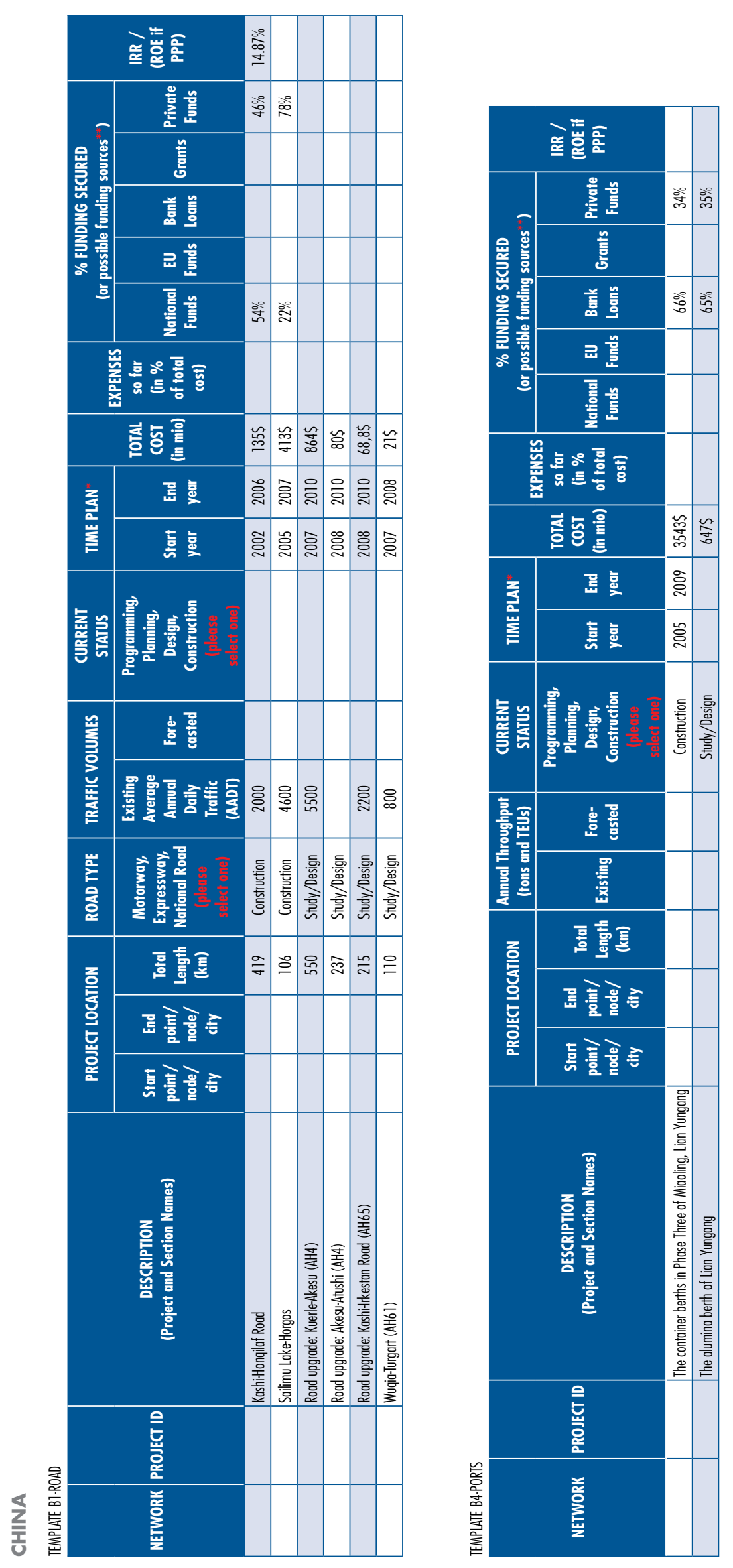




\begin{tabular}{|c|c|c|c|c|c|c|c|c|c|c|c|c|c|}
\hline & \multicolumn{12}{|c|}{ 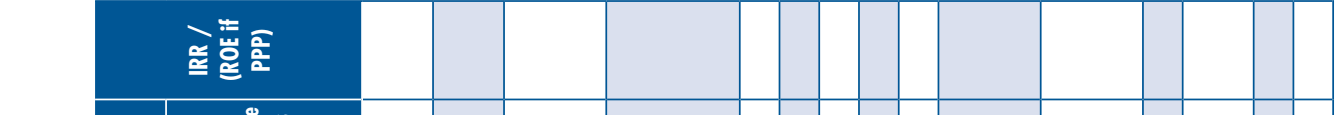 } \\
\hline \multirow{5}{*}{ 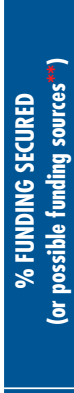 } & 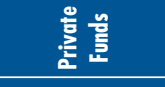 & & & & & & & & & & & & \\
\hline & 喜 & & & & & & & & & & & & \\
\hline & 善产 & & & & & & & & & & & & \\
\hline & 르 & & & & & & & & & & & & \\
\hline & 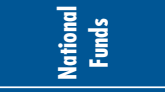 & & & & & & & & & & & & \\
\hline & 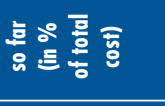 & & & & & & & & & & & & \\
\hline & 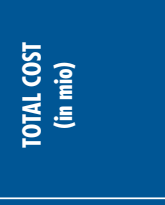 & $\stackrel{n}{0}$ & 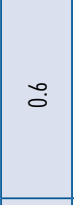 & 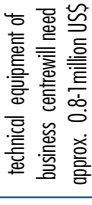 & 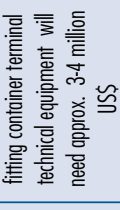 & స్ & & $\cong$ & $\approx$ & 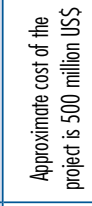 & $\approx$ & $\approx$ & 离 \\
\hline$\frac{z}{3}$ & $\underline{\underline{*}}$ & 高 & : & ఏ & ఏे & : & 을 & పิ & 음 & 음 & 을 & & \\
\hline 諳 & 言意 & 亏े & ఃे & ఏ్ & ఏิ & ڤั ڤั & ఏ & ఏి & ڤั & ఏે & ڤั่ & & \\
\hline 遃总 & 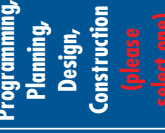 & 墨 & 总 & $\begin{array}{l}\text { 罯 } \\
\text { 言 }\end{array}$ & 墨 & 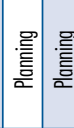 & & $\mid$ & 墨 & 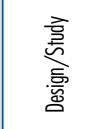 & 墨 & 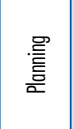 & 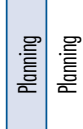 \\
\hline 高 & 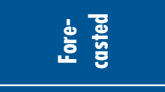 & & & & & & & & & & & & \\
\hline 言 & 墨 & & & & 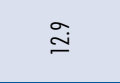 & $\approx$ & बे & $\approx$ & 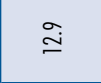 & & 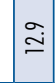 & $\stackrel{\Xi}{\beth}$ & 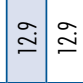 \\
\hline 匐 & 递 $\frac{\bar{g}}{\mathrm{~g}}$ & & & & & & & & & & & & \\
\hline 莺 & $\frac{\frac{9}{3}}{\frac{3}{4}}$ & & & & $\infty$ & $\infty \infty$ & $\infty$ & $\infty \infty$ & $\infty$ & & $\infty$ & $\infty$ & $\infty$ \\
\hline ż & 言童要 & & & & 寅 & 总 & & 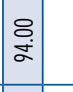 & 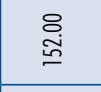 & 亳高 & 8 & 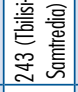 & : \\
\hline 递 & 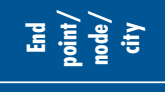 & & & & & & & & & & & & \\
\hline 导 & 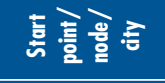 & & & & & & & & & & & & \\
\hline & 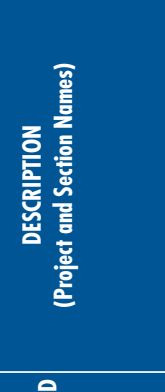 & 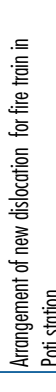 & 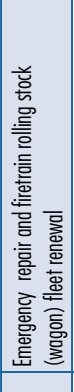 & 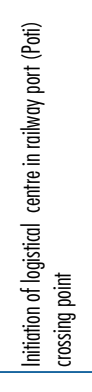 & 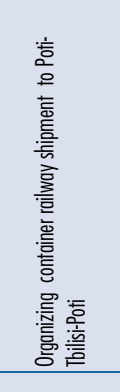 & 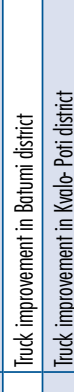 & 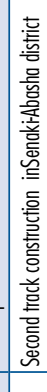 & 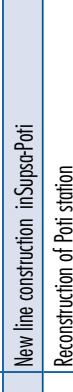 & 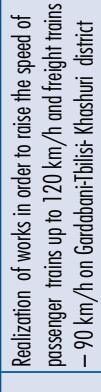 & 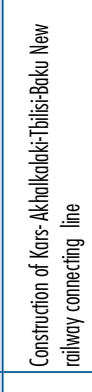 & 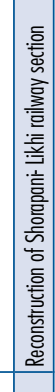 & 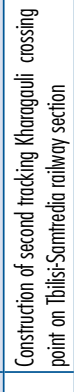 & 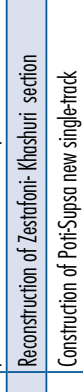 \\
\hline & 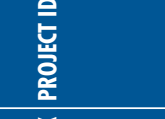 & 墙 & 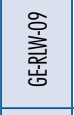 & 旁 & 㪯 & 竧㪯 & & 竧产 & 言 & 咅 & 厗 & 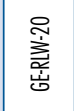 & 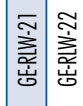 \\
\hline & $z$ & & & & & & & & & & & & \\
\hline
\end{tabular}




\begin{tabular}{|c|c|c|c|c|c|c|c|c|}
\hline \multicolumn{2}{|c|}{ 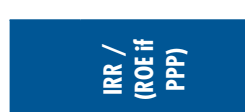 } & & & & & & & \\
\hline \multirow{5}{*}{ 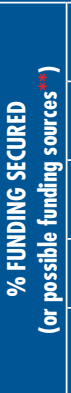 } & 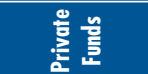 & & & & & & & \\
\hline & $\overline{\mathrm{E}}$ & & & & & & & \\
\hline & 善言 & & & & & & & \\
\hline & 童 & & & & & & & \\
\hline & 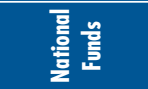 & & & & & & & \\
\hline \multicolumn{2}{|c|}{ 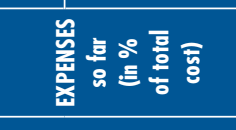 } & & & & & & & \\
\hline \multicolumn{2}{|c|}{ 绨 } & 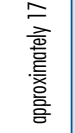 & $\stackrel{n}{\varrho}$ & $\bar{\infty}$ & $\simeq$ & 0 & $\approx$ & ల్ల \\
\hline \multirow{2}{*}{$\frac{z}{\frac{z}{a}}$} & 豆壱 & & & & & & & \\
\hline & 䓌 & & & & & & & \\
\hline 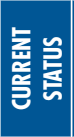 & 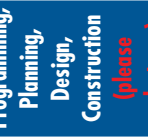 & $\begin{array}{l}\text { 䂴 } \\
\text { 言 }\end{array}$ & 㢇 & 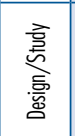 & 㢇 & 㢇 & $\begin{array}{l}\text { 墨 } \\
\text { 言 }\end{array}$ & $\begin{array}{l}\text { 墨 } \\
\text { 言 }\end{array}$ \\
\hline \multirow{2}{*}{ 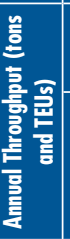 } & 㝘总 & & & & & & & \\
\hline & 善 & 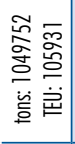 & 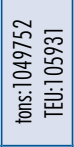 & 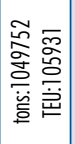 & 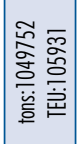 & 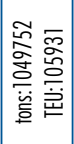 & 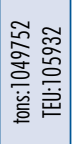 & 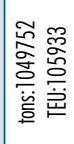 \\
\hline \multirow{3}{*}{ 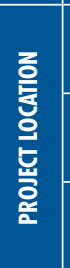 } & 言善害 & & & & & & & \\
\hline & 롭 言望 & & & & & & & \\
\hline & 톻 言总 & & & & & & & \\
\hline & 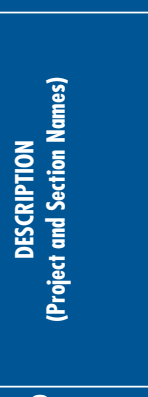 & 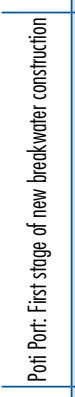 & 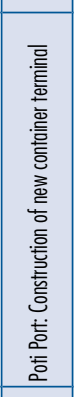 & 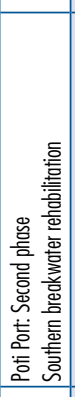 & 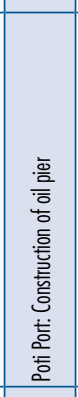 & 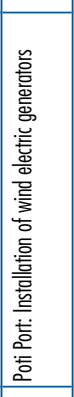 & 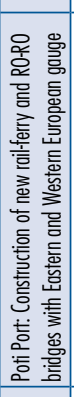 & 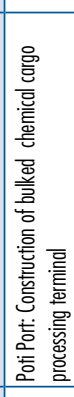 \\
\hline & 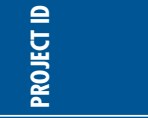 & 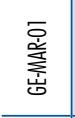 & 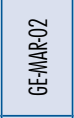 & 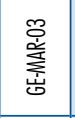 & $\begin{array}{l}\text { 要 } \\
\text { 盖 } \\
\end{array}$ & 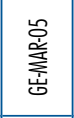 & 总 & $\begin{array}{l}\text { 产 } \\
\text { 密 } \\
\end{array}$ \\
\hline & 送 & & & & & & & \\
\hline
\end{tabular}




\begin{tabular}{|c|c|c|c|c|c|c|c|c|c|c|c|c|c|c|c|c|c|c|c|}
\hline \multicolumn{2}{|c|}{ 拳讋言 } & & & $\because 2$ & & & a & & & & & & & & & & \% & & \\
\hline & 善首 & & & & & & & & & & & & & & & & & & \\
\hline & 彦 & & & & & & & & & & & & & & & & & & \\
\hline & 薏薏 & & & & & & & & & & & & & & & & & & \\
\hline & $\equiv \underline{\underline{m}}$ & & $\vdots$ & & & & & & & & & & & & & & & & \\
\hline & 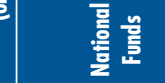 & so & & 今气 & ò & : & & 高 & so & & & 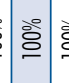 & 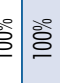 & 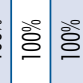 & & 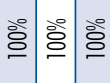 & 桨 & & : \\
\hline & 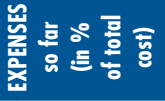 & & & & & & & & & & & & & & & & & & \\
\hline & 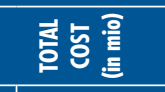 & 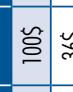 & & 管管 & 等 & $\cong$ & ఓळ & F & 検 & 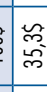 & & 岁 & $\tilde{a}$ & 签 & $\cong$ & 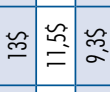 & 筒 & & 等 \\
\hline$\frac{z}{2}$ & 롬 & ذ્ટે & $\stackrel{2}{2}$ & & : & ‡ั่ํํำ & ఏे & 壳 & ڤ્a & ڤั & 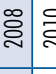 & ปे & : & : & : & 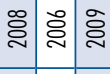 & 离 & & 今 \\
\hline 訔 & 喜总 & $\overline{\mathrm{ล}}$ & : & & $\stackrel{2}{\circ}$ & ธ్సิ & & $\stackrel{\Xi}{\Xi}$ & 承 & 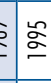 & ธ్ธิ & s: & : & פ & & 空言 & 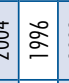 & & . \\
\hline$E^{n}$ & & & & & & & & & & & & & & 喜憘 & & 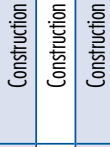 & 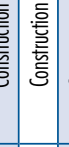 & & 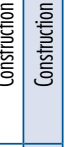 \\
\hline 产 & 㟥 & & & & & & & & & & & & & & & & & & \\
\hline & (2) & & & & & & & & & & & & & & & & & & \\
\hline
\end{tabular}

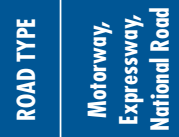

글

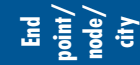

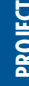

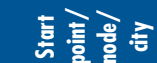

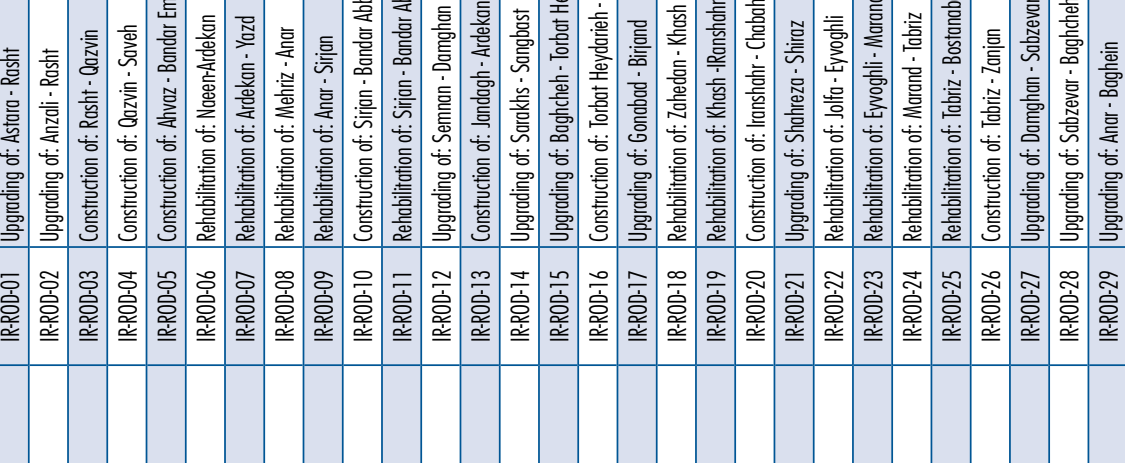




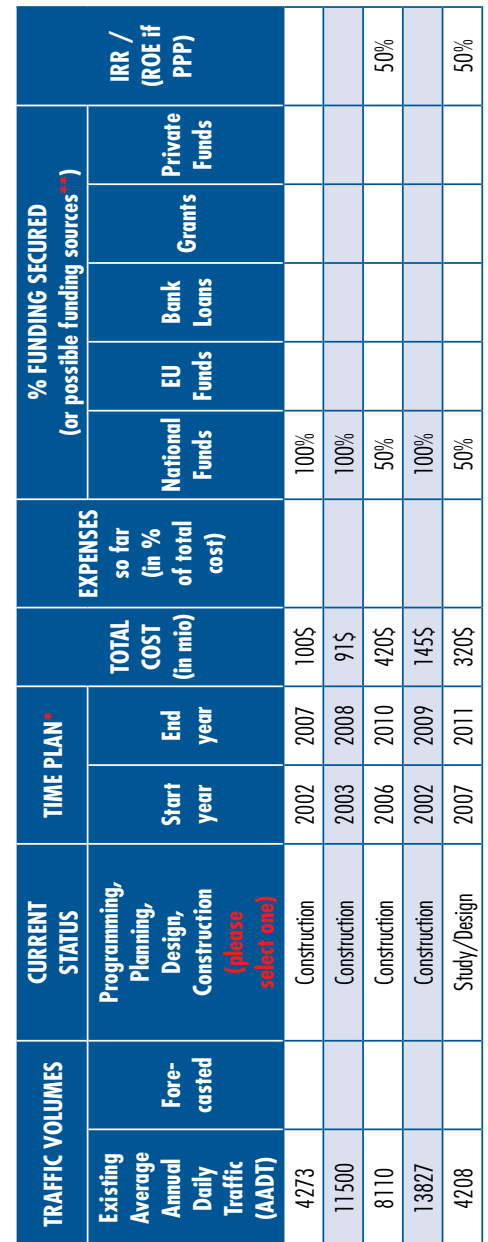

\section{Ill}
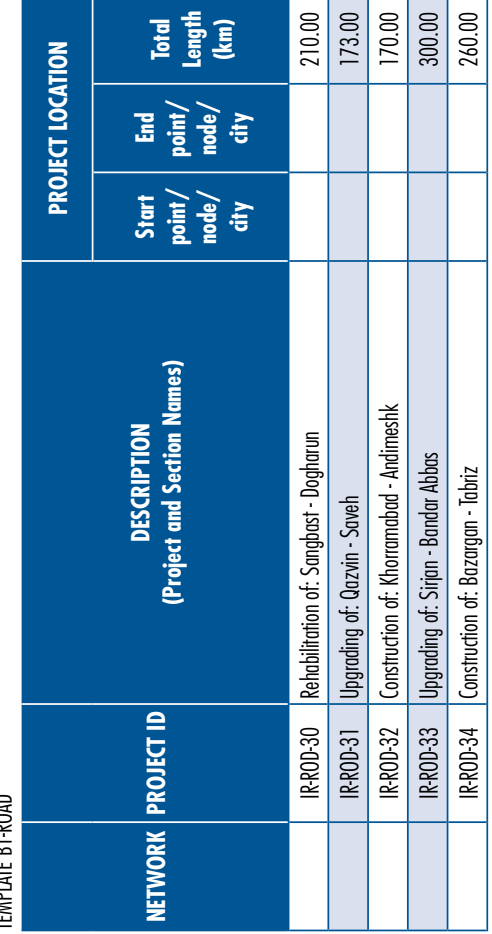

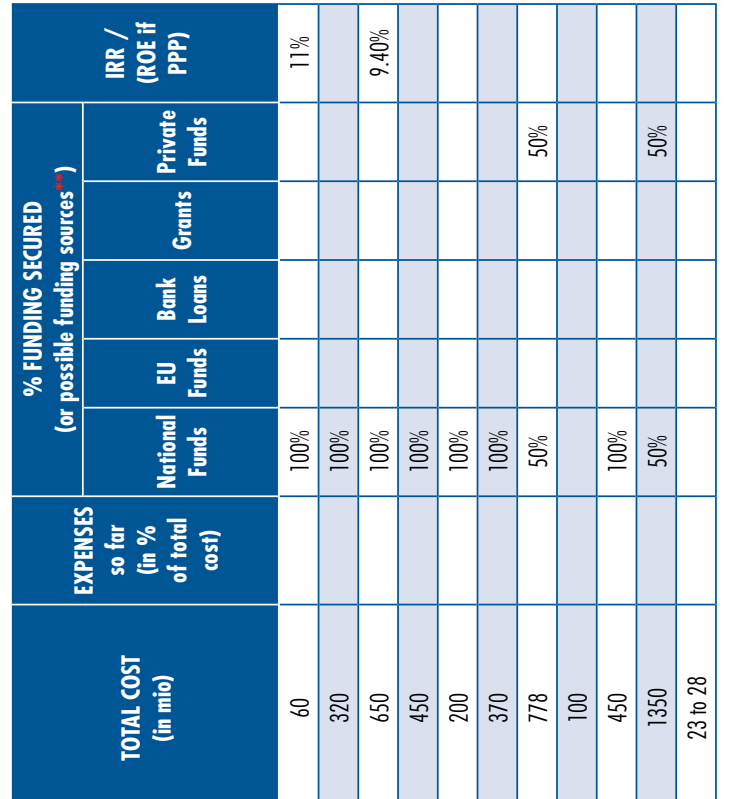

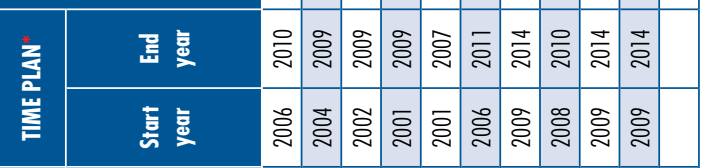

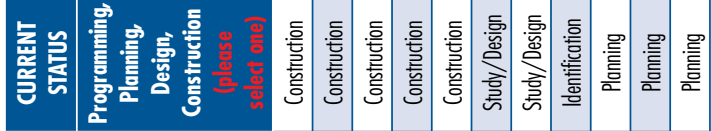

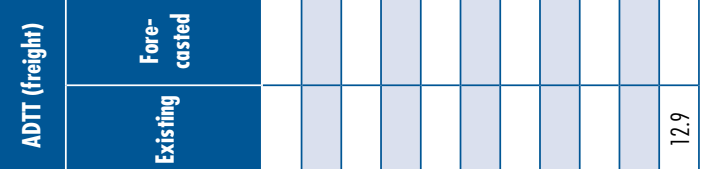

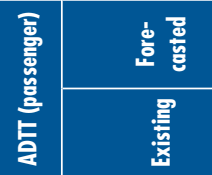

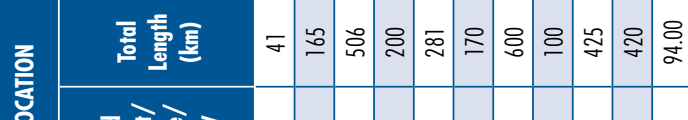
홍 폴

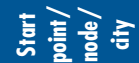

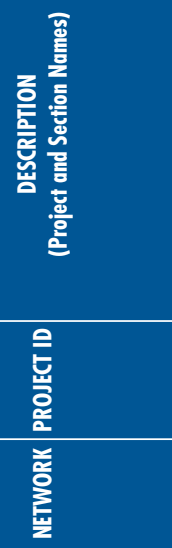

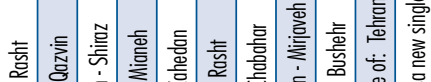

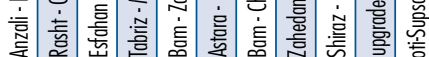
范

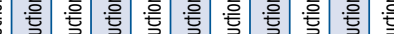

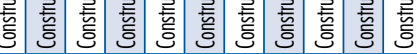

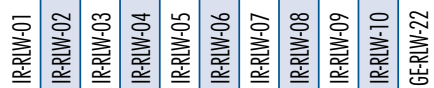




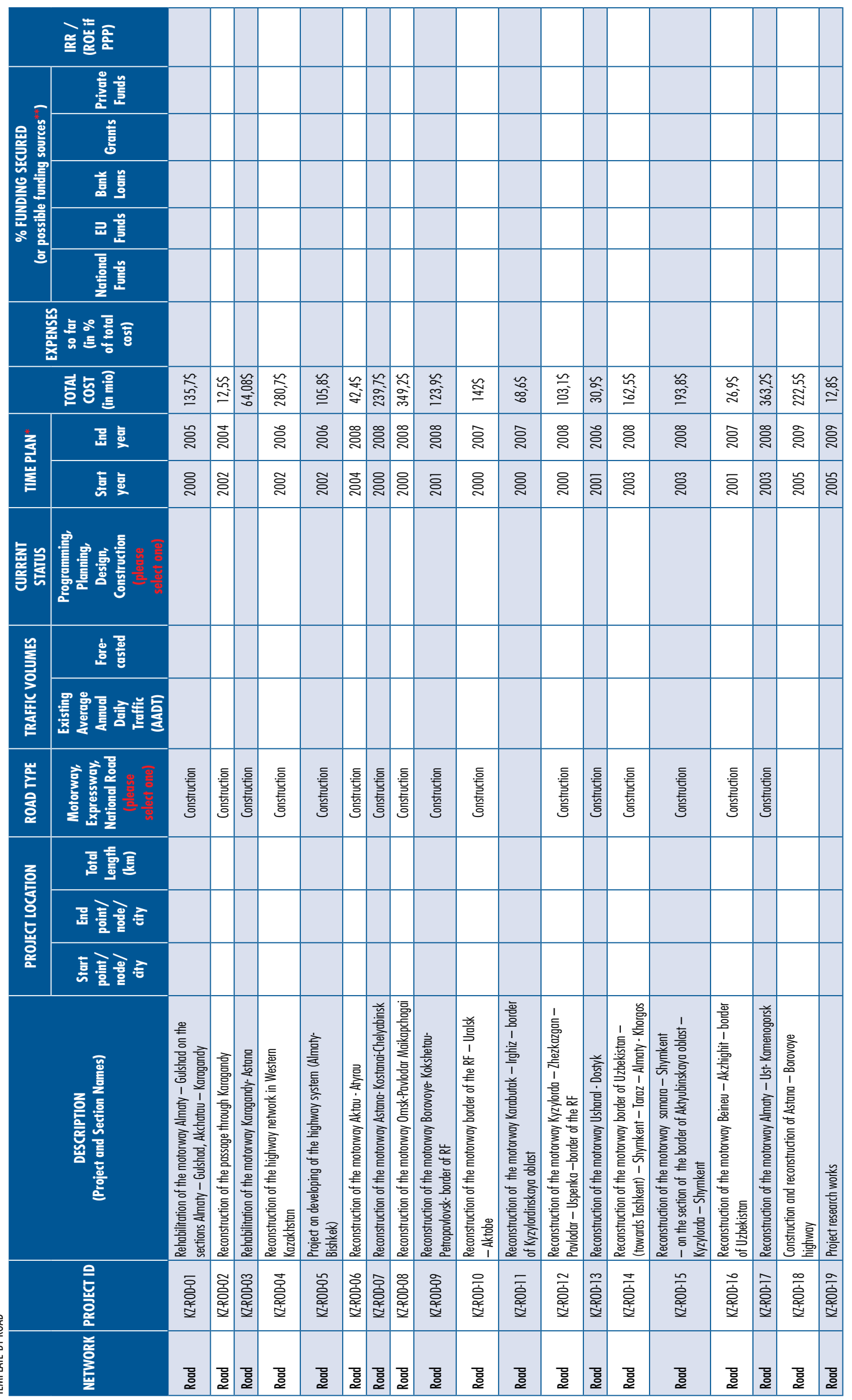




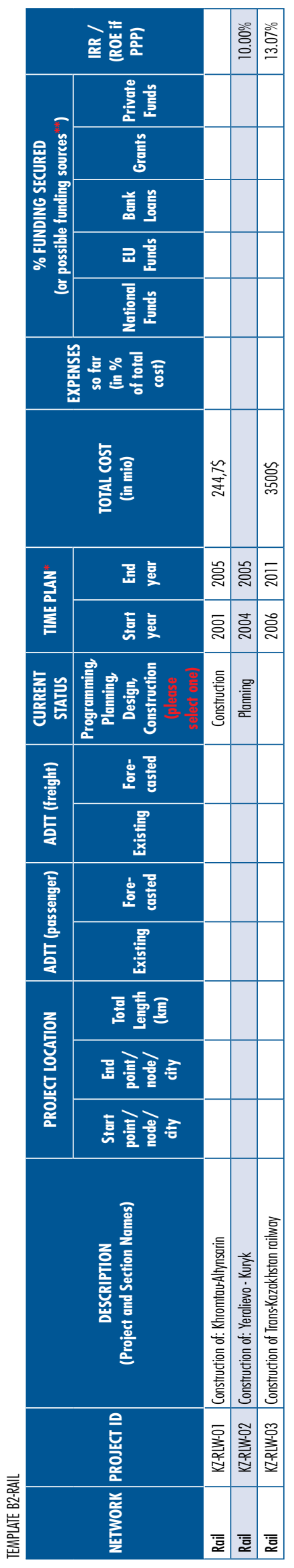



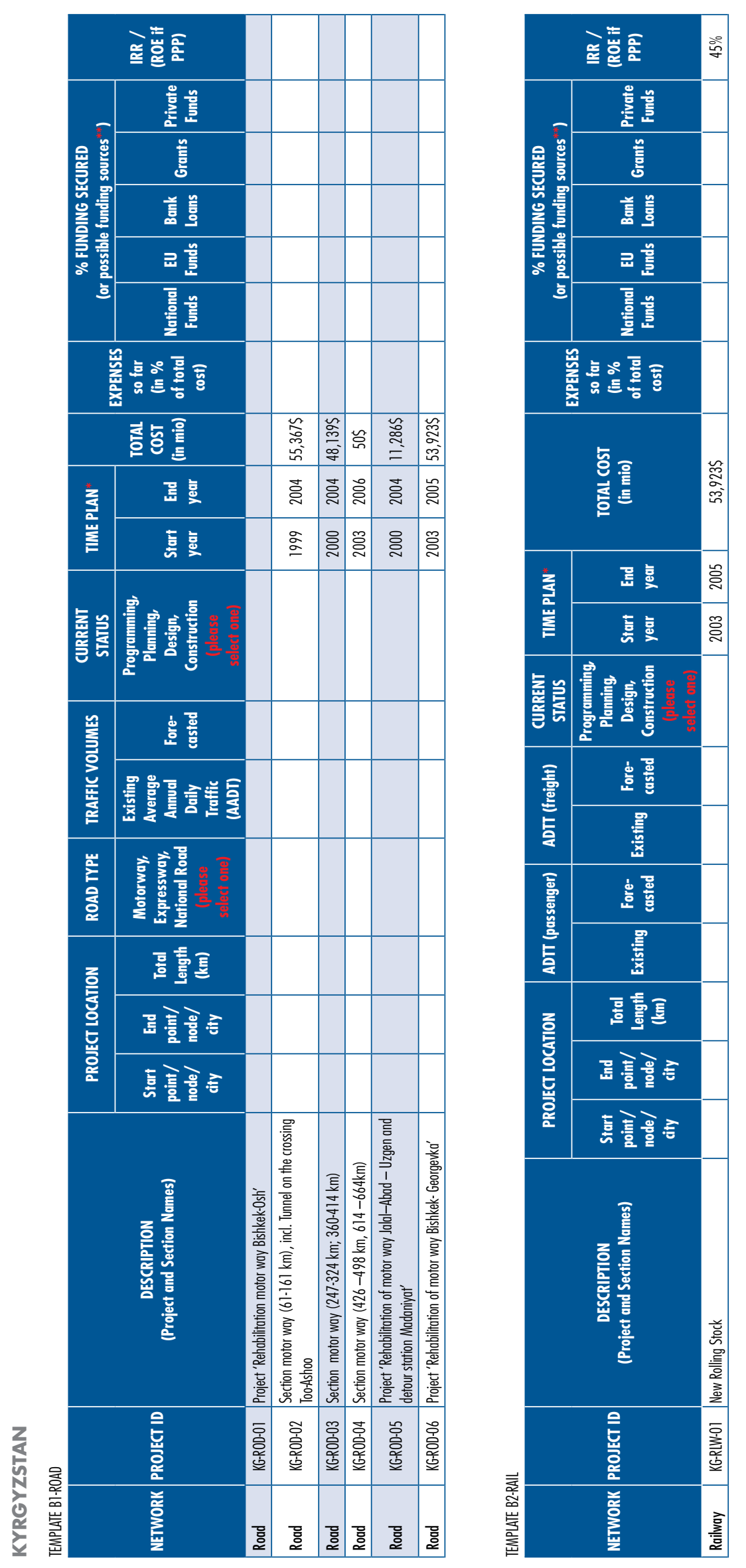


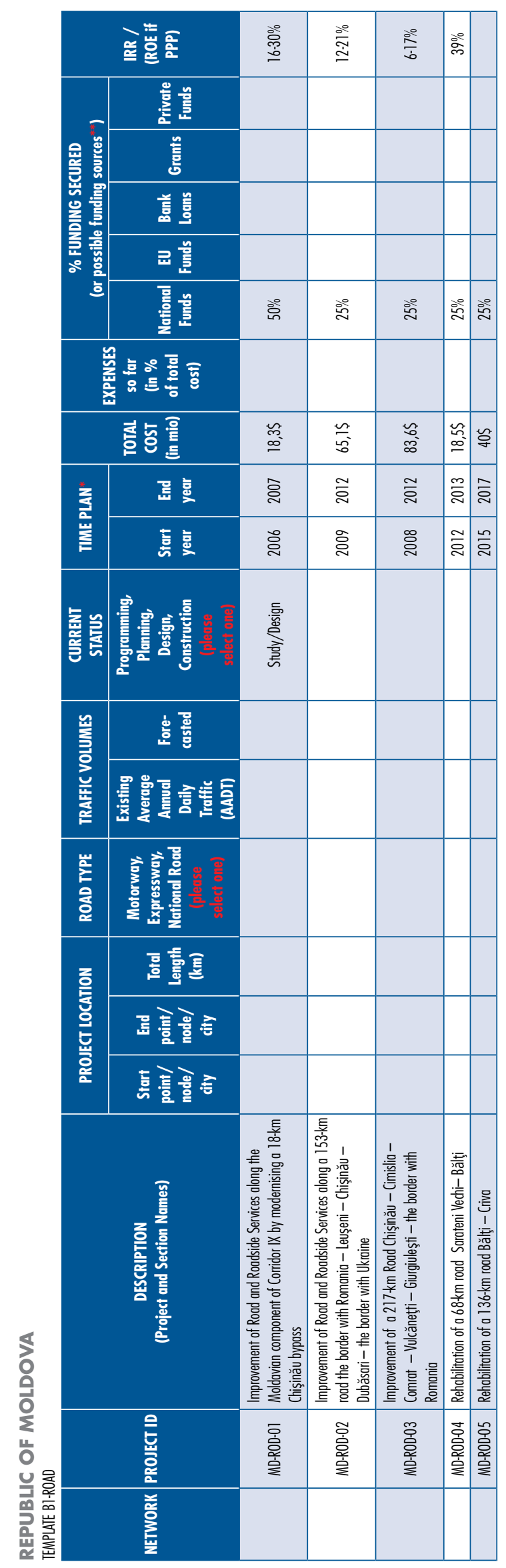



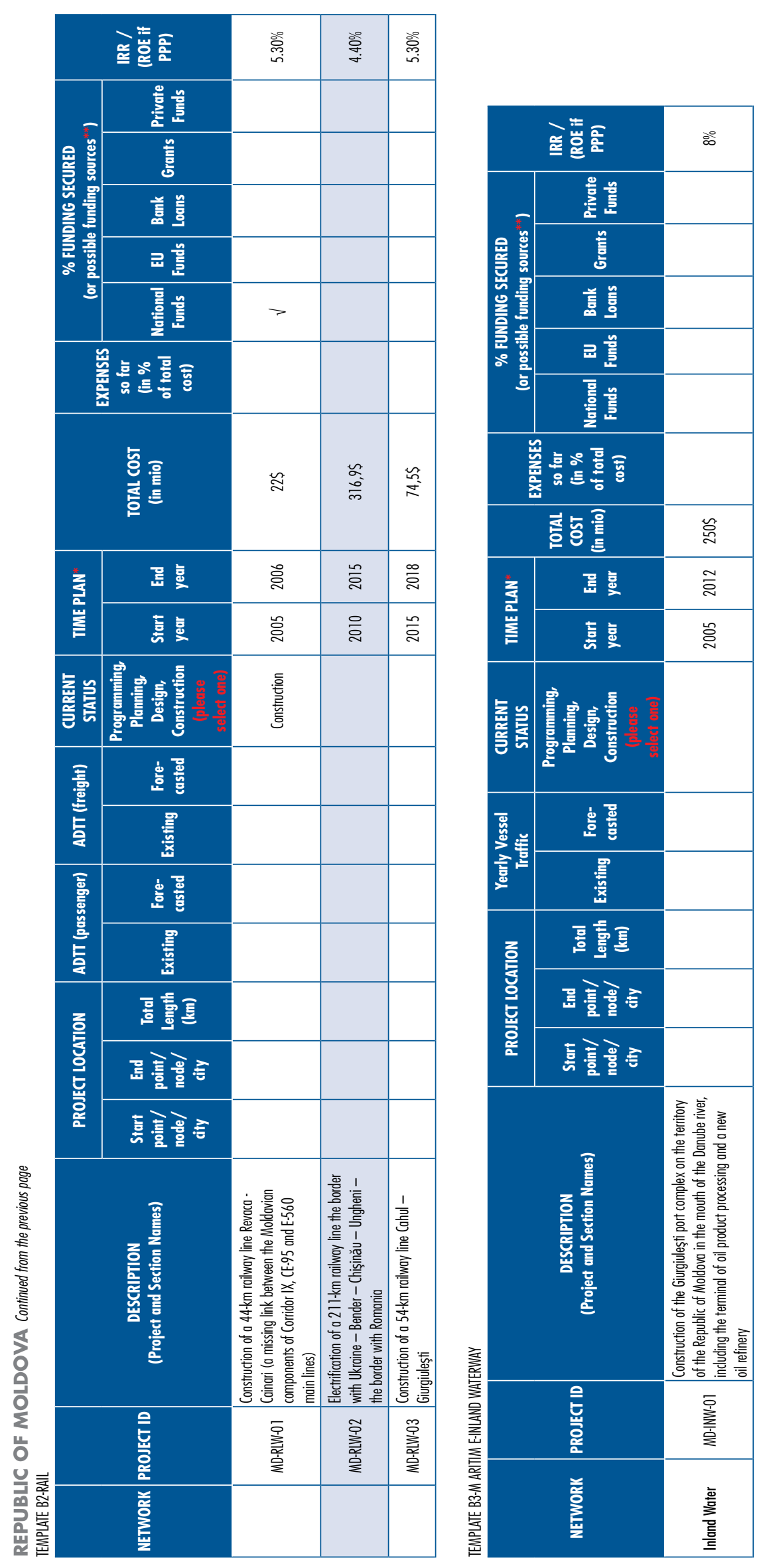


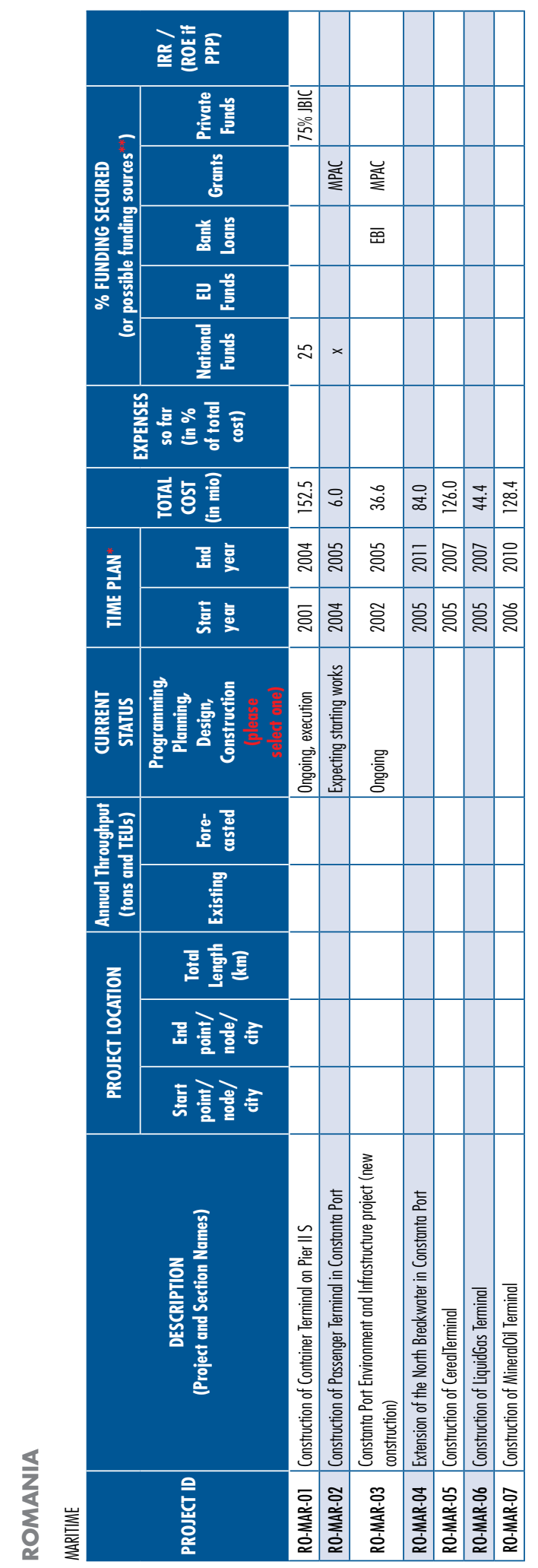

\begin{tabular}{|c|c|c|c|c|c|c|}
\hline \multicolumn{2}{|c|}{ œ } & & & & & \\
\hline \multirow{5}{*}{ 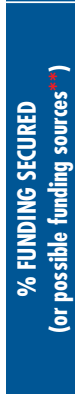 } & 产䓂 & & & & & \\
\hline & 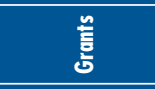 & & & & & \\
\hline & 善言 & $\begin{array}{l}\overline{\bar{m}} \\
\text { 宮 }\end{array}$ & & & 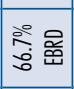 & \\
\hline & 룰 & & 总氞 & 离崖 & & $\times$ \\
\hline & 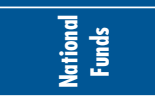 & on & $\approx$ & $\approx$ & & $\times$ \\
\hline \multicolumn{2}{|c|}{ 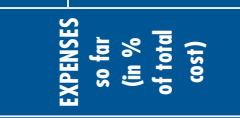 } & & & & & \\
\hline \multicolumn{2}{|c|}{ 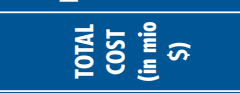 } & 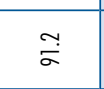 & ذ્త & $\stackrel{\infty}{\subseteq}$ & $\stackrel{\infty}{\sim}$ & ఏ̊. \\
\hline \multicolumn{2}{|c|}{ 홓항을을 } & & & & & \\
\hline \multirow{2}{*}{$\begin{array}{l}\underset{z}{z} \\
\text { 旁 } \\
\text { 岁 }\end{array}$} & 롤 & పે & 总 & 空 & ڤั & 음 \\
\hline & 志 & 空 & 总 & 总 & ڤ్ి & 总 \\
\hline 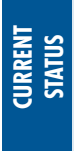 & 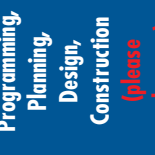 & 訔 & 镸 & 亳 & & \\
\hline \multirow{2}{*}{ 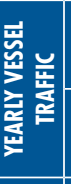 } & 兽 & & & & & \\
\hline & 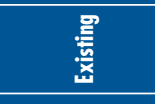 & & & & & \\
\hline \multirow{3}{*}{ 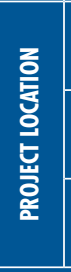 } & 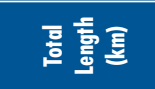 & $\simeq$ & ¿ & $\stackrel{n}{\varrho}$ & & 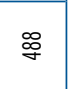 \\
\hline & 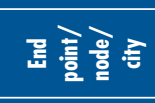 & 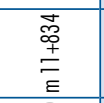 & 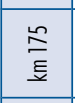 & 总 & & 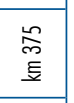 \\
\hline & 홓 言产 & $\begin{array}{l}\text { 总 } \\
\text { 至 } \\
\text { E }\end{array}$ & $\begin{array}{l}\text { 命 } \\
\text { 章 } \\
\end{array}$ & $\begin{array}{ll}\text { 管 } \\
\text { 至 }\end{array}$ & & 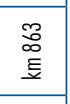 \\
\hline \multicolumn{2}{|r|}{ 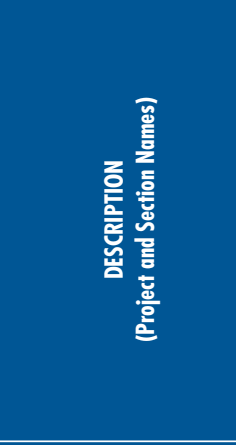 } & 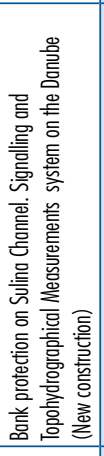 & 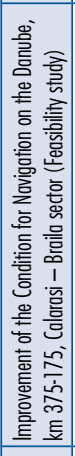 & 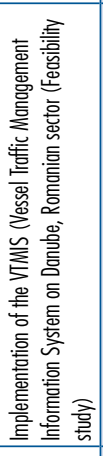 & 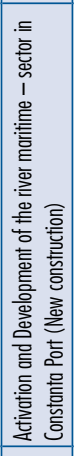 & 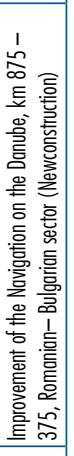 \\
\hline & 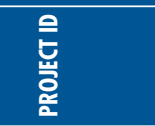 & 产 & 产 & 䗆 & 章 & 幾 \\
\hline
\end{tabular}



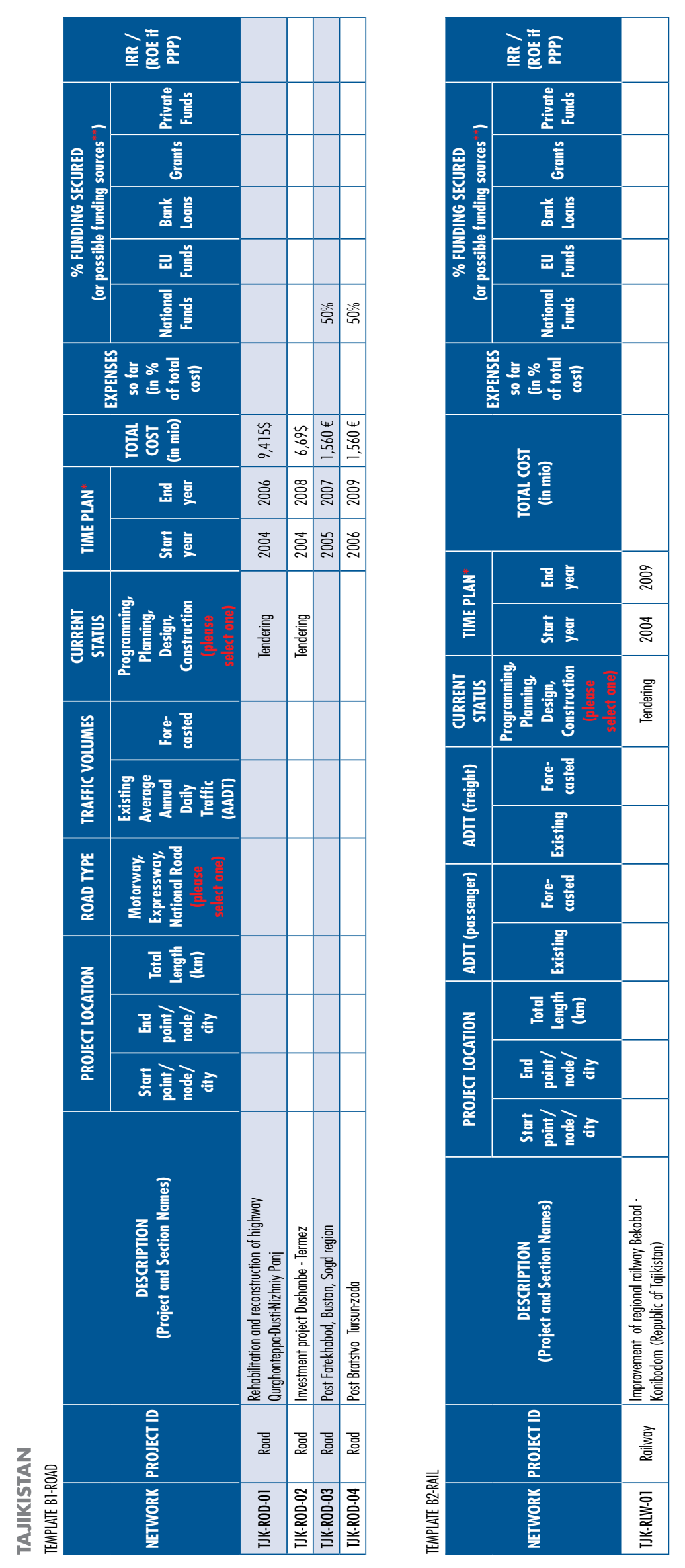


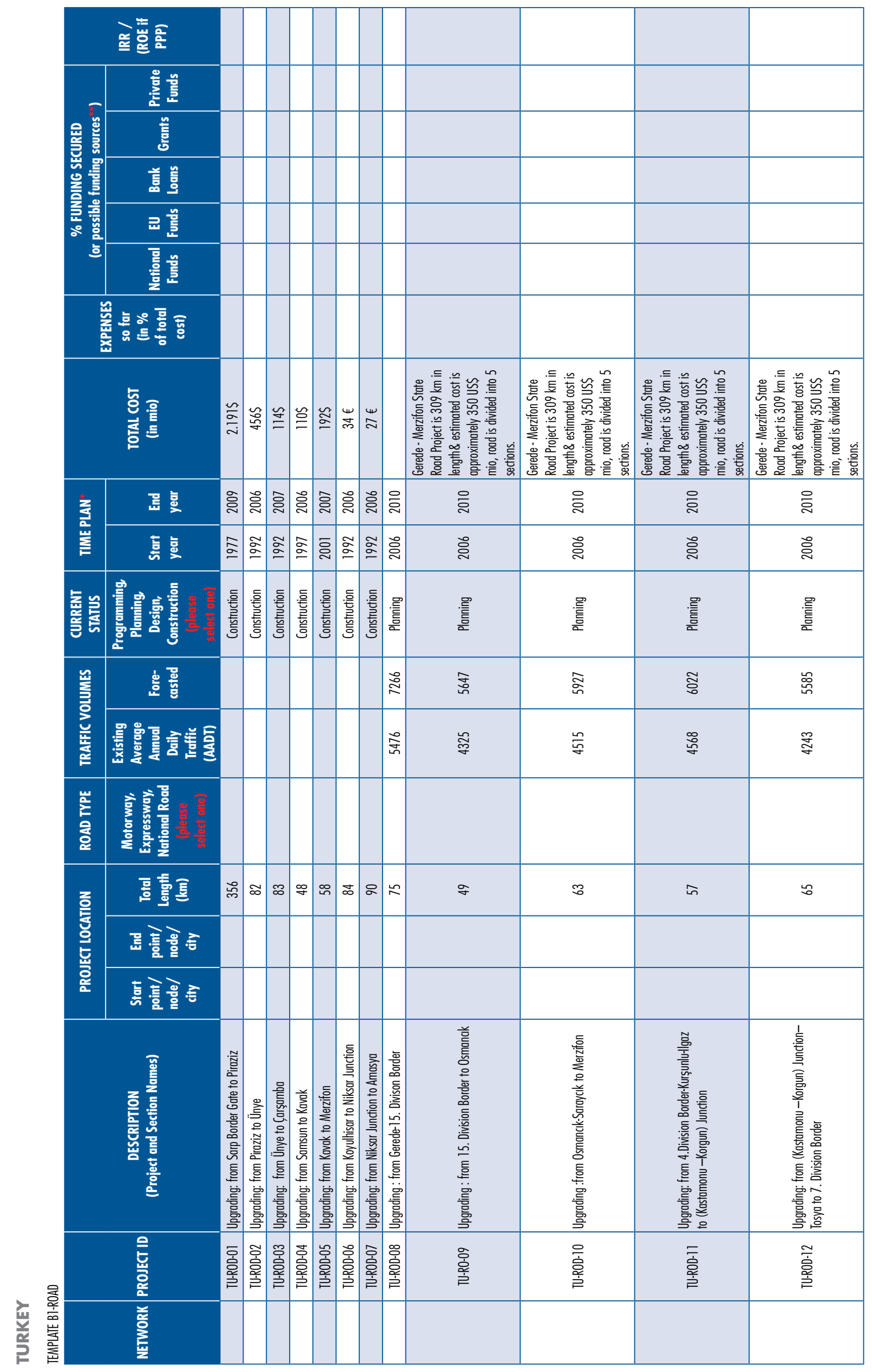




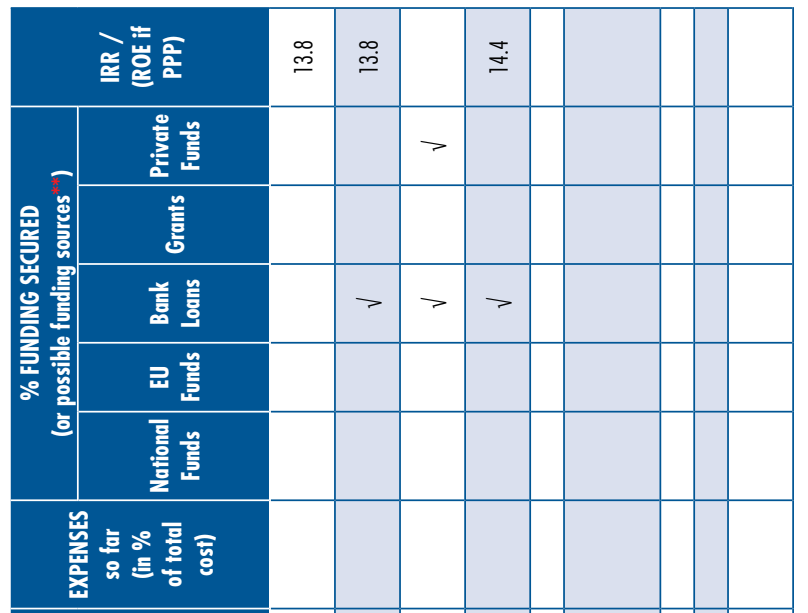

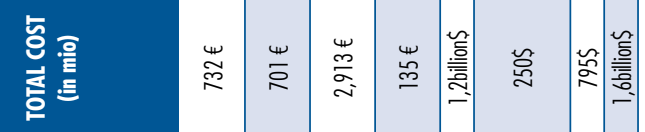

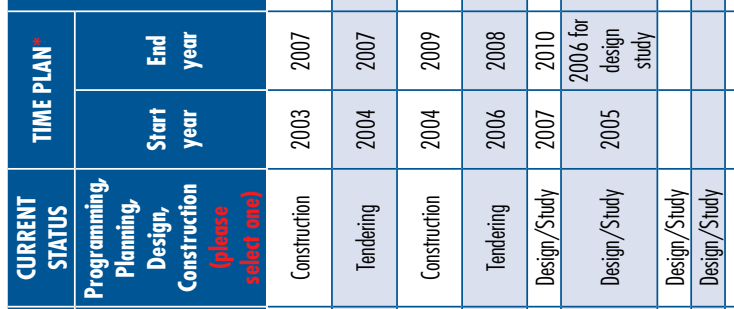

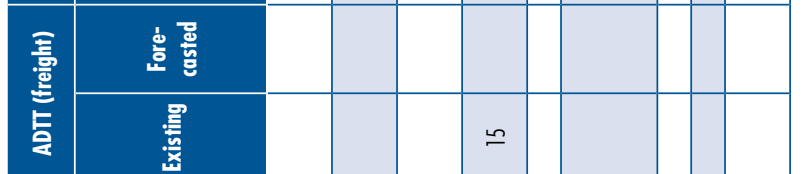

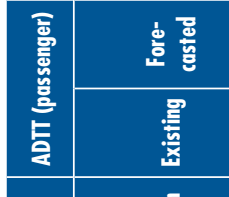

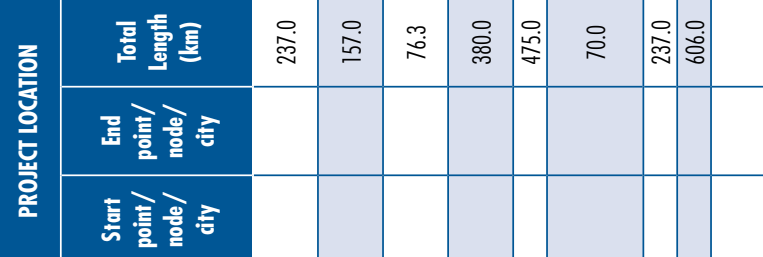

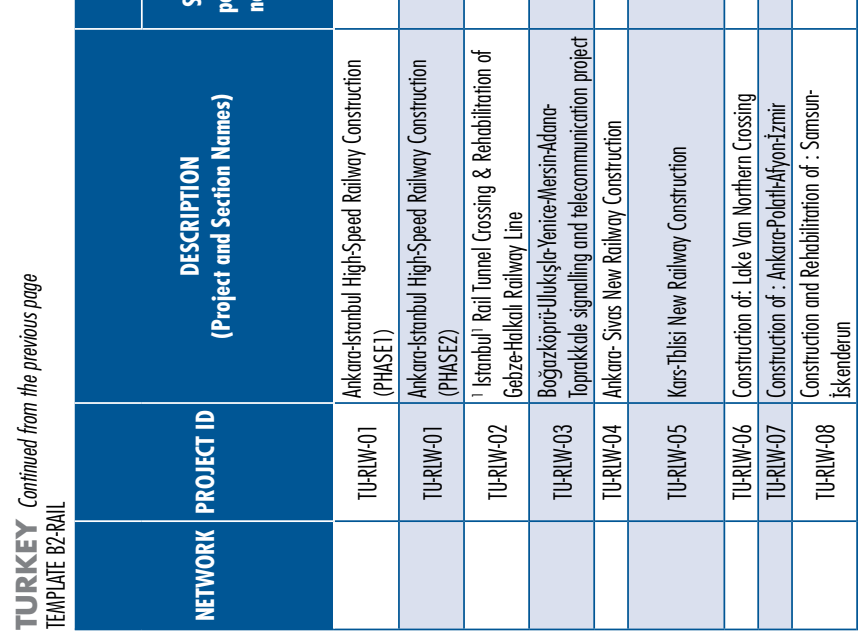

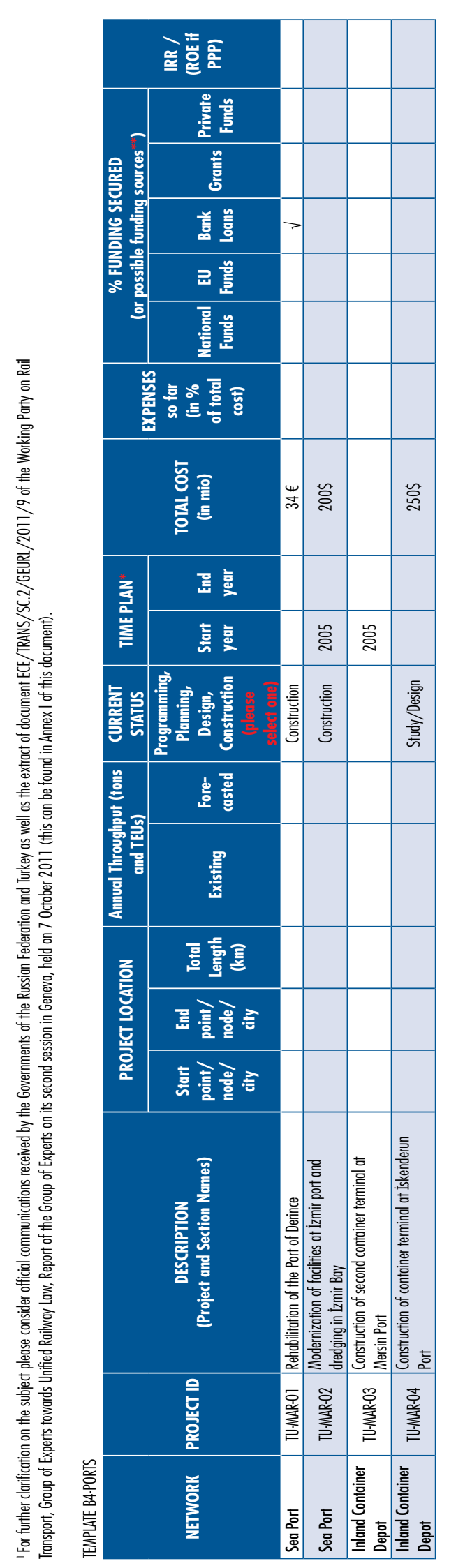




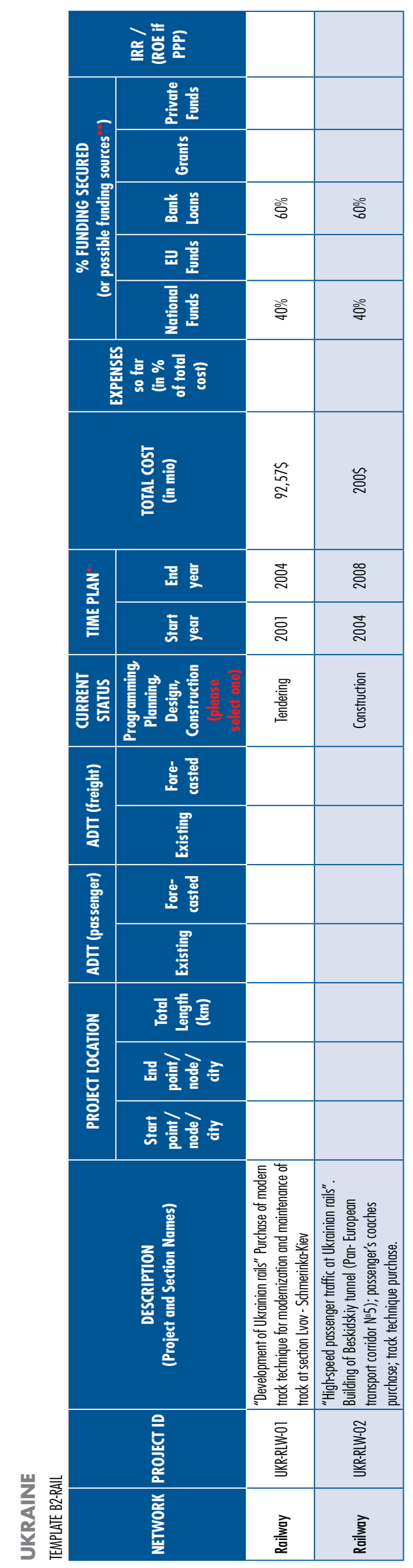

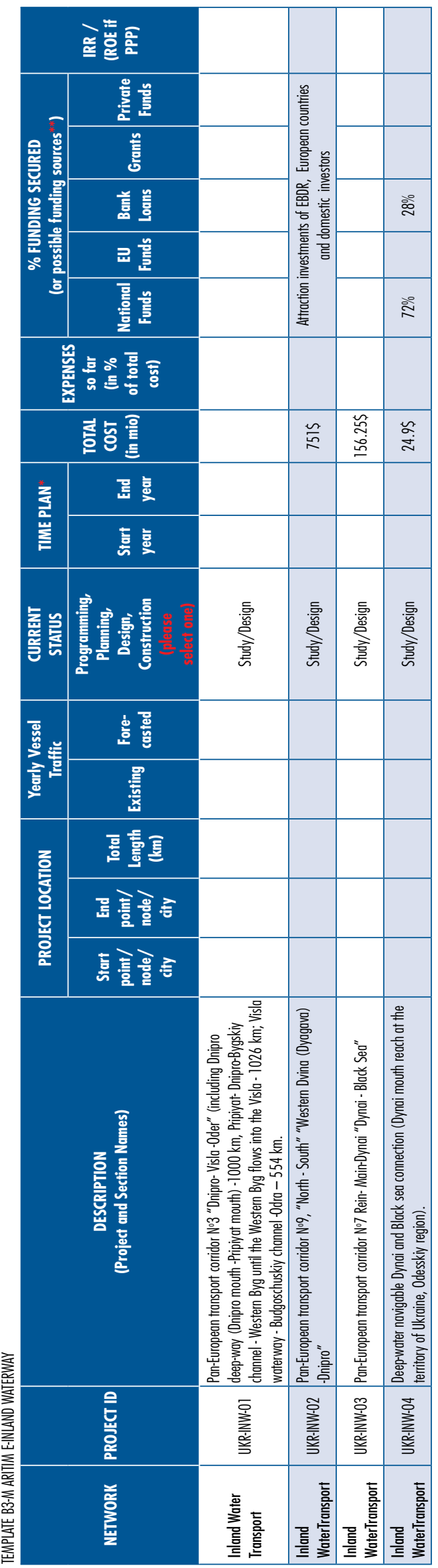



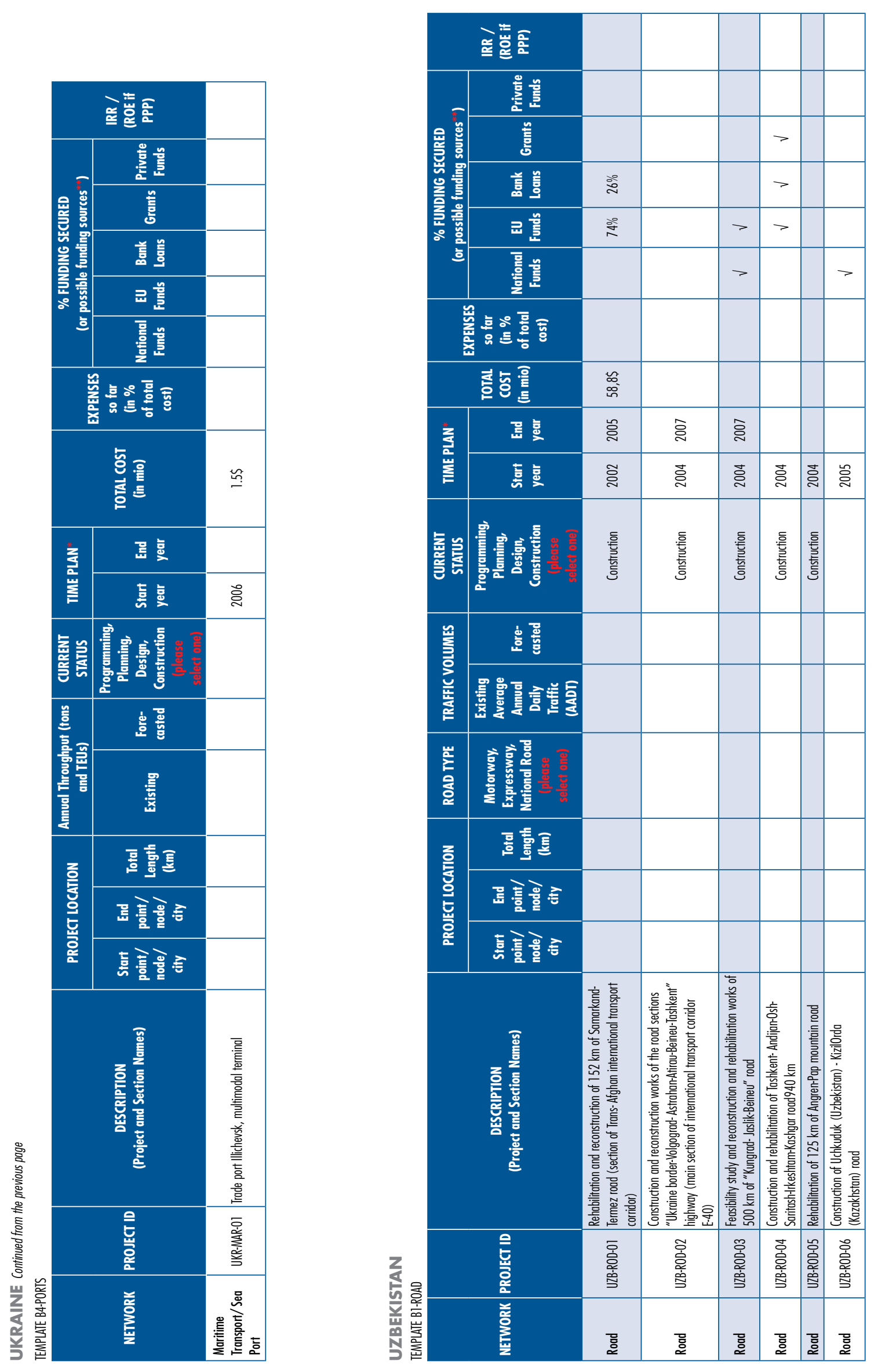


\begin{tabular}{|c|c|c|c|c|c|c|c|c|c|}
\hline \multicolumn{10}{|c|}{ 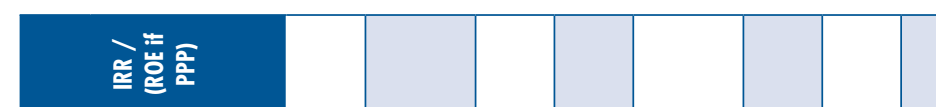 } \\
\hline \multirow{5}{*}{ 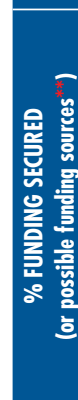 } & 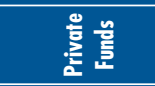 & & & & & & & & \\
\hline & 言 & & & & & & & & \\
\hline & 善言 & ळे & 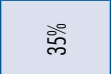 & 总 & हे & 户े & & & \\
\hline & 屏 & & & & & ळे & & & \\
\hline & 言号 & ڤ్ & के & 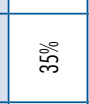 & ळิ & ڤે & & & \\
\hline \multicolumn{2}{|c|}{ 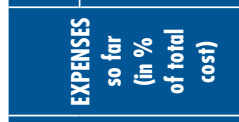 } & & & & & & & & \\
\hline & 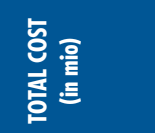 & 岕 & 等 & 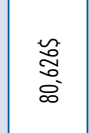 & 第 & $\stackrel{\stackrel{\leftrightarrow}{\alpha}}{=}$ & & & \\
\hline \multirow{2}{*}{ 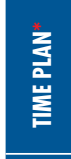 } & 롭 & 总 & 음 & ڤิ & 음 & : & & & \\
\hline & 壳音 & వ్ర & $\stackrel{\breve{a}}{\sigma}$ & 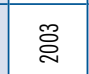 & ప્d & 总 & & & \\
\hline 氮器 & 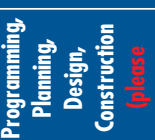 & 墪 & $\begin{array}{l}\text { 흘 } \\
\text { 竘 }\end{array}$ & $\begin{array}{l}\text { 흘 } \\
\text { 亳 }\end{array}$ & $\begin{array}{l}\text { 㞗 } \\
\text { 意 }\end{array}$ & 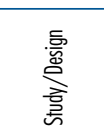 & & & \\
\hline \multirow{2}{*}{ 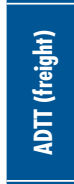 } & s. & & & & & & & & \\
\hline & 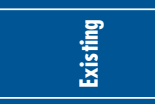 & & & & & & & & \\
\hline \multirow{2}{*}{ 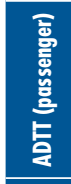 } & d훙 & & & & & & & & \\
\hline & 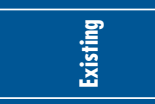 & & & & & & & & \\
\hline \multirow{3}{*}{ 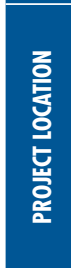 } & 흥 喆要 & & & & & & & & \\
\hline & 몹 言旁 & & & & & & & & \\
\hline & 咅言言晋 & & & & & & & & \\
\hline & 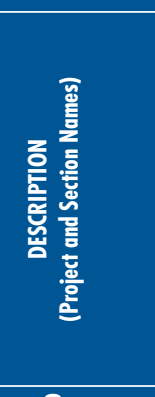 & 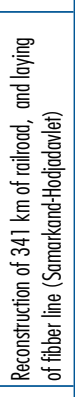 & 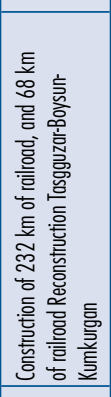 & 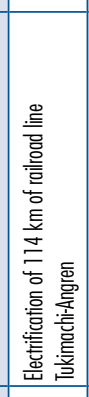 & 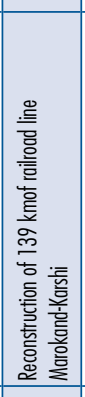 & 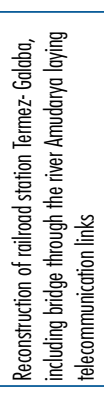 & 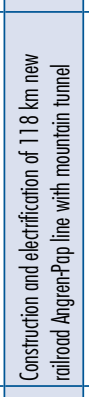 & 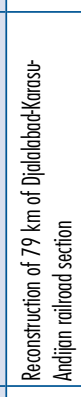 & 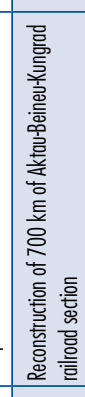 \\
\hline & 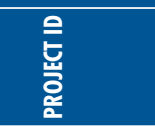 & $\begin{array}{l}\text { 高 } \\
\text { 产 } \\
\text { 兽 }\end{array}$ & $\begin{array}{l}\text { 旁 } \\
\text { 旁 } \\
\text { 严 }\end{array}$ & $\begin{array}{l}\text { o } \\
\text { 产 } \\
\text { 产 }\end{array}$ & 高 & 旁 & $\begin{array}{l}\text { 亭 } \\
\text { 言 } \\
\text { 产 }\end{array}$ & $\begin{array}{l}\text { 总 } \\
\text { 产 } \\
\text { 兽 }\end{array}$ & 竞 \\
\hline & 产 & 竟 & 亨 & $\frac{\underline{\underline{z}}}{\frac{z}{2}}$ & 喜 & $\frac{\text { 豆 }}{\text { 童 }}$ & 亨 & 哼 & 商 \\
\hline
\end{tabular}
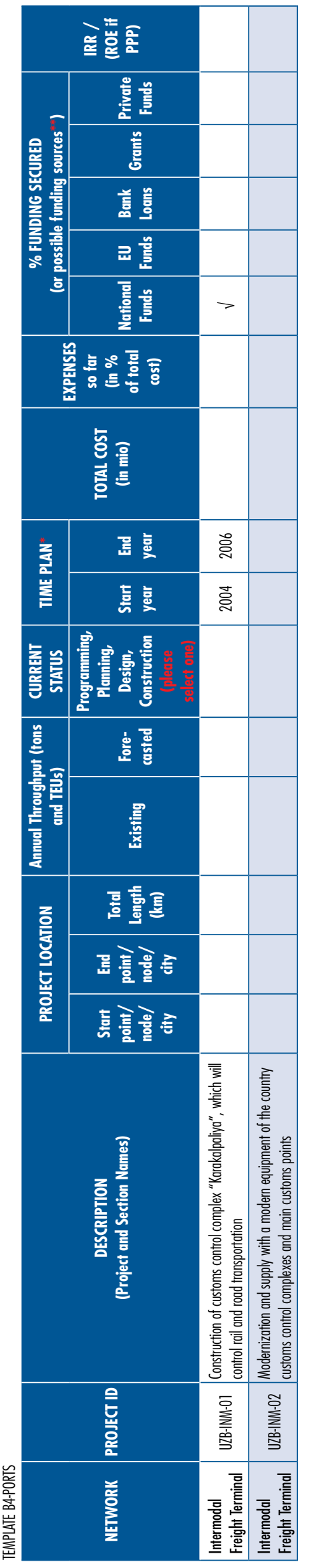


\section{Appendix 4.2}

\section{TEMPLATES 2 (2A, 2B, 2C, 2D)}

\section{TEMPLATE 2A - Road and related infrastructure Project Fiche}

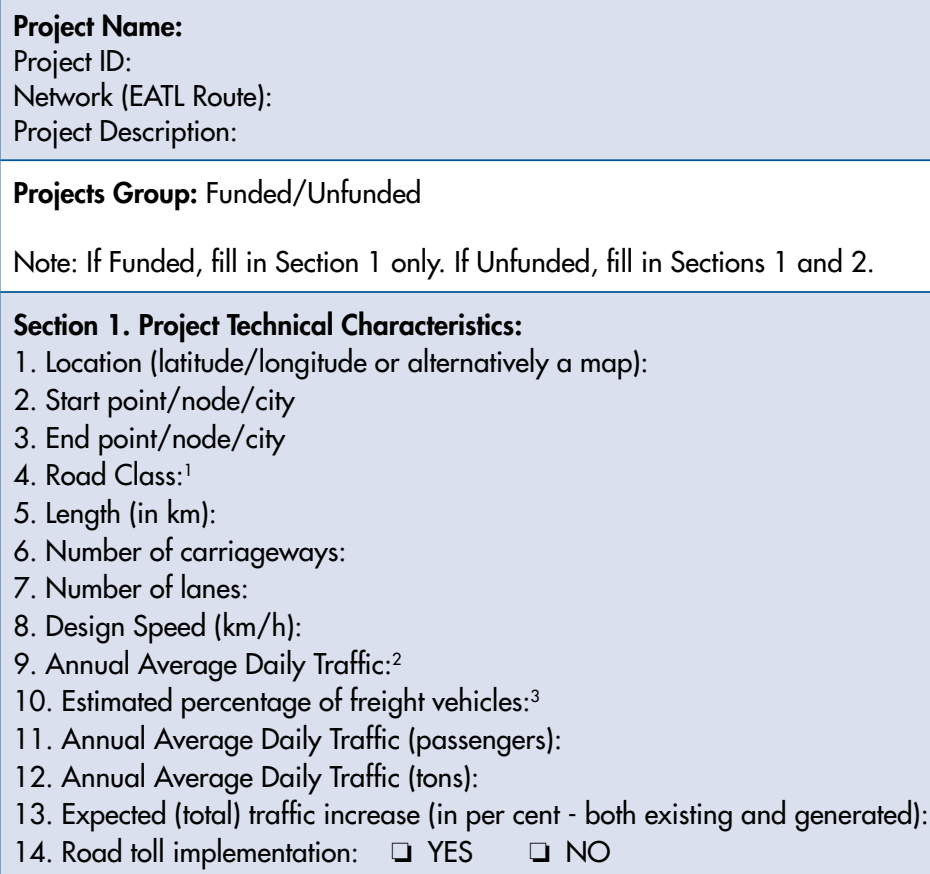

Section 2. Project Information Concerning Criteria of CLUSTER A

15. Is the project serving international connectivity? $\square$ YES $\square$ NO If yes is it expected to:

A: Greatly improve connectivity, B: Significantly improve connectivity, C: Somewhat improve connectivity, D: Slightly improve connectivity, E: Does not improve connectivity.

16. Will the project promote solutions to the particular transit transport needs of the landlocked developing countries? $\square$ YES $\square \mathrm{NO}$ If yes is the project providing solutions:

A: Greatly, B: Significantly, C: Somewhat, D: Slightly, E: Does not

17. Will the project connect low income and/or least developed countries to major European and Asian markets? $\square$ YES $\square \mathrm{NO}$ If yes is the project providing connection:

A: Greatly, B: Significantly, C: Somewhat, D: Slightly, E: Does not

18. Will the project cross natural barriers, remove bottlenecks, raise substandard sections to meet international standards, or fill missing links in the EATL? $\square$ YES $\square$ NO

If yes is the project doing this:

A: Greatly, B: Significantly, C: Somewhat, D: Slightly, E: Does not

19. Will the project have a high degree of urgency due to the importance attributed by the national authorities and/or social interest? $\square$ YES $\square \mathrm{NO}$

If yes the projects is:

A: In the national plan and immediately required (for implementation up to 2013), B: In the national plan and very urgent (for implementation up to 2016), C: In the national plan and urgent (for implementation up to 2020), D: In the national plan but may be postponed until after 2020, E: Not in the national plan.

20. Will the project potentially create negative environmental or social impacts (pollution, safety, etc.)?

$\square$ YES $\square \mathrm{NO}$

If yes the size of the impact is:

A: No impact, B: Slight impact, C: Moderate impact, D: Significant impact, E; Great impact. 


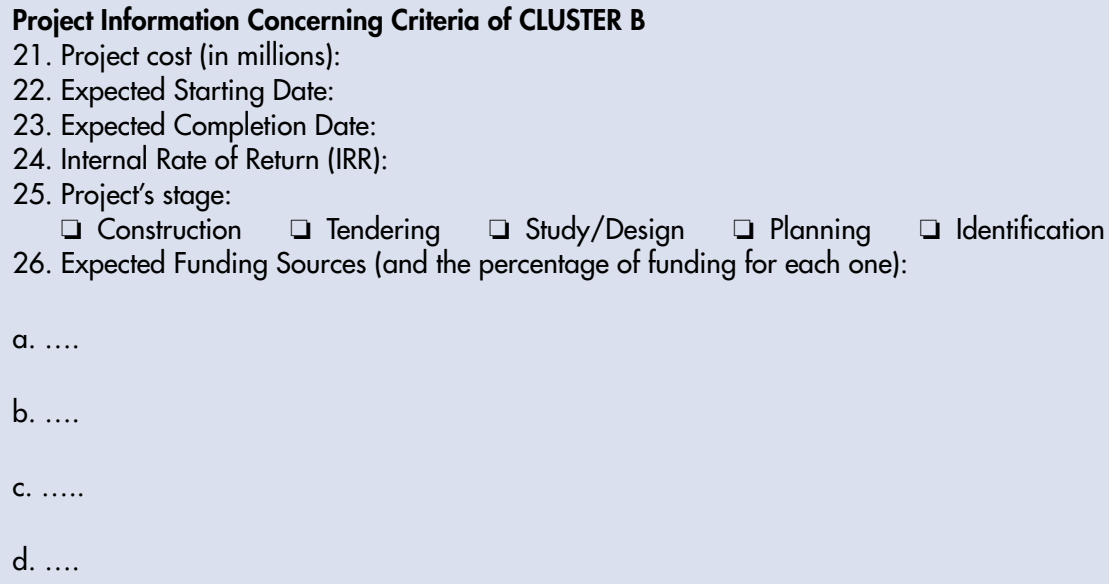

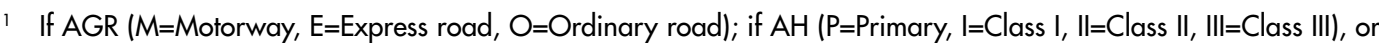
both if applicable.

2 For 2008 and latest year, if available.

3 Freight vehicles include any vehicles used to transport freight, such as trucks and trailers.

\section{TEMPLATE 2B - Rail and related infrastructure Project Fiche}

\section{Project Name:}

Project ID:

Network (EATL Route):

Project Description:

\section{Projects Group: Funded/Unfunded}

Note: If Funded, fill in Section 1 only. If Unfunded, fill in Sections 1 and 2.

\section{Section 1. Project Technical Characteristics:}

1. Location (latitude/longitude or alternatively a map):

2. Start point/node/city:

3. End point/node/city:

4. Length (in $\mathrm{km}$ ):

5. Track gauge $(\mathrm{mm})$ :

6. Number of tracks:

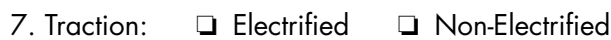

8. Signalling type: $\square$ Automatic $\square$ Manual

9. Maximum allowed speed - passenger trains:

10. Maximum allowed speed - freight trains:

11. Average Daily Train Traffic - Passenger trains: ${ }^{1}$

12. Average Daily Train Traffic - Freight trains: ${ }^{1}$

13. Expected (passenger) traffic increase (in per cent - both existing and generated):

14. Expected (freight) traffic increase (in per cent - both existing and generated)

15. Volume of cargo moved (tons and TEUs): ${ }^{1}$

\section{Section 2. Project Information Concerning Criteria of CLUSTER A}

16. Is the project serving international connectivity? $\square$ YES $\square$ NO If yes is it expected to:

A: Greatly improve connectivity, B: Significantly improve connectivity, C: Somewhat improve connectivity, D: Slightly improve connectivity, E: Does not improve connectivity

17. Will the project promote solutions to the particular transit transport needs of the landlocked developing countries? $\square$ YES $\square \mathrm{NO}$

If yes is the project providing solutions:

A: Greatly, B: Significantly, C: Somewhat, D: Slightly, E: Does not 
18. Will the project connect low income and/or least developed countries to major European and Asian markets? $\square$ YES $\square$ NO

If yes is the project providing connection:

A: Greatly, B: Significantly, C: Somewhat, D: Slightly, E: Does not

19. Will the project cross natural barriers, remove bottlenecks, raise substandard sections to meet international standards, or fill missing links in the EATL?

$\square$ YES $\square$ NO

If yes is the project doing this:

A: Greatly, B: Significantly, C: Somewhat, D: Slightly, E: Does not

20. Will the project have a high degree of urgency due to the importance attributed by the national authorities and/or social interest? $\square$ YES $\square$ NO

If yes the projects is:

A: In the national plan and immediately required (for implementation up to 2013), B: In the national plan and very urgent (for implementation up to 2016), C: In the national plan and urgent (for implementation up to 2020),

D: In the national plan but may be postponed until after 2020, E: Not in the national plan.

21. Will the project potentially create negative environmental or social impacts (pollution, safety, etc.)?

$\square$ YES $\square$ NO

If yes the size of the impact is:

A: No impact, B: Slight impact, C: Moderate impact, D: Significant impact, E; Great impact.

\section{Project Information Concerning Criteria of CLUSTER B}

22. Project cost (in millions):

23. Expected Starting Date:

24. Expected Completion Date:

25. Internal Rate of Return (IRR):

26. Project's stage: Construction Tendering Study/Design

27. Planning Identification

28. Expected Funding Sources (and the percentage of funding for each one):

a. ....

b. ....

c. .....

d. ....

${ }^{1}$ For 2008 and latest year, if available.

\section{TEMPLATE 2C - Inland waterways and related infrastructure Project Fiche}

\section{Project Name:}

Project ID:

Network (EATL Route):

Project Description:

Projects Group: Funded/Unfunded

Note: If Funded, fill in Section 1 only. If Unfunded, fill in Sections 1 and 2.

\section{Section 1. Project Technical Characteristics:}

1. Location (latitude/longitude or alternatively a map):

2. Start point/node/city:

3. End point/node/city:

4. Length (in $\mathrm{km}$ ):

5. Maximum admissible LNWL: ${ }^{1}$

6. Minimum bridge clearance at $\mathrm{HNWL}:^{2}$

7. Lock dimensions:

8. Permitted operational speed $(\mathrm{km} / \mathrm{h})$ :

9. Yearly vessel traffic: ${ }^{3}$

10. Expected (total) traffic increase (in per cent - both existing and generated): 


\section{Section 2. Project Information Concerning Criteria of CLUSTER A}

11. Is the project serving international connectivity? $\square$ YES $\square \mathrm{NO}$ If yes is it expected to:

A: Greatly improve connectivity, B: Significantly improve connectivity, C: Somewhat improve connectivity, D: Slightly improve connectivity, E: Does not improve connectivity.

12. Will the project promote solutions to the particular transit transport needs of the landlocked developing countries? $\square$ YES $\square$ NO

If yes is the project providing solutions:

A: Greatly, B: Significantly, C: Somewhat, D: Slightly, E: Does not

13. Will the project connect low income and/or least developed countries to major European and Asian markets? $\square$ YES $\square$ NO

If yes is the project providing connection:

A: Greatly, B: Significantly, C: Somewhat, D: Slightly, E: Does not

14. Will the project cross natural barriers, remove bottlenecks, raise substandard sections to meet international standards, or fill missing links in the EATL? $\square$ YES $\square$ NO

If yes is the project doing this:

A: Greatly, B: Significantly, C: Somewhat, D: Slightly, E: Does not

15. Will the project have a high degree of urgency due to the importance attributed by the national authorities and/or social interest? $\square$ YES $\square \mathrm{NO}$

If yes the projects is:

A: In the national plan and immediately required (for implementation up to 2013), B: In the national plan and very urgent (for implementation up to 2016), C: In the national plan and urgent (for implementation up to 2020), D: In the national plan but may be postponed until after 2020, E: Not in the national plan.

16. Will the project potentially create negative environmental or social impacts (pollution, safety, etc.)?

$\square$ YES $\square \mathrm{NO}$

If yes the size of the impact is:

A: No impact, B: Slight impact, C: Moderate impact, D: Significant impact, E; Great impact.

\section{Project Information Concerning Criteria of CLUSTER B}

17. Project cost (in millions):

18. Expected Starting Date:

19. Expected Completion Date:

20. Internal Rate of Return (IRR):

21. Project's stage: $\square$ Construction $\square$ Tendering $\square$ Study/Design

$\square$ Planning $\square$ Identification

22. Expected Funding Sources (and the percentage of funding for each one):

a. ....

b. ....

c. .....

d. ......

1 Lowest Navigable Water Level

2 Highest Navigable Water Level

3 For 2008 and latest year, if available. 
TEMPLATE 2D - Ports (sea and inland waterway), Inland container depot/Intermodal freight terminal/Freight village/Logistic centre and related infrastructure Project Fiche

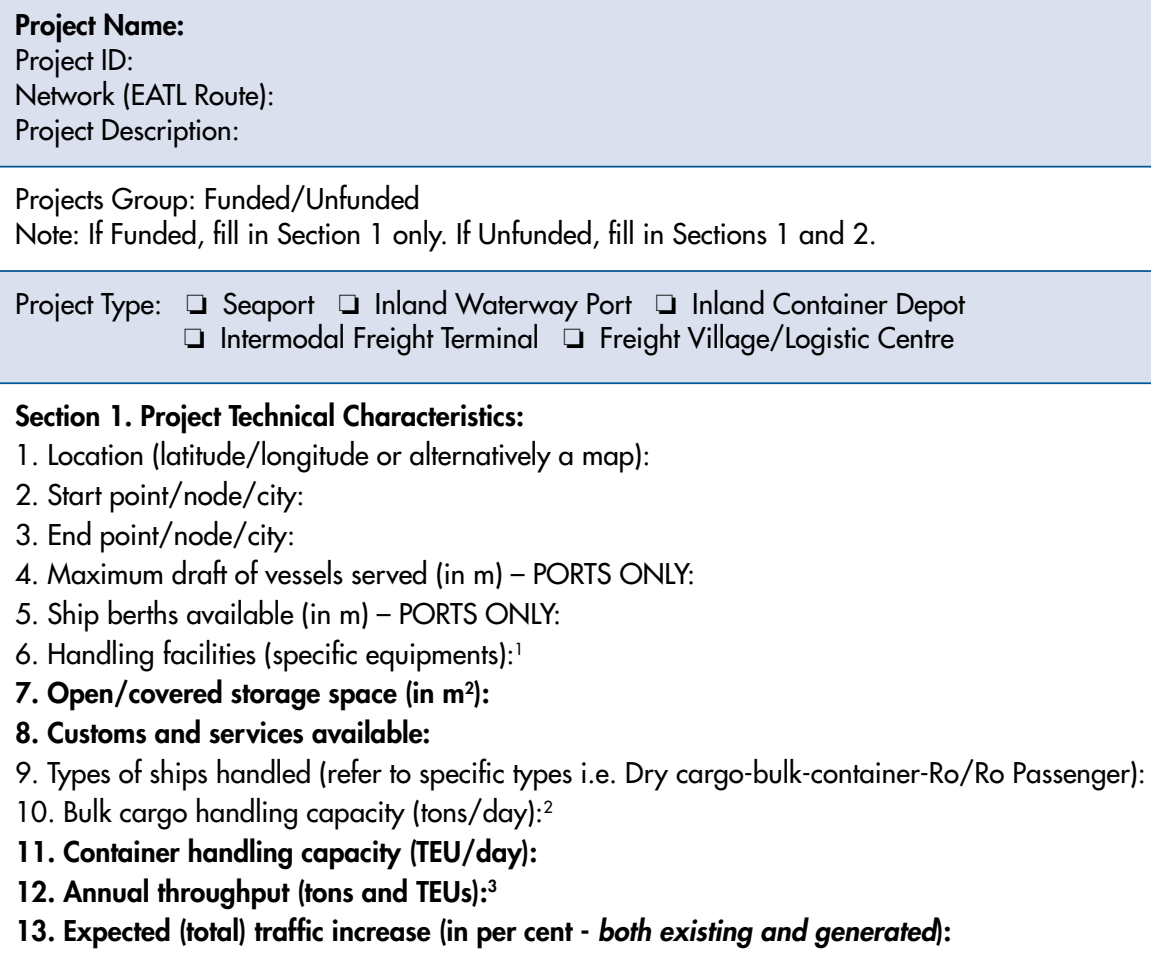

\section{Section 1. Project Technical Characteristics:}

1. Location (latitude/longitude or alternatively a map):

2. Start point/node/city:

3. End point/node/city:

4. Maximum draft of vessels served (in $\mathrm{m}$ ) - PORTS ONLY:

5. Ship berths available (in $\mathrm{m}$ ) - PORTS ONLY:

6. Handling facilities (specific equipments): ${ }^{\prime}$

7. Open/covered storage space (in $\mathrm{m}^{2}$ ):

8. Customs and services available:

9. Types of ships handled (refer to specific types i.e. Dry cargo-bulk-container-Ro/Ro Passenger):

10. Bulk cargo handling capacity (tons/day): ${ }^{2}$

11. Container handling capacity (TEU/day):

12. Annual throughput (tons and TEUs): ${ }^{3}$

13. Expected (total) traffic increase (in per cent - both existing and generated):

\section{Section 2. Project Information Concerning Criteria of CLUSTER A}

14. Is the project serving international connectivity?

$\square$ YES $\square \mathrm{NO}$

If yes is it expected to:

A: Greatly improve connectivity, B: Significantly improve connectivity, C: Somewhat improve connectivity,

D: Slightly improve connectivity, E: Does not improve connectivity.

15. Will the project promote solutions to the particular transit transport needs of the landlocked developing countries? $\square$ YES $\square$ NO

If yes is the project providing solutions:

A: Greatly, B: Significantly, C: Somewhat, D: Slightly, E: Does not

16. Will the project connect low income and/or least developed countries to major European and Asian markets?

$\square$ YES $\square \mathrm{NO}$

If yes is the project providing connection

A: Greatly, B: Significantly, C: Somewhat, D: Slightly, E: Does not

17. Will the project cross natural barriers, remove bottlenecks, raise substandard sections to meet international standards, or fill missing links in the EATL?

$\square$ YES $\square$ NO

If yes is the project doing this:

A: Greatly, B: Significantly, C: Somewhat, D: Slightly, E: Does not

18. Will the project have a high degree of urgency due to the importance attributed by the national authorities and/or social interest?

$\square$ YES $\square$ NO

If yes the projects is:

A: In the national plan and immediately required (for implementation up to 2013), B: In the national plan and very urgent (for implementation up to 2016), C: In the national plan and urgent (for implementation up to 2020),

D: In the national plan but may be postponed until after 2020, E: Not in the national plan.

19. Will the project potentially create negative environmental or social impacts (pollution, safety, etc.)?

$\square$ YES $\square \mathrm{NO}$

If yes the size of the impact is:

A: No impact, B: Slight impact, C: Moderate impact, D: Significant impact, E; Great impact. 


\section{Project Information Concerning Criteria of CLUSTER B}

20. Project cost (in millions):

21. Expected Starting Date:

22. Expected Completion Date:

23. Internal Rate of Return (IRR):

24. Project's stage: Construction Tendering Study/Design

Planning Identification

25. Expected Funding Sources (Name the sources and the percentage of funding for each one):

a. ....

b. ....

c. .....

d. ....

1 Cranes-gantries-mobile-forklifts-20'/40' containers. Also indicate availability of rail/road trans-shipment facilities.

${ }^{2}$ Where applicable.

${ }^{3}$ For 2008 and latest year, if available. 


\section{Appendix 4.3}

Completed Templates B

Projects Along Proposed EATL Phase II Routes

Projects of National Importance 


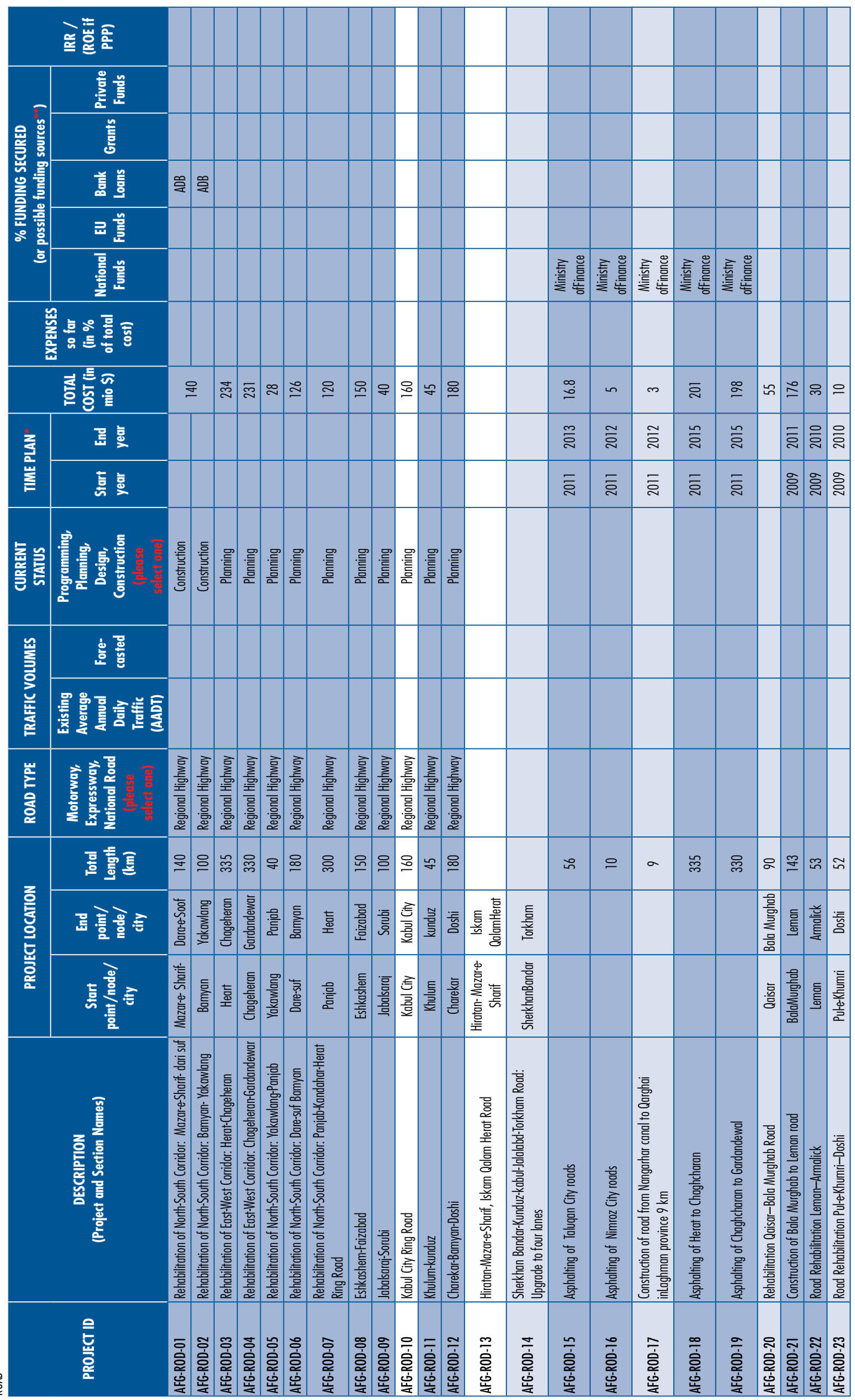




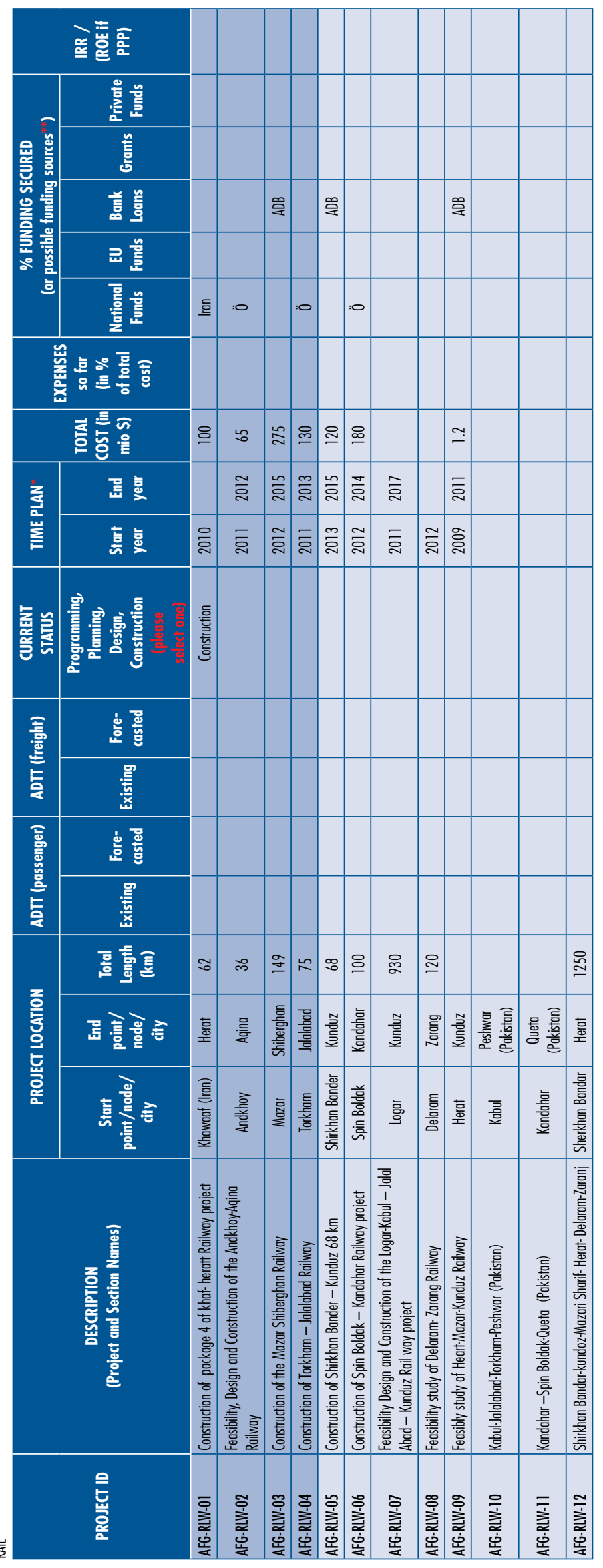




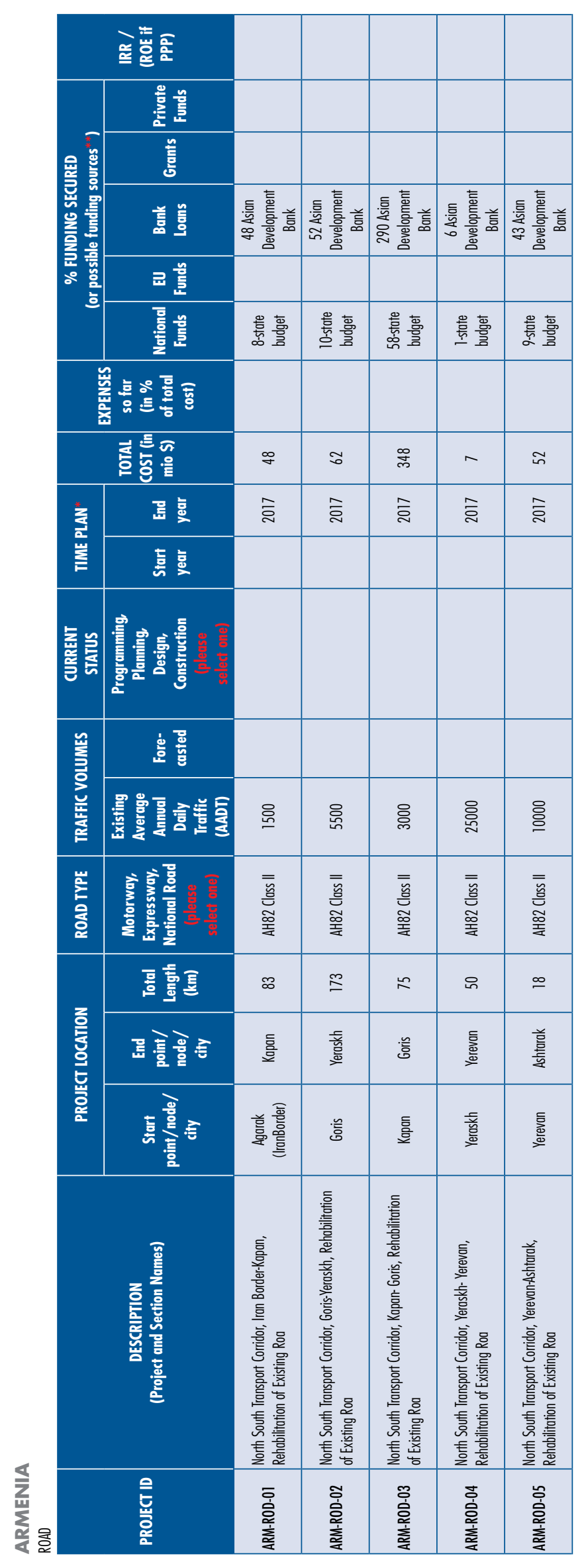




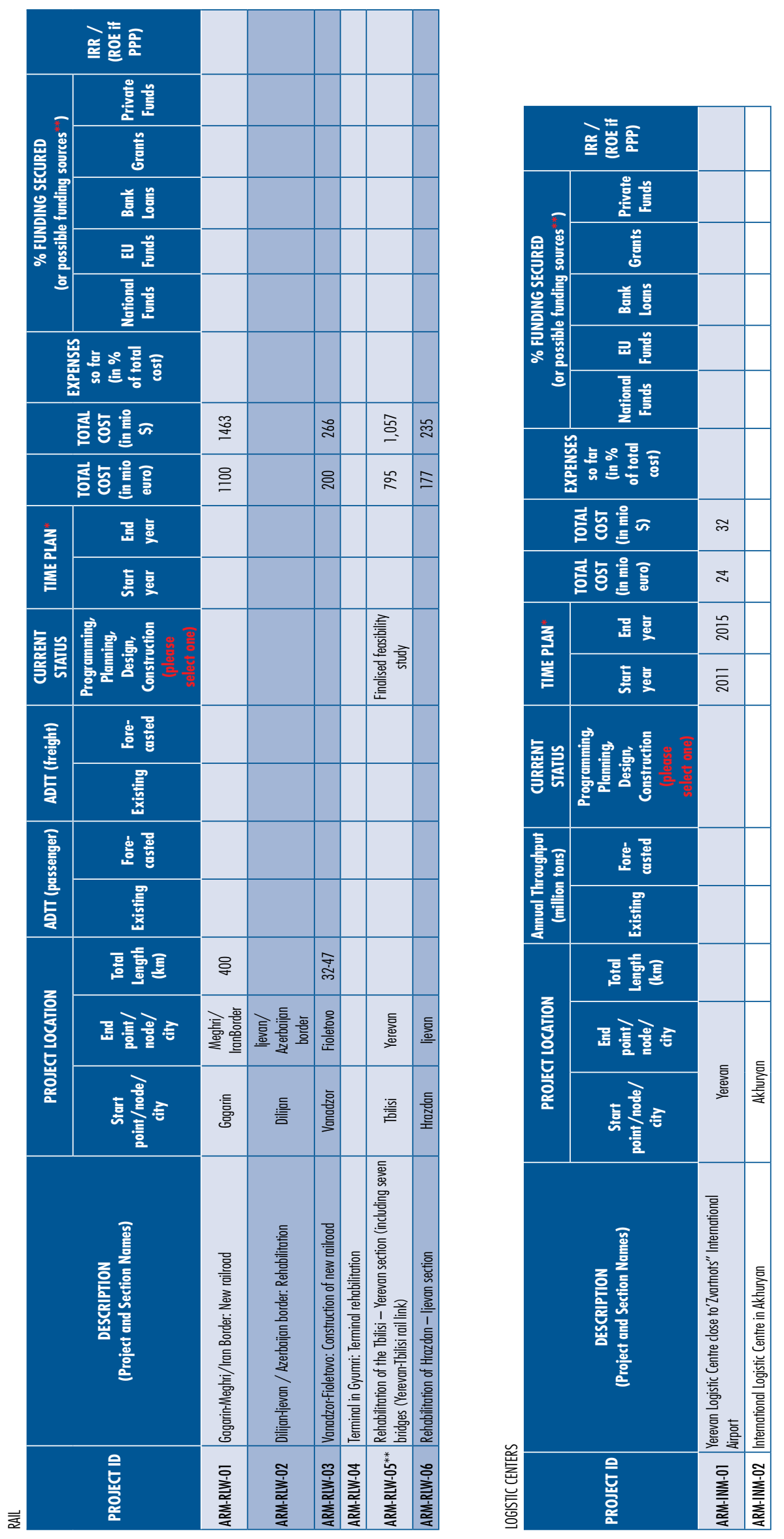



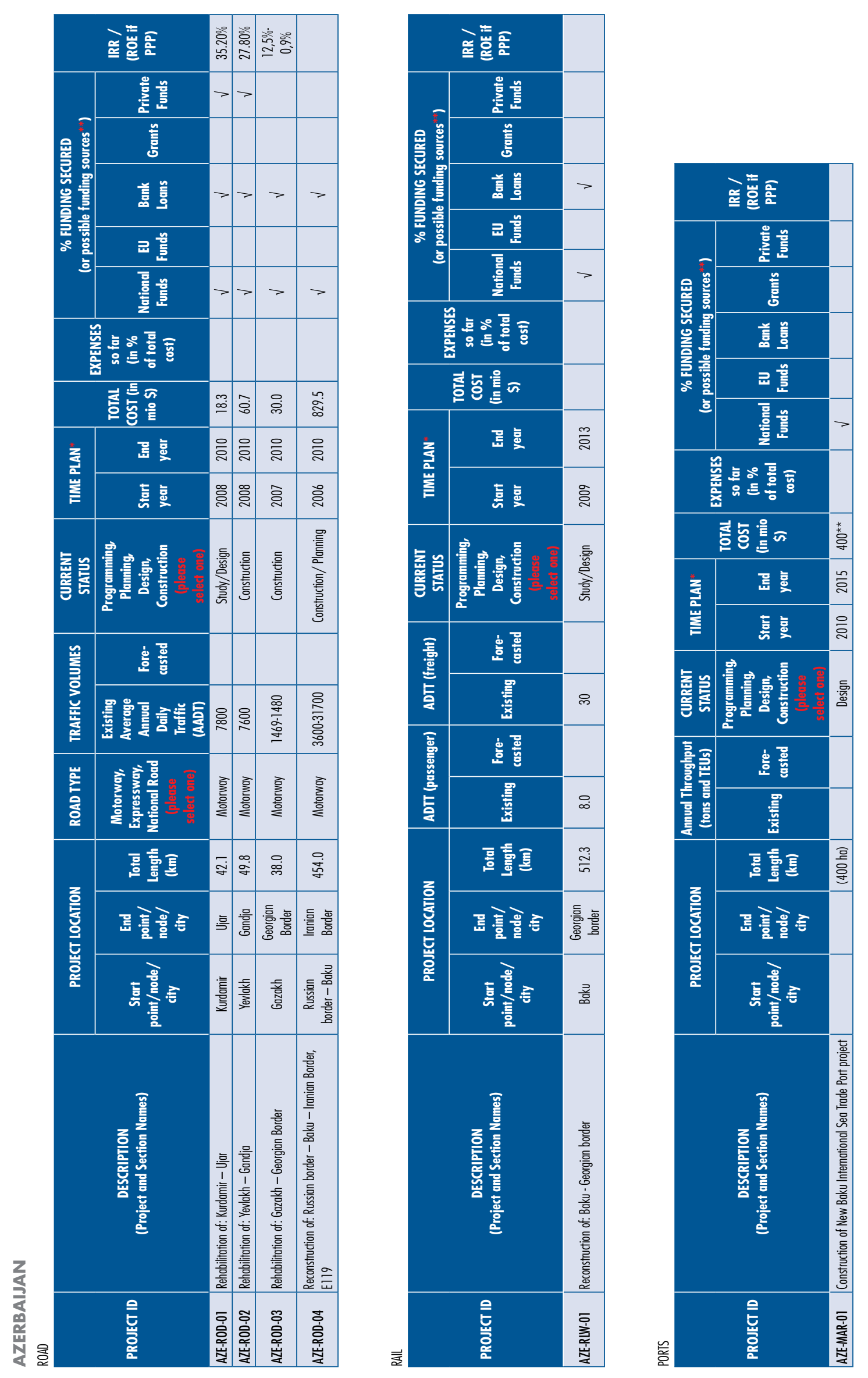
E C O N O M I C

C O M M I S S I O N

$\mathrm{F} O \mathrm{R}$

$\begin{array}{llllll}E & U & \mathrm{R} & \mathrm{P} & \mathrm{P} & \mathrm{E}\end{array}$

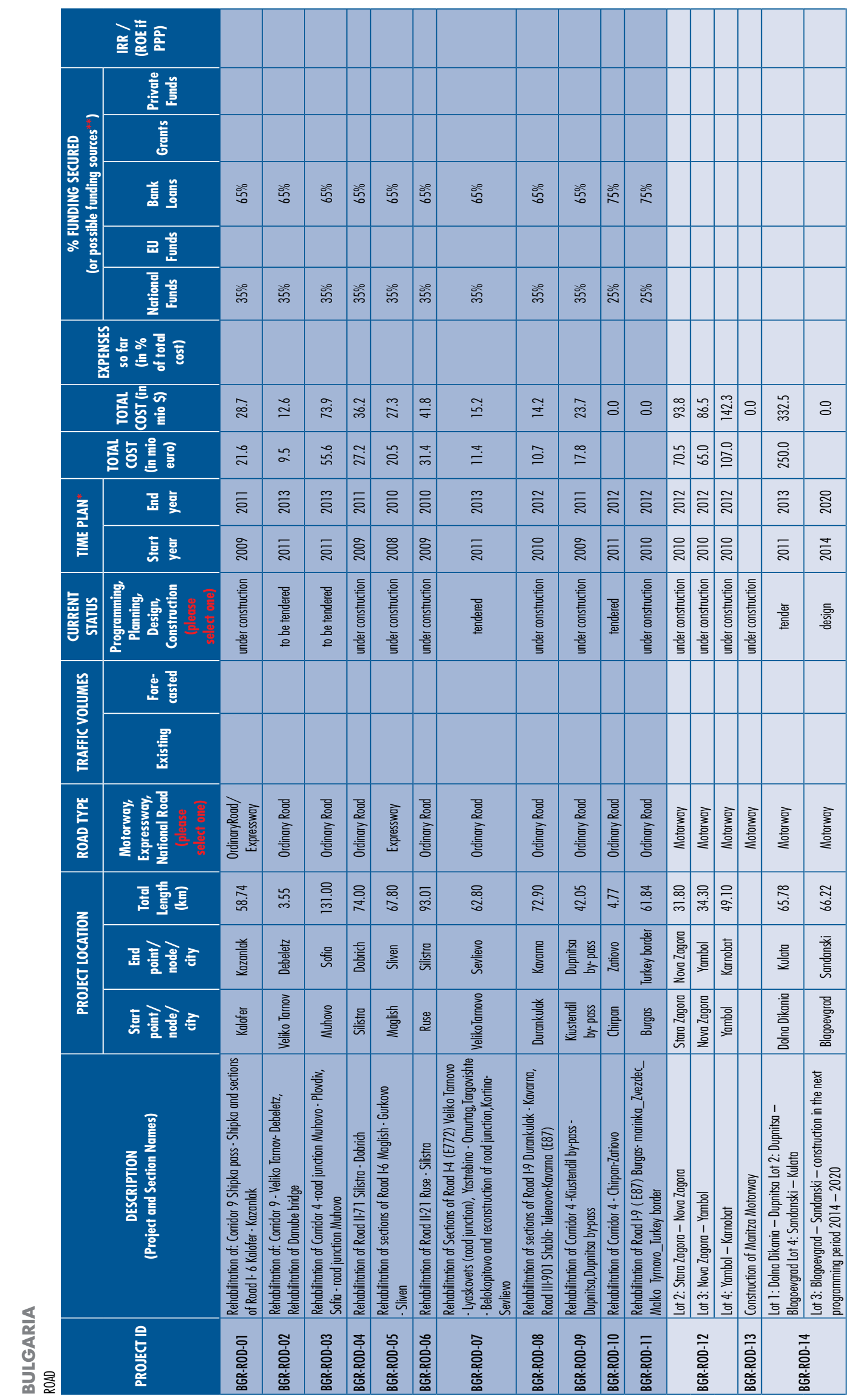




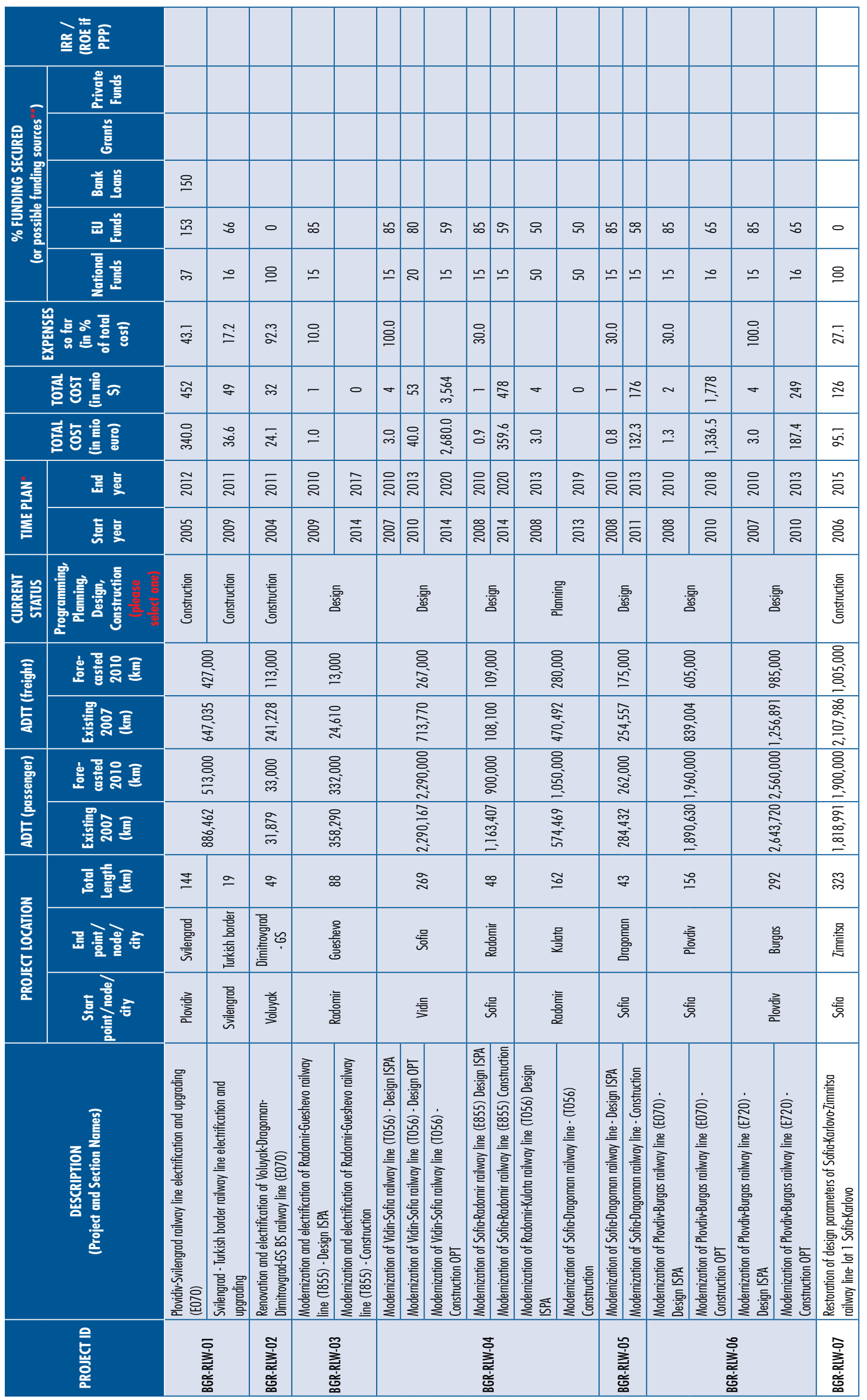




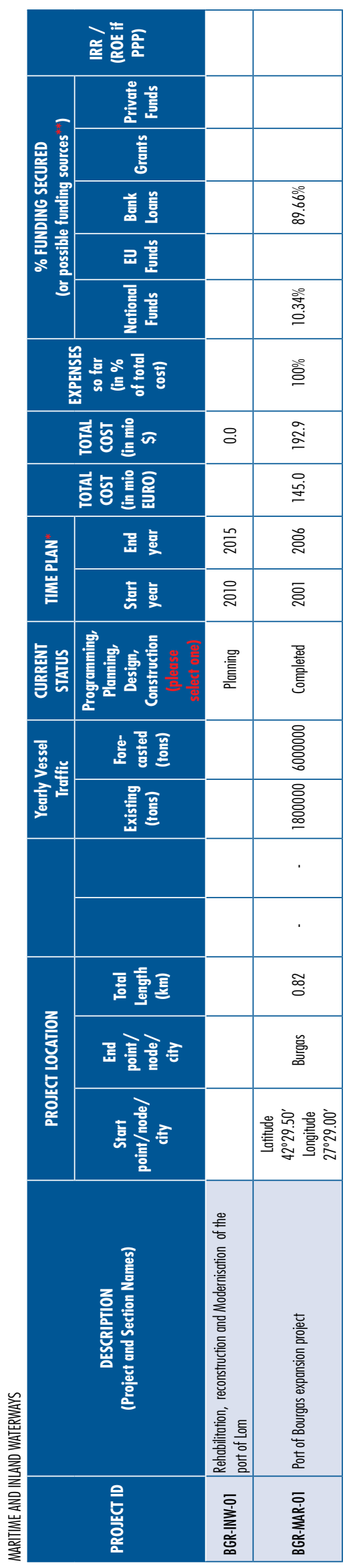




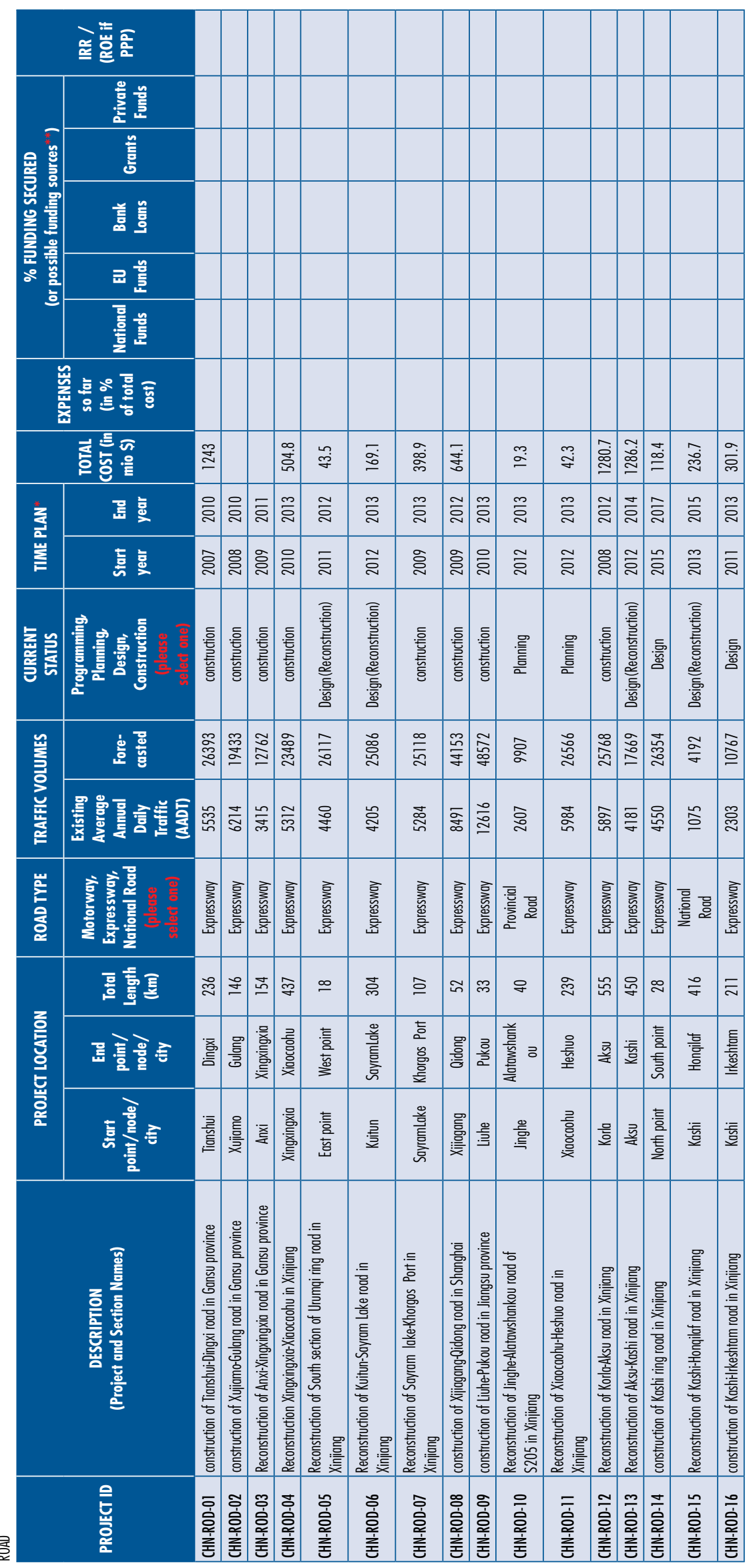




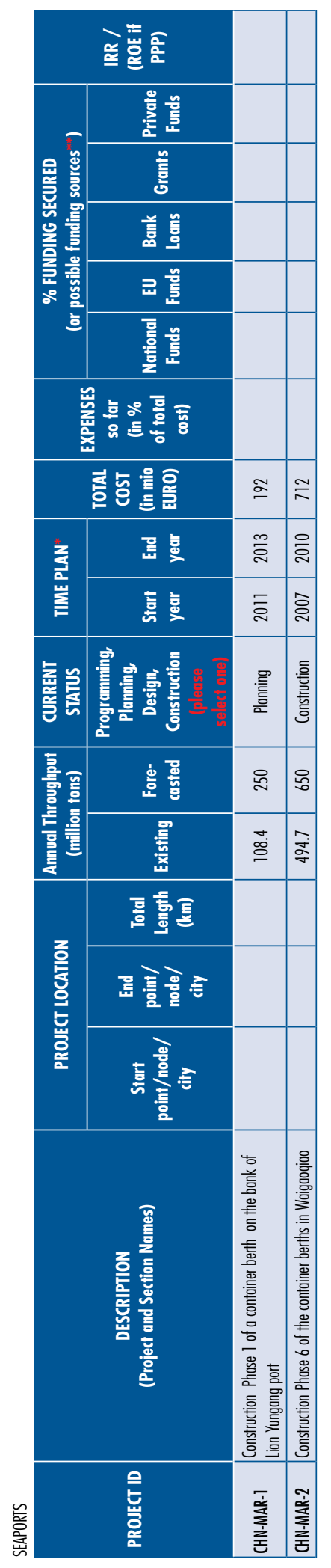




\begin{tabular}{|c|c|c|c|c|c|c|c|c|c|c|c|c|c|c|}
\hline \multicolumn{15}{|c|}{ 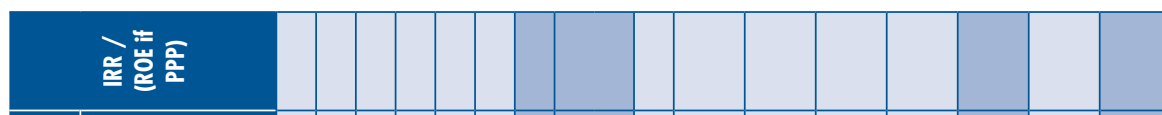 } \\
\hline & 旁曾 & & & & & & & & & & & & & \\
\hline & 产 & & & & & & & & & & & & & \\
\hline & 善兹 & ळे & 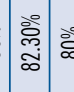 & & ڤे & & & & & & & & & \\
\hline & 료 & & & & & & & & & & & & & \\
\hline & 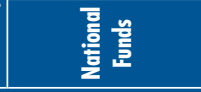 & ฉั & & ڤั่ & 亏े & & & & & & & & & \\
\hline \multicolumn{2}{|c|}{ 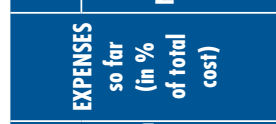 } & $\therefore$ & & $=$ & 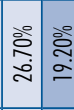 & & & & & & & & & \\
\hline \multicolumn{2}{|r|}{ 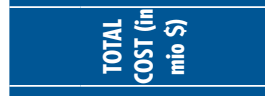 } & ¿̊ำ & $\underset{q}{g}$ & $\infty$ & $\nexists ⿱ 乛 ⿻ 上 丨$ & & & & & & & & & \\
\hline & 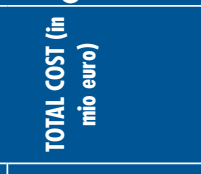 & $\sigma$ & & & $\stackrel{+}{\infty}$ & & & 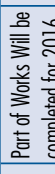 & 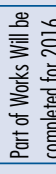 & 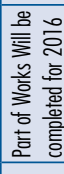 & 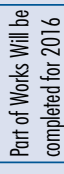 & 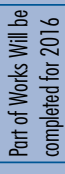 & & 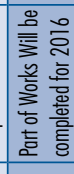 \\
\hline \multirow{2}{*}{ 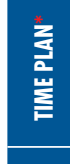 } & 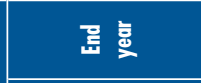 & పิ & ฉั สิ & 司 & ปิ & ลี & ลี & 言 & 亏े & పे & 亏े & 亏ิ & ลे & 六 \\
\hline & 嘉歖 & 亏ัญे & ํำ & (ิ) & 亏ัญे & $\bar{\vdots}$ & $\overline{\bar{\Xi}}$ & $\bar{\vdots}$ & 品 & 壳 & 言 & 品 & $\stackrel{\circ}{a}$ & ลี \\
\hline 点哭 & 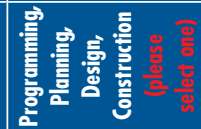 & 意䇏 & $\frac{5}{5}$ & 悥 & 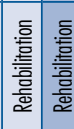 & 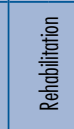 & 嬄 & $\begin{array}{l}\text { 墨 } \\
\text { 言 }\end{array}$ & $\begin{array}{l}\text { 啻 } \\
\text { 至 }\end{array}$ & 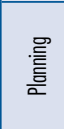 & 墨 & 墨 & 墨 & $\begin{array}{l}\text { 总 } \\
\text { 旁 }\end{array}$ \\
\hline \multirow{2}{*}{ 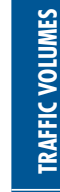 } & sᄒ & & & & & & & & & & & & & \\
\hline & 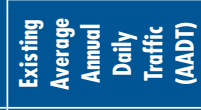 & $\frac{5}{8}$ & $\because$ & & 品 & & 恕 & ま & \% & Б్ & 畹 & 䋹 & $\stackrel{2}{\stackrel{2}{2}}$ & $\stackrel{ః}{\infty}$ \\
\hline 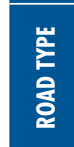 & 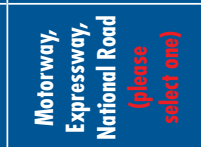 & 意咅 & 謩站 & $=$ & $\mid$ & 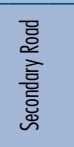 & 穜 & 昱 & 暜 & 喜 & 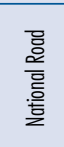 & 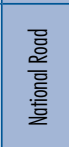 & 喜 & 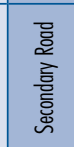 \\
\hline \multirow{3}{*}{ 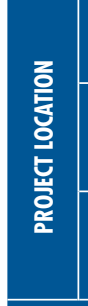 } & 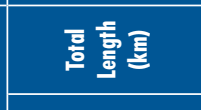 & $=0$ & $\infty$ & - & $\approx 2$ & $\approx$ & \% & in & in & $\pi$ & के & m & $\simeq$ & \pm \\
\hline & 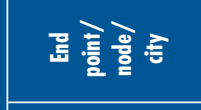 & 产量 & 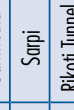 & $\frac{5}{b}$ & 言高 & 喜 & 亨 & 言 & $\begin{array}{l}\text { 言 } \\
\text { 寅 } \\
\end{array}$ & \begin{tabular}{|l} 
言 \\
旁 \\
\end{tabular} & 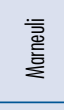 & 总 & 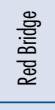 & 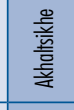 \\
\hline & 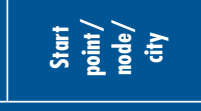 & 衰言 & 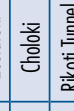 & $\frac{E}{5}$ & 言竞 & 旁 & 谅 & 畜 & 辜 & 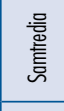 & 登 & 语 & 亳 & 焉 \\
\hline & 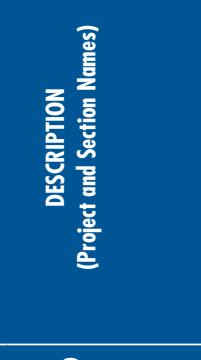 & & & 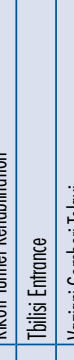 & & 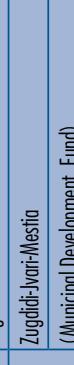 & & 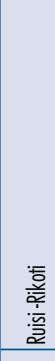 & $\begin{array}{l}\text { 言 } \\
\text { 童 } \\
\text { 言童 }\end{array}$ & 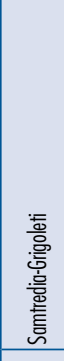 & 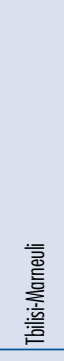 & \begin{tabular}{|l} 
总 \\
高 \\
譥
\end{tabular} & 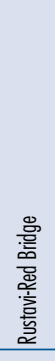 & 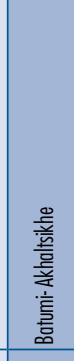 \\
\hline & 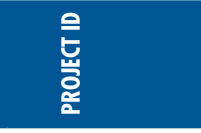 & 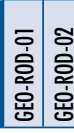 & 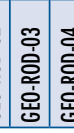 & 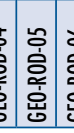 & 递商 & $\begin{array}{l}\text { o } \\
\text { 产 } \\
\text { 竞 }\end{array}$ & 产 & 울 & 嗙 & $\begin{array}{l}\text { 音 } \\
\text { 飬 } \\
\end{array}$ & 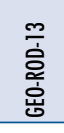 & 咅 & 产 & $\begin{array}{l}\text { 웅 } \\
\text { 형 }\end{array}$ \\
\hline
\end{tabular}




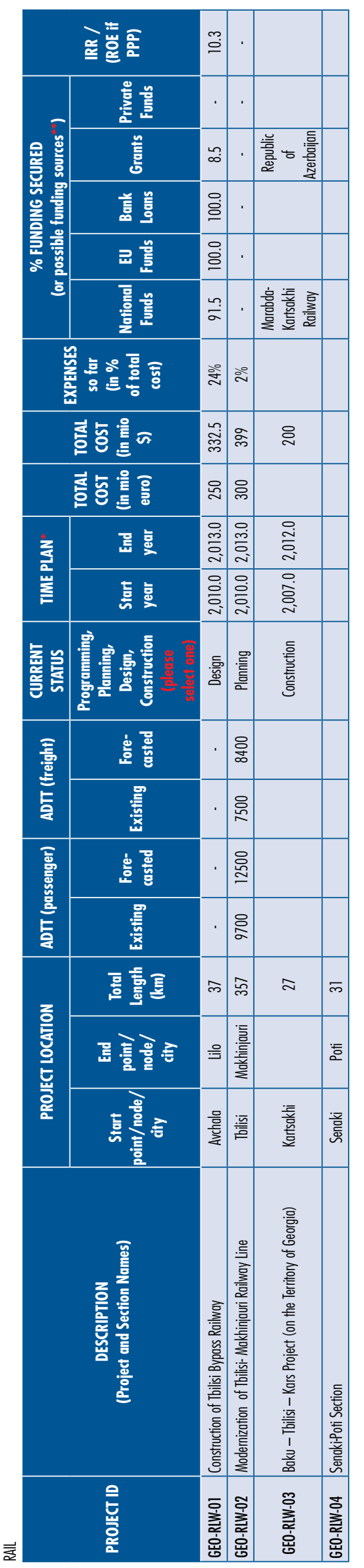




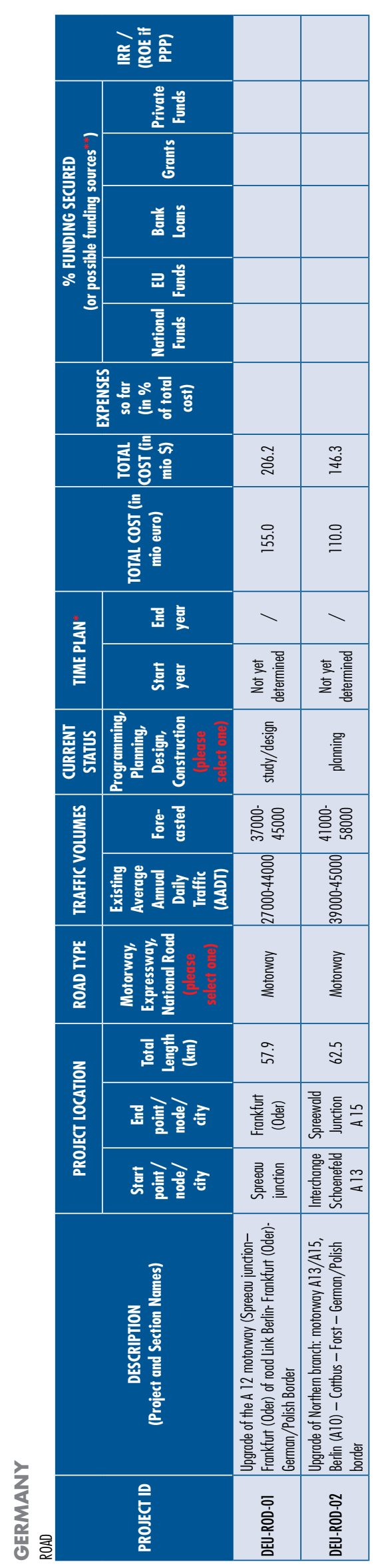

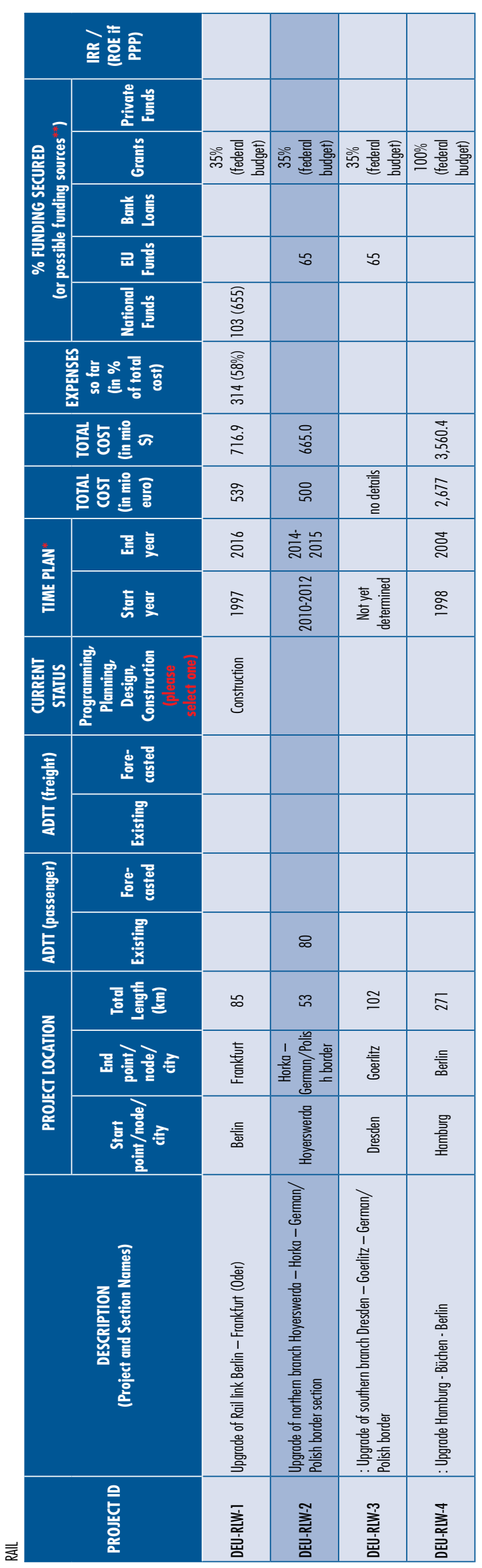



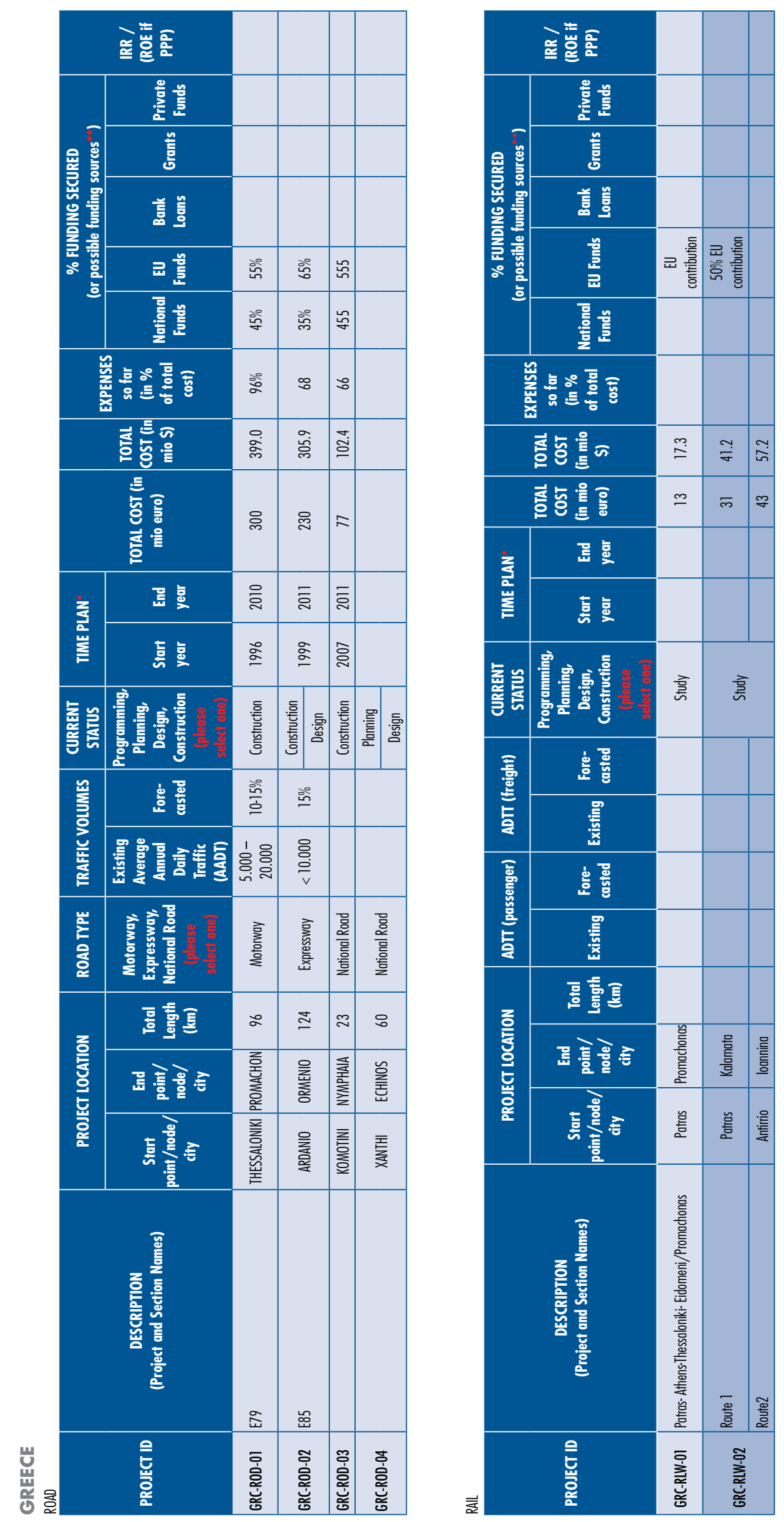


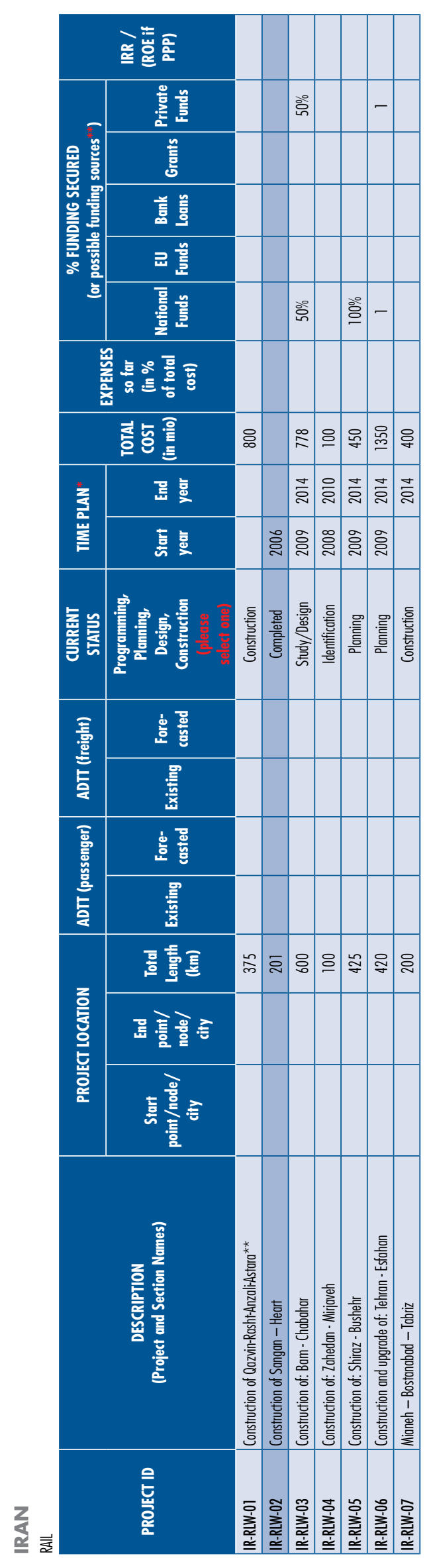




\section{초ำํํำ}

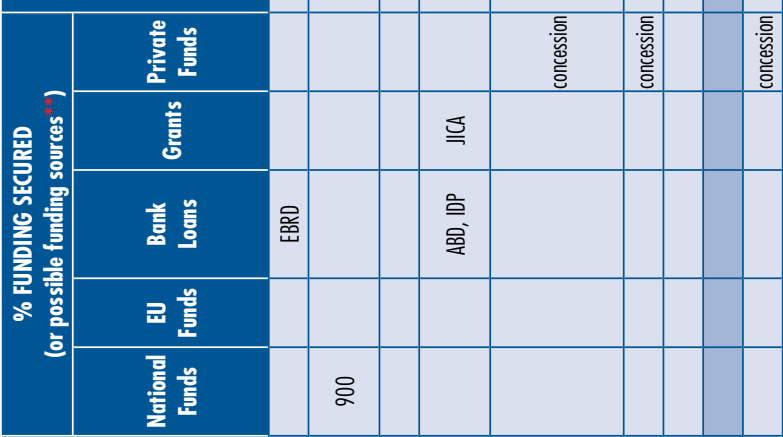

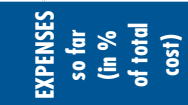

\begin{tabular}{|c|c|c|}
\hline 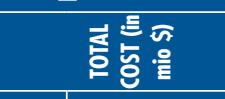 & $\Xi \approx$ & \\
\hline 焉 & & 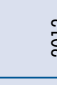 \\
\hline 翼 & & 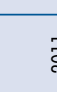 \\
\hline
\end{tabular}

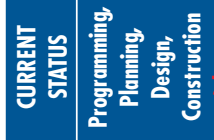

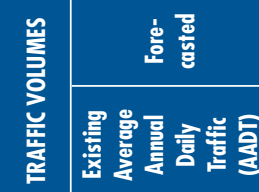

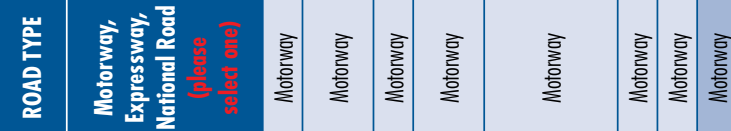

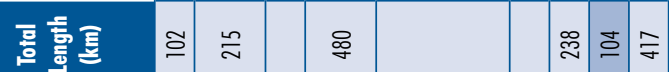

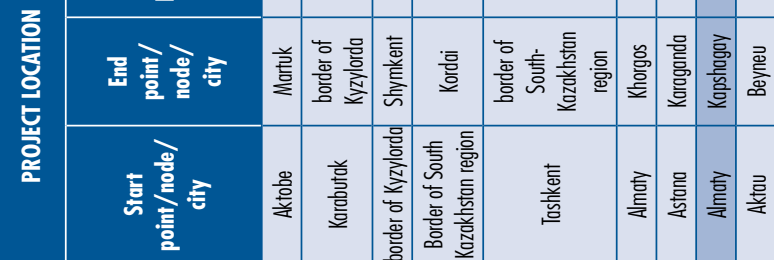

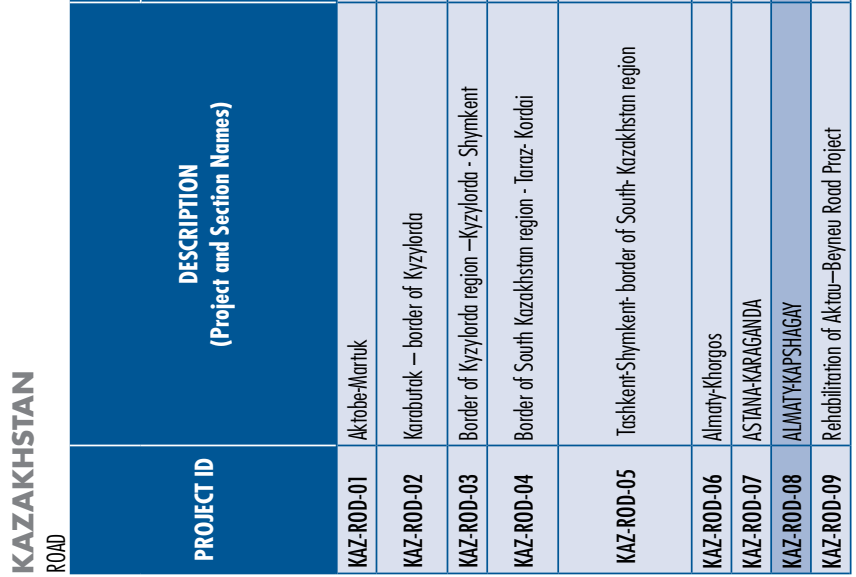

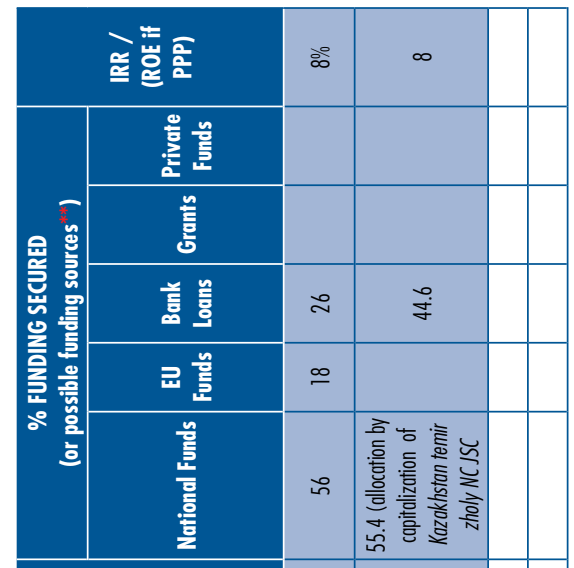

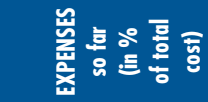

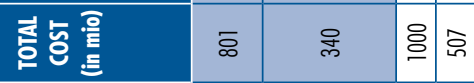

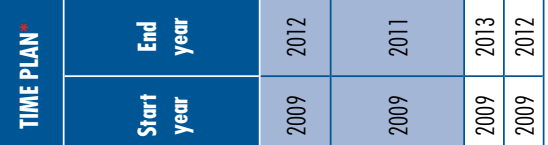

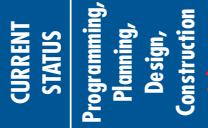

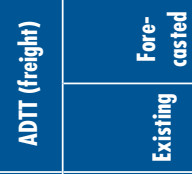

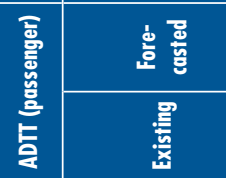

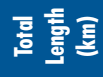

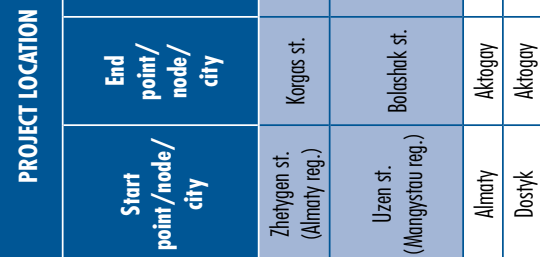

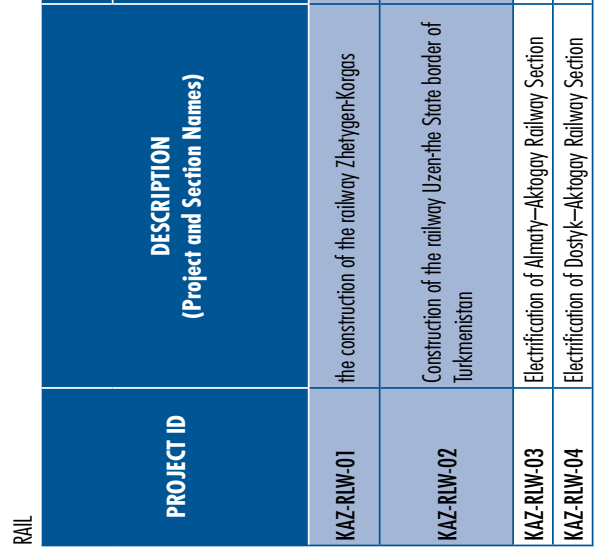




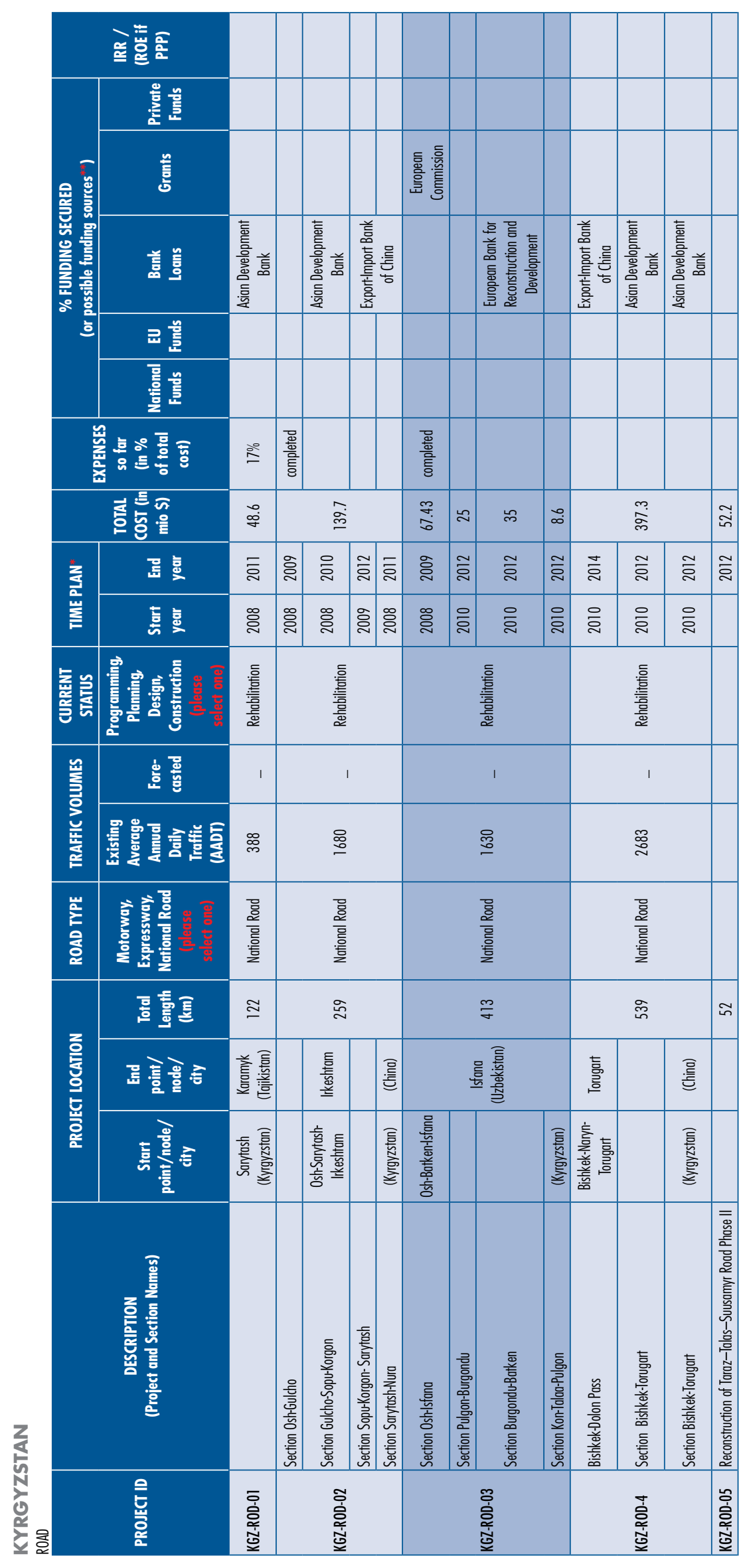




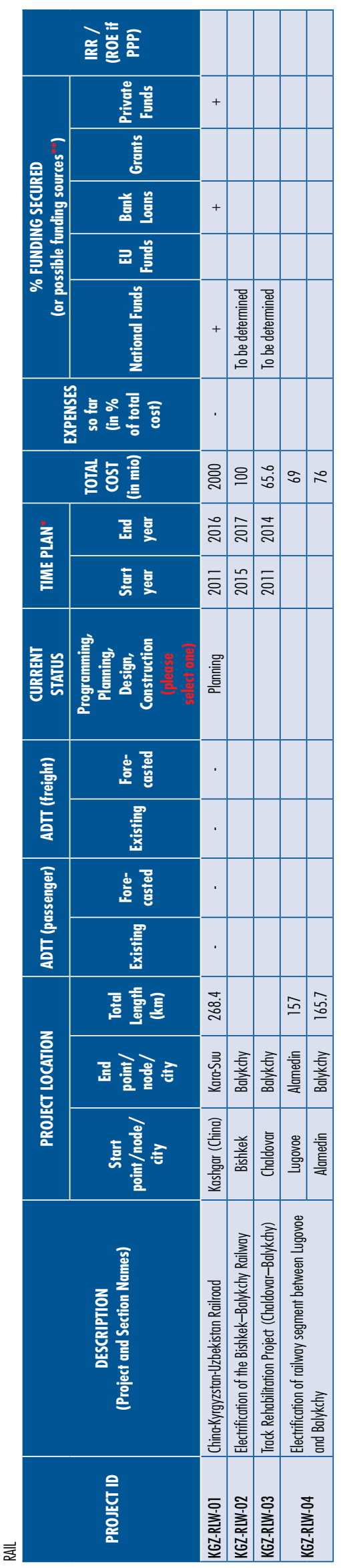




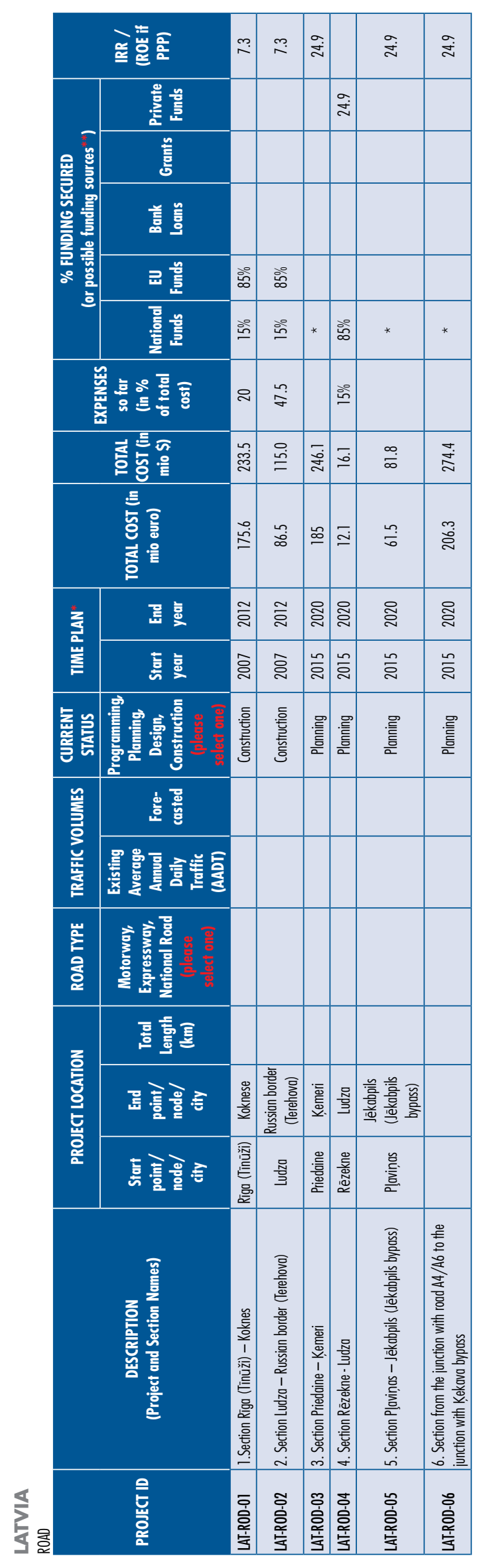




\begin{tabular}{|c|c|c|c|c|c|c|c|c|c|c|c|}
\hline \multicolumn{2}{|c|}{ 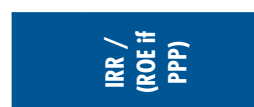 } & & & & & & & & & & \\
\hline \multirow{5}{*}{ 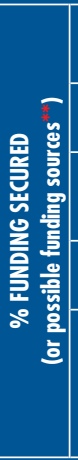 } & 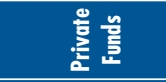 & & & & & & & & & & \\
\hline & 产 & & & & & & & & & & \\
\hline & 言高 & $\dddot{8}$ & ळ & & & m & 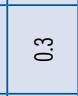 & & \% & $\approx$ & 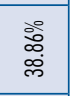 \\
\hline & 료 & ò & $\hat{o}$ & $\square$ & & $\stackrel{\infty}{\circ}$ & $\bar{o}$ & 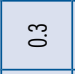 & 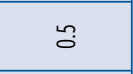 & $\stackrel{\infty}{0}$ & $\because$ \\
\hline & $\begin{array}{l}\underline{n} \\
\overline{\underline{\mathbf{E}}} \\
\overline{\bar{z}} \\
\text { 言 } \\
\end{array}$ & & & 口 & & & & & m & & $\bar{o}$ \\
\hline \multirow{2}{*}{\multicolumn{2}{|c|}{ 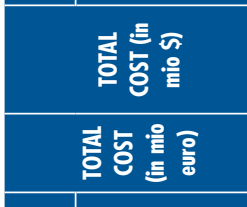 }} & $\stackrel{2}{q}$ & : & 总 & : & $\bar{\AA}$ & 욜 & 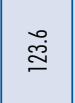 & $\bar{n}$ & 宁 & $\stackrel{\infty}{=}$ \\
\hline & & $\stackrel{\circ}{\circ}$ & ஓீ & 悤 & 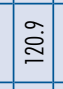 & $\Xi$ & \& & ঞू & $\stackrel{\vec{\gamma}}{ }$ & 号 & $\underset{\infty}{+}$ \\
\hline \multirow{2}{*}{$\begin{array}{l}\frac{3}{3} \\
\frac{3}{2} \\
\text { 产 }\end{array}$} & 畐 & $\stackrel{ \pm}{\grave{2}}$ & 亏े & ఏ్ิ & & 을 & స్ & 을 & $\overline{\bar{a}}$ & $\stackrel{m}{\grave{n}}$ & 을 \\
\hline & 志壱 & 음 & ฐิ & $\stackrel{n}{\overline{2}}$ & & ฐ్ & 음 & ప్ & ఏ్ & $\bar{\Sigma}$ & ప్ర \\
\hline 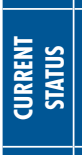 & 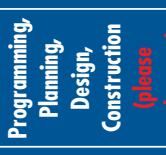 & 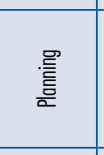 & 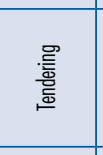 & 意 & 竞 & $\frac{\text { 言 }}{\text { 言 }}$ & 衰 & 毫 & 毫 & 裘 & 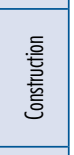 \\
\hline \multirow{2}{*}{ 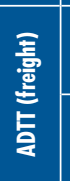 } & 훈 & & & ळे & & & ळे & ळे & ळे & & \\
\hline & 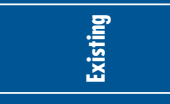 & & & $\therefore$ & $\approx$ & & $\approx$ & $\approx$ & $\cong$ & & \\
\hline \multirow{2}{*}{ 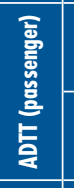 } & 安 홍 & & & & & & & & & & \\
\hline & 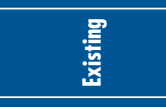 & & & in & & & n & & in & & \\
\hline \multirow{3}{*}{ 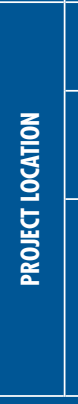 } & 豆言害焉 & $\stackrel{\circ}{i}$ & & $\equiv$ & 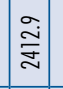 & 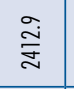 & $\approx$ & 吕 & 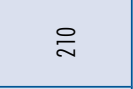 & & $\stackrel{d}{~}$ \\
\hline & 롭 言㕩 & $\begin{array}{l}\text { 童 } \\
\text { 离 } \\
\end{array}$ & $\begin{array}{l}\text { 离 } \\
\text { 善 } \\
\end{array}$ & & 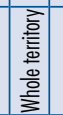 & 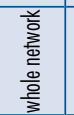 & 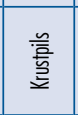 & 亳 & 咳 & 言 & 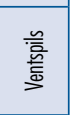 \\
\hline & 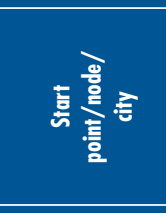 & 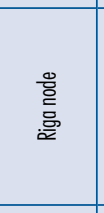 & 咅 & 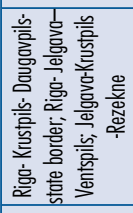 & : & 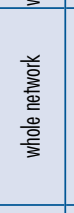 & 离 & 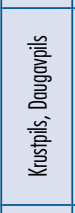 & 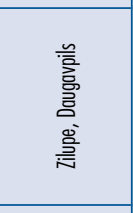 & 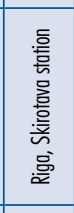 & 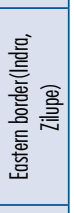 \\
\hline & 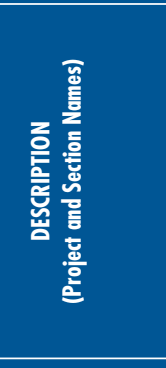 & 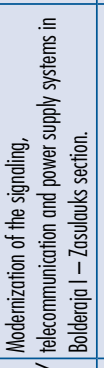 & 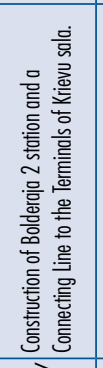 & 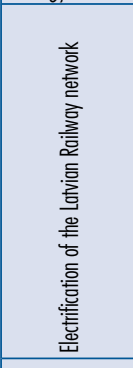 & 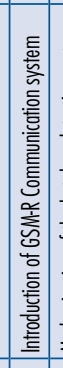 & 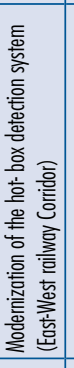 & 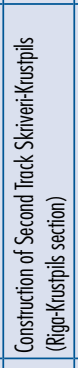 & 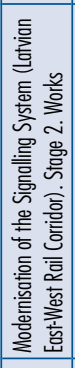 & 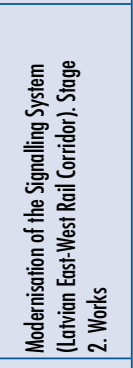 & 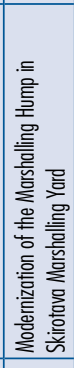 & 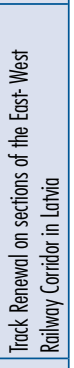 \\
\hline & 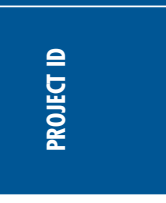 & 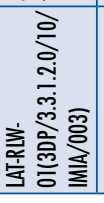 & 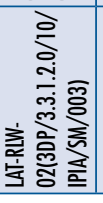 & $\begin{array}{l}\text { *. } \\
\text { 旁 } \\
\text { 产 } \\
\text { 安 }\end{array}$ & 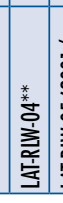 & 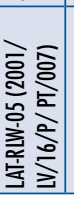 & \begin{tabular}{|l|} 
产 \\
产窎 \\
\end{tabular} & 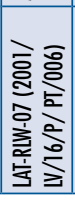 & 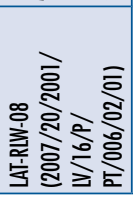 & 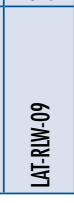 & 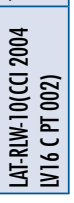 \\
\hline
\end{tabular}




\begin{tabular}{|c|c|c|c|c|c|c|c|}
\hline \multicolumn{8}{|c|}{ 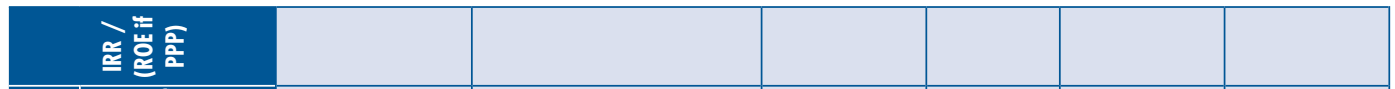 } \\
\hline \multirow{5}{*}{ 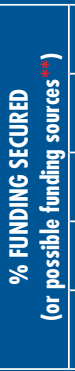 } & 产咅 & & & & & & \\
\hline & 言 & & & & & & \\
\hline & 善言 & & & & & & \\
\hline & 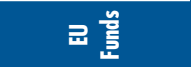 & $\approx$ & 요 & 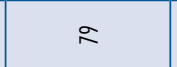 & 음 & 요 & $\bar{\sigma}$ \\
\hline & 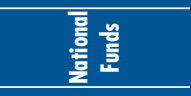 & $\stackrel{q}{q}$ & ○ & $\bar{\sim}$ & 0 & $\circ$ & in \\
\hline \multicolumn{2}{|c|}{ 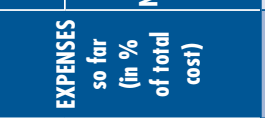 } & $\infty$ & 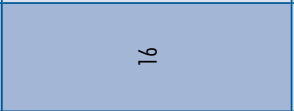 & ది & $\approx$ & 0 & 0 \\
\hline \multicolumn{2}{|c|}{ 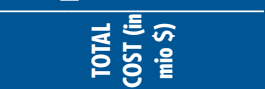 } & $\stackrel{\circ}{F}$ & 户ें & $\stackrel{2}{\check{n}}$ & Fे & ஓ̊. & iे \\
\hline \multicolumn{2}{|r|}{ 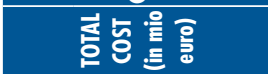 } & $\frac{m}{m}$ & $\tilde{\sim}$ & $\underset{m}{\mathscr{g}}$ & $\bar{i}$ & $\stackrel{n}{\approx}$ & $\bar{\infty}$ \\
\hline \multirow{2}{*}{ 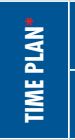 } & 롭 & 을 & $\overline{\bar{a}}$ & 음 & $\overline{\bar{a}}$ & $\tilde{\text { స్ }}$ & $\stackrel{m}{\grave{2}}$ \\
\hline & 言总 & 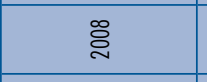 & ఏ్ & 吕 & ఏ్ & 음 & $\overline{\bar{\Sigma}}$ \\
\hline \multirow{3}{*}{ 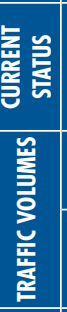 } & 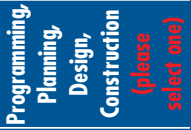 & 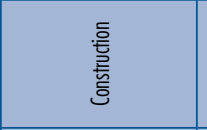 & 竞 & $\begin{array}{l}\text { 言 } \\
\text { 言 } \\
\text { 窎 }\end{array}$ & 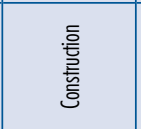 & $\begin{array}{l}\text { 흘 } \\
\text { 䲻 }\end{array}$ & 㞗 \\
\hline & 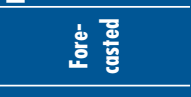 & 商 & 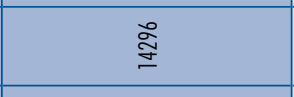 & $\stackrel{\leftrightarrow}{\simeq}$ & $\stackrel{\infty}{\equiv}$ & 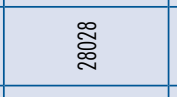 & 怘 \\
\hline & 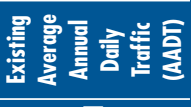 & ฐ & $\approx$ & 咒 & 吅 & $\begin{array}{c}\infty \\
\stackrel{m}{m} \\
\stackrel{\infty}{m}\end{array}$ & 商 \\
\hline | & 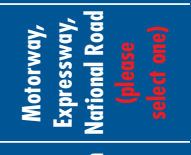 & 哀 & $\begin{array}{l}\text { 믈 } \\
\text { 产 } \\
\text { 产 }\end{array}$ & 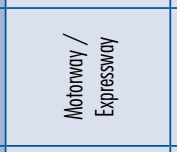 & 亳 & 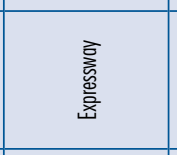 & 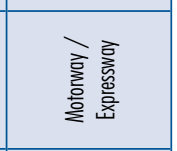 \\
\hline \multirow{3}{*}{ 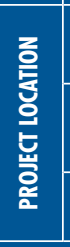 } & 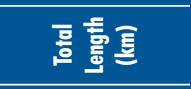 & ळ & Бु & 용 & $\tilde{\sim}$ & $\cong$ & \\
\hline & 롭 言总 & 善 & 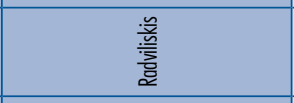 & 兽 & $\begin{array}{l}\text { 兽 } \\
\text { 咅 } \\
\end{array}$ & 瓷 & 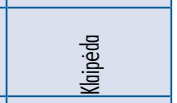 \\
\hline & 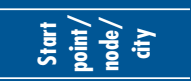 & 爰 & $\frac{\text { 言 }}{\text { 竞 }}$ & 产 & 产 & 爰 & 高 \\
\hline \multicolumn{2}{|r|}{ 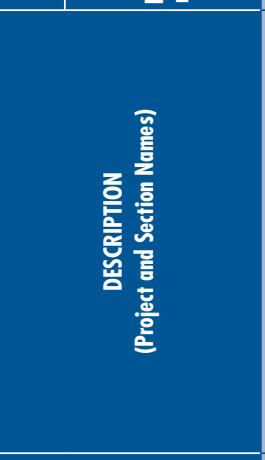 } & 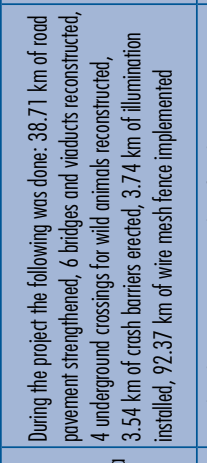 & 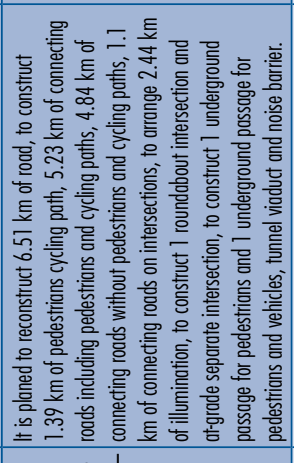 & 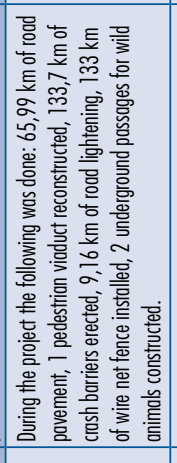 & 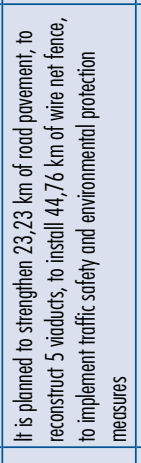 & 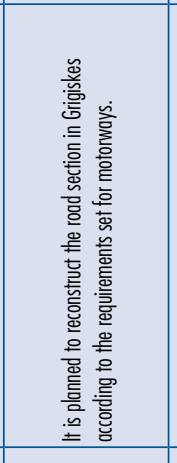 & 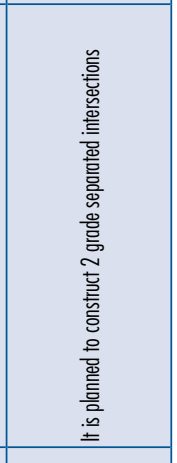 \\
\hline \multirow{2}{*}{\multicolumn{2}{|c|}{ 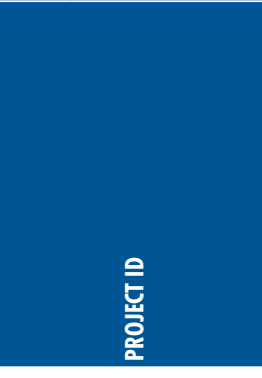 }} & 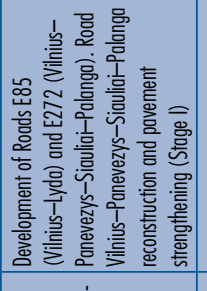 & 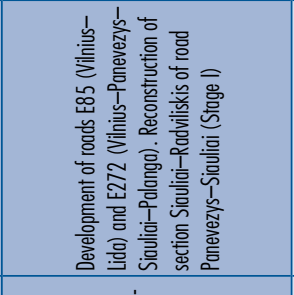 & 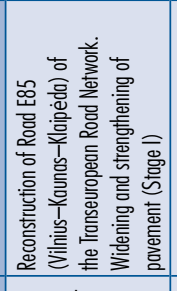 & 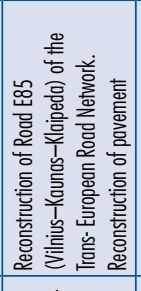 & 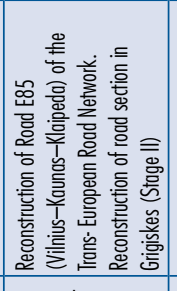 & 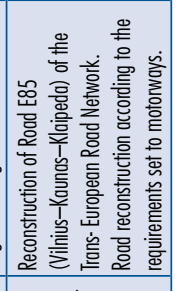 \\
\hline & & 产 & 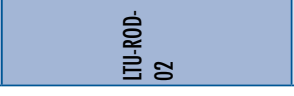 & $\begin{array}{l}\text { 产 } \\
\text { 言 } 8 \\
\end{array}$ & 产 & 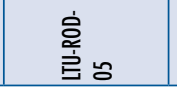 & 产 \\
\hline
\end{tabular}




\begin{tabular}{|c|c|c|c|c|c|c|c|}
\hline \multicolumn{2}{|c|}{ 彭哀 } & & & & & & \\
\hline \multirow{5}{*}{ 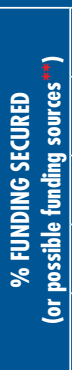 } & 总 & & & & & & \\
\hline & 言 & & & & & & \\
\hline & 盖言 & & & & & & \\
\hline & च & $\approx$ & 으 & $\infty$ & $\stackrel{\infty}{\infty}$ & 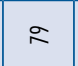 & 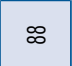 \\
\hline & 咅高 & in & 0 & $\stackrel{n}{n}$ & $\stackrel{n}{n}$ & $\bar{\sim}$ & $\simeq$ \\
\hline \multicolumn{2}{|c|}{ 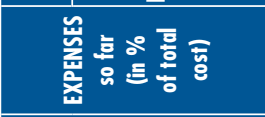 } & $\hat{m}$ & 0 & 0 & 0 & $\approx$ & 0 \\
\hline \multicolumn{2}{|r|}{ 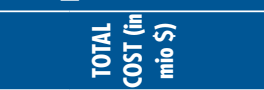 } & Fु & $\ddot{q}$ & 瓷 & $\begin{array}{l}\infty \\
\stackrel{\rho}{\rho}\end{array}$ & స్ర & $\stackrel{\infty}{\stackrel{p}{q}}$ \\
\hline \multicolumn{2}{|r|}{ 동능을 } & : & లై & $\stackrel{\infty}{\rightleftharpoons}$ & ळे & $\bar{\sigma}$ & लें \\
\hline \multirow{2}{*}{$\begin{array}{l}\text { za } \\
\text { 宸 } \\
\end{array}$} & 뭅 향 & $\overline{\bar{\nu}}$ & $\overline{\bar{~}}$ & $\stackrel{m}{\tilde{\sigma}}$ & స̃ & $\overline{\bar{\nu}}$ & $\overline{\bar{\Sigma}}$ \\
\hline & 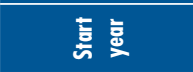 & 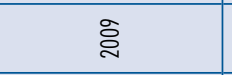 & 음 & 음 & $\overline{\bar{్}}$ & ळे & ळे \\
\hline 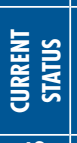 & 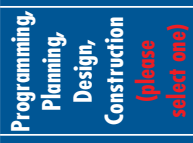 & 墪 & 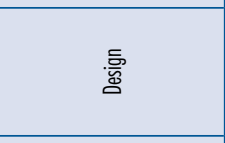 & .5 & 稁 & 咅 & 蓑 \\
\hline \multirow{2}{*}{ 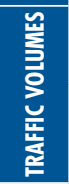 } & 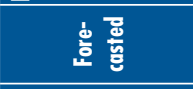 & 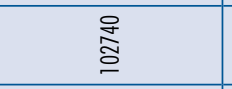 & 总 & స్త & 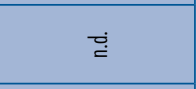 & & \\
\hline & 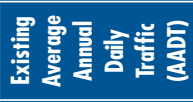 & $\overline{\bar{g}}$ & $\begin{array}{l}\underset{\sigma}{\infty} \\
\stackrel{\sigma}{\sigma}\end{array}$ & $\overline{\bar{\varpi}}$ & ت्் & & \\
\hline 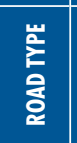 & 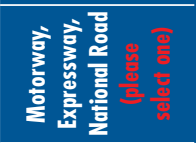 & 㐔 & 商 & $\begin{array}{l}\text { 흘 } \\
\text { 产 } \\
\text { 言 } \\
\text { 产 }\end{array}$ & 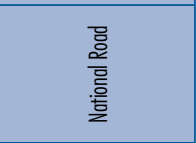 & 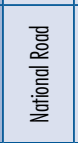 & 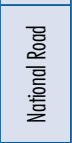 \\
\hline \multirow{3}{*}{ 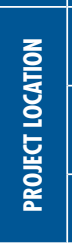 } & 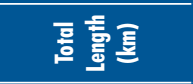 & 总 & 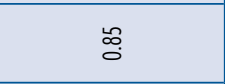 & $\stackrel{\circ}{\sim}$ & $\underset{\sim}{\infty}$ & $=$ & 志 \\
\hline & 뭅 言 홀 즐 & 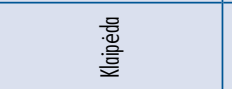 & 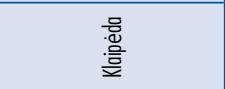 & 耪 & 咅 & 咳 & $\frac{2 . \frac{2}{5}}{\frac{2}{5}}$ \\
\hline & 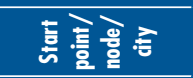 & $\begin{array}{l}\text { 焉 } \\
\text { 言 } \\
\underline{y}\end{array}$ & 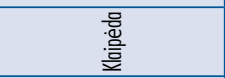 & 誉 & : & 誉 & 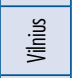 \\
\hline \multicolumn{2}{|r|}{ 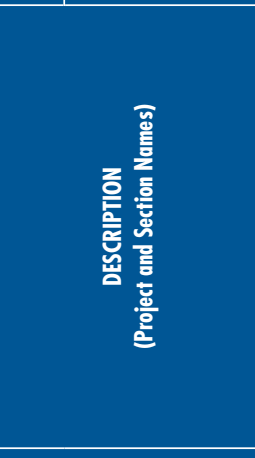 } & 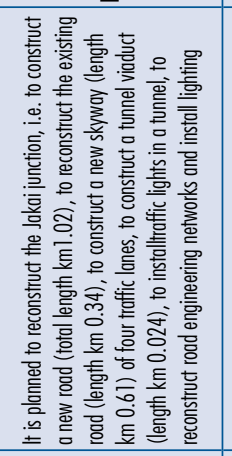 & 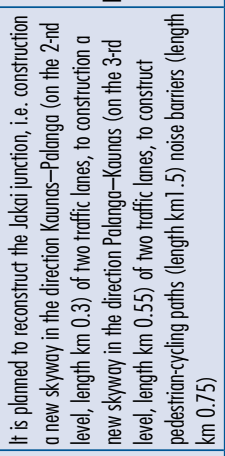 & 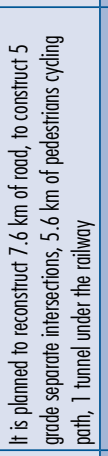 & 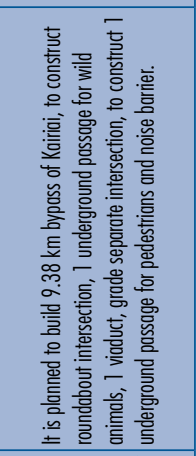 & 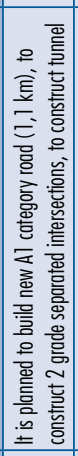 & 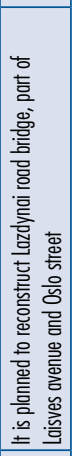 \\
\hline \multirow{2}{*}{\multicolumn{2}{|c|}{$\begin{array}{l}\text { 을 } \\
\text { 일 } \\
\text { 롤 }\end{array}$}} & 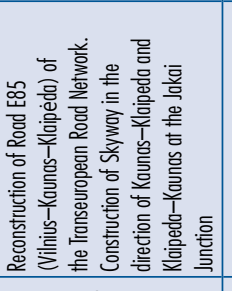 & 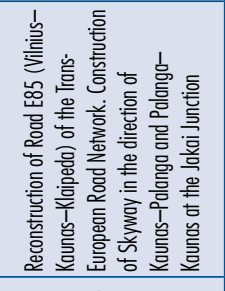 & 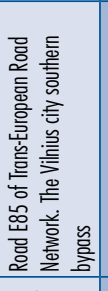 & 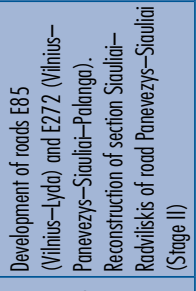 & 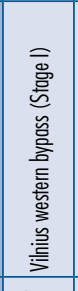 & 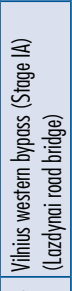 \\
\hline & & 产 & 产 & 㝘 & 产。 & 容 & 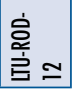 \\
\hline
\end{tabular}




\begin{tabular}{|c|c|c|c|c|c|c|}
\hline \multicolumn{7}{|c|}{ 童酸高 } \\
\hline \multirow{5}{*}{ 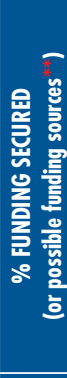 } & 童童 & & & & & \\
\hline & 言 & & & & & \\
\hline & 善言 & & & & & \\
\hline & 표 & $\check{\infty}$ & $\infty$ & $\infty$ & $\stackrel{\leftrightarrow}{\infty}$ & $\stackrel{\infty}{\infty}$ \\
\hline & 吾品 & $\cong$ & 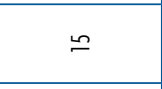 & 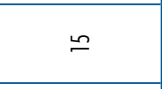 & $\bumpeq$ & $\cong$ \\
\hline \multicolumn{2}{|c|}{ 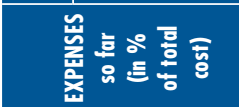 } & $\stackrel{\Xi}{=}$ & $\infty$ & 8 & $\therefore$ & 8 \\
\hline \multicolumn{2}{|c|}{ 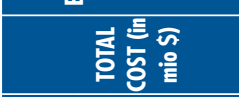 } & $\stackrel{+}{=}$ & fี & $\infty$ & $\stackrel{\sim}{\infty}$ & $\underset{I}{I}$ \\
\hline \multicolumn{2}{|c|}{ 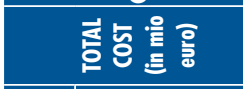 } & $\overline{\underline{\rho}}$ & 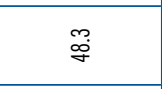 & $\stackrel{\star}{\sim}$ & $\underset{త}{\infty}$ & $\widehat{\mathrm{s}}$ \\
\hline \multirow{2}{*}{ 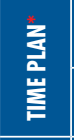 } & 롭 & $\bar{a}$ & $\vec{a}$ & $\tilde{\Xi}$ & $\stackrel{m}{a}$ & సิ \\
\hline & 壳 & ఏ્े & ఏ્े & ఏ્ेે & 음 & $\overline{\bar{a}}$ \\
\hline 苨管 & 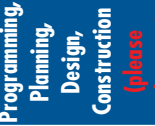 & 愛 & $\begin{array}{l}\text { 毫 } \\
\text { 妾 }\end{array}$ & $\begin{array}{l}\text { 흘 } \\
\text { 警 }\end{array}$ & 产 & 高 \\
\hline \multirow{2}{*}{ 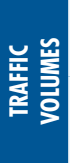 } & 홍 흉을 & . & $\stackrel{\infty}{\infty}$ & 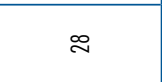 & $\bar{\tau}$ & 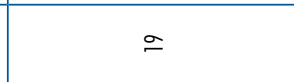 \\
\hline & 謩 & . & $\therefore$ & $\therefore$ & $\simeq$ & $\simeq$ \\
\hline \multirow{2}{*}{ 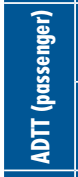 } & 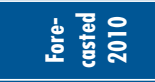 & . & . & . & . & . \\
\hline & 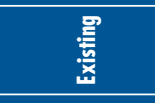 & · & . & . & . & . \\
\hline \multirow{3}{*}{ 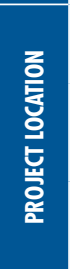 } & 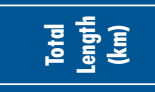 & . & $\cong$ & - & 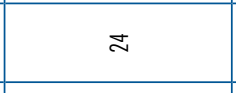 & $\infty$ \\
\hline & 몹 言 흘 & 䜌 & 磅 & 磅 & 鲸 & 旁 \\
\hline & 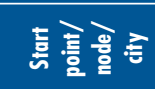 & 爰 & 喜 & 喜 & 辜 & 鲸 \\
\hline & 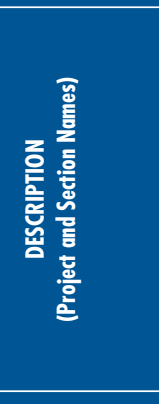 & 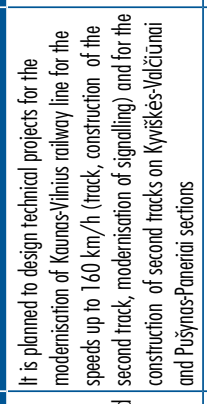 & 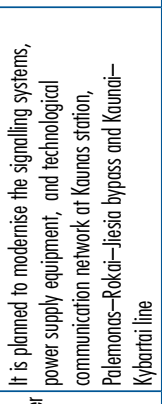 & 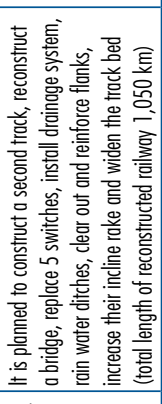 & 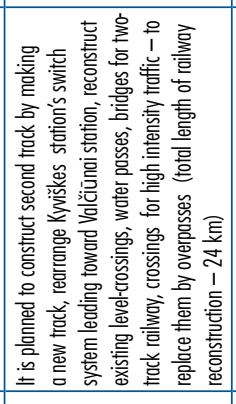 & 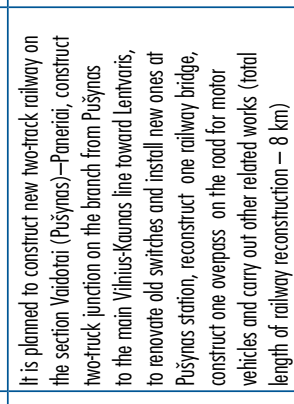 \\
\hline \multirow{2}{*}{\multicolumn{2}{|c|}{ 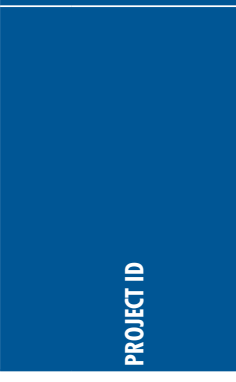 }} & 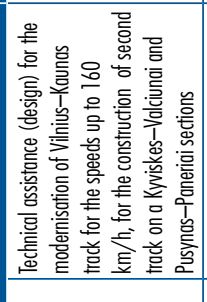 & 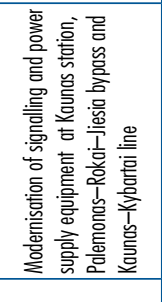 & 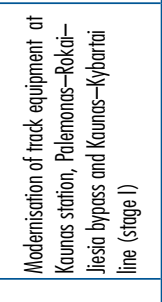 & 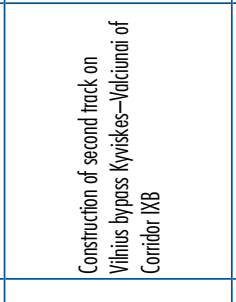 & 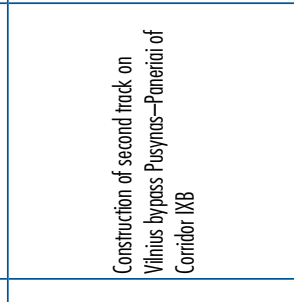 \\
\hline & & 䒠产 & 官害 & 它总 & 官产 & 它蒡 \\
\hline
\end{tabular}




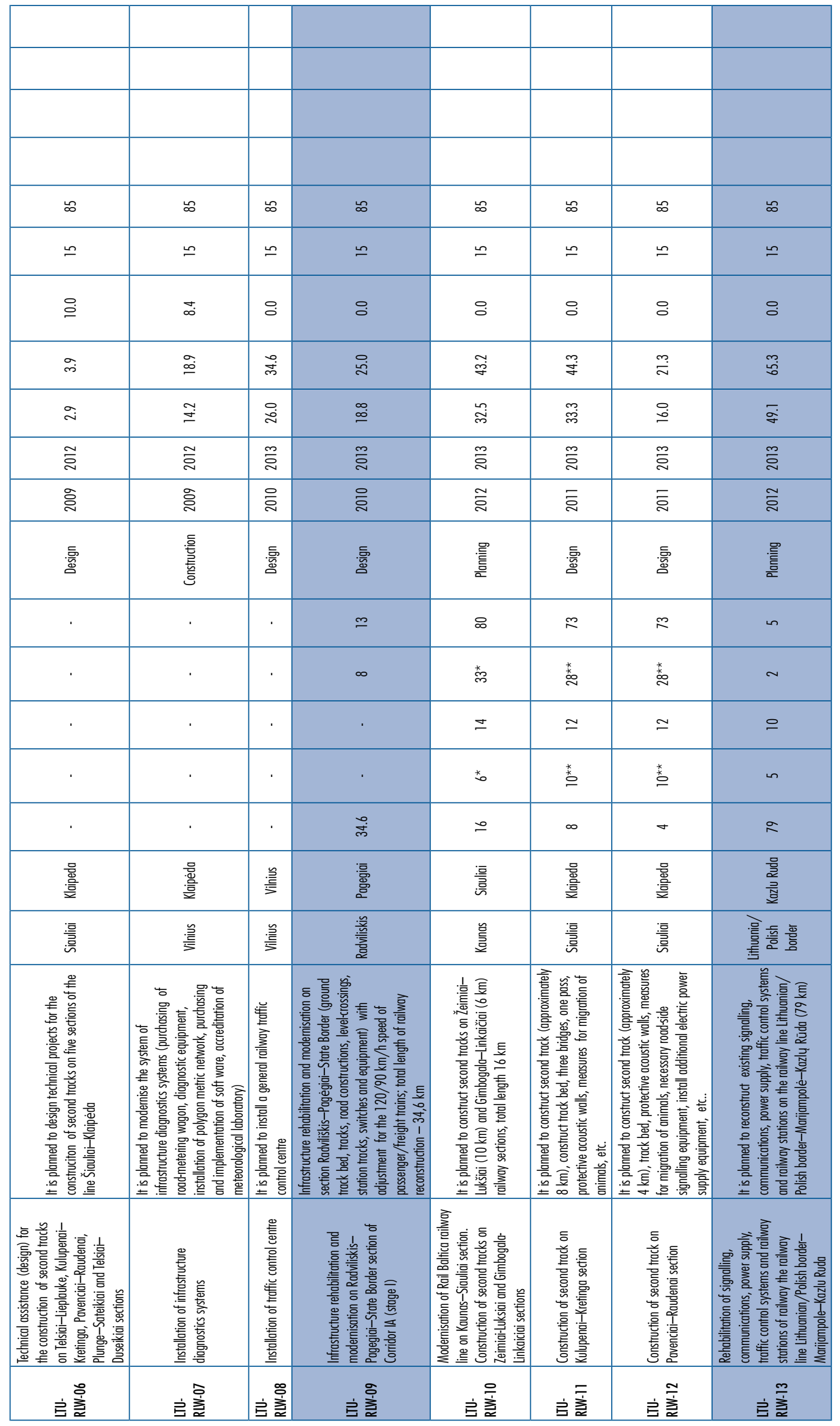




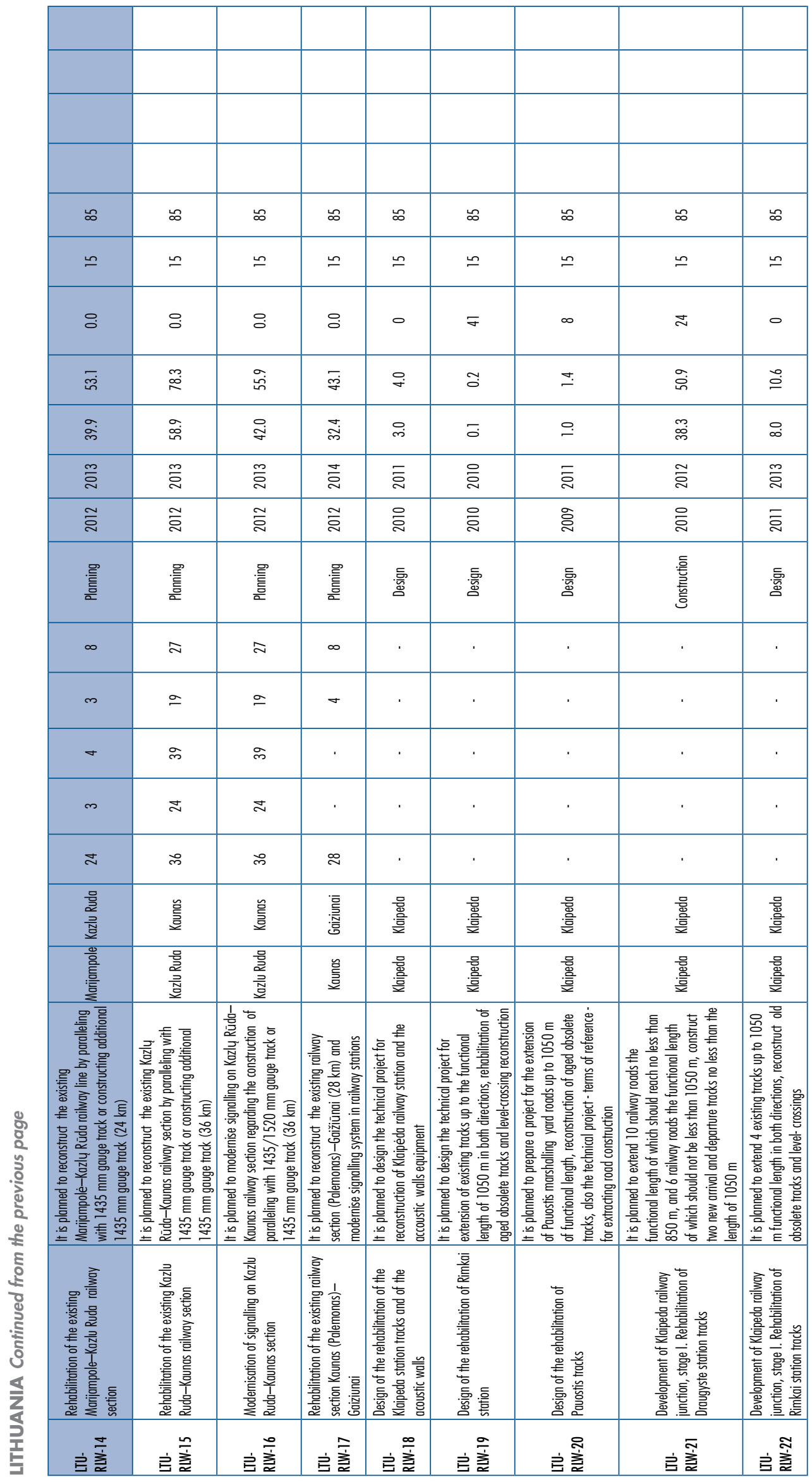




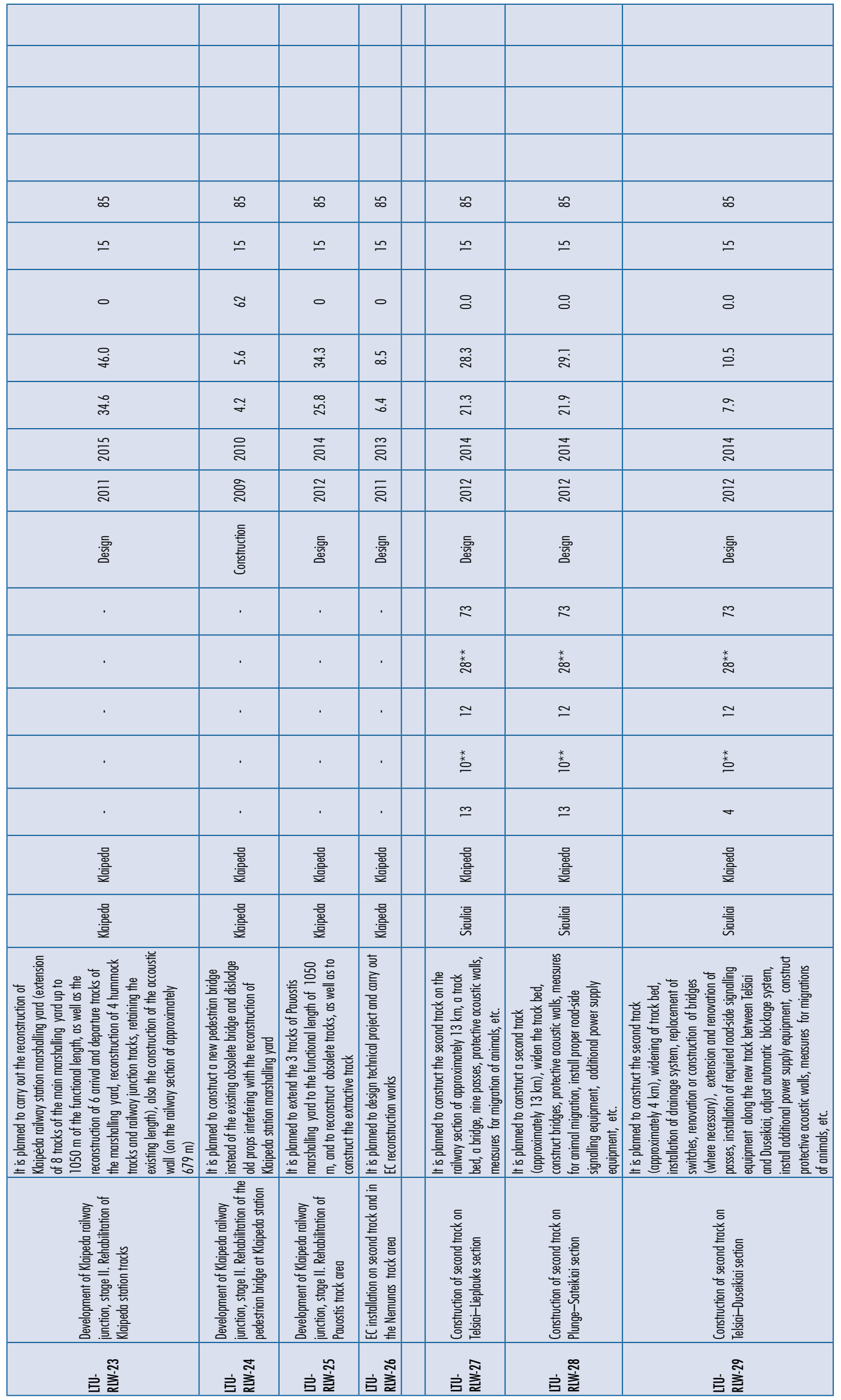




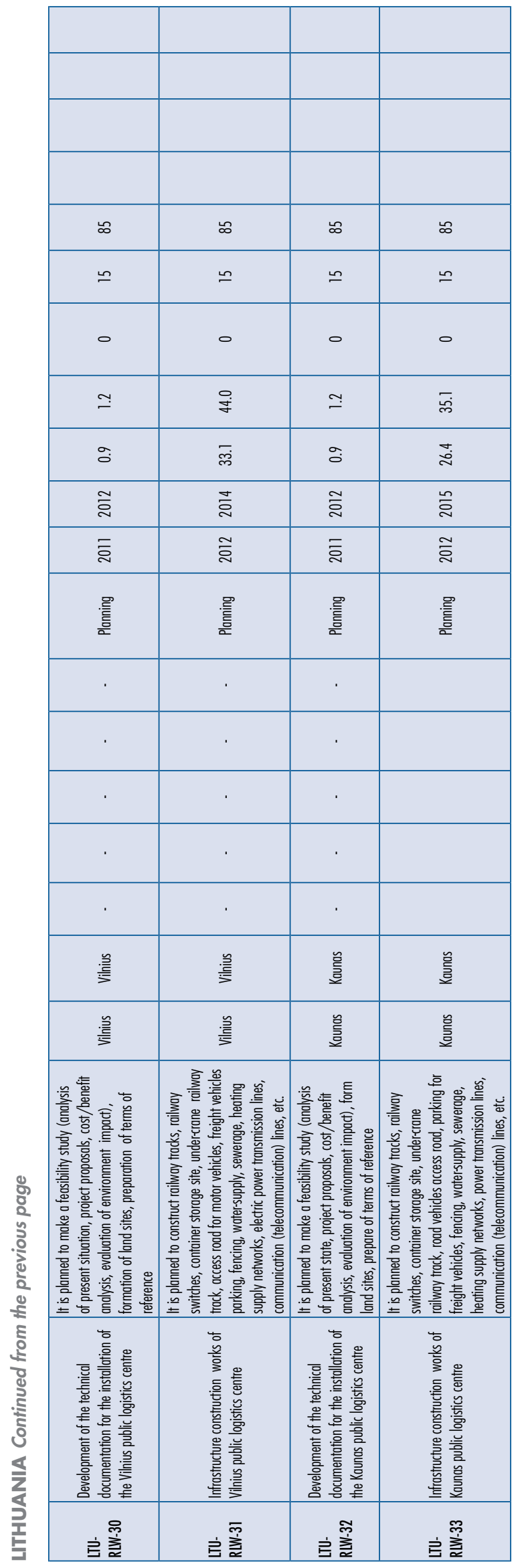




\begin{tabular}{|c|c|c|c|c|c|}
\hline \multicolumn{2}{|c|}{ 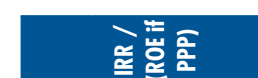 } & & & & \\
\hline \multirow{5}{*}{ 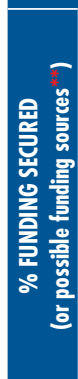 } & 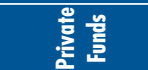 & & & & \\
\hline & 言 & & & & \\
\hline & 善言 & & & & \\
\hline & 吾菅 & $\infty$ & $\infty$ & $\infty$ & $\infty$ \\
\hline & 产䓂 & $\cong$ & $\cong$ & $\simeq$ & $\simeq$ \\
\hline \multicolumn{2}{|c|}{ 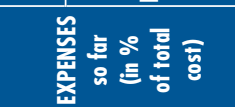 } & 으 & 0 & 0 & 0 \\
\hline \multicolumn{2}{|c|}{ 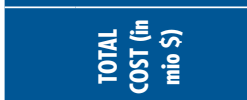 } & $\bar{\sigma}$ & $\bar{~} \bar{n}$ & $\bar{\sigma}$ & $\hat{m}$ \\
\hline \multicolumn{2}{|r|}{ 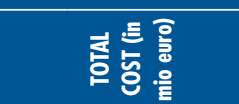 } & $\bar{\sigma}$ & $\stackrel{\infty}{\infty}$ & $\bar{\sigma}$ & $\stackrel{\infty}{\sim}$ \\
\hline \multirow{2}{*}{ 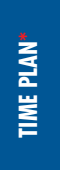 } & 롤 & 음 & 亏్ & $\overline{\bar{~}}$ & 亏్ \\
\hline & 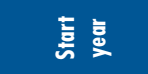 & ఏ & 음 & 음 & $\overline{2}$ \\
\hline 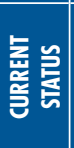 & 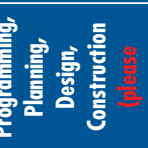 & 㩊 & 毫 & 带 & 带 \\
\hline \multirow{2}{*}{ 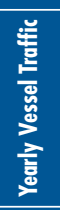 } & 兘 & & & & \\
\hline & 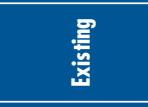 & & & & \\
\hline \multirow{3}{*}{ 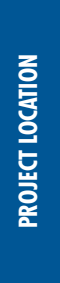 } & 言㶻焉 & & & & \\
\hline & 홉 흘ㅎㅎㅎ & 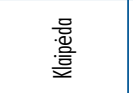 & 总 & 产 & 言 \\
\hline & 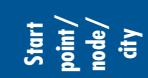 & 喜 & 衰 & 衰 & 喜 \\
\hline & 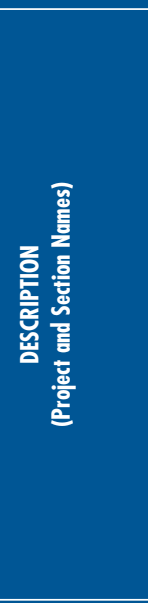 & 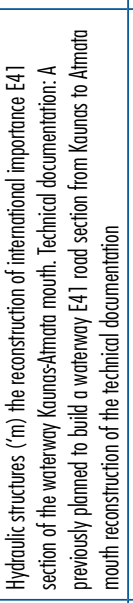 & 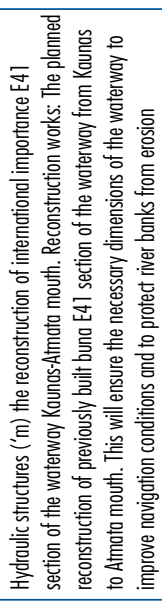 & 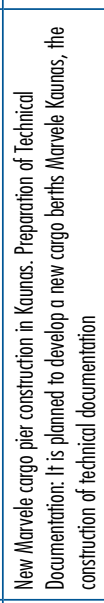 & 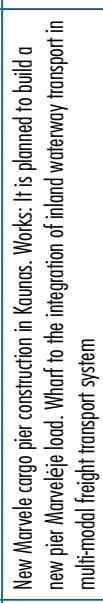 \\
\hline & 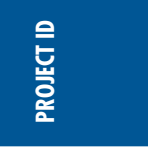 & $\begin{array}{l}\overline{\bar{p}} \\
\text { 产 } \\
\text { 它 }\end{array}$ & $\begin{array}{l}\text { 景 } \\
\text { 主 }\end{array}$ & 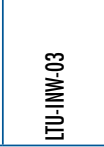 & $\begin{array}{l}\text { to } \\
\text { 产 } \\
\text { 言 }\end{array}$ \\
\hline
\end{tabular}




\begin{tabular}{|c|c|c|c|c|c|c|c|}
\hline \multicolumn{8}{|c|}{ 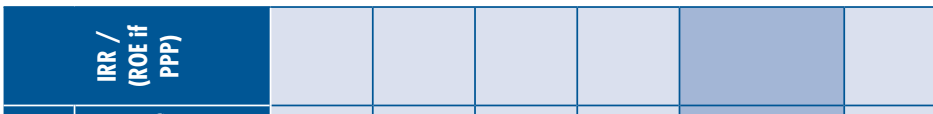 } \\
\hline \multirow{5}{*}{ 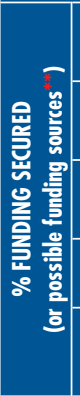 } & 善产 & & & & & & \\
\hline & 毵 & & & & & & \\
\hline & 善善 & & & & & & \\
\hline & 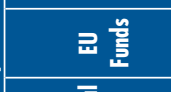 & $\ddot{\infty}$ & $\infty$ & 8 & $\ddot{\infty}$ & 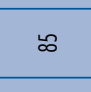 & $\ddot{\infty}$ \\
\hline & 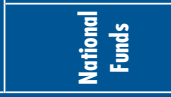 & $\simeq$ & $\simeq$ & $\approx$ & $\simeq$ & $\simeq$ & $\simeq$ \\
\hline \multicolumn{2}{|c|}{ 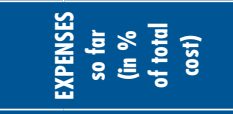 } & $\circ$ & - & 。 & $\circ$ & 。 & 。 \\
\hline \multicolumn{2}{|c|}{ 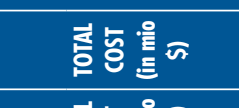 } & $\overline{\mathrm{D}}$ & $\Xi$ & s & $\approx$ & $\bar{s}$ & 8 \\
\hline \multicolumn{2}{|c|}{ 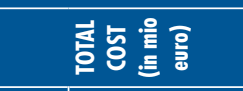 } & $\stackrel{i}{i}$ & $\stackrel{q}{\underline{\underline{x}}}$ & 梁 & $\stackrel{\infty}{\approx}$ & $\infty$ & 9 \\
\hline \multirow{2}{*}{ 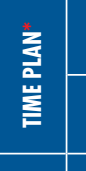 } & $\underline{\underline{m}}$ & \pm & 亏 & $\frac{1}{3}$ & 亏ั & 商 & 亏ิ \\
\hline & 焉豆 & $\overline{\bar{a}}$ & ‡ & ‡ & $\overline{\bar{a}}$ & $\overline{\bar{\Xi}}$ & 高 \\
\hline \multicolumn{2}{|c|}{ 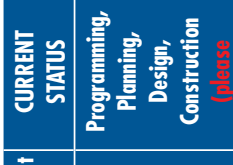 } & 总 & 量 & 憘 & 墨 & 墨 & 喜 \\
\hline \multicolumn{8}{|c|}{ 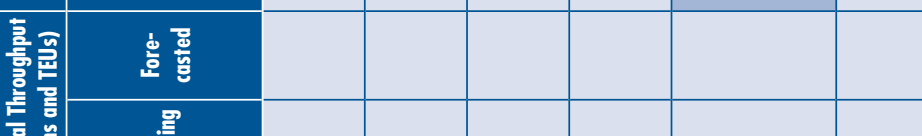 } \\
\hline & 䰹 & & & & & & \\
\hline \multirow{3}{*}{ 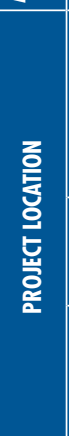 } & 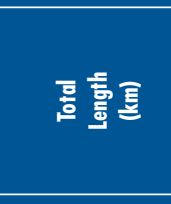 & 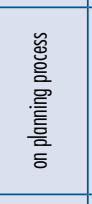 & 锫 & 管 & 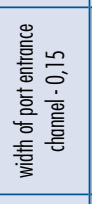 & 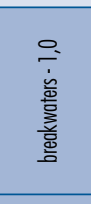 & 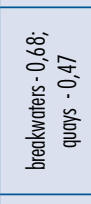 \\
\hline & 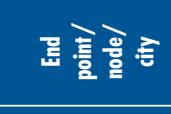 & $\begin{array}{l}\text { 量 } \\
\text { 竞 } \\
\end{array}$ & 量 & 量 & 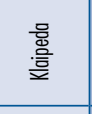 & 喜 & 兽 \\
\hline & 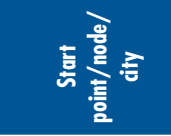 & 量 & 量 & 量 & 量 & 高 & 兽 \\
\hline & 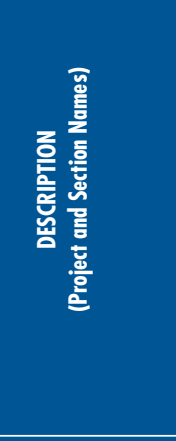 & 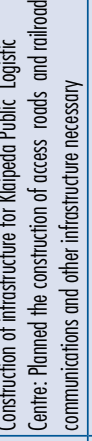 & 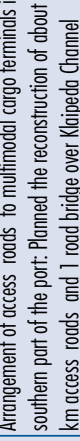 & & & 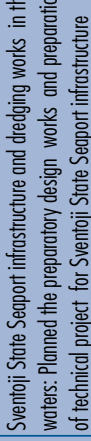 & 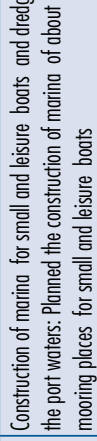 \\
\hline & $\begin{array}{l}\text { 童 } \\
\text { 产 }\end{array}$ & $\begin{array}{l}\overline{\bar{s}} \\
\text { 善 } \\
\end{array}$ & 䇾 & 爰 & $\begin{array}{l}\text { 旁 } \\
\text { 音 } \\
\end{array}$ & 旁 & 軎 \\
\hline
\end{tabular}




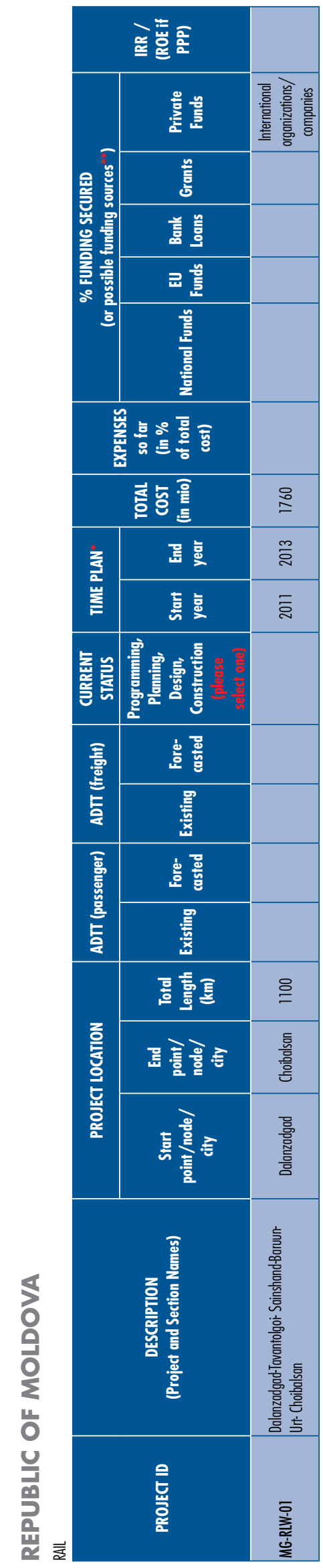




\begin{tabular}{|c|c|c|c|c|c|c|c|c|c|c|c|c|c|c|c|c|c|}
\hline \multicolumn{18}{|c|}{ 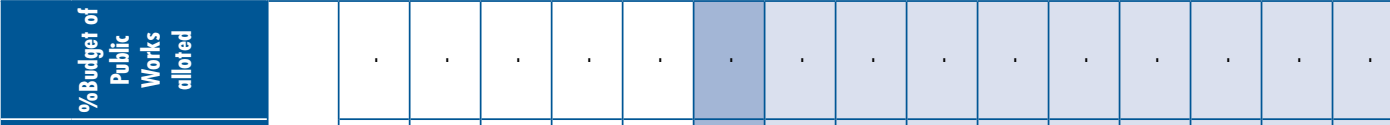 } \\
\hline \multicolumn{18}{|c|}{ 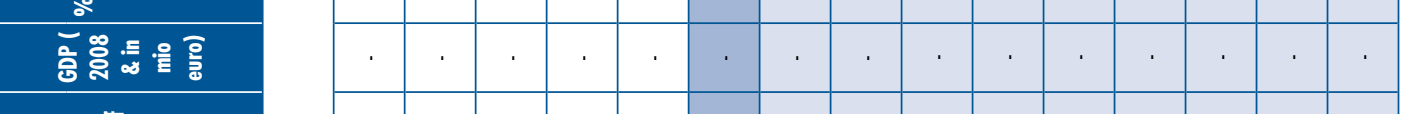 } \\
\hline \multicolumn{3}{|c|}{ 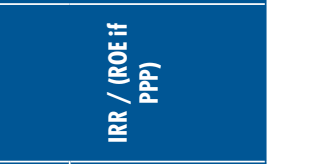 } & 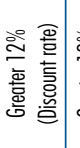 & & & & & & & 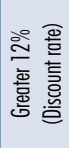 & & & & & \multicolumn{3}{|c|}{ 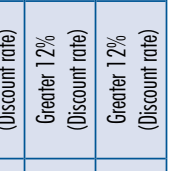 } \\
\hline & 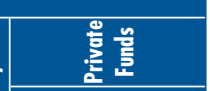 & & & & & & & & & & & r. & & & & & \\
\hline & 耪 & & & & & & 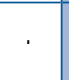 & & & & & & & & & & \\
\hline & 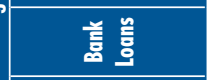 & & & & & & & & & & & & & & & & \\
\hline & $\underline{z \underline{\underline{m}}}$ & & & & & & & & & & & & & & & & \\
\hline & 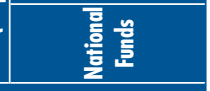 & & & & & & & & & & & & & & & & \\
\hline & 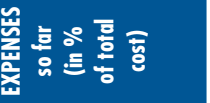 & & & & & & 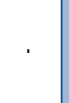 & & & & & . & & & & & \\
\hline & 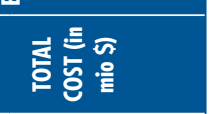 & & 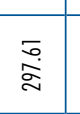 & 善 & 省 & $\frac{9}{2}$ & : & ڤે̀ & 商 & 菢 & 总 & $\overline{\bar{~}}$ & 営 & 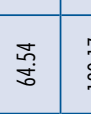 & 啇 & 卷 & $\frac{8}{5}$ \\
\hline & 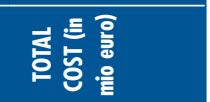 & & $\overline{\mathrm{g}}$ & 等 & ฐ & 总 & $\stackrel{\square}{\dddot{F}}$ & 惫 & 产 & $\stackrel{\square}{\sharp}$ & 商 & 渠 & 离 & 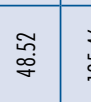 & 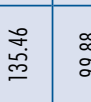 & 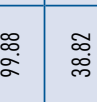 & జ \\
\hline & 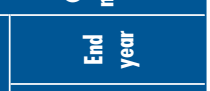 & & & & & & & & & & & 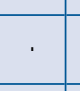 & & & & & \\
\hline & & & & & & & & & & & & 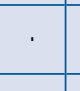 & & & & & \\
\hline & & & 咅 & 喜 & 哀 & 言 & 哀 & 豆 & $\begin{array}{l}\text { 嘉 } \\
\text { s. }\end{array}$ & 㖺 & 音 & 音 & 哀 & 哀 & 言 & 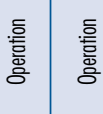 & 言 \\
\hline & 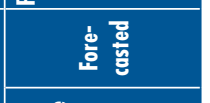 & & & & 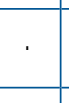 & & 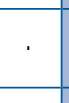 & & & . & & . & & . & & & \\
\hline & 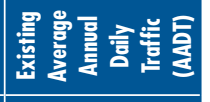 & & 总 & 言 & 悉 & & : & 鱼 & $\stackrel{\circ}{\varrho}$ & 今. & 密 & $\approx$ & $\underline{\underline{p}}$ & $\Xi$ & 盇 & 绕 & : \\
\hline & 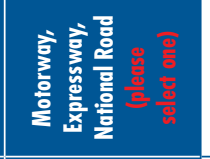 & & 喜 & 喜 & 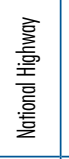 & 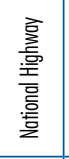 & 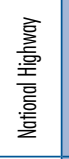 & 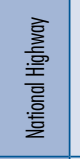 & $\begin{array}{l}\text { 罍 } \\
\text { 喜 }\end{array}$ & $\begin{array}{l}\text { 量 } \\
\text { 旁 } \\
\end{array}$ & 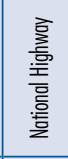 & 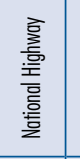 & 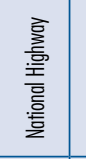 & 毫: & 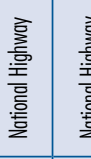 & 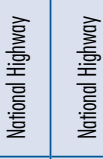 & \\
\hline & 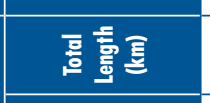 & 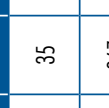 & 5 & $\underline{\underline{z}}$ & 志 & $\bar{n}$ & 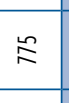 & 品 & 웅 & 壾 & \% & $\approx$ & $\Xi$ & $\Xi$ & $\%$ & $\approx \approx$ & $\therefore$ \\
\hline & 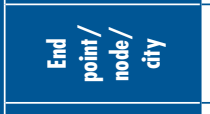 & 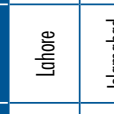 & 量 & 毫 & 旁 & 喜 & 咅 & 豆 & 㞗 & 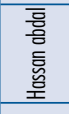 & 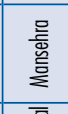 & 暜 & 言 & 案 & 高高 & 言 & 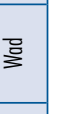 \\
\hline & 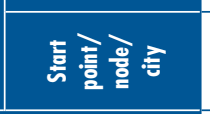 & 䜌彭 & 兽 & 咅 & 章 & 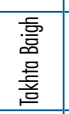 & 高 & 喜 & 謇 & 殕 & \begin{tabular}{|l} 
홍 \\
章 \\
\end{tabular} & 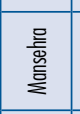 & 홀 & 咅: & $\frac{5}{\frac{5}{2}}$ & 意 & 言 \\
\hline & 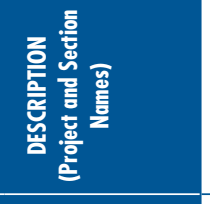 & 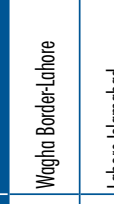 & 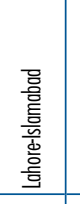 & $\begin{array}{l}\text { 量 } \\
\text { 旁 } \\
\text { 辜 }\end{array}$ & & $\begin{array}{l}\text { 喜 } \\
\text { 旁 } \\
\text { 害 }\end{array}$ & 喑 & $\vec{n}$ & $\begin{array}{l}\text { 喜 } \\
\text { 毫 }\end{array}$ & $\frac{15}{10}$ & 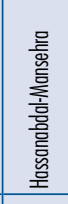 & 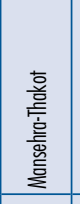 & 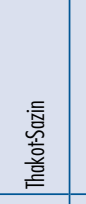 & 譬 & 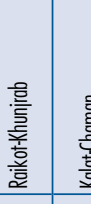 & 喜 & \\
\hline & $\bar{E}$ & & $\cong$ & $\overline{\underline{z}}$ & $z$ & $z$ & $\underline{z}$ & 鉒 & 量 & $\underline{\underline{z}}$ & $\frac{u_{2}^{2}}{2}$ & $\underline{\underline{\underline{z}}}$ & 䇥 & 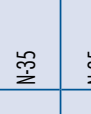 & $\underline{\underline{z}}$ & 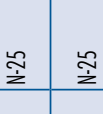 & $\underline{\underline{z}}$ \\
\hline & & & & & & & & & & & & & & & & & \\
\hline
\end{tabular}




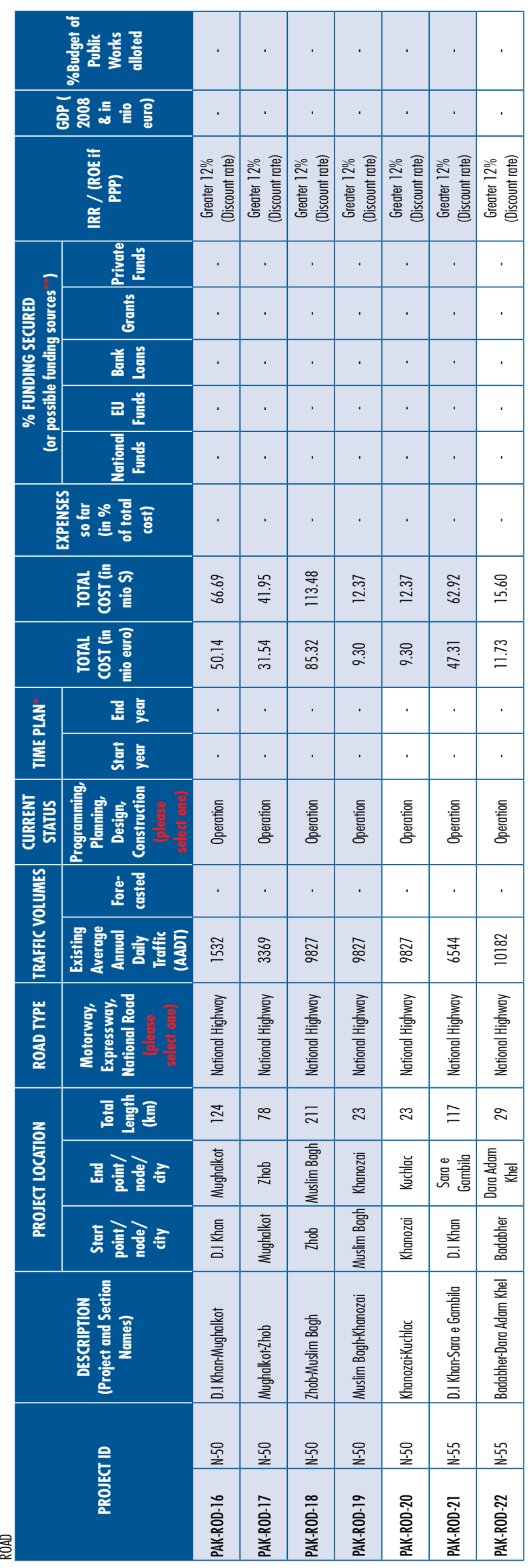



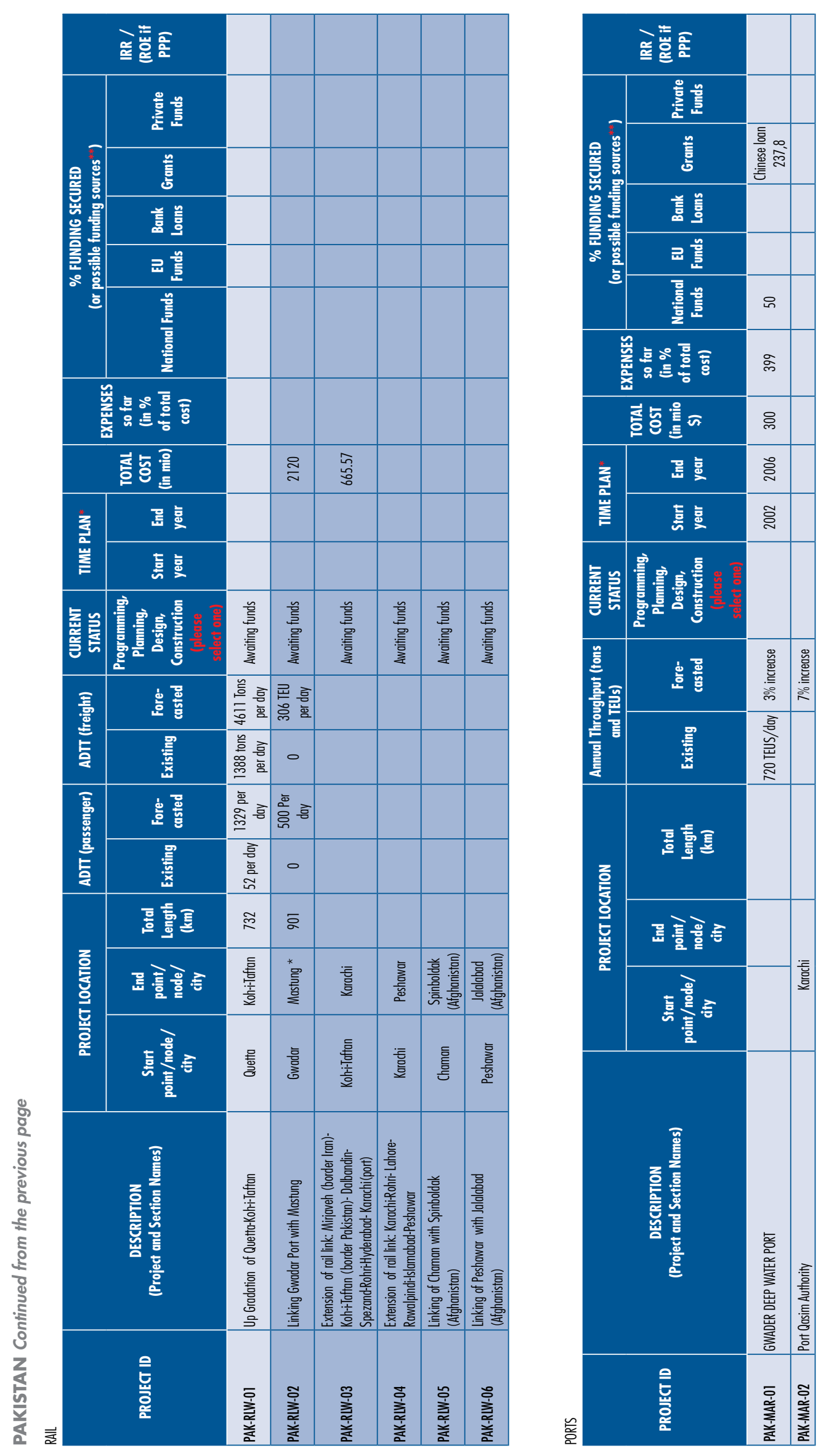


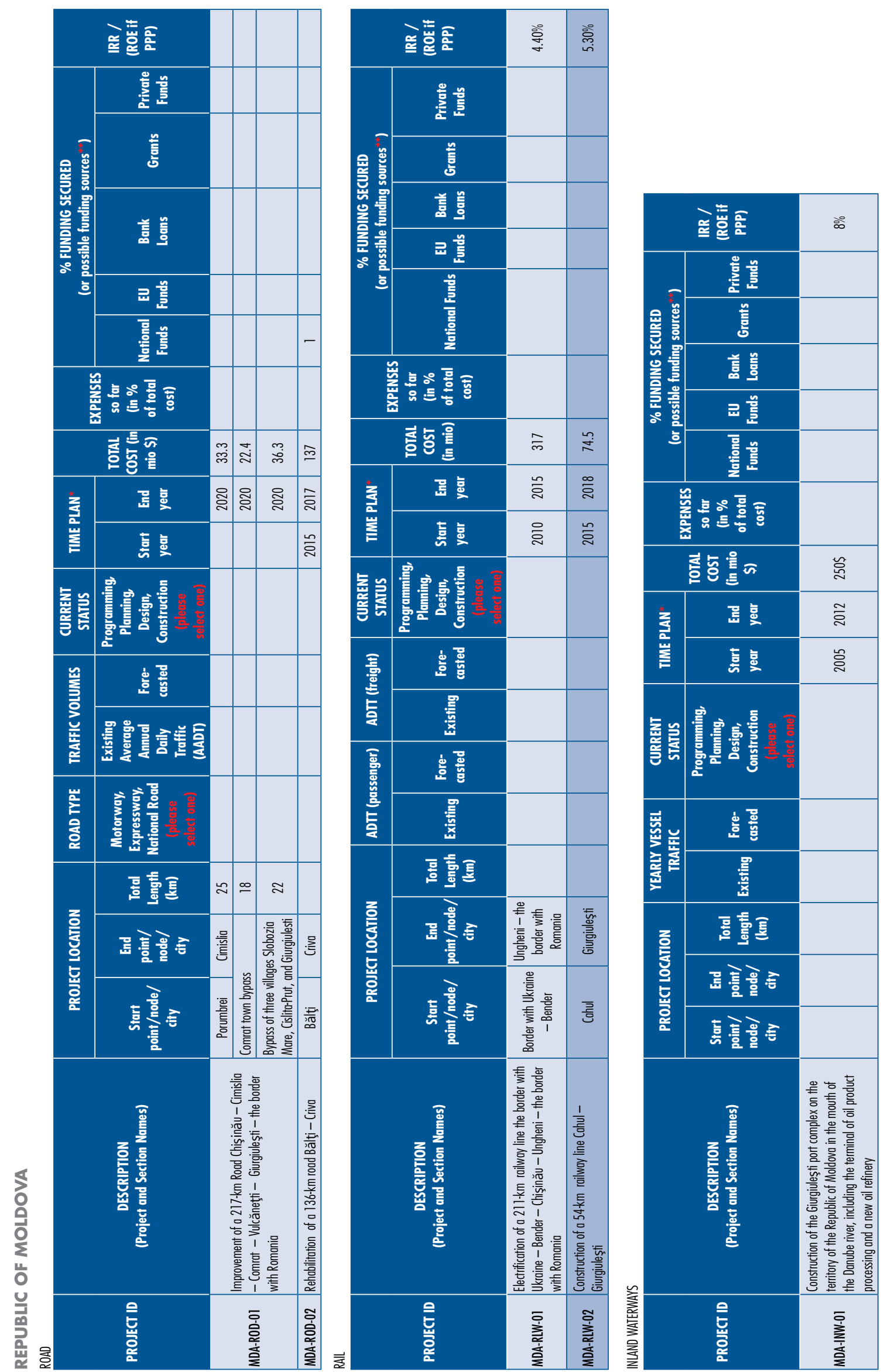




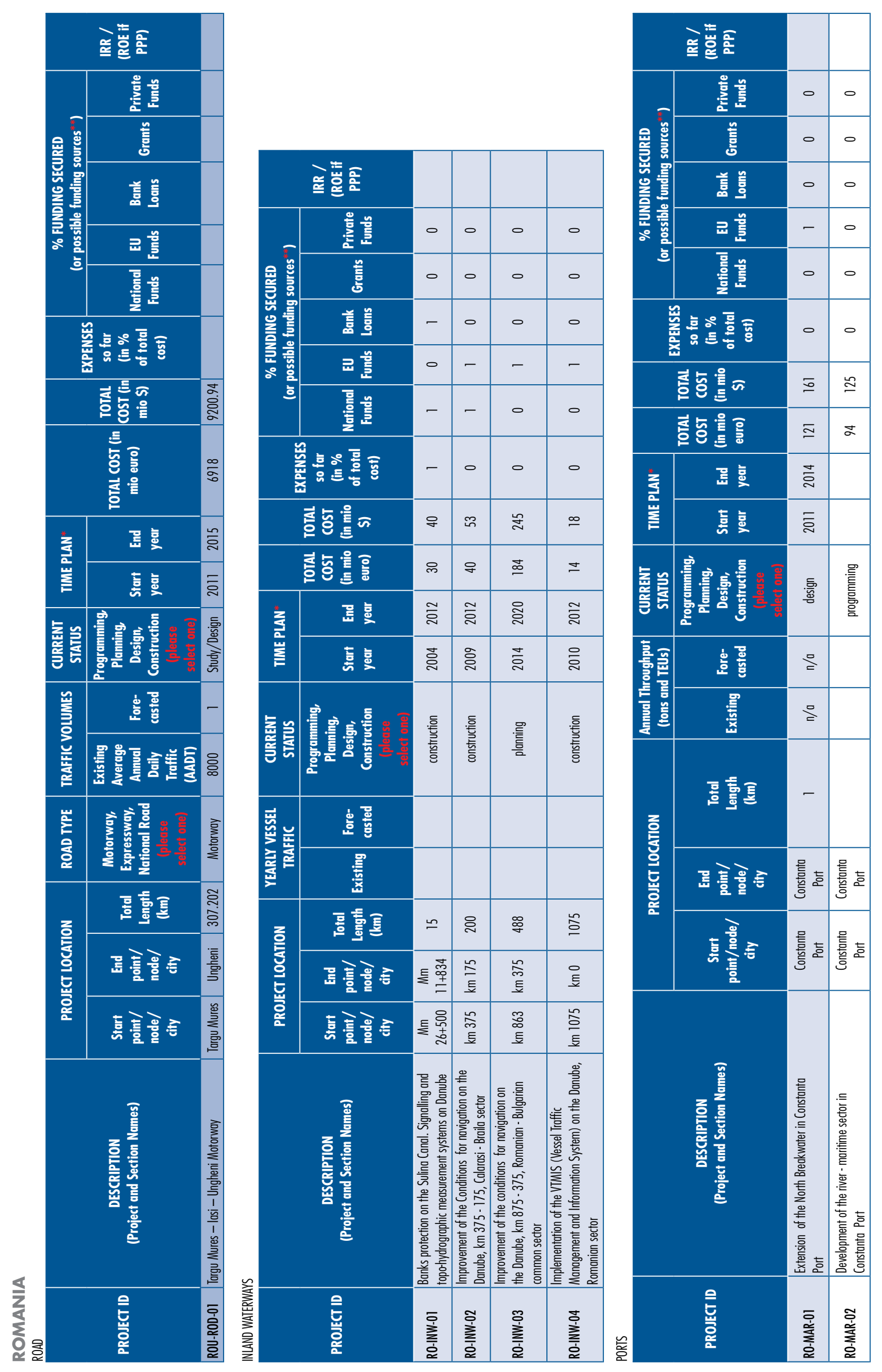




\begin{tabular}{|c|c|c|c|c|}
\hline \multicolumn{2}{|c|}{ 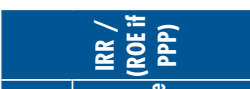 } & & & \\
\hline \multirow{5}{*}{ 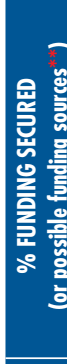 } & 善童 & & & \\
\hline & 言 & & & \\
\hline & 善言 & & & \\
\hline & 居 & & & \\
\hline & 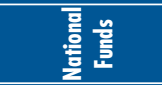 & & & \\
\hline \multicolumn{2}{|c|}{ 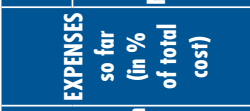 } & & & \\
\hline \multicolumn{2}{|c|}{ 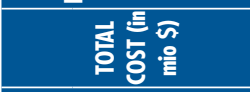 } & 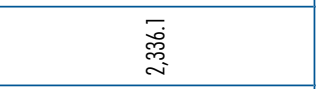 & 粱 & $\begin{array}{l}\bar{j} \\
\text { ळ. } \\
\bar{m}\end{array}$ \\
\hline \multicolumn{2}{|c|}{ 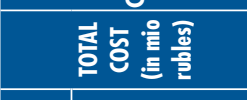 } & 恿 & 䇫 & 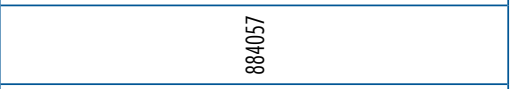 \\
\hline \multirow{2}{*}{ 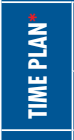 } & 로 & 竞 & సે & 竞 \\
\hline & 喜害 & 을 & 을 & 을 \\
\hline 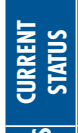 & 害高高 & & & \\
\hline \multirow{2}{*}{ 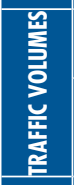 } & 容 & & & \\
\hline & 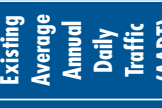 & & & \\
\hline & 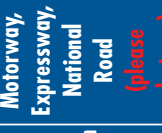 & & & \\
\hline \multirow{3}{*}{ 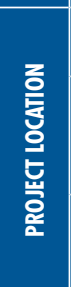 } & 豆言言豆 & & & \\
\hline & 폴 & 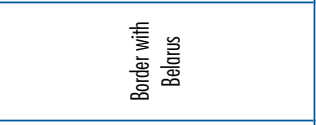 & 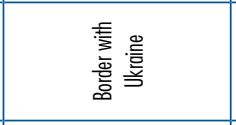 & 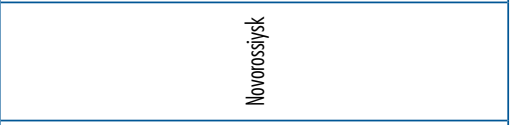 \\
\hline & 홓 言 훌 & 窨 & 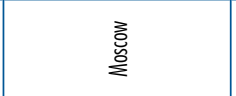 & 譬 \\
\hline \multicolumn{2}{|r|}{ 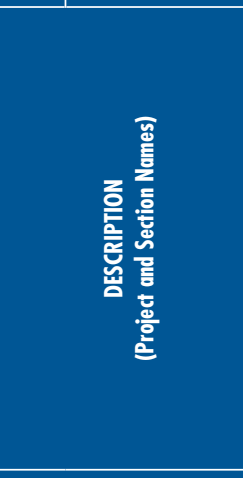 } & 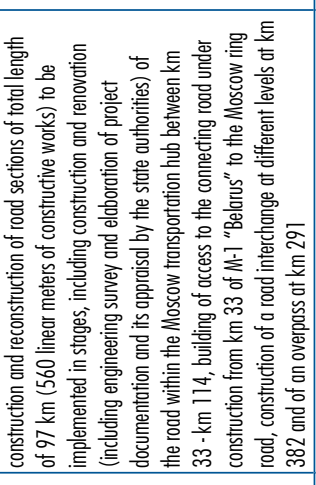 & 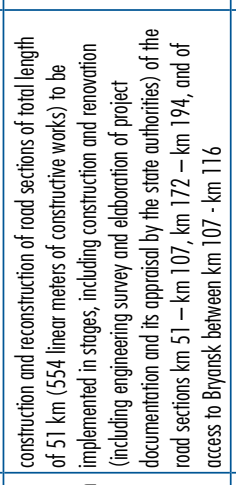 & 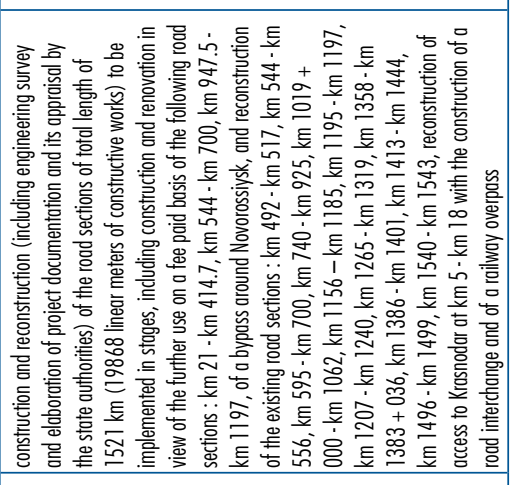 \\
\hline \multirow{2}{*}{\multicolumn{2}{|c|}{ 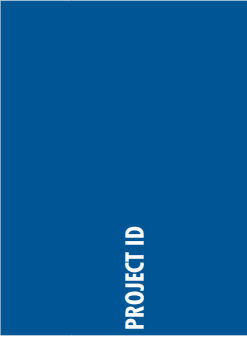 }} & 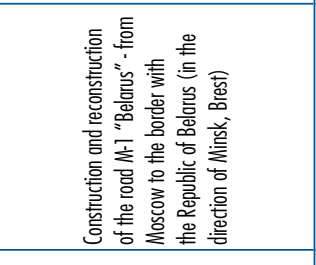 & 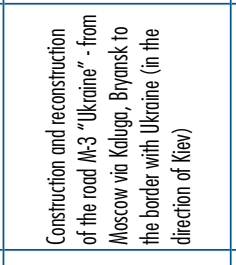 & 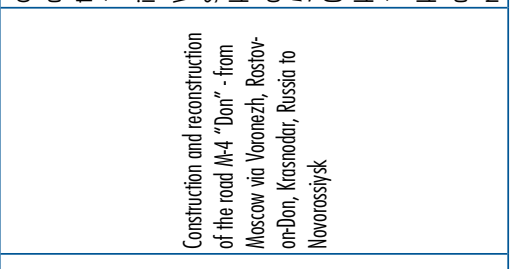 \\
\hline & & 蛋 & 定嘀 & 定产 \\
\hline
\end{tabular}




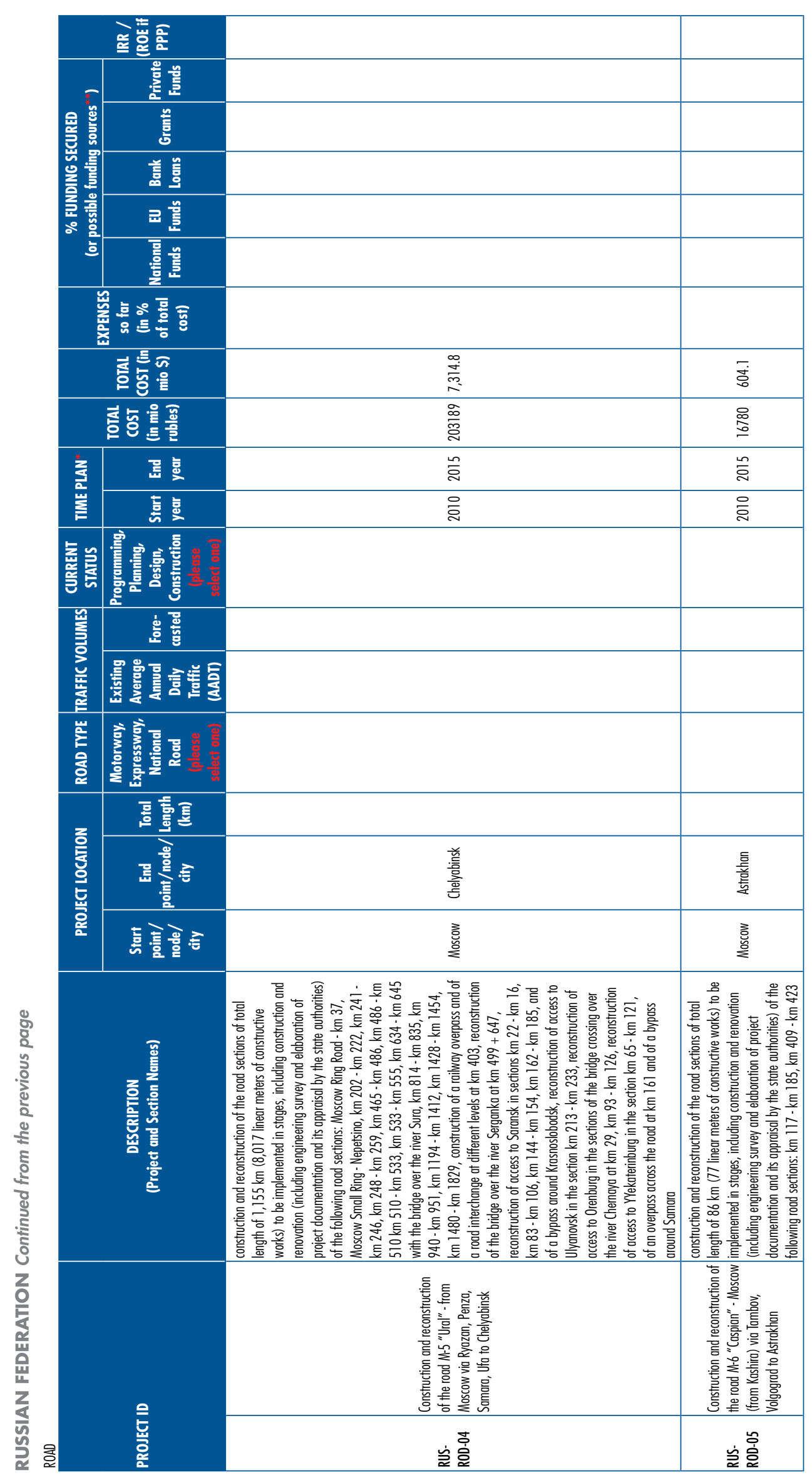




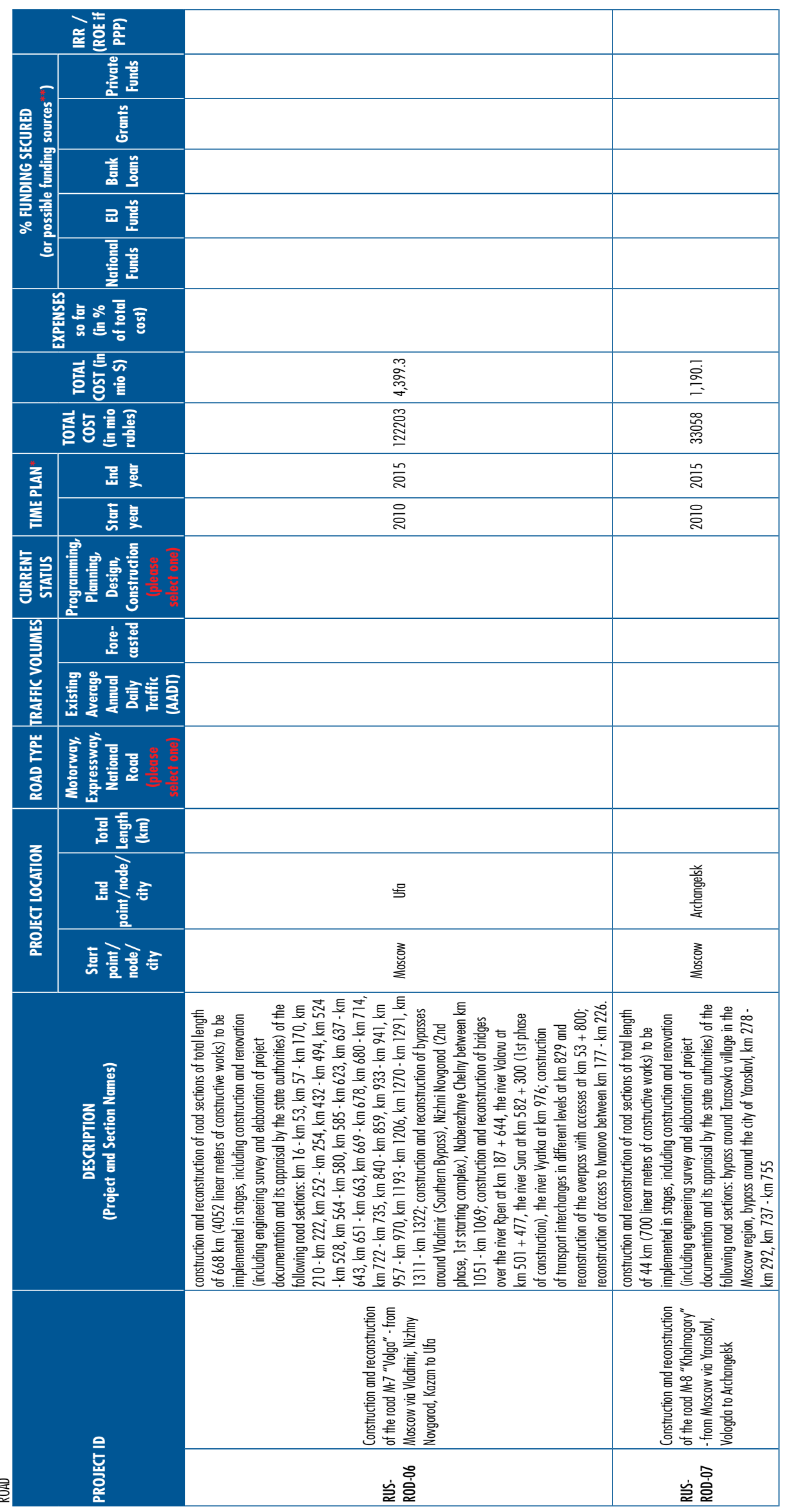




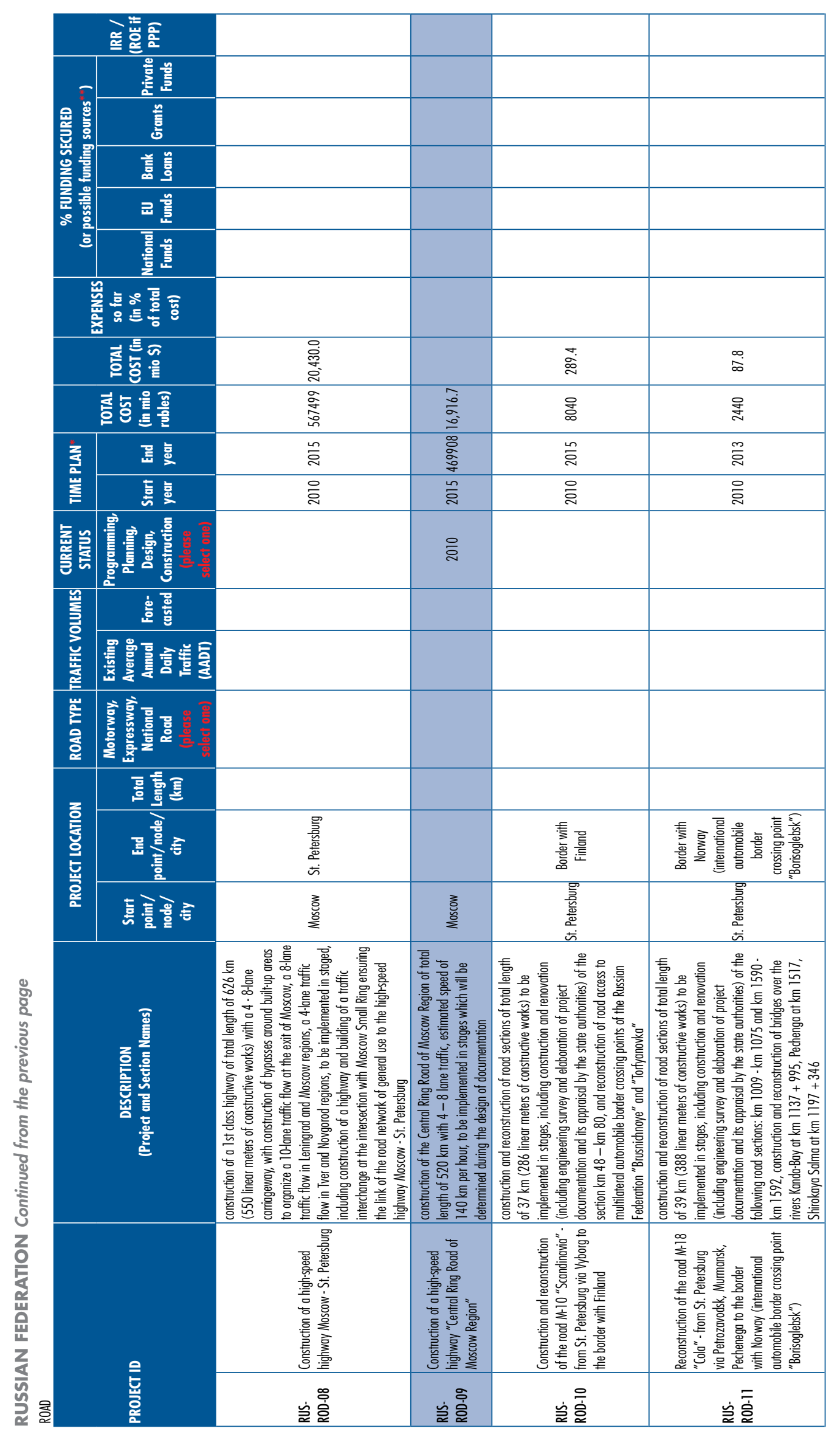




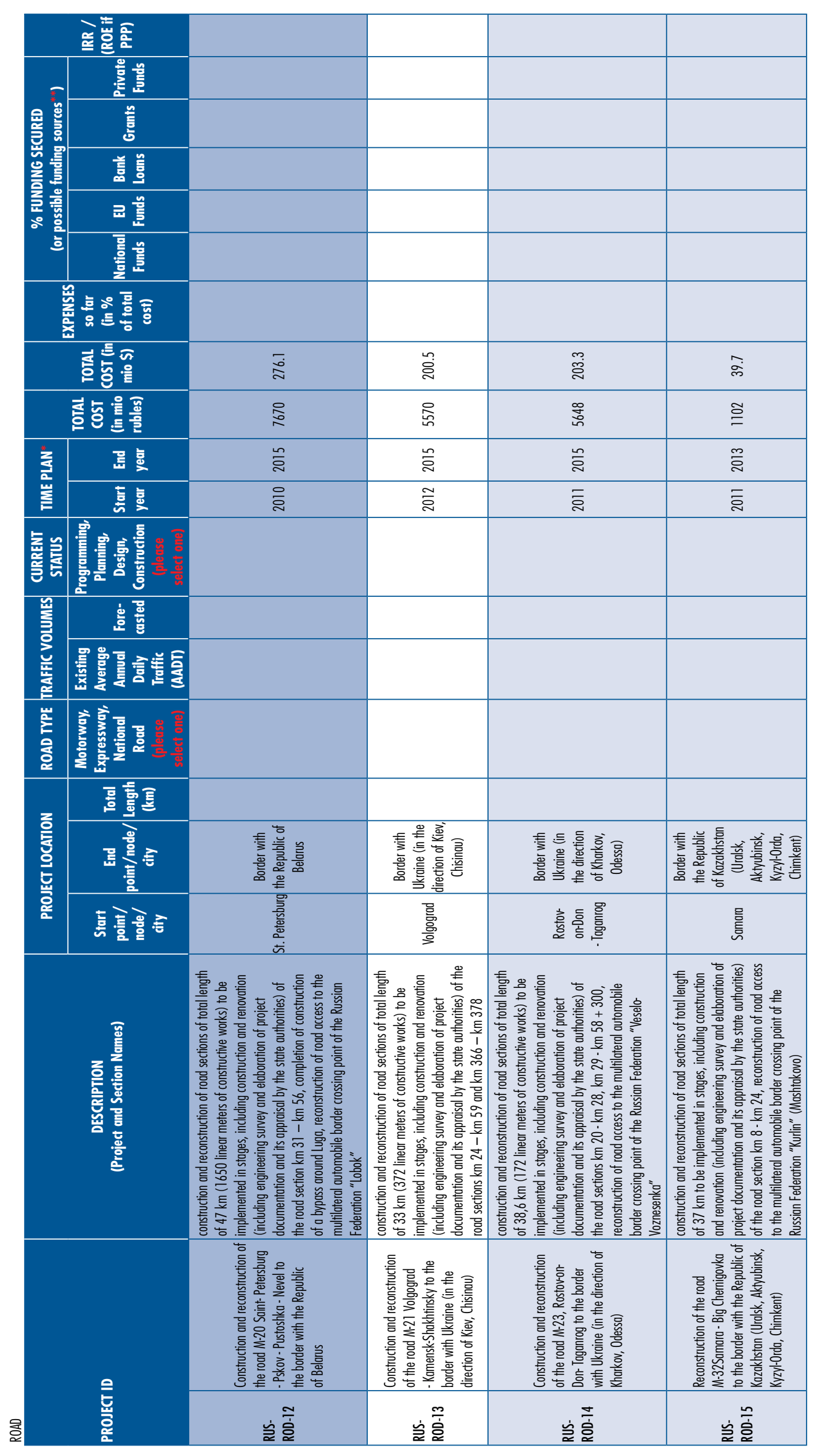




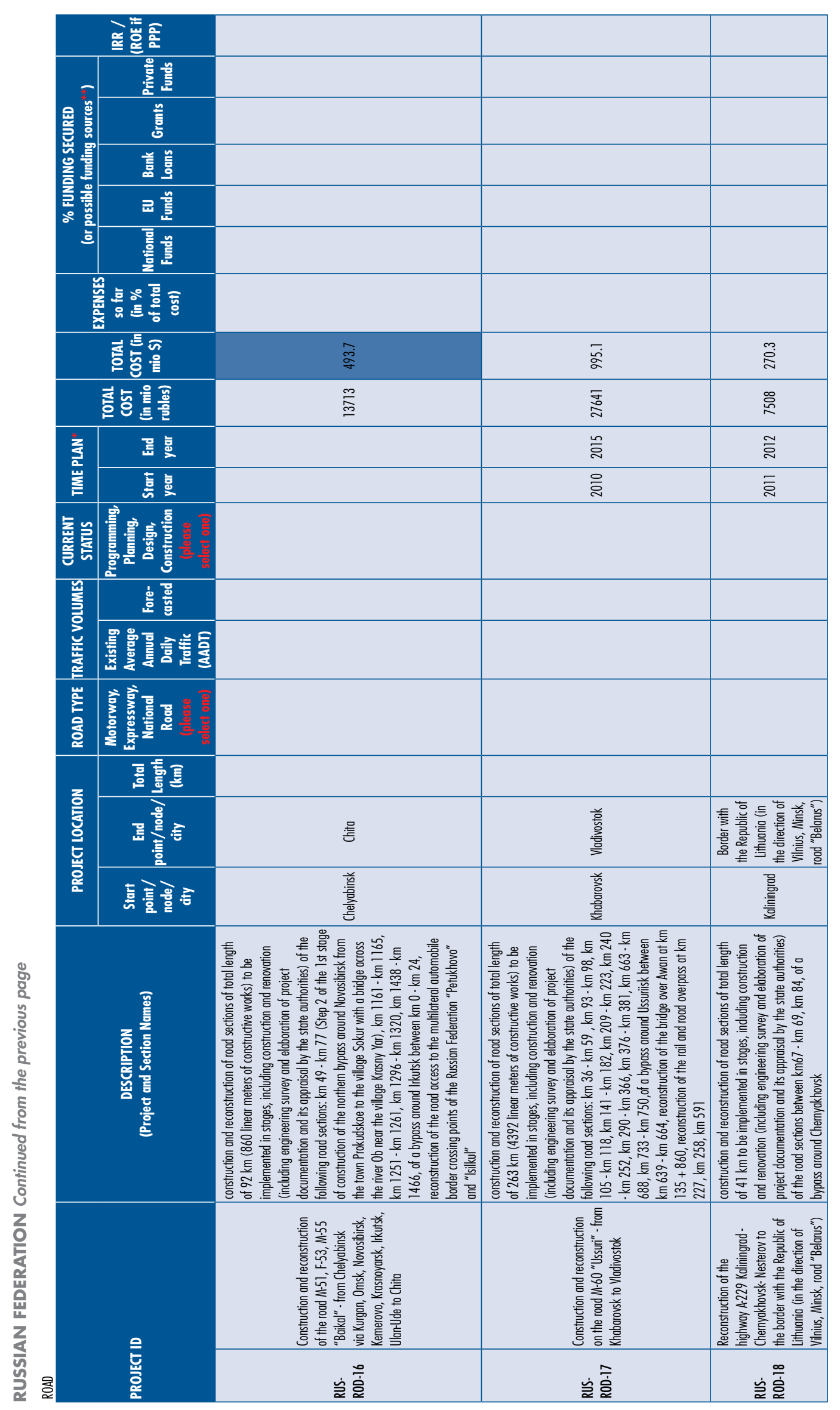




\begin{tabular}{|c|c|c|c|c|}
\hline \multicolumn{2}{|c|}{ 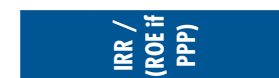 } & & & \\
\hline \multirow{5}{*}{ 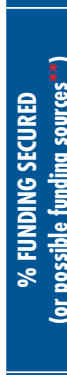 } & 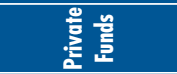 & & & \\
\hline & 言 & & & \\
\hline & 盖言 & & & \\
\hline & 표 & & & \\
\hline & 言号 & & & \\
\hline \multicolumn{2}{|c|}{ 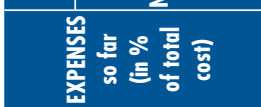 } & & & \\
\hline \multicolumn{2}{|c|}{ 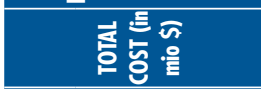 } & 苛 & $\stackrel{\infty}{\gtrless}$ & 怘 \\
\hline \multicolumn{2}{|c|}{ 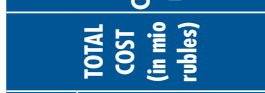 } & 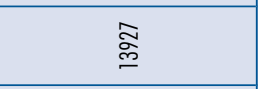 & 参 & శ్ఞ \\
\hline \multirow{2}{*}{ 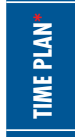 } & 焉咅 & $\stackrel{n}{\vdots}$ & $\stackrel{\varrho}{\vdots}$ & 亏ิ \\
\hline & 言高 & 음 & $\overline{\bar{\alpha}}$ & $\overline{\bar{ล}}$ \\
\hline 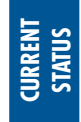 & 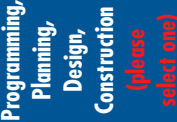 & & & \\
\hline \multirow{2}{*}{ 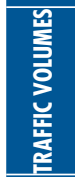 } & 홍 흄 & & & \\
\hline & 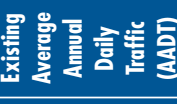 & & & \\
\hline 差 & 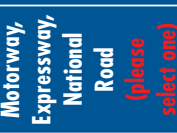 & & & \\
\hline \multirow{3}{*}{ 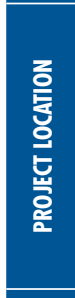 } & 豆害要 & & & \\
\hline & 롤 & 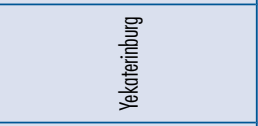 & 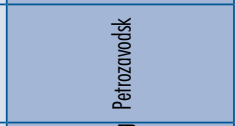 & 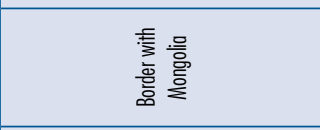 \\
\hline & 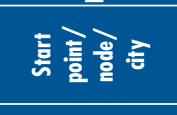 & 巨్⿱亠凶禸心 & 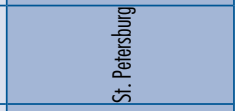 & 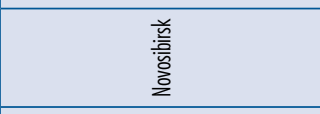 \\
\hline \multicolumn{2}{|r|}{ 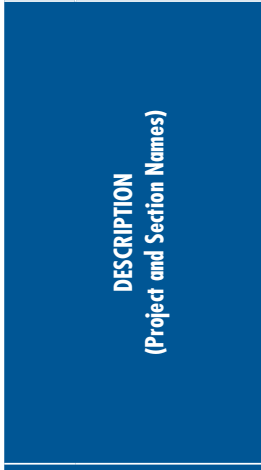 } & 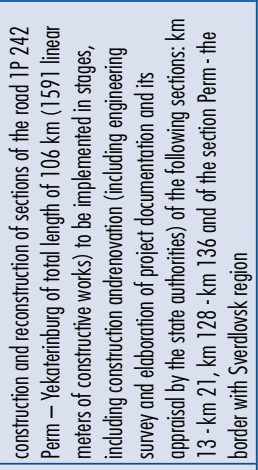 & 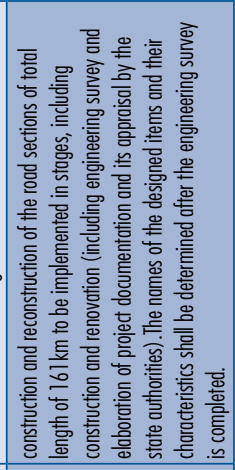 & 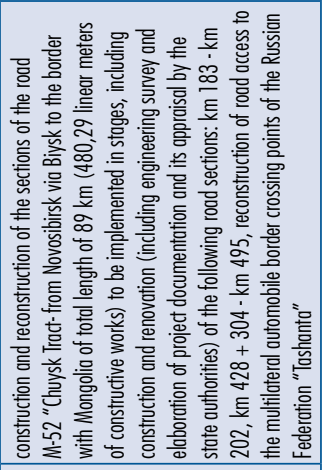 \\
\hline \multirow{2}{*}{\multicolumn{2}{|c|}{ 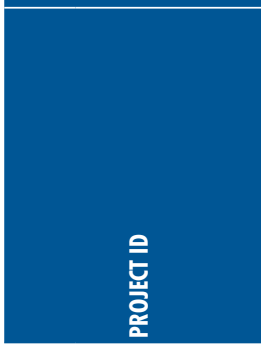 }} & 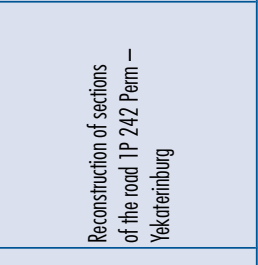 & 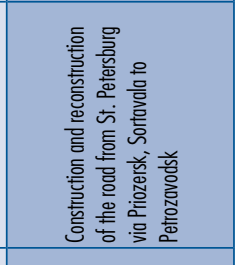 & 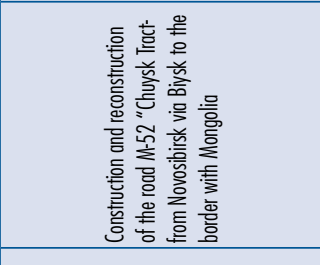 \\
\hline & & 寅容 & 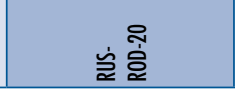 & 岂 \\
\hline
\end{tabular}




\begin{tabular}{|c|c|c|c|c|c|c|c|c|c|c|c|c|c|c|c|c|}
\hline \multicolumn{17}{|c|}{ 搒哀 } \\
\hline \multirow{4}{*}{ 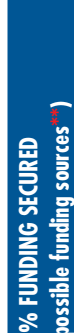 } & 衰尊 & & & & & & & & & & & & & & & \\
\hline & 产 & & & & & & & & & & & & & & & \\
\hline & 善言 & & & & & & & & & & & & & & & \\
\hline & 를 & & & & & & & & & & & & & & & \\
\hline$\stackrel{5}{\mathrm{~s}}$ & & & & & & & & & & & & & & & & \\
\hline & 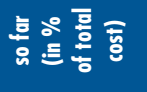 & & & & & & & & & & & & & & & \\
\hline & $=\frac{0}{0}$ & 商 & $\stackrel{?}{F}$ & $\stackrel{\infty}{\infty}$ & $\stackrel{\infty}{\infty}$ & g. & 庐 & 霑 & 8 & 8 & 8 & 票 & 言 & 蓎 & 垔 & 芯 \\
\hline & 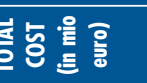 & \begin{tabular}{l|l}
$\stackrel{g}{\Xi}$ \\
\end{tabular} & 을 & $\stackrel{8}{\circ}$ & \& & \&্ & 客 & $\stackrel{\circ}{\stackrel{0}{0}}$ & ( & & & $\stackrel{\circ}{\check{g}}$ & 品 & \& & $\stackrel{\circ}{=}$ & 危 \\
\hline \multirow{2}{*}{ 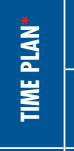 } & 焉咅 & $\stackrel{\circ}{\vdots}$ & 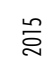 & 음 & 음 & 음 & 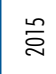 & 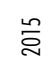 & 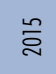 & 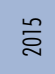 & 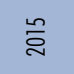 & 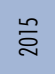 & $\stackrel{n}{\Xi}$ & 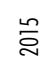 & 흠 & 음 \\
\hline & 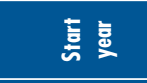 & & & & & & 음 & & & & & & & 음 & & \\
\hline 鸢 & & & & & & & & & & & & & & & & \\
\hline 裏 & 兽害 & & & & & & & & & & & & & & & \\
\hline E & 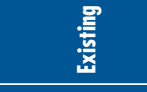 & & & & & & & & & & & & & & & \\
\hline$\overline{\overline{\mathrm{d}}}$ & 这 & & & & & & & & & & & & & & & \\
\hline 总 & & & & & & & & & & & & & & & & \\
\hline \multirow{5}{*}{ 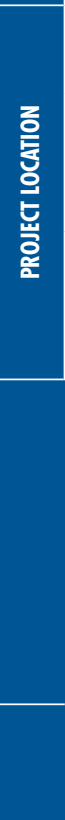 } & 票言产 & $=$ & $\underline{-}$ & $\infty$ & $\approx$ & & & $\stackrel{\infty}{\infty}$ & + & 8 & & & & & $\infty$ & $\underset{\forall}{\infty}$ \\
\hline & 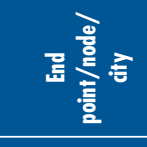 & 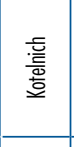 & $\begin{array}{l}\text { 咅 } \\
\text { 章 } \\
\end{array}$ & 喭 & 謩 & 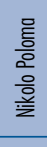 & 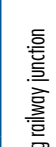 & $\begin{array}{l}\text { 咅 } \\
\text { 咅 } \\
\end{array}$ & 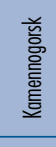 & 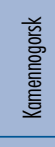 & 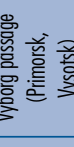 & $\begin{array}{l}\text { 酸 } \\
\text { 旁 } \\
\end{array}$ & \multirow{2}{*}{ 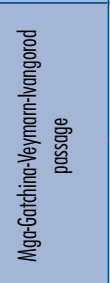 } & \multirow{2}{*}{$\begin{array}{l}\text { 言 } \\
\text { 言 } \\
\text { 言 }\end{array}$} & $\begin{array}{l}\text { 产 } \\
\text { 产 } \\
\end{array}$ & 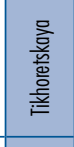 \\
\hline & 亳衰 & $\begin{array}{l}\text { 产 } \\
\text { 寒 }\end{array}$ & 言 & 鈭 & కె & 器 & 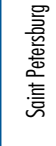 & $\begin{array}{l}\text { 愛 } \\
\text { 喜 }\end{array}$ & 喜 & 高 & 言 & $\begin{array}{l}\text { 咅 } \\
\text { s. }\end{array}$ & & & 言 & 憘 \\
\hline & 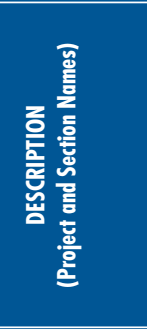 & 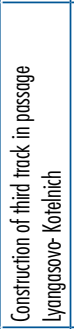 & 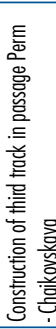 & & 惫 & & & 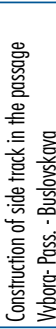 & 5 & 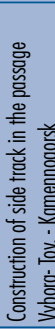 & 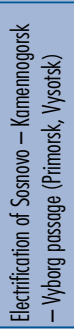 & 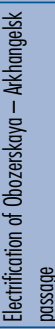 & 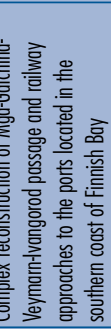 & 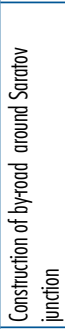 & 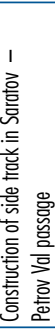 & 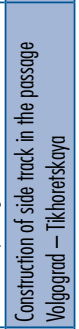 \\
\hline & 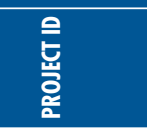 & 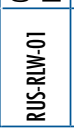 & $\begin{array}{l}\text { 旁 } \\
\text { 产 }\end{array}$ & $\begin{array}{l}\text { 辠 } \\
\text { 产 }\end{array}$ & $\begin{array}{l}\text { 咳 } \\
\text { 产 }\end{array}$ & 䇠 & $\begin{array}{l}\text { 厗 } \\
\text { 产 }\end{array}$ & 咳 & $\begin{array}{l}\text { 总 } \\
\text { 言 } \\
\text { 产 }\end{array}$ & 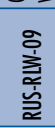 & 产 & 章 & 章 & $\begin{array}{l}\text { me } \\
\text { 产 } \\
\text { 产 }\end{array}$ & 訔 & 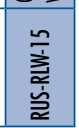 \\
\hline
\end{tabular}




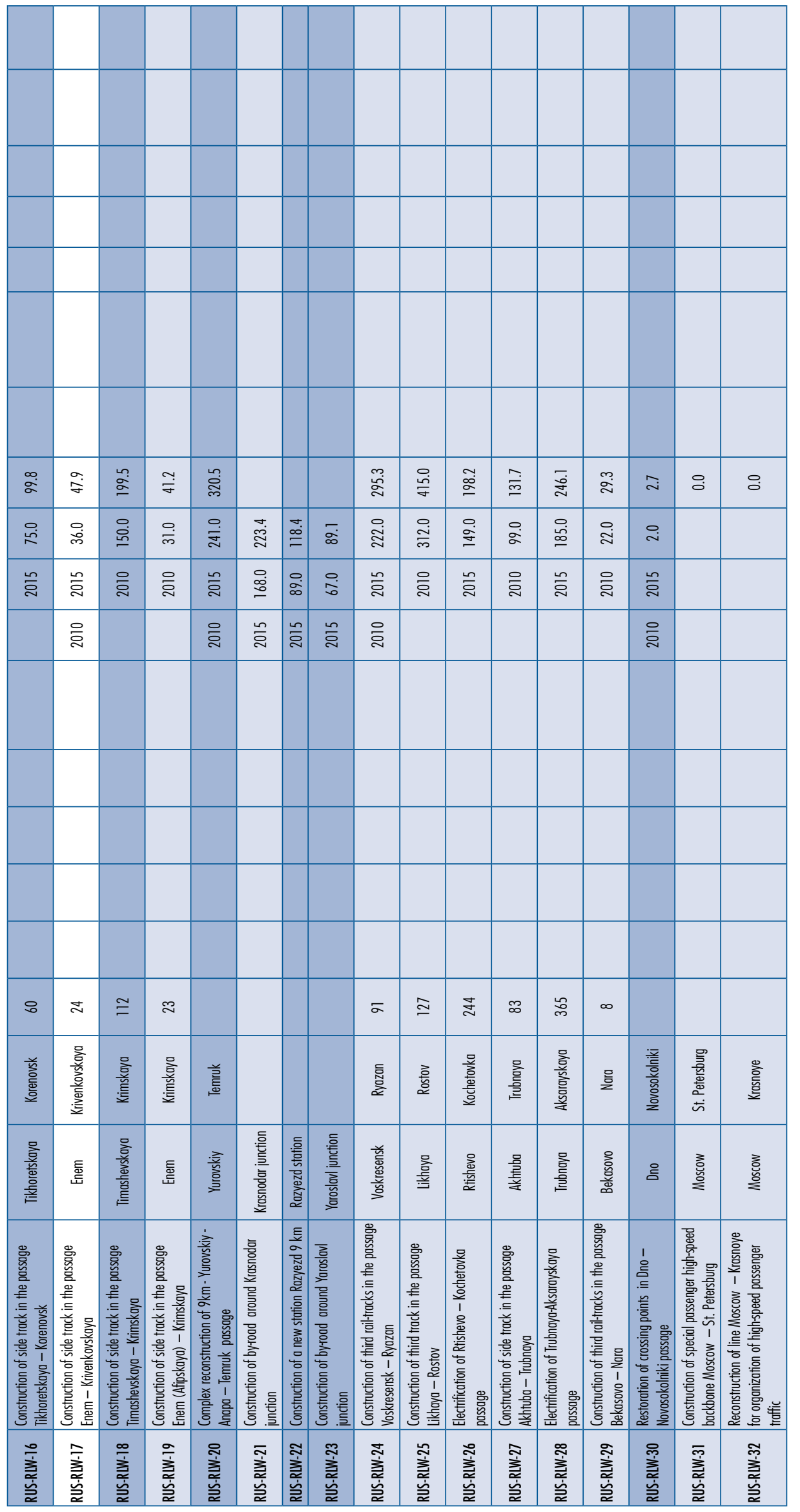




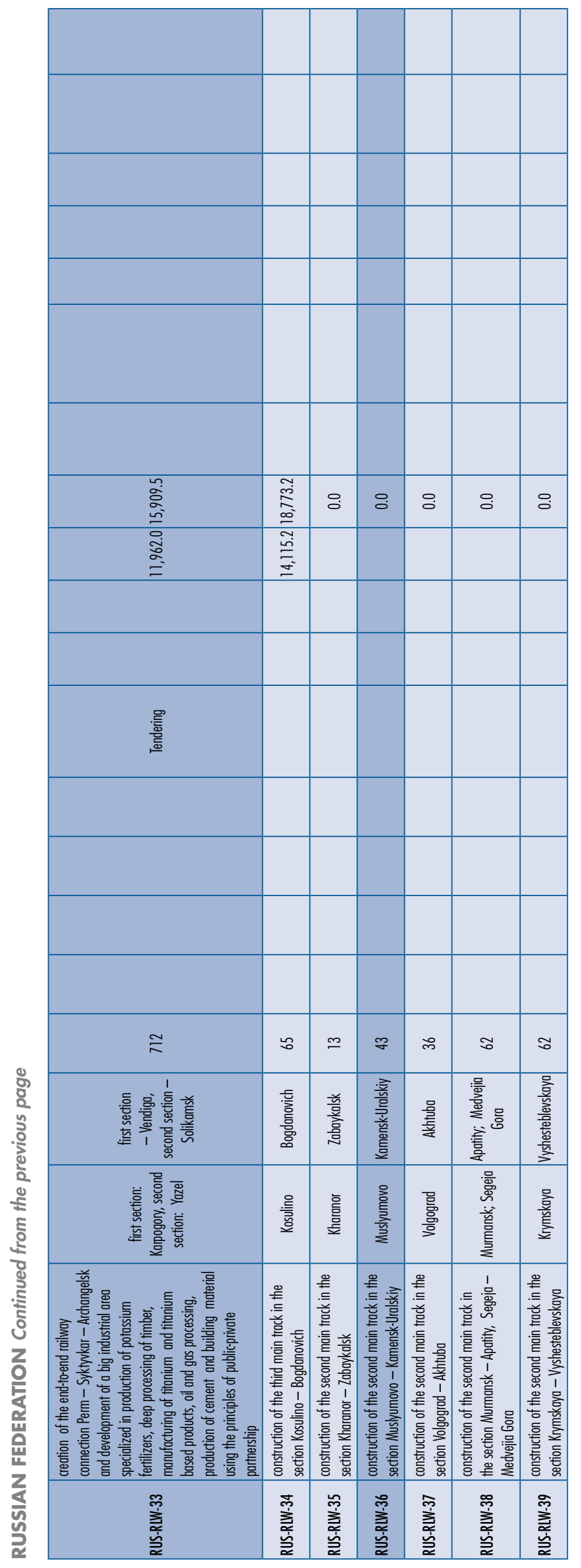




\begin{tabular}{|c|c|c|c|c|c|c|c|c|}
\hline \multicolumn{9}{|c|}{ 慈䒿 } \\
\hline \multirow{5}{*}{ 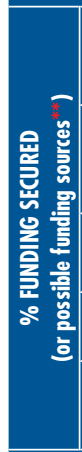 } & 言童 & & & & & & & 产 \\
\hline & 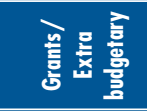 & & & & & & & \\
\hline & 善言 & & & & & & & \\
\hline & 료 흘 & & & & & & & \\
\hline & 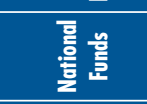 & & & & & & $\stackrel{\circ}{\circ}$ & 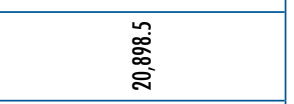 \\
\hline \multicolumn{2}{|c|}{ 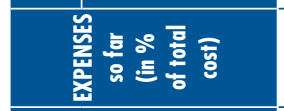 } & & & & & & & \\
\hline \multirow{2}{*}{\multicolumn{2}{|c|}{ 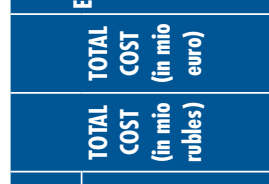 }} & & & & & & స્்ّ & 㝘 \\
\hline & & & & & & & 高 & 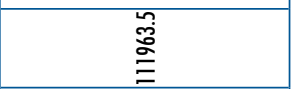 \\
\hline \multirow{2}{*}{ 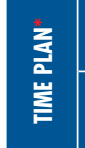 } & 象 总 & & & & & & $\stackrel{n}{\bar{\Sigma}}$ & 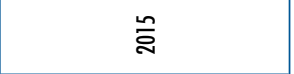 \\
\hline & 喜壱 & & & 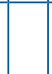 & & & $\stackrel{n}{2}$ & 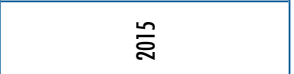 \\
\hline \multirow{3}{*}{ 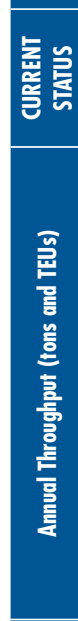 } & 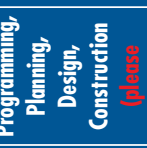 & & & & & & 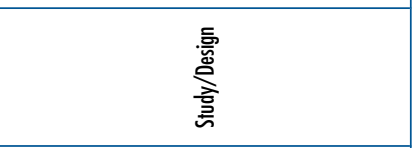 & 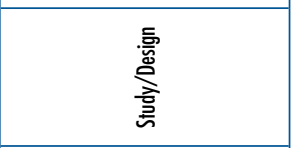 \\
\hline & 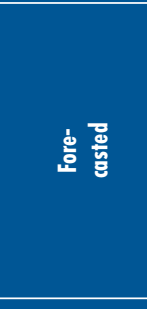 & 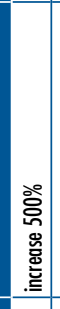 & 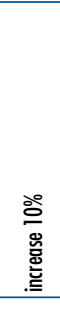 & 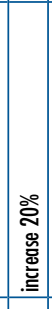 & 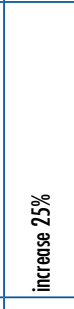 & 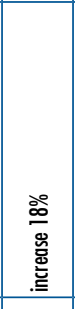 & 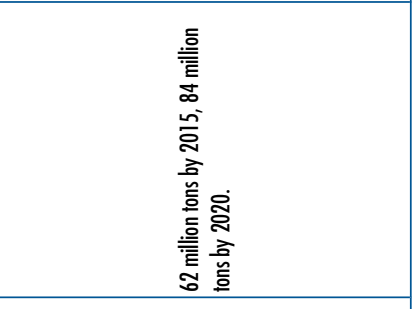 & 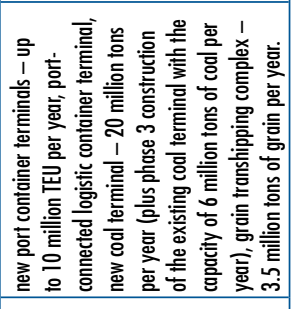 \\
\hline & 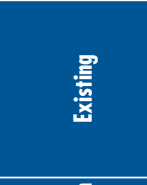 & 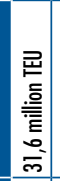 & 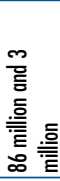 & 亭 & 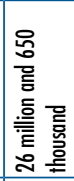 & 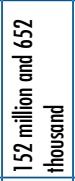 & & \\
\hline \multirow{4}{*}{ 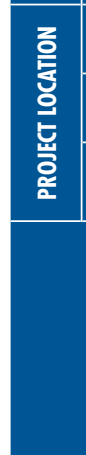 } & 言意要 & & & & & & & \\
\hline & 롭 言产 & & & & & & & \\
\hline & 혼 & & & & & & & \\
\hline & 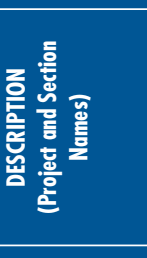 & & & & & & 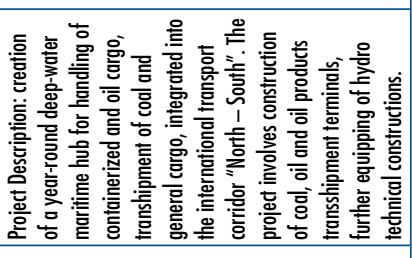 & \\
\hline \multirow{2}{*}{ 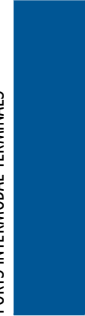 } & 을 & 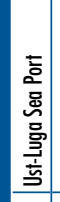 & 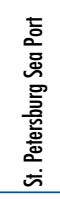 & 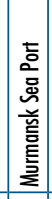 & 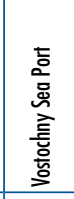 & 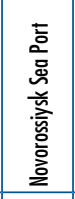 & 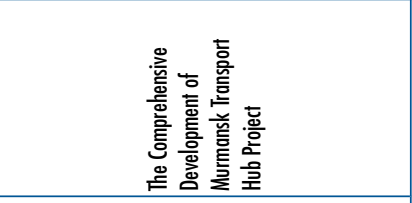 & 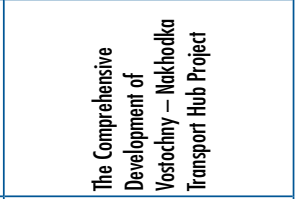 \\
\hline & & 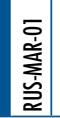 & 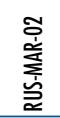 & 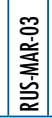 & 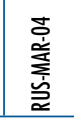 & 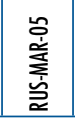 & 홀 & 莖 \\
\hline
\end{tabular}




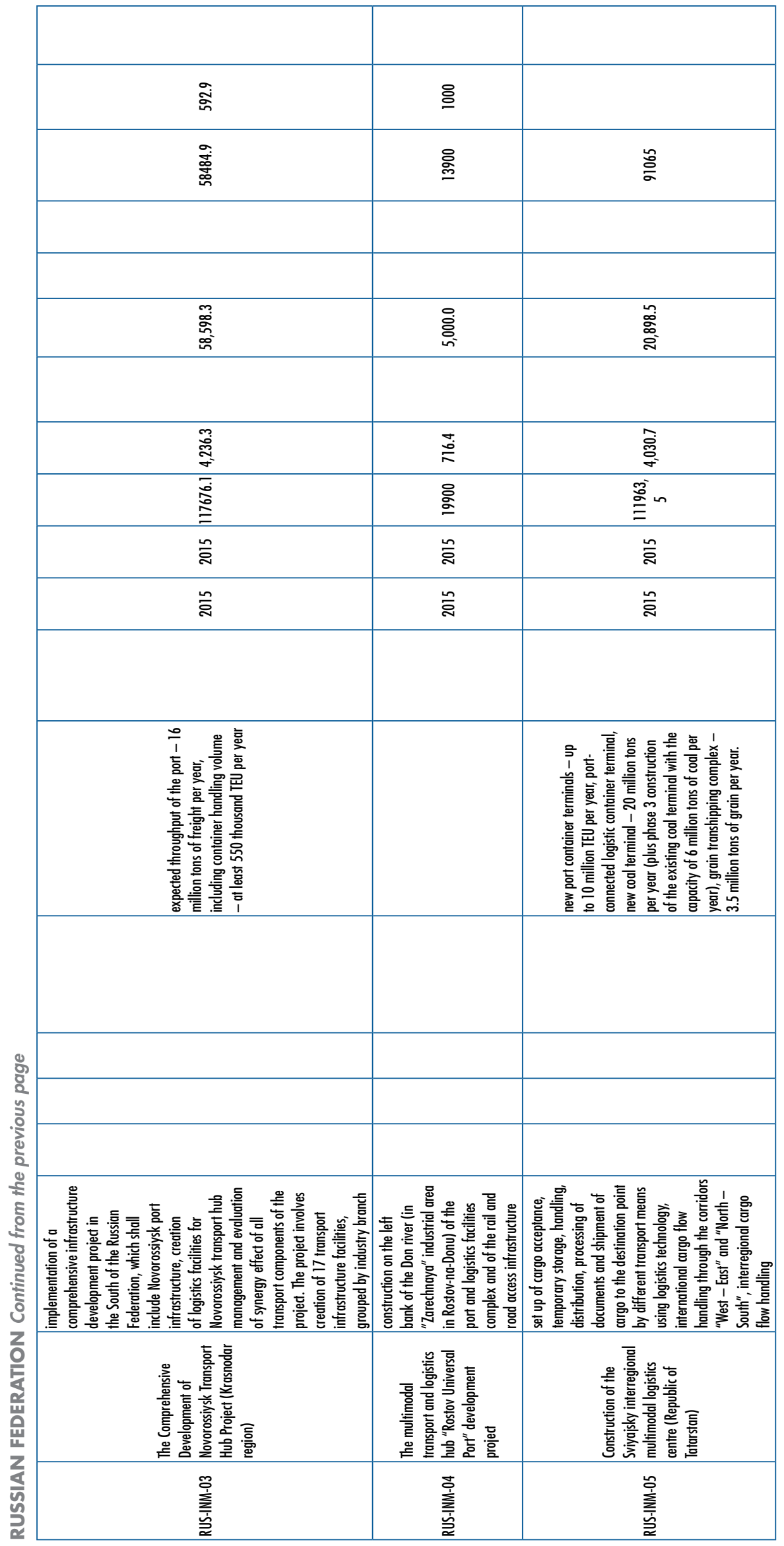


E C O N O M I C

$C O M M I S S$ I O N

$\mathrm{F} O \mathrm{R}$

E $U$ R $O P \quad P \quad E$

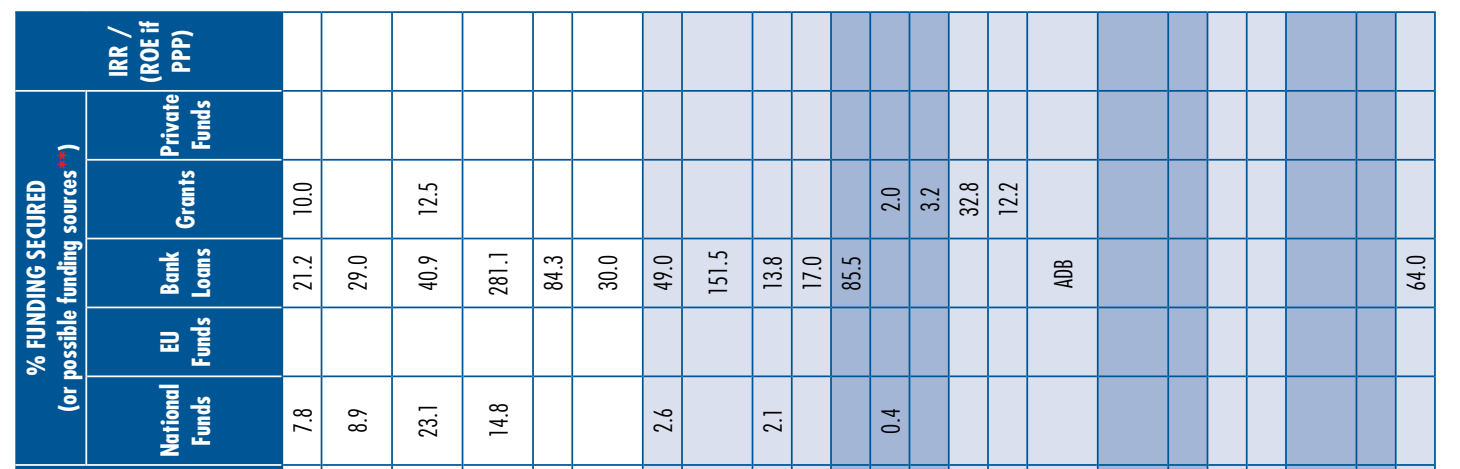

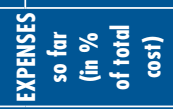

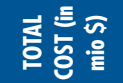

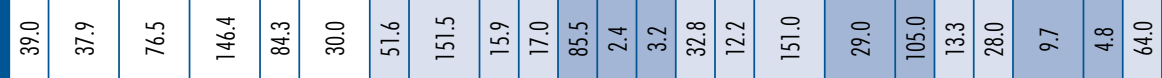

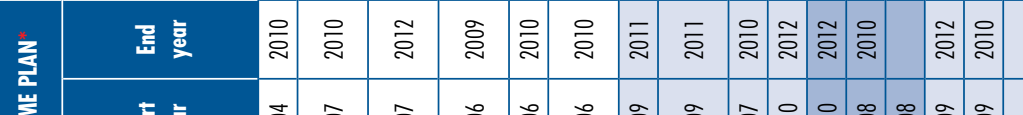

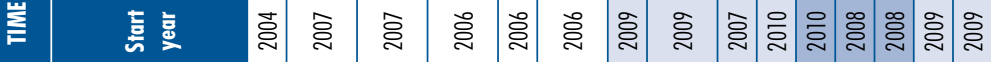

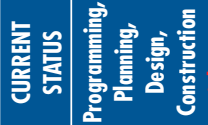

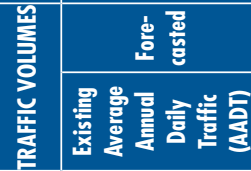

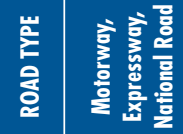

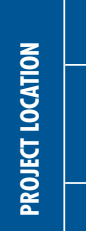

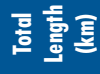

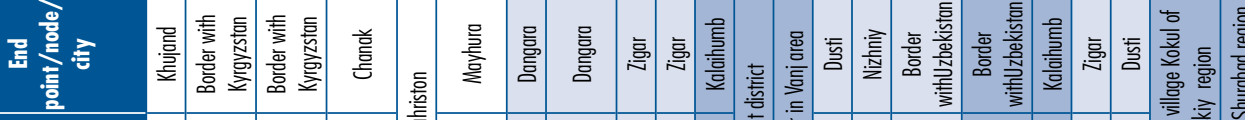

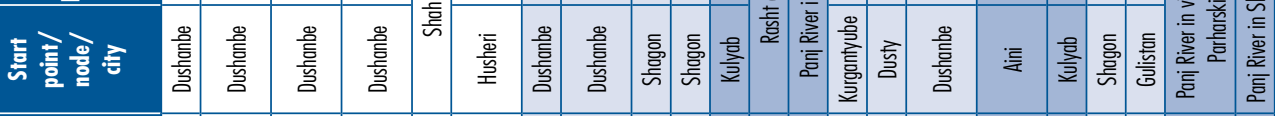

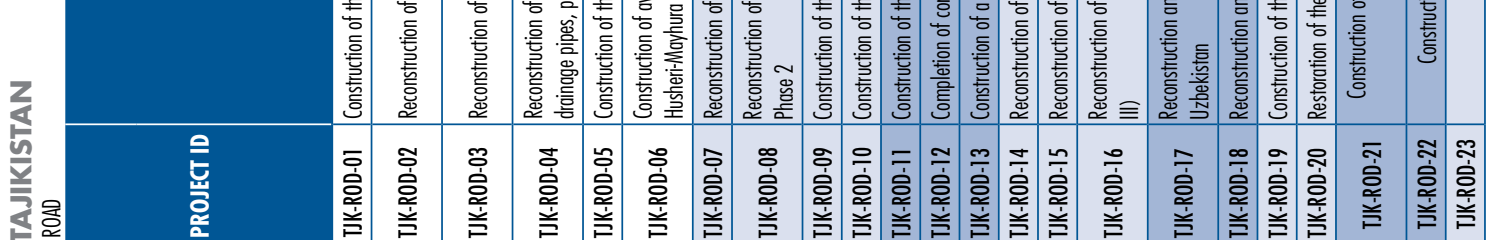



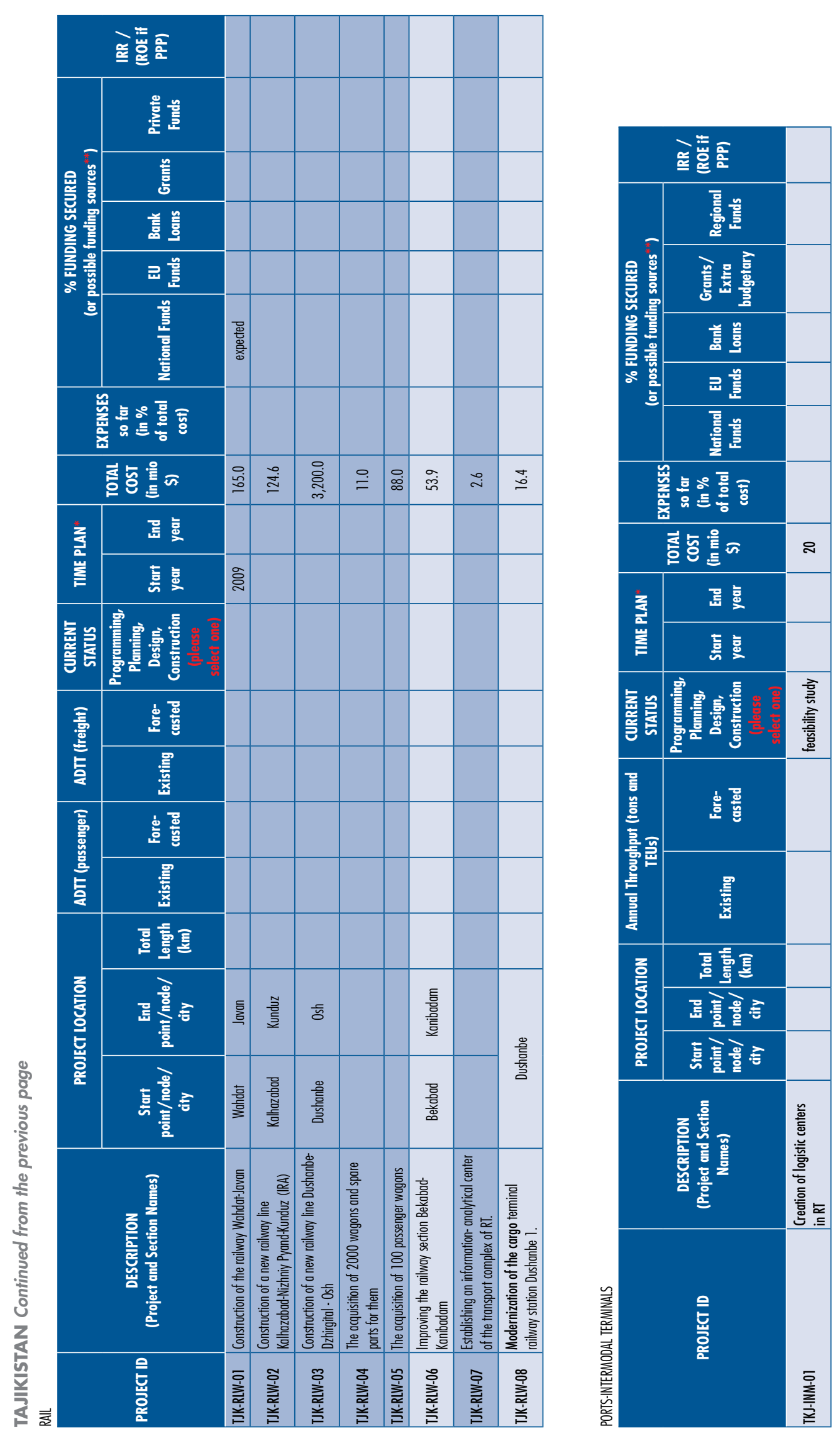


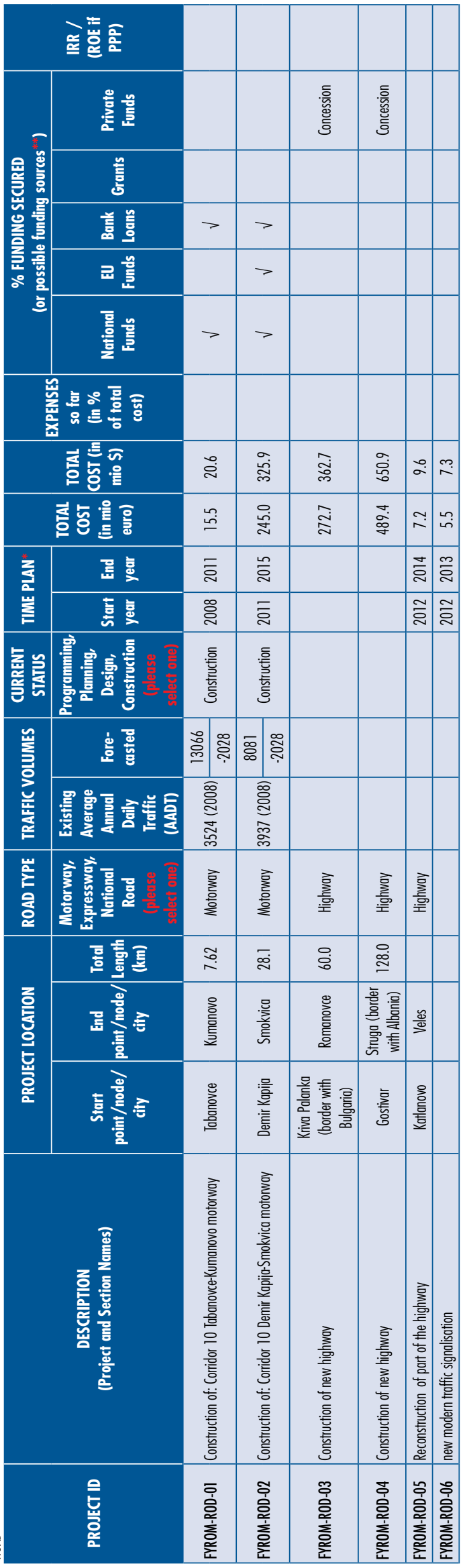

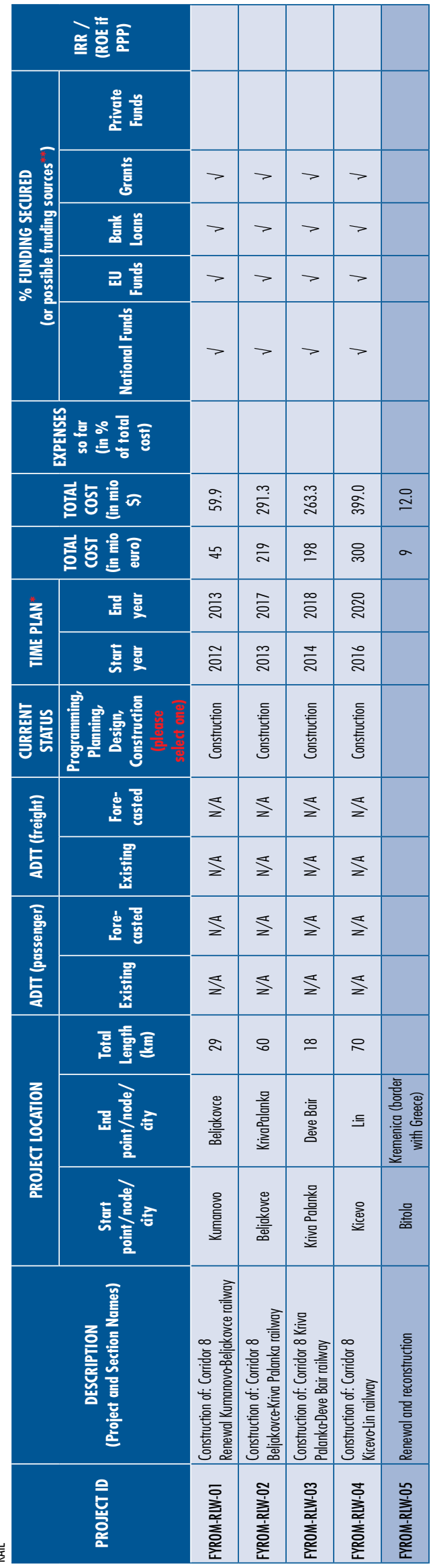




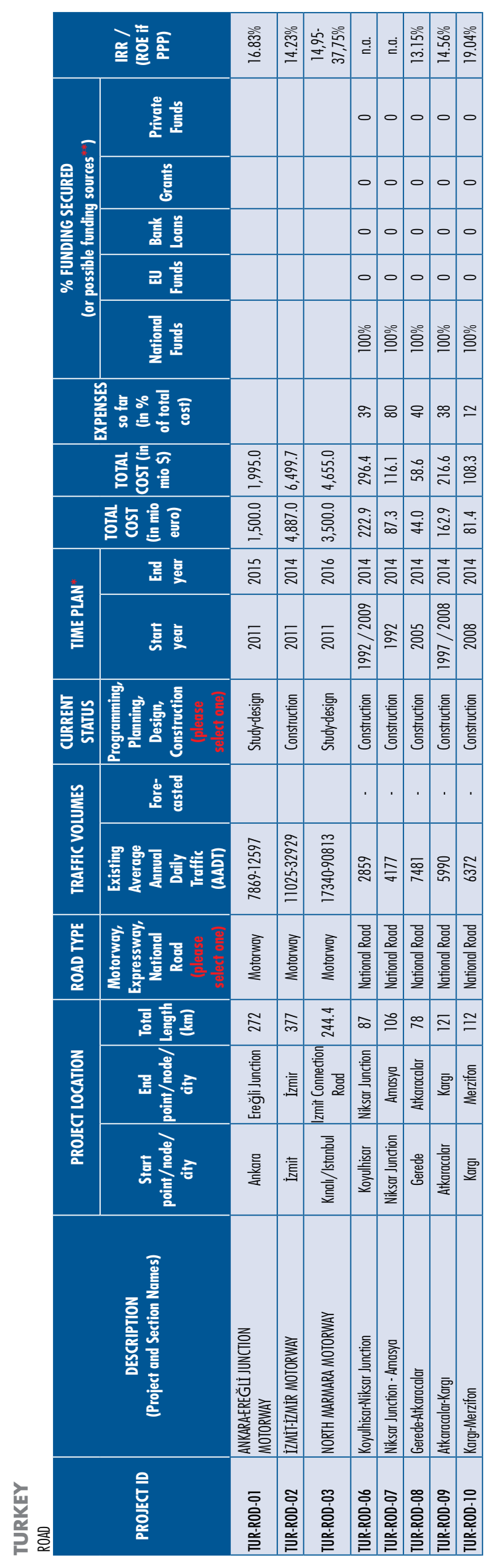




\begin{tabular}{|c|c|c|c|c|c|c|c|c|c|c|c|}
\hline & 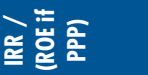 & ڤั & 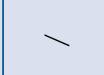 & $\stackrel{\circ}{\stackrel{亠}{~}}$ & ळ & - & - & - & & & \\
\hline & & - & - & - & $\gamma$ & - & 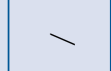 & $\gamma$ & & & \\
\hline 薝产 & 言 & - & - & - & - & - & - & - & & & \\
\hline 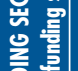 & 善言 & $\times$ & sे & $\times$ & - & - & $\gamma$ & $\gamma$ & & & \\
\hline 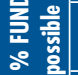 & 료 & - & - & - & - & - & - & - & & & \\
\hline aे & 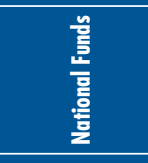 & $x$ & $\gamma$ & $x$ & $\times$ & ذે & - & $\times$ & - & - & \\
\hline 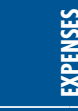 & 홍을 흥 & $\stackrel{\infty}{\sigma}$ & ま & $\underline{m}$ & o & 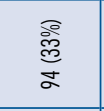 & $\gamma$ & - & & & 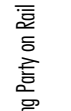 \\
\hline & 氮哭 & 葛 & 絭 & ఏे & 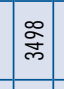 & $\stackrel{\vec{m}}{2}$ & $\overline{\underline{g}}$ & $\frac{8}{\sigma}$ & ఏ્مి & ఏ్రి & \\
\hline & 들을 & 鬲 & 怘 & In & : & $\bar{\sim}$ & $\stackrel{\varrho}{\approx}$ & 鬲 & & & \\
\hline$\frac{z}{2}$ & 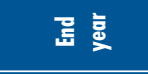 & 离 & $\stackrel{0}{\bar{D}}$ & $\stackrel{m}{\grave{n}}$ & $\stackrel{n}{\grave{\Omega}}$ & $\tilde{\Xi}$ & $\underline{z}$ & పे & $\Sigma$ & $\Sigma$ & \\
\hline 遃 & 䓌 & ڤ్مి & ప్ & 음 & ఏ్d & పे & 음 & $\overline{\bar{\alpha}}$ & $\bar{z}$ & 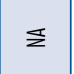 & \\
\hline 氪总 & & 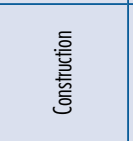 & 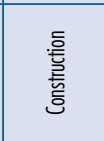 & 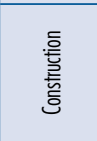 & 毫 & $\begin{array}{l}\frac{\overline{0}}{\bar{E}} \\
\text { 竘 }\end{array}$ & 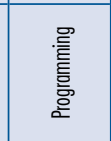 & $\begin{array}{l}\text { 墨 } \\
\text { 言 }\end{array}$ & $\begin{array}{l}\text { 墨 } \\
\text { 言 }\end{array}$ & $\begin{array}{l}\text { 高 } \\
\text { 言 } \\
\text { a }\end{array}$ & 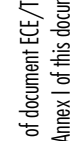 \\
\hline $\begin{array}{l}\text { 吾 } \\
\text { 冞 }\end{array}$ & b & $\gamma$ & $\gamma$ & 8 & $\approx$ & 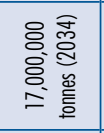 & 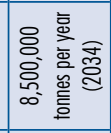 & - & 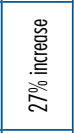 & 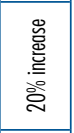 & $\stackrel{\underline{m}}{\underline{\underline{m}}}$ \\
\hline 旨 & $\begin{array}{l}\frac{D}{\bar{Z}} \\
\frac{\bar{n}}{x} \\
\end{array}$ & $\gamma$ & - & f & $\stackrel{s}{z}$ & $\frac{\pi}{z}$ & $\underline{z}$ & - & 峷 & 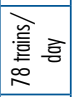 & 苇 \\
\hline $\begin{array}{l}\overline{\overline{\mathbf{w}}} \\
\text { 要 }\end{array}$ & $\dot{\Delta}$ & 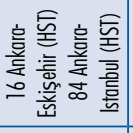 & 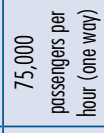 & $\underline{z}$ & 0 & 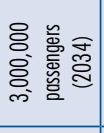 & 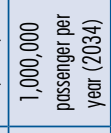 & - & 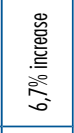 & 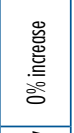 & \\
\hline 妾 & 善 & 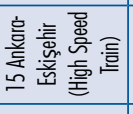 & $\underline{z}$ & $\sigma$ & $\Sigma$ & $\underline{z}$ & $\underline{z}$ & - & 产 & 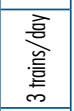 & $\begin{array}{l}\text { 产 } \\
\text { 产 } \\
\text { 产 } \\
\text { 产 }\end{array}$ \\
\hline$z$ & 言㶻害 & o্ & : & $\bar{q}$ & 歺 & $\therefore$ & $\approx$ & 趸 & 吕 & $\stackrel{\leftrightarrow}{\sim}$ & \\
\hline 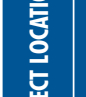 & 롭 言帮 & 䜾 & 咅 & 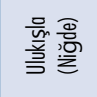 & 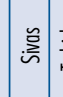 & 蒡喜鄫 & 홓 & 怠 & 衰 & 長 & \\
\hline בై & 豆竞 & 量 & 罳 & 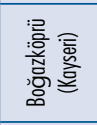 & 喜 & 豊 & 唇 & 喜 & 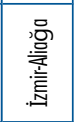 & 㝘 & \\
\hline & 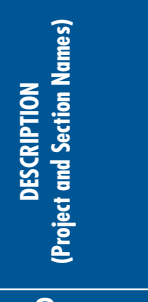 & 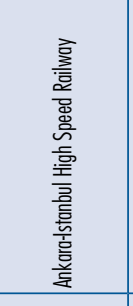 & 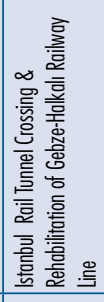 & 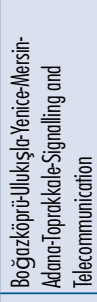 & 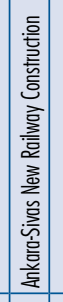 & 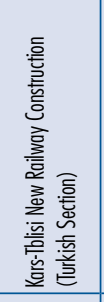 & 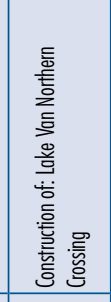 & 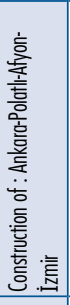 & 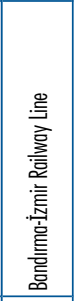 & 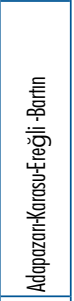 & 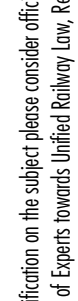 \\
\hline & 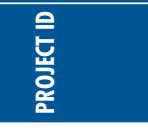 & $\begin{array}{l}\overline{\bar{a}} \\
\text { 雍 } \\
\end{array}$ & 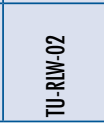 & 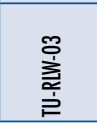 & 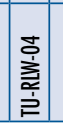 & $\begin{array}{l}\text { 旁 } \\
\text { 产 } \\
\end{array}$ & 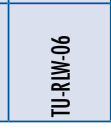 & 骧 & \begin{tabular}{|l|} 
产 \\
产 \\
\multirow{2}{*}{}
\end{tabular} & \begin{tabular}{|l|} 
高 \\
产 \\
\end{tabular} & 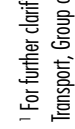 \\
\hline
\end{tabular}




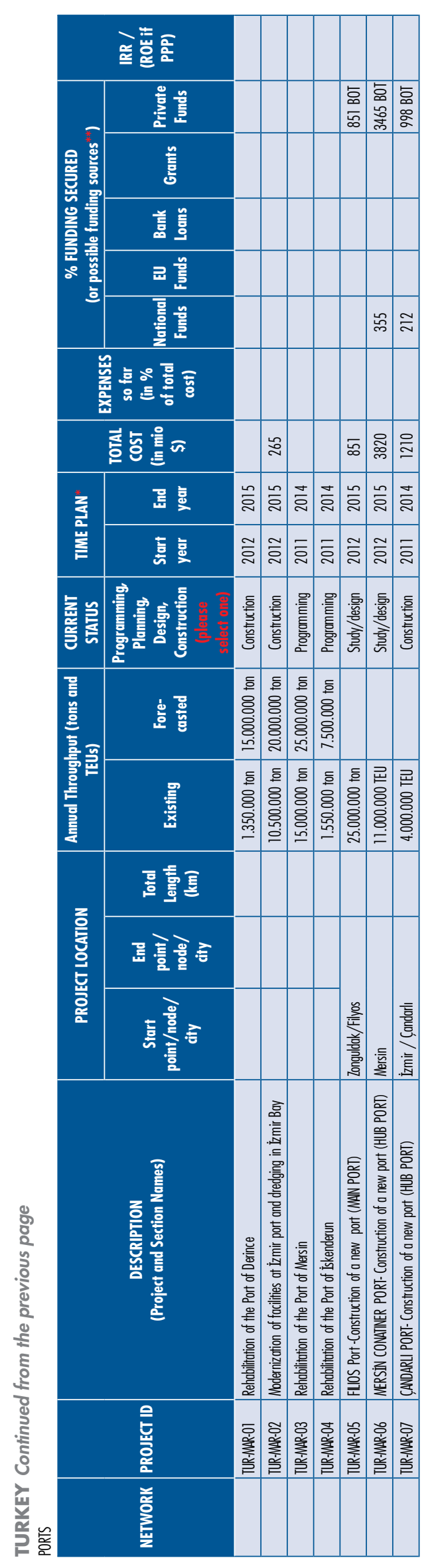




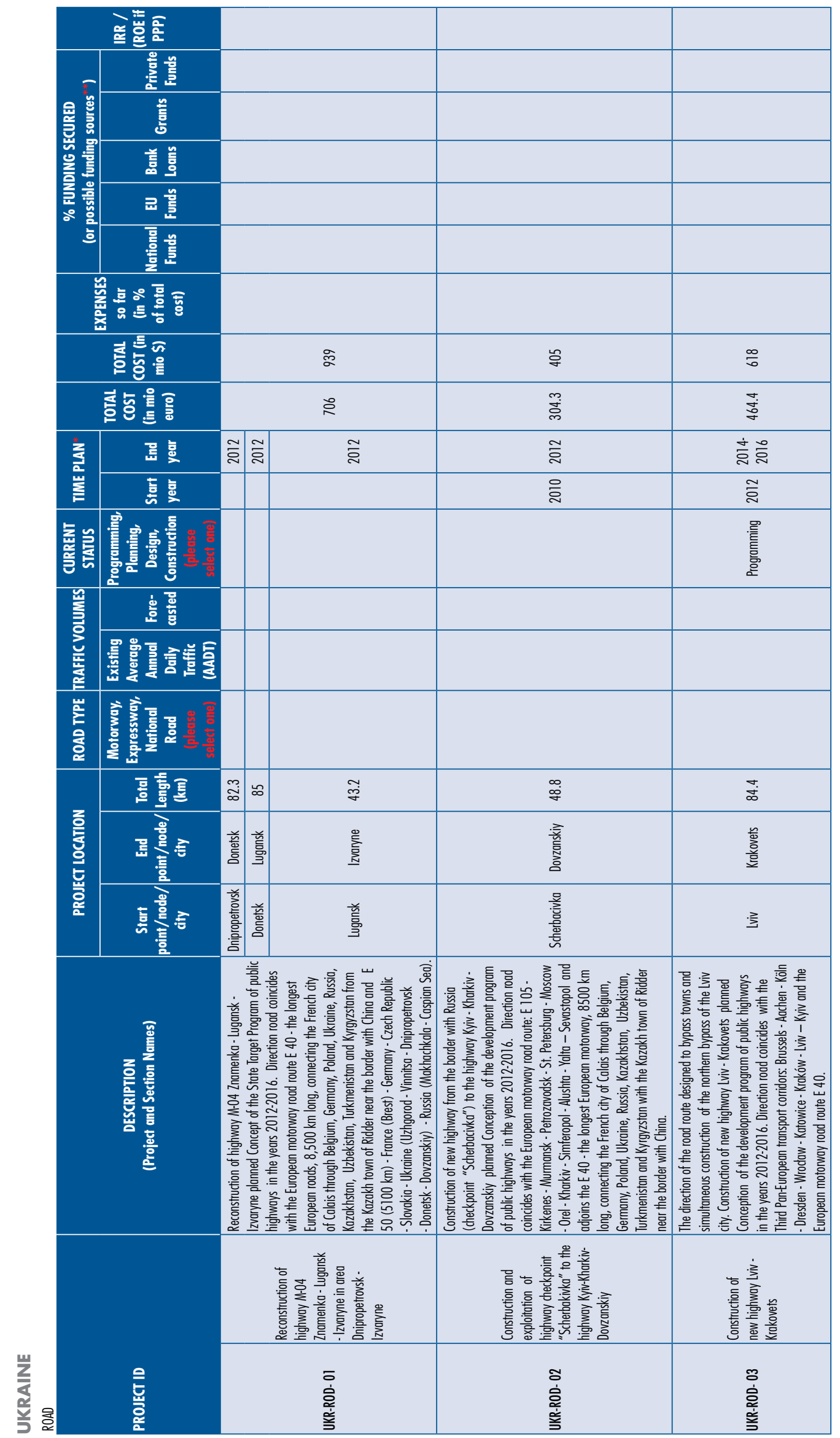




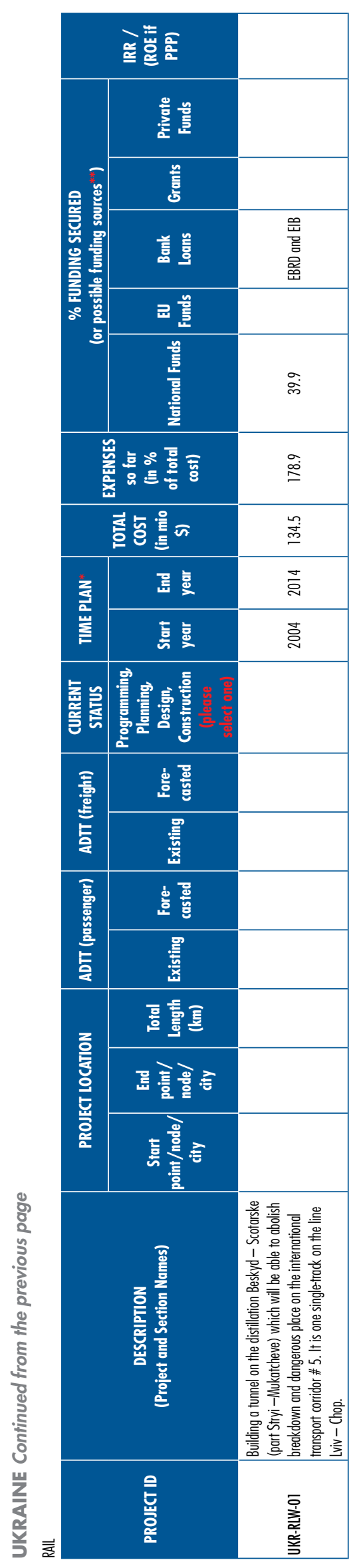




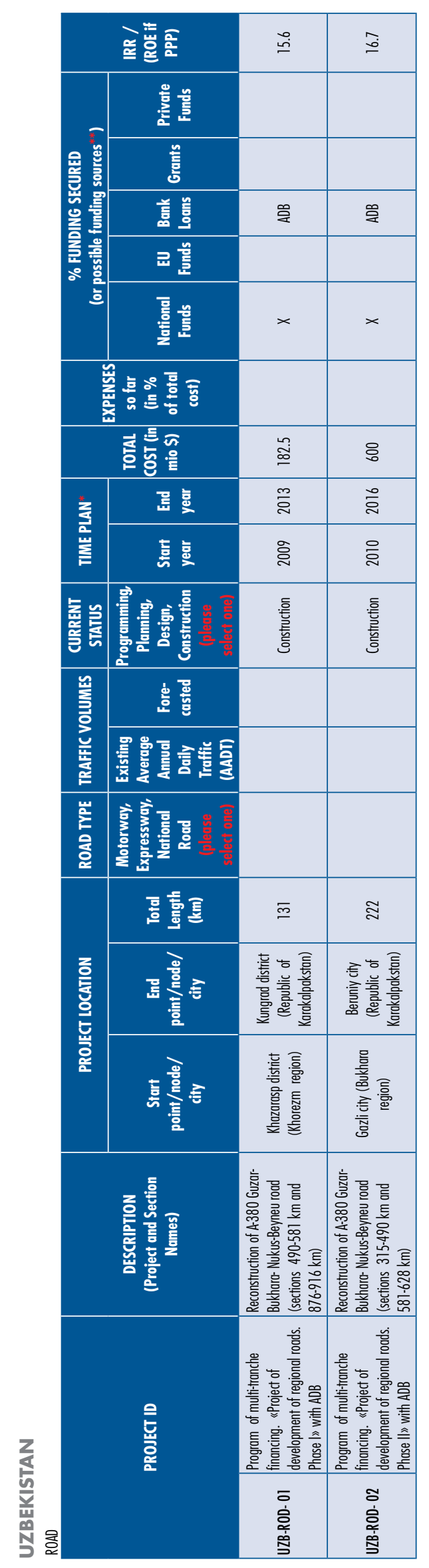




\begin{tabular}{|c|c|c|c|c|c|c|c|c|c|c|c|c|}
\hline \multicolumn{13}{|c|}{ 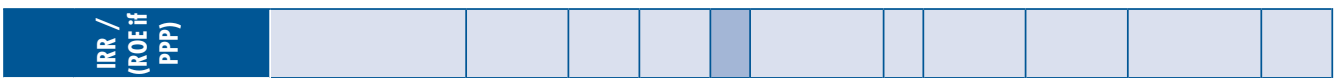 } \\
\hline \multirow{5}{*}{ 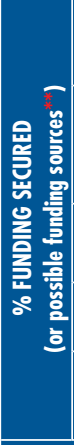 } & 产 & & & $\stackrel{\Xi}{\Rightarrow}$ & & & 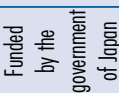 & & & & & \\
\hline & 言 & 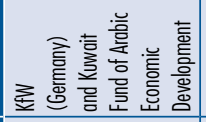 & & & 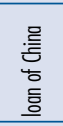 & & & & & & & \\
\hline & 善言 & & & & & $\frac{8}{2}$ & 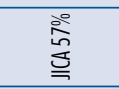 & 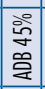 & & & & \\
\hline & 루 & & & & & & & & s。 & 亏ิ & ذิ & ذิ \\
\hline & 吾品 & 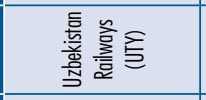 & 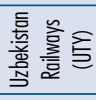 & $\Xi$ & & & ஓे & 菺 & & & & \\
\hline \multicolumn{2}{|c|}{ 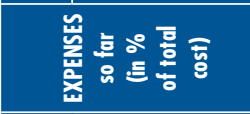 } & & & & & & & & & & & \\
\hline \multicolumn{2}{|c|}{ 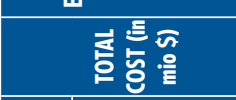 } & 岕 & 烁 & \begin{tabular}{l}
$\stackrel{n}{\tilde{F}}$ \\
\multirow{F}{*}{}
\end{tabular} & $\approx$ & $\stackrel{\check{\sim}}{\sim}$ & 总 & $\mid \begin{array}{l}a \\
\dot{p} \\
\dot{y} \\
\end{array}$ & $\lesssim$ & $\approx$ & 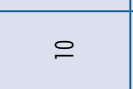 & 疍 \\
\hline \multirow{2}{*}{ 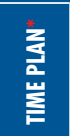 } & 焉 & & 을 & & సี & 亏े & 亏े & 文 & 亏్ & 亏ั & 亏్ & $\overline{\bar{\Xi}}$ \\
\hline & 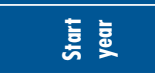 & & & & ఏ్ & ฉ్ & $\tilde{\check{\Sigma}}$ & 咅 & 음 & 亏े & ఏ్ & ఏे \\
\hline 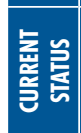 & 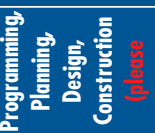 & 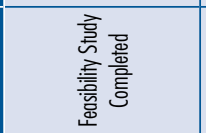 & & 稁 & & 番 & 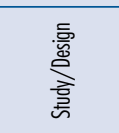 & 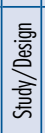 & 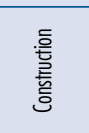 & $\begin{array}{l}\text { 言 } \\
\text { 言 } \\
\text { है }\end{array}$ & 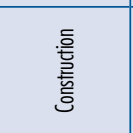 & 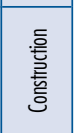 \\
\hline \multirow{2}{*}{ 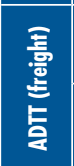 } & 홍 홍 & & & & & & & & & & & \\
\hline & 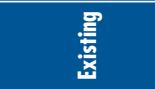 & & & & & & & & & & & \\
\hline \multirow{2}{*}{ 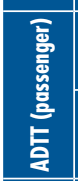 } & 安 & & & & & & & & & & & \\
\hline & 趌 & & & & & & & & & & & \\
\hline \multirow{3}{*}{ 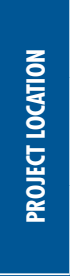 } & 言言要 & $\stackrel{\alpha}{=}$ & 웅 & & & 9 & $\nsim$ & $:$ & 专 & $\stackrel{F}{=}$ & $\bar{\Sigma}$ & 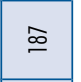 \\
\hline & 풀 言产 & 产 & 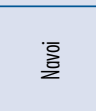 & 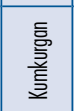 & & 言 & 蒙 & \begin{tabular}{|l|} 
言 \\
咅 \\
\end{tabular} & $\begin{array}{l}\text { 믈 } \\
\text { 言 } \\
\text { 赛 }\end{array}$ & $\begin{array}{l}\overline{\overline{\underline{i}}} \\
\text { 言 } \\
\text { 旁 }\end{array}$ & 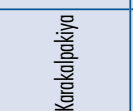 & $\begin{array}{l}\text { 意 } \\
\text { 咅 }\end{array}$ \\
\hline & 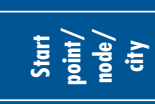 & $\begin{array}{l}\overline{\bar{z}} \\
\text { 鉝 } \\
\end{array}$ & 䈉 & $\begin{array}{l}\overline{2} \\
\text { 耪 } \\
\end{array}$ & & 毫 & 言 & \begin{tabular}{|l|} 
褰 \\
\end{tabular} & 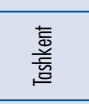 & 产 & 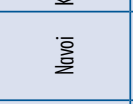 & 产 \\
\hline & 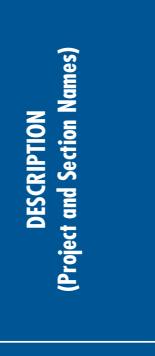 & 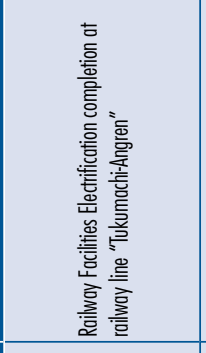 & 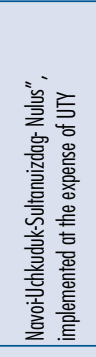 & 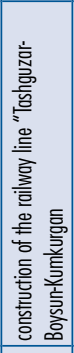 & 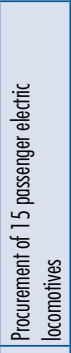 & 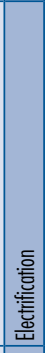 & 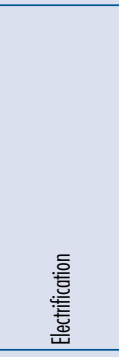 & 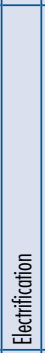 & & & & \\
\hline & $\begin{array}{l}\text { 을 } \\
\text { 햄 } \\
\text { 을 }\end{array}$ & 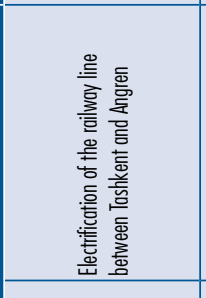 & 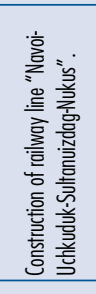 & 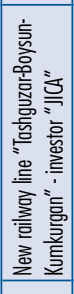 & 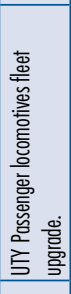 & 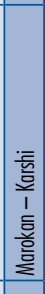 & 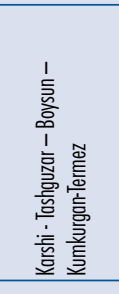 & 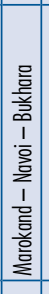 & 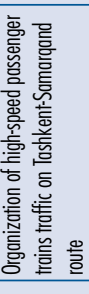 & 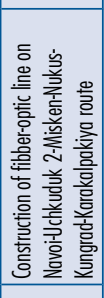 & 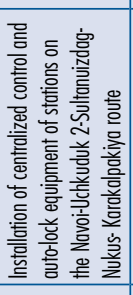 & 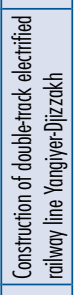 \\
\hline & & $\begin{array}{l}\text { 홀 } \\
\text { 产 } \\
\text { 突 }\end{array}$ & 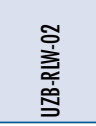 & 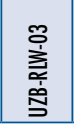 & $\begin{array}{l}\text { to } \\
\text { 产 } \\
\text { 产 }\end{array}$ & 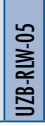 & $\begin{array}{l}\text { 早 } \\
\text { 产 } \\
\text { 宊 }\end{array}$ & 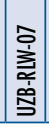 & 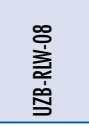 & $\begin{array}{l}\text { ồ } \\
\text { 产 } \\
\text { 苞 }\end{array}$ & $\begin{array}{l}\text { 울 } \\
\text { 产 } \\
\text { 穿 }\end{array}$ & 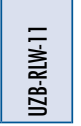 \\
\hline
\end{tabular}




\section{Appendix 4.4}

\section{Application of the Results}

Table T-1 China

EVALUATION

1. Answers (based on country's input)

\begin{tabular}{|c|c|c|c|c|c|c|}
\hline \multirow{2}{*}{ Project ID } & \multicolumn{4}{|c|}{ Criteria A } & \multicolumn{2}{|c|}{ Criteria B } \\
\hline & $\overline{C A 1}$ & CA2 & CA3 & CA4 & CB1 & C B2 \\
\hline $\mathrm{CH}-\mathrm{ROD}-\mathrm{O} 4$ & A & A & A & B & $\mathrm{A}$ & A \\
\hline $\mathrm{CH}-\mathrm{ROD}-\mathrm{O} 5$ & A & A & A & $\mathrm{B}$ & A & A \\
\hline CH-ROD-O6 & $\mathrm{A}$ & A & $\mathrm{A}$ & $\mathrm{B}$ & $\mathrm{A}$ & $\mathrm{A}$ \\
\hline $\mathrm{CH}-\mathrm{ROD}-\mathrm{O} 7$ & $A$ & A & $A$ & $\mathrm{~B}$ & $\mathrm{~A}$ & $A$ \\
\hline $\mathrm{CH}-\mathrm{ROD}-1 \mathrm{O}$ & $\mathrm{A}$ & $\mathrm{A}$ & $\mathrm{A}$ & $\mathrm{B}$ & $\mathrm{A}$ & $\mathrm{A}$ \\
\hline CH-ROD-1 1 & $\mathrm{~A}$ & A & A & B & A & $\mathrm{A}$ \\
\hline CH-ROD-13 & B & B & B & B & B & A \\
\hline $\mathrm{CH}-\mathrm{ROD}-14$ & $\mathrm{~B}$ & B & $B$ & $\mathrm{~B}$ & $C$ & A \\
\hline $\mathrm{CH}-\mathrm{ROD}-15$ & $\mathrm{~B}$ & $\mathrm{~B}$ & $\mathrm{~B}$ & $\mathrm{~B}$ & $\mathrm{~B}$ & $\mathrm{~A}$ \\
\hline $\mathrm{CH}-\mathrm{ROD}-16$ & B & B & B & B & $\mathrm{A}$ & $\mathrm{A}$ \\
\hline
\end{tabular}

2. Raw scores

\begin{tabular}{|l|c|c|c|c|c|c|}
\hline \multirow{2}{*}{ Project ID } & \multicolumn{3}{|c|}{ Criteria A } & \multicolumn{2}{c|}{ Criteria B } \\
\cline { 2 - 7 } & CA1 & CA2 & CA3 & CA4 & C B 1 & C B2 \\
\hline CH-ROD-O4 & 5 & 5 & 5 & 4 & 5 & 5 \\
\hline CH-ROD-O5 & 5 & 5 & 5 & 4 & 5 & 5 \\
\hline CH-ROD-O6 & 5 & 5 & 5 & 4 & 5 & 5 \\
\hline CH-ROD-O7 & 5 & 5 & 5 & 4 & 5 & 5 \\
\hline CH-ROD-10 & 5 & 5 & 5 & 4 & 5 & 5 \\
\hline CH-ROD-11 & 5 & 5 & 5 & 4 & 5 & 5 \\
\hline CH-ROD-13 & 4 & 4 & 4 & 4 & 4 & 5 \\
\hline CH-ROD-14 & 4 & 4 & 4 & 4 & 3 & 5 \\
\hline CH-ROD-15 & 4 & 4 & 4 & 4 & 4 & 5 \\
\hline CH-ROD-16 & 4 & 4 & 4 & 4 & 5 & 5 \\
\hline
\end{tabular}

\begin{tabular}{|c|c|c|c|c|c|c|}
\hline \multirow{3}{*}{ Weights } & \multicolumn{4}{|c|}{ Criteria A } & \multicolumn{2}{c|}{ Criteria B } \\
\cline { 2 - 7 } & WCA1 & WCA2 & WCA3 & WCA4 & WCB1 & WCB2 \\
\cline { 2 - 7 } & $3,13 \%$ & $9,38 \%$ & $19,79 \%$ & $17,71 \%$ & $40,00 \%$ & $10,00 \%$ \\
\hline
\end{tabular}

3. Weighted scores
\begin{tabular}{|c|c|c|c|c|c|c|}
\hline \multirow{2}{*}{ Project ID } & \multicolumn{3}{|c|}{ Criteria A } & \multicolumn{2}{c|}{ Criteria B } \\
\cline { 2 - 7 } & CA1 & CA2 & CA3 & CA4 & C B 1 & C B2 \\
\hline CH-ROD-O4 & 0,16 & 0,47 & 0,99 & 0,71 & 2,00 & 0,50 \\
\hline CH-ROD-05 & 0,16 & 0,47 & 0,99 & 0,71 & 2,00 & 0,50 \\
\hline CH-ROD-O6 & 0,16 & 0,47 & 0,99 & 0,71 & 2,00 & 0,50 \\
\hline CH-ROD-O7 & 0,16 & 0,47 & 0,99 & 0,71 & 2,00 & 0,50 \\
\hline CH-ROD-10 & 0,16 & 0,47 & 0,99 & 0,71 & 2,00 & 0,50 \\
\hline CH-ROD-11 & 0,16 & 0,47 & 0,99 & 0,71 & 2,00 & 0,50 \\
\hline CH-ROD-13 & 0,13 & 0,38 & 0,79 & 0,71 & 1,60 & 0,50 \\
\hline CH-ROD-14 & 0,13 & 0,38 & 0,79 & 0,71 & 1,20 & 0,50 \\
\hline CH-ROD-15 & 0,13 & 0,38 & 0,79 & 0,71 & 1,60 & 0,50 \\
\hline CH-ROD-16 & 0,13 & 0,38 & 0,79 & 0,71 & 2,00 & 0,50 \\
\hline
\end{tabular}

\begin{tabular}{|c|c|c|}
\hline Project ID & $\begin{array}{c}\text { Project Total } \\
\text { Scores }\end{array}$ & $\begin{array}{c}\text { Evaluation } \\
\text { Categories }\end{array}$ \\
\hline CH-ROD-O4 & 4,82 & II \\
\hline CH-ROD-O5 & 4,822916667 & II \\
\hline CH-ROD-O6 & 4,822916667 & II \\
\hline CH-ROD-O7 & 4,822916667 & II \\
\hline CH-ROD-10 & 4,822916667 & II \\
\hline CH-ROD-11 & 4,822916667 & II \\
\hline CH-ROD-13 & 4,1 & II \\
\hline CH-ROD-14 & 3,7 & III \\
\hline CH-ROD-15 & 4,1 & II \\
\hline CH-ROD-16 & 4,5 & II \\
\hline
\end{tabular}


Table T-2 Germany (Road projects)

\section{EVALUATION}

1. Answers (based on country's input)

\begin{tabular}{|c|c|c|c|c|c|c|}
\hline \multirow{2}{*}{ Project ID } & \multicolumn{4}{|c|}{ Criteria A } & \multicolumn{2}{c|}{ Criteria B } \\
\cline { 2 - 7 } & CA1 & CA2 & CA3 & CA4 & CB1 & CB2 \\
\hline DEU-ROD-01 & B & E & B & B & D & B \\
\hline DEU-ROD-02 & B & E & B & B & D & D \\
\hline
\end{tabular}

2. Raw scores
\begin{tabular}{|c|c|c|c|c|c|c|}
\hline \multirow{2}{*}{ Project ID } & \multicolumn{9}{c|}{ Criteria A } & \multicolumn{2}{c|}{ Criteria B } \\
\cline { 2 - 7 } & CA1 & CA2 & CA3 & CA4 & CB1 & C 22 \\
\hline DEU-ROD-01 & 4 & 1 & 4 & 4 & 2 & 4 \\
\hline DEU-ROD-02 & 4 & 1 & 4 & 4 & 2 & 2 \\
\hline
\end{tabular}

\begin{tabular}{|c|c|c|c|c|c|c|}
\hline \multirow{3}{*}{ Weights } & \multicolumn{4}{|c|}{ Criteria A } & \multicolumn{2}{c|}{ Criteria B } \\
\cline { 2 - 7 } & WCA1 & WCA2 & WCA3 & WCA4 & WCB1 & WCB2 \\
\cline { 2 - 7 } & $3,13 \%$ & $9,38 \%$ & $19,79 \%$ & $17,71 \%$ & $40,00 \%$ & $10,00 \%$ \\
\hline
\end{tabular}

\section{Weighted scores}

\begin{tabular}{|c|c|c|c|c|c|c|}
\hline \multirow{2}{*}{ Project ID } & \multicolumn{4}{|c|}{ Criteria A } & \multicolumn{2}{c|}{ Criteria B } \\
\cline { 2 - 7 } & CA1 & CA2 & CA3 & CA4 & CB1 & CB2 \\
\hline DEU-ROD-01 & 0,13 & 0,09 & 0,79 & 0,71 & 0,80 & 0,40 \\
\hline DEU-ROD-02 & 0,13 & 0,09 & 0,79 & 0,71 & 0,80 & 0,20 \\
\hline
\end{tabular}

\begin{tabular}{|c|c|c|c|c|c|c|}
\hline \multirow{2}{*}{ Project ID } & Project Total & \multirow{2}{*}{$\begin{array}{l}\text { Evaluation } \\
\text { Scores }\end{array}$} & Categories & \multicolumn{4}{|c|}{ Priorities } \\
\cline { 5 - 7 } & & I & II & III & IV \\
\hline DEU-ROD-01 & 2,91875 & $I V$ & 0 & - & - & IV \\
\hline DEU-ROD-02 & 2,71875 & $I V$ & 0 & - & - & IV \\
\hline
\end{tabular}

Table T-3 Germany (Rail projects)

\section{EVALUATION}

1. Answers (based on country's input)

\begin{tabular}{|c|c|c|c|c|c|c|}
\hline \multirow{2}{*}{ Project ID } & \multicolumn{4}{|c|}{ Criteria A } & \multicolumn{2}{c|}{ Criteria B } \\
\cline { 2 - 7 } & CA1 & CA2 & CA3 & CA4 & CB1 & CB2 \\
\hline DEU-RLW-01 & B & E & B & B & B & C \\
\hline
\end{tabular}

2. Raw scores
\begin{tabular}{|c|c|c|c|c|c|c|}
\hline \multirow{2}{*}{ Project ID } & \multicolumn{3}{c|}{ Criteria A } & \multicolumn{2}{c|}{ Criteria B } \\
\cline { 2 - 8 } & CA1 & CA2 & CA3 & CA4 & CB1 & CB2 \\
\hline DEU-RLW-01 & 4 & 1 & 4 & 4 & 4 & 3 \\
\hline
\end{tabular}

\begin{tabular}{|c|c|c|c|c|c|c|}
\hline \multirow{3}{*}{ Weights } & \multicolumn{4}{|c|}{ Criteria A } & \multicolumn{2}{c|}{ Criteria B } \\
\cline { 2 - 7 } & WCA1 & WCA2 & WCA3 & WCA4 & WCB1 & WCB2 \\
\cline { 2 - 7 } & $3,13 \%$ & $9,38 \%$ & $19,79 \%$ & $17,71 \%$ & $40,00 \%$ & $10,00 \%$ \\
\hline
\end{tabular}

\section{Weighted scores}

\begin{tabular}{|c|c|c|c|c|c|c|}
\hline \multirow{2}{*}{ Project ID } & \multicolumn{4}{|c|}{ Criteria A } & \multicolumn{2}{c|}{ Criteria B } \\
\cline { 2 - 7 } & CA1 & CA2 & CA3 & CA4 & CB1 & CB2 \\
\hline DEU-RLW-01 & 0,13 & 0,09 & 0,79 & 0,71 & 1,60 & 0,30 \\
\hline
\end{tabular}

\begin{tabular}{|c|c|c|c|c|c|c|}
\hline \multirow{2}{*}{ Project ID } & Project Total & Evaluation & \multicolumn{5}{|c|}{ Priorities } \\
\cline { 4 - 7 } & Scores & Categories & I & II & III & IV \\
\hline DEU-RLW-01 & 3,61875 & III & - & - & III & - \\
\hline
\end{tabular}


Table T-4 Pakistan

EVALUATION

1. Answers (based on country's input)

1. Answers (based on country's input)
\begin{tabular}{|c|c|c|c|c|c|c|}
\hline Project ID & CA1 & CA 2 & CA 3 & CA4 & CB1 & Criteria B \\
\cline { 2 - 7 } & A 2 \\
\hline PAK-ROD-01 & A & A & B & B & A & C \\
\hline PAK-ROD-02 & B & B & C & B & A & C \\
\hline PAK-ROD-03 & B & B & C & B & A & D \\
\hline PAK-ROD-07 & B & B & B & C & A & C \\
\hline PAK-ROD-10 & B & B & C & C & A & B \\
\hline PAK-ROD-11 & B & B & C & B & A & C \\
\hline PAK-ROD-12 & B & B & B & B & A & C \\
\hline PAK-ROD-14 & B & B & C & C & A & C \\
\hline PAK-ROD-16 & B & B & B & C & A & C \\
\hline PAK-ROD-19 & B & C & C & B & A & C \\
\hline PAK-ROD-2O & B & C & B & C & A & C \\
\hline
\end{tabular}

2. Raw scores

\begin{tabular}{|c|c|c|c|c|c|c|}
\hline \multirow{2}{*}{ Project ID } & \multicolumn{9}{|c|}{ Criteria A } & \multicolumn{2}{c|}{ Criteria B } \\
\cline { 2 - 7 } & CA1 & CA2 & CA3 & CA4 & CB1 & CB2 \\
\hline PAK-ROD-01 & 5 & 5 & 4 & 4 & 5 & 3 \\
\hline PAK-ROD-O2 & 4 & 4 & 3 & 4 & 5 & 3 \\
\hline PAK-ROD-03 & 4 & 4 & 3 & 4 & 5 & 2 \\
\hline PAK-ROD-07 & 4 & 4 & 4 & 3 & 5 & 3 \\
\hline PAK-ROD-10 & 4 & 4 & 3 & 3 & 5 & 4 \\
\hline PAK-ROD-11 & 4 & 4 & 3 & 4 & 5 & 3 \\
\hline PAK-ROD-12 & 4 & 4 & 4 & 4 & 5 & 3 \\
\hline PAK-ROD-14 & 4 & 4 & 3 & 3 & 5 & 3 \\
\hline PAK-ROD-16 & 4 & 4 & 4 & 3 & 5 & 3 \\
\hline PAK-ROD-19 & 4 & 3 & 3 & 4 & 5 & 3 \\
\hline PAK-ROD-20 & 4 & 3 & 4 & 3 & 5 & 3 \\
\hline
\end{tabular}

\begin{tabular}{|l|c|c|c|c|c|c|}
\hline \multirow{3}{*}{ Weights } & \multicolumn{4}{|c|}{ Criteria A } & \multicolumn{2}{c|}{ Criteria B } \\
\cline { 2 - 6 } & WCA1 & WCA2 & WCA3 & WCA4 & WCB1 & WCB2 \\
\cline { 2 - 6 } & $3,13 \%$ & $9,38 \%$ & $19,79 \%$ & $17,71 \%$ & $40,00 \%$ & $10,00 \%$ \\
\hline
\end{tabular}

3. Weighted scores
\begin{tabular}{|c|c|c|c|c|c|c|}
\hline Project ID & \multicolumn{3}{|c|}{ Criteria A } & \multicolumn{2}{c|}{ Criteria B } \\
\cline { 2 - 7 } & CA1 & CA2 & CA3 & CA4 & CB1 & CB2 \\
\hline PAK-ROD-01 & 0,16 & 0,47 & 0,79 & 0,71 & 2,00 & 0,30 \\
\hline PAK-ROD-02 & 0,13 & 0,38 & 0,59 & 0,71 & 2,00 & 0,30 \\
\hline PAK-ROD-O3 & 0,13 & 0,38 & 0,59 & 0,71 & 2,00 & 0,20 \\
\hline PAK-ROD-07 & 0,13 & 0,38 & 0,79 & 0,53 & 2,00 & 0,30 \\
\hline PAK-ROD-10 & 0,13 & 0,38 & 0,59 & 0,53 & 2,00 & 0,40 \\
\hline PAK-ROD-11 & 0,13 & 0,38 & 0,59 & 0,71 & 2,00 & 0,30 \\
\hline PAK-ROD-12 & 0,13 & 0,38 & 0,79 & 0,71 & 2,00 & 0,30 \\
\hline PAK-ROD-14 & 0,13 & 0,38 & 0,59 & 0,53 & 2,00 & 0,30 \\
\hline PAK-ROD-16 & 0,13 & 0,38 & 0,79 & 0,53 & 2,00 & 0,30 \\
\hline PAK-ROD-19 & 0,13 & 0,28 & 0,59 & 0,71 & 2,00 & 0,30 \\
\hline PAK-ROD-20 & 0,13 & 0,28 & 0,79 & 0,53 & 2,00 & 0,30 \\
\hline
\end{tabular}

\begin{tabular}{|c|c|c|}
\hline Project ID & $\begin{array}{c}\text { Project Total } \\
\text { Scores }\end{array}$ & $\begin{array}{c}\text { Evaluation } \\
\text { Categories }\end{array}$ \\
\hline PAK-ROD-01 & 4,425 & II \\
\hline PAK-ROD-02 & 4,102083333 & II \\
\hline PAK-ROD-03 & 4,002083333 & II \\
\hline PAK-ROD-07 & 4,122916667 & II \\
\hline PAK-ROD-10 & 4,025 & II \\
\hline PAK-ROD-1 1 & 4,102083333 & II \\
\hline PAK-ROD-12 & 4,3 & II \\
\hline PAK-ROD-14 & 3,925 & III \\
\hline PAK-ROD-16 & 4,122916667 & $I I$ \\
\hline PAK-ROD-19 & 4,008333333 & $I I$ \\
\hline PAK-ROD-20 & 4,029166667 & $I I$ \\
\hline
\end{tabular}


Table T-5 The former Yugoslav Republic of Macedonia

\section{EVALUATION}

1. Answers (based on country's input)

\begin{tabular}{|c|c|c|c|c|c|c|}
\hline \multirow{2}{*}{ Project ID } & \multicolumn{9}{|c|}{ Criteria A } & \multicolumn{2}{c|}{ Criteria B } \\
\cline { 2 - 7 } & CA1 & CA2 & CA3 & CA4 & CB1 & CB2 \\
\hline FYROM-RLW-01 & A & A & A & A & A & A \\
\hline FYROM-RLW-02 & A & A & A & A & A & A \\
\hline FYROM-RLW-03 & A & A & A & A & A & A \\
\hline FYROM-RLW-04 & A & A & A & A & B & A \\
\hline
\end{tabular}

\begin{tabular}{|c|c|c|c|c|c|c|}
\hline \multicolumn{7}{|l|}{ 2. Raw scores } \\
\hline \multirow{2}{*}{ Project ID } & \multicolumn{4}{|c|}{ Criteria A } & \multicolumn{2}{|c|}{ Criteria B } \\
\hline & CA1 & $\overline{C A 2}$ & CA3 & CA4 & CB1 & CB2 \\
\hline \begin{tabular}{|l|l} 
FYROM-RLW-O \\
\end{tabular} & 5 & 5 & 5 & 5 & 5 & 5 \\
\hline \begin{tabular}{|l|} 
FYROM-RLW-02 \\
\end{tabular} & 5 & 5 & 5 & 5 & 5 & 5 \\
\hline $\begin{array}{l}\text { FYROM-RLW-03 } \\
\end{array}$ & 5 & 5 & 5 & 5 & 5 & 5 \\
\hline \begin{tabular}{|l|l} 
FYROM-RLW-04 \\
\end{tabular} & 5 & 5 & 5 & 5 & 4 & 5 \\
\hline
\end{tabular}

\begin{tabular}{|c|c|c|c|c|c|c|}
\hline \multirow{3}{*}{ Weights } & \multicolumn{4}{|c|}{ Criteria A } & \multicolumn{2}{c|}{ Criteria B } \\
\cline { 2 - 7 } & WCA1 & WCA2 & WCA3 & WCA4 & WCB1 & WCB2 \\
\cline { 2 - 7 } & $3,13 \%$ & $9,38 \%$ & $19,79 \%$ & $17,71 \%$ & $40,00 \%$ & $10,00 \%$ \\
\hline
\end{tabular}

\section{Weighted scores}

\begin{tabular}{|c|c|c|c|c|c|c|}
\hline \multirow{2}{*}{ Project ID } & \multicolumn{4}{|c|}{ Criteria A } & \multicolumn{2}{|c|}{ Criteria B } \\
\hline & CAI & CA2 & CA3 & CA4 & CB1 & CB2 \\
\hline FYROM-RLW-01 & 0,16 & 0,47 & 0,99 & 0,89 & 2,00 & 0,50 \\
\hline FYROM-RLW-02 & 0,16 & 0,47 & 0,99 & 0,89 & 2,00 & 0,50 \\
\hline FYROM-RLW-03 & 0,16 & 0,47 & 0,99 & 0,89 & 2,00 & 0,50 \\
\hline FYROM-RLW-04 & 0,16 & 0,47 & 0,99 & 0,89 & 1,60 & 0,50 \\
\hline
\end{tabular}

\begin{tabular}{|c|c|c|}
\hline Project ID & $\begin{array}{c}\text { Project Total } \\
\text { Scores }\end{array}$ & $\begin{array}{c}\text { Evaluation } \\
\text { Categories }\end{array}$ \\
\hline $\begin{array}{c}\text { FYROM- } \\
\text { RLW-01 }\end{array}$ & 5 & il \\
\hline $\begin{array}{l}\text { FYROM- } \\
\text { RLW-02 }\end{array}$ & 5 & $\|$ \\
\hline $\begin{array}{l}\text { FYROM- } \\
\text { RLW-03 }\end{array}$ & 5 & $\|$ \\
\hline $\begin{array}{l}\text { FYROM- } \\
\text { RLW-04 }\end{array}$ & 4,6 & $\|$ \\
\hline
\end{tabular}


Table T-6 Turkey

EVALUATION

1. Answers (based on country's input)

\begin{tabular}{|c|c|c|c|c|c|c|}
\hline \multirow{2}{*}{ Project ID } & \multicolumn{9}{|c|}{ Criteria A } & \multicolumn{2}{c|}{ Criteria B } \\
\cline { 2 - 7 } & CA1 & CA2 & CA3 & CA4 & CB1 & CB2 \\
\hline TUR-ROD-01 & A & A & A & A & B & A \\
\hline TUR-ROD-02 & A & A & A & A & B & A \\
\hline TUR-ROD-03 & A & A & A & A & B & A \\
\hline
\end{tabular}

2. Raw scores

\begin{tabular}{|c|c|c|c|c|c|c|}
\hline \multirow{2}{*}{ Project ID } & \multicolumn{5}{|c|}{ Criteria A } & \multicolumn{2}{c|}{ Criteria B } \\
\cline { 2 - 7 } & CA1 & CA2 & CA3 & CA4 & CB1 & CB2 \\
\hline TUR-ROD-01 & 5 & 5 & 5 & 5 & 4 & 5 \\
\hline TUR-ROD-02 & 5 & 5 & 5 & 5 & 4 & 5 \\
\hline TUR-ROD-03 & 5 & 5 & 5 & 5 & 4 & 5 \\
\hline
\end{tabular}

\begin{tabular}{|c|c|c|c|c|c|c|}
\hline \multirow{3}{*}{ Weights } & \multicolumn{4}{|c|}{ Criteria A } & \multicolumn{2}{c|}{ Criteria B } \\
\cline { 2 - 7 } & WCA1 & WCA2 & WCA3 & WCA4 & WCB1 & WCB2 \\
\cline { 2 - 7 } & $3,13 \%$ & $9,38 \%$ & $19,79 \%$ & $17,71 \%$ & $40,00 \%$ & $10,00 \%$ \\
\hline
\end{tabular}

3. Weighted scores

\begin{tabular}{|c|c|c|c|c|c|c|}
\hline \multirow{2}{*}{ Project ID } & \multicolumn{4}{|c|}{ Criteria A } & \multicolumn{2}{c|}{ Criteria B } \\
\cline { 2 - 7 } & CA1 & CA2 & CA3 & CA4 & CB1 & CB2 \\
\hline TUR-ROD-01 & 0,16 & 0,47 & 0,99 & 0,89 & 1,60 & 0,50 \\
\hline TUR-ROD-02 & 0,16 & 0,47 & 0,99 & 0,89 & 1,60 & 0,50 \\
\hline TUR-ROD-03 & 0,16 & 0,47 & 0,99 & 0,89 & 1,60 & 0,50 \\
\hline
\end{tabular}

\begin{tabular}{|c|c|c|c|c|c|c|}
\hline \multirow{2}{*}{ Project ID } & Project & Evaluation & \multicolumn{5}{|c|}{ Priorities } \\
\cline { 4 - 7 } & Total & Categories & I & II & III & IV \\
\hline $\begin{array}{c}\text { TUR-ROD- } \\
\text { O1 }\end{array}$ & 4,6 & $\|$ & - & II & - & - \\
\hline $\begin{array}{c}\text { TUR-ROD- } \\
\text { O2 }\end{array}$ & 4,6 & $\|$ & - & $\|$ & - & - \\
\hline $\begin{array}{c}\text { TUR-ROD- } \\
\text { O3 }\end{array}$ & 4,6 & $\|$ & - & $\|$ & - & - \\
\hline
\end{tabular}




\section{Appendix 4.5}

Project Maps Road and Rail

ROAD 


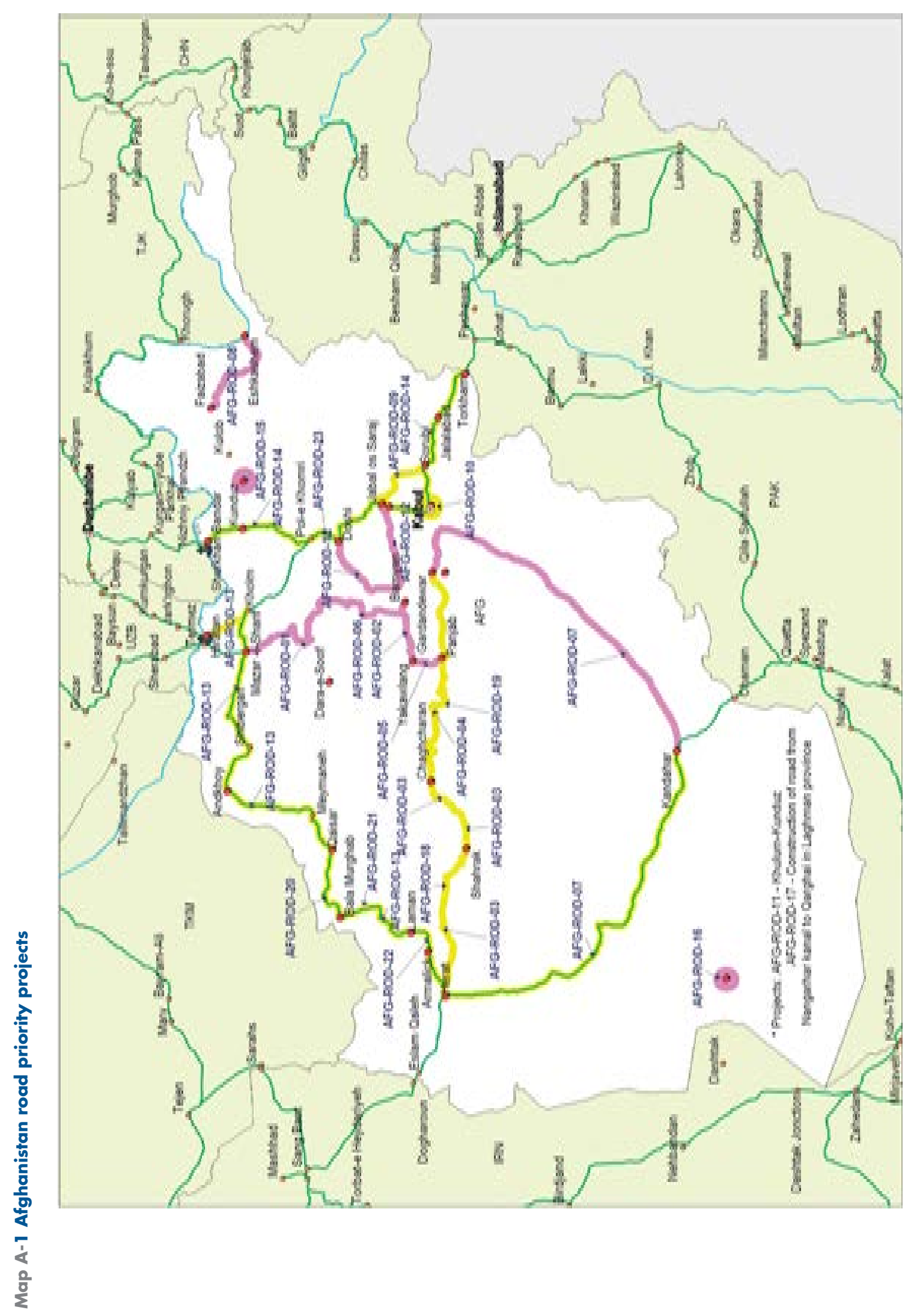




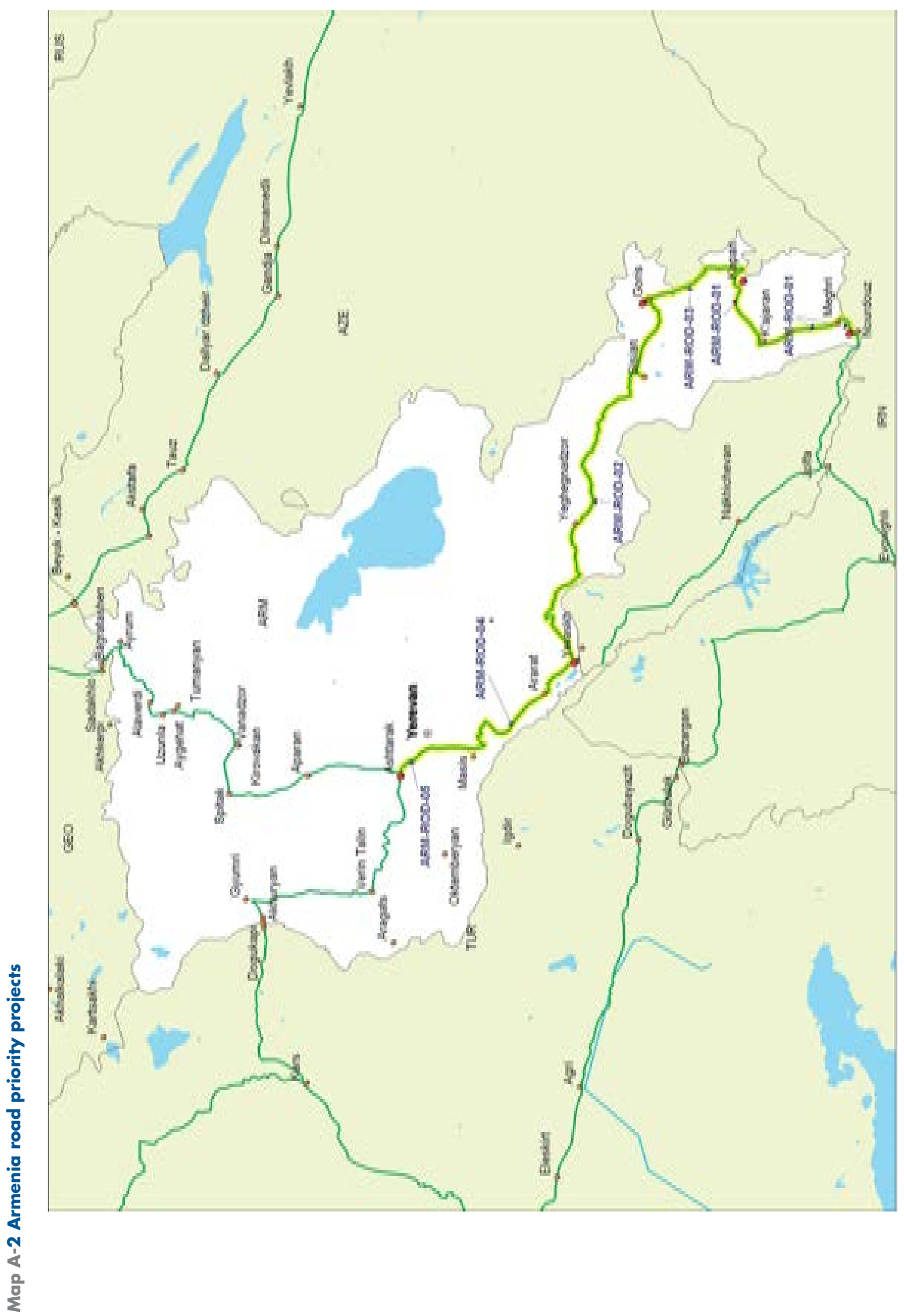




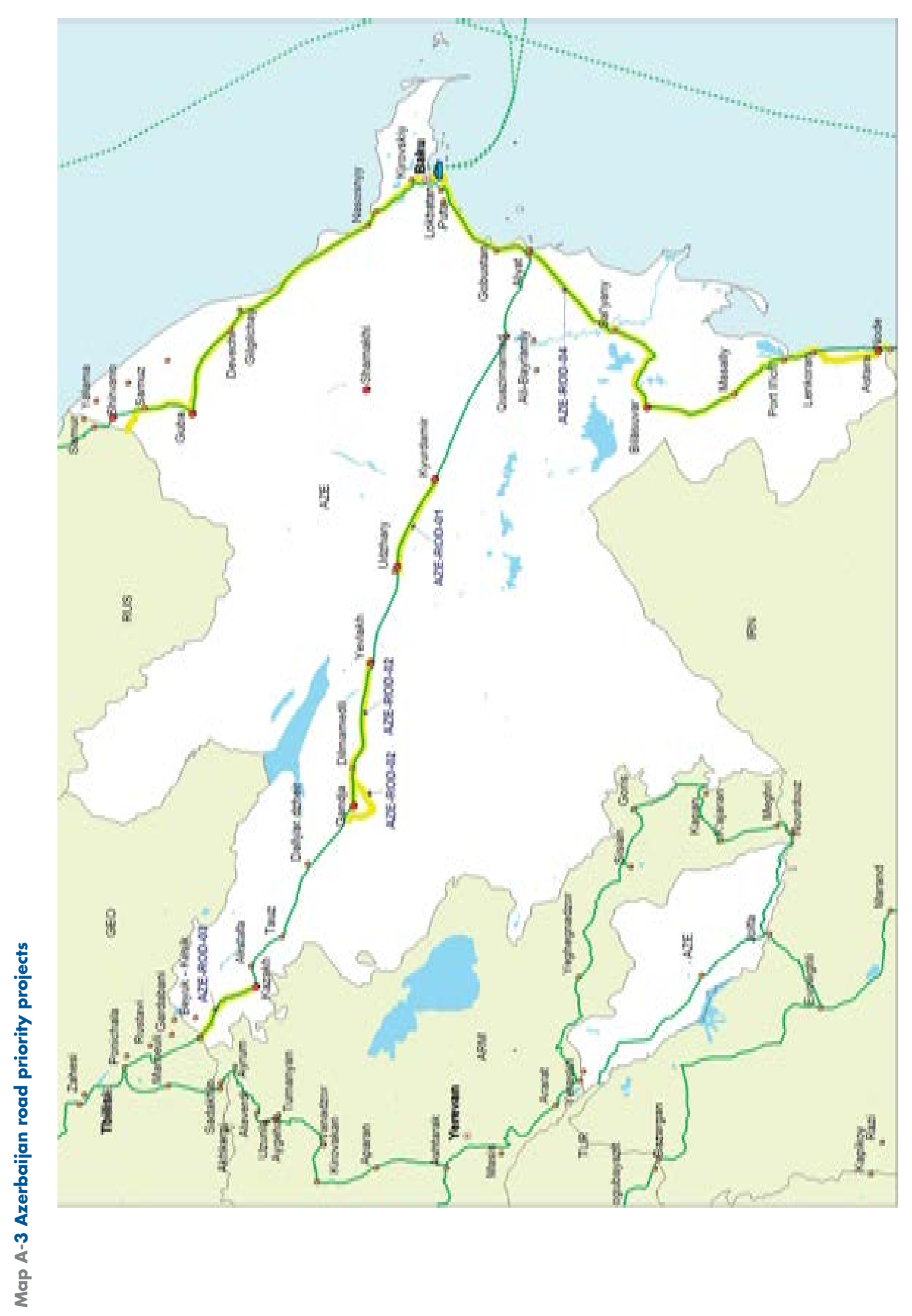




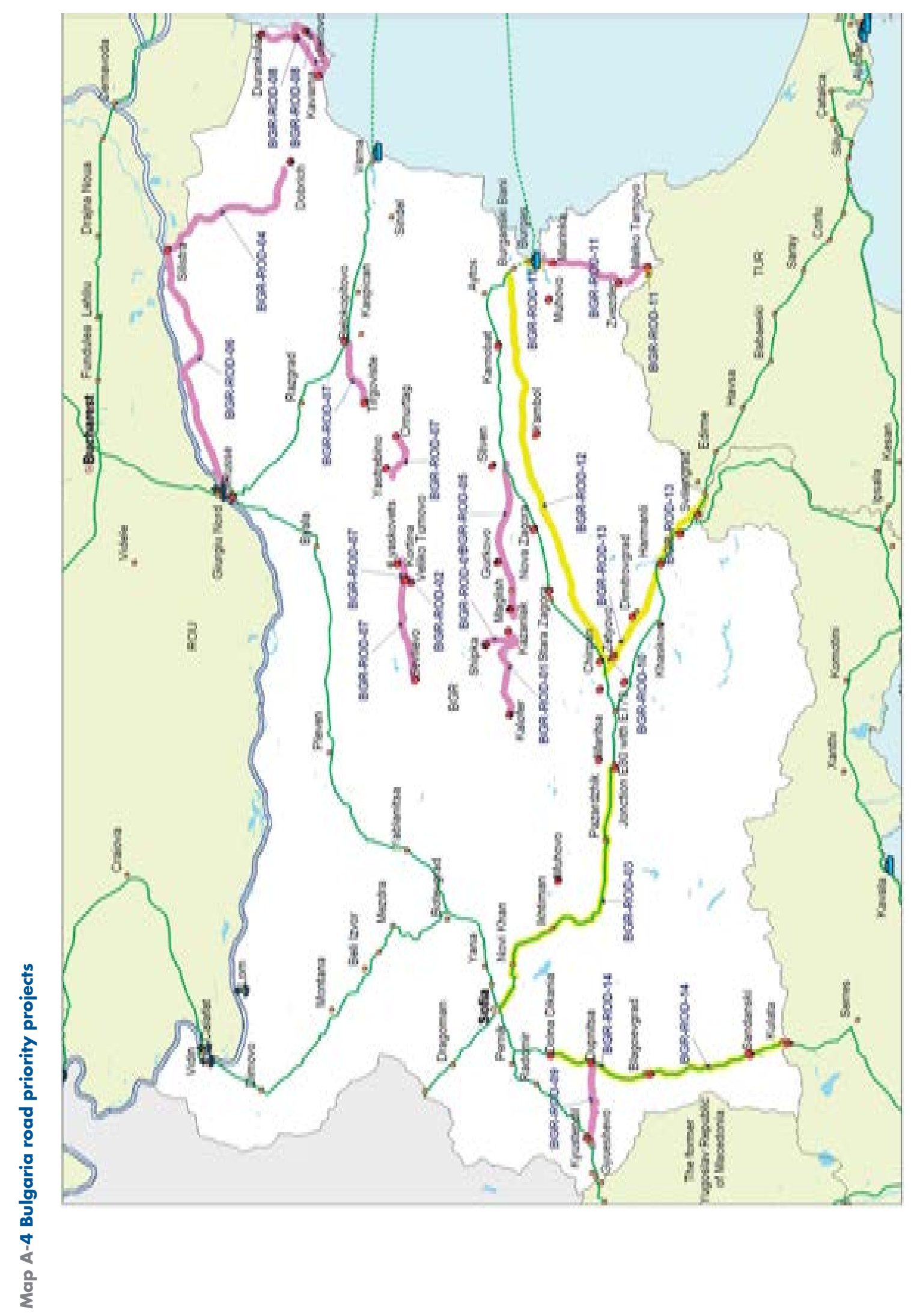




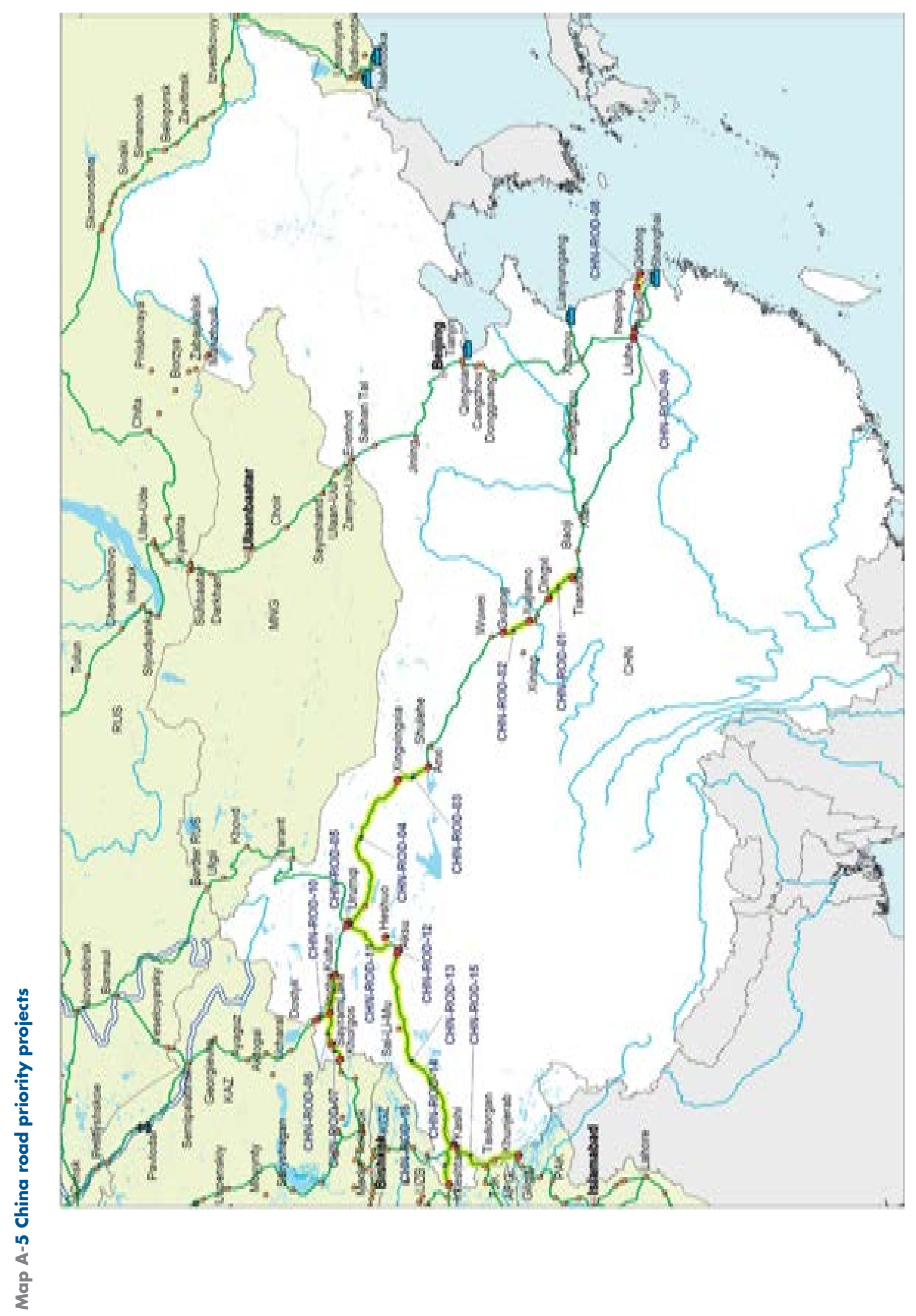




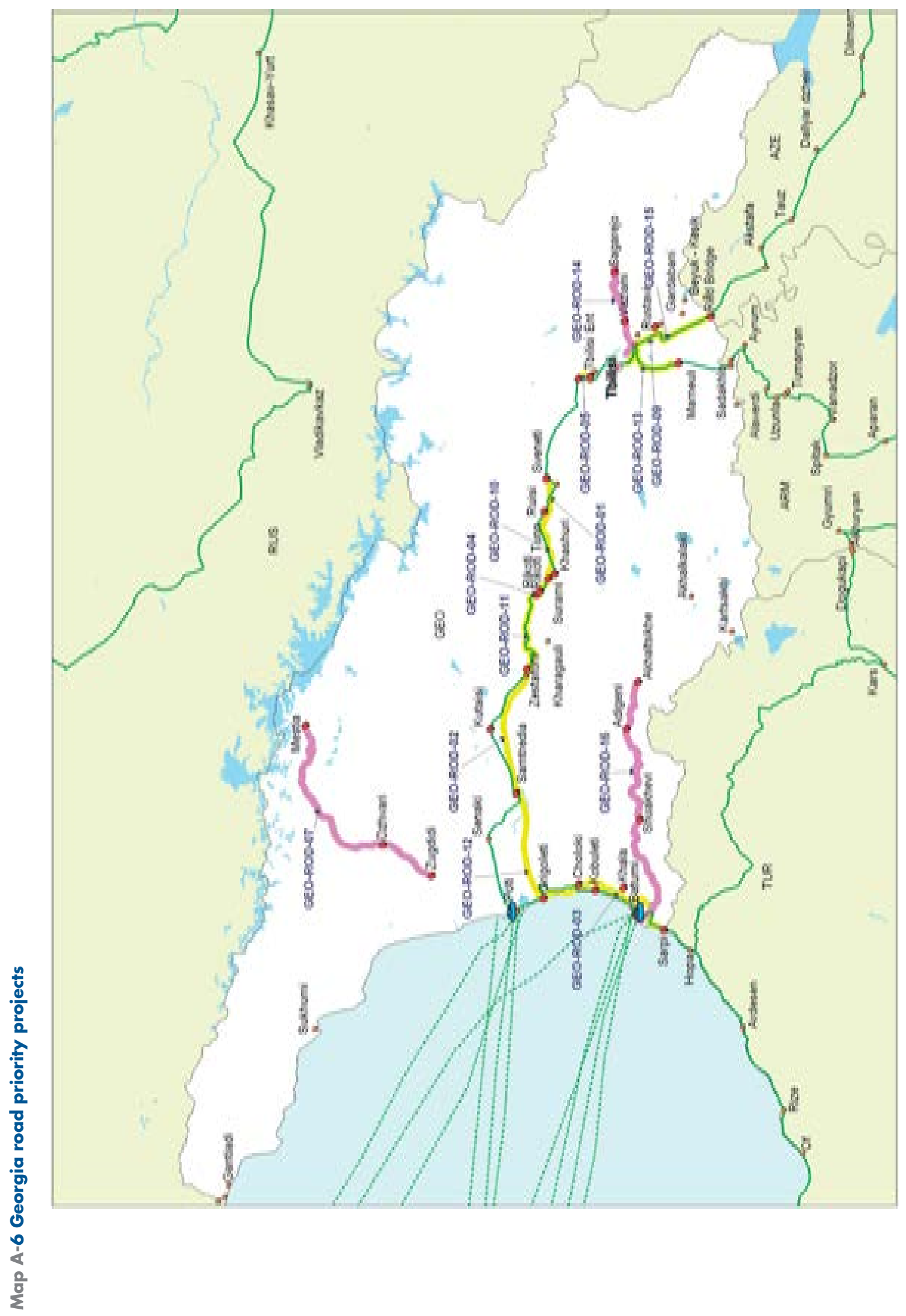




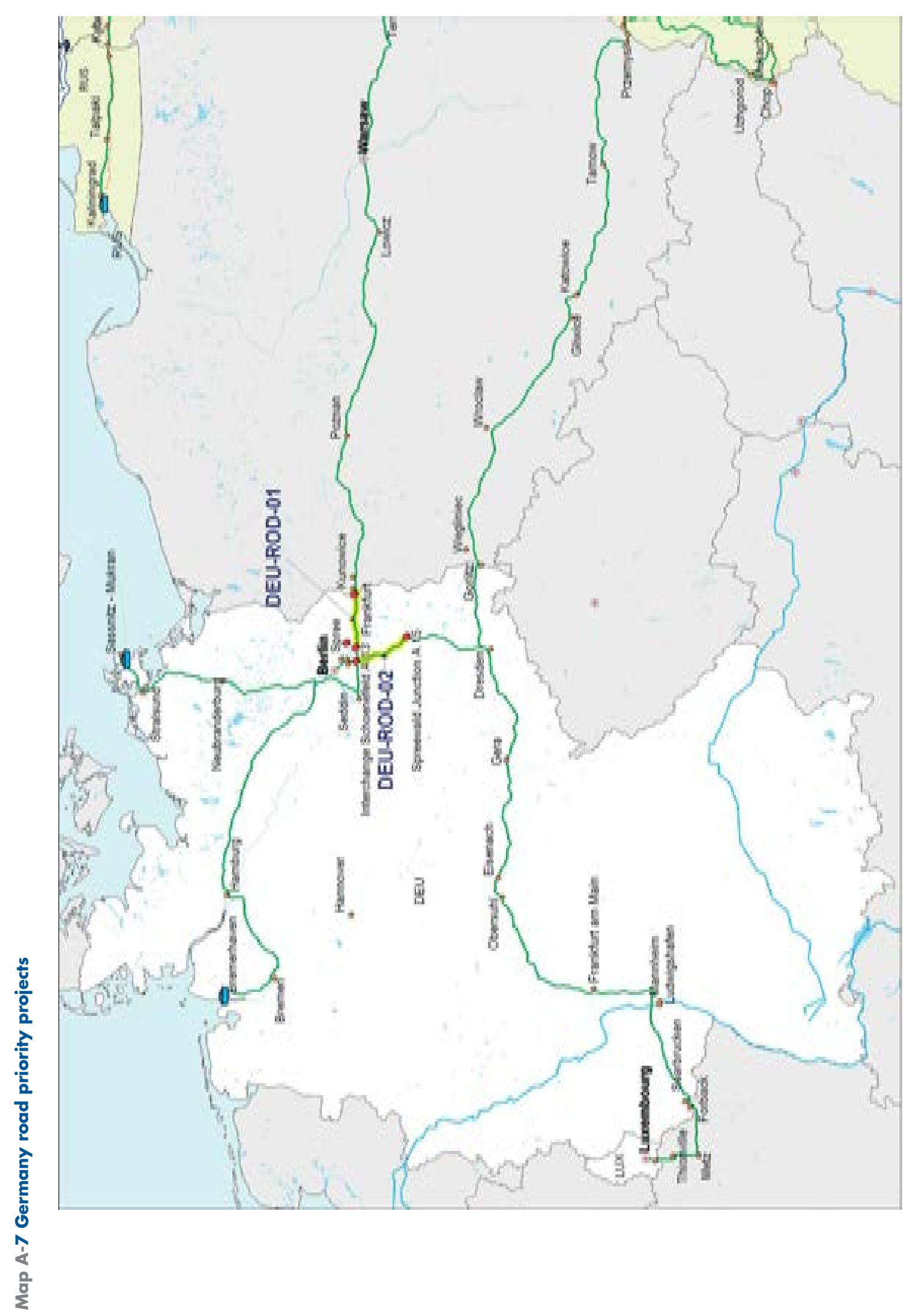




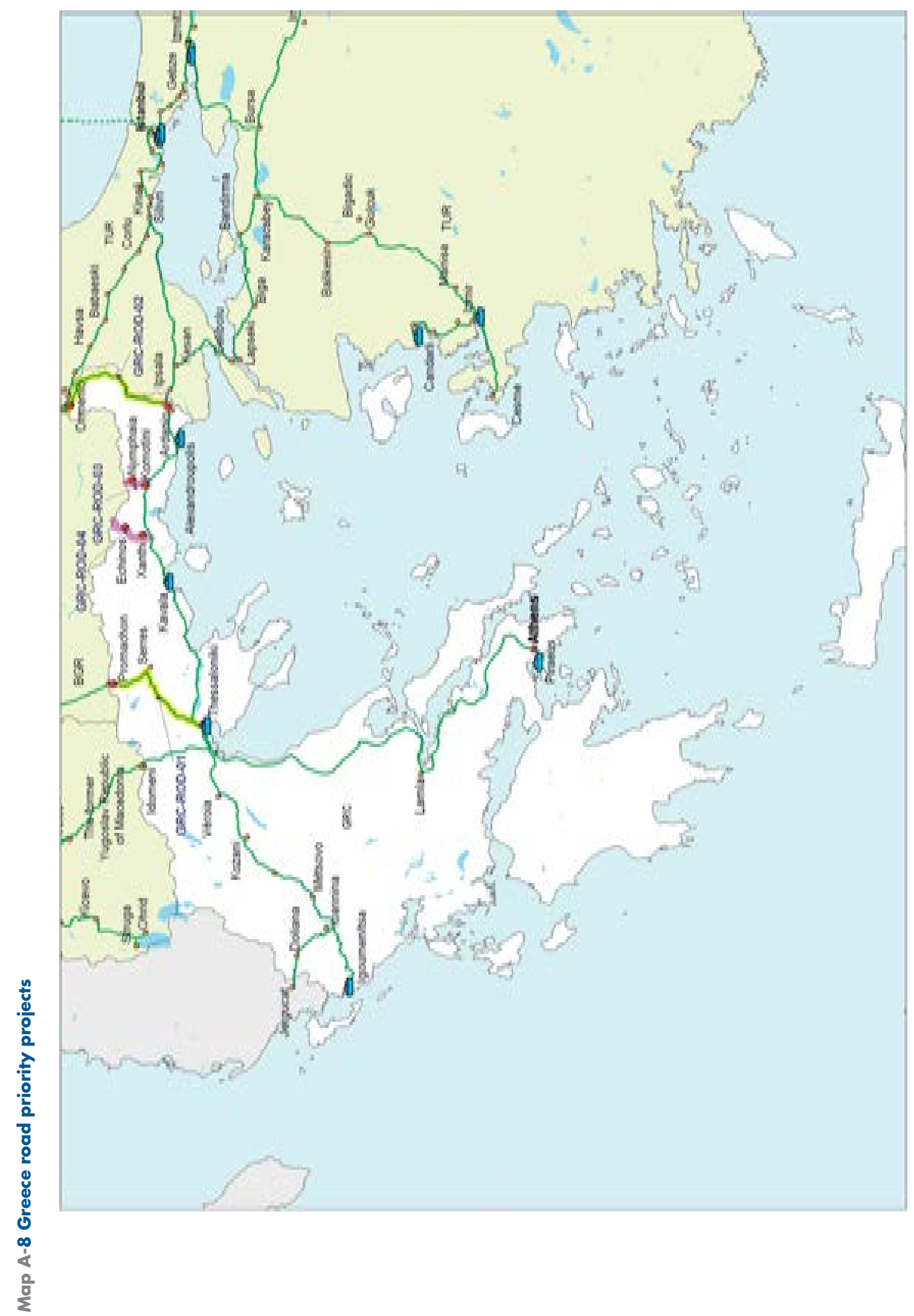




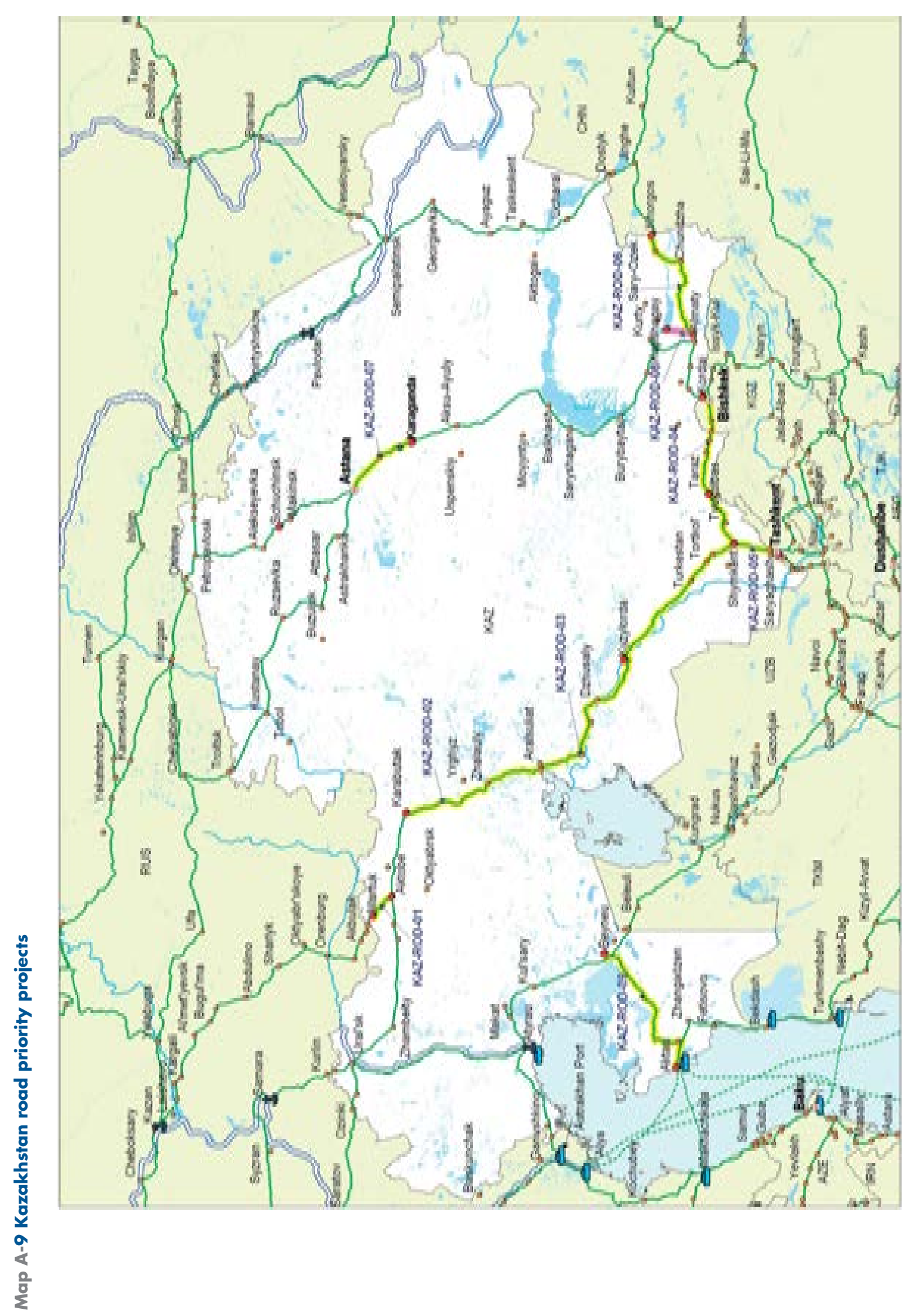




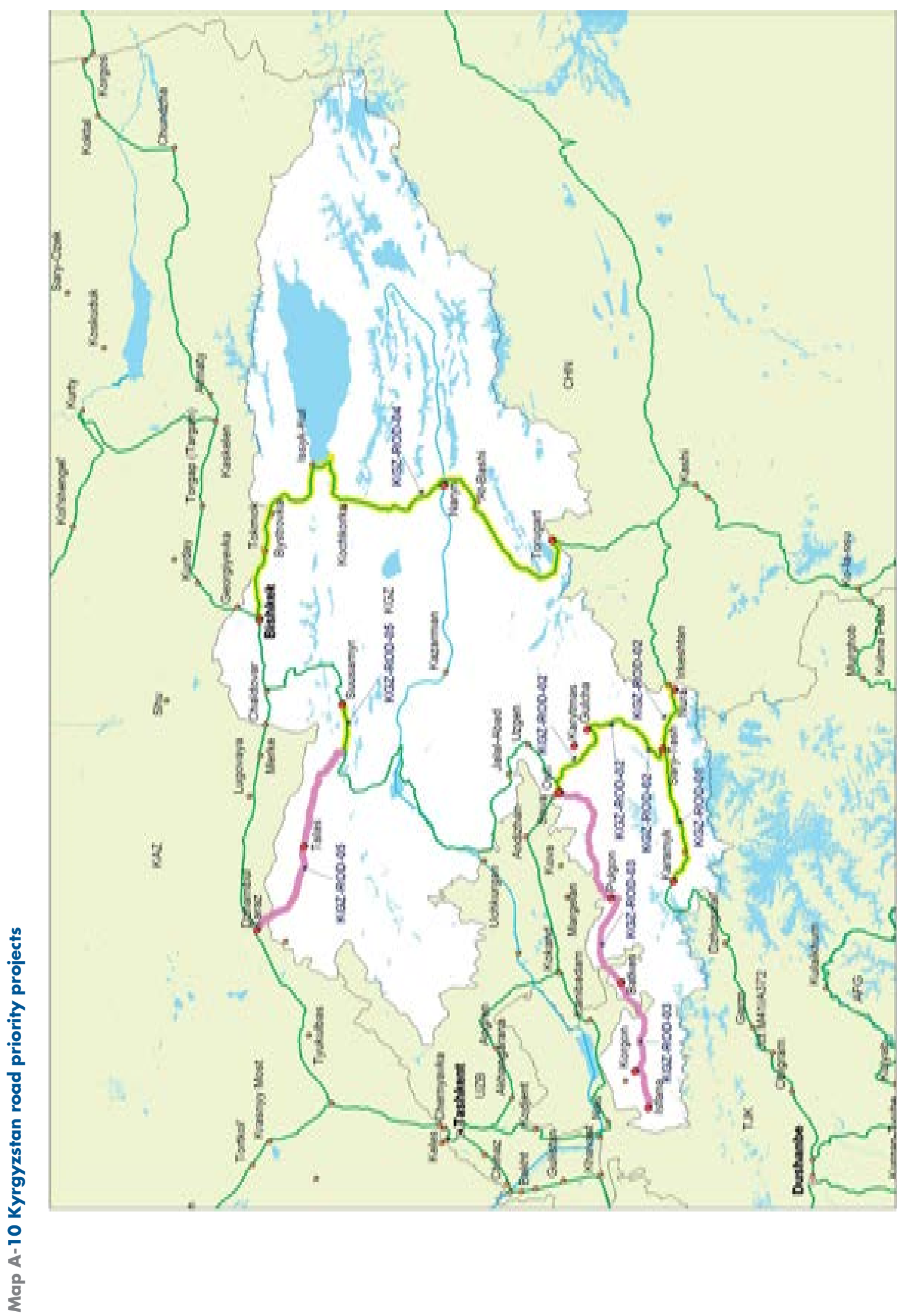




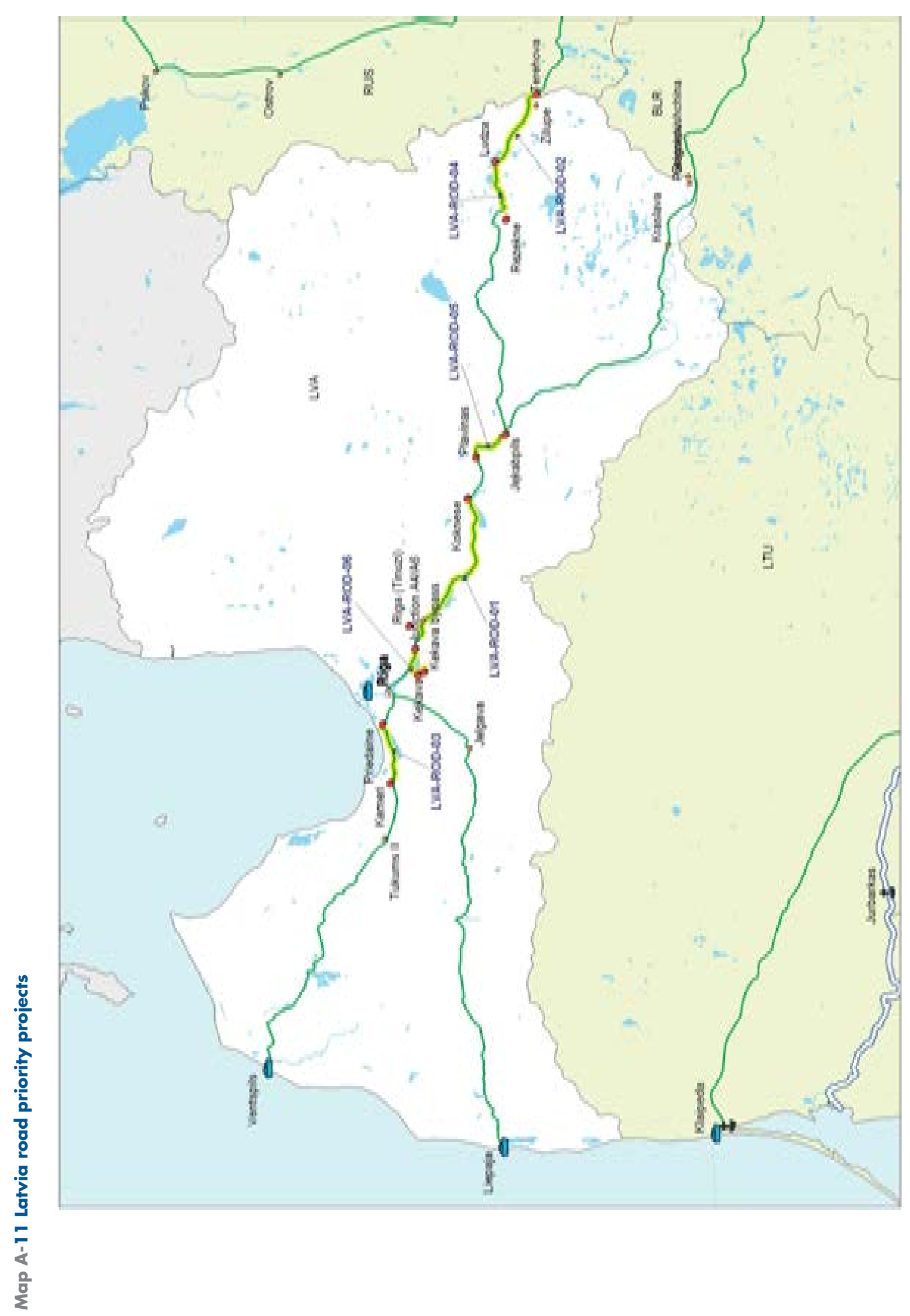




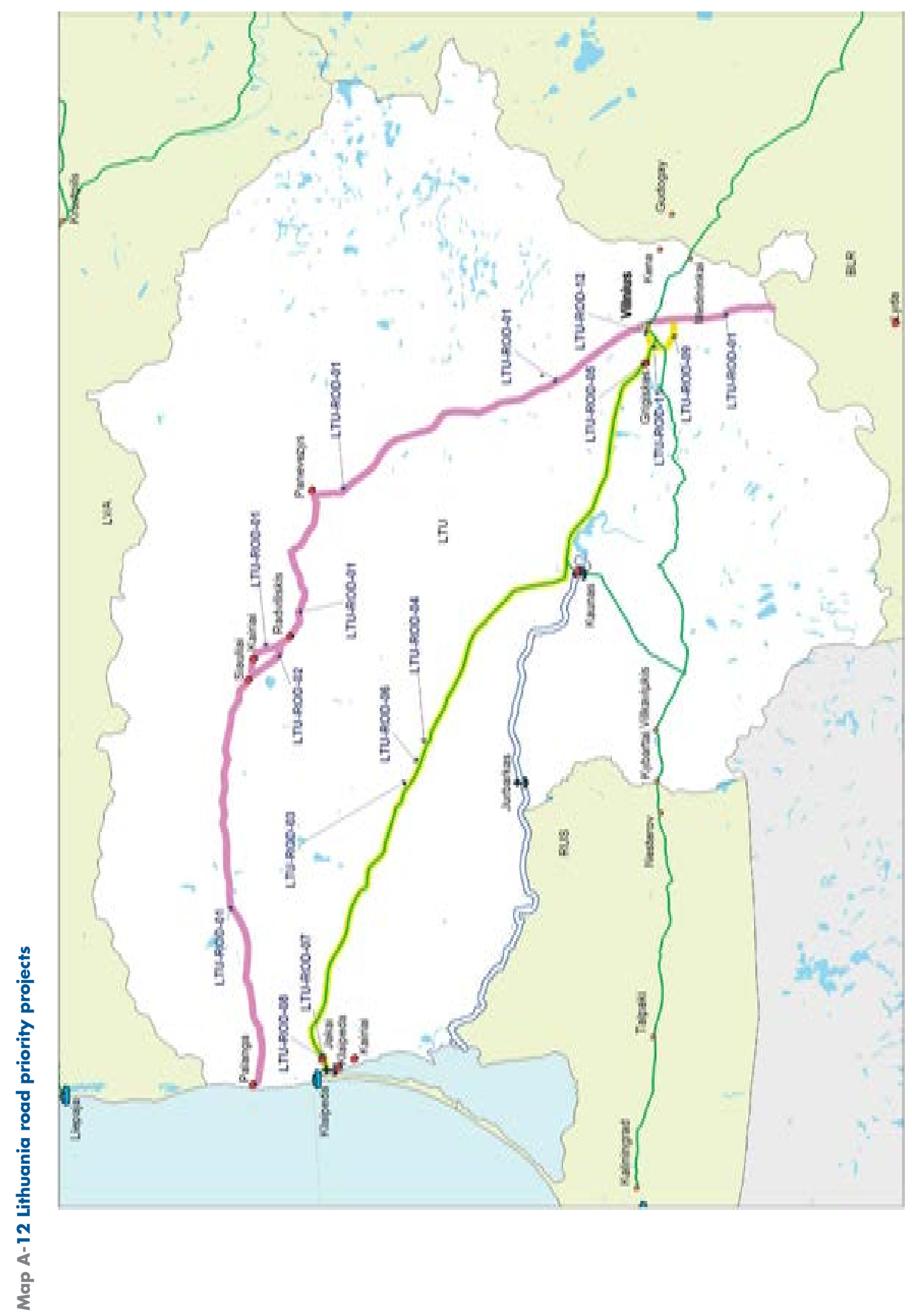




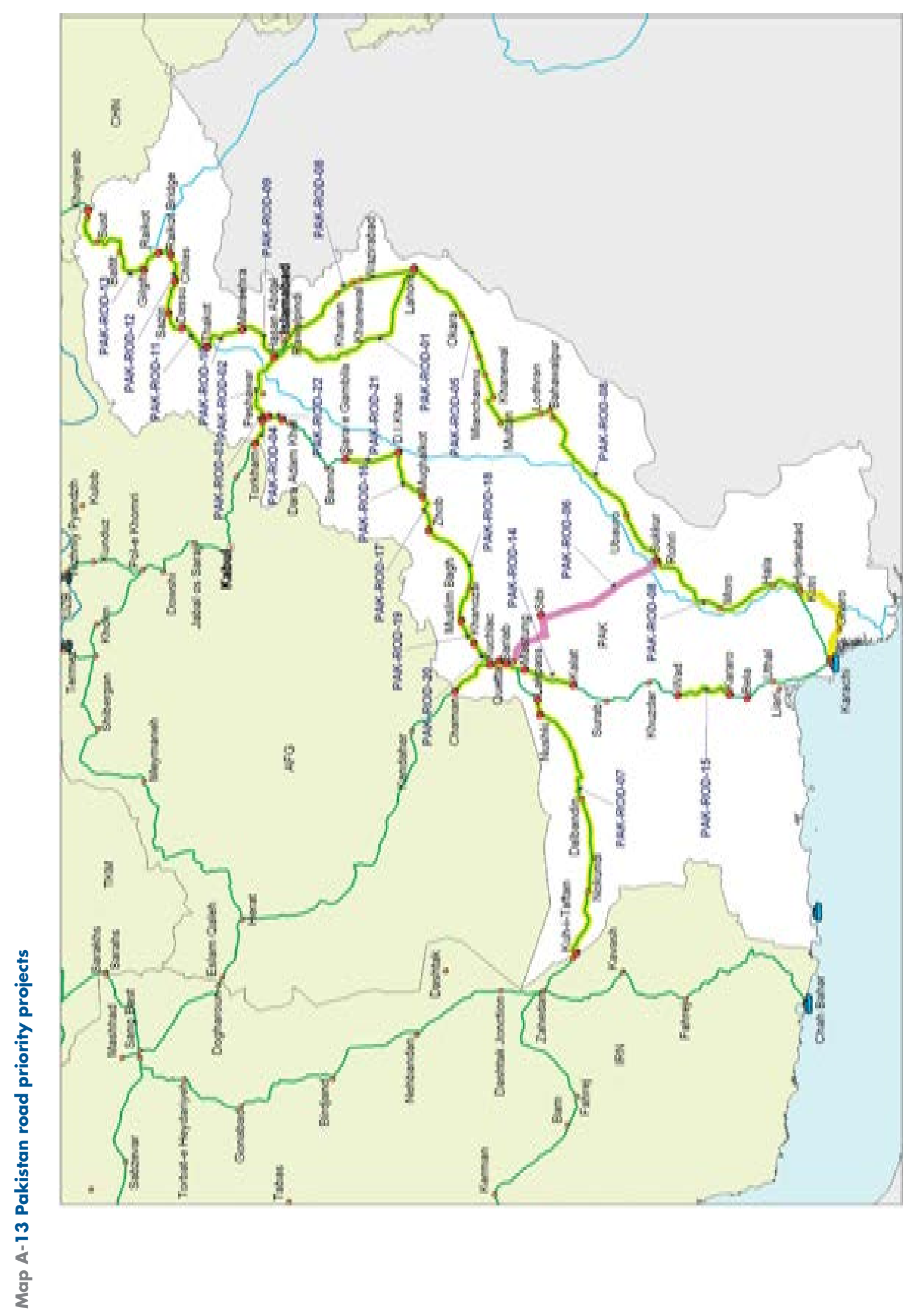




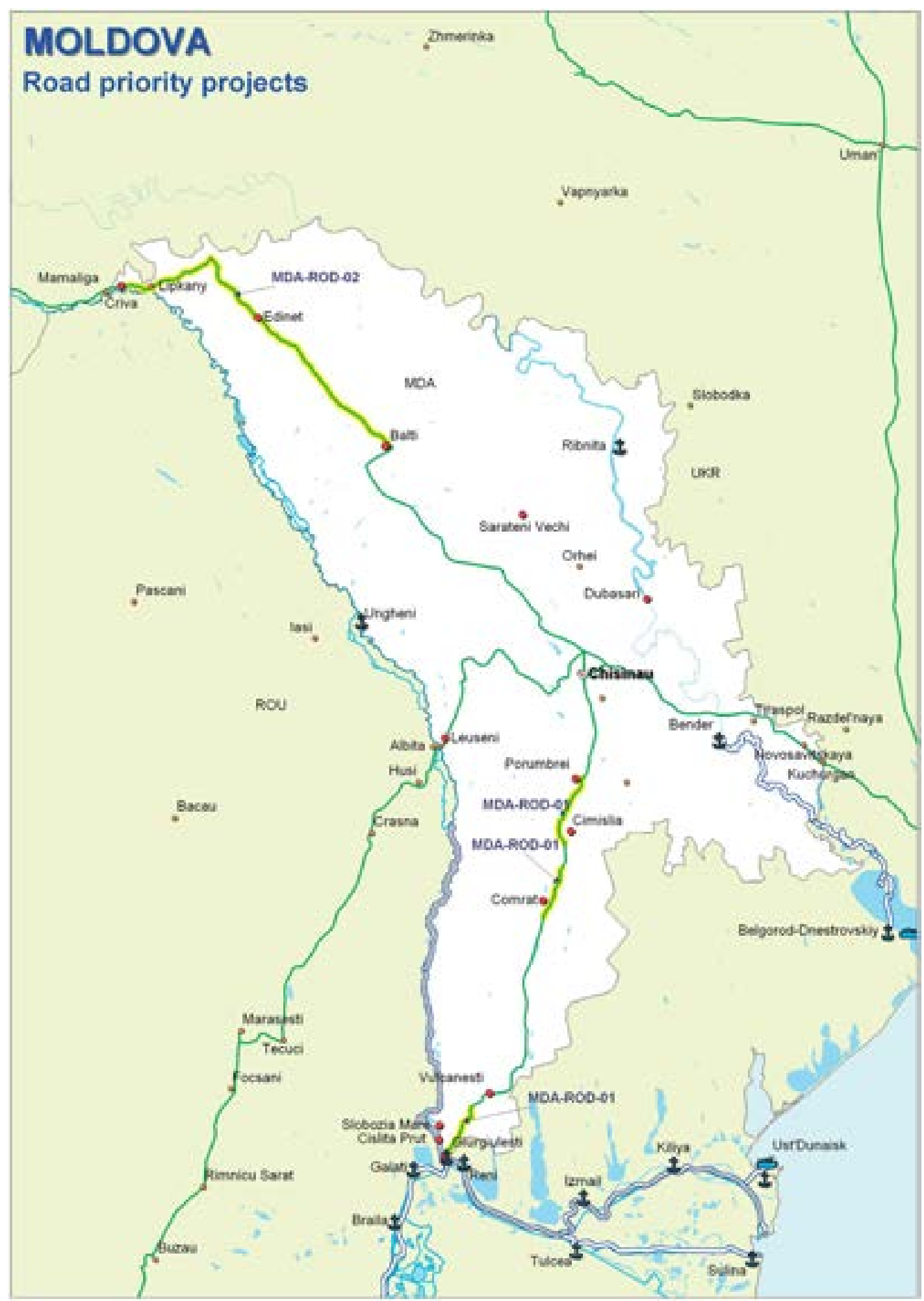




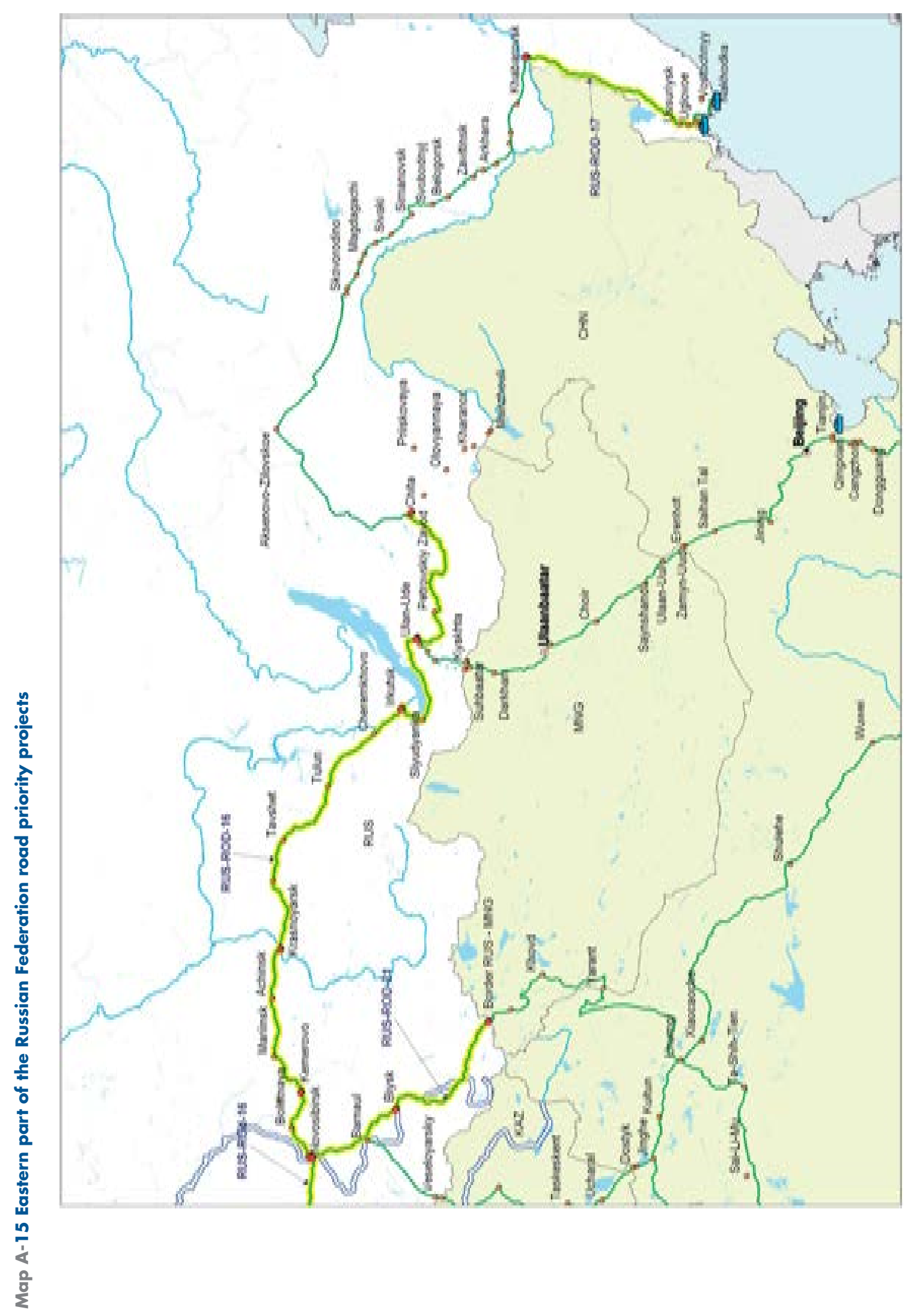




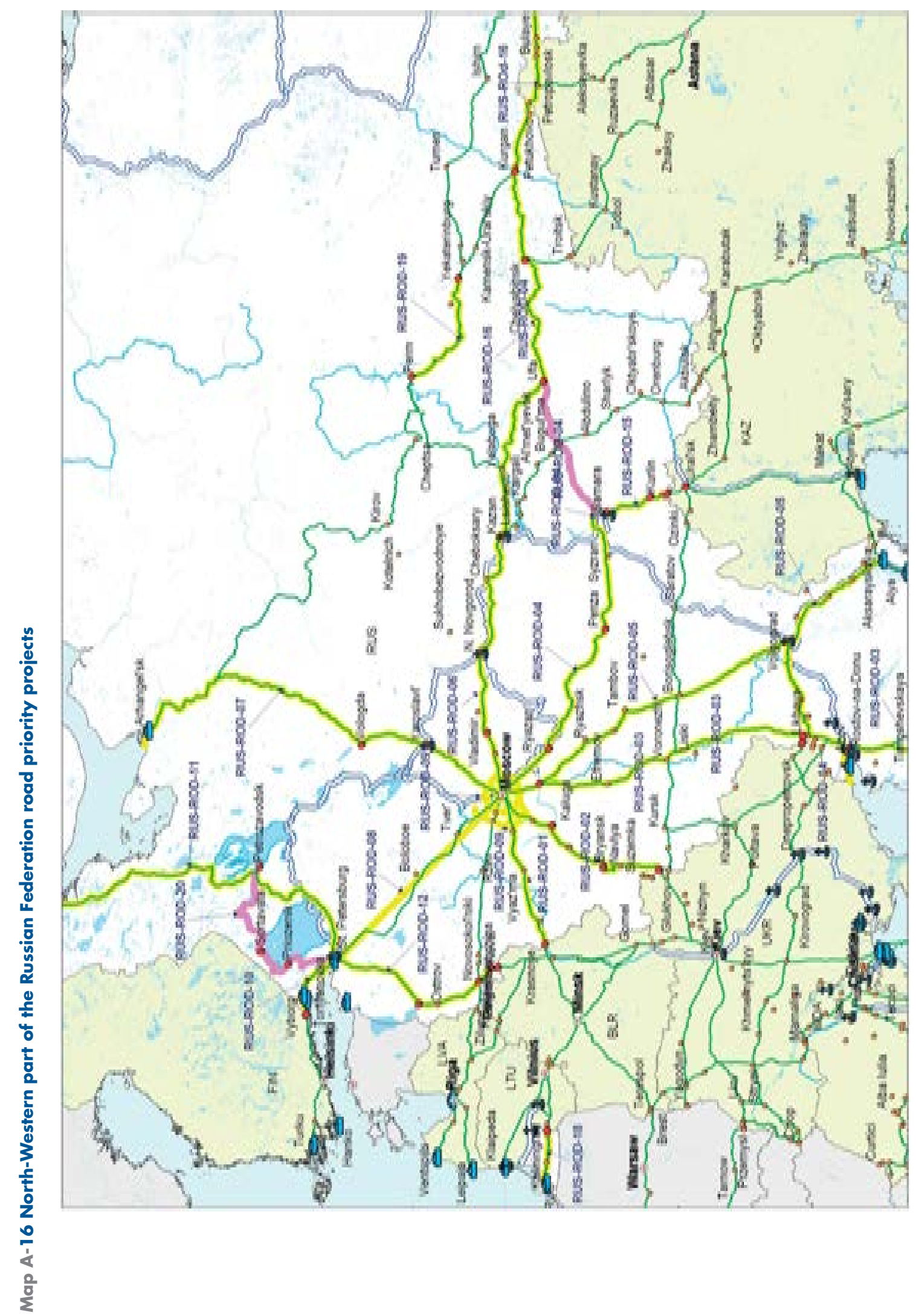




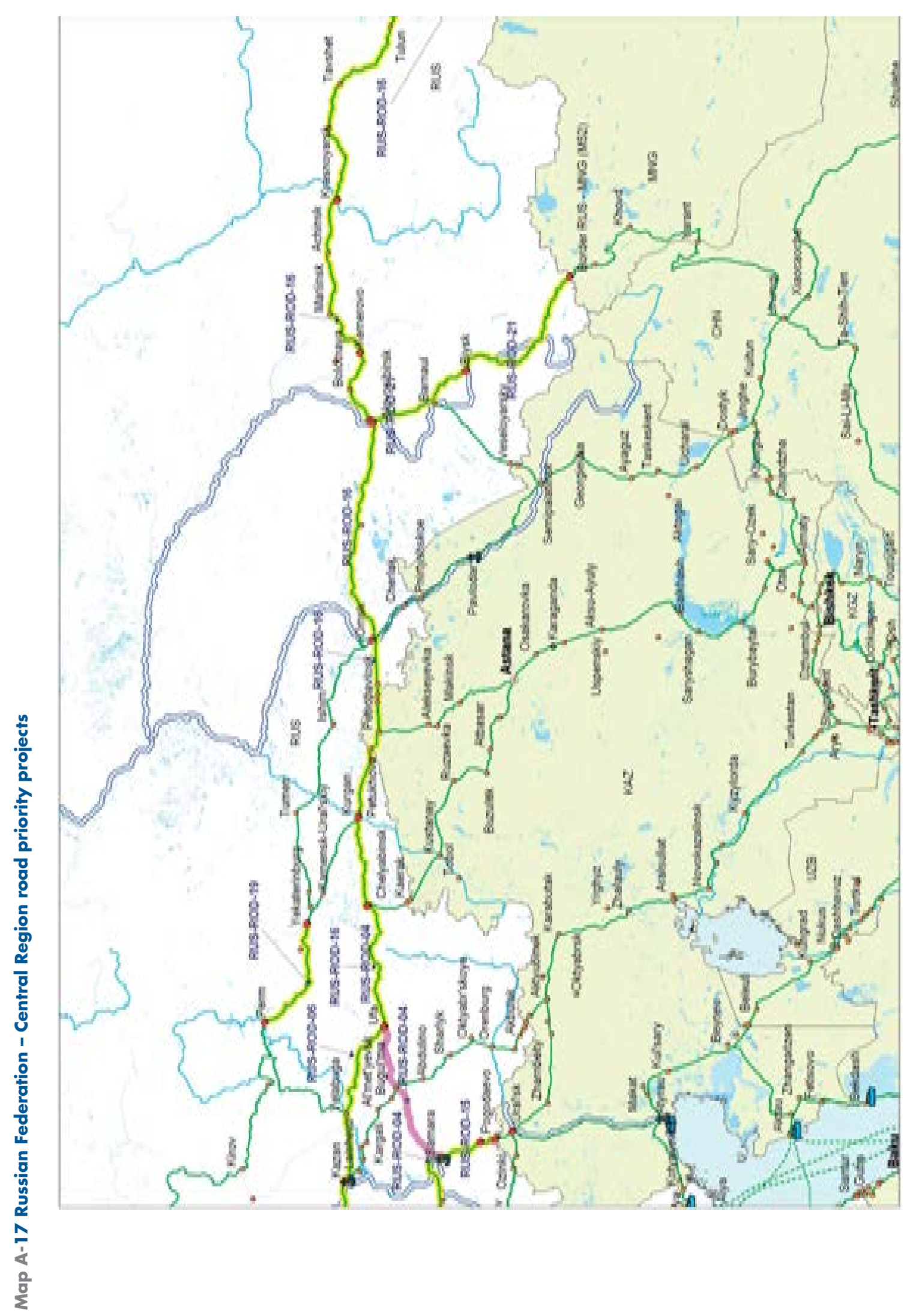

400 


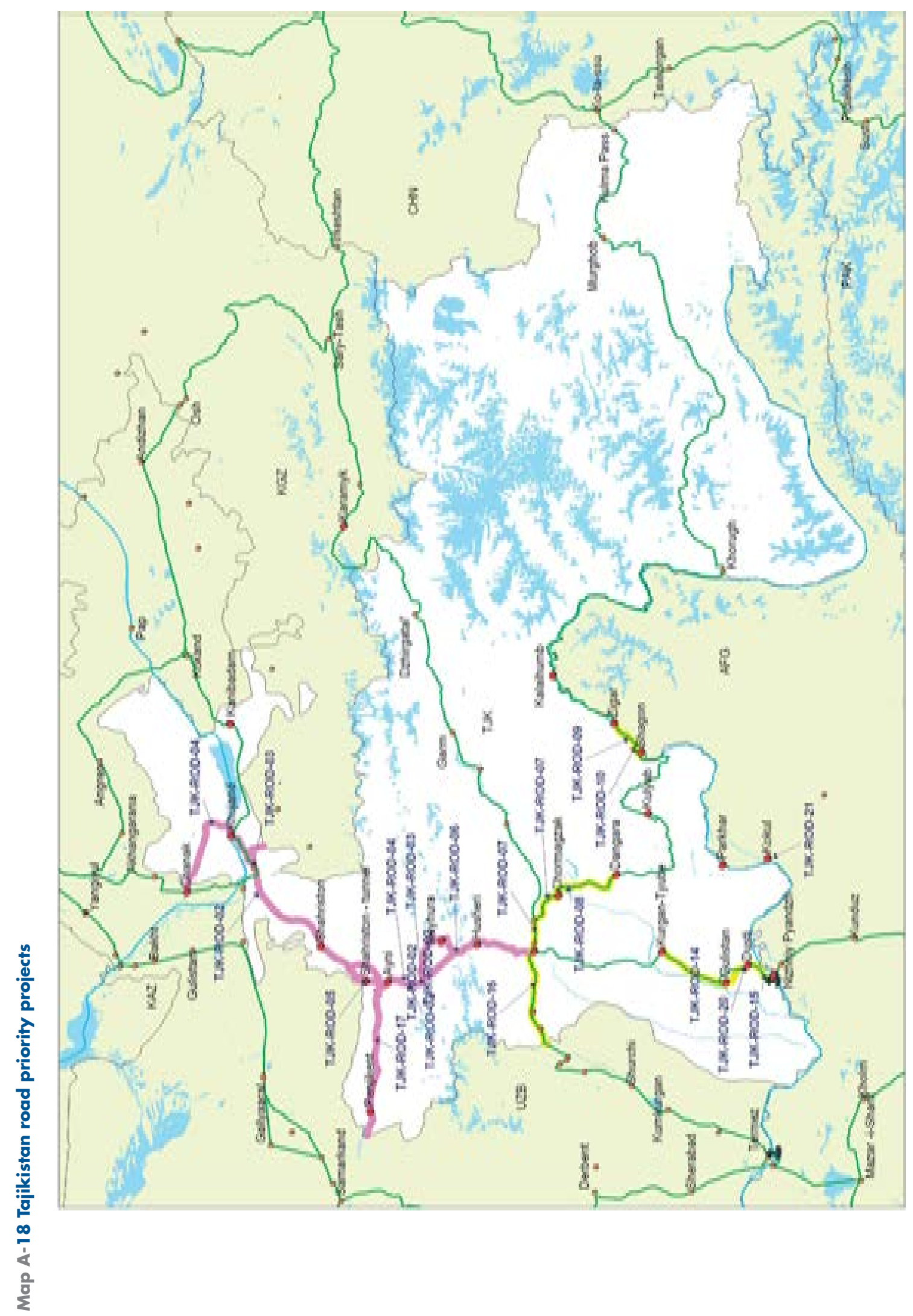




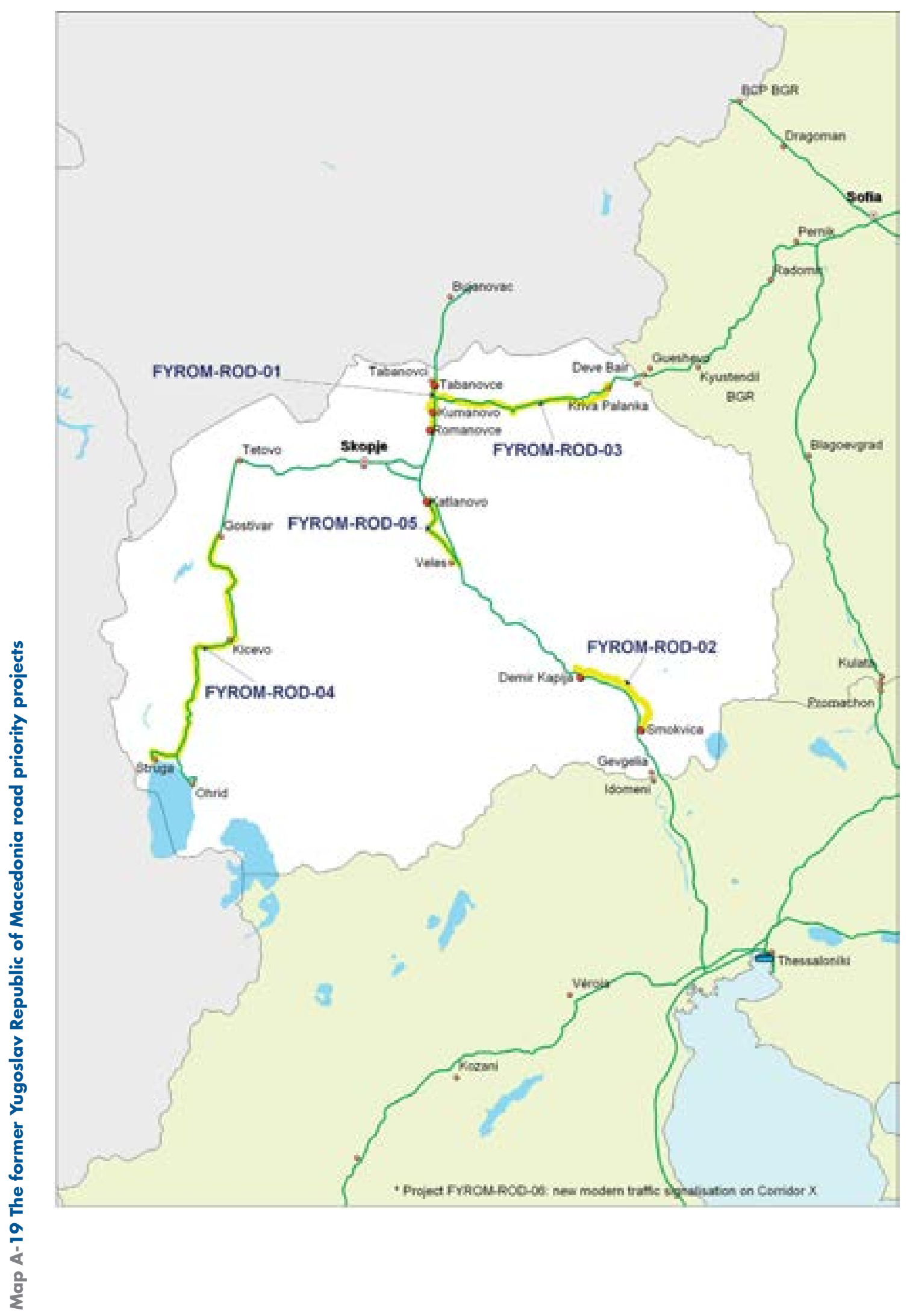




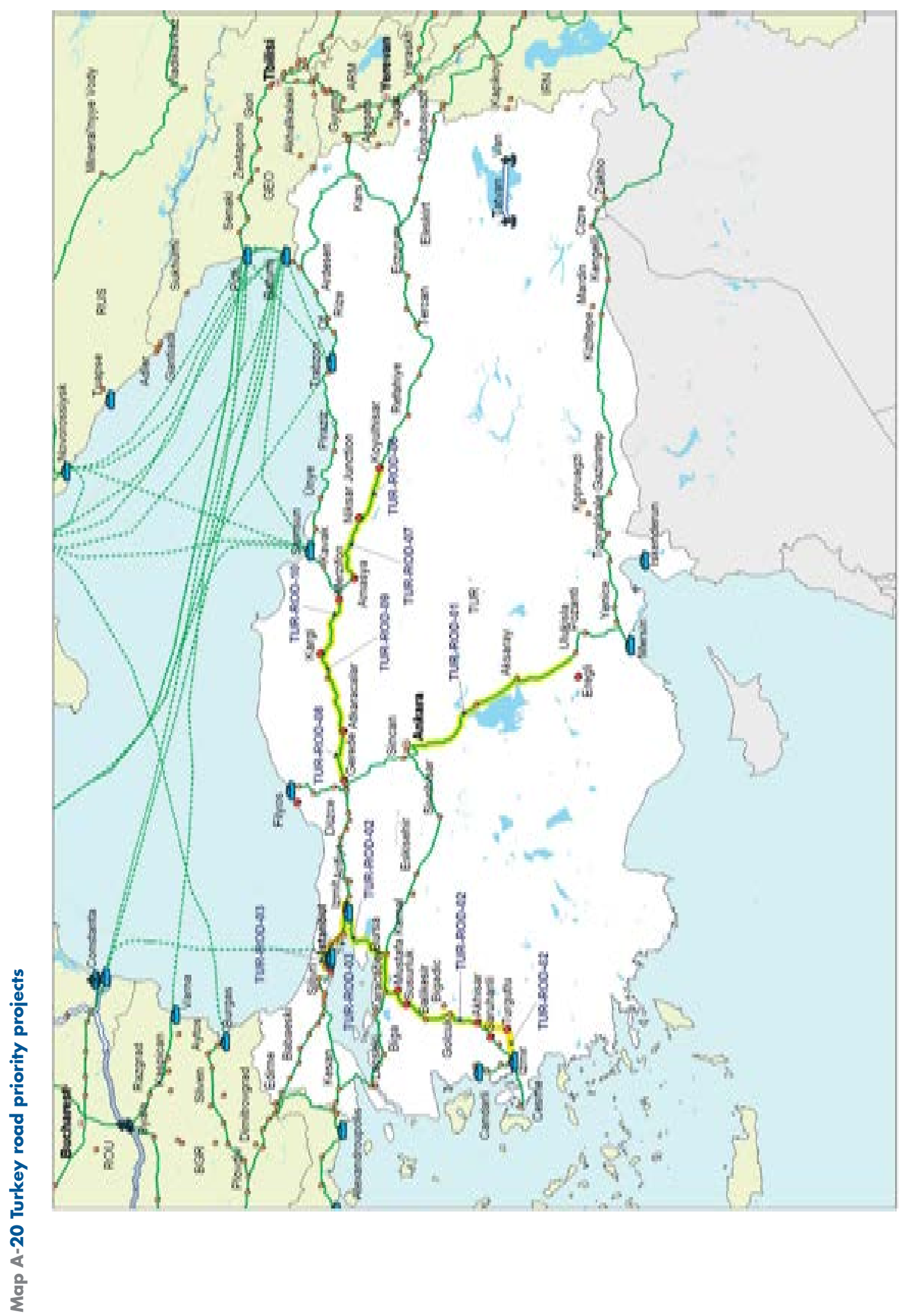




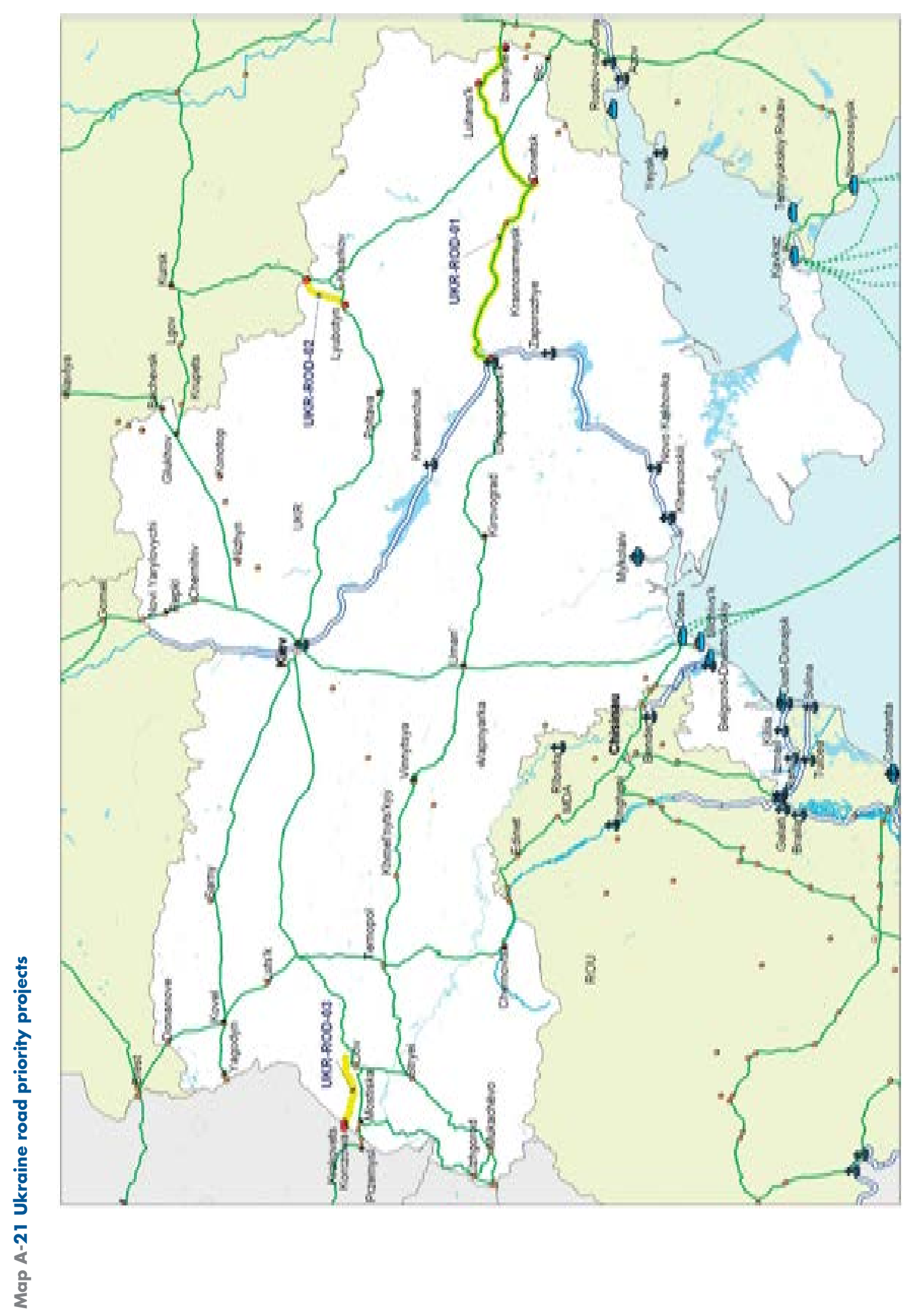

404

4 BACK TO THE TABLE OF CONTENTS SEARCH EATL WEBSITE




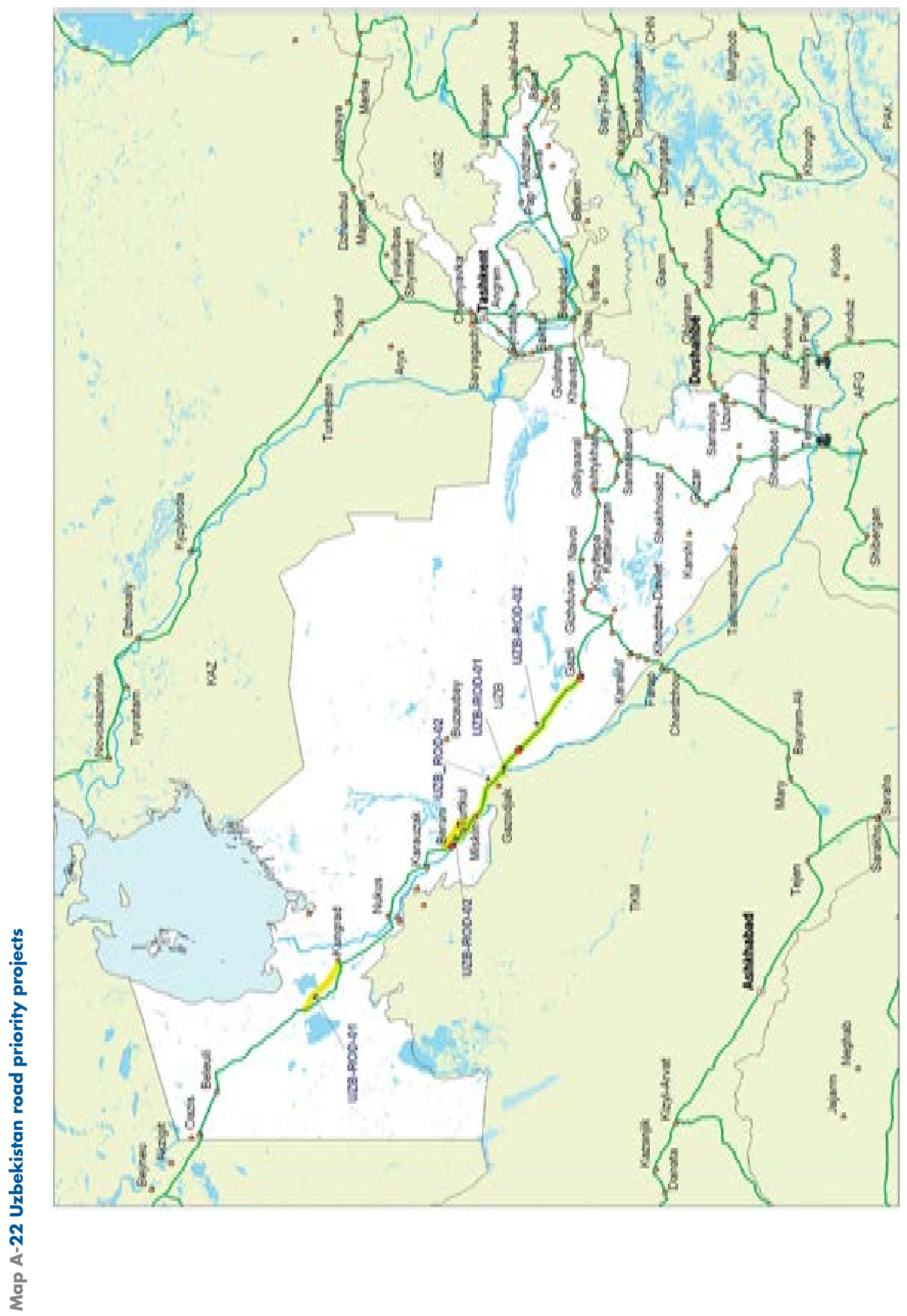




\section{RAIL}

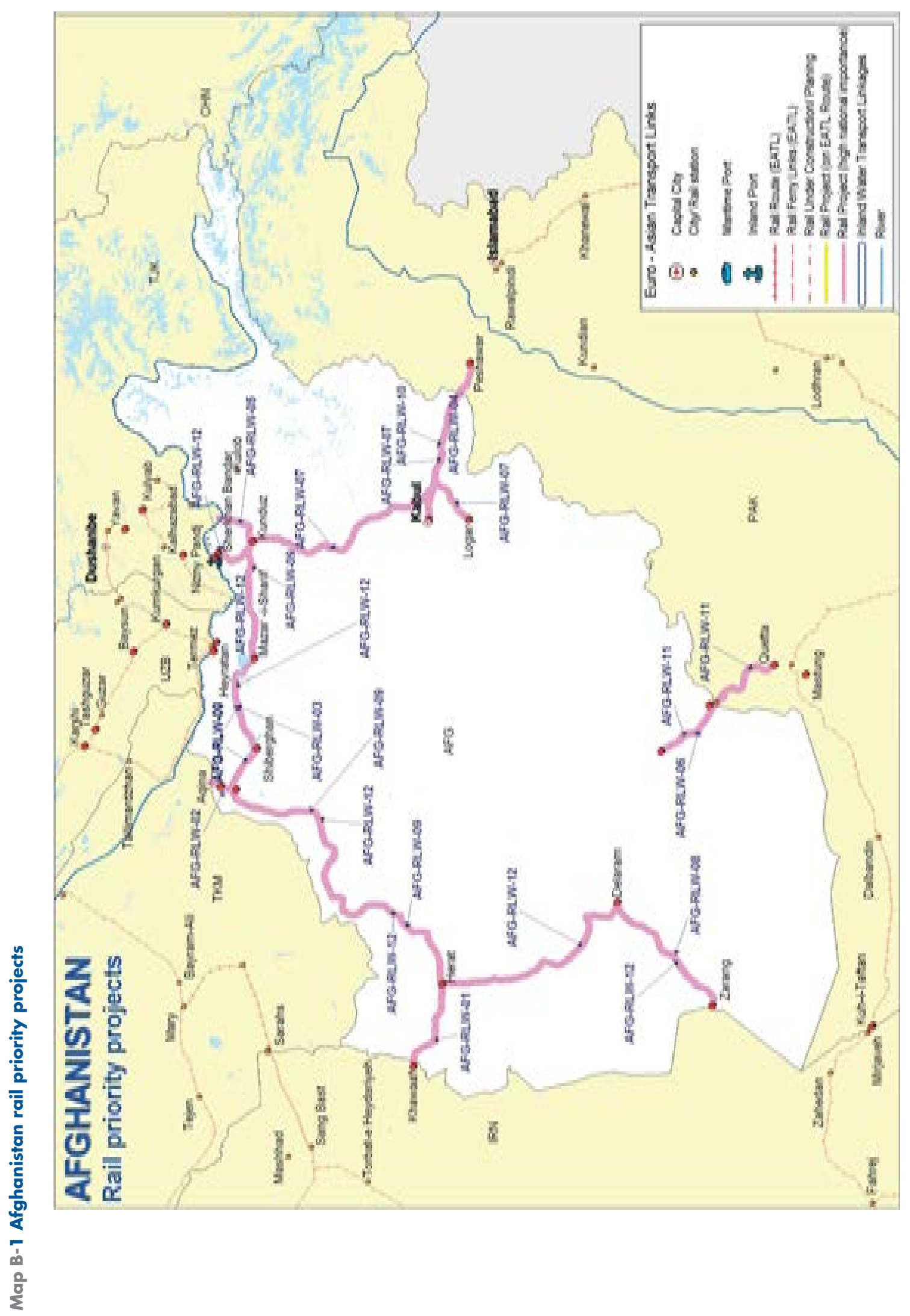

406 


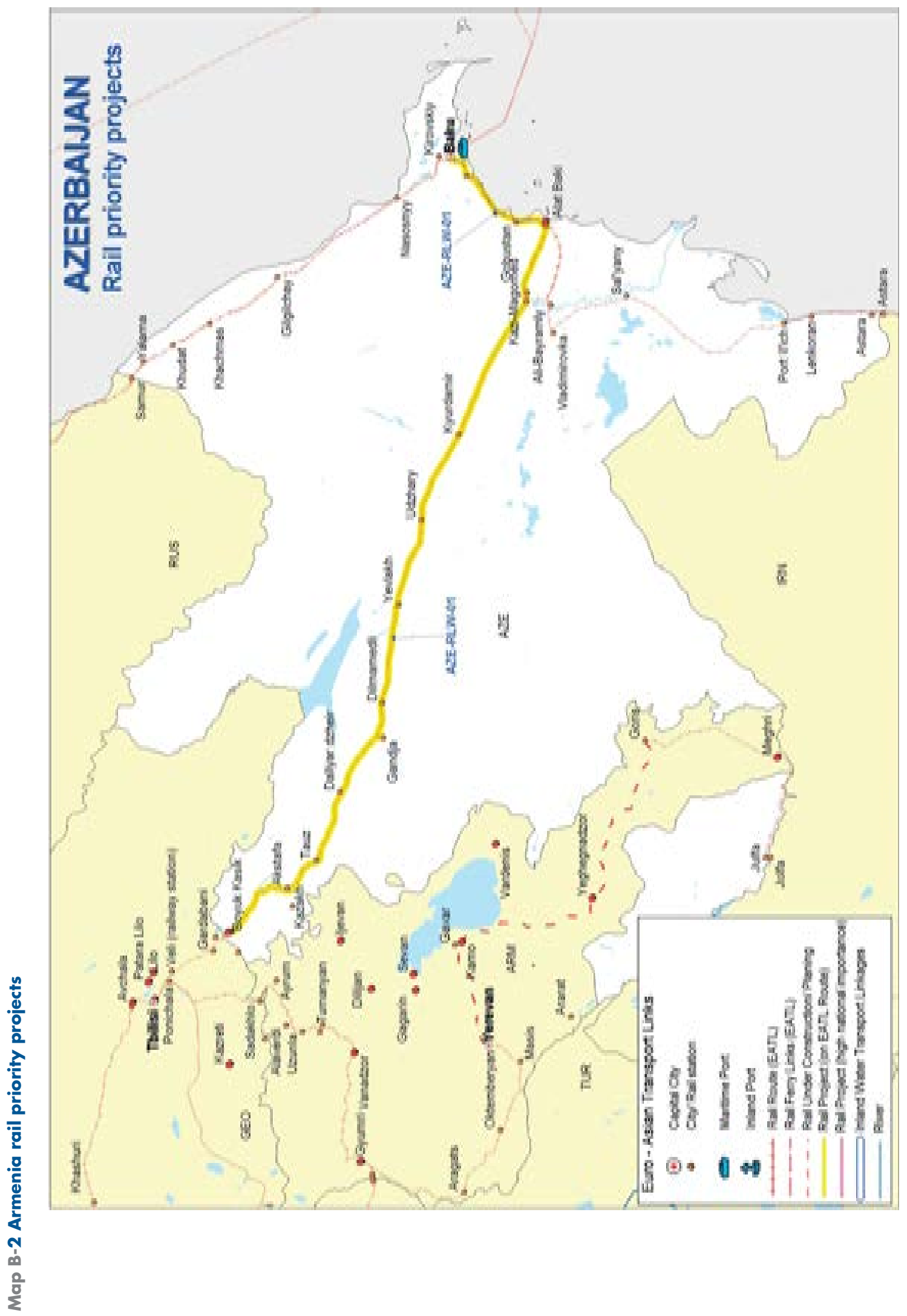




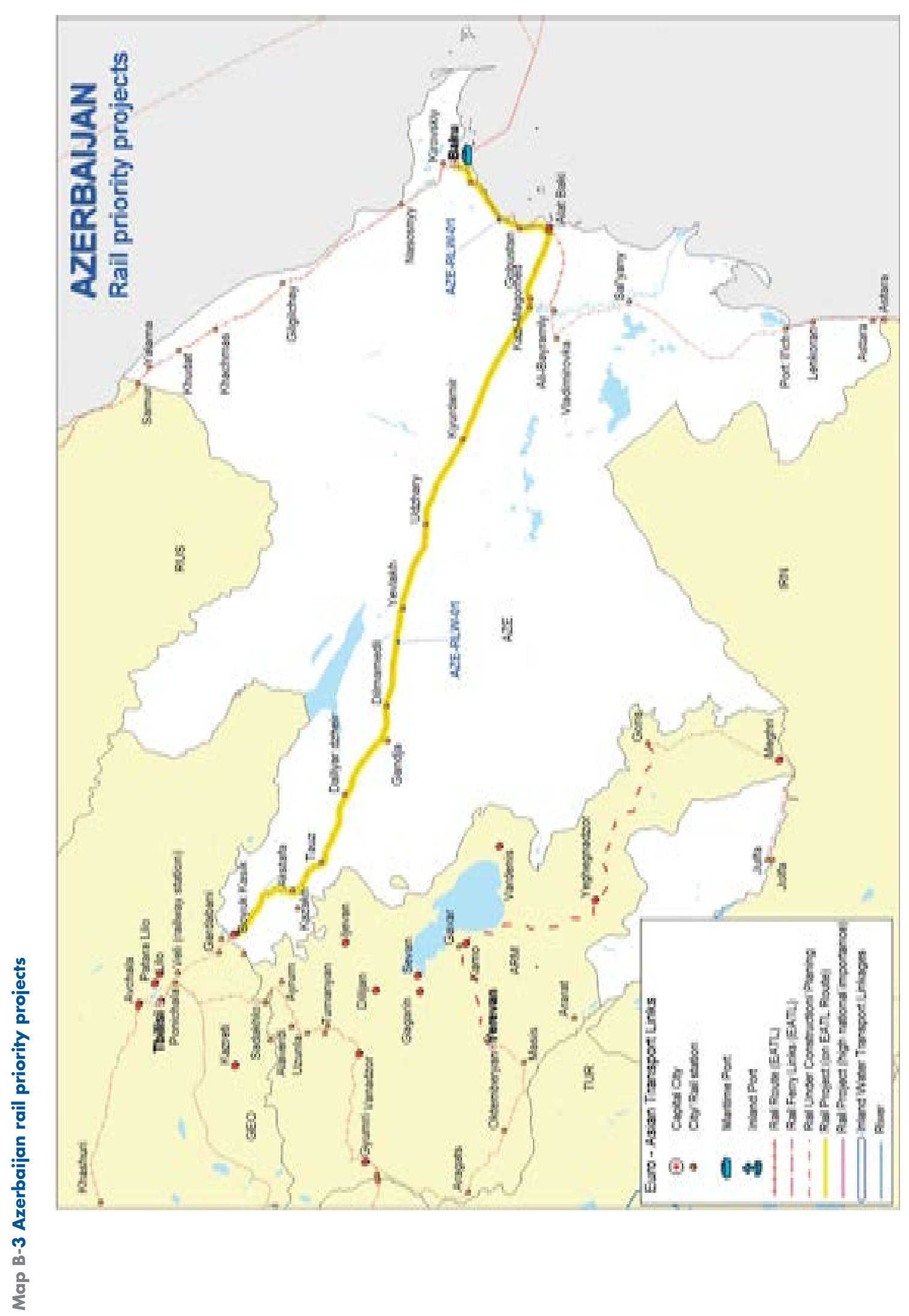

408 


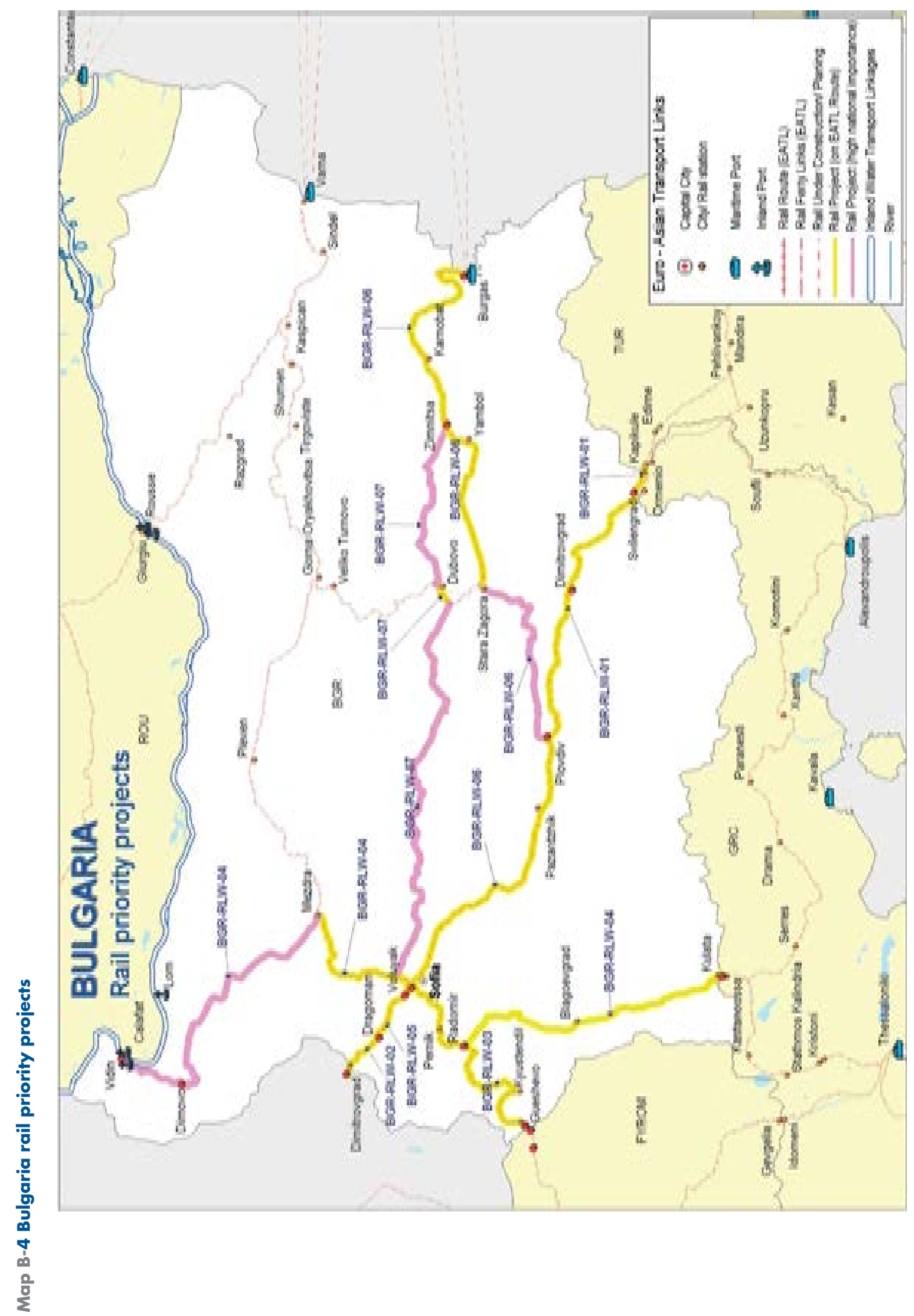




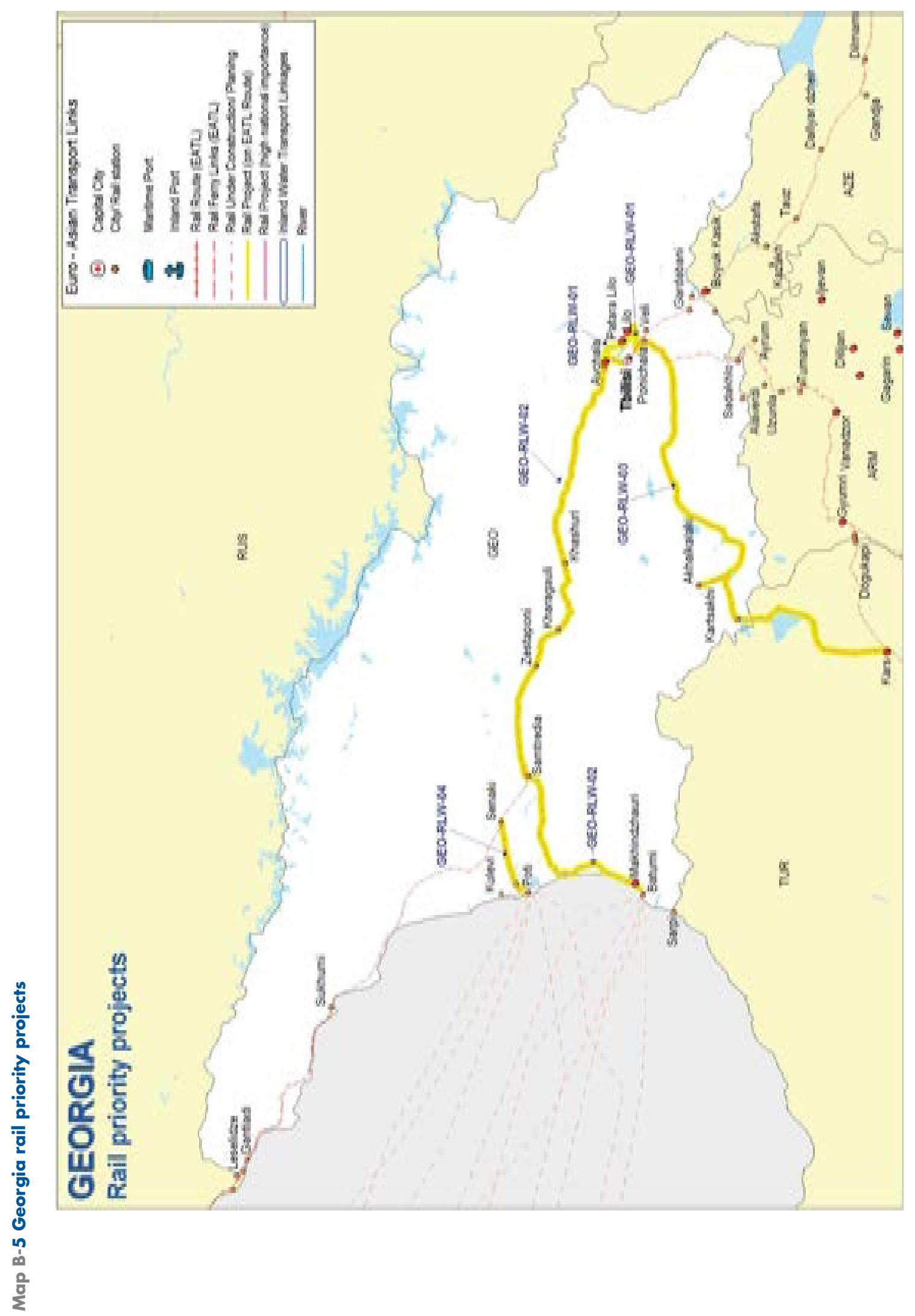




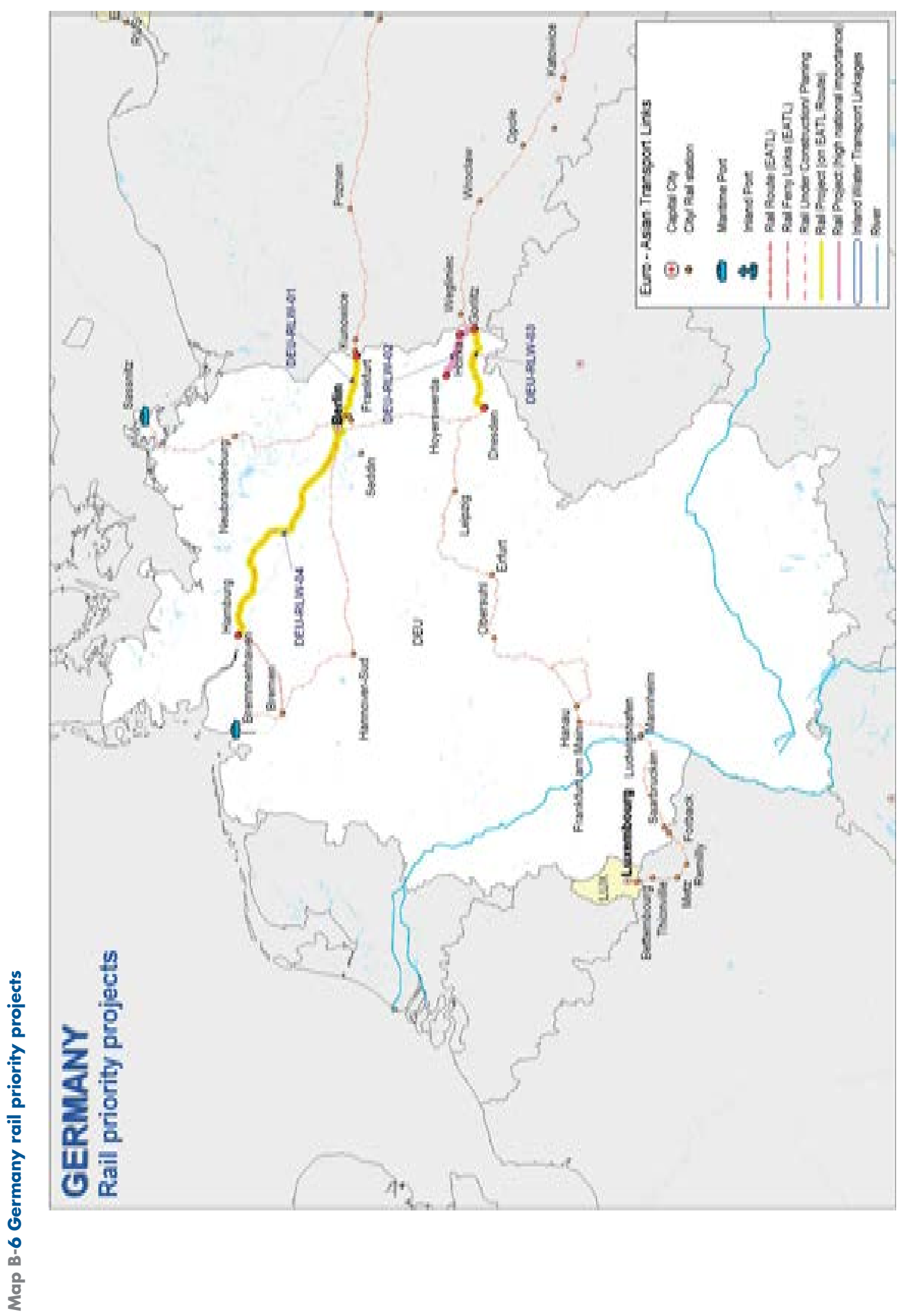




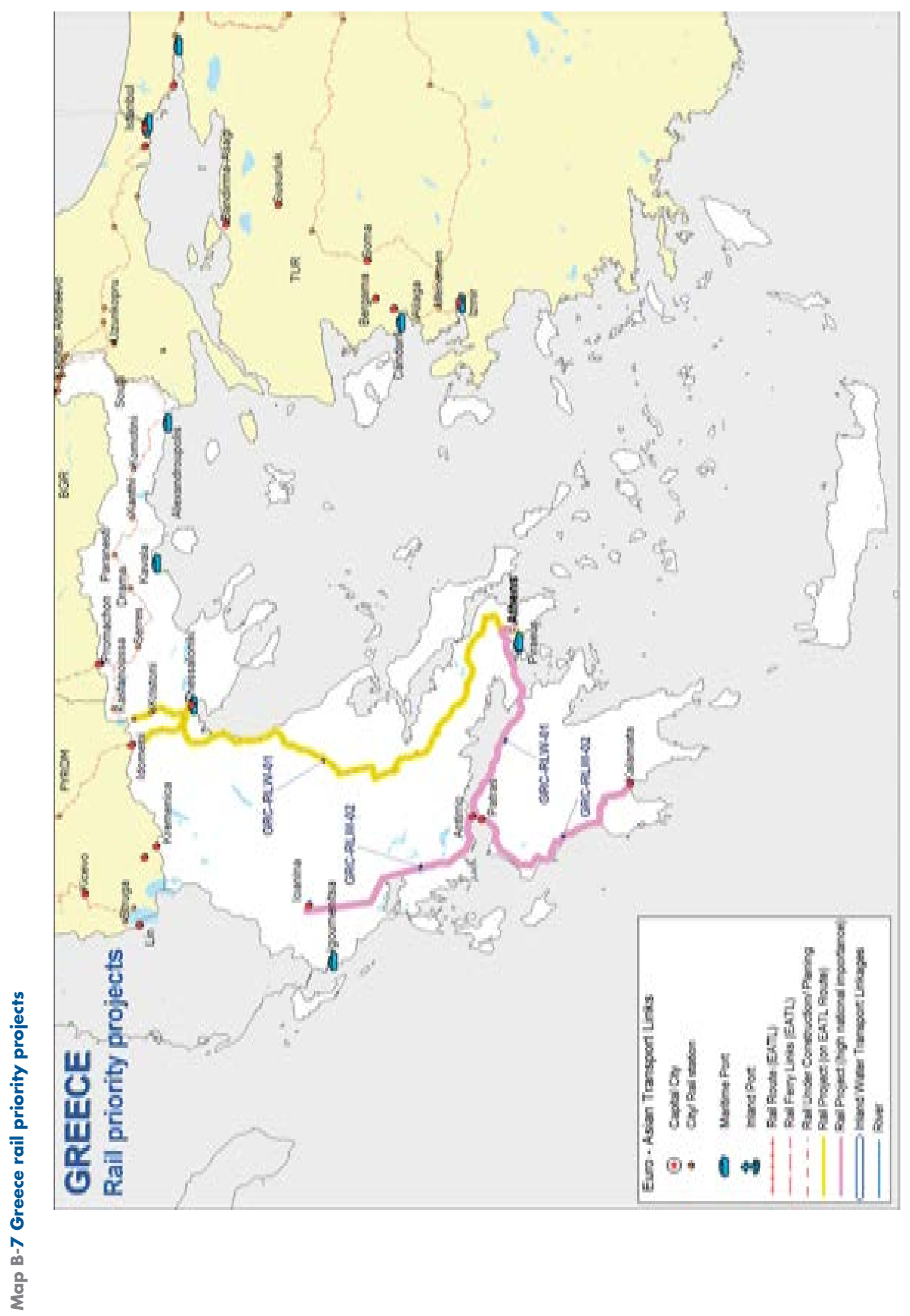




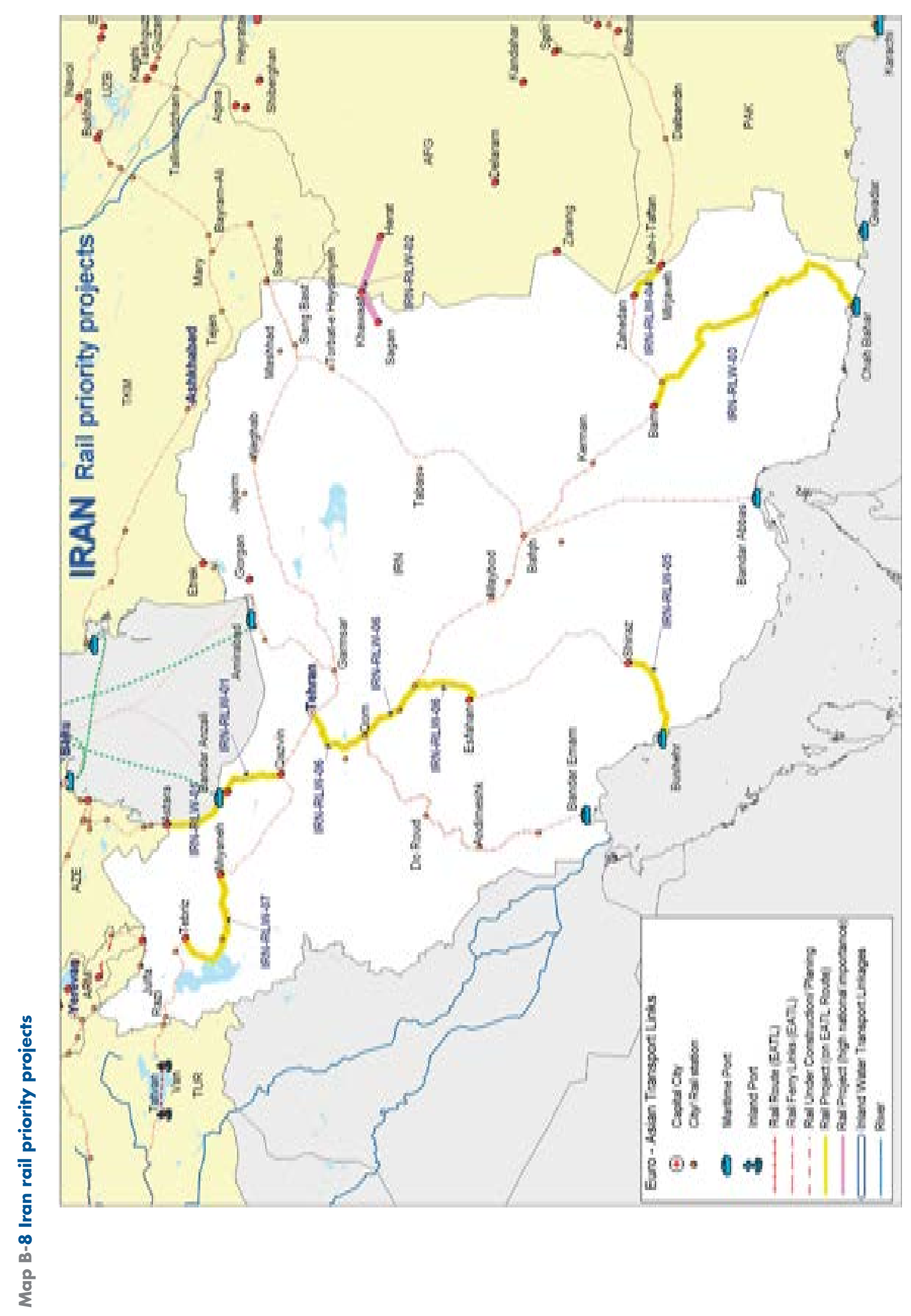




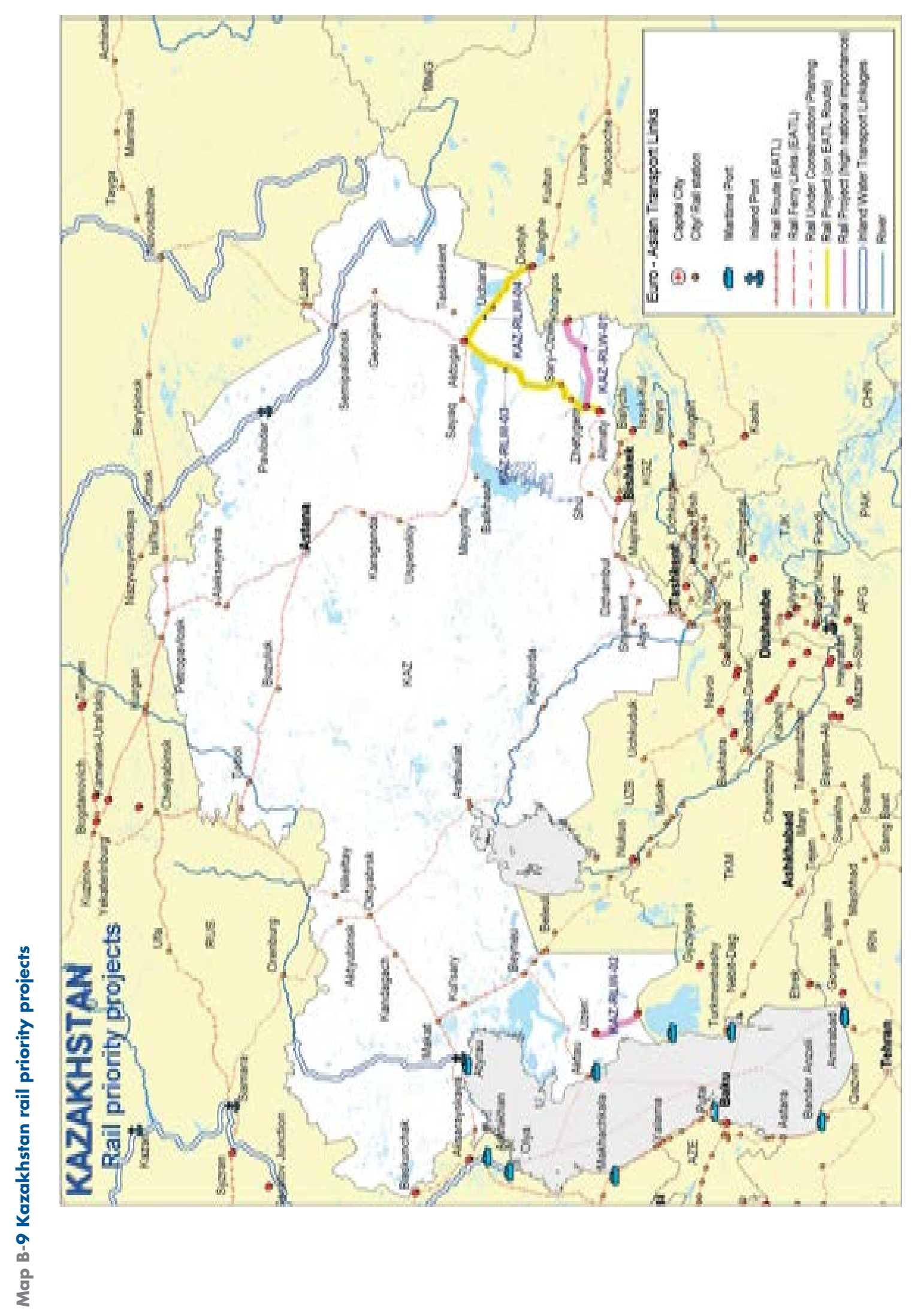




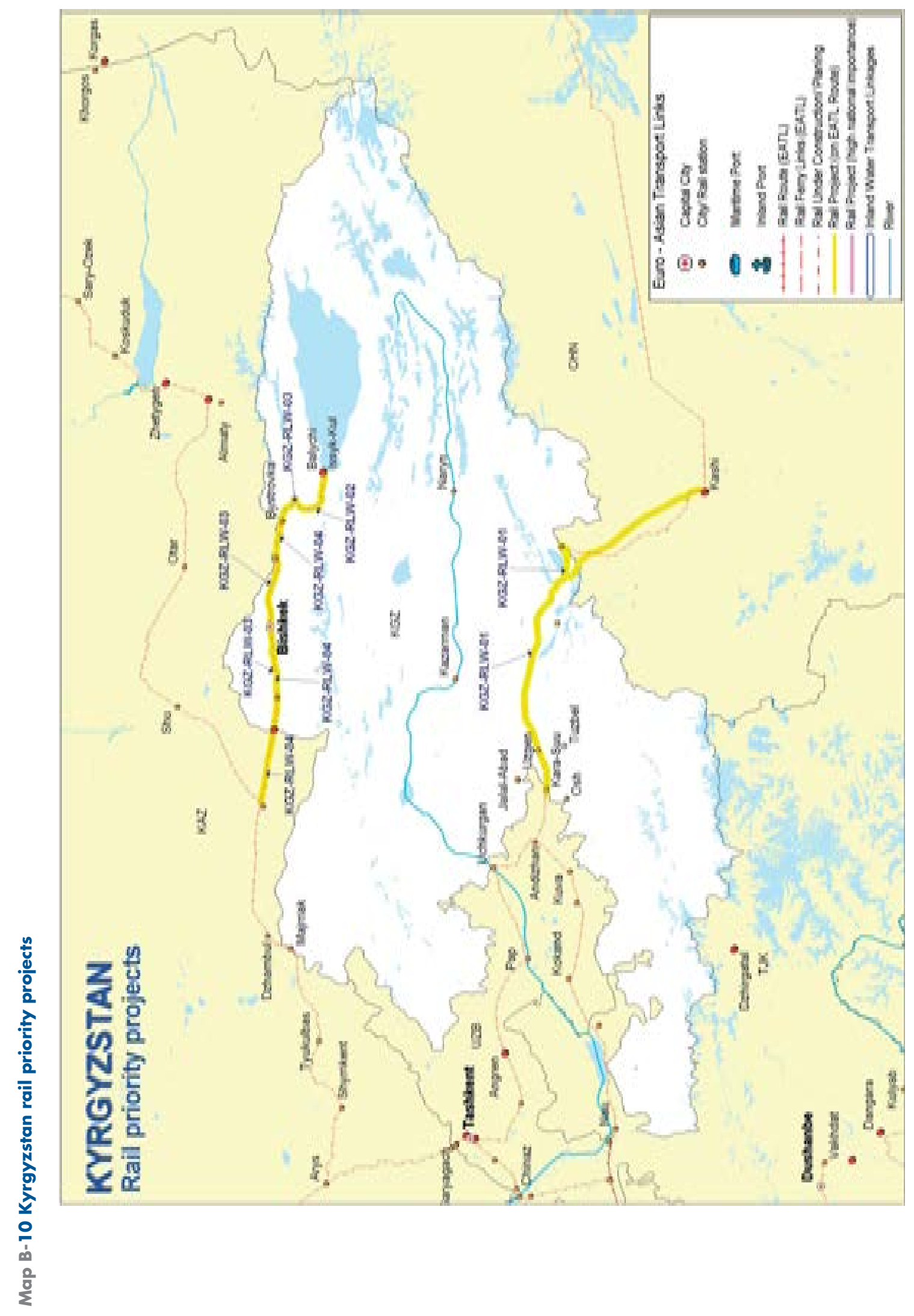




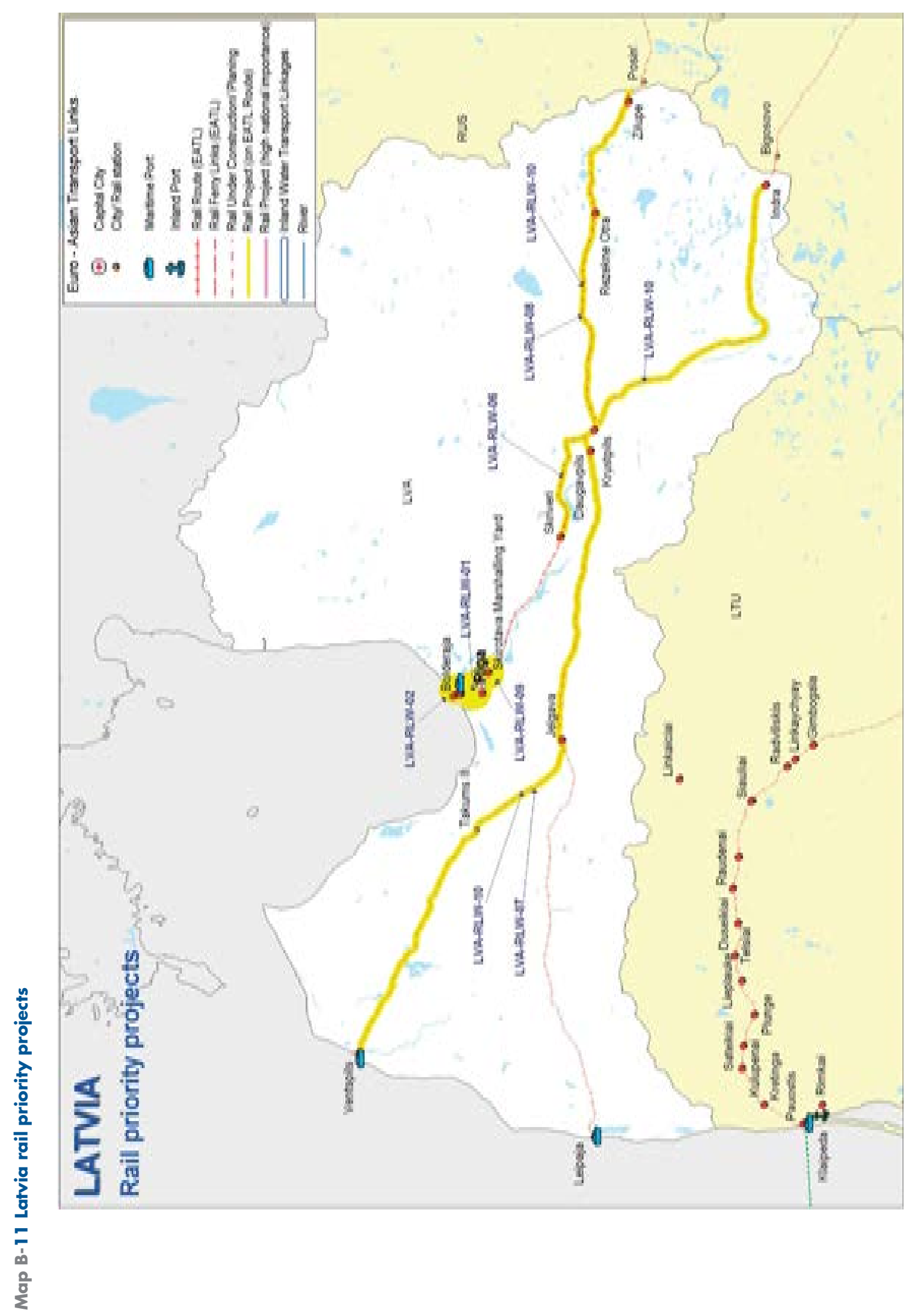




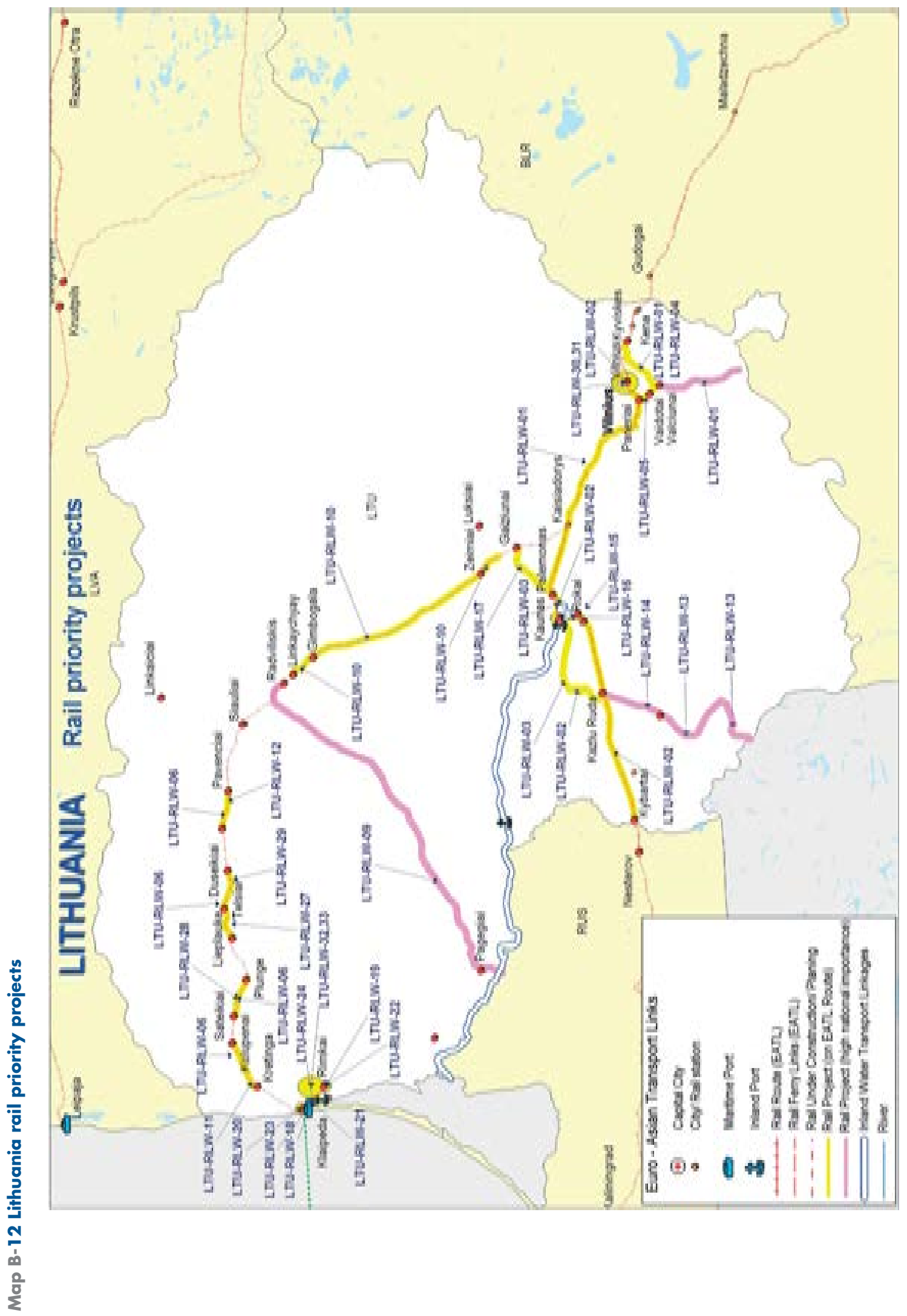




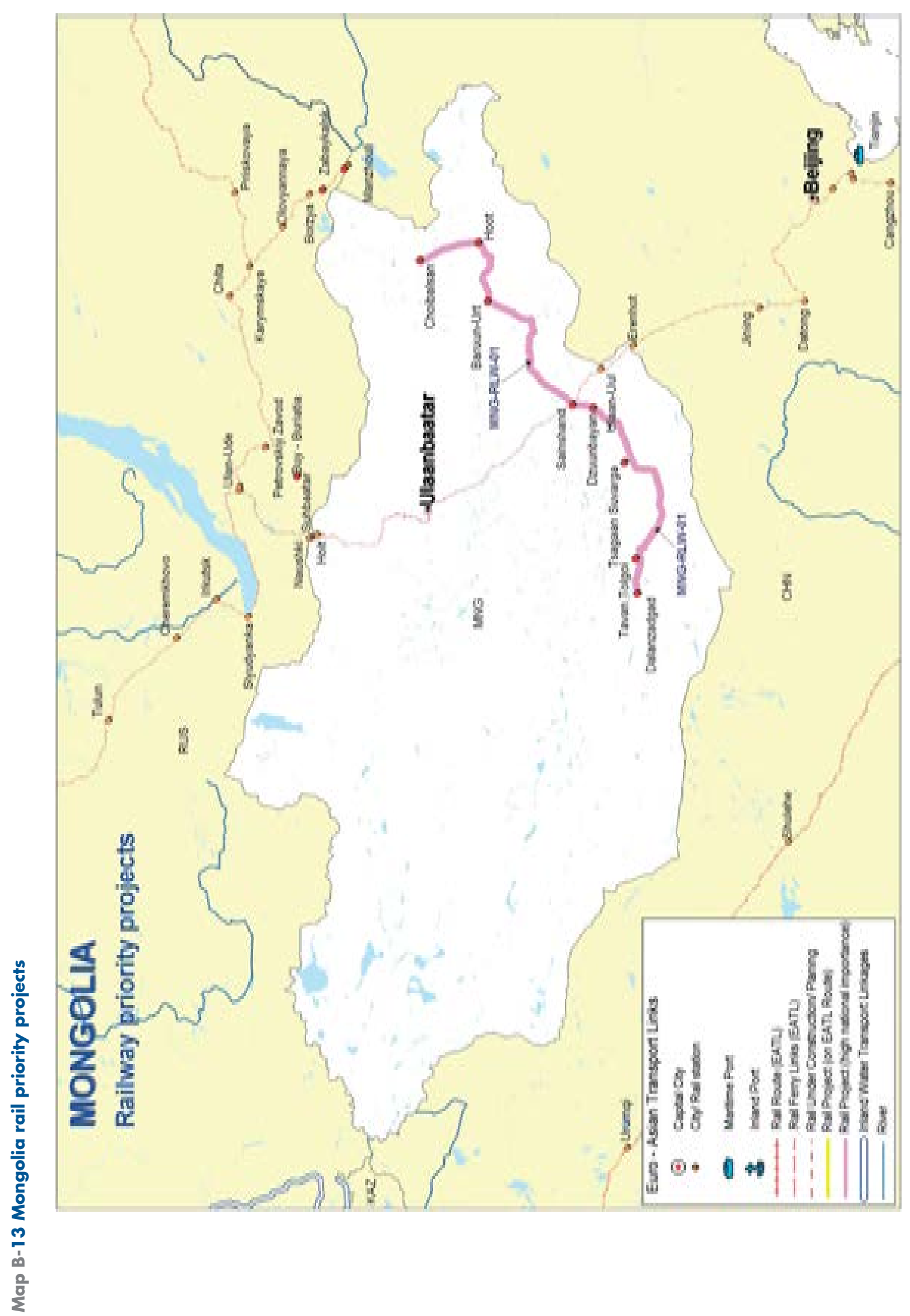




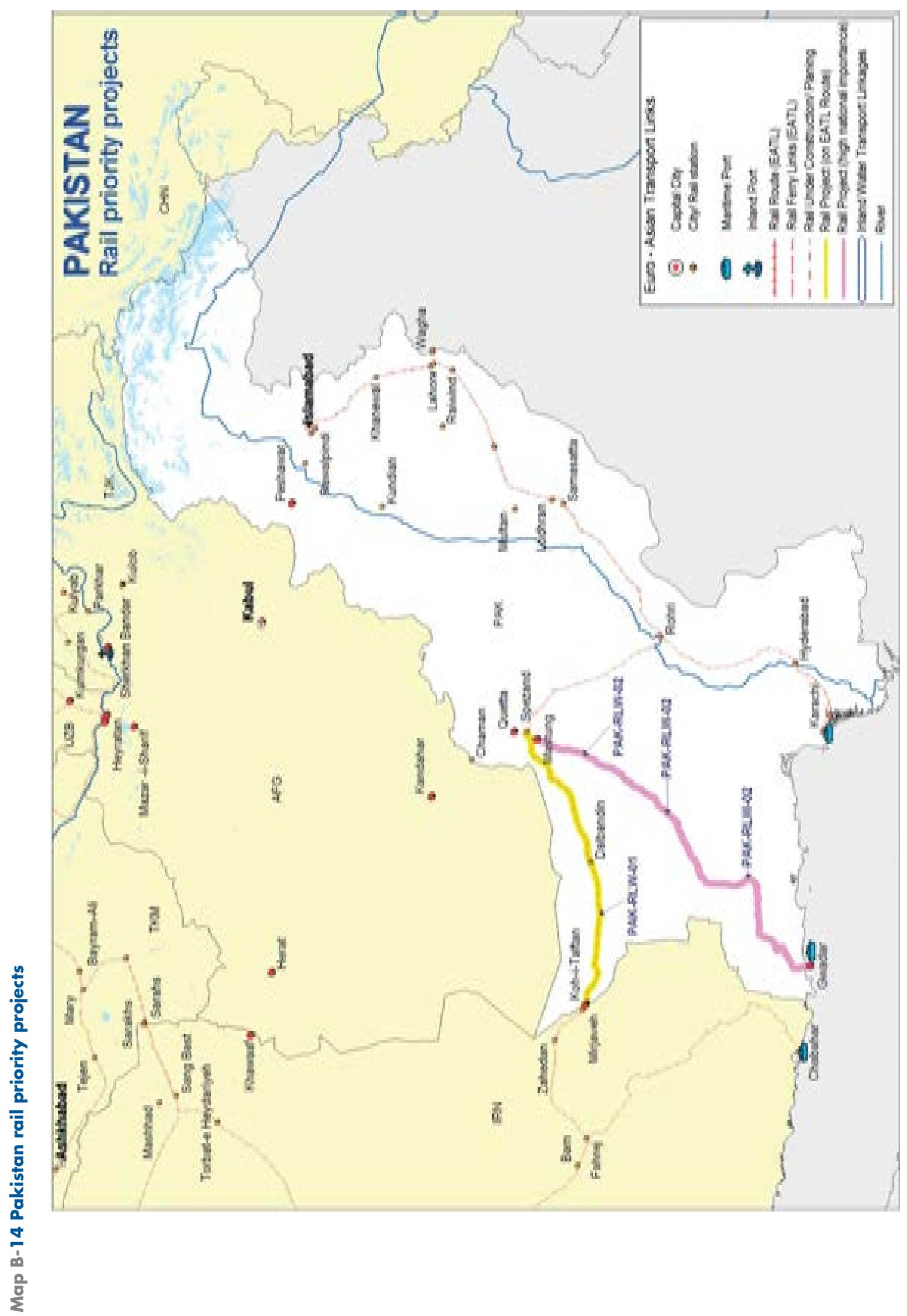




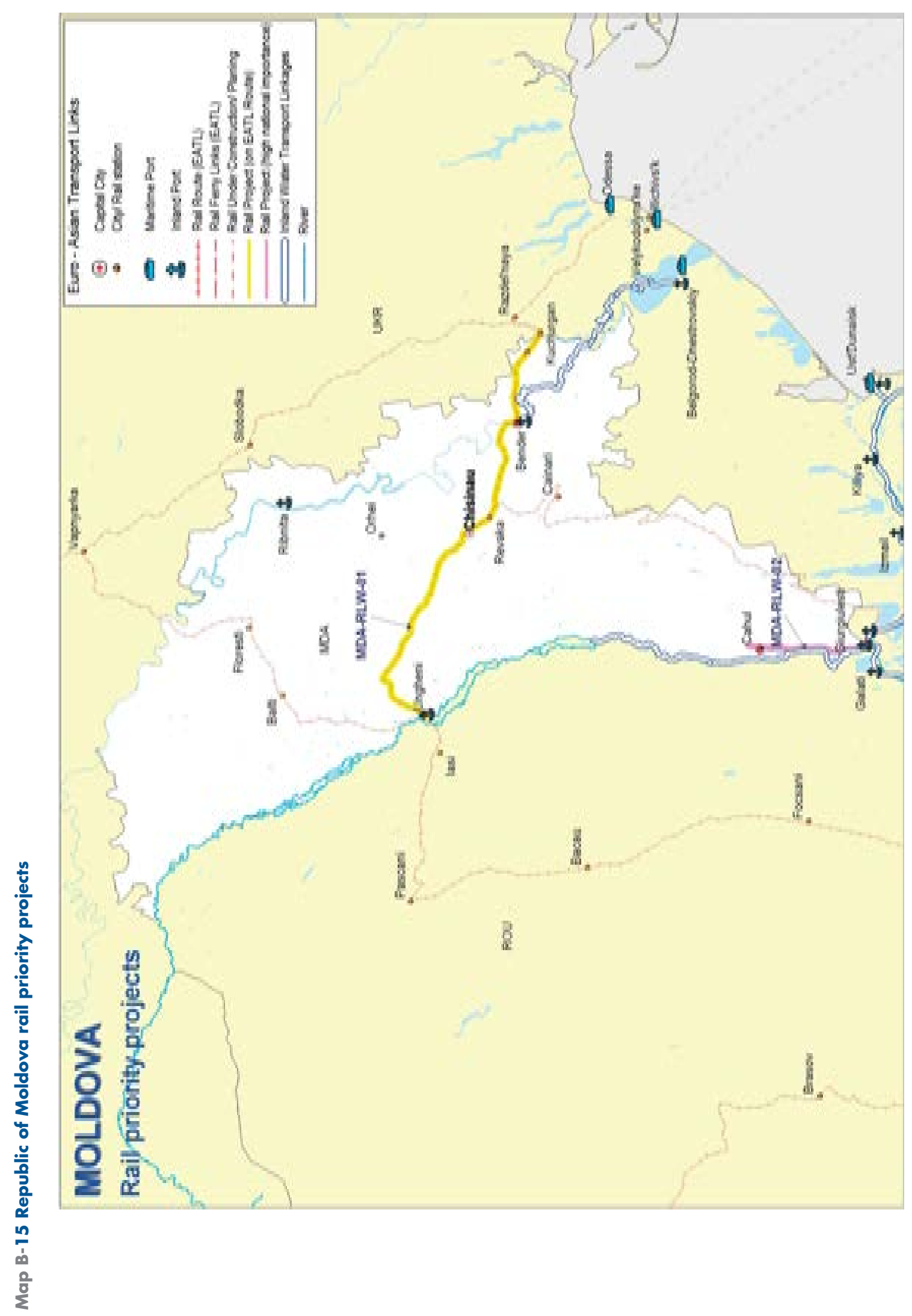




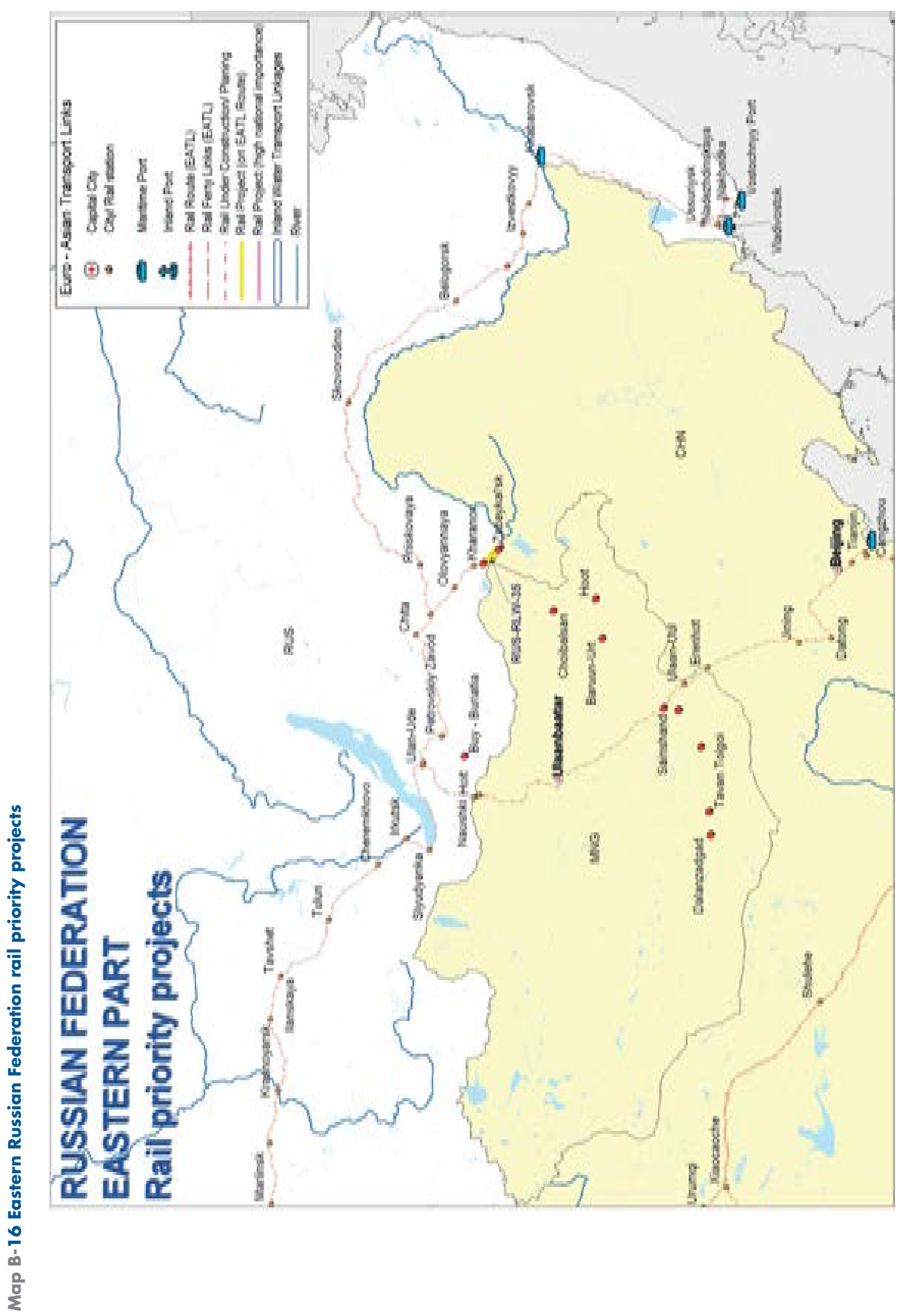




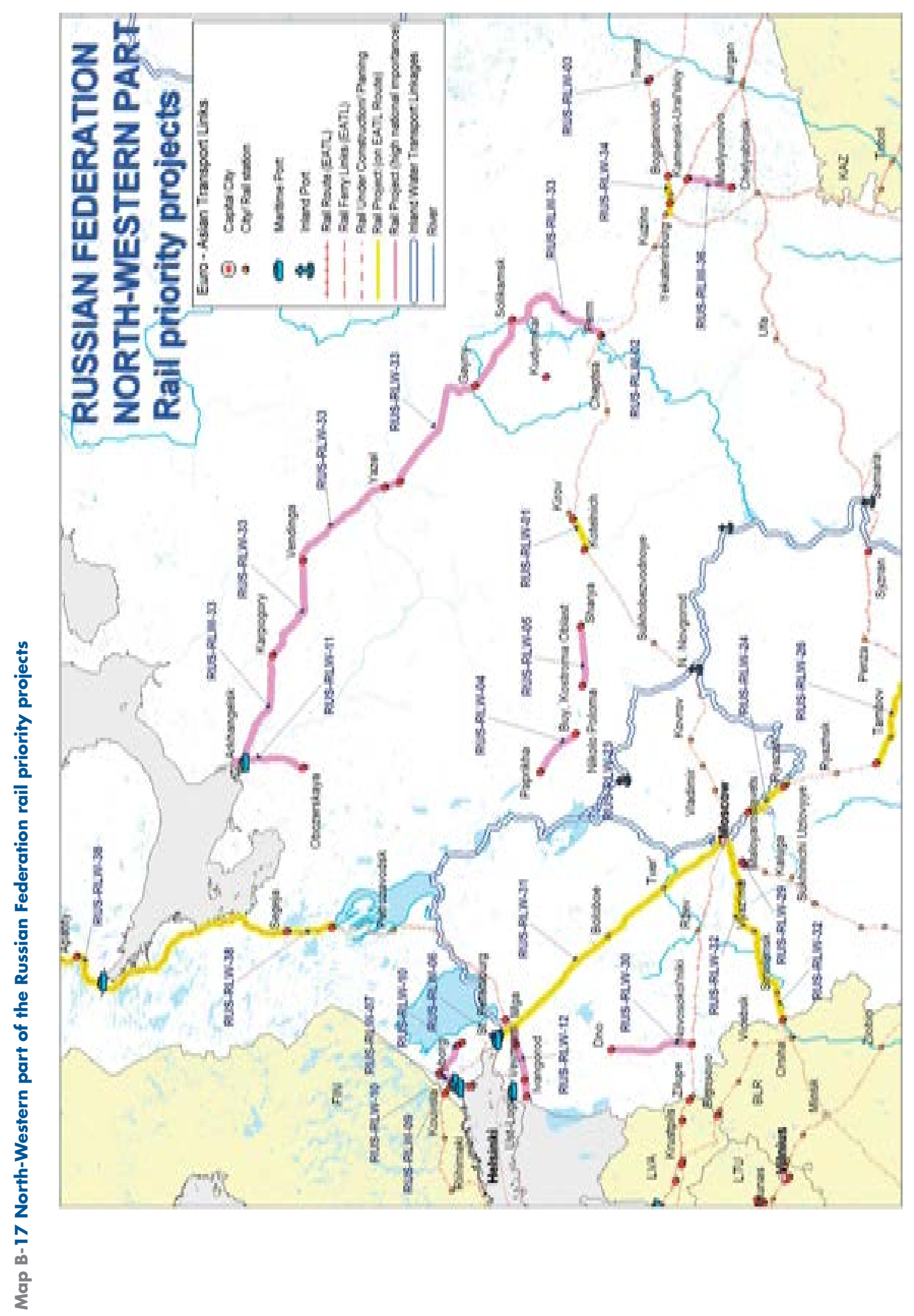




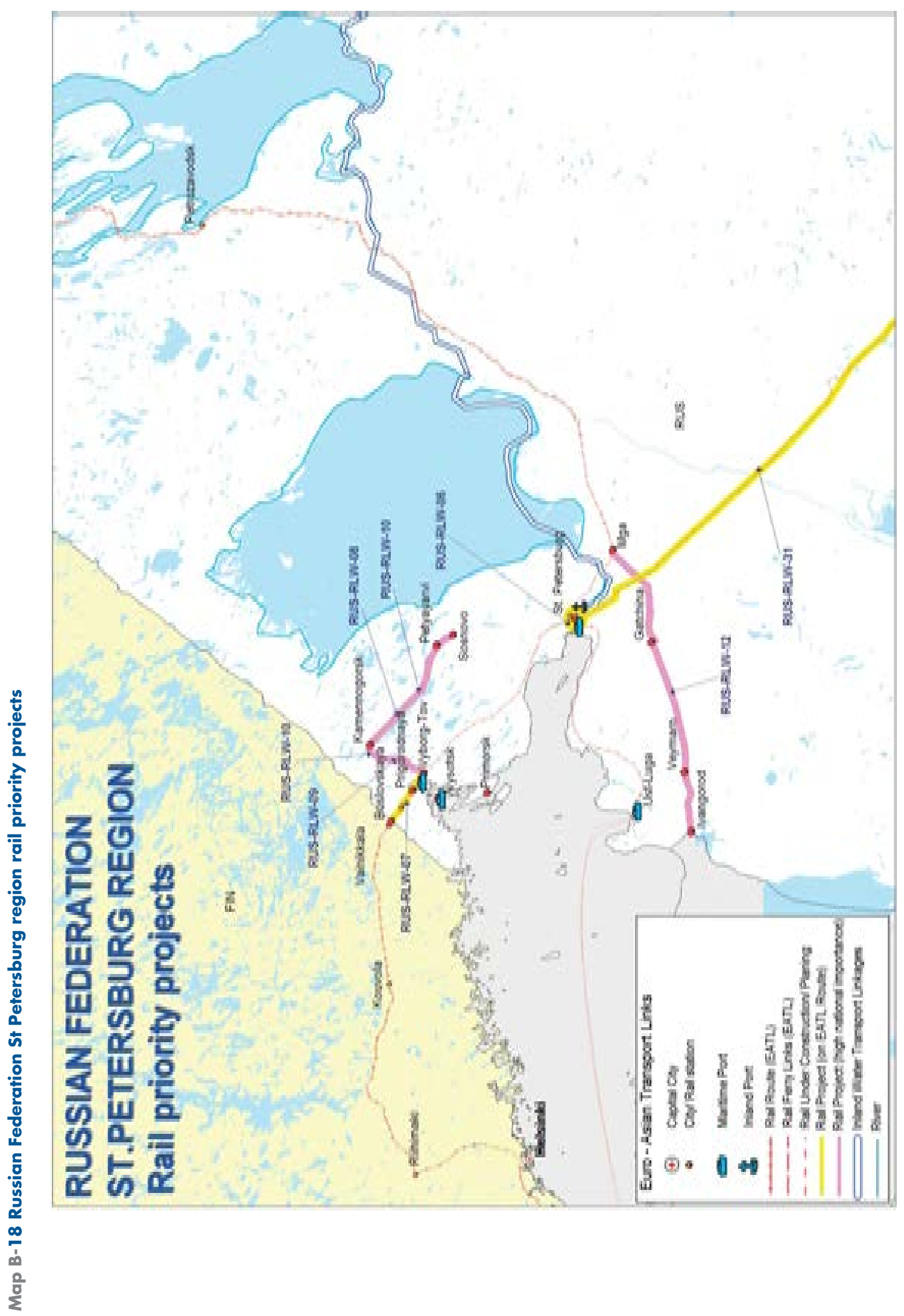




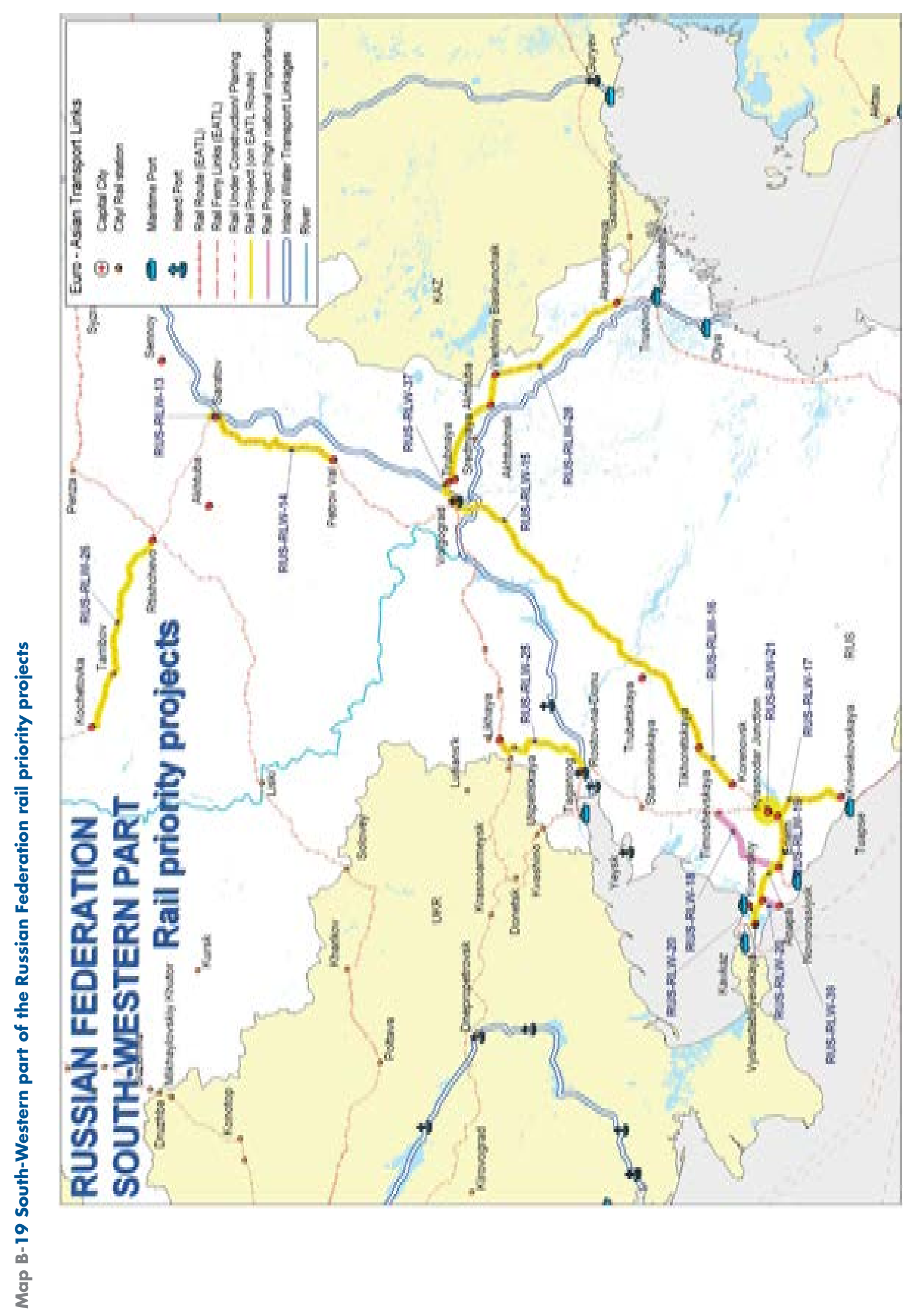




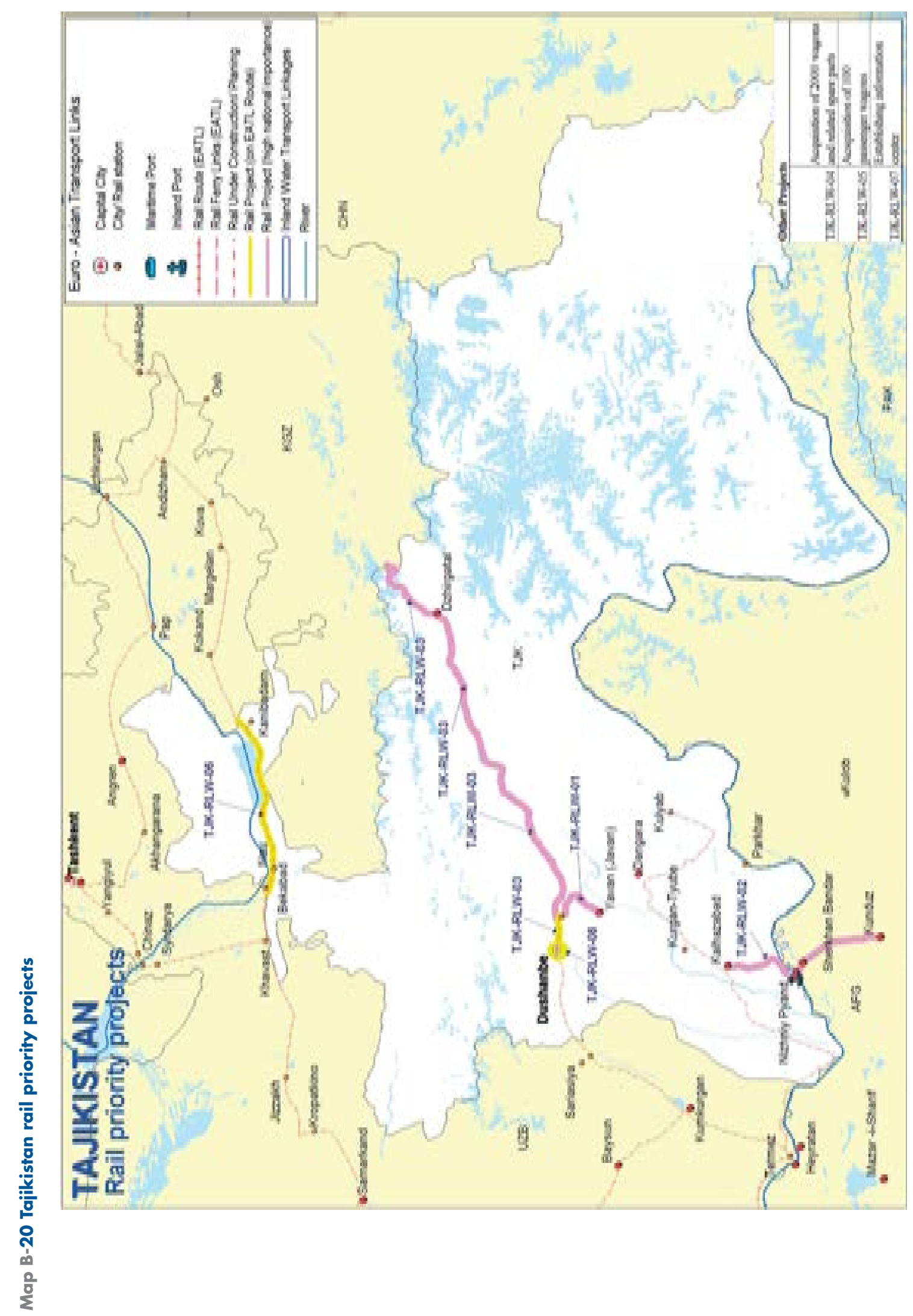




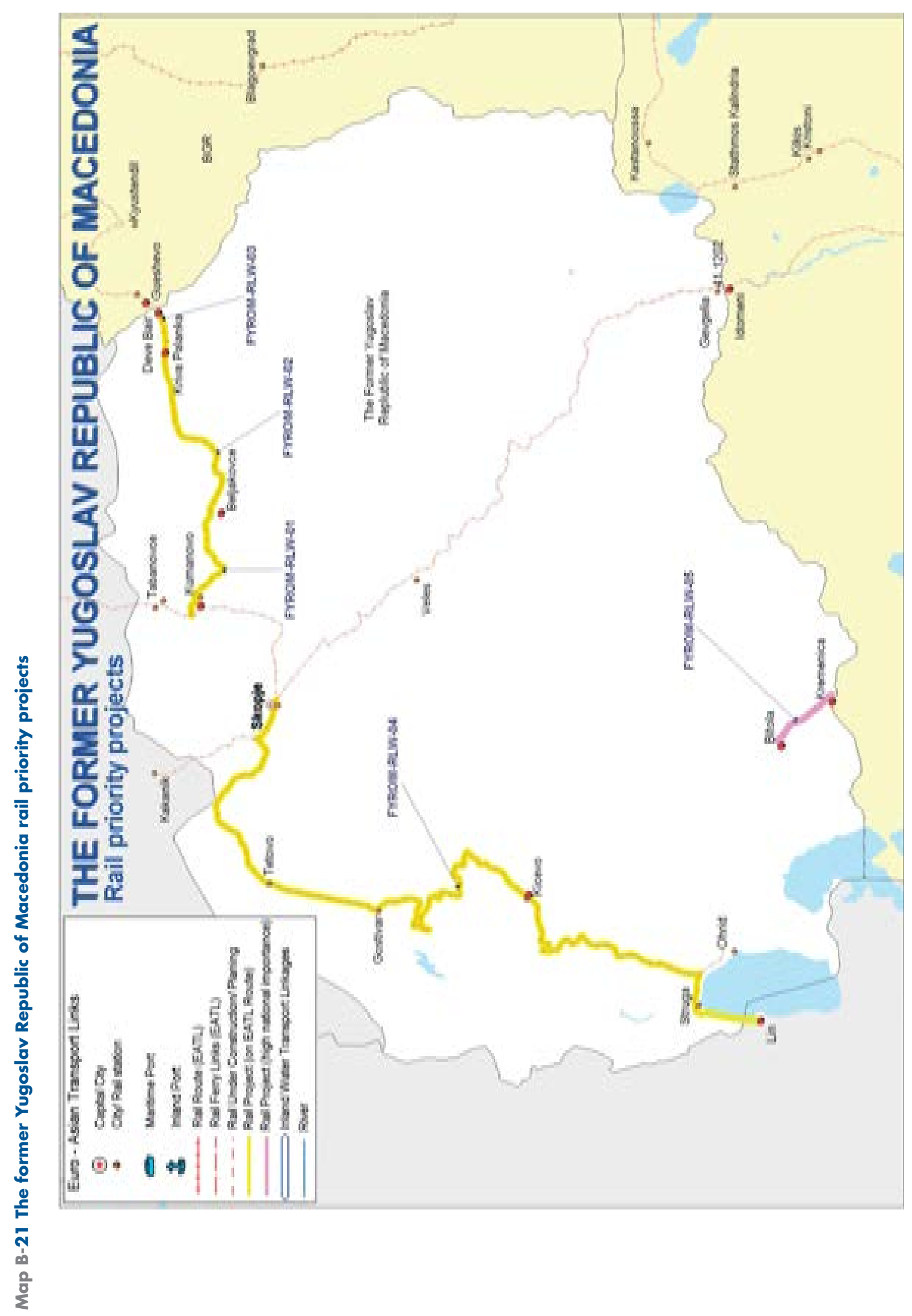




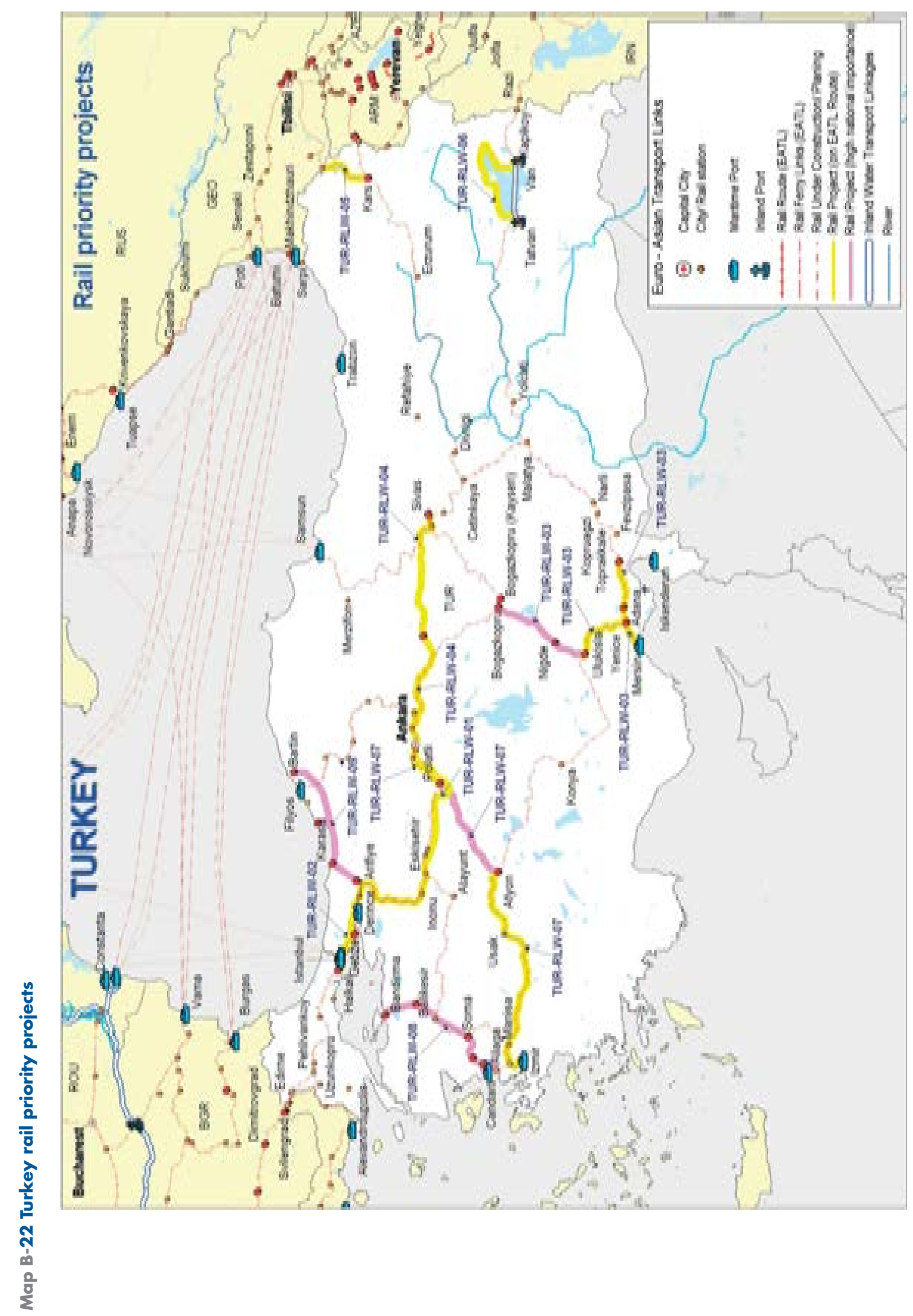




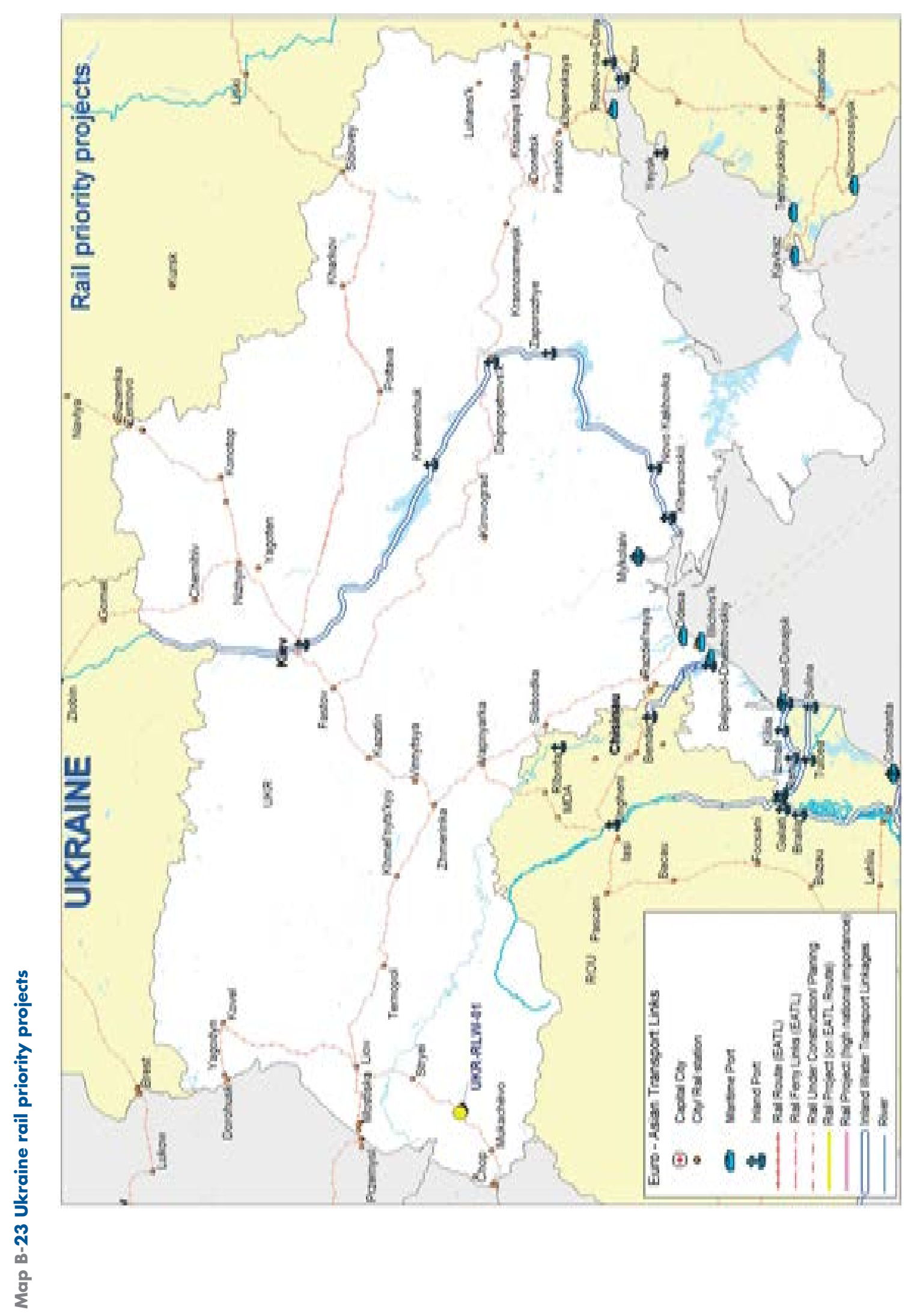




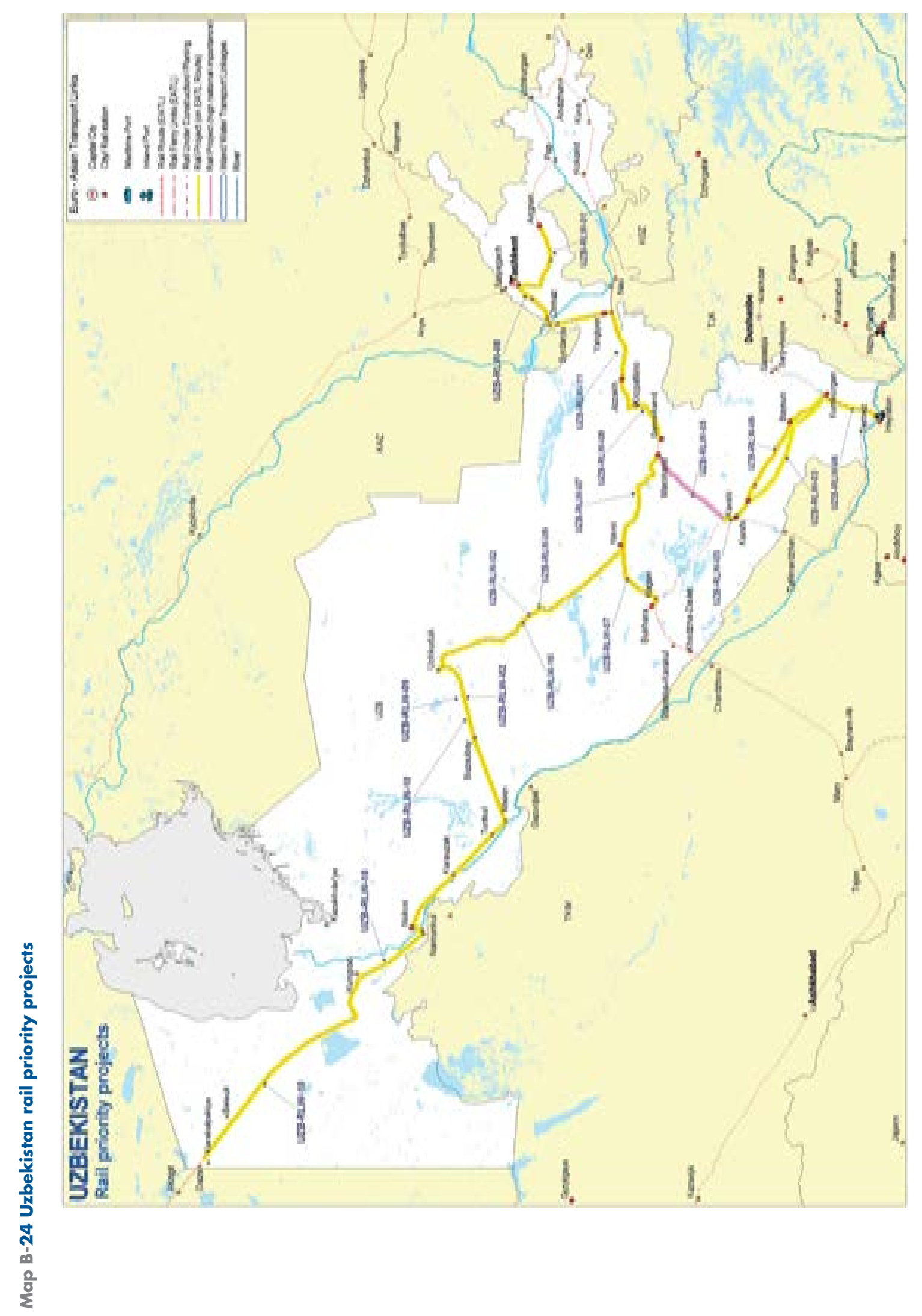




\section{Appendix 4.6}

Project prioritization per EATL Priority Route 


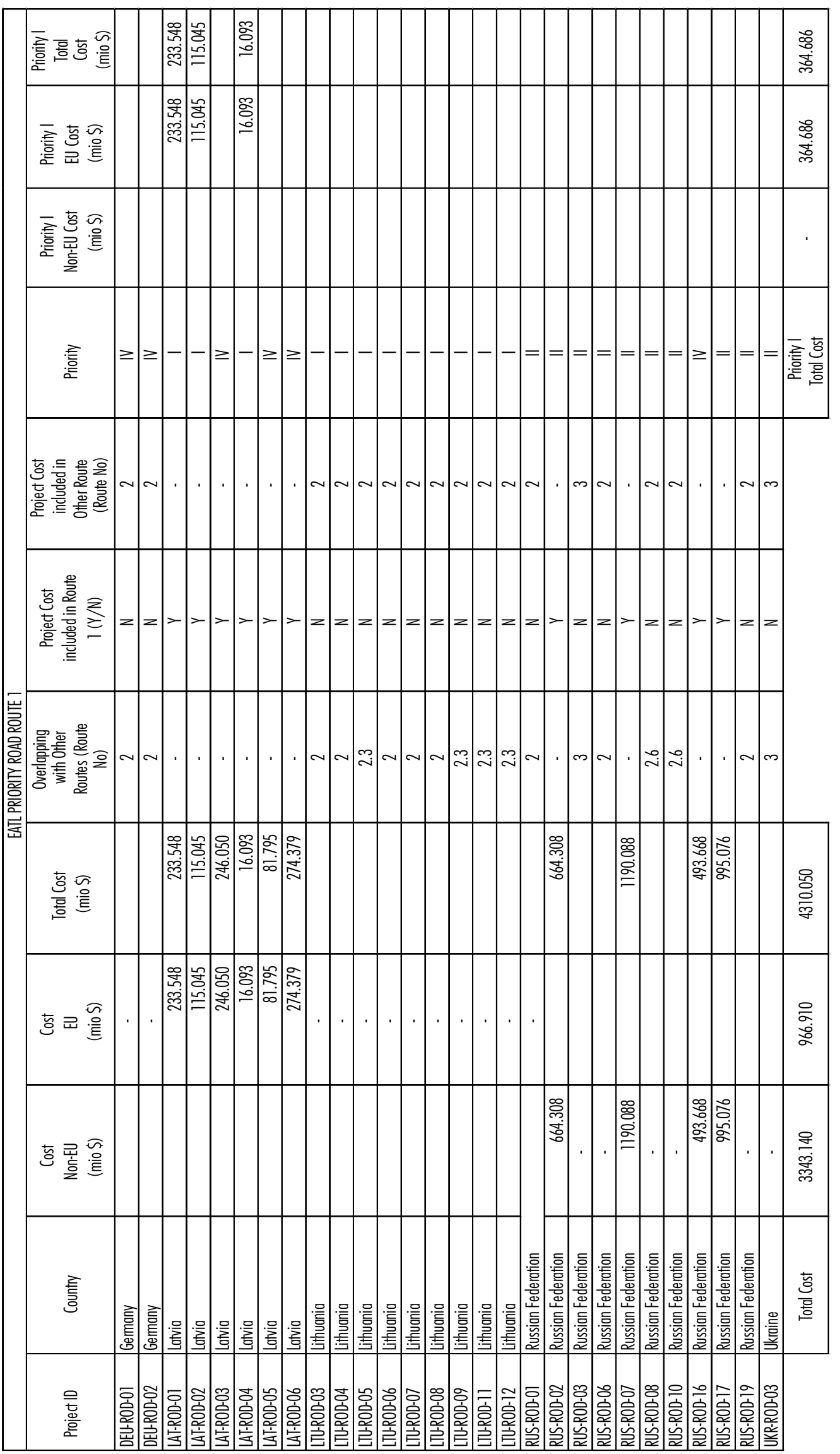




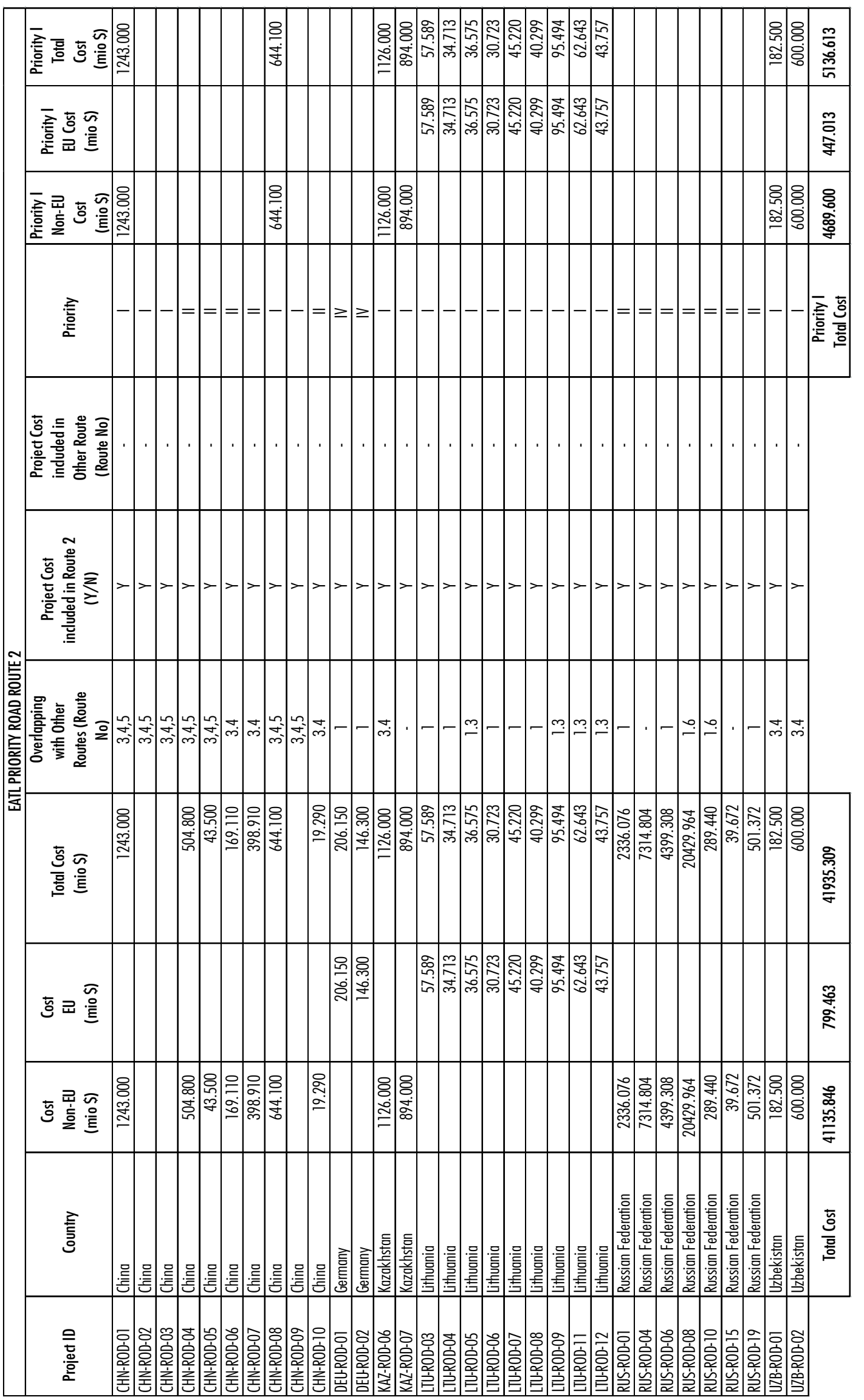




\begin{tabular}{|c|c|c|c|c|c|c|c|c|c|c|c|c|c|c|c|c|c|c|c|c|c|c|c|c|c|}
\hline & 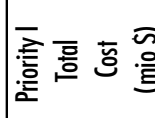 & 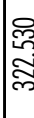 & & & & & & & & & \begin{tabular}{l} 
8 \\
0 \\
$\infty$ \\
\hdashline
\end{tabular} & 冬 & 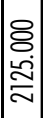 & 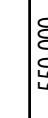 & & & & & | & & & 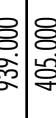 & & & 莽 \\
\hline & 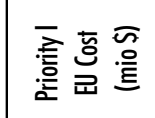 & $\pi$ & & & & & & & & & & & & 5 & & & & & & & & & & & 髉 \\
\hline & 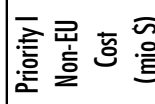 & & & & & & & & & & 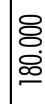 & 要 & $\mid$ & & & & & & 究 & & & : & & & 䥽 \\
\hline & 袞 & & - & - & & & $=$ & $=$ & & $=$ & $=-$ & - & - & -1 & - & - & - & $=$ & - & $=$ & $=-$ & & & & - \\
\hline & 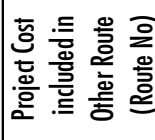 & & & & & & & & & & & & & & & & & & & & & & & & \\
\hline & 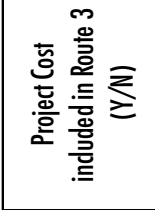 & $>$ & $z$ & & & & $z$ & $z$ & $z z$ & $z z$ & $=>$ & $>$ & $>$ & $z \mid>$ & $-z$ & z & $z=2$ & $=1>$ & $>$ & $>$ & & $-1>$ & & $z=$ & \\
\hline & 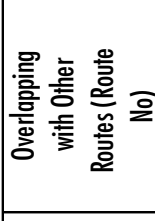 & & 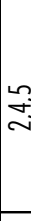 & & & 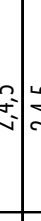 & $\approx$ & $\underset{\sim}{\sim}$ & $\stackrel{2}{\approx}=$ & $f$ & & & & 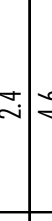 & & $\cong$ & $\simeq \approx$ & $\because-$ & & & & . & & $\stackrel{\sim}{\sim}$ & \\
\hline & 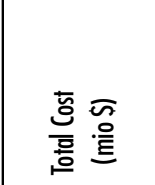 & 応 & & & & & & & & & 要 & 要 & 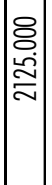 & $\mid$ & & & & 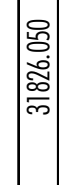 & 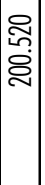 & & & : & 薃 & & 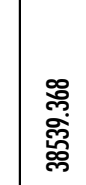 \\
\hline & 훙료 & š & & & & & & & & & & & & & & & & & & & & & & & 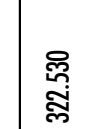 \\
\hline & 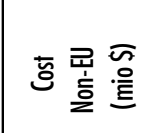 & & & & & & & & $\begin{array}{lll} & . \\
\end{array}$ & & 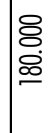 & 要 & 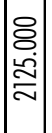 & 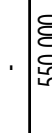 & & & & 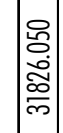 & 空 & 商 & & : & $\frac{\sqrt{0}}{0}$ & & 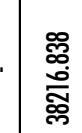 \\
\hline & 衰 & & & & & & & & 믕 & 믈 & $\begin{array}{l}\text { 喜 } \\
\text { 咅 }\end{array}$ & 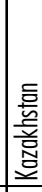 & 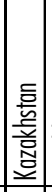 & 吉 & 童: & & 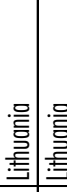 & 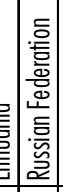 & 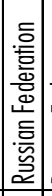 & 흘 & 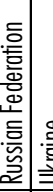 & 递递 & & 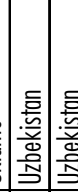 & 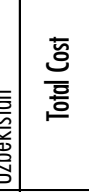 \\
\hline & 은 & & & & & ț & & & 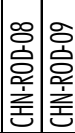 & 食浐 & 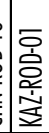 & ఫે & 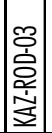 & g & 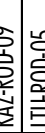 & & $\overline{\overline{\mathbf{s}}}$ & 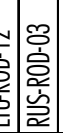 & 前 & $\frac{5}{2}$ & 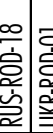 & 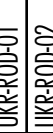 & & 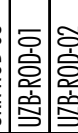 & \\
\hline
\end{tabular}




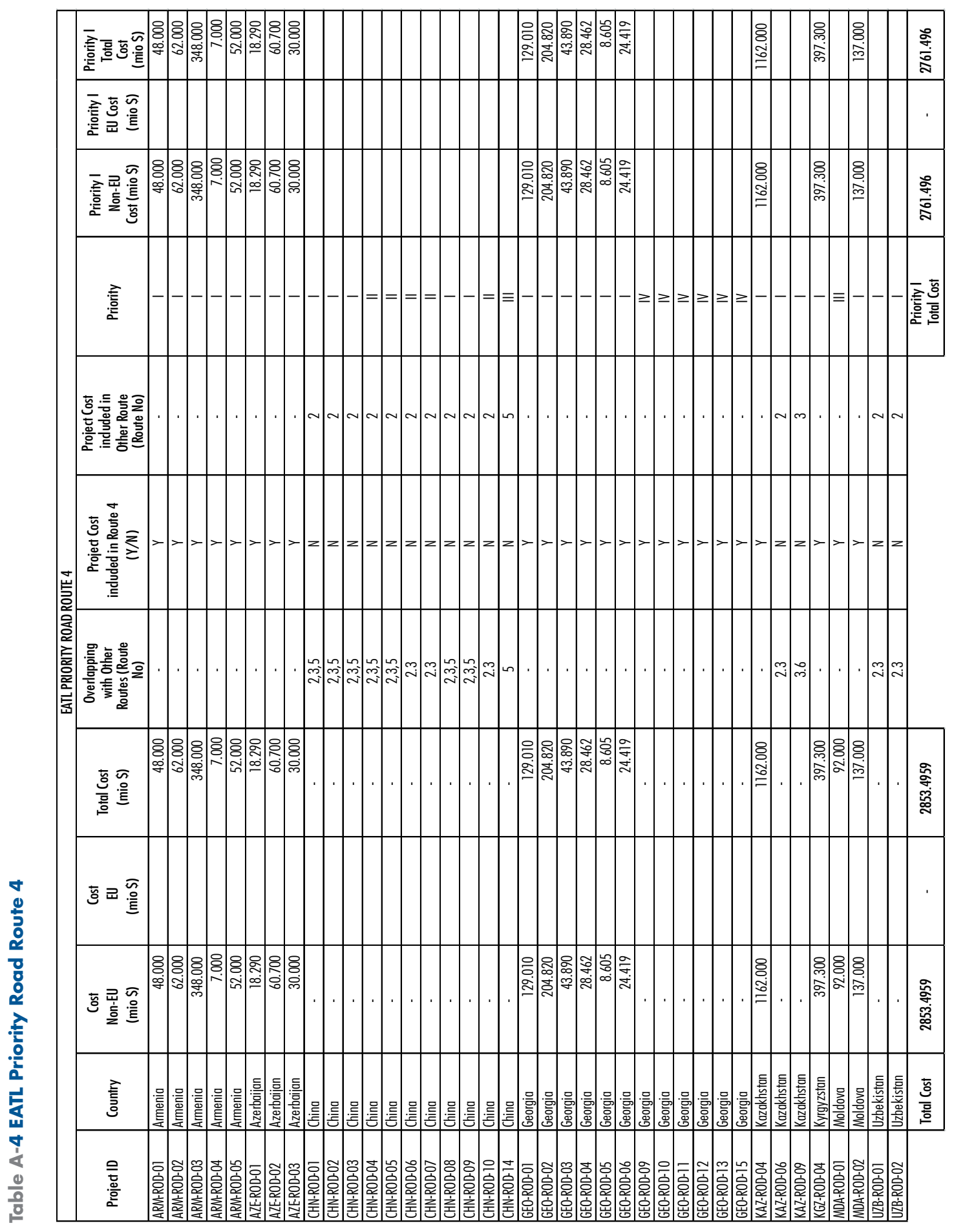


Table A-5 EATL Priority Road Route 5

\begin{tabular}{|c|c|c|c|c|c|c|c|c|c|c|c|}
\hline \multicolumn{12}{|c|}{ EATL PRIORITY ROAD ROUTE 5} \\
\hline Project ID & Country & $\begin{array}{l}\text { Cost } \\
\text { Non-EU } \\
\text { (mio S) }\end{array}$ & $\begin{array}{c}\text { Cost } \\
\text { EU } \\
\text { (mio \$) }\end{array}$ & $\begin{array}{r}\text { Total Cost } \\
\text { (mio S) }\end{array}$ & $\begin{array}{c}\text { Overlapping } \\
\text { with Other } \\
\text { Routes (Route } \\
\text { No) }\end{array}$ & $\begin{array}{c}\text { Project Cost } \\
\text { included in Route } 5 \\
\text { (Y/N) } \\
\end{array}$ & $\begin{array}{l}\text { Project Cost } \\
\text { induded in } \\
\text { Other Route } \\
\text { (Route No) } \\
\end{array}$ & Priority & $\begin{array}{c}\text { Priority I } \\
\text { Non-EU } \\
\text { Cost(mio } \\
\text { S) } \\
\end{array}$ & $\begin{array}{l}\text { Priority I } \\
\text { EU Cost } \\
\text { (mio \$) } \\
\end{array}$ & $\begin{array}{c}\text { Priority I } \\
\text { Total Cost } \\
\text { (mio \$) }\end{array}$ \\
\hline AFG-ROD-10 & Afghanistan & 160.000 & & 160.000 & $\cdot$ & $Y$ & $\cdot$ & IV & & & \\
\hline AFGROD-13 & Afghanistan & $\cdot$ & & & $\cdot$ & Y & $\cdot$ & IV & & & \\
\hline AFGROD-14 & Afghanistan & $\cdot$ & & & $\cdot$ & Y & $\cdot$ & IV & & & \\
\hline AFG-ROD-17 & Afghanistan & 3.000 & & 3.000 & $\cdot$ & Y & $\cdot$ & 1 & 3.000 & & 3.000 \\
\hline AFGROD-20 & Afghanistan & 55.000 & & 55.000 & $\cdot$ & Y & $\cdot$ & IV & & & \\
\hline AFGROD-23 & Afghanistan & 10.000 & & 10.000 & $\cdot$ & Y & $\cdot$ & IV & & & \\
\hline BGR-ROD-13 & Bulgaria & & & & $\cdot$ & $Y$ & $\cdot$ & 1 & & & \\
\hline BGR-ROD-14 & Bulgaria & & 332.500 & 332.500 & $\cdot$ & Y & $\cdot$ & II & & & \\
\hline CHN-ROD-01 & China & $\cdot$ & & & $2,3,4$ & $\mathrm{~N}$ & 2 & 1 & & & \\
\hline CHN-ROD-02 & China & $\cdot$ & & & $2,3,4$ & $\mathrm{~N}$ & 2 & 1 & & & \\
\hline CHN-ROD-03 & China & $\cdot$ & & & $2,3,4$ & $\mathrm{~N}$ & 2 & 1 & & & \\
\hline CHN-ROD-04 & China & $\cdot$ & & & $2,3,4$ & $\mathrm{~N}$ & 2 & II & & & \\
\hline CHN-ROD-05 & China & $\cdot$ & & & $2,3,4$ & $\mathrm{~N}$ & 2 & II & & & \\
\hline CHN-ROD-08 & China & $\cdot$ & & & $2,3,4$ & $\mathrm{~N}$ & 2 & 1 & & & \\
\hline CHN-ROD-09 & China & $\cdot$ & & & $2,3,4$ & $\mathrm{~N}$ & 2 & 1 & & & \\
\hline CHN-ROD-11 & Chinu & 42.300 & & 42.300 & $\cdot$ & Y & $\cdot$ & $\|$ & & & \\
\hline CHN-ROD-12 & Chinu & 1280.700 & & 1280.700 & $\cdot$ & Y & $\cdot$ & 1 & 1280.700 & & 1280.700 \\
\hline CHN-ROD-13 & China & 1286.200 & & 1286.200 & $\cdot$ & Y & $\cdot$ & II & & & \\
\hline CHN-ROD-14 & China & 118.400 & & 118.400 & 4 & $Y$ & $\dot{-}$ & III & & & \\
\hline CHN-ROD-15 & China & 236.700 & & 236.700 & $\cdot$ & Y & $\cdot$ & $\|$ & & & \\
\hline CHN-ROD-16 & Chino & 301.900 & & 301.900 & $\cdot$ & Y & - & II & & & \\
\hline FYROM-ROD-01 & FYROM & 20.615 & & 20.615 & $\cdot$ & Y & - & 1 & 20.615 & & 20.615 \\
\hline FYROM-ROD-02 & FYROM & 325.850 & & 325.850 & $\cdot$ & Y & $\cdot$ & 1 & 325.850 & & 325.850 \\
\hline FYRON-ROD-03 & FYROM & 362.691 & & 362.691 & $\cdot$ & Y & - & 1 & 362.691 & & 362.691 \\
\hline FYRON-ROD-04 & FYROM & 650.902 & & 650.902 & $\cdot$ & Y & - & $\mathrm{I}$ & 650.902 & & 650.902 \\
\hline FYROM-ROD-05 & FYROM & 9.603 & & 9.603 & $\cdot$ & Y & - & 1 & 9.603 & & 9.603 \\
\hline FYROM-ROD-06 & FYROM & 7.315 & & 7.315 & $\cdot$ & Y & $\cdot$ & 1 & 7.315 & & 7.315 \\
\hline GRC-ROD-01 & Greece & $\cdot$ & 399.000 & 399.000 & $\cdot$ & Y & . & 1 & & 399.000 & 399.000 \\
\hline GRC-ROD-02 & Greece & $\cdot$ & 305.900 & 305.900 & $\cdot$ & Y & $\cdot$ & $\mathrm{I}$ & & 305.900 & 305.900 \\
\hline KAZ-ROD-05 & Kazokhstan & 474.000 & & 474.000 & $\cdot$ & $Y$ & $\cdot$ & 1 & 474.000 & & 474.000 \\
\hline KGZ-ROD-01 & \begin{tabular}{|l|} 
Kyrgyzstan \\
\end{tabular} & 48.600 & & 48.600 & $\cdot$ & Y & $\cdot$ & 1 & 48.600 & & 48.600 \\
\hline KGZ-ROD-02 & Kyrgyzstan & 139.700 & & 139.700 & $\cdot$ & $Y$ & $\cdot$ & 1 & 139.700 & & 139.700 \\
\hline PAK-ROD-01 & Pakistan & 297.610 & & 297.610 & $\cdot$ & Y & $\cdot$ & II & & & \\
\hline PAK-ROD-02 & Pakistan & 298.536 & & 298.536 & $\cdot$ & $Y$ & $\cdot$ & $\|$ & & & \\
\hline PAK-ROD-03 & \begin{tabular}{|l|l|} 
Pakistan \\
\end{tabular} & 114.734 & & 114.734 & $\cdot$ & Y & $\cdot$ & $\|$ & & & \\
\hline PAK-ROD-04 & Pakistan & 27.429 & & 27.429 & $\cdot$ & $Y$ & $\cdot$ & 1 & 27.429 & & 27.429 \\
\hline PAK-ROD-05 & \begin{tabular}{|l|l|} 
Pakistan \\
\end{tabular} & 602.054 & & 602.054 & $\cdot$ & Y & $\cdot$ & 1 & 602.054 & & 602.054 \\
\hline PAK-ROD-07 & Pakistan & 328.067 & & 328.067 & $\cdot$ & $Y$ & $\dot{-}$ & III & & & \\
\hline PAK-ROD-08 & Pakistan & 1230.520 & & 1230.520 & $\cdot$ & $Y$ & $\cdot$ & 1 & 1230.520 & & 1230.520 \\
\hline PAK-ROD-09 & Pakistan & 50.555 & & 50.555 & $\cdot$ & Y & $\cdot$ & 1 & 50.555 & & 50.555 \\
\hline PAK-ROD-10 & Pakistan & 52.168 & & 52.168 & $\cdot$ & $Y$ & $\cdot$ & $\|$ & & & \\
\hline PAK-ROD-11 & Pakistan & 86.588 & & 86.588 & $\cdot$ & Y & $\cdot$ & II & & & \\
\hline PAK-ROD-12 & Pakistan & 64.538 & & 64.538 & $\cdot$ & $Y$ & $\cdot$ & $\|$ & & & \\
\hline PAK-ROD-13 & Pakistan & 180.168 & & 180.168 & $\cdot$ & $Y$ & $\cdot$ & 1 & 180.168 & & 180.168 \\
\hline PAK-ROD-14 & Pakistan & 132.840 & & 132.840 & 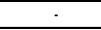 & $Y$ & . & III & & & \\
\hline PAK-ROD-15 & Pakistan & 51.630 & & 51.630 & $\cdot$ & $Y$ & $\cdot$ & 1 & 51.630 & & 51.630 \\
\hline PAK-ROD-16 & Pakistan & 66.689 & & 66.689 & 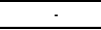 & $Y$ & - & II & & & \\
\hline PAK-ROD-17 & Pakistan & 41.950 & & 41.950 & $\cdot$ & $Y$ & $\cdot$ & 1 & 41.950 & & 41.950 \\
\hline PAK-ROD-18 & \begin{tabular}{|l} 
Pakistan \\
\end{tabular} & 113.479 & & 113.479 & $\cdot$ & $Y$ & $\cdot$ & 1 & 113.479 & & 113.479 \\
\hline PAK-ROD-19 & Pakistan & 12.370 & & 12.370 & $\cdot$ & Y & 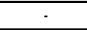 & II & & & \\
\hline PAK-ROD-20 & Pakistan & 12.370 & & 12.370 & $\cdot$ & $Y$ & $\cdot$ & II & & & \\
\hline PAK-ROD-21 & Pakistan & 62.924 & & 62.924 & $\cdot$ & $Y$ & $\cdot$ & 1 & 62.924 & & 62.924 \\
\hline PAK-ROD-22 & Pakistan & 15.597 & & 15.597 & $\cdot$ & $Y$ & $\dot{-}$ & 1 & 15.597 & & 15.597 \\
\hline TJKK-ROD-07 & Tajikistan & 51.578 & & 51.578 & $\cdot$ & $Y$ & $\cdot$ & 1 & 51.578 & & 51.578 \\
\hline TJK-ROD-08 & Tajikistan & 151.500 & & 151.500 & $\cdot$ & Y & 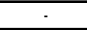 & $\mathrm{I}$ & 151.500 & & 151.500 \\
\hline TJK-ROD-09 & Tojikistan & 15.900 & & 15.900 & $\cdot$ & $Y$ & $\dot{-}$ & 1 & 15.900 & & 15.900 \\
\hline TJK-ROD-10 & Tojikistan & 17.000 & & 17.000 & $\cdot$ & $Y$ & $\cdot$ & 1 & 17.000 & & 17.000 \\
\hline JJK-ROD-14 & Tajikistan & 32.755 & & 32.755 & $\cdot$ & Y & $\cdot$ & 1 & 32.755 & & 32.755 \\
\hline TJK-ROD-15 & Tajikistan & 12.214 & & 12.214 & $\cdot$ & $Y$ & $\cdot$ & 1 & 12.214 & & 12.214 \\
\hline TJK-ROD-16 & Tajikistan & 151.000 & & 151.000 & $\cdot$ & $Y$ & $\cdot$ & IV & & & \\
\hline TJK-ROD-19 & Tajikistan & 13.300 & & 13.300 & $\cdot$ & $Y$ & $\cdot$ & IV & & & \\
\hline TJK-ROD-20 & Tajikistan & 28.000 & & 28.000 & $\cdot$ & $Y$ & $\cdot$ & IV & & & \\
\hline TJK-ROD-23 & Tajikistan & 64.000 & & 64.000 & $\cdot$ & Y & $\cdot$ & 1 & 64.000 & & 64.000 \\
\hline TUR-ROD-01 & Turkey & \begin{tabular}{|l|l|}
1995.000 \\
\end{tabular} & & 1995.000 & $\cdot$ & Y & $\cdot$ & II & & & \\
\hline TUR-ROD-02 & Turkey & 6499.710 & & 6499.710 & $\cdot$ & $Y$ & $\dot{-}$ & 1 & 6499.710 & & 6499.710 \\
\hline TUR-ROD-03 & Tukkey & \begin{tabular}{ll|}
4655.000 \\
\end{tabular} & & 4655.000 & $\cdot$ & Y & $\dot{-}$ & ॥I & & & \\
\hline TURR-ROD-06 & Turkey & 296.424 & & 296.424 & $\cdot$ & $Y$ & $\cdot$ & 1 & 296.424 & & 296.424 \\
\hline TUR-ROD-07 & Turkey & 116.102 & & 116.102 & . & Y & - & 1 & 116.102 & & 116.102 \\
\hline TUR-ROD-08 & Turkey & \begin{tabular}{l|l|}
58.571 \\
\end{tabular} & & 58.571 & $\cdot$ & Y & 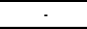 & $\mathrm{I}$ & \begin{tabular}{|l|l|}
58.571 \\
\end{tabular} & & 58.571 \\
\hline TUR-ROD-09 & Tukkey & \begin{tabular}{|l|}
216.605 \\
\end{tabular} & & 216.605 & $\cdot$ & $Y$ & $\cdot$ & 1 & 216.605 & & 216.605 \\
\hline TUR-ROD-10 & Tukkey & 108.321 & & 108.321 & $\cdot$ & $Y$ & $\cdot$ & 1 & 108.321 & & 108.321 \\
\hline & Total Cost & 23859.268 & 1037.4 & 24896.66822 & & & & $\begin{array}{l}\text { Priority I } \\
\text { Total Cost }\end{array}$ & 13339.959 & 704.900 & 14044.859 \\
\hline
\end{tabular}



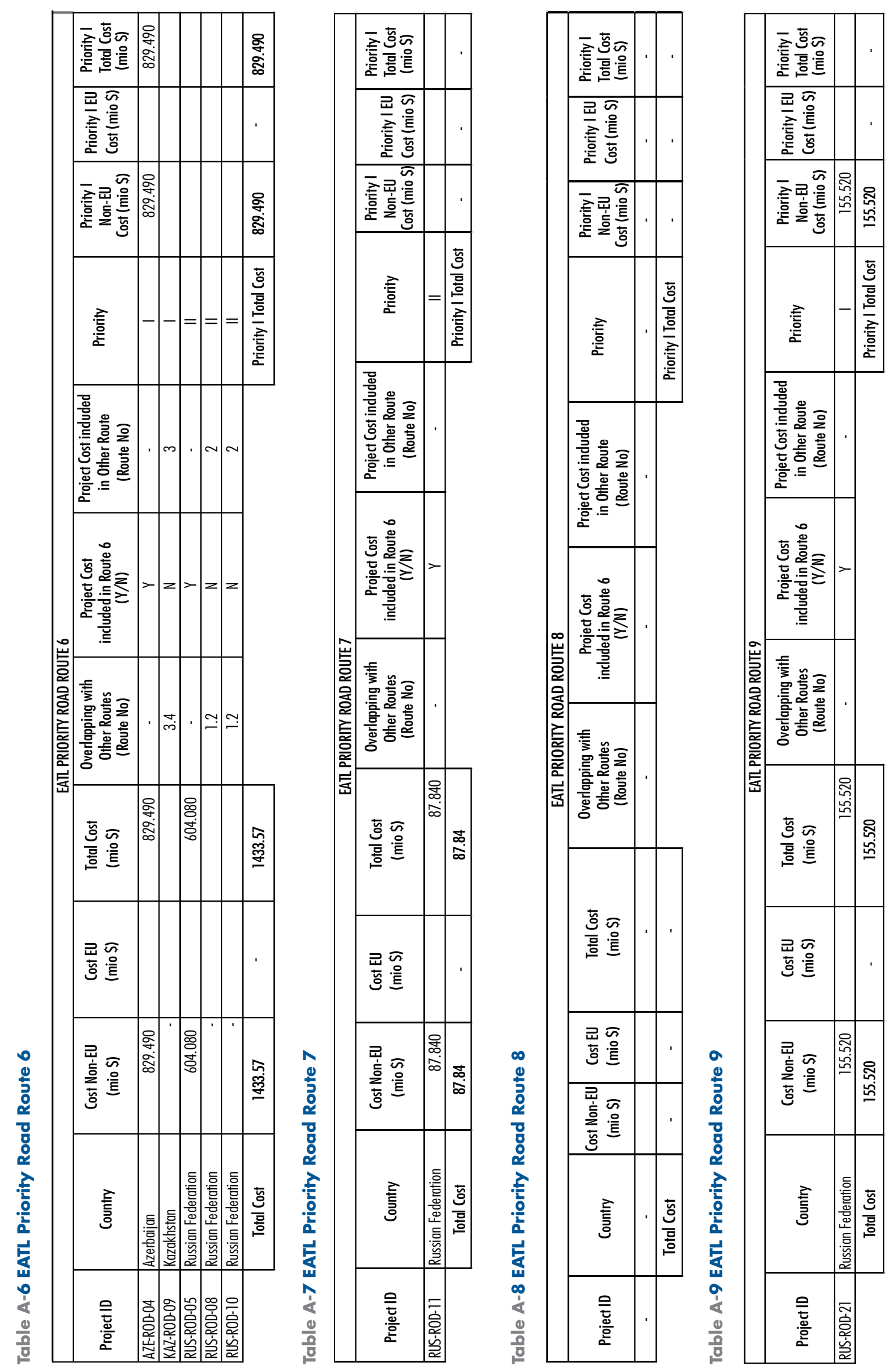


\section{Project priotarization - Rail}

\section{Table B-1 EATL Priority Rail Route 1}

\begin{tabular}{|c|c|c|c|c|c|c|c|c|c|c|c|}
\hline \multicolumn{12}{|c|}{ EATL PRIORITY RAIL ROUTE 1} \\
\hline Project ID & Country & $\begin{array}{c}\text { Cost } \\
\text { Non-EU } \\
\text { (mio \$) }\end{array}$ & $\begin{array}{c}\text { Cost } \\
\text { EU } \\
\text { (mio \$) }\end{array}$ & $\begin{array}{c}\text { Total Cost } \\
\text { (mio \$) }\end{array}$ & $\begin{array}{c}\text { Overlapping } \\
\text { with Other } \\
\text { Routes (Route } \\
\text { No) }\end{array}$ & $\begin{array}{l}\text { Project Cost } \\
\text { included in } \\
\text { Route } 1(\mathrm{Y} / \mathrm{N})\end{array}$ & $\begin{array}{l}\text { Project Cost } \\
\text { included in } \\
\text { Other Route } \\
\text { (Route No) }\end{array}$ & Priority & \begin{tabular}{|c} 
Priority I \\
Non-EU \\
Cost \\
(mio \$) \\
\end{tabular} & $\begin{array}{c}\text { Priority I } \\
\text { EU Cost } \\
\text { (mio \$) } \\
\end{array}$ & \begin{tabular}{|c} 
Priority I \\
Total Cost \\
(mio \$) \\
\end{tabular} \\
\hline DEU-RLW-1 & Germany & & 716.870 & 716.870 & 2 & Y & . & |II & & & 0.000 \\
\hline |LTT-RLW-01 & Latria & & 14.497 & 14.497 & 8 & Y & $\cdot$ & 1 & & 14.497 & 14.497 \\
\hline LAT-RLW-02 & Latvia & & 60.648 & 60.648 & 8 & Y & $\cdot$ & 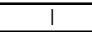 & & 60.648 & 60.648 \\
\hline \begin{tabular}{|l|} 
LAT-RLW-04 \\
\end{tabular} & Latvia & & 160.850 & 160.850 & 8 & Y & $\cdot$ & IV & & & 0.000 \\
\hline \begin{tabular}{|l|l|} 
LAT-RLW-05- \\
\end{tabular} & Latvia & & 20.083 & 20.083 & $\cdot$ & $Y$ & - & 1 & & 20.083 & 20.083 \\
\hline LAT-RLW-06 & Latvia & & 125.020 & 125.020 & 8 & Y & $\cdot$ & 1 & & 125.02 & 125.020 \\
\hline LAT-RLW-07 & Latvia & & 123.557 & 123.557 & $\cdot$ & Y & . & I & & 123.557 & 123.557 \\
\hline \begin{tabular}{|l|l|} 
LAT-RLW-08 \\
\end{tabular} & Latria & & 57.057 & 57.057 & . & $Y$ & . & 1 & & 57.057 & 57.057 \\
\hline 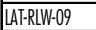 & Latria & & 40.565 & 40.565 & 8 & $Y$ & . & I & & 40.565 & 40.565 \\
\hline 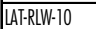 & Latria & & 118.929 & 118.929 & 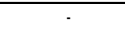 & $Y$ & $\cdot$ & 1 & & 118.9286 & 118.929 \\
\hline 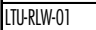 & Lithuania & & 17.423 & 17.423 & 2.8 & $Y$ & $\cdot$ & $\mathrm{I}$ & & 17.423 & 17.423 \\
\hline LTU-RLW-02 & Lithuania & & 64.239 & 64.239 & 2.8 & 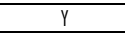 & $\cdot$ & 1 & & 64.239 & 64.239 \\
\hline LTU-RLW-03 & Lithuania & & 9.842 & 9.842 & 2.8 & Y & $\cdot$ & I & & 9.842 & 9.842 \\
\hline LTU-RLW-04 & Lithuania & & 83.524 & 83.524 & 2.8 & $Y$ & $\cdot$ & I & & 83.524 & 83.524 \\
\hline LTU-RLW-05 & Lithuania & & 14.231 & 14.231 & 2.8 & $Y$ & $\cdot$ & I & & 14.231 & 14.231 \\
\hline LTU-RLW-06 & Lithuania & & 3.857 & 3.857 & 2 & $Y$ & - & 1 & & 3.857 & 3.857 \\
\hline LTU-RLW-07 & Lithuania & & 18.886 & 18.886 & 2 & Y & $\cdot$ & I & & 18.886 & 18.886 \\
\hline LTU-RLW-08 & Lithuania & & 34.580 & 34.580 & 2.8 & $y$ & $\cdot$ & 1 & & 34.58 & 34.580 \\
\hline LTURLW-10 & Lithuania & & 43.225 & 43.225 & 2 & 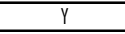 & $\cdot$ & I & & 43.225 & 43.225 \\
\hline 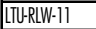 & Lithuania & & 44.289 & 44.289 & 2 & $Y$ & . & 1 & & 44.289 & 44.289 \\
\hline LTU-RLW-12 & Lithuania & & 21.280 & 21.280 & 2 & Y & $\cdot$ & 1 & & 21.28 & 21.280 \\
\hline LIU-RLW-15 & Lithuania & & 78.337 & 78.337 & 2.8 & $Y$ & $\cdot$ & 1 & & 78.337 & 78.337 \\
\hline LTU-RLW-16 & Lithuania & & 55.860 & 55.860 & 2.8 & $Y$ & 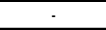 & 1 & & 55.86 & 55.860 \\
\hline LTU-RLW-17 & Lithuania & & 43.092 & 43.092 & 2.8 & $Y$ & - & 1 & & 43.092 & 43.092 \\
\hline LTU-RLW-18 & Lithuania & & 3.950 & 3.950 & 2 & Y & $\cdot$ & I & & 3.9501 & 3.950 \\
\hline LTURLW-19 & Lithuania & & 0.160 & 0.160 & 2 & Y & $\cdot$ & 1 & & 0.1596 & 0.160 \\
\hline LTU-RLW-20 & Lithuania & & 1.357 & 1.357 & 2 & $y$ & . & 1 & & 1.3566 & 1.357 \\
\hline 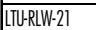 & Lithuania & & 50.939 & 50.939 & 2 & $Y$ & . & 1 & & 50.939 & 50.939 \\
\hline 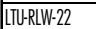 & Lithuania & & 10.640 & 10.640 & 2 & $Y$ & $\cdot$ & 1 & & 10.64 & 10.640 \\
\hline 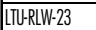 & Lithuania & & 46.018 & 46.018 & 2 & $Y$ & $\cdot$ & 1 & & 46.018 & 46.018 \\
\hline LTU-RLW-24 & Lithuania & & 5.586 & 5.586 & 2 & Y & $\cdot$ & I & & 5.586 & 5.586 \\
\hline LTU-RLW-25 & Lithuania & & 34.314 & 34.314 & 2 & Y & $\cdot$ & I & & 34.314 & 34.314 \\
\hline LTU-RLW-26 & Lithuania & & 8.512 & 8.512 & 2 & 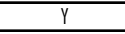 & $\cdot$ & I & & 8.512 & 8.512 \\
\hline LTU-RLW-27 & Lithuania & & 28.329 & 28.329 & 2 & Y & $\cdot$ & 1 & & 28.329 & 28.329 \\
\hline LTURLW-28 & Lithuania & & 29.127 & 29.127 & 2 & Y & - & 1 & & 29.127 & 29.127 \\
\hline LTU-RLW-29 & Lithuania & & 10.507 & 10.507 & 2 & $Y$ & - & 1 & & 10.507 & 10.507 \\
\hline LTU-RLW-30 & Lithuania & & 1.197 & 1.197 & 2.8 & y & - & 1 & & 1.197 & 1.197 \\
\hline LTU-RLW-3I & Lithuania & & 44.023 & 44.023 & 2.8 & 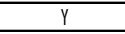 & $\cdot$ & I & & 44.023 & 44.023 \\
\hline LTU-RLW-32 & Lithuania & & 1.197 & 1.197 & 2.8 & $y$ & $\cdot$ & $\mathrm{I}$ & & 1.197 & 1.197 \\
\hline LTURLW-33 & Lithuania & & 35.112 & 35.112 & 2.8 & Y & . & 1 & & 35.112 & 35.112 \\
\hline RUS-RLW-01 & \begin{tabular}{|l|l} 
Russian FED \\
\end{tabular} & 238.070 & & 238.070 & 2 & $y$ & $\cdot$ & $\|$ & & & \\
\hline RUS-RLW-02 & Russian FED & 41.230 & & 41.230 & 2 & Y & 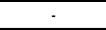 & $\|$ & & & \\
\hline RUS-RLW-06 & Russian FED & 532.000 & & 532.000 & $2,5,9$ & Y & $\cdot$ & $\|$ & & & \\
\hline RUS-RLW-07 & Russian FED & 1564.080 & & 1564.080 & $2,5,9$ & Y & - & II & & & \\
\hline RUS-RLW-29 & Russian FED & 29.260 & & 29.260 & $\cdot$ & Y & - & I & 29.260 & & 29.260 \\
\hline RUS-RLW-3I & Russian FED & & & & $2,5,9$ & Y & $\cdot$ & IV & & & \\
\hline RUS-RLW-32 & \begin{tabular}{|l|} 
Russian FED \\
\end{tabular} & & & & 2 & $y$ & . & IV & & & \\
\hline \begin{tabular}{|l|} 
RUS-RLW-34 \\
\end{tabular} & Russian FED & \begin{tabular}{|l|}
18773.163 \\
\end{tabular} & & 18773.163 & 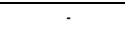 & 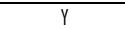 & . & IV & & & \\
\hline RUS-RLW-35 & Russian FED & & & & $\cdot$ & Y & $\cdot$ & IV & & & \\
\hline \multirow[t]{2}{*}{ UKR-RLW-01 } & Ukraine & 178.885 & & 178.885 & $6,7,8$ & $Y$ & - & 1 & 178.885 & & 178.885 \\
\hline & Total Cost & 21356.688 & 2281.708 & 23638.396 & & & & $\begin{array}{l}\text { Priority I } \\
\text { Total Cost }\end{array}$ & 208.145 & 1403.988 & 1612.133 \\
\hline
\end{tabular}


Table B-2 EATL Priority Rail Route 2

\begin{tabular}{|c|c|c|c|c|c|c|c|c|c|c|c|}
\hline \multicolumn{12}{|c|}{ EATL PRIORITY RAIL ROUTE 2} \\
\hline Project ID & Country & $\begin{array}{c}\text { Cost } \\
\text { Non-EU } \\
\text { (mio \$) }\end{array}$ & $\begin{array}{c}\text { Cost } \\
\text { EU } \\
\text { (mio \$) }\end{array}$ & $\begin{array}{l}\text { Total Cost } \\
\text { (mio \$) }\end{array}$ & $\begin{array}{c}\text { Overlapping } \\
\text { with Other } \\
\text { Routes (Route } \\
\text { No) }\end{array}$ & $\begin{array}{l}\text { Project Cost } \\
\text { included in } \\
\text { Route } 2(\mathrm{Y} / \mathrm{N})\end{array}$ & $\begin{array}{l}\text { Project Cost } \\
\text { included in } \\
\text { Other Route } \\
\text { (Route No) }\end{array}$ & Priority & $\begin{array}{l}\text { Priority I } \\
\text { Non-EU } \\
\text { Cost } \\
\text { (mio \$) }\end{array}$ & $\begin{array}{c}\text { Priority I } \\
\text { EU } \\
\text { Cost (mio } \\
\$)\end{array}$ & \begin{tabular}{|} 
Priority I \\
Total \\
Cost (mio \\
\$)
\end{tabular} \\
\hline DEU-RLW-1 & Germany & & $\cdot$ & & 1 & $\mathrm{~N}$ & 1 & III & & & \\
\hline KAZ-RLW-04 & Kazakhstan & $\cdot$ & & & $3,4,7$ & $\mathrm{~N}$ & 4 & 1 & & & \\
\hline LTU-RLW-0] & Lithuania & & $\cdot$ & & 1.8 & $\mathrm{~N}$ & 1 & 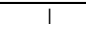 & & & \\
\hline LTU-RLW-02 & Lithuania & & $\cdot$ & & 1.8 & $\mathrm{~N}$ & 1 & $\mathrm{I}$ & & & \\
\hline LTU-RLW-03 & Lithuania & & $\cdot$ & & 1.8 & $\mathrm{~N}$ & 1 & 1 & & & \\
\hline LTU-RLW-04 & Lithuania & & $\cdot$ & & 1.8 & $\mathrm{~N}$ & 1 & 1 & & & \\
\hline LTU-RLW-05 & Lithuania & & $\cdot$ & & 1.8 & $\mathrm{~N}$ & 1 & $\mathrm{I}$ & & & \\
\hline LTU-RLW-06 & Lithuania & & $\cdot$ & & 1 & $\mathrm{~N}$ & 1 & $T$ & & & \\
\hline LTU-RLW-07 & Lithuania & & . & & 1 & $\mathrm{~N}$ & 1 & 1 & & & \\
\hline LUU-RLW-08 & Lithuania & & $\cdot$ & & 1.8 & $\mathrm{~N}$ & 1 & 1 & & & \\
\hline LTU-RLW-10 & Lithuania & & $\cdot$ & & 1 & $\mathrm{~N}$ & 1 & $\mathrm{I}$ & & & \\
\hline LTU-RLW-1T & Lithuania & & $\cdot$ & & 1 & $\mathrm{~N}$ & 1 & 1 & & & \\
\hline LTU-RLW-12 & Lithuania & & $\cdot$ & & 1 & $\mathrm{~N}$ & 1 & 1 & & & \\
\hline LTU-RLW-15 & Lithuania & & $\cdot$ & & 1.8 & $\mathrm{~N}$ & 1 & $\mathrm{I}$ & & & \\
\hline LTU-RLW-16 & Lithuania & & $\cdot$ & & 1.8 & $\mathrm{~N}$ & 1 & $\mathrm{I}$ & & & \\
\hline LTU-RLW-17 & Lithuania & & $\cdot$ & & 1.8 & $\mathrm{~N}$ & 1 & 1 & & & \\
\hline LTU-RLW-18 & Lithuania & & $\cdot$ & & 1 & $\mathrm{~N}$ & 1 & $\mathrm{I}$ & & & \\
\hline LTU-RLW-19 & Lithuania & & $\cdot$ & & 1 & $\mathrm{~N}$ & 1 & 1 & & & \\
\hline LTU-RLW-20 & Lithuania & & - & & 1 & $\mathrm{~N}$ & 1 & $\mathrm{I}$ & & & \\
\hline LTU-RLW-2l & \begin{tabular}{|l} 
Lithuania \\
\end{tabular} & & 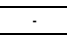 & & 1 & $\mathrm{~N}$ & 1 & 1 & & & \\
\hline LTU-RLW-22 & Lithuania & & $\cdot$ & & 1 & $\mathrm{~N}$ & 1 & $\mathrm{I}$ & & & \\
\hline LTU-RLW-23 & Lithuania & & $\cdot$ & & 1 & $\mathrm{~N}$ & 1 & $\mathrm{I}$ & & & \\
\hline LTU-RLW-24 & Lithuania & & $\cdot$ & & 1 & $\mathrm{~N}$ & 1 & 1 & & & \\
\hline LTU-RLW-25 & Lithuania & & 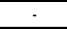 & & 1 & $\mathrm{~N}$ & 1 & $\mathrm{I}$ & & & \\
\hline LTU-RLW-26 & Lithuania & & - & & 1 & $\mathrm{~N}$ & 1 & $\mathrm{I}$ & & & \\
\hline LTU-RLW-27 & Lithuania & & . & & 1 & $\mathrm{~N}$ & 1 & 1 & & & \\
\hline LTU-RLW-28 & Lithuania & & - & & 1 & $\mathrm{~N}$ & 1 & 1 & & & \\
\hline LTU-RLW-29 & Lithuania & & $\cdot$ & & 1 & $\mathrm{~N}$ & 1 & 1 & & & \\
\hline LTU-RLW-30 & Lithuania & & $\cdot$ & & 1.8 & $\mathrm{~N}$ & 1 & $\mathrm{I}$ & & & \\
\hline LTU-RLW-31 & Lithuania & & $\cdot$ & & 1.8 & $\mathrm{~N}$ & 1 & 1 & & & \\
\hline LTU-RLW-32 & Lithuania & & 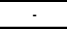 & & 1.8 & $\mathrm{~N}$ & 1 & 1 & & & \\
\hline LTU-RLW-33 & Lithuania & & $\cdot$ & & 1.8 & $\mathrm{~N}$ & 1 & $\mathrm{I}$ & & & \\
\hline \begin{tabular}{|l|} 
RUS-RLW-01 \\
\end{tabular} & Russian FED & . & & & 1 & $\mathrm{~N}$ & 1 & II & & & \\
\hline RUS-RLW-02 & Russian FED & $\cdot$ & & & 1 & $\mathrm{~N}$ & 1 & $\|$ & & & \\
\hline RUS-RLW-06 & Russian FED & $\cdot$ & & & $1,5,9$ & $\mathrm{~N}$ & 1 & II & & & \\
\hline RUS-RLW-07 & Russian FED &. & & & $1,5,9$ & $\mathrm{~N}$ & 1 & $\|$ & & & \\
\hline RUS-RLW-3I & Russian FED & & & & $1,5,9$ & $\mathrm{~N}$ & 1 & IV & & & \\
\hline RUS-RLW-32 & Russian FED & & & & 1 & $\mathrm{~N}$ & 1 & IV & & & \\
\hline & Total Cost & - & - & - & & & & $\begin{array}{c}\text { Priority I } \\
\text { Total Cost }\end{array}$ & - & - & - \\
\hline
\end{tabular}


Table B-3 EATL Priority Rail Route 3

\begin{tabular}{|c|c|c|c|c|c|c|c|c|c|c|c|}
\hline \multicolumn{12}{|c|}{ EATL PRIORITY RAIL ROUTE 3} \\
\hline Project ID & Country & $\begin{array}{c}\text { Cost } \\
\text { Non-EU } \\
\text { (mio \$) }\end{array}$ & $\begin{array}{c}\text { Cost } \\
\text { EU } \\
\text { (mio \$) }\end{array}$ & $\begin{array}{c}\text { Total Cost } \\
\text { (mio \$) }\end{array}$ & $\begin{array}{c}\text { Overlapping } \\
\text { with Other } \\
\text { Routes (Route } \\
\text { No) }\end{array}$ & $\begin{array}{l}\text { Project Cost } \\
\text { induded in } \\
\text { Route } 3(\mathrm{Y} / \mathrm{N})\end{array}$ & $\begin{array}{l}\text { Project Cost } \\
\text { included in } \\
\text { Other Route } \\
\text { (Route No) }\end{array}$ & Priority & $\begin{array}{l}\text { Priority I } \\
\text { Non-EU } \\
\text { Cost } \\
\text { (mio \$) }\end{array}$ & $\begin{array}{l}\text { Priority I } \\
\text { EU } \\
\text { Cost (mio } \\
\$ \text { ) }\end{array}$ & \begin{tabular}{|c|} 
Priority I \\
Total \\
Cost (mio \\
$\$$ \$)
\end{tabular} \\
\hline ARM-RLW-01 & Armenia & 1463.000 & & 1463.000 & 8 & 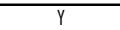 & . & IV & & & 0.000 \\
\hline ARM-RLW-04 & Armenia & & & & 8 & $Y$ & . & IV & & & 0.000 \\
\hline ARM-RLW-05 & Ammenia & 1057.284 & & 1057.284 & 8 & Y & 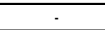 & IV & & & 0.000 \\
\hline AZE-RLW-01 & Azerbaijon & & & & 8 & Y & - & 1 & & & 0.000 \\
\hline BGR-RLW-03 & Bulgaria & & $\cdot$ & & 4 & $\mathrm{~N}$ & 4 & $\mathrm{I}$ & & & 0.000 \\
\hline BGR-RLW-04 & Bulgaria & & . & & 4 & $\mathrm{~N}$ & 4 & I & & & 0.000 \\
\hline FYROM-RLW-01 & FYROM & . & & & 4 & $\mathrm{~N}$ & 4 & $\|$ & & & 0.000 \\
\hline FYROM-RLW-02 & FYROM & $\cdot$ & & & 4 & $\mathrm{~N}$ & 4 & $\|$ & & & 0.000 \\
\hline FYROM-RLW-03 & FYROM & . & & & 4 & $\mathrm{~N}$ & 4 & $\|$ & & & 0.000 \\
\hline FYROM-RLW-04 & FYROM & $\cdot$ & & & 4 & $\mathrm{~N}$ & 4 & $\|$ & & & 0.000 \\
\hline GEO-RLW-0] & Georgia & 332.500 & & 332.500 & 8 & $Y$ & $\cdot$ & 1 & 332.500 & & 332.500 \\
\hline GEO-RLW-02 & Georgia & 399.000 & & 399.000 & . & Y & . & $\|$ & & & 0.000 \\
\hline GEO-RLW-03 & Georgia & 200.000 & & 200.000 & $\cdot$ & $\begin{array}{r} \\
\end{array}$ & - & $\mathrm{I}$ & 200.000 & & 200.000 \\
\hline GEO-RLW-04 & Georgia & & & & $\cdot$ & 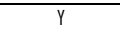 & $\cdot$ & IV & & & 0.000 \\
\hline KAZ-RLW-03 & Kazakhstan & $\cdot$ & & & 4.7 & $\mathrm{~N}$ & 4 & 1 & & & 0.000 \\
\hline KAZZRLW-04 & Kazokhstan & . & & & $2,4,7$ & $\mathrm{~N}$ & 4 & I & & & 0.000 \\
\hline KGZ-RLW-0l & Kyrgyzstan & 2000.000 & & 2000.000 & 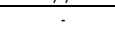 & $Y$ & $\cdot$ & IV & & & 0.000 \\
\hline KGZ-RLW-02 & Kyrgyzstan & 100.000 & & 100.000 & $\cdot$ & $Y$ & - & IV & & & 0.000 \\
\hline KGZ-RLW-03 & \begin{tabular}{|l} 
Krgrgyzstan \\
\end{tabular} & 65.600 & & 65.600 &. & $\gamma$ & $\cdot$ & $\|$ & & & 0.000 \\
\hline KGZ-RLW-04 & Kyrgyzstan & 145.000 & & 145.000 & $\cdot$ & $\gamma$ & $\cdot$ & IV & & & 0.000 \\
\hline MDA-RLW-01 & Moldova & 317.000 & & 317.000 & . & $\gamma$ & . & IV & & & 0.000 \\
\hline TJK-RLW-06 & Taijkistan & 53.900 & & 53.900 &. & $Y$ &. & IV & & & 0.000 \\
\hline TJK-RLW-08 & Taijkistan & 16.400 & & 16.400 & 9 & $Y$ & $\cdot$ & IV & & & 0.000 \\
\hline TU-RLW-03 & Turkey &. & & & 4 & $\mathrm{~N}$ & 4 & 1 & & & 0.000 \\
\hline TU-RLW-05 & Tukkey & 373.730 & & 373.730 & - & $Y$ & 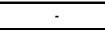 & I & 373.730 & & 373.730 \\
\hline UZB-RLW-01 & Uzbekistan & 85.400 & & 85.400 & $\cdot$ & $Y$ & 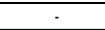 & I & 85.400 & & 85.400 \\
\hline UZB-RLW-02 & Uzbekistan & 40.460 & & 40.460 & $5,7,9$ & Y & $\cdot$ & 1 & 40.460 & & 40.460 \\
\hline UZB-RLW-03 & Uzbekistan & 447.500 & & 447.500 & 9 & $\gamma$ & $\cdot$ & 1 & 447.500 & & 447.500 \\
\hline UZB-RLW-04 & Uzbekistan & 75.000 & & 75.000 & $\cdot$ & $Y$ & $\cdot$ & 1 & 75.000 & & 75.000 \\
\hline UZB-RLW-06 & Uzbekistan & 388.300 & & 388.300 & 9 & $Y$ & $\cdot$ & II & & & 0.000 \\
\hline UZB-RLW-07 & Uzbekistan & $\cdot$ & & & 4 & $\mathrm{~N}$ & 4 & $\|$ & & & 0.000 \\
\hline UZB-RLW-08 & Uzbekistan & $\cdot$ & & & $4,7,9$ & $N$ & 4 & 1 & & & 0.000 \\
\hline UZB-RLW-09 & Uzbekistan & 9.200 & & 9.200 &. & $Y$ &. & I & 9.200 & & 9.200 \\
\hline UZB-RLW-10 & Uzbekistan & 10.000 & & 10.000 & $5,7,9$ & $Y$ & $\cdot$ & I & 10.000 & & 10.000 \\
\hline \multirow[t]{2}{*}{ UZB-RLW-II } & \begin{tabular}{|l|} 
Uzbekistan \\
\end{tabular} &. & & & $4,7,9$ & $\mathrm{~N}$ & 4 & 1 & & & 0.000 \\
\hline & Total Cost & 7579.274 & - & 7579.274 & & & & $\begin{array}{c}\text { Priority I } \\
\text { Total Cost }\end{array}$ & 1573.790 & - & 1573.790 \\
\hline
\end{tabular}

Table B-4 EATL Priority Rail Route 4

\begin{tabular}{|c|c|c|c|c|c|c|c|c|c|c|c|}
\hline \multicolumn{12}{|c|}{ EATL PRIORITY RAIL ROUTE 4} \\
\hline Project ID & Country & $\begin{array}{c}\text { Cost } \\
\text { Non-EU } \\
\text { (mio \$) }\end{array}$ & $\begin{array}{c}\text { Cost } \\
\text { EU } \\
\text { (mio \$) }\end{array}$ & $\begin{array}{c}\text { Total Cost } \\
\text { (mio \$) }\end{array}$ & $\begin{array}{c}\text { Overlapping } \\
\text { with Other } \\
\text { Routes (Route } \\
\text { No) }\end{array}$ & $\begin{array}{l}\text { Project Cost } \\
\text { included in } \\
\text { Route } 4(\mathrm{Y} / \mathrm{N})\end{array}$ & $\begin{array}{l}\text { Project Cost } \\
\text { included in } \\
\text { Other Route } \\
\text { (Route No) }\end{array}$ & Priority & $\begin{array}{c}\text { Priority I } \\
\text { Non-EU } \\
\text { Cost } \\
\text { (mio \$) }\end{array}$ & $\begin{array}{c}\text { Priority I } \\
\text { EU } \\
\text { Cost (mio } \\
\$ \text { ) }\end{array}$ & $\begin{array}{c}\text { Priority I } \\
\text { Total Cost } \\
\text { (mio \$) }\end{array}$ \\
\hline BGR-RLW-01 & Bulgaria & & 500.834 & 500.834 & $\cdot$ & Y & . & I & & 500.834 & 500.834 \\
\hline BGR-RLW-02 & Bulgaria & & 31.992 & 31.992 & . & Y & . & I & & 31.992 & 31.992 \\
\hline BGR-RLW-03 & Bulgania & & 1.351 & 1.351 & 3 & $Y$ & . & 1 & & 1.351 & 1.351 \\
\hline BGR-RLW-04 & Bulgaria & & 4105.034 & 4105.034 & 3 & Y & $\cdot$ & 1 & & 4105.034 & 4105.034 \\
\hline BGR-RLW-05 & Bulgaria & & 176.913 & 176.913 & 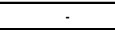 & Y & $\cdot$ & $\mathrm{I}$ & & 176.913 & 176.913 \\
\hline \begin{tabular}{|l|} 
BGR-RLW-06 \\
\end{tabular} & \begin{tabular}{|l} 
Bulgaria \\
\end{tabular} & & 2032.432 & 2032.432 & $\cdot$ & $Y$ & $\cdot$ & 1 & & 2032.432 & 2032.432 \\
\hline FYROM-RLW-01 & FYROM & 59.850 & & 59.850 & 3 & 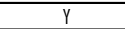 & . & $\|$ & & & \\
\hline FYROM-RLW-02 & FYROM & 291.270 & & 291.270 & 3 & $y$ & . & $\|$ & & & \\
\hline FYROM-RLW-03 & FYROM & 263.340 & & 263.340 & 3 & Y & $\cdot$ & $\|$ & & & \\
\hline FYROM-RLW-04 & FYROM & 399.000 & & 399.000 & 3 & Y & $\cdot$ & $\|$ & & & \\
\hline GRC-RLW-0] & Greece & & 17.290 & 17.290 & . & Y & . & 1 & & 17.290 & 17.290 \\
\hline \begin{tabular}{|l|} 
IR-RLW-04 \\
\end{tabular} & Iran & 100.000 & & 100.000 & . & 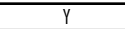 & . & $\mathrm{I}$ & 100.000 & & 100.000 \\
\hline \begin{tabular}{|l|l|} 
R-RLW-07 \\
\end{tabular} & Iran & 400.000 & & 400.000 & $\cdot$ & Y & 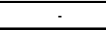 & $\mathrm{I}$ & 400.000 & & 400.000 \\
\hline KAZ-RLW-03 & Kazokhstan & 1000.000 & & 1000.000 & 3.7 & Y & $\cdot$ & $\mathrm{I}$ & 1000.000 & & 1000.000 \\
\hline KAZ-RLW-04 & Kazokhstan & 507.000 & & 507.000 & $2,3,7$ & Y & - & $\mathrm{I}$ & 507.000 & & 507.000 \\
\hline PAK-RLW-01 & Pakiston & & & & . & $y$ & . & IV & & & \\
\hline TU-RLW-01 & Turkey & 4655.000 & & 4655.000 & . & $Y$ & . & 1 & 4655.000 & & 4655.000 \\
\hline TU-RLW-02 & Turkey & 4455.500 & & 4455.500 & $\cdot$ & Y & . & $\mathrm{I}$ & 4455.500 & & 4455.500 \\
\hline TU-RLW-03 & Turkey & 208.810 & & 208.810 & 3 & Y & . & 1 & 208.810 & & 208.810 \\
\hline TU-RLW-04 & Turkey & 3497.900 & & 3497.900 & 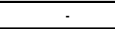 & Y & $\cdot$ & $\mathrm{I}$ & 3497.900 & & 3497.900 \\
\hline TU-RLW-06 & Turkey & 1030.750 & & 1030.750 & $\cdot$ & $Y$ & $\cdot$ & IV & & & \\
\hline TU-RLW-07 & Turkey & 4149.600 & & 4149.600 & $\cdot$ & $y$ & . & IV & & & \\
\hline TU-RLW-08 & Turkey & 2000.000 & & 2000.000 & $\cdot$ & $Y$ & $\cdot$ & III & & & \\
\hline TU-RLW-09 & Turkey & 2000.000 & & 2000.000 & $\cdot$ & $Y$ & 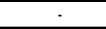 & $\|$ & & & \\
\hline UZB-RLW-07 & Uzbekistan & 443.900 & & 443.900 & 3 & $Y$ & $\cdot$ & II & & & \\
\hline UZB-RLW-08 & Uzbekistan & 76.700 & & 76.700 & $3,7,9$ & Y & $\cdot$ & I & 76.700 & & 76.700 \\
\hline \multirow{2}{*}{ UZB-RLW-II } & Uzbekistan & 334.300 & & 334.300 & $3,7,9$ & $Y$ & 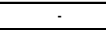 & $\mathrm{I}$ & 334.300 & & 334.300 \\
\hline & Total Cost & 25872.920 & 6865.846 & 32738.766 & & & & $\begin{array}{c}\text { Priority I } \\
\text { Total Cost }\end{array}$ & 15235.210 & 6865.846 & 22101.056 \\
\hline
\end{tabular}


Table B-5 EATL Priority Rail Route 5

\begin{tabular}{|c|c|c|c|c|c|c|c|c|c|c|c|}
\hline \multicolumn{12}{|c|}{ EATL PRIORITY RAIL ROUTE 5} \\
\hline Project ID & Country & $\begin{array}{c}\text { Cost } \\
\text { Non-EU } \\
\text { (mio \$) }\end{array}$ & $\begin{array}{c}\text { Cost } \\
\text { EU } \\
\text { (mio \$) }\end{array}$ & $\begin{array}{c}\text { Total Cost } \\
\text { (mio \$) }\end{array}$ & $\begin{array}{c}\text { Overlapping } \\
\text { with Other } \\
\text { Routes (Route } \\
\text { No) }\end{array}$ & $\begin{array}{l}\text { Project Cost } \\
\text { included in } \\
\text { Route } 5(\mathrm{Y} / \mathrm{N})\end{array}$ & $\begin{array}{l}\text { Project Cost } \\
\text { included in } \\
\text { Other Route } \\
\text { (Route No) }\end{array}$ & Priority & \begin{tabular}{|c} 
Priority I \\
Non-EU \\
Cost \\
(mio \$)
\end{tabular} & \begin{tabular}{|c} 
Priority I \\
EU \\
Cost (mio \\
$\$$ )
\end{tabular} & \begin{tabular}{|c} 
Priority I \\
Total \\
Cost \\
(mio \$)
\end{tabular} \\
\hline $\mid$ IR-RLW-0| & Iran & 800.000 & & 800.000 & - & $Y$ & & I & 800.000 & & 800.000 \\
\hline \begin{tabular}{|l|l|} 
IR-RLW-03 \\
\end{tabular} & Iran & 778.000 & & 778.000 & . & $y$ & & $\mathrm{I}$ & 778.000 & & 778.000 \\
\hline IR-RLW-05 & Iran & 450.000 & & 450.000 & - & $Y$ & & 1 & 450.000 & & 450.000 \\
\hline IR-RLW-06 & Iran & 1350.000 & & 1350.000 & . & $Y$ & & $\|$ & & & \\
\hline \begin{tabular}{|l|} 
RUS-RLW-06 \\
\end{tabular} & \begin{tabular}{|l|} 
Russian FED \\
\end{tabular} & - & & & 1,29 & $\mathrm{~N}$ & 1 & $\|$ & & & \\
\hline \begin{tabular}{|l|l|} 
RUS-RLW-07 \\
\end{tabular} & \begin{tabular}{|l|l|} 
Russian FED \\
\end{tabular} & . & & & 129 & $\mathrm{~N}$ & 1 & $\|$ & & & \\
\hline \begin{tabular}{|l|} 
RUS-RLW-13 \\
\end{tabular} & \begin{tabular}{|l|} 
Russian FED \\
\end{tabular} & 106.400 & & 106.400 & $\frac{116}{9}$ & y & & $\|$ & & & \\
\hline \begin{tabular}{|l|} 
RUS-RLW-14 \\
\end{tabular} & Russian FED & 154.280 & & 154.280 & 9 & $Y$ & & I & 154.280 & & 154.280 \\
\hline RUS-RLW-24 & \begin{tabular}{|l} 
Russian FED \\
\end{tabular} & 295.260 & & 295.260 & 9 & $Y$ & & $\|$ & & & \\
\hline \begin{tabular}{|l|} 
RUS-RLW-26 \\
\end{tabular} & Russian FED & 198.170 & & 198.170 & 9 & $y$ & & $\|$ & & & \\
\hline RUS-RLW-27 & Russian FED & 131.670 & & 131.670 & 9 & $Y$ & & I & 131.670 & & 131.670 \\
\hline RUS-RLW-28 & Russian FED & 246.050 & & 246.050 & 9 & $y$ & & $\|$ & & & \\
\hline RUS-RLW-31 & Russian FED & - & & & $1,2,9$ & $\mathrm{~N}$ & 1 & IV & & & \\
\hline RUS-RLW-37 & Russian FED & & & & 9 & Y & & IV & & & \\
\hline RUS-RLW-38 & Russian FED & & & & . & $y$ & & IV & & & \\
\hline $\begin{array}{l}\text { UZB-RLW-02 } \\
\end{array}$ & Uzbekistan & - & & & $3,7,9$ & $\mathrm{~N}$ & 3 & I & & & \\
\hline \multirow[t]{2}{*}{ UZB-RLW-10 } & \begin{tabular}{|l} 
Uzbekistan \\
\end{tabular} & - & & & $3,7,9$ & $\mathrm{~N}$ & 3 & 1 & & & \\
\hline & Total Cost & 4509.830 & - & 4509.830 & & & & $\begin{array}{c}\text { Priority I } \\
\text { Total Cost }\end{array}$ & 2313.950 & - & 2313.950 \\
\hline
\end{tabular}

Table B-6 EATL Priority Rail Route 6

\begin{tabular}{|c|c|c|c|c|c|c|c|c|c|c|c|}
\hline \multicolumn{12}{|c|}{ EATL PRIORITY RAIL ROUTE 6} \\
\hline Project ID & Country & $\begin{array}{c}\text { Cost } \\
\text { Non-EU } \\
\text { (mio \$) }\end{array}$ & $\begin{array}{c}\text { Cost } \\
\text { EU } \\
\text { (mio \$) }\end{array}$ & $\begin{array}{c}\text { Total Cost } \\
\text { (mio \$) }\end{array}$ & $\begin{array}{c}\text { Overlapping } \\
\text { with Other } \\
\text { Routes (Route } \\
\text { No) }\end{array}$ & $\begin{array}{l}\text { Project Cost } \\
\text { induded in } \\
\text { Route } 6(\mathrm{Y} / \mathrm{N})\end{array}$ & $\begin{array}{l}\text { Project Cost } \\
\text { included in } \\
\text { Other Route } \\
\text { (Route No) }\end{array}$ & Priority & $\begin{array}{l}\text { Priority } \\
\text { I Non- } \\
\text { EU Cost } \\
\text { (mio \$) }\end{array}$ & $\begin{array}{l}\text { Priority I } \\
\text { EU Cost } \\
\text { (mio \$) }\end{array}$ & \begin{tabular}{|c|} 
Priority I \\
Total \\
Cost \\
(mio \$)
\end{tabular} \\
\hline \begin{tabular}{|l|} 
DEU-RLW-3 \\
\end{tabular} & Germany & & & & - & 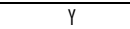 & . & IV & & & \\
\hline \begin{tabular}{|l|} 
RUS-RLW-03 \\
\end{tabular} & Russian FED & 13.300 & & 13.300 & 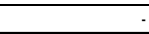 & $Y$ & - & I & 13.300 & & 13.300 \\
\hline \multirow[t]{2}{*}{\begin{tabular}{|l|} 
UKR-RLW-01 \\
\end{tabular}} & Ukraine & - & & & $1,7,8$ & $\mathrm{~N}$ & 1 & $\mathrm{I}$ & & & \\
\hline & Total Cost & 13.300 & - & 13.300 & & & & $\begin{array}{l}\text { Priority I } \\
\text { Total Cost }\end{array}$ & 13.300 & - & 13.300 \\
\hline
\end{tabular}

Table B-7 EATL Priority Rail Route 7

\begin{tabular}{|c|c|c|c|c|c|c|c|c|c|c|c|}
\hline \multicolumn{12}{|c|}{ EATL PRIORITY RAIL ROUTE 7} \\
\hline Project ID & Country & $\begin{array}{c}\text { Cost } \\
\text { Non-EU } \\
\text { (mio \$) }\end{array}$ & $\begin{array}{c}\text { Cost } \\
\text { EU } \\
\text { (mio \$) }\end{array}$ & $\begin{array}{c}\text { Total Cost } \\
\text { (mio \$) }\end{array}$ & $\begin{array}{c}\text { Overlapping } \\
\text { with Other } \\
\text { Routes (Route } \\
\text { No) }\end{array}$ & $\begin{array}{l}\text { Project Cost } \\
\text { included in } \\
\text { Route } 7(\mathrm{Y} / \mathrm{N})\end{array}$ & $\begin{array}{l}\text { Project Cost } \\
\text { included in } \\
\text { Other Route } \\
\text { (Route No) }\end{array}$ & Priority & $\begin{array}{c}\text { Priority I } \\
\text { Non-EU } \\
\text { Cost } \\
\text { (mio \$) }\end{array}$ & $\begin{array}{c}\text { Priority I } \\
\text { EU Cost } \\
\text { (mio \$) }\end{array}$ & \begin{tabular}{|c|} 
Priority I \\
Total \\
Cost \\
(mio \$) \\
\end{tabular} \\
\hline KAZ-RLW-03 & Kazakhstan & - & & & 3.4 & $\mathrm{~N}$ & 4 & 1 & & & \\
\hline KAZ-RLW-04 & Kazakhstan & $\cdot$ & & & $2,3,4$ & $\mathrm{~N}$ & 4 & $\mathrm{I}$ & & & \\
\hline UKR-RLW-01 & Ukraine & . & & & $1,6,8$ & $\mathrm{~N}$ & 1 & $\mathrm{I}$ & & & \\
\hline \begin{tabular}{|l|} 
UZB-RLW-02 \\
\end{tabular} & Uzbekistan & . & & & $3,5,9$ & $\mathrm{~N}$ & 3 & $\mathrm{~T}$ & & & \\
\hline UZB-RLW-08 & Uzbekistan & - & & & $3,4,9$ & $\mathrm{~N}$ & 3 & 1 & & & \\
\hline UZB-RLW-10 & Uzbekistan & - & & & $3,5,9$ & $\mathrm{~N}$ & 3 & I & & & \\
\hline \multirow[t]{2}{*}{ UZB-RLW-11 } & Uzbekistan & $\cdot$ & & & $3,4,9$ & $\mathrm{~N}$ & 3 & 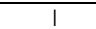 & & & \\
\hline & Total Cost & - & - & - & & & & $\begin{array}{c}\text { Priority I } \\
\text { Total Cost }\end{array}$ & - & - & - \\
\hline
\end{tabular}


Table B-8 EATL Priority Rail Route 8

\begin{tabular}{|c|c|c|c|c|c|c|c|c|c|c|c|}
\hline \multicolumn{12}{|c|}{ EATL PRIORITY RAIL ROUTE 8} \\
\hline Project ID & Country & $\begin{array}{c}\text { Cost } \\
\text { Non-EU } \\
\text { (mio \$) }\end{array}$ & $\begin{array}{c}\text { Cost } \\
\text { EU } \\
\text { (mio \$) }\end{array}$ & $\begin{array}{c}\text { Total Cost } \\
\text { (mio \$) }\end{array}$ & $\begin{array}{c}\text { Overlapping } \\
\text { with Other } \\
\text { Routes (Route } \\
\text { No) }\end{array}$ & $\begin{array}{l}\text { Project Cost } \\
\text { included in } \\
\text { Route } 8(\mathrm{Y} / \mathrm{N})\end{array}$ & $\begin{array}{l}\text { Project Cost } \\
\text { included in } \\
\text { Other Route } \\
\text { (Route No) }\end{array}$ & Priority & \begin{tabular}{|c} 
Priority I \\
Non-EU \\
Cost \\
(mio \$)
\end{tabular} & $\begin{array}{c}\text { Priority I } \\
\text { EU } \\
\text { Cost (mio } \\
\$ \text { ) }\end{array}$ & $\begin{array}{c}\text { Priority I } \\
\text { Total } \\
\text { Cost (mio } \\
\$ \text { ) }\end{array}$ \\
\hline ARM-RLW-01 & Armenia & - & & & 3 & $\mathrm{~N}$ & 3 & IV & & & \\
\hline ARM-RLW-04 & Armenia & - & & & 3 & $\mathrm{~N}$ & 3 & IV & & & \\
\hline ARM-RLW-05 & Armenia & - & & & 3 & $\mathrm{~N}$ & 3 & IV & & & \\
\hline AZE-RLW-01 & Azerbaijan & - & & & 3 & $\mathrm{~N}$ & 3 & 1 & & & \\
\hline GEO-RLW-01 & Georgia & $\cdot$ & & & 3 & $\mathrm{~N}$ & 3 & $\mathrm{I}$ & & & \\
\hline \begin{tabular}{|l|l|} 
LAT-RLW-01 \\
\end{tabular} & Latvia & & $\cdot$ & & 1 & $\mathrm{~N}$ & 1 & 1 & & & \\
\hline LAT-RLW-02 & Latvia & & - & & 1 & $\mathrm{~N}$ & 1 & $\mathrm{I}$ & & & \\
\hline LAT-RLW-03 & Latvin & & 1995.000 & 1995.000 & - & Y & - & IV & & & \\
\hline LAT-RLW-04 & Latvia & & $\cdot$ & & 1 & $\mathrm{~N}$ & 1 & IV & & & \\
\hline LAT-RLW-06 & Latvia & & - & & 1 & $\mathrm{~N}$ & 1 & $\mathrm{I}$ & & & \\
\hline LAT-RLW-09 & Latvia & & - & & 1 & $\mathrm{~N}$ & 1 & $\mathrm{I}$ & & & \\
\hline LTU-RLW-01 & Lithuania & & - & & 1.2 & $\mathrm{~N}$ & 1 & $\mathrm{I}$ & & & \\
\hline LTU-RLW-02 & Lithuania & & - & & 1.2 & $\mathrm{~N}$ & 1 & 1 & & & \\
\hline LTU-RLW-03 & Lithuania & & - & & 1.2 & $\mathrm{~N}$ & 1 & $\mathrm{I}$ & & & \\
\hline LTU-RLW-04 & Lithuania & & - & & 1.2 & $\mathrm{~N}$ & 1 & 1 & & & \\
\hline LTU-RLW-05 & Lithuania & & - & & 1.2 & $\mathrm{~N}$ & 1 & $\mathrm{I}$ & & & \\
\hline LTU-RLW-08 & Lithuania & & $\cdot$ & & 1.2 & $\mathrm{~N}$ & 1 & $\mathrm{I}$ & & & \\
\hline LTU-RLW-15 & Lithuania & & - & & 1.2 & $\mathrm{~N}$ & 1 & $\mathrm{I}$ & & & \\
\hline LTU-RLW-16 & Lithuania & & - & & 1.2 & $\mathrm{~N}$ & 1 & $\mathrm{I}$ & & & \\
\hline LTU-RLW-17 & Lithuania & & - & & 1.2 & $\mathrm{~N}$ & 1 & $\mathrm{I}$ & & & \\
\hline LTU-RLW-30 & Lithuania & & - & & 1.2 & $\mathrm{~N}$ & 1 & $\mathrm{I}$ & & & \\
\hline LTU-RLW-31 & Lithuania & & - & & 1.2 & $\mathrm{~N}$ & 1 & 1 & & & \\
\hline $\begin{array}{l}\text { LTU-RLW-32 } \\
\end{array}$ & Lithuania & & - & & 1.2 & $\mathrm{~N}$ & 1 & 1 & & & \\
\hline \begin{tabular}{|l|l|l|l|l|} 
LTU-RLW-33 \\
\end{tabular} & Lithuania & & $\cdot$ & & 1.2 & $\mathrm{~N}$ & 1 & $\mathrm{I}$ & & & \\
\hline RUS-RLW-17 & \begin{tabular}{|l|} 
Russian FED \\
\end{tabular} & 47.880 & & 47.880 & - & $Y$ & $\cdot$ & II & & & \\
\hline RUS-RLW-19 & \begin{tabular}{|l|l} 
Russian FED \\
\end{tabular} & 41.230 & & 41.230 & - & $Y$ & - & 1 & 41.230 & & 41.230 \\
\hline RUS-RLW-2l & \begin{tabular}{|l|l|l} 
Russian FED \\
\end{tabular} & $\cdot$ & & & 9 & $\mathrm{~N}$ & 9 & II & & & \\
\hline RUS-RLW-39 & \multicolumn{2}{|l|}{$\begin{array}{l}\text { Russian FED } \\
\end{array}$} & & & - & $Y$ & $\cdot$ & IV & & & \\
\hline \multirow[t]{2}{*}{ UKR-RLW-01 } & Ukraine & - & & & $1,6,7$ & $\mathrm{~N}$ & 1 & 1 & & & \\
\hline & Total Cost & 89.110 & 1995.000 & 2084.110 & & & & $\begin{array}{r}\text { Priority I } \\
\text { Total Cost } \\
\end{array}$ & 41.230 & - & 41.230 \\
\hline
\end{tabular}

Table B-9 EATL Priority Rail Route 9

\begin{tabular}{|c|c|c|c|c|c|c|c|c|c|c|c|}
\hline \multicolumn{12}{|c|}{ EATL PRIORITY RAIL ROUTE 9} \\
\hline Project ID & Country & $\begin{array}{c}\text { Cost } \\
\text { Non-EU } \\
\text { (mio \$) }\end{array}$ & $\begin{array}{c}\text { Cost } \\
\text { EU } \\
\text { (mio \$) }\end{array}$ & $\begin{array}{c}\text { Total Cost } \\
\text { (mio \$) }\end{array}$ & $\begin{array}{c}\text { Overlapping } \\
\text { with Other } \\
\text { Routes (Route } \\
\text { No) }\end{array}$ & $\begin{array}{l}\text { Project Cost } \\
\text { included in } \\
\text { Route } 9(\mathrm{Y} / \mathrm{N})\end{array}$ & $\begin{array}{l}\text { Project Cost } \\
\text { included in } \\
\text { Other Route } \\
\text { (Route No) }\end{array}$ & Priority & \begin{tabular}{|c|} 
Priority I \\
Non-EU \\
Cost \\
(mio \$)
\end{tabular} & \begin{tabular}{|c} 
Priority I \\
EU \\
Cost (mio \\
\$)
\end{tabular} & $\begin{array}{c}\text { Priority I } \\
\text { Total } \\
\text { Cost (mio } \\
\text { \$) }\end{array}$ \\
\hline RUS-RLW-06 & Russian FED & - & & & $1,2,5$ & $\mathrm{~N}$ & 1 & $\|$ & & & \\
\hline \begin{tabular}{|l|l|} 
RUS-RLW-07 \\
\end{tabular} & \begin{tabular}{|l|} 
Russian FED \\
\end{tabular} & . & & & $1,2,5$ & $\mathrm{~N}$ & 1 & $\|$ & & & \\
\hline RUS-RLW-13 & Russian FED & - & & & 5 & $\mathrm{~N}$ & 5 & $\|$ & & & \\
\hline RUS-RLW-14 & Russian FED & - & & & 5 & $\mathrm{~N}$ & 5 & I & & & \\
\hline RUS-RLW-2] & \begin{tabular}{|l|l|} 
Russian FED \\
\end{tabular} & 223.440 & & 223.440 & 8 & $\mathrm{Y}$ & - & II & & & \\
\hline RUS-RLW-24 & Russian FED & - & & & 5 & $\mathrm{~N}$ & 5 & $\|$ & & & \\
\hline RUS-RLW-25 & Russian FED & 414.960 & & 414.960 & - & Y & - & I & 414.960 & & 414.960 \\
\hline RUS-RLW-26 & Russian FED & $\cdot$ & & & 5 & $\mathrm{~N}$ & 5 & $\|$ & & & \\
\hline RUS-RLW-27 & Russian FED & - & & & 5 & $\mathrm{~N}$ & 5 & I & & & \\
\hline RUS-RLW-28 & Russian FED & - & & & 5 & $\mathrm{~N}$ & 5 & $\|$ & & & \\
\hline RUS-RLW-3] & Russian FED & & & & $1,5,9$ & $\mathrm{~N}$ & 1 & IV & & & \\
\hline RUS-RLW-37 & Russian FED & & & & 5 & $\mathrm{~N}$ & 5 & IV & & & \\
\hline TJK-RLW-08 & Tajikistan & - & & & 3 & $\mathrm{~N}$ & 3 & IV & & & \\
\hline UZB-RLW-02 & Uzbekistan & - & & & $3,5,7$ & $\mathrm{~N}$ & 3 & I & & & \\
\hline UZB-RLW-03 & Uzbekistan & - & & & 3 & $\mathrm{~N}$ & 3 & I & & & \\
\hline UZB-RLW-06 & Uzbekistan & - & & & 3 & $\mathrm{~N}$ & 3 & $\|$ & & & \\
\hline UZB-RLW-08 & Uzbekistan & - & & & $3,4,7$ & $\mathrm{~N}$ & 3 & I & & & \\
\hline UZB-RLW-10 & Uzbekistan & 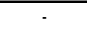 & & & $3,5,7$ & $\mathrm{~N}$ & 3 & $\mathrm{I}$ & & & \\
\hline \multirow[t]{2}{*}{ UZB-RLW-II } & Uzbekistan & - & & & $3,4,7$ & $\mathrm{~N}$ & 3 & 1 & & & \\
\hline & Total Cost & 638.400 & - & 638.400 & & & & $\begin{array}{c}\text { Priority I } \\
\text { Total Cost }\end{array}$ & 414.960 & - & 414.960 \\
\hline
\end{tabular}




\section{GEOGRAPHIC INFORMATION SYSTEM (GIS) INTERNET APPLICATION}

\subsection{GIS in the Euro-Asian transport linkages project}

The Euro-Asian transport linkages project has an important geographical feature; it defines road, rail and inland waterway routes, analysing and evaluating projects proposed by participating countries. Almost all the data collected for the project have a geographic information system (GIS) feature as visual representations of the analyses are more readable and have greater impact than text or data in tables. The results of the GIS project database were thus used during the process of identifying priority routes and project prioritization. GIS Internet application goals included:

- Conveying data by integrating a spatial component

- Putting the GIS data to work rather than working out the data to understand it

- Incorporating a visual tool for decision makers

- Ensuring the data can be exported to other database systems

\subsection{Status}

- The GIS software used was MapInfo Professional version 7.5.

- The basic "layers" and data were merged.

- All the workspaces and maps were designed to be published on the Internet in electronic format or in printed documents.

- The EATL GIS database was fully implemented; the data introduction and object localization tasks were completed for most of the data types.

- An evaluation of different software systems and solutions was conducted. The solution selected was consistent with project objectives and constraints.

- An Internet application for EATL data visualization and query was designed and developed.

The EATL GIS database has two data types:

- Predefined general data

- EATL specific data

All the data of the same type were grouped together in a "table" called a "layer" in GIS.

The GIS layers defined in the EATL Study were:

- Predefined - from official sources

- Borders

- Rivers and lakes

- Cities (capitals, small cities, populated places, build-up areas)

- All railway lines

- Railway stations

- Roads (by category)

- EATL specific

- Nodes 
- cities and/or railway stations (rail)

- cities/nodes/junctions (road)

- cities/stations/etc. defining road projects

- cities/stations/etc. defining rail projects

- border crossings

- EATL rail routes

- EATL road routes

- EATL rail projects (ongoing and planned)

- EATL road projects (ongoing and planned)

- EAL inland waterways

- EATL maritime ports

- EATL inland ports

\subsection{Sources}

The data used to build and populate the EATL database originated from various sources:

- Data collected from the Member Countries, based on reports and predefined questionnaires

- ADC WorldMap Version 4.0A: predefined data acquired by the project

- Studies and reports published on the Internet from official websites (government, international bodies and projects, including Central Asia Regional Economic Cooperation, Transport Corridor Europe-Caucasus-Asia, Economic and Social Commission for Asia and the Pacific, Asian Development Bank)

- GIS data from Google Earth, Bing, OpenStreets

\subsection{Objectives}

The GIS data have the following attributes:

- Precision: 1:100,000

- Map scale: 1:1,000,000

- Projection: category: longitude/latitude WGS 1984

- Coordinates collected in decimal degrees

The intended use of the EATL GIS database was:

- as a base for designing maps needed in the project

- to depict the routes and inform decision makers

- as an Internet application to present the routes, projects and other types of data from their geographical perspective in dynamic, online generated maps and views

The EATL GIS database was not intended for use by contractors and builders as design support for their projects.

The EATL project maps were designed to show:

- individual transport modes per country

- overall transport modes per country

- project prioritization

- technical characteristics of particular transport links

- the entire EATL region 
The maps generated were used in the project prioritization process.

The EATL GIS database is useful for:

- EATL Member Countries in the framework of the project

- UNECE EATL

- the greater public via Internet users through an Internet application

\subsection{Results}

The results of the GIS included:

- the EATL GIS database (available for MapInfo, ArcGIS, Google Map)

- an Atlas in the form of a collection of predefined maps (as individual pictures, CD/DVD, available to be published on the Internet)

- a GIS Internet Application Viewer, to view the GIS database on the Internet and find data identified by their attributed numbers.

\begin{tabular}{|c|c|c|}
\hline Maps Category/Title & Level & Number \\
\hline Project Area & Region & 1 \\
\hline All Rail Projects & Region & 1 \\
\hline All Road Projects & Region & 10 \\
\hline Rail Routes & Region & 8 \\
\hline Road Routes & Region & 18 \\
\hline Rail Routes per Group & Region & 9 \\
\hline Road Routes per Group & Region & 24 \\
\hline Road Projects & Country & 28 \\
\hline Rail Projects & Country & 30 \\
\hline Road, Rail and Inland Waterways & Country & \\
\hline
\end{tabular}

- Predefined maps generated from the GIS Environment by an administrator for inclusion in:

- Electronic and printed documents

- Web pages

- Presentations CDs

- Printed maps (atlas)

- Office documents with maps and analytical data tables

- Predefined maps available for desktop freeware GIS viewers - ESRI ArcView, MapInfo (workspaces (integrated environment of GIS layers) used with MapInfo Viewer, together with the GIS database)

\subsection{Application}

\subsubsection{Assumptions}

GIS is an expensive business. Enterprise and large GIS databases require special GIS software. Because of the computer resources needed to compute and respond quickly to queries in these large GIS databases, the special GIS software usually requires multiple servers with multiple processors and large memories. 
The EATL GIS database is relatively small, with a low rate of changes.

Use of the GIS database and GIS application must take into consideration that:

- the existing mapping software is MapInfo 7.5

- no available special computer resources exist for the EATL project

- expensing GIS software should be avoided

- the countries provided information and data as office documents

\subsubsection{Solutions evaluated}

Three software applications were considered:

1. A Web application designed to use dedicated GIS server software

2. An application using GIS servers and services provided for public access based on Google technology (Google Map, Google Earth) or OpenStreets

3. An application using freeware libraries and technologies, not requiring special GIS software

1. Application using dedicated GIS server software

- Cost

- Basic software

- GIS Web server software

- Operating system + Internet Web server

- Database system

- Hardware

- Hardware platform for GIS Web server

- Server for database

- Development and deployment

- Help desk, support and maintenance

- Updating data

- Advantages

- Full range of Web application technologies

- Stable environment and applications/maximum availability

- Rapid development

- Quick answers to Web requests

- Issues

- Initial costs for basic software and hardware platform

- Costs for help desk, support, maintenance

- Costs to update data

- Requires trained personnel to administer the GIS Web server and database

This solution addresses the needs of enterprise and large GIS databases employed by a number of simultaneous Internet users.

The software considered was ESRI GIS server. The test application for evaluation was designed in .Net 2008 software.

The project does not currently have the license for GIS server software or the required hardware platform. 
2. Application using GIS servers and services provided for public access based on Google technology

- Requires

- GIS collected data

- Web server (Microsoft IIS/Apache/Zend Server)

- JavaScript/HTML development environment (MS VS2008, Macromedia Dreamweaver)

- Advantages

- Reduced costs of implementation

- No GIS Web server required. Only one server platform with Internet server (not GIS) configured

- Some technologies do not require installation of additional software on the client computer and/or on the Web server

- The results (application) work on most main Internet browsers

- No specially trained personnel needed to administer the Web server relative to the GIS application

- Easy to publish applications on the Internet

- Issues

- Not suitable for presentation of large amounts of GIS data

- Applications possibly unstable - freeware software provided as the applications are not guaranteed

- Execution and results dependent on availability of GIS Online server (ArcGIS Online, Google Earth, Google Maps, Bing, OpenStreets, etc.)

- Good Internet connection (stable broadband connection) needed

- Speed of results dependent on end users' computer processing power - Users' computer performance dependent on response of Web GIS applications

- Slow application response. Time needed to load, query and present GIS data

- Poor documentation and development of the application using multiples technologies cause time constraints

- All GIS data will become public and can be download by anyone

- The application must be non-commercial

Two draft test applications were designed:

- One using Google Map technology and JavaScript

- One using Google Earth technology, JavaScript and Dojo library

The applications are good for presenting data on maps by pointing and clicking over a GIS object. If requesting more complex queries over the data is needed, the development process requires using special JavaScript libraries. The application is browser dependent. The important issue is that the data must be available for access on the Internet; as the code is JavaScript, anyone with computer knowledge can determine the location of the data and download them. Dependency on the availability of GIS dedicated public servers and services is also an issue. To obtain the software license from Google, the deployed applications must be non-commercial. 
Conclusions

- Google Maps + JavaScript $+\mathrm{KML}^{53} / \mathrm{KMZ}^{54}$ (Keyhole Markup Language is an XMLbased language schema for expressing geographic annotation and visualization on Internet-based, two-dimensional maps and three-dimensional Earth browsers)

- The application can be installed on multiple Web servers (for example, IIS, Apache, Zend Server). No additional hardware required

- No additional software installation on the part of the client required

- No special software administration required

- Publicly available GIS data can be downloaded

- Easy to update (simply replacing data files)

- Performance dependent on client Internet connection, computer performance and availability of Google GIS servers

Google Earth + JavaScript + KML/KMZ

- The application can be installed on multiple Web servers (IIS, Apache). No additional hardware required

- Google Earth plug-in software installation required on the client computer to be integrated with the browser used

- No special software administration required

- Publicly available GIS data can be downloaded

- Easy to update (simply replacing data files)

- Performance dependent on client Internet connection, computer performance and availability of Google GIS servers

- Very good graphical user interface

- Quick manipulation of $10 \mathrm{MB}$ of GIS data for an overlay KMZ layer

3. Application using freeware libraries and technologies, not requiring special GIS software

- Requires

- GIS collected data

- Web server (Microsoft IIS/Apache/Zend Server)

- Development environment (MS VS2008 Sp1, .Net Framework 3.5 Sp1,Silverlight Toolkit 3.0, ESRI Silverlight SDK, SharpMap v2.0, etc.)

- Advantages

- Reduced costs of implementation

- No GIS Web server required. Only one server platform with Internet server (not GIS) configured

${ }^{53}$ Keyhole Markup Language (KML) is an XML notation for expressing geographic annotation and visualization within Internet-based, two-dimensional maps and three-dimensional Earth browsers. KML was developed for use with Google Earth, which was originally named Keyhole Earth Viewer. It was created by Keyhole, Inc, which was acquired by Google in 2004. KML became an international standard of the Open Geospatial Consortium in 2008. Google Earth was the first program able to view and graphically edit KML files. Other projects such as Marble have also started to develop KML support.

${ }^{54}$ Zipped Keyhole Markup Language (KMZ) KML files. KML files are very often distributed in KMZ files, which are zipped files with a .kmz extension. These must be legacy (ZIP 2.0) compression compatible (i.e. stored or deflate method), otherwise the. $\mathrm{kmz}$ file might not uncompress in all geobrowsers. The contents of a KMZ file are a single root KML document (notionally "doc.kml") and optionally any overlays, images, icons, and COLLADA 3D models referenced in the KML including network-linked KML files. The root KML document is typically a file named "doc.kml" at the root directory level but the first .kml file entry in the KMZ file is the actual one selected in Google Earth regardless of its name. By convention, the root $\mathrm{KML}$ document is at root level and referenced files are in subdirectories (e.g. images for overlay images). 
- Some technologies do not require installation of additional software on the client computer and/or on the Web server

- The results (application) work on most main browsers

- No specially trained personnel needed to administer the Web server relative to the GIS application

- Easy to publish applications on the Internet

- High level of GIS data security. GIS data not available for public access or need to be uploaded to external GIS servers

- Issues

- Not suitable for presentation of large amounts of GIS data

- Execution and results dependent on availability of GIS Online server (ArcGIS Online, Google Earth, Google Maps, Bing, OpenStreets, etc.)

- Good Internet connection (stable broadband connection) needed

- Speed of results dependent on end users' computer processing power - Users' computer performance dependent on response of Web GIS applications

- Slow application response when large number of GIS objects presented on map. Time needed to load, query and present GIS data

The test application designed used ESRI Silverlight Client Technology together with Development Environment MS VS2008 Sp1, .Net Framework 3.5 Sp1, Silverlight Toolkit 3.0, ESRI Silverlight SDK, and the GIS services provided by SharpMap v2.0.

Background layers are required from ESRI Online, OpenStreets or Bing.

The end user must install Silverlight Runtime. This means the application is available only for Windows platforms. The application requires an Internet information server.

The main advantages are:

- Data security

- Application security

- Modern graphical user interface

- No additional cost for GIS server software and dedicated hardware platform

- Suitable for future developments

- Technology examples

- ESRI GIS Server Online + Silverlight + SharpMap

- Must request Web GIS services from ESRI Online

- Requires Silverlight plug-in installation on end user computer

- Looks great, works fine, sometimes crashes, slow for large amounts of data

- Takes time to be designed

- Requires a set of libraries to be installed in the application publisher's Microsoft IIS server (in this case the UNECE-EATL's)

\subsubsection{Application presentation}

The technology selected for the development of the Web GIS application was the one using ESRI Silverlight Client Technology together with ESRI GIS Server Online, Silverlight and SharpMap. 
The purpose of the Web application is to:

- Present GIS data on maps

- Identify the "object" placed on maps

- Query the visible data

The GIS data types visible on the maps are:

- Road routes

- Rail routes

- Seaports

- Inland ports

- Road nodes (cities or junctions)

- Rail nodes (railway stations, cities or junctions)

- Road projects

- Rail projects

- Road project nodes

- Rail project nodes

The application allows the following queries:

- Point and click to identify the GIS object

- Mouse over to obtain the figures of the pointed GIS "object"

- Query the data of the selected layer based on their attributed numbers

Three types of background can be selected:

- Street view

- Topographic map

- Worldwide satellite imagery map

The tools implemented are:

- Toggle visibility of the base map switcher

- Toggle visibility of the overview map

- Toggle visibility of the magnifying glass

- Area object select

The application is fully configurable.

GIS data layers can be added by updating the XML configuration file. For each GIS data layer, it is possible to set which attributes are visible and can be queried.

\subsubsection{Future developments}

- Improvement of database contents:

- Updated figures

- Updated line sections included in routes (rail/road/inland waterways)

- Introduction of missing data (freight terminals and other intermodal transport infrastructure)

- Publication on the Web of countries' approved maps (atlas)

- Implementation of the GIS data presentation applications in production

Load the selected rail route group (the Group 4 rail routes are selected).

Point and click on projects. When there are several projects in the same location, a list is offered for selection. The user must choose one project to view the figures.

Figures for the selected rail project appear.

Query data for a selected visible layer appear. 


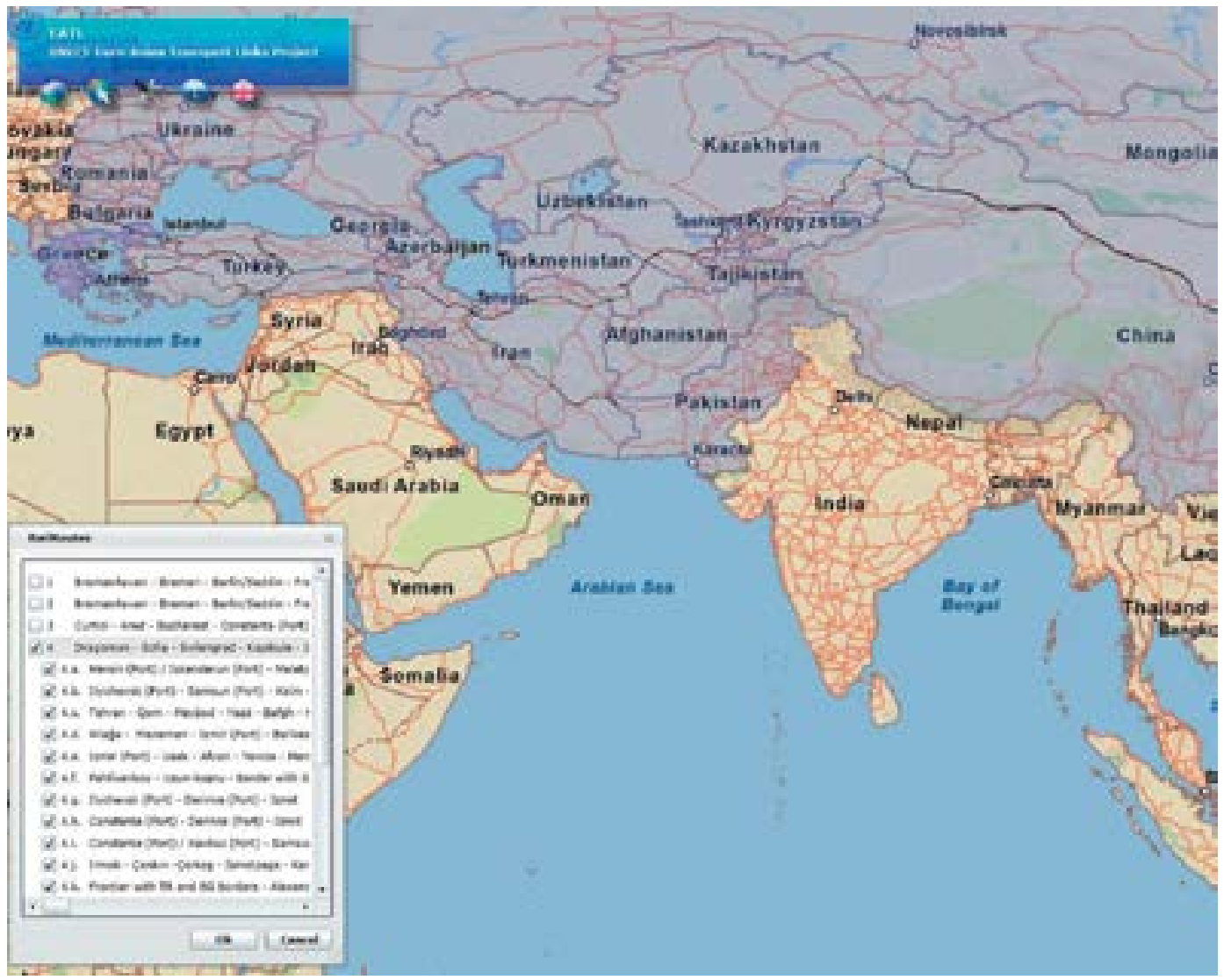

Load the selected rail route group (the Group 4 rail routes are selected).

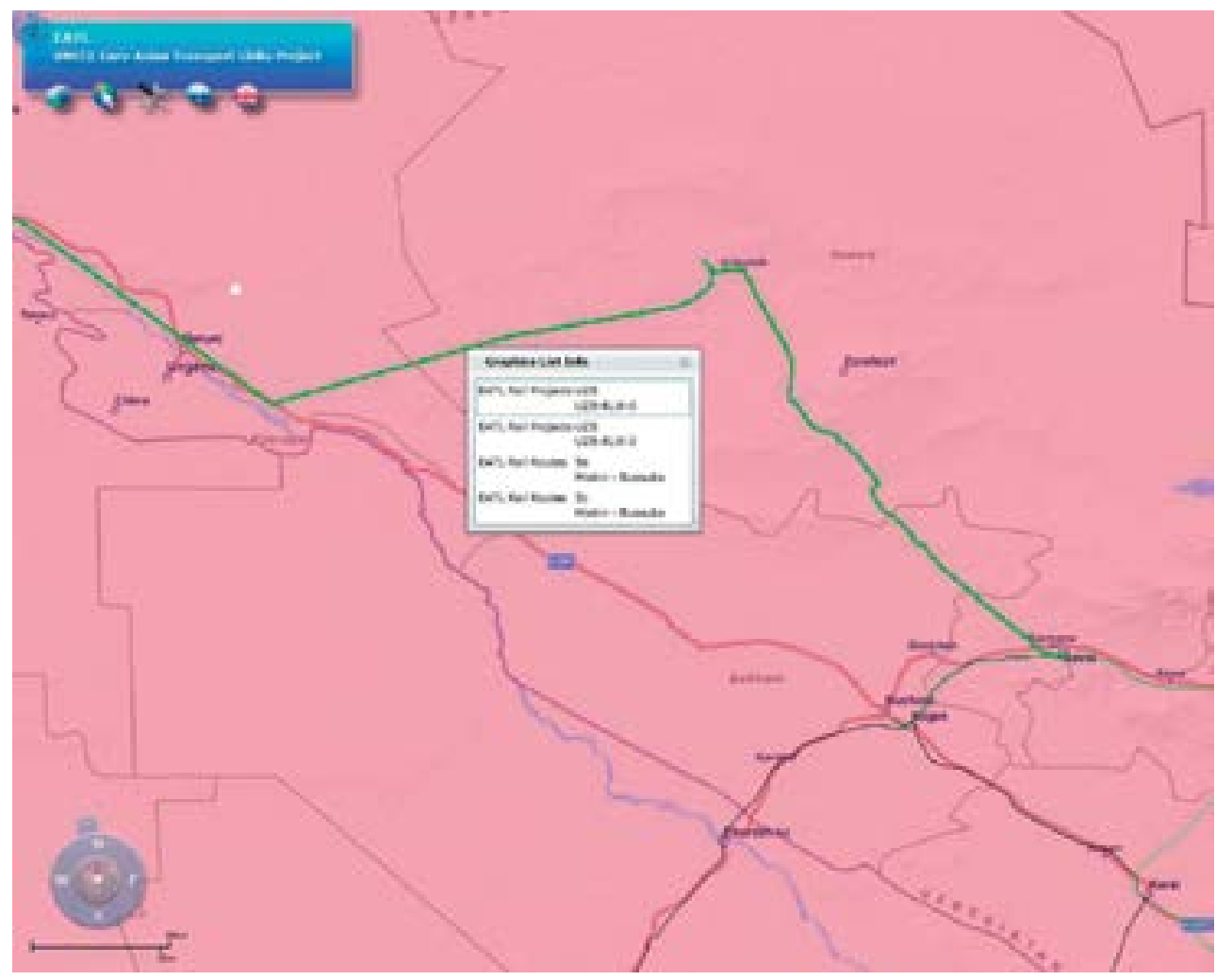

Point and click on projects. When there are several projects in the same location, a list is offered for selection. The user must choose one project to view the figures. 


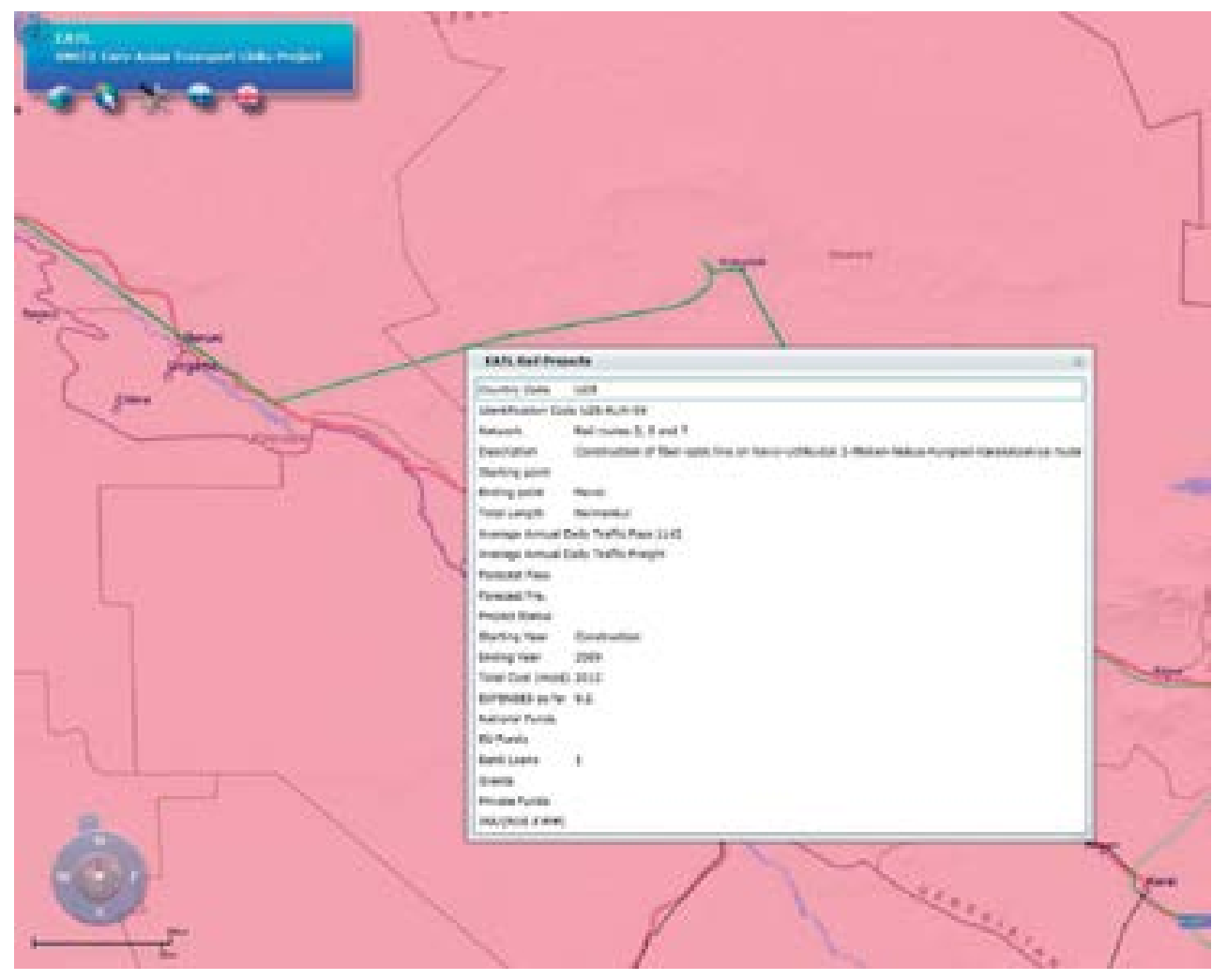

Figures for the selected rail project appear.

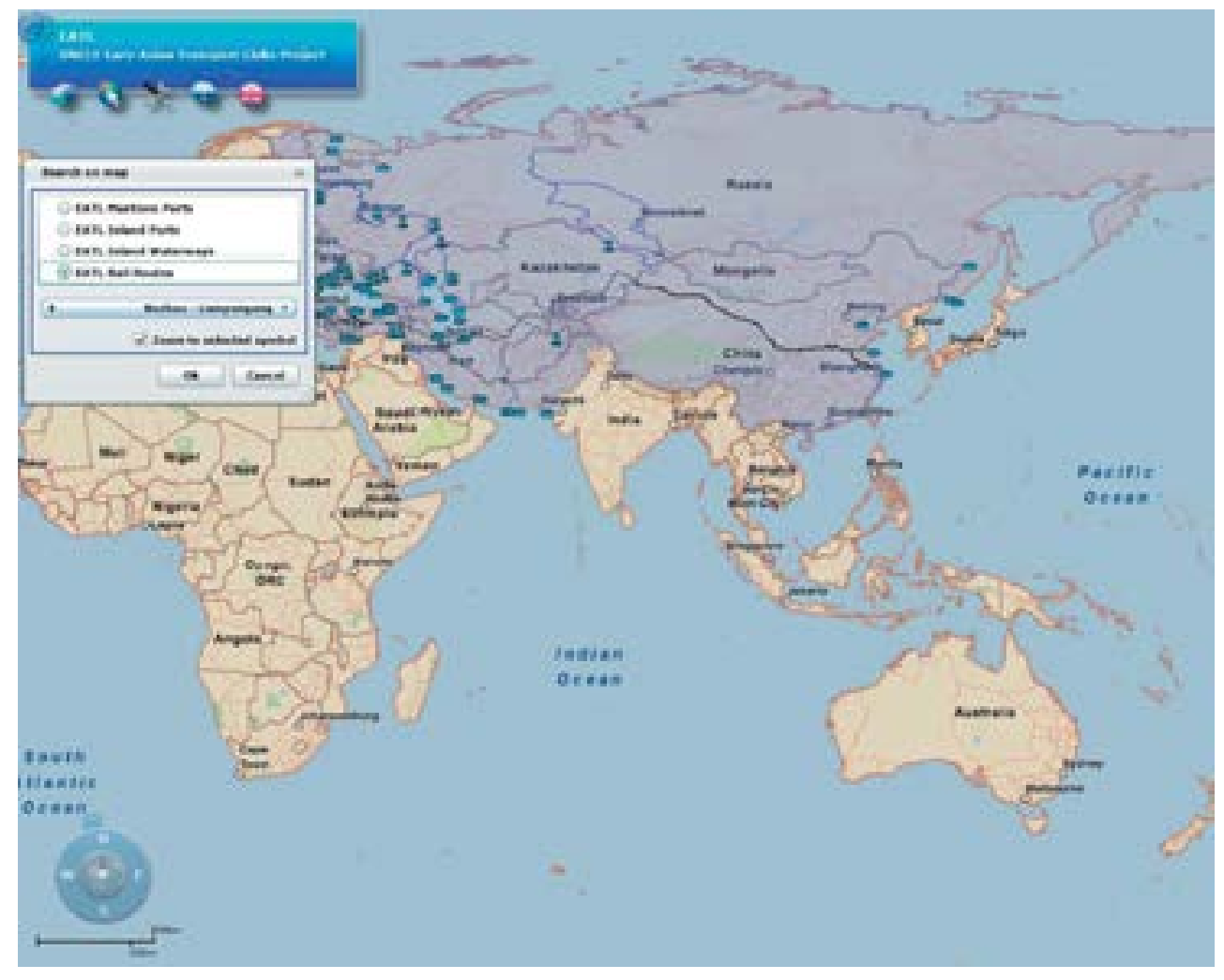

Query data for a selected visible layer appear. 
Appendix 5.1

\section{Acronyms and Definitions related to the GIS}

\begin{tabular}{|c|c|c|}
\hline Acronym & Definition & Meaning/ Explanation \\
\hline ADC & $\begin{array}{l}\text { American Digital } \\
\text { Cartography }\end{array}$ & $\begin{array}{l}\text { ADC Inc. is the company that sells the ADC WorldMap Digital Atlas, which } \\
\text { provides coverage for the whole Earth GIS basic data (http://www.adci } \\
\text { com/html/worldmap/adc_worldmap_digital_atlas.php). }\end{array}$ \\
\hline ArcGIS & & $\begin{array}{l}\text { ArcGIS is a suite consisting of a group of geographic information system } \\
\text { (GIS) software products produced by ESRI. }\end{array}$ \\
\hline ArcView & & $\begin{array}{c}\text { ArcView is software that allows one to view spatial data, create layered } \\
\text { maps and perform basic spatial analysis. }\end{array}$ \\
\hline BING & & $\begin{array}{c}\text { BING is a Microsoft Web search engine used in documents labelled BING } \\
\text { Maps. }\end{array}$ \\
\hline BING MAPS & & $\begin{array}{l}\text { Bing Maps (previously known as Live Search Maps, Windows Live Maps, } \\
\text { Windows Live Local and MSN Virtual Earth) is a Web mapping service } \\
\text { provided as part of Microsoft's Bing suite of search engines and powered } \\
\text { by the Bing Maps for Enterprise framework. }\end{array}$ \\
\hline Dojo & & $\begin{array}{l}\text { The Dojo Toolkit is an open source modular JavaScript library (or more } \\
\text { specifically JavaScript toolkit) designed to ease the rapid development of } \\
\text { cross-platform, JavaScript/Ajax-based applications and websites. It was } \\
\text { started by Alex Russell, Dylan Schiemann, David Schontzler and others in } \\
2004 \text { and is dual-licensed under the modified BSD license or the Academic } \\
\text { Free License ( } \geq 2.1 \text { ). The Dojo Foundation is a non-profit organization } \\
\text { designed to promote the adoption of the toolkit. }\end{array}$ \\
\hline ESRI & $\begin{array}{l}\text { Environmental Systems } \\
\text { Research Institute }\end{array}$ & $\begin{array}{l}\text { ESRI is a software development and services company that provides } \\
\text { Geographic Information System (GIS) software and geodatabase } \\
\text { management applications. Its headquarters are in Redlands, } \\
\text { California. }\end{array}$ \\
\hline GIS & $\begin{array}{l}\text { Geographic Information } \\
\text { System }\end{array}$ & $\begin{array}{l}\text { A geographic information system, geographical information science or } \\
\text { geospatial information studies is a system designed to capture, store } \\
\text { manipulate, analyse, manage and present all types of geographically } \\
\text { referenced data. In the simplest terms, GIS is the merging of cartography, } \\
\text { statistical analysis and database technology. }\end{array}$ \\
\hline GUI & Graphical User Interface & $\begin{array}{l}\text { In computing, a GUI (sometimes pronounced gooey) is a type of user } \\
\text { interface that allows users to interact with electronic devices with images } \\
\text { rather than text commands. GUls can be used in computers, hand } \\
\text { held devices such as MP3 players, portable media players or gaming } \\
\text { devices, household appliances and office equipment. A GUI represents } \\
\text { the information and actions available to a user through graphical icons } \\
\text { and visual indicators, such as secondary notation, as opposed to text } \\
\text { based interfaces, typed command labels or text navigation. The actions } \\
\text { are usually performed through the direct manipulation of the graphica } \\
\text { elements. }\end{array}$ \\
\hline HTML & Hypertext Markup Language & $\begin{array}{c}\text { HTML is the predominant markup language for Web pages. HTML elements } \\
\text { are the basic building-blocks of Web pages. }\end{array}$ \\
\hline
\end{tabular}




\begin{tabular}{|c|c|c|}
\hline IIS & Internet Information Services & $\begin{array}{l}\text { IIS - formerly called Internet Information Server - is a Web server } \\
\text { application and set of feature extension modules created by Microsoft for } \\
\text { use with Microsoft Windows. It is the most used Web server after Apache } \\
\text { HTTP Server. IIS } 7.5 \text { supports HTTP, HTTPS, FTP, FTPS, SMTP and NNTP. It } \\
\text { is an integral part of the Windows Server family of products, as well as } \\
\text { certain editions of Windows XP, Windows Vista and Windows 7. IIS is not } \\
\text { turned on by default when Windows is installed. }\end{array}$ \\
\hline JavaScript & & $\begin{array}{l}\text { JavaScript is a prototype-based scripting language that is dynamic, } \\
\text { weakly typed and has first-class functions. It is a multi-paradigm language, } \\
\text { supporting object-oriented, imperative and functional programming styles. } \\
\text { JavaScript was formalized in the ECMAScript language standard and is } \\
\text { primarily used in the form of client-side JavaScript, implemented as part of } \\
\text { a Web browser in order to provide enhanced user interfaces and dynamic } \\
\text { websites. This enables programmatic access to computational objects } \\
\text { within a host environment. }\end{array}$ \\
\hline KML & $\begin{array}{l}\text { Keyhole Markup } \\
\text { Language }\end{array}$ & $\begin{array}{l}\text { KML is an XML notation for expressing geographic annotation and } \\
\text { visualization within Internet-based, two-dimensional maps and three- } \\
\text { dimensional Earth browsers. KML was developed for use with Google } \\
\text { Earth, which was originally named Keyhole Earth Viewer. It was } \\
\text { created by Keyhole, Inc., which was acquired by Google in } 2004 \text {. } \\
\text { KML is an international standard of the Open Geospatial Consortium. } \\
\text { Google Earth was the first program able to view and graphically edit } \\
\text { KML files. Other projects such as Marble have also started to develop } \\
\text { KML support. }\end{array}$ \\
\hline KMZ & $\begin{array}{l}\text { Keyhole Markup } \\
\text { Language Zipped }\end{array}$ & Keyhole Markup Language files when compressed. \\
\hline WWW & World Wide Web & $\begin{array}{l}\text { The WWW (also abbreviated as W3 and commonly known as the } \\
\text { Web) is a system of interlinked hypertext documents accessed via } \\
\text { the Internet. With a Web browser, one can view Web pages that } \\
\text { may contain text, images, videos and other multimedia, and navigate } \\
\text { between them via hyperlinks. }\end{array}$ \\
\hline WGS 1984 & $\begin{array}{l}\text { World Geodetic } \\
\text { System }\end{array}$ & $\begin{array}{l}\text { WGS is a standard for use in cartography, geodesy and navigation. } \\
\text { It comprises a standard coordinate frame for the Earth, a standard } \\
\text { spheroidal reference surface (the datum or reference ellipsoid) for raw } \\
\text { altitude data, and a gravitational equipotential surface (the geoid) that } \\
\text { defines the nominal sea level. The latest revision is WGS } 84 \text {. }\end{array}$ \\
\hline XML & Extensible Markup Language & $\begin{array}{l}\text { XML is a set of rules for encoding documents in machine-readable } \\
\text { form. It is defined in the XML } 1.0 \text { Specification produced by the W3C, } \\
\text { and several other related specifications, all gratis open standards. The } \\
\text { design goals of XML emphasize simplicity, generality and usability over } \\
\text { the Internet. It is a textual data format with strong support via Unicode } \\
\text { for the languages of the world. Although the design of XML focuses } \\
\text { on documents, it is widely used for the representation of arbitrary } \\
\text { data structures, for example in Web services. Many application } \\
\text { programming interfaces (APIs) have been developed that software } \\
\text { developers use to process XML data, and several schema systems exist } \\
\text { to aid in the definition of XML-based languages. }\end{array}$ \\
\hline
\end{tabular}




\section{STRENGTHS, WEAKNESSES, OPPORTUNITIES AND THREATS (SWOT) ANALYSIS}

\subsection{Introduction}

SWOT stands for Strengths, Weaknesses, Opportunities and Threats. A SWOT analysis is a quick and simple tool to gain the overall picture of a project, business or initiative. It helps focus and analyse strengths, minimize threats and take the greatest possible advantage of opportunities. The SWOT analysis can be used in decision-making, enabling proactive thinking rather than relying on habitual or instinctive reactions. It is, therefore, the starting point of strategic planning.

The SWOT analysis is a useful tool to better understand a project's status and potential. Carrying out this analysis may be illuminating - both in terms of revealing what needs to be done and in putting problems into perspective. However, a SWOT analysis can be subjective. Therefore, it is recommended to use the analysis as a guide and not as a prescription.

Strengths and weaknesses look internally. They help identify what a project can do. Many projects successfully look inward but fail to look outside their area. Threats and opportunities are external, focusing on the conditions of the real world. This is where a SWOT analysis is most helpful. It helps see beyond the project's walls, determines what opportunities are open to it and how to capitalize on the project's strengths.

Strengths should be seen in relation to "competitors" and from "customers' perspectives". Anything the market needs that the project can provide and the "competitor" doesn't is a possible strength.

Weaknesses may include any existing limitation, including high costs of operation or production, human resources and staff, products or services similar or of less quality than competitors'.

Opportunities arise from the external environment; every project or business is influenced by legal, political, technological and cultural factors, among others. Considering what can make a project obsolete and what will replace it may help act proactively. Threats can become opportunities or vice versa. They can include government regulation softening, the development of new technologies, a growing trend or a customer base.

Threats can consist of new substitute services or emerging products, price competition or economic pressure.

\subsection{Elaboration of a SWOT analysis for EATL inland transport connections}

\subsubsection{Strengths}

The following are considered to be EATL inland transport connection strengths:

a. EATL inland transport routes in terms of distance are up to three times shorter and often faster than maritime routes for the transport of goods between the EU and the Asia-Pacific region. ${ }^{55}$

55 Shorter delivery time is a critical factor for certain cargoes (perishable goods or urgent door-to-door shipments). In addition, faster delivery means shortened transaction times, thus quicker settlement of payment and less capital investment for trade. 
b. EATL inland transport routes are an important transport option for EATL landlocked developing countries in the region for their access to international markets and their participation in globalization. ${ }^{56}$

c. The main EATL priority routes and projects along them have been identified. ${ }^{57}$

d. There are unutilized capacities along some parts of the EATL road and railway routes running East-West and North-South.

e. New transport infrastructure is being constructed along certain segments of the inland EATL routes.

f. Some EATL routes are currently the preferred and most economic way for certain countries along the EATL to reach their major trade partners.

g. EATL routes are an integral part and physical extensions of the Trans-European Transport Networks, Pan-European Corridors, AGR, AGC, European Agreement on Important International Combined Transport Lines and Related Installations (AGTC), Asian Highway (AH) network, Trans-Asian Railway (TAR), Trans-European Motorway (TEM), Trans-European Railway (TER), TRACECA and other related corridors and networks of high significance for Europe and Asia.

h. There is political commitment for the development of EATL inland transport routes from concerned governments $s^{58}$ and various international and subregional organizations promoting related initiatives. ${ }^{59}$

i. Partnerships are being developed along the inland EATL routes among key players, including non-governmental organizations and bodies.

j. Since a good portion of EATL routes are in the planning and design phase, environmental risks can be better integrated by certain EATL countries.

\subsubsection{Weaknesses}

The following are considered to be general weaknesses observed on EATL inland transport links (not necessarily present in all countries):

a. The costs of goods transported via inland EATL routes are too high compared to those via maritime transport. International shipping companies with extensive and cost-efficient fleets can keep their freight rates and port charges low. ${ }^{60}$

b. The quality of services by the inland EATL transport of goods is low compared to that of maritime transport. Moreover, maritime transport offers additional quality advantages to shippers, including cargo tracking and tracing, sophisticated logistics networks and guarantees of on-time and secure delivery.

c. Multimodal transport and logistics along inland EATL routes, seen from the perspective of end-to-end cost efficiency, are insufficiently developed and inadequately functioning in a complementary way with different transport modes and potential EATL itineraries,

56 The other option is air freight transport which has grown rapidly over the course of the last few years.

57 This was accomplished under EATL Phase I. However, given the Russian Federation's lack of participation and the rather limited participation of China in the EATL project evaluation exercise, the assumption is that fewer than one half of the projects were identified in EATL Phase I.

58 They include a joint statement of ministers of transport of 19 countries, support from the Inland Transport Committee, the Almaty programme of Action, etc.

59 They include the EU and TRACECA, the Black Sea Economic Cooperation, the EurAsian Economic Community, the Trans-European Motorway and Trans-European Railway, the Special Programme for the Economies of Central Asia, the International Road Transport Union, the International Union of Railways, the Organization for Cooperation of Railways, Shanghai Cooperation, the Hinterland Connection of Seaports, etc.

60 Maritime transport offers an extremely competitive unit cost compared to that of inland transport. In many cases, the cost of transport is the main consideration for consignors as they strive to minimize the transportation component of the price of their products. 
or using seaports/logistic centres/freight villages and being part of main EATL supply chains. ${ }^{61}$

d. The imbalance of trade flows (westbound-eastbound) poses more problems for inland transport modes than for maritime transport, since the unit cost of returning empty wagons, trucks and containers is higher.

e. Many physical and non-physical barriers along the inland EATL routes render transport operations difficult, costly, time-consuming, unpredictable and uncertain. These include:

- inadequate, underdeveloped and poorly maintained road and rail networks, and bottlenecks and missing links

- long delays at borders, cumbersome and inefficient controls together with mandatory transit convoys, multiple cargo checks en route, numerous agencies at borders requesting to approve documentation and numerous fiscal charges payable at certain points along the routes.

f. The absence of a harmonized customs transit regime along all EATL road routes poses serious problems to EATL road transport. ${ }^{62}$

g. High transit tariffs, fees and fiscal charges add unnecessary transport costs to some parts of the inland EATL routes.

h. Transport restrictions, rules and procedures are frequently changed without notice.

i. Widespread corruption along some EATL road routes forces international operators to make illegal payments.

j. There are safety concerns along parts of the EATL road routes and international operators lack security.

k. Many border posts are poorly equipped and some are closed.

1. International road permit quotas that reduce competition are in force along EATL, while the grant of visas to professional drivers is cumbersome and costly.

$\mathrm{m}$. Rail rates are uncompetitive, unpublished and have to be negotiated separately for some parts of the EATL. Moreover, hidden charges exist along with a lack of common through tariffs for container transport.

n. Although many truck hauliers along EATL countries are now private, transport monopolies (public or private) are still in place in some counties, operating under high tariffs and offering inadequate levels of service.

o. Due to the high number of transit countries involved in inland EATL routes and the many border crossings, heterogeneous transport and transit rules and regulations are real barriers to international transport and trade.

p. The heterogeneity of existing transport and transit rules and regulations along the inland EATL routes adds difficulty to the collection, consolidation and update of relevant data.

q. Limited institutional and human resource capacities exist.

r. Inaction and the lack of coordinated action or insufficient action in addressing the non-physical obstacles that persist in many parts of the inland EATL routes result in unnecessary border-crossing delays, an undue increase in transport costs, and prolonged and uncertain delivery times that discourage shippers from using inland EATL routes.

s. EATL countries' tendency not to devote the necessary investment needed to develop priority transport infrastructure is aggravated by a lack of sufficient funds as a result of other urgent, competing needs in a number of EATL countries (health, education, housing, etc.).

t. A weak segment or missing link in one country can render a whole EATL route economically unviable for international transport.

${ }^{61}$ Focusing on the multimodal transport of goods (from their production point to their final destination) seems to be the most suitable approach for developing inland EATL transport.

${ }^{62}$ China and certain other EATL countries are not TIR members yet. 


\subsubsection{Opportunities}

The following are considered to be EATL inland transport connection opportunities: ${ }^{63}$

a. Globalization increases the transport of goods between Europe and Asia. The rapid growth of China and India generates greater transport demand and thus new opportunities for inland EATL.

b. Trade between the EU and the Asia-Pacific region is expected to grow. ${ }^{64}$

c. A portion of "time-sensitive" transit can be redirected through inland EATL routes. ${ }^{65}$

d. The start of China's “Go West: Xinjang Uigur Autonomous Region (XUAR) development programme", designed to increase the manufacture of goods for export to Europe, will potentially use inland EATL routes.

e. The congestion of main ports and hinterland routes, particularly in Western Europe, offers new openings to increase the use of inland EATL to absorb higher shares of future transport needs. ${ }^{66}$

f. Creation of the Customs Union between the Russian Federation, Belarus and Kazakhstan and consequently the expected removal of the internal borders among these countries would offer new opportunities for EATL inland transport along northern EATL routes. ${ }^{67}$

g. Accession of the Russian Federation and Kazakhstan to WTO would also facilitate transit along EATL routes.

h. Further expanding coverage of the CIM/SMGS consignment note along EATL railway routes would facilitate rail EATL transport.

i. Container shipment via the Suez Canal is limited and soon will reach its maximum capacity for container vessels, while the Cape of Good Hope alternative maritime route will increase ships' operating costs and transit time.

j. Increased security concerns along existing EATL maritime routes offer new opportunities for inland transport options. ${ }^{68}$

k. Developing inland EATL is an important tool for socioeconomic development, integration into the global economy and the prosperity of EATL countries, in particular for landlocked developing countries and their transit developing neighbours.

1. Developing trade among EATL countries, in particular between landlocked developing countries and their transit developing neighbours, offers new opportunities.

$\mathrm{m}$. Increased efforts and progress in regional cooperation and integration among countries offer new opportunities to address existing challenges in a coordinated way.

\subsubsection{Threats}

The following are considered to be EATL inland transport connection threats:

n. The competitive transport costs of maritime routes would maintain them as consignors'

\footnotetext{
${ }^{63}$ Careful consideration of the elements contained here suggests that these should be seen in a long-term perspective.

${ }^{64}$ According to the Eurasian Development Bank sector report on EurAsEC Transport Corridors of March 2009, trade between the EU and Asia-Pacific regions reached US $\$ 700$ billion in 2007 and is expected to rise to US\$ 1 trillion by 2013-2015. In 2007, 17.7 million TEU were transported from Asia to Europe, and 10 million from Europe to Asia. By 2015, containerized transportation from Asia to Europe is expected to reach 26.1 million TEU and from Europe to Asia 17.7 million, suggesting enormous transit potential along inland EATL routes.

${ }^{65}$ Most conservative estimates are of 16 million tons annually. This includes westbound: chemicals, foodstuffs, instrumentation, stereo, video and audio systems, mobile communication equipment, television sets, electrical goods, electric cables, furniture, clothes and shoes, cosmetics, and eastbound: industrial and agricultural equipment, metals, integrated circuits, various fine chemical products and polymers, consumer goods, foodstuff (meat).

66 The situation is not too serious currently due to the reduction of freight as a result of the global economic crisis.

67 This is expected in the near future.

68 These include pirate attacks on ships in Somalia, Strait of Malacca, etc.
} 
most attractive transport option for goods originating from the most important points of Euro-Asian trade, i.e. the eastern and southern provinces of China and other South-East Asian countries, travelling to European destinations and vice versa.

o. The call for more efficient transport systems may be an additional threat to inland EATL transport. ${ }^{69}$

p. Global warming and the expected opening of the Arctic North-West passage to container traffic may result in even more competitive maritime routes. ${ }^{70}$

q. Cost-reducing innovation in the air transport sector also offers challenges.

r. The increasing trend of economic nationalism, persisting conflicts and political instability along some parts of EATL routes are additional hazards.

\subsection{Conclusions}

The SWOT analysis for EATL inland transport connections has provided useful information to identify their strong and weak points, their existing potential for further development and their potential threats.

It has also confirmed that the recommendations contained in the UNECE-UNESCAP Study on Developing Euro-Asian Transport Links, which is the outcome of 5 years of work on the part of the countries concerned together with the UNECE and UNESCAP secretariats and other involved bodies, are still valid and should be pursued intensively.

It has also affirmed the usefulness of the establishment of the Group of Experts on EuroAsian Transport Links and its workplan of activities, focusing on enhanced cooperation in the region, the coordinated development of priority transport infrastructure, and intensive efforts for transport and transit facilitation. To stress the need for enhanced coordination and cooperation among all countries along the EATL routes, it is enough to highlight a weakness mentioned above: "A weak segment or missing link in one country can render a whole EATL route economically unviable for international transport.”

Finally, the SWOT analysis has made it clear that the real development potential of EATL inland transport connections lies in their capacity to become part of the main EATL supply chains, functioning in a complementary way with the various transport modes, focusing on the cost/ time efficiency and reliability of end-to-end transportation as well as on the urgent facilitation of cost/time-reducing transportation measures and reforms that need to be undertaken in the EATL transition economies involved.

An overview of the SWOT analysis for EATL inland transport connections appears in the following table.

\footnotetext{
69 Some believe that it may also be an opportunity for EATL, through better integration of some EATL routes into the global supply chains and more efficient and effective use of EATL intermodal options.

${ }^{70}$ Some scientists and experts argue that, in spite of the enthusiasm, it seems unlikely that the Arctic North-West passage can be utilized for the transit of international container ships for various reasons, including technical, commercial and political constraints, while transport insurance coverage aspects remain unclear. Further information on the subject is necessary.
} 


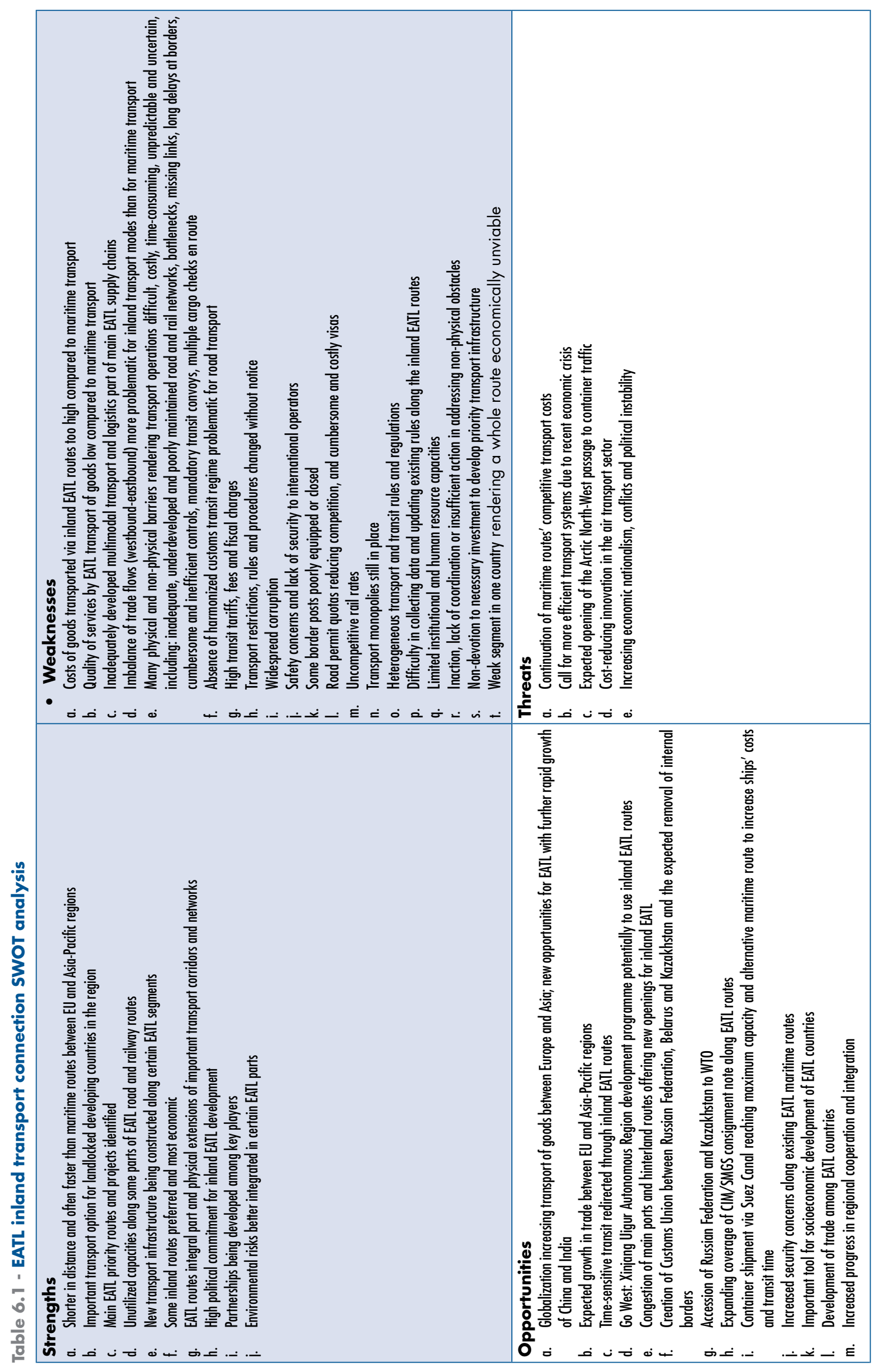




\section{REVIEW OF INTERNATIONAL TRANSPORT NETWORKS AND INITIATIVES LINKING ASIA AND EUROPE}

\subsection{United Nations transport networks in the EATL region}

Transport is vital to the good functioning of economic activities and a key to ensuring the social well-being and cohesion of populations. Transport ensures the daily mobility of people and is crucial to the production and distribution of goods. Adequate infrastructure is a fundamental precondition for transport systems. In their endeavour to facilitate transport, however, decision makers in governments and international organizations face difficult challenges. These include the existence of such physical barriers or hindrances as insufficient or inadequate transport infrastructures, bottlenecks and missing links, as well as the lack of funds to remove them. Solving these problems is not an easy task, requiring action on the part of the governments concerned actions that are coordinated with other governments at the international level.

The UNECE governments have long-standing experience and expertise in the development of coherent international transport networks in Europe. They have created four main transport network agreements aimed at the development of coherent networks for road, rail, inland waterways and combined transport respectively. The UNECE transport network agreements include:

- The European Agreement on Main International Traffic Arteries (AGR), established in 1975

- The European Agreement on Main International Railway Lines (AGC), established in 1985

- The European Agreement on Important International Combined Transport Lines and Related Installations (AGTC), established in 1991

- The European Agreement on Main Inland Waterways of International Importance (AGN), established in 1996. 


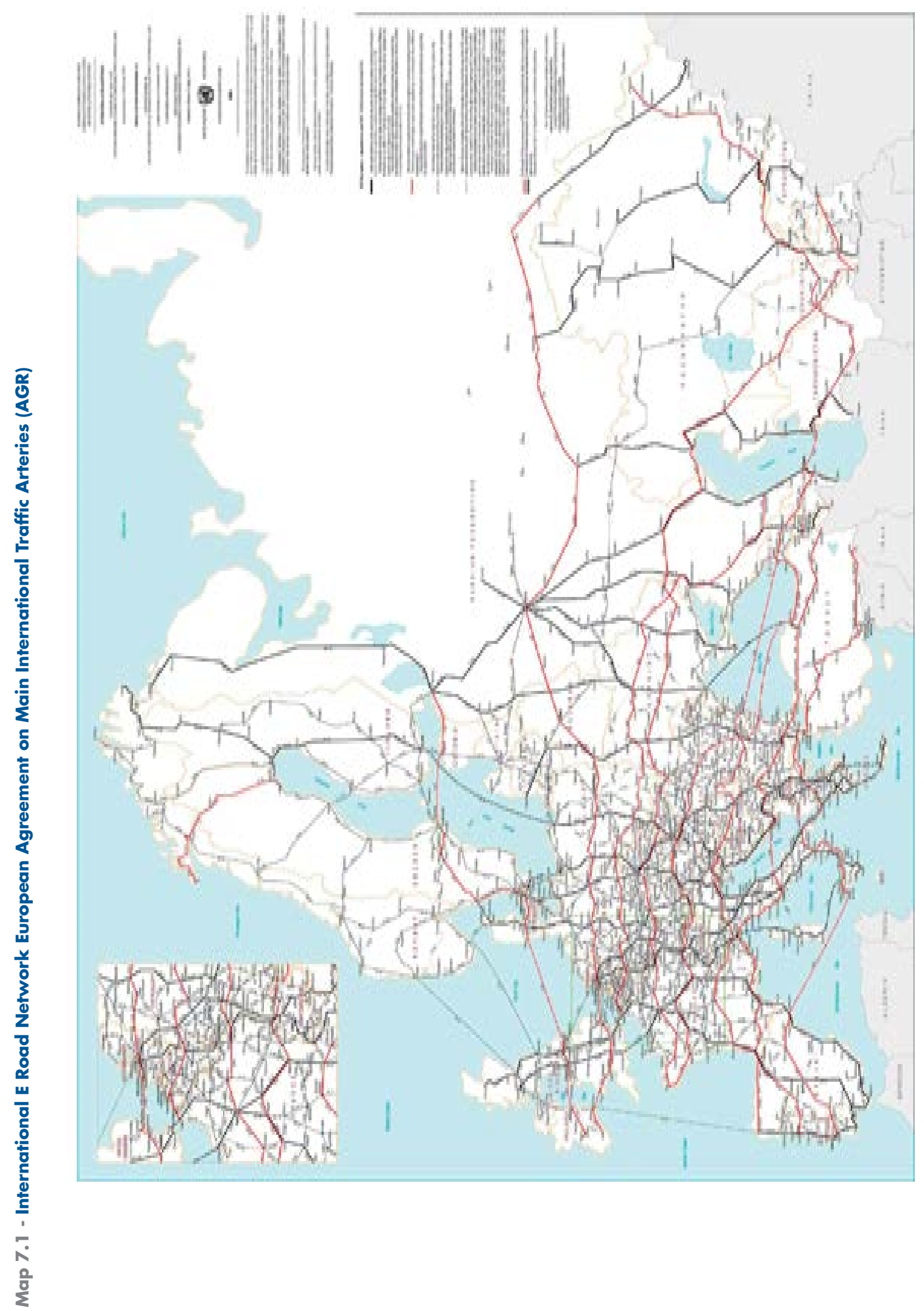



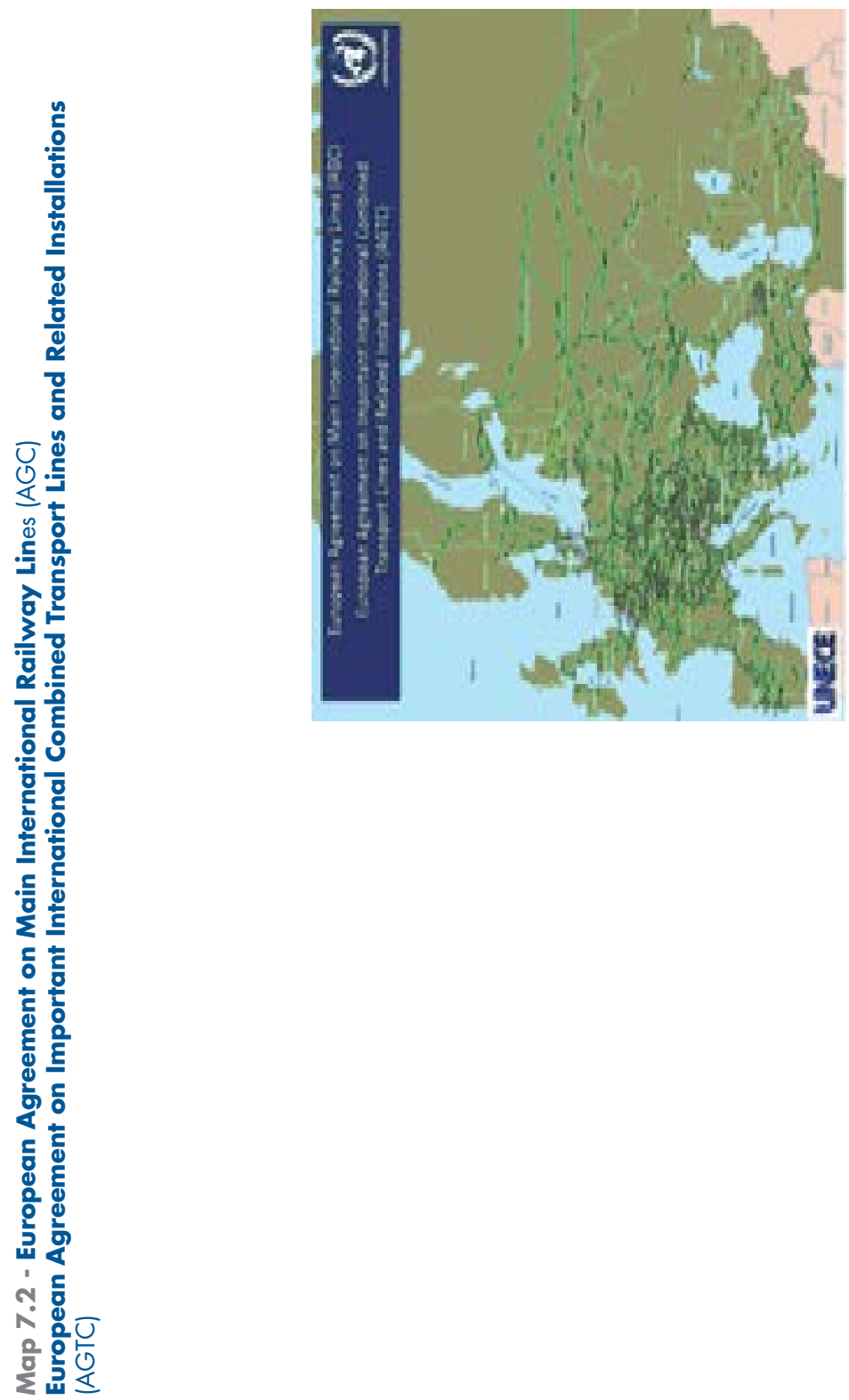


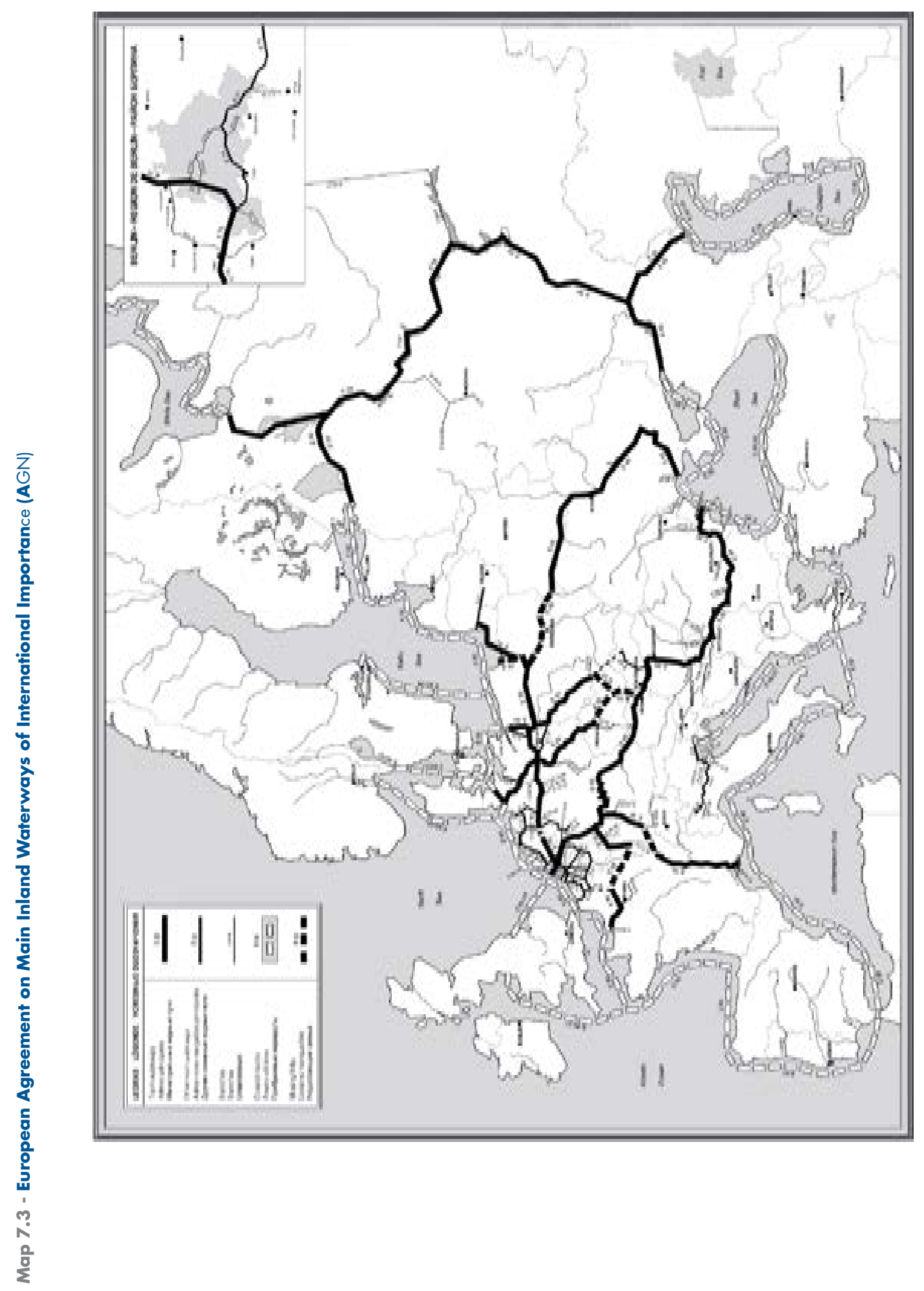


These four international Agreements define respectively the E road, rail, combined and inland waterway transport networks. They also determine the minimum technical norms and requirements according to which the relevant infrastructures should be built. The AGTC also includes operational parameters for combined transport services. Finally, they establish a wellknown numbering system, in general following a North-South and East-West grid system.

Although legally binding for countries that become parties to them, the UNECE infrastructure agreements give governments ample latitude for implementation. In particular, they establish neither deadlines nor priorities. Nevertheless, constantly kept up to date, these UNECE infrastructure agreements are the only Pan-European governmental basis for the longterm development of coherent international networks for the various modes of inland transport. As such, they were taken as a basis for the determination of the Pan-European transport corridors at the Pan-European Transport Conferences in Crete and Helsinki.

The $\mathrm{E}$ road and $\mathrm{E}$ rail networks represent the most useful basis for the identification of priority Euro-Asian transport corridors as they already incorporate the main roads and rail lines planned for the eastern parts of the Russian Federation and for the Caucasus and Central Asian countries.

The European Agreement on Main International Traffic Arteries (AGR) provides UNECE governments with the international legal framework for the construction and development of a coherent international road network with a view to developing international road transport and traffic throughout the UNECE region. The AGR defines the E-road network, consisting of the arteries channelling major international road traffic flows in Europe, and the infrastructure parameters to which those arteries should conform. The AGR is constantly kept under review and updated whenever necessary to adapt it to new political and transport developments, such as the need for new roads in new States or those created by new traffic flows. It underwent a major revision in the early 1990s following the fall of the Iron Curtain in order to take into account new East-West traffic flows. It has undergone another major revision in recent years in order to also include the international roads of the countries in the Caucasus and Central Asia. States that become Contracting Parties to the AGR commit themselves to its implementation, including the construction or upgrade of the E-roads in their territories, within the framework of their national investment programmes, although they are given complete latitude as to the timing for the completion of construction works. To date, 33 UNECE Member States have become Contracting Parties to the AGR.

The European Agreement on Main International Railway Lines (AGC) similarly provides the legal and technical framework for the development of a coherent international rail network in the region. The AGC identifies the rail lines of major international importance, the E-rail network, and defines the infrastructure parameters to which they should conform. It defines infrastructure parameters for two categories of lines: those already existing and those to be newly constructed. The latter are again divided into the lines for goods and passenger traffic and those for passenger traffic only. The AGC is also revised whenever necessary to take account of political and transport changes in Europe. It has undergone a major revision in recent years also to include the international rail networks of the Caucasus and Central Asian countries. In becoming Contracting Parties to the AGC, European States commit themselves to its implementation, including the construction or the upgrade of the E-rail lines in their territories, within the framework of their national programmes but without any time constraints. To date, 24 UNECE Member States are Parties to the AGC.

The European Agreement on Important International Combined Transport Lines and Related Installations (AGTC) provides the technical and legal framework for the development of efficient international combined road/rail transport infrastructure and services. Combined $\mathrm{road} /$ rail transport comprises the transport of containers, swap bodies and entire trucks on railway wagons to and from especially equipped terminals. The AGTC determines all important 
European railway lines used for international combined transport, identifies all terminals, bordercrossing points, ferry links and other installations important for international combined transport services. It also establishes internationally acceptable infrastructure standards for those lines and related combined transport installations, and prescribes internationally acceptable performance parameters of trains and combined transport installations and equipment. European States that become Contracting Parties to the AGTC commit themselves to its implementation, including the construction or the upgrade of the railway lines and related combined transport installations in their territories, within the framework of their national programmes but without any time constraints. The AGTC entered into force on 20 October 1993. To date, 26 UNECE Member States have become Parties to the AGTC.

The European Agreement on Main Inland Waterways of International Importance (AGN) establishes the internationally agreed European network of inland waterways and ports as well as the uniform infrastructure and operational parameters to which they should conform. The geographical scope of the E-waterways network, consisting of navigable rivers, canals and coastal routes extends from the Atlantic to the Ural, connecting 37 countries and reaching beyond the European region. By acceding to the AGN, governments commit themselves to the development and construction of their inland waterways and ports of international importance in accordance with the uniform conditions agreed upon and within their investment programmes. The AGN entered into force on 26 July 1999 . To date, 13 UNECE Member States have become Parties to the AGN.

\subsection{Trans-European Motorway and Trans-European Railway}

The Trans-European North-South Motorway (TEM) and the Trans-European Railway (TER) projects are subregional cooperative frameworks established by the governments of the Central, Eastern and South Eastern European countries under the aegis of UNECE for the purpose of developing coherent road, rail and combined transport infrastructure networks in the region and facilitating international traffic in Europe.

\subsubsection{TEM}

The TEM project, initiated in 1977, established and assisted in the construction of the TEM network (Map 7.4) comprised of more than 22,000 km, of which 6,118 km are in operation (26.4 per cent of the TEM network) and $1,575 \mathrm{~km}$ are under construction. It contributed to the formation of the future Trans-European Transport Networks (TEN-T), constituting an integral part. The TEM network formed the backbone of the Trans-European road corridors in the CEE region by decision of the second and third Pan-European Transport Conferences (in Crete in 1994 and in Helsinki in 1997 respectively). This provided a valuable contribution to the establishment of the new strategic transport plan of Europe and placed TEM as the backbone of the Transport Infrastructure Needs Assessment (TINA) exercise for the CEE road network. Finally, the TEM network contributed to the formation of the priority plan for the extension of EU Trans-European Networks in the candidate countries for EU membership.

The project aims at facilitating road traffic in Europe among and through the participating countries; ${ }^{71}$ improving the quality and efficiency of transport operations; reducing imbalances in the network between Western, Eastern, Central and South-Eastern Europe; and assisting the integration process of European transport infrastructure systems in order to promote the overall development of the region.

71 The 15 TEM Member Countries are Armenia, Austria (associate member), Bosnia and Herzegovina, Bulgaria, Croatia, Czech Republic, Georgia, Hungary, Italy, Lithuania, Poland, Romania, Slovakia, Slovenia and Turkey. Four other countries have observer status: Montenegro, Serbia, Sweden and Ukraine. 


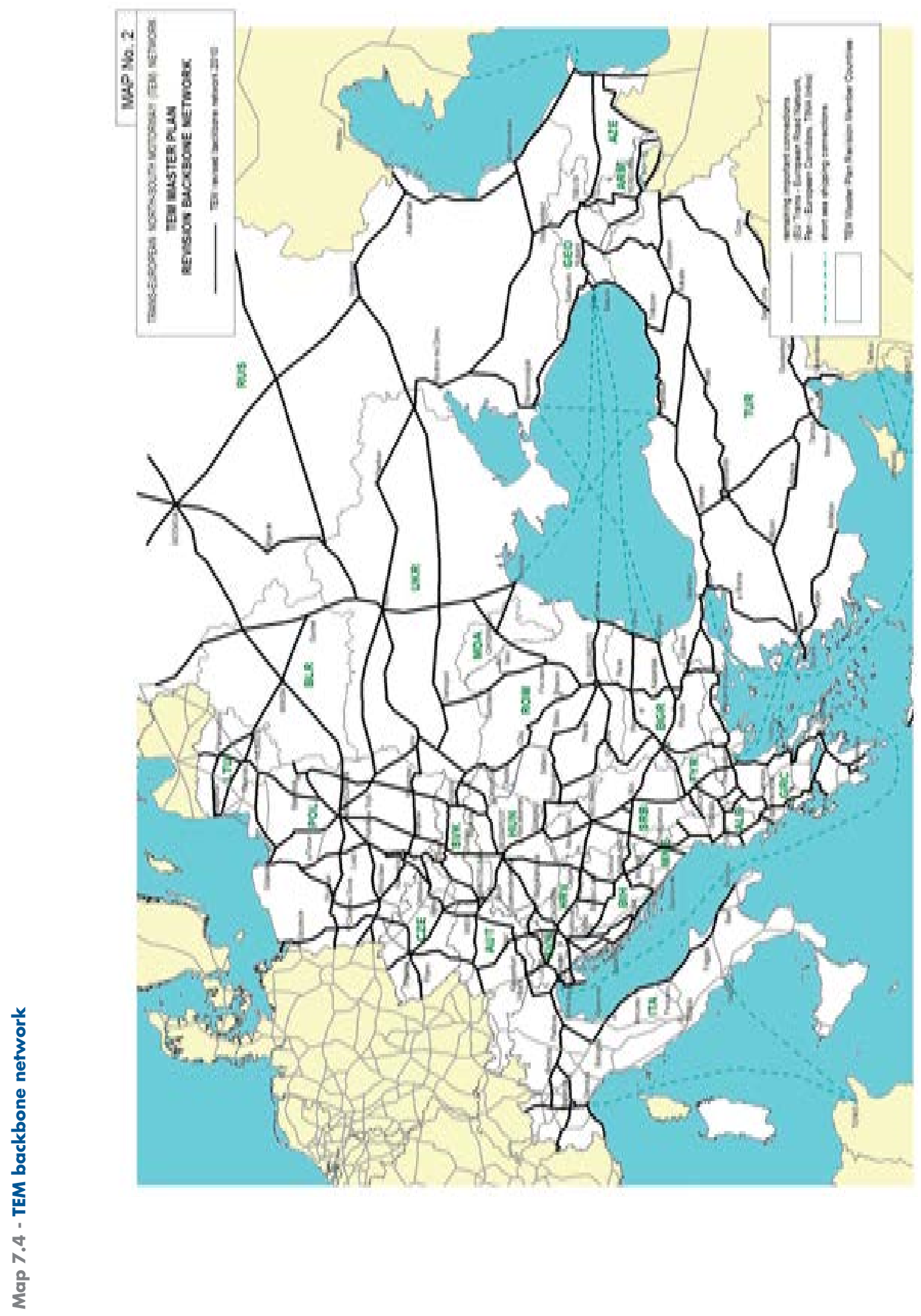




\subsubsection{TER}

The TER project was launched in 1990. The objective of the TER is to facilitate and develop coherent and efficient international railway and combined transport systems among Central and Eastern European countries and through the territories of the participating countries ${ }^{72}$ as well as between them and other European countries. This objective will be achieved by, for example, upgrading network infrastructure which extends over 24,000 km (Map 7.5), and by eliminating obstacles at border crossings. The project aims at developing rail infrastructure, improving cooperation in all matters concerning the rail transport between TER countries and supporting the European integration process by assisting in the implementation of EU directives.

\subsubsection{TEM and TER Master Plan revision}

In 2006, UNECE published the original Trans-European North-South Motorway (TEM) and the Trans-European Railway (TER) Master Plan, presenting a reliable and pragmatic short-, medium- and long-term investment strategy for developing road, rail and combined transport backbone networks in the participating countries.

Following important economic, political and technological changes in the region, the objectives of the original Master Plan's revision, which took place between 2008 and 2011, were: (a) to analyse the results of road and rail infrastructure development in 25 participating countries in Central, Eastern, South-Eastern Europe and the Caucasus; (b) to describe the existing status of road and rail networks; and (c) to set out their development programme until the year 2020. Four additional countries - Albania, Armenia, Azerbaijan and Montenegro - joined the revision process.

The revised Master Plan proved to be an important step towards improving transport sector performance in the Study region. Many targeted investments - for example, about 45 per cent of the 491 road and rail projects contained in the original Master Plan - have been completed in the meantime.

The revised Master Plan reflected changes in traffic flows, political changes in the region, the needs of new participating countries, the desire to harmonize TEM and TER networks with other international transport networks, changed priorities, and the need to connect these networks in the best way with important international combined transport routes and with trans-shipment points and nodes.

The original Master Plan did not deal with Intelligent Transport Systems (ITS). ITS applications could enhance overall service levels by improving transport management and use of infrastructure. The revised Master Plan underlines that the wider application of ITS could be increased by their integration. ITS integration is also a necessary precondition for the interoperability of ITS systems at the European level.

Finally, the revised Master Plan focused on the most important transport impacts on the environment, i.e. carbon dioxide emissions and noise pollution, as well as on road safety and transport security issues. These issues, at present, are basic elements of the definition of transport service quality - provided that there is balance between operational needs and security requirements.

72 The 17 TER Member Countries are Armenia, Austria, Bosnia and Herzegovina, Bulgaria, Croatia, Czech Republic, Georgia, Greece, Hungary, Italy, Lithuania, Poland, Romania, Russian Federation, Slovakia, Slovenia and Turkey. In addition, a number of observer countries participate in certain activities of the project: Belarus, Latvia, Montenegro, Republic of Moldova, Serbia, the former Yugoslav Republic of Macedonia and Ukraine. 


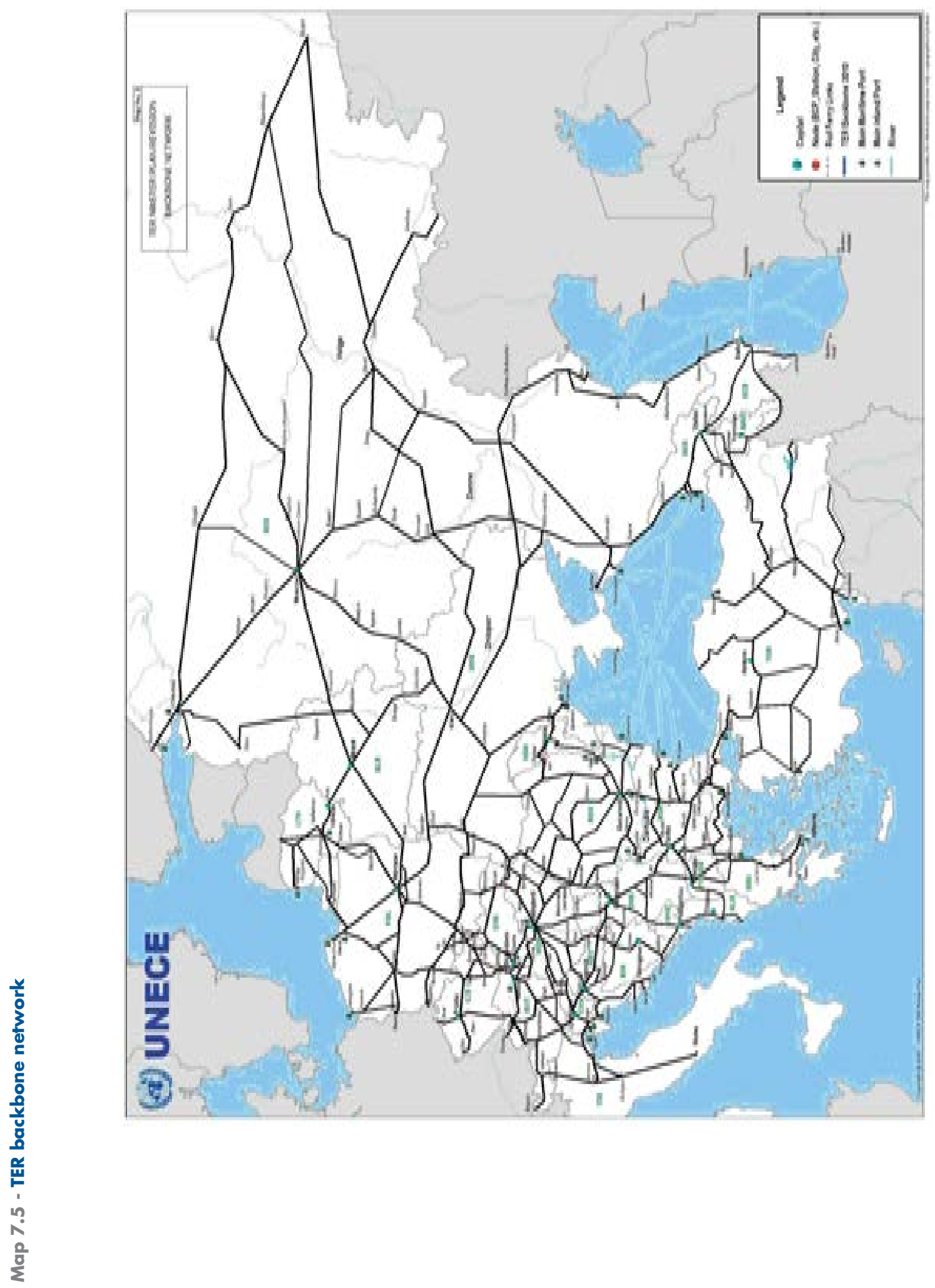




\section{References}

This section is based on publicly available information:

the TEM and TER websites, available at

http://www.unece.org/trans/main/tem/tem.html

http://www.unece.org/trans/main/ter/ter.html

UNECE (2011). TEM and TER revised Master Plan, Final Report, Volumes I and II. UNECE Transport Division, Executive Summary. New York and Geneva. Available from http://www.unece.org/fileadmin/DAM/trans/main/ temtermp/docs/TEM_and_TER_Vol_I.pdf and http://www.unece.org/fileadmin/DAM/trans/main/temtermp/ docs/TEM_and_TER_Vol_ll.pdf.

\subsection{United Nations Economic and Social Commission for Asia and the Pacific}

The United Nations Economic and Social Commission for Asia and the Pacific (UNESCAP) is a regional development arm of the United Nations for the Asia-Pacific region, composed of 62 governments, 58 of which are in the region. Its headquarters are in Bangkok, Thailand. ${ }^{73}$ UNESCAP was founded in 1947 to overcome regional challenges in areas of poverty and development.

\subsubsection{Relevant initiatives/projects}

The Transport Division has carried out a project called Operationalization of international intermodal transport corridors in North-East and Central Asia. The main objectives of the project are to support countries to identify priority intermodal transport corridors linking countries in North-East and Central Asia, and to establish and implement cooperative mechanisms for the development and operationalization of the selected corridors. Under the project, six intermodal corridors (Map 7.6) have been identified, based on existing routes of the Asian Highway (AH) network and the Trans-Asian Railway (TAR).

Both the AH project and the TAR project were implemented under the framework of the Asian Land Transport Infrastructure Development Project, which was launched in 1992 to promote the coordinated development of a regional transport network.

To meet the increasing demand for reliable and efficient land transport linkages and services in the region, the $\mathrm{AH}$ project was established in 1959 to foster international road transport. Member Countries have adopted a network of $141,000 \mathrm{~km}$ in 32 Asian countries with linkages to Europe (Map 7.7). This network provides access to capitals, main industrial and agricultural centres, major air, sea and river ports, major container terminals and depots and major tourist attractions. The $\mathrm{AH}$ network was formalized through the Intergovernmental Agreement on the Asian Highway Network, which entered into force in $2005 .{ }^{74}$ The Agreement has been signed by 28 countries, of which 23 are Parties.

\footnotetext{
${ }^{73}$ For more membership details, see http://www.unescap.org/about/member.asp.

${ }^{74}$ For details of the $\mathrm{AH}$ Intergovernmental Agreement, see http://www.unescap.org/ttdw/common/tis/AH/AHAgreement-E.pdf.
} 


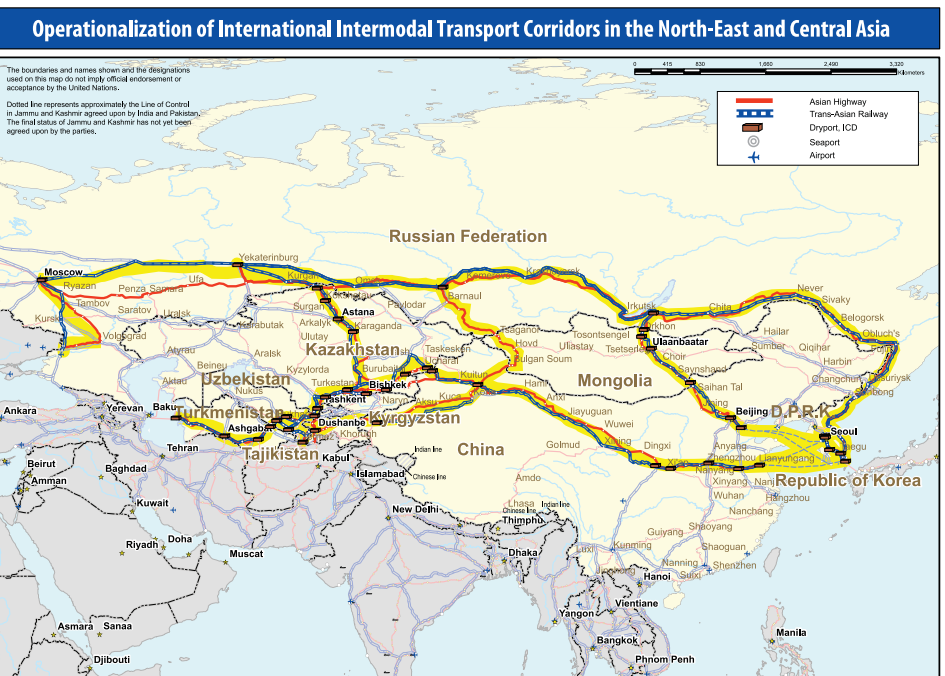

Map 7.7 - AH route

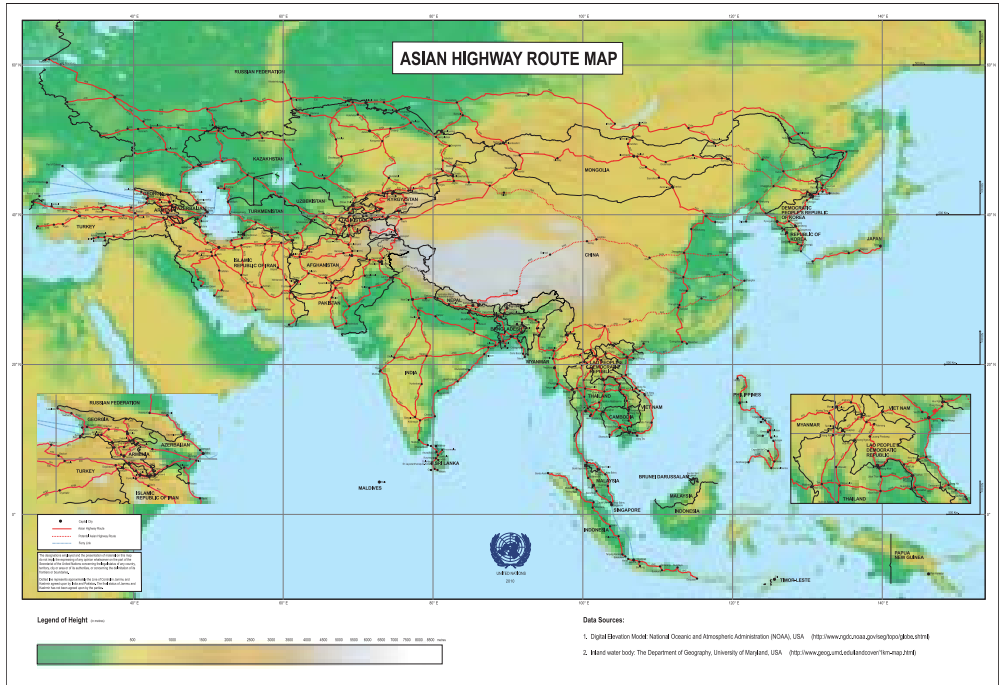

The TAR project was initiated in the early 1960s to offer efficient rail transport services within the region and between Asia and Europe. The network has extended to 114,000 km of railways across 28 countries (Map 7.8) through three phases of the project: Network Identification by four corridor studies ${ }^{75}$ (1994-2001); Network Operationalization by demonstration runs of container block trains ${ }^{76}$ (1997-2005); and Network Formalization by negotiation and finalization of the Intergovernmental Agreement on the Trans-Asian Railway Network ${ }^{77}$ (2001-2006).

75 The four corridors are the Northern Corridor connecting China, Kazakhstan, Mongolia, the Russian Federation and the Korean Peninsula (1995, refined in 1999); the ASEAN and Indo-China subregional network covering Cambodia, China, Indonesia, Lao People's Democratic Republic, Malaysia, Myanmar, Singapore, Thailand and Viet Nam (1996); the Southern Corridor connecting Thailand and the southern Chinese province of Yunnan with Turkey through Bangladesh, India, Iran, Myanmar, Pakistan and Sri Lanka (1999); and the North-South Corridor linking Northern Europe to the Persian Gulf through the Russian Federation, Central Asia and the Caucasus region (2001).

76 Demonstration runs were operated along the TAR Northern Corridor.

77 For details of the TAR Intergovernmental Agreement, see http://www.unescap.org/ttdw/common/tis/tar/ TARintergovagreement.asp. 


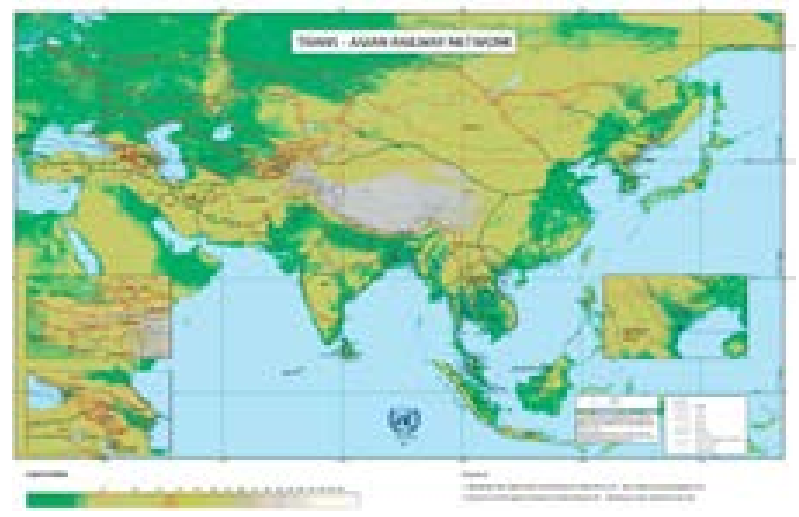

This Agreement entered into force in June 2009. Under the terms of the Agreement, a working group was established to regularly discuss policies and issues relating to the development of the rail network.

\section{References}

This section is based on publicly available information accessed on the UNESCAP website at http://www.unescap.org/, especially:

http://www.unescap.org/about/index.asp

http://www.unescap.org/ttdw/

http://www.unescap.org/about/committee_t.asp

http://www.unescap.org/ttdw/index.asp?MenuName=Infrastructure

http://www.unescap.org/ttdw/index.asp?MenuName=Facilitation

http://www.unescap.org/ttdw/index.asp?MenuName=Tourism

http://www.unescap.org/ttdw/index.asp?MenuName=AsianHighway

http://www.unescap.org/ttdw/common/tis/ah/IGA_intro.asp

http://www.unescap.org/ttdw/common/TIS/TAR/tar_home.asp

http://www.unescap.org/unis/press/2009/jun/g41.asp

\subsection{United Nations Special Programme for the Economies of Central Asia}

The United Nations Special Programme for the Economies of Central Asia (SPECA), a joint UNECE-UNESCAP initiative, began in 1998. At present, the participating countries include Afghanistan, Azerbaijan, Kazakhstan, Kyrgyzstan, Tajikistan, Turkmenistan and Uzbekistan. Various Project Working Groups have been established to promote greater regional cooperation. ${ }^{78}$ Under this framework, the Project Working Group on Transport and Border Crossing (PWGTBC) was launched with Kazakhstan as the lead country. The main aim of PWG-TBC is further development of Euro-Asian transport corridors as the SPECA region is a potential transport hub connecting Europe and Asia.

78 SPECA Project Working Groups are on Gender and Economy, Knowledge-based Development, Statistics, Trade, Transport and Border Crossing, and Water and Energy Resources. 


\subsubsection{Relevant initiatives/projects}

Draft SPECA road and rail networks were developed on the basis of regional agreements, such as the Intergovernmental Agreement on the Asian Highway Network, the Intergovernmental Agreement on the Trans-Asian Railway Network, the European Agreement on Main International Traffic Arteries (AGR), the European Agreement on Main International Railway Lines (AGC) and the European Agreement on Important International Combined Transport Lines and Related Installations (AGTC), as well as on the basis of routes and networks defined under the framework of ECO (Economic Cooperation Organization), CIS (Commonwealth of Independent States), TRACECA (Transport Corridor Europe-Caucasus-Asia), and OSJD (Organization for Cooperation of Railways). The SPECA road and rail networks and their respective maps are shown in Maps 7.9 and 7.10.

The PWG-TBC developed four priority transport databases (rail routes, road routes, bordercrossing points and intermodal transport). These databases assume a key role in monitoring the transport sector situation in SPECA countries.

In 2008, the PWG-TBC reviewed initiatives of SPECA countries in relation to the implementation of the Almaty Programme of Action at the national level, and noted the importance of the Busan Declaration on Transport Development in Asia and the Pacific. ${ }^{79}$ It also noted problems hampering international transport in the SPECA region, including significant border-crossing delays, high transit costs, numerous and unnecessary national check points, non-

\section{References} official charges, low standard infrastructure, and bottlenecks and missing links.

This section is based on publicly available information about SPECA accessed on the UNECE website at http://www.unece.org/speca/, especially:

http://www.unece.org/speca/tbc.html

http://www.unece.org/trans/main/speca/speca_12.html

http://www.unece.org/trans/main/speca/speca_13.html

http://www.unece.org/trans/main/speca/speca_14.html

79 The Busan Declaration on Transport Development in Asia and the Pacific was adopted at the Ministerial Conference on Transport in Busan, Republic of Korea in 2006. For details see http://www.unescap.org/ttdw/ common/TIS/TAR/text/busan_declaration_1 1 nov06.pdf, and also Resolution 63/9 Implementation of the Busan Declaration on Transport Development in Asia and the Pacific and the Regional Action Programme for Transport Development in Asia and the Pacific, phase I (2007-2011), available at http://www.unescap.org/EDC/English/ Committee/CMG/CMG4-I/Resoloution63_9.pdf. 


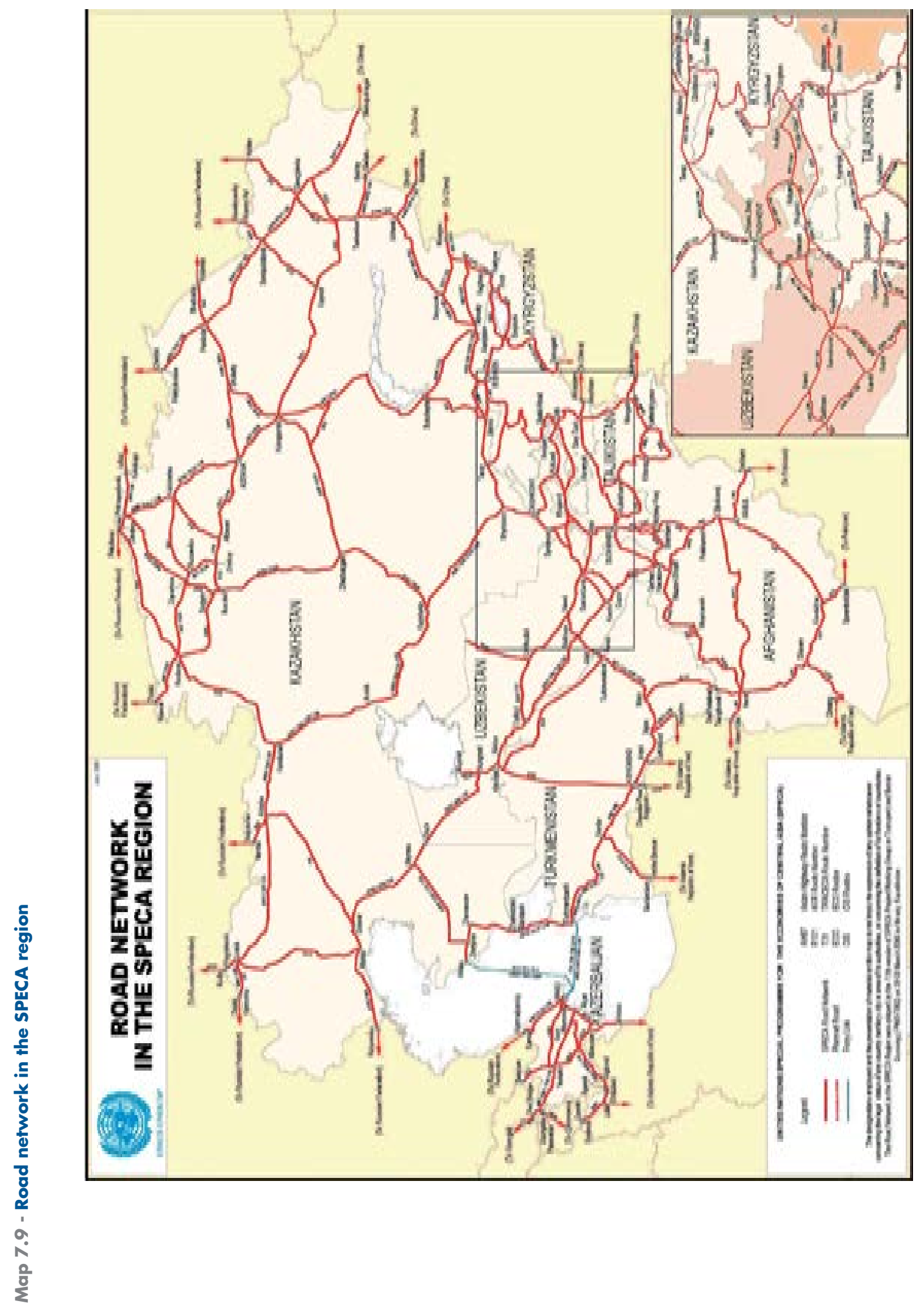




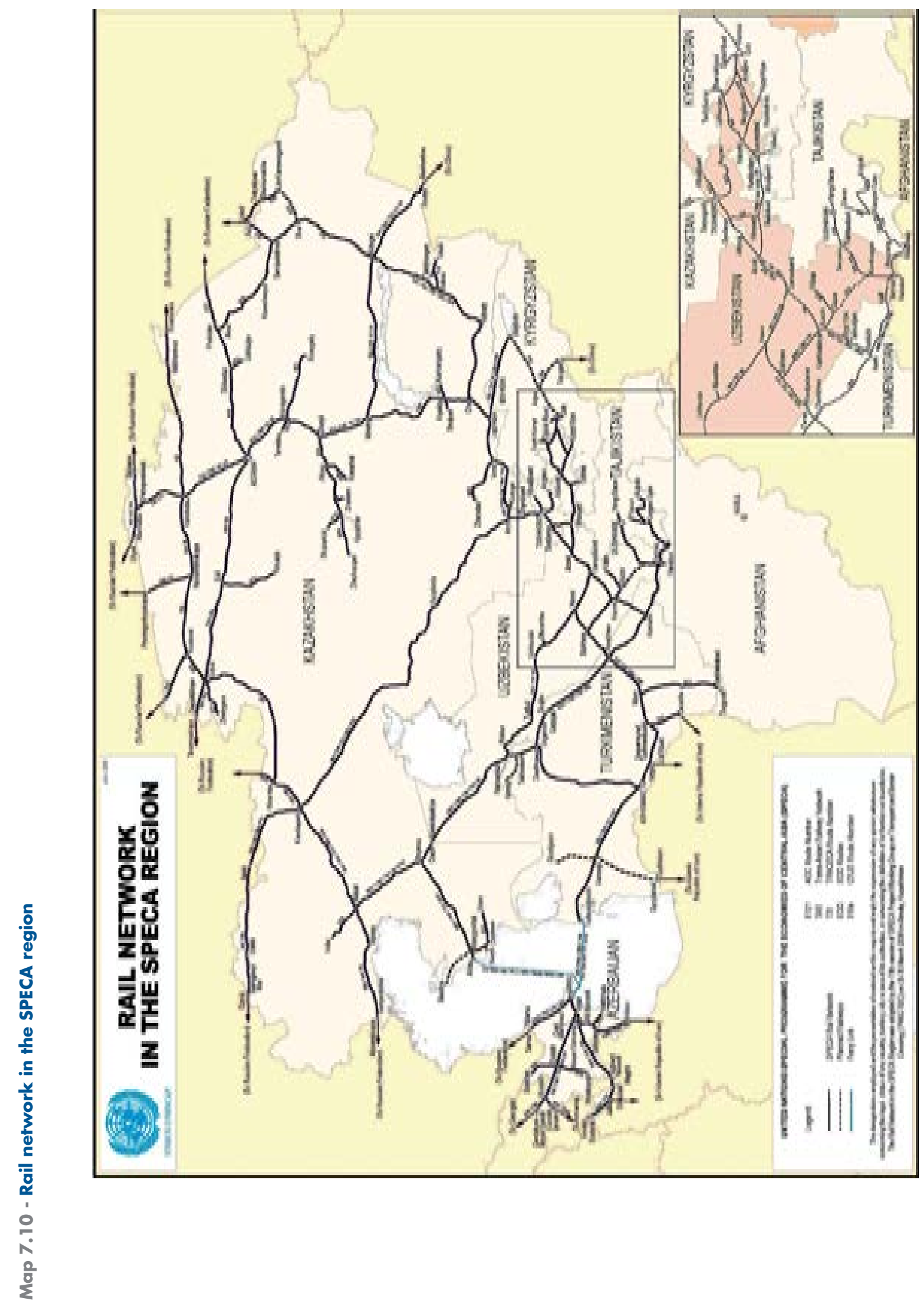




\subsection{United Nations Office of the High Representative for the Least Developed Countries, Landlocked Developing Countries and Small Island Developing States}

The United Nations Office of the High Representative for the Least Developed Countries, Landlocked Developing Countries and Small Island Developing States (UN-OHRLLS) was established by the United Nations General Assembly in 2001 through its resolution 56/227 with functions recommended by the Secretary-General in his report A/56/645 ${ }^{80}$ to provide appropriate support to least developed countries, landlocked developing countries and small island developing states.

\subsubsection{Relevant initiatives/projects}

To deal with constraints facing landlocked countries, the "International Ministerial Conference of Landlocked and Transit Developing Countries and Donor Countries and International Financial and Development Institutions on Transit Transport Cooperation" was held in Almaty, Kazakhstan, in 2003. The "Almaty Programme of Action: Addressing the Special Needs of Landlocked Developing Countries within a New Global Framework for Transit Transport Cooperation for Landlocked and Transit Developing Countries" was adopted at the Ministerial Conference for the purpose of developing efficient transit transport systems in landlocked and transit developing countries.

The goal of the Programme of Action is to forge partnerships to overcome the specific problems of landlocked developing countries, resulting from their remoteness and isolation from the world market. The Programme focuses on five priorities: policy improvements by reducing customs bureaucracy and fees; infrastructure development and the maintenance of rail, road, ports, inland waterway, pipeline and air transport sectors; international trade facilitation; technical and financial international assistance; and monitoring and follow-up on agreements, to archive aims to:

- secure access to and from the sea by all means of transport

- reduce costs and improve services so as to increase the competitiveness of their exports

- reduce the delivered costs of imports

- address problems of delays and uncertainties in trade routes

- develop adequate national networks

- reduce loss, damage and deterioration en route

- open the way for export expansion

- improve the safety of road transport and the security of people along the corridor.

The midterm review of the Almaty Programme of Action was implemented from 2007 to 2008. The review identified progress and obstacles in the implementation of the Almaty Programme of Action along its five priority areas, and provided action-oriented recommendations and deliverables aimed at harmonizing the legal regime, adopting an integrated approach to trade and transport facilitation, eliminating physical and non-physical bottlenecks to transport, promoting integrated training programmes in both the public and private sectors, establishing national transit and trade facilitation committees, completing missing links, promoting intermodal transport, developing integrated transport corridors and logistics services, and mobilizing domestic and external resources.

${ }^{80}$ Report of the Secretary-General, Follow-up mechanism for coordinating, monitoring and reviewing the implementation of the Programme of Action for the Least Developed Countries for the Decade 2001-2010 available at http://www.unohrlls.org/UserFiles/File/LDC\%20Documents/Reports/N0165665_A\%2056\%20645.pdf. 


\section{References}

This section is based on publicly available information accessed on the UN-OHRLLS website at http://www.unohrlls.org/, especially:

http://www.unohrlls.org/en/about/

http://www.unohrlls.org/en/lldc/40/

http://www.unohrlls.org/en/lldc/673/

http://www.unohrlls.org/en/orphan/644/

\subsection{United Nations Conference on Trade and Development}

The United Nations Conference on Trade and Development (UNCTAD), established in 1964, promotes the development-friendly integration of developing countries into the world economy by carrying out three key functions: operating as a forum for intergovernmental deliberations supported by discussions with experts and exchanges of experience for consensus building; undertaking research, policy analysis and data collection; and providing technical assistance to developing countries.

The objective of the Division on Technology and Logistics is to enhance the economic development and competitiveness of developing countries through efficient trade logistics services, transit transport systems, increased access to and sustainable utilization of information and communication technology, and training and capacity-building programmes for local institutions.

\subsubsection{Relevant initiatives/projects}

As part of the preparatory process of the midterm review of the Almaty Programme of Action, the "UNCTAD Expert Meeting held in 2007 provided a forum to explore models and best practices to improve international transit transport operations based on practical solutions with a view to enhancing transit transport for the benefit of landlocked and transit developing countries.

In July 2008, UNCTAD organized a global preparatory meeting on the midterm review of the Almaty Programme of Action to affirm progress on the implementation of trade facilitation for the benefit of landlocked and transit developing countries. The meeting recommended that relevant international organizations continue and intensify their efforts to improve transit facilitation along transit corridors during the period from 2008 to 2013.

\section{References}

This section is based on publicly available information accessed on the UNCTAD website at http://www.unctad.org/Templates/StartPage.asp?intItemID=2068, especially:

http://unctad.org/Templates/Page.asp?intItemID=1530\&lang=1

http://www.unctad.org/Templates/Page.asp?intItemID=1536\&lang=1

the UNCTAD Trade Logistics Branch, Transport and Trade Logistics website, available at http://r0.unctad.org/ttl/

UNCTAD Transport Newsletters No. 35 to No. 39, available at http://archive.unctad.org/ Templates/Page.asp?intItemID=2651\&lang=1.

\subsection{European Union}

EU transport policies aim to foster a clean, safe and efficient transport network throughout Europe. The comprehensive network comprises $95,700 \mathrm{~km}$ of road, 106,000 km of railway, 
including 32,000 km of high-speed links, 13,000 km of inland waterways, 411 airports and 404 seaports; however, almost 20,000 km of roads, over 20,000 km of railways and $600 \mathrm{~km}$ of inland waterways remain to be built or substantially upgraded at an estimated cost of $€ 500$ billion. $^{81}$

\subsubsection{Relevant initiatives/projects}

The recommendation on Transport Infrastructure Needs Assessment (TINA) was developed at the first structural dialogue between the Transport Council of the EU and the Transport Ministers of the EU-associated countries. On the basis of this recommendation, the Commission launched the TINA process (Maps 7.11 and 7.12) with the objective to define the future TransEuropean Transport Infrastructure Network.

Map 7.11 - TINA road network

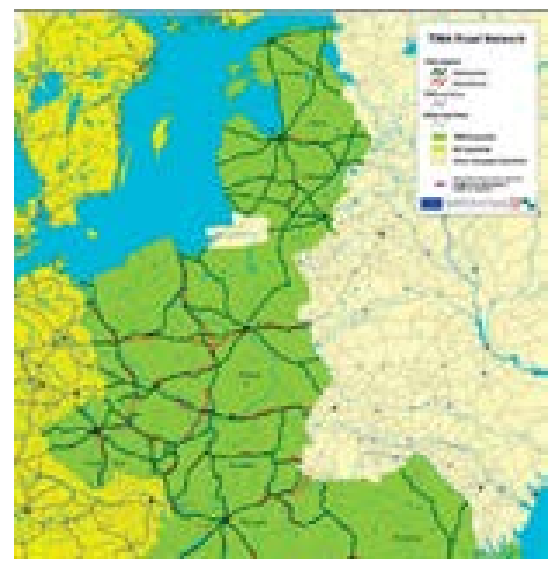

Map 7.12 - TINA rail network

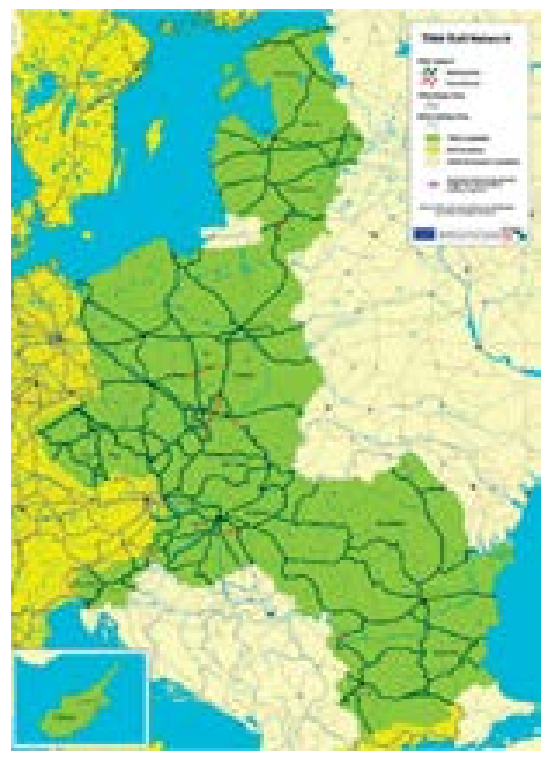

Trans-European Transport Network (TEN-T) projects have taken a notable role in providing a single market with free movement of people and goods, in reinforcing economic and social cohesion and in promoting economic competitiveness and sustainable development, with financial support from the European Investment Bank. ${ }^{82}$ Thirty priority projects were identified based on proposals from Member States (Map 7.13). Of the 30 projects, 18 are railway projects and 3 are mixed rail-road projects. ${ }^{83}$

\footnotetext{
81 Commission of the European Communities (2009). Green Paper TEN-T: A policy review, Towards a Better Integrated TransEuropean Transport Network at the Service of the Common Transport Policy, 4 February. Available from http://eur-lex.europa.eu/LexUriServ/LexUriServ.do?uri=COM:2009:0044:FIN:EN:PDF.

82 For the 2007-2013 period, the investment needs in TEN infrastructures are expected to total some $€ 300$ billion.

${ }^{83}$ For more details on TEN-T Projects, see http://tentea.ec.europa.eu/en/ten-t_projects/30_priority_projects/ and European Commission Directorate-General for Energy and Transport (May 2008). TEN-T: Implementation of the Priority Projects, Progress Report. Available from http://ec.europa.eu/transport/publications/doc/2008_ brochure_tent_t_implementation_priority_projects_progress_report.pdf.
} 


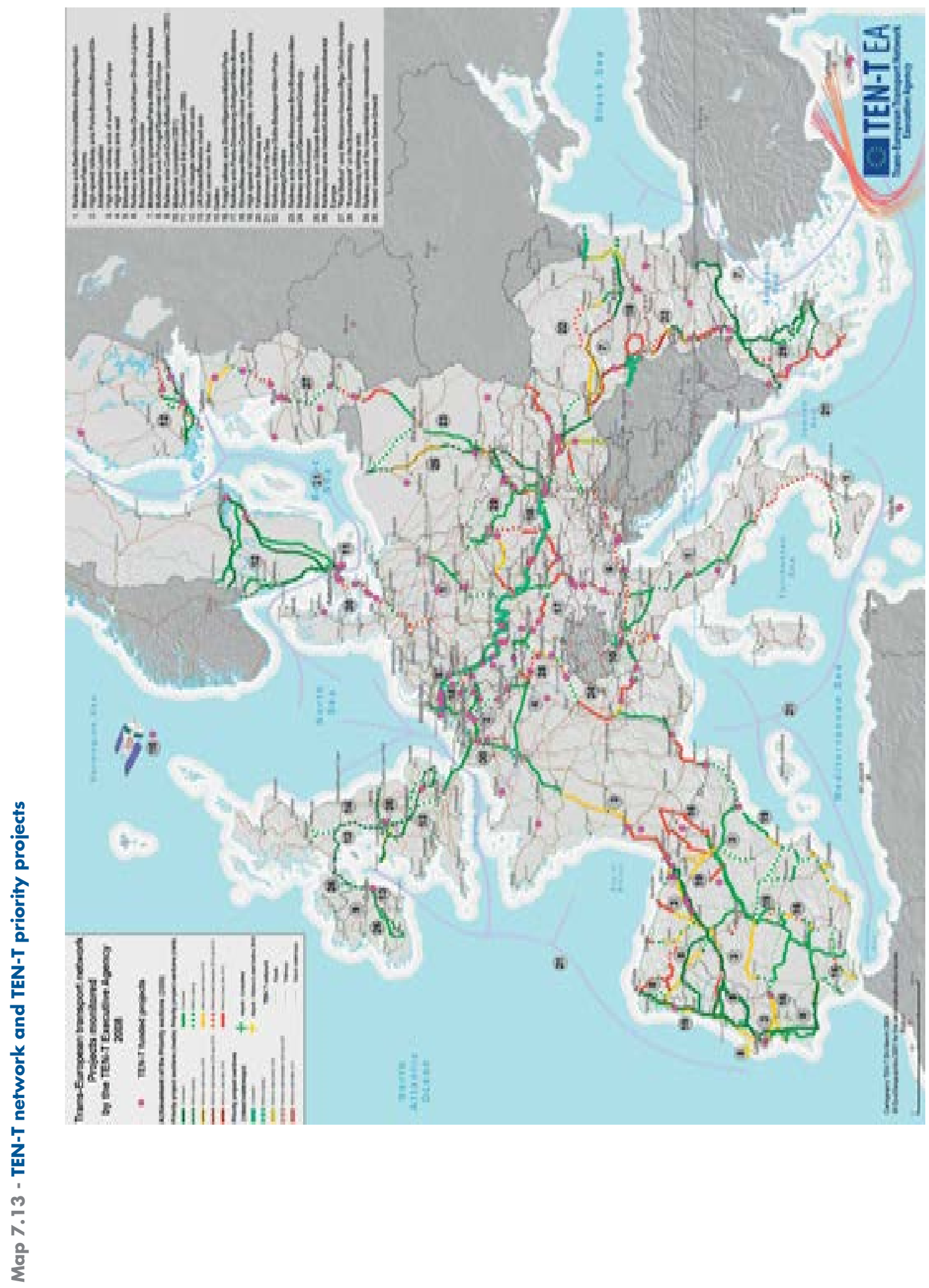


The TEN-T has developed through key processes:

- the first action plan, adopted in 1990

- the list of 14 priority projects, adopted in 1994

- the related financial regulation, adopted in 1995

- the first guidelines, established in $1996^{84}$

- revised guidelines and financial regulations, adopted in 2004 to integrate infrastructures of new Member States ${ }^{85}$ into the TEN-T.

A 2004 study, entitled "Scenario, traffic forecasts and analysis of corridors on the TransEuropean Network", analysed traffic, bottlenecks and environmental issues on 25 corridors.

In 2006, the Brussels-based TEN-T Executive Agency was launched to provide an efficient and effective service in realizing the technical and financial implementation of the TEN-T programme with close cooperation with the Commission. The Commission makes decisions regarding the TEN-T programme, defines strategies, objectives and priority areas of action, takes the final financing decisions, and monitors and supervises the TEN-T Executive Agency, while the Agency implements the TEN-T programme on behalf of the Commission, and under its responsibility efficiently manages entire project lifecycle, prepares financing decisions and provides key feedback to the Commission.

To strengthen the relationship between Europe and Asia, the Asia-Europe Meeting (ASEM) is a fundamental informal dialogue promoting cooperation that brings together the $27 \mathrm{EU}$ Member States, the European Commission, 16 Asian countries and the ASEAN Secretariat to address political, economic and cultural issues. The first ASEM Transport Ministers Meeting was held in October 2009 in Vilnius, Lithuania, to discuss the development of international transport and trade, in parallel with the Asia-Europe Transport Development Forum, aiming to provide a business approach towards transportation issues between Asia and Europe.

The European Commission's TEN-T programme constitutes an important EU financing means for European transport infrastructure projects. Over $€ 8$ billion has been allocated for this programme during the 2007-2013 financial period. TEN-T projects are located in every EU Member State and include all modes of transport. The TEN-T Executive Agency's mandate has been extended until the end of 2015 .

\section{References}

This section is based on publicly available information accessed on the EU website at http:// europa.eu/, especially:

http://europa.eu/abc/panorama/index_en.htm

http://europa.eu/abc/panorama/howorganised/index_en.htm

http://europa.eu/legislation_summaries/enlargement/2004_and_2007_enlargement/ e50017_en.htm

the European Commission Transport website at http://ec.europa.eu/transport/index en.htm, especially: http://tentea.ec.europa.eu/en/ten-t_projects/30_priority_projects/

the ASEM website at http://www.aseminfoboard.org/, especially: http://www. aseminfoboard.org/about-asem-menu.html

${ }^{84}$ The guidelines form "Decision No. 1692/96/EC of the European Parliament and of the Council of 23 July 1996 on Community guidelines for the development of the trans-European transport network". Available from http://eurlex.europa.eu/LexUriServ/LexUriServ.do?uri=CELEX:31996D1692:EN:HTML.

85 On 1 May 2004, ten new countries (Cyprus, Czech Republic, Estonia, Hungary, Malta, Latvia, Lithuania, Poland, Slovakia and Slovenia) joined the EU. 


\subsection{Transport Corridor Europe-Caucasus-Asia}

The Transport Corridor Europe-Caucasus-Asia (TRACECA) programme is an EU-funded project aiming at improvements in trade and transport. The current 13 participating states ${ }^{86}$ work together to reach the following objectives:

- stimulating cooperation among the participating states for trade development in the region

- promoting the optimal integration of TRACECA into the Trans-European Networks (TEN)

- identifying factors hindering the development of trade and transport systems

- promoting TRACECA projects as means to attract loans from international financial institutions and private investors

The programme was launched at a conference in Brussels in 1993, for the purpose of developing a transport corridor on a West-East axis from Europe, across the Black Sea, through the Caucasus and the Caspian Sea, to Central Asia (Map 7.14). The Brussels Conference identified a number of problems and deficiencies in the region's trade and transport systems. The programme was developed through four sectoral working groups: Trade Facilitation, Road, Rail and Maritime Transport.

Map 7.14 - TRACECA network

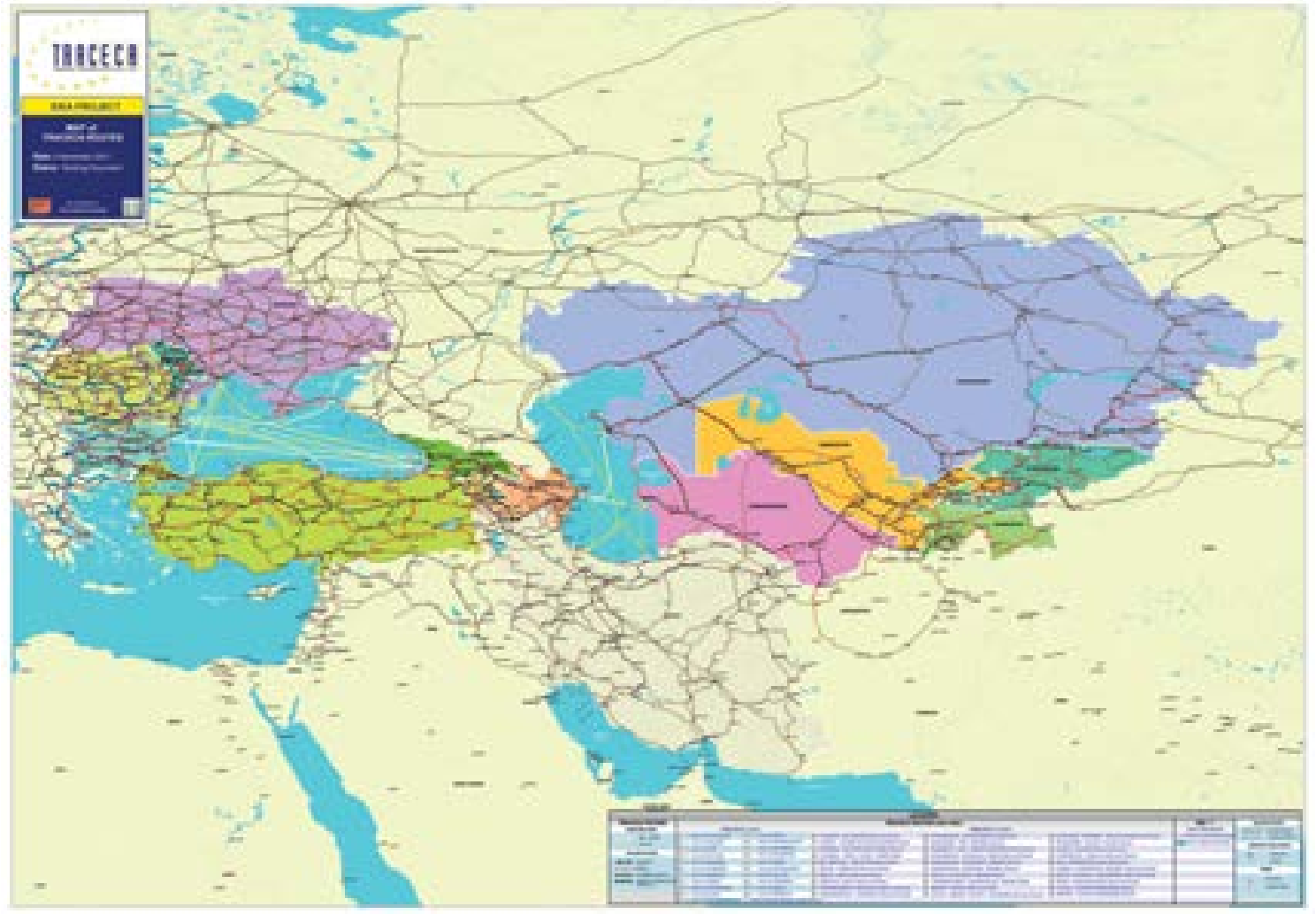

${ }^{86}$ Armenia, Azerbaijan, Bulgaria, Georgia, Iran, Kazakhstan, Kyrgyzstan, Republic of Moldova, Romania, Tajikistan, Turkey, Ukraine and Uzbekistan. 
Between 1996 and 2006, 61 technical assistance projects ${ }^{87}$ and 15 investment projects ${ }^{88}$ were supported by the TRACECA programme, for a total of about $€ 160$ million. These projects were identified and developed in the framework of the Action Programme ${ }^{89}$ and in accordance with the TACIS $^{90}$ regulations and programming cycle. The technical assistance provided through TRACECA helped to attract investments from development partners, including the European Bank for Reconstruction and Development, the World Bank, the Asian Development Bank and the Islamic Development Bank.

At a Meeting in Sofia in 2006, a new strategy for the development of the TRACECA to 2015 was presented. This strategy proposed the development of a number of actions and principles, summarized as follows:

- strengthening and modernizing the institutional dimensions of transport through organizational restructuring and the reinforcement of human resources

- aiding in the integration and cohesion of infrastructure networks through establishing principles for the development of such networks, planning methodology, traffic forecasts, the establishment of key transport projects and the continuous refinement of the network

- developing sound multimodal chains via port modernization, motorways of the sea and modernized road transport, putting the railway system in perspective, border-crossing and integrated multimodal plans, advanced logistics and sophisticated IT solutions

- exploring air transport and boosting air passenger traffic

- ensuring safe, secure and sustainable transport

- securing funding by developing national funding plans, mobilizing regional and international resources and promoting public private partnerships

- enhancing TRACECA as an international organization

\section{References}

This section is based on publicly available information accessed on the TRACECA website at http://www.traceca-org.org/default.php?l=en

\subsection{Organization for Security and Co-operation in Europe}

With 56 States from Europe, Central Asia and North America, the Organization for Security and Co-operation in Europe (OSCE) is the world's largest regional security organization. It offers a forum for political negotiations and decision-making in the fields of early warning, conflict prevention, crisis management and post-conflict rehabilitation.

\subsubsection{Transport mandate}

In the field of transport, the Office of the Co-ordinator of OSCE Economic and Environmental Activities (OCEEA), in cooperation with the OSCE field presences, continues to implement the relevant Ministerial Council Decisions adopted over past years on the Future Transport Dialogue in the OSCE, on the Follow-Up to the Sixteenth Economic and Environmental Forum on

\footnotetext{
87 For details, see http://www.traceca-org.org/en/home/.

$88 \mathrm{lbid}$.

89 The Action Programme comprises projects proposed by the Member States and agreed upon by the EC under $\mathrm{EC}$ regulations and goals.

90 The EU's Tacis Programme aimed to promote the transition to a market economy and to reinforce democracy and the rule of law in the partner states in Eastern Europe and Central Asia. For more information, see the EU website, Tacis Programme (2000-2006). Available from http://europa.eu/legislation_summaries/ external_relations/relations_with_third_countries/eastern_europe_and_central_asia/r17003_en.htm.
} 
Maritime and Inland Waterways Co-operation and the most recent Decision on Strengthening Transport Dialogue in the OSCE.

Based on these documents, the OCEEA has engaged in activities to:

- support the dissemination of best practices and standards

- encourage the adoption and implementation of legal instruments related to transport, trade and border-crossing facilitation

- provide political (and practical) support for the development of multimodal transport and logistics systems, including further development of the UNECE EATL Phase I-II and TEM-TER projects as a contribution to the implementation in the OSCE region of the UN Almaty Programme of Action: Addressing the Special Needs of Landlocked Developing Countries

- assist in combating corruption in the transport and customs field

- promote public-private sector dialogue, including through the introduction of trusted trader programmes

- provide training on the prevention and detection of illegal transboundary waste transportation and its disposal

\subsubsection{Transport activities}

7.9.21 Developing the OSCE/UNECE Handbook of Best Practices at Border Crossings

In February 2012, the OCEEA and the UNECE Transport Division jointly published a Handbook of Best Practices at Border Crossings - A Trade and Transport Facilitation Perspective. The Handbook offers reference material and over 120 best-practice examples at border crossings, on the basis of which countries can develop new, innovative policies that both increase security and more efficiently facilitate international trade and transport. It is currently only available in English but a Russian translation is expected to be ready by the end of 2012 .

Growing cross-border trade and transportation in the globalized world economy are compelling governments to develop more efficient border management procedures. Cumbersome procedures at borders increase the cost of transport operations, hampering international trade and foreign investment. With this in mind, the Handbook provides tools that can be used to harmonize and simplify existing procedures and regulations and to improve inter-agency cooperation. It also draws attention to the need to apply best practices and internationally accepted norms and standards. By promoting existing best practices in the field, the Handbook's main purpose is to assist OSCE participating States and UNECE Member States - particularly landlocked countries, many of which are EATL Members - with limited access to world markets to develop more efficient border and customs policies.

The target audience is:

- high and mid-level officials from transport, trade and finance ministries, customs agencies as well as senior staff of border-crossing points

- transport, freight and logistics communities as well as business associations seeking an improved operating environment

- civil society, academia and researchers

The Handbook aims to raise awareness among the above-mentioned groups of the range of instruments at their disposal for developing and implementing better trade, transport, border and customs policies. Drawing upon operational evidence and case studies, it offers best practices from both the public and private perspectives. The publication primarily focuses on road bordercrossing points, but also touches on rail and sea crossings. 
Accessing the Handbook

E-copies are available online at http://www.osce.org/eea/88200 and at http://www.unece. org/trans/publications/wp30/best_practices.html.

\section{Follow-up}

In the course of 2012 and beyond, the Handbook will be made available and promoted through a series of capacity building and training events. Its content could serve as a basis for further discussion of non-physical obstacles to transport in the eventual next stage of the EATL project.

\subsubsection{Ensuring transport security}

In the course of 2012, jointly with the UNECE Transport Division, the OCEEA intends to publish the proceedings of last year's Inland Transport Security Discussion Forum Expert Round Table held in Vienna in December 2011. The publication will also contain a number of expert papers that identify weaknesses and threats in the area of transport security and outline ways to further improve coordination and the effectiveness of national and international efforts in making inland transport more secure. The publication will be made available both in English and Russian. Subsequently, follow-up activities could be held across the region.

\subsubsection{Promoting the implementation of international legal instruments}

A number of international legal instruments, conventions, standards and norms have been developed over the years that, when implemented, could well lead to a considerable improvement in cross-border trade and transport operations.

In this regard, the OCEEA assists participating States in organizing regional training activities and national seminars to promote the implementation of the following international legal instruments and concepts, designed to tackle these issues:

- UNECE International Convention on the Harmonization of Frontier Controls of Goods ("Harmonization Convention")

- World Customs Organization Revised Kyoto Convention on the Simplification and Harmonization of Customs Procedures

- World Customs Organization SAFE Framework of Standards to Secure and Facilitate Global Trade

In close cooperation with the Transport Division of the UNECE and the OSCE field presences, the OCEEA offers States national, tailor-made technical assistance. Such assistance seminars have been organized in Kazakhstan, Turkmenistan and Uzbekistan, as well as in other countries across the region.

\subsubsection{Fostering good governance and anti-corruption}

International trade and transport play a vital role in the economic development of the OSCE participating States, but procedural impediments at border crossings hamper international trade and foreign investment, and create high costs for trade transactions and delays for the crossborder movement of traded goods. To address these challenges, building integrity in border and customs services has a potential to boost economic development while also preventing crossborder criminal activities. In line with the OSCE's mandate in the economic and environmental dimensions, the OCEEA assists participating States in capacity building and regional training activities aimed at combating corruption in customs and border services. In carrying out these activities, the OCEEA aims to raise awareness on the existing tools to fight corruption in border services and to offer the opportunity to identify concrete national follow-up activities in this 
field. The WCO and the World Bank have been main partners in this endeavour. One of the key activities held in this field was a WCO supported Regional Conference on Promoting Integrity in Customs and Border Services in Central Asia and the South Caucasus, which took place in Almaty, Kazakhstan in July 2010.

\subsubsection{Preventing and detecting illegal transboundary waste transportation}

In the field of environment, the Office's work focuses on the transport of dangerous goods and hazardous substances. With the support of the Basel Convention Secretariat, trainings have been organized in Eastern Europe and Central Asia on the prevention and detection of illegal transboundary waste transportation and its disposals.

\subsubsection{Other OSCE supported initiatives}

Other OSCE supported initiatives inter alia include:

- Tajikistan - Transborder Trade Promotion Centres

- The OSCE Office in Tajikistan has continued to promote trade growth between Tajikistan and Afghanistan and supported the operations of four permanent transborder trade promotion centres, three in the Gorno Badakhshan Region and one in the Khatlon Region, serving the major border crossings to Afghanistan. The centres provide information on customs and markets to entrepreneurs from both sides of the border and offer business training focused on small enterprises involved in transborder trade.

- OSCE Border Management Staff College in Dushanbe Since 2009, the OSCE Border Management Staff College in Dushanbe has provided training on a wide range of borderrelated issues to senior border management and security officials.

\section{References}

This section is based on an OSCE submission as well as on publicly available information accessed on the OSCE website at http://www.osce.org/, especially:

http://www.osce.org/who

http://www.osce.org/eea/45046

http://www.osce.org/eea/45050

http://www.osce.org/eea/60738

http://www.osce.org/eea/45546

Office of the Co-ordinator of OSCE Economic and Environmental Activities (2009). Activity Report, June 2008-May 2009. Vienna. Available from http://www.osce.org/eea/37329.

\subsection{Organization of the Black Sea Economic Cooperation (BSEC)}

The Organization of the Black Sea Economic Cooperation (BSEC) was established in 1999 to foster interaction and to ensure peace, stability and prosperity among its Member States. ${ }^{91}$

At the Meeting of the Ministers of Transport of the BSEC Member States in 2005, it was concluded that the development of transport axes connecting the Trans-European Transport Network with the Black Sea transport network should be based on the Euro-Asian transport corridors and on the major routes under the UNECE-UNESCAP EATL framework as well as on other international agreements and initiatives.

91 The eleven founding States are Albania, Armenia, Azerbaijan, Bulgaria, Georgia, Greece, Republic of Moldova, Romania, Russian Federation, Turkey and Ukraine. Serbia is also a member since accession in 2004. 


\subsubsection{Relevant initiatives/projects}

BSEC has worked collaboratively with UNECE on issues related to transport facilitation. The Cooperation Agreement between BSEC and UNECE, signed in 2001, aims at accelerating the development of international transport infrastructure networks, transport and border-crossing facilitation, and also harmonizing safety and environment standards in the area of transport. These objectives have been the main considerations of BSEC under the transport development strategy.

The Transport Action Plan of the Black Sea Economic Cooperation proposes the promotion of a highly efficient and sustainable regional transport system. Priority activities of the Action Plan include the rehabilitation, modernization and construction of transport infrastructure; the simplification and harmonization of border-crossing procedures; and the harmonization of transport legislation.

The transport infrastructure development plan was incorporated into the Memorandum of Understanding for the Coordinated Development of the Black Sea Ring Highway. ${ }^{92}$ The Black Sea Ring Highway promotes cooperation in the development of multimodal transport infrastructure for interconnections with the Trans-European, Pan-European and Euro-Asian transport networks for the approximately $7,000 \mathrm{~km}$ route.

\section{References}

This section is based on BSEC's report entitled BSEC Contribution into the Development of the Euro-Asian Links and publicly available information accessed on the BSEC website at http://www.bsec-organization.org/Pages/ homepage.aspx, especially:

http://www.bsec-organization.org/Information/Pages/testt.aspx

http://www.bsec-organization.org/aoc/Transport/Pages/Information.aspx

http://www.bsec-organization.org/aoc/Transport/Pages/ActionP.aspx

\subsection{Economic Cooperation Organization}

The Economic Cooperation Organization (ECO) is an intergovernmental organization founded in 1985 to promote economic, technical and cultural cooperation for its Member States. ${ }^{93}$ The main goals of the ECO include sustainable economic development, economic liberalization and privatization, mutually beneficial cooperation with regional and international organizations, the removal of trade barriers, and the development of transport and communications infrastructure. ECO's activities are conducted by six Directorates under the supervision of a Secretary-General and Deputies.

\subsubsection{Relevant initiatives/projects}

The Directorate of Transport and Communications has played a significant role in facilitating ECO Agreements and Declarations in the transport and communications field to foster economic cooperation, integration and cohesiveness in the ECO region. The ECO transport sector has achieved considerable progress in, for example, interconnecting road and railway networks in Central Asian Republics with Iran, Pakistan and Turkey, and in international road transport among all ECO countries via bilateral agreements and the construction of missing links in the ECO region. This work was accomplished under the framework of the Almaty Outline Plan for

92 The Memorandum of Understanding was signed in 2007 and entered into force in 2008. It is available at http:// www.bsec-organization.org/documents/LegalDocuments/agreementmous/m3/Documents/MoU\%20BSRH\%20 0711227.pdf.

93 Iran, Pakistan and Turkey are founding Members. Afghanistan, Azerbaijan, Kazakhstan, Kyrgyzstan, Tajikistan, Turkmenistan and Uzbekistan became Member States in 2002. 
the Development of Transport Sector in the ECO region, adopted at the first meeting of ECO Ministers of Transport in 1993.

In 2006, the First Meeting of the Transit Transport Coordination Council was held to discuss important issues and to develop cooperative activities in line with the ECO Transit Transport Framework Agreement. The Agreement's aims are adequate transit traffic arrangements for regional and international trade as well as economic progress as a result of the following objectives:

- to facilitate the movement of goods, luggage and passengers and to provide all necessary facilities for transit transport

- to ensure the safety of goods, luggage and passengers and to avoid unnecessary delays during the transit traffic

- to cooperate and coordinate efforts to avoid the incidence of customs frauds and tax evasion

- to harmonize the necessary administrative affairs dealing with transit traffic

The Meeting established four committees of the Transit Transport Coordination Council: the Road Committee, Railway Committee, Legal Committee and Insurance Committee. The Second Meeting of the Council, held in 2007, finalized the arrangements to establish an ECO Fund for the implementation of the Transit Transport Framework Agreement.

ECO's transport sector has developed transport infrastructure to link Member States as well as that between those States and other regions. The First Regional Workshop of Euro-Asian Transport Links Phase II, co-organized by ECO and UNECE, was held in Tehran, Iran, in April 2009.

\section{References}

This section is based on publicly available information accessed on the ECO website at http:// www.ecosecretariat.org/

\subsection{EurAsian Economic Community}

The EurAsian Economic Community (EurAsEC) is an intergovernmental organization, established in 2000, consisting of six Member States. ${ }^{94}$ The two main objectives of the EurAsEC are the establishment of a customs union and the creation of a single economic space. Its activities encompass various domains, pursued by four principal bodies: the Inter-State Council, comprising heads of State and Governments; the Integration Committee, formed by Deputy Prime Ministers; the Inter-Parliamentary Assembly; and the Secretary-General.

The EurAsEC Integration Committee launched the Council on Transport Policy to address transport-related challenges.

\subsubsection{Relevant initiatives/projects}

The Council on Transport Policy brings together the Ministers of Transport of all EurAsEC countries to develop coordinated activities, such as the creation of international transport corridors between Europe and Asia, the development of transport infrastructure and the standardization of technical and technological parameters, and to refine the legal framework at border crossings.

The EurAsEC is focusing on developing a Unified Transport System and a Transport Union of its Member Countries. For this purpose, the Inter-State Council adopted the Unified Transport System Development Concept in January 2008, and approved Measures for Developing the Unified Transport Space in EurAsEC 2008-2010. The Measures include the harmonization of

${ }_{94}$ Member States are Belarus, Kazakhstan, Kyrgyzstan, Russian Federation, Tajikistan and Uzbekistan. In addition, Armenia, Republic of Moldova and Ukraine are observer countries. 
regulations within the EurAsEC pertaining to transportation and agreements between EurAsEC and third countries, and the development of transport infrastructure, shared information systems and a system of logistics centres.

\section{References}

This section is based on the report of the Eurasian Development Bank ${ }^{95}$ entitled The EurAsEC Transport Corridors published in March 2009, available at http://mpra.ub.uni-muenchen.de/20908/1/MPRA_paper_20908.pdf, and on publicly available information:

United Nations Educational, Scientific and Cultural Organization (2008). Relations between UNESCO and the EurAsian Economic Community. Paris. Available from http://unesdoc.unesco.org/images/0016/001618/161885e.pdf

Ministry of Foreign Affairs of the Republic of Belarus

\subsection{International Transport Forum}

The International Transport Forum (ITF) is a global platform and meeting place at the ministerial level to advance transport, logistics and mobility policy. Its Member States include OECD Member Countries as well as Central and Eastern European countries. ${ }^{96}$

\subsubsection{Relevant initiatives/projects}

UNECE organised a joint seminar ${ }^{97}$ with the European Conference of Ministers of Transport (the predecessor of $\mathrm{ITF}^{98}$ ) on intermodal transport between Europe and Asia. The seminar emphasized work on the following issues to create effective intermodal land transport links between Europe and Asia:

- development of technical and technological capacities of transport infrastructures

- simplification of border-crossing procedures

- removal of physical and non-physical obstacles

- enlargement of the network of intermodal transport

- development and implementation of joint investment projects and ensuring their financing

- creation of a network of logistics centres and information support

- implementation of a harmonized tariff and price policy

- improved usage of the inland waterways for intermodal transportation

- harmonization of the regulatory and legal frameworks

The International Transport Forum (ITF) aims to foster a deeper understanding of the essential role of transport in the economy by organizing annual forums in Leipzig. The different themes of the annual events have been so far the following:

- in 2008 Transport and Energy. The challenge of climate change

- in 2009 Transport for a Global Economy

- in 2010 Transport and Innovation

- in 2011 Transport and Society

- in 2012 Semaless Transport: Making Connections.

\footnotetext{
95 The Eurasian Development Bank is an international financial institution established by intergovernmental agreement signed in 2006 by the Russian Federation and Kazakhstan to support economic growth and integration processes in Eurasia.

96 The list of Member Countries is available at $\mathrm{http}: / / \mathrm{www}$.internationaltransportforum.org/about/members.html. For OECD Member States, see http://www.oecd.org/pages/0,3417,en_36734052_36761800_1_1_1_1_1,00. html.

97 Transport Links between Europe \& Asia. Paris. Available from http://internationaltransportforum.org/pub/ pdf/06Europe-Asia.pdf

98 http://www.internationaltransportforum.org/
} 


\section{References}

This section is based on publicly available information accessed on the ITF website at http:// www.internationaltransportforum.org.

\subsection{Organization for Cooperation of Railways}

The Organization for Cooperation of Railways (OSJD) is an international organization focusing on developing international railway traffic and exchanging information between Member Countries. ${ }^{99}$ It has established five commissions: Transport Policy, Transport Law, Freight Traffic, Passenger Traffic, and Infrastructure and Rolling Stock.

\subsubsection{Relevant initiatives/projects}

In 1996, 13 main railway routes between Europe and Asia were identified by the OSJD on the basis of flows of goods between countries on the two continents. Between 1996 and 2001, the OSJD performed an analysis of technical and operational indicators and technical equipment of these 13 routes, collected data on infrastructure and border crossings and studied ways of improving the freight transport technology. This work resulted in comprehensive measures being drafted to improve the organization of international rail transport operations along the transport corridors between Europe and Asia. The interested countries signed memoranda of understanding for the development of these corridors, which served as a basis for coordinated actions by States to reorganize and modernize pertinent railway lines.

The OSJD is constantly adapting and refining its strategies for the development of intercontinental links along the main railway routes. For example, its programme of work for 2005-2015 calls for the development within the Organization of comprehensive plans for the improvement of transport and the development of transport corridors. The Comprehensive Plans for OSJD corridors No. 1, 9 and 11 were completed in 2006 and the Comprehensive Plans for corridors No. 2, 3, 4, 6, 10 and 12 were adapted in 2007. The OSJD's 13 rail corridors are shown on Map 7.15.

\section{References}

This section is based on publicly available information accessed on the OSJD website at http://osjd.jdvm.cz/, especially:

http://osjd.jdvm.cz/u-index_uvod_dokumenty.htm http:// osjd.org Organization for Cooperation of Railways (2010). Report on OSJD activities in 2010 Warsaw. Available from www.osjd.org.

Map 7.15 - OSJD

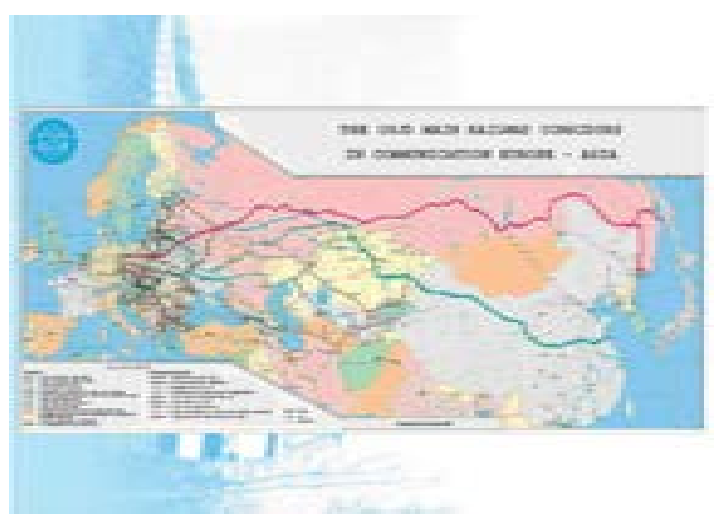

99 Members are listed at http://osjd.jdvm.cz/u-index_uvod_dokumenty.htm. 


\subsection{The World Bank}

The World Bank is an international institution, owned by 185 Member Countries, ${ }^{100}$ charged with providing financial and technical assistance to developing countries. The World Bank Group consists of two development institutions, namely the International Bank for Reconstruction and Development, focusing on middle income and creditworthy poor countries, and the International Development Association, focusing on the poorest countries, and three affiliates. ${ }^{101}$

\subsubsection{Relevant initiatives/projects}

The transport sector constitutes a significant part of the World Bank's portfolio. The Bank's Transport Business Strategy for 2008-2012 emphasizes the need for safe, clean and affordable transport, thus enabling economic growth and poverty reduction. With International Development Association funding, over the last ten years approximately $260,000 \mathrm{~km}(150,000 \mathrm{~km}$ of rural and $110,000 \mathrm{~km}$ of non-rural) roads and 10,700 bridges were constructed, rehabilitated or maintained, benefiting about 75 million people. In fiscal year 2011, World Bank lending in the transport sector amounted to $\$ 8,638$ million.

According to World Bank statistics, the transport sector accounted for 56 per cent of the Bank's portfolio of active projects in 2010 (Figure 7.1).

Figure 7.1 - Portfolio of active projects, 2010

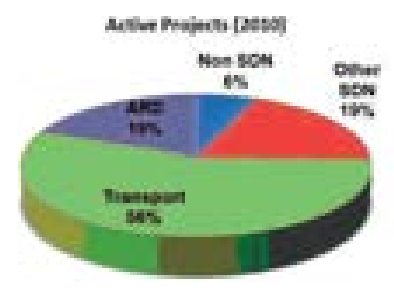

Source: World Bank Group

http://web.worldbank.org/WBSITE/EXTERNAL/TOPICS/EXTTRANSPORT/EXTRURALT/0\%2c\%2cmenuPK:5 15376 page PK: $149018 \sim$ piPK: $149093 \sim$ theSitePK:515370\%2c00.html

Note: As of November 2010, 225 active Bank projects contain rural road activities:

- $94 \%$ of these activities are housed under the Sustainable Development Network (SDN)

- The Transport Sector Board accounts for $56 \%$ of the Bank portfolio

- The Agriculture and Rural Development (ARD) Sector Board has a share of around 19\%

The Transport Business Strategy for 2008-2012 seeks "to help partner countries to establish the governance, strategies, policies and services that will deliver transport for development in a way that is economically, financially, environmentally and socially sustainable". ${ }^{102}$ To achieve this goal, the Strategy sets five priorities:

- to create the conditions for increased support for transport investment

- to deepen engagement in the roads and highways subsector

- to increase engagement in the urban transport subsector

- to diversify engagement in transport for trade

- to control emissions and to mitigate impact on climate change.

100 The list of Member Countries is available at http://web.worldbank.org/WBSITE/EXTERNAL/EXTABOUTUS/0, contentMDK:20103870 menuPK: 1697011 pagePK:5 1 123644 piPK:329829 theSitePK:29708,00.html.

101 The affiliates of the World Bank Group are the International Finance Corporation, the Multilateral Investment Guarantee Agency and the International Centre for Settlement of Investment Disputes.

102 International Bank for Reconstruction and Development and the World Bank Group, Safe, Clean, and Affordable... Transport for Development: The World Bank Group's Transport Business Strategy for 2008-2012 (Washington, D.C., 2008), p. 80. 
The World Bank participates with the European Union, the Asian Development Bank and other institutions in building better transport networks between Europe and Asia via Central Asia and the Caucasus. The Bank focuses increasingly on promoting trade growth and regional integration through projects creating better international transport links, such as highway improvements, railway modernization and multimodal transport corridor development.

\section{References}

This section is based on publicly available information accessed on the World Bank website at http://www.worldbank.org/, especially:

http://web.worldbank.org/WBSITE/EXTERNAL/EXTABOUTUS/0,,pagePK:50004410 piPK:36602 theSitePK:29708,00.html

http://web.worldbank.org/WBSITE/EXTERNAL/TOPICS/EXTTRANSPORT/0,,content MDK:21517582 menuPK:337124 pagePK:148956 piPK:216618 theSitePK:337116,00.html

International Bank for Reconstruction and Development and the World Bank Group (2008). Safe, Clean, and Affordable... Transport for Development: The World Bank Group's Transport Business Strategy for 2008-2012. Washington, D.C. Available from http://siteresources.worldbank.org/ INTTRANSPORT/Resources/336291-1211381200616/Transport_Business_Strategy_web.pdf.

\subsection{Islamic Development Bank}

The Islamic Development Bank (IDB) is an international financial institution with headquarters in Jeddah, Saudi Arabia and regional offices in Almaty (Kazakhstan), Kuala Lumpur (Malaysia), Rabat (Morocco) and Dakar (Senegal). IDB was established in 1973 to support the economic development and social progress of its Member Countries. ${ }^{103}$

\subsubsection{Relevant initiatives/projects}

\subsubsection{IDB Group Infrastructure Strategic Plan (1431H-1433H / 2009-201 1G)}

From 2009 to 2011, IDB Group focused on core infrastructure sectors, including the transport sector which covers the road, railway, airport, port and multimodal facilities subsectors.

As the IDB underwent major reform, its 2009-2011 Infrastructure Strategic Plan transitioned to fully adopt the proposed new approach to infrastructure. The transition period was needed to allow the gradual build up of IDB Group internal capacity and the absorptive capacity of the Member Countries in the various categories.

The objective of several ongoing and planned transport sector projects is to provide year-round, reliable and direct land transport service between the eastern part of Europe and the western part of the Asian region to enhance trade and the flow of passengers and freight traffic between Europe and Asia in line with the Central Asia Regional Economic Cooperation programme.

\subsubsection{IDB investments}

IDB funding in transport, trade and energy involved \$716 million in the period 2005-2010. The principal projects included:

- Kazakhstan. IDB, together with its co-financiers, $\mathrm{ADB}$ and Japan International Cooperation Agency, approved improving the $480 \mathrm{~km}$ road section in Zhambyl Oblast ${ }^{104}$

\footnotetext{
${ }_{103}$ The membership of IDB includes 56 countries listed at http://www.isdb.org/irj/portal/anonymous? Navigation Target=navurl://750e5 1a0219adf78e6329e889512714e.

104 The cost of improving the Zhambyl Oblast section is estimated at about $\$ 1.5$ billion and is being financed by ADB ( $\$ 700$ million), IDB ( $\$ 414$ million), JICA (\$150 million), and the Government (\$216 million).
} 
within the Western Europe-Western China International Transport corridor. ${ }^{105}$ IDB approved \$186 million in February 2009 to cover the financing of the $58 \mathrm{~km}$ section in Jambul Oblast.

- Kyrgyzstan. ADB approved a $\$ 20$ million grant to rehabilitate the Bishkek-Torugart road in November 2008. An additional \$50 million was planned for approval in 2009. To complete this road corridor, a memorandum of understanding was signed to consider the financing of the road stretch from Dolon Pass to Atbashi in the Bishkek-Torugart road corridor. Furthermore, IDB-funded phases of the "Reconstruction of Taraz-TalasSuusamyr" project progressed satisfactorily.

- Tajikistan. A Co-financiers' meeting held in Dushanbe was attended by the members of the Coordination Group (IDB, Kuwait Fund for Arab Economic Development, Abdu Dhabi Fund for Development, OPEC Fund for International Development and Saudi Fund for Development) in 2008 and a memorandum of understanding was signed to consider the financing of the Kulyab-Khalaikum road corridor. In addition, the IDB planned another appraisal mission to Tajikistan in the second half of 2009 to provide financing for the third phase of the Shagon-Zhigar road project, subject to successful completion of the second phase.

\section{References}

This section is based on IDB submissions and on publicly available information accessed on the IDB website at http://www.isdb.org/irj/portal/anonymous?guest_user=idb_eng, especially:

http://www.isdb.org/irj/portal/anonymous?NavigationTarget=navurl:// fd0cb8101ac50bfe83d6477ba087e1b8

http://www.isdb.org/irj/go/km/docs/documents/IDBDevelopments/Internet/English/ IDB/CM/Publications/Annual_Reports/31st/Contents-1426H.pdf

\subsection{Asian Development Bank}

The Asian Development Bank (ADB) is a Manila-based international development finance institution founded in 1966 to support its members in reducing poverty and improving quality of life. ADB's main partners are governments, non-governmental organizations, development agencies and the private sector. It has 67 members. ${ }^{106}$

ADB's operations in the transport sector promote economic growth and sustainable increases in welfare in its developing Member States. ADB's main areas of focus for the transport sector are interventions in roads and highways, urban transport systems, railways, ports and waterways, and civil aviation areas with other donors such as IDB.

\subsubsection{Relevant initiatives/projects}

The CAREC programme is an ADB-supported initiative established in 1997 to encourage economic cooperation among countries in the Central Asia region in a partnership between the Central Asian republics ${ }^{107}$ and six multilateral institutions: ADB, European Bank for Reconstruction and Development, IDB, International Monetary Fund, United Nations

105 The total length of the corridor is about 2,715 km, of which 2,237 km will be constructed and/or reconstructed. The total investment plan for the corridor is estimated at about $\$ 6.7$ billion, shared as follows: Asian Development Bank ( $\$ 700$ million), European Bank for Reconstruction and Development (\$181 million), Islamic Development Bank (\$414 million), Japan International Cooperation Agency (\$150 million), the World Bank $(\$ 2,125$ million), the private sector $(\$ 2,221$ million) and the Government (\$909 million).

106 The list of Member Countries is available at http://www.adb.org/About/membership.asp.

107 Afghanistan, Azerbaijan, China, Kazakhstan, Kyrgyzstan, Mongolia, Tajikistan and Uzbekistan. 


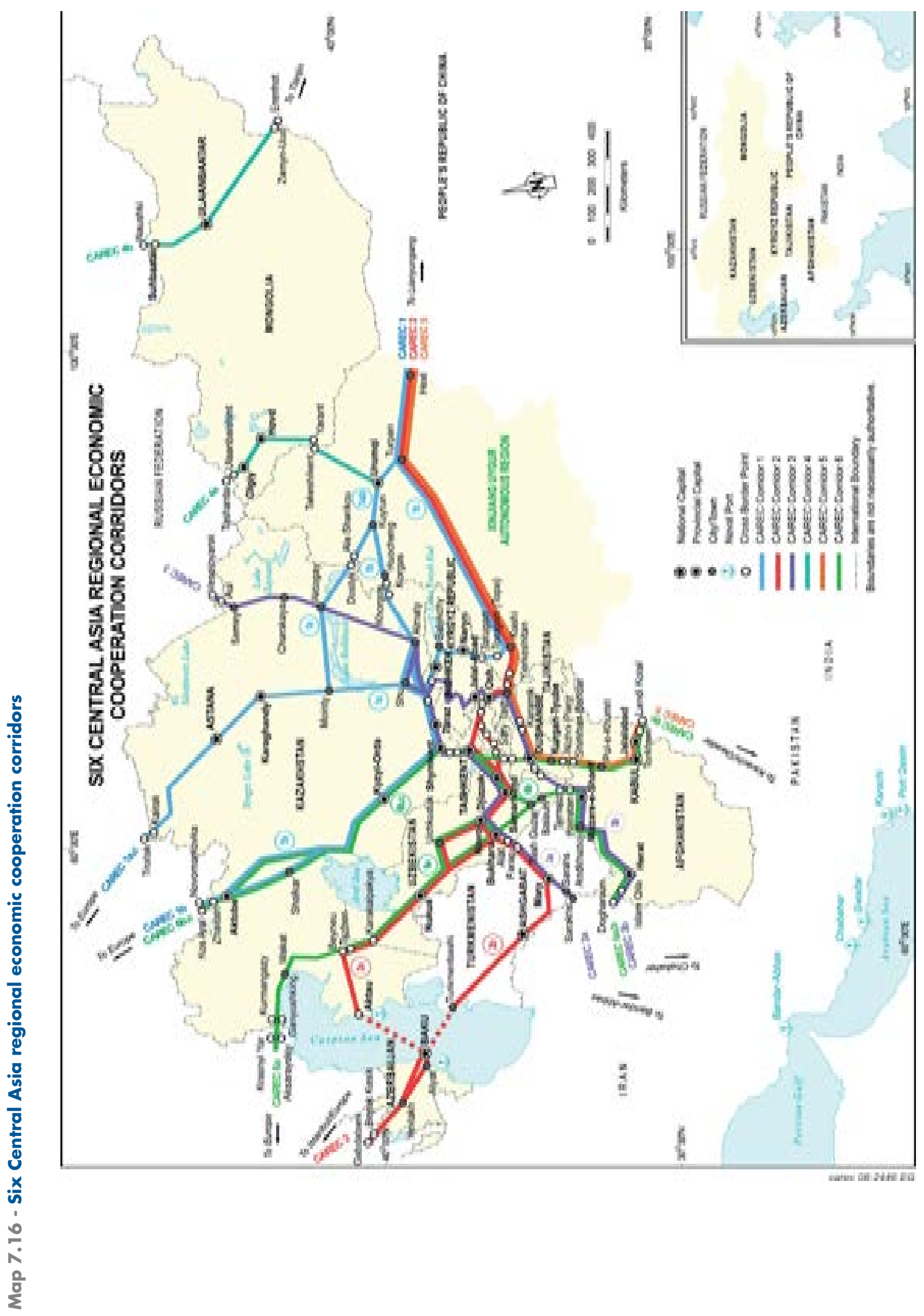


Development Programme and the World Bank. Main concerns about inland transport in the CAREC region are:

- inefficient cross-border and transit movement due to excessive bureaucratic procedures

- lack of unified transport regulations among CAREC countries

- inadequate regional transport networks

- lack of competition in railways due to the monolithic and monopolistic nature of organizations

- limited institutional and human resource capacities

- lack of a regional approach in civil aviation

To deal with these issues, the CAREC Transport Sector Coordinating Committee developed a Regional Transport Sector Road Map (2005-2010) in 2005 (updated in 2006) for cooperative activities in the transport sector among CAREC countries. The Regional Transport Sector Road Map sets six strategic priorities for an integrated and efficient transport system in the CAREC region:

- harmonization and simplification of cross-border transport procedures

- harmonization of transport regulations among CAREC countries

- development and improvement of regional and international transport corridors

- restructuring and modernization of railways

- improvement of sector funding and management

- adoption of an incremental approach to the liberalization of civil aviation

The Transport Sector Coordinating Committee also worked on establishing the CAREC Transport and Trade Facilitation Strategy ${ }^{108}$ jointly with other participants, such as the Customs Cooperation Committee. The Strategy aims at three overarching goals: to establish competitive transport corridors across the CAREC region; to facilitate efficient movement through corridors and across borders; and to develop sustainable, safe and user-friendly transport and trade networks.

The total CAREC road network runs $271,000 \mathrm{~km}$ and the rail network measures $25,700 \mathrm{~km}$. The six CAREC corridors have undertaken a significant role in facilitating transport (Map 7.17).

\section{Map 7.17 - Six CAREC corridors}

\section{References}

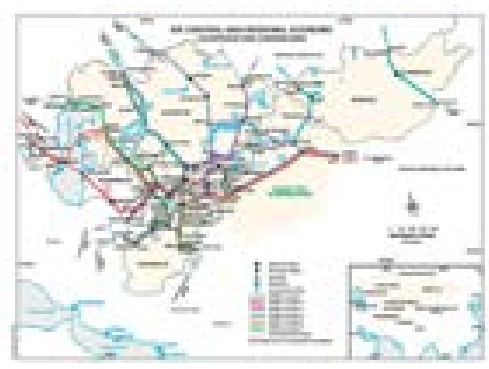

This section is based on publicly available information accessed on the ADB website at http:// www.adb.org/, especially:

http://www.adb.org/About/default.asp

http://www.adb.org/Transport/default.asp

http://www.adb.org/countries/subregional-programs/carec

http://www.carecprogram.org/index.php?page=transport

108 The Strategy was endorsed by the Six Ministerial Conference in 2007 and its assessments are reported in: Asian Development Bank, Transport and Trade Facilitation Strategy Report: Final Report (December 2008). Available from http://www2.adb.org/Documents/Reports/Consultant/37362-REG/37362-REG-TACR.pdf. 
7.18 European Bank for Reconstruction and Development The European Bank for Reconstruction and Development (EBRD) is an international financial institution that was established in 1991 to help create a democratic environment in the former communist countries. The EBRD is funded by 63 countries and two intergovernmental institutions. ${ }^{109}$ It supports projects in 29 countries from Central Europe to Central Asia ${ }^{110}$ for the purpose of promoting entrepreneurship and transition towards open and democratic market economies.

The transport sector is EBRD's major concern in the context of economic development. The Transport Operations Policy ${ }^{111}$ establishes the framework for EBRD's activities in the transport sector. The principal objective of the policy is to review and update the means by which the EBRD achieves its mission in the areas of airports and aviation, ports, shipping and inland waterways, and railway and road infrastructure.

\subsubsection{Relevant initiatives/projects}

The EBRD fosters the development of efficient, reliable and secure transport systems. In 2012, the EBRD was involved in 200 transport-related projects totalling $€ 30.8$ billion. ${ }^{112}$

EBRD invests in both the public and private sectors. The South-West Corridor road project ${ }^{113}$ aims to rehabilitate and upgrade the $102 \mathrm{~km}$ section of road between the Russian Federation border and the city of Aktobe in Kazakhstan as part of the Western Europe-Western China corridor linking Europe and China through Kazakhstan and the Russian Federation by financial assistance to the Kazakh Government.

\section{References}

The section is based on publicly available information accessed on the EBRD website at http://www.ebrd.com/, especially:

http://www.ebrd.com/pages/about.shtml

http://www.ebrd.com/pages/sector/transport.shtml

and the EBRD's Annual Report 2011, available at http://www.ebrd.com/downloads/research/ annual/ar1le.pdf.

\subsection{International Road Transport Union}

The International Road Transport Union (IRU) was founded in 1948 to represent the interests of the international road transport industry. The goals of IRU are to ensure the mobility of people and goods while improving the safety and environmental performance of road transport. The IRU holds Euro-Asian Road Transport Conferences biennially to promote and revive the "Silk Road" linking Europe and Asia.

\subsubsection{Relevant initiatives/projects}

The fifth IRU Euro-Asian Road Transport Conference, held in June 2009 in Almaty, discussed the implementation of the New Eurasian Land Transport Initiative (NELTI). This

\footnotetext{
109 The list of countries and organizations is available at http://www.ebrd.com/pages/about/who/shareholders. shtml.

110 For project details, see http://www.ebrd.com/pages/project.shtml.

111 The Policy (2005-2008) was approved by the Board of Directors in 2005 and is the third policy replacing the Transport Operations Policy of 1997. The full text of the Policy is available at http://www.ebrd.com/downloads/ policies/sector/transpor.pdf.

112 http://www.ebrd.com/pages/sector/transport.shtml.

113 The project details are available at http://www.ebrd.com/english/pages/project/psd/2008/39258.

shtml.
} 
project, developed by the IRU, was inaugurated in September 2008. It has played a significant role in providing data on corridors connecting Europe and China through Central Asia with support from international organizations and governments. The project aims to encourage regular road freight shipments between Europe and China and to assist in achieving the transit potential particularly of nations in Central Asia and the Caucasus. The objectives of the project are to:

- contribute to the implementation of the UN Millennium Development Goals and of the Almaty Programme of Action for landlocked developing countries in order to develop Eurasian land transport links

- assist in the development of trade in landlocked countries and regions and to broaden access for their goods to international markets

- increase the contribution of road transport to international trade and socioeconomic development

- offer alternative delivery routes to maritime shipments to assist businesses in landlocked countries

NELTI networks have exceeded 1,100,000 km through three corridors (Map 7.18):

\section{Map 7.18 - NELTI routes}

- the Northern Route covers approximate $6,500 \mathrm{~km}$ from Chinese borders to Europe, crossing 13 countries

- the Central Route covers approximate $5,100 \mathrm{~km}$ from China to Europe

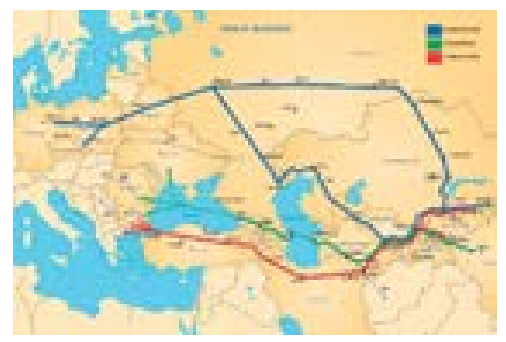

- the Southern Route covers approximate 4,000 km from Kyrgyzstan to Europe

Issues of the NELTI project include delays at border crossings, disharmonized regulations among NELTI countries and the lack of infrastructure on NELTI routes. The second phase of NELTI (NELTI-2) was implemented from 2009 to 2011 to monitor the situation in the bottlenecks and lobby the governments of the transit countries and regional economic organizations to implement recommendations based on the conclusions of the first NELTI phase. During NELTI-2, a Road Map was drafted for national and international decision makers to implement the measures identified to develop international road transport along Europe-Asia routes.

The sixth Euro-Asian Road Transport Conferenceheld in Tbilisi on 16-17June 2011 considered connecting every business and every transport mode between Europe and Asia, with an emphasis on seamless and smooth transport and trade relations.

\section{References}

This section is based on publicly available information accessed on the IRU website at http:// www.iru.org/, especially:

http://www.iru.org/index/en_event_Almaty2009_programme

http://www.iru-nelti.org/index/en_nelti_problems 
IRU reports and publications:

International Road Transport Union (2008). Final Countdown ... to 16 September 2008. Geneva. Available from http://www.iru-nelti.org/index/cms-filesystem-action?file=nelti/nelti_ en.pdf

International Road Transport Union (2009). IRU NELTI...creating new business opportunities. Geneva.Availablefrom http://www.iru-nelti.org/index/cms-filesystem-action?file=publications/ nelti_join_us_en.pdf

International Road Transport Union (2009). Report on the First Six Months of the Implementation of the NELTI Project. Geneva. Available from http://www.iru-nelti.org/index/ cms-filesystem-action?file=nelti/report_6_months_eng.pdf

NEA Transport Research Institute \& IRU (2009). NELTI Final Report: Analysis of Monitoring Data Collected on NELTI Project Routes in 2008-2009. Available from

http://www.iru.org/index/cms-filesystem-action?file=events_2009_almaty/NELTI-reportEN.pdf.

NEA Transport Research Institute \& IRU (2011).NELTI-2 Final Report:Road Map. Available from http://www.iru-nelti.org/index/cms-filesystem-action?file=nelti3/Nelti2011.E.pdf 


\section{PART VIII}

\section{CONCLUSIONS}

Within the general framework of globalization, fragmented international production and market liberalization, the volume of international trade between Europe and Asia has been growing sharply in recent years, partly as a result of the development of eastern Asian countries, mainly China, but also due to the growth of the economies of the Russian Federation and Central Asian countries, as well as that of other countries such as Turkey and India. In addition, the newly industrialized countries of Asia have experienced their trade flows rebound more strongly than those of developed economies, suggesting that much of their recent growth could be attributed to the trade within Asia. Therefore, the intra-Asian trade flows are increasing and could become as important as the Euro-Asian flows in the coming years. Maritime transport has been the dominant transport mode for Euro-Asian trade flows to date, and trade growth is increasingly concentrated on a certain number of major maritime hubs in both Europe and Asia. An additional challenge for international transportation operators is trade imbalance, with a large number of empty containers being transported from Europe to Asia.

The above needs call for the diversification of existing routes and the opening up of alternative passages between the two continents. One direction in which current efforts are moving is towards the development of corridors and, hence, UNECE and UNESCAP have promoted a number of initiatives to improve "Euro-Asian Linkages" along land routes. These efforts are geared to the opening up of the almost untapped traffic capacity potential of land transport infrastructure, as well as to the promotion of infrastructure development in order to improve transport linkages between Central Asia and Europe, as well as between East Asia and Central Asia.

Building on the results of the work jointly implemented by UNECE and UNESCAP between 2003 and 2007 during the EATL Phase I, the present Study is the outcome of the work of designated National Focal Points from 27 participating countries along the Euro-Asian land bridge involved in EATL Expert Group during Phase II (2008-2011) with the support of the UNECE secretariat and consultants.

More specifically, the EATL Phase II Study achieved the following key results:

- identified major road, rail and inland water routes as extensions of existing EATL Phase I routes considered for priority development, including new priority and high priority projects on the territory of the new Phase II participating countries (Finland, Germany, Latvia, Lithuania, Luxembourg, Mongolia and the former Yugoslav Republic of Macedonia)

- identified a number of key container depots, intermodal terminals and ports along the selected routes

- assessed the status of implementation of projects identified under EATL Phase I

- developed a new infrastructure Investment Plan by prioritizing 311 investment projects of priority importance, which amount to a total cost of approximately US\$215 billion and by selecting 188 projects of high priority importance with an approximate cost of US $\$ 78$ billion

- updated and expanded the comprehensive Geographic Information System (GIS) database built during EATL Phase I with new GIS maps prepared for the EATL region and each 
participating country involved, and made it available on the Internet

- reviewed the international transport networks and initiatives linking Asia and Europe

- reviewed Euro-Asian transport flows, statistics and trends

- elaborated a SWOT Analysis specifying the strong and weak points of the EATL land transport links, the potential for their further development, as well as related threats

- elaborated a comparison study of Euro-Asian maritime routes with selected rail routes, showing that in most cases - under certain conditions - rail transport performs better than maritime in terms of both cost and time

- identified non-physical obstacles to transport along the Euro-Asian transport routes, with one thousand questionnaires sent to EATL road, rail and combined transport operators, supply chain managers, forwarders and important shippers seeking inputs on existing problems and potential solutions along the EATL routes used

- compared existing Euro-Asian maritime routes with selected rail routes identified in the EATL project

- maintained the coordinating mechanism in the form of the Group of Experts appointed by participating governments

- provided recommendations on three strategic areas of action, that is, infrastructure, facilitation and policies

- drafted Country Reports for each participating country detailing current conditions on transport infrastructure, as well as National Transport Plans

The priority routes identified by the EATL Study constitute a promising prospect for transportation on Europe-Asia links, primarily taking into account the vast transit traffic capacity potential of land routes through northern Eurasia, which at present are very much underutilized. The review of the EATL Phase I Investment Plan depicted that half of the infrastructure network has been completed, while 25 per cent of the proposed projects could be considered in the EATL Phase II. Hence, the development of these new and extended EATL transport routes would provide additional Euro-Asian transport solutions to the existing maritime routes and at the same time become a development tool for many countries in the Euro-Asian region, particularly for the landlocked states.

It is acknowledged that the implementation of the EATL Phase II network is a long-term process steered foremost by political will and commitment from all participating countries' national authorities. Continuous close cooperation among the 27 EATL Member Countries, ${ }^{114}$ between them and their immediate neighbouring countries, the respective National Focal Points and UNECE, is therefore imperative to achieve the goal of an effective and sustainable EATL network.

Furthermore, the provision of transport infrastructure is not the sole condition for the movement of Euro-Asian traffic flows. Therefore, linking some of the EATL countries into the global trading system is further complicated, while they stay outside the 57 transport legal instruments, continue to use wooden rail boxcar wagons instead of containers, continue to choose to purchase rail grain hoppers instead of using the international good practice of lined 20-foot containers, and continue to treat TIR trucks in the same way as other trucks when processing export, import and transit trucks at border-crossing points. Key steps of the process include removing or minimizing non-physical barriers, harmonizing regulatory framework, promoting the accession and implementing various international conventions, building institutional and human capacity, as well as improving the business environment in the road, rail, inland waterway and maritime sectors. 
To this end, the EATL Phase II Study culminates in a set of recommendations, classified into four areas, namely, infrastructure, facilitation, operation and services and policy, as effective means of identifying the impediments to transit traffic, and with the scope to set the ground for developing strategic action plans.

To sum up, inland transport offers shorter geographical distance and faster delivery time than the alternative maritime link between the EU and the Asia-Pacific region. It offers the advantage of end-to-end transportation, time efficiency and reliability. In this light EATL Phase II identified priority road and rail routes and projects; revealed that transport on certain inland routes is less costly than transport of goods by sea; encouraged the development of partnerships among key players for an integrated expansion of infrastructure and the tackling of environmental risks through cooperation among the National Focal Points, which was supported by the UNECE secretariat; and promoted high political commitment for the development of EATL.

The globalization of economic activity and expanding economic relations between Europe, on the one hand, and China and India, on the other, offers further opportunities to the EATL project. This is reinforced by economic development in the western part of China; congestion in the principal maritime ports and certain routes (the Suez Canal); economic integration between Belarus, Kazakhstan and the Russian Federation, as well as the expansion of this economic group; and increased economic cooperation among the EATL countries.

Challenges to the development of the EATL appear from the possible offer of competitive prices by maritime transporters; underutilized possibilities offered by intermodal transport; political instability; economic crisis and cuts in public expenditure that may affect infrastructure development and maintenance; and the opening of the Arctic passage for container transport. Non-physical obstacles, such as regulation, lack of coordination and various rent-seeking practices, pose serious challenges that policy measures should tackle along the EATL routes. 


\section{PART IX RECOMMENDATIONS}

The implementation of the EATL Phase II priority projects is a long-term process that first and foremost requires political will and commitment from all the countries involved. Seeing it to fruition also entails continuous close cooperation among the participating Member Countries, their respective Focal Points, as well as international, governmental and non-governmental transport organizations, financial institutions and the Inland Transport Committee and its subsidiary bodies of UNECE. It is equally important that countries continue to collaboratively address all aspects of transport development,. The EATL network has infrastructure at its core, as a prerequisite element; accomplishment of the project however hinges on several factors. The EATL Phase II Study puts forward a set of recommended strategic actions, classified into three key areas, namely, infrastructure, facilitation and policy. The needs and issues that would potentially be addressed in a subsequent third phase of the EATL Study are also stipulated at the end of this part.

\section{Recommendations on Infrastructure Development}

It should be noted that it is crucial to secure the necessary funds for the implementation of the proposed infrastructure projects. Participating countriessubmitted data on the EATL projects for evaluation and prioritization on the basis of the agreed methodology. They employed a set of criteria reflecting social values, priorities and available resources as well as the viability of the projects and their global/international character.

The overall project costs amount to approximately $\$ 215$ billion for the 311 projects, which can be summarized as follows:

- road projects with an estimated value of $\$ 114$ billion, representing 53 per cent of the total investment cost

- rail projects with an estimated value of $\$ 75$ billion, representing 35 per cent of the total investment cost

- other projects (maritime, inland waterway, etc.) with an estimated value of $\$ 26$ billion, representing 12 per cent of the total investment cost

Out of the 311 projects 188 were rated as high priority. Their estimated investment costs are $\$ 78$ billion. (60\%) Another $47 \%$ of planned investment ( $\$ 100$ billion) is associated with 68 priority projects $(22 \%)$ that lack secure funding to date. The remaining $2 \%$ of infrastructure investment ( $\$ 33$ billion) planned by the authorities is associated with $52(17 \%)$ projects that were classified in the low-priority category or could not be evaluated due to insufficient data.

Finally, 100 per cent funding has only been secured for the projects submitted by Azerbaijan, Greece, Kazakhstan and Lithuania. Given that the development of transport infrastructure is the responsibility of the governments concerned, the international community needs to further assist countries in securing the remaining investments in the near future.

To see all these projects be implemented, however, governments need to further improve their transport investment planning in a way that their part of the EATL priority projects are incorporated in their national plans. 
Improvement of infrastructure so as to provide a technically viable and commercially attractive alternative to maritime transport and to facilitate intermodal transport operations
Maritime transport has carried the bulk of Europe-Asia trade flows to date; however it is increasingly concentrated in just a few major maritime hubs, partly because of the increase in vessel size. Inland transport routes are generally shorter than maritime routes however maritime transport is usually preferred due to lower transport costs. Development of modern and well-designed land transport infrastructure can lead to lower operational costs and thus offer road and rail transport along Euro-Asian routes a competitive advantage as compared to maritime transport.

Over congestion and saturation problems on land access to ports is another concernf. If this obstacle is removed, it could raise functional advantages of road and rail transport and further enhanceopportunities for development of intermodal Euro-Asian transport. EATL countries could become more attractive for foreign direct investments, increase their exports and benefit from participation supply chains that include a maritime leg.

\section{Key Recommendations of the EATL Project}

\section{Recommendations on Infrastructure Development}

- Improve infrastructure so as to provide a technically viable and commercially attractive alternative to maritime transport and facilitate intermodal transport development and operations;

- Provide adequate financial resources for the implementation of priority infrastructure investment projects along the identified road and rail routes

- Coordinate and implement national infrastructure investment plans, and include the EATL programme in national investment plans and programmes

- Improve large scale-investment and programme management practice at multicountry, national and project levels;

\section{Recommendations on Facilitation}

- Streamline and simplify border crossing procedures and practices and harmonize rules and regulations, including accession to relevant international conventions for border crossing facilitation (see Annex II);

- Ensure technical and operational interoperability of systems

- Identify and remov physical bottlenecks

- Use available customs transit systems (e.g. TIR) to expedite transit operations and increase the security of vehicles, crew and cargo in transport and transit

- Simplify visa requirements and formalities

- Standardize trade and transport documents; eventually consider shift to electronic documents

- Reduce and remove the hidden costs of transport and transport-related services, as well as of the non-physical barriers

- Strengthe institutional and human resources capacity 


\section{Recommendations on Policy}

- Develop national transport master plans using EATL achievements as a backbone

- Design and implement needed reforms of the transport sector, border crossing facilitation and of the management of large-scale transport investment programmes

- Reduce the pressure of domestic transport and trade-related monopolies

- Create conditions to facilitate integration of the country into the production, supply and transport chains of modern production

- Improve the monitoring of infrastructure developments and the execution of transport facilitation plans

- Set targets and benchmarks for the appraisal of policy achievements

- Support of the expansion of trade between the EU and Far East, as well as along the EATL routes

- Encourage public-private partnerships in infrastructure development

- Improve the exchange and implementation of international best and good practices

- Improveme data collection and dissemination and the quality and coverage of overall transport statistics

The development of intermodal Euro-Asian routes that include the maritime transport requires reliable and efficient services of Ro-Ro and Ro-Pax (termed also ferry lines) at the Black and Caspian Seas. Ferrycrossing operations represent one of the important components of the international shipping business. The results of using new policies and greater cooperation must include:

- provision of a predictable and reliable schedule of Ro-Ro and Ro-Pax lines; publication of timetables to improve planning of transportation by road transporters dealing with export, import and transit cargo operations between Asia and Europe

- provision of additional Ro-Ro and Ro-Pax services in case of a significant increase in road transport haulage between Europe and Asia

- cooperation among the shipping industry and port operators of Azerbaijan, Georgia, Kazakhstan and Ukraine to simplify and speed up the administrative procedures at seaports

- cooperation of the shipping industry with the forwarding companies in order to introduce and manage advanced Ro-Ro and Ro-Pax reservations, which will reduce waiting time for vehicles at seaports

Several of the identified EATL routes are intermodal and, as a result, the efficiency of the emerging EATL network lies to a significant extent in the trans-shipment capabilities of the transport terminals. Hence, special focus should be placed on the need for efficient intermodal "interfaces", including ports, dry ports, inland container terminals, freight villages, etc. Landlocked countries, in particular, together with their transit neighbours, need to consider the development and maintenance of adequately equipped dry ports, i.e. inland container depots, logistic centres, dedicated warehousing and other related facilities at the interface of different modes of transport. In this context, the use of financial and economic planning models should be promoted in partnership with 
Procurement of and provision for adequate financial resources for the implementation of transport investment projects along the priority road and rail routes various organizations. In addition, private-sector provision of logistics services, particularly for small and medium-sized enterprises, should be enhanced.

Additional recommendations and actions promoting intermodal integration through the development of dry ports in the region include:

- strengthening transit cooperation between landlocked and transit EATL countries to promote intermodal transport connectivity

- prioritizing the development of dry ports in each EATL country to constitute a network of dry ports connected with the maritime ports in the EATL region

- assessing the challenges and opportunities for the development of dry ports

- coordinating the different government ministries/departments and the private sector to create a conducive environment for the development of dry ports

The participating countries of EATL Phase I agreed on the routes that formed the "Euro-Asian transport linkages". It is of outmost importance that they continue to support the development of these links and concentrate their efforts towards integrating their national transport networks with the extended EATL Phase II routes. The newly participating countries in EATL Phase II should also incorporate the identified EATL routes in their networks. In any case, network expansion should be realized pursuant to a satisfactory level of demand, and with functionality and coherence.

In order to maximize the competitiveness of the EATL routes, feasibility studies must be carried out or completed for the priority projects. Further efforts should focus on obtaining the necessary funding for the execution of the investments.

In addition, for projects currently lacking the necessary financial resources, an examination of possible sources of funding is required. In this respect, it is also necessary to identify and analyse the eligibility criteria by which countries are selected to receive funds. Funding sources to be examined include, among others:

- national financing

- banks, such as the EBRD, ADB, IDB and the World Bank. In addition, any national development banks that could potentially finance the realization of infrastructure should be identified

- TRACECA, CAREC, BSEC, ECO, EurAsEC

- alternative funding schemes, such as public-private partnerships (i.e. build-operate-transfer schemes) for infrastructure delivery and operation, as well as private finance initiatives for services/ operations delivery or other cross-border financing.

Increased provision of adequate funds for infrastructure implementation should also be supported at the policy level by the competent administrations. To proceed with any type of securitization of financing, infrastructure project must, at the minimum, fulfil the following characteristics: 
Coordination of national infrastructure investment plans and of their implementation, as well as inclusion of the EATL programme in national investment plans and programme

Improvement of large scale-investment and programme management at multi-country, national and project levels alike
- assessment of the level of traffic to justify the investment

- data related to on-going and expected investment expenditures

- readiness of the project

- start and completion years

- already secured sources of funding

- institutional capacity to manage the project and carry out the works

Finally, data collection and monitoring are key elements in identifying, planning and funding infrastructure projects. The monitoring of EATL route performance and programme/project implementation is required to identify problems and recommend remedial action. More specifically, transparent monitoring should aim at:

- observing, measuring, recording, collating, processing information for necessary decision/action

- providing information on the current status of programmes/ projects for comparison with their original plan and costs

- identifying constraints to implementation and suggesting solutions

- securing the involvement of stakeholders

- enhancing the management of resources, accountability, transparency

Based on the above, it is recommended that the National Focal Points of participating countries submit data on a continuous basis to UNECE.

Network monitoring could be presented in a GIS-like format with a Decision Support Sys tem, with direct graphical displays of the network's progress and time frames for completion, depending on the status of the infrastructure's implementation.

Synergies and coordinated action should be encouraged among countries in terms of infrastructure implementation, coordinating implementation time periods, to ensure consistency, interoperability and seamless transport and to reduce the potential risks of marginalizing hinterlands and landlocked countries.

The development and endorsement of the priority routes and projects should be based on national Master Plans and funding possibilities, while taking into account the existing international, regional, interregional and subregional agreements, on infrastructure.

Several EATL projects could easily be seen as large scale investments already when the section within a country is taken into account. The internationally interconnected series of national projects in total however are large scale beyond any doubt. The implications for planning and project management are numerous. The combination of complexity, discontinuities and the consequences of potential delays or failures call for increased attention to risks.

The mechanisms, the institutions to minimize these risks are therefore critical success factors. At international level experience shows that regular exchange of information about investment plans and project implementation progress serves as bare minimum. Corridor 
Streamlining and simplification of procedures and practices and harmonization of rules and regulations, including accession to relevant international conventions for border crossing facilitation

Standardization of trade and transport documents; eventual shift to electronic documents observatories on the other hand could be seen as a more developed level of international cooperation where not only national investment projects are harmonised, but also their impact is monitored.

\section{Recommendations on Facilitation}

The provision of transport infrastructure is a necessary, but not sufficient, condition for the movement of international trade and the efficient operation of the Euro-Asian priority routes, since obstacles and bottlenecks, particularly at borders,occur due to the lack of policy and administrative interoperability and harmonization of legislation. It is vital to address transport facilitation in an integrated manner by all the authorities concerned and in direct partnership with the private sector.

The UNECE secretariat puts considerable emphasis on legal, technical and administrative harmonization of operations onidentified routes and will continue to work with countries, at their request, to assist them in acceding to and implementing international legal instruments.

While the facilitation measures include a broad set of items that can include simplification of procedures and practices, improvement of equipment, infrastructure, as well as skills of officials at border-crossing points, there are some that are of particular importance for the EATL countries at present:

The streamlining of national procedures and harmonization of rules and regulations can lead to major reductions in transport costs and time. Therefore, facilitation measures should be directed towards the standardization, harmonization and simplification of transit policies, regulations, formalities, procedures and documents, as well as institutional issues. This is of vital importance for transit trade and crossing borders, particularly in the case of landlocked countries.

The following issues could be considered:

- simplification and harmonization of documents and procedures for crossing borders and transit, improving customs clearance and border agency inspections

- harmonization and integration of border-management procedures and controls through the application of the Harmonization Convention. ${ }^{115}$ This Convention provides a framework for national authorities to establish integrated control procedures harmonized with neighbourin countries and, where possible, joint control stations that reduce border-crossing times

- promoting common standards and certification in such areas as vehicle and operator permits and safety

- supporting measures related to the official control, promotion and use of standards, customs operations, commercial trade practices, payment procedures, insurance and the use of information technology

- using integrated information systems, as well as the electronic Single Window system, for electronic data submission to reduce

115 United Nations Economic Commission for Europe, International Convention on the Harmonization of Frontier Controls of Goods (Geneva, 1982). 
the number of import and export documents (Georgia with only four export and import documents represents a "best-practice" example for EATL countries)

- computerizing transit documentation as part of a customs modernization reform to reduce the time spent in initiating transit or in final clearance; ASYCUDA and other systems comprise transit modulesconnect border posts to customs administration headquarters

- incorporating transport facilitation measures in bilateral and multilateral arrangements

Greater and more effective effort is needed to promote, accede to and implement the international legal instruments relating to transport facilitation in general, and in the area of border-crossing facilitation in particular. For countries to accede to international conventions there is a need to understand the implications and benefits of the conventions, and to establish mechanisms in the form of committees and bodies necessary to accelerate the process of accession. It is also necessary to monitor and promote the implementation of the agreements at the policy and operational levels. This would also contribute to coordination between the EATL Focal Points and other stakeholders. Various institutional mechanisms for facilitating transit transport need to be explored, and participating countries' governments could consider initiating the following activities:

- formulating national action plans for acceding to the international conventions

- translating international conventions into national languages for wider dissemination and improved understanding

- organizing training programmes for creating awareness and the efficient implementation of the conventions

- sharing experiences and best practices in the implementation of conventions and cooperation between developing/neighbouring countries

- examining domestic legislation with a view to ascertaining the changes that may be necessary to incorporate the provisions of the UN transport conventions.

Ensured interoperability of systems

Identification and removal of physical bottlenecks
Time losses stemming from the lack of interoperability between national systems (in the case of the railway transport in particular) become even more evident with reduced customs and passenger controls and in a liberalized transport market. Gradually eliminating obstacles to interoperability issues at borders, while aiming for efficient controls and security levels, will be crucial for the future competitiveness and viability of EATL routes.

Different methods, including UNESCAP time/cost-distance methodology could be used to identify the bottlenecks, and to assess the success of facilitation measures and the competitiveness of the identified routes during periodic reviews. In addition, modern information and decision-support systems together with corridor studies are effective 
Utilization of available customs transit systems, like the TIR) to expedite transit operations and increase the security of vehicles, crew and cargo in transport and transit means of supporting the planning, development and maintenance of infrastructure facilities, facilitating transit traffic, identifying bottlenecks and monitoring the adherence to agreements.

A revision of existing customs procedures and policies is highly recommended. Their implementation will increase the effectiveness of international transport, reduce freight costs and increase the volume of shipments:

- expediting the process of synchronizing existing customs procedures in transit countries with international norms, regulations and the documentation required when crossing State borders by implementing Annex 8 of the 1982 UN International Convention on the Harmonization of Frontier Controls of Goods - accelerating the process of upgrading border-crossing points, equipping them with modern non-intrusive security controls(vehicle scanning equipment, etc.), as well as with the necessary ITinfrastructure to share data with customs bodies in other countries

- adopting a risk-based management approach to inspection, in contrast to the current and prevalent practice of conducting 100 per cent physical inspection on incoming goods

- encouraging customs authorities in transit countries to improve the use of information and communication technologies (ICT) in order to securely exchange Customs related data across borders as well as to introduce measures to accept electronic pre-declarations lodged by transporters based on principles developed in the eTIR Project, for example by means of the IRU's TIR-EPD system ${ }^{116}$

- using best practices successfully applied in Georgia, the EU and by customs authorities in transit countries who use this experience and measures to fight corruption and illegal activities

Furthermore, it is recommended that customs administrations develop and implement border- crossing performance indicators to evaluate the results of investment in projects and changes in procedures at border-crossing points.

Border performance indicators such as those developed by the Trade and Transport Facilitation project in Southeast Europe ${ }^{117}$ :

- total number of inspections

- total number of irregularities/number of inspections

- average border exit time

- average border entry time

- surveyed case of corruption

- reported case of corruption

could be further elaborated to better reflect performances related to the transport supply chain.

116 TIR-EPD system: TIR Electronic Pre-Declaration system: See: www.iru.org/en_iru_tir_ epd and www.iru.org/cms-filesystem-action?file=tir/en_TIR-EPD_HolderUserManual.pdf. 117 The Trade and Transport Facilitation in Southeast Europe project is funded by the World Bank. 
The TIR

Simplification of visa requirements and formalities

Reduction and removal of the hidden costs of transport and transport-related services, as well as of the non-physical barriers
The Customs Convention on the International Transport of Goods under Cover of TIR Carnets in 1975 (TIR Convention, 1975), provides an International Customs Transit system that allows goods to transit from a country of departure to a country of destination in sealed load compartments with Customs control recognition along the supply chain. This minimises administrative and financial burdens and Customs duties and taxes that may become due are covered by an international guarantee. The TIR system is designed for global international transit and offers transport operators and Customs authorities a simple, flexible, cost-effective and secure system for the international transport of goods across frontiers.

Visa procedures have a significant negative impact on the shipment of cargoes from Asia to Europe and, therefore, new policies are recommended to reduce long processing times and high consular charges:

- synchronize visa issuing procedures

- simplify visa requirements

- introduce long-term multi-entry visas

The operationalization of the identified EATL routes and related supply of transport services is of equal importance for the creation of an efficient network, since high transport costs and unreliable service have a significant impact on the market and on the mobility of people and goods. To this end, it is recommended to perform corridor specific operational profiles for the identified EATL routes, which could form the basis for developing action plans and act as effective means of identifying the impediments to transit traffic. EATL route studies should indicatively explore, among others, the following:

- operational and technical characteristics along routes (total weight, length of trucks, length of trains, axle weight, gradient, speed, all-weather roads, etc.)

- travel time

- prices/travel costs

- frequency of services

- supply chain and logistic services

- terminals/trans-shipment centres capacity, charges and services

Government and border-control agencies are recommended to develop and implement policies to achieve the largest potential reductions in total logistics costs:

- measures that enhance supply chain predictability, thereby reduce hedging costs

- measures (some of which may be part of broader governance reforms) that reduce rent-seeking activities and, therefore, overhead logistics costs

- market structure reforms, moving from a cartel/syndicate freight organization to an efficient market structure, inducing decreased fixed cost of transportation

It is also recommended that government and border-control agencies:

- measure the time that is required for the product to reach the market for each major export product 
Actions for strengthened institutional and human resources capacity
- measure the time that is required to supply import cargo to national companies and foreign direct investors

- implement policies that reduce the number of days to get products to export markets and reduce the number of days to import cargo

- consider using good practice performance benchmarks for customs administration and border-crossing agencies such as the World Bank Doing Business Trading Across Borders and Logistics Performance Indicators.

Countries participating in the EATL project should focus on cooperating for capacity building. It is necessary to ensure that national officials responsible for the day-to-day application of the various conventions, agreements, rules and regulations are fully aware of their provisions. There is also a need to strengthen the freight-forwarding and logistic industry, particularly at the small and medium-scale level.

In addition, driver education in the road transport sector is of significant importance. Hence, it is recommended to develop professional truck driver training and professional staff training in road transport companies and government institutions responsible for national transportation networks along Europe-Asia routes. Traffic growth along identified routes, as well as the introduction of new vehicles (e.g. longer and heavier lorries, commonly called mega trucks) will require new quality training systems to further develop and improve drivers' skills and the knowledge of foreign languages. Educating reliable and effective professional drivers includes policies that will:

- expand the implementation of educational programmes aimed at increasing the professionalism of international transport haulage participants, including the teaching process in national transport institutes

- utilize the potential of the IRU Academy to train the administrative staff of road transportation companies and provide advanced training to professional drivers carrying out international road transport operations

- modernize the selection criteria for employment of professional drivers; make use of international experience and recommended practices related to the issuance of permits for the international driver's profession for the purpose of increasing the quality and safety of transportation

- support language skills training for drivers employed for longdistance international transport

\section{Recommendations on policies}

To achieve the goal of successfully building and operating an efficient and sustainable EATL transport network, the infrastructure and facilitation measures mentioned above need to be embedded in a sound policy framework. Therefore, a number of policy recommendations for both the participating countries and the international organizations concerned are put forward. 
Development of national transport master plans using EATL achievements as a backbone
Design and implementation of needed reforms of the transport sector, border crossing facilitation and of the management of large-scale transport investment programmes
Reduction of the pressure that might arise from domestic transport and trade-related monopolies ensure that the country fits well into the production, supply and transport chain of modern production
Improvement of the monitoring of infrastructure and the execution of transport facilitation plans
It is indispensable to continue building on the experiences gained from the implementation of both phases of the Euro-Asian Transport Links project. These experiences should include outcomes linked to the identification of priority routes, project prioritization, the application of the time/cost-distance methodology, the creation of a GIS database, new IT technologies and capacity building. These experiences should also be incorporated in national transport policy plans and technical projects.

Government and border-control agencies need to eliminate the mismatch between public and private company interests and formally create committees, forums and public-private partnerships to develop solutions agreed by both parties.

- Government and border-control agencies need to develop policies that link the modernization of transport and border-crossing "hard" infrastructure with the development and implementation of international good practice procedures and asset management methods.

- Government and border-crossing point agencies must use integrated and "whole-of-government" policies to avoid situation of potentially conflicting or overlapping responsibilities.

Performance of transport services and the level of satisfaction of the clients, i.e. the shippers and cargo owners are usually determined by the level of competition among the transport operators or at least by the capacity of the regulator and overall the transport ministry to curb potential abuse by monopolies. While a country targets at higher level integration with the global economy, to improve its national competitiveness and participate in the global supply chains, it is also on the way to address the traditional structure of the transport sector. Transport reforms do not come easy. They require a lot of preparation both in terms of design and of convincing. The role and responsibility of governments is particularly significant during the transition from centrally planned transport systems with state-owned monopolies to competitive service industries.

The establishment of a suitable mechanism ensuring the efficient coordination and monitoring of activities related to the proposed EATL network should be considered.

In addition, also subject to available funding, cooperation should be promoted in support of ongoing or new initiatives and projects such as:

- TEM, TER and TEN-T with regard to transport corridors and networks

- North South rail - sea route (Russian Federation, Iran, India)

- ECO rail routes/demonstration trains: (i) Istanbul-TeheranAlmaty, (ii) Almaty-Bandar Abbas, (iii) Islamabad-TehranIstanbul

- BSEC ring highway

- Analysis/corridor performance

- German Railway pilot rail route China-Germany 


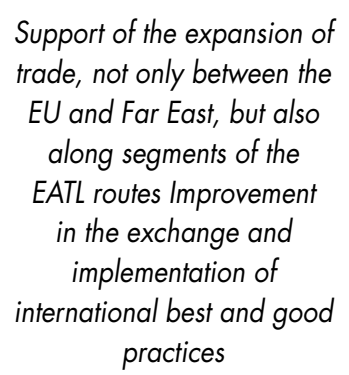

Improvement of data collection and dissemination and improvement of overall transport statistics Encouragement of public-private partnerships in infrastructure development
Other related programmes, activities and referent studies could be sources of useful information:

- the EU High Level Group on the extension of the major transEuropean transport axes to neighbouring countries and regions

- the Transport Corridor Europe-Caucasus-Asia (TRACECA) programme

- the Coordinated Development of the Black Sea Ring Highway

- the Central Asia Regional Economic Cooperation (CAREC) programme

- OSCE/UNECE Handbook of Best Practices at Border Crossings

- the UNESCAP time/cost-distance methodology

The "best practices" on developing transport infrastructure and facilitating international transport in Europe and Asia identified from national governments and international organizations should be widely disseminated. To this end, it is proposed to identify areas and promote concerted actions with other related parties, such as BSEC, CAREC, ECO, EurAsEC, IDB, OSCE, TRACECA and UNESCAP, and with regard to regional integration transport activities and projects implemented by international regional and subregional organizations and concerned bodies. The feasibility for revised road, rail and intermodal transport network agreements (AGC, AGR, AGTC, AH, TAR) should also be examined, subject to available funding.

It is also necessary to promote the dissemination and awareness of the EATL Study by commencing an official dialogue with other international bodies (European Commission, BSEC, IRU, ECO, etc.) and international financing institutions to endorse the work and to exchange information.

An EATL Observatory to serve as an information centre for intermodal transport infrastructure investments and operations along the identified corridors, could be useful mechanism to provide a forum for the exchange of views among all interested stakeholders, related bodies and participating countries. The operating modalities of the Observatory could be decided jointly by UNECE and participating countries. It would be an integrating resource allowing better use to be made of the Study's results and outputs.

While increased competition can result in improved resource allocation efficiency, competition issues related to the implementation of transport infrastructure in general could prove to be serious challenges for several countries in the region. To this end, arrangements to establish an institutional environment for the development of public-private partnerships need to be promoted in a regional context. While best practices in competition and PPP schemes have been well documented in the industry, each case/project has its own specificities. Hence, models for replication are required that are tailored to the needs of each respective country in the region so they can be readily adopted.

Policy recommendations for government and border-control agencies for the EATL countries experiencing difficulty attracting private-sector participation that will remove some of the barriers to enhance PPP development include, among others: 
- raising awareness/understanding of PPPs by politicians/decision makers

- strengthening institutional capacity in the public and private sectors concerning project development and implementation

- enhancing coverage of PPP legal regimes/institutional frameworks

- ensuring the transparency of the PPP process

- increasing the number of model concession agreements

- increasing public-sector project development funds

- increasing government incentives/subsidies/viability gap funding

- facilitating the process of land acquisition, which is difficult and time consuming

- strengthening the coordination between central and local governments

- making the domestic/regionaleconomic and political environment more conducive to the development of EATL networks

\section{Continuation of the EATL project}

The EATL Phase II final Report in its conclusions and strategic objectives clearly indicates that intensive follow-up work is required to increase the awareness for priority EATL network and infrastructure project implementation, to disseminate its results, and to obtain the missing information on the status and planned progress in some parts of the backbone network.

Hence, there is considerable merit in continuing the work of the EATL Study in a Third Phase, which could comprise the following tasks:

- determine the socioeconomic status and scenarios of growth of EATL Phase II participating countries

- update and/or complete data related to EATL Phase II proposed projects

- update data concerning EATL project funding securitization

- involve new countries in the Study

- identify new extensions on proposed EATL routes, as well as new infrastructure projects

- identify service provision along proposed EATL routes

- identify service provision along intermodal transit nodes

- establish the EATL Observatory

- create synergies with, and integrate, the results of related programmes

- review border-crossing issues and obstacles

- review progress on transport facilitation and related technical and institutional actions

- review progress on policy recommendations

- disseminate EATL Study work and outputs

In addition to the infrastructure projects located along the identified EATL Phase II routes, most participating countries proposed projects beyond these routes which, for the purpose of the current Study, were considered to be of national importance. Depending on their significance and priorities, as well as their potential to impact the established connections with EATL routes, these national projects could be considered for inclusion in a potential continuation of the EATL Study. 


\section{COUNTRY REPORTS}

\section{Afghanistan}

Afghanistan is located at the point where four of the most densely populated and resourcerich regions in the world converge: South Asia, Central and North Asia and the Middle and Far East. The main purpose of the Afghan National Trade and Transport Facilitation Committee, as well as the Afghanistan National Development Strategy, is to bring the modernization of trade, transit and transport to international best-practice and technology levels in Afghanistan.

\section{Road transport}

Afghanistan faces the major challenge of post-war reconstruction. As of 2005, the length of roads amounted to $34,782 \mathrm{~km}$, of which 6.8 per cent were paved, representing overall road density of $53.3 \mathrm{~km}$ per $1,000 \mathrm{~km} 2$. Moreover, $3,300 \mathrm{~km}$ represent regional highways that foster regional trade and economic linkages with neighbouring countries. The restoration of an efficient transport infrastructure is essential to strengthen the unity of the country and promote economic recovery and development.

The Kabul-Kandahar highway is a $483 \mathrm{~km}$ road that links Afghanistan's two largest cities and it is a key portion of Afghanistan's national road system, known as the "ring road". Of 20.6 million Afghans, 13.6 million or 66 per cent, live within $50 \mathrm{~km}$ of the ring road. Approximately 35 per cent of the population lives within $50 \mathrm{~km}$ of the Kabul to Kandahar portion of the ring road. In addition, the Kandahar-Herat highway is a $557 \mathrm{~km}$ road that links the cities of Kandahar and Herat. This highway is also part of the larger ring road network.

\section{Rail transport}

At present, there are only two railway links:

- Termez (Uzbekistan) to Hairatan (Afghanistan) in the north

- Kushak (Turkmenistan) to Tourghundi (Afghanistan)

Railway links from adjacent countries include:

- Iran - no railway link, but nearest railhead at Mashhad - 1,435 mm gauge. Construction of a railway connection between Mashhad and Herat has started

- Pakistan - no railway, but railhead on border at Chaman - 1,676 mm gauge

\section{Seaports and inland waterway ports}

Afghanistan has no seaports. Among landlocked developing countries, it has one of the longest distances to a seaport, more than 2,000 km, over harsh terrain. A large proportion of Afghanistan's inhabitants remain physically cut off. The main inland waterway is predominantly the Amu Darya (1,200 km, which allows vessels of up to 500 deadweight tons (DWT)). The main river ports are Kheyrabad and Shir Khan. 


\section{International border-crossing points (road and rail)}

The following road border crossings are operational:

- With Pakistan $(2,430 \mathrm{~km})$ :

- Towr Kham

- Wesh (or Chaman)

- Barikot

- Torkhan,

- Husain Nika

- Speenboldak

- With Iran $(936 \mathrm{~km})$ :

- Dogharoun (Iran) - Islam Quala (Afghanistan)

- Zarang

- With Tajikistan (1,206 km):

- Ishkashim

- Across the Amu Darya from Panj-e Payon (Nizhny Panj) in Tajikistan - Shir Khan (Afghanistan)

- With Turkmenistan $(744 \mathrm{~km})$ :

- Serkhetabat (or Gushgy/Kushka) in Turkmenistan - Tourghondi on Afghan side

- Imam Nazar

- With China $(76 \mathrm{~km})$ : none

- With Uzbekistan (137 km):

- Across the friendship bridge at Hairatan (Termez)

The following borders are already employing the ASYCUDA:

- Torkham - Nangrahar - Kabul (bordering Pakistan)

- Islamqala - Hirat - Kabul (bordering Iran)

- Torghundai - Hirat - Kabul (bordering Turkmenistan)

- Hairatan - Balkh - Kabul (bordering Uzbekistan)

Future implementation of ASYCUDA is envisioned for the following borders:

- Aqina (bordering Turkmenistan)

- Sherkhan (bordering Tajikistan)

- Wesh (bordering Pakistan)

- Milak (bordering Iran)

- Ghulam Khan (bordering Pakistan)

Ongoing and planned transport infrastructure projects of international importance and related investment costs

The Afghanistan National Development Strategy presented to donors at the end of April 2006, included the following Transport Sector Strategic Benchmarks over five years:

- Afghanistan was expected to have a fully upgraded and maintained ring road, as well as roads connecting the ring road to neighbouring countries by end-2008, and a fiscally sustainable system for road maintenance.

- By end-2010: Kabul International Airport and Herat Airport were expected to achieve full International Civil Aviation Organization compliance; Mazar-i-Sharif, Jalalabad and Kandahar airports were to be upgraded with runway repairs, air navigation services, fire 
and rescue and communications equipment; seven other domestic airports were expected to be upgraded to facilitate domestic air transportation; and air transport services and costs were planned to increasingly be made competitive in line with international market standards and rates.

With the support of the World Bank, a number of projects have been initiated:

- The Emergency Transport Rehabilitation Project, focusing on roads and highways (80 per cent) and aviation (20 per cent), incurs lending project costs of US\$128.8 million plus a supplement grant of US\$ 45 million exclusively for roads and highway reconstruction.

- The National Emergency Employment Project for Rural Access focuses on repairing provincial and district roads and highways (50 per cent) and on other social services (50 per cent). The project costs amount to US\$39.2 million.

The rehabilitation of the ring road has been given top priority. The total cost of the project is US\$ 160 million. Afghanistan has initiated a priority road rehabilitation project, which will cost US\$ 305 million. Five project sites were identified:

- Kabul to Jalalabad to Turkan $(224 \mathrm{~km})$

- Doshi to Sheberghan $(250 \mathrm{~km})$

- Pul-e Khumri to Mazar-e Sharif $(220 \mathrm{~km})$

- Mazar-e Sharif to Shebergan to Herat $(760 \mathrm{~km})$

- Herat to Dugharan $(121 \mathrm{~km})$

New proposed transport infrastructure projects of international importance and related investment costs

After completion of the regional highways, the following road projects are planned:

- rehabilitation of the North-South corridor

- rehabilitation of the East-West corridor

- Hiratan-Mazar-e-Sharif, Iskam Qalam Herat

- Sherkhan Bandar-Kunduz-Kabul-Jalalabd-Torkham (upgrade to four lanes)

- road construction from Nangarhar Kanal to Qarghai in Laghman province (9 km)

- rehabilitation of Qaisar-Bala Murghab road

- rehabilitation of Pul-e-Khumri-Doshi road

With regard to the railway sector, the following projects are planned:

- Kabul-Jalalabad-Torkham-Peshwar (Pakistan)

- Kandahar-Spin Boldak-Queta (Pakistan)

- Iran-Tajikistan-China (630-km railway study estimates the cost at US\$2 billion. The railway crosses the Tajikistan border at Shirkhan Bandar)

- Torkham (Afghanistan-Pakistan Border) up to one of the Central Asian countries' border crossings.

An additional project involves route Kashghar-Irkeshdam (in China) - Saritash-Karamic (Kyrgyzstan) - Jirgatal-Tajikabad-Noorabad-Abigharm-feizabad-Yanghibazar Iliyak station Kurghan Tubeh-Kalkhozabad-Nighnipanj (in Tajikistan) - Shirkhan Bandar-Kundoz-Mazari Sharif - Heart-Delaram-Zaranj (in Afghanistan) - Zahedan-Chabahar (in Iran). The total length of this route is around 2,155 km, of which $215 \mathrm{~km}$ is in China, $194 \mathrm{~km}$ is in Kyrgyzstan, $496 \mathrm{~km}$ is in Tajikistan and 1,250 km (from Sherkhan Bandar to Heart) is in Afghanistan.

\section{Challenges}

Afghanistan needs to restore and rebuild its physical infrastructure and transport services to promote the country's economic recovery and help its people to avail themselves of new social and economic opportunities. The country faces the following major challenges: 
- weak capacity of relevant ministries (Ministry of Public Works, Ministry of Transport \& Civil Aviation, Ministry of Rural Rehabilitation \& Development)

- insufficient and unreliable funding for the reconstruction and development of the transport system and inability to mobilize and manage locally collected funds

- a poorly developed consulting and contracting industry

- war-damaged roads and structures and significant deterioration due to lack of maintenance

- large-scale deterioration of the civil aviation infrastructure and the shortage of a qualified workforce

Conflicts and weak security that still exist in the country represent major constraints to the reconstruction and development of the transport sector.

Sources: World Bank, USAID, http://www.ands.gov. af

Yalda Natiq. National Report of Afghanistan on Transport Sector, United Nations Economic Commission for Europe. Kabul. Available from http://www.unece.org/fileadmin/DAM/trans/doc/2009/wp5/ECE-TRANS-WP5-GE2-02pres07e.pdf.

\section{Armenia}

\section{Contribution of transport to GDP}

The Ministry of Transport and Communication (in cooperation with the National Statistical Service of Armenia) does not separate the contribution of transport to GDP from communication. Thus the data on the contribution of transport and communication to GDP appears below in Table A1.1.

Table A1.1 - Contribution of transport and communication to GDP in Armenia, 2000-2010

\begin{tabular}{|c|c|}
\hline Year & Contribution (\%) \\
\hline $\mathbf{2 0 0 0}$ & 7.2 \\
\hline $\mathbf{2 0 0 1}$ & 7.0 \\
\hline $\mathbf{2 0 0 2}$ & 6.1 \\
\hline $\mathbf{2 0 0 3}$ & 5.9 \\
\hline $\mathbf{2 0 0 4}$ & 6.0 \\
\hline $\mathbf{2 0 0 5}$ & 6.0 \\
\hline $\mathbf{2 0 0 6}$ & 6.3 \\
\hline $\mathbf{2 0 0 7}$ & 6.9 \\
\hline $\mathbf{2 0 0 8}$ & 6.8 \\
\hline $\mathbf{2 0 0 9}$ & 7.2 \\
\hline $\mathbf{2 0 1 0}$ & 6.8 \\
\hline
\end{tabular}

Length of roads and rail

The total length of roads in Armenia is $7,800 \mathrm{~km}$, including:

- interstate roads $-1,780 \mathrm{~km}$

- republican roads $-4,060 \mathrm{~km}$

- local roads - $1,960 \mathrm{~km}$

The total length of railways in Armenia is $840 \mathrm{~km}$, out of which $342 \mathrm{~km}$ are in operation (Yeraskh - Yerevan - Ayrum).

\section{Basic description of principal modes of transport}

\section{Road transport}

Armenia's road network serves as the backbone of the country's economic development, providing connectivity within the country, to neighbouring countries and to mainland Asia and Europe. The Aragatsotn region has the lowest road density disparity (274 metres per square $\mathrm{km}$ ). The government has improved almost 13 per cent of total road length $(7,704 \mathrm{~km})$, has left 49 per 
cent in fair condition, and is planning to improve the remaining 38 per cent. The government has rehabilitated 15 per cent of the 1,686 km highway network; roughly 75 per cent of the highway network is in fair condition and 10 per cent (about $169 \mathrm{~km}$ ) requires rehabilitation. About 62 per cent (about $1,083 \mathrm{~km}$ ) of the $1,747 \mathrm{~km}$ secondary road system has been improved or is in fair condition, leaving about $1,540 \mathrm{~km}$ in need of rehabilitation. Of $1,962 \mathrm{~km}$ of local roads, about 61 per cent need immediate upgrading.

\section{Rail transport}

The length of the entire railway network in the Republic of Armenia is $1,328.6 \mathrm{~km}$, of which $780 \mathrm{~km}$ are main routes. The length of the rail line currently in operation is $726 \mathrm{~km}$.

The exploited rail lines are fully electrified, with a semi-automated blocking system and modern systems of communication. The railway system consists of 75 stations, four of which are nodes.

Presently, only a railway connection with Georgia is operating. As a result of the unilateral border closures with Turkey and Azerbaijan, there is no operating connection with these countries, nor with Iran since 1993 as the rail line from Armenia to Iran crosses the Azeri territory of Nakhichevan, which is also unilaterally closed by Azerbaijan.

In 2008 Armenian Railways was transferred to Russian Railways' subsidiary South Caucasus Railways for concession management over a 30-year period. The main objectives of the company include the modernization of Armenian railway infrastructure and the development of interstate and international passenger and cargo transportation routes. The company's investment amounts to US\$ 572 million, of which 220 million is scheduled in 2013.

Since 2008, the company has undertaken extensive work to rehabilitate rail lines, including work on the longest and oldest railway bridge, "Zamarlu", on the railway sector from Armenia to Georgia. The official opening ceremony at the bridge took place on 21 April 2012.

In addition to rehabilitation and modernization programmes, new rail line construction projects are also planned. These involve the construction of the Armenia-Iran direct rail line and the Vanadzor-Fioletovo rail line. Work is in progress to complete the feasibility study for the construction of the Armenia-Iran line, after which the Republic of Armenia will be able to integrate the relevant financial means needed to implement it. The feasibility study for the construction of the Vanadzor-Fioletovo rail line is being conducted by Russian company SibGIProTrans OJSC. The study will be completed in the near future and the civil works for the construction of the railway will commence shortly thereafter.

Table A1.2 - Rail freight traffic in Armenia, 2005-2009

\begin{tabular}{|c|c|c|c|c|}
\hline Year & $\begin{array}{c}\text { Import } \\
\text { (in \%) }\end{array}$ & $\begin{array}{c}\text { Export } \\
\text { (in \%) }\end{array}$ & $\begin{array}{c}\text { Local } \\
\text { (in \%) }\end{array}$ & $\begin{array}{c}\text { Total } \\
\text { (in \%) }\end{array}$ \\
\hline 2005 & $\begin{array}{c}1108 \\
(42.40)\end{array}$ & $\begin{array}{c}426 \\
(16.30)\end{array}$ & $\begin{array}{c}1079 \\
(41.29)\end{array}$ & $\begin{array}{c}2613 \\
(100.00)\end{array}$ \\
\hline 2006 & $\begin{array}{c}1274 \\
(46.86)\end{array}$ & $\begin{array}{c}513 \\
(18.87)\end{array}$ & $\begin{array}{c}932 \\
(34.28)\end{array}$ & $\begin{array}{c}2719 \\
(100.00)\end{array}$ \\
\hline 2007 & 1537 & 710 & 746 & 2993 \\
& $(51.35)$ & $(23.72)$ & $(24.92)$ & $(100.00)$ \\
\hline 2008 & 1374 & 636 & 745 & 2755 \\
& $(49.87)$ & $(23.09)$ & $(27.04)$ & $(100.00)$ \\
\hline 2009 & 1350 & $(1969.74)$ & $(33.44)$ & 2883 \\
& $(44.83)$ & $(100.00)$ \\
\hline
\end{tabular}




\section{Air transport}

Armenia has three main airports: Zvartnots, Shirak and Erebuni. Zvartnots International Airport is the principal gateway to the country. Armenian International Airports manages and maintains the airports in Zvartnots and Shirak under a 30-year concession.

Table A1.3 - Air traffic in Armenia, 2005-2008

\begin{tabular}{|c|c|c|c|c|}
\hline Traffic Category & 2005 & 2006 & 2007 & 2008 \\
\hline Passengers ('000) & 1158 & 1172 & 1406 & 1507 \\
\hline Flights (kilometres) & 7397 & 7104 & 8119 & 8791 \\
\hline $\begin{array}{c}\text { Freight and mail } \\
\text { (tons) }\end{array}$ & 9268 & 9294 & 10010 & 10839 \\
\hline $\begin{array}{c}\text { Overflights } \\
\text { (kilometres) }\end{array}$ & 25937 & 26741 & 29155 & 32282 \\
\hline
\end{tabular}

Table A1.4 - Public transport users - Urban and interurban in Armenia

\begin{tabular}{|c|c|c|c|c|c|c|c|c|c|}
\hline $\begin{array}{c}\text { Transport Mode } \\
\text { (passengers in } \\
\text { millions) }\end{array}$ & 2001 & 2002 & 2003 & 2004 & 2005 & 2006 & 2007 & 2008 & $\%$ share 2008 \\
\hline Bus and minibus & 121.9 & 128.9 & 147.5 & 158.6 & 174.0 & 214.0 & 216.0 & 207.7 & 84.0 \\
\hline Taxi & 0.0 & 0.7 & 1.2 & 2.8 & 7.8 & 10.0 & 12.5 & 14.9 & 6.0 \\
\hline Rail & 1.2 & 1.3 & 1.1 & 0.8 & 0.7 & 0.7 & 0.6 & 0.7 & 0.5 \\
\hline Air & 0.8 & 0.9 & 0.9 & 1.1 & 1.2 & 1.2 & 1.4 & 1.5 & 0.5 \\
\hline Metro & 15.3 & 15.1 & 16.2 & 16.6 & 15.8 & 15.4 & 17.3 & 18.9 & 7.0 \\
\hline $\begin{array}{c}\text { Trolleybus, tram, } \\
\text { cable car }\end{array}$ & 12.7 & 9.9 & 7.1 & 5.7 & 4.8 & 4.1 & 3.6 & 3.4 & 1.5 \\
\hline Total & 151.9 & 156.8 & 174.0 & 185.6 & 204.8 & 230.7 & 251.4 & 247.1 & 100.00 \\
\hline
\end{tabular}

\section{Border-crossing points (road and rail)}

Armenia has three roads that connect it with Georgia (Bagratashen/Sadakhlo, Gogavan/ Guguti and Bavra/Jdanovi), two with Turkey (Akhuryan/Dogukapi, Margara/Igdir, both are currently closed), one with Iran (Agarak/Tabriz) and six with Azerbaijan (Ijevan/Kazakh, Vardenis/Qelbajar, Goris/Lachin, Yeraskh/Sadarak, Meghri/Ordubad and Meghri/Minjevan, all six are currently closed).

Two railroads connect it with Azerbaijan (Yeraskh/Sadarak, Ijevan/Kazakh, both are currently closed), one with Turkey (Akhuryan/Dogukapi [Kars - Gyumri], currently closed) and one with Georgia (Ayrum/Sadakhlo).

\section{Freight terminals}

Armenia's major terminal is currently Karmir Blur, which includes a container facility and a storage and sorting facility for cargo. The terminal has been operating since 2000 and has its branch-terminals in Gyumri, Vanadzor and Ayrum. Since January, 2011, the administrative and operational functions of the terminal are handled by Apaven LLC.

The container facility has two 20-ton overhead cranes and a side loader capable of handling 40ton containers. The container terminal handles an average of six containers a day (three inbound and three outbound) and records about 150 to 200 handlings a month. The freight yard at Karmir Blur is used to store excess wagons and wagons for local shippers and is switched by a shunting locomotive and crew operating from the Yerevan locomotive depot to and from Massis.

The Ayrum terminal is used to marshal wagons for interchange with Georgian Railway. Ayrum is a busy yard with 12 tracks for chambering inbound and outbound trains. Tracks are 
15 to 20 wagon lengths long. Normally, five and six freight trains are interchanged each day with Georgian Railway. Cars are pre-cleared for customs in Ayrum, proceed to the bordercrossing point for document checking and then to a terminal on the Georgian Railway side. A similar process is used for reverse movements. A freight forwarder handles most customs information and a freight expediting and forwarding company handles imports into Armenia.

The Gyumri Terminal is a marshalling, originating and terminating location. Primary use of the terminal in current operations is as a staging area for trains operating between Ayrum and Yerevan. Crews and locomotives are changed at Gyumri with VL10 locomotive sets hauling trains north of Gyumri and VL8 locomotive sets working trains to the south of Gyumri. Only a few cars terminate in Gyumri. The terminal does shunt and form trains to operate through Massis to Yerevan. One shunting assignment works in Gyumri.

Ongoing and planned transport infrastructure projects of international importance and related investment costs

\section{North-South Armenian road corridor (Meghri-Yerevan-Bavra - 556 km)}

Armenia has received a loan from the Asian Development Bank for the North-South Road Corridor Investment Programme, Tranche 1 and Tranche 2 projects.

The Ministry of Transport and Communication of Armenia has invited bids for the rehabilitation and reconstruction works in three sections:

\section{Section 1:}

- upgrading and widening the existing M1 Ashtarak-Talin road from a two-lane single carriageway to a four-lane dual carriageway from $\mathrm{km} 29+600$ to $\mathrm{km} 71+500$ The total length of the Ashtarak-Talin section is $41.9 \mathrm{~km}$.

\section{Section 2:}

- rehabilitating and improving road safety measures on the existing M2 Yerevan-Ararat fourlane road from $\mathrm{km} \mathrm{9+312} \mathrm{to} \mathrm{km} 47+400$

- performing works on the existing M2, Yerevan-Ararat (approx. $38 \mathrm{~km}$ ) four-lane section

Section 3:

- rehabilitating the existing M1 Yerevan-Ashtarak road from km 18+370 to km 29+773

- performing works on the M1, Yerevan-Ashtarak (approx. $12 \mathrm{~km}$ ) section, repaving, improving drainage and shoulders, and repairing existing concrete structures.

The completion periods are:

- Section 1 - 36 months (1,096 days)

- Section 2 - 18 months (548 days)

- Section $3-18$ months (548 days)

The completion of the entire project is scheduled for the end of 2017.

\section{Rehabilitation of Armenian Railway infrastructure}

This project is part of the West-East railway corridor $(180 \mathrm{~km}$, Turkish border-Georgian border-Azeri border). Three activities are planned for its implementation:

Activity 1: Rehabilitating the existing Yerevan-Tbilisi rail link

After 12 months of activity, three main studies have been completed:

- a feasibility study for the rehabilitation of the railway line between Tbilisi and Yerevan

- a feasibility study for the rehabilitation of the Hrazdan-Ijevan section of the line towards Azerbaijan, where a severe landslide blocked traffic

- a feasibility study for the rehabilitation of the technology of Georgian Railways 
The project has also made a preliminary assessment on the possibility of opening a new link between Vanadzor and Fioletovo, shortening the current route between Yerevan and Tbilisi by approximately $100 \mathrm{~km}$.

Activity 2: Complete reopening the Hrazdan-Ijevan section

This section was constructed in 1984 and was only partially operating due to nearly two km in a landslide zone.

Complete renewal costs amount to: $€ 176.5$ million.

Partial renewal in the landslide zone and general overhaul costs amount to: $€ 121.85$ million.

Activity 3: Constructing the new Vanadzor-Fioletovo rail link

The total estimated cost is $€ 200$ million ( $€ 5$ million per $\mathrm{km}$ ).

South Caucasus Railways intends to invest in the design and research of the new VanadzorFioletovo rail link construction (US\$ 96 million). The works will be implemented by the Russian company, Sibgiprotrans. The company has already proposed five rail routes for Vanadzor-Fioletovo, one of which is being considered in connection with the acquisition of a total of 200 hectares of land for the construction.

\section{International Logistics Centre}

Plans to establish an international logistics centre on the territory adjacent to Zvartnots International Airport were developed within the TRACECA programme, as were its master and business plans. The proposed logistics centre will also be a constituent part of the TRACECA network.

The project stakeholders are the Government of Armenia (which is planning to establish a Free Economic Zone near the cargo complex of Zvartnots International Airport) and the Concessionaire of Zvartnots International Airport.

Three main operational areas have been defined for the logistics centre:

- logistics services (occupying about 60 per cent of the territory)

- a container terminal (occupying about 20 per cent of the territory)

- logistic-intensive industry and commerce (occupying about 20 per cent of the territory)

The key goal of the planned logistics centre is to support the development of intermodal transport and other logistics services in the Yerevan region, which will contribute to exports. The Zvartnots international logistics centre is scheduled to secure 375,000 tons of goods in the first year of its exploitation, with demand growth amounting to 4.5 per cent. The annual volume of the cargo in the final year of the centre's development has been evaluated at 525,000 tons.

The expected deadlines for the logistic centre are:

- 2011 - processing of documents, including the feasibility study, as well as negotiations with interested investors

- 2012 - start of construction

- 2013 - implementation of certain services and provision of spaces for rent under privileged conditions, for the purpose of business integration

- 2015 - completion of the project and thorough exploitation

The investment required to establish the logistic centre is as follows:

- preparatory construction work - €8,320,000

- infrastructure - $€ 4,287,000$, including transport infrastructure of $€ 2,260,000$ and utility infrastructure of $€ 2,027,000$ 
- warehouse buildings - €450,000

- buildings for services - €6,060,000

- buildings/equipment for loading and unloading goods- $€ 1,110,000$

- fencing and security - €334,000

- other buildings - €639,000

- planning, examination, soil study - €2,120,000

- other costs - €1,060,000

- total - €24,379,000

An Armenian Law on Free Economic Zones was adopted on 25 May 2011. According to this law, participants setting up in the free economic zone are offered tax-related privileges, including exemption from value-added tax, income tax, property taxes, etc. ${ }^{118}$ The main goal of establishing free economic zones is to attract foreign direct investment. Foreign investors are expected to bring and employ advanced technologies, increase exports, contribute to sustainable development and create new jobs. ${ }^{119}$

\section{The challenges of transport and transport infrastructure}

\section{Key challenges}

- completing road network rehabilitation

- upgrading international railway and road infrastructure

- overcoming urban transport problems, particularly achieving a sustainable balance between private and public transport

- successfully implementing the railway concession

- further developing air services

- reducing the negative impact of increased transport demand

- achieving long-term sustainability in transport asset management, particularly in the road network

- reducing transport costs

- maintaining road assets

- overcoming financial issues

- ensuring traffic safety

\section{Azerbaijan}

The key location of Azerbaijan on the crossroads of major international traffic arteries, such as the Silk Road and the South-North corridor, highlights the strategic importance of the transportation sector for the country's economy. Azerbaijan is considered a door of Europe opening to Asia.

In 2002, the Azerbaijani Government established the Ministry of Transport with a broad range of policy and regulatory functions. The comprehensive Transport Sector Development Strategy for Azerbaijan was prepared at the Ministry of Transport with the assistance of international consultants and financial support from the Asian Development Bank. The Strategy sets the sector's strategic agenda and development priorities and proposes the necessary reforms in transport policies, regulations and organizational structures.

$118 \mathrm{http}: / /$ www.mineconomy.am/am/138/(in Armenian).

119 Interview with Tigran Davtyan, Minister of Economy of Armenia, 28 December 2011. Available from http:// www.panorama.am/am/economy/2011/12/28/economics-armenia/ (in Armenian). 


\section{Road transport}

In 2004, the road sector accounted for 33 per cent of transport freight turnover. Azerbaijan has $25,000 \mathrm{~km}$ of roads, of which some 92 per cent are paved. According to the World Bank, in early 2006 more than 50 per cent of roads in Azerbaijan were in need of urgent repair. Highways, main and rural roads are being upgraded according to international standards with a view to accommodate growing transit traffic.

The main highways carrying international traffic are the Baku-Alat-Ganja-Kazakh-Georgian Border corridor (the Azerbaijani section of TRACECA) with a length of $503 \mathrm{~km}$ and the NorthSouth corridor that stretches out from the Russian Federation to the Iranian border along $521 \mathrm{~km}$.

The EATL network consists of three international roads (E60-AH5, E119-AH8, E002AH81), stretching $1,551 \mathrm{~km}$. According to the authorities, all three EATL roads are in need of major reconstruction.

\section{Rail transport}

Azerbaijan has 2,125 km of railway lines, excluding several small industrial lines. Most lines are $1,520 \mathrm{~mm}$ gauge, and the principal routes are electrified $(1,278 \mathrm{~km})$. About 60 per cent of the railway routes $(1,126 \mathrm{~km})$ are equipped with full automatic blocks and $479 \mathrm{~km}$ with a centralized dispatcher.

In 2004 the rail sector accounted for 35 per cent of tons-km, significantly less than 71 per cent in 1991 and 45 per cent in 1998. The sector experienced major disruptions associated with armed conflict in the region, including the confrontation with Armenia over the disputed territory in Nagorno-Karabakh and the two Chechnya wars. Much of the track and rolling stock is in need of repair or replacement. The 1,439-km long EATL network consists of three electrified lines within the E-rail system (E60, E595, E694) and a non-electrified stretch (198 km on the E694). A section of the electrified E694 line (Fizuli - Armenian border) is closed to international traffic because of the existing conflict in the South Caucasus region.

\section{Seaports and inland waterways ports}

Sea transport accounted for 32 per cent of transport freight turnover in 2004, up from 21 per cent in 1991 but down from 42 per cent in 1998. Azerbaijan has direct maritime connections to all other Caspian littoral states. The nation's capital, Baku, is the largest port on the Caspian Sea. Although there are maritime routes to Turkmenistan, the southern Russian Federation and Kazakhstan, little is exported along them. However, there are some transit earnings from the export of Kazakh and Turkmen oil across the Caspian Sea, through Azerbaijan, to the Black Sea oil terminals in Georgia and the Russian Federation.

\section{Freight terminals and other intermodal transport infrastructure}

The Baku port has freight, container and oil terminals where the cargoes are loaded on Ro-Ro ferries, dry cargo ships and oil tankers, respectively. All terminals operate daily around the clock. Reconstruction of the maritime station in the container terminal is ongoing.

\section{International border-crossing points (road and rail)}

Five road border crossings are situated on EATL routes. All are open daily and operate around the clock with the exception of the border crossing with Iran at Astara that operates from 9 a.m. to 8 p.m. only. Except for the narrow approach at Astara, there are no physical impediments to traffic. Waiting times range between 5 and 15 minutes for buses to between 10 and 20 minutes for trucks. Three rail border crossings on EATL routes are open around the clock. Average waiting times amount to 2 minutes for both freight and passenger trains. 
Ongoing and planned transport infrastructure projects of international importance and related investment costs

The whole Central Asia Regional Economic Cooperation corridor 2 road segment (East-West highway improvement) has been fully funded by the Government of Azerbaijan and external sources. The project is proceeding well.

Four ongoing road rehabilitation and reconstruction projects totalling US\$939 million are to be completed soon, financed from national funds and bank loans, such as the EBRD and World Bank. They are:

- rehabilitation of the Kurdamir - Ujar section

- rehabilitation of the Yevlakh - Gandja section

- rehabilitation of the Gazakh - Georgian Border section

- reconstruction of the Russian Federation border - Baku - Iranian Border section, E119

The railway line from Baku to Beyuk Kesik at the Georgian border along corridor 2 carries a significant volume of transit cargo of oil and oil products from Kazakhstan and Turkmenistan to European markets. CAREC 2 railway corridor improvement has started with World Bank financing. The project aims to provide reliable and fast freight and passenger transportation services by rehabilitating the main East-West railway line.

Two reconstruction projects at the port of Baku were completed; the related investment expenditure reached some $\$ 10$ million. The construction of the New Baku International Sea Trade Port project totalling $\$ 400$ million is scheduled to be completed in 2015. From 2008 to 2011 the first stage of construction was completed, allowing an increase in cargo transportation volumes to 7-8 million tons a year. The second stage (2011-2013) will increase cargo transportation volumes to 10 million tons and in the third, final stage it will reach 15 million tons a year. The port was commissioned in 2011. In addition, the government plans to acquire new high-capacity ferries and Ro-Ro vessels to meet transit trade demands between Europe and Central Asia along CAREC corridor 2 effectively.

A major railway project linking the Russian Federation, Azerbaijan and Iran was proposed to start after the signing of an official trilateral agreement in June 2006. The project entailed the construction and commissioning of the Gazvin-Rasht-Astara (Iran) - Astara (Azerbaijan) railway. The works were to be completed in Azerbaijan first, followed by the construction of a connecting $400-\mathrm{km}$ rail line in Iran. The project is currently under construction.

\section{New proposed transport infrastructure projects of international importance and related investment costs}

A new railway project, the construction of the Baku-Tbilisi-Kars railway connection, has been proposed, of an approximate cost exceeding US $\$ 500$ million, which has committed funding from national funds, as well as bank loans. According to expert forecasts, initially the Baku-TbilisiKars line will convey about 1 million passengers and 6.5 million tons of cargo. Predictions to 2030 estimate traffic will increase to 3 million passengers and 17 million tons of cargo.

The construction of the Baku-Tbilisi-Kars railway is expected to be completed in 2012. The corridor is expected to be in full operation from 2013. ${ }^{120}$

Sources: CIS Statistical Committee, Economist Intelligence Unit, NFP Country Report, http://www.abc.az/eng/ news/23628.html

Central Asia Regional Economic Cooperation. Azerbaijan: Country Progress Report on the Implementation Action Plan for the Transport and Trade Facilitation Strategy. 2009. Available from http://www.carecprogram.org/ uploads/events/2009/8th-TSCC/TTFS-Country-Progress-Report-AZE.pdf

\footnotetext{
120 http://en.trend.az/capital/business/1944251.html.
} 


\section{Belarus}

The transport sector is an important economic sector in Belarus, contributing 6.7 per cent of GDP in 2008 and 6.6 per cent in 2009. Belarus has been a net exporter of practically all modes of transport services. The country has a strategic geographical location, serving as a transit transport corridor between the European Union and the Russian Federation and potentially between the EU and Asia.

\section{Road transport}

The road network of Belarus comprises a relatively dense republican road network (including main roads and regional roads) of about $15,000 \mathrm{~km}$, which carries more than 75 per cent of total traffic, and a local road network of about $70,000 \mathrm{~km}$. The overall density of the country's network of Category 1 roads (motorways) is $112 \mathrm{~km}$ of network per 1 million people. In 2009, 87 per cent of the total length of its road network was paved. While the overall condition of one third of republican roads is good to fair, two thirds need major repairs or rehabilitation.

\section{Rail transport}

The density and accessibility of the railway network comprising $5,514.4 \mathrm{~km}$ of railway lines in Belarus is comparable to other Central European countries, and the technical condition of the railway infrastructure is satisfactory. However, the infrastructure is relatively old, requiring medium- and long-term modernization. Nevertheless, Belarusian Railways has excellent operational performance results and is considered very efficient. Belarusian Railway predominantly operates international freight services, and railway transport occupies an important position in the transportation market in Belarus compared to EU-25 countries, carrying 35 per cent of the total volume of freight (ton-km) in 2008.

\section{Freight terminals and other intermodal transport infrastructure}

The formation in recent years of the transport and logistics system and the creation of logistics centres and joint logistics enterprises have been of great importance for Belarusian railroads. To this end, the network of transport and logistics centres formed the basis for the creation of the state-owned enterprise BELINTERTRANS-Transport-Logistics Centre.

The transport-logistics centre has divisions in Minsk, Brest, Gomel, Grodno, Mogiliov and Vitebsk oriented to the development of transport-dispatch services, intensified usage of storehouse terminals and equipment, improvement of export transportation organizations and increased volumes of transit cargo transport. There are 16 container terminals for the recycling of large-capacity 20- and 40-foot containers, and 19 stations recycling medium-tonnage 3 - and 5-ton freight containers.

\section{Ongoing and planned transport infrastructure projects of international importance and related investment costs}

Belarus has the equivalent of a national transport strategy and action plan. The Programme for Ensuring Efficient Use of Transit Potential of the Republic of Belarus for 2006-2010, the draft Programme of the Development of Transit Potential of the Republic of Belarus for 2011-2015 and the Roads of Belarus programme constitute the three key pillars of the national transport strategy. In addition, the strategy for the Development of Transit Potential of the Republic of Belarus for 2011-2015 and the Concept of Belarus Transport System Development until 2025 have recently been approved by the government. The Concept defines the goal, priorities, tasks, key focuses and parameters of the country's transport system development until 2025, including the mitigation of impacts generated by $\mathrm{CO}$ and $\mathrm{CH} 2$ emissions. 
The Roads of Belarus programme aims to:

- increase the length of the motorway network

- improve road traffic operating conditions

- raise the capacity of the most heavily used road sections

- improve road traffic safety

- attract private investment

The programme includes a list of priority investments with some indicative cost estimates. The main task is to upgrade the sections of the two international transport corridors (corridor II and corridor IX) that pass through its territory, which are important West-East and NorthSouth transit routes. In 2009, the programme was reviewed jointly by the Ministry of Transport and Communications and the Ministry of Finance to prioritize the major investments proposed, which are:

- the upgrade of a section of the M5 road between Minsk and Gomel (74 km in total)

- the upgrade of M4 road from Minsk to Mogilev (97 km in total)

- the construction of a bypass around Minsk ( $85 \mathrm{~km}$ in total)

According to the government's programme, the road network's development needs over the 2011-2016 period are presented in the table below.

Table A1.5 Roads of Belarus programme priorities and estimated costs

\begin{tabular}{|c|c|c|c|c|c|}
\hline Desativion & inetr & Cal nabimse & 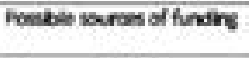 & $\begin{array}{l}\text { Impteminesion } \\
\text { troframe }\end{array}$ & seatin \\
\hline 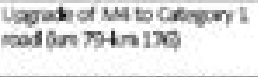 & $9 / 5$ & $\begin{array}{l}\text { Es } 309 \\
\text { milion }\end{array}$ & 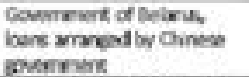 & $x 015012$ & $\begin{array}{l}\text { Ginder } \\
\text { constouction }\end{array}$ \\
\hline 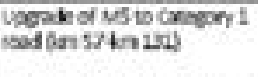 & $74 n$ & $\begin{array}{l}\text { USS1Gat } \\
\text { nilion }\end{array}$ & 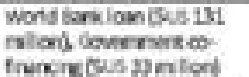 & xe118612 & $\begin{array}{l}\text { Feparions } \\
\text { indirwor }\end{array}$ \\
\hline New rine nod acand Mea: & Tais & $\begin{array}{l}\text { Uas } 100 \\
\text { milion }\end{array}$ & 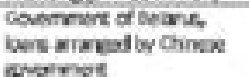 & $x 430012$ & 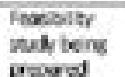 \\
\hline
\end{tabular}

Regarding the railway sector, the development needs of the network require approximately US\$ 340 million for the modernization of corridors II and IX over the next 25 years. To keep its current market position, Belarusian Railway needs to modernize the infrastructure and systems of these corridors to achieve full interoperability with the EU network. This includes the full electrification of lines, increased transport speed, increased use of electronic interlocking systems, the extension of automatic block systems and the introduction of European train control systems. These are presented in the following table.

Table A1.6 - Modernization of railway corridors in Belarus

\begin{tabular}{|c|c|c|}
\hline Railwary Corridors in Eelarus & $\begin{array}{l}\text { length } \\
(\mathrm{km})\end{array}$ & $\begin{array}{l}\text { Modemization Cost } \\
\text { (uss million) }\end{array}$ \\
\hline Corridor II & 611 & $3, \cos .29$ \\
\hline 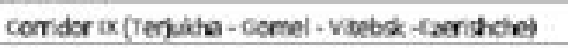 & 489 & 278938 \\
\hline 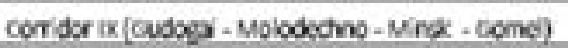 & $3 / 2$ & $2,121.98$ \\
\hline Total & 1,472 & 8.706 .65 \\
\hline Amual twernes (25 vears Moderniontion itan) & sess & 335.87 \\
\hline
\end{tabular}

Sources: Belarusian Railway at http://www.rw.by/en/index.php?option=com_content\&view=article\&id=297\&ltemid=1 World Bank. Transport Unit, Sustainable Development Department, Europe and Central Asia Region. Belarus: Transport Sector Policy Note. 14 December 2010. Report No. 55015-ECA. Available from http://www-wds.worldbank.org/ external/default/WDSContentServer/WDSP/IB/2011/02/03/000356161_20110203004308/Rendered/PDF/55 0150ESWOwhit1Box358280B01PUBLIC1.pdf. 


\section{Bulgaria}

\section{Road transport}

The road share of inland freight transport increased until 2004, when it accounted for 67 per cent of ton-kilometre. The infrastructure includes $18,957 \mathrm{~km}$ of paved roads (category III or higher), comprising $308 \mathrm{~km}$ of motorways. The motorway-building programme has slowed considerably due to legal disputes in recent years. The length of E-roads on Bulgarian territory measure 2,580 km. The EATL road network in Bulgaria is $1,564 \mathrm{~km}$ long and consists of the following six arteries:

- E80 Kalotina-Sofia-Plovdiv-Capitan Andreevo BCP (Bulgaria/Turkey)

- BCP (Macedonia/Bulgaria)-Gueshevo-Pernik-Sofia (E871)-Plovdiv (E80)-Stara ZagoraBurgas (E773)-Varna (E87)

- Russe-Veliko Turnovo-Haskovo (E85)-Capitan Andreevo (E80)

- Sofia-Botevgrad (E79)-Jablanitza (E771)-Veliko Turnovo-Shoumen (E772)-Varna (E70)

- Russe-Varna (E70)

These routes are within PETC IV, VIII, IX and X.

\section{Rail transport}

Rail is still a significant domestic mode of transport for freight, although road transport now accounts for a larger (and increasing) share of the total. The total length of Bulgaria's railway lines is $5,923 \mathrm{~km}$. At the end of 2001, the state-owned railway company was split into two firms, one responsible for managing the rail track and the other, Bulgarian State Railways, for rail operations. In addition, private operators are now permitted to run rolling stock for freight, although the first two such companies were licensed only in 2005 and still account for very small volumes of freight.

The following rail lines, extending over 2,500 km, define the EATL network on Bulgarian territory:

- E070 BCP (Serbia/Bulgaria)-Kalotina-Sofia-Plovdiv-Svilengrad-BCP (Bulgaria/Turkey)

- E680 Sofia-Mezdra-Gorna Orjahovitza-Varna (ferry link to Ilyichevsk (Ukraine)/Poti/ Batumi (Georgia)

- E855 Sofia-Radomir (link with T855)

- T855 (link with E855) Radomir-Gueshevo

- E720 Stara Zagora (link with E070)-Karnobat-Bourgas

- E095 BCP (Romania/Bulgaria)-Russe-Gorna Orijahovitza-Stara Zagora (link with E070 and E720)-Dimitrovgrad

The track along these lines conforms to the standard gauge $(1,435 \mathrm{~mm})$. There is a missing link with the former Yugoslav Republic of Macedonia on the T855 line. Bottlenecks are imposed by the non-electrified $14 \mathrm{~km}$ stretch of the E070 line leading to the Serbian border and by an unfinished bridge project on the T056 line.

\section{Seaports and inland waterway ports}

Bulgaria has two seaports belonging to the EATL network: Varna and Burgas. Together they account for 60 per cent of national import and export volumes, the remainder being transported over land. The ports have sufficient capacity for general cargo, solid and liquid bulk cargo, containers, heavy parcels and Ro-Ro units.

The network also includes $236 \mathrm{~km}$ of Danube and three inland waterway ports on the river: Russe, Lom and Vidin. The biggest port is Russe, located at the multimodal crossroads of 
transport corridors VII and IX. The port's facilities are generally outdated, including the lack of equipment and poor condition of the piers. Also, seven infrastructure bottlenecks hamper traffic on the Bulgarian section of the Danube. Inland waterway transport is predominantly used for the transportation of international cargo (and passengers to a small extent) and inland waterway shipping companies have become profitable in recent years.

\section{Freight terminals and other intermodal transport infrastructure}

The main freight villages are situated in Sofia, Russe, Stara Zagora and Dimitrovgrad. Seaports have been modernized extensively in recent years. Both the Varna and Burgas ports are well connected with railways and can handle $300 \mathrm{TEU} /$ day and $200 \mathrm{TEU} /$ day, respectively. The annual throughput in Varna exceeds 7 million tons of bulk cargo and 64,000 TEU; the corresponding figures for Burgas are 6 million tons and 25,000 TEU. The handling capacity of inland ports on the Danube is significantly smaller. Further modernization of intermodal infrastructure is expected from the evolving system of 30-year concessions in Bulgarian ports and terminals. The first tenders, for two relatively small ports, took place in early 2005 and others should follow. Lom, for instance, on the Danube, is expected to enjoy a $€ 30$ million upgrade to handle container traffic, allowing it to benefit from its position on the EU NorthSouth PETC IV.

\section{International border-crossing points (road and rail)}

Four international rail border crossings are open around the clock, while another two operate 15 and 18 hours per day. Average waiting times range between 50 and 70 minutes for passenger trains, and between 180 and 240 minutes for freight trains.

\section{Ongoing and planned transport infrastructure projects of international importance and related investment costs}

The country is building upon its favourable geographic position, with the development of major roads and rail transport infrastructure projects. To this end, its strategic framework for infrastructure planning includes the following:

- Strategy for Development of the Transport Infrastructure of the Republic of Bulgaria until 2015 - approved by the Council of Ministers in 2006 (budget: $€ 4,712$ million)

- Operational Programme on Transport 2007-2013 - officially signed on 27 November 2007 in Brussels (budget: $€ 2,003$ million)

- General Transport Master Plan for Bulgaria

- Strategy for Development of the Transport Infrastructure of the Republic of Bulgaria through the Concession Schemes

- National Programme for Development of Public Ports

Recently completed and ongoing infrastructure projects have rehabilitated sections of the E79, E80, E85 and E773 roads along the PETC IV, VIII, IX and X, while extending the Trakia motorway, a part of the North-South TEM connecting the countries of Central and Eastern Europe with the Near East. The related investment, amounting to $€ 159$ million, was financed by loans from international financial institutions and the state budget. Most of the road projects should have been completed. A major rail modernization project ( $€ 340$ million) along the E070 main line from Plovdiv to Svilengrad on the Turkish border was still under construction and was planned to be completed in 2011. It is financed mainly by a European Investment Bank loan and an Instrument for Structural Policies for Pre-Accession (ISPA) grant, covering 45 per cent and 44 per cent of total cost respectively, while the state budget contributes the residual amount (11 per cent). 


\section{New proposed transport infrastructure projects of international importance and related investment costs}

The infrastructure projects proposed for the road sector, which are along proposed EATL routes, amount to some US\$ 655 million. These include the construction of three motorways, namely the Trakia motorway, the Maritza motorway and the Struma motorway. Financing has been secured for the Trakia and Maritza motorway projects, which are under construction and scheduled for completion in 2012. Struma" motorway project lots 1,2 and 4 are at the tender stage and planned to be completed in 2013. There is no information on the sources of funding.

Six rail-sector projects scheduled to be completed between 2010 and 2019 would cost over US\$ 6,849 million. Approximately 85 per cent of this sum would be financed with the aid of EU structural funds, while the state budget should contribute the remaining 15 per cent. The projects focus on the modernization of existing infrastructure and the further electrification of tracks:

- renewal of railway sections along the Plovdiv-Burgas line

- modernization and electrification of Radomir-Gueshevo railway line

- modernization of Sofia-Radomir railway line

- modernization of Sofia-Dragoman railway line

- modernization of Radomir-Kulata railway line

- renovation and electrification of Voluyak-Dragoman-Dimitrovgrad-GS BS railway line

No major expansion of the existing rail network is envisaged.

In addition, the expansion of the Port of Bourgas (costing US\$ 145 million) has been completed, while an inland waterway project, the rehabilitation, reconstruction and modernization of the port of Lom, is planned for 2015.

Altogether, Bulgaria submitted eleven EATL projects for evaluation: three road projects, six railway projects, one maritime project and one inland waterway project.

Sources: Economist Intelligence Unit, NFP Country Report

\section{China}

China's achievements in economic growth and poverty reduction over recent years have been impressive. The development of China's transport infrastructure has contributed to that success. In recent years China has seen the unprecedented transformation of its transport sector: it has created one of the world's most comprehensive expressway networks and it has significantly increased the capacity of its railway network. Ports and inland waterways have also benefitted from major investments. There have been major improvements in airports. At the same time, changes in policies across all sectors have attracted private sector investment and helped China be competitive.

\section{Road transport}

Today, China is linked by a still evolving network of roads (China National Highways) and expressways (Expressways of China). By the end of 2010, China's highways extended over $74,000 \mathrm{~km}$, with the length of all public roads reaching a total of 3,984,000 km. Paved roads totalled $770,265 \mathrm{~km}$ in 2004 , the remainder being gravel, improved earth standard or merely earth tracks. Highways (totalling 130,000 km) were critical to China's economic growth, mitigating a poor distribution network as authorities sought to spur economic activity directly.

The road transport sector has contributed greatly to, and has also been strongly stimulated by, China's continuing economic and social development. Among the surface modes, road transport has seen its modal share grow over the last ten years between 45 per cent and 60 per cent in terms of passenger-kilometre and between 24 per cent and 30 per cent in terms of freight ton-kilometre. 


\section{Rail transport}

Rail is the major mode of transport in China. Carrying some 24 per cent of the world's railway transport volume, China's railway system is critical to its economy. China has the world's second largest rail network, with total track length at $86,000 \mathrm{~km}$ in 2009 . The national rail system is modernizing and expanding rapidly. Some $5,000 \mathrm{~km}$ of track were added in 2010 . The total mileage is $91,000 \mathrm{~km}$, of which approximately 40 per cent is electrified.

\section{Seaports and inland waterway ports}

China has more than 2,000 ports and has become one of the most dynamic global shipping markets in the world. It has 16 major shipping ports with a capacity of over 50 million tons per year. Combined, China's total shipping capacity is in excess of 2,890 million tons. By 2010, 35 per cent of the world's shipping was expected to originate from China. The seven largest port terminals are Dalian, Guangzhou, Nanjing, Ningbo, Qingdao, Qinhuangdao and Shanghai. In addition, Hong Kong SAR is a major international port that serves as an important trade centre for China.

China's inland waterway transport network is the world's largest, in terms of length and freight volume. In 2006, the total length of inland waterways was $123,388 \mathrm{~km}$, while in 2005 they carried nearly 3,855 billion ton-kilometre of freight and transported 7.36 billion people in terms of passenger-kilometre. The main navigable rivers are the Heilong Jiang, Yangtze River, Xiang River, a short branch of the Yangtze, Pearl River, Huangpu River, Lijiang River and $X_{i}$ Jiang. Despite the above, inland ports are not yet equipped to make best use of inland waterways.

\section{Freight terminals and other intermodal transport infrastructure}

China's international trade has stimulated a rapidly developing logistics industry. The logistics industry is most active along China's east coast, where the manufacturing industry is centred. There are three different areas of major development: the Bohai Rim region in the north, including Liaoning, Shandong, Beijing, Tianjin and Hebei; the Yangtze River delta around Shanghai, including Jiangsu and Zhejiang; and the Pearl River delta, centred on Shenzhen and Guangzhou. In each of these areas numerous large logistics parks have been developed or are under construction.

\section{Ongoing and planned transport infrastructure projects of international importance and related investment costs}

In 2004, the Chinese Government approved further plans for the National Expressway Network, also called the "7-9-18 Highway Network", which is to be completed by 2020 . Incorporating and expanding the National Trunk Highway System, this highway network will have some $85,000 \mathrm{~km}$ of high-grade expressways consisting of 7 capital radials, 9 North-South major highways and 18 East-West corridors. China has also embarked on the biggest programme of railway building in any country since the nineteenth century. In 2004, the State Council approved the Ministry of Railways' Mid- to Long-Term Railway Network Plan, which sets out the investments required through 2020 to keep pace with the demand. This plan, the first of its kind approved by the State, sets out the main steps for expanding rail transport capacity and improving service quality, with an emphasis on ensuring maximum value for the proposed investment, while supporting both rural and urban development in a sustainable manner. By 2020, the total operational length of China Railways is expected to reach 100,000 km, with separate high-speed passenger and freight routes on the main corridors and with 50 per cent of the network either double-tracked or electrified or both. 
The Central Government wishes to increase the role of inland waterway transport. As part of the 11th Five-Year Plan, the Central Government aimed to increase the contribution of China's waterways to meet its transport needs. During the 11th Five-Year Plan, it planned to invest almost $\$ 3$ billion in the form of government subsidies into inland waterway transport industry development, half of which was slated to go to waterway improvements.

\section{New proposed transport infrastructure projects of international importance and related investment costs}

China has proposed the following road projects totalling US\$ 6,288 billion, expected to be completed between 2010 and 2017:

- construction of Tianshui-Dingxi road in Gansu Province

- construction of Xujiamo-Gulang road in Gansu Province

- reconstruction of Anxi-Xingxingxia road in Gansu Province

- reconstruction of Xingxingxia-Xiaocaohu in Xinjiang

- reconstruction of the southern section of Urumqi ring road in Xinjiang

- reconstruction of Kuitun-Sayram Lake road in Xinjiang

- reconstruction of Sayram Lake-Khorgos Port in Xinjiang

- construction of Xijiagang-Qidong road in Shanghai

- construction of Liuhe-Pukou road in Jiangsu Province

- reconstruction of Jinghe-Alatawshankou S205 road in Xinjiang

- reconstruction of Xiaocaohu-Heshuo road in Xinjiang

- reconstruction of Korla-Aksu road in Xinjiang

- reconstruction of Aksu-Kashi road in Xinjiang

- construction of Kashi ring road in Xinjiang

- reconstruction of Kashi-Honqilaf road in Xinjiang

- construction of Kashi-Irkeshtam road in Xinjiang

In addition, China proposed two projects to construct additional berths at the Lianyungang and Shanghai seaports.

Sources: China Auto Web at hitp://chinaautoweb.com/2010/12/chinas-highway-network-expands-74000kilometers/World Bank.

An Overview of China's Transport Sector - 2007: Easte Working Paper No. 15: Transport, Energy and Mining Sector Unit, Sustainable Development Department East Asia and Pacific Region. Washington, D.C.

Available from http://siteresources.worldbank.org/INTEAPREGTOPTRANSPORT/34004324-1 $189182692007 /$ 2 1600796/07-12-19_China_Transport_Sector_Overview_.pdf.

\section{Finland}

Finland's location far from the main transport and logistics arteries of Central Europe poses major challenges to the country's transport policy. Smooth and well-organized logistics are very important for business, and particularly for the competitiveness of imports. Finland is located on the periphery of Europe and transport journeys within the country are long. Logistics costs, therefore, amount to 13 per cent of businesses' turnover. Although removed from the main market areas of Central Europe, Finland's location next to the Russian Federation has made it an important transit country for goods transport. Transit goods to the Russian Federation arrive in Finland by sea and are mainly transported to their destination by road.

\section{Road transport}

The total length of public roads in Finland is approx. 78,000 km, of which the main road network (class I and II main roads) accounts for about $13,300 \mathrm{~km}$. The total length of motorways in Finland is $765 \mathrm{~km}$. Approximately two thirds of all public roads in Finland are paved. 


\section{Rail transport}

The length of the operational rail network in Finland is $5,900 \mathrm{~km}$, of which 52 per cent has been electrified. About 90 per cent of the network consists of single-track lines.

\section{Seaports and inland waterway ports}

The network of maritime and inland waterway routes maintained by a state enterprise is approximately $16,200 \mathrm{~km}$ in length. Less than $4,000 \mathrm{~km}$ of the network consists of merchant shipping routes, while the total length of fairways with a minimum depth of $8 \mathrm{~m}$ is $2,100 \mathrm{~km}$. This includes all fairways leading into winter ports.

\section{Freight terminals and other intermodal transport infrastructure}

The goods transported in containers via Finland to the Russian Federation arrive from Far Eastern ports mainly to the ports of Helsinki, Kotka and Hamina. From there, after intermediate storage the majority of goods for the Russian Federation are transported by truck to Moscow and St Petersburg. The ports also handle a great volume of Finnish import and export transports.

\section{International border-crossing points (road and rail)}

The most important border-crossing point in Finland is Vaalimaa (it handled 69 per cent of road transits in 2006), although it has been suffering increasingly from traffic congestion, causing long queues outside the actual border crossing area. In the worst cases, the queue reached over $50 \mathrm{~km}$.

The Trans-Siberian railway from the Far East of the Russian Federation to Finland was previously a significant mode of transport for containers carrying valuables. From 2003 to 2005, the number of containers exceeded 100,000 TEU per year. At the beginning of 2006, the Russian Federation raised transport charges, causing the number of containers to collapse to less than 10,000 TEU. Suppliers shifted their transports to the sea. Russian Railways established a joint venture entitled Container Trans Scandinavia Oy with the Finnish rail operator VR. It aimed to develop rail transport between Finland and the Russian Federation, including transit by regularly scheduled container trains to Moscow.

\section{Ongoing and planned transport infrastructure projects of international importance and related investment costs}

Current figures present an investment of over $€ 300$ million for transport infrastructure development, as per the following:

roads: $€ 158$ million

railways: $€ 161$ million

waterways: $€ 22$ million

According to preliminary proposals, projects valued at about $€ 2.2$ billion were to be implemented during 2008-2013. A summary of the projects is presented in Table A1.7. 
Table A1.7 - Project summary, 2008-2013

\begin{tabular}{|l|c|c|}
\hline & Number & EMillion \\
\hline Road projects & 19 & 1175 \\
\hline Railway projects & 8 & 984 \\
\hline Waterway projects & 1 & 5 \\
\hline Total & 28 & 2164 \\
\hline \multicolumn{2}{|c|}{} \\
\hline Large investments & 23 & $1928(89 \%)$ \\
\hline Thernatic projects & 5 & $236(11 \%)$ \\
\hline Total & 28 & $2164(100 \%)$ \\
\hline
\end{tabular}

Thematic projects include the following:

- electrification of rail sections in Joensuu region as well as of the Hyvinkää - Hanko and Seinäjoki - Vaasa rail sections

- removal of level crossings on the Luumäki - Imatra, Seinäjoki - Oulu, Jyväskylä - Kuopio and Turku - Toijala rail sections

- upgrade of the Tampere and Riihimäki rail yards as well as the upgrade of the Jämsänkoski - Rauma rail section to allow for 25-ton axle loads

- development of a real-time traffic monitoring system for the most important main road segments and the largest urban areas

Large investments include the following:

- MARJA railway

- improving the level of service on Seinäjoki - Oulu rail section, phase 2

- E18 (main road 7) Koskenkylä - Loviisa - Kotka

- adding track on the Luumäki - Vainikkala rail section

- upgrading the Luumäki - Imatra rail section

- E18 (main road 7) Hamina - Vaalimaa

- upgrading main road 12 Lahti - Kouvola

- upgrading main road 3 Tampere (Ylöjärvi) - Vaasa

- upgrading main road 8 Turku - Pori

- upgrading main road 15 Kotka - Kouvola with port connection

- upgrading main road 21 Palojoensuu - Kilpisjärvi

New proposed transport infrastructure projects of international importance and related investment costs

The Finnish Transport Agency presented two big construction projects to possible constructors and financiers in Brussels on 19 May 2010. The projects are a second track between Kokkola and Ylivieska and the motorway construction of highway 7 as part of the international E18 road.

The second track project is one of the biggest railway projects in Finland in recent years. Between 2011 and 2014, a 76.5 kilometre-long second track will be built between the cities of Kokkola and Ylivieska. The total construction cost is $€ 263$ million. It will be implemented using a Public-Private Partnership model.

The motorway construction involves the following three road plans:

- conversion of the road into a motorway between Koskenkylä and Loviisa, road plan inspection

- construction of a motorway between Loviisa and Kotka

- improvement in noise control between Karhula and Rantahaka 
It was decided in 2010 that $€ 650$ million would be authorized for the project and that it would start at the end of 2011.

Sources: Finnish Ministry of Transport and Communications at http://www.lvm.fi/web/en/home.

Ministry of Transport and Communications of Finland (2004). Strategy for the development and maintenance of Finland's transport infrastructure in 2004-2013: Report of the Ministerial Working Group. Helsinki. Available from http://www.lvm.fi/fileserver/strategy\%20for\%20the\%20development\%20and\%20maintenance\%20of\%20 finland's\%2Otransport\%20infrastructure.pdf.

European Railway Review at http://www.europeanrailwayreview.com/5310/rail-industrynews/finnish-public-private-partnership-projects-introduced-for-constructors-and-financiersin-brussels/.

Finnish Centre for Economic Development, Transport and the Environment at http://www. ely-keskus.fi/fi/Liikenne/tiehankkeet/kaakkoissuomi/Vt7\%28E18\%29Koskenkyla-LoviisaKotka/Documents/koskenkyla-kotka-eng-esite.pdf.

\section{Georgia}

Figure A1.1 - GDP and transport share in Georgia

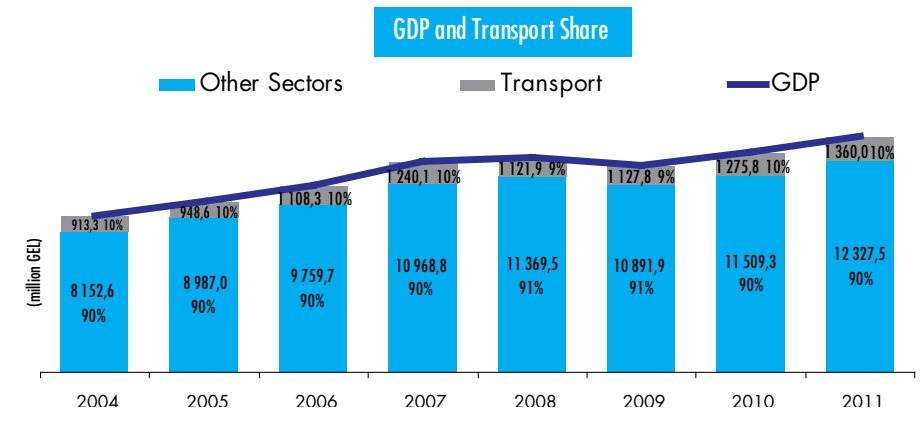

Road transport

Road freight transport in Georgia declined significantly since the early 1990s, reaching in 2004 only 34 per cent of the 1991 level. Nevertheless, it now accounts for some 10 per cent of freight transport (ton-kilometre), up from 3-4 per cent in the 1990s. The network includes $1,495 \mathrm{~km}$ of international roads, $5,446 \mathrm{~km}$ of internal roads and $15,439 \mathrm{~km}$ of local roads. The rehabilitation and reconstruction of roads of international importance were initiated in 2005 and the process is still under way. Their maintenance is relatively costly because of severe weather conditions. The 1,222 km-long EATL network is defined by a number of E-roads (E60, E70, E97, E117, E001, E691, E692), with design speeds ranging from $60 \mathrm{~km} / \mathrm{h}$ to $110 \mathrm{~km} / \mathrm{h}$.

Georgia has bilateral agreements concerning road transport with 21 states. Also, Georgia is a party to the following Multilateral Agreements and Conventions:

- European Agreement on Main International Traffic Arteries (AGR)

- Vienna Convention on Road Traffic

- Vienna Convention on Road Signs and Signals

- European Agreement supplementing the Convention on Road Signs and Signals

- Protocol on Road Markings, additional to the European Agreement supplementing the Convention on Road Signs and Signals

- Agreement Concerning the Adoption of Uniform Conditions for Periodical Technical Inspections of Wheeled Vehicles and the Reciprocal Recognition of such Inspections

- Convention on the Contract for the International Carriage of Goods by Road

- Protocol to the Convention on the Contract for the International Carriage of Goods by Road

- Customs Convention on the International Transport of Goods under Cover of TIR Carnets (TIR Convention) 
- Customs Convention on Containers

- International Convention on the Harmonization of Frontier Controls of Goods

- Agreement on the International Carriage of Perishable Foodstuffs and on the Special Equipment to be Used for such Carriage

On the basis of Decree \#187 of 7 April 2011 of the president of Georgia, Georgia acceded to the European Agreement concerning the Work of Crews of Vehicles engaged in International Road Transport developed by the United Nations Economic Commission for Europe. After expiration of the accession period (six months), Georgia will become a member of the Agreement.

Table A1.8 - International Truck Transportation by Regime in Georgia

\begin{tabular}{|c|c|c|c|c|c|c|c|}
$\begin{array}{c}\text { (Units) } \\
\text { Regime }\end{array}$ & 2007 & 2008 & $\begin{array}{c}\text { Growth, } \\
\text { y-o-y (\%) }\end{array}$ & 2009 & $\begin{array}{c}\text { Growth, } \\
\text { y-o-y (\%) }\end{array}$ & 2010 & $\begin{array}{c}\text { Growth, } \\
\text { y-o-y (\%) }\end{array}$ \\
\hline Transit & 56102 & 71172 & 27 & 77430 & 9 & 90342 & 17 \\
\hline Import & 57825 & 62794 & 9 & 61548 & -2 & 69721 & 13 \\
\hline Export & 12377 & 9313 & -25 & 12338 & 32 & 7022 & -43 \\
\hline Total & 126304 & 143279 & 13 & 151316 & 6 & 167085 & 10 \\
\hline
\end{tabular}

\section{Rail transport}

Rail freight turnover in 2004 reached only 40 per cent of the 1991 level. However, rail transport performance improved in relative terms and by 2004 it accounted for 88 per cent of ton-kilometre, up from 24 to 25 per cent in the 1990s. The complicated geographical relief of Georgia motivated the construction of artificial engineering buildings, which include more than 3,700 constructions. Total length of the Georgian Railway line is $2,344 \mathrm{~km}$. The busiest line links Tbilisi to Black Sea ports; until completion of the Baku-Supsa oil pipeline, this was also used to transport Azeri oil to the Black Sea. The Georgian railway system has direct connections to the railway systems of Armenia, Azerbaijan and the Russian Federation. The EATL network includes $1,564 \mathrm{~km}$ of electrified rail lines.

At present, the Container Block Train Poti-Baku pilot project is being prepared within the TRACECA programme. The pilot project will be presented on the TRACECA Investment Forum in 2012.

In 2011, in accordance with its legislation, Georgia joined the Convention concerning International Carriage by Rail. The Convention will enter into force after the expiration of accession procedures.

Table A 1.9 - Transported cargo by regime in Georgia (million tons)

\begin{tabular}{|c|c|c|c|c|c|}
\hline Regime & 2007 & 2008 & 2009 & 2010 & Growth, $y-0-y(\%)$ \\
\hline Transit & 14.4 & 13.8 & 11.4 & 13.2 & 16 \\
\hline Import & 3.6 & 3.5 & 2.7 & 3.1 & 15 \\
\hline Export & 1.4 & 1.5 & 1.4 & 1.5 & 7 \\
\hline Local & 2.8 & 2.4 & 1.7 & 2.1 & 24 \\
\hline Total & 22.2 & 21.2 & \multicolumn{2}{|c|}{17.119 .9} & 16.4 \\
\hline
\end{tabular}




\section{Seaports}

Sea transport declined rapidly from the early 1980s when it accounted for 73 per cent of freight transport turnover. By 2004, its share fell to 1 per cent. This decline was partly caused by the civil war and subsequent loss of territory to separatist forces in the early 1990s. Georgia has two main seaports, Poti and Batumi, and two sea terminals on the Black Sea, Kulevi and Supsa. The terminals are mainly engaged in oil processing.

Table A 1.10 - Sea transport in Georgia

\begin{tabular}{|c|c|c|c|c|}
\hline Regime & $\mathbf{2 0 0 8}$ & $\mathbf{2 0 0 9}$ & $\mathbf{2 0 1 0}$ & Growth, y-0-y (\%) \\
\hline Poti Seaport & 8.0 & 6.1 & 7.3 & 20 \\
\hline Batumi Seaport & 8.6 & 7.8 & 8.0 & 3 \\
\hline Kulevi Sea terminal, Liquid & 1.3 & 2.1 & 3.4 & 62 \\
\hline Supsa Sea terminal, Liquid & 0.6 & 4.2 & 4.0 & -5 \\
\hline Total & 18.5 & 20.2 & 22.7 & 12 \\
\hline
\end{tabular}

Ferry lines from the Batumi and Poti Black Sea ports directly connect the Caucasus and Central Asia with the Black Sea regions of Europe. The Poti and Batumi seaports are directly linked by ferry service with Ukraine (Ilyichevsk; Kerch), Bulgaria (Varna) and the Russian Federation (Kavkaz; Novorossiysk). The Ro-Ro service is only on the Poti-Novorossiysk line.

\section{Poti Seaport}

The MAERSK-Danish subsidiary of the APM Terminals company is owner of 80 per cent of Poti seaport shares; the remaining 20 per cent of shares is owned by "Rakeen Georgia".

APM is slated to invest over US\$100 million in port infrastructure development in the next five years.

Strategically located, Poti Seaport is the largest port in Georgia, handling liquid and dry bulk, ferries as well as containers. It has 15 berths, with total berth length of 2,900 metres and more than 20 quay cranes. The port currently serves as the European gateway for international trade in Georgia, Armenia and Azerbaijan, and is ideally located to become a future hub for Central Asian trade. Poti Seaport mainly processes dry cargo.

Table A1.11 - Poti seaport berths

\begin{tabular}{|c|c|c|c|c|}
\hline Berth \# & Characteristics & Length $(\mathbf{m})$ & Depth $(\mathbf{m})$ & Max. Draft $(\mathbf{m})$ \\
\hline $\mathbf{1}$ & Liquid Cargo & 200 & 10.0 & 8.0 \\
\hline $\mathbf{2}$ & Rail Ferry Terminal & 185 & 10.0 & 8.0 \\
\hline $\mathbf{3}$ & General-Bulk Cargo & 215 & 8.5 & 8.0 \\
\hline $\mathbf{4}$ & General-Bulk Cargo & 154 & 8.5 & 7.9 \\
\hline $\mathbf{5}$ & General-Bulk Cargo & 173 & 8.5 & 8.0 \\
\hline
\end{tabular}




\begin{tabular}{|c|c|c|c|c|}
\hline Berth \# & Characteristics & Length $(\mathrm{m})$ & Depth $(\mathrm{m})$ & Max. Draft $(\mathrm{m})$ \\
\hline $\mathbf{6}$ & General-Bulk Cargo & 212 & 9.75 & 9.0 \\
\hline $\mathbf{7}$ & Container & 211 & 8.5 & 8.5 \\
\hline $\mathbf{8}$ & General-Bulk Cargo & 215 & 9.75 & 9.25 \\
\hline $\mathbf{9}$ & General-Bulk Cargo & 220 & 8.0 & 7.5 \\
\hline 10 & General-Bulk Cargo & 264 & 8.0 & 7.5 \\
\hline 11 & General-Bulk Cargo & 71 & 8.0 & 7.4 \\
\hline 12 & Passenger & 250 & 6.5 & 6.5 \\
\hline 13 & Ro-Ro Ferry Terminal & 97 & 6.5 & 6.5 \\
\hline 14 & Multifunctional Container Terminal & 253 & 8.4 & \\
\hline 15 & Grain Terminal (under design) & 155 & 8.5 & \\
\hline
\end{tabular}

Table A1.12 - Poti seaport cargo volumes and main infrastructure

\begin{tabular}{|c|c|}
\hline \multicolumn{2}{|c|}{ Volume (million tons) } \\
\hline 2008 & 8.0 \\
\hline o/w Dry cargo & 7.0 \\
\hline 2009 & 6.1 \\
\hline o/w Dry cargo & 5.2 \\
\hline 2010 & 7.3 \\
\hline o/w Dry cargo & 6.1 \\
\hline
\end{tabular}

\begin{tabular}{|c|c|c|}
\hline \multicolumn{3}{|c|}{ Main Infrastructure } \\
\hline \multirow{3}{*}{ Navigable all year round } \\
\hline \multirow{3}{*}{ Area } & Closed and opened storage & $298800 \mathrm{~m}^{2}$ \\
\hline \multirow{3}{*}{ Including } & Berths & $2715 \mathrm{~m}$ \\
\cline { 2 - 3 } & Breakwater & $1810 \mathrm{~m}$ \\
\cline { 2 - 3 } & Overall water area & $653400 \mathrm{~m}^{2}$ \\
\hline
\end{tabular}

\section{Batumi Seaport}

Kazakhstan's National Oil and Gas Company, Kazmunaigaz, owns 100 per cent of shares in Batumi Seaport and Batumi Oil Terminal.

Throughput efficiency of the oil terminal amounts to 15 million tons annually. The terminal specializes in refining raw oil and almost all types of oil products: diesel fuel, petrol, reduced cruel and so on. The 1, 2, 3 berths are leased to Batumi Oil Terminal until 2019.

Throughput efficiency of the container terminal is 100,000 TEU annually. The container terminal has open storing areas and possesses trans-shipment equipment, which specializes in direct and storage operations.

The ferry runs between Varna, Iliychevsk, Poti and Batumi. Operation of the ferry is totally automated. The nominal throughput efficiency of the terminal is approximately 700,000 tons. From November 2007, berths 4, 5, 6 and the railway ferry terminal were leased to Batumi International Container Terminal, a member of the International Container Terminal Services Inc. group of companies.

Berths 7, 8 and 9 are used for dry cargo handling. Maximum throughput of the dry cargo terminal is 2 million tons annually.

The marine passenger terminal is situated in the centre of the city, on the seaside boulevard. Throughput efficiency is about 180,000 passengers annually. Passenger berths No.10 and No.11 ensure handling passenger ships as well as small-capacity cargo and passenger ferries (Ro-Ro). 
Table A1.13 - Batumi seaport cargo volumes and main infrastructure

\begin{tabular}{|c|c|}
\hline \multicolumn{2}{|c|}{ Volume (million tons) } \\
\hline 2008 & 8.7 \\
\hline o/w Liquid cargo & 7.2 \\
\hline 2009 & 7.8 \\
\hline o/w Liquid cargo & 6.4 \\
\hline 2010 & 8.0 \\
\hline o/w Liquid cargo & 6.1 \\
\hline
\end{tabular}

\begin{tabular}{|c|c|c|}
\hline \multicolumn{3}{|c|}{ Main Infrastructure } \\
\hline \multicolumn{3}{|c|}{ Navigable all year round } \\
\hline \multirow{3}{*}{ Area } & Closed Storage & $13221 \mathrm{~m}^{3}$ \\
\cline { 2 - 3 } & Open Storage & $18889 \mathrm{~m}^{2}$ \\
\hline \multirow{3}{*}{ Capacity } & Water Depth Range & $8-16 \mathrm{~m}$ \\
\cline { 2 - 3 } & Dry Cargo Vessel & 30000 tons \\
\cline { 2 - 3 } & Oil Tankers & 120000 tons \\
\hline
\end{tabular}

Figure A1.2 - Road border crossings, 2010 Border-crossing points (road and rail)

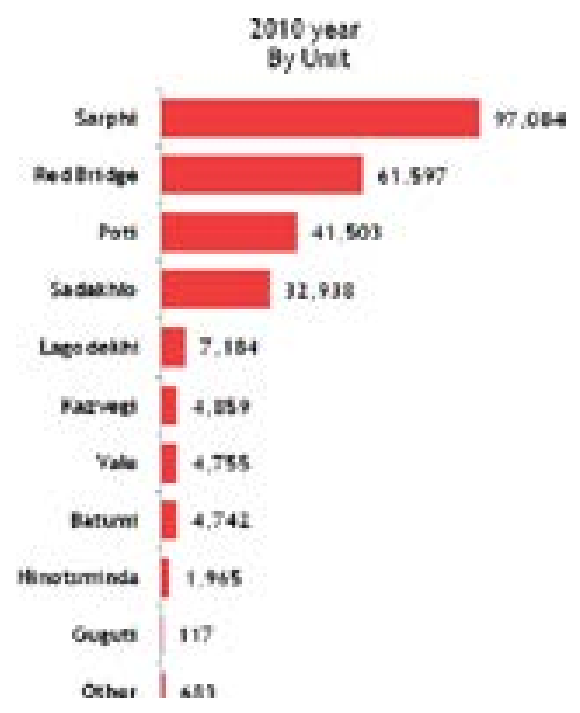

\section{Road border-crossing points:}

- $\quad$ Red Bridge - with Azerbaijan

- $\quad$ Lagodekhi - with Azerbaijan

- $\quad$ Samtatskaro - with Azerbaijan

- $\quad$ Mtkvari - with Azerbaijan

- $\quad$ Sadakhlo - with Armenia

- Ninotsminda - with Armenia

- Guguti - with Armenia

- $\quad$ Akhkerpi - with Armenia

- $\quad$ Sarphi - with Turkey

- Vale - with Turkey

- Kazbegi - with the Russian Federation

- Batumi Seaport

- $\quad$ Poti Seaport

Note: Data include transit in both directions

\section{Railway border-crossing points:}

- Gardabani - with Azerbaijan (12.9 million tons in 2010)

- Sadakhlo - with Armenia (1.7 million tons in 2010)

- Poti Seaport (5.3 million tons in 2010)

- Batumi Seaport (7.4 million tons in 2010)

- Kulevi Sea Terminal (3.6 million tons in 2010)

Note: Data include transit in both directions

Since 2010, the Single Window system has been in operation on the border, such that the passport control of individuals crossing the border by vehicle at check points and the registration of these vehicles in the database of the Ministry of Internal Affairs of Georgia have been delegated to the authorized officer of the portal. In addition, the portal infrastructure was rebuilt, making it possible to check drivers' passports without getting out of vehicles.

In 2010, the computerized databases of the Ministry of Internal Affairs of Georgia and of the Revenue Service of the Ministry of Finance of Georgia were integrated, which allowed the implementation of the Single Window principle. This has significantly facilitated border crossing procedures, reduced the time of service and also increased the level of service. Before the integration of the databases, the service procedure for unloaded vehicles took 5-6 minutes and for loaded vehicles took 20-25 minutes. After their integration, the procedure for unloaded vehicles took 2-3 minutes, for loaded 10-12 minutes. 


\section{Germany}

Length of roads (structure), rail, inland waterways in $\mathrm{km}$, as well as ports (sea and inland)

Germany has one of the densest and best-developed transport networks in Europe: 12,800 km of motorways, $41,000 \mathrm{~km}$ of federal highways plus $170,000 \mathrm{~km}$ of regional and local roads, $34,000 \mathrm{~km}$ of railways and 7,300 km of inland waterways. In addition, Germany has important ports and airports that function as international hubs.

\section{Principal modes of transport}

Following a massive slump as a result of the recent financial and economic crisis, in 2010 the amount of freight moved in Germany increased again for all modes of land transport. The amount of freight moved by rail and inland waterway, for instance, increased by approximately 12 per cent each, and that moved by road increased by 4.9 per cent. In 2010, the various modes of transport were split into the following shares:

- road freight 71.9 per cent

- railways 17.8 per cent

- inland waterways 10.3 per cent

\section{Border-crossing points (road, rail, sea and inland waterways)}

Germany's location at the centre of Europe with nine neighbouring states and its strongly export-driven economy make cross-border transport an important subject of national transport policy. Germany is part of the Schengen area and, with the exception of Switzerland, all its neighbours are EU Member States. In the preparation of cross-border infrastructure projects, the usual procedure is to establish joint working groups that assess the economic viability of any given project and subsequently prepare the relevant agreements.

According to a recent study entitled Optimizing Long Distance Transport ${ }^{121}$, Germany is bearing the main part of the traffic load generated by the European Single Market. In 2007, for instance, the share of transit traffic in Germany amounted to 16.2 per cent of all freight moved. This kind of traffic will continue to grow, in particular in the East-West and North-West/SouthEast directions, with a clear focus on road freight. Moreover, cross-border transport shows a much stronger growth dynamic than inland transport. In 2025, it will account for nearly 57 per cent, i.e. the majority of all freight moved. Within international road freight, transit traffic will show the biggest increase, namely to just over 20 per cent of all freight moved.

\section{Freight terminals}

More than 120 combined transport trans-shipment facilities for railborne and waterborne cargo are currently being operated in Germany. The Federal Government has provided financial assistance for the construction and upgrade of these facilities. This has helped to significantly improve the terminal infrastructure in Germany and bring about a considerable increase in the volume of cargo handled from 45.5 million gross tons (1998) to 92.7 million gross tons (2008). In addition, there are freight villages at 35 locations. More than 1,300 companies with more than 50,000 employees are located there. Overall, with a turnover of more than 200 billion euros and 2.7 million employees in 2009, freight transport and logistics were the third largest sector of the German economy. The further promotion of combined transport is part of the Freight Transport and Logistics Action Plan published by the Federal Ministry of Transport, Building and Urban Development. $^{122}$

${ }^{121}$ http://www.bmvbs.de/SharedDocs/DE/Artikel/Ul/langstreckenverkehre-optimieren.html.

$122 \mathrm{http}: / /$ www.bmvbs.de/cae/servlet/contentblob/59840/publicationFile/30825/aktionsplan-22-1 1-2010.pdf. 


\section{Challenges that face transport and transport infrastructure}

Despite the economic and financial crisis, a further strong increase in freight transport must be foreseen. On the whole, an increase of approximately 70 per cent is expected in the period to 2025: 79 per cent in road freight and 84 per cent in long-distance road haulage. Growth will vary enormously from region to region and will concentrate on certain arteries and conurbations, mainly on seaport hinterland traffic and North-South connections. In view of this development, the quality of the existing network will have to be preserved and safeguarded. In addition, the efficiency of the overall system will have to be increased to ensure that it can cope with the forecast growth. The most important measures to achieve this are:

- improved logistics and freight transport chains: consolidation of transport operations, avoidance of empty running, strategies for logistics in urban areas, European logistics chains making use of short sea shipping

- active traffic management systems on motorways; they can be used inter alia to allow hard shoulder running during periods of congestion (up to now, more than $2,500 \mathrm{~km}$ of motorway have been equipped)

- better roadworks management, since 35 per cent of all congestion on motorways is caused by roadworks

- innovative vehicle technologies: vehicles are to communicate and exchange information with one another and with the infrastructure and thus make road traffic safer, more effective and more environmentally sound

- expansion of capacity on the railways by means of new signalling and rolling stock engineering technologies

- satellite transport applications and telematics technologies

- strengthening of seaports, inland ports and airports as hubs of national and international trade and centres of logistics activities; the Federal Government's National Ports Strategy ${ }^{123}$ and Airports Strategy ${ }^{124}$ provide policy guidance in these sectors

- development of a strategy for moving away from fossil energy carriers; this strategy involves a wide range of modern technologies, such as the development of alternative fuels, the increased use of renewable energy in the transport and buildings sectors and the evolution of energy-efficient conventional drivetrains in vehicle construction

The key challenge, however, is the issue of funding.

\section{Ongoing and planned transport infrastructure projects of international importance and related investment costs}

In April 1991, shortly after German reunification, the Federal Government agreed on 17 German Unity transport projects in order as quickly as possible to provide the infrastructure linking the old and new federal states, which was required to enable an economic upturn. Of the 17 projects, 9 are rail projects, 7 are road projects and 1 is a waterway project. The main focus of the German Unity transport projects is on West-East connections. Up to now, more than 29 billion euros have been invested. The annual status report provides an up-to-date overview of the projects. ${ }^{125}$

${ }^{123} \mathrm{http}: / /$ www.bmvbs.de/cae/servlet/contentblob/31316/publicationFile/3887/nationales-hafenkonzept-fuerdie-see-und-binnenhaefen.pdf.

124 http://www.bmvbs.de/cae/servlet/contentblob/30822/publicationFile/446/flughafenkonzept-2009-derbundesregierung.pdf.

125 http://www.bmvbs.de/cae/servlet/contentblob/68032/publicationFile/40375/sachstandsberichtverkehrsprojekte-deutsche-einheit-stand-mai-2011.pdf. 
The routes identified within the framework of EATL Phase II are among the busiest routes in Germany. For the rail links listed there alone, the total investment made or planned for the years ahead amounts to more than 7 billion euros. And the upgrade of the important A6 East-West motorway will cost more than 1.8 billion euros. Details on all surface transport modes are provided in the current framework investment plan of the Federal Ministry. ${ }^{126}$

The 2010 federal budget - plus two economic stimulus programmes - made provision for expenditure totalling 11.8 billion euros for investment in transport infrastructure. Of this total, around 4.3 billion euros have been used for the federal railways, around 5.3 billion euros for the federal trunk roads and around 1 billion euros for the federal waterways. One hundred and fifty million euros are available for combined transport installations that improve co-modality. However, more than 4.5 billion euros of these funds have been used for the renewal of railways and roads. Between 2011 and 2014, around 10 billion euros per year will be spent for the construction of new and the upgrade of existing transport infrastructure as well as for the structural and routine maintenance of infrastructure.

\section{Greece}

\section{Contribution of transport to GDP}

In Greece, the transport sector represents an important part of the economy and accounts for about 7-8 per cent of GDP, with a special contribution to exports, imports, investment and employment.

\section{Road transport}

Road transport is the principal means of transport for both passengers and goods. The share of road in inland freight transport increased slightly in past years and, as a consequence, the share of rail freight transport decreased slightly over the same period. Greece recorded one of the highest shares of road freight transport of all EU Member States (97.8 per cent with 27,791 million tonkilometre reported in 2009), instead of 2.3 per cent ( 835 million ton-kilometre) in rail transport. The following table shows that road transport increased from 97.3 to 97.8 per cent during 2008/09.

Table A1.14 - Modal split of freight transport in Greece, 2008-2009

\begin{tabular}{|c|c|c|}
\hline \multicolumn{3}{|c|}{ Modal split of freight transport } \\
\hline & Road & Railways \\
\hline 2008 & $97.3 \%$ & $2.7 \%$ \\
\hline 2009 & $97.8 \%$ & $2.3 \%$ \\
\hline
\end{tabular}

The same situation occurred in passenger transport, where the mode split of passengers between train, car and bus noted the following fluctuation for 2007-2008:

Table A1.15 - Modal split of passenger transport in Greece, 2007-2009

\begin{tabular}{|c|c|c|c|}
\hline \multicolumn{5}{|c|}{ Modal split of passenger transport } \\
\hline & Trains & Passenger cars & Motor coaches, buses and trolley buses \\
\hline 2007 & $1.6 \%$ & $79.9 \%$ & $18.5 \%$ \\
\hline 2008 & $1.3 \%$ & $80.8 \%$ & $17.5 \%$ \\
\hline 2009 & $1.1 \%$ & $80.8 \%$ & $17.8 \%$ \\
\hline
\end{tabular}

126 http://www.bmvbs.de/DE/VerkehrUndMobilitaet/Verkehrspolitik/Infrastrukturplanung/ Verkehrsinvestitionsbericht/verkehrsinvestitionsbericht_node.html. 
The following table shows safety records for both road and rail transport. It is obvious that fatal road and rail accidents have decreased:

Table A1.16 - People killed in inland transport accidents in Greece, 2008-2010

\section{People killed in inland transport accidents}

\begin{tabular}{|c|c|c|}
\hline & Road & Railways \\
\hline 2008 & 1555 & 40 \\
\hline 2009 & 1453 & 42 \\
\hline 2010 & - & 39 \\
\hline \% change & -6.6 & -2.5 \\
\hline
\end{tabular}

The total length of motorways increased from $958 \mathrm{~km}$ to $1,120 \mathrm{~km}$ (almost 14.5 per cent) from 2003 to 2008. Main or national roads extended $10,189 \mathrm{~km}$, secondary or regional roads $30,864 \mathrm{~km}$ and other roads $75,600 \mathrm{~km}$ at the end of 2008 .

\section{Rail transport}

Railway transport, both freight and passenger, decreased significantly between 2009 and 2010. In figures, from 540,064 ton-kilometre reported in 2009, rail freight patronage fell to 393,166 ton-kilometre in 2010 (a decrease of 27.2 per cent). Passenger performance decreased from 1,343,919 passenger-kilometre reported in 2009 to $1,059,065$ passenger-kilometre in 2010, a 21.2 per cent decrease.

Table A1.17 - Freight and passenger railway transport, 2009-2010

\begin{tabular}{|c|c|c|}
\hline & Freight - in ton-kilometre total & Passengers - in passenger-kilometre total \\
\hline 2009 & 540064 & 1343919 \\
\hline 2010 & 393166 & 1059065 \\
\hline $\begin{array}{c}\text { \% variation compared to } \\
\text { previous year }\end{array}$ & -27.2 & -21.2 \\
\hline
\end{tabular}

The total length of railway line in use is $2,552 \mathrm{~km}$, of which $368 \mathrm{~km}$ are electrified, $475 \mathrm{~km}$ high-speed lines and 2,077 km conventional lines. Main railway gauge used is 600, 1,000 and $1,435 \mathrm{~mm}$. Electric current used is 25000 and $50 \mathrm{~Hz}$.

The following tables list the active networks and those under construction.

Table A1.18 - Active rail networks in Greece

\begin{tabular}{|c|c|}
\hline \multicolumn{2}{|c|}{ Active Network } \\
\hline Network & Axes \\
\hline Main PATHEP & Piraeus-Athens-Platy-Thessaloniki-Eidomeni \\
\hline \multirow{4}{*}{ Branches } & Lianoklada-Lami-Stylida \\
\hline & Palaiofarsalos-Kalampaka \\
\hline & Larissa-Volos \\
\hline & Ano Lehonia-Milees \\
\hline Western Macedonia & Thessaloniki-Platy-Edessa-Arnissa \\
\hline \multirow{2}{*}{ Branches } & Arnissa-Amyndaio-Florina \\
\hline & Amyndaio-Kozani \\
\hline Eastern Macedonia & Thessaloniki-Strymonas-Alenxandroupolis-Dikaia-Ormenio \\
\hline
\end{tabular}




\begin{tabular}{|c|c|}
\hline \multicolumn{2}{|c|}{ Active Network } \\
\hline Network & Axes \\
\hline Branches & Strymonas-Promahonas \\
\hline \multicolumn{2}{|l|}{ Peloponnesus } \\
\hline \multirow{6}{*}{ Branches } & Diakofto-Kalavryta \\
\hline & Rio-Patra-Agios Andreas \\
\hline & Pyrgos-Olympia \\
\hline & Pyrgos-Katakolo \\
\hline & Corinth-Argos-Tripoli \\
\hline & Argos-Nafplio \\
\hline \multirow{3}{*}{ Suburban } & Piraeus-Liosia-Kiato \\
\hline & Airport-SKA-Liosia-Kiato \\
\hline & Athens-Chalkis \\
\hline
\end{tabular}

Table A1.19 - Rail networks under construction in Greece

\begin{tabular}{|l|l|}
\multicolumn{2}{|c|}{ Network under construction } \\
\hline \multicolumn{1}{|c|}{ Peripheral network } & \multicolumn{1}{c|}{ Route } \\
\hline MAINLAND GREECE (normal gauge) & Tithorea-Domokos \\
\hline SUBURBAN (ATHENS) & Thriasio Pedio-Neo Ikonio \\
\hline PELOPONNESUS (normal gauge) & Kiato-Rododafne- Rio \\
\hline PELOPONNESUS (metric gauge) & Tripoli-Lefktro-Zevgolatio \\
\hline WESTERN MACEDONIA (normal gauge) & Polykastro-Eidomeni (new line) \\
\hline
\end{tabular}

At the beginning of 2007, the state-owned railway company was split in two, one responsible for the management of infrastructure and the other named TRAINOSE, responsible for rail operations.

Infrastructure expenditure, both for the conventional and the high-speed network, for maintenance, renewals and enhancements, was the following for 2010. The forecast for 2011 was also indicated.

Table A1.20 - Rail infrastructure expenditure in Greece

\begin{tabular}{|l|c|c|}
\hline Conventional lines 2010 (in euro) & Maintenance & Renewals \\
\hline (in km worked on) & $869 \mathrm{~km}$ & 23.5 million \\
\hline Forecast for $\mathbf{2 0 1 1}$ (in euro) & $6.1 \mathrm{million}$ & $405 \mathrm{~km}$ \\
\hline (in km worked on) & $878 \mathrm{~km}$ & \\
\hline High-speed lines $\mathbf{2 0 1 0}$ (in euro) & & 7.79 million \\
\hline (in km worked on) & & $224 \mathrm{~km}$ \\
\hline Forecast for 2011 (in euro) & & 1.7 million \\
\hline (in euro) & & \\
\hline
\end{tabular}


Maritime transport - seaports and inland waterway ports

Greece is one of the strongest and most important maritime countries in the world and commercial shipping, along with tourism, are the mainstays of the national economy.

Nevertheless, the following table shows a decrease in the number of passengers who embarked and disembarked in Greek ports, between 2008 and 2009.

Table A1.21 - Passengers embarked and disembarked in Greece, 2008-2009

\begin{tabular}{|c|c|}
\hline \multicolumn{2}{|c|}{ Passengers embarked and disembarked in all ports (in millions) } \\
\hline Peripheral network & Route \\
\hline 2008 & 91.101 \\
\hline 2009 & 88.351 \\
\hline
\end{tabular}

Passenger traffic at major seaports is indicated below; only in the port of Igoumenitsa was there an increase, between 2007 and 2009.

Table A1.22 - Passenger traffic at major seaports in Greece, 2007-2009

Passenger traffic at major seaports

Passenger embarked and disembarked (in thousands)

\begin{tabular}{|c|c|c|c|c|}
\hline & $\mathbf{2 0 0 7}$ & $\mathbf{2 0 0 8}$ & $\mathbf{2 0 0 9}$ & \% change 2008-2009 \\
\hline Paloukia Salaminas & 13066 & 13063 & 12821 & -1.9 \\
\hline Perama & 13066 & 13066 & 12821 & -1.9 \\
\hline Piraeus & 11063 & 11079 & 10444 & -5.7 \\
\hline Igoumenitsa & 2683 & 2631 & 2741 & 4.2 \\
\hline
\end{tabular}

A decrease in the number of tons of goods transported to/from the main ports of Greece was also registered.

Table A1.23 - Maritime transport of goods in main ports, 2008-2009

Maritime transport - Goods - Annual data - Main ports (in thousands of tons)

$$
2008
$$$$
2009
$$

The only inland waterway that Greece has (navigable canals, rivers and lakes regularly used for transport) is the Korinthos canal, with a total length of $6 \mathrm{~km}$ in use.

\section{Border-crossing points}

The border-crossing points of Greece with neighbouring countries, for both the road and railway networks, are the following:

Table A1.24 - Border-crossing points of Greece

Border-crossing points of Greece with neighbouring countries

\begin{tabular}{|c|c|c|}
\hline & Road & Railway \\
\hline Bulgaria & Promachonas & Promachonas \\
\hline $\begin{array}{c}\text { The former Yugoslav Republic } \\
\text { of Macedonia }\end{array}$ & Evzoni & Idomeni \\
\hline Albania & Kakavia & Kristallopigi \\
\hline Turkey & $\begin{array}{c}\text { Kipi (temporary: to be decided in the } \\
\text { context of TEN-T recast) }\end{array}$ & $\begin{array}{l}\text { Pithio (temporary: to be decided in the } \\
\text { context of TEN-T recast) }\end{array}$ \\
\hline
\end{tabular}

More data will be provided after the recast of TEN-T policy. 


\section{Freight terminals}

The most important freight centre, designed to collect activity currently scattered in the area of the capital (sorting station, container terminal, freight stations and terminals, warehouses, etc.), is located in the area of Thriasio Pedio. The freight centre is linked directly with the cargo ports of Ikonio and Piraeus in the south-east, Thessaloniki in the north and Patra and Megalopoli in the west. There is also easy road access via the direct connection between Thriasio and Attiki Odo and the national road. The implementation of other freight centres in the main cities of Greece is also planned.

\section{Ongoing and planned transport infrastructure projects of international importance and related investment costs}

The most significant ongoing and planned transport infrastructure projects of international importance, in the context of Trans-European policy, are the following:

Priority Project 7: Motorway axis Igoumenitsa/Patra-Athina-Sofia-Budapest will provide significant improvements to the road network of south-eastern Europe, by connecting the ports of Patras, Igoumenitsa, Athens (Piraeus), Thessaloniki and Constanta to the heart of the enlarged European Union. The completion of this project demands:

- studies to realign/upgrade the Thessaloniki-Serres-Promachonas vertical axis. The cost is estimated at around $€ 4,700,000$, with 50 per cent EU contribution

- studies to develop the motorway project, the cost of which is estimated at around $€ 2,250,000$, with 50 per cent EU contribution

Priority Project 21: Motorways of the Sea, one of which is located in South-Eastern Europe and connects the Adriatic Sea with the Ionian and the Eastern Mediterranean, with an extension to the Black Sea. The total cost of this project is estimated at around $€ 5,643,000$, with 50 per cent EU contribution.

Priority Project 22: Railway axis Athina-Sofia-Budapest-Wien-Praha-Nurnberg/ Dresden, part of which comprises railway axis Patras-Athens-Thessaloniki-Eidomeni/ Promachonas. The completion of the project will improve connectivity between all national networks on the basis of common standards. Its cost will be around $€ 13,000,000$, with EU contribution.

Priority Project 29: The Ioanian/Adriatic intermodal corridor railway axis project consists of two interlinked routes (Kozani-Kalambaka-Igoumenitsa and Ioannina-Antirrio-RioKalamata), which will lead to an increase in capacity for intermodal links between sea and rail transport. These routes aim to connect the major ports in Greece with each other, and with the main rail routes to the rest of Europe.

The completion of the project demands:

- studies to improve and upgrade the existing Patras-Kalamata railway line and the change of its gauge from 1,000 to $1,435 \mathrm{~mm}$, for an estimated cost of $€ 31,000,000$, with 50 per cent EU contribution

- studies to design the new Antirrio-Ioannina line, the cost of which is estimated at around $€ 43,000,000$, with 50 per cent EU contribution

\section{Challenges that face transport and transport infrastructure}

The challenges that face transport and transport infrastructure are particularly defined in the white paper: Roadmap to a Single European Transport Area: Towards a competitive and resource efficient transport system. They can be concluded, as follows: 
- establish a genuine Single European Transport Area by eliminating all residual barriers between modes and national systems, easing the process of integration and facilitating the emergence of multinational and multimodal operators (Single European Sky, Single European Railway Area, Blue Belt)

- focus on the most promising technologies, such as the air traffic management system of the future, the European rail traffic management system and rail information systems, maritime surveillance systems, River Information Services, intelligent transport systems, and interoperable interconnected solutions for the next generation of multimodal transport management and information systems (including for charging)

- promote territorial cohesion and economic growth through a European mobility network, which integrates the eastern and western part of the European Union, shapes the Single European Transport Area and concentrates on the components of the TEN-T network

- establish a concrete framework for the development of PPPs and introduce a formal screening of TEN-T projects to identify those with the potential for funding through PPPs

- develop the conditions to extend the transport and infrastructure policy of Greece to our immediate neighbours, to deliver improved infrastructure connections and closer market integration, including the preparation of mobility continuity plans

\section{Iran}

\section{Road transport}

The EATL network in Iran covers eight major routes on nine international roads (AH1, AH2, AH8, AH70, AH71, AH72, AH75, AH78, AH82) totalling 10,716 km $\left(15,149 \mathrm{~km}^{127}\right)$ of roadways. As 68 per cent of the sections of these routes are considered to be in "good" or "good to fair" condition, the road system's improvement and upgrade are needed.

\section{Rail transport}

The total length of railway lines is $8,676 \mathrm{~km}$, while $4,000 \mathrm{~km}$ are currently under construction. Between 21 March 2004 and 20 March 2005, around 18,182 ton-kilometre net freight were transported by Iranian Railways, while currently the freight volume transported amounts to 33 metric tons.

The EATL network spans 11,164 km and six major routes (A21-24, B21-22).

Problems regarding bottlenecks and missing links are addressed as follows:

- construction of railway connections between Astara and Rasht, Anzali (port) and Rasht as well as Bam to Chabahar have been proposed

- missing links between Rasht and Qazvin, between Sangbast-Torbat/Heydarieh-TabasBafgh as well as between Kerman and Bam are under construction

A considerable amount of freight traffic is moving over the railway that opened between Bafgh and Mashhad in 2005: According to the Railway Gazette (January 2007) three passenger trains a week operate between the port of Bandar Abbas on the Gulf of Hormuz and Mashhad in northeastern Iran, but most trains over the line are carrying freight. Providing a direct link between the Turkmenistan border and the sea, the line handles considerable quantities of bulk liquids, mainly oil, petroleum and other oil derivatives. Goods, such as compressed gases, aggregates, sulphur and steel coils are moving over the line, with much of the traffic bound to, or from the Central Asian republics. While most traffic is carried in bulk cargo wagons, there is evidence of a considerable increase in volume of container business.

127 This is the sum of the overall lengths of the individual routes, without excluding the lengths of shared sections of the route. 


\section{Seaports and inland waterway ports}

Iran maintains four seaports (Bandar Emam, Bandar Abbas, Chabahar and Bushehr) and two inland ports (Anzali and Amirabad). The length of available inland waterways (on the Karun River) is $850 \mathrm{~km}$. The actual annual throughput amounts to about 64 million tons. For the majority of ports, construction and improvement projects are planned or under way.

\section{Freight terminals and other intermodal transport infrastructure}

The seaports in Bandar Emam and Bandar Abbas offer modern container carrying terminals with lifting and displacing equipment (rail/sea - rail/road trans-shipment facilities). Amirabad inland port also has modern container carrying terminals with lifting and displacing equipment (rail/sea - rail/road - Ro-Ro trans-shipment facilities).

\section{International border-crossing points (road and rail)}

Iran has numerous international border-crossing points with neighbouring countries (Figure A1.3), including:

- Milak (road), Dogharoun (road) and Sangan (rail) with Afghanistan

- Bazargan (road) and Razi (rail) with Turkey

- Astara (rail and road), Nourdouz and Jolfa (rail and road) border with Azerbaijan

- Mirjaveh (rail) with Pakistan

Furthermore, three formal border-crossing points with Iraq were established:

- Khosravi on the $\mathrm{AH} 2$ opposite Mantharye in Iraq, which is on the M40

- Mehran in front of Zorbatye in Iraq that is connected to the AH2 through the cities of Ilam and Kermanshah

- Shalamcheh opposite to Basreh in Iraq (on the M70) that is connected to Ahvaz and Bandar Emam on the AH8 via Khorramshahr

\section{Figure A1.3 - Border-crossing points}

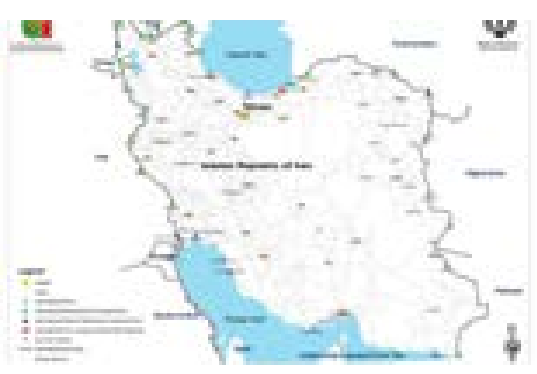

While only some of the international road border-crossing points (Bazargan, Nourdouz and Jolfa) are open 24 hours each day, all seven rail border-crossing points operate on a 24-hour basis. The majority of the other road border-crossing points have opening hours only during the daytime.

The international border crossing with Turkmenistan at Sarakhs (rail and road) disposes of bogie exchange facilities for container and the handling capacity amounts to about 200 containers $/ 24$ hours.

Obstacles hindering seamless and efficient transit and transport are the following:

- lack of unified agreements among the neighbouring states

- complex documents and regulations

- lack of harmony in the procedures and the border crossing documents

- lack of clarity for following the procedures

- unconformity of weights and dimension of vehicles

- lack of state-of-the-art logistic services 
Ongoing and planned transport infrastructure projects of international importance and related investment costs

Iran considers the following measures to remove existing bottlenecks in the transport sector:

- promote integrity and cooperation among regional countries to establish compatibility

- create trade and customs facilities

- establish a competitive and flexible tariff system

- decrease travelling time by reducing the extra stops of trains at the borders and taking measures to decrease the running time of the transit trains inside the countries

- promote the role of forwarders in the CIS countries, Iran and Turkey, and the involvement of the private sector on this route

- construct rail lines on the missing links

- unify transport documents, regulations, information and technical systems

- ensure the accession of all Member States to a joint rail convention

In addition, major road, railway and port development programmes are being undertaken to expand and modernize the transport infrastructure.

\section{New proposed transport infrastructure projects of international importance and related investment costs}

Iran and the Russian Federation have prepared all the necessary technical and economic plans to build a highway to link Iran's northern city of Rasht to Moscow via Azerbaijan, through the construction of the Baku-Astara highway. A working group comprising representatives from Iran, Azerbaijan and the Russian Federation held a meeting in Tehran late March 2008, during which the railway organizations of the three countries signed a memorandum of understanding on practical cooperation in the project. Under the Tehran agreement, feasibility studies in relation to the Iranian segment were due to be completed in six months and submitted to Azerbaijan and the Russian Federation. Once the feasibility studies were confirmed, terms of construction were determined, according to the same agreement. Cargo transportation volumes by this route will total around 5-7 million tons in the first phase with a further increase of up to 15-20 million tons. According to Iranian experts' calculations, the Rasht-Anzali segment would cost $\$ 600$ million and Anzali-Astara would need a construction budget of $\$ 200$ million.

Two rail projects are currently under construction and are to be completed soon, the construction of the Qazvin-Rasht-Anzali-Astara line, which is a missing link in the NorthSouth corridor that may decrease the length of the route from Finland to India, and the construction of the Mianeh-Bostanabad-Tabriz line, which will shorten the current $300 \mathrm{~km}$ line to $200 \mathrm{~km}$.

The following three projects, also along EATL routes, have committed funding and are planned to be completed by 2014:

- construction of section Bam - Chabahar

- construction of section Zahedan - Mirjaveh

- construction of section Shiraz - Bushehr

In addition, the project to build and upgrade the Tehran-Esfahan section, totalling US\$ 1,350 million, is in the planning stage and has not secured 100 per cent of its funding.

Other railway projects of national importance include:

- construction work for the Khorramshahr-Shalamcheh-Bassra link which has started, connecting Iranian railways to Iraq in the south 
- a rail link with Iraq by a land bridge between the Mediterranean Sea and the Persian Gulf via Arak-Kermanshah-Khosravi, a long-term project over $610 \mathrm{~km}$

Sources: CIA Factbook, Railway Gazette (2007), Islamic Republic of Iran Country Report presented in Amman in 2005 , other information provided by the country. H. Jamali, The first regional workshop of Euro-Asian transport links Phase II: Facilitation of Euro-Asia transport in the ECO region.

Available from http://www.unece.org/fileadmin/DAM/trans/doc/2009/wp5/GE2-wkshp1-Iran.pdf. Trend. Iran to Link Northern City to Russia via Azerbaijan, 3 October 2010. Available from http://en.trend.az/ capital/transport/1760595.html.

\section{Kazakhstan}

The economic and geographic features of Kazakhstan (vast territory, landlocked position, uneven spatial distribution of population clusters and natural resources) result in the economy's high dependence on its transport networks.

Road and railway routes account for a major share of total land transport routes (about 88.4 and 14 thousand $\mathrm{km}$, respectively).

Currently, the poor condition of the transport sector's fixed assets, as well as obsolete infrastructure and technology, are evident. The share of transport costs in the final cost of goods account for 8 per cent and 11 per cent for in-land railways and road traffic, respectively. As a result, the transport burden on the economy exceeds that of major industrialized nations by twice on average. According to the cargo intensity index, Kazakhstan's economy is about five times less efficient, as the transport component per every 1 dollar of GDP comprises no less than 9 tonkilometre, while in the EU, cargo intensity is less than 1 ton-kilometre per dollar of GDP.

Four international transport corridors cross the territory of Kazakhstan, formed on the basis of transport infrastructure existing in the country. These are:

- Northern corridor of Trans-Asian Railway Main: Western Europe - China, Korean Peninsula and Japan via Russian Federation and Kazakhstan (Dostyk - Aktogai - Sayak Mointy - Astana - Petropavlovsk (Presnogorkovskaya) section).

- Southern corridor of Trans-Asian Railway Main: South-Eastern Europe - China and South-Eastern Asia via Turkey, Iran, Central Asian states and Kazakhstan (Dostyk Aktogai - Almaty - Shu - Arys - Saryagash section).

- TRACECA: Eastern Europe - Central Asia via the Black Sea, Caucasus and the Caspian Sea (Dostyk - Almaty - Aktau section).

- North-South: Northern Europe - Gulf States via the Russian Federation and Iran, with Kazakhstan's participation in the following sections: Aktau seaport - Ural regions of the Russian Federation and Aktau - Atyrau.

\section{Road transport}

Kazakhstan possesses a road network totalling more than 88.9 thousand $\mathrm{km}$, of which 13 thousand $\mathrm{km}$ are of international significance, linking the Asian and European motorways. In recent years, major repairs and reconstruction of existing infrastructure and construction of new roads have taken place ( 14.4 thousand $\mathrm{km}$ of roads were repaired). All given, the roads are toll-free. The overall road density in Kazakhstan is $32.4 \mathrm{~km}$ per $1,000 \mathrm{~km} 2$; approximately 94 per cent of roads are paved.

The EATL network in Kazakhstan covers 22 major routes on 23 international roads (AH5, AH6, AH7, AH60-64, AH67, AH68, AH70, E011-016, E38, E40, E121, E123, E125, E127) totalling $28,472 \mathrm{~km}$ of roadways. ${ }^{128}$

Rail transport

128 This is the sum of the overall lengths of the individual routes, without excluding the lengths of shared route sections. 
The EATL network spans four major routes with a total length of 4,588.5 km:

- Petropavlovsk to Dostyk $(1,910.8 \mathrm{~km})$

- Presnogorkovskaya to Kokshetau (346.5 km)

- Saryagash to Aktogai $(1,505.4 \mathrm{~km})$

- Aksaraiskaya to Oazis $(825.8 \mathrm{~km})$

The overall rail network in Kazakhstan covers $14,200 \mathrm{~km}$ (as of 2005) and has a density of $5.1 \mathrm{~km}$ per $1,000 \mathrm{~km} 2$. Kazakhstan railways account for 70 per cent of overall freight traffic turnover and 50 per cent of passenger turnover in the country. In 2005, freight shipments amounted to 171.9 billion ton-kilometre.

\section{Seaports and inland waterway ports}

Kazakhstan, a landlocked country (the closest distance to the sea is $3,750 \mathrm{~km}$ ), has access only to the Caspian Sea and, thus, relies to some extent on transport via inland waterways, mainly on the Irtysh and Syr Darya Rivers. Four major inland waterways covering 3,912 km in length allow transport for vessels with navigable water levels of no less than $2.5 \mathrm{~m}$ for river vessels and $4.5 \mathrm{~m}$ for "river-sea" vessels, respectively. The density per every $1,000 \mathrm{~km} 2$ stands at $1.5 \mathrm{~km}$ for inland navigable waterways. These have a limited navigation period averaging 200 days per year. In 2000, yearly traffic amounted to 552 units ( 402 units of transport fleet and 150 units of technical fleet). The inland waterways require some infrastructure investment to remedy existing bottlenecks.

The main transit flow passes via reconstructed Aktau International Sea Commercial Port, which has a capacity for oil shipments of up to 8 million tons, and general and bulk cargo of 1.5 million tons, 24 thousand containers per year. The Aktau Port is considered a strategic junction on one of the TRACEKA routes and International Transport Corridor North-South, connecting North Europe with South Asia and India.

\section{Freight terminals and other intermodal transport infrastructure}

To function, the container sites at Tura-Tam station, Arys station and Turkestan station require major renovation work. In 2003, the annual throughput of the freight terminals amounted to 31,116 tons or 567 TEUs. Additional ports are Atyrau river port (Gur'yev), Pavlodarsk river port, Aqtau (Shevchenko), Oskemen (Ust-Kamenogorsk) and Semey (Semipalatinsk).

\section{International border-crossing points (road and rail)}

Along EATL roads, Kazakhstan has 42 international border-crossing points. While the bordercrossing points at Khorgos, Dostyk (road and rail), Kegen and Kolzhat have limited opening hours between 9 a.m. and 6 p.m., all others operate daily on a 24-hour basis. Furthermore, an additional 16 rail border-crossing points are operational. At the rail border crossing with the Russian Federation, non-physical obstacles exist, resulting in delays caused by extensive checks and the lengthy processing of documents by the Russian Federation customs service.

\section{Ongoing and planned transport infrastructure projects of international importance and related investment costs}

The Kazakhstan Government has elaborated and approved the Strategy of Transport Sector Development to 2015. The amount of investment required to build the respective infrastructure within 10 years totals US\$ 26 billion. The Strategy covers the period 2006-2015 and is to be implemented in two stages: the first stage between 2006 and 2011, and the second stage between 2011 and 2015. The ultimate goal of the Transport Strategy is to ensure the progressive development of the transport and communications network in line with the economic strategy of the State. 
The Strategy envisages the construction of approximately $1,600 \mathrm{~km}$ and the electrification of $2,700 \mathrm{~km}$ of railway, the construction and reconstruction of about $50,000 \mathrm{~km}$ of road, and the development of a national merchant fleet and seaport infrastructure.

\section{New proposed transport infrastructure projects of international importance and related investment costs}

Construction of the new Western Europe-Western China transport corridor will increase truck deliveries almost fourfold. Deliveries along this corridor are expected to grow from the current 900 thousand tons to 3.5 million tons. The government supported the idea of financing a feasibility study for the corridor. Apart from freight volumes from China and Europe, the project will enable the country to attract transport flows from Central Asia. The total project cost is US\$ 2,500 million. The government invited the World Bank, ADB/Japan International Cooperation Agency, EBRD and IDB to co-finance separate sections of the Western Europe-Western China corridor. To formalize this collaboration, a memorandum of understanding was signed by the Ministry of Transport and Communications and all participating IFIs. The loan amount is US\$ 2,125 million.

The following four investment projects (along proposed EATL routes) seek to rehabilitate road segments in Kazakhstan:

- Astana-Karaganda

- Almaty-Kapchagay

- Aktau-Beyneu

- Western Europe-Western China transit corridor

All investment projects have committed funding and should be completed by 2013 .

Three investment projects with committed funding involve the electrification of existing railway lines to be completed by 2013 within EATL routes, and one new railway construction project (Korgas-Zhetygen section).

Finally, an ongoing project is the expansion of Aktau Port, which seeks to increase its capacity to 20 million tons of oil cargo and 3 million tons of general cargo per year.

Sources: World Bank, UNCTAD, CIA World Factbook, Kazakhstan Railways at http://www.railways.kz/, International Union of Railways, Embassy of the Republic of Kazakhstan at http://www.kazakhembus.com/index. php?page=infrastructure

Central Asia Regional Economic Cooperation. Kazakhstan: Country Progress Report on the Implementation Action Plan for the Transport and Trade Facilitation Strategy, 22 April 2009.

Available from http://www.carecprogram.org/uploads/events/2009/8th-TSCC/TTFS-Country-Progress-ReportKAZ.pdf.

Presentation of the Kazakh delegate: "Development of Road and Rail Transport Infrastructure, Kazakhstan. Vienna November 2010 on the occasion of the OSCE/UNECE Conference on the Financing of Transport Infrastructure.

\section{Kyrgyzstan}

\section{Road transport}

Transport contributes approximately 2-3 per cent to the GDP of Kyrgyzstan; the country has low road density $(0.17 \mathrm{~km} / \mathrm{km} 2)$. Gross production of transport services amounted to 14.4 billion Kyrgyzstani som (US\$ $1=47$ som) and increased compared with January-July 2010 to 10.9 per cent. The volume of all freight increased over the same period in 2010 to 3.5 per cent. The growth in freight transported by road has been the result of increasing traffic moved by individual entrepreneurs. The transport of passengers, in all transport modes, rose by 3.5 per cent in the same period. 
Kyrgyzstan does not have access to the sea. More than three quarters of the territory of Kyrgyzstan is mountainous; more than 97 per cent of goods are transported by automobile and 80 per cent of passengers are also transported by road.

The EATL network in Kyrgyzstan covers five major routes on four international roads (AH5, $\mathrm{AH} 7, \mathrm{AH} 61, \mathrm{AH} 65),{ }^{129}$ totalling $1,715 \mathrm{~km}$ of roadways.

All the roads are undergoing reconstruction with funds from international financial institutions and/or from donor countries. Reconstruction of the AH7(5) Bishkek-Osh road has been completed. The reconstruction of roads AH61 and AH65 should be finished by 2012-2014.

\section{Rail transport}

According to the Kyrgyz Ministry of Transport and Communications, the total length of the railroad system in Kyrgyzstan is $424.6 \mathrm{~km}$, consisting of two unconnected lines: a Southern line of $101.2 \mathrm{~km}$, and a Northern line of $323.4 \mathrm{~km}$.

The EATL network spans three corridors in Kyrgyzstan:

- Northern line

- Corridor from Lugovaya station (Kazakhstan) - Rybach'e station (Balykchi) (Kyrgyzstan)

- Southern line

- Corridor from Uchkyrgan station (Uzbekistan) - the border Shamaldy_Sai station (Uzbekistan) - Tach-Kumyr station (Kyrgyzstan)

- Corridor from Savai station (Uzbekistan) - Kara-Cuu-Osh station (Kyrgyzstan) and Xanabad (Russian Federation) - "Kok-Jangak” (Kyrgyzstan)

\section{Seaports and inland waterway ports}

Kyrgyzstan is a landlocked country. Nevertheless, a small volume of transport on the $600 \mathrm{~km}$ of inland waterways occurs on Issyk-Kul Lake (Balykchy port).

\section{International border-crossing points (road and rail)}

Kyrgyzstan and its four neighbours have 14 border-control points, two of which are major rail corridor crossing points. The largest rail control point is in Bishkek (about $40 \mathrm{~km}$ from the border with Kazakhstan), whereas the largest road control point is in Akzhol (on the border with Kazakhstan). Osh, another rail border-crossing point covers the traffic through the Ferghana Valley. According to 2003 data, these two points handle over 1.1 million tons and 1.3 million tons of goods per year, respectively. The border-control points process 20,000 rail wagons and approximately 125,000 trucks annually. With the exception of the new facilities at Akzhol, the main problems are the poor condition of the buildings/offices and inadequate communication and data processing facilities.

Kyrgyzstan has a number of international border-crossing points with neighbouring countries, which include:

- Kazakh-Kyrgyz border (1,051 km): Akzhol (road), Georgievka, Kegan

- Kyrgyz-Uzbek border (1,099 km): Osh (rail), Kara-Suu, Kizibl-Kiya (Kaytpas and Gazprom checkpoints)

- Kyrgyz-Tajik border (870 km): Isfand, Sari-Tash (Kyzylart Pass), Karamik

- Kyrgyz-Chinese border $(858 \mathrm{~km})$ : Torugart Pass

129 An ADB report uses different denominations for two of the routes: Osh to Irkeshtam is AH64 instead of AH65 and Kara Balta to Osh is AH74 instead of AH7. 


\section{Ongoing and planned transport infrastructure projects of international importance and related investment costs}

A number of road rehabilitation projects, at an estimated cost of US\$ 585.6 million, are planned, including:

- Osh-Sary Tash-Irkeshtam (AH is road 65 and E007) - loan amount: US\$139.7 million ADB - US\$ 32.8 million; Government of the Russian Federation - US\$ 6.3 million; Eximbank of China - US\$75.3 million; China Development Bank - US\$25.3 million.

Bishkek-Naryn-Torugart (AN61, E125) - loan amount: US\$ 397.3 million Eximbank of China - US\$200 million; Arab Coordination Group - US\$72.35 million; ADB US\$ 125 million

- Sary Tash-Karamik roads (AN65, E60) - loan amount: US\$48.6 million ADB

The total length of regional transport corridors in Kyrgyzstan is $2,242 \mathrm{~km}$, which include eight routes:

- Bishkek-Osh road (AH65, E007) - $672 \mathrm{~km}$

- Bishkek Georgiyevka (continuation of the Osh-Bishkek road to Kazakhstan) - 16 km

- Bishkek Chaldovar (Karabalta Chaldovar section) - $31 \mathrm{~km}$

- Bishkek-Naryn-Torugart (AH61,E125) - $539 \mathrm{~km}$

- Taraz-Talas-Suusamyr - $199 \mathrm{~km}$

- Osh-Sary Tash-Irkeshtam (AH65, E60) - 258 km

- Osh-Isfana - $385 \mathrm{~km}$

- Sary Tash-Karamik (AH65, E60) - 142 km

New proposed transport infrastructure projects of international importance and related investment costs

Kyrgyzstan's existing dead-end railway lines totalling $425 \mathrm{~km}$ are sparse and inadequate to satisfy the country's transport demand. Moreover, a lack of direct transport routes accessing world markets significantly impedes the development of the Republic's foreign economic relations and results in increases in the transport share of export goods' cost. Therefore, the priority to further develop the national railway network is the creation of the South corridor of the Euro-Asian transcontinental railroad, which will connect the ports of the Pacific to the Persian Gulf and to the Mediterranean by passing over the territory of Kyrgyzstan.

Kyrgyzstan needs to build railway lines connecting the north and south of the country, as well as transit routes to neighbouring countries. In 2003 the Government of China funded a feasibility study on the China-Kyrgyzstan-Uzbekistan railway. In addition, new railway construction is planned from Kochkor via Kazarman to both Torugart and Jalal-Abad. The railroad line connecting Balykchy-Jalal-Abad-Torugart to China is in the design phase.

To this end, a new railway line will be constructed on the territories of China and Kyrgyzstan. After a lengthy debate on the route, Kyrgyzstan approved the line's north direction: from the Chinese city of Kashgar, which is the end point of the railway in southern Xinjiang, through the valley of the Arpa Torugart, Fergana ridge with access to the Uzgen and the border with Uzbekistan, Kara-Suu. The planned length of the Kyrgyz section is $268.4 \mathrm{~km}$ while the Chinese section is $165 \mathrm{~km}$.

China and Kyrgyzstan still have not agreed on the gauge. The Kyrgyz authorities insist on the standard $1,520 \mathrm{~mm}$, while the Chinese insist on $1,435 \mathrm{~mm}$.

The 2003 the Chinese funded a preliminary feasibility study for the railway which notes a number of advantages to planning new routes rather than maintaining existing transport corridors: the new line would be shorter than the current transport corridor over more than 
$900 \mathrm{~km}$, the railway construction would improve transport links between Central Asian countries and would provide them with convenient access to the sea. According to preliminary calculations, Kyrgyzstan would receive approximately US $\$ 200$ million annually for the transit of goods across its territory. Best estimates suggest the volume of domestic cargo within Kyrgyzstan would amount to no more than 5 per cent. At the time of initial calculations, the cost of building the railway on the territory of Kyrgyzstan was estimated at US\$ 1,340 million; currently it would cost almost US\$ 2 billion. Unfortunately Kyrgyzstan does not have proper funding for this Euro-Asian rail link, so the current intention is that construction will be funded by the Government of China. As compensation, China may receive mineral deposits from Kyrgyzstan worth US\$ 2 billion.

However, at this time the Government of China has expressed real interest in the construction of the China-Kyrgyzstan-Uzbekistan railway. In this connection, the Ministry of Transport and Communications has requested, and China Group Corporation for the construction of communication facilities has expressed willingness at their expense, to conduct research and prepare a feasibility study for the project, as well as to develop a railway network programme for the country of Kyrgyzstan. This work was expected to be completed by the Chinese partner before November 2011. A re-examination of the issues related to the construction of the railway may start in 2012.

Another proposed project is the electrification of $322.7 \mathrm{~km}$ of railway between Lugovoe and Balykchy. The estimated total cost of construction is US\$ 145 million. The cost of the first stage of construction (the Lugovoe-Alamedin segment - $157 \mathrm{~km}$ ) is US\$ 69 million, while the second part (Alamedin-Balykchy - $165.7 \mathrm{~km}$ ) will cost US\$ 76 million.

Two additional rail projects include the electrification of the Bishkek-Balykchy railway (at the cost of US\$100 million) and track rehabilitation of the Chaldovar-Balykchy segment (amounting to US\$ 65.6 million). The funding is yet to be secured, however, the electrification of the Bishkek-Balykchy railway has been identified as low priority, and hence was assigned to Category IV, while the track rehabilitation of the Chaldovar-Balykchy segment is medium priority, and hence was assigned to Category II.

\section{Latvia}

\section{GDP and transport (contribution of transport to GDP in percentage)}

The transport sector represents an important part of Latvia's economy, accounting for about 11-12 per cent of GDP. Approximately 9 per cent of those employed work in the transport and storage sector.

\section{Road transport}

Table A1.25 - Road transport infrastructure in Latvia

\begin{tabular}{|c|c|}
\hline Road classes & Total length of road network (km) \\
\hline State roads, including: & 20150.10 \\
\hline Main roads (A) & 1652.73 \\
\hline Regional roads (P) & 5315.75 \\
\hline Local roads (V) & 13181.61 \\
\hline Municipal roads and streets & 38775.70 \\
\hline Forest roads & 10142.00 \\
\hline Private roads & 3500.00 \\
\hline Roads and streets, total & 72567.81 \\
\hline
\end{tabular}


The density of the road network in Latvia is $1,124 \mathrm{~km}$ per $1 \mathrm{~km} 2$, considered sufficient for the number of inhabitants and the size of the territory. The basic road network includes almost all major State roads and has been identified as Trans-European Transport Networks (TEN-T).

In 2010, the transport of goods by national road carriers amounted to 46,809 thousand tons. The transport of goods by road constituted approximately 46 per cent of the total amount of goods transported in the country.

\section{Rail transport}

The State joint stock company Latvijas dzelzcel̦s is the largest carrier of rail freight. The track gauge of the public usage rail network is $1,520 \mathrm{~mm}$; total operating length is $2,206.3 \mathrm{~km}$; 23.5 ton axle loads are permitted on the public usage railway network. The allowed speed on public usage railway infrastructure for passenger trains is $120 \mathrm{~km} / \mathrm{h}$, and $80 \mathrm{~km} / \mathrm{h}$ for freight trains.

The railway network has 152 stations (operating points) with extended tracks; 70 are open to freight operations. Among stations conducting freight operations, there are two marshalling (sorting) yards (Šķirotava and Daugavpils), and four district stations (Jelgava, Rēzekne, Krustpils, Gulbene).

Table A1.26 - National and international freight transport by rail in Latvia, 2008-2010

\begin{tabular}{|c|r|r|r|}
\hline (in thousand tons) & 2008 & 2009 & 2010 \\
\hline Freight transported & 56061 & 53679 & 49164 \\
\hline Domestic traffic & 1687 & 1299 & 1263 \\
\hline International traffic & 51374 & 52380 & 47901 \\
\hline Exports & 2652 & 2222 & 3206 \\
\hline Imports & 47116 & 47092 & 40973 \\
\hline Transit cargoes & 4606 & 3066 & 3722 \\
\hline $\begin{array}{c}\text { Of international freight transport- } \\
\text { transport through ports }\end{array}$ & 43871 & 45117 & 39056 \\
\hline Freight turnover, mlt t-km & 19581 & 18725 & 17179 \\
\hline
\end{tabular}

Ten months in 2011 show substantial increase in freight transport volumes of 18.5 per cent (comparing the same period in 2010) and in total 48,405 million tons.

Rail freight carriage constituted 48 per cent of total transport in Latvia and about 80 per cent was freight carriage to the three largest ports of Latvia - Rìga, Ventspils and Liepāja, including from the Russian Federation and Belarus via the large junctions of Eastern Latvia in Daugavpils and Rēzekne.

\section{Maritime transport}

Three large ports operate in Latvia (Riga Freeport, Ventspils Freeport and Liepaja Port), the proportion of which in total freight turnover was 98 per cent, as well as seven small ports (Engure, Lielupe, Mērsrags, Pāvilosta, Roja, Salacgrīva, Skulte). 
Table A1.27 - Cargo loaded and unloaded from domestic and foreign vessels at Latvian ports, 2008-2010

\begin{tabular}{|c|c|c|c|c|c|}
\multirow{2}{*}{ Year } & \multirow{2}{*}{ Total } & \multicolumn{4}{|c|}{ (in thousand tons) of which in ports } \\
\cline { 3 - 6 } & & Riga & Ventspils & Liepaja & Small ports \\
\hline 2008 & 63649 & 29566 & 28570 & 4188 & 1326 \\
\hline 2009 & 61980 & 29724 & 26640 & 4381 & 1234 \\
\hline 2010 & 61160 & 30476 & 24816 & 4384 & 1485 \\
\hline
\end{tabular}

Riga Freeport is open for navigation all year round. Up to 80 per cent of Riga Freeport cargo turnover is comprised of transit cargoes forwarded to or received from the CIS. Main types of cargo handled at Riga Freeport are coal, oil products, timber, containers, mineral fertilizers, chemical cargoes and food products.

The Riga - Stockholm (Sweden) ferry line has maximum port depth of $14.5 \mathrm{~m}$; after dredging it will achieve $17 \mathrm{~m}$.

Ventspils Freeport is ice-free the whole year round. Main types of cargo handled at Ventspils Freeport are oil products, coal, mineral fertilizers, ore and timber.

Ferry lines include: Ventspils - Nynäshamn (Sweden), Ventspils - Travemünde (Germany) and Lübeck (Germany) - Ventspils - St Petersburg (Russian Federation). Maximum port depth is $17.5 \mathrm{~m}$.

Liepaja Port is ice free the whole year round. Main types of cargo handled at Liepaja Port are timber, metals and metal products, oil products, crude oil and coal.

The ferry line travels from Liepaja - Travemünde (Germany). Maximum port depth is $10.5 \mathrm{~m}$; after dredging it will achieve $12.5 \mathrm{~m}$.

\section{Air transport}

There are four airports in Latvia: Riga international airport, Liepaja international airport, Ventspils international airport and Daugavpils international airport.

Ninety-nine per cent of flights operate from Riga airport. The number of passengers and aircrafts serviced by the airport has increased significantly and the airport has become dominant among the airports of the three Baltic States. In 2010, the network of destinations from Riga airport expanded in the direction of Scandinavia, Southern Europe, the Middle East and Eastern Europe. The most popular destination in 2010 was London.

Table A1.28 - Passenger and cargo turnover at Riga airport, 2008-2010

\begin{tabular}{|c|c|c|}
\hline Year & Passenger turnover & Cargo turnover (tons) \\
\hline 2008 & 3690549 & 7669 \\
\hline 2009 & 4066793 & 9429 \\
\hline 2010 & 4663647 & 12294 \\
\hline
\end{tabular}

\section{Border-crossing points}

Railway border-crossing points are the following:

- with the Russian Federation - Kārsava, Rēzekne Preču station, Zilupe

- with Belarus - Indra, Daugavpils Preču station

- with Estonia - Lugaži

- with Lithuania - Daugavpils, Eglaine, Kurcums, Meitene, Reņgée, at Priekule and Vainode stations, train traffic is closed. 
Road border-crossing points:

- with the Russian Federation - Vientul,i (Latvia)-Ludonka (Russian Federation), Grebñeva (Latvia)-Ubilịnka (Russian Federation), Terehova (Latvia)-Burački (Russian Federation), Pededze (Latvia LV)-Bruniševo (Russian Federation)

- with Belarus - Paternieki (Latvia)-Grigorovščina (Belarus), Silene (Latvia)-Urbani (Belarus)

Key challenges and planned transport infrastructure projects of international importance

- completion of road network rehabilitation (construction of main roads in four lanes)

- upgrade of railway and road infrastructure

- development of RailBaltica railway project

- construction of railway route to Riga international airport

- elaboration of New Passenger/Cruise Ship Terminal in Riga Freeport

- reconstruction of Access Channel for Ships Entering the Port of Riga, Phase II

- reconstruction of East and West breakwaters, development of new territory beyond the West breakwater in the Port of Riga

- construction of Ventspils Northern port

\section{Lithuania}

Due to Lithuania's geographic location, the transport sector, particularly freight transit, plays a key role in the country's economy. Freight shipments between the East and the West are the core of the transit industry. The transport, storage and communication sector has increased its importance to the economy of Lithuania. In 2008, it accounted for 12.1 per cent of the country's GDP. Lithuania has become a well-developed transport corridor between the East and the West. With a dense road network, the country has achieved significant growth in the amount of goods carried both by road and by rail transport.

\section{Road transport}

Lithuania's total road network is $69,067 \mathrm{~km}$. The network size and its reach are adequate but the quality is not. The national Government owns and maintains $21,335 \mathrm{~km}$ of roads. Three hundred and seventy six km of European standard motorways serve the highest density routes of Vilnius-Kaunas-Klaipeda and Vilnius-Panevezys.

\section{Rail transport}

The Lithuanian rail network consists of $1,775.3 \mathrm{~km}$ with $557 \mathrm{~km}$ of double track. Lithuanian Railways is a profitable State-owned company (in 2003 profit was US\$ 5.1 million). The main rail corridor is situated on the Russian Federation mainland-Kaliningrad-Corridor IX-KlaipedaKaunas-Belarus route. The present railway sector is rather behind in technical, economic, technological and organizational terms in relation to the modern interacting railway systems of EU Members. Insufficient funding for maintenance and development has led to obsolescence of the rolling stock, lack of spare parts and limited train speed.

\section{Seaports and inland waterway ports}

Lithuania's major seaport, Klaipeda Port, has several advantages in cargo shipment over other ports in the region; it has a four-lane European standard motorway to Vilnius and rail connection to the East and Moscow, and it offers a faster transport route to the Russian Federation from the West compared to land transport through Poland, avoiding rail trans-shipment before entering into Poland and bottlenecks at border crossings. The port has well-developed intermodal transport capacities, comprising maritime and land transport infrastructure. This forms a strong basis for the facilitation of transport and logistics services between Europe and Asia. 


\section{Freight terminals and other intermodal transport infrastructure}

Transit services for freight flow are provided along three main corridors:

- East-West (major): to/from the Russian Federation and other CIS countries, via Belarus, Vilnius and Kaunas to Klaipeda Port, and on to Scandinavia and Western Europe

- North-South: to/from Finland, via Estonia, Latvia, Kaunas and Sastokai, on to Poland, Germany and Central Europe (road section known as Via Baltica)

- East-West (minor): to/from the Russian Federation and other CIS countries, through Kaunas, on to Kaliningrad

Lithuania has more than $600,000 \mathrm{~m} 2$ of modern logistics and warehousing facilities. The biggest supply of new, modern warehousing facilities is in the capital city Vilnius (after the completion of several new projects in the third quarter of 2009, the supply of modern warehousing premises has increased by nearly 12 per cent in Vilnius and currently reaches $334,400 \mathrm{~m} 2$ in rentable area). Kaunas is in second place (around 200,000 m2), and Klaipeda comes in third (122,500 m2).

\section{Ongoing and planned transport infrastructure projects of international importance and related investment costs}

Along the North-South axis, the Via Baltica and Rail Baltica projects are focused on the modernization of road and rail infrastructure, connecting the eastern part of the Baltic Sea with Western Europe by inland transport.

Along the East-West axis, projects are focused on enhancing road, rail and Klaipeda deepwater seaport infrastructure, as well as developing the motorways of the Baltic Sea (intermodal extension of the IXB corridor towards Western Europe). Special attention is given to the development of public logistics centres and to the modernization of railway infrastructure.

Six road projects are currently under way with regard to the reconstruction of a section of Road E85 (Vilnius-Kaunas-Klaipeda).

With regard to the rail sector, the modernization of track equipment, power supply equipment and the technological communication network at Kaunas station, at Palemonas-Rokai-Jiesia bypass and at the Kaunai-Kybartai line is under implementation.

In addition, the reconstruction of international importance of the $E 41$ section of the mouth of Kaunas-Atmata waterway is currently being carried out, as well as the construction of infrastructure for passenger and cargo ferry terminal in Klaipeda port.

\section{New proposed transport infrastructure projects of international importance and related investment costs}

Three road projects are at the design stage as part of the reconstruction of Road E85 (VilniusKaunas-Klaipeda). Another 24 railway projects are also at the design/planning stage for the modernization of the Baltica railway line on the Kaunas-Siauliai section, the rehabilitation of the existing Kazlu Ruda-Kaunas railway section, the development of Klaipeda railway junction, and that of the Vilnius and Kaunas public logistics centres.

Additional projects are planned for the inland waterway sector pertaining to Kaunas Port. Finally, two projects are at the planning stage involving Klaipeda Port.

Source: World Bank at http://web.worldbank.org/WBSITE/EXTERNAL/TOPICS/EXTTRANSPORT/0,,menuPK:337 122 pagePK:1 49018 piPK:1 49093 theSitePK:3371 16,00.html. 


\section{Luxembourg}

Investments in the road and rail network of Luxembourg have contributed to an efficient transport network for goods and freight. Compared to other countries, public investment is quite high when expressed as a share of GDP. The transport and handling sectors make up roughly 5 per cent of GDP. Transport in Luxembourg is ensured principally by road, rail and air. There are also services along the Moselle River, which forms the border with Germany. The road network has been significantly modernized in recent years with motorways to adjacent countries.

\section{Road transport}

The six Luxembourg motorways cover a total distance of $147 \mathrm{~km}$, linking the capital with Trier (Germany), Thionville (France) and Arlon (Belgium), as well as with Esch-sur-Alzette and Ettelbruck in Luxembourg with a density of $56.8 \mathrm{~km}$ of motorway per $1,000 \mathrm{~km} 2$.

\section{Rail transport}

Operated by Chemins de Fer Luxembourgeois, Luxembourg's railways form the backbone of the country's public transport network, linking the most important towns. The total length of operational (standard gauge) track is $274 \mathrm{~km}$.

\section{Seaports and inland waterway ports}

The Moselle River forms a $42 \mathrm{~km}$ natural border between Luxembourg and Germany in the south-east of the country. Mertert near Grevenmacher on the Moselle is Luxembourg's only commercial port. With two quays covering a total length of $1.6 \mathrm{~km}$, it offers facilities connecting river, road and rail transport. It is used principally for coal, steel, oil, agricultural goods and building materials.

\section{Freight terminals and other intermodal transport infrastructure}

The logistics sector is a rapidly growing part of the Luxembourg economy. Over 80 per cent of the goods and services produced in Luxembourg are bound for foreign markets.

\section{Ongoing and planned transport infrastructure projects of international importance and related investment costs}

With regard to the railway field, the Department of Transport has charged national company Luxembourg Railroads not only with the maintenance of the railway network, but also with the realization of the rail network's extension projects.

\section{New proposed transport infrastructure projects of international importance and related investment costs}

No information on any major road or railway infrastructure projects of international importance was provided.

Sources: Luxembourg Department of Transport at http://www.mt.public.lu/.

Luxembourg for Finance at http://www.lff.lu/finance/news/news-detail/browse/1/article/luxembourg-asa-european-logistics-hub/21/.

\section{Mongolia}

Mongolia's geographical location, far from the sea and surrounded by two large neighbours, China and the Russian Federation, enables external transport links only via these countries, according to the terms of international trade with Mongolia. Mongolia is one of the world's 44 landlocked countries. 
Mongolia currently uses the Chinese port of Tianjin for almost all of its overseas imports and exports. There is also slight transport by rail to/from Europe through the Russian Federation, and via Russian Federation Pacific ports/Vostovhnyi for freight traffic to and from North America. In recent years, Mongolia's landlocked position between the Russian Federation and China has become a positive advantage as an important link between the two, with Mongolia benefiting from rail transit traffic moving through it between the Russian Federation and China.

The transport sector consists of four modes: railway, road, air and waterway transport

Table A1.29 - Modes of transport in Mongolia, 2007-2010

\begin{tabular}{|c|c|c|c|c|}
\hline Modes of transport & 2007 & 2008 & 2009 & 2010 \\
\hline \multicolumn{5}{|c|}{ Freight turnover, million ton-kilometre } \\
\hline Total & 9030.2 & 9051.4 & 9016.4 & 12124.8 \\
\hline Railway & 8360.7 & 8261.4 & 7852.1 & 10286.7 \\
\hline Road & 661.9 & 782.1 & 1160.7 & 1834.0 \\
\hline Air & 7.7 & 7.9 & 3.7 & 4.2 \\
\hline \multicolumn{5}{|c|}{ Carried freight, thousand tons } \\
\hline Total & 23281.6 & 23904.4 & 24736.7 & 29415.9 \\
\hline Railway & 14072.6 & 14646.9 & 14171.5 & 16804.0 \\
\hline Road & 9207.1 & 9255.7 & 10563.8 & 12610.2 \\
\hline Air & 1.9 & 1.8 & 1.4 & 1.6 \\
\hline \multicolumn{5}{|c|}{ Passenger turnover, million passenger-kilometre } \\
\hline Total & 3263.1 & 3607.3 & 3179.2 & 3372.4 \\
\hline Railway & 1406.4 & 1400.4 & 1008.5 & 1220.0 \\
\hline Road & 869.7 & 1215.0 & 1535.9 & 1480.2 \\
\hline Air & 987.1 & 991.9 & 634.9 & 672.2 \\
\hline \multicolumn{5}{|c|}{ Carried passenger, million passengers } \\
\hline Total & 209.9 & 231.6 & 232.5 & 250.7 \\
\hline Railway & 4.5 & 4.3 & 3.1 & 3.5 \\
\hline Road & 205.0 & 226.9 & 229.0 & 246.7 \\
\hline Air & 0.4 & 0.4 & 0.3 & 0.4 \\
\hline
\end{tabular}

Transportation and storage share of GDP for 2010 is 8.1 per cent; GDP per capita is $\$ 2,394$; the rate for US\$1=1,250 tugrugs

\section{Road transport}

The country's road network totals $49,250 \mathrm{~km}$, including international, state, internal and local government road networks. Total state roads account for $12,722 \mathrm{~km}$ while the remaining $36,528 \mathrm{~km}$ are provincial and local roads. Most Mongolian roads are poorly maintained gravel and earth roads; approximately 5.2 per cent of the road network $(2,597 \mathrm{~km})$ is currently paved.

Being bound by two large neighbours - China and the Russian Federation - means that Mongolia's road transport links take on significance in terms of domestic and international trade. 
In April 2004, the Government of Mongolia signed the Intergovernmental Agreement on the Asian Highway Network.

The Asian highway routes in Mongolia are the following:

- AH-3- $990 \mathrm{~km}$

- $\mathrm{AH}-4-749 \mathrm{~km}$

- $\mathrm{AH}-32-2,520 \mathrm{~km}$

- TOTAL: $4,259 \mathrm{~km}$

In recent years, the number of vehicles in the capital Ulaanbaatar has increased by 20 per cent yearly. However, the existing deteriorated road network, which is overloaded and functions above its capacity, is a root cause of congestion in the city and increases the incidence of road accidents. Eighty per cent of the city's total road network has been in use for more than 15 years and has deteriorated to a large extent due to the lack of or poor routine maintenance and rehabilitation.

\section{Rail transport}

The railway is the dominant mode of freight transportation in Mongolia and the main means of transit transportation. In total in 2010, 16.8 million tons of freight (including 4.6 million tons of exports, 1.5 million tons of imports and 2.3 million tons in transit) and 3.5 million passengers were transported.

The railway transport sector consists of the Mongolian-Russian Federation joint venture Ulaanbaatar Railway; the state shareholding company Mongolian Railway; Bold Tumur Yeruu Gol Co., Ltd; Ded Buttsiin Hugjil (Infrastructure Development) Co., Ltd; and small railway entities.

Currently, the railway network consists of main and branch railway lines, the total length of which is $1,908 \mathrm{~km}$. The $1,110 \mathrm{~km}$-main line, which connects the Russian Federation and China via Ulaanbaatar, is the key route on Trans-Mongolian Railways. The 239-km Bayantumen railway line located in north-eastern Mongolia connects the main eastern city of Choibalsan with the border between Mongolia and the Russian Federation. The 98-km railway line of Boldtumur Yeruu Gol Co., Ltd is linked to the main line.

State policy on railway transportation was adopted by resolution No. 32 of 24 June 2010 by the Parliament of Mongolia. Its purpose is to increase the carrying and transit capacities of the railway and expand the efficiency and integration of the domestic network to meet increasing freight transport demand, as well as to improve the country's national transit capability, utilize the large mining deposits and export its products to accelerate socioeconomic development and ensure sustainable development for the future.

Owing to the speed of development of the mining industry in Mongolia, over 5,600 km of railway lines will be built in three stages to transport the raw and processed mineral materials to and from abroad.

\section{Air transport}

Because of the large distances between cities and the sparse populations across Mongolia, the aviation subsector is relatively well developed. The national airline, MIAT, supplements its domestic routes with international destinations that include China, the Republic of Korea, the Russian Federation, Japan and Germany. Plans for route expansion include the Hong Kong SAR and Thai markets. Recently, private companies, such as Aero Mongolia, Eznis Airways and four others, have entered the market and are attempting to increase their market share. MIAT currently transports 45 per cent of international passengers, while the private companies only carry three per cent. Conversely, in the domestic market, the six private-sector operators enjoy a 70 per cent market share. 
In recent years, the focus of the aviation subsector has been to increase the number of airports in the country with paved runways and increase the number of international overflights. At the same time, privatization measures have been pursued, aiming to involve the private sector more in aviation activities, including airport management and airline operations. Throughout the development of the subsector, promoting safety remains a primary concern.

\section{Road transport subsector}

The history of the road transport sector goes back to the 1920s. It played an important role in the country's transport sector when other means of transport were insufficiently providing services nationwide.

In the 1990s, 15 major entities comprised a fleet of 300 to 1,000 vehicles for intercity transport and over 20 local entities handled cargo, passenger and postal deliveries. These entities' total number of vehicles made up only 30 per cent of the entire vehicle population of the country but carried over 70 per cent of freight transport and 98.5 per cent of passenger transport.

With the transition into the market economy, the demand for road transport increased among the population and private entities; as a result the government policy on privatization effectively privatized the whole road transport sector except for three city public bus companies in Ulaanbaatar.

The road transport subsector stands to benefit greatly from Mongolia's strategic location between the two vast economies of China and the Russian Federation. Three highways within the country have been designated Asian Highways as part of the ESCAP classification system: the vertical axes of $\mathrm{AH} 3$ and $\mathrm{AH} 4$, as well as the horizontal axis of $\mathrm{AH} 32$, which largely follows the alignment of the Millennium Road. The establishment of roadside facilities by the private sector along these alignments for vehicle maintenance and repair workshops, fuel stations, accommodation, restaurants and communication facilities under standards approved by the Ministry of Road, Transportation, Construction and Urban Development are encouraged.

\section{Water and maritime transport}

As a landlocked country, Mongolia has been taking measures to establish maritime travel under its own flag, to use and own ocean resources and to coordinate the management of marine transportation. Among steps taken is the Maritime Law of Mongolia approved by Ikh Khural State in 1999. To implement this law, the Mongolian Government has taken such measures as appointing the person in charge of carrying out the ship registration process, approving related rules and regulations and gathering relevant documents including international conventions to conform with and implement international requirements for ocean transport.

Two ship registry companies exist, one of which is Mongolia Registry Ship Company. It has successfully operated since its establishment, with 1,200 ships registered from 40 countries. Over 300 ships are sailing under the Mongolian flag.

The Internal Water Transport Division of Mongolia is carrying out inspections and surveying the boats and ferries on Khuvsgul Lake. A total of 120 boats and ferries operate on the lakes and rivers of Mongolia, mainly for tourism.

\section{The Transit Mongolia programme}

On 14 May 2008, the Government of Mongolia adopted Resolution No. 183, approving the national programme Transit Mongolia and its Action Plan for Implementation. Transit Mongolia is the first attempt by the Government to develop a key regional asset, the country's favourable geographic location, in a coordinated manner, with the Ministry of Roads, Transportation, 
Construction and Urban Development leading its implementation. In the "Background" section of the Transit Mongolia programme, the Government acknowledges the following:

"In current times of globalization, using its geographic privileges Mongolia can benefit by becoming a transit country through being part of a integrated network of international trade, transport and logistics, and thus by implementing certain activities to increase its competitiveness in international trade, transport and logistics markets, accelerating its economic growth and resolving many outstanding economic and social issues."

\section{International agreements concluded pertaining to integrated transport}

People's Republic of China (1991.08.26)

Russian Federation (1992.10.29)

Republic of Kazakhstan (1993.10.22)

Democratic Republic of Korea (1996.05.10)

In addition:

The National Road Transport Association of Mongolia is a member of the International Road Transport Union

Mongolia has existing bilateral agreements with eight countries.

Mongolia has existing bilateral agreements with the Russian Federation and China. Mongolian Railway is a member of the Organization for Cooperation of Railways, which has 27 members.

The Government of Mongolia has a bilateral agreement with the EU on certain aspects of civil aviation transport. It has entered into an air services agreement with 35 countries.

Mongolia is a member of the International Maritime Organization, which has 170 Member States.

\section{Pakistan}

Transportation in Pakistan is extensive and varied but still in its developing stages and serving a population of over 170 million people. The transportation sector accounts for about 10.5 per cent of the country's GDP. Although the sector is functional, its inefficiencies with long waiting and travelling times, high costs and low reliability are dragging the country's economic growth. These factors also reduce the competitiveness of the country's exports, increase the cost of doing business in Pakistan, and constrain Pakistan's ability to integrate into global supply chains which require just-in-time delivery.

\section{Road transport}

Road transport is the backbone of Pakistan's transport system. The 9,574-km-long National Highway and Motorway network - which forms 3.65 per cent of the total road network - carries 80 per cent of Pakistan's total traffic. Over the past years, road traffic (both passenger and freight) has grown significantly faster than the national economy. Currently, it accounts for 91 per cent of national passenger traffic and 96 per cent of freight. The quality of road transport services is low. Over half the national highway network is in poor condition, and the road safety record is poor.

\section{Rail transport}

The railway network comprises $8,163 \mathrm{~km}$, of which $1,676 \mathrm{~mm}$ broad gauge forms $7,718 \mathrm{~km}$, including $293 \mathrm{~km}$ of electrified track. The network consists of the main North-South corridor, connecting the Karachi ports to the primary production and population centres in Pakistan. The track is in good condition with an axle load of 23 tons and maximum permitted speeds 
of 100/110 km per hour. Pakistan Railways needs to take major steps to make freight services more competitive. It has a very low and stagnant market share, carrying less than 10 per cent of passenger traffic and 5 per cent of freight.

\section{Seaports and inland waterway ports}

Port traffic in Pakistan has grown 8 per cent annually in recent years. Two major ports, Karachi Port and Qasim Port, handle 95 per cent of all international trade. Gwadar Port, which was inaugurated in March 2007 and is operated by Singapore Port Authority, is aiming to develop into a central energy port in the region. Fourteen dry ports cater to high-value external trade. The performance of port operations is improving, but remains insufficient for the long term.

\section{Freight terminals and other intermodal transport infrastructure}

The Freight Business Unit with 12,000 personnel operates over 200 freight stations on the railway network. The Unit serves Karachi Port and Qasim Port as well as various other stations along the network and generates revenue from the movement of agricultural, industrial and imported products, such as wheat, coal, fertilizer, cement and sugar.

Ongoing and planned transport infrastructure projects of international importance and related investment costs

There is growing recognition within the Government of Pakistan that the sustainability of economic growth is closely linked to the efficiency of its transport system. To support sustained growth and increase competitiveness, the Government is taking a strategic and holistic approach to the transport sector and has launched a major initiative to improve the trade and transport logistics chain along the North-South National Trade Corridor linking Pakistan's major ports in the south and south-west with its main industrial centres and neighbouring countries in the north, north-west and east. The National Trade Corridor Improvement Programme consists of key policy reforms along with a comprehensive investment programme implemented over the Medium Term Development Framework period of 2005-2010.

\section{New proposed transport infrastructure projects of international importance and related investment costs}

There are 21 infrastructure projects of international significance proposed for the road sector, along the following sections:

- Lahore (Wahga)-Islamabad-Peshawar-Torkham

- Lahore-Multan-Rohri-Quetta-Taftan

- Khunjerab-Islamabad-Lahore-Multan-Karachi

- Chaman- Quetta-Kalat-Karachi

- Peshawar-Islamabad

- Dera Ismail Khan-Quetta

In addition, the upgrade of the Quetta-Koh-i-Taftan section has been proposed for the rail sector.

Finally, several projects are foreseen for Quasim Port.

Source: World Bank, Pakistan Transport Sector at http://web.worldbank.org/WBSITE/EXTERNAL/COUNTRIES/ SOUTHASIAEXT/EXTSARREGTOPTRANSPORT/O, ,contentMDK:20699058 menuPK:869060 pagePK:3400417 3 piPK:34003707 theSitePK:579598,00. html. 


\section{Republic of Moldova}

\section{Road transport}

There are 10,531 km of public roads on Moldovan territory, including 9,462 km managed by the central public administration, and $1,069 \mathrm{~km}$ managed by the local public administration of the left bank of the Nistru River. The EATL road network consists of four international AGR arteries, including the East-West oriented E58 road along the (Iaşi) - Chişinău - (Odessa) sector and three connectors: E581 along the Leuşeni - Chişinău - (Odessa) sector, E583 along the (Iaşi) - Balți - (Mogilev-Podolsky) sector, and E 584 along the Dubăsari - Chişinău - Giurgiuleşti sector.

The country continues to suffer from the internal "frozen" conflict in the eastern region of Transnistria, which has been de facto outside the control of the Central Government since 1991. Road transport operators have to bypass the Transnistrian part of the Republic of Moldova to avoid possible difficulties with the region's self-proclaimed authorities. Nevertheless, the road sector's performance improved noticeably between 1998 and 2010, its share in freight turnover measured by ton-kilometre rising from 13 per cent to 60 per cent. This improvement materialized in spite of the continued deterioration of the Republic of Moldova's road network due to the limited investment undertaken in recent years.

\section{Rail transport}

The volume of rail freight increased slowly between 1998 and 2010, while its share of freight transport declined from 87 per cent to 40 per cent. Similar to the road sector, rail continues to suffer from the inadequate maintenance and rehabilitation of the network. The Moldovan components of Pan-European corridors VII and IX, national main railway lines, as well as the OSJD rail corridors and lines on Moldovan territory are considered to be direct links or branches within the EATL network.

\section{Inland waterway ports}

The E-Waterway Network in the Republic of Moldova covers two branches of West-East oriented main inland E-waterways specified in the AGN agreement: E80-07 - the Prut River from its mouth to Ungheni, E90-03 - the Nistru River from the Belgorod-Dnestrovsky port (Ukraine) to Bender, including two inland navigation ports: P90-03-02 Bender (the Nistru, $228 \mathrm{~km}$ ) and P80-62 Giurgiuleşti (the Danube, $133 \mathrm{~km}$ ).

The importance of inland waterways became negligible in the early 1990s when the Central Government lost control of the major port situated in Transnistria. The Government intends to increase the marginal share of inland waterways in freight turnover by developing the new Giurgiuleşti Port, which would ensure the direct connection of the landlocked Republic of Moldova to the Black Sea.

\section{Freight terminals and other intermodal transport infrastructure}

The multimodal Transport Corridor Europe-Caucasus-Asia (TRACECA) crosses both the Black Sea and the Caspian Sea, connecting them with the Moldovan components of PETC IX, which reach the Black Sea port of Odessa along the railway line from the Moldovan-Ukrainian border, via Ukrainian stations Cuciurgan (Kuchurgan) and Razdelnaia and along the Chişinău - Tiraspol - Odessa motorway. The authorities are convinced that this route could be extended along the water from the port of Odessa to the Giurgiulesti Port complex, which has been constructed on Moldovan territory at the mouth of the Danube River (the national component of PETC VII). 


\section{International border-crossing points (road and rail)}

Five road border crossings are situated on EATL routes. All of them are open daily and operate around the clock. The customs checkpoints at two of these crossings are beyond the control of the Government of the Republic of Moldova. Waiting times range between 5 and 15 minutes for passenger cars, to between 20 and 30 minutes for buses, and between 30 and 60 minutes for trucks. Two rail border crossings on EATL routes are open around the clock. The operation of customs and other services at one of them is not controlled by the Government of the Republic of Moldova. Average waiting times at the second railway crossing (on the Romanian border), including the change of carriage bogies, amount to 120 minutes for passenger trains and between 100 and 185 minutes for freight trains.

\section{New proposed transport infrastructure projects of international importance and related investment costs}

The Government of the Republic of Moldova is at the initiation phase of the new investment project to build a new Marculesti-Soroca railway line and the bridge over the Nistru River. The existing railway section that connects Ungheni terminal (Republic of Moldova) and Vapniarca terminal (Ukraine) is $450 \mathrm{~km}$ long. It belongs to PETC IX and EATL routes 3.g. and 6.a. The proposed project will reduce the travel distance from $450 \mathrm{~km}$ to $216 \mathrm{~km}$.

Four road infrastructure projects are ready for implementation (feasibility study, detailed design and bidding documents were developed) along EATL road routes 4.k. and 4.i: one rehabilitation project (4.i.) and three new construction projects. The Balti-Criva project is $133 \mathrm{~km}$ long, with a cost of US\$ 137 million. The other three projects are new construction along EATL road route 4.k. These projects have a length of $65 \mathrm{~km}$ and will cost US\$92 million. They have no secured funds although the Government is planning to complete them by 2020 .

Such priority rail and road infrastructure projects as the rehabilitation and electrification of the Moldovan rail segment of PETC IX and CE95 main line were included in the Land Transport Infrastructure Strategy, which has been developed with the support of the World Bank.

The Republic of Moldova proposed four road rehabilitation projects costing US\$225 million, of which, according to information received, one has committed funding and thus belongs to Category I, while three were classified as Category III.

One new infrastructure project proposal aims at the rehabilitation and electrification of the railway line traversing Moldovan territory from the Ukrainian border through the capital city of Chişinău to the Romanian border. At present, this 209-km main line, which constitutes the Moldovan part of TEN corridor IX and the E95 line defined by the AGC and AGTC, is being operated with diesel locomotives. Project preparation and implementation would take seven years. The project is still proposed with an estimated cost of US\$ 317 million, but funding remains to be secured and hence was assigned to Category IV.

Altogether, the Republic of Moldova has submitted five EATL projects for evaluation, and one road and one rail project of national importance.

Sources: CIS Statistical Committee, NFP Country Report 


\section{Romania}

Transport is an important element in the economy, with a share of 7.15 per cent of GDP in 2010.

\section{Road transport}

Romania's public road network covered $82,386 \mathrm{~km}$ in 2010 , comprising national roads $(16,552 \mathrm{~km})$, county roads $(35,221 \mathrm{~km})$ and communal roads $(30,613 \mathrm{~km})$. In addition, approximately $30,000 \mathrm{~km}$ of village roads serve the needs of rural communities. The EATL road network along PET corridors IV and IX is $1,614 \mathrm{~km}$ long and includes a number of E-roads that coincide with sections of Asian Highways AH1, AH2 and AH3. Four bottlenecks have been identified by the authorities along the E68 and E81 roads (AH3).

Greater flexibility in freight road transport has resulted in it being the most significant share of total freight transport (58.6 per cent of the total volume of goods transported) despite the fact that the freight road transport share of the total amount of freight transported decreased in 2010 from previous years.

\section{Rail transport}

The rail network is extensive; railway infrastructure manager CFR S.A. in 2010 operated a network 10,777 km long, with 971 railway stations and halts. Most of the lines are standard gauge $-1,435 \mathrm{~mm}$ - but the network in operation also has $135 \mathrm{~km}$ of wide gauge railway lines and $4 \mathrm{~km}$ of narrow gauge lines. The total length of electrified railway lines is $4,032 \mathrm{~km}$ (37 per cent of the total line length) and the power supply is $25 \mathrm{kV} / 50 \mathrm{~Hz}$. Much of the rolling stock needs urgent replacement. In 2010, in comparison to previous years, freight rail transport (freight volume-tons) and freight route (ton-kilometre) have recorded an increase. Passenger routes and the number of passengers have decreased.

The EATL network overlaps the railway sections of PETC IV and IX within Romanian territory. The length of these sections (which for corridor IV are considered both the northern and the southern branches) is about $1,990 \mathrm{~km}$.

At present, the main challenge for the Romanian railway sector is to enhance the quality of services offered, with a view to attracting increased flows on the international transport corridors within the country's territory.

\section{Seaports and inland waterway ports}

Three Romanian seaports form part of the EATL network: Constanta, Mangalia and Midia. In addition, the network includes nine inland water ports. In 2010 the length of inland waterways was $1,691 \mathrm{~km}$. Shipping along the Danube, which flows for $1,075 \mathrm{~km}$ within PETC VII, provides Romania with important trade links to Central Europe.

The authorities identified 16 bottlenecks along this EATL route. The $64-\mathrm{km}$ Danube-Black Sea canal, stretching from the lower part of the river to Constanta, has strong development potential as the newly independent Caspian States seek outlets for their hydrocarbon exports that bypass the Bosporus ${ }^{130}$ Strait. The shorter $(28-\mathrm{km})$ Poarta Alba-Midia-Navodari canal also connects inland waters to a Black Sea port. In 2010, the most significant quantities of goods loaded or unloaded in Romanian ports were destined for Turkey (17.6 per cent of total loaded/ unloaded goods), the Russian Federation (14.5 per cent) and Spain (5.1 per cent).

${ }^{130}$ For further clarification on the subject, see official communications received by the Governments of the Russian Federation and Turkey, as well as the extract of document ECE/TRANS/SC.2/GEURL/201 1/9 of the Working Party on Rail Transport, Group of Experts towards Unified Railway Law, the Report of the Group of Experts at its second session in Geneva, held on 7 October 2011 (this can be found at the end of this Annex). 


\section{Freight terminals and other intermodal transport infrastructure}

The container handling capacity of Romania amounts to 1,334 TEU per day. Currently in Romania there are 26 railway terminals with a capacity of 10,500 TEU, some of which, however, are closed. In addition, there are 19 terminals, private industrial tracks for loading or unloading containers. In 2010 the share of the volume of cargo containers loaded and unloaded in ports was 12.5 per cent of total goods loaded and unloaded in Romanian ports.

The ports with greatest activity in 2010 were Constanta ( 79.7 per cent), Midia ( 11.4 per cent) and Galati (4.7 per cent). Constanta Port has oil, ore and container terminals, which are well equipped with handling facilities and operate around the clock.

\section{International border-crossing points (road and rail)}

Romania has five international road border crossings, for both freight and passengers, which operate around the clock. Average waiting times range from 1 to 5 minutes. Three rail border crossings for both freight and passengers are also open 24 hours per day. Average waiting times are longer than at road border crossings, ranging between 4 and 40 minutes for passenger trains and between 150 and 240 minutes for freight trains.

\section{Ongoing and planned transport infrastructure projects of international importance and related investment costs}

The cost of the national programme to construct and upgrade the road infrastructure amounted to approximately $\$ 3.3$ billion over the $2004-2007$ period. Almost $\$ 1$ billion has been allocated to EATL projects. About one quarter of the funding was provided by the State; the remainder included EU pre-accession grants (ISPA and PHARE programmes) and loans from the World Bank, the European Investment Bank, the European Bank for Reconstruction and Development and the Japan Bank for International Cooperation.

Investment expenditure on projects to upgrade EATL railway routes up to 2010 exceeded $\$ 2.1$ billion. The funds were provided by the Government, EU grants and the financial institutions mentioned above.

Romanian inland waterways are subject to improvements in navigation conditions in order to ensure the $2.5 \mathrm{~m}$ minimum depth recommended by the Danube Commission. Different projects are in different stages of implementation with environmental protection duly taken into consideration (i.e. before, during and after their implementation, for instance the Călăraşi-Brăila sector is subject to environmental monitoring). Also on the inland waterways, the Romanian River Information Service and other projects in the information services field are under implementation to increase the safety of navigation.

\section{New proposed transport infrastructure projects of international importance and related investment costs}

Altogether, in Phase II Romania submitted seven projects for evaluation. One road project of national importance ( $\mathrm{Tg}$. Mureş-Iaşi-Ungheni motorway), one maritime project (costing US\$ 196 million) and four inland waterway projects, totalling US\$298 million, along proposed EATL routes were assigned to Category I. Another inland waterway project was assigned to Category IV due to insufficient data.

According to the 2020 intermodal transport strategy of Romania, the construction of at least one terminal is foreseen in one of the six main sites that were identified (the areas of Timisoara,

1) Federal State Statistics Service of the Russian Federation. Basic indicators of Transport in Russia 2010. Official Handbook of Statistics. (Moscow, 2010). 
Constanta, Bucharest, Giurgiu/Oltenita, Brasov and Suceava) with the Sectoral Operational Programme for Transport 2007-2013. Currently the budget is 18,019,383 euros: the Regional Development Fund is a funding source for 12,814,778 euros, with the remaining 5,204,605 euros coming from national public funds within the Sectoral Operational Programme for Transport, Priority Axis 3 - Modernization of the transport sector with an aim to improving environmental protection, human health and passenger safety, Key Area of Intervention 3.1 - Promotion of intermodal transport.

\section{Russian Federation}

The transport network of the Russian Federation is one of the world's most extensive. The country has adopted two national transport strategies in recent years. On 12 May 2005, the Russian Ministry of Transport adopted the Transport Strategy of the Russian Federation to 2020. Three years later, in 2008, the Government adopted a revised strategy, extending to 2030.

The export of transport services is an important component of Russian Federation GDP. The Government anticipated that between 2007 and 2030, the measures included in its 2008 transport strategy would increase the export of transport services to a total value of $\$ 80$ billion, a sevenfold increase on its 2008 value. Foreign cargo weight transported is expected to increase from 28 million tons to 100 million tons over the same period.

\section{Road transport}

As of 2009, the Russian Federation had 982,000 km of roads, of which 776,000 were paved. ${ }^{1)}$ Some of these make up the Russian Federation federal motorway system.

The road network under the EATL framework in the Russian Federation covers 15,716 km with 78 per cent of the roads in good or at least fair condition.

\section{Rail transport}

The Russian Federation has the world's third largest railway network (after that of the United States and China), with a total track length of 85.6 thousand $\mathrm{km}$ as of 2011. Electrified track accounts for around half of the Russian Federation railway network - totalling 44 thousand $\mathrm{km}$ (51.4 per cent) - but carries the majority of railway traffic. Russian Railways moves 1.3 billion tons of freight each year.

\section{Seaports and inland waterway ports}

The Russian Federation has two ports on the Caspian seaboard: Astrakhan and Makhachkala. Additional sea and river ports related to EATL routes are Vladivostok, Nakhodka, Vanino, Vostochny, St Petersburg, Murmansk, Arkhangelsk, Kandalaksha, Dudinka, Omsk, Novosibirsk, Krasnoyarsk, Osetrovo, Blagoveshensk, Vyborg, Vysotsk, Novorossiysk, Tuapse, Taganrog, Kavkaz, Temryuk, Nizhny Novgorod, Volgograd, Cherepovets and Kazan.

Inland waterways in the Russian Federation:

- Branches (TSW):

- TSW 1: Irtysh - (Omsk - Khanty-Mansiysk)

- TSW3: Ob (Novosibirsk - Khanty-Mansiysk)

- TSW5: Yenisey (Krasnoyarsk)

- TSW7: Lena (Osetrovo)

- TSW9: Amur (Blagoveschensk)

- Main route (NSW): St Petersburg - Vytegra - Cherepovets - Nizniy Novgorod - Kazan - Volgograd - Astrahan - Caspian Sea 
- Branches (NSW):

- NSW1: White Sea - Baltic Sea canal

- NSW2: Cherepovets - Bolshaya Volga -- Moscow canal - Moscow

- NSW3: Kama River (Kazan - Perm - Solicamsk)

- NSW4: Volgograd - Volga-Don canal - Rostov-on-Don

\section{Freight terminals and other intermodal transport infrastructure}

In terms of intermodal transport infrastructure, TransContainer, the intermodal daughter company of Russian Railways, conducted trials for fast transit of more than 150 TEU container trains on different routes in 2010. The volume of transit transportation of containers in 2010 was 152 thousand TEUs (28.2 per cent more than in 2009). Furthermore, enhanced infrastructure allows container trans-shipment at docks in Olja Port. Due to demand for the development of specialized container terminals on inland waterways providing transportation and trans-shipment on the international North-South transport corridor, additional container terminals in St Petersburg, Moscow-North, Yaroslavl, Nizhniy Novgorod, Kazan, Samara, Volgograd, Astrakhan, Ust-Donetsk, Rostov-on-Don and Azov riverports were planned to be constructed by 2010.

International border-crossing points (road and rail)

Major road border-crossing points with EATL countries are situated on borders with Azerbaijan $(284 \mathrm{~km})$, Belarus (959 km), China $(3,645 \mathrm{~km})$, Georgia $(723 \mathrm{~km})$, Kazakhstan $(6,846 \mathrm{~km})$ and Ukraine $(1,576 \mathrm{~km})$. As of September 2006, there were six rail border-crossing points to Belarus and 17 to Ukraine.

Ongoing and planned transport infrastructure projects of international importance and related investment costs

Road projects that were expected to be completed by 2010 include:

- "Chujsky trakt" (52/A-4 motorway): Novosibirsk - Barnaul - Tashanta - border with Mongolia to become the main route connecting the Siberian federal district region with other parts of the Russian Federation and China

- East Khabarovsk - Nakhodka highway: $824 \mathrm{~km}$, of which $342 \mathrm{~km}$ are already operational

- Khabarovsk - Lidoga - Vanino highway: $527 \mathrm{~km}$, construction of Lidoga - Vanino section already started and $24.4 \mathrm{~km}$ are operational; investment of US\$145 million)

Rail projects envisaged to be completed by Russian Railways by 2010:

- development of routes linking the Kuznetsk coal basin with the Far East, the Azov Sea and Black Sea, and with transport hubs in the north-west (US\$ 4.5 billion)

- construction of the Berkakit - Tommot - Kerdem (Yakutsk) line (US\$ 0.1 billion in 2006-2008)

- reconstruction of the Mga-Gatchina - Veimarn - Ivangorod line and the rail approaches to ports along the south coast of the Gulf of Finland (US\$ 1.0 billion by 2010)

improvement of the rail approaches to Ust-Luga (US\$ 0.37 billion)

New proposed transport infrastructure projects of international importance and related investment costs

The Russian Federation proposed 17 projects of international importance with an estimated total cost of US\$72,565 million, to be completed by 2015 . These mainly involve the construction and reconstruction of road sections between Moscow and the border with Belarus, the border 
with Ukraine, Novorossiysk, Chelyabinsk, Astrakhan, Ufa, Archangelsk and St Petersburg. Other projects include:

- construction and reconstruction of the M-10 Scandinavia road - from St Petersburg via Vyborg to the border with Finland

- reconstruction of the M-18 Cola road - from St Petersburg via Petrozavodsk, Murmansk, Pechenega to the border with Norway (international automobile Borisoglebsk bordercrossing point)

- construction and reconstruction of the M-21 Volgograd - Kamensk - Shakhtinsky road to the border with Ukraine (in the direction of Kyiv, Chisinau)

- construction and reconstruction of the M-23 Rostov-on-Don - Taganrog road to the border with Ukraine (in the direction of Kharkov, Odessa)

- reconstruction of the M-32 Samara - Big Chernigovka road to the border with Kazakhstan (Uralsk, Aktyubinsk, Kyzyl-Orda, Chimkent)

- construction and reconstruction of the M-51, F-53, M-55 Baikal road - from Chelyabinsk via Kurgan, Omsk, Novosibirsk, Kemerovo, Krasnoyarsk, Irkutsk, Ulan-Ude to Chita

- construction and reconstruction of the M-60 Ussuri road - from Khabarovsk to Vladivostok

- reconstruction of the A-229 Kaliningrad - Chernyakhovsk - Nesterov highway to the border with Lithuania (in the direction of Vilnius, Minsk, Belarus road)

- reconstruction of sections of the 1P 242 Perm - Yekaterinburg road

- construction and reconstruction of the M-52 "Chuysk Tract" road - from Novosibirsk via Biysk to the border with Mongolia

With regard to the rail sector, 23 rail projects of international significance were proposed:

- construction of third track in Lyangasovo - Kotelnich passage

- construction of third track in Perm - Chaikovskaya passage

- construction of third track in Tumen - Voinovka passage

- reconstruction of St Petersburg railway junction

- construction of side track in Vyborg-Pass - Buslovskaya passage

- construction of byroad around Saratov junction

- construction of side track in Saratov - Petrov Val passage

- construction of side track in Enem - Krivenkovskaya passage

- construction of side track in Enem (Afipskaya) - Krimskaya passage

- construction of byroad around Krasnodar junction

- construction of third track in Voskresensk - Ryazan passage

- construction of third track in Likhaya - Rostov passage

- electrification of Rtishevo - Kochetovka passage

- construction of side track in Akhtuba - Trubnaya passage

- electrification of Trubnaya-Aksarayskaya passage

- construction of third track in Bekasovo - Nara passage

- construction of special passenger Moscow - St Petersburg high-speed backbone

- reconstruction of Moscow - Krasnoye line for organization of high-speed passenger traffic

- construction of third main track in Kosulino - Bogdanovich section

- construction of second main track in Kharanor - Zabaykalsk section

- construction of second main track in Volgograd - Akhtuba section

- construction of second main track in Murmansk - Apatity, Segeja - Medvejia Gora section

- construction of second main track in Krymskaya - Vyshesteblevskaya section 
In addition, the Russian Federation envisages projects for five major ports aimed at increasing annual throughput, namely Ust-Luga Seaport, St Petersburg Seaport, Murmansk Seaport, Vostochny Seaport and Novorossiysk Seaport.

Finally, five intermodal terminals projects are proposed, totalling US\$17,240 million, which have committed funding. These include the:

- comprehensive development of the Murmansk transport hub project

- comprehensive development of the Vostochny - Nakhodka transport hub project

- comprehensive development of the Novorossijsk transport hub project (Krasnodar region)

- development of the multimodal transport and logistics Rostov Universal Port hub project

- construction of the Sviyajsky interregional multimodal logistics centre (Republic of Tatarstan)

\section{Tajikistan}

Tajikistan, a landlocked country with mountainous territory, has one of Central Asia's least developed transport sectors and one the world's highest transport costs. Since 2000, Tajikistan has dramatically improved its transport infrastructure due to rapid growth in regional trade especially with China and other Central Asian countries.

The goal of the Tajikistan country partnership strategy for 2010-2014 is to meet soaring demand by developing transport infrastructure, building human capacity and achieving good governance. In addition, the country is actively participating in the CAREC programme. To this end, Tajikistan has developed a national transport sector master plan with the assistance of ADB, supportive of CAREC's Transport and Trade Facilitation Strategy (2008-2018) and Tajikistan's national development programme.

\section{Road transport}

The Tajik road system covers $27,767 \mathrm{~km}$ with road density of $194 \mathrm{~km}$ per $1,000 \mathrm{~km} 2$. The Ministry of Transport and Communications, Tajikistan's central governing body for the transport sector, has jurisdiction over roughly 14,000 km of the country's road network. About 29 per cent of these roads are paved in asphalt.

The EATL road network in Tajikistan covers four major routes on three international roads (AH7, AH65, AH66) with a total length of $1,924 \mathrm{~km}$ :

- Tursunzade (border with Uzbekistan) to Kofirnigan

- Kofirnigan to border with Kyrgyzstan

- Kofirnigan to Kulma Pass (border with China)

- Chavast (border with Uzbekistan) to Nihiniy Panj (border with Afghanistan)

The major part is within the TRACECA, except for the Nizhiniy Panj to Afghan border $(0.2 \mathrm{~km})$ and Murgab to Kulma Pass $(91 \mathrm{~km})$ sections. The current physical status of the AH network ( $141,000 \mathrm{~km}, 32$ countries) with a missing link (no road) of $100 \mathrm{~km}$ indicates that $33 \mathrm{~km}$ of that missing link are located on AH66 in Tajikistan.

\section{Rail transport}

The railway network covers $951 \mathrm{~km}$ and has one of the lowest densities in the Central Asian region, mainly due to topographical constraints.

Railways carry 50 per cent of Tajikistan's exports and imports. There are three domestic networks: northern, central and southern. The northern line dominates freight transit traffic, the central line is mainly for imports and the southern line has a low volume of freight traffic. 
Apart from the topography, restricted network interconnectivity, too few and ageing rolling stock and locomotives, and heavy dependence on the Uzbek and Turkmen railway systems hinder the expansion of the railway network.

\section{Seaports and inland waterway ports}

Although Tajikistan is a landlocked country, a small volume of transport is conducted on the $200 \mathrm{~km}$ of inland waterways along the Vakhsh River.

\section{International border-crossing points (road and rail)}

The following border-crossing points are operational:

- Afghanistan (1,206 km): Nihiniy Panj, Ashkasham (both road)

- China (414 km): Kulma Pass (road)

- Kyrgyzstan (870 km): Oktajabr'sk, Bekabad (both rail)

- Uzbekistan (1,161 km): Tursun-zadeh (road), Ajvadz (rail), Chavast (road), Sughd Oblast (Navruzobod)

The Bratsvo international checkpoint facility at Tursun-zadeh is fully equipped with computers and passport readers, allowing the transmission of information on the border crossing to all applicable Tajik agencies. As a result of the EU Border Management Programme in Central Asia, border-crossing points on the Tajik-Afghan border at Darvoz, Tem and Ishakashim are currently under construction. The new facilities will encourage inter-agency cooperation and facilitate trade and transit while enhancing border security.

\section{Ongoing and planned transport infrastructure projects of international importance and related investment costs}

The Government has adopted an ambitious Tajik transport development programme to be implemented by 2015 that focuses on the international transport corridors.

The Government needs to take the following actions pertaining to road transport:

In the short term (by 2015):

- rehabilitate CAREC corridors

- increase maintenance funding

- improve road data collection and compilation

- improve efficiency with unbundling, privatization, mechanization and quality control

- introduce systematic road-user charges, based on the costs of vehicular road damage

- simplify and harmonize border-crossing requirements

In the medium term (2016-2020):

- continue rehabilitating international corridors

- start rehabilitating key national roads

- improve and complete connections to China

In the long term (post 2020):

- complete the rehabilitation of international and national roads

- gradually expand investment to local roads

The following actions are envisaged pertaining to rail transport:

In the short term (by 2015):

- rehabilitate existing assets (wagons, coaches and locomotives); repair facilities, tracks and quarries

- explore better provisions for Tajik Railways' existing traffic base, particularly for 
international and Uzbek transit traffic

- establish business development and planning units

- prepare for containerization and multimodal traffic

- create a database for use by Tajik Railways and the Ministry of Transport and Communications that includes:

- comprehensive track inventory and condition surveys, with regular updates

- passenger travel and cargo shipments, by origin and destination

- cost-accounting information by service and line section

- regional development and expansion

- corporatize railway operations

In the medium term (2016-2020):

- continue to rehabilitate existing infrastructure and modernize rolling stock

- investigate subsidizing selected railway lines that have high social importance

In the long term (post 2020):

- expand major railway lines, depending on committed regional development programmes that involve sections of the domestic rail network

- privatize Tajik Railways

New proposed transport infrastructure projects of international importance and related investment costs

Tajikistan submitted 12 projects along EATL routes, amounting to a total cost of US\$ 627 million. The road projects planned for completed in 2011 included the reconstruction of existing sections, as well as the construction of new roads:

- reconstruction of the Dushanbe-Kulma road, Dushanbe-Dangara section

- construction of the Chormagzak tunnel

- construction of the Shagon-Zigar road, Phase 2

- reconstruction of the Kurgantyube-Dusti road

- reconstruction of the Dusty-Nizhniy Panj road, Phase 2

- reconstruction of the Dushanbe-border with Uzbekistan road (CAREC III project)

- restoration of the Gulistan-Parhar-Panj-Dusti road

Two railway projects along EATL routes were proposed, which required foreign investment:

- improving the Bekabad-Kanibadam railway section

- modernizing the Dushanbe 1 railway station cargo terminal, which has been privatized

In addition to these, several other projects were proposed along routes of national importance.

Finally, the creation of logistics centres in the country is envisaged, for a total cost of US\$ 20 million. Currently, with the assistance of the TRACECA programme, the feasibility study for the Nizhniy Panj Logistic Centre is being developed, estimated at US\$13.3 million, although it needs to attract foreign or domestic investment.

Sources: CIA World Factbook

http://www.asiandevbank.org/Documents/Reports/CAREC/Transportation-Facilitation.pdf

http://bomca.eu-bomca.org/en/taj

http://dushanbe.usembassy.gov/pr_012606.html

http://www.iselinconsulting.com/Afghanistan/Afghanistan_9.htm

Asian Development Bank, Transport and Communications. Developing Tajikistan's Transport Sector: Transport Sector

Master Plan (Manila, 2011). Available from http://www.adb.org/sites/default/files/pub/2011/transport-taj.pdf. 


\section{The former Yugoslav Republic of Macedonia}

The contribution of transport to GDP in 2009 in the former Yugoslav Republic of Macedonia was 7.9 per cent.

\section{Road transport}

Road infrastructure in the former Yugoslav Republic of Macedonia in 2009 included $8,024 \mathrm{~km}$ of paved roads. Motorways comprise $224 \mathrm{~km}$. E-road length is $553 \mathrm{~km}$. The EATL road network in the former Yugoslav Republic of Macedonia is $553 \mathrm{~km}$ in length, and consists of the following highways: E-75 Serbian border crossing-Tabanovce-Kumanovo-Miladinovci-PetrovecVeles-Negotino-Gevgelija-Bogorodica-Idomeni (Greece) (part of corridor X) and E-871, E-65 Bulgarian border crossing-Deve Bair- Kriva Palanka-Kumanovo-Skopje-Tetovo-GostivarKicevo-Struga-Albanian border crossing (part of corridor VIII.

There is a bottleneck on the corridor $\mathrm{X}$ highway in the section consisting of $1+1$ lanes.

\section{Rail transport}

The rail network is not fully completed along corridors X and VIII. In 2009 there were $699 \mathrm{~km}$ of rail track, of which $233.5 \mathrm{~km}$ were electrified and $466.1 \mathrm{~km}$ were non-electrified.

The Tabanovce-Kumanovo-Skopje-Veles-Gevgelija-Bogorodica rail line is part of EATL network corridor X in the former Yugoslav Republic of Macedonia, and from Deve Bair-Kriva Palanka-Beljakovce-Kumanovo-Skopje-Kicevo-Struga it is part of corridor VIII. This rail corridor is fully electrified over its length of $214.9 \mathrm{~km}$. The track along all rail lines in the former Yugoslav Republic of Macedonia is in 1,435 mm standard gauge. Missing links on corridor VIII are from Kumanovo to the Bulgarian border and from Kicevo to the Albanian border. Bottlenecks on the tracks occur at those locations where the speed of movement is slow as a result of the rail lines' geometric characteristics.

In 2007 the state-owned railway company was split into two companies: one responsible for rail infrastructure and other responsible for rail operations.

\section{International border-crossing points (road and rail)}

The former Yugoslav Republic of Macedonia has four international border-crossing points on the road infrastructure along corridor X: Tabanovce-border with Serbia, Bogorodica-border with Greece, and on corridor VIII Deve Bair-border with Bulgaria and Kafasan-border with Albania. The rail border-crossing points are on corridor X: Tabanovce-border with Serbia, and Bogorodicaborder with Greece. Average waiting times range from 30 minutes for passenger trains to between 90 and 120 minutes for freight trains.

\section{Freight terminals}

There are no freight terminals in the former Yugoslav Republic of Macedonia. A tender procedure to prepare a study on the development of strategic multimodal transport nodes is under way, to be completed in 2013.

\section{Ongoing and planned transport infrastructure projects of international importance}

The existing ongoing and planned transport infrastructure projects of international importance include: works are under way to upgrade the section of corridor X from Tabanovce (border with Serbia) to Kumanovo ( $7.5 \mathrm{~km}$ in length) to the level of motorway, at a total cost of 15.5 million euros. This section was scheduled for completion in September 2011.

Completion of the last section of the highway within corridor X from Demir Kapija to Smokvica $(28.2 \mathrm{~km})$ is planned. 
A new, modern traffic signalling system will be introduced (totalling 5.5 million euros) in corridor X in 2012-2013.

Other road infrastructure projects are planned, including the construction of new highways from Kriva Palanka (border with Bulgaria)-Romanovce $(60 \mathrm{~km})$ and from Gostivar-Struga (border with Albania) $(128 \mathrm{~km})$ which are to be financed by concession.

Planned activities also include the reconstruction of part of the highway on the KatlanovoVeles section of corridor X in both directions, between 2012 and 2014, as well as the construction of new highways that are not part of the corridors along EATL routes.

Planned rail infrastructure projects include the renewal of rail sections on corridor $\mathrm{X}(54 \mathrm{~km})$ to improve safety and increase the speed on some sections to a maximum of $120 \mathrm{~km} / \mathrm{h}$ by the end of 2013. Planned activities also include renewal with reconstruction of the Bitola-Kremenica (border with Greece) railway section, as part of corridor X, branch Xd, for a total cost of 9 million euros, and rehabilitation of the largest rail stations along corridor $\mathrm{X}$, totalling 8.9 million euros. On corridor X, equipment for European Train Control System (level 1) will be supplied and installed for a total of 3 million euros. Planned activities for corridor VIII are: construction of a new rail line from Kriva Palanka (border with Bulgaria) to Beljakovce $(60 \mathrm{~km})$, construction and reconstruction of the existing railway line from Beljakovce to Kumanovo $(29 \mathrm{~km})$ and the preparation of detailed design and tender documentation for construction of a new railway section from Kicevo to the border with Albania.

\section{Challenges that face transport and transport infrastructure}

Toll system modernization and the introduction of an integrated system for toll collection on five existing stations are needed, as well as the construction of four new stations with electronic toll collection equipment, which is planned for implementation between 2012 and 2016 on corridor X. Another challenge is the need to construct modern roads (transforming State roads into modern highways with two $2+1$ lanes) that are not part of corridor $\mathrm{X}$ and VIII but that are of high importance for the road network.

Challenges are also being faced pertaining to rail infrastructure due to plans to improve and modernize the rail lines along corridor $\mathrm{X}$ and VII (on EATL routes), rebuild and modernize railway stations and modernize the rolling stock, and introduce new electronic equipment.

\section{Turkey}

\section{Road transport}

The General Directorate of Highways administers $65,219 \mathrm{~km}$ of roads, including 2,236 km of motorways. The total length of the state and provincial road network is $62,983 \mathrm{~km}$. Road is the dominant transport mode; in 201091.8 per cent of passenger-kilometre and 88.8 per cent of tonkilometre were carried by road. In recent years, road surfaces have been considerably improved, and some roads have been widened. The length of dual carriageway roads opened to traffic reached $15,126 \mathrm{~km}$ including motorways in the 2003-2011 period; it totals $21,227 \mathrm{~km}$ today. Thirty-three per cent of the total network consists in dual carriageways. The motorways and two bridges across the İstanbul ${ }^{131}$ Strait are toll roads.

${ }^{131}$ For further clarification on the subject, see official communications received by the Governments of the Russian Federation and Turkey, as well as the extract of document ECE/TRANS/SC.2/GEURL/201 1/9 of the Working Party on Rail Transport, Group of Experts towards Unified Railway Law, the Report of the Group of Experts at its second session in Geneva, held on 7 October 2011 (this can be found at the end of this Annex). 


\section{Rail transport}

The total rail network is $12,000 \mathrm{~km}$, characterized by mountainous terrain, tight curves and steep gradients. The total length of the main lines, including the high speed lines, is $9,642 \mathrm{~km}$. Ninety per cent of main lines are single track and 26 per cent are electrified. Rail plays a relatively modest role in inland transport, in 2010 accounting for 1.6 per cent of passenger-kilometre and 5.3 per cent of ton-kilometre.

Turkish State Railways runs major seaports in Turkey, which are generally State owned. Turkish State Railways also operates the following international trains:

- H.Paşa-Almaty (Kazakhstan) block container train

- H.Paşa-Tehran-Islamabad block container train

- Cologne-Köseköy train

- Halkali-Sopron container train

- Çukurhisar-Vienna block train (container and conventional wagons)

- Halkal1-Vienna, Sopron block container trains

- Halkal1-Ljubljana block container train

- Halkal1-Czech Republic conventional block train

- Cologne-Derince conventional block train

A number of planned projects aim to increase the role of railways. Branch lines are being built to industrial zones to increase the share of railways in freight transport. Since 2002, the number of branch lines has increased from 281 to 326.

In passenger transport, high-speed train operations are gaining in importance. Within this framework, the construction of a high-speed railway line between the two biggest cities in Turkey, İstanbul and Ankara, has started. The operation of high-speed trains already began in March 2009 on the Ankara-Eskişehir section, which is an important part of the whole Ankara-Istanbul high-speed line, while construction between Eskişehir-İstanbul continues. High-speed trains reaching $250 \mathrm{~km} / \mathrm{h}$ will decrease travel time between İstanbul and Ankara from seven hours to three hours. This project's integration with the Marmaray project that will connect Europe and Asia through a tube-tunnel crossing under the Istanbul ${ }^{132}$ Strait will allow passengers to travel from the middle of Turkey to the middle of Europe without interruption. In addition, high speed train operations between Ankara-Konya were started in August 2011. Furthermore, the AnkaraSivas high-speed railway line is being constructed; the contract for construction of the BursaOsmaneli high-speed line, which will connect Bursa to the Ankara-İstanbul line, was concluded in December 2011; the tendering process for the first phase of the Ankara-İzmir high-speed railway line is continuing while applications for the second phase are being revised.

Since the track gauge is different in Turkey $(1,435 \mathrm{~mm})$ than in the Eastern Europe, Caucasus and Central Asian countries $(1,520 \mathrm{~mm})$, during transport to these countries either the axles of the wagons must be changed or the goods must be transferred to other wagons. One exception is provided by the ferry link between the ports of Derince (Turkey) and Ilyichevsk (Ukraine) which permits Eastern Europe, Caucasus and Central Asian wagons to be loaded with freight in Turkey, bypassing the gauge change. Also, a bogie exchange station was constructed on Samsun Port and demonstration train-ferry runs between Samsun Port and Kavkaz Port (Russian Federation) were started in December 2010.

${ }^{132}$ For further clarification on the subject, see official communications received by the Governments of the Russian Federation and Turkey, as well as the extract of document ECE/TRANS/SC.2/GEURL/201 1/9 of the Working Party on Rail Transport, Group of Experts towards Unified Railway Law, the Report of the Group of Experts at its second session in Geneva, held on 7 October 2011 (this can be found at the end of this Annex). 


\section{Seaports and inland waterway ports}

Sea transport is important for domestic and international trade and travel, with three of Turkey's major industrial agglomerations (İstanbul-İzmit, İzmir and Adana-Mersin) located on the coast. The share of maritime transport in merchandise trade is almost 90 per cent by volume and 50 per cent by value. The ports of Derince, Haydarpaşa and İzmir, operated by Turkish State Railways, are important components of the EATL network. Mersin, Samsun, Bandirma and İskenderun Ports (previously operated by Turkish State Railways) were privatized. All are well connected to railways and roads. The privately owned port of Trabzon is also an EATL facility but has no railway connection, although it has effective road connections.

Major Turkish ports have active Ro-Ro and train-ferry connections with some important ports in Algeria, Egypt, Georgia, Italy, the Russian Federation, Slovenia and Ukraine.

Inland water transport of freight is of marginal importance. Van Lake is the only part of the EATL inland water system in Turkey. The train-ferry operating on the lake is an essential link in an EATL rail route connecting South-East Europe to Iran.

\section{Freight terminals and other intermodal transport infrastructure}

Logistic centres, considered the heart of modern freight transport, are being constructed in Turkey as well. Modern logistics centres are being built in 16 different locations (those close to organized industrial zones and with high freight potential), namely İstanbul, İzmit (Köseköy), Samsun (Gelemen), Eskişehir (Hasanbey), Kayseri (Boğazköprü), Balıkesir (Gökköy), Mersin (Yenice), Uşak, Erzurum (Palandöken), Konya (Kayacık), Denizli (Kaklık) ve Bilecik (Bozüyük), Kahramanmaraş (Türkoğlu), Mardin, Kars and Sivas.

Apart from Turkish State Railway ports, container terminals are located in Halkalı, Başpınar (Gaziantep) and Bozüyük. Halkalı has a container handling capacity of $400 \mathrm{TEU} /$ day.

\section{International border-crossing points}

There are two road border crossings with Bulgaria (one for freight only), one with Georgia and one with Iran. All operate around the clock. Average waiting times range between 20 and 30 minutes for private cars, between 1 and 8 hours for buses, and between 20 minutes and 2 hours for trucks.

Three rail border crossings exist. On the border with Bulgaria, the average waiting time is 75 minutes for freight trains, while for passenger trains the average waiting time is between 70 and 95 minutes. On the Iranian border, the average waiting time for freight trains is 156 minutes and for passenger trains it is 95 minutes. The border crossing with Armenia remains closed.

\section{Ongoing and planned transport infrastructure projects of international importance and related investment costs}

In the road sector, five projects totalling US\$ 800 million are still ongoing and are planned to be completed by 2014. They are part of a bigger project to develop an important existing road connection (Gerede-Koyulhisar) on EATL route-5 connecting Europe with Iran.

There are seven ongoing projects pertaining to the rail sector. The estimated aggregate cost of these projects is approximately US $\$ 20$ billion. Five projects are under construction. Two are still at the planning stage with no funding secured. Railway projects include the high-speed railway connections of Ankara-İstanbul, Ankara-Sivas and Ankara-İzmir, the new railway connection of Kars-Tbilisi-Baku and the Van Lake northern crossing point.

There are four ongoing and planned port projects related to the rehabilitation and modernization of Derince, İzmir, Mersin and İskenderun Ports. 


\section{New proposed transport infrastructure projects of international importance and related investment costs}

A number of proposals for new infrastructure road projects have been reported. These include work on the Ankara-Eregli Junction motorway, the İzmit-İzmir motorway and the North Marmara motorway, amounting to total costs of US\$ 13 billion. The İzmit-İzmir motorway has already been awarded and construction started in 2011. According to available information, these were assigned to Category II.

Two new rail projects were submitted for a total cost of approximately US $\$ 4$ billion. One (Adapazarı-Bartın) was assigned to Category II and the other (Bandırma-İzmir) to Category III.

Three new port construction projects, Mersin Container Port, Filyos Port and Çandarlı Port, were reported. These three projects are on EATL routes and are expected to be major ports in the Mediterranean Sea, Black Sea and Aegean Sea, respectively. The total expected cost of these projects is approximately US\$ 6.3 billion. The Çandarlı Port project was assigned to Category I, and the Filyos Port and Mersin Container Port projects were assigned to Category II.

Altogether, Turkey submitted 24 EATL projects for evaluation. Fifteen of these projects were assigned to Category I, six were assigned to Category II, one was assigned to Category III and two were assigned to Category IV.

\section{Turkmenistan}

By virtue of its geographical location, history and economic circumstances within the region of Greater Central Asia, Turkmenistan should be a major crossing point for both regional and continental transport. The new century witnessed important changes both within Turkmenistan and in the country's relationship to issues of transport and trade. In 2006, the Government announced its intention to redouble its efforts to integrate its highway and railroad systems more closely with continental East-West routes across Iran, and to begin by upgrading its main roads to both Afghanistan and Iran.

\section{Road transport}

In 2001, Turkmenistan had an estimated $22,000 \mathrm{~km}$ of roads, about $18,000 \mathrm{~km}$ of which were paved. One major highway runs westward from Mary, along the Iranian border through Ashgabat and then to Turkmenbashi on the Caspian Sea, while a second runs north-westward from the Afghan border through Turkmenabat, along the Uzbek border to Dashhowuz. In the early 2000s, major road-building projects improved sections of the highway connecting Ashgabat with Turkmenbashi and Mary.

\section{Rail transport}

In 2005, Turkmenistan had 2,440 km of railroad line, most of which runs close to the northern and southern borders. The Tejen-Serakhs-Mashhad railroad, built in 1996 by Turkmenistan and Iran, has become a vital link of the Central Asian, Russian Federation and European railroad systems with South Asia and the Persian Gulf. In February 2006, the final construction phase began on the Trans-Garagum Railway, a direct link between Ashgabat and Dashhowuz that will halve travel time between the southern and northern borders.

\section{Seaports and inland waterway ports}

The main port is Turkmenbashi on the Caspian Sea; the main shipping lines cross the Caspian to Astrakhan in the Russian Federation and Baku in Azerbaijan. Smaller Caspian ports are Alaja, Chekelen and Ekarem. Plans call for expansion of Ekarem into a second major Caspian port. 
The main inland waterways are the Amu Darya River, which runs along the northern border, and the Garagum Canal, which runs east to west from the Amu Darya near the Afghan border through Mary and Ashgabat to Turkmenbashi on the Caspian coast. The 1,400-km canal, designed mainly for irrigation, is navigable for $450 \mathrm{~km}$ from its Caspian terminus. Because water is withdrawn for irrigation, the Amu Darya is navigable only about $250 \mathrm{~km}$ downstream from the Afghan border to Turkmenabat.

\section{Ongoing and planned transport infrastructure projects of international importance and related investment costs}

Turkmenistan participated in the six-country (Afghanistan, Iran, Pakistan, Tajikistan, Turkmenistan and Uzbekistan) Central-South Asian Transport and Trade Forum. This undertaking was expected to reopen a series of road corridors centring on north-western Afghanistan at a cost of US\$ 5.7 billion, which would come mainly from international donors.

Turkmenistan recently joined CAREC. As a result, improvements are planned to certain important regional transport infrastructure, including key Caspian seaport infrastructure projects, along CAREC corridors, with other international financial institutions or key bilateral donors.

Also proposed was the implementation of the construction of a railway line from Turkmenistan to Afghanistan with a view to extending it onward in the territory of Afghanistan. The project entails construction of the $85-\mathrm{km}$ Atamyrat-Imamnazar section on the territory of Turkmenistan.

Source: Railways of Afghanistan at http://www.andrewgrantham.co.uk/afghanistan/3745/turkmenistanto-afghanistan-railway-discussed/

\section{Ukraine}

On 20 October 2010 the Cabinet of Ministers of Ukraine adopted the Transport Strategy of Ukraine for the Period Up to 2020, which identifies the main priorities for the development of all modes of transport.

According to the State Statistics Committee of Ukraine, in 2009 the share of transport in GDP amounted to 11.3 per cent.

\section{Road transport}

As of 2010, the share of freight transport by road is 72.7 per cent. There are 169.5 thousand $\mathrm{km}$ of roads (category III or higher): 20.1 thousand $\mathrm{km}$ are state roads and 149.4 thousand $\mathrm{km}$ are regional roads; there are a total of 16.2 thousand bridges. The State Programme of Road Development for the 2012-2016 Period has been adopted. It corresponds to the main EATL routes and to the priority road network of Ukraine connecting the TEN-T.

\section{Rail transport}

Rail is still a significant domestic mode of transport for freight, although road transport now accounts for a larger (and increasing) share of the total. Cargo transport by rail could be increased; in 2010 its share was 26.6 per cent. The operational length of railways in Ukraine is 21.68 thousand $\mathrm{km}$, which includes electrified lines of 9.85 thousand $\mathrm{km}$. Railways are operated by the State Railway Administration of Ukraine, which consists of six regional railways. Railway infrastructure includes 121.3 thousand freight cars and 7.3 thousand passenger coaches.

\section{Seaports and inland waterway ports}

Eighteen commercial seaports are located on the Black Sea, Azov Sea and Danube basins. There are also 4 fishing ports, 13 private trans-shipment complexes and 12 river ports operating in Ukraine. The length of the largest European river waterways, Danube and Dnepr, is 2.2 thousand $\mathrm{km}$. All ports are developing according to the Programme of Port Development, adopted for each port separately. 


\section{International border-crossing points}

On the Ukrainian border, 148 international border-crossing points are in operation: 57 automobile, 34 rail, 29 sea, 24 air, 3 river and 1 ferry. Most operate around the clock.

Ongoing and planned transport infrastructure projects of international importance and related investment costs

Infrastructure development is realized according to the development programmes of the different modes of transport. The Development of International Transport Corridors Programme for the 2006-2010 period is finished; it comprised 1,394.2 million euro in investment, including 201.3 million euros from the State.

Ukraine cooperates with international financial institutions. For instance EBRD's credit portfolio for investment projects totalled 2,467.6 million euros, including credit investment of 1,129.4 million euros. The credit portfolio for investment projects of the International Bank of Reconstruction and Development totalled 386.5 million euros, including credit investment of 298.5 million euros. The credit portfolio for European Investment Bank investment projects totalled 1,721.4 million euros, including credit investment of 650 million euros.

\section{New proposed transport infrastructure projects of international importance and related investment costs}

Four investment projects were proposed. The total amount of investment amounted to $1,568.85$ million euros.

\section{Uzbekistan}

\section{Road transport}

The road system in Uzbekistan covers an estimated 183 thousand $\mathrm{km}$ with road density of $409 \mathrm{~km}$ per 1,000 km2. The EATL network spans 3,626 km along AH5, AH7, AH62, AH63 and AH65.

\section{Rail transport}

The railway network covers $4,230 \mathrm{~km}$ and provides a rail density of $13.5 \mathrm{~km}$ per $1,000 \mathrm{~km} 2$. Freight services amount to 23 billion ton-kilometre per annum. The EATL network spans approximately $2,154 \mathrm{~km}$ (excluding shared route sections) on the following routes:

- Keles to Karakalpakiya (1,686 km)

- Keles to Hodjadavlet $(732 \mathrm{~km})$

- Havast to Bekabad on the route from Karakalpakiya to Osh, Kyrgyzstan (33 km)

- Karakalpakiya to Termez port $(1,732 \mathrm{~km})$

\section{Seaports and inland waterway ports}

Uzbekistan, a landlocked country, shares a 420-km shoreline on the southern edge of the Aral Sea. Uzbekistan operates the inland port on the Amu Darya River at Termez. The waterways within the country measure $1,000 \mathrm{~km}$ in length.

\section{Freight terminals and other intermodal transport infrastructure}

Overall, eight inland container depots, intermodal freight terminals (rail/road) and freight villages/logistics centres operate along the EATL: Chukursai, Tashkent, Sergeli, Ulugbek (Samarkand), Termez, Margilan, Bukhara-2 and Andijan (north). General opening hours are from 8 a.m. to 8 p.m. every day. 


\section{International border-crossing points (road and rail)}

Uzbekistan operates border-crossing points along the border with the following countries:

Afghanistan 137 km: Galaba, Termez, Amuzang (all rail), Hayraton (road)

Kazakhstan 2,203 km: Karakalpakiya and Keles (rail), Karakalpakiya and Yallama (road)

Kyrgyzstan 1,099 km: Savay, Sultanobod, Xonobod, Uchkurgan (rail), Dustlik (road)

Tajikistan 1,161 km: Bekobod, Suvanobod/Andarhon, Amuzang, Kudukli/Uzun (rail), Gulbahor, Sariasiya, Djartepo, Aybek, Andarhon (road)

Turkmenistan 1,621 km: Nishon, Pitnyak, Hodjadavlet, Hodjeyli, Alat (rail), Hodjeyli and Alat (road)

As of 2010, 89 customs points were operational. Of these, 26 are mobile customs points, 13 are rail border-crossing points, 49 are road border-crossing points and 1 is a river border-crossing. Fifty-eight customs points are dedicated to "foreign economic relations".

\section{Ongoing and planned transport infrastructure projects of international importance} and related investment costs

Currently six infrastructure projects (four concerning rail and two concerning road infrastructure) of international importance are being undertaken.

The following railway projects costing US $\$ 430.2$ million are under way:

- organization of high-speed passenger train traffic on Tashkent-Samarqand route (US\$ 76.7 million)

- construction of fibre-optic line on Navoi-Uchkuduk 2-Misken-Nukus-KungradKarakalpakiya route

- installation of centralized control and auto-lock station equipment on the NavoiUchkuduk 2-Sultanuizdag-Karakalpakiya route (both projects costing a total of US\$19.2 million)

- construction of double-track electrified Yangiyer-Djizzakh railway line (US\$ 334.3 million)

The following road projects costing US\$ 782.5 million are under way:

- programme of multi-tranche financing: Project of Development of Regional Roads. Phase I, with ADB (US\$182.5 million);

- programme of multi-tranche financing: Project of Development of Regional Roads. Phase II, with ADB (US\$ 600 million)

New proposed transport infrastructure projects of international importance and related investment costs

In addition to the ongoing infrastructure projects, Uzbekistan has proposed one project with a medium-term and two projects with a long-term perspective on implementation:

- electrification of Marokand-Karshi railway line (by 2014)

- electrification of Marokand-Navoi-Bukhara railway line (by 2018)

- electrification of Karshi-Tashguzar-Baysun-Kumkurgan-Termez railway line (by 2017)

On 21 December 2010, the Programme of Accelerated Development of Infrastructure, Transport and Communications Construction 2011-2015 was adopted. It envisages the construction or reconstruction of sections of the Uzbek national highway (total length of $2,306 \mathrm{~km}$ ) and of road infrastructure facilities and services (240 units), the upgrade of $1,030 \mathrm{~km}$ of railway tracks, the renewal of the vehicle fleet of the intermodal logistics centres (212 units), etc. 
Total amount of foreseen investment for 2011-2015 (excluding the communications sector) exceeds US\$ 5.6 billion including foreign investment and loans of US\$ 2.1 billion.

The Programme supports the accelerated implementation of projects to establish a unified national automobile transportation system, connecting all regions of the country, expanding the construction and reconstruction of four-lane road sections of the Uzbek national highway, applying modern cement concrete and asphalt pavement technologies that meet the highest international standards, developing and modernizing railway transport, reconstructing railways, building and commissioning the high-speed Tashkent-Samarkand railway line, electrifying railway stations to the cities of Bukhara and Karshi, renewing rolling stock with modern highperformance locomotives, freight and passenger cars, etc. 


\section{OFFICIAL COMMUNICATIONS}
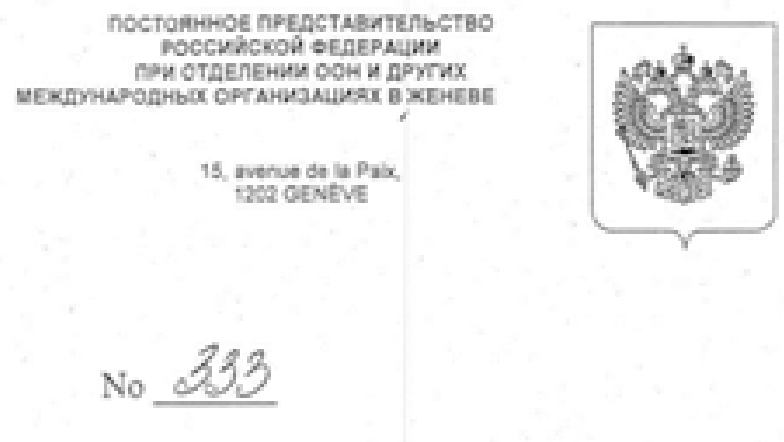
MISSION PERUANENTE OF LA FECERATON CE RUSSIE Auakts of rofFCE DES NATONS UNItS ET DeS AUTRES OROANISATICNS BTtERKATIONULES AYANT LEUR SIEQE A GENIVE
Telephones: 733 is $75,7345458,7346630$ Telotax 734644

The Permanent Mission of the Russian Federation to the United Nations Office and other International Organizations in Geneva presents its compliments to the Secretariat of the United Nations Economic Commission for Europe and with reference to documents ECE/TRANS/SC.2/GEURL/2011/1 and ECE/TRANS/SC.2/GEURL 2011/1/Corr.1 has the honour to inform of the following.

The term "Istanbul Strait", proposed by Turkey for inclusion in the document ECE/TRANS/SC.2/GEURL/2011/1 does not appear in any international legal instruments and thus is unknown to international practice.

The Russian Federation suggests that the term "Bosporus Strait" should be retained in line 5 of the item 8 on page 4 of the document ECE/TRANS/SC.2/GEURL/2011/1 as well as in the "InterGovernmental Document - EurAsia", which will be drafted by group of experts later this year. The term "Bosporus Strait" is used in the Montreux Convention Regarding the Régime of the Straits of 1936 and is widely recognized by international law.

The Permanent Mission avails itself of this opportunity to renew to the Secretariat the assurances of its highest consideration.

Secretariat of the United Nations

Economic Commission for Europe

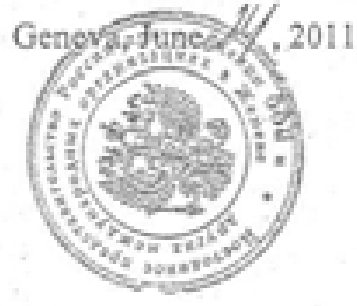

24 JUIN 2011 


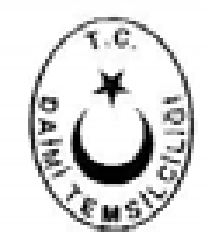

PERMAOENT MISSION OF TURKEY

TO THE UNITED NATIONS

CENENA

$2011 / \mathrm{BMCO} / 2319963$

The Permanent Mission of the Republic of Turkey to the United Nations Office at Geneva and other Internationd Organizations in Switzerlard presents its compliments to the Secretariat of the UN Economic Commission for Europe and has the bonor enclose herewith the statement made by the Turkish Delegation at the meeting of the Group of Experts on Unified Railway Law, held in Geneva on 7 October 2011, in response to the objection raised by the Russian Federation, on the "corrigenda" issued by the Secretariat, on documents ECETRANS/2011/3/ and ECE/TRANS/SC.2/GEURL/2011/1.

The Permanent Mission of the Republic of Turkey would highly appreciate if due consideration be given to the position of the Republic of Turkey reflected in this statement, in the drafting of the fortheoming documents of the Inland Transport Committee (ITC) and its subsidiacy bodies.

The Permanent Mission of the Republic of Turkey avails itself of this opportunity to renew to the Secretariat of the UN Economic Commission for Eusope the assurances of jts highest consideration.

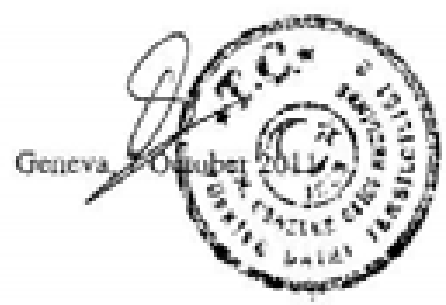

Encl. 1

Secretariat of the UNECE.

Transport Disision

Fax: 0229170039 


\section{STATEMENT OF TURKEY MADE AT THE MEETING OF THE GROUP OF EXPERTS ON UNIFIED RAIL WAY LAW}

"The use of the term "Turkish Straits" or "Straits of Istanbul and Canakkale" has historical, political and legal justification, such as; respect for past and present general practice, due regard to Turkey's sovereign rights over this particular area and to its jurisdiction according to the established principles of isternational law. There is also a considecable accumulation of agreemeats and principles developed by the UN coscerning the standardization of geographical names which states inter alia that when a geographical feature is completely within sovereignty of a country then official name given by the authorized national organization should be used in international documents.

Conotming the terminology in the 1936 Montreux Convention, it is useful to remind that Montreux was enacted only with the purpose of regulating navigation through the Straits. Turkey has beta strictly implementing this Convention for 75 years and intends to do so in the future.

Beyond this purpose, however, Montreux doss bot pumport to establish names for localities or States Parties for that matter. Otberwise, we would bave been forced to refer to some signatory countries with names such as the Kingdom of Bulgarians, the King of the Hellenes, the Emperor of India or The Central Executive Cormmittee of the Union of Soviet Sociallist Republies without paying attention to the fact that only States themselves are authorized to determine how they are called and governed.

In fact, the terra "Turkish Straits" or "Straits of Lstunbul and Canakkale" have been continously used in many international documents, including IMO and NATO resolutions and documents. A case in point is the Turkish Straits Regulations registered within IMO in 1994 and again in $1998 . "$ 
Document ECE/TRANS/SC.2/GEURL/2011/9 of the Working Party on Rail Transport, Group of Experts towards Unified Railway Law, Report of the Group of Experts on its second session held in Geneva on 7 October 2011 states the following:

"11. The Group of Experts was informed about communications received from the Russian Federation and Turkey regarding the corrigenda to the UNECE position paper and the agenda for the first session of the Group (ECE/TRANS/2011/3/Corr.1 and ECE/TRANS/SC.2/ GEURL/2011/1/Corr.1). The corrigenda, issued at the request of Turkey, had replaced the term "Bosporus" used in both documents by the term "Istanbul Strait". Referring to its communication to the UNECE secretariat on 24 June 2011, the representative of the Russian Federation stated that the term "Istanbul Strait" did not appear in any international legal instrument and was thus unknown in international practice. The Russian Federation, therefore, considered that the term "Bosporus Strait" should be retained in both documents, as this term was used in the Montreux Convention Regarding the Régime of the Straits of 1936 and was widely recognized by international law.

In response to the communication of the Russian Federation, the representative of Turkey made the following statement:

"The use of the term "Turkish Straits" or "Straits of Istanbul and Çanakkale" has historical, political and legal justification, such as; respect for past and present general practice, due regard to Turkey's sovereign rights over this particular are and to its jurisdiction according to the established principles of international law. There is also a considerable accumulation of agreements and principles developed by the United Nations concerning the standardization of geographical names which states inter alia that when a geographical feature is completely within sovereignty of a country then official name given by the authorized national organization should be used in international documents. Concerning the terminology in the 1936 Montreux Convention, it is useful to remind that Montreux was enacted only with the purpose of regulating navigation through the Straits. Turkey has been strictly implementing this Convention for 75 years and intends to do so in the future.

Beyond this purpose, however, Montreux does not purport to establish names for localities or States Parties for that matter. Otherwise, we would have been forced to refer to some signatory countries with names such as the Kingdom of Bulgarians, the King of the Hellenes, the Emperor of India or the Central Executive Committee of the Union of Soviet Socialist Republics without paying attention to the fact that only States themselves are authorized to determine how they are called and governed.

In fact, the term "Turkish Straits" or "Straits of Istanbul and Çanakkale" have been continuously used in many international documents, including IMO and NATO resolutions and documents. A case in point is the Turkish Straits Regulations registered within IMO in 1994 and again in 1998."

12. The Group of Experts agreed that the decision on the term to use with respect to this strait was outside the scope and mandate of the group. Moreover, the term in question was not included in the future IGD EurAsia. Therefore, the Group of Experts agreed to take note of the positions of the Russian Federation and Turkey and asked the secretariat to reflect both positions in the report of the meeting."

The full Report is available at:

http://www.unece.org/fileadmin/DAM/trans/doc/2011/sc2/ECE-TRANS-SC2-GEURL2011-09e.pdf

http://www.unece.org/trans/main/sc2/sc2_geurl_02.html 


\section{SUMMARY LIST OF INTERNATIONAL UNECE LEGAL INSTRUMENTS IN THE FIELD OF TRANSPORT}

\section{MAIN INTERNATIONAL UNECE TRANSPORT CONVENTIONS}

\section{A. Transport Infrastructure Agreements}

1. The European Agreement on Main International Traffic Arteries (AGR), of 1975, provides the international legal and technical framework for the development of a coherent international road network in the UNECE region. The AGR defines the E-road network, consisting of the arteries channelling major international road traffic flows in Europe, and the infrastructure parameters to which those arteries should conform. The AGR has undergone major revisions to include the international roads of the countries in the Caucasus and Central Asia. States that become Contracting Parties to the AGR commit themselves to its implementation, including the construction or upgrading of the E-roads in their territories, within their national investment programmes, although they are given latitude as to the timing for the completion of construction. Contracting Parties at 7 March 2012: 37 States.

2. The European Agreement on Main International Railway Lines (AGC), of 1985, similarly provides the legal and technical framework for the development of a coherent international rail network in the region. The AGC identifies the rail lines of major international importance, the E rail network, and defines the infrastructure parameters to which they should conform. The AGC is also revised whenever necessary to take account of political and transport changes in Europe. It has undergone a major revision in recent years in order to also include the international rail networks of the Caucasus and Central Asian countries. In becoming Contracting Parties to the AGC, European States commit themselves to its implementation, including the construction or the upgrading of the E-rail lines in their territories, within the framework of their national programmes but without any time constraints. Contracting Parties at 7 March 2012: 27 States.

3. The European Agreement on Important International Combined Transport Lines and Related Installations (AGTC), of 1991, provides the technical and legal framework for the development of efficient international combined road/rail transport in Europe. Combined $\mathrm{road} /$ rail transport comprises the transport of containers, swap bodies and entire trucks on railway wagons to and from especially equipped terminals. The AGTC determines all important European railway lines used for international combined transport, identifies all terminals, bordercrossing points, ferry links and other installations important for international combined transport services. It also establishes internationally acceptable infrastructure standards for those lines and related combined transport installations, and prescribes internationally acceptable performance parameters of trains and combined transport installations and equipment. European States who become Contracting Parties to the AGTC, commit themselves to its implementation in their territories within the framework of their national programmes but without any time constraints. Contracting Parties at 7 March 2012: 32 States. 
4. The European Agreement on Main Inland Waterways of International Importance (AGN), of 1996, establishes the internationally agreed European network of inland waterways and ports as well as the uniform infrastructure and operational parameters to which they should conform. The geographical scope of the $\mathrm{E}$ waterways network, consisting of navigable rivers, canals and coastal routes extends from the Atlantic to the Ural, connecting 37 countries and reaching beyond the European region. By acceding to the AGN, Governments commit themselves to the development and construction of their inland waterways and ports of international importance in accordance with the uniform conditions agreed upon and within their investment programmes. Contracting Parties at 7 March 2012: 17 States.

\section{B. Main Road Traffic and Road Safety Conventions}

5. The Convention on Road Traffic, of 1968, aims at facilitating international road traffic and at increasing road safety through the adoption of uniform road traffic rules. The Convention sets up commonly agreed rules on all factors influencing international road traffic and its safety, including the driver and the vehicle. Contracting Parties must comply and ensure compliance with these rules. The Convention establishes - without affecting the right of a Contracting Party to make the admission of vehicles in their territory subject to an applicable national law - that Contracting Parties are bound to admit to their territories in international traffic motor vehicles and drivers that fulfil the conditions laid down in the Convention and to recognize vehicle registration certificates issued by other Contracting Parties. In addition, the Convention details the basic conditions for the admission of vehicles and drivers in international traffic. The Convention is crucial for facilitating international road traffic, international transport and trade as well as tourism. Contracting Parties at 7 March 2012: 70 States.

6. The Convention on Road Signs and Signals, of 1968, sets up a set of commonly agreed road signs and signals. It classifies road signs in three categories: danger warning, regulatory and informative, and provides for each of them definitions and physical appearance, including dimensions, shapes and colours, graphic symbols and norms for ensuring their visibility and legibility. The Convention also prescribes common norms for traffic light signals and signals for pedestrians. Moreover, the Convention prescribes uniform conditions for road markings, signs for road works and signals and gates for level crossings. Contracting Parties at 7 March 2012: 62 States.

7. The European Agreement supplementing the 1968 Convention on Road Traffic, of 1971, sets up more specific provisions than the Convention in order to further enhance road safety. Contracting Parties at 7 March 2012: 34 States.

8. The European Agreement supplementing the 1968 Convention on Road Signs and Signals, of 1971, similarly establishes more specific rules for signs and signals to increase safety. Contracting Parties at 7 March 2012: 32 States.

9. Protocol on Road Markings, Additional to the European Agreements supplementing the 1968 Convention on Road Signs and Signals, of 1973, sets up the rules according to which marking should be placed on the roads to better organize road traffic and prevent road accidents. Contracting Parties at 7 March 2012: 27 States.

\section{Agreements on Regulations for the Construction of Vehicles}

10. The Agreement concerning the Adoption of Uniform Technical Prescriptions for Wheeled Vehicles, Equipment and Parts which can be fitted and/or be used on Wheeled Vehicles and the Conditions for Reciprocal Recognition of Approvals granted on the Basis of these Prescriptions, 
of 1958, provides the legal framework for the development of the safety and emissions regulations according to which motor vehicles must be manufactured in Europe and in many other parts of the world. Altogether more than 120 such regulations have been developed. These regulations and the successive amendments they have undergone have considerably increased vehicle safety and drastically reduced vehicle emissions. Contracting Parties at 7 March 2012: 46 States and the European Union.

11. The Agreement concerning the Establishing of Global Technical Regulations for Wheeled Vehicles, Equipment and Parts which can be fitted and/or be used on Wheeled Vehicles, of 1998, provides the framework for the development of global technical regulations for vehicles. Two global technical regulations have already been adopted. Contracting Parties at 7 March 2012: 32 States and the European Union.

12. The Agreement concerning the Adoption of Uniform Conditions for Periodical Technical Inspections of Wheeled Vehicles and the Reciprocal Recognition of Such Inspections, of 13 November 1997, provides the legal framework for the technical inspections of vehicles. It has annexed to it 2 Rules, which are aimed at maintaining vehicles' safety during their entire life. Contracting Parties at 7 March 2012: 12 States and 17 signatories pending ratification.

\section{Other Road Transport Conventions}

13. The European Agreement concerning the Work of Crews of Vehicles engaged in International Road Transport (AETR), of 1970, aims at preventing drivers and crews of commercial vehicles of more than 3.5 tonnes, or transporting more than 9 people, engaged in international road transport, from driving excessive hours. Driver fatigue is known to increase the risk of serious road accidents. Non-standardized working hours may create disparities in the working conditions of professional drivers and may impact a company's competitive. To this end, the AETR regulates the driving times and rest periods of professional drivers. The Agreement also defines control devices that are used to control those periods, and sets up technical requirements for the construction, testing, installation and inspection of these devices. Additionally, the AETR also sets up requirements for the checking of driving hours by competent authorities. By regulating the driving times and rest periods of drivers of commercial vehicles engaged in international transport, the AETR creates a level playing field in the road haulage industry and helps prevent road accidents. Contracting Parties at 7 March 2012: 51 States.

The Convention on the Contract for the International Carriage of Goods by Road (CMR), of 1956, facilitates international road transport by providing a common transport contract, including a common consignment note and harmonized liability limits. The CMR fixes the conditions governing the contract for the international carriage of goods by road between the carrier and the shipper and sets the conditions of liability of the carrier in case of total or partial loss of goods. The CMR has no direct implications for governments as it regulates through private law. However, in order for transport operators to take advantage of the Convention, it must be included in national legislation. An additional Protocol to the CMR has entered into force to facilitate the use of an electronic consignment note. The CMR Convention helps to maintain fair competition between carriers and limits the costs of international road transport, including insurance costs. Contracting Parties at 7 March 2012: 55 States.

The Protocol to the Convention on the Contract for the International Carriage of Goods by Road, of 1978, modifies the provisions concerning the liability of the carrier for compensation in respect of loss of goods, set out in article 23 of the Convention. Contracting Parties at 7 March 2012: 41 States. 


\section{E. Border-Crossing Facilitation Conventions}

16. The Convention concerning Customs Facilities for Touring, of 1954, facilitates the development of international touring by providing temporary admission, free of import duties and import taxes, of the personal effects imported by a tourist, provided they are for the personal use of the tourist, that they are carried on the person of or in the luggage accompanying the tourist, that there is no reason to fear abuse, and that these personal effects will be re-exported by the tourist on leaving the country. Contracting Parties at 7 March 2012: 79 States.

17. The Additional Protocol to the Convention concerning Customs Facilities for Touring, relating to the Importation of Tourist Publicity Documents and Materials, of 4 June 1954, establishes the special conditions for the admission of such documents and materials. Contracting Parties at 7 March 2012: 74 States.

18. The Customs Convention on the Temporary Importation of Private Road Vehicles, of 1954, facilitates the temporary admission into a country Contracting Party to the Convention of private road vehicles registered in another country, also Contracting Party to the Convention, without payment of import duties and taxes for the vehicles. The Convention defines the concept of private road vehicle and establishes the principle of temporary importation of such vehicles under the cover of the international "Carnet de passage en douane". These Carnets guarantee payment of import duties and taxes of the vehicles to national competent authorities if the vehicle that has been temporarily admitted is not re-exported. The "Carnets de passage en douane" are issued by authorized organizations or associations, which guarantee the payment. The Convention describes in detail the functioning of the temporary importation procedures and the documents to be used as well as claims procedures to be applied when exportation of vehicles has not been done within the time limits prescribed. The Convention is open to all United Nations Members. It introduces a uniform procedure and provides for an internationally recognized document, which replace national procedures and documents, often different from one country to another. The procedure also avoids the operation of national guarantee systems, as all taxes and duties are covered. In addition, it ensures accurate filling-in by competent authorities and associations or private vehicle drivers. As a result, the Convention helps minimize procedures and delays at border crossings. Contracting Parties at 7 March 2012: 79 States and the European Union.

19. The Customs Convention on the International Transport of Goods under Cover of TIR Carnets (TIR Convention), of 1975, sets up the procedure that permits the international carriage of goods by road vehicles or containers from one customs office of departure to a customs office of arrival, through as many countries as necessary, without intermediate check of the goods carried and without the deposit of a financial guarantee at each border. The procedure includes the use of secure vehicles or containers that have to be approved by authorities according to standards prescribed in the Convention in order for them to be used for TIR operations. It also includes an international guarantee chain, set up under the Convention, to cover duties and taxes at risk throughout the journey and whereby in each Party a duly authorized association provides a guarantee towards national competent authorities. In addition, each vehicle must carry an international customs document, the TIR Carnet, which certifies the contents of the cargo as checked at the customs office of departure and which is also a guarantee document. The customs authorities at intermediate borders recognize the TIR Carnets, trust the information contained therein and do not undertake checks unless deemed appropriate for any reason. Finally, the procedure foresees a controlled access to the TIR system and the exclusion from the system of operators that misuse it for illegal purposes. An Administrative Committee, composed of all Parties to the TIR Convention, administers the Convention, which is open to all members of the United Nations. Through efficient control procedures and an international guarantee system, the TIR 
Convention of 1975 permits to avoid physical inspections of goods in transit as well as payment of taxes and duties for the goods en route. It also permits to avoid a national guarantee system and national customs document and control systems. All this results in minimum procedures and delays at borders and in lower transport costs, which in turn results in lower export and import costs. Contracting Parties at 7 March 2012: 67 States and the European Union.

20. The Customs Convention on the Temporary Importation of Commercial Road Vehicles, of 1956, facilitates the temporary admission into a country Party to the Convention of commercial road vehicles registered in another country also Party to the Convention without payment of import duties and taxes for the vehicle. The Convention sets up the principle of temporary importation of such vehicles under cover of the international document "Carnet de passage en douane". These Carnets guarantee payment of import duties and taxes of the vehicles to national competent authorities if the vehicle that has been temporarily admitted is not re-exported. The Carnets are issued by authorized organizations or associations, which guarantee the payment. The Convention describes the functioning of the temporary importation procedures and the documents to be used as well as claims procedures to be applied when the exportation of vehicles has not been done within the time limits prescribed. The Convention introduces a standardized procedure and provides for an internationally recognized document, which replace national procedures and documents, often different from one country to another. The procedure also avoids the operation of national guarantee systems, as all taxes and duties are covered. In addition, it ensures accurate filling-in by competent authorities and transport operators. As a result, the Convention helps minimize procedures and delays at border crossings. The Convention is open to all United Nations Members. Contracting Parties at 7 March 2012: 40 States and the European Union.

21. The International Convention to Facilitate the Crossing of Frontiers for Passengers and Baggage carried by Rail, of 1952, facilitates the crossing of borders for passengers carried by rail by providing procedures for control of the entry and exit of passengers and their baggage by competent authorities of two adjoining countries linked by a railway line carrying a considerable volume of passengers crossing the frontier. Contracting Parties at 7 March 2012: 10 States.

22. The International Convention to Facilitate the Crossing of Frontiers for Goods Carried by Rail, of 1952, facilitates the crossing of frontiers by goods carried by rail by providing procedures and conditions for harmonizing and ensuring a high level of efficiency in the controls of goods carried by rail at borders between two adjoining countries on a railway line carrying a considerable volume of goods. Contracting Parties at 7 March 2012: 12 States.

23. The Customs Convention on Containers, of 1972, facilitates the temporary use of containers in international transport by deferring payment of taxes and duties for the temporary use in a Contracting Party of containers registered in another Contracting Party. Contracting Parties at 7 March 2012: 38 States.

24. The International Convention on the Harmonization of Frontier Controls of Goods, of 1982, aims at facilitating border crossing in international transport of goods through harmonization and reduction of the requirements for completing formalities and the number and duration of border controls. The Convention establishes the procedures for carrying out efficiently all types of controls that may be necessary at borders, including customs controls, medicosanitary inspections, veterinary inspections, phytosanitary inspections, controls of compliance with technical standards and quality controls. Procedures largely call for national cooperation and coordination of the various services among them, as well as for international cooperation between the respective border services of the adjacent countries. The Convention foresees measures that include joint controls of goods and documents through the provision of shared facilities, same 
opening hours and same types of services at the same border. These procedures apply to all goods being imported, exported or in transit and to all modes of transport. An Administrative Committee manages the Convention, which is foreseen for global application. The Convention provides for a reduction in the number and duration of all types of controls and best practices for efficient controls of goods at border crossings. It aims at promoting the one-stop-shop principle for border controls. As a result, the Convention reduces border delays, which results in lower transport costs and, therefore, in lower export and import costs. Contracting Parties at 7 March 2012: 55 States and the European Union.

25. The Convention on Customs Treatment of Pool Containers Used in International Transport, of 1994, aims at the duty- and tax-free admission of containers belonging to a Pool by simplifying the regime set up by the Customs Convention on Containers, of 1972. Contracting Parties at 7 March 2012: 14 States.

\section{F. Transport of Dangerous Goods}

26. The European Agreement concerning the International Carriage of Dangerous Goods by Road (ADR), of 1957, aims at ensuring the highest possible level of safety in the transport of dangerous goods at an economically acceptable cost. It identifies the substances that are considered as dangerous goods and that can be admitted in international transport as well as those that cannot be admitted. For the former, the ADR establishes the conditions under which they can be carried. These include the classification of substances according to their specific type of danger (explosives, flammable liquids, flammable gases, corrosive substances, etc.), packing conditions, labelling, marking, placarding, documentation and special requirements for tanks. The ADR also contains requirements on transport operations, driver training as well as vehicle construction and approval. Security provisions have recently been included. The Annexes to the ADR are usually amended every two years. While obliging Contracting Parties to accept vehicles coming from other Parties if they comply with the ADR, the Agreement preserves the right of Contracting Parties to prohibit, for reasons other than safety during carriage, the entry of dangerous goods into their territory. Contracting Parties also retain the right to arrange less stringent conditions of international transport on their territories, by special bilateral or multilateral agreements. The ADR is open for accession to all United Nations Member States. Accession to the ADR has no financial implications for countries. However, for exporting countries, it imposes administrative structures for testing and approval of packagings, tanks and vehicles, for driver and dangerous goods safety adviser training and for issuing the corresponding certificates. The ADR provides for a high level of safety and security during international carriage of dangerous goods. It also facilitates transport and trade of such goods resulting from mutual recognition of packaging, tank, vehicle and driver training certificates. Being harmonized with the United Nations Model Regulations that serve as a basis for all modes of transport and most national regulations at worldwide level also facilitates compliance, enforcement and control. Annexes A and B may be, and actually are, used for also regulating domestic traffic in EU countries. Contracting Parties at 7 March 2012: 48 States.

27. The Protocol amending article 1(a), article 14 (1) and article 14(3)(b) of ADR, of 1993, simplifies the procedures for amending the annexes to the ADR, and harmonizes the definition of the term "vehicle" with the definition used in various EC directives. Contracting Parties at 7 March 2012: 29 States.

28. The European Agreement concerning the International Carriage of Dangerous Goods by Inland Waterways (ADN), of 2000, entered into force on 28 February 2008. It aims at ensuring a high level of safety at an economically acceptable cost. The Regulations annexed to the ADN, 
which became applicable twelve months after the Agreement entered into force, namely on 28 February 2009, contain provisions concerning dangerous substances and articles, provisions concerning their carriage in packages and in bulk on board inland navigation vessels or tank vessels, as well as provisions concerning the construction and operation of such vessels. They also address requirements and procedures for inspections, the issue of certificates of approval, recognition of classification societies, monitoring, and training and examination of experts. Contracting Parties at 7 March 2012: 17 States.

\section{G. Transport of Perishable Foodstuffs}

29. The Agreement on the International Carriage of Perishable Foodstuff and on the Special Equipment to be used for such Carriage (ATP), of 1970, establishes uniform prescriptions for the preservation of the quality of the perishable foodstuffs during their international transport. It defines uniform norms and standards for the special transport equipment required as well as for the checking of insulation and sets up uniform distinguishing marks to be affixed to the special equipment. Also uniform equipment and temperature conditions for deep-frozen and frozen foodstuffs are specified. Contracting Parties at 7 March 2012: 46 States. 


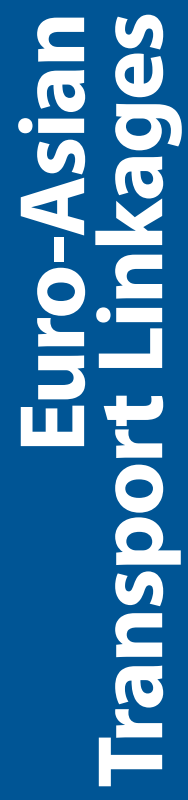

The United Nations has a long history of support for developing transport connections between Europe and Asia. The Euro-Asian Transport Linkages (EATL) project in Phase I (2003-2007) identified the principal international EATL transport linkages in order to connect the European and Asian transport networks. The present EATL Phase II (2008-2012) study involves 27 countries and covers 9 EATL road routes, 9 EATL rail routes, 17 water transport links, 52 inland river ports and 70 maritime ports. Threehundred-and-eleven transport infrastructure projects totalling US $\$ 215$ billion were included in the study, out of which 188 were identified as high priority with a total cost of US\$78 billion. In addition to the multi-country transport investment needs assessment, the paper includes the comparative analysis of the maritime and land transport between Europe and Asia. By taking a door-to-door approach, we can see that the land-bridge and railways, in particular, can be competitive when border crossing facilitation measures are in place. In the past four years participating governments have reviewed the non-physical obstacles to international transport along the EATL routes and identified the needed actions in order to reduce the economic distance among themselves, as well as from their major markets. Finally, the EATL project developed its Geographic Information System (GIS) database and thus improved EATL maps are available not only in the paper, but also on the UNECE web site at http://apps.unece.org/eatl/. 